\title{
Mens rea and defences in European criminal law
}

Citation for published version (APA):

Blomsma, J. H. (2012). Mens rea and defences in European criminal law. [Doctoral Thesis, Maastricht University]. Maastricht University. https://doi.org/10.26481/dis.20121011jb

Document status and date:

Published: 01/01/2012

DOI:

10.26481/dis.20121011jb

Document Version:

Publisher's PDF, also known as Version of record

\section{Please check the document version of this publication:}

- A submitted manuscript is the version of the article upon submission and before peer-review. There can be important differences between the submitted version and the official published version of record.

People interested in the research are advised to contact the author for the final version of the publication, or visit the DOI to the publisher's website.

- The final author version and the galley proof are versions of the publication after peer review.

- The final published version features the final layout of the paper including the volume, issue and page numbers.

Link to publication

\footnotetext{
General rights rights.

- You may freely distribute the URL identifying the publication in the public portal. please follow below link for the End User Agreement:

www.umlib.nl/taverne-license

Take down policy

If you believe that this document breaches copyright please contact us at:

repository@maastrichtuniversity.nl

providing details and we will investigate your claim.
}

Copyright and moral rights for the publications made accessible in the public portal are retained by the authors and/or other copyright owners and it is a condition of accessing publications that users recognise and abide by the legal requirements associated with these

- Users may download and print one copy of any publication from the public portal for the purpose of private study or research.

- You may not further distribute the material or use it for any profit-making activity or commercial gain

If the publication is distributed under the terms of Article $25 \mathrm{fa}$ of the Dutch Copyright Act, indicated by the "Taverne" license above, 
Mens rea and defences in European criminal law 
Cover: Caravaggio, Judith Beheading Holofernes (c. 1598-1599)

School of Human Rights Research Series, Volume 54

A commercial edition of this dissertation will be published by Intersentia under ISBN 978-1-78068-104-7.

The titles published in this series are listed at the end of this volume.

No part of this publication may be reproduced, stored in an automated data system or transmitted in any form or by any means, electronic, mechanical or photocopying, recording, or otherwise, without the prior written permission from the author/publisher. 
Mens rea and defences in European criminal law

\section{PROEFSCHRIFT}

ter verkrijging van de graad van doctor

aan de Universiteit Maastricht, op gezag van de Rector Magnificus, Prof. dr. L.L.G. Soete, volgens het besluit van het College van Decanen, in het openbaar te verdedigen op donderdag 11 oktober 2012 om 16.00 uur

door

Jeroen Herman Blomsma 


\section{Promotor:}

Prof. mr. A.H. Klip

\section{Co-promotor:}

Dr. P.L. Bal†

\section{Beoordelingscommissie:}

Prof. mr. T.N.M.B. Spronken (voorzitter)

Prof. mr. G.P.M.F. Mols

Dr. D. Roef

Prof. J.R. Spencer (University of Cambridge)

Prof. dr. T. Weigend (Universität zu Köln) 


\section{ACKNOWLEDGements}

Writing a $\mathrm{PhD}$ is a lonely experience, yet I would not have been able to do this without the help of many others. I thank everyone working at Maastricht University and its Faculty of Law for enabling me to write this book. Whether it was by copying books, reimbursing travel costs, improving my writing skills or by discussing my research, you all have contributed to this book.

Some people should be mentioned by name. I thank Taru Spronken, Gerard Mols, David Roef, Thomas Weigend and John Spencer for reading and approving the text published in this book. In particular, thank you Thomas Weigend for your comments on perhaps the most significant proposal of my book. The work you did already in 1981 has also been very helpful to me. David Roef, thank you also for continuously putting the foundations of criminal law on the department's agenda. You have significantly widened my horizon as a scholar.

I want to thank Maartje Krabbe for taking the time to discuss my drafts on defences in European criminal law. Our lunch meetings were very useful to me. Thank you also Alwin van Dijk, for reading and commenting on my chapter on fault elements, and of course for your invaluable research on intention.

Part of the methodology consisted of verifying the data gathered behind my desk with scholars and practitioners in the countries under investigation. In Aachen, Oberstaatsanwalt Lutz Bernklau and Richter Gerd Nohl helped improve my understanding of the law in practice and legal culture of German law. I am also grateful to Peter Alldridge, David Ormerod and William Wilson for welcoming me in London and helping me with my questions on English law.

Andrew Ashworth, I appreciate very much how you meticulously read my report on English law. Your guided tour through some of Oxford University's buildings was truly inspiring. Jeremy Horder, our discussions in London and your contributions during the conference in Maastricht were very valuable to my research. Thank you so much.

I am very grateful to my supervisor, André Klip. You have aided me in so many ways. Your clear vision on criminal law and legal research has helped me not to lose sight of what is really important. You taught me to be more patient and pragmatic, which proved to be very useful skills during these last five years. You supported me in dealing with external issues, thereby minimizing distractions. Thank you for the opportunities you gave me and your continuous confidence in me.

I was saddened by the sudden death of Peter Bal, my co-supervisor. With his passion and anecdotes, he made any get-together with the department so much more fun. I regret we did not have more time to discuss this research and life in general. Only after your death, Peter, I realized what an important role communication plays in attributing criminal liability. Communication being a 
central issue of your doctoral thesis, I would have loved to discuss this with you. You have inspired me to also give it an important role in this book.

I am happy to have been part of a research team with Johannes Keiler, AnneSophie Massa and Christina Peristeridou. Even though we come from very different backgrounds, we immediately formed a great team. I cherish the time we spent, discussing legal and other important issues in our lives. The cooperation in our team has taken our individual projects to a next level. At the same time, I could share with you any problems I encountered. Although perhaps not the typical problem a PhD-student runs into, I vividly recall when we were in Sicily in 2007 and I had managed to cover both of my hands in cactus needles. Anne-Sophie took my left hand, Cristina my right and you helped me to get rid of them. To me, that says it all.

Johannes, you were always there to talk, always willing to sacrifice and always looking for the closest thing to truth. I could not have wished for a better academic sparring partner than you. Thank you also for putting up me with me as a roommate, which must not always have been easy.

I also want to thank Roland Moerland for putting up with me. You welcomed me into your room in 2006 and we quickly became friends. Although our research projects seem completely different, we found a lot of common ground.

Marelle, although you left room D1.223 already many years ago, our friendship has only grown since then. Thank you and Kim for your kindness and hospitality. I want to thank all my friends and family for taking my mind of this book when I really needed to.

Opa, you have always encouraged me to study. Every time we talked, you showed a great interest in my book and Europe in general. Although I don't think this makes me a professor in de weet-niet-kunde, I know you will still be proud of me. Oma, you passed away just before I finished this book. It would have been great if you could have held it.

Noah, thank you for not depriving me of too much sleep during the first months of your life. Your mom also played a big part in that. Without her support, I would also not be where I am right now. Dear Judith, thank you for your understanding and patience.

Mom and dad, it is only because of your constant support and encouragement throughout my life that this work has been possible. Thank you.

Den Haag,

9 August 2012 


\section{Contents}

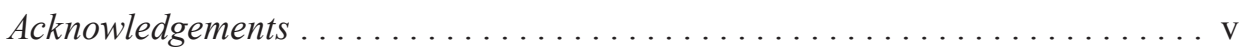

List of abbreviations ..........................................

\section{Part 1}

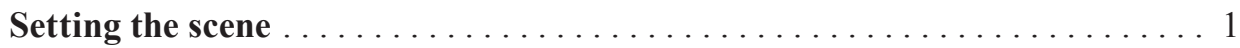

\section{Chapter I}

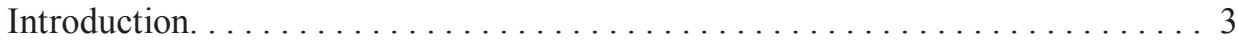

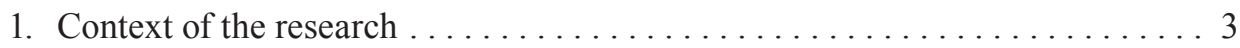

1.1. Mens rea and defences............................. 3

1.2. The general part of criminal law . . . . . . . . . . . . . . 3

1.3. European criminal law........................ 4

2. The need for a general part of European criminal law ............ 5

2.1. Implementation of Union legislation in national law $\ldots \ldots \ldots \ldots \ldots 6$

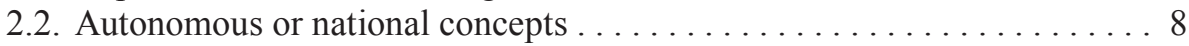

2.3. Recklessness or dolus eventualis................... 8

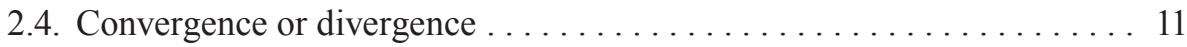

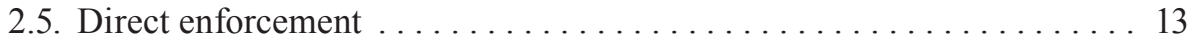

2.6. Guidance ................................... 14

3. Outline ..................................... 15

Chapter II

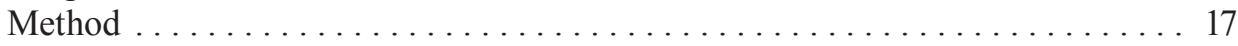

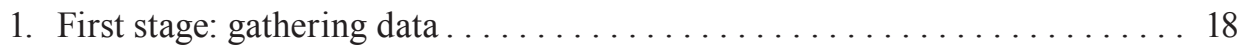

1.1. Comparative legal research . . . . . . . . . . . . . . . . . . . 18

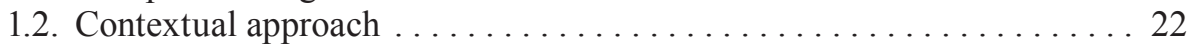

1.3. EU Perspective: from fragments to a whole $\ldots \ldots \ldots \ldots \ldots \ldots \ldots 23$

1.4. Criminal law ................................. 24

2. Second stage: synthesis ............................ 25

2.1. The scope of the general part. . . . . . . . . . . . . . . . . 26

2.2. Consistency and coherency ....................... 28

2.3. Enforceability............................ 30

2.4. Compatibility with human rights and constitutional traditions . . . . . 31

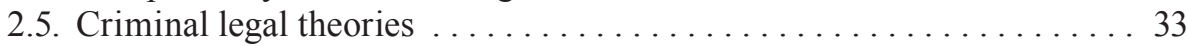

2.5.1. The object of punishment .................... 33 
2.5.2. The character of criminal law................. 33

2.5.3. The purpose of general principles. . . . . . . . . . . 35

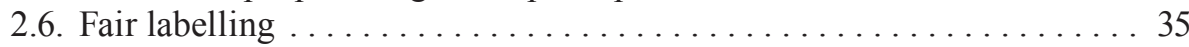

2.7. Conclusion ............................... 36

\section{Part 2}

Mens rea.

Chapter III

What is mens rea? ................................ 43

1. Analytical tool................................... 43

2. Fault element ............................... 44

3. Demarcation from other subjective elements $\ldots \ldots \ldots \ldots \ldots \ldots \ldots \ldots, \ldots 4$

4. Demarcation from blameworthiness ...................... 46

5. Framework of criminal liability $\ldots \ldots \ldots \ldots \ldots \ldots \ldots \ldots \ldots \ldots \ldots \ldots$

6. Demarcation from actus reus ............................ 50

6.1 . Verbs that imply a subjective element ................. 50

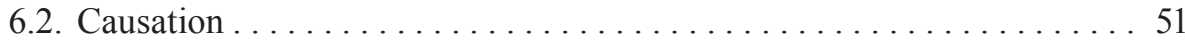

6.3. Attempt, participation and more .................... 53

7. Objectivism and subjectivism ........................ 54

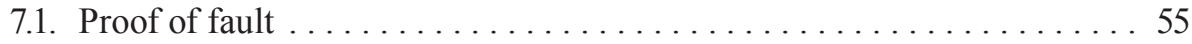

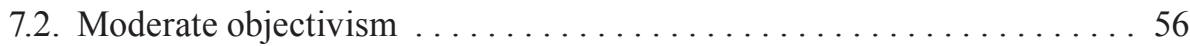

Chapter IV

Fault elements .......................................... 59

1. Introduction ..................................... 59

1.1. Kinds of fault, reflecting degrees of culpability . . . . . . . . . . . 59

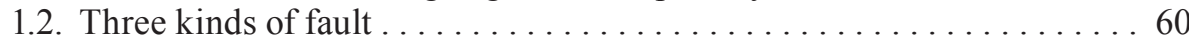

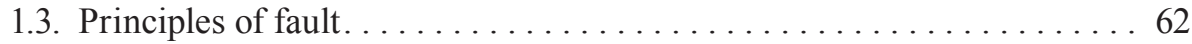

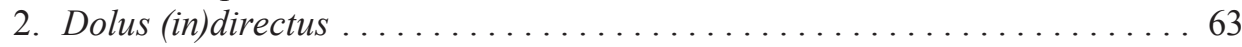

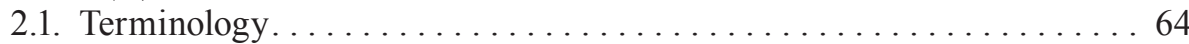

2.2. Dolus directus ................................ 65

2.2.1. Rationale ............................. 65

2.2.2. Criteria ..............................66 66

2.2.3. Goal and necessary means .................... 67

2.2.4. Chance of result occurring ................... 67

2.3. Dolus indirectus. ................................ 69

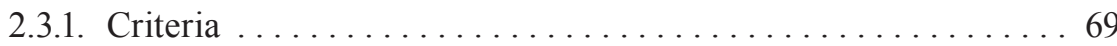

2.3.2. Rationale .......................... 70

2.3.3. Certainty ............................. 72

2.3.4. Necessary means versus side-effects . . . . . . . . . . 73

2.4. A neutral concept............................ 74 
2.4.1. Moral enrichment of intent in England. . . . . . . . . . . 75

2.4.2. Ulterior intent ......... . . . . . . . . . . . . . . 79

2.4.3. The use of ulterior intent. . . . . . . . . . . . . . 80

2.4.4. Ulterior intent and motive $\ldots \ldots \ldots \ldots \ldots \ldots \ldots \ldots \ldots$

2.4.5. Proof of ulterior intent. . . . . . . . . . . . . . . . 82

2.4.6. No dolus malus .......................... 85

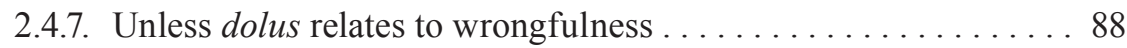

2.4.8. Unless dolus relates to normative elements . . . . . . . . . 93

2.5. Knowledge ............................... 94

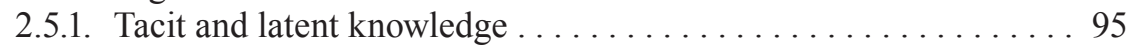

2.5.2. Knowledge and belief ....................... 96

2.5.3. Wilful blindness ........................ 97

3. Dolus eventualis ................................... 99

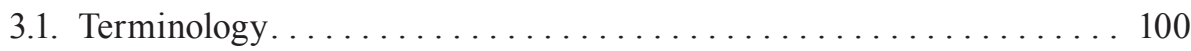

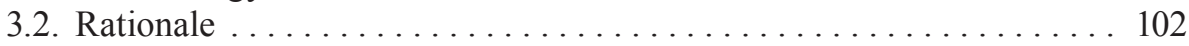

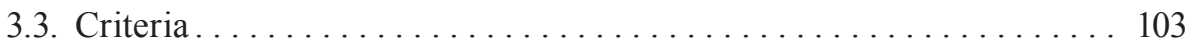

3.4. Risk ................................. 104

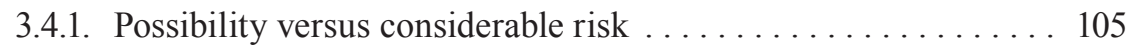

3.4.2. Chance of being infected with HIV . . . . . . . . . . . 105

3.4.3. The likelihood and its acceptance. . . . . . . . . . . . 107

3.4.4. The assessment of risks. . . . . . . . . . . . . . . . 108

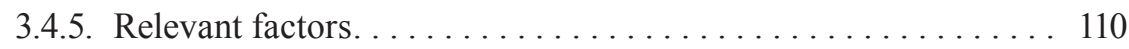

3.5. Awareness of the risk . . . . . . . . . . . . . . . . . 112

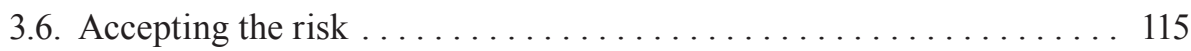

3.6.1. Acceptance of the risk. . . . . . . . . . . . . . . . 116

3.6.2. Proving the volitional element .................... 118

3.6.3. Acceptance inferred from probability . . . . . . . . . . . 119

3.6.4. Acceptance of lethal results . . . . . . . . . . . . . . . 120

3.6.5. Acceptance inferred from possibility . . . . . . . . . . 126

3.6.6. Cognitive theories on intent ................... 126

3.6.7. Acceptance inferred from foreseeability . . . . . . . . 128

3.6.8. Normative theories . . . . . . . . . . . . . . . . . 130

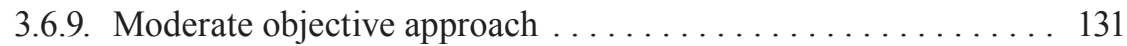

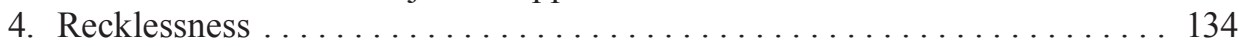

4.1. Rationale ................................. 134

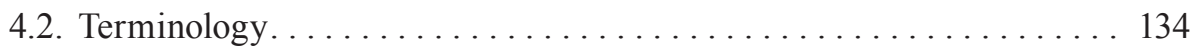

4.3. Criteria ................................. 135

4.4. Awareness ................................... 136

4.5. Unreasonable risk .......................... 136

4.5.1. Unreasonable. . . . . . . . . . . . . . . . . . . . 137

4.5.2. Unjustified........................... 138

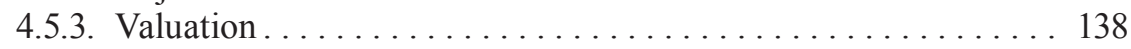

4.6. Caldwell recklessness . . . . . . . . . . . . . . . . . . . . . 139 
5. Dolus eventualis versus recklessness . . . . . . . . . . . . . . . . . . 142

5.1. Differences. . . . . . . . . . . . . . . . . . . . . . . . . . . . . . 142

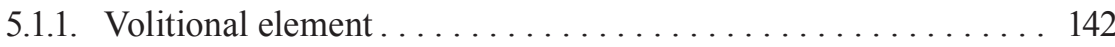

5.1.2. Normative risk . . . . . . . . . . . . . . . . . . . 143

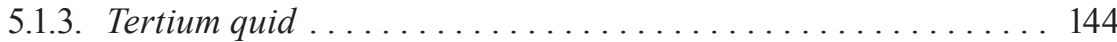

5.2. Three instead of two . . . . . . . . . . . . . . . . . . 144

5.2.1. Intended versus foreseen results . . . . . . . . . . . . . 144

5.2.2. Dolus eventualis distorts intent . . . . . . . . . . . . 145

5.3. Awareness over volition. . . . . . . . . . . . . . . . . . . . . . . . 148

5.3.1. Dolus eventualis is controversial . . . . . . . . . . . . . . . . . 148

5.3.2. Controversy due to volition. . . . . . . . . . . . . . . . . . 149

5.3.3. Proving fault from awareness or objective danger . . . . . . . . 150

5.3.4. Proof of volition by rules of general experience. . . . . . . . . . 151

5.3.5. Is it warranted to distinguish by volition? . . . . . . . . 152

5.3.6. Awareness is the better dividing line . . . . . . . . . . . 154

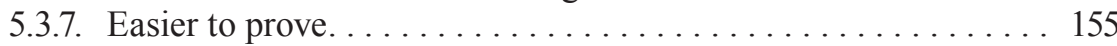

5.4. Normative aspects . . . . . . . . . . . . . . . . . . . . 158

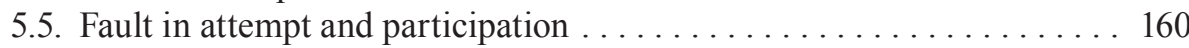

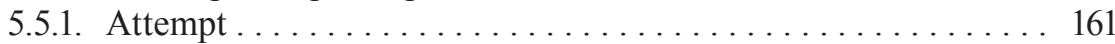

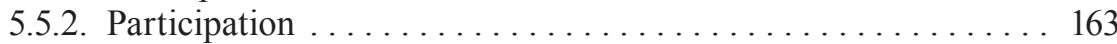

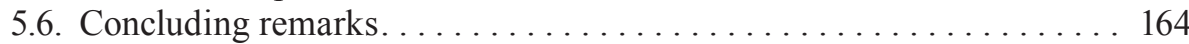

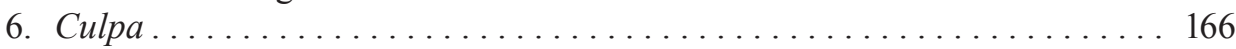

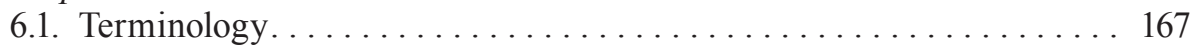

6.2. Rationale ............................... 168

6.2.1. A balanced approach. . . . . . . . . . . . . . . . 168

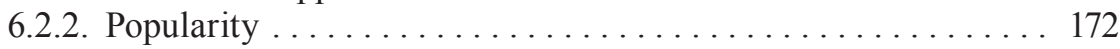

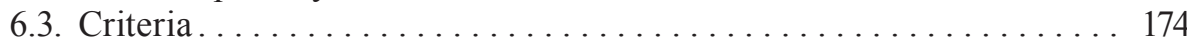

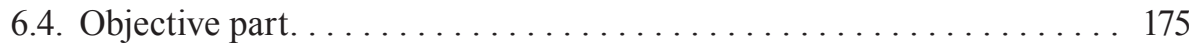

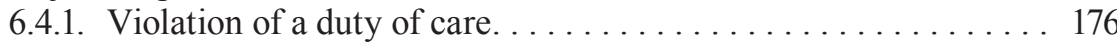

6.4.2. Contra-indications. . . . . . . . . . . . . . . . . . . . . . . 179

6.4.3. Reasonable person. . . . . . . . . . . . . . . . . . 183

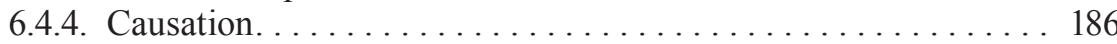

6.4.5. Gross carelessness. . . . . . . . . . . . . . . . . . . . 191

6.5. Subjective part . . . . . . . . . . . . . . . . . . . . . 193

6.5.1. Assumed with the objective part. . . . . . . . . . . . . . . . 193

6.5.2. Negated by an excuse . . . . . . . . . . . . . . . . . . . 195

6.5.3. Position in the framework of criminal liability . . . . . . . . . . 197

6.6. Minus or aliud . . . . . . . . . . . . . . . . . . . . . . . 198

6.7. Luxuria. . . . . . . . . . . . . . . . . . . . . . . . . . . . . . . 199

6.7.1. Criteria ........................... 200

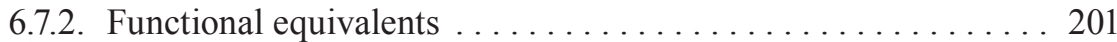

6.7.3. Reconsidering recklessness. . . . . . . . . . . . . . 203 


\section{Chapter V}

Principles of mens rea ............................... 205

1. Introduction...................................... 205

2. Correspondence principle ............................ 206

2.1. Fault requirement............................. 206

2.2. Referential principle.......................... 208

2.3. Strict liability .................................... . 209

2.3.1. Terminology . . . . . . . . . . . . . . . . . . . . . . . 210

2.3.2. Rationale .............................. 211

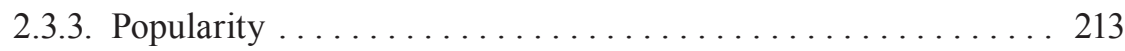

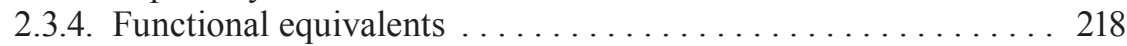

2.3.5. Valuation............................. 224

2.3.6. Traffic offences ........................ 228

2.3.7. Concluding remarks $\ldots \ldots \ldots \ldots \ldots \ldots \ldots \ldots \ldots \ldots \ldots \ldots \ldots \ldots \ldots$

2.4. Mistake on the offence definition .................... 234

2.4.1. Terminology .......................... 234

2.4.2. Overcoming the inexorable logic $\ldots \ldots \ldots \ldots \ldots \ldots \ldots 236$

2.5. Unintended outcomes ........................... 239

2.5.1. Error in persona vel obiecto. . . . . . . . . . . . . . . . . 240

2.5.2. Aberratio ictus . . . . . . . . . . . . . . . . . . . . . . . . 242

2.5.3. Transferred fault ......................... 246

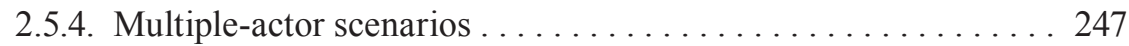

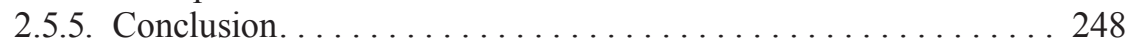

3. Principle of contemporaneity . ........................ 250

3.1. Dolus antecedens and subsequens. . . . . . . . . . . . . . . 251

3.2. Dolus generalis ................................ 252

3.3. Reversed dolus generalis....................... 255

3.4. Actio libera in causa .......................... 256

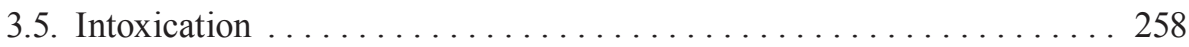

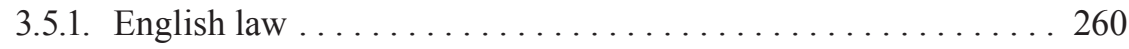

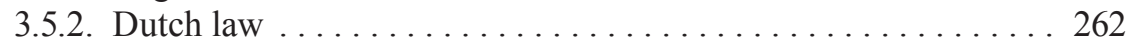

3.5.3. German law.............................. 264

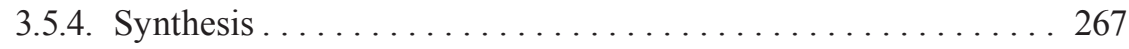

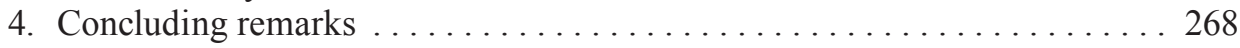

\section{Part 3}

Defences .............................................. 273

Chapter VI

What are defences? ................................ 277

1. Affirmative defences............................... 277

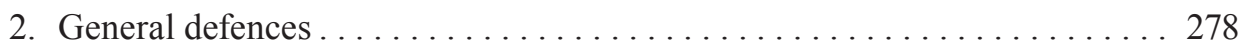


3. Substantive defences . . . . . . . . . . . . . . . . . . . . . . . . . 279

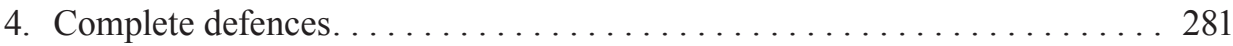

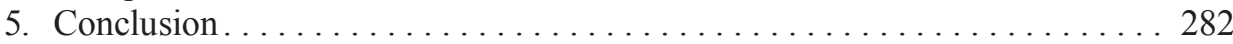

Chapter VII

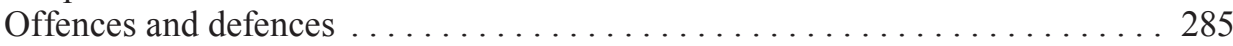

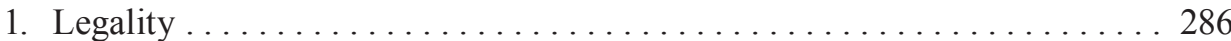

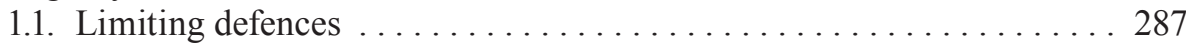

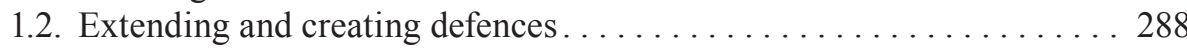

1.3. Guidelines . . . . . . . . . . . . . . . . . . . . . . . . . . 290

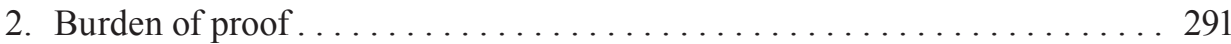

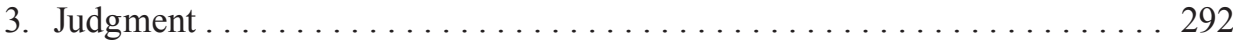

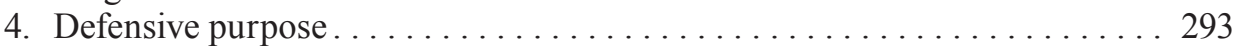

4.1. Dual requirement. . . . . . . . . . . . . . . . . . . . . . . . . 294

4.2. Purpose versus mere awareness . . . . . . . . . . . . . . . 296

4.3. Negligent offences . . . . . . . . . . . . . . . . . . . . . . . . . . . 297

4.4. Unknowing justification . . . . . . . . . . . . . . . . . . . 298

5. Putative defences. . . . . . . . . . . . . . . . . . . . . . . . 299

5.1. The distinction . . . . . . . . . . . . . . . . . . . 300

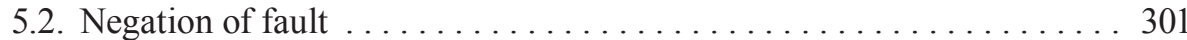

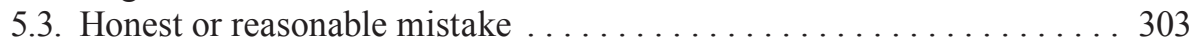

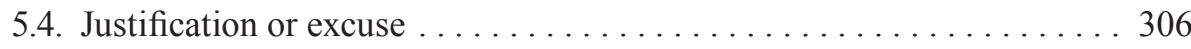

5.5. Error in persona and aberratio ictus . . . . . . . . . . . . . . 309

5.6. The distinction reconsidered . . . . . . . . . . . . . . . . . . . 310

5.7. Putative excuses. . . . . . . . . . . . . . . . . . . . . 310

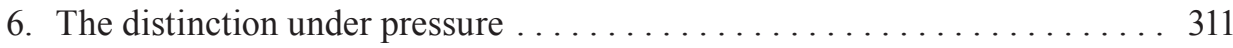

6.1. Non-ideal offences . . . . . . . . . . . . . . . . . . . . . . . . . . . . 312

6.2. Affirmative or failure of proof defence . . . . . . . . . . . . . . 314

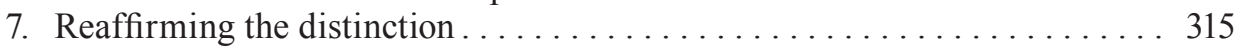

7.1. Different meanings of non-ideal elements. . . . . . . . . . . . 316

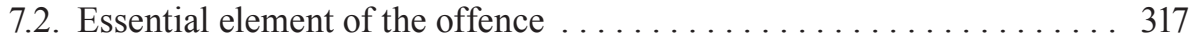

Chapter VIII

Justifications and excuses . . . . . . . . . . . . . . . . 321

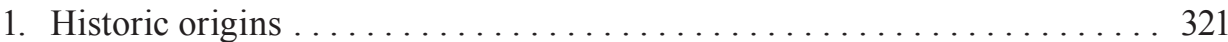

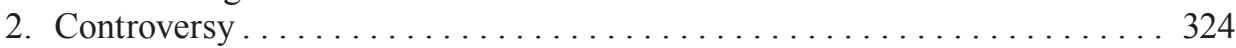

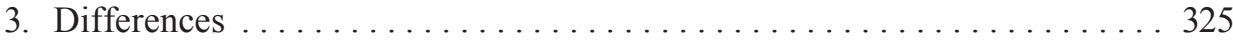

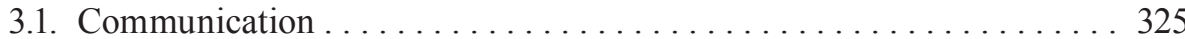

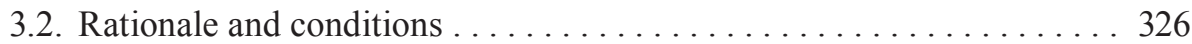

3.3. Enabling measures. . . . . . . . . . . . . . . . . . 326

3.4. Complete or partial negation of the implied element . . . . . . . 327 
3.5. Personal and universal application . . . . . . . . . . . . . 329

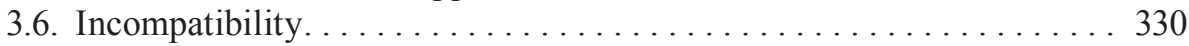

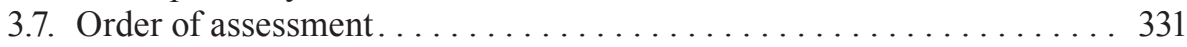

3.8. Conclusion .............................. 332

\section{Chapter IX}

Justifications . . . . . . . . . . . . . . . . . . . . . . . . 333

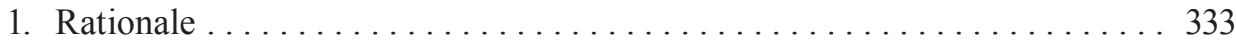

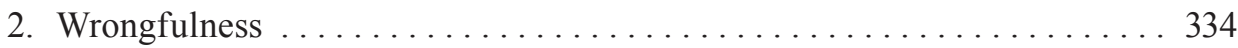

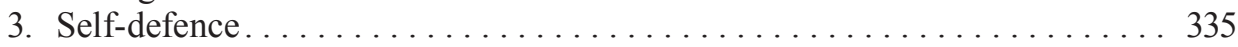

3.1. Rationale ................................. 335

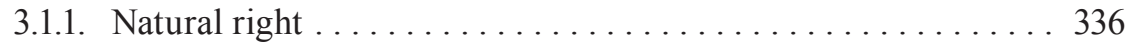

3.1.2. Legal order . . . . . . . . . . . . . . . . . . 337

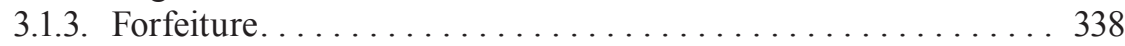

3.1.4. Weighing of interests . . . . . . . . . . . . . . . . 339

3.2. Scope ................................... 340

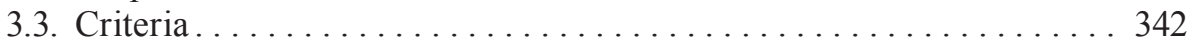

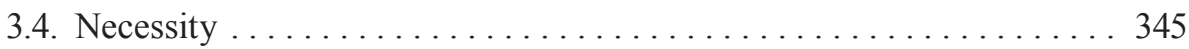

3.4.1. Wrongful attack ......................... 345

3.4.2. Legitimate interests. . . . . . . . . . . . . . . . . 348

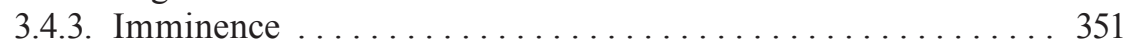

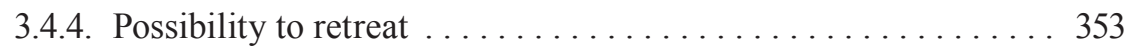

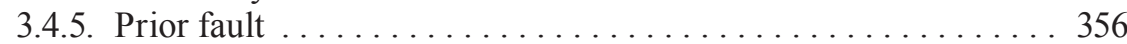

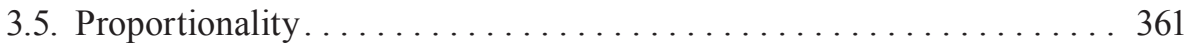

3.5.1. Least intrusive means . . . . . . . . . . . . . . . . . . . . 362

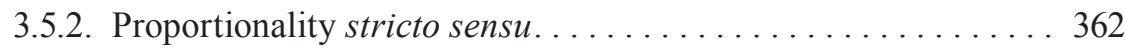

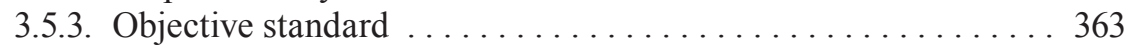

3.5.4. Developments ............................. 365

4. Necessity . . . . . . . . . . . . . . . . . . . . . . . . . . . . . 369

4.1. Rationale ................................ 371

4.2. Sources. . . . . . . . . . . . . . . . . . . . . . . 374

4.3. Criteria ................................... 377

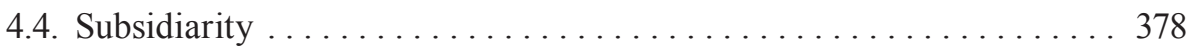

4.4.1. Legitimate interests. . . . . . . . . . . . . . . . . 378

4.4.2. Imminence ............................ 379

4.4.3. No other means of aversion. . . . . . . . . . . . . . 382

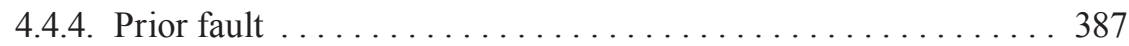

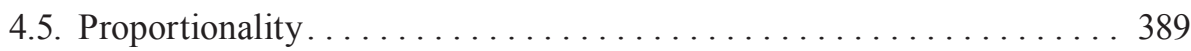

4.5.1. Legal interests . . . . . . . . . . . . . . . . . . . . . 390

4.5.2. Concrete interference . . . . . . . . . . . . . . . . . . . . 392

4.5.3. Joint risky ventures . . . . . . . . . . . . . . . . . . . . . . 393

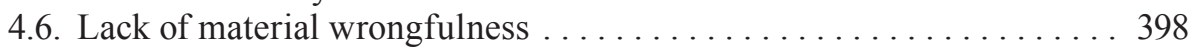


5. Consent ............................. 401

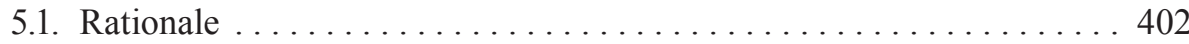

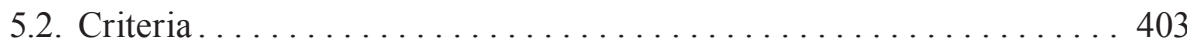

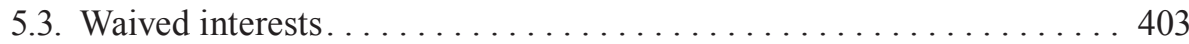

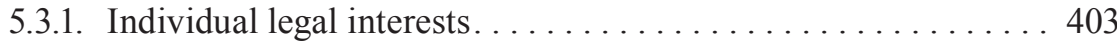

5.3.2. Public policy limitations . . . . . . . . . . . . . . . . . . 404

5.4. Capacity ............................. 407

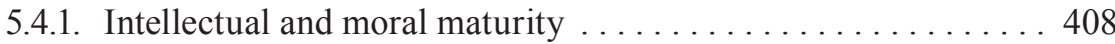

5.4.2. Presumed consent ........................ 409

5.4.3. Free and informed consent ................ 411

5.5. Affirmative or failure of proof defence . . . . . . . . . . . . . 413

5.5.1. Distinguishing feature . . . . . . . . . . . . . . 414

5.5.2. Defensive purpose. . . . . . . . . . . . . . . . 415

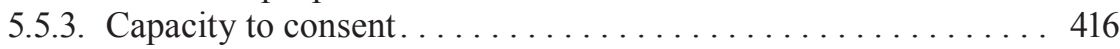

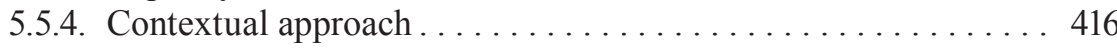

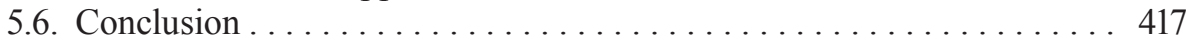

Chapter X

Excuses ... . . . . . . . . . . . . . . . . . . . . . . . . . . . . . 419

1. Rationale ................................. 419

2. Blameworthiness ............................ 421

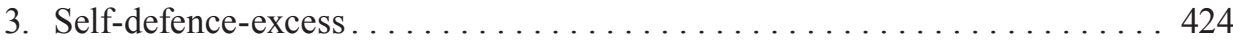

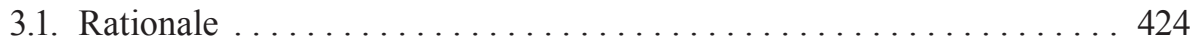

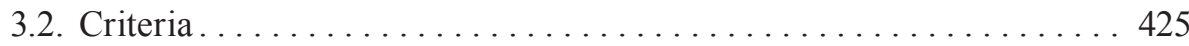

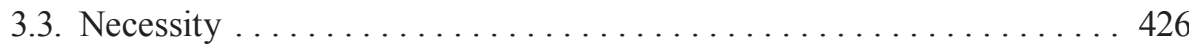

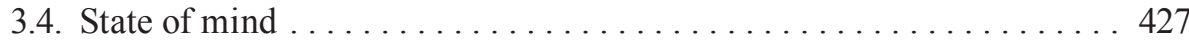

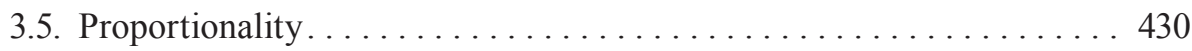

3.6. Partial defences in English law . . . . . . . . . . . . . . 431

3.6.1. Loss of control. . . . . . . . . . . . . . . . . . . . . . 432

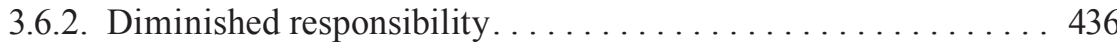

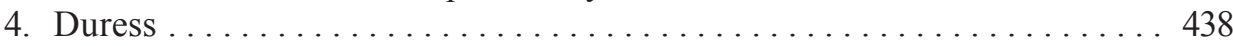

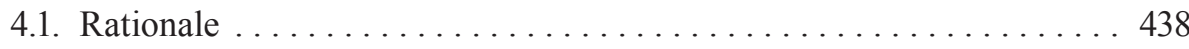

4.2. Sources. . . . . . . . . . . . . . . . . . . . . . . . 441

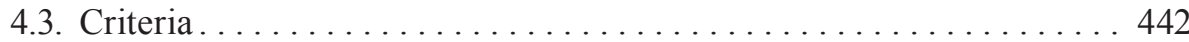

4.4. Subsidiarity ... . . . . . . . . . . . . . . . . . . . . 444

4.4.1. Legitimate interests. . . . . . . . . . . . . . . . . . 444

4.4.2. Source of the danger . . . . . . . . . . . . . . . . . . 446

4.4.3. Imminent danger. . . . . . . . . . . . . . . . . . . . . . . 450

4.4.4. No other means of aversion. . . . . . . . . . . . . 450

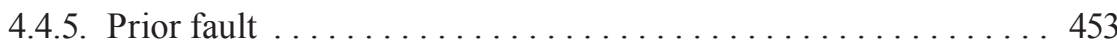

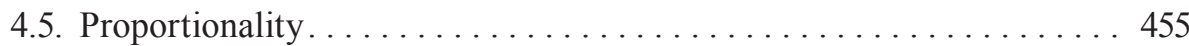

4.5.1. Murder. ........................... 457

4.5.2. Ticking bomb scenarios . . . . . . . . . . . . . 460 


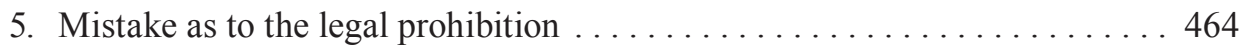

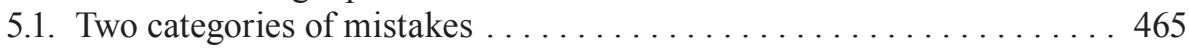

5.2. Rationale ................................ 467

5.3. Only an unavoidable mistakes excuses . . . . . . . . . . . . . 469

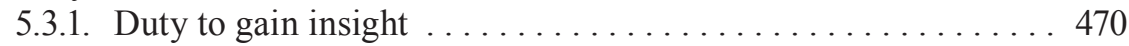

5.3.2. Official advice....................... 471

5.3.3. Unpublished legislation. . . . . . . . . . . . . . . . . 473

5.3.4. Other considerations . . . . . . . . . . . . . . . . . . . . 474

5.4. Conclusion ................................. 474

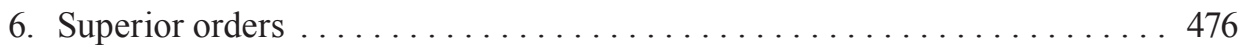

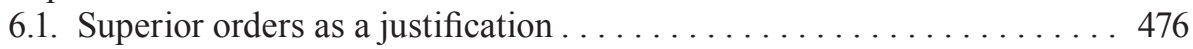

6.2. Rationale ............................... 477

6.3. Scope .................................. 479

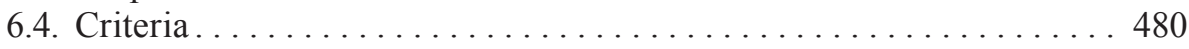

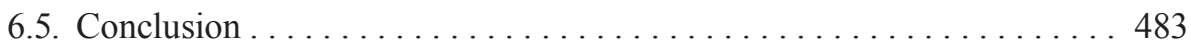

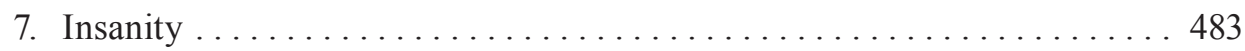

7.1. Rationale ............................... 483

7.2. Related issues........................... 486

7.2.1. Two-lane approach ...................... 486

7.2.2. Punishment according to guilt $\ldots \ldots \ldots \ldots \ldots \ldots \ldots \ldots 487$

7.2.3. Unfit to plead. . . . . . . . . . . . . . . . . . . . 487

7.3. Criteria................................. 489

7.4. Mental disorder ............................ 490

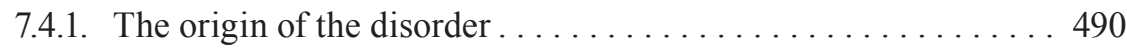

7.4.2. Affect and intoxication ..................... 492

7.4.3. Other disorders . . . . . . . . . . . . . . . . . . 493

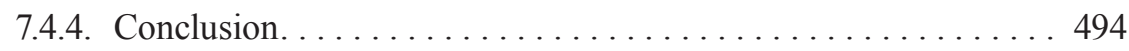

7.5. Capacities. .............................. 494

7.5.1. Evaluative capacities. . . . . . . . . . . . . . . . . 495

7.5.2. Cognitive capacities ........................ 496

7.5.3. Volitional capacities . . . . . . . . . . . . . . . . . . . 497

7.5.4. Attribution. . . . . . . . . . . . . . . . . . . . . . 499

7.5.5. Diminished capacity ..................... 501

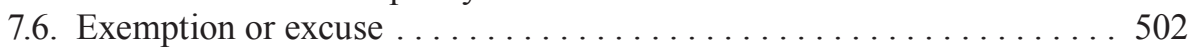

\section{Part 4}

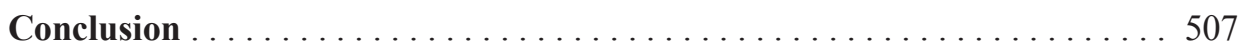

Chapter XI

Conclusion ........................................ 509

1. General conclusions ............................... 509

1.1. Recklessness instead of dolus eventualis . . . . . . . . . . . 510 


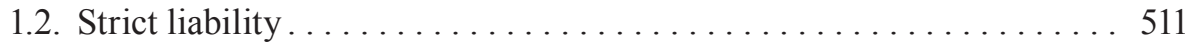

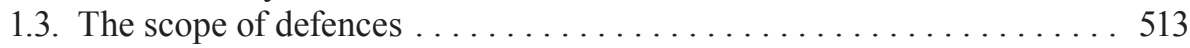

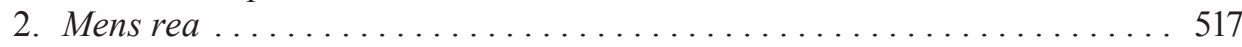

2.1. Rationale ........................... 517

2.2. Actus non facit reum nisi mens sit rea . . . . . . . . . . . . . . . . 519

2.3. Fault elements .......................... 521

2.4. Relevant factors ............................ 524

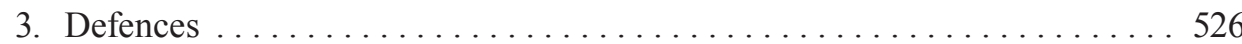

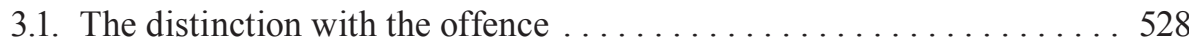

3.2. Justifications and excuses . . . . . . . . . . . . . . . . 530

3.3. General principles governing defences $\ldots \ldots \ldots \ldots \ldots \ldots \ldots \ldots \ldots$

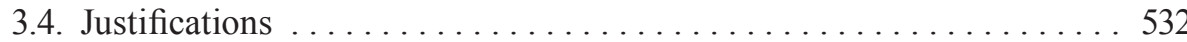

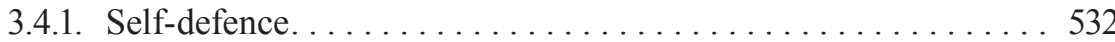

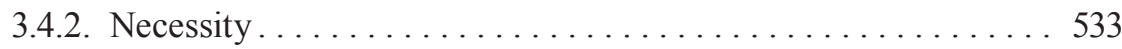

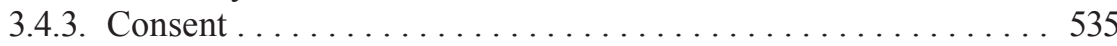

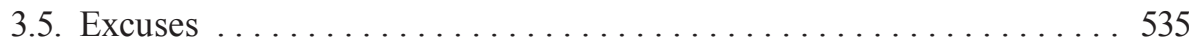

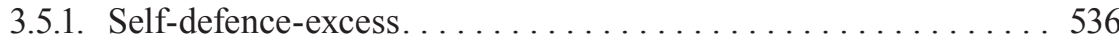

3.5.2. Duress ........................ 537

3.5.3. Mistake as to the legal prohibition, putative defences and

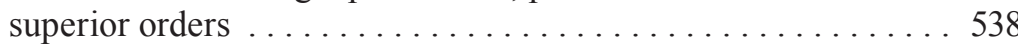

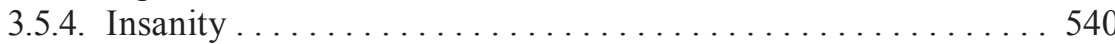

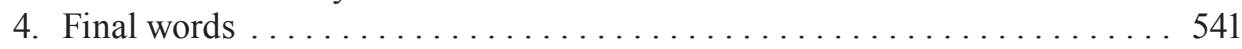

Summary.................................. 543

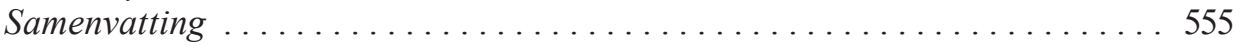

Selected bibliography............................. 569

Curriculum Vitae of Jeroen Blomsma . . . . . . . . . . . . . . . . . 621 


\section{LIST OF ABBREVIATIONS}

$\begin{array}{ll}\text { AC } & \text { Appeals Cases } \\ \text { AG } & \text { Advocate General } \\ \text { appl. no. } & \begin{array}{l}\text { application number } \\ \text { article }\end{array} \\ \text { art. } & \text { All England Law Reports } \\ \text { All ER } & \text { Bayerisches Oberstes Landesgericht } \\ \text { BayObLG } & \text { Beck-Rechtsprechung } \\ \text { BeckRS } & \text { Bürgerliches Gesetzbuch } \\ \text { BGB } & \text { Bundesgerichtshof } \\ \text { BGH } & \text { Bundesgerichtshof's Official Gazette, criminal cases } \\ \text { BGHSt } & \text { Bundesgerichtshof's Official Gazette, civil cases } \\ \text { BGHZ } & \text { Betäubungsmittelgesetz } \\ \text { BtMG } & \text { (Decision of the) Bundesverfassungsgericht } \\ \text { BVerfG(E) } & \text { (Decision of the) Bundesverwaltungsgericht } \\ \text { BVerwG(E) } & \text { Charter of Fundamental Rights of the EU } \\ \text { CFR } & \text { Commonwealth Law Reports } \\ \text { CLR } & \text { Document originating from the EU Commission } \\ \text { COM } & \text { Crown Prosecution Service } \\ \text { CPS } & \text { Criminal Appeal Reports } \\ \text { Cr App R } & \text { Criminal Law Review } \\ \text { Crim LR } & \text { Director of Public Prosecutions } \\ \text { DPP } & \text { European Communities } \\ \text { EC } & \text { European Convention of Human Rights } \\ \text { ECHR } & \text { European Court of Human Rights } \\ \text { ECtHR } & \text { European Court of Justice } \\ \text { ECJ } & \text { European Court Reports } \\ \text { ECR } & \text { European Parliament } \\ \text { EP } & \text { European Public Prosecutor's Office } \\ \text { EPPO } & \text { European Union } \\ \text { EU } & \text { England \& Wales Court of Appeal } \\ \text { EWCA } & \text { England \& Wales High Court } \\ \text { EWHC } & \text { Goltdammer's Archiv für Strafrecht } \\ \text { GA } & \text { German Democratic Republic } \\ \text { GDR } & \text { Grundgesetz } \\ \text { GG } & \text { Hoog Militair Gerechtshof } \\ \text { HMG } & \text { Hoge Raad } \\ \text { HR } & \text { International Criminal Tribunal for Rwanda } \\ \text { ICTR } & \text { International Criminal Tribunal for the former Yugoslavia } \\ \text { ICTY } & \text { Gesetz über die internationale Rechtshilfe in Strafsachen } \\ \text { IRG } & \\ & \end{array}$


List of abbreviations

$\begin{array}{ll}\text { jo. } & \text { juncto } \\ \text { JR } & \text { Juristische Rundschau } \\ \text { JZ } & \text { Juristenzeitung } \\ \text { KB } & \text { King's Bench } \\ \text { LJ(J) } & \text { Lord Justice(s) of Appeal } \\ \text { MDR } & \text { Monatsschrift für Deutsches Recht } \\ \text { MPC } & \text { Metropolitan Police Commissioner } \\ \text { NbSr } & \text { Nieuwsbrief Strafrecht } \\ \text { NJ } & \text { Nederlandse Jurisprudentie } \\ \text { NJB } & \text { Nederlands Juristenblad } \\ \text { (N)JW } & \text { (Neue) Juristische Wochenschrift } \\ \text { NStZ(-RR) } & \text { Neue Zeitschrift für Strafrecht (-Rechtsprechungsreport) } \\ \text { NVwZ } & \text { Neue Zeitschrift für Verwaltungsrecht } \\ \text { OJ L } & \text { Official Journal of the EU - Legislation } \\ \text { OJ C } & \text { Official Journal of the EU - Information and notices } \\ \text { OLAF } & \text { European Anti-Fraud Office } \\ \text { OLG } & \text { Oberlandesgericht } \\ \text { OWiG } & \text { Ordnungswidrigkeitengesetz } \\ \text { QB(D) } & \text { Queen's Bench (Division) } \\ \text { R. } & \text { Regina } \\ \text { Rb. } & \text { Rechtbank } \\ \text { Re } & \text { Regarding (ablative of res) } \\ \text { REV } & \text { Revised version of a EU document } \\ \text { RG } & \text { Reichsgericht } \\ \text { RGSt } & \text { Reichsgericht, criminal cases } \\ \text { RvdW } & \text { Rechtspraak van de week } \\ \text { s. } & \text { Section } \\ \text { SIEC } & \text { Significantly impede effective competition } \\ \text { StV } & \text { Strafverteidiger } \\ \text { StVG } & \text { Straßenverkehrsgezetz } \\ \text { StVO } & \text { Straßenverkehrs-Ordnung } \\ \text { Stb. } & \text { Staatsblad } \\ \text { StGB } & \text { Strafgesetzbuch } \\ \text { StPO } & \text { Strafprozessordnung } \\ \text { TEU } & \text { Treaty on the European Union } \\ \text { TFEU } & \text { Treaty on the functioning of the European Union } \\ \text { UK } & \text { United Kingdom } \\ \text { UKHL } & \text { United Kingdom House of Lords } \\ \text { UKPC } & \text { United Kingdom Privy Council } \\ \text { US } & \text { United States (of America) } \\ \text { v. } & \text { versus } \\ \text { VRS } & \text { Verkehrsrechts-Sammlung } \\ \text { WLR } & \text { Weekly Law Reports } \\ & \\ & \end{array}$




\section{Part 1}

Setting The SCEne 



\section{Chapter I INTRODUCTION}

\section{Context OF THE RESEARCH}

\subsection{Mens rea and defences}

If John refused to kill the police commissioner, the drug syndicate would kill his family. He therefore felt he had no choice but to assassinate the man. John heads over to a press conference, where the police commissioner is presenting his department's latest successful operation against the drug syndicate. However, just as he is about to shoot, a police officer spots John, jumps in front of the commissioner and is killed instead.

After John is arrested, several questions arise. First of all, did he commit murder? Does it matter that he killed the police officer and not the planned target? Can it be said that he intended to kill the commissioner, if all he wanted was to save his family? Or should the reasons for his actions be considered under a defence instead? After all, should he be punished for favouring the lives of his wife and child over that of one person? Finally, should a member of the drug syndicate be tortured in order to find the whereabouts of John's family?

These questions illustrate some of the issues of mens rea and defences. In short, mens rea encompasses the subjective elements of a crime, like intention, as well as the doctrines that govern its application. Defences, simply put, refer to those situations where the defendant should not be held liable, even though he formally committed an offence. For example, John will argue that although he killed the police officer, he should be acquitted because of invincible coercion.

Mens rea and defences are both legal tools that enable courts to communicate why the defendant is blamed, tools that enable courts to explain what degree of reproach is directed against the defendant. This degree is based on the level of control and choice of the defendant over his actions. A specific category of defences, called justifications, communicates what exactly is a criminal wrong. Under certain circumstances, committing an offence is not wrongful, but right, or at least permissible conduct. An excuse makes sure that only those who deserve to be punished are held criminally liable. It communicates that an offence has been committed but emphasizes that the defendant cannot be blamed for it.

\subsection{The general part of criminal law}

Mens rea and defences are principles that are generally applicable to all or almost all crimes. Together with principles such as attempt and legality, they form the general part of criminal law. This is contrasted with the collection of different 
offences that exist in a criminal legal system, called the special part. General principles of criminal law provide clarity and simplify the criminal code. Instead of having to repeat the rules governing mens rea or defences in each offence, one can refer to these rules provided for in detail by the general part.

A general part of criminal law serves a normative purpose as well, in the sense that liability for an offence can only follow in conformity with the general part. An offence can define whether somebody has done something wrong, but the general part determines whether or not that person is, or ought to be held liable for the wrongdoing. Regardless of the definition of an offence, general principles of criminal law safeguard that a person cannot be convicted for an offence if he has not committed a wrongful act and can be held blameworthy for it. For example, where manslaughter is considered a crime in the special part, the general principle of self-defence can preclude criminal liability. ${ }^{1}$ The general part of criminal law thus enables a critical evaluation of criminal liability. It is the foundation of every criminal justice system, whether codified or not. The aim of this book is to provide such general principles for the European criminal justice system, which is currently still lacking most of these principles.

\subsection{European criminal law}

This research deals with mens rea and defences in European criminal law. In the past decades, the process of European integration has influenced all fields of law, and eventually also substantive criminal law. Whereas the creation and enforcement of criminal liability used to be purely a national matter, this has changed into a shared responsibility of the European Union and its Member States. For example, Union law can limit the scope of domestic criminal law by precluding criminal penalties that, due to their excessive or discriminatory effects, violate one of the rights to free movement. ${ }^{2}$ On the other side of the coin, the Union can oblige its Member States to create or extend criminal liability. This competence of the Union has developed from a mere requirement of Member States to take measures that are effective, dissuasive and proportionate, which could bring about an obligation to apply criminal law in some cases, ${ }^{3}$ to a full-fledged competence of the Union to require the Member States to criminalize certain conduct. ${ }^{4}$

Besides this indirect enforcement of criminal offences through national law, the Union also enforces its own legislation, as it investigates and in some cases

Cane 2007, pp. 467-470.

See for example, 29 February 1996, Case C-193/94, Criminal proceedings against Sofia Skanavi and Konstantin Chryssanthakopoulos [1996] ECR I-929.

321 September 1989, Case 68/88, Greece v. Commission [1989] ECR 2965. In this case, the ECJ held in $\$ 24$ that Member States must make sure that "infringements of Community (JHB: now Union) law are penalised under conditions, both procedural and substantive, which are analogous to those applicable to infringements of national law of a similar nature and importance." Article 83 TFEU. 
sanctions fraud relating to the EU budget. The possibility under the Lisbon Treaty to establish a European Public Prosecutor's Office can be seen as an extension of the direct competences in criminal law of the Union. European criminal law can thus be described as a hybrid system, a multi-layered patchwork of legislation and case-law of European and national origin. ${ }^{5}$ It ranges from Union law that can be directly enforced by the Union's institutions, bodies, offices and agencies to national law that has somehow been influenced by Union law. The Union has exclusive competence in some areas, like competition law, but usually shares the competence to determine and enforce criminal liability with its Member States. ${ }^{6}$

For example, in Framework Decision 2002/475, as amended by Framework Decision 2008/919, the European Union obligates its Member States to criminalize certain terrorist conduct. The responsibility for the so-called 'fight against terrorism' is shared, because the European Union determines (to a large extent) the scope of criminal liability, which the Member States must implement and enforce. A Directive or Framework Decision cannot of itself determine or aggravate criminal liability. Implementation is required, as legal subjects can only be held liable for infringing the national law that implements the European legal instrument. ${ }^{7}$ Secondly, the European Union creates numerous instruments to assist the Member States in enforcing anti-terrorist legislation, such as the simplification of surrender procedures by the introduction of the European Arrest Warrant ${ }^{8}$ and the extension of powers of investigation in the obligation to retain communication data for a longer period. ${ }^{9}$

\section{The neEd for a general PART OF European CRIMinal LAW}

This shift of competences in criminal matters raises numerous issues. We can question the democratic legitimacy of decision-making in the $\mathrm{EU}^{10}$ or even the process of Europeanization itself. We can ask ourselves which issues of criminal law should remain national and for what reason. ${ }^{11}$ This research concentrates on a practical legal consequence of this shared responsibility, namely the need to identify a

Klip 2012, p. 1.

Articles 3(2) TEU, 3 TFEU and 4(2)(j) TFEU. Competition law is also criminal law, see II.1.4. Even in this field of law (article 105 TFEU), the responsibility is shared. In order to counter fraud against the EU budget, the Union also depends on Member States for coercive measures.

7 Articles 288 and 291 TFEU; 16 June 2005, Case C-105/03, criminal proceedings against Maria Pupino [2005] ECR I-5285 and 8 October 1987, Case 80/86, criminal proceedings against Kolpinghuis Nijmegen BV [1987] ECR 3969.

8 Framework Decision 2002/584 of 13 June 2002 on the European arrest warrant and the surrender procedures between Member States, OJ 2002 L 190/1.

9 Directive 2006/24 of 15 March 2006 on the retention of data generated or processed in connection with the provision of publicly available electronic communications services or of public communications networks and amending Directive 2002/58, OJ 2006 L 105/54.

10 In regard to the creation of a 'European Corpus Juris Criminalis', see Gle $\beta$ 2002, p. 128.

11 See Verheijen 2006. 
general part of criminal law for the European Union. The European Union has obliged Member States to criminalize different forms of undesired behaviour, but has not established the complete scope of this 'criminalization', ${ }^{12}$ omitting to define general principles, doctrines, elements or conditions of criminal law that apply to these crimes. ${ }^{13}$ For example, the Union refers to 'attempt' and 'intention' in its legislation, but it has not determined what qualifies as such. In other words, the so-called general part of criminal law remains somewhat of a blind spot in a Union that focuses predominantly on the special part of substantive criminal law.

I will explain below that as a consequence, national principles and concepts are applied to EU legislation, which leads to diverging outcomes in criminal liability. This is incompatible with the purpose of EU legislation, which is the convergence of legal systems by approximation. In addition, this is inconsistent with the idea of one area of Freedom, Security and Justice. As this field of law continuously grows, the lack of general principles of European criminal law is becoming increasingly problematic. This research aims to contribute to the conceptualization of mens rea and defences as important elements of the general part. It is part of a bigger project that aims to identify the whole general part of criminal law for the EU. ${ }^{14}$ By answering the central question of this book - what mens rea and defences should look like in a general part of European criminal law - an important portion of this general part is fleshed out.

\subsection{Implementation of Union legislation in national law}

When the EU determines there is certain conduct within the Area of Freedom, Security and Justice ${ }^{15}$ that merits punishment, but is not criminalized by all Member States, minimum standards are drawn up in Directives, and before the entering into force of the treaty of Lisbon, in Framework Decisions. This technique is called approximation or 'minimum harmonization'. ${ }^{16}$ In the preambles of the abovementioned Framework Decision on terrorism, we can read that terrorism undermines universal principles, common to the Member States and on which the Union is based, and that the approximation of the definition of terrorist offences is necessary to combat and prevent terrorism.

12 Clearly, the terms 'criminalization' and 'offence definition' do not apply to the definitions of conduct given in Framework Decisions and Directives, as they are merely an obligation to create a criminalization or offence definition.

13 The term 'general principles of Union law', see Tridimas 2006, should be distinguished from 'general principles of criminal law', see Ashworth 2006. The former concept is broader, also encompassing principles of a non-criminal nature.

For example, in other books, it will be discussed whether and on what basis the terrorists can be held liable for the attempted assassination committed by John and whether the Union should have jurisdiction based on the circumstance that the assassination was directed against a Member of its Parliament.

15 Article 29 TEU and Article 67 TFEU.

16 Article 31(1)(e) TEU. See also Article 83 TFEU. 
The purpose of these instruments is usually to create a minimum level of criminalization. It obligates Member States to criminalize conduct that fulfils certain minimum elements. For example, the required minimum elements of a terrorist offence can be an explosion that is committed intentionally and with a terrorist intent, such as the view to seriously intimidate a population. Member States must at least criminalize this conduct and they are thus free to adopt wider definitions of criminal offences, provided this does not violate fundamental rights, freedoms or other provisions of Union Law. ${ }^{17}$ This means that a Member State also fulfils its obligation to implement, if it (also) makes punishable the negligent rather than intentional causing of an explosion. ${ }^{18}$

These legislative instruments can be considered the special part of European criminal law. It is common to refer to concepts of the general part of criminal law in legislation, but in the EU this technique leads to problems because the scope of that general part is uncertain. Article 1(1) of Framework Decision 2002/475 defines terrorist offences:

"Each Member State shall take the necessary measures to ensure that the intentional acts referred to below in points (a) to (i), as defined as offences under national law, which, given their nature or context, may seriously damage a country or an international organisation where committed with the aim of $(. .)$.

I have italicized the elements of the offence that refer to general concepts of criminal law, namely the subjective elements or mens rea standards. Article 2(2) of the said Framework Decision reads:

"Each Member State shall take the necessary measures to ensure that the following intentional acts are punishable: (a) directing a terrorist group; (b) participating in the activities of a terrorist group, including by supplying information or material resources, or by funding its activities in any way, with knowledge of the fact that such participation will contribute to the criminal activities of the terrorist group."

17 Some Framework Decisions and Directives aim for 'maximum' or 'full harmonisation', which implies that the Member State is not allowed any discretion in implementation. The scope of intended harmonisation can be derived from the wording, goal(s) and legal basis of the instrument, see Kristen 2004, pp. 44-49. For example, in Directives that grant procedural rights to the suspect and accused, Member States are free to provide for more protection, see also Article 82(2) TFEU.

18 See by way of example, recital 12 of the preamble of Directive 2008/99 of 19 November 2008 on the protection of the environment through criminal law, OJ 2008 L 328/28. By contrast, Nilsson 2011 argues that if an offence element has been included to restrict the scope of the criminalization, like the adding of the element 'seriously' to intimidating a population in the mentioned Framework Decision, Member States are not free to implement national offences that do include the 'simple' intimidation. 


\subsection{Autonomous or national concepts}

The numerous references to general concepts beg the question as to what the intended scope of criminal liability is supposed to be. The special part of criminal law cannot be understood without reference to the principles that are generally applicable to it. Are the Member States to apply their own general concepts of criminal law or does the Framework Decision refer to 'EU general concepts of criminal law'? On the one hand, it can generally be said that elements of an 'offence definition' in a Directive or Framework Decision must be interpreted autonomously; the national judge is required to interpret the implementation legislation in light of the wording and purpose of the Union instrument rather than national law. ${ }^{19}$

On the other hand, we see that Member States do interpret these definitions according to their national law. In the absence of a clear indication of their meaning in the legal instrument and given the availability of the instrument in all national languages, it is quite understandable that these notions are interpreted in a national way. ${ }^{20}$ It could even be perceived as a margin of discretion for the Member States when implementing the Union instrument. After all, one can argue that, given the traditionally sovereign view on criminal law, the responsibility for criminal matters can only be shifted explicitly. When there is no clear obligation to approximate, Member States will use this discretion to retain their national law.

I will explain that when general concepts in EU law are given a national meaning, this results in very different outcomes as to the question of criminal liability. This is contrary to the harmonizing purpose of EU legislative instruments and the policies of the area of Freedom, Security and Justice. For this reason, Union law should be interpreted autonomously, which brings about that a general part of European Criminal law must be developed. I will illustrate this divergence here by reference to the legal systems of England, Germany and the Netherlands. The legal system of England includes that of Wales, but I will refer to England from now on, also when referring to UK legislation.

\subsection{Recklessness or dolus eventualis}

Consider the offence element of intention. As will be explained in this book, all three legal systems distinguish between direct and indirect intent. The most serious subjective element in all three legal systems consists of a form of intention that concentrates on the will or desire of the actor to bring about a certain result. A second type of 'indirect intent' exists when the actor knows his conduct will almost 
certainly bring about consequences, which he does not desire or primarily aim at. It deals with side-effects, of which the actor knows that they are almost certain to occur.

So far, there is no difference between the three legal systems. This changes, however, when we consider that indirect intention is the lowest form ${ }^{21}$ of intention in England, whereas in Germany and the Netherlands, there exists an even lower form of intention called 'bedingter Vorsatz' and 'voorwaardelijk opzet' respectively. Translated into Latin, this dolus eventualis is about the conscious acceptance of a substantial risk. When distinguished from indirect intention, the consequence need not almost certainly occur, but merely probably. In addition, the actor should accept that these consequences can occur or at least take this for granted. Consider that the police are pursuing a person, who is suspected of terrorist acts. They drive at a very high speed through a pedestrian-only area. The suspect knows there is a considerable chance a pedestrian might get hurt or even die when hit by the car but accepts this possibility, as he wants to shake off his pursuers at any cost. Any pedestrian killed, is killed with dolus eventualis. In conclusion, the concept of intention is much broader in Dutch and German law than in English law.

As an illustration, let us assume that Hans belongs to an organisation that aims for separation of the province of Friesland from the rest of the Netherlands. In order to show the Dutch government and people that this is an organisation to be reckoned with, Hans places a bomb inside an aircraft and warns the authorities. Ten minutes after the bomb alert is given, the aircraft explodes. The authorities report one fatality, an employee of the KLM Royal Dutch Airlines, who was servicing the landing gear at the time. We can alter this case to a German or English setting to apply different jurisdictions.

It is not likely that Hans knew that there would be a fatality in the ordinary course of events, which is required to prove indirect intention as to this death. It is more likely that he appreciated there was a substantial chance that someone would be killed by the explosion, for example someone who would try to defuse the bomb, and that this awareness did not stop him from carrying out his plans. He thus consciously accepted the risk of fatalities, which qualifies as (conditional) intent as to these fatalities in Germany and the Netherlands. He would be liable for an intentional attack upon a person's life that may cause death, with a view to seriously intimidating a population. This qualifies under Article 1(a) of Framework Decision 2002/475. By contrast, in English law this attack would not be deemed intentional, because in England dolus eventualis is insufficient to qualify as intention.

The English legal system operates with three subjective elements as to conduct and consequences, whereas the German and Dutch only distinguish between intention and negligence. The English apply the concept of 'recklessness' that can be positioned in between intention and negligence. Recklessness resembles dolus eventualis because it is about the conscious taking of an unacceptable risk. In fact,

21 It should be noted that indirect intention is not a 'form' or type of intention in England, but merely evidence from which intention may be inferred, see IV.2.3.2. 
it is even broader than that because it requires no additional element of accepting or taking this chance for granted. The illustration of Hans is therefore not meant to show that criminal liability is stricter in England, but merely to show that when European legislation refers to 'intention', the national scope of this concept is very different. Recklessness is no form of intention. Hans' attack could be qualified under English law as a reckless attack, but this is not what the Framework Decision aims to criminalize. He could even be convicted of manslaughter (reckless killing) under English law, or under less grave variations of terrorist offences under this Framework Decision. However, the attack cannot be labelled under English law as an intentional attack upon a person's life with a 'terrorist' intent, whereas it could be labelled as such in other Member States. The starting point of Framework Decision 2002/475 is that Hans' attack would be qualified similarly in all Member States, and more importantly, that Hans' attack would be qualified as an intentional attack upon a person's life with a 'terrorist' intent, thus labelled as a specific terrorist offence. $^{22}$

I have shown that one difference in the implementation of EU legislation arises out of the different concepts of intention in the legal systems. From this difference in the scope of intention, another major difference follows with regard to the scope of attempt. The three legal systems are also different as to attempt, because in England, the subjective element that is encompassed in the doctrine of attempt must at least be one of indirect intention. There can be no construction of dolus eventualis to bring about criminal liability for an attempt, such as in Germany or the Netherlands.

Article 4 of Framework Decision 2002/475 requires Member States to criminalize the incitement, aiding or abetting and attempt of most of the offences mentioned in articles 1(1), 2 and 3. It should be emphasized that the Commission is aware of the problem here illustrated. It recognizes that harmonization is hampered by the lack of a definition in Framework Decision 2002/475 of 'incitement' and 'aiding and abetting' and substantial differences in the national legal systems regarding these forms of participation and attempt. ${ }^{23}$

Finally, the Union has determined very little in relation to general defences, which brings about that the application of defences to an offence based on a Framework Decision or Directive remains a national matter. The availability of self-defence, necessity or duress to the implemented criminal offence, depends on the national general part and consequently, so does the scope of criminal liability. In the aforementioned example, John would be charged with (attempted) murder.

22 See, for example, the Report of 8 June 2004 from the Commission based on Article 11 of the Framework Decision 2002/475 of 13 June 2002 on combating terrorism, COM (2004) 409, p. 5: "Although structurally similar to other instruments aimed at the harmonisation of a particular field of criminal law, this Framework Decision thus differs from those that do not require the incorporation of "specific offences" as long as the conduct to be criminalised is already covered by a generic incrimination." aforementioned follow-up report of 6 November 2007, SEC (2007) 1463. 
Before an English court, he could not raise the defence of duress to a charge of murder, which thus seriously seem to limit his possibilities to be acquitted.

\subsection{Convergence or divergence}

The lack of any guidance by the Union on the general part of criminal law can be explained by the fact that the Treaties of Maastricht, Amsterdam, Nice and Lisbon have always focused on the special part. Article 83 TFEU, for example, only deals with the definition of criminal offences and sanctions. Nevertheless, the lack of a general part of European criminal law brings about problems. The effect of the current technique of approximation through Framework Decisions and Directives differs from its harmonizing purpose. In the absence of clarity on what these general concepts exactly refer to, Member States interpret these concepts in a national manner. The English legislator thus reads 'intentional' as encompassing only direct and indirect intention, whereas the German and the Dutch legislator would also include dolus eventualis as a form of intent that suffices to make the act criminal.

These differences in criminal liability are contrary to the goal of approximation by implementing Directives and Framework Decisions and contrary to the idea of one area of Freedom, Security and Justice as well as the equal treatment of EU Citizens. ${ }^{24}$ The result is divergence rather than convergence. This is not what the EU aimed at by approximating criminal law. The uniform application of Union law throughout the Union requires an autonomous and uniform interpretation throughout the Union of that legislative instrument. ${ }^{25}$ The elements of Directives and Framework Decisions refer to European general concepts of criminal law, although no one is quite sure on the exact content of this general part. Some of these concepts have already been identified and applied by the ECJ, such as the principle of non-retroactivity, ${ }^{26}$ lex mitior, ${ }^{27}$ and proportionality. ${ }^{28}$ The identification of these concepts strengthens the argument that EU legislation refers indeed to European general concepts of criminal law and moreover, that currently unidentified concepts will also eventually become clear.

Defining the general part of criminal law can enhance the quality of EU law and its implementing provisions. In the absence of an indication on how these general concepts used in EU legislation should be interpreted, autonomously or nationally, it is unclear for Member States what the Union wants them to minimally

24 Articles 2, 3 and 29 TEU and Articles 67(3) and 325(4) TFEU.

2517 July 2008, Case C-66/08, Szymon Kozlowski [2008] ECR I-6041, §42. See also the Opinion of AG Ruiz-Jarabo Colomer of 22 February 2005, Case C-498/03, Kingscrest Associates Ltd, Montecello Ltd v. Commissioners of Customs and Excise [2005] ECR I-4427, §23.

2610 July 1984, Case C-63/83, Regina v. Kent Kirk [1984] ECR 2689.

273 May 2005, C-387, 391 and 403/02, criminal proceedings against Silvio Berlusconi and others [2005] ECR I-3565.

2829 February 1996, Case C-193/94, criminal proceedings against Sofia Skanavi and Konstantin Chryssanthakopoulos [1996] ECR I-929. 
criminalize. AG Kokott tried to put into perspective the problem of non-uniform interpretation and application by reference to general concepts such as 'serious negligence' in Directive 2005/35 on ship-source pollution. She argued that, "the directive does not lay down a definitive, uniform standard but merely minimum requirements which by their nature do not call for uniform transposition in the Member States." 29 In other words, divergence is not a problem, as long as Member States transpose the required minimum level of criminalization into their national law and Member States are allowed to adopt more stringent measures.

However, in the absence of any guidance by the EU, how are Member States to fulfil this obligation if they cannot know what the minimum requirements are supposed to encompass? Should the yardstick be the lowest common denominator of all national concepts, that is, the law of the Member State with the strictest interpretation of a certain general concept? In that case, the strict English meaning of intention, for example, would probably be deemed to be the minimum requirement under EU law. Besides the fact that the lowest common denominator would first have to be established, another problem of constructing a general part of European criminal law in this way is that such a general part will be inconsistent. When a certain Member State applies a strict meaning of a specific concept, this is generally counterbalanced by a wider scope of another concept or rule of procedure to avoid legal loopholes. For example, the lack of dolus eventualis in England is counterbalanced by the concept of recklessness. If we were to adopt from different Member States the concepts with the strictest meaning, this would result in a patchwork of concepts that lacks consistency and coherency and would bring about legal loopholes. As a result, it is questionable whether such a general part is useful at all.

The EU can enact legislation of better clarity by realizing that the scope of criminal liability depends on the interaction between a specific offence and the general part that applies to it. The legislator and judiciary in the Union also need to realize that approximation is made difficult from the outset if general concepts from domestic legal systems, such as recklessness, are merely translated in different language versions of legislation and case-law. ${ }^{30}$ Currently, European legislation refers to either European concepts of unidentified content or national general concepts. Regardless of the point of view one takes, the Union cannot possibly foresee the scope of its intended criminalization.

This blind spot on the general part also influences procedural European criminal law. For example, the European Arrest Warrant lists offences for which persons can be surrendered without a test of double criminality. The assumption is that these offences are criminalized in all Member States. Whereas that may be true, the different versions of the Framework Decision mention very different offences. For example, the Dutch version refers to 'opzettelijke brandstichting', which as mentioned above can thus also be fulfilled by dolus eventualis. The English version

Opinion of AG Kokott on 20 November 2007, Case C-308/06, Intertanko a.o. v. Secretary of State for Transport [2008] ECR I-4057, §150.

See IV.6.7.2. 
refers to arson, for which intention but also recklessness suffices. The German version, on the contrary, merely refers to 'Brandstiftung', an offence which can be committed either by intention or negligence. ${ }^{31}$ In case of a surrender request of a person suspected of starting a fire negligently, the German authorities, in contrast to the Dutch authorities, would thus be able to merely check the list.

\subsection{Direct enforcement}

With the growing number of Directives on criminal law, the number of diverging examples will also increase. As the scope of European criminal law expands, the need to identify a general part of criminal law thus becomes greater. Regardless of whether one is in favour of the process of European integration or not, we need to realize that this process will undoubtedly continue; the only question is at what speed this will happen. There eventually will be a 'genuine' or 'independent European criminal law'. The establishment of a European Public Prosecutor's Office (EPPO) is likely to be one of the first key developments in this progression. Under article 86(1) TFEU, the EPPO is competent for crimes affecting the financial interests of the Union, which may be extended under article 86(4) TFEU to other serious cross-border crimes.

Clearly, article 86(2) TFEU states that the EPPO is supposed to prosecute certain crimes before national courts, which arguably implies that the EPPO should rely on national law when prosecuting the crimes under his jurisdiction. In other words, a conservative way to establish the EPPO would be to have a national prosecutor with an 'EPPO-hat' prosecuting crimes affecting the financial interests of the EU in his national court under the already existing national rules on substantive and procedural criminal law, which may be subject to harmonization by EU law. ${ }^{32}$

However, one of the most important rationales to establish the EPPO is that Member States do not fulfil their obligations to implement or ratify on time. In the context of offences affecting the financial interests of the Union, only a few States have implemented the pertinent legislation fully. Secondly, there is the problem of significant differences in the legal framework relating to these offences. As noted, European legislation loses much of its approximative function due to the application of national general principles of criminal law to EU criminalizations. Because of this, the financial interests of the EU are not equivalently protected, leaving gaps in criminal liability, which hampers judicial cooperation and encourages forum shopping by perpetrators. ${ }^{33}$

31 Article 157 of the Dutch Criminal Code; section 1(3) of the English Criminal Damage Act 1971 and $\S 306$ and 306a-f of the German Criminal Code.

32 Green Paper of 11 December 2001 on criminal-law protection of the financial interests of the Community and the establishment of a European Prosecutor, COM 2001/715, §4.2 and 5.1.

33 Communication from the Commission on the protection of the financial interests of the European Union by criminal law and by administrative investigations, 26 May 2011, COM (2011) 293. 
Only direct application of Union law can truly overcome these problems. The creation of a Directive, ${ }^{34}$ which (correct) implementation into national law the Commission can monitor and enforce is only a second best option. A Regulation containing Union offences and Union general principles of criminal law can be applied immediately and uniformly by the EPPO. It would increase legal certainty for defendants that operate in multiple Member States and make the legal system that the EPPO has to work with less much clearer, even if it would take national judges some time to get used to this new legal system. From a perspective of subsidiarity, autonomous EU criminal law, as an alternative to further harmonization by Directives, limits the influence of European law on the national legal system and thus helps it to remain more consistent.

The need to identify a general part of criminal law for the EU does not, however, depend on the existence of an autonomous or directly applicable European criminal law. This need also follows, as I have demonstrated, from the current use of general concepts of criminal law in EU legislation. It will only become more acute when a system of direct enforcement enters into force. The Council apparently recognizes the need for a general part, concluding that model provisions for criminal law can overcome problems of interpretation and implementation of EU law. ${ }^{35}$ Since 2011, it is clear that the Commission also appreciates the need to provide for uniform interpretations of general principles of substantive criminal law in order to ensure an efficient implementation of EU legislation. ${ }^{36}$ As part of a more efficient legislative instrument on the protection of the EU's financial interests, the Commission foresees that such a proposal "may include (...) more systematic rules on aiding and abetting, instigation, attempt, as well as on intent and negligence."37

\subsection{Guidance}

It can be expected that Member States will oppose the (autonomous) European interpretation of these concepts. ${ }^{38}$ Nonetheless, when a question on the interpretation of one of these concepts in a certain Framework Decision or Directive comes up in a preliminary procedure before the ECJ, it is interpreted in an

34 Proposal for a Directive on the criminal-law protection of the Community's financial interests, Brussels, 23 May 2001, COM (2001)272, as amended by COM (2002) 577. A new proposal may be expected soon, see the Communication mentioned above.

35 Draft Council conclusions on model provisions, guiding the Council's criminal law deliberations, Brussels, 27 November 2009 16542/2/09 REV 2.

36 Commission Communication: Towards an EU Criminal Policy: Ensuring the effective implementation of EU policies through criminal law, 20 September 2011 COM (2011) 573, p. 12.

37 Communication from the Commission on the protection of the financial interests of the European Union by criminal law and by administrative investigations, 26 May 2011, COM (2011) 293, p. 11.

38 Note for example that the several Member States and the Commission had reservations to the above-mentioned Council conclusions, see p. 2 and Council document 16798/09 of 27 November 2009. 
autonomous manner. Clearly, the interpretation of 'serious negligence' in the case of Intertanko and others ${ }^{39}$ is strictly limited to the use of that concept in Article 4 of the pertinent Directive, but it can be expected that the Court will adopt the same interpretation of this concept when it is used in other EU legislation. The ECJ will continue to play a role of paramount importance in identifying this general part of criminal law of the EU. The Court has always taken a pro-active role in the process of European integration in criminal law, which will only be strengthened by its extended competences under the Lisbon Treaty. ${ }^{40}$

The results of this research may therefore guide the Union legislator as well as its judiciary. I hope to promote a thorough debate on the contents of such a general part within the institutions and Member States of EU. In addition, this legal research can be of assistance to acceding and candidate countries, showing what the EU standards in criminal law are. The comparative legal research can also be useful for domestic legislative and judicial powers in the Member States that want to know how a similar problem is dealt with in another legal system.

Furthermore, this research can foster the understanding of national authorities of the approaches to substantive criminal law in other Member States. In this way, the mutual trust between judges, prosecutors and police officers in the EU will increase, which is essential to cooperation and further integration in criminal matters. In any event, this academic exercise contributes to the international exchange of scholarly thought. It stimulates debate on the need and scope of European criminal law and paves the way for future research.

\section{Outline}

As noted, this research focuses only on mens rea and defences, leaving other general principles of substantive criminal law to related projects. The central question of this research is therefore: what should mens rea and defences look like in a general part of criminal law for the European Union?

In the chapters on mens rea, I will formulate answers on questions relating to the scope of fault elements like intention. Should it encompass the foresight of risks or should dolus eventualis be deemed a relic of the past? Should intention relate to each and every single offence element of should strict liability be allowed in European criminal law? What is the effect of mistakes on fault? Does it matter if the mistakes merely relate to the identity of the victim or whether they originate from intoxication? Did John intend to kill the police officer? Did Hans intend to kill the KLM employee?

In the chapters relating to defences, I will first discuss whether such a concept can be distinguished from the offence definition? Is there a difference between

393 June 2008, Case C-308/06, Intertanko a.o. v. Secretary of State for Transport [2008] ECR I-4057.

40 Article 267 TFEU. 
negating the charge and raising a defence? Can we discern another category of defences, besides justifications and excuses? What if the defendant was mistaken on the facts giving rise to a defence? Should an excusatory version of self-defence be available in European criminal law? Should John be able to rely on duress when prosecuted by the European Public Prosecutor's Office? What about torturing terrorists or shooting down an airplane that is hijacked by terrorists?

I will present the results to this question in an integrated manner. Rather than first describing the different national perspectives, as is common in legal comparison, I will immediately submit, wherever possible, what mens rea and defences should look like in a general part of criminal law for the EU. This is founded on the fragments of Union law and the common ground of national legal concepts. Only when significant national differences exist, are these addressed explicitly and separately, after which a choice is made in favour of one of those approaches. The choices are based on certain criteria, which are defined next.

In the following chapter, I will explain in detail how I set up and conducted this research. I will account for which legal systems were included into the comparative legal research and which conditions were used to make a synthesis. At the same time, features of those legal systems that are important to understand the comparative results are introduced. In the second and third part of this book, the results of the research on mens rea and defences are presented. In the final part of this book, I summarize the results and conclude with general observations. 


\section{Chapter II METHOD}

The research was divided into two stages. In order to identify what mens rea and defences in a general part of criminal law for the European Union should look like, I first established what mens rea and defences look like in national and Union law. After all, a general part of European criminal law should be construed out of the legal traditions of the Member States and the fragments of criminal law originating from Union law. In addition, it needs to be in line with the requirements that can be derived from the ECHR and the Charter of Fundamental Rights of the EU (CFR). As will be explained here, the selection of these sources follows from article $6 \mathrm{TEU}$, article 67(1) TFEU and the case-law of the ECJ.

In a second stage of this research, I compared the concepts of national and Union law and made a synthesis of mens rea and defences. The synthesis is based upon fundamental rights and the common ground of mens rea and defences in national and Union law. In choosing between competing approaches to legal concepts, I applied certain criteria, such as that a general part of European criminal law should be consistent, coherent and enforceable. I will explain why these requirements were selected and what they entail. The synthesis is presented and defended in the second and third parts of the book.

In the past, similar endeavours have been undertaken. Consider the Model Penal Code of the United States, the Rome Statute on an International Criminal Court established, the draft Common Frame of Reference on European civil law and the Corpus Juris projects on the protection of the financial interests of the EU by criminal law. Before I started to collect the data for this research, I studied the method applied in these projects in order to learn from past experience and scrutinize my own method. In this chapter, I will refer to these projects to highlight the similarities and differences of this research. Amongst others, this project differs with the Corpus Juris projects, because in those studies, national contact points gathered the information, rapporteurs wrote comparative law analyses and finally, experts wrote syntheses. ${ }^{1}$ In this project, the person gathering the national 'data' is the same person doing the comparative analyses and synthesis.

As noted, the increasing influence of the EU in criminal matters raises numerous issues. This research does not apply to institutional issues, such as what the legal basis of a general part of criminal law for the European Union could be. I do not address the question whether a political will can be found to establish a general part of criminal law. Neither do I attempt to answer the question whether this general part should be codified or not. To emphasize, this project does not aim at codification. A European general part is not the same as a 'European Model Code'.

Delmas-Marty \& Vervaele 2000, foreword, p. VI and 33 and Cullen 2003, p. 7.

See Enschedé 1990. 
I will rather provide an extensive and complete discussion on what mens rea and defences should look like. These results will offer to political bodies a set of arguments to evaluate what formal legislation on a general part should look like. By separating this academic task from political negotiations, it was possible to keep out any political considerations in constructing the synthesis, which also distinguishes this project from the Corpus Juris projects.

\section{First STAGe: GATHERING DATA}

In the first stage of this research, I gathered all the relevant sources for comparison. Like the Corpus Juris, this general part is based on the law of the representative Member States (acquis commun) and the EU (acquis communautaire), the latter consisting of the general principles of Union law identified by the ECJ and the requirements of the ECHR. ${ }^{3}$ The ECJ identifies the general principles of Union Law, including those on criminal law, by considering the constitutional traditions of the Member States and the guidelines supplied by the international treaties on human rights. ${ }^{4}$ The domestic traditions of the Member States and the ECtHR caselaw are therefore the most important inspirations for the Court in identifying Union law. This has been codified in articles 6 TEU and 67(1) TFEU. A general part of criminal law for the EU must follow the constitutional traditions of the Member States and it must comply with the requirements under the ECHR and the CFR. ${ }^{5}$

\subsection{Comparative legal research}

It follows that a general part of criminal law for the EU needs to be based on the general principles of criminal law of its Member States. Hence, the comparative law method was used. It is a common method for the ECJ to fill the lacunae in Union law by recourse to the domestic legislation, case law and doctrine of its Member States. ${ }^{6}$ The ECJ establishes certain principles as a part of the constitutional traditions common to the Member States and regards these principles as part of the general principles of Union law. ${ }^{7}$ It is therefore obvious to fill in the missing general principles of mens rea and defences by comparative law. Another reason to apply the comparative law method is that its goals coincide with the goals of this research. Amongst others, comparative law aims to aid and inform the legislative process and law reform, elucidate the application of foreign law in the courts and

3 Cullen 2003, p. 314 and Delmas-Marty 1997, p. 40. See also the Resolution of 30 July 1999 on criminal procedure in the European Union (Corpus Juris), OJ 1999 C 219/106.

28 March 2000, Case C-7/98, Dieter Krombach v. André Bamberski [2000] ECR I-1935.

See also article 83(3) TFEU and the abovementioned Resolution, pp. 106-107.

Tridimas 2006, pp. 17-18.

See 28 March 2000, Case C-7/98, Krombach v. Bamberski [2000] ECR I-1935 and 3 May 2005, Case C-387/02, Criminal proceedings against Silvio Berlusconi and others [2005] ECR I-3565. 
contribute to the unification and harmonisation of laws and international cooperation. ${ }^{8}$

First, I established the scope and meaning of mens rea and defences as they appeared in the legal systems of the Member States of the EU. Ideally, a comparative research should be conducted in all relevant Member States. It was however impossible to deal with all $29^{9}$ legal systems of the European Union, because of the lack of the necessary linguistic skills of all 23 European languages. After all, legal words cannot usually be translated without losing their unique meaning. Similar terms can have different meanings, and different terms can have a very similar meaning. ${ }^{10}$ In order to avoid errors, the sources of law were therefore studied in their original language. This meant that the researcher had to master the languages of the Member States under investigation, bringing about a first reason to limit the number of States that were studied. Another reason is that it was impossible to carry out an in-depth study of mens rea and defences in all legal systems within the four years allocated for this research.

The Member States were therefore divided into four 'legal families'. The term 'legal family' is common in comparative law and serves to designate groups of legal systems having similar legal features enabling one to speak of the relative unity of those systems. ${ }^{11}$ The following division was made: a first group of States consist of 'Common law States', including England and Wales, Ireland, Scotland, Northern Ireland, Malta and Cyprus. A second group can be called 'Germanic and Scandinavian States'. This group includes Germany, Spain, Sweden, Denmark, Finland, Estonia, Portugal, Greece and Austria. A third group consists of 'Napoleonic States', which are the Netherlands, France, Belgium, Luxemburg and Italy. Finally, a group of Eastern European States was identified, including Poland, Hungary, Lithuania, Latvia, Czech Republic, Slovakia, Slovenia, Bulgaria and Romania. ${ }^{12}$

It turned out that the research had to be limited to representative states of the first three groups. Including an Eastern European state would demand disproportional investments in time, costs and efforts to meet the necessary linguistic requirements. Moreover, it was assumed that the fourth family is highly influenced by common historical antecedents of the other three families and that when these States acceded to the EU, they have adapted their law to the other legal families. ${ }^{13}$ The risk of not incorporating relevant aspects of a specific domestic system was furthermore reduced by a conference held on January 20-21, 2011, where some of the results were presented to legal experts from many different

8 De Cruz 1999, p. 223; Nijboer 2005, p. V; Eser 1997, p. 501-504; Smits in Reimann \& Zimmermann 2006, p. 477-512 and Pakes 2004, p. 3.

9 The United Kingdom consists of three separate jurisdictions that each have their own legislator and judiciary.

10 De Cruz 2002, p. 212-214 and Eser 1997, p. 513.

11 Saidov 2003, p. 110 and Zweigert \& Kötz 1998, pp. 40-42.

12 Another classification can be found in Nijboer 2005, pp. 33-35. A classification can be neither right nor wrong; it is merely an intelligible summary of information, Reichel 2002, p. 24.

13 See Fletcher in Eser, Hassemer \& Burkhardt 2000, p. 242 and Cullen 2003, pp. 83 and 318. 
nationalities, including experts from the Eastern European States. ${ }^{14}$ Like in the Corpus Juris ${ }^{15}$ the comments made during this conference and at other points during the research were taken into account. ${ }^{16}$

As far as the three legal families are concerned, England was chosen to represent the states with a common law tradition, Germany has been chosen to represent the Scandinavian and Germanic states and the Netherlands have been selected to represent the Napoleonic states. England and Germany are selected as the classic representatives of two very different legal traditions. The Dutch legal system was selected because of the easy access to legal sources when doing research in the Netherlands. Furthermore, being born and raised in Netherlands and trained in Dutch law, it would have been impossible to do comparative law without at least unconsciously comparing the findings with Dutch law. Apart from these obvious reasons, the Dutch legal system was selected because it forms a middle ground between the dogmatic German and the pragmatic English legal system. In contrast to the two other legal systems, it also has an open character, welcoming insights through comparative legal analysis. ${ }^{17}$

Since the object of this research is normative, I also took into account books and articles from scholars originating from and/or residing in other countries than the three Member States that focused on what mens rea and defences should look like. ${ }^{18}$ Many of those scholars originate from the US, some of whom have made important contributions to comparative criminal law. It is warranted to draw inspiration from the Model Penal Code and US scholars because of the common law tradition that it shares with England..$^{19}$ Moreover, the criminal policy of the US influences that of the EU, examples of which are the concept of corporate criminal liability in the general part and the crimes of money laundering and terrorism in the special part. ${ }^{20}$ Nonetheless, I have kept in mind that 'Anglo-American' law remains very different from English law, and only of secondary relevance to our general part. ${ }^{21}$

Important sources for this research are legal texts and history, doctrine and caselaw. Nonetheless, extra-legal rules were taken into account. These may be informal customs and practices, which operate outside strict law or various legal attitudes and non-legal phenomena, which ultimately influence the state of the law. By using all possible legal sources, working with foreign experts and discussing the research

$14 \quad$ See Blomsma in Klip 2011.

15 Delmas-Marty \& Vervaele 2000, p. 249.

16 See Weigend in Klip 2011.

17 It can be said that Dutch substantive law has been influenced, like many countries, by German legal doctrine, see Mevis 2006, p. 546. Nijboer 2005, p. 35 therefore puts the Netherlands somewhere in between the Scandinavian/Germanic family and the Napoleonic family. See for example the excellent monograph on self-defence of Sangero 2006.

19 Dubber in Reimann \& Zimmermann 2006, p. 1299. In earlier times, for example, the US and England used the same test to establish the defence on insanity, see Reichel 2002, p. 65.

$20 \quad$ Vogel 2002, p. 521.

21 De Cruz 1999, p. 224. 
on national law within an international research group of Austrian, Belgian, Dutch and Greek researchers, the danger of ignoring these rules was minimized. ${ }^{22}$

I started gathering the national data by studying handbooks on the domestic criminal justice system. I studied commentaries, articles, books and case-law and used its references to find other literature and case-law. Besides this technique of snowballing, I gathered information by browsing and searching online databases and catalogues. Because of the enormous amount of national case-law and literature on mens rea and defences, I made a selection based on relevancy, topicality, status of authors and journal, as well as topics which required further attention.

Parliamentary pieces and proposals were studied too, although the impact on the general part of criminal law is relatively small, given the fact that most legislators have left the details of the general part to practice and academia. For instance, in Dutch law, the scope of the different types of mens rea, like intent and negligence, are not laid down in the law. Legal texts generally thus give a very limited understanding of the scope of mens rea and defences. In England, legislative history of the general part is almost absent. There is no such thing as a Criminal Code. Traditionally, the judiciary identifies general principles of law.

The English Law Commission deserves special attention in this regard. Its task is to submit proposals for reform and codification of English law. ${ }^{23}$ It has drafted and redrafted a Criminal Code, and numerous proposals to legislate on general principles of criminal law in the last decades. They are used here as influential reports on what the law of England is and what it should be, according to the Law Commission and those scholars and practitioners consulted by it. Although the codification project was recently dropped, some of the other proposals of the Law Commission have been enacted. With the enactment of proposals, its reports function as legislative history.

The methodology of legal interpretation thus differs from state to state, which required me to adapt my method to the legal system under investigation. Besides the differing weight given to scholarly work, case-law and legislative history in deciding concrete cases, another example is the different roles of the domestic courts. For instance, Germany has a Constitutional Court whereas in the Netherlands, one cannot even invoke in court that a criminal law violates the constitution. The Supreme Court of the United Kingdom, which was called the House of Lords until 2009, decides cases on the merits, whereas the Dutch Supreme Court only checks whether the legal principle is stated correctly, and whether the lower court has substantiated its decision sufficiently. Therefore, when it quashes a judgment, this generally does not imply that the facts and circumstances of the case do not justify its verdict. It only means that the verdict is not properly argued for. Accordingly, it is more difficult to deduce general principles from these decisions.

Before finishing the study of every legal system, national experts were consulted to gain confirmation of the results and to clarify any remaining questions on the

23 Section 3(1) of the Law Commission Act 1965. 
subjects and the legal system as a whole. The research on the different legal systems culminated in country reports on mens rea and defences. The reports were structured in a similar way so as to facilitate a subsequent comparative crossreference of the basic features of every element. In this manner, I wrote a country report of England first, followed by the Netherlands and finally a report on mens rea and defences in Germany. Sometimes, I had to take into account changes of the law, new insights or proposals made after the finalizing of a country report. For instance, after the report on England had been finalised, the English law on provocation and diminished responsibility changed in 2010, following a proposal by the Law Commission. This research takes into account all developments in law until March 2012.

\subsection{Contextual approach}

In a thematic approach, one would have ordered the study in a thematic way, investigating the different elements in all legal systems. For example, self-defence would be studied in the legal systems under investigation, after which duress could be investigated. The advantage of the contrasting country-by-country approach I chose, is that it provided for an easy collaboration within the research group, making it possible to gear our activities to one another, discuss the peculiarities of the legal systems and identify relationships between the different elements under investigation, like actus reus and mens rea.

More importantly, by studying one legal system before moving on to the next one, I gained a better perspective of mens rea and defences in the legal context in which they operate. This context includes the broader legal framework, such as the special part and procedural law, but also the interrelationship between the different aspects of mens rea and defences. First, these elements form a coherent whole that can hardly be studied in isolation. Liability for being aware of side-effects of one's actions can only be understood in relation to liability for intended consequences. Why is foresight less culpable than intending consequences? Secondly, mens rea and defences are not always easy to distinguish. Particularly in English law, the subjects tend to overlap. The claim that he did not intend a consequence is sometimes interpreted as constituting a defence.

In order to grasp the correct context and interrelation of the elements of criminal liability, they need to be put into categories that are ordered in a logical manner. This is most evident regarding defences. In order to understand defences, one must first understand what is required to be liable for committing an offence. Before one can answer the question when criminal liability is lacking, one must establish when criminal liability is present. In the next chapter, a framework of criminal liability is therefore presented. In short, it consists of the offence definition, which can be divided into actus reus and mens rea, in a tier of wrongfulness and a tier of blameworthiness. The latter two elements are negated by defences. 
Other general principles of substantive criminal law, as well as aspects of procedural law, sentencing and legal culture ${ }^{24}$ also influence this research. ${ }^{25}$ As will become clear, the limited scope or complete lack of certain defences in English law is mitigated by discretion in sentencing. The English solution to appropriate outcomes is found in a more pragmatic way, such as the executive discretion to secure an early release or by a decision not to prosecute. By contrast, in a criminal justice system where the public prosecutor as a rule has no right to waive prosecution, like in Germany, this will virtually be impossible. The rules on criminal liability need to provide for a comprehensive toolkit, enabling the decision maker to establish fair outcomes. By putting legal differences in such a broader national context, it seems that every society faces essentially the same problems, but they deal with it through different means, often with very similar results. It was therefore important to look at the function of the different concepts. If other concepts in substantive or procedural law perform the same function to solve certain legal problem as an element of mens rea or a defence, this 'functional equivalent' was investigated too. ${ }^{26}$

A contextual approach in comparative criminal law also means the researcher has to look at the social, cultural, historical, philosophical and political context of the criminal justice system under enquiry. ${ }^{27} \mathrm{~A}$ basic knowledge of this context is required to put the results into perspective; this does not require an investigation in great depth for its own sake. ${ }^{28}$ In order to grasp the broader context of the legal systems I was less familiar with, I started that research with consulting introductory textbooks on the English and German legal system.

\subsection{EU Perspective: from fragments to a whole}

After having investigated the concepts in national settings, I identified the fragments of a general part in the existing European law. The European perspective consists of the law of the EU and the regime of the ECHR. Concerning the EU, all relevant legal instruments were analysed: Conventions, Joint Actions, Common Positions, Decisions, Directives and Framework Decisions. The analysis of these instruments is in most cases limited to a comparison of authentic versions only. Apart from the preamble, the EU legislative history does not give much information on the interpretation. Implementation reports and policy documents sometimes provide for more insights on the purpose of the drafter. Moreover, legislative instruments generally only refer to general principles of criminal law, whereas the scope and meaning of those principles is identified by the ECJ. With regard to its

\footnotetext{
24 “(...) the ideas, values, attitudes and opinions people in some society hold, with regard to law and the legal system.” Alldridge 1999, p. 142.

De Cruz 2002, p. 231.

Zweigert \& Kötz 1998, pp. 33-47; Reitz 1998, pp. 620-623 and Zieschang 2001, pp. 263-264.

Reichel 2002, p. 11-13; Nijboer 2005, p. 21; Fijnaut 1999, p. 212 and de Cruz 2002, pp. 214-216.

De Cruz 2002, p. 227.
} 
case law, the considerations of the Court itself, the Opinion of the AdvocateGeneral and to a lesser extent, observations by Member States and the Commission, as well as the writings of legal scholars provided more information.

Concerning the ECHR and its case-law, the minimum requirements of a general part of criminal law for the EU have been deduced to some extent from the cases brought against England, Germany and the Netherlands. In this part of the research, cases against other States have been taken into account too. Most of the requirements of the ECHR deal with procedural law, but from the case-law on for example the right to life and the presumption of innocence, conclusions can be drawn regarding the scope of self-defence and the principle of guilt. These fundamental rights are also partially included in the CFR, which are addressed to the bodies and institutions of the Union. Until the Union has acceded to the Convention, its institutions cannot be challenged before the ECtHR. I will discuss the weight that should be given to these requirements in the synthesis below.

\subsection{Criminal law}

It is difficult to determine what criminal law is, given the different national views on what the purpose and effects of criminal punishment are. In order to make a selection, I adopted the ECtHR approach on what criminal law is. ${ }^{29}$ Many Member States have outsourced the enforcement of criminal offences to administrative law, which body of law includes fewer rights for the party concerned. In such quasicriminal law, proof of mens rea is usually not required and administrative authorities can impose a fine, thus making enforcement easier, simpler and cheaper. Article 6 ECHR is applicable only to a criminal charge. Similarly, the ECJ has held that principles of criminal law like that of nulla poena sine culpa and in dubio pro reo are only applicable to sanctions of a criminal nature. ${ }^{30}$

If the national authorities could sideline these safeguards by labelling something as non-criminal, the protection by legal principles would be eroded. The character of the law should therefore be determined autonomous of its national label. Instead, it should be assessed whether or not something can be qualified as a criminal charge, focusing on the nature of the offence and/or the severity of the (possible) punishment. ${ }^{31}$ In assessing the nature of a sanction, the ECJ also looks at the severity, purpose and the overall context in which the penalty is situated. ${ }^{32}$ AG van Gerven proposed to implement the 'criminal charge' criteria of the ECtHR in Union

29 See the Opinion of AG Mazák on 28 June 2007, Case C-440/05, Commission v. Council [2007] ECR I-9097.

3018 November 1987, Case 137/85, Maizena [1987] ECR 4587 and 18 October 1989, Case C-374/87, Orkem SA v. Commission [1989] ECR I-3283.

31 Öztürk v. Germany, appl. no. 8544/79, 21 February 1984, and Sergey Zolotukhin v. Russia, appl. no. 14939/03, 10 February 2009.

3211 July 2002, Case C-210/00, Käserei Champignon Hofmeister [2002] ECR I-6482, §33. 
law, but the ECJ has so far managed to circumvent the question of what criminal law is. ${ }^{33}$

As far as Union law is concerned, this also means that competition law can be regarded criminal law, even though article 23(5) of Regulation 1/2003 explicitly states that decisions in competition law are not of a criminal nature. In practice, the ECJ treats competition law as criminal law and applies all rights under the ECHR to it. ${ }^{34}$ Articles 101 and 102 TFEU operate with a prohibition system and therefore read like a criminal offence. They are also directly applicable by any national judge and are meant to serve purposes like special and general prevention. ${ }^{35}$ Competition law thus forms a source of law in this research, although I take into account the special setting of competition rules, which brings about that not all concepts are easily transferred to a less economical setting.

\section{SECOND STAGE: SYNTHESIS}

In a second stage of this comparative legal analysis, the descriptive results from the first stage were brought together. I identified similarities, tried to explain and put into perspective the differences of the legal systems and finally, made a choice in favour of one or the other approach, interpretation, concept and so on. This choice is based on criteria that I elaborate on below. In some cases, provided the differences relate to a detailed aspect of minor importance, which all lead to the same outcome and are not objectionable in the light of the criteria set out, I made no choice and limited myself to listing the differences.

I chose to report on this research in a manner that focuses on this second stage of the research. It is common in comparative legal analysis to first describe the different rules, norms, concepts and institutions of the selected legal systems. I also incorporated these descriptive results in aforementioned country reports, but do not include these in this book. After all, that is not the main interest of this research: those interested in a description of the law in the States under investigation may consult national handbooks. The purpose of this research is to provide for a synthesis. I therefore focus on the comparison: the similarities, the differences and the reasons for these differences.

Starting from a description of the common ground of the legal systems under investigation, which forms the basis of the synthesis, I will highlight differences and put them into context in an attempt to explain them. Reference will be made to concepts that are functionally equivalent. Next, I will argue in favour of one the different approaches, rejecting other(s). It will not be explicitly stated every time that the legal concepts in the different legal systems correspond. This should be

\footnotetext{
33 Opinion of AG van Gerven on 26 September 1991, Case C-273/90, Meico-Fell v. Hauptzollamt Darmstadt [1991] ECR I-5569.

$34 \quad$ Klip 2012, pp. 2-3.

35 Report on Competition Policy 2008, 23 July 2009, COM (2009) 374, p. 4.
} 
presumed unless the opposite is made clear and can be inferred from the references to sources of different legal systems. I will present the synthesis right away. Only the differences between national concepts will be made explicit, because in that context, a choice must be made. I thus report thematically on what mens rea and defences should look like, and only go into a national description of different approaches when this is necessary for a proper understanding of fundamental differences between Member States, like the approach to intoxicated defendants.

The terminology used for the elements in this synthesis is neutral to and supersedes national systems. ${ }^{36}$ The terms do not have a specific meaning in a national legal system and therefore prevent misunderstandings with equivalents in national law. ${ }^{37}$ Latin, the old European legal scholars' common language with an independent meaning, was therefore used to differentiate the element in the synthesis from its domestic sources. ${ }^{38}$ When no appropriate Latin term was available, English terminology is used, but clearly demarcated from its domestic counterparts. In addition, sometimes Latin can also have national connotations, which also called for clear demarcation. For example, 'mens rea' is common in English law and has been given different and sometimes limited meanings. I will be explicit when I refer to the English concept. Finally, I generally only use the male form to refer to defendants and victims, but it will be obvious that this could also be replaced by a female defendant or victim. I will now describe the criteria that determine the outcome of this research.

\subsection{The scope of the general part}

The content of the general part is inextricably bound up with the special part of criminal law. ${ }^{39}$ Although general principles apply to (almost) all offences, their application always depends on the context in which they operate. This context is usually determined by the offence charged. ${ }^{40}$ Consider the field of international criminal law, which brings about particular rules of attribution. For example, the role of defences in this field of law is quite marginal, because it's hard to imagine the exclusion of criminal liability with crimes of this nature and gravity. ${ }^{41}$ Secondly, the seriousness of such crimes militates against liability without proof of mens rea.

The scope of this general part thus follows and is influenced by the special part it applies to, which makes it necessary to identify that special part. One approach is to look at the crimes or fields of law on which the Union is competent to legislate on. Under article 83(1) TFEU, the Union can legislate on serious crime with a cross-

\footnotetext{
$36 \quad$ Nijboer 2005, p. 23-24; Eser 1997, p. 511 and de Cruz 2002, p. 220.

37 Delmas-Marty 2003, p. 18.

38 Ristviki 2005.

39 Ambos 2002, p. 72 and Klip 2002, p. 110.

40 A general principle need not be invariant across all crimes to qualify as such, see Tadros 2002.

41 Ambos 2002, p. 515. In other words, there will not often be proportionality between the attack or danger on the one hand and the international crime committed by the defendant on the other.
} 
border dimension. These crimes include terrorism, trafficking in human beings, sexual exploitation of women and children, illicit drug and arms trafficking, money laundering and so on. Under article 83(2) TFEU, the Union is also competent to approximate criminal law relating to areas of a much more regulatory nature, like road transport and environmental protection ${ }^{42}$ provided this is essential in order to ensure the effective implementation of a Union policy in an area which has been subject to harmonisation. ${ }^{43}$

Third, article 325 TFEU creates a legal base for criminal law on the topic of fraud affecting the financial interests of the Union. If the general principles developed here would only apply to offences that protect the financial interests of the EU, it would look very different than if it would also apply to lethal offences. As mentioned above, not requiring mens rea as to each and every offence element is not as controversial in the 'regulatory context' as opposed to 'truly criminal' or serious offences. The scope of defences would also look very different, as one would not expect the accused to raise self-defence against a financial offence.

On the one hand, such a limited application of a general part of criminal law for the EU may be read into article 86(1) TFEU, which enables the establishment of a European Public Prosecutor's Office for the protection of the financial interests of the Union. The general part in the Corpus Juris was established with a view to apply only to these offences. Ever since the debate on this EPPO started ${ }^{44}$ has it been related to the EU's financial interests. The case for an EPPO is strongest in relation to offences affecting these interests. Besides the difficulty of prosecution because of the often complex nature and transnational character of the crimes, the fight against these crimes is hampered by a lack of ownership. Because it is not the national budget that is detrimented, national authorities appear to be more reluctant in prosecuting offences detrimenting the EU budget than their national budget, especially taking into account that they have only limited capacities for investigation and prosecution. If there are multiple States that have jurisdiction over a set of offences against the EU budget, they often look at each other to take action or only prosecute those acts committed on their territory.

On the other hand, article 86(4) stipulates that the European Council may also extend the competency of the EPPO to serious crimes with a cross-border dimension. Moreover, it is not just the creation of the EPPO that warrants the identification of a general part of European criminal law. As explained, the current technique of harmonisation requires such general principles too. In that respect, article 83(1)

42 Commission Communication: Towards an EU Criminal Policy: Ensuring the effective implementation of EU policies through criminal law, 20 September 2011 COM (2011) 573, pp. $10-11$.

43 It can be questioned whether this codifies 13 September 2005, Case C-176-03, Commission v. Council [2005] ECR I-7879 and 23 October 2007, Case C-440/05, Commission v. Council [2007] ECR I-9097, or whether these cases still constitute a separate legal basis for competence in criminal law.

44 See the Green Paper on criminal-law protection of the financial interests of the Community and the establishment of a European Prosecutor, 11 December 2001, COM 2001/715. 
TFEU refers almost exclusively to serious crime. Hence, the possible scope of application of a general part of criminal law for the EU is quite broad, ranging from criminal penalties for not properly documenting the number of hours one has driven to terrorist offences. The general principles of mens rea and defences in this research are therefore not established to apply merely to regulatory offences. They are established, similar as in national law, to apply to crimes of diverging seriousness. The general part could be applied to the prosecution of both human trafficking and violations of fishing quota. ${ }^{45}$

The general part established here takes into account the different contexts in which it may operate. Although these principles in theory apply to all offences, consideration is given to the different contexts in which it may operate. For example, although strict liability, which does not require proof of mens rea in relation to all or some offence elements, should be the exception, it is less controversial in the context of regulatory offences. In all Member States under investigation, intention is also established much easier in the regulatory context. If a general part of criminal law is therefore only deemed necessary for the direct enforcement by the Union of offences affecting the criminal interests of the EU, the aspects relevant for that context can be deduced easily from this synthesis.

\subsection{Consistency and coherency}

One of the most important criteria of the synthesis is that a general part of criminal law for the EU must be coherent and consistent. ${ }^{46}$ Coherency requires there can be no logical gaps in their construction. Consistent means that the elements of mens rea and defences must be in line with each other and that they should not conflict. The application of a concept should lead to foreseeable, clear outcomes. Similar cases should be solved similarly. The synthesis that is provided for in this research aims to be a counterweight to the current fragmentary character of European criminal law. The national general parts are generally assumed to be consistent and coherent, but the research enables us to reconsider this. After all, European criminal codes also "still include irrational and anachronistic features which are usually not based on cultural specifics but on accidents of history or the casual compromises made by politicians in parliamentary disputes." 47

45 Of course, criminal penalties to enforce fishing quotas should be available and imposed only as a last resort.

46 Articles 11(3) and 13(1) TEU; articles 7 and 334 TFEU; The Stockholm Programme - an open and secure Europe serving and protecting citizens, 4 May 2010, OJ 2010 C 115/1, under 3.3.1; Commission Communication: Towards an EU Criminal Policy: Ensuring the effective implementation of EU policies through criminal law, 20 September 2011 COM (2011) 573, p, 3-4; EP Committee on Civil Liberties, Justice and Home Affairs, draft report on harmonisation of criminal law in the EU of 18 January 2012, no. 2010/2310 and Asp, Bitzilekis a.o. 2009.

Sieber 1999, p. 466. 
On a broader perspective, coherency and consistency requires that this thesis should be in line with the related research projects on actus reus and participation, jurisdiction and locus delicti and finally, legality. For example, the choices on mens rea also determine the principle of attempt, which consists of elements of actus reus and mens rea. I have tried to take into account these other doctrines of the general part in arguing what mens rea and defences should look like. For instance, in arguing in favour of recklessness over dolus eventualis, it is considered what the impact of this choice is for attempt liability and participation.

As mentioned before, several EU institutions have acknowledged that the further development of European criminal law should be coherent and consistent. These requirements can also be grounded in the obligation of Member States to enforce EU law under article 4(3) TEU. As explained in the introduction, the effective enforcement and uniform application of Union law presupposes that Union law is consistent. The conditions also follow from the attempt to identify a general part itself. A general part presupposes a logical, consistent and coherent ordering of legal principles. Without this, there would be no general part, no legal system. By identifying general principles of criminal law and separating them from the mistakes and anomalies that do not fit in this whole, a logical, coherent whole can be construed. Such a general part can further the clarity and understanding of the law and make it more rational, predictable and fair. ${ }^{48}$

This also brings about that the goal of this research may be criticized as biased from the start. After all, the existence and use of a general part is still criticized by English lawyers. It could even be argued there is no such thing a general part in England. ${ }^{49}$ There is a traditional reluctance of Anglo-American criminal law to work with general concepts. ${ }^{50}$ On the continent, general principles are used as tools to solve a case top-down, whereas in England, the focus is on the instant case and the facts of that case as such, or on the offence at hand. General principles are only distilled bottom-up from cases when they seem to share common features. ${ }^{51}$

Only in recent decades, English scholars in general have gained an interest in general principles. Still, English law is very focused on facts and offences, as can be illustrated by most textbooks on substantive criminal law, of which one half usually deals with general principles, whereas the other half discusses frequent and/ or grave offences. English law is relatively less interested in general principles because of a perceived lack of practical relevance. Being much more pragmatic, the desired outcome is considered most important. For example, I will explain in this book that the English acknowledge that the distinction between basic and specific intent in cases of intoxication is inconsistent and unprincipled. However, that is taken for granted as the distinction leads to appropriate outcomes. By contrast,

\footnotetext{
48 Elliott \& de Than 2007, pp. 225-227; Smith, C. E. 2009; Cane 2007, p. 474 and MacCormick 1990, pp. 556-558.

49 See Ashworth 2006, p. 95.

50 Erenius 1976, p. 83.

$51 \quad$ Alldridge 1999, pp. 144-147. See also Zweigert \& Kötz 1998, p. 37.
} 
German legal doctrine seems to value internal consistency and coherence as one of the most important goals of criminal theory, even when it leads to overcomplexities, rigidity and absurd outcomes. ${ }^{52}$

The concept of a general part is not only firmly anchored in legal thinking in Germany; it also has a legal basis. ${ }^{53}$ The use of identifying a general part and the emphasis on the criteria of consistency and coherency thus appear to be quite German. As a result, one could fear that the legal elements of German criminal law will be overrepresented in the synthesis. However, consistency and coherency are in fact values that are considered important in all European criminal legal systems. The English reluctance to general principles is increasingly diminishing in recent decades. Secondly, these criteria are not the only ones taken into account. Legal coherency and consistency can be incompatible with understandable and foreseeable outcomes. Sometimes the criminal law must sacrifice its consistency in favour of a simple, clear and fair outcome.

\subsection{Enforceability}

Another important condition for the synthesis is therefore that its principles must be enforceable. The application of the law must remain simple enough to enable the efficient prosecution of offenders, enabling the Member States to meet the enforcement obligation under article 4(3) TEU. The condition seeks to find a balance between dogmatic complexity and practical application. Whereas important legal distinctions should be taken into account, complexities devised solely to bring a solution into line with other legal principles should be avoided. The outcome of a legal case should be as simple as possible. Simple law is clearer and better to predict, thus strengthening the foreseeability of what is criminal. ${ }^{54}$

After all, a great intellectual but abstract dogmatic construct is useless when courts and judges cannot apply it. A general part of criminal law for the EU must be comprehensible, accessible to and usable by lawyers from all legal traditions. ${ }^{55}$ Notwithstanding jury trials and lay magistrates, professionals apply the law. However, the law impacts the life of the individual defendant and also sends a message to the general public. This message is distorted when only few can understand the legal reasoning in a case.

52 Gropengiesser 2008, pp. 186-190. Nevertheless, the difference should not be exaggerated. Whereas English lawyers are very direct and clear about the fact that the result is most important, German (and Dutch) lawyers tend to hide common sense and public policy arguments in arguments of legal logic, see Bohlander 2009, p. 36.

The Criminal Code is subdivided into a general and special part, and $\S 1$ of its enactment law (Einführungsgesetz Strafgesetzbuch, 2 March 1974) determines that the general part applies to all existing and future provisions of federal and state law.

55 Ambos 2006, p. 661 and Ambos 2002, p. 54. 


\subsection{Compatibility with human rights and constitutional traditions}

A general part of criminal law for the Union should be founded on the principles of liberty, democracy, rule of law and respect for human rights and fundamental freedoms. Article 6 TEU holds that the human rights laid down in the ECtHR are general principles of Union law. Accordingly, a general part of criminal law for the Union must comply with the requirements under the ECHR. Prior to the Lisbon Treaty, the ECJ already declared in 1969 that human rights form an integral part of the general principles of law protected by the Court. ${ }^{56}$ The ECHR has always had special significance in that regard. ${ }^{57}$ Human rights should be complied with in the framework of Union law. ${ }^{58}$ A violation of a human right is therefore incompatible with Union law. ${ }^{59}$

The requirements under the ECHR are generally regarded as minimum criteria, implying a threshold that may not be crossed. It is in this context that the supremacy of Union law, specifically the requirements of the ECHR, becomes apparent. The principles identified here may not be contrary to the ECHR. The rights guaranteed by the ECHR are not all absolute, but exceptions to those rights can only be made under the strict conditions set out by the ECtHR. A general part of criminal law for the EU may therefore offer more protection than required by the ECHR, but never less. According to its article 52(3), the CFR may provide for more extensive protection than the ECHR.

To a lesser extent, general principles of Union law also receive more weight in the synthesis than their domestic counterparts, because these principles are already the product of comparative legal analysis. The goal of this research is to fill in the gaps of the general part of European criminal law. The elements of mens rea and defences identified here thus need to fit in with the existing acquis of European criminal law, unless there are good reasons to deviate from that acquis.

As noted, a general part also needs to be in line with the constitutional traditions of the Member States. These should be interpreted as the fundamental principles of criminal law, common to the EU Member States. These principles need not necessarily be guaranteed by a Constitution. ${ }^{60}$ Despite the weight attributed in the TEU to the constitutional traditions of the Member States, they carry less weight in the synthesis than Union law. First of all, legal traditions develop and change over time. For example, the Belgian legislator let go of its objections to criminal liability of legal entities in $1999 .{ }^{61}$

\footnotetext{
5612 November 1969, Case 29/69, Erich Stauder v. City of Ulm [1969] ECR 419.

5718 June 1991, Case 260/89, ERT [1991] ECR I-2925, §41.

5814 May 1974, Case 4/73, Nold v. Commission [1974] ECR 491.

5913 July 1989, Case 5/88, Wachauf v. Federal Republic of Germany [1989] ECR 2633, §17 and

13 December 1979, Case 44/79, Lisotte Hauer v. Land Reinland-Pfalz [1979] ECR 3727, §15.

6014 October 2004, Case C-36/02, Omega Spielhallen, [2004] ECR I-9641, §34. See also art. 67(1) TFEU.

61 Roef 2001, pp. 134-162.
} 
Secondly, the solution offered in the synthesis cannot be in line with all the domestic legal systems. In dealing with different legal approaches, solutions and rules, a choice in favour of one legal system is automatically a choice that may be at odds with another. If the synthesis would need to be in line with the criminal legal traditions of the Member States, only lowest common denominators could be identified, consisting of the similarities of mens rea and defences between the legal systems under investigation. As explained before, such a general part of European criminal law would be incoherent. The ECJ also does not seek the lowest common denominator, but the most appropriate solution, with a view to the Union's objectives. $^{62}$

What is important for the ECJ is that a concept is popular in many national legal systems. If a principle is common to the law of most Member States, the ECJ will recognize it as a general principle of Union law. If differences between the domestic concepts are not inconsiderable, the ECJ is reluctant to identify something as a fundamental principle of Union law. ${ }^{63}$ Nevertheless, in order for the ECJ to discover a general principle of Union law, it need not be recognized in all Member States. The scope and conditions of a Union principle may also differ in domestic law. ${ }^{64}$ What suffices is that the rationales of these principles are similar in multiple Member States. ${ }^{65} \mathrm{I}$ will therefore pay considerable attention to the rationales of mens rea, defences and their elements.

Although a quantitative criterion is more than a mere argument of authority, the choice in favour of national legal solutions in the synthesis is not based on the popularity or political feasibility of such choices, as was the case in the context of the Corpus Juris. ${ }^{66}$ The emergency break procedure of article 83(3) TFEU may be considered as an incentive not to infringe upon the fundamental aspects of a national criminal legal system. However, if a State would consider that this general part affects such an aspect, other States may still use the method of enhanced cooperation under the same article and continue with the adoption of the Directive. In other words, no political majority is required. ${ }^{67}$

This enables for instance, that even though dolus eventualis is more popular than the similar recklessness, it is rejected in favour of the latter. ${ }^{68}$ As noted before, such political considerations have been kept out of this research by separating the academic stage of establishing the general principles and the political stage of negotiating and decision-making. This is a lesson learned from the efforts to construct a European Civil Code, which project was rescued in the end by establishing such a clear distinction. The Rome Statute also illustrated that the negotiation of a general

Tridimas 2006, p. 21.

21 September 1989, Cases 46/87 and 227/88, Hoechst AG v. Commission [1989] ECR 2859.

Tridimas 2006, p. 6.

Tridimas 2006, p. 26.

Delmas-Marty \& Vervaele 2000, pp. 61 and 75.

Unanimity is also no longer required, as legislation under article 83 TFEU is adopted by the regular, co-decision, procedure.

See Reitz 1998, pp. 624-625. 
part by diplomats and politicians with a view to find compromises that are more or less acceptable to all legal systems involved, can lead to a vague, incoherent and inconsistent general part, which runs counter to the object of this research. ${ }^{69}$

\subsection{Criminal legal theories}

\subsubsection{The object of punishment}

The reasons for punishing offenders can vary. Traditionally, there are those who believe the defendant should be punished because this will contribute to the prevention of future crime and those who believe the defendant should be punished because he can be blamed for the offence. A focus on deterrence will lead to a distinctly different conception of general principles than a focus on deterrence. For example, insanity has been created out of the concern that if the mentally disordered would simply be acquitted, they would commit new crimes. By contrast, duress clearly aims to acquit the blameless because there should be no retribution against these defendants. ${ }^{70}$ On the other hand, it can also be said that duress excuses because the threat of punishment would not have motivated the actor to act differently anyway. In applying these perspectives, caution is therefore required.

It may be warranted in many contexts to categorize the English legal system as utilitarian, focused on prevention and the German as deontological, focusing on retribution. However, nowadays, every criminal justice system combines retribution and deterrence as goals of punishment. ${ }^{71}$ Even if prevention can be argued to be paramount in a society that focuses on the identification and minimalization of risks, pleas to increase (maximum) penalties for offenders are primarily based on giving the defendant what he deserves. For this synthesis, it is therefore important that if a legal concept or condition thereof does not serve any goal of punishment, it is not to be included in the general part of criminal law for the EU. By identifying the rationales for legal principles and concepts, the different choices that can be made will become clear.

\subsubsection{The character of criminal law}

The purpose of criminal law is not only to effectively punish offenders, but also to guarantee the defendant's rights. At the opposing ends of a spectrum on the character of criminal law, one can find a repressive and a more liberal perspective, a

69 Ambos 1999, p. 1; Bassiouni 1999, p. 460-464; Triffterer 2002, p. 389 and Dubber in Reimann \& Zimmermann 2006, p. 1307.

70 Cane 2007, p. 471-472 and 476.

71 Dubber in Reimann \& Zimmermann 2006, p. 1309; Section 142(1) Criminal Justice Act 2003; Ormerod 2005, p. 5; Hart 2008, p. 52; $\S 46$ and 47 of the German Criminal Code; Krey 2002, pp. 108-109 and 112-113; Weigend in Sieber \& Albrecht 2006, p. 50; Nieboer 1991, pp. 8-12; Buruma in Buruma 1999, p. 45 and Kelk 2008B, p. 31. 
crime control and a due process model, a focus on protection by or from the state, a perspective of criminal law as a sword or as a shield. Just like criminal theories are nowadays unified, these apparently opposing views also need to be seen as two sides of the same coin. ${ }^{72}$

In other words, the purpose of criminal law is not only to protect the individual defendant from state power but also to protect other citizens against criminal perpetrators. The citizen needs to be protected against the State, but also against other citizens. If the defendant's rights are not guaranteed, criminal law risks punishing the innocent, which serves no good. However, if the criminal law fails to sufficiently protect its citizens against other citizens, he is hardly free either. His freedom must therefore be ensured, if necessary by criminal law. If the criminal law fails to maintain law and order, the system with its safeguards will not be accepted. As a consequence, people may take the law in their own hands, sidelining the protective character of the law.

Just like the Corpus Juris, this general part is therefore built on the assumption that "effectiveness is not incompatible with the strengthening of guarantees. (...) (The) objective (...) is to bring them together." 73 The double function of shield and sword follows from the area of freedom, security and justice. Security, as mentioned in article 67(3) TFEU, is associated with the autonomy of possible victims of crime and the repression of crime. It can be contrasted with the individual freedom of the defendant that is limited by the criminal legal system. Justice means that both perspectives should be accounted for. As the Commission noted, effectively protecting the rights of both defendants and victims promotes the quality of justice. ${ }^{74}$

There will always remain a struggle between the competing perspectives. Like the perspectives on the purpose of punishment, the different views have an enormous impact on the scope of general principles. Bluntly put, by focusing on the efficient prosecution of offences, the scope of criminal liability will become broader. It is thus again imperative to make explicit the underlying perspectives in discussing the synthesis. The general climate in the Member States tends to be increasingly repressive. ${ }^{75}$ In addition, the victim is getting a more prominent role in criminal proceedings, often to the detriment of the defendant. In the EU legal system, the focus always seems to have been on the efficient repression of crime. This is not in the least because the Union is a victim of crime itself in the context of the protection of the EU's financial interests. Nevertheless, the position of the

72 Beulke 2008, p. 2; Prittwitz 1993, p. 377; Packer 1964; Peters 1972 in Buruma 1999; de Jong, D.H. \& Knigge 2003, pp. 27-30 and Remmelink (1986) in Buruma 1999, p. 105.

73 Delmas-Marty \& Vervaele 2000, p. 33.

74 Commission Communication: Towards an EU Criminal Policy: Ensuring the effective implementation of EU policies through criminal law, 20 September 2011 COM (2011) 573, p. 4. See also the Hungarian Presidency in its discussion paper for Justice Minister's lunch- Towards an EU Criminal Policy, 7 June 2011, no. 11155/11.

Kelk 2008B. 
individual defendant has also received more attention in EU law, evident by the strengthening of his procedural rights in criminal proceedings. ${ }^{76}$

\subsubsection{The purpose of general principles}

The scope of general principles also depends on other, more specific goals or rationales of those principles. For example, the scope of self-defence differs according to which rationale one believes to be dominant. The defence is broader under a rationale of autonomy of the attacked person than under a rationale that focuses on the legal order as a whole. Only from the broader perspective of the legal order, can the interests of the aggressor be taken into account, resulting in a proportionality requirement. It is also for that reason important to establish the underlying values of the different elements of mens rea and defences. These are presented under the heading of 'rationale' in the beginning of every discussion.

\subsection{Fair labelling}

Criminal law is all about communication. The criminal penalty reflects social disapproval, which enables it to be distinguished from other penalties. The assessment of criminal liability in a court is conducted through communication between the defendant, his lawyer, the prosecutor, the judge, a witness, expert, interpreter, jury member and/or public. The legal judgment consists of a message to the defendant and the public, expressed by the label given to the defendant and his actions. Effective communication is essential to the goals of criminal law. Without it, goals of deterrence and retribution cannot be achieved. For example, because of the clear message in the verdict, it is clear to everyone what the norms are and what is criminal. In order for communication to be effective, the determination of his criminal liability should be correct, legitimate, clear and understandable. ${ }^{77}$

The principle of fair labelling requires that "the criminal law should articulate as clearly and precisely as possible the nature of the moral judgments being passed on citizens' conduct." 78 This label ought to fairly represent what the perpetrator did wrong and why he is blamed for this. The verdict should neither understate nor overstate the defendant's actions or state of mind. ${ }^{79}$ The principle underlies the creation of many different offences, reflecting for example the difference in killing someone on purpose or negligently. The different standards of mens rea reflect a different moral judgment on the defendant and his conduct. The reproach against

\footnotetext{
76 Resolution of the Council of 30 November 2009 on a Roadmap for strengthening procedural rights of suspected or accused persons in criminal proceedings, OJ 2009 C 295/1.

$77 \quad$ See Bal \& Ippel 1982.

78 Roberts in Simester 2005, p. 179. See also Williams 1983; Horder 1994, p. 339 and Ashworth 2006, pp. 88-90.

79 Williams 1983.
} 
the intentional actor is more serious. This should be reflected in liability and thereby in the range of sentences that can be imposed.

Criminal law must distinguish between different concepts of criminal law, like intention and negligence, justification and excuse and perhaps even more finegrained distinctions that are morally significant. Should intent for example encompass the conscious acceptance of risks or should this be considered a different fault element? It will be argued that if the determination of criminal liability should provide a fair label of what the defendant did, intent should not be given such a broad scope. Otherwise, the liability of the defendant risks being overstated. For instance, if the driver of a car ignores a stop sign and a police officer has to jump aside to escape collision with the vehicle, that driver is generally assumed to have intended to kill in the Netherlands. I believe that equating the driver with someone who shoots a firearm at the victim is unwarranted.

The question remains how fine-grained morally significant distinctions in criminal law should be. In any case, the differentiation should be limited by the aforementioned condition of simplicity. The law should not make overly complex distinctions. A general part must be conceptually rich enough to enable a judge to make all those distinctions that must play a role in the administration of criminal justice and at the same time, be simple and easy enough to apply. ${ }^{80}$ As a criterion for synthesis, fair labelling is only used to invalidate outcomes that clearly overstate the reproach that can be made to the defendant. The clear understatement of the defendant's actions or state of mind in the conviction is also rejected, but less important given the ultimum remedium character of the criminal law and the principle that it is better to acquit ten guilty persons than to convict one innocent.

\subsection{Conclusion}

Like the other principles that are criteria for the synthesis, it is almost impossible to exactly pinpoint when a criterion is met or not. Some of them are more determinate than others. As principles however, they all constitute aspirations, ideal situations for the general part of criminal law. They may even conflict with each other, as illustrated by consistency and simplicity. These circumstances do not invalidate the criteria.

In fact, the criteria need to be balanced. More importantly, this balance needs to be argued for, whilst clearly identifying the underlying criteria and principles. In order to establish a general part of criminal law of the EU, there must be a transparent debate about what these principles should look like and for what reasons. The reader may thus strike a different balance by adhering more weight to a criterion or its underlying interest. One may for example reach different conclusions based on a preference to mainly protect the rights of the individual defendant. The debate on what mens rea and defences should look like in European 
criminal law thus inevitably triggers a debate on what the underlying purposes of criminal law and punishment are. I have explained my views on these issues in this chapter.

By using comparative legal analysis as an important source for the creation of a genuine European criminal justice system and by striking a balance between security and freedom, this research is in line with the recommendation of the European Parliament to the Council that it will "establish, together with the Commission and with Parliament, a committee of wise persons (jurists) with the task of preparing a study on similarities and differences between the criminal law systems of all Member States and submit proposals for the development of an EU criminal justice area that will balance effectiveness in criminal proceedings with safeguarding individual rights". ${ }^{81}$

81 EP recommendation of 7 May 2009 to the Council on development of an EU criminal justice area, no. 2009/2012. 

Part 2

MENS REA 

The paradigm of criminal liability consists of actus reus and mens rea. In order to be held liable, the defendant must not only have acted, he must also have been culpable in doing so. This is expressed in the maxim actus non facit reum nisi mens sit rea. This means that "the act is not culpable under the law unless the actor is culpable for acting as he did," " or, "an act does not make a man guilty unless his mind is (also) guilty." 2 This combined requirement of act and concomitant state of mind safeguards that citizens are not held liable for mere thoughts or the causing of unforeseeable accidents. If the defendant thought about killing his enemy, without turning his thoughts into action, he cannot be held liable. In the absence of an actus reus, there is no crime. If the victim jumped in front of the train that the defendant was driving, the defendant can also not be held liable. However serious the consequence, he is not at fault for the victim's death. In the absence of mens rea, there is no crime.

These starting points of criminal law have come under pressure however. It is doubted whether in all cases of criminal liability there can be said to be an actus reus and a mens rea. In cases of strict liability, proof of mens rea is made irrelevant, the defendant convicted upon mere proof of the criminal conduct. By criminalizing preparatory acts, innocuous conduct is criminalized, challenging the act requirement. This chapter aims to identify the scope and weight of mens rea as an essential element of criminal liability in a general part of criminal law for the EU. It will be investigated whether mens rea still is a fundamental pillar of criminal liability. Are exceptions legitimate and if so, under what conditions?

This chapter is structured as follows. I will first explain what should be understood by the term mens rea by demarcating it from related legal concepts. Mens rea and defences are introduced as tiers of a coherent framework of criminal liability. In the next chapter, I will take a closer look at what I will call fault elements, like intention and negligence. It will be argued that a general part of criminal law for the European Union should apply three kinds of fault; dolus, recklessness and culpa. This brings about, most importantly, that the lower limit of intention, dolus eventualis, is rejected. Under the heading of correspondence, several principles will be discussed that determine the application of mens rea. Modern forms of liability, like strict liability, are positioned as exceptions to these principles. 



\title{
Chapter III \\ WHAT IS MENS REA?
}

\begin{abstract}
Mens rea can literally be translated into 'evil mind'1 or 'guilty mind'. ${ }^{2}$ The Latin term is commonly used in English law to refer to the mental element required for conviction of the offence charged..$^{3}$ Its functional equivalent in the Netherlands and Germany is named 'subjective element'. I use the term mens rea in a broader meaning so it can serve as an analytical tool. It encompasses not only the 'subjective' or 'mental' elements of the offence definition, but its related doctrines and principles as well. The referential principle, for example, holds that a subjective element like intention must relate to all objective elements of the offence definition.
\end{abstract}

\section{Analytical tool}

Mens rea is a collection of subjective offence elements and principles that regulate the application of these elements. The word 'collection' implies that mens rea is an analytical tool for both scholars and practitioners. ${ }^{4}$ The constituent elements of a crime are either mens rea or actus reus and categorized accordingly. The dichotomy is grounded in Cartesian dualism, which is the strict separation of corpus and animus, the body and the mind, the objective and the subjective, the material and the immaterial, the actus reus and mens rea. This dualism has been subject to much criticism, but is still dominant. ${ }^{5}$ The dichotomy of actus reus and mens rea helps to limit the scope of research and understand mens rea better.

The dualist perspective brings about that the definition of a criminal charge can be divided into a subjective and objective part. From Article 1(a) of Framework Decision 2008/913 on racism and xenophobia, we can deduce the following offence definition:6 "(Punishable is) he who intentionally publicly incites to violence or hatred directed against a group of persons or a member of such a group defined by reference to race, colour, religion, descent or national or ethnic origin." I have italicized the subjective element in this offence, which implies that the other elements belong to actus reus.

Finkel \& Parrott 2006, p. 23.

Oxford Dictionary of Law.

Simester \& Sullivan 2007 p. 676 and Fletcher 1971, p. 410.

DPP for Northern Ireland v. Lynch [1975] UKHL 5; Ashworth 2006, p. 95 and Smith, A.T.H. in Glazebrook 1978, p. 96.

5 Shapira-Ettinger 2007, pp. 2579-2582 and Robinson in Shute, Gardner, J. \& Horder 1993.

6 The Framework Decision needs to be implemented in national law. It is assumed here that this is done in the popular fashion of copying the wording of the Framework Decision into national law. Often, criminalizations also include the maximum and/or minimum punishment that follows upon a conviction. This is not included in my use of the term 'offence definition'. An offence definition only deals with the elements of criminal liability, not its consequences. 


\section{Fault element}

Mens rea is classically understood as a state of mind, a psychological disposition or mental element that relates to the actus reus, the objective offence element. The definition of 'fault element' provided by the English Law Commission in its draft Criminal Code, section 5(6), is enlightening;

"Fault element means an element of an offence consisting -

a) of a state of mind with which a person acts; or

b) of a failure to comply with a standard of conduct; or

c) partly of such a state of mind and partly of such a failure."7

The Law Commission uses 'fault element' as a rough translation of mens rea. Although 'mens rea standards' are often referred to as states of mind or mental elements, certain of those standards cannot be called a state of mind. Rather, they can be described as an absence of a state of mind at best. For example, the negligent actor is not aware of a risk. Thus, negligence should be categorized most appropriately under b) as a failure to comply with a standard of conduct. Recklessness features the same failure but also a state of mind of awareness and thus fits category c) best. ${ }^{8}$ In Germany and the Netherlands, negligence and intention are labelled generally as subjective, mental or psychological elements of the offence definition. ${ }^{9}$ The label is also somewhat controversial, yet the debate has focused more on the correct dogmatic position of these elements in the framework of criminal liability than on the perceived linguistic imprecision of the term. I will turn to this issue shortly.

The term 'fault element' is best equipped to refer to the offence elements of intention, recklessness and negligence. Any reference to mens rea is problematic, because the lack of a state of mind characteristic to negligence has often been used to argue that it is no form of mens rea. Secondly, the term mens rea is used here as an analytical tool to cover not only the 'standards', but also its related principles. 'Mental element' suffers from the same shortcoming. 'Mental' is derived from the Latin mens, and the lacking function of the mind is paramount in negligence. 'Subjective element' is most popular on the continent, but also a quite broad term that is used there for more than merely intention and negligence, such as motives.

Law Commission 1989, p. 45.

Law Commission 1989, p. 190.

Krey 2003, pp. 26-27; Beulke 2008, p. 46; de Hullu 2009, p. 201 and Politoff \& Koopmans 1991, p. 63. 


\section{DEMARCATION FROM OTHER SUBJECTIVE ELEMENTS}

Some offence definitions contain more subjective elements than the fault elements intention, recklessness and/or negligence. These elements are excluded from the research, because they are not as widespread as fault elements and very much related to a specific (national) offence. Moreover, these elements usually do not constitute liability, but rather aggravate or mitigate it. The addition of such an element to a basic offence either aggravates or mitigates the reproach and thereby the sentencing range.

For example, premeditation is an aggravating circumstance of homicide in the Netherlands. ${ }^{10}$ It defines the most serious form of intentional killing as murder by adding the aggravating element of premeditation. The increase of the maximum punishment is based on the defendant's weighing of contrasting motives and the decision to break the law, the planning, the increased degree of directing the course of events, implying a higher degree of free decision, control, danger and legal hostility. This is juxtaposed with spontaneous or impulsive killing.. ${ }^{11}$ Given this rationale, it is not strange that premeditation has been referred to as a fault element. It has been called dolus premeditatus, in distinction to dolus repentinus, sudden intent, ${ }^{12}$ and put at one extreme end of a spectrum on fault elements..$^{13}$ However, it is generally distinguished from fault elements because premeditation precedes the intentional act of killing. ${ }^{14}$ Moreover, the psychological element of reflection is not only proven very objectively, it could even be said that the criterion of premeditation consists of the mere opportunity to reflect. ${ }^{15}$

Homicide will often be used as an example in this book, so it is important to note that the definition of homicide differs significantly in the three Member States. To distinguish on the basis of premeditation used to be common in Germany too. ${ }^{16}$ At present however, murder is defined as intentional killing coupled with an array of possible motives and modi operandi, not including premeditation. ${ }^{17}$ Homicide is very broad in England and extends far beyond intentional killing. ${ }^{18}$ Premeditation is named in numerous sentencing guidelines as aggravating.

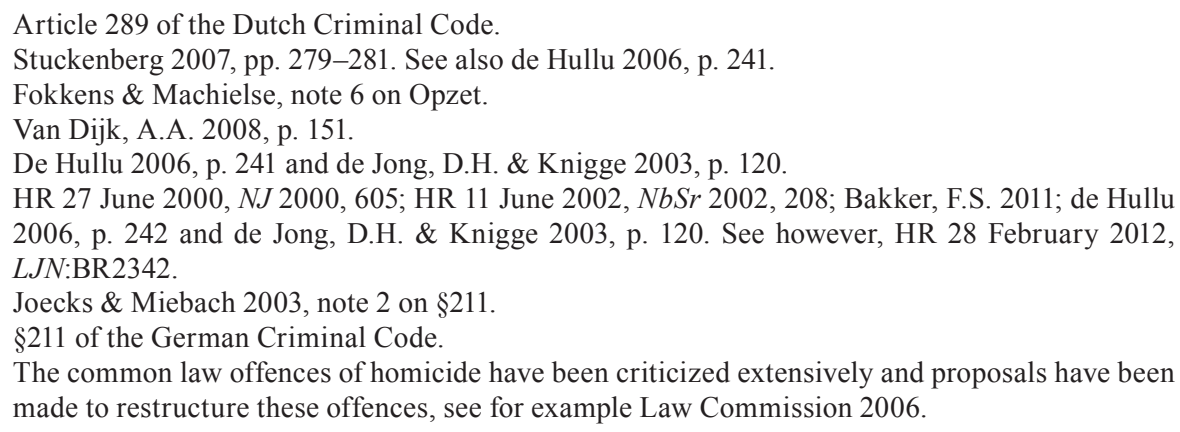




\section{DEMARCATION FROM BLAMEWORTHINESS}

In order to understand the difference between fault elements and excuses, mens rea must be distinguished from blameworthiness. Intention and negligence differ from blameworthiness. ${ }^{19}$ The latter is negated when an excuse like duress applies. The defendant, who was coerced to rob a bank because his family would otherwise be killed, has committed a criminal offence. He acted intentionally, because his direct purpose was to rob the bank. Therefore, on a first level of assessing criminal liability, the defendant is liable. It is only because of his special motive to commit the crime that the defendant is excused for committing an intentional offence. This excusing occurs on another level of criminal liability, namely the level of blameworthiness.

The communication in this distinction is important: the defendant committed an offence, which is illegal and wrong(ful), but he should not be blamed for this crime, given exceptional circumstances recognized by law in the defence of duress. This will be further elaborated in the next chapter. For now, it is important to introduce the three-layered structure of criminal liability. This structure or framework is of German origin. It is an analytical tool to organize doctrines, concepts and principles of criminal law, and it provides the decision maker with a logical order of assessing these different elements of criminal liability. For example, it first needs to be established that the defendant did in fact fulfil the offence definition, before it makes sense to ask whether he should be excused for this crime.

The framework can therefore be seen as a ladder with three rungs that need to be climbed in order to reach a confirmative judgment on criminal liability. ${ }^{20}$ The first rung consists of the offence definition that encompasses objective and/or subjective elements, including fault elements. Bluntly put, actus reus and mens rea belong to this first tier. When the offence elements have been proven, it is assumed that the two other conceptual tiers of criminal liability have been fulfilled as well. ${ }^{21}$ Only when a justification applies, can it be said that the act was not wrongful and only when an excuse applies, blameworthiness is negated. ${ }^{22}$ Wrongfulness and blameworthiness are thus called the 'implied' elements of criminal liability because they are assumed after proof of the charge. ${ }^{23}$

Moreover, they need not be included in the definition of the offence in contrast to the 'express' elements of intention, recklessness and negligence. They are an implied element of every crime. If the offence definition does not include intention

\footnotetext{
19 Beulke 2008, p. 141. See also Schönke \& Schröder, H. 2006, p. 206.

20 Horder 2006A, pp. 99-101.

21 Kelk 2005, pp. 123-124; Roxin 2006, pp. 1105-1106; Beulke 2008, p. 49; Schönke \& Schröder, H. 2006, p. 169-171.

22 Bohlander 2009, pp. 16 and 29; Krey 2003, pp. 2-3; Schönke \& Schröder, H. 2006, pp. 154-155; Beulke 2008, pp. 27-28 and Naucke 1984.

23 Bosch 2008, p. 161; Machielse 1986, p. 698; Wolswijk 1998, p. 244; de Hullu 2006, pp. 65 and 272; Schönke \& Schröder, H. 2006, p. 170; Krey 2003, pp. 8-9 and Beulke 2008, pp. 41-42.
} 
and the court also does not read this into the offence, this element does not have to be proven in order to hold the defendant liable. By contrast, regardless of whether wrongfulness and blameworthiness are included into the offence definition, there can be no criminal liability when these elements are lacking. A criminal act is thus commonly described as a human act, which fulfils the requirements of the offence definition and is both wrongful and blameworthy. ${ }^{24}$

This framework is generally accepted in all three Member States, although this may still be questioned as far as the English legal system is concerned. Rather than an ordered, three tiered structure of criminal liability, English law used to, and still tends to apply a 'holistic approach', or 'flat legal reasoning', whereby the order of assessing the different elements of criminal liability is irrelevant. The main elements of the crime, actus reus and mens rea, are put on the same footing, and the order of assessing is considered immaterial. ${ }^{25}$ Nevertheless, it is explained below that English law is moving more and more towards the Germanic framework. European criminal law should adopt a structure or ordering of the elements of criminal liability, because structure is a precondition for consistency. It ensures that all defendants are treated the same and that the outcome of cases is foreseeable. ${ }^{26}$

A word of caution is required. The framework's clear demarcation only applies to the intentional offence. When defences apply to reckless or negligent offences, the offence definition is negated. All three levels of criminal liability are centred on one. This is because the fault elements of recklessness and negligence are partially normative. These fault elements subsume the normative element of wrongfulness and blameworthiness with the consequence that the acceptance of a defence negates the offence definition, more specifically, recklessness or negligence.

Recklessness requires that the actor must be aware of a risk, which is unreasonable or unjustifiable. Hence, if a justification like necessity applies, there is no recklessness. The driver who is speeding knows this creates a risk for others and himself, but if he is speeding in order to get a seriously injured person to hospital, the risk can be deemed reasonable. As a result, there is no reckless act, and thus no fulfilment of the offence definition. The justification negates the offence definition rather than the element of wrongfulness. As will be discussed in the next chapter, the affirmative defence becomes a failure of proof defence. Accordingly, the language changes. Rather than stating that the actor is justified in committing a reckless offence, it should be stated that he did not commit a reckless offence. ${ }^{27}$

Negligence is a very normative concept, since it holds in essence that a person could and should have acted differently. Crimes of negligence also absorb the

24 Krey 2003, pp. 6-7; Fischer, T. 2009, p. 65; Beulke 2008, p. 27; Bosch 2008, p. 178; Kelk 2005, p. 50; Dolman 2006, p. 313; Koopmans 2007, p. 49 and Mevis 2006, pp. 564 and 581.

25 Eser in Eser \& Fletcher 1988, pp. 22-23 and Fletcher 1985, p. 951.

26 See Eser in Eser \& Fletcher 1988, p. 22.

27 See IV.4.5. 
element of wrongfulness and are therefore negated by a justification. ${ }^{28}$ In addition, negligence absorbs blameworthiness. As a result, in Dutch law, the effect of accepting an excuse to a charge of committing a negligent offence is that it negates the charge and results in an acquittal. ${ }^{29}$ It is accepted nonetheless, that the fault element negligence differs from the implied element blameworthiness. As will be explained later, the latter refers to any degree of blame, whereas negligence must be gross. ${ }^{30}$ This brings about that negligent offences require gross negligence, whereas strict offences only require some degree of blame. ${ }^{31}$ In other words, criminal liability always requires blameworthiness, even when no fault is required. The reproach of blameworthiness is therefore more basic than the reproach expressed by fault. This is just one example of the use of combining an investigation of mens rea and defences.

\section{FRAMEWORK OF CRIMINAL LIABILITY}

As mentioned above, there has been an extensive debate on the correct position of fault elements in the framework of criminal liability. It is most fiercely debated in German law where bluntly put, fault elements developed out of blameworthiness. In time, it was recognized that the structure of criminal liability consists not only out of wrongfulness and blameworthiness, but also out of an additional first layer of the offence definition. The insight that intention is a fault element of the offence definition, rather than part of blameworthiness, gained influence due to the popularity of the teleological theory of conduct ('finale Handlungslehre'). ${ }^{32}$ This is one of the main merits of a theory that has otherwise mostly been rejected.

The current prevailing theory in Germany still separates fault from blameworthiness, but nonetheless believes that both negligence and intention include aspects of blameworthiness. Accordingly, the two fault elements are positioned not only on the level of the offence definition, but partially on the level of blameworthiness too. ${ }^{33}$ The quest for a correct dogmatic framework of criminal liability has not been pursued with the same vigour in the Netherlands. Less concerned with the dogmatic framework of criminal law, all the more with its practical procedural consequences, Dutch legal scholars and practitioners have accepted the abovementioned insights, and focused on cases where the acceptance of a defence brought about the negation of an offence element. The practical

De Hullu 2006, pp. 251 and 257; Kelk 2005, p. 207; Roxin 2006, p. 1077 and Schönke \& Schröder, H. 2006, pp. 299, 305 and 319.

in more detail, German law positions the element of negligence that is negated by an excuse on the third tier of criminal liability.

See IV.6.5.1.

Vellinga, W.H. 1982, p. 114 and de Hullu 2006, p. 266.

Krey 2003, pp. 32-33; Schönke \& Schröder, H. 2006, pp. 161-162 and Beulke 2008, pp. 49 and 315-316. 
consequences of a defence, like duress having the effect of denying negligence rather than blameworthiness, have generally been accepted as a technical legal issue with implications for procedural aspects such as the burden of proof, the verdict and its grounds stated. These and other practical consequences are discussed in the beginning of the next part.

The correct dogmatic positioning of fault elements has never been considered very relevant in England. Apart from the fact that a profound interest on dogmatic questions is relatively young in England, this is also due to the failure to distinguish between blameworthiness and fault. ${ }^{34}$ As a result of this failure, the acceptance of duress was interpreted as to negate intention. ${ }^{35}$ Steane lived in Germany during the Second World War and was coerced by the Nazi's to help them broadcast in English. If he continued to refuse, his family would be send to a concentration camp. $\mathrm{He}$ thus intentionally assisted the enemy, but should have been excused under duress. In appeal, his conviction was in fact quashed, but because his acts were not conducted with the intent to assist that enemy. In contrast, he did this with a view to save his family. This solution, although fair in outcome, is criticized for not acknowledging that Steane in fact intended to help the enemy. Blameworthiness and intention are confused. ${ }^{36}$ "The common law world has never settled on a word to refer to this moral dimension negated by excuses." ${ }^{\prime 37}$

The confusion can be explained by the oversimplification of English law along the lines of (either) actus reus and (or) mens rea. Justifications used to be seen as part of actus reus and excuses as part of mens rea. ${ }^{38}$ There is, however, an increasing tendency in Anglo-American law to separate blameworthiness from fault and thus to create at least one additional tier of criminal liability, that of defences. Although one will find not many references to the tiers in case-law or legislation, it is now widely accepted by English academia. ${ }^{39}$ The House of Lords has acknowledged the difference between fault elements and blameworthiness in the context of duress. ${ }^{40}$

In all three legal systems, there has been a similar development since the second half of the last century. A dualistic system based on the dichotomy of body and mind has evolved into a three-tiered system. The current systems are more or less identical and therefore constitute a framework of criminal liability for the EU. Only

34 For example, Hart 2008 (reprint 1967), pp. 30-35 and 187. Compare Vogel in Tiedemann 2002, p. 137.

35 R. v. Steane [1947] KB 997.

36 See also Smith, J.C. 1989, pp. 61-71 and Stuckenberg 2007, pp. 236-240. Note that in Steanelike cases that were prosecuted right after WWII in the Netherlands, necessity and duress have been often accepted, see de Hullu 2009, p. 294.

37 Fletcher 2007, p. 312. See also Fletcher 1978, pp. 395, 398-399 and Robinson in Dressler 2002, p. 995.

38 See for example Glazebrook 1972, pp. 91-92.

39 Simester \& Sullivan 2007, pp. 19-20 and Ormerod 2005, p. 40.

40 DPP for Northern Ireland v. Lynch [1975] UKHL 5. See also R. v. Hasan [2005] UKHL 22; Ormerod 2005, p. 298; Law Commission 1977, p. 3 and Fletcher 1978, pp. 395-401. 
the development of the three tiers has been very different. In England, wrongfulness and blameworthiness were soaked off the dichotomy of actus reus and mens rea. Defences were developed out of and separated from the offence definition. By contrast, in Germany, the fault elements have been soaked off the dichotomy of wrongfulness (Unrecht) and blameworthiness (Schuld), which are now commonly considered to relate to defences.

\section{DEMARCATION FROM ACTUS REUS}

So far, mens rea has been discussed in some detail. In order to demarcate mens rea, I will now turn to actus reus, which consists of (a combination of) certain conduct, consequences and/or circumstances. This threefold distinction of objective elements is common in all Member States investigated. ${ }^{41}$ In the offence definition mentioned above of intentionally inciting violence or hatred directed against a group of persons defined by reference to race, colour and so on, we can identify all three categories. Inciting is a form of conduct, the feelings of hate are a consequence, and the group to which this hate or violence is directed is characterized by circumstances like race.

Like mens rea, actus reus also consists of more doctrines and concepts. In this section, the mental or subjective elements in concepts generally categorized as belonging to the actus reus will be identified. In doing so, the difficulty in drawing a clear border between actus reus and mens rea is demonstrated and the objects of this research are delineated.

\subsection{Verbs that imply a subjective element}

A first illustration that a sharp distinction of objective and subjective elements is not always possible is found in certain verbs that operate as offence elements. By their nature, some of these verbs encompass a subjective element like intention or knowledge. For example, appropriating cannot be done inadvertently, neither can resisting or forcing someone, forging or even driving. The verbs imply a specific intention and therefore combine objective and subjective elements. ${ }^{42}$ If the nature of a verb does not indisputably imply a subjective element, this is also sometimes read in. Possession of for example, drugs, firearms or child pornography is

41 Kadish 1989A, p. 73 and de Jong, D.H. \& Knigge 2003, p. 65. German criminal theory distinguishes many more elements than these three categories, see Schönke \& Schröder, H. 2006, pp. 262 and 270-271; Krey 2003, pp. 134-135 and Beulke 2008, p. 84.

42 Krey 2003, pp. 106-107; Beulke 2008, p. 47; Schönke \& Schröder, H. 2006, p. 173; Bohlander 2009, p. 67; Lynch 1982, pp. 128-130; de Hullu 2006, pp. 197 and 207-208; Pompe 1935, p. 73; van Bemmelen 1959, pp. 43-44 and Nieboer 1991, pp. 157-158. 
interpreted as requiring the subjective element of awareness. ${ }^{43}$ The subjective aspects of the different verbs will not be discussed in detail, but sometimes reference will be made to them. For example, the nature of certain verbs implies that they cannot be committed with anything less than intention.

\subsection{Causation}

Causation deals with the old and basic question of who can be labelled as the causer of harm. It consists of a set of principles that determines whether the causal link between the actor's conduct and the result is sufficiently strong to hold this actor criminally liable. Before the $18^{\text {th }}$ century, there was hardly any interest in fault and all the more focus on the question of causation for attributing liability. ${ }^{44}$ It is common to view causation as belonging to the category of actus reus. After all, causation connects the objective element of conduct with the objective element of harm. For that reason, causation will not be discussed in much detail here.

Nonetheless, the categorization is put into perspective when more focus is placed on causation's secondary function of connecting result to fault. The causal reasons for a result to occur are not only determined by the conduct of the actor but are also influenced by the concomitant fault element. It is generally recognized, for example, that 'intended consequences are never too remote', which expresses the principle that the causal link between conduct and consequence can easily be accepted if the consequence was intended. For instance, agreements that have as their object anti-competitiveness do not have to be tested to actual effects; these effects are presumed. ${ }^{45}$ Intention has a strong effect in hastening a finding of causation. Thus, even if there consequence was unlikely to occur, or occurred in a manner that deviated to a great extent from what the actor expected or planned, there is no problem of attributing the harm to the actor causally. ${ }^{46}$ The relationship is also apparent in the conversed case, where a strong element of causation facilitates a finding of mens rea. As a matter of evidence, close or direct consequences can facilitate the inference of a fault element like intention. When someone is shot from close range, it is easily accepted that the results caused were intended.

The approach here is that the collection of principles regarding causation differs according to the pertinent subjective element. This perspective is common in

43 R. v. Sleep [1861-1873] All ER Rep 248; Warner v. MPC [1969] 2 AC 256; HR 10 June 1986, NJ 1987, 85 and HR 26 January 1999, NJ 1999, 537.

44 Interview with Jeremy Horder at the Law Commission, London, on January 16, 2009.

45 As submitted in a Communication from the Commission: Notice - Guidelines on the application of Article 81(3) of the Treaty, 27 April 2004, OJ 2004 C 101/97 and confirmed as standing caselaw by 6 October 2009, Cases C-501, 513, 515 and 519/06 P, GlaxoSmithKline Services and others v. Commission [2009] ECR I-9291.

46 Ashworth 2006, p. 124; Duff 1990, p. 66; de Hullu 2006, p. 210; de Jong, F., van Roomen \& Sikkema 2007, pp. 950-952; de Jong F. 2009, pp. 339-340 and Bohlander 2009, p. 69. 
Germany, but also implicitly accepted in the Netherlands and England. It warrants a discussion of causation connected to the fault elements. For intentional offences, this means its peculiarities regarding causation will be discussed in the paragraph on the principle of contemporaneity, which requires that actus reus and mens rea coincide in time. Issues of causation in intentional offences are seen as both the origin and the possible solution to problems of contemporaneity between actus reus and mens rea. Suppose the actor injures the victim with the intent to kill and thinks he has died, after which he buries the body. In reality, the victim dies from suffocation after being buried alive. The problem in the context of causation is that the actor did not intend for the victim to die in this way. It will be explained that this presents problems in German law, where intention must relate to the causal chain of events in its essential features. Nonetheless, causation also can be used to rebut these problems, by arguing that the intended consequence has been realized or that the deviation in the causal chain of events was not substantial enough to negate intention. ${ }^{47}$

Special rules on the required causal relationship between conduct and result that relate to negligent offences are discussed in the section on negligence. In German law, these rules are so much intertwined with negligence that they are treated as belonging to the 'objective part of negligence'. As a result, there is no negligence if the result would have also been caused if the actor had not been careless. ${ }^{48}$ In the Netherlands, it is also accepted that causation and negligence are difficult to separate. $^{49}$

Accepting that rules on causation are dependent on the concomitant fault element does not imply that causation dogmatically belongs to mens rea. Even though causation and mens rea are not always easily separated, they can be separated, because there can be instances where there is causation, but no fault. ${ }^{50}$ Suppose a movie actor is given a firearm, in order to 'kill' the villain in a scene of a movie. The villain is shot dead, because the firearm was in fact loaded with live ammunition. There is causation between the death and the shooting, but the actor did not intend, nor can be said to be negligent in bringing about the result. Causation is a test that precedes a finding of fault and that does not negate fault. It seems that only in Germany, the perspective that causation affects fault is still accepted, although it is diminishing in favour of the view that causal issues can negate liability directly. ${ }^{51}$

$47 \quad$ See V.3.2.

48 See IV.6.4.4.; Beulke 2008, p. 246 and 342 and Bohlander 2009, pp. 60 and 117.

49 De Jong, D.H. \& Knigge 2003, pp. 85 and 127-128 and annotator Knigge in HR 1 June 2004, NJ 2005, 252. The peculiarities relating to reckless offences will not be discussed in detail.

50 De Jong, D.H. \& Knigge 2003, p. 128; Keulen \& Otte 1999, p. 40 and de Hullu 2006, pp. 247248.

51 Schönke \& Schröder, H. 2006, pp. 188-189 and Krey 2003, pp. 62-63. 


\subsection{Attempt, participation and more}

Fault elements also play a significant role in concepts that do not fall under the scope of this research. In attempt liability, the intention must be directed at the result. This form of intention differs hardly from intention to completed crimes and will often be referred to in the discourse on intention. Forms of participation and liability for omissions contain subjective elements too. For example, aiding and abetting requires a double intent that relates to the act itself and to its awareness of being able to assist. However, the subjective elements in these concepts are intertwined with the objective requirements of those forms of liability to an extent that makes it more appropriate to be discussed in that context. ${ }^{52}$

This research focuses on criminal liability of the natural person who acts individually. The liability of legal entities differs much from the classic view that only natural persons can be legal subjects. It is often argued that a legal entity does not have a mind. It is clear that for legal entities to be held liable, the conduct of a natural person must be attributed to the entity. ${ }^{53}$ This attribution is often positioned as a fiction. Yet attributing conduct of someone to a legal entity or another natural person at least requires a subjective connection between the physical and legal actor. This required connection differs greatly however from the fault elements such as intention and will be discussed in a related research project.

Some important mental or subjective elements in concepts that are generally categorized as belonging to the actus reus have now been identified. Defences carry with them subjective elements as well, which will be highlighted in the next chapter. The enumeration has not been exhaustive, and is only meant to illustrate that actus reus and mens rea cannot always be clearly differentiated. In general therefore, it has become clear that a strict dualistic view cannot be upheld. A clear separation of subjective and objective elements, of actus reus and mens rea, even of the offence definition and defences, ${ }^{54}$ is hardly possible. ${ }^{55}$ This does not, however, warrant the conclusion that the dichotomy is redundant. As an analytical tool, the distinction between actus reus and mens rea helps to understand the principles of criminal law.

Amongst others, the relationship of actus reus and mens rea has been labelled as one of 'communicating vessels' ${ }^{56}$ The theory is one of mutual interrelatedness. It holds that when there are hardly any subjective elements required to hold someone liable, more should be required from the objective elements of the offence definition to ensure that the holding liable of the defendant is warranted and vice versa. The two basic ingredients of an offence are made into an analogy of two vessels. A little

52 Ashworth 2006, p. 158 and van Dijk, A.A. 2008, pp. 265-271. See Keiler 2012, forthcoming. Exceptionally, questions relating to these concepts force themselves upon us and are important to answer with a view to fault elements in general, see for example IV.5.5.

53 De Hullu 2006, pp. 260-261.

54 See VII.

55 Schönke \& Schröder, H. 2006, p. 175; Tadros 2005, p. 12 and Ormerod 2005, p. 254.

56 Van der Wilt 2006, p. 256 and Buruma in Buruma 1999, p. 29. 
less of actus reus in relation to the normal case needs to be compensated by an additional degree of mens rea. ${ }^{57}$ For example, in the doctrine of preparation, the mere creation of conditions to further the ultimate goal must be compensated by an additional intention that this contributes to the completion of the crime. ${ }^{58}$ The abovementioned relationship between mens rea and causation also fits in this perspective. ${ }^{59}$

\section{OBJECTIVISM AND SUBJECTIVISM}

Another example of using the dichotomy for analytical purposes is to juxtapose actus reus and mens rea, or objectivism and subjectivism, as extreme approaches to principles, doctrines and concepts of criminal law. These are distinct perspectives on what is paramount for criminal liability, both in substance and procedure, and can have an enormous impact on the scope or proof of an element of criminal liability. Using this dichotomy helps to clarify views and approaches on the general part of criminal law that are discussed in this book. I will now introduce these perspectives here, as well as the appropriate approach in a general part of criminal law for the EU.

In short, an objectivist approach regarding substance grounds liability first and foremost in the conduct or harm, whereas a subjectivist lays emphasis on morally defective choices or fault. Subjectivism gives fuller recognition to significance of the fault element. In subjectivism, criminal liability is tied as closely as possible to what the defendant intended, knew or believed. ${ }^{60}$ A person should be judged on the facts or circumstances as he or she believed them to be at the time, rather than the actual facts. ${ }^{61}$ An extreme subjectivist view is that a defendant should not be convicted if he did not advert to the (possibility) of the consequences occurring. Fault that does not require awareness, such as negligence, is thus thought to be insufficient for liability. ${ }^{62}$

As far as evidence is concerned, an objectivist approach does not require that fault elements have to be based on the actual state of mind of an individual person. Fault is rather equated with or inferred from the so-called 'reasonable person'. ${ }^{63}$ In a more moderate version of this approach, knowledge on the psyche is deduced from non-psychological factors like the conduct and circumstances of the case, as well as rules of general experience. ${ }^{64}$

57 Compare Law Commission 2010, p. 79.

58 Ashworth 2006, p. 423 and Kamerstukken II 1991/92, 22 268, no. 5, p. 19.

59 See Ashworth 2006, p. 311 and Husak in Simester 2005, p. 96.

60 Ashworth 2008A, pp. 235-236.

61 Ashworth 2006, pp. 159 and 452: 'belief principle.'

62 Simester \& Sullivan 2007, pp. 9-10 and Ashworth 2006, p. 471.

63 Simester \& Sullivan 2007, p. 9 and Ashworth 2006, p. 86.

64 HR 25 March 2003, NJ 2003, 552 and van Dijk, A.A. 2008, p. 234. 
If pressed to categorize the sources of synthesis, the German legal system could be labelled as most subjective. After all, German criminal law rejects strict liability and takes the most moderate objective approach to proving fault. European legislation in criminal matters is also characterized by a relative lack of strict elements, as the rule appears to be that fault must be proven as to each and every offence element. However, the manner in which fault elements are proven in, for example, competition law is very objective. In general, criminal law in Europe is becoming more objective, evidenced by the increase in the last decades of the number of crimes of strict liability, objective evidential inferences and reversed onuses. ${ }^{65}$

\subsection{Proof of fault}

An account of fault elements without reference to how they are proven in practice, is hardly useful. This will become very clear in the context of dolus eventualis. Rules of substantive and evidential law are often inextricably linked to each other. Evidential difficulties, such as denying or silent suspects and the lack of objective proof and witnesses, can be solved by either modifying substantive or procedural law. It is possible to lower the substantive criteria of liability by striking offence elements, including fault, or by creating offences that are easier to prove, such as offences criminalizing abstract endangerment.

The proof of offence elements can be facilitated as well, by creating procedural investigative measures that make the gathering of evidence easier, or by proving fault elements by reference to circumstances and conduct. In some cases, this objective inference of fault from facts is explicitly recognized in criminal statutes. In English and Dutch law, when a defendant is found in possession of an article made or adapted for use in committing a burglary shall be evidence that he had it with him for such use. ${ }^{66}$ The defendant needs to rebut the presumption that the crowbar found in his possession was meant to be used in a burglary, in order to negate intention. In effect, this rebuttable presumption thus reverses the burden of proving intention from the Prosecutor to the defendant. ${ }^{67}$

The problem of proving fault is that "substantive rules regarding the mental element require the actual occurrence of a subjective mental state, whereas the law of evidence can provide only an assumption that the required state may have occurred."68 The dilemma is therefore that, on the one hand, objectifying proof of fault elements appears essential for an efficient operation of criminal law but on the

\footnotetext{
65 Roef in Vos \& van Calster 2004. See V.2.3.

66 Section 25 (3) of the English Theft Act 1968; Ashworth \& Blake 1996, p. 312 and HR 28 February 1989, NJ 1989, 687.

67 See V.2.3.4.

68 Shapira-Ettinger 2007, p. 2585, my italicization. See also annotator Buruma in HR 24 April 2007, NJ 2007, 544.
} 
other hand, it has the risk of inferring fault where there was none. ${ }^{69}$ In order to minimize this risk, an objective approach must be moderate. A general part of criminal law for the EU needs to be positioned somewhere in between the extremes of objectivism and subjectivism. The character of criminal law brings about that one has to strike a satisfactory balance between the interests of society and those of the individual defendant.

\subsection{Moderate objectivism}

The approach to proving fault that is commonly applied in the three Member States and the EU can be called moderately objective. ${ }^{70}$ Subjective awareness is proven objectively, it is inferred from objective circumstances, conduct and general knowledge. At the same time, the risks inherent in this objective approach are minimized by keeping the approach within 'moderate', that is, acceptable and safe limits. An example can be found in art. 1 (5) of Directive 2005/60 on money laundering: "Knowledge, intent or purpose required as an element of the activities mentioned in paragraphs 2 and 4 may be inferred from objective factual circumstances." 71 Another example is art. 1 (4) of the 1995 Convention on the protection of the European Communities' financial interests: "The intentional nature of an act or omission as referred to in paragraphs 1 and 3 may be inferred from objective, factual circumstances."

Shooting at close range at someone is deemed to express the intention to kill. This is uncontroversial. When a risk is obvious, a jury or court will also easily infer awareness even if the accused denies this. ${ }^{72}$ For example, the risk is obvious that someone dies when a house is set on fire with someone sleeping in it. Thus, the defendant is assumed to have known this too. So is the fact that an item is stolen when the person giving it to the defendant refers to it as 'hot', because this is commonly understood as meaning that it is stolen. ${ }^{73}$ In practice, this inference of fault reverses the burden of proof to the defendant, as in these cases, it is up to the defendant to argue that he did not intend or foresee the obvious.

The moderate approach is not only accepted in practice, it is also a reliable manner of finding fault. First of all, the aspects of wanting and knowing that make up fault elements are not profoundly psychological. This means that they are basic and therefore easily established. Justice Oliver Wendell Holmes jr. said that even a

See de Hullu in Borgers, Koopmans \& Kristen 1998, pp. 181-187.

See Fokkens \& Machielse, note 9 on Culpa, referring to a similar trend (as to negligence) in Germany and Section 8 of the English Criminal Justice Act 1967. See also Stuckenberg 2007, pp. 504, 511 and 515 and Vrolijk 2004, p. 170.

See also article 1 of Directive 91/308 of 10 June 1991 on prevention of the use of financial system

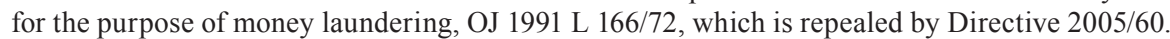
R. v. Stephenson [1979] EWCA Crim 1.

Law Commission 1989, p. 156 and van Bemmelen 1959, p. 41. 
dog knows the difference between being stumbled over and being kicked. ${ }^{74}$ Intention is a basic concept because it is neutral and general: it does not relate to the illegality of the conduct and is more basic than a motive or end-goal. Offence definitions usually mention merely the immediate purpose of the pertinent conduct, such as killing. It does not require that the motive of killing, like being left an inheritance, is proved..$^{75}$

Secondly, this basic character of fault makes it possible to pronounce upon the psyche of another. The knowledge on the state of mind of the other is based on the analogy between others and ourselves. We understand what knowledge and will means and we can recognize it in behaviour of others. By experience, human beings can interpret feelings and intentions of others; man is homo psychologicus. ${ }^{76}$ The judge or jury is perfectly able to interpret fault elements; there is no need to involve psychologists in the criminal trial. In many cases there is a relation between the psychological and the external manifestation, like the aimed shooting at somebody. In these cases it is possible - save exceptional circumstances - to judge with sufficient certainty on the intention of the perpetrator. ${ }^{77}$ The external manifestation of certain acts can be so much directed at a certain consequence that the only conclusion can be that the defendant accepted the consequences, barring contraindication. ${ }^{78}$

Clearly, there is a limit in allowing proof of fault elements to follow from facts and circumstances. Research has shown that intention seems to be established sooner when either very serious consequences have occurred or when the actor was very blameworthy. This can be explained by a number of psychological biases, such as hindsight bias. If a serious harm occurred, people - including judges - tend to estimate the chance that this harm occurred higher in retrospect, because of the fact that the risk materialized. This objective awareness on the risk is then attributed to the defendant. ${ }^{79}$ From a subjectivist point of view, this is problematic because it significantly deviates from the actual state of mind of the defendant. It risks equating actual awareness that is required for intention or recklessness with the lack of awareness of the risk where he should have been aware, that suffices for negligence. ${ }^{80}$ Such a normative approach to proving intent must be rejected. In proving awareness, a judge may therefore hold that given the objective circumstances and the experience and knowledge of the defendant, he must have known,

\footnotetext{
$74 \quad$ Stuckenberg 2007, p. 408.

75 Van Dijk, A.A. 2008, pp. 285-303 and 375. See IV.2.2.2.

76 Van Dijk, A.A. 2008, pp. 280-284. The psyche of the other is private to a certain extent, but not fundamentally unknowable as Peters, A.A.G. argued, according to van Dijk, A.A. 2008, p. 240. See also de Hullu 2006, p. 216, Siekmann 2005, p. 170 and Stuckenberg 2007, p. 408.

77 Van Dijk, A.A. 2008, pp. 272-288. See IV.3.6.2.-IV.3.6.3.

78 HR 24 February 2004, NJ 2004, 375; R. v. Stephenson [1979] EWCA Crim 1; 4 November 1988 BGHSt 36, 1 and IV.3.6.3.

79 Prittwitz 1993, pp. 360 and 381-382; van Dijk, A.A. 2008, pp. 291-295 and AG Jörg in HR 25 March 2003, NJ 2003, 556.

80 See IV.3.6.9.
} 
but he makes a major mistake if he proves this by holding that the defendant should have known.

There is a risk that objectivism, the application of general experience and objective logic to individuals might not lead to a correct result for every defendant. We need to take into account the serious possibility that the mind of the defendant differed from that of the average person. A balance is required between general experience and individual, concrete circumstances. ${ }^{81}$ An important limitation of the moderate objective approach should therefore be that we should be sure that something is in fact general experience. Examples will be provided where this assumption is questionable. ${ }^{82}$ Secondly, in an 'individualized objective standard', capacity-based exceptions are taken into account. The harshness of an objective standard is thus mitigated by taking into account some characteristics of the person involved. The reasonableness is transferred to a person in the circumstances of the defendant, that is, a defendant of the same profession, experience, age and so on. ${ }^{83}$ Be that as it may, it is important to realize that the risk inherent in objectifying proof of fault can be minimized, but never excluded. It remains possible that fault is assumed, where it was lacking.

I will now focus more in detail on fault elements. Chapter IV will present what these elements should look like in the criminal legal system of the EU. In chapter V, the principles that set out additional rules for these elements and their relationship to actus reus are discussed. Strict liability and presumptions of fault will be discussed in more detail too.

81 De Hullu 2006, p. 262 and de Hullu in Borgers, Koopmans \& Kristen 1998, pp. 181-182 and 186-187.

82 See IV.3.4.3.

83 See IV.6.4.3.; Robinson in Shute \& Simester 2002, pp. 85-91; Ashworth 2006, p. 195; de Jong, D.H. \& Knigge 2003, pp. 133-134 and van Dijk, A.A. 2008, p. 45. 


\section{Chapter IV \\ FAult ELEMENTS}

\section{INTRODUCTION}

\subsection{Kinds of fault, reflecting degrees of culpability}

There are kinds of fault, reflecting degrees of culpability. The distinction of fault elements enables a differentiation of culpability, reflecting a difference in the reproach directed against the actor. The intentional actor is considered most reprehensible because he wants to cause harm or is aware that he causes harm. All other circumstances being equal, he can therefore be punished more severely than a negligent actor.

By distinguishing fault in kinds, strict differences are created between the elements of intention and negligence. This is to be applauded from the point of view of legal certainty and fair labelling, which requires that fault elements should be mutually exclusive and not leave open any grey area. ${ }^{1}$ However, the degree of culpability that this difference is supposed to reflect is not so strict. It will become clear that in some cases, the negligent actor may almost be as culpable as the intentional actor. Moreover, the intentional actor who aimed to kill is more culpable than the intentional actor who merely accepted the risk of death. In other words, whereas fault comes in kinds, culpability comes in degrees. The transition may be fluent. $^{2}$

Homicide can be committed intentionally or by negligence. Such a difference in culpability is often expressed in the range of punishment that can be imposed. Intentional homicide usually enables the judge to impose the most severe punishment of a legal system. The fault element thus determines the range within which the judge has to determine which sentence is most appropriate. It is only in that stage of sentencing, that the degree of harm, motives, regrets and so on are taken into account.

Besides the aggravation of punishment in relation to the negligent or reckless offence, fault can also enable punishment. Some offences can only be committed intentionally. Intent thus limits liability. For example, transporting persons is a legitimate occupation. Only when the purpose of the transporter is to further exploitation of those persons, is he trafficking human beings. ${ }^{3}$ This intent is characteristic for the offence. It is essential because without it, there can be no

Weigend 1981 p. 693.

Compare Ormerod 2006, p. 116 and Fletcher 2007, p. 314-316.

See Article 2(1) of Directive 2011/36 of 5 April 2011 on preventing and combating trafficking in human beings and protecting its victims, and replacing Framework Decision 2002/629, OJ 2011 L 101/1. 
liability. Like the offence of theft, trafficking human beings cannot be committed negligently.

As noted, this function of intent to limit liability has been greatly reduced in comparison to earlier times, where intention was considered to be the paramount element of criminal liability, expressing criminal energy, deserving punishment and requiring preventive measures. Most or all offences had to be committed intentionally for criminal liability. In time however, this picture has changed radically. Mens rea can no longer be equated with intent. European society is a risk society, a society in which the risks have increased in seriousness and number due to technological development and globalization. Many persons can be severely harmed when risks are neglected and materialize. This warrants punishing those who fail to recognize danger where they should and those who fail to behave carefully, where appropriate. Therefore, more and more offences either require negligence or no proof of fault at all.

\subsection{Three kinds of fault}

An important conclusion of this comparative research on fault elements is that the most serious and the least serious fault elements are very similar in all three Member States under investigation. This makes a synthesis based on the traditions of the Member States under investigation straightforward, the common ground being the starting point. These similarities also facilitate an integrated discourse of fault elements. National differences and peculiarities will either be put into perspective or they will be highlighted as the exception. The order of discourse will follow culpability in descending order. In other words, I will start by discussing the most serious fault element that entails the highest reproach and punishment, and end with the lower limit of fault.

I refer to the most serious fault element as dolus directus. It consists of a form of intention that concentrates on the will of the actor to bring about a certain result. It is about acting because the actor wants to bring about a result. A slightly less serious form of intent is dolus indirectus. Conduct is also deemed intentional if the actor knows it will almost certainly bring about consequences that he does not desire or primarily aim at. The result is not directly aimed at, but is equated as intended because the actor knows it will certainly occur as a side-effect. The two fault elements are both forms of the fault element dolus, sufficing for any offence definition that requires intention as an offence element. Dolus usually relates to consequences and will therefore be discussed mainly in that context. It can however also relate to conduct or circumstances, in which case it is common to refer to knowledge.

The lowest standard of fault, called negligence or culpa, is about a normative failure to advert to and avoid a certain risk, which in fact materialised. It communicates the reproach that the actor has violated a duty of care that caused harm, whereas he should and could have foreseen and avoided this. A lesser kind of 
fault does not exist, but offences can also be strict. In strict liability, no fault is required in respect to one, more or all offence elements. Fault thus also limits liability in comparison to strict liability. This exception to the fault requirement, the principle that criminal liability should be based on a fault element, is discussed in the next chapter.

This short overview raises some questions. What should we do with those actors who did not want to further the exploitation of the people they transported, but knew there was such a risk? What should we do with the accused of murder who argues he did not want to kill, but merely injure? If it cannot be proven that the actor either wanted to fulfil an offence element or knew this was almost certain to happen, there can be no liability for dolus directus or indirectus. If intention would be negated, the actor may be punished and stigmatized less severely than he deserves. If negligence liability does not exist, this would even mean there can be no liability at all.

An adequate legal protection of interests therefore demands an additional fault element. All Member States under investigation have adopted such an element, albeit in different forms. In the English legal system, recklessness is a tertium quid that encompasses less culpability than intention but more than negligence. Its functional equivalent in Germany and the Netherlands is not a separate kind of fault. In contrast, intent has been extended to include the conscious acceptance of side-effects. This lowest form of intent is quite similar in both Member States and will be referred to as dolus eventualis. In other words, on the continent there are two major categories of fault, intention and negligence, whereas in England, recklessness is the third kind of fault in between intention and negligence. ${ }^{4}$

In merging the different fault elements into a general part of criminal law for the $\mathrm{EU}$, an obvious choice has to be made between recklessness and dolus eventualis. This choice is the most fundamental choice to be made in the context of mens rea, reflecting the greatest differences between the Member States. As usual in comparative legal research, the common and civil law are juxtaposed. I will first discuss dolus eventualis in an integrated manner, dwelling on some differences in the Dutch and German concept, after recklessness will be presented.

In a subsequent section, the two fault elements are juxtaposed and discussed as possible concepts in a general part of criminal law by testing them to the aforementioned criteria of synthesis. I will conclude that recklessness is favoured over dolus eventualis. In short, the use of recklessness keeps dolus within proper limits. Eventualis is rejected because it distorts the meaning of intent, it is very different from dolus directus and indirectus and it leads to inconsistent outcomes. Fault should not be distinguished based on attitude, but based on awareness. This reflects the difference in culpability better and is easier to prove in practice. Together with its explicit normative elements, recklessness is best equipped to deal with foreseen side-effects in this day and age.

4 Taylor, G. 2004A, p. 117 and Weigend 1981, p. 692. 


\subsection{Principles of fault}

Fault elements are recognized as general principles of criminal law in all Member States under investigation. The offence definition can refer to a requirement of intention by using many different terms. For example, in England, words like 'will', 'wantonness', 'volition', 'purpose', 'aim', 'design', 'deliberation', 'means to' and all conjugations of 'to intend' in criminal offences reflect intention. ${ }^{5}$ This implies that in principle, all manifestations of fault are supposed to be covered by a kind of fault. The system of fault is supposed to be closed. No other fault elements exist, apart from subjective elements like premeditation. Whereas recognized in English legal system too, it is not as self-evident as on the continent. This is due to the aforementioned difference in legal culture that focuses more on the specific than the general.

The English legislator does not deem itself restricted to the basic range of fault elements. It is therefore not reluctant in creating 'new' fault elements in offence definitions like 'reasonable belief', 6 or 'awareness of a risk' ${ }^{7}$ to create a tailored offence definition. This marks an important difference with German and Dutch law, which as a rule selects only from the few fault elements that have been recognized as general principles of criminal law, like intention, awareness and negligence. In principle, similar elements can also have a different meaning, depending on the offence definition.

Another difference is that fault is often made objective in England by creating specific offences that criminalize a particular manifestation of intent or negligence. Rather than criminalizing the intentional or negligent causing of a result, the result is criminalized when, for example, death in traffic is caused whilst driving unlicensed. Furthermore, the legislator created different modes of driving, such as dangerous driving, careless driving or furious driving. Mens rea and actus reus are intertwined and general principles therefore hard to deduce. ${ }^{8}$

Because this synthesis must be consistent, I will identify the general principles of mens rea, focusing on those fault elements that apply to a wide range of offences. The great number of fault elements in English law may be viewed as an obstacle to this task. Nonetheless, comparative legal research is possible, since intention, recklessness and negligence are also the most common fault elements in English offence definitions. At the same time, intention and negligence are not so uniform as one would expect in the Netherlands and Germany either. It will become clear that in some contexts, these fault elements are interpreted differently. ${ }^{9}$

These fault elements have in common that they lack a legal definition in national criminal codes. As general principles of criminal law, they do not lend themselves

Williams 1953, p. 31-32.

Section 1 of the Sexual Offences Act 2003.

Section 6(1) of the Public Order Act 1986: “(...)or is aware that his conduct may be violent."

Sections 2-2B and 3ZB of the English Road Traffic Act 1988.

Examples are intention in the context of HIV-infection, see IV.3.4.2. and in the context of lethal offences, see IV.3.6.4. 
to straightforward definitions. ${ }^{10}$ In Germany, drafts of intention and negligence were struck before the criminal code was enacted. ${ }^{11}$ The Dutch legislator also thought it best to leave the development of its contents to the judiciary and scholars. ${ }^{12}$ As a result, dolus eventualis could be developed as the lower limit of fault in intentional crimes. In England, the general fault elements are a product of judicial creation.

\section{DoLUS (IN)DIRECTUS}

There should be two forms of intention in EU criminal law. We can distinguish intention stricto sensu from its extended alternative, the foresight of certainty. Dolus directus concentrates on the will of the actor to bring about a certain result. Dolus indirectus focuses on the fact that the actor knows with almost complete certainty that he will bring about a consequence. ${ }^{13}$ In a next section, the lesser standard of dolus eventualis will be rejected as a third alternative. Dolus, or intention, the most serious kind of fault therefore comes in but two forms. ${ }^{14}$

Dolus consists of knowing and wanting. ${ }^{15}$ Accordingly, the elements of dolus can be distinguished in a cognitive part on the one hand and a volitional part on the other. ${ }^{16}$ Whereas it is true that both elements are required, dolus directus and indirectus are characterized by the fact that one of those aspects dominates. Dolus either has a strong cognitive or a strong volitional aspect. Dolus directus is characterized by a very strong volitional element. The actor shoots at the victim with a firearm because he intends to, he wants to kill him. By contrast, dolus indirectus is characterized by a very strong cognitive aspect. A textbook example is the person who blows up passenger jet in order to collect the insurance money. ${ }^{17}$ The actor does not want the passengers and crew to die, but knows this is a certain consequence of blowing up the jet. The person acting with dolus indirectus does not aim at these deaths but knows they are almost certain to occur. The volitional aspect of wanting is indirect, weak and balanced by the high degree of knowledge.

See Halpin 2004, p. 148.

Roxin 2006, p. 449.

Smidt 1881 I, p. 76 and Schönke \& Schröder, H. 2006, p. 261.

See also van Dijk, A.A. 2008, pp. 347-349.

14 Notwithstanding the fact that this second form of indirect intention is not considered a second 'form' or type of intention in England, but merely evidence from which intention may be inferred, see IV.2.4.1.

15 Van Dijk, A.A. 2008, p. 212; Smidt 1881 I, p. 74, de Jong, D.H. \& Knigge 2003, p. 97; de Hullu 2006, p. 207; Schönke \& Schröder, H. 2006, p. 261; Beulke 2008, p. 75; Bohlander 2009, pp. 60-61; Fischer, T. 2009, p. 105 and Fahl \& Winkler 2007, p. 9.

16 See Schönke \& Schröder, H. 2006, p. 276; Krey 2003, pp. 110-111; Badar 2005, pp. 222-223 and Roxin 2006, pp. 437 and 439.

17 Law Commission 1989, p. 157 and Krey 2003, pp. 108-109. 


\subsection{Terminology}

The most serious form of intention is called 'purpose' or 'direct intent', 'Absicht' or 'dolus directus ersten Grades' and 'doelopzet'. The second form of dolus is called 'indirect' or 'oblique intent', 'direkter Vorsatz' or 'dolus directus zweiten Grades' and 'zekerheidsopzet'. ${ }^{18}$ It appears evident to label these forms as direct and indirect intention respectively. However, it is necessary to distinguish fault elements in a general part of criminal law for the EU from those in England. An equation of both concepts should be avoided. Indirect intention differs from its counterpart in a general part of criminal law for the EU, most importantly because there is an albeit decreasing - tendency in England to add moral connotations to intent. I will reject this in favour of a neutral concept of dolus, after I have established what its two forms should look like in EU criminal law.

The terms used for the two forms of intention are therefore dolus directus and dolus indirectus. Dolus is indirectus because the state of mind of the actor is not aimed directly at the result of the offence definition - the killing of the passengers and crew - but at another, further, goal that does not form part of the offence definition, such as the payment of insurance. This implies that death is an indirect goal of the actual purpose of payment. In comparison with this indirect form of intention, dolus directus is aimed directly at the result expressed in the offence definition. ${ }^{19}$

In German and international criminal law, the dichotomy is usually expressed as 'first' and 'second degree direct intention', or dolus directus in a first and second degree. ${ }^{20}$ Dolus indirectus is not used. This can be explained because in German law, dolus indirectus has other connotations as well. The term dolus indirectus was coined in the Middle Ages for attribution of those consequences that usually follow from a willed act as indirectly willed, but were not foreseen. ${ }^{21}$ Secondly, it could be argued that in dolus indirectus, the result is also directly connected to the purpose of the actor, albeit to a lesser extent, because the result certainly occurs when the bomb explodes. Why would we label a result as indirect or as side-effects when they are outcomes which are so immediately and invariably connected to normally intended outcomes? ${ }^{22}$ Every terminology has its shortcomings, ${ }^{23}$ but the terminology used here has the benefit that it avoids confusion with counterparts in other legal systems.

18 Krey 2003, pp. 110-111; Bohlander 2009, p. 63; Beulke 2008, p. 77; Roxin 2006, p. 436; Fischer, T. 2009, pp. 105-106 and van Dijk, A.A. 2008, pp. 347-349, 355-356 and 360-362.

19 Kelk 2005, p. 182 and Stolwijk 2009, p. 110.

20 Badar 2007, pp. 368-372 and Politoff \& Koopmans 1991, pp. 133-134.

21 Stuckenberg 2007, pp. 539-542 and 556-569; Jakobs 2002, p. 589; Kindhäuser in Arnold a.o. 2005, pp. 345-346; Hsu 2007, pp. 196-197; Kelk 2005, p. 182 and Politoff \& Koopmans 1991, pp. 73-74.

22 Simester \& Sullivan 2007, pp. 127-129.

23 See IV.2.3.4 


\subsection{Dolus directus}

\subsubsection{Rationale}

Intention stricto sensu is considered the most serious fault element in all three legal systems. Dolus directus reflects the highest degree of reproach of the fault elements, because behaviour carried out willingly is considered to reflect the highest possible degree of control and choice. The conviction that intentional acts are necessary to ground a reproach is a strongly rooted principle of attributing responsibility in both criminal law and everyday life. Consider a child who breaks something and replies 'I did not do it on purpose'.

Dolus directus as the highest degree of culpability is therefore in the first place a prerequisite for liability. Traditionally, criminal offences needed to be committed with dolus. The intentional actor embodies the actor who typically needs to be punished ${ }^{24}$ making dolus directus the paramount form of intent. In Roman law, dolus consisted of only this element and was limited to dolus directus. ${ }^{25}$ Currently, a limited number of offences can still only be committed with dolus directus. More often than being a prerequisite for liability, the more severe reproach warrants the aggravation of liability in comparison to the offence committed with a lesser fault element like negligence. For example, killing someone negligently can not be punished as severe as intentional killing. When the offence definition requires a form of dolus, it is argued that dolus directus in comparison to dolus indirectus and eventualis functions as an aggravating factor in sentencing. The assassin who wanted to kill is punished more severely than the person who took the possibility of death for granted. ${ }^{26}$

The highest degree of culpability is grounded in reasons of control and choice. The person who shoots another with a firearm in order to kill, has great control over the events and the outcome. Clearly, the shot might not be lethal or the firearm might be jammed, but it is the actor who has most influence on the conduct and outcome, which warrants the highest reproach. Even if the goal of the actor is not fulfilled, this dolus directus warrants liability for either attempt or preparation. In other words, intentional acts are avoidable to a larger extent. ${ }^{27}$

Secondly, by being aware of what he is doing and the consequences it may have, an actor can fairly be said to have chosen the behaviour and its consequences. In a retributive perspective, the moral culpability of intent hinges on the choice for doing evil. ${ }^{28}$ The intentional fulfilment of the offence definition provides a warning to the actor that he is violating a legal interest. ${ }^{29}$ By his own choice the actor can

Frisch 1983, pp. 49-50.

Vrijheid 1918, pp. 61 and $78-81$.

See Stuckenberg 2007, p. 279.

R. v. Mohan [1976] QB 1. See also Ashworth 2006, p. 175.

Van Dijk, A.A. 2008, pp. 306-309 and Kugler 2002, pp. 83-85.

A legal interest is an interest, value or good recognized and protected by law. 
stay out the realms of criminal law. In deciding to direct his conduct to bring about a result, the actor should be reproached for his choice. ${ }^{30}$ According to mainly German scholars, this choice to fulfil the offence elements reflects hostility or indifference towards the pertinent legal interest and the legal order as such. Intention means that the norm was not relevant for the decision of the actor to act and therefore it expresses a greater lack of motivation to obey the norms. ${ }^{31}$

Against this, it can be argued that the defendant need not demonstrate a hostile disposition towards the law. By intentionally killing a man, the actor appears to be hostile towards the norms that are protected by the legal order, but this assumption can be rebutted if the victim was for example a terrorist holding a child under gunpoint. By applying self-defence, there are justified reasons for killing, which imply that the actor served rather than violated the legal order. However, the lack of a hostile disposition does not affect intention. The police man who shot the terrorist is justified, but he acted intentional. Therefore, in principle, dolus does not encompass this hostility: it is neutral. At most, it reflects that the actor chose to violate the legal interest of the victim, that he was hostile to his specific interests. ${ }^{32}$ Others argue that intentional conduct indicates the hostile disposition towards the legal order which can be rebutted, just as the fulfilment of the offence definition merely indicates wrongfulness, which can be rebutted by a justification. ${ }^{33}$

\subsubsection{Criteria}

Dolus directus is intention in its purest legal and linguistic meaning. It is 'acting in order' or 'deciding or seeking' 'to bring about'. ${ }^{34}$ The defendant has the completion of the offence (element) as his purpose. ${ }^{35}$ It is 'the will to realize'. ${ }^{36}$ The result is the reason for his conduct; it is what matters to the actor. As a consequence, it is characterized by the sense of having failed when the result is not achieved. ${ }^{37}$

\footnotetext{
30 Ashworth 2006, pp. 158-159; Schönke \& Schröder, H. 2006, pp. 269 and 351 and Arzt 1976, p. 657.

31 Schünemann 1985, p. 364; Kindhäuser in Arnold a.o. 2005; Roxin 2006, pp. 451-452 and Frisch 1983, p. 301. The view is however not uncommon in other countries, see Halpin 2004, p. 146; Tadros in Shute \& Simester 2002, p. 229 and van Dijk, A.A. 2008, p. 250. Stuckenberg 2007, pp. 418-421 and 429-430 and Greco 2009, pp. 813-816. Beulke 2008, pp. 48-49, 149 and 356. Simester \& Sullivan 2007, p. 121-123. Bohlander 2009, p. 63; Fischer, T. 2009, p. 105 and Beulke 2008, p. 77. Schultz in Seebode 1992; Stuckenberg 2007, p. 242 and Roxin 2006, p. 447.

Simester \& Sullivan 2007, p. 122; Duff 1990, pp. 61-62; van Dijk, A.A. 2008, p. 347; Stuckenberg 2007, p. 218; Krey 2003, pp. 108-109 and Roxin 2006, pp. 438-439.
} 


\subsubsection{Goal and necessary means}

A defendant "intends to cause a result if he acts with the purpose of doing so."38 The basic definition is thus 'purpose' or any other synonym like 'desire'. ${ }^{39}$ It is important to note however that dolus directus "does not refer to the ultimate objective of the conduct: it refers to whether one has chosen to produce the prohibited consequence." 40 The use of words like purpose and desire has been criticised, because they could be misunderstood as to include the motive or ultimate reason for acting. To the contrary, intention is only required as to an immediate aim, like killing, and not the end-goal, like receiving an inheritance. ${ }^{41}$

Confusion can be avoided by defining dolus directus not as purpose, but more neutral as deciding or acting in order to bring about, as: "a decision to bring about (...), no matter whether the accused desired that consequence of his act or not." 42 It is irrelevant whether the actor wished for or in fact mourns the consequence. For example, he might mourn the consequence of death because he killed an innocent person, but want it anyway to cover up his crime. The death is the means to further the end of covering up the crime. Not primarily desired goals that are understood as necessary means for the end-goal qualify as dolus directus as well. ${ }^{43}$

\subsubsection{Chance of result occurring}

Dolus is about knowing and wanting. Its cognitive and volitional components operate as communicating vessels. The volitional component is dominant in dolus directus, which explains why the cognitive component may be very weak. ${ }^{44} \mathrm{~A}$ weak cognitive aspect of foreseeing only a small chance of establishing the result is compensated by a strong volitional aspect of wanting the result.

It is about the actor's subjective assessment on his chances of causing the intended consequence. It is not required that the actor was aware of the certainty or highly likelihood of occurrence of a consequence. The actor also acts with intention if he only perceives the desired consequence as possible. ${ }^{45}$ In fact, by focusing on the purpose of bringing about a consequence, it is not even a problem that the

\footnotetext{
38 Ormerod 2005, pp. 93-94.

39 Law Commission 1993, p. 9; Williams 1953, p. 31; van Dijk, A.A. 2008, p. 346 and Krey 2003, pp. 108-109.

$40 \quad$ Ashworth in Simester \& Smith, A.T.H. 1996, p. 179.

41 Khan 2002, p. 237; Kadish 1989A, p. 74; Norrie 2006A; Stuckenberg 2007, p. 219; Krey 2003, pp. 108-109; Fischer, T. 2009, p. 105; Beulke 2008, p. 77; Roxin 2006, pp. 439-440; HR 18 November 1975, NJ 1976, 164 and de Hullu 2006, p. 196.

42 R. v. Mohan [1976] QB 1.

43 Ormerod 2008, pp. 101-103; van Dijk, A.A. 2008, p. 350; 23 February 1961 BGH NJW 1961, 1172; 6 February 1963 BGHSt 18, 246; 26 July 1967 BGH NJW 1967, 2319; Schönke \& Schröder, H. 2006, p. 277 and Beulke 2008, p. 78. See IV.2.3.4.

44 Krey 2003, pp. 110-111; Badar 2005, pp. 222-223 and Roxin 2006, pp. 437 and 439.

45 Fischer, T. 2009, p. 105 and Beulke 2008, p. 77.
} 
defendant knows there is a very small chance of a consequence occurring. For example, dolus directus is not absent, if the defendant wants to kill the victim, but shoots at him from a great distance, while he also knows he is a poor shot. ${ }^{46}$ This demonstrates that a weak cognitive aspect, foreseeing only a small chance of establishing the result, is compensated by a strong volitional aspect of wanting the result.

It has been established that any possibility of bringing about the wanted result suffices. However, a mere coincidence that is wanted is insufficient for liability. Consider the nephew who sends his uncle to go on a cruise, hoping the boat will sink and kill him, so he is left an inheritance. ${ }^{47}$ When the ship sinks due to a misfortune, the nephew cannot be held liable for the death of his uncle. There can also be no dolus directus if the defendant does not believe that he is capable of affecting the events to some extent. A result of which the actor thinks he had no control over or is impossible, can be desired and hoped, but not intended. Intention must be distinguished from hope. For a finding of dolus directus, the actor must believe there was a chance of fulfilling the offence element. If the actor knows the victim is definitely beyond range, he cannot intend to hit him. ${ }^{48}$ Thus, there must at least be some foresight of being able to achieve what is wanted. Even dolus directus requires some cognitive element. Wanting, in law, presupposes knowing.

Another perspective is to exclude these cases from liability based on causation. The nephew cannot be said to be the cause of the result and can therefore not be held liable for his uncle's death. ${ }^{49}$ Under the doctrine of objective attribution, the lack of control over the causal chain of events is a reason to exclude causation. ${ }^{50}$ The perspective to exclude these cases under causation can be preferred because in cases such as these, it is the connection between conduct and result that is questionable. This negation of causation implies that the (subsequent) question of intention is not even raised. It would be irrelevant to assess whether the defendant intended a result that he did not cause.

Since the results are usually equal, there are no practical objections to treat the issue under either causation or dolus directus. A sharp distinction might not even be warranted. After all, the greater the chance of success, the easier it is to establish both causation and dolus directus. For example, when someone shoots a person dead at close range, causation as well as dolus directus are easily deduced from the external conduct. By contrast, there does seem to be only one correct perspective in

46 Fokkens \& Machielse, note 6 on Opzet; Politoff \& Koopmans 1991, p. 133; Simester 1997, pp. 706-708; Bohlander 2009, p. 64; Krey 2003, pp. 110-111; Roxin 2006, p. 439 and Schönke \& Schröder, H. 2006, p. 278. In contrast, van Dijk, A.A. 2008, p. 368 submits that the chance must be substantial and Ross 1979 , p. 112, submits that this is merely theory and that he knows of no such decision in practice.

$47 \quad$ Strijards 1983, p. 182.

486 February 1963 BGHSt 18, 246; Beulke 2008, p. 78; Fischer, T. 2009, p. 105; Stuckenberg 2007, pp. 242-243 and Duff 1990, pp. 55-58.

49 Strijards 1983, pp. 182 and 218 and Politoff \& Koopmans 1991, p. 133.

$50 \quad$ Krey 2003, pp. 64-67 and Schönke \& Schröder, H. 2006, p. 192. 
cases where the defendant was mistaken about his possibility to achieve the result. For dolus directus, the subjective perception of the actor is decisive, not whether a possibility to achieve the result objectively exists. ${ }^{51}$ This means that if the victim was hit but the actor thought he was out of range, there is causation, but no dolus directus. The objective possibility was not foreseen. This also implies that in the conversed case, where the actor mistakenly believes that the victim is within range, shoots and thus fails, amounts to dolus directus. The actor only thought there was a possibility of success. It is important to establish dolus in this case if we want to hold the actor liable for an attempt. ${ }^{52}$

\subsection{Dolus indirectus}

\subsubsection{Criteria}

A defendant acted with dolus indirectus with respect to a result when he is aware that it will occur in the ordinary course of events. Acting with foresight of certainty that an offence element will be fulfilled is a form of dolus too. In 1875, a man named Thomas had set explosions on his ship that left from the port of Bremen. His plan was that the freight would explode on high seas, so he could collect the insurance money. Clearly, Thomas must have foreseen that due to the explosion on high seas, at least some of the crew would almost certainly die. The explosion occurred in the port of Bremen however. Moreover, Thomas was killed, so a trial never followed. A modern textbook example is the person who plants a bomb on a plane in order to blow it up, after which he can collect the insurance money. ${ }^{53}$ In EU law, it has been held that the aim to restrict competition is also intended if it was foreseen as the necessary consequence of an agreement. ${ }^{54}$

The high degree of the cognitive element, knowledge of certainty, eclipses any volitional requirement. Thus, the result known or believed to be a condition of the achievement of the purpose is considered to be intended, even if it is not wanted. In dolus indirectus, the consequence can be wished for by the actor, but it does not form the (main) reason for acting. Dolus directus is about acting because of a consequence, not acting despite a consequence. ${ }^{55}$ This also means that by adopting

51 Duff 1990, pp. 55-58.

52 The subjective yardstick for attempt could be limited to those beliefs that are rational, so as to exclude from purpose beliefs that are based on irrational grounds like superstition, see Stuckenberg 2007, pp. 242-243. If the nephew therefore thought the ship would sink because he put a curse on it, there can be no dolus directus and no attempt.

53 Law Commission 1989, pp. 51 and 157; Ashworth 2006, p. 176; Stolwijk 2009, p. 110; van Dijk, A.A. 2008, p. 216 and Kelk 2005, p. 182.

54 Opinon of AG Trstenjak of 4 September 2008, Case C-209/07, Competition Authority v. Beef Industry Development Society Ltd and Barry Brothers (Carrigmore) Meats Ltd [2008] ECR I-8637.

55 Ormerod 2005, pp. 97-98; Williams 1953, p. 35; Krey 2003, pp. 112-115, Fischer, T. 2009, p. 106; Beulke 2008, p. 78 and van Dijk, A.A. 2008, pp. 217-218 and 350-351. 
a test of failure, dolus directus and indirectus are distinguished. Thomas had dolus directus as to the explosion and indirectus as to the death of the crew. He would not have seen his plan as failed when none of the shipping crew would have died. ${ }^{56}$

\subsubsection{Rationale}

The indirect form of dolus was created as an extension of liability based on dolus directus. It should be attributed to actors when "justice may not be done unless an expanded understanding of intention is given." 57 Intention need not only be grounded in a 'will', but it can also be based on a high degree of knowing. This extension beyond the traditional will has been perceived as problematic in the past. For example, at the end of the $19^{\text {th }}$ century, some Members of Dutch Parliament argued that when a purpose, specific intent or wish was missing, there could be no intention. ${ }^{58}$ Nonetheless, dolus indirectus was accepted in the Dutch and German criminal legal system as an alternative form of dolus. In England, indirect intent was not only considered, but also shaped as a public policy extension, for which reason it is not considered a second form of intent, but merely evidence from which intention may be inferred. ${ }^{59}$

Already in Roman law, consequences that were likely to occur in the ordinary course of events were presumed to be intended. ${ }^{60}$ In English law, it also used to be common to hold that a man is presumed to intend the natural consequences of his acts. ${ }^{61}$ In medieval times, the 'doctrina Bartoli' grounded liability for the results that went beyond the purpose of the actor but which are very likely or common to follow from the defendant's actions. As noted, the term dolus indirectus was also coined in those days. Thomas Aquinas departed from the classic view that the will is decisive for an ethical valuation of the act and its intention, and came to the conclusion that necessary or typical consequences of an act are very relevant too. Hence, he distinguished consequences that were directly wanted from those that were indirectly wanted. ${ }^{62}$ It can be said that the result is indirectly willed because it is inextricably connected to the defendant's purpose. If the ship detonates as wanted, the deaths are certain to follow and therefore indirectly wanted.

As a rule, criminal liability can be established or aggravated by either of the two forms of dolus. There exists no legal difference. The equation in law is based on the

\footnotetext{
56 Van Dijk, A.A. 2008, p. 349 and Taylor, G. 2004A, p. 106. See Duff 1990, pp. 61-62.

57 Law Commission 2006, pp. 58-59 and Bohlander 2009, p. 62.

58 Van Dijk, A.A. 2008, p. 216. See also Smidt 1881 I, pp. 80-82 and Fokkens \& Machielse, note 3.1 on Opzet.

59 R. v. Woollin [1998] UKHL 28; R. v. Hancock and Shankland [1986] AC 455; section 18(b) draft Criminal Code, Law Commission 1989, p. 51 and 193; Ormerod 2005, pp. 95-96 and 100 and Ashworth 2006, pp. 176-178.

60 Stuckenberg 2007, pp. 536-537.

61 See for example DPP v. Smith [1961] AC 290. What a reasonable person could foresee, the defendant is presumed to have foreseen.

62 Stuckenberg 2007, pp. 538-541.
} 
assumption that there is little if any moral difference between the two forms of intent. ${ }^{63}$ Both types manifest that the defendant accepted the outcome, reflecting his bad character, showing that he was insufficiently motivated by the interests of his fellow citizens, and therefore deserves and needs to be punished. ${ }^{64}$ The great degree of knowledge, the awareness of the certainty that the result will follow, also makes the rationale of control and that of choice apply to dolus indirectus. Because the actor is aware of the certain consequences of his actions, he controls the events and he could choose not to violate the law. ${ }^{65}$ It is this similarity that enables dolus indirectus to be put on the same footing as dolus directus. ${ }^{66}$ Experience has taught us that unwanted side-effects can be even more harmful than intended goals. ${ }^{67} \mathrm{In}$ some cases, the "(...) advertent taking of an obvious and overwhelming risk of a certain result" can be "considered to be just as deplorable as if it had been his or her primary purpose to bring about the result (...)."68

On the other hand, there may be good reason to distinguish when the harm is relatively trivial, because only in his direct intentions the agent shows some commitment to bring about a certain state of affairs. ${ }^{69}$ In dolus indirectus, the actor acts despite a consequence, rather than because of that consequence. This is recognized in offences that can only be committed with direct intent. As discussed later, offences of ulterior intent, like theft, often require nothing less than a direct intent as to the element of appropriation. Moreover, the difference between the two forms of dolus is usually reflected in sentencing. A homicide that was wanted is generally punished more severe than one that was merely taken for granted as a certain side-effect. It is therefore also argued that there is in fact a moral difference between the two forms of dolus.

All other circumstances being equal, it is assumed that the actor who acts with dolus directus can be reproached more than the actor who acted with dolus indirectus (or eventualis). Generally, this is explained by the 'doctrine of double effect'. The doctrine permits actions with a double (bad and good) effect under certain conditions. Most importantly, the actor must have wanted the good consequence and not the bad one. To illustrate this relative increase in culpability of dolus directus, consider 'strategic' and 'terror bomber'. Terror bomber wants to bomb a school for terrorist purposes, whereas strategic bomber wants to bomb a munitions factory merely to shorten the war. However, strategic bomber knows that by doing so, he will also kill the children inside the school. In the perspective of the

\footnotetext{
63 Taylor, G. 2004A, p. 107 and Kessler Ferzan 2007, p. 2537.

64 Tadros 2005, pp. 88, 90, 100 and 314; Taylor, G. 2004B, p. 350 and Kugler 2002, pp. 77-80.

65 See Fletcher 2007, p. 315.

66 Schönke \& Schröder, H. 2006, pp. 277-278.

67 Prittwitz 1993, p. 369.

68 Bohlander 2009, p. 62.

69 Tadros 2005, pp. 229-236.
} 
double effect doctrine, the intuitively more culpable terror bomber acts with dolus directus, whereas strategic bomber acts with dolus indirectus. ${ }^{70}$

It is assumed that usually the person who acts with dolus directus will be more culpable, because his motive was worse or because the chance that the consequence would occur is greater. However, the ultimate reproach depends on many factors such as harm, modus operandi, motive and fault. Yet the harm, modus operandi and 'laudable' motive of strategic bomber do not form part of fault, of dolus, just as the laudable motive in the earlier mentioned example of the police man who shot the terrorist to save the hostage did not negate dolus directus. Shooting in self-defence is dolus directus. The fallacy in many examples used to demonstrate a moral difference is that they are not ceteris paribus. For example, the case that is supposed to be less culpable is modified by applying a defence or by decreasing the number of victims. Moreover, direct intent not necessarily brings about a greater chance that the result will occur. As noted, terror bomber might only have a chance of fifty percent in blowing up the school, whereas strategic bomber knows this is almost a hundred percent certain to follow. There is thus no intrinsic difference. In all forms of dolus, the actor has the same amount of control to avoid the consequences. ${ }^{71}$

\subsubsection{Certainty}

In dolus directus, it is immaterial whether the result was believed to be certain or almost certain to occur, as long as the purpose is proven. We have seen that even a small chance of bringing about the result suffices. In dolus indirectus, the cognitive element dominates, requiring a high probability of the prohibited result occurring. "Lack of purpose can be compensated by an excess of knowledge."72 The actor must know with a high degree of certainty that his conduct will result in the prohibited consequences. ${ }^{73}$ Since no one can ever know that a result is certain to follow, certain means almost certain, virtually certain or certain, barring some unforeseen intervention. It requires "such a high degree of probability that common sense would pronounce it certain."74 Mere foresight is insufficient for dolus indirectus and brings us in the realm of dolus eventualis and recklessness. ${ }^{75}$

\footnotetext{
70 Van Dijk, A.A. 2008, pp. 350-362 and Fletcher 2007, p. 316. See also Cavanaugh 2006, pp. 114117 and Kugler 2002, pp. 37-38.

71 Van Dijk, A.A. 2008, pp. 359-363 and Simester in Simester \& Smith, A.T.H. 1996, pp. 75-77.

72 Bohlander 2009, p. 63.

73 Van Dijk, A.A. 2008, p. 347; Fokkens \& Machielse, note 2 on Opzet; Law Commission 1989, p. 193; Simester 1997, pp. 706-708; Bohlander 2009, p. 64 and Beulke 2008, p. 78.

74 Citation Williams 1953, p. 37. See also Ormerod 2005, p. 97 and Ashworth 2006, p. 177.

75 Simester \& Sullivan 2007, pp. 124-126; Law Commission 1989, pp. 192-193; Law Commission 1993, p. 10 and Williams 1953, p. 39.
} 
The outcome must not only be almost certain, the defendant must also believe it to be almost certain. ${ }^{76}$ The point of reference for assessing the certainty of the result occurring is subjective ex ante. It is about what the defendant thought at the time of acting. This might seem evident, but is important to emphasize in order to avoid hindsight bias. Dolus is a subjective concept, because it is says something about the state of mind of the specific actor. Even though the subjective belief is mostly inferred from the objective fact that the result was almost certain, the substantive criterion of dolus remains subjective. ${ }^{77}$ If there are good reasons to suspect the defendant did not foresee this, he cannot be deemed to have acted intentionally. There are good reasons to argue that only the subjective perspective is relevant. ${ }^{78}$ Consider that the airplane the defendant sabotaged contains enough parachutes for all the crew. Due to this circumstance that was unknown to the defendant, all people on board the airplane that crashed survive. This means that objectively, there was no certainty of death. If this would preclude dolus, there can be no liability for an attempt.

\subsubsection{Necessary means versus side-effects}

What must be almost certain to occur? It is not the explosion on the airplane that must be certain to occur. The actor can have doubts whether the bomb goes off at all, since he made it himself. Rather, it is required that the death of the crew and passengers is almost certain to occur if the airplane is blown up. The defendant must think it will go off in the ordinary course of events as planned. The fulfilment of the offence definition of intentional killing must be an almost certain side-effect of the actor's purpose, like the causing of an explosion. The uncertain side-effects are inextricably linked with the purpose, so when the bomb does go off, the sideeffects will also certainly occur. ${ }^{79}$

Distinguishing dolus directus from indirectus proves to be a difficult task. However, a useful criterion is to determine whether the results are known to be a necessary condition of or almost certain to accompany the achievement of the purpose. Dolus is directus when the actor shoots someone through a window. Not primarily desired goals that are understood as necessary condition for the end goal fall under dolus directus as well. Dolus directus thus also relates to the destruction of the window, as "any fact that is a necessary or indispensable interim or ulterior

76 R. v. Woollin [1998] UKHL 28; R. v. Nedrick [1986] EWCA Crim 2; Sullivan in Shute \& Simester 2002, p. 209 and Ormerod 2005, p. 94.

77 Ormerod 2008, p. 99. See also Reijntjes in Groenhuijsen \& Simmelink 2003, pp. 476-477.

78 Simester \& Sullivan 2007, p. 130; Law Commission 2006, pp. 57-59; Tadros 2005, p. 180; Krey 2003, pp. 112-115 and Fischer, T. 2009, p. 106.

79 Law Commission 2006, p. 56; Law Commission 1993, p. 10; Schönke \& Schröder, H. 2006, p. 278 and Taylor, G. 2004A, p. 107. It may be intuitively difficult to accept dolus indirectus when the change that the bomb goes off is for example only ten percent. However, to demarcate this fault element properly from dolus eventualis and recklessness, one needs to focus on the statistical relationship between the primary goal and its side-effect(s). 
consequence of his primary purpose (...)." ${ }^{\prime 80}$ In situations of dolus indirectus, the death of the crew is not necessary for the actor's purpose of collecting insurance to be achieved. It is possible that the ship, or its cargo, are destroyed and insurance thus collected without any fatalities. The actor knows however, that this is highly unlikely and fatalities almost certain. ${ }^{81}$

In other words, dolus indirectus is about almost certain side-effects and dolus directus deals with means or interim goals. Shooting grandmother to inherit is not a side-effect or incidental consequence but a means or interim goal. It is the actor's purpose to kill her, and even if this is mourned, it is a wanted result, necessary for receiving the inheritance. In contrast, burning down grandmothers building in order to collect insurance money for the building, whilst knowing she is in it, makes her almost certain death a side-effect. ${ }^{82}$ Grandma does not need to die in order to collect the insurance, but it is an almost certain side-effect. The setting of fire of the building is an act of dolus indirectus. This distinction corresponds with the aforementioned test of failure. Consider that grandma survives. If grandma should have died as a necessary means to inherit, the actor's plans have failed. If grandma was certain to die as a side-effect of burning the building to collect insurance, the actor does not consider this attempt failed.

Difficult situations and room for debate remain. ${ }^{83}$ Fortunately, the distinction of directus and indirectus is usually without legal consequences. I have tried to identify the difference as precisely as possible, not only because sometimes only directus suffices, but also in order to capture the essence of dolus as knowing and wanting. The two forms of dolus are founded on different pillars, yet are considered to be equal in ethics and therefore also equal in law. This similarity will be used to juxtapose these forms of dolus with the lowest form of intent in Dutch and German law. The different character of this dolus eventualis militates against including it as a form of dolus in a general part of criminal law for the EU. First, however, I will explain that, as a rule, dolus is neutral.

\subsection{A neutral concept}

The modern concept of dolus is value-neutral and does not deal with motives. ${ }^{84}$ Especially in England, mens rea used to encompass not only thoughts in the mind but also the dark motives and roiling emotions that lay beneath. In time, emotions and motive have been cut from the concept's core. ${ }^{85}$ For example, because the term 'malice aforethought' was held to have connotations to 'ill will' or 'wickedness', it

Citation Bohlander 2009, p. 64. See also the sources in IV.2.2.3.

Ormerod 2008, p. 103 and Schönke \& Schröder, H. 2006, pp. 277-278.

Krey 2003, pp. 108-115 and Fischer, T. 2009, p. 106. See also Kugler 2002, p. 6.

See 23 February 1961 BGH NJW 1961, 1172, discussed in IV.2.4.4-IV.2.4.5.

Weigend 1981, p. 662; Simester \& Sullivan 2007, p. 120, Stephen 1890, p. 88-89 and Ormerod 2005, p. 118.

Finkel \& Parrott 2006, p. 23. 
was judicially disapproved ${ }^{86}$ Nevertheless, intention is still sometimes interpreted as encompassing motives in English law. Be that as it may, dolus does not include evil motives. Intentionally killing a person refers to exactly that and not to killing because of an additional evil motive. Only in exceptional cases, the offence definition is drafted in a manner that intent must relate to motives or a point of law, but this confirms that dolus itself is neutral.

In this section, the exceptions to this rule will be revealed as confirmations of the rule. The EU concept of dolus should have no moral connotations. After discussing the abovementioned tendency in English law to include motive in intent, I will describe a class of offences that in fact seems to include the ultimate goal of the actor into its definition. Next, I will explain that dolus is also neutral from the perspective that it does not relate to the illegality of the conduct. The actor need not know he is committing a criminal offence. Sometimes, the offence definition is drafted in a manner that intent must relate to legal aspects, but this confirms that dolus as such is neutral.

\subsubsection{Moral enrichment of intent in England}

The neutrality of dolus is put under pressure by the English concept of intent, which is sometimes interpreted as encompassing bad motives or the lack of an excuse or justification. This brings about that when the defendant had good reasons to act, for example because he was acting under self-defence, the courts will acquit the defendant based on the negation of fault. This approach to 'morally enrich' intent will be explained and rejected. Intention is neutral and good motives should operate to either justify or excuse the intentional act or actor respectively. This is increasingly recognized in England too.

A first feature of English law that enables the negation of intent in case of laudable motives is the failure to clearly distinguish fault from the ultimate normative question on blameworthiness. This was mentioned already in the introduction of the framework of criminal liability. For example, the court held that Steane did not intend to assist the enemy in broadcasting, because he acted under duress. ${ }^{87}$ As widely accepted in Dutch and German law, excuses however negate the assumption that the actor is blameworthy, not his intention. Although this is now also commonly recognized in England, some still see mens rea as encompassing blameworthiness, which is thus negated when an excuse applies.

Confusion and disagreement on the scope of mens rea enable more judicial discretion to reject intent in cases where a conviction seems inappropriate. Such discretion is also enabled by the so-called 'golden rule' of English law to leave

\footnotetext{
86 R. v. Cunningham [1957] 2 All ER 412; Attorney-General's Reference no. 3 of 1994 [1998] AC 245; Finkel \& Parrott 2006, p. 23; Law Commission 2004, p. 18 and Law Commission 2006, p. 55.

87 R. v. Steane [1947] KB 997. See also III.5.
} 
intention undefined for the jury. ${ }^{88}$ "The courts have not kept to consistent and welldefined concepts of intention, recklessness, or causation, but have striven to adapt them in order to reflect the necessary moral distinctions." 89 This aspect is not foreign to Dutch and German law, where the legislator omitted to define intention, in order for it to be developed by scholars and practitioners. ${ }^{90}$ This brings about increased flexibility for judges to decide cases in all Member States, ${ }^{91}$ but apparently not as much as in England.

A third aspect that grants English courts the discretion to negate intent is to offer only guidelines on how to infer indirect intention. As noted, English law does not consider indirect intention as a second form of intent, but merely evidence from which intention may be inferred. The rule that a man is presumed to intend the natural consequences of his acts has been rejected in general today, but by requiring a court or jury to take into account all of the evidence, this rule can still contribute to the inference of intention. ${ }^{92}$ The difference with the old evidential connection is that the current connection is framed negatively. Consequences that are almost certain to follow from conduct, may be deemed intentional, but need not. The jury is "not entitled to infer the necessary intention, unless (...)".93 Later, it was even held that the word 'infer' should be replaced by the word 'find' 94 This seemingly small chance of the jury direction gave even more room not to find intention despite foresight. 95

This permissive approach allows the decision maker to exclude intention when this is considered appropriate. It allows for 'moral elbow-room' when the defendant acted with good motives. ${ }^{96}$ Intention is enriched with motive, which brings about that a good motive will negate intention. For example, in Gillick, a doctor had prescribed contraceptives to a girl under 16, knowing that this would assist a man to have unlawful sexual intercourse. His motive to prevent damage to the health of the girl was held to negate his (indirect) intention. ${ }^{97}$ In medical contexts, the negation of intent (or causation) was often based on the doctrine of double effect. For

88 R. v. Moloney [1984] UKHL 4; Simester 1997, pp. 705-706 and Law Commission 1989, p. 193. Most English scholars who replied to a questionnaire of the Law Commission favoured a definition of intention, whereas most judges replied that they favour the golden rule, see Law Commission 2006, p. 56. 
example, surgery might kill the patient but it is important for his well-being. Thus, liability "for a bad consequence is avoided by treating the defendant's intention in the light of an alternative good consequence. (...) Intentions (...) are enriched through moral double-effect doctrine by a substantive moral judgment of what the intention in its content was." 98

The approach enables the exclusion of 'hard cases' from criminal liability. A case is hard when it is felt necessary to make exceptions or strained interpretations to the law in order to achieve justice in that particular case. Unless a legal concept is altered, the defendant will be convicted. However, the extension of intention in these cases was unnecessary to achieve justice. In Gillick the correct approach with the same result would have been to accept intention, but to justify the conduct of the doctor under the justification of necessity. ${ }^{99}$ After all, the girl's health was most important and secondly, the doctor could fear that unlawful sexual intercourse would also follow if he had not prescribed contraceptives. As already argued, Steane should have been excused for intentionally assisting the German enemy under duress.

The exclusion of motives from dolus does not necessarily lead to counterintuitive findings of intention in difficult and unusual cases. An often-used example in this regard is the father who is trapped in an attic of a burning house with his children. If he throws his children out of the window, they will almost certainly die, but they will definitely die if he does not. Because the fatalities are virtually certain, the defendant could be convicted for (attempted) murder. It seems logical to exclude criminal liability in this case, because it is his purpose to prevent harm. How can we say that a result was intended, when it was the actor's purpose to avoid it? It seems paradoxical to label behaviour as intentional when the consequence was exactly what the defendant was trying to avoid. For this reason, the Law Commission considered to add to the definition of intention the proviso that a person is not deemed to have intended any result, which it was his specific purpose to avoid. ${ }^{100}$ However, defences are the proper way to avoid conviction. The father may choose the almost certain death of his children over the absolute certain death of his children. The father is justified or excused for (attempted) murder. ${ }^{101}$

In other English cases, it was held that a law-abiding motive was irrelevant in establishing intention: "Nobody can doubt that Needham was acting courageously and with the best of motives; he was trying to break a drug ring. But equally there can be no doubt that the method he chose and in which the police in Hong Kong acquiesced involved the commission of the criminal offence of trafficking in drugs by exporting heroin from Hong Kong without a licence. Needham intended to commit that offence by carrying the heroin through the customs and on to the

\footnotetext{
98 Norrie 2006A, pp. 499-500. See also Ashworth 2006, pp. 250-251.

99 See also Smith, J.C. 1989, pp. 61-71 and IX.4.

100 Law Commission 2005, pp. 93-110; Law Commission 1993, pp. 10-11 and Tadros 2006, p. 606.

101 See 28 July 1970 BGH JZ 1973, 173 and Tadros 2006, p. 606.
} 
aeroplane bound for Australia."102 The approach is thus inconsistent. Judges adopt a narrower and broader meaning of intention to distinguish on public policy grounds between those with 'worthy' and those with 'unworthy' motives. Such an approach is common in English law, ${ }^{103}$ but rejected in a general part that must be consistent.

Motives should be treated in the context of defences and sentencing. ${ }^{104}$ Intention is a neutral fault element of basic character that is not negated by good motives. If these motives negate liability, a different verdict is warranted, one that expresses both the validity of the violated norm and the reasons of the actor. To say that the actor did not intend to cause harm is different than to say he was justified to cause harm. It is the only principled approach, providing for a clear demarcation of dolus, wrongfulness and blameworthiness, safeguarding that the verdict in each case is labelled appropriately. This correct approach is clearly gaining ground in the English legal system too and has been accepted by the Court of Appeal in the case of Re v A. ${ }^{105}$ Two conjoined twins needed to be separated. It was certain that if nothing was done, both Mary and Jodie would die soon, whereas the surgery would certainly lead to the death of Jodie. Jodie's death was thus undesired, yet certain. The doctrine of double effect was held not to apply and the neutral meaning of intention was affirmed. The 'murderous intent' of the doctors was justified under necessity.

In medical contexts in the Netherlands and Germany, the doctrine of double effect has also occasionally been applied but prevailing opinion now rejects any influence of good motives on the establishment of (indirect) intent. For example, indirect euthanasia is characterized by an unwanted but unavoidable side-effect of palliative treatment. Although it used to be argued in Germany, under the doctrine of double effect, that there is no intention on death in these cases, criminal liability is now considered negated because the doctor can rely on a justification. ${ }^{106}$ In the Netherlands, the general defence of necessity can apply to those cases that are not already covered by the statutory defence. ${ }^{107}$ However, lower Dutch courts also still occasionally deny intention in cases where the defendant submitted he only gave the patient the fatal dose of medicine to stop the pain. ${ }^{108}$ In conclusion, the "moral

102 R. v. Yip Chiu-Cheung [1994] UKPC 2. See also DPP v. Smith [1961] AC 290.

103 Compare the distinction between internal and external disorders to differentiate automatism and insanity and the distinction between specific and basic intent to distinguish between the effect of intoxication on intent. See respectively X.7.4.1. and V.3.5. Ashworth in Simester \& Smith, A.T.H. 1996, pp. 175-179.

105 Re A. (Children) [2000] EWCA Civ 254; Norrie 2006A, pp. 495-499; Ormerod 2005, p. 98 and Ashworth 2006, pp. 250-251.

107 Article 293(2) of the Dutch Criminal Code; Kelk 2005, pp. 157-160; de Hullu 2006, pp. 291-295; Dolman 2006, pp. 252-308 and Rozemond 2006, pp. 83-95.

108 Rb. Breda 10 November 2004, LJN:AR5394 and Rb. Almelo 4 January 2008, LJN:BC1180. 
enrichment' or, from my perspective, 'moral pollution' of intention under the double effect doctrine is by no means exclusive to English law. ${ }^{109}$

\subsubsection{Ulterior intent}

The foregoing should not be interpreted as that motives and specific intentions are only relevant in sentencing. They have an influence on criminal liability too. First of all, motives relate to wrongfulness and blameworthiness and are therefore reflected through the application of justifications and excuses. ${ }^{110}$ For example, the purpose of self-defence is to defend life, limb and goods of yourself or another. It is inconsistent with motives of revenge. The case against Steane was presented as another example. He committed an offence in order to save his family from the Nazi's. His reasonable motive made him blameless. Secondly, motives can help the decision maker in establishing whether the defendant acted intentionally, because it indicates the attitude of an actor towards the result. ${ }^{11}$ When a person throws Molotov cocktails at an asylum seekers centre, his right-wing extremist motive indicates he wanted or at least accepted casualties. ${ }^{112}$

Some offence definitions include specific subjective elements that aggravate or mitigate liability. These elements are often motives, like lust and greed, which makes intentional killing into the most serious form of homicide in Germany. ${ }^{113}$ Another example is the mother who kills her child because she fears the birth will be discovered. This creates a specialis and thereby a mitigation in relation to the generalis offences of intentional killing. ${ }^{114}$ As mentioned before however, these motives are not fault elements and should thus be distinguished from dolus.

There are also offences that seem to include the ultimate goal of the actor into its definition. I will discuss these offences here in light of the rule that dolus is neutral. An ulterior intent is the intent to do something that is further than, or not part of the actus reus. ${ }^{115}$ In other words, the goal is ulterior to the actus reus. For example, in theft, the intent to appropriate, to permanently deprive the owner of his property goes beyond the mere taking away. That intent is ulterior to the offence definition and thus needs not to be fulfilled in order to convict the defendant for the completed crime. It needs to be intended, not achieved. The ulterior result merely needs to be

109 Compare also Remmelink 2001.

110 See Ashworth in Simester \& Smith, A.T.H. 1996, pp. 175-179.

111 Schönke \& Schröder, H. 2006, p. 286; Philipps in Schünemann a.o. 2001; 8 May 2001 BGH NStZ 2001, 475 and 17 December 2009 BGH NStZ 2010, 571.

11228 April 1994 BGH NStZ 1994, 483.

$113 \$ 211$ of the German Criminal Code. Section 28 of the English Crime and Disorder Act 1998 aggravates the sentence of offences committed with a racial or religious motive.

114 Articles 290 and 291 of the Dutch Criminal Code and Kelk 2005, pp. 176-177.

115 In some national legal systems and in international criminal law, the same is expressed by dolus specialis, special intent, specific intent or extended mental element. 
present at the time the defendant took away the object. ${ }^{116}$ The ulterior intent is expressed in offence definitions by terms as 'with a view to' or 'with intent to'.117 For example, the offence of theft often includes 'taking away with a view to appropriate'. Directives 2005/60 on money laundering and 2011/36 on trafficking in human beings use the wording 'for the purpose of'.

\subsubsection{The use of ulterior intent}

From the above, it becomes clear that the use of ulterior intentions helps to overcome evidential problems. If a conviction of theft would require that the actor succeeded in depriving the owner of his property, the defendant can only be convicted of attempt liability if he was apprehended in flagranto delicto. These offences resemble the structure of attempts, also enabling the advancement of criminal liability in time. ${ }^{118}$ They can be an alternative to criminalizing attempts, even though both have a separate justification and thus an independent right of existence. Offences of ulterior intent are said to fill the gap between attempt and mere possession of, for example, a firearm, which is important for a legal system that does not criminalize preparation in general, like the English one. ${ }^{119}$

This also implies that when a legal system recognizes attempt and preparation as general principles of criminal law that apply to all (serious) offences, the necessity for ulterior intent offences diminishes. On the one hand, offences of ulterior intent are clearly defined and are therefore better equipped to further goals like foreseeability and fair warning of criminalization. On the other hand, general principles of attempt and preparation can make criminal law more simple and dogmatic, that is, further the quality of internal logic and consistency and thereby also further foreseeability. For example, in England, it is an offence of ulterior intent to possess a shotgun with the intent to endanger life but it is not a crime to possess a knife with the same intent. Under the general principle of preparation, these cases would be accessorial to a life-threatening offence.

A second reason to use ulterior intentions in offence definitions is that it gives the offence its character. The intention to permanently deprive the owner of his property is the most characteristic element of theft. The ulterior intent gives the offence its criminal character, the animus furandi. ${ }^{120}$ Without this intention, we would not be able to distinguish between the thief of a vehicle and the person who

116 Section 1 of the English Theft Act 1968, article 310 of the Dutch Criminal Code; $\$ 242$ of the German Criminal Code, see Simester \& Sullivan 2007, p. 132; van Dijk, A.A. 2008, p. 213; de Jong, D.H. \& Knigge 2003, p. 101; de Hullu 2006, p. 235; Keulen \& Otte 1999, pp. 17-18; Badar 2005, p. 223; Beulke 2008, p. 78 and Schönke \& Schröder, H. 2006, p. 278.

In Dutch 'met het oogmerk' or in German 'in der Absicht'. Directive 2005/60 on money laundering used the terms 'for the purpose of.'

118 Stuckenberg 2007, p. 267.

119 Horder in Simester \& Smith, A.T.H. 1996, pp. 157-158.

120 Simester 2008, pp. 10-13. See also Ormerod \& Williams 2007, p. 116 and Schönke \& Schröder, H. 2006 , p. 351. 
merely wanted to use it furtum usus for a joy-ride. This nature is also very clear in genocide, where the actors aims to destroy, in whole or in part, a national, ethnical, racial or religious group. ${ }^{121}$ It is this ulterior intent that is the most characteristic element of genocide. Without it, we would not be able to distinguish between massmurder and genocide.

The ulterior intent can limit offence definitions that would otherwise be too broad. As a characteristic offence element, it is an essential criterion for criminal liability. It distinguishes those actors worthy of punishment from those that should not be punished. ${ }^{122}$ An example is the offence called 'going equipped', that is to have with one an item to be used for a burglary or theft. Similarly, the offence of 'carrying an offensive weapon' is to have with one an item to be used for injuring someone. It is the purpose that makes the innocent possession criminal. ${ }^{123}$ Without it, there can and should be no criminal liability. Transporting persons is legitimate, and a professional occupation for many. Only when the actor transports human beings for the purpose of labour or sexual exploitation, does this become the offence of trafficking human beings. ${ }^{124}$ The reason for punishment lies in the ulterior intent.

\subsubsection{Ulterior intent and motive}

The existence of offences of ulterior intent may question the rule that dolus is neutral. However, although an ulterior intent resembles a motive in character, it is different. An ulterior intent constitutes merely a very general motive. ${ }^{125}$ An ulterior intent is not necessarily the ultimate goal of the crime. For example, one can steal something with a view to unlawfully appropriate, but the motive is to get money by selling the stolen good. The underlying motive of getting money can be a desired lifestyle or an expensive surgery. An end can be the means to another end and so on and so forth. ${ }^{126}$ The distinction between ulterior intent and motive may seem difficult, yet a sharp line can be drawn. The offence definition distinguishes an ulterior intent from other motives by labelling it as an offence element to which dolus directus must relate, like 'with a view to unlawfully appropriate'. What is not included in the offence definition, like financial gain, is therefore a motive and irrelevant to criminal liability.

121 Article 6 of the Rome Statute.

122 Stuckenberg 2007, p. 267; de Jong, D.H. \& Knigge 2003, p. 116 and Politoff \& Koopmans 1991, p. 132.

123 R. v. Lambert [2001] UKHL 37; Warner v. MPC [1969] 2 AC 256; Ashworth 2006, p. 158; section 25 of the English Theft Act 1968 and section 1 of the English Prevention of Crime Act 1953.

124 Moreover, either fraud or coercion or abuse of position and so on, must have been employed. See Article 2(1) of Directive 2011/36 of 5 April 2011 on preventing and combating trafficking in human beings and protecting its victims, and replacing Framework Decision 2002/629, OJ 2011 L 101/1.

125 Kelk 2005, p. 178.

126 De Jong, D.H. \& Knigge 2003, p. 117 and Williams 1953, p. 41. 
When multiple motivations exist, the law is also only interested in establishing the intent required by the offence definition. For example, in burglary, it does not matter whether the primary motive was shelter, and the ulterior intent to steal only secondary. ${ }^{127}$ Under article 101 TFEU, intention to restrict competition need not be the only or predominant purpose of an agreement. ${ }^{128}$ In a German case, the defendant had not paid his fare for the train and he was charged with fraud. The ulterior intent of the offence is obtaining benefit, which he denied. He argued that he had forgotten his ticket, did not have enough money for another and he 'only' wanted to be on time for a course. The Supreme Court held that it did not matter that the enrichment was only a means to an end and therefore not the primary goal. ${ }^{129}$

\subsubsection{Proof of ulterior intent}

An ulterior intent is a form of dolus directus. ${ }^{130}$ Direct intent must be proven, which can lead to evidential problems. Consider that in the abovementioned case, the defendant argued that the benefit he obtained was only a certain side-effect of his non-criminal purpose, not a necessary means to achieving his goal. In other words, he had dolus indirectus, but not directus. The State Supreme Court had therefore acquitted the defendant. In order to establish direct intent, the Federal Supreme Court had to argue that he in fact wanted the benefit too, after which it could hold that it was irrelevant that it was only a secondary goal. ${ }^{131}$ The awareness of a certain side-effect is translated into a direct intent relating to multiple goals, putting the distinction between the forms of dolus under pressure. There were public policy reasons to hold that the defendant directly intended enrichment, because everything short of that would lead to an acquittal and would thus present people who did not pay their fare with a formidable defence.

An alternative approach to secure convictions is to hold that dolus indirectus also suffices to establish an ulterior intent. The Dutch Supreme Court has argued that when the defendant knows that the ulterior intent is a certain side-effect of his conduct, he wanted this conduct. In that case, the defendant was charged with fraud. He had posed as someone who had to be imprisoned and thereby unlawfully obtained benefit by receiving prison food. This was not his purpose, but it was

127 Another example is laid down explicitly in section 51(5) of the English Criminal Justice and Public Order Act 1994.

12820 November 2008, Case C-209/07, Competition Authority v. Beef Industry Development Society Ltd and Barry Brothers (Carrigmore) Meats Ltd [2008] ECR I-8637, §21: "Indeed, an agreement may be regarded as having a restrictive object even if it does not have the restriction of competition as its sole aim but also pursues other legitimate objectives." See also the Opinion of AG Trstenjak in this case of 4 September 2008.

130 De Hullu 2006, p. 235; Nieboer 1991, pp. 157-158; Smidt 1881 I, pp. 71 and 74 and Brouns 1988, p. 283.

131 See Roxin 2006, pp. 440-444. 
accepted as wanted because he knew it was a certain side-effect of his deception. ${ }^{132}$ In some German cases, indirect intent is also explicitly held to be sufficient as an ulterior intent. ${ }^{133}$ Some scholars have militated against the inclusion of certain sideeffects, arguing the wording 'with a view to' does not allow for the extending of ulterior intent to more than purpose. ${ }^{134}$ This perspective is particularly strong in Germany, where it is prevailing opinion that nothing less than direct intent suffices for offence that uses terms like 'Absicht' or teleological verbs. ${ }^{135}$ The extension of ulterior intent to forms of fault beyond purpose is problematic if it is considered that this purpose is the most essential character of the offence. To convict someone of such an offence, the most essential element should also be proven.

In order to strike a balance, a rule in Germany is applied that if the ulterior intent gives the offence its specific character and thus distinguishes it from similar offences, only direct intent should suffice. In cases where the ulterior intent is not constitutive of the offence in question, indirect intent can suffice. For example, in murder as defined under $\$ 211$ of the German criminal code, the ulterior intent gives the offence its specific character in comparison to intentional killing. The ulterior intent is therefore limited to purpose. ${ }^{136}$ A less principled approach is to establish the concrete meaning of an ulterior intent in every offence and case. ${ }^{137}$ The legislator would provide for most clarity on the issue by explicitly using dolus indirectus as an alternative ulterior intent when this is deemed legitimate. Offence definitions like these read 'doing $\mathrm{X}$ with the intent to or knowingly causing $\mathrm{Y}$ '.

An even lesser form of intent, mere dolus eventualis, is insufficient for ulterior intent. ${ }^{138}$ Recklessness, often labelled as the common law counterpart of dolus eventualis, is no form of intent and therefore insufficient too. ${ }^{139}$ However, in many offences, the interpretation of other offence elements has been stretched to an extent that this limitation of ulterior intent is hardly noticed. The Dutch offence of theft, for example, covers so many cases, that only cases where the actor had or thought he had permission will preclude ulterior intent. ${ }^{140}$ Furthermore, sometimes the ulterior intent relates to multiple objective elements, of which one does not

132 HR 5 January 1982, NJ 1982, 232. See also HR 21 April 1998, NJ 1998, 610; de Hullu 2006, p. 236 and Keulen \& Otte 1999, p. 17.

133 Krey 2003, pp. 110-111.

134 Van Dijk, A.A. 2008, p. 346.

1352 October 1953 BGHSt 5, 245; Beulke 2008, p. 82 and Schönke \& Schröder, H. 2006, pp. 277278 and 286-287.

136 Badar 2005, p. 224.

137 Beulke 2008, p. 78; de Hullu 2006, p. 237 and de Jong, D.H. \& Knigge 2003, pp. 98-99.

138 HR 25 October 1983, NJ 1984, 300; HR 21 February 1978, NJ 1978, 384; de Jong, D.H. \& Knigge 2003, pp. 117-119; Fokkens \& Machielse, note 9-10 on Opzet; Keulen \& Otte 1999, p. 18 and de Hullu 2006, p. 236. In contrast: Brouns 1988, p. 284.

139 Ormerod 2005, p. 113.

140 Article 310 of the Dutch Criminal Code; de Jong, D.H. \& Knigge 2003, pp. 117-119 and Keulen \& Otte 1999, pp. 18-19. In HR 25 October 1983, NJ 1984, 300 the conviction for theft was quashed, because the finding of ulterior intent was grounded in a reasoning that resembled dolus eventualis. 
require proof of dolus directus. In the German offence of theft, the ulterior intent is to appropriate wrongfully. The appropriation requires dolus directus, but the fact that this appropriation is wrongful, can also be fulfilled by dolus eventualis. The defendant for example merely needed to have been aware of the possibility that there was no permission and taken this for granted. ${ }^{141}$

In the criminal law of Member States, ulterior intentions are usually found in offences of fraud, hate crimes and terrorist offences, all of which have been the object of EU legislation. Surprisingly, in the context of hate crimes, Framework Decision 2008/913 on racism and xenophobia does not oblige the use of ulterior intent. Although Article 4 stipulates that Member States must ensure that racist and xenophobic motivation is considered an aggravating circumstance, ${ }^{142}$ they may also choose to take racist and xenophobic motivation into consideration in sentencing.

It seems that the EU also did not use ulterior intent in the context of fraud affecting its revenue and expenditure. Whereas it is common in Member States to define fraud by using an ulterior intent to the profit or enrichment of oneself or loss to another, because it is this intent that gives fraud its (criminal) character, the EU seems to do away with such an ulterior intent in the 1995 Convention on the protection of the European Communities' financial interests. Article 1(1) defines expenditure fraud affecting the EC financial interests amongst others as: “(..) any intentional act or omission relating to (...) the use or presentation of false, incorrect or incomplete statements or documents, which has as its effect the misappropriation or wrongful retention of funds from the general budget of the European Communities (...) (italicizations added)."143

Rather than framing the offence definition as conduct with an ulterior intent to prejudice the EU budget, this aspect seems to be made objective due to the wording 'which has as its effect' instead of, for example, 'with a view to'. It seems irrelevant whether the economic operator pursued to prejudice the budget, whether he knew this was almost certain to occur, or even merely possible. In other words, the prejudice to the budget is a strict element. It merely needs to be shown that the budget was prejudiced. ${ }^{144}$ Similarly, in Regulation 2988/95, 'irregularity' is defined in Article 1(2) as: "any infringement of a provision of Community law (...) by an economic operator, which has, or would have the effect of prejudicing the general budget of the Communities (...) (italicizations added)." This definition even encompasses actions that could, but did not prejudice the budget.

From a perspective of efficiency of protecting the EU budget, which is the driving force behind this Convention, it is preferable to make any detrimental effect

$141 \$ 242$ of the German Criminal Code; Roxin 2006, p. 439 and Beulke 2008, p. 78.

142 See for example Section 28(1) of the English Crime and Disorder Act 1998.

143 Revenue fraud is defined similarly by reference to its effect on the illegal dimunition on the resources of the budget.

144 'Effect' in Article 101 TFEU is also given this interpretation, contrasted with the alternative 'object.' 
on this budget strict. There needs to be no discussion on what the required degree of dolus is as to this effect - direct, indirect or less - and there can be no evidential problems. Defendants cannot argue they did not know the effect. However, this strict element is what gives the offence its character. If the defendant had no intention to prejudice the budget, or should not have even been aware, it is incorrect to argue this is fraud. The EU also recognizes this. In contrast to what one would expect from the terminology used in the Convention, its explanatory report states that intention must relate to all elements of the offence definition, including the effect. ${ }^{145}$ When a criminal charge applies and the element is essential for the offence, all Member States require at least intent. The detriment to the budget of the $\mathrm{EU}$ is an essential element because it demarcates this criminalization from 'simple' fraud.

\subsubsection{No dolus malus}

A second aspect of the neutral character of dolus is that it does not require that the actor wanted to violate the criminal law or knew his conduct was illegal. Fault elements do not relate to the fact that conduct or consequences are illegal or wrong. ${ }^{146}$ There is no mens mala. Dolus is therefore also not malus, but 'neutral'. ${ }^{147}$ In other words, a mistake of law does not affect intention. ${ }^{148}$ At best, it can negate blameworthiness as an excuse.

A formal explanation for this rule is that fault elements only relate to elements that are included in the offence definition. Wrongfulness or illegality is almost never an offence element. ${ }^{149}$ Only some offences are drafted in a way that dolus is required as to the illegality or wrongfulness of conduct. This is called 'dolus malus ${ }^{\prime}{ }^{150}$ In these cases, the lack of intention results in a complete acquittal based on the inexorable logic of not fulfilling the required offence element. ${ }^{151} \mathrm{~A}$ mistake or ignorance in relation to an offence element is inconsistent with intention. It is the opposite of knowledge and thus negates intention. For example, dolus refers to legal

145 Explanatory Report on the Convention on the protection of the European Communities' financial interests, 23 June 1997 OJ 1997 C 191/1. I assume that Regulation 2988/95 requires intention as to the effect too, because it builds upon the Convention.

146 Simester \& Sullivan 2007, pp. 120 and 627-628; Stephen 1890, pp. 88-89 and Ormerod 2005, p. 118.

147 Smidt 1881 I, p. 70; de Jong, D.H. \& Knigge 2003, pp. 100-101; Kelk 2005, p. 179; de Hullu 2006, p. 208; HR 18 March 1952, NJ 1952, 314; HR 24 April 2007, NJ 2007, 544; Krey 2003, pp. 136-137; Beulke 2008, p. 85; Schönke \& Schröder, H. 2006, p. 261 and 18 March 1952 BGHSt 2, 194.

148 Krey 2003, pp. 136-137; Beulke 2008, p. 85; Bohlander 2009, p. 61; Badar 2005, pp. 217-218 and Strijards 1983, pp. 105-106.

149 March 1952 BGHSt 2, 194; Fischer, T. 2009, p. 113 and Schönke \& Schröder, H. 2006, p. 350351.

150 Fokkens \& Machielse, note 6 on Opzet; Kelk 2005, p. 179; Krey 2003, pp. 138-139 and Schönke \& Schröder, H. 2006, p. 263.

151 Law Commission 1989, p. 158; Fletcher 1978, p. 687 and Bohlander 2009, p. 71. 
aspects when the offence definition requires that the defendant intended to appropriate wrongfully. Dolus is not fulfilled if the accused erroneously believed he had a claim against someone and executed this claim by appropriating property of that person. The mistake operates no different from the situation in which the actor thought the 'stolen' object already belonged to him. In that case, knowledge on an essential element of the offence - that it belonged to someone else - is missing and intention negated. ${ }^{152}$

When the offence defines dolus as malus, a 'mistake of law' thus negates intention, just as it would have when it was a 'mistake of fact'. Both mistakes on points of law and facts or circumstances can become a 'mistake on the offence definition' and negate intention. The legal or factual character of the mistake is less important than whether or not they are included in the pertinent offence definition. This leaves mistakes that are irrelevant to the offence definition and thereby intention as a 'mistake as to the legal prohibition'. These two categories of mistake will be discussed in detail later. ${ }^{153}$

Dolus malus has not always been the exception. Although the common understanding is that mistakes as to the legal prohibition, in contrast to factual mistakes, have always been irrelevant to intention in Europe, mistakes of law were not generally precluded from negating intention under Roman law. In both Roman and Canon law, dolus could also be malus, encompassing awareness of wrongfulness. ${ }^{154}$ Of the three Member States under investigation, the approach to allow a mistake as to the legal prohibition to negate intention too is most visible in Germany. Under the 'theory of intention', the prosecution generally would have to prove that the defendant knew that he was doing was wrong. ${ }^{155}$ This theory has been rejected now however. ${ }^{156}$

In the Netherlands too, dolus malus has not always been unusual. In both countries, there existed offences that required intention on the illegality of the conduct, especially in the regulatory field of economic crimes. In case the actor did not know what he did was forbidden, he could only be convicted of a negligent offence. A decision of the German and a decision of the Dutch Supreme Court, nota bene on the same day in 1952, mark a clear turning point, making dolus malus the exception. ${ }^{157}$ In England, it is also recognized that dolus malus is the exception that follows from the drafting of specific offences. ${ }^{158}$ However, the absence of the possibility to excuse the defendant who is mistaken on the lawfulness of his conduct

152 Schönke \& Schröder, H. 2006, p. 267; Christopher 1995, pp. 230 and 237; R. v. Smith [1974] QB 354 and Law Commission 1989, p. 158.

153 See V.2.4 and X.5.

154 Stuckenberg 2007, pp. 507-516.

155 Arzt 1976, p. 666. Nonetheless, the defendant had to raise the issue in order for the burden to be applicable in practice, see Schönke \& Schröder, H. 2006, p. 366.

156 See however Weigend in Tiedemann 2002, pp. 412-413.

15718 March 1952 BGHSt 2, 194; Arzt 1976, pp. 650-653; HR 18 March 1952, NJ 1952, 314 and Kelk 2005, pp. 179-180.

158 Ormerod 2008, p. 318. See also Vogel in Tiedemann 2002, p. 134. 
has put this starting point under pressure. As will be explained in the next chapter, the unavailability of the excuse has resulted in courts interpreting offences as requiring dolus malus, since that would be the only way to acquit the defendant who made an excusable mistake.

A practical explanation for this neutral character of dolus is that inclusion of elements of wrongfulness and illegality makes proof of the offence definition more difficult. Adding elements of a legal character increases the possibilities of acquittal. If intention on the illegality of conduct would be a standard requirement for liability, a defendant could easily escape liability by arguing that he did not know what he did was forbidden. Courts may have difficulty rejecting these pleas, because in order for a mistake to negate dolus, it need only be honest, not reasonable. The inclusion of dolus malus may even bring about that only the lawyer or those proven to have explicit knowledge of the law can be held criminally liable. ${ }^{159}$

A dogmatic explanation for the lack of wrongfulness as an offence element is that as a rule, wrongfulness is an implied element of criminal liability, which we positioned on the second rung of the ladder of liability. Conduct that fulfils an offence definition is assumed to be wrongful, unless a justification applies. For example, killing someone is prima facie wrongful. It is only justified, that is, tolerated by the legal order and therefore not illegal, if it was done in self-defence.

The supposed justification for not requiring knowledge on the illegality of the act is that everyone is supposed to know the law. This is grounded in the belief that morality coincides with the law, which is not controversial regarding traditional crimes mala in se; murder is criminal in character regardless of it being criminalized by law. Unlike mala prohibita, it is not only a legal wrong but also an ethical or pre-legal wrong. The rule can also be grounded in the legality principle and the social contract, which creates a possibility and duty to know the law. In a highly regulated field of law however, these foundations become weak and the assumption itself problematic. 160

The modern perspective is that knowledge of the law is a fictional assumption that is best understood as a normative duty to know the law. It is warranted to require from an actor that he knows or gets to know the legal rules concerning norms that are essential to everyone and norms that concern his life in particular. For example, he needs to educate himself on the rules relating to spheres in which he is participating professionally. It is argued that if not knowing the law would negate intention, legal indifference would be rewarded. It is desirable to encourage knowledge of the law rather than to promote ignorance of it. ${ }^{161}$

159 See Nieboer 1991, p. 156; Pompe 1935, pp. 80-81; van Verseveld 2011, p. 82; Simester \& Sullivan 2007, p. 728; Williams 1953, p. 385; Ormerod 2005, p. 121; Beulke 2008, p. 164; Schönke \& Schröder, H. 2006, p. 361 and Arzt 1976, pp. 654-659.

160 Kelk 2005, pp. 179-180; Visser in Borgers, Koopmans \& Kristen 1998, pp. 73-74; Kessler 2001, pp. 200-209; Williams 1953, p. 385 and Stuckenberg 2007, pp. 451-460 and 467-469.

161 Stuckenberg 2007, pp. 451-460 and 467-469; Simester \& Sullivan 2007, p. 728; Ashworth 2006, p. 233 and Williams 1953, p. 385. 
These assumptions not only justify treating dolus as a neutral concept, but they also lead to another maxim, namely error iuris non excusat: a mistake as to the legal prohibition does not excuse. The latter will be discussed in the next chapter, where many arguments mentioned above return to the fore. It will be argued there, that a mistake of law can negate blameworthiness, if it was unavoidable. We are concerned here however with the question whether such a mistake can negate intention. In conclusion, the principal answer is negative, because intention is neutral and does not relate to the legal aspects. The answer however also implies that such a mistake can negate intention in offences where dolus is malus. To these cases we will now turn our attention.

\subsubsection{Unless dolus relates to wrongfulness}

As an exception to the rule that dolus is neutral, some offence definitions are drafted in a way that dolus is required as to the illegality or wrongfulness of conduct. Inter alia, this is the case when wrongfulness is included in the offence definition, either literally or by terms as 'without right', 'without permission' or 'misappropriation' and intention relates to it. ${ }^{162}$ As mentioned above, wrongfulness is normally an implied element, a general criterion of criminal liability that need not be proven, that is assumed when the offence definition is fulfilled and negated when a justification applies. When wrongfulness is included in some way in the offence definition, it is an express element. The meaning can vary per offence definition, although it usually means without right or permission, rather than in violation of the law. ${ }^{163}$

As will be discussed in detail in the subsequent part of this book on defences, wrongfulness is part of the offence definition in behaviour that is frequently carried out in accordance with the law. Consider destruction of property, sexual intercourse and detention of persons. ${ }^{164}$ These offences are characterized by the fact that the conduct is wrongful. Without the inclusion of an element of wrongfulness, the scope of liability would be too broad. After all, consensual intercourse should not be labelled rape. Wrongfulness is included because it is essential to the character of the particular offence. ${ }^{165}$ We start our working day by accessing an information

162 Beulke 2008, p. 86; de Hullu 2006, pp. 211-212; Fokkens \& Machielse, note 13 on Opzet and de Jong, D.H. \& Knigge 2003, pp. 101-102.

163 Without right is defined in Article 1(d) of Framework Decision 2005/222 of 24 February 2005 on attacks against information systems, OJ 2005 L 69/67 as: "access or interference not authorised by the owner, other right holder of the system or of part of it, or not permitted under national legislation."

164 De Hullu 2006, pp. 180-181; Bosch 2008, p. 165; Mevis 2006, p. 591 and Fokkens \& Machielse, note 1 on Wederrechtelijkheid. See articles 350 and 282(1) of the Dutch Criminal Code; $\$ 303$ of the German Criminal Code and section 1 of the English Criminal Damage Act 1971.

165 See Kristen in Borgers, Koopmans \& Kristen 1998, p. 51, referring to HR 27 June 1995, NJ 1995, 662 . 
system. Only when this access is unauthorized, does it become wrongful and criminally relevant. ${ }^{166}$

As a consequence of its essential character, dolus must also relate to wrongfulness. After all, the actor must at least be aware of the offence elements that ground the wrong. He must know the circumstances that give the offence its typical character; he must know the facts and understand the essential wrong of the offence. ${ }^{167}$ The 'rapist' must know the victim did not consent. The 'hacker' must know he is accessing a system without authorisation. A function of this cognitive component of dolus is to enable the actor to understand the meaning of his actions and thus incite him to stop or omit those actions. Because the actor is aware that what he is doing constitutes a wrong, he has the opportunity to omit the criminal act. Because he is aware of the essential elements of the wrong, he must know it is illegal. As a consequence, the circumstance that he continues increases the reproach. ${ }^{168}$ Conversely, the fact that the defendant does not know his conduct is wrongful, implies the lack of a hostile disposition against the law. It does not imply his convictions are in line with the norms of the legal order, but it does imply that he believes them do be in line with those norms. ${ }^{169}$ This is also the rationale for excusing the defendant who makes a mistake of law.

On the other hand, we have already seen that offences that require intention as to wrongfulness can give rise to evidential problems. Legal logic requires that all defendants who are mistaken, however unreasonable, on any issue that relates to wrongfulness, ranging from a non-existent permission to ignorance of the law, are acquitted. To prevent acquittals that are contrary to public policy, Member States use numerous approaches in order to mitigate this inexorable logic. They are discussed and assessed here for possible application in a EU criminal justice system.

Let us consider offences against property, where defendants holding a civil claim take matters into their own hands by effectuating this claim by committing a criminal offence. I explained that offences like fraud and theft usually require an ulterior intent as to the obtaining of benefit or appropriation. In addition, the ulterior intent relates to the wrongfulness of that conduct. There are numerous cases in Germany where defendants mistakenly believed they were entitled to a sum of money. In order to collect this, they either stole the money, deceived or coerced the

166 Article 2 of the abovementioned Framework Decision 2005/222 and Article 3 of the Proposal for a Directive on attacks against information systems and repealing Framework Decision 2005/222, 30 September 2010, COM (2010) 517.

167 Schönke \& Schröder, H. 2006, pp. 261-262, 266 and 270-271; Krey 2003, pp. 134-135 and 138; Roxin 2006, p. 503; Beulke 2008, p. 84 and art. 11(1) of the Corpus Juris in Delmas-Marty 1997, p. 66: "Mistake about the essential elements of the offence excludes fraud; (...)."

168 Schönke \& Schröder, H. 2006, pp. 269 and 351; Beulke 2008, p. 88 and Arzt 1976, p. 657.

169 Stuckenberg 2007, pp. 442-443. 
'debtor' to pay. Such mistakes negate the intention as to the wrongfulness of the enrichment and therefore lead to an acquittal. ${ }^{170}$

Apparently, it does not matter that the defendant used clearly illegal means of realizing his claim. Even if the means of collecting this money is clearly illegal, the purpose of the appropriation does not become wrongful. Falsifying documents and manipulating evidence, for example, does not make a justified but hard to prove claim wrongful. ${ }^{171}$ Even though the law does not provide for such rights to collect debts, the German Supreme Court argued that creditors will often not know this and even possibly believe that they are entitled to take away money from the person who owes them money. ${ }^{172}$ This reasoning can be connected to the view where dolus is seen as expressing hostility towards the legal order. If the mistake implies that the defendant thought he was acting in conformity with the norms of the legal order, his intention must be negated. ${ }^{173}$

However, citizens may be incited to take matters into their own hands, because the law does not condemn the use of extra-legal means to effectuate a claim. This has led the Dutch to take a more restrictive approach. A mistaken belief that one has a civil claim can also negate intention as to wrongfulness, but when the means of realizing this claim are considered illegal or even inappropriate, the intention as to wrongfulness is fulfilled. Wrongfulness is interpreted broadly as 'excessively exceeding what is considered decent in society'. ${ }^{174}$ Wrongfulness not only relates to violations of legal rules, but also to the law as a broader concept, including norms from other fields of law, even 'decorum' and 'decency'. This approach allows the courts to reject a failure of proof defence on intention, in cases where the actors had a legal right, but used this in a way that is in itself unseemly, so the whole conduct cannot be said to stand the test of law in the broadest sense of the word. ${ }^{175}$ Taking justice into one's own hands is usually not allowed. Even if the defendant had a civil claim, he is not allowed to set aside civil means of revindication. ${ }^{176}$ The Dutch interpretation of wrongfulness serves this purpose. ${ }^{177}$

For example, a defendant had tried to extort money from two persons by writing a threatening letter, thinking he was entitled to that money. The courts held that, even if he would have been entitled to the money, he must have known that he had gravely exceeded what was decent in society and that he thus had acted with a view

17012 January 1962 BGHSt 17, 87; 26 April 1990 BGH NJW 1990, 2832; 21 February 2002 BGH NStZ 2002, 481; 7 August 2003 BGH NJW 2003, 3283 and Beulke 2008, p. 86.

17117 October 1996 BGHSt 42, 268.

172 January 1962 BGHSt $17,87$.

173 Beulke 2008, p. 88. See IV.2.2.1.

174 De Hullu 2006, p. 212. 'Verregaande overschrijding van de grenzen van de maatschappelijke betamelijkheid.'

175 Kelk 2005, p. 128.

176 Annotator van Veen in HR 16 October 1990, NJ 1991, 153.

177 Kelk 2005, pp. 132-133 submits that outside this field of law, there are (only) a few decisions where a broad interpretation of wrongfulness was used. 
to appropriate wrongfully, making him criminally liable for theft. ${ }^{178}$ In another case, two persons were looking for a stolen car. When they found it in a service station, they asked for a test drive and drove the car to the police. They were convicted of fraud, despite the claim that they did not intend to act wrongful, because they acted by order of the original owner. ${ }^{179}$

In England, mistakes of civil law also generally negative criminal liability for offences like theft and fraud as in Germany. This is, however, not due to the lack of intention at wrongful behaviour, but due to the functionally equivalent, normative offence element of 'dishonesty' in theft and fraud. The appropriation of property belonging to another is not regarded as dishonest when the actor believes he has in law the right to deprive the other of it. The defendant may intentionally lie in order to reclaim property, this is not considered dishonest. 180

The pragmatic Dutch approach to dolus on wrongfulness can be criticized as violating the principle that dolus must relate to the offence elements that are characteristic for the offence. The typical element of wrongful appropriation is the circumstance that the actor has no right to appropriate. If the actor thinks he has a legal claim over the object, he has no intention on this characteristic offence element. How can we then say that the actor fulfilled the offence definition? The offence is fulfilled although the 'typical' nature of the crime is absent. Wrongfulness loses its typical, characteristic meaning and becomes redundant. The difference between offences with or without such an ulterior intent is blurred. ${ }^{181}$ As a consequence, in establishing the EU concept of dolus, the Dutch approach should be rejected.

The choice in favour of the English and German approach does not necessarily open the floodgates of self-help. The intention-negating effect of mistakes of civil law has its limits in all three Member States. Dolus can be grounded in many other ways than by interpreting wrongfulness in a broad way. First of all, it is warranted to limit relevant mistakes by requiring that claims must be legitimate, that is, protected by the legal order. Drug dealers are not making a mistake of fact on the wrongfulness of appropriation if they try to coerce the victim to pay the money they owe or give back the drugs. The dealer cannot be mistaken that his claim is accepted by the legal order and can be enforced by civil law. ${ }^{182}$ Second, even if a mistake leads to the negation of an ulterior intent such as to wrongfully appropriate in robbery, there usually is a possibility to hold the defendant liable for an offence that does not require such an ulterior intent, like coercion. ${ }^{183}$

178 HR 9 February 1971, NJ 1972, 1. See also Kelk 2005, pp. 128-130.

179 HR 16 October 1990, NJ 1991, 153 and Kelk 2005, p. 130. In contrast, a similar English case mentioned in Ormerod \& Williams 2007, p. 134 does not lead to criminal liability.

180 Sections 1-2 of the Theft Act 1986, sections 1-4 of the Fraud Act 2006; Ormerod 2005, p. 294; Simester \& Sullivan 2007, pp. 624-625; Ormerod \& Williams 2007, pp. 103-110 and 133-135.

181 Kelk 2005, pp. 85-86 and 129-131 and annotator Bronkhorst in HR 9 February 1971, NJ $1972,1$.

1827 August 2003 BGH NJW 2003, 3283. See also 17 October 1996 BGHSt 42, 268 and 21 February 2002, BGH NStZ 2002, 481.

183 26 February 1998 BGH NStZ-RR 1998, 235. 
Third, the intention to wrongfully appropriate can also be fulfilled by dolus eventualis. This means that if the actor accepted the possibility that there exists no (such) claim or that it is not protected by the legal order, intention is established. In a case where the defendant had send people to collect with force money that was owed from receipts of a techno party, the German Supreme Court held that the awareness of wrongfulness is only absent when the actor has a clear conception on the grounds and height of a claim. Since he only estimated the money he was owed, knowing the tickets sales had been conducted all but orderly, a mistake of fact was rejected and he was convicted to 5 and a half years of imprisonment. ${ }^{184}$ In England, similar solutions can be reached by letting recklessness suffice. There are also crimes of 'ulterior recklessness', where recklessness goes 'beyond' the actus reus. ${ }^{185}$

Courts can also find intention by specifying the claim and thereby distinguishing it from the object of the crime. If the defendant intends to appropriate something else than the thing to which he has a claim of right, it can be argued that intention on wrongfulness is not affected. ${ }^{186}$ A mistaken claim on money might negate the intention of wrongful appropriation of money, but not of jewellery ${ }^{187}$ Consider the employee who 'lends' money from the till, with the intention to replace the money as soon as he can. There is no doubt that the defendant has the intent to deprive the employer of these particular notes. ${ }^{188}$ Courts have also argued that a defendant might have a right to money but not to thís money (appropriated thís way). ${ }^{189}$ Even in Germany, the student who argued he wanted to lend a book rather than steal it was convicted, based inter alia on the argument that the bookstore lost its specific value of a new book. ${ }^{190}$

The mistake on wrongfulness can also be required to be reasonable or unavoidable, allowing liability for intentional acts when the mistake was easy to avoid or unreasonable. This is a popular legislative technique in England. ${ }^{191}$ However, an ulterior intent can dogmatically not be fulfilled by an unreasonable mistake. Requiring a reasonable mistake means that one is punished for being negligent. The fear of hampering effective prosecution by providing defendants an easy defence appears unwarranted, even more when it is considered that mistakes need to be honest, and thus so-called 'abuses' of the failure of proof defence can be

18416 December 1997 BGH NStZ-RR 1999, 6. See also 23 December 1952 BGH NJW 1953, 431; Bohlander 2009, p. 120; Schönke \& Schröder, H. 2006, p. 362; Arzt 1976, p. 665 and Keulen \& Otte 1999, pp. 14-15.

Horder in Simester \& Smith, A.T.H. 1996, pp. 154-155. See, for example, section 1(2) of the Criminal Damage Act 1971.

186 Ormerod \& Williams 2007, p. 134.

18721 February 2002 BGH NStZ 2002, 481.

188 Ormerod \& Williams 2007, p. 108.

189 HR 29 April 1935, NJ 1936, 50. See also HR 23 March 1936, NJ 1936, 563; Kelk 2005, p. 128 and Ormerod \& Williams 2007, p. 134.

190 Arzt 1976, pp. 665-666.

191 Compare sections 1 to 4 of the English Sexual Offences Act 2003. 
rejected based on the fact and circumstances of the case. If a defendant intentionally deceived someone and made profit thereby, the ulterior intent is easily proven. The defendant will have to have a good story in order to negate this.

The most extreme approach to limiting the scope of relevant mistakes is to disconnect dolus from wrongfulness altogether. One can decide to make wrongfulness or other normative elements strict. Mistakes as to strict elements are irrelevant, because intention does not relate to it. An example is the offence of resisting the lawful actions of a civil servant. The defendant needs to intend the resistance and know the person he resists is a civil servant, but he need not be aware that the actions are lawful. If this would be required, a mistake, however unreasonable it may be, would preclude liability for the offence. ${ }^{192}$ Another example is the destruction of property under article 350 of the Dutch Criminal Code. The offence requires wrongfulness but intention need not relate to it; the express element has been made strict. ${ }^{193}$ In the latter example however, the technique violates the rule that if wrongfulness gives the offence its typical character, intention must relate to it. ${ }^{194}$

When incorrect claims in civil law may be effectuated by clearly illegal means, the fear that people will take justice into one's own hands is legitimate. We should however not create dogmatic inconsistencies by extending the scope of wrongfulness, by requiring a reasonable mistake or by making essential offence elements strict. The fear can be put into perspective, because there are other approaches to limit this restrictive effect of mistakes on criminal liability. These approaches strike a balance between on the one hand, the efficient protection of legal interests such as property and on the other hand, the principle that wrongfulness is an essential element of such offences and that dolus must therefore relate to it.

\subsubsection{Unless dolus relates to normative elements}

Dolus is also not very neutral in relation to other normative offence elements like 'forging' or 'indecency'. Here, the element also refers to an intention to do the illegal or at least improper thing. We can identify similar strategies to reach convictions as mentioned in relation to wrongfulness. Another approach applied in this context is to merely require that the defendant knew of the factual circumstances that ground a normative element. If the actor is mistaken about the facts that ground a normative element like 'reprehensible', his intention can be

192 Fokkens \& Machielse, note 5 on art. 180. In R. v. Lee [2000] EWCA Crim 53, the English Court of Appeal held the mistake on the lawfulness of the officer's actions irrelevant too, see section 38 of the Offences Against the Persons Act 1861.

193 Article 350 of the Dutch Criminal Code reads “(...) intentionally and wrongfully (...)”. The connector 'and' indicates that intent does not relate to wrongfulness, see Kelk 2005, pp. 200-201 and Pompe 1935, pp. 79-80. In the similar $§ 303$ of the German Criminal Code, wrongfulness is also included in the offence, but treated generally as an implied element. Moreover, the mistake is treated as a mistake of law, not negating intention, see Joecks \& Miebach 2006, notes 61-63 on $\S 303$.

194 Schönke \& Schröder, H. 2006, p. 351. 
negated, but if he knows all the facts grounding this reproach but thinks it is not reprehensible as such, only the excuse mistake of law might apply. ${ }^{195}$ The difference between a relevant mistake on the underlying facts and an irrelevant mistake regarding the valuation of a risk as unreasonable is also paramount in the fault element recklessness. ${ }^{196}$

An alternative approach that warrants particular emphasis in this context, is the German one of letting the layman perception of normative offence elements like wrongfulness suffice. ${ }^{197}$ The actor need not appreciate normative elements like a lawyer, as that would make only the latter criminally liable. Intention is not negated when despite a mistake, the actor appreciates the social impact of his actions, realizes the wrongful character of the pertinent element. This is the case, for example, when the actor mistakenly believes he is acting within the limits of a legal loophole. Intention is not negated when the person who knowingly received stolen goods thought he would only be criminally liable if he had paid money for the goods. It suffices that the actor knows that he is harming the legal interest of property, which is protected by that offence. ${ }^{198}$

The subjects of this section can be illustrated with a final example. Under earlier mentioned EU legislation, a hacker is someone who accesses an information system without right. The latter element of wrongfulness gives the offence its typical character, which brings about that the defendant must have intended his access to be wrongful. Whether or not the defendant had good intentions by accessing the information system, is irrelevant for intention. Some experts distinguish 'hackers' as persons acting with bona fide motives, like exposing a security risk, from 'crackers' as persons accessing information systems for material gain or (reprehensible) ideological convictions. Motive is however irrelevant for intention and the offence does not include an ulterior intent as to these ultimate goals. Therefore at most, the motive of the hacker can be assessed within the framework of defences.

\subsection{Knowledge}

In discussing dolus, we focused on results, but dolus can also relate to conduct and circumstances. Intention as to a circumstance is commonly referred to as know-

195 Beulke 2008, pp. 87 and 172, Schönke \& Schröder, H. 2006, pp. 176-177, Schönke \& Schröder, H. 2006, pp. 263 and 355-356 and Roxin 2006, pp. 489-490.

196 See IV.4.5.3.

197 Krey 2003, pp. 138-147; Badar 2005, p. 237; Fischer, T. 2009, pp. 116-117 and Beulke 2008, p. 86. See also Schönke \& Schröder, H. 2006, p. 262.

198 'Parallelwertung in der Laiensphäre', see 19 May 1999 BGHSt 45, 97; Arzt 1976, pp. 664-665; Beulke 2008, p. 163; Bohlander 2009, pp. 62 and 72; Schönke \& Schröder, H. 2006, pp. 262-263 and Strijards 1987, p. 10. See V.2.4.2. 
ledge. ${ }^{199}$ Dolus indirectus applies to the actor who knows a circumstance exists. Dolus directus applies when the actor hopes that a circumstance exists or will exist. The latter is sometimes rejected, submitting that one can only want something in the future and as regards to what is, this can only be known, not wanted. In other words, wanting cannot be directed at something that the actor cannot influence or change. ${ }^{200}$ However, dolus directus can relate to circumstances, because they can be the grounds for the actions. The actor aims at an action in a specific context, such as conducting sexual acts with a minor. The actor can make his actions dependent on circumstances and manipulate these by planning. The criminally relevant circumstances always determine the conduct itself, because the actor wants a certain conduct under certain circumstances and the lack of those circumstances means failure to him. ${ }^{201}$

Be that as it may, the most common form of knowledge consists of awareness that a circumstance exists. ${ }^{202}$ Like in dolus indirectus, it is not required that the defendant should think a circumstance exists with provable certainty. After all, in the strictest sense of the word, one cannot know that something will be the case in the future. On the other hand, suspicion or awareness of a mere possibility is insufficient. ${ }^{203}$ There must be real and present knowledge; potential knowledge does not suffice. For example, the actor must know that he was in an accident in order to commit the offence of leaving the scene of an accident. It is, however, not required that the actor consciously or continuously reflected about the objective elements. The requirements of coincidence of actus reus and mens rea are not strict, as a more detailed discussion in chapter $\mathrm{V}$ will show. The knowledge needs to be present at one point in time, not continuously. It is also of no avail to the actor that he abandoned his dolus after the fact, or that he tries to undo the consequences. ${ }^{204}$

\subsubsection{Tacit and latent knowledge}

Knowledge is easily accepted because it need not be very conscious or explicit. So called tacit (subconscious) or latent (background) knowledge suffices. ${ }^{205}$ There can be instances where the actor knew something, but was not consciously aware of it at

199 Law Commission 1989, p. 191; Badar 2005, p. 210; Weigend 1981, p. 674; de Jong, D.H. \& Knigge 2003, p. 124 and Fokkens \& Machielse, note 3 on Culpa.

200 Stuckenberg 2007, p. 244.

201 Law Commission 1989, p. 192; Simester \& Sullivan 2007, p. 131 and Stuckenberg 2007, pp. 244-246. See also section 2.02(2) of the Model Penal Code, American Law Institute 1985A, p. 225, where hope as to circumstances is also equated with purpose.

202 Simester \& Sullivan 2007, p. 131; de Hullu 2006, pp. 238-239 and de Jong, D.H. \& Knigge 2003, p. 99.

203 Keulen \& Otte 1999, p. 19; Simester \& Sullivan 2007, p. 142, Law Commission 1989, p. 192 and Shute in Shute \& Simester 2002, pp. 195-196.

204 Schönke \& Schröder, H. 2006, p. 266-269.

205 See Shute in Shute \& Simester 2002, pp. 187-190 and 199-201 and Sullivan in Shute \& Simester 2002, pp. 211-212. 
the time of commission. The denial of knowledge is not likely to be successful. ${ }^{206}$ For example, when a person carrying a gun steals something - without the use of the gun - it is not necessary that he contemplated on the possession of the gun to be liable for aggravated theft under $\$ 244$ of the German criminal code. ${ }^{207}$ 'Nonreflected coconsciousness' or tacit knowledge, can be based on awareness grounded in facts. ${ }^{208}$

Moreover, latent knowledge can be based on knowledge that is permanently available to the defendant since he has internalized it. A civil servant who is receiving a bribe, for example, does not need to reflect on his official position. ${ }^{209}$ The 'problem' is similar to that in the context of the voluntary act requirement, where it is argued that habitual acts like shifting while driving a car might not qualify as voluntary acts since they are said to be subconscious. ${ }^{210}$ The paradoxical character of tacit and latent knowledge is that the more someone is familiar with a certain type of conduct, the less likely he will actually reflect on it. The higher the degree of knowledge, the more it retreats into sub-consciousness. It is therefore no surprise that knowledge has been 'extended' in this way. ${ }^{211}$

Critics of these two forms of knowledge warn that it might delude the distinction between real and possible knowledge, the difference between dolus and culpa, intention and negligence. After all, does a negligent driver also not possess the latent knowledge of risks in general ${ }^{212}$ This basic difference between actual knowledge and ignorance where one should have known brings about that at all times current reproducibility without actual reflection must be distinguished from what does not qualify as dolus, namely the mere possibility to reproduce knowledge by exercising the memory or thought. ${ }^{213}$

\subsubsection{Knowledge and belief}

Knowledge and belief are distinguished in English law only by the condition that belief must be true in order to count as knowledge. ${ }^{214}$ The belief need not be founded on a reliable base; a true belief based on some relevant data suffices. ${ }^{215}$

Fokkens \& Machielse, note 4 on Opzet and Brady 1996, pp. 187-188 and 199.

Schönke \& Schröder, H. 2006, pp. 269-270. See also Schild in Dencker a.o. 1993, p. 266.

'Sachgedankliches Mitbewußtsein', see Schönke \& Schröder, H. 2006, p. 364; Stuckenberg 2007, p. 285 and Shute in Simester and Shute 2002, pp. 199-200.

'Begleitwissen', Krey 2003, pp. 132-137; Fischer, T. 2009, p. 105; Roxin 2006, pp. 497-499;

Schönke \& Schröder, H. 2006, pp. 269 and 364 and Beulke 2008, p. 85.

Habitual bodily movements that often lack an express order of the mind are voluntary too however, see Schönke \& Schröder, H. 2006, p. 166-167.

Schild in Dencker a.o. 1993.

Duff 1990, p. 160.

Krey 2003, pp. 134-135; Roxin 2006, pp. 497-501 and Schönke \& Schröder, H. 2006, p. 270.

R. v. Saik [2006] UKHL 18; Shute in Shute \& Simester 2002, pp. 191 and 201; Simester \& Sullivan 2007, p. 131 and Williams 1953, p. 133.

Shute in Shute \& Simester 2002, pp. 207-208, who criticizes this limited legal distinction. 
Therefore, belief in contradistinction with knowledge is only important when it concerns a false rather than a true belief. It seems only English law uses belief as a fault element, sometimes as an alternative to knowledge by including terms like 'which he knows or believes'. ${ }^{216}$ This implies that a defendant can also be held liable if he mistakenly believed that a circumstance was present. ${ }^{217}$ The lack of a clear idea on what belief requires in the only legal system under investigation that seems to apply it is problematic. Belief will therefore not be investigated or discussed in detail.

\subsubsection{Wilful blindness}

Besides knowledge and belief, many more states of minds can be distinguished in relation to circumstances. These are however not similar to dolus. For example, an offence can require 'reckless knowledge', which exists when the defendant knows there might be a risk that a prohibited circumstance is present, but refrains from checking it. ${ }^{218}$ For example, the defendant may suspect that the person he intends to have sexual intercourse with is not consenting or not of age. ${ }^{219}$ However, if the reason for this failure was that he was virtually certain his suspicion would be confirmed, English law upgrades it to actual rather than reckless knowledge. ${ }^{220}$ "(...a person acts) "knowingly" with respect to a circumstance not only when he is aware that it exists or will exist, but also when he avoids taking steps that might confirm his belief that it exists or will exist."221

The aforementioned follows from the application of the doctrine of wilful blindness. A person who is wilfully blind may be as culpable as the person with explicit knowledge. This wilful blindness is a suspicion coupled with a deliberate failure to use readily available and effective means that he knows of to resolve the suspicion, in short, suspicion and the blameworthiness of not checking. 222 This form of actual knowledge is thus called wilful blindness, or 'connivance'. ${ }^{223}$ When ignorance is based on indifference, intentional liability is warranted. ${ }^{224}$

216 See section 114(2) of the Anti-terrorism, Crime and Security Act 2001 and sections 2-5 of the Forgery and Counterfeiting Act 1981.

217 Simester \& Sullivan 2007, p. 615 and Sullivan in Shute \& Simester 2002, p. 221-223. Liability can also be based on section 1(2) of the Criminal Attempts Act 1981, see for example R. v. Shivpuri [1986] UKHL 2. Ashworth 2006, p. 190. In section 41(3) of the English Human Fertilisation and Embryology Act 1990 , for example, both knowledge and reckless knowledge suffice.

219 R. v. Khan [1990] 1 WLR 815.

220 Simester \& Sullivan 2007, p. 144 and Williams 1953, p. 127.

221 Section 18(a) draft Criminal Code, see Law Commission 1989, p. 51. See also R. v. Stephenson [1979] EWCA Crim 1.

222 Sullivan in Shute \& Simester 2002, pp. 213-214.

223 Westminster City Council v. Croyalgrange Ltd and another [1986] 2 All ER 353; Simester \& Sullivan 2007, p. 143, Williams 1953, p. 127 and Ashworth 2006, p. 191.

224 Jakobs 2002; Kindhäuser in Arnold a.o. 2005, pp. 345-346 and Hsu 2007, pp. 196-197. See also Brady 1996, pp. 192-198. 
In continental Europe, merely knowing that a circumstance might exist is similarly upgraded to actual knowledge through the concept of dolus eventualis, which is the lowest form of dolus on the continent and alien to English law. For example, in the context of intentionally handling stolen goods, knowledge on the illegal origin of a good was said to include dolus eventualis. ${ }^{25}$ The Dutch Supreme Court deduced awareness on the possibility that it was illegally obtained from the circumstances surrounding the sale of a television, such as the price, the fact the defendant had sold it himself soon after buying and the fact that other persons involved were aware of this possibility. As will be argued later, dolus eventualis is primarily used to facilitate proof. If the lowest form on intent suffices, no one will try to establish more than this, even if dolus (in)directus may be evident. However, in cases of handling stolen goods, actual knowledge could also be inferred by inferring it from the facts and circumstances. The fact that the defendant was found in possession of the goods, under the abovementioned suspicious circumstances, leads to a prima facie case of knowledge. The burden to rebut this case rests upon the defendant. ${ }^{226}$

Dolus eventualis is established in cases where the defendant did not inquire into the fact or only conducted a clearly insufficient investigation, whereas there was, considering the circumstances, every reason to conduct such an investigation. ${ }^{227}$ Knowing or suspecting so much that one prefers not to know can qualify as dolus eventualis. ${ }^{228}$ The difference with wilful blindness is however that it is not required that the actor remained ignorant because he looked away from the obvious. Almost any suspicion may suffice for dolus eventualis.

From this aspect, controversy follows in the Netherlands regarding the question whether awareness of a possibility can be equated with knowledge. It is difficult to reconcile an interpretation of knowledge that includes dolus eventualis with the literal wording of knowledge, which is consciousness of a reasonable degree of certainty. ${ }^{229}$ From this, it follows that dolus eventualis should not suffice to accept knowledge. ${ }^{230}$ However, the Dutch Supreme Court has interpreted elements of knowledge in many offence definitions as including dolus eventualis, and although some scholars have tried to mitigate this by arguing that the element is interpreted per offence, it seems the Supreme Court has taken the approach that dolus eventualis suffices for every form of knowledge in offence definitions. This is accepted by most scholars as consistent in a legal system that operates with three forms of dolus. ${ }^{231}$

HR 19 January 1993, NJ 1993, 491. In the context of money laundering, see Hof Amsterdam 14 December 2010, LJN:BO9264.

Edwards 1954, pp. 295-298.

Kessler 2001, pp. 237 and 253.

De Hullu 2006, p. 222.

Fokkens \& Machielse, note 8 on Opzet.

Keulen \& Otte 1999, p. 19 and Nieboer 1991, p. 157.

See HR 30 May 2008, NJ 2008, 318; de Hullu 2006, pp. 239-241; Kelk 2005, pp. 195-197; annotator D.H. de Jong in HR 3 December 2002, NJ 2004, 353; Fokkens \& Machielse, note 8 on Opzet and Smidt 1881 I, p. 72. 
In contrast, most scholars in Germany seem to exclude dolus eventualis for fault elements that are drafted as a form of knowledge. Only when a more general term of intention is used in the offence definition, can this lower form of dolus suffice. ${ }^{232}$ After all, knowledge is also sometimes used as an aggravating factor in comparison to the mere intention (dolus eventualis) as to a circumstance. Consider $\$ 109 \mathrm{~g}$ of the German Criminal Code, where 'knowingly' creating a danger can be punished with up to five years of imprisonment, whereas if the danger is brought about with intention or gross negligence there is a maximum penalty of only two years.

This manner of drafting offences can thus be seen as alternative strategy to include this latter knowledge into dolus by using dolus eventualis or wilful blindness. The advantage of this approach is that defendants can be held criminally liable in all cases and that knowledge is clearly distinguished from suspicion (and ignorance). Moreover, this difference is not only expressed in the verdict but also expressed in sentencing, as the lesser offence is punished less severely.

In conclusion, the following definition grasps dolus best: "(... a person acts) "intentionally" with respect to- i) a circumstance when he hopes or knows that it exists or will exist; ii) a result when he acts either in order to bring it about or being aware that it will occur in the ordinary course of events." 233 Knowledge should include only a reasonable degree of certainty. Wilful blindness resembles the degree of certainty required in dolus indirectus, and may therefore be equated with it. By contrast, the suspicion that a circumstance exists should be distinguished clearly from knowledge. It is considered desirable to criminalize this as well, it should thus be expressly indicated in the offence definition, for example as reckless knowledge. Ignorance where one should have known is the counterpart of negligence. When an offence definition holds the defendant liable who 'knew or ought reasonably to have known' all kinds of fault therefore suffice for liability. ${ }^{234}$

\section{Dolus EVENTUALIS}

The fault element discussed here equates foreseen side-effects with intended results. It requires that the defendant was aware of the possible side-effects of his actions and he decided to act nonetheless, accepting these side-effects. This fault element does not exist in English law. The comparable English concept of recklessness will therefore be discussed next, after which I will argue in favour of that concept in a general part of criminal law for the EU.

\footnotetext{
232 October 1953 BGHSt 5, 245; Beulke 2008, p. 82; Krey 2003, pp. 112-115; Fischer, T. 2009, p. 106 and Schönke \& Schröder, H. 2006, pp. 277-279.

233 Section 18(b) draft Criminal Code, Law Commission 1989, p. 51.

234 See for example section 4(1)(b) of the English Animal Welfare Act 2006.
} 


\subsection{Terminology}

The lowest possible form of dolus will be addressed by the term dolus eventualis, or in short, eventualis. As elsewhere in this book, the use of Latin denotes that it is the product of comparative legal analysis and thereby a candidate fault element for a general part of criminal law for the EU. In order to distinguish this integrated concept from its sources, the term 'conditional intent' is used (only) to refer to characteristics of the corresponding fault element of a specific Member State under investigation. This is a literal translation of the commonly used terms in Germany and the Netherlands, respectively 'bedingter Vorsatz' and 'voorwaardelijk opzet'.

Dolus eventualis has been a bone of contention since it was adopted in both countries. $^{235}$ The controversy starts with its terminology. The term 'conditional intent' has been attributed to Frank, who tested intention by asking whether the defendant would also have acted, if he were certain the consequence would occur. If he would have gone ahead, intention could be confirmed. The second formula holds that intention is given when the actor has decided that he will act in any case, regardless of whether the circumstances are so or so. These questions or formulae are however better seen as auxiliaries than the decisive test for the decision on whether or not the actor accepted the risk or not. ${ }^{236}$

'Conditional intent' is confusing, because the intent is not conditional; the occurrence of the result is merely dependent (conditional) on uncertain circumstances. In order to hold the accused liable for a completed offence, the risk that he consciously accepted must occur. If the risk does not materialize, there is still conditional intent, which can ground attempt liability. The intent itself is unconditional, independent of a further condition like realization of the risk. Consider someone who throws another person in a cold river with a strong current, realizing the lethal danger beforehand but continuing anyway to teach the victim a lesson. The intent to kill is given when the victim is pushed off the bridge, regardless of whether the victim dies or survives. The actor might even mourn the consequence when it happens, but he acts regardless of whether the condition is fulfilled, regardless of whether the risk materializes. ${ }^{237}$

When a will is literally conditional, expressing inner indecisiveness, this does not constitute intention. The dividing line between intention and negligence is whether the actor has decided to act. Every intention requires an unconditional will

235 Smidt 1881 I, p. 80; Pols (1889) in Buruma 1999; de Hullu 2006, pp. 220-221; Nieboer 1991, pp. 177-178; van Dijk, A.A. 2008, pp. 216-220; Schönke \& Schröder, H. 2006, pp. 279, 282 and 286 and Bohlander 2009, pp. 64-65. The first references to this concept in Germany stem from the eighteenth century, but it has been given its current contours only in the late nineteenth century, see Taylor, G. 2004A, pp. 103-105. Kelk 2005, p. 185 submits the Dutch Supreme Court used the term conditional intent for the first time explicitly in HR 9 November 1954, NJ 1955, 55. 460-461; Badar 2005, p. 231 and Taylor, G. 2004B, pp. 357-358.

237 Kelk 2005, pp. 184-186; Krey 2003, pp. 114-115; Beulke 2008, pp. 78-79 and Schönke \& Schröder, H. 2006, p. 279. 
to act. Intent is literally conditional in cases where the actor still has to decide what to do. In those cases, there has not yet been a decision to act. The actor, for example, takes out a gun but has not yet decided to threaten or shoot. When the gun goes off, he can be held merely negligent for the results caused. ${ }^{238}$ Consider also Wilhelm Tell, who was forced to shoot an apple from the head of his son with a crossbow. After succeeding, the villain landlord Geßler asked Tell why he had taken two arrows. Tell replied that if he had killed his son, he would have shot him with the second arrow. There was literal but not legal conditional intent on the death of Geßler. ${ }^{239}$

In these cases, the actor is still undecided and does not act with intention to kill. The actor remains in complete control to choose to complete his act or to abandon it altogether, in contrast to cases of legal conditional intent, where the actor no longer has control over the outcome of the case. When the defendant threw the victim in the cold river with a strong current, his death is not a condition on which the defendant could act. ${ }^{240}$ Intention is even direct, as opposed to merely conditional intent, when the actor is already firmly determined to commit the act, such as killing, provided that specific circumstances will occur. Consider the actor wants to kill his ex-wife if she does not want get back together. He could not influence this decision as it was the choice of his ex-wife. He had already decided to act. ${ }^{241}$ Consider that English lawyers use the term conditional intent to indicate that a direct (ulterior) intent also exists in case of breaking and entering with a view to steal valuables if they are present. As accepted in all Member States, if there would be no valuables, he still acted with a view to steal them. ${ }^{242}$

For these reasons, many Dutch and German scholars reject the term conditional intent. Many German scholars prefer 'Eventualvorsatz' or even use its Latin counterpart dolus eventualis. ${ }^{243}$ This term is used for similar concepts in other Member States too. ${ }^{244}$ The actor wants a consequence eventualiter when he in eventum of the occurrence accepts (consentit) this. ${ }^{245}$ Other alternatives could be 'intention on possibility' or 'chance-intent' in order to demarcate it from indirect intent. ${ }^{246}$ These terms must be rejected too however, as the concept is not only separated from

238 Krey 2003, pp. 114-115; Beulke 2008, pp. 78-79; Schönke \& Schröder, H. 2006, p. 279; Stuckenberg 2007, p. 317 and Roxin 2006, p. 447.

239 Schultz in Seebode 1992.

240 Schultz in Seebode 1992.

2412 February 1966 BGH NJW 1966, 787.

242 Simester \& Sullivan 2007, pp. 132-133; Ashworth 2006, p. 394 and Stuckenberg 2007, pp. $317-$ 318.

243 Taylor, G. 2004A, p. 102. The Dutch Minister of Justice Modderman argued that 'even if he did not desire death, he wanted it eventually'. Eventually means conditionally here however, see Smidt 1881 I, pp. 80-81 and Kelk 2005, p. 184.

244 In Belgium, the similar concept is called 'eventueel opzet', see Kelk 2005, p. 184. In France and Italy respectively, 'dol éventuel' and 'dolo eventuale', see Badar 2009, pp. 455-456.

245 Stuckenberg 2007, p. 257.

246 Nieboer 1991, p. 163; de Hullu 2006, p. 221 and van Dijk, A.A. 2008, pp. 348, 370 and 410-411. Indirect intent is then referred to as 'certainty-intent.' 
indirect intention by probability of the result occurring. Most importantly, it is characterized by an additional attitude of the defendant as to the possibility that the result will occur. ${ }^{247}$

\subsection{Rationale}

Dolus eventualis serves two interrelated purposes. First of all, it enables an extended interpretation of dolus, just as dolus indirectus, in order to hold that results have been intended even though they were not wanted. If it cannot be proven that the accused either wanted to fulfil an offence element or knew this was almost certain, there can be no liability for dolus directus or indirectus. Without the extended form of dolus, this accused could not be convicted for an intentional offence. In legal systems that operate with only two kinds of fault, intention and negligence, this implies that only negligence liability is possible. A conviction for a negligent rather than intentional offence not only generally brings about a lower sentencing range; it also labels the actor's conduct as less reprehensible in comparison to the same conduct or result brought about intentionally. If intention would not apply to foreseen side-effects, the actor may be punished and stigmatized less severely than he deserves. In other words, eventualis is the application of criminal policy to cases, where it is felt that the punishment for the offence committed with negligence would be too low. ${ }^{248}$

Moreover, not every intentional offence has a counterpart that criminalizes its negligent commission. Attempt also requires at least a conditional intent. In those contexts, the negation of intent would negate liability completely. By the extension of dolus to eventualis, the actor who was aware of a lethal risk but accepted this as collateral damage is put on the same footing as the actor who intended to kill. To justify this, it is argued that by being aware of the possible consequences his conduct may have, the actor is warned he may possibly cause harm and incur criminal liability. Since he decided to act notwithstanding the risks, the actor is reproached for his choice. The actor shows that he was insufficiently motivated not to violate legal interest and to act in conformity with the law. ${ }^{249}$

Secondly, eventualis plays an important role in facilitating the convictions of defendants for intentional offences. In general, an offence element that resembles intention can be fulfilled by either proof of dolus directus, indirectus or eventualis. Some elements imply that the actor at least had dolus directus or indirectus. This can either follow from the terminology or the nature of the element to which intention refers. For example, driving can hardly be imagined as done with anything

247 Most scholars who use the term 'chance-intent' reject this volitional element and focus solely on the cognitive part of conditional intent, reducing it to acting despite awareness of a risk, see IV.3.6.6.

248 Politoff \& Koopmans 1991, p. 135 and Puppe in Kindhäuser, Neumann \& Paeffgen 2010 notes $14-22$ on $\$ 15$.

249 See IV.2.2.1.; Schönke \& Schröder, H. 2006, pp. 269 and 351 and Arzt 1976, p. 657. 
else than direct intent. Offences of ulterior intent usually imply by terms as 'with a view to' that they can only be fulfilled by dolus directus, but it has become clear that in many cases, dolus eventualis also suffices. ${ }^{250}$ For the greater part, offences that require intent can therefore be fulfilled by proof of eventualis. As a consequence, the prosecution generally only seeks to prove that the defendant acted with dolus eventualis. This is easier to prove, because its cognitive and volitional criteria are of a much lesser degree than in dolus (in)directus. It does not need to be proven that the actor knew something was almost certain to happen, merely that he was aware of a(ny) chance that a result would materialize. It does not need to be proven that the actor wanted a result to occur; merely that he accepted that this could happen.

Proof of intent is not only facilitated because eventualis suffices for almost all intentional charges and only requires proof of diluted manifestations of knowledge and wanting. This facilitation is further reinforced by the manner in which these criteria of eventualis are procedurally established. Of all fault elements, eventualis is most likely to be objectively inferred from facts and circumstances. I will demonstrate that the awareness of a chance is often inferred from general knowledge that specific conduct is dangerous and that the acceptance of the risk is established usually on the omission to stop the conduct after realizing the danger. ${ }^{251}$ In practice, this may go as far as holding the defendant liable for intentional homicide when a reasonable person would have foreseen the risk of fatalities. I will reject such an objective evidential approach, after having explained the conditions of dolus eventualis.

\subsection{Criteria}

Dolus eventualis can be defined as the conscious acceptance of a considerable chance to a consequence. The actor foresees the result's occurrence as possible and accepts the fact that his conduct could cause the result.252 For example, the defendants wanted to subdue the victim by strangling him with a leather belt. They knew there was a possibility that the victim might die, but wanted to put him out of action at all costs. ${ }^{253}$ I will generally refer to the conscious acceptance of a consequence, because this is usually charged and easiest to imagine. Nonetheless, eventualis can relate to the fulfilment of any offence element, including conduct

250 See IV.2.4.5.; Bohlander 2009, p. 67; Schönke \& Schröder, H. 2006, p. 27 and Fischer, T. 2009, p. 105.

251 De Hullu 2006, p. 219 and van Dijk, A.A. 2008, p. 349. Framed even more negatively, dolus eventualis can also be regarded as a way out for the judge who did not sufficiently investigate the circumstances of the case, see Politoff \& Koopmans 1991, p. 141.

252 De Hullu 2006, p. 222; HR 15 October 1996, NJ 1997, 199; Krey 2003, pp. 118-121; Fischer, T. 2009, p. 107 and Beulke 2008, p. 78.

25322 April 1955 BGH NJW 1955, 1688. 
and circumstances. An example of the latter is the actor who consciously accepts the chance that the person he has sexual intercourse with may be of minor age.

The fault element can be distinguished as other forms of dolus into a cognitive and a volitional part. ${ }^{254}$ The cognitive part consists of the awareness of a considerable chance; the volitional part is about the attitude of the actor, about whether he accepted and took the risk that the offence element would be fulfilled into the bargain. This second feature of eventualis enables the demarcation of dolus and culpa. It limits intentional criminal liability. If a person accepts that the result could occur he acts intentionally, but if a person is aware of this chance but trusts in a good outcome, the volitional element is missing and he can only be held liable under conscious or advertent negligence. The volitional element is therefore very important, but at the same time controversial. As will be explained later, many scholars reject such an element as a criterion of eventualis and explain the difference between dolus and culpa differently. Under the theory that the cognitive element is most or only important, it is assumed that when an actor acts, despite awareness of the risk, he must have wanted or at least accepted that risk. The volitional element need not be established separately. ${ }^{255}$

The volitional part of dolus eventualis consists of a heavily diluted form of the element of wanting traditionally required for proof of dolus directus. ${ }^{256}$ It does not need to be proven that the actor wanted a result to occur; merely that he accepted that this might happen. Compared to dolus indirectus, its cognitive part is just as diluted. It does not need to be proven that the actor knew something was almost certain to happen; merely that he was aware of a chance that a result would materialize. It is said that dolus eventualis is about knowing and wanting, but it could therefore just as easily be argued that eventualis is about neither knowing nor wanting. In other words, dolus directus and indirectus consist of a great degree of volition or knowledge. They either have a strong volitional or cognitive aspect, and this similarity allows them to be viewed as equally culpable. ${ }^{257}$ Eventualis, in contrast, consists only of residues of both aspects. This difference militates against an equation, suggesting instead a strict separation of dolus directus and indirectus on the one hand and eventualis on the other.

\subsection{Risk}

The cognitive component of dolus eventualis focuses on the knowing that there is a possibility a result will occur as a consequence of the defendant's actions. Two aspects are distinguished, on the one hand the risk that a result will occur and on the other the awareness of this risk. ${ }^{258}$ The distinction is warranted because

HR 9 November 1954, NJ 1955, 55 and 22 April 1955 BGH NJW 1955, 1688.

Mevis 2006, p. 593. See IV.3.6.6.

Roxin 2006, p. 437.

257 See IV.2.3.2.

258 De Hullu 2006, p. 222 and AG Hofstee in HR 26 October 2010, $L J N$ :BO2514. 
although the actor must be aware of a chance subjectively, the likelihood of that chance is assessed mostly objective. I will now focus on the latter element.

\subsubsection{Possibility versus considerable risk}

There must be a chance that the result will occur. The question is exactly how likely this occurrence must be. In the Netherlands, it is common to refer to a considerable chance that a consequence occurs. ${ }^{259}$ Most German scholars also require the perpetrator to seriously consider the possibility. ${ }^{260}$ It could be concluded therefore that the risk of dolus eventualis must be considerable, but the German Supreme Court consistently holds that any possibility that is not entirely unlikely suffices. ${ }^{261}$ In other words, there is hardly any threshold as to probability in German criminal law. This can be contrasted with the considerable chance in the Netherlands and is perhaps the most important comparative difference to be taken into account.

\subsubsection{Chance of being infected with HIV}

By merely requiring that the fulfilment of the offence element is possible, it could be expected that the German judiciary tends to establish conditional intent in relatively more instances than the Dutch judiciary. This assumption is confirmed in the context of having unprotected sexual intercourse whilst knowingly being HIVpositive. These cases have resulted in defendants being charged with the intentional infliction of serious bodily injury, ${ }^{262}$ and judgments on just how likely the consequence of infection must be in order to accept conditional intent.

The conclusion that can be drawn from Dutch case-law is that unprotected sexual intercourse only brings about a considerable chance under 'certain riskincreasing circumstances'. ${ }^{263}$ Generally considered to increase the risk are repeated instances of unprotected intercourse, anal rather than vaginal intercourse and being

259 De Hullu 2006, p. 222. Kouwen \& Bruinberg 2006, p. 485 translate 'aanmerkelijk' as 'considerable'. The older and lesser criterion of 'geenszins als te verwaarlozen kans', is insufficient now, see HR 9 November 1954, NJ 1955, 55; Rozemond 2006, p. 62 and Rozemond 2007B.

260 Krey 2003, pp. 120-121, Fischer, T. 2009, p. 107 and Beulke 2008, p. 78: 'ernstlich für möglich halten'. The draft German Criminal Code referred to a mere possibility, but the alternative draft added that this possibility should be serious, see Roxin 2006, p. 449.

2617 July 1999 BGH NStZ 1999, 507; 12 August 2009 BGH BeckRS 2009, 25029; Krey 2003, pp. 118-119, Fischer, T. 2009, p. 107: 'nur möglich und nicht ganz fernliegend'. Translation from Badar 2005, p. 234.

262 The charge of (attempted) intentional killing is not deemed appropriate to these cases. In the Netherlands, this is accepted as evident, but in Germany, the question whether HIV-infection consitutes killing or inflicting bodily injury has been fiercely debated. See Roxin 2006, pp. 476477; Frisch in Joerden a.o. 2009, pp. 504-520; Schünemann in Szwarc 1996; Schünemann in Arnold a.o. 2005; Herzberg in Szwarc 1996 and Canestrari 2004, p. 214.

263 HR 18 January 2005, NJ 2005, 154: 'bijzondere risicoverhogende omstandigheden' which is translated as 'certain, risk-inducing circumstances' by Kouwen \& Bruinberg 2006, p. 486. 
on the receiving end as far as penetration and ejaculation is concerned. The Supreme Court, nonetheless, dismissed that the chance was considerable in a case that included all the above-mentioned circumstances, holding that the risk was increased, but not in a manner that amounted to 'certain risk-increasing circumstances'. This begged the question what then would qualify as such circumstances. $^{264}$

In sharp contrast, the decision to accept conditional intent to bodily injury based on an empirically small chance was approved by the German Supreme Court in 1988. The defendant had had unprotected anal sex two times, 'but' had used a condom before ejaculating. ${ }^{265}$ Many more convictions have followed since then, including the conviction in 2010 of singer Nadja Benaissa, who received a conditional sentence of two years imprisonment. ${ }^{266}$ A consideration on the degree of the risk is absent in these judgments, holding merely that having unprotected sexual intercourse can infect the victim. This seems to demonstrate that the threshold of the considerable risk in conditional intent is much lower in Germany. However, we need to be extremely careful when inferring general conclusions from this context.

Considering that in the Dutch case mentioned above, the considerable risk was empirically far greater than in many other cases where conditional intent was accepted, ${ }^{267}$ the express consideration in the judgment on the reluctance of the Minister to criminalize the (possibility of) HIV-infection can lead one to conclude that the Dutch Supreme Court just did not want to establish liability in these cases. $^{268}$ In all the four times the Supreme Court was requested to decide on the issue, it quashed a conviction based on conditional intent. This suggests that the application of conditional intent to these cases was evident to the courts that convicted the defendants. ${ }^{269}$

The Dutch criminal policy is to avoid criminalization altogether, in contrast to Germany, where the liability to inflict bodily injury has been considered as a compromise between considerations of retribution and considerations of public health, such as the fear that liability would prevent people from testing themselves. ${ }^{270}$ It

264 HR 20 February 2007, NJ 2007, 313.

2654 November 1988 BGHSt 36, 1.

266 Süddeutsche Zeitung, 17 August 2010.

267 Van Asperen de Boer 2007 argues that the chance of infection of 1 in 300, has increased to 1 in 7 when the defendant and victim had unprotected sex for 50 times.

268 Van der Wilt, C. J. 2007; Rozemond 2007A and de Jong, F., van Roomen \& Sikkema 2007, pp. 946-949 and Lensing 2008.

269 HR 25 March 2003 NJ 2003, 552; HR 24 June 2003, NJ 2003, 555; HR 18 January 2005, NJ 2005, 154 and HR 20 February 2007, NJ 2007, 313. The cases of 25 March 2003 and 18 January 2005 concern the same defendant and the same charges.

270 Other arguments against criminalization are the responsibility of both partners having sexual intercourse, the private sphere of the conduct, the difficulty to enforce and the arbitrariness as to other diseases. For example, Spong \& van Dijk, J-H 2007A submit that the chance to get hepatitis B from unprotected sexual intercourse is much higher, namely 1 in 3 or 4 . For more arguments in favour and against criminalization see Szwarc 1996. 
therefore seems better to view this and similar decisions as decisions on HIV, rather than intent. ${ }^{271}$ These cases have been used nonetheless, as they most clearly illustrate the difference in the two versions of conditional intent.

\subsubsection{The likelihood and its acceptance}

It should therefore not be concluded that this lower threshold on the risk occurring generally leads to a finding of conditional intent in more cases in Germany. In fact, rather the opposite seems to be the case. Amongst others, this is because of the relationship between the degree of the risk and its acceptance. In Germany, low probability is often seen as an evidential indication that the actor did not accept the consequences occurring. The less likely a result was to occur, the more likely a court will decide that the defendant did not accept this possibility. ${ }^{272}$

Let us reconsider cases of HIV-infection. German scholars have criticized the acceptance of conditional intent because the low probability of infection could give rise to a justifiable argument that the defendant trusted nothing would happen. This means that the low probability is therefore not directly a problem relating to the required degree of the risk, as this is no substantial hurdle to liability in Germany. The degree of the risk is seen as an indirect problem to establish that the actor took the risk into the bargain. It is considered unlikely that someone has accepted the small chance that someone might get infected. ${ }^{273}$ The German Supreme Court has consistently held that the objective magnitude and proximity of the danger can be used as indications of acceptance. ${ }^{274} \mathrm{~A}$ contrario, a less than considerable chance should thus help the defendant in making probable he trusted in a good outcome.

It frequently occurs that a driver of a vehicle is ordered to stop by a police officer, but he refuses and continues to drive, whereby the officer has to jump aside to escape collision with the vehicle. Whereas this is generally charged and often accepted as attempted intentional killing in the Netherlands, ${ }^{275}$ it is not considered to constitute this offence in Germany. German courts have argued that the defendants bank on the reaction of the policeman. They accept endangering them, but they do not actually contemplate that they will be killed. The defendants are thought to have considered the chance of death as improbable, as the defendant trusts the officer expects such actions and is mentally prepared to jump, which is confirmed by the fact that these situations hardly ever lead to fatal results. There is

\footnotetext{
271 Annotator Buruma in HR 20 February 2007, NJ 2007, 313 and Tanghe 2007, p. 311.

272 Fischer, T. 2009, p. 107 and Schönke \& Schröder, H. 2006, p. 286. See also Kwakman in Keulen, Knigge \& Wolswijk 2007, p. 299-300.

273 Bohlander 2009, p. 66; Roxin 2006, p. 476; Fischer, T. 2009, p. 107; Schönke \& Schröder, H. 2006, p. 286 and Frisch in Joerden a.o. 2009, pp. 498-501.

2744 November 1988 BGHSt 36, 1 and Bohlander 2009, p. 65.

275 Van Dijk, A.A. 2008, pp. 236-237; de Hullu 2006, p. 221; Peters, A.A.G. 1966, pp. 133-135 and for example, HR 15 January 2008, NJ 2008, 609. See also HR 6 February 1951, NJ 1951, 475.
} 
therefore no acceptance of death and no liability based on conditional intent. ${ }^{276}$ The awareness of only a small chance suggests the accused did not accept the death of the officer.

The degree of the risk will have to be given a minimum threshold, because there is a difference between the mere general abstract possibility of a consequence occurring and a concrete one: we take risks all the time. ${ }^{277}$ There must be a certain threshold, short of which there can be no criminal liability. After all, should criminal liability also follow in those HIV-cases where the defendant used a condom? ${ }^{278}$ In distinguishing criminally relevant from irrelevant risks, there are two options. We can either set the lower limit of the degree of the chance itself as in the Netherlands, or exclude merely possible risks through the volitional element of acceptance as in Germany. Either way, this implies in effect that a risk must be considerable in order to enable intentional liability, be it directly through the cognitive or indirectly through the volitional limb.

In shaping dolus eventualis, the direct solution is favoured, because the appropriate dogmatic positioning of the degree of the risk is in the cognitive limb, which is also acknowledged by most German scholars. The indirect approach whereby a small chance indicates non-acceptance blurs the distinction between the two limbs, because the awareness of a risk is assessed under both limbs of eventualis. Second, the volitional limb is considered most controversial. There is much debate on the question whether we should require a volitional component at all, what it requires and how this should be established. Therefore, the volitional element is best kept as simple as possible. The more aspects or functions are attributed to this limb, the more controversial it becomes, the more difficult it is to separate the different aspects of eventualis and so on.

\subsubsection{The assessment of risks}

A judgment on a chance can be either qualitative or quantitative. Qualitative chances are expressed with terms like probable, considerable and certain; quantitative risks can be expressed in percentages. In criminal law, a chance is rarely expressed quantitatively. However, in all three Member States lawyers tend to approach the criterion of risk in conditional intent and recklessness more and more empirically. Dutch courts, in contrast to German courts, have approached the chances of HIV-infection very quantitatively, by having experts assess the risk in

276 Bohlander 2009, pp. 65-66; Frisch 1983, pp. 330-331 and 335; Roxin 2006, pp. 467 and 471; Krey 2003, pp. 128-129 and Schönke \& Schröder, H. 2006, p. 285. For example, 21 November 1995 BGH NStZ-RR 1996, 97. It should be noted that these drivers could be held liable for violating $\S \S 315 \mathrm{~b}$ or $315 \mathrm{c}$ of the German Criminal Code, which is punishable by up to 10 years of imprisonment. Morkel 1981.

278 See Frisch in Joerden a.o. 2009 and Bottke in Szwarc 1996, pp. 293-301. I will argue that in the similar concept of recklessness, this scenario is also excluded from liability, but not by reference to an empirical threshold of the risk, see IV.4.5.1. 
probabilities. This trend is to be applauded in light of the principle of legal certainty. Additionally, it helps to make judicial decisions more understandable and well reasoned. The consulting of experts seems to lead to a more substantial discussion in court on whether the risk was considerable or not.

We must be wary again, however, of attaching too much weight on an empirical assessment, considering that chances can often not be established very precisely. Most criminal charges do not lend itself to statistical calculation of a risk. Assumptions underlying the use of statistical information are that the future will be like the past and that cases compared are comparable. This is however hardly ever correct. ${ }^{279}$ For example, in traffic offences we can estimate the risk to fatal accidents as a result of speeding by reference to casualty statistics. This estimation does not, however, prove the risk of that specific case of speeding under those circumstances. What about the weather, the driver, the car, the victim? In the past, the risk of accidents due to speeding in bad weather conditions was greater due to the lack of technology like anti-lock braking system. It is often impossible to pinpoint the exact objective chance. Statistical or empirical research on many chances is lacking, so often, we are merely guessing. Nonetheless, as science continuously advances, objective chances may be established more and more precise.

Another problem is that we do not know what quantitative chance corresponds to the qualitative label 'considerable'. By using a table that transposes qualitative into quantitative risks, we could argue that a 'considerable risk' implies a chance of at least fifty percent. ${ }^{280}$ However, from case-law we can deduce that the required threshold is set much lower. It is the context of a case that co-determines what quantitative chance suffices for a qualitative label. In some contexts, such as in routine medical operations, small chances are perceived as considerable. When a range of chances varies between 0.01 and 0.50 percent, the latter chance is not considered as small as it seems from a mathematical point of view. By contrast, a chance of 1 in 200 of winning a lottery is extraordinarily great.

Some have set the lower limit of a considerable chance of a consequence occurring at 10 percent. ${ }^{281}$ It is argued that the Dutch Supreme Court is not as keen on statistics as might appear from the rulings on HIV-infection. ${ }^{282}$ This seems likely when we consider that in many cases, the chances of the result occurring will not have been as great as 10 percent. Given the abovementioned problem that usually there is no empirical information on chances, the judiciary tends to use the more general criterion whether a chance is substantial according to 'general experience'. ${ }^{283}$ General experience consists of knowledge on risks as perceived by society. This yardstick leaves room for many factors to be taken into account and provides the courts with more discretion. Whereas experts can therefore help the

\footnotetext{
279 Van Dijk, A.A. 2008, p. 395.

280 Van Dijk, A.A. 2008, p. 399.

281 See de Hullu 2006, p. 224 and by contrast, de Hullu 2009, p. 232.

282 De Jong, F., van Roomen \& Sikkema 2007, pp. 946-949.

283 HR 25 March 2003, NJ 2003, 552 and HR 22 March 2011, LJN:BP2715.
} 
court in deciding whether a chance is considerable, in the end, it is a legal question and thereby decision of the court.

'General experience' enables the courts to hold that the risk is considerable and that since this is generally known, the defendant also knew this. In principle, this approach need not be problematic, but under the umbrella of general experience many risks are deemed to be considerable, which conclusion is only rarely based on data or expert calculation. It is for example remarkable that the chance that a police officer dies when the driver of a car does not stop is considered to be small in Germany, based on casualty statistics of such situations, yet is generally perceived to be considerable in the Netherlands. It appears that the Dutch courts overrate the statistical chance in order to attribute intent to the defendant. The use of general experience can therefore be criticized as camouflaged normativism.

The defendant should therefore try to dispute the generality of this knowledge. He can rebut that something is in fact not generally known in society, or at least not by him. The defendant can point at the specific circumstances of the case that seem not to have been taken into account. An example deals with the situation where the victim lies on the ground and is kicked in the head. The defendant usually faces a combined charge of inflicting serious bodily injury and attempting to kill. ${ }^{284}$ This is based on the (empirical) fact that this conduct often leads to severe injuries or death. Moreover, almost everybody recognizes the seriousness of the possible results and most people also recognize the possibility of death. At the same time, however, relevant facts that influence the risk, such as the nature of the shoes, sex, bodily stature and physical shape of the defendant seem to be irrelevant for the outcome. ${ }^{285}$

\subsubsection{Relevant factors}

What factors should then be taken into account in assessing the chance in eventualis? The rule under Dutch law is that the chance must be considerable based on general experience, depending on the circumstances of the case, such as the nature and circumstances of the act. ${ }^{286}$ I already gave the example of having unprotected sexual intercourse. The nature and circumstances of that act greatly influence the chances of infection.

In theory, it is irrelevant for the chance whether it also occurred. The fact that the victim was infected with HIV does not make the chance considerable. What matters after all, is the assessment ex ante. Neither can the severity of the consequence be taken into account. Being infected with HIV is more serious than being infected with herpes, but that aspect does not affect the chance of infection. ${ }^{287}$ This differs from risk-assessment in other contexts, where the acceptability of the

28412 August 2009 BGH BeckRS 2009, 25029.

285 Heinke 2010.

286 HR 25 March 2003, NJ 2003, 552 and de Jong, D.H. \& Knigge 2003, p. 111.

287 HR 20 February 2007, NJ 2007, 313; de Hullu 2006, p. 223-224 and Fokkens \& Machielse, note 3.4 on Opzet. 
fulfilment of the risk is co-determined by its expected damage, weighed against the costs for preventing a risk to occur.

Assessing a risk that way can be called normative. We have used the terms 'risk' and 'chance' interchangeably so far, but they can be distinguished accordingly. A chance can be small, but a risk great, such as the small chance a nuclear plant might explode. The question on whether a risk is great, is determined by both the chance of the consequence occurring and the seriousness of these consequences. Taking into account the seriousness of the result makes the assessment normative. Many scholars have argued in favour of assessing the chance normatively, where a very serious legal interest would lower the required empirical likelihood of the chance occurring. ${ }^{288}$ For example, some Dutch scholars advocated criminal liability in the HIV-cases by assessing the risk normatively. The fact that the chance might lead to serious bodily harm and that it can easily be avoided, does not influence the question of whether unprotected sexual intercourse amounts to a substantial chance to HIV-infection, but it does confirm the question whether there was a considerable risk. ${ }^{289}$

A normative risk begs the question on the relationship of the chance, the legal interest and other factors. How do we weigh the legal interests? On a scale of 10, do we give a factor of 10 for the interest of human life and a factor of 2 for the interest of property of a bicycle? Do we use this factor as a multiplier for the empirical chance? This implies that the more valuable a legal interest is, the sooner a risk becomes considerable. This could very well lead to a disparity depending on the seriousness of the charges. ${ }^{290}$ In a normative concept of dolus eventualis, creating a small, yet lethal chance would lead to a considerable risk. As a result, drivers of automobiles would, as a rule, be held intentionally liable for any casualties they cause.

This can be countered by also taking into account whether the conduct has value or social interest. ${ }^{291}$ If conditional intent is seen as a 'legally unacceptable chance', ${ }^{292}$ normativism includes more than the legal interest involved. Driving a car is legal conduct that is considered to be useful, in contrast to stunting with fireworks. Consider that the former conduct leads to a pedestrian being lethally injured due to collision and that the latter conduct leads to a spectator losing his sight to one eye. The empirical chances of these results occurring are equal. Now, the adequacy of the conduct can bring about that the death of the pedestrian is not considered a relevant risk, whereas the injury to the spectator does fulfil the

288 Kessler 2001, pp. 218-219; de Jong, D.H. \& Kessler 2002; de Jong, D.H. in Groenhuijsen \& Simmelink 2003, p. 218; AG Vellinga in HR 18 January 2005, NJ 2005, 154; Fokkens \& Machielse, note 3.5 on Opzet and de Jong, D.H. 2004B, p. 77, referring to Nieboer and Strijards. See also the annotator and AG in HR 25 March 2003, NJ 2003, 552. 
criterion of eventualis. ${ }^{293}$ Assessing risks normatively can thus both extend and limit liability in comparison to the empirical chance.

The normative risk can further be enriched with the question whether or not the risk was easy to avoid. For example, using a condom easily reduces the risk of infection to almost nil. ${ }^{294}$ We can then make a list of factors influencing the question on whether or not the risk is considerable: the nature and degree of the risk of harm, the social interest of the act, the actual goal of the actor, the probability that the risk occurs versus the probability that the actual goal is fulfilled and precautionary measures. ${ }^{295}$ The result is a normative criterion that depends on many valuations. Rather than assessing whether the risk is considerable, it would be determined whether the risk was unreasonable. ${ }^{296}$

Although a normative risk is quite popular among scholars, the official position of the Dutch and German judiciary is that risks are not assessed normatively. The law as it stands neither takes into account the nature of the legal interest, nor the seriousness of the consequences. ${ }^{297}$ Nonetheless, I discussed this in quite some detail because in practice, normative considerations do seem to play a role, which also demonstrates the conflict inherent in the concept. More importantly, a normative concept of dolus eventualis is very similar to its functional equivalent recklessness. The only important difference is that eventualis is not a third kind of fault in between dolus and culpa. It is problematic to treat the risk normative in the context of dolus, which is a psychological concept, yet I will argue that a normative assessment of the risk is not problematic when it is conducted within the scope of recklessness. In the concept of recklessness, the theoretical concept and its applications in practice coincide.

\subsection{Awareness of the risk}

At the time of acting, the accused must have been aware of the possible fulfilment of the offence definition. The legal ex post risk assessment is carried out by using empirical data, general experience and/or normative considerations. However, this objective $^{298}$ chance not necessarily coincides with the subjective perception of the chance tempore delicti. People are generally unaware of the specific chances of

293 Some argue that self-endangerment should also be taken into account in assessing the normative risk, see Frisch in Joerden a.o. 2009, p. 503.

294 De Jong, D.H. in Groenhuijsen \& Simmelink 2003, p. 218 and Frisch in Joerden a.o. 2009, p. 503.

295 Canestrari 2004.

296 Frisch 1983, pp. 462-462, 474 and 495.

297 De Roos in Cleiren, de Roos \& van der Woude 2006, p. 267; Fokkens \& Machielse, note 3.4 on Opzet; de Hullu 2006, pp. 223 and 230 and annotator Buruma in HR 20 February 2007, NJ 2007, 313.

298 The assessment of a chance in criminal law is hardly ever truly objective like the rolling of a dice. It is 'intersubjective' as it is derived by the accumulated knowledge and information of society, see van Dijk, A.A. 2008, p. 392. 
risky behaviour. For example, people driving too fast are usually not aware of how this increases the risk of fatalities (in \%) and people who make a habit out of this, sometimes tend to assess or dismiss the chances too low as result of risk habituation. On the contrary, people tend to assess spectacular risks like airplanes crashing as greater than they are in reality.

In the night of 26 to 27 October 2005, a fire broke out in a detention centre near the Dutch international airport Schiphol. Eleven people lost their lives and several more were severely injured. A person, who was awaiting deportation from the Netherlands, was charged with intentionally causing this fire, creating a lethal danger for others. ${ }^{299}$ The Dutch courts established that it was most likely that the fire was caused by the defendant's cigarette. He testified that he had smoked a cigarette whilst lying on his bed. Thinking the cigarette, because it was rolled with rice paper, had already stopped smouldering, he did not stub it out, flicked it in the direction of the foot and went to sleep. Apparently not much later, he awoke due to heat in the vicinity of his feet. He saw the sheets burning, and fire rapidly spreading through the room.

The Dutch Court of Appeal established that the defendant must have had conditional intent and convicted the defendant to 18 months imprisonment. The Court held that it is general experience, confirmed by tests run by experts, that the risk of a cigarette causing fire in such a situation is considerable. Because the defendant had not stubbed out the cigarette in an ashtray or made sure it was not smouldering anymore, whilst knowing there was a crumpled up bed sheet and toilet paper in the direction where he shot the butt, the Court assumed that he consciously accepted the risk. 300

The degree of likelihood that a fire would be started was fiercely debated. Defence had persistently requested additional statistical research on this degree in these specific circumstances. What if the defendant, in throwing away the cigarette, thought there was some risk to setting a fire, but believed that this chance was minimal because he used rice paper to roll the cigarette, which makes the cigarette stop smouldering after a short while? Defence had argued that this circumstance was important in assessing the risk and had requested for another expert to do additional tests. The fact that the Court of Appeal rejected this was a reason for the Supreme Court to quash the conviction, especially since the decision that the chance was considerable was based on such research. ${ }^{301}$

The case demonstrates we can separate an objective chance from the question whether or not the defendant is aware that there is a possibility the offence element

299 He was also charged with the more serious crime of intentional killing, but causation between the defendant's actions and the fatalities was held to be lacking. Suspicion was confirmed in 2006 by the so-called Safety Board, that the extent of this disaster could be attributed amongst others to the poor construction of the building, the materials used, the fact that a door had been left open allowing the fire to spread, the poor functioning or non-existence of safety measures and the fact that the fire brigade arrived very late.

301 HR 14 December 2010, $L J N$ :BO2966. 
will be fulfilled. ${ }^{302}$ In theory, conditional intent requires that the defendant was subjectively aware that the chance was considerable. This implies that intentional liability should be negated if the defendant thought that the chance was much smaller. ${ }^{303}$ In practice however, it seems that this will hardly ever present difficulties in finding conditional intent. It seems dolus eventualis requires that defendant must be aware of $a$ chance. This chance must also be considerable, but this is established objectively: the defendant need not be aware of this. ${ }^{304}$

The practical explanation for this result is that subjective awareness is usually assumed from the objective chance. In theory, only the subjective perception on the degree of the chance is decisive, but in practice it is derived from the objective assessment of the chance. ${ }^{305}$ In case-law, this is evident in phrases such as 'that the defendant must have known.' Since the two perceptions are not distinguished, courts can implicitly infer the subjective perception from the objective chance, ${ }^{306}$ and a difference between the two is hardly ever discussed. In the Schiphol-case, the Court of Appeal established that the chance of causing a fire was considerable by reference to general experience and expert evidence. Without considering the defendant's perception on the likelihood of the risk occurring, the question was asked whether the defendant took this chance into the bargain. Hence, the subjective awareness of the defendant was implicitly deduced from the objectively assessed chance.

Another practical explanation why the formal approach hardly ever presents difficulties for conviction is that the criterion of 'considerable' itself is vague enough for courts to overcome any evidential problems in these scenarios. Since there is no exact threshold on what is considerable, it can be questioned whether the defendant did not also assess the chance similarly but attached a lesser label to it. If on both views, the chance was about 10 percent, why should it be decisive that the defendant thought this was not considerable?

I have demonstrated how in practice, the requirement of subjective awareness of a considerable chance is no obstacle to liability. As far as chances that are subjectively perceived as less than considerable, similar solutions could be reached in a more principled way by taking the approach of recklessness. Dolus eventualis could merely require that the defendant must be aware of a risk, but the valuation of that risk is conducted objectively. In the Schiphol-case, eventualis could then be

302 Frisch 1983, pp. 487-494 and van Dijk, A.A. 2008, pp. 392-394.

303 Fokkens \& Machielse, note 3.5 on Opzet; AG Machielse in HR 14 December 2010, LJN:BO2966 and Beulke 2008, p. 81.

304 See HR 25 March 2003, NJ 2003, 552; AG Hofstee in HR 26 October 2010, $L J N$ :BO2514; de Jong, D.H. \& Knigge 2003, p. 111 and van Dijk, A.A. 2008, pp. 392-394. The wording in HR 19 June 2007, NJ 2008, 169 implies this too: “(...) of zij willens en wetens de naar algemene ervaringsregels aanmerkelijk te achten kans heeft aanvaard (...).” takes an objective approach, not even requiring subjective awareness of any chance.

306 Van Dijk, A.A. 2008, p. 394; Reijntjes in Groenhuijsen \& Simmelink 2003, p. 484 and 4 November 1988 BGHSt 36, 1 . 
accepted if the defendant was aware that a smouldering cigarette could cause a fire. It would not matter that he considered this chance as less than considerable due to the nature of that particular cigarette. Only such an approach can theoretically explain the acceptance of conditional intent in cases where the subjective perception of the chance diverges from the objective chance.

Both fault elements should however at the very least safeguard that the defendant was aware of a risk. If the defendant did not think about a risk at all, he should be held liable for negligence at most. ${ }^{307}$ Foreseeability should not be equated with foresight of risks. The most severe reproach in criminal law is based on the strong subjective connection between the actor and the result. This foundation is lacking if there is no subjective awareness. There are many competing theories on conditional intent, but they all concur that the defendant must have been aware that his actions may lead to an offence being committed. ${ }^{308}$

\subsection{Accepting the risk}

The awareness of the risk is insufficient to demarcate dolus from culpa in Dutch and German law, because in cases of conscious negligence, the defendant is also aware of the risk. The distinction between dolus eventualis and conscious negligence hinges on the question whether he accepted the risk or not. ${ }^{309}$ Dolus eventualis requires that the defendant accepted the possibility that the risk may occur. He considered the risk and decided he wanted to act nonetheless. This volitional element is negated when the actor believed the risk would not materialize, when he trusted in a good outcome. ${ }^{310}$ In case the volitional component is absent or cannot be proven, only conscious negligence exists. As an important consequence, he cannot be held liable for an intentional offence.

As the wording is concerned, it should be noted that accepting the risk is not the same as accepting the consequences. ${ }^{311}$ The volitional element requires acceptance of the possibility that the risk may materialize, that the offence element will be fulfilled. Strictly speaking, the actor can also accept the risk because he trusts in a good outcome. In that case, there is no volition and thus, no dolus eventualis. Wherever I refer to the mere acceptance of the risk, I use it as an abbreviation of accepting that the risk may materialize.

307 Annotator Buruma in HR 25 March 2003, NJ 2003, 552 and 556 and HR 10 October 2000, NJ 2001, 4.

308 Bohlander 2009, p. 64. Moreover, without being aware of a risk, a person cannot have either accepted the possibility or dismissed it as unlikely to happen.

309 Remmelink 1996, p. 206; Machielse 2004, p. 158; de Jong, D.H. \& Knigge 2003, p. 97; Keulen \& Otte 1999, p. 22; 22 April 1955 BGH NJW 1955, 1688; 4 November 1988 BGHSt 36, 1; Bohlander 2009, p. 65; Fischer, T. 2009, p. 106; Krey 2003, pp. 128-129 and Beulke 2008, p. 78.

310 Roxin 2006, pp. 457-459 and Schönke \& Schröder, H. 2006, p. 283.

311 HR 15 October 1996, NJ 1997, 199. 
Since German law does not require that the risk must be considerable, the limiting function of the volitional element is more important than in the Netherlands. I explained that it is often assumed that the defendant did not accept the realization of a risk that was merely possible, whereas under Dutch law, a small chance has already been excluded from conditional intent under the cognitive limb. ${ }^{312}$ In addition, the volitional element is taken more serious in Germany, because the Supreme Court applies strict requirements to a finding of volition and any remaining doubt is solved to the benefit of the defendant. As will be explained, all circumstances, those that indicate and those that militate against acceptance, must be considered explicitly. The volitional element may not be simply inferred from acting whilst being aware of the risk.

Although the volitional element provides for a clear theoretical demarcation between dolus eventualis and conscious negligence, it will be shown that in practice there seems to be a fluent transition between the two, ${ }^{313}$ which puts its demarcating potential in perspective, if not in doubt. The contents of the volitional limb are even more controversial than the cognitive. Minority opinions even go as far as denying any volitional element at all. ${ }^{314}$

\subsubsection{Acceptance of the risk}

The exact extent to which the defendant must have accepted the risk is expressed in numerous ways. The extent ranges from a form of volition that falls short of desire to indifference. I encountered, amongst others, the following terms in German law: 'agree', 315 'approve', ${ }^{316}$ and 'accept the result and approve of it'. 317 The German Supreme Court uses 'approval' or 'taking into the bargain' but when the consequence is undesired, it also uses 'acquiescence,'318 the latter which is favoured by German scholars. ${ }^{319}$ In the Netherlands, there is consensus on the wordings '(conscious) acceptance' 320 or 'taking the consequences into the bargain'. ${ }^{321}$

312 This also explains why in this section, relatively more reference is made to German law, whereas in the previous section, most of the sources mentioned in the footnotes were of Dutch origin.

313 Beulke 2008, p. 82. See also de Hullu 2006, pp. 243-244.

314 Bohlander 2009, pp. 64-65 and Schönke \& Schröder, H. 2006, pp. 279 and 282. See IV.3.6.6. and IV.3.6.8.

315 'Einverstanden sein', see Fischer, T. 2009, p. 107.

316 'Billigen', see 6 June 1952, BGHSt 3, 105.

317 'Billigend in Kauf nehmen' is the common term for the BGH. See for example 12 August 2009 BGH BeckRS 2009, 25029. For most German terms, see Krey 2003, pp. 116-121.

318 'Sich damit abfinden', see 4 November 1988 BGHSt 36, 1; 7 July 1999 BGH NStZ 1999, 507; 18 September 2003 BVerwG NVwZ-RR 2004, 426 and 8 May 2001 BGH NStZ 2001, 475.

319 Krey 2003, pp. 120-121; Fischer, T. 2009, p. 107; Beulke 2008, p. 78 and Schönke \& Schröder, H. 2006, pp. 282-284.

320 HR 20 February 2007, NJ 2007, 313; Fokkens \& Machielse, note 3.2 on Opzet and Politoff \& Koopmans 1991, pp. 138-140.

321 Compare 'op de koop toenemen' in HR 15 October 1996, NJ 1997, 199 with 'billigend in Kauf nehmen.' 
The terms are quite similar but the nuance is different regarding the degree to which it is wanted. The actor must either endorse the result or at least come to terms with it for the sake of the desired goal. ${ }^{322}$ The terms of approval or consent seem to imply mental consent or a positive value judgment on the risk occurring. However, approval is used in a legal meaning, thus also encompassing those cases where the consequence was undesired and thus not 'approved' in the normal meaning of the word. ${ }^{323}$ It only means that the defendant accepts a result nevertheless in order to reach his or her ulterior goal. The actor decides to accept the whole package, both the wanted results and its possible but undesired side-effects. ${ }^{324}$ Acquiescence denotes this meaning better.

Therefore, the consequences can be anything from approved of to mere acquiescence. It has even been accepted that indifference suffices as a volitional element. ${ }^{325}$ By his indifference against the legal interest, the defendant also shows his hostile disposition against the legal order. Acceptance, approval and indifference are all characterized by the fact that the actor was not deterred from acting because of the possible consequence. ${ }^{326}$ The different volitional elements are not exclusive. Courts can cherry pick the disposition that confirms the volitional element. Acquiescence and the similar reconciling oneself with a result materializing are very weak forms of volition and therefore popular to use in judgments.

The negative of the volitional element can be described as trusting in a good outcome. The defendant realizes the risk, but dismisses it as very unlikely. He trusted in the non-occurrence of the consequence, or thinks everything will be all right. ${ }^{327}$ Even frivolous trust only amounts to negligence. ${ }^{328}$ On the other hand, the German Supreme Court requires that conscious negligence can only be accepted if the actor sincerely and seriously trusted the consequence would not occur. Thus, a vague, pious or uncertain hope does not suffice. ${ }^{329}$ The difference between frivolous trust and hope is hard to draw, ${ }^{330}$ yet essential in deciding whether the defendant can be held liable for an intentional offence.

\footnotetext{
322 Badar 2005, pp. 232-234.

323 Schönke \& Schröder, H. 2006, p. 282.

32422 April 1955 BGH NJW 1955, 1688; Fischer, T. 2009, p. 107; Badar 2005, p. 234; Beulke 2008, p. 80 and Taylor, G. 2004A, pp. 111-112.

325 Fokkens \& Machielse, note. 3.3 on Opzet; Keulen \& Otte 1999, p. 22; Remmelink 1996, p. 206; Modderman according to van Dijk, A.A. 2008, p. 220; 12 August 2009 BGH BeckRS 2009, 25029; 26 June 2003 BGH NStZ 2004, 35; Krey 2003, pp. 128-129; Jakobs 1995, pp. 862-863 and Roxin 2006, pp. 449-450 and 454.

326 Schönke \& Schröder, H. 2006, pp. 282-283.

327 HR 18 June 1996, NJ 1996, 750; Krey 2003, pp. 116-117; Fischer, T. 2009, p. 109; Roxin 2006, p. 1087 and Beulke 2008, pp. 79 and 247.

328 Krey 2003, pp. 122-123.

3294 November 1988 BGHSt 36, 1; 7 July 1999 BGH NStZ 1999, 507; 8 May 2001 BGH NStZ 2001, 475; Krey 2003, pp. 118-119 and Schönke \& Schröder, H. 2006, p. 284.

330 Schünemann 1985, pp. 363-364.
} 


\subsubsection{Proving the volitional element}

The contents of the volitional element are best understood by reference to how it is proven. This is no surprise when we reconsider that an important function of dolus eventualis is to facilitate proof of dolus as the most diluted form of knowing and wanting. Moreover, as the dividing line between dolus and culpa, the legal debate often focuses on (proof of) the volitional element.

It is difficult to prove the volitional element because it concerns an inner disposition of the actor, which is therefore mostly hidden from us. Attitudes or dispositions are very intimate. In order to avoid dealing with such complicated psychological processes, courts therefore prefer to focus on the "externalization of the presumed will." 331 From conduct under certain circumstances and through rules of general experience, it is inferred what the defendant thought and wanted. ${ }^{332}$ The ECJ deduces the anti-competitive nature of an agreement not only "from the content of its causes but also from a series of factors including, precisely, the intention of the parties as it arises from the 'genesis' of the agreement and/or manifests itself in the 'circumstances in which it was implemented' and in the 'conduct' of the companies concerned." 333

The Dutch Supreme Court held that objectification of the acceptance is only relevant when the testimonies of the defendant or witnesses do not lead to more insight in the state of mind of the defendant. Only then, the factual circumstances of the case become important, including the nature of the act and its circumstances. $^{334}$ It should be noted however that more insight could also be deemed necessary regardless of these testimonies. If the accused argues that he trusted in a good outcome, the credibility of that submission will be tested by reference to objective facts and circumstances. Eventualis is still accepted if the objective circumstances indicate that it is more than probable that he did accept the possibility that the risk would occur. ${ }^{335}$

In the next subsections, I will describe in which ways this volitional element tends to be proven in practice. These approaches have led scholars to conclude that a volitional element is irrelevant, that conditional intent is an objective or normative concept. I will argue however that the substantive criteria of eventualis must not be confused with its procedural definition, the manner in which it is proven. ${ }^{336}$ In line with the earlier developed moderate objective approach to proving fault, I will propose the proper limits of objectifying proof of volition.

Fokkens \& Machielse, note 4 on Opzet and van Dijk, A.A. 2008, p. 234. HR 25 March 2003, NJ 2003, 552.

Opinon of AG Tizzano of 25 October 2005, Case C-551/03 P, General Motors v. Commission [2006] ECR I-3173, §78 and 8 November 1983, Cases C-96-102, 104, 105, 108 and 110/82, IAZ and others v. Commission [1983] ECR 3369. See also III.7.2.

HR 25 March 2003, NJ 2003, 552; de Hullu 2006, p. 223 and de Jong, F., van Roomen \& Sikkema 2007, p. 935.

Bohlander 2009, p. 67.

Beulke 2008, p. 80 and Schönke \& Schröder, H. 2006, p. 284. 


\subsubsection{Acceptance inferred from probability}

In proving eventualis, two evidential presumptions operate. If, on the fact of the external facts and circumstances of the case, the risk seemed considerable, it is presumed that the defendant was also aware of this. Secondly, from the fact that the defendant acted despite this knowledge, it is inferred that he also accepted the risk. In other words, the defendant is held to know what the normal person knows. If that knowledge is coupled with or about a sufficiently high probability, it is often assumed that he accepted the risk. Wanting thus seems to be reduced to 'acting despite knowing'.

The inference of subjective awareness from objective danger was discussed in the previous subsection. I will now take a closer look at the inference of volition from acting despite the knowledge of the risk. The approach is hardly controversial in cases where the probability of the risk occurring was quite considerable. If conduct is so serious and death can be the only consequence, acceptance of the risk is easily assumed. For example, the defendant threw a hatchet with full force through a glass door at a police officer standing only 5 metres away from him. ${ }^{337}$ The fact that it is clear to anybody that this brings about a lethal risk, is enough to infer that the defendant knew this too, after which it is easily accepted that since he acted in that way, he took this risk for granted. The highly likely can hardly be anything but accepted. ${ }^{338}$ It is argued that the external manifestation of certain acts can sometimes be so much directed at a certain consequence, that the only conclusion can be that the defendant accepted the consequences, barring contraindication. ${ }^{339}$ This 'external manifestation' is a concept that is familiar in doctrines such as attempt and preparation, referring to the impression that the conduct could make to the reasonable citizen. ${ }^{340}$

In other words, an average person is more likely to trust in a good outcome because the chance of the risk materializing is small. By contrast, if the risk is probable, the actor generally can only hope, not trust the consequence will not occur. ${ }^{341}$ A claim of trusting nothing bad would happen can easily be rejected when the facts indicate that a deadly consequence was so likely, that only a coincidence

\footnotetext{
33716 July 1980 BGH NStZ 1981, 22.

338 Fokkens \& Machielse, note 3.5 on Opzet; de Jong, D.H. 2004B, p. 77; de Jong, D.H. \& Knigge 2003 pp. 104-107 and annotator Buruma in HR 25 March 2003, NJ 2003, 552 and HR 10 October 2000, NJ 2001, 4. See for example HR 8 July 1992, NJ 1993, 13.

339 De Hullu 2006, p. 223; HR 24 February 2004, NJ 2004, 375; 4 November 1988 BGHSt 36, 1; 7 July 1999 BGH NStZ 1999, 507; 27 February 1997 BGH NStZ-RR 1997, 199; Bohlander 2009, p. 65 and Beulke 2008, pp. $80-81$.

340 De Jong, F., van Roomen \& Sikkema 2007, p. 935.

341 Gatzweiler 2008, pp. 158-160; Roxin 2006, pp. 450-451 and R. v. G. [2003] UKHL 50, §9 per Lord Bingham of Cornhill: "Of course the mere fact that this probability was an obviously manifest one will be strong evidence to warrant the jury in finding, if they think fit, that the prisoner did, in fact, thus recognise the danger and regard it with indifference."
} 
could prevent it. Consider a stab of a knife in the upper body and neck. ${ }^{342}$ In most of these cases, it may be suspected that the defendant acted with dolus directus or indirectus. The lesser dolus eventualis is established because it is easier to prove and suffices to convict the defendant for an intentional offence.

The likelihood of the risk materializing thus seems to be the paramount criterion for eventualis. Supreme Courts now and then however quash decisions where the inference of acceptance follows too easily from a high probability of the risk. If the volitional element is fulfilled when the accused acted despite knowing, this puts strain on the theoretical distinction between the awareness and the acceptance of the risk. After all, the accused could have also acted despite knowledge, because he trusted in a good outcome. It has been made clear that knowledge of a risk in itself is insufficient to conclude this risk was accepted, thereby strengthening the volitional requirement. ${ }^{343}$ Particularly if the facts also allow the possibility of conscious negligence, the verdict requires careful consideration of all the circumstances of the case. ${ }^{344}$ In other words, in order to infer eventualis from factual circumstances, those facts must clearly point in no other direction than the materialized risk. ${ }^{345}$

\subsubsection{Acceptance of lethal results}

Although the likelihood is great, the volitional element can thus be negated when circumstances indicate that the defendant did not accept the consequences. ${ }^{346}$ An example of a so-called contra-indication in Dutch case-law is the danger to the actor himself. In a case where the defendant had driven very dangerously in a Porsche, which resulted in a lethal accident, it was held that if he had accepted the consequences of causing a collision, he would also have accepted the possibility of being killed himself. This was held to be unlikely, the more because the defendant had aborted some of the dangerous overtaking manoeuvres before causing the fatal one. ${ }^{347}$ In other cases of dangerous driving, conditional intent has been accepted in the absence of conduct that indicated the will to avoid a collision, like aborting overtaking manoeuvres. ${ }^{348}$ The assumption that the accused does not accept a consequence if it can also cause his own death is to no avail to the driver of a car that collides with weaker participants in traffic, like bicyclists. ${ }^{349}$

34214 December 2004 BGH BeckRS 2005, 00267 and Beulke 2008, p. 81.

343 HR 25 March 2003, NJ 2003, 552; HR 5 December 2006, NJ 2006, 663 and 23 June 1983 BGH NStZ 1984, 19. See also IV.3.6.6.

3444 August 1987 BGH NJW 1988, 79.

345 Annotator Mevis in HR 2 April 2002, NJ 2002, 421.

346 Schönke \& Schröder, H. 2006, p. 284.

347 HR 15 October 1996, NJ 1997, 199.

348 HR 5 December 2006, NJ 2006, 663; HR 23 January 2000, NJ 2001, 327 and HR 10 February 2009, NJ 2009, 111.

349 HR 17 February 2004, NJ 2004, 323. This implies that the defendant is assumed to have accepted a collision with bicyclists but not with other cars, buses and so on. 
Recalling the fire in the detention facilities of Schiphol, this criterion could therefore also be used to negate the assumption that the defendant accepted the risk. For if he did, this brings about that he also accepted the possibility of his own death or serious injury. He was locked in the cell in which the fire was started. However, this was rejected by the Court of first instance and on appeal. ${ }^{350}$ It can be argued that the taking serious of acceptance by considering the possibility of personal harm to the actor himself is limited to the context of dangerous driving. It seems less problematic to negate eventualis in those cases, because of the relatively severe maximum penalty for causing accidents with (conscious) negligence and the possibility to increase that maximum punishment when negligence was serious. ${ }^{351}$

German courts also operate with a contra-indication of the volitional element related to fatal consequences. However, this relates to the death of the victims, not to the possibility that the defendant might also die himself. 352 If a risk materialized into lethal consequences, there is a presumption that the defendant did not take these fatalities for granted, based on the assumed aversion of humans against killing other humans. It also operates in cases where the defendant inflicted serious injuries upon the victim and is charged with attempting to kill the victim.

Hence, a distinction can be made between lethal and non-lethal offences. In the context of non-lethal offences, intent can easily be inferred from the knowledge of an objectively high risk, like in the Netherlands. On the contrary, in charges concerning lethal offences, the volitional element must be considered with more caution. Although the German Supreme Court acknowledges that intent is obvious with extremely violent acts, only in cases of really extremely violent acts, will it allow an inference of intent to kill from these dangerous acts. ${ }^{353}$ Extreme violent acts may, but must not lead to an inference of conditional intent to kill. 354

This careful consideration is based on the assumption that there exists a natural instinctive threshold for all against killing other people. This duty does not apply to acts of omissions, because no comparable psychological threshold is said to operate in these cases. The assumption is that the passive act of letting someone die is emotionally easier to fulfil. ${ }^{355}$ This so-called 'Hemmschwelle' against active killing requires courts to consider the possibility of conscious negligence in lethal acts, regardless of whether the facts indicate this possibility. ${ }^{356}$ The evidential requirement limits the inference or attribution of intention from external

350 Rb. Haarlem 15 June 2007, $L J N$ :BA7326 and Hof Amsterdam 3 September 2009, $L J N: B J 6879$.

351 Article 175 of the Dutch Road Traffic Act 1994; Kelk 2005, p. 192 and de Jong, F., van Roomen \& Sikkema 2007, p. 936.

35222 August 1996 BGHSt 42, 235. Gatzweiler 2008, p. 149 does argue that the possibility to seriously hurt or even kill oneself usually militates against taking something for granted, but I did not find any such explicit reasoning in German case-law.

35413 March 2007 BGH BeckRS 2007, 06625; 15 April 1997 BGH NStZ-RR 1997, 233 and Gatzweiler 2008, pp. 172-173.

3557 November 1991 BGH NStZ 1992, 125 and Gatzweiler 2008, p. 136.

35622 November 1990 BGH NStZ 1991, 126. 
circumstances. The inference of acceptance may not follow directly from objective circumstances in lethal offences. The grounds stated in the judgment should reflect consideration of all circumstances that might cast doubt on conditional intent. ${ }^{357}$ In cases that straddle the borders of conditional intent and conscious negligence, the defendant is thus more likely to succeed in his defence that he trusted nothing would happen when he is charged with a lethal offence. ${ }^{358}$ It has been submitted that the approach of German courts to proving less serious offences is more objective. ${ }^{359}$

The threshold especially applies to cases of dangerous acts of violence where a motive to kill is not evident. ${ }^{360}$ Although no criterion for dolus, motive appears important in proving conditional intent. For example, the German Supreme Court considered that the defendant who had manipulated the sockets in his house so the next user would be sure to get an electric shock, probably did this not to directly injure or even kill the next user, but to indirectly harm his landlord, with whom he had an argument. ${ }^{361}$ Motive is thus related to the relationship between accused and victim. An even higher threshold is applied when a mother kills her child. ${ }^{362}$ Conversely, the extremist right-wing convictions of a defendant can also be seen as a motive that confirms he accepted the possibility of killing asylum seekers. ${ }^{363}$

As a result of the threshold, lower courts sometimes seem reluctant to prove that the defendant accepted the possibility of death. However, the German Supreme Court not only quashes decisions that hold that the defendant accepted the possibility of death; it also quashes decisions where this is rejected despite extreme violent behaviour. Consider the case in which the victim, for the purpose of sexual gratification, had requested to be tied to a bed, have gasoline poured over him and asked the accused to kindle a lighter. At a given time, the gasoline caught on fire and the victim burned to death. The District Court was not convinced that the volitional element was fulfilled but was remanded for requiring too much. The Supreme Court held that this was already fulfilled by the statement of the defendant that she was happy that nothing happened the first times she ignited the lighter. If the actor acts despite knowing the great risk, extremely dangerous conduct makes it obvious that he took the occurrence of the result into the bargain,

35713 March 2007 BGH BeckRS 2007, 06625; 8 May 2001 BGH NStZ 2001, 475 and Schönke \& Schröder, H. 2006, p. 285.

358 Gatzweiler 2008, p. 178.

359 Gritter 2003, pp. 190-191 and Seitz in König \& Seitz 2006, note 14 on $\$ 66$ OWiG.

3607 November 1991 BGH NStZ 1992, 125. The threshold assumes the defendant had no motive to kill.

3618 May 2001 BGH NStZ 2001, 475; 27 February 1997 BGH NStZ-RR 1997, 199 and 2 July 1996 BGH NStZ-RR 1996, 355.

3621 June 2007 BGH BeckRS 2007, 10549.

36328 April 1994 BGH NStZ 1994, 483, see also IV.2.4.2. 
leaving the outcome to chance. The mere hope nothing would happen cannot negate the reconciliation to the result. ${ }^{364}$

This decision strengthens the argument that the likelihood that the result will occur is paramount. If the risk is probable, no threshold whatsoever stands in the way of a finding of conditional intent. The threshold therefore applies especially to those cases where the violence was not so extreme as to leave open the possibility of trusting in a non-lethal outcome. ${ }^{365}$ The distinction between the two categories of cases is not always easy to make, which explains the importance of the specific circumstances of each case. ${ }^{366}$ For example, strangling the victim can, but need not be sufficiently serious to objectively ground a finding of conditional intent. It depends on the circumstances such as the manner of strangulation. ${ }^{367}$

When the doctrine of the threshold applies, the judge is required in particular to make sure that the actor accepted that risk would occur. He has to take into account all circumstances and show that he has weighed them all. These circumstances are also relevant in assessing the volitional element of eventualis in the context nonlethal charges, but are given special evidential consideration when the defendant is charged with intentionally causing death. I already mentioned goal and motive of the act and the dangerousness inherent in the act as relevant circumstances.

What also needs to be taken into account is the defendant's psychological condition or personality. ${ }^{368}$ We can think of intoxication, rage, despair, impulsive behaviour and general immatureness. ${ }^{369}$ In contrast to killing after contemplation in a long-lasting conflict situation, it is more difficult to establish intention when the act was impulsive, emotional and/or conducted under the influence of alcohol or drugs. ${ }^{370}$ Consider the case where the defendant had killed the victim by hitting him several times on the head with a shovel. The German Supreme Court upheld the mere conviction for negligent bodily harm occasioning death, pointing at

36420 June 2000 BGH NStZ 2000, 583. The fact that the accused herself also got severely burned was therefore to no avail to her. See also 15 December 2010 BGH NStZ 2011, 210 and 22 March 2012 BGH BeckRS 2012, 07957.

365 Gatzweiler 2008, pp. 143-144.

366 Consider that in 6 March 2008 BGH BeckRS 2008, 04800, a police officer had shot a fleeing burglar in the back at a range of 3 metres. Despite the extreme risk of death, the volitional element was rejected.

367 Compare 7 July 1992 BGH NStZ 1995, 587 and 2 July 1996 BGH NStZ-RR 1996, 355 with 27 February 1997 BGH NStZ-RR 1997, 199.

3688 May 2001 BGH NStZ 2001, 475; Schönke \& Schröder, H. 2006, p. 286 and Gatzweiler 2008, p. 141.

36911 December 2001 BGH NStZ 2002, 315; Bohlander 2009, p. 66 and Schönke \& Schröder, H. 2006, p. 285. In 8 May 2001 BGH NStZ 2001, 475, even the fact that the defendant recently had brain surgery to remove a tumour was held to be relevant.

37023 June 2009 BGH NStZ 2009, 629; Bohlander 2009, p. 66 and Schönke \& Schröder, H. 2006, p. 285 and Gatzweiler 2008, p. 144. See also 22 April 2009 BGH NStZ 2009, 503 and 7 July 1992 BGH NStZ 1995, 587. 
circumstances that might militate against intention such as the trivial occasion for the attack and the high level of alcohol in the defendant's blood. ${ }^{371}$

When we consider this case and cases where 'bar-fights' end up in fatalities, a distinct difference with Dutch courts becomes apparent. The Dutch (and English) judiciary hardly ever let these circumstances operate to the defendant's benefit. This is very clear in the context of voluntary intoxication, to be discussed later. The possibility that fault may be lacking tempore delicti is rejected because intentional conduct is very basic. Emotional states of mind are generally just as irrelevant to establish conditional intent in the Netherlands. Some German scholars also criticize the rejection of the volitional element based on such factors. They argue it is unclear how these factors must ground the serious trust in non-occurrence of the result. Perhaps intoxication and state of mind can affect the awareness of the danger, but in the context of acceptance, it is more likely that the actor became unrestrained through such a state or was at least indifferent to the result. ${ }^{372}$ The German Supreme Court has confirmed the latter in a more recent decision. ${ }^{373}$

More in general, German scholars also criticize decisions where despite the fact that the actor recognizes a great mortal danger, it is still held to be possible that he seriously trusted in the victim's survival. ${ }^{374}$ If the probability of the risk occurring comes close to being almost certain, the negation of intent based on the volitional requirement is hard to accept. I believe this criticism is warranted in some instances, although one needs to be careful to draw strong conclusions from verdicts of Supreme Courts alone. After all, a Supreme Court generally only scrutinizes the reasoning of the lower court and its verdicts only provide for a limited amount of information on the case.

Let us consider a striking case, in which the intoxicated and short-statured defendant had been scaring people by faking telephone calls to a fictional sniper, describing which of the people on the street should be shot. In an attempt to stop the accused, the victim attacked him, and when this did not help, pushed him to the ground and started beating him in the face. The defendant then took a knife and stabbed the victim thrice in the region of the heart and kidney. Notwithstanding such extreme violent behaviour, the victim survived and only suffered one deep cut and two superficial cuts. However, the German Supreme Court held that the defendant did not attempt to kill the victim.

The District Court explained this fortunate outcome by the fact that the blade must have bounced of the breastbone and ribs of the victim, yet the Supreme Court rejected this and held that the explanation must be that the stabbing was directed more parallel with the body rather than aimed to enter the body. I think this is questionable because one wound was six centimetres deep. As a second step, the

15 April 1997 BGH NStZ-RR 1997, 233.

372 Roxin 2006, pp. 474-475 and Miebach \& Sander 2003, note 50 on §212. See V.3.5. and Philipps in Schünemann a.o. 2001.

37324 February 2010 BGH NStZ-RR 2010, 214.

374 Krey 2003, pp. 120-121. 
Supreme Court argued that the defendant could not freely choose where he would stab as he was lying on the ground, defending himself. Finally, it held that a referral was unnecessary as far as the question of conditional intent was concerned, because a new trial would not indicate the existence of intent. Therefore, the verdict was changed into the dangerous infliction of bodily injury. ${ }^{375}$

I believe that many Dutch cases are criticized for inappropriately stretching the concept of conditional intent whereas in Germany, most criticism is directed at the denial of this fault element when lethal offences are charged. It seems that in general, Dutch courts are less reluctant in holding a defendant liable for conditional intent than a German court. An important reason for this difference lies in the doctrine of the Hemmschwelle that requires German courts to be extra careful in accepting the volitional element in the context of lethal offences. This threshold amounts to an additional threshold to criminal liability in comparison to Dutch law.

A second explanation, which also applies to non-lethal offences, is that the principle of in dubio pro reo is taken very seriously and therefore applied stricter than in Dutch (or English) case-law, in which references to this principle in the context of conditional intent are rare. In fact, Dutch judges are more likely to reject the credibility of the defendant's statement when it is not in line with other evidence or when his testimony lacks credibility in general. In contrast, German courts take the sequence of events that is most favourable to the defendant when this cannot be ascertained with certainty. 376

Third, the dogmatic legal thinking common in Germany precludes courts and scholars from making exceptions to principles based on considerations of public policy. A pragmatic approach is followed in the Netherlands, which explains why intoxication and emotional states of mind (almost) never lead to a negation of intent. In the next paragraph, it will be made clear that intent, including conditional intent, is less likely to be negated when the fault element is kept general. In Germany, by contrast, intent often must relate to elements not included in the offence definition, such as the specific identity of the victim and the way the result was achieved.

A final note needs to be made regarding lethal offences. The absence of conditional intent is mitigated in English law, because the most serious form of homicide, murder, is not only fulfilled when the defendant had direct or indirect intent as to the death of the victim, but also when this intention related to grievous bodily harm and the victim died as a result thereof. Just like dolus eventualis is criticized for equating dolus with the foreseeing of side effects, the English offence of murder is criticized for also labelling the defendant who only wanted to injure a murderer. It has been suggested the offence should be redrafted to make the distinction, but so far, this has been without success. ${ }^{377}$

37517 September 2008 BGH BeckRS 2008, 21295.

376 See 17 April 1962 BGHSt 17, 210; 18 August 1983 BGHSt 32, 48; 17 October 1996 BGHSt 42, 268; 25 March 1999 BGH JR 2000, 297; 12 December 2001, BGH NJW 2002, 1057; Roxin 2006, pp. 1091-1092 and Schönke \& Schröder, H. 2006, p. 350. 


\subsubsection{Acceptance inferred from possibility}

In some cases, the chance that the risk might materialize can be less than probable. When the risk is not very likely to occur, the volitional element may not be inferred solely from the subjective awareness of a risk. The inference should be conducted with scrutiny and by taking into account all the relevant facts and circumstances of the case, just as in the context of lethal charges in Germany. This careful consideration should not be based on a supposed threshold against killing people. It should apply to all charges, and is grounded in the fact that dolus eventualis and conscious negligence are closely positioned next to each other on a spectrum of fault elements. ${ }^{378}$ The line between dolus and culpa is small, yet the consequences of what type of fault is established are great. Moreover, knowing and wanting are interrelated elements. With the decrease in likelihood that the risk will materialize, its acceptance becomes less plausible to infer. ${ }^{379}$

In assessing dolus eventualis to any intentional charge, circumstances such as motive of the act, the dangerousness inherent in the act, including the manner of execution, behaviour before and after the offence and the defendant's personality should be taken into account. Other features that should be taken into account are risk habituation, prior experience with a good and bad outcome, the actor's control over the outcome, efforts made to avoid the result, the possibility of the victim to protect himself, and the degree to which the victim causes his own harm. Finally, the degree to which the consequence is undesirable to the defendant is relevant, which is evident in case the risk (also) presents a danger to the defendant himself or someone close to him. ${ }^{380}$ Some of these features have been advocated by scholars as the decisive criterion of conditional intent, ${ }^{381}$ but their correct place is in a framework of features that can either confirm or negate conditional intent. ${ }^{382}$

\subsubsection{Cognitive theories on intent}

It was submitted above that every now and then, the Supreme Courts reveal themselves as guardians of a subjective interpretation of conditional intent, quashing a decision for insufficiently taking this into account. If the judgment implies that conditional intent is established on the awareness of danger alone without any reference to the acceptance of it, it is quashed because it leaves open

3785 March 2008 BGH BeckRS 2008, 05898 and 4 November 1988 BGHSt 36, 1.

379 Recall that results that are foreseen as practically certain side-effects of intended results are simply considered to be indirectly wanted too. The volitional limb in dolus indirectus is minimal because of the overwhelming cognitive limb.

380 Schönke \& Schröder, H. 2006, p. 286.

381 See for example, Herzberg in Szwarc 1996, p. 73. See also Roxin 2006, pp. 459-460 and 465467.

382 Philipps in Schünemann a.o. 2001; Krey 2003, pp. 126-127; Roxin 2006, pp. 468-472; Weigend 1981, p. 667 and Beulke 2008, pp. 80 and 82. 
the possibility of conscious negligence. ${ }^{383}$ In other words, the volitional element must be proven explicitly and not based solely on the fact that the defendant was aware of a risk. However, the effect of judgments like these must not be overstated. The evidential approach used in the majority of cases is still very objective. Moreover, both Supreme Courts focus on the reasoning, not the facts. When all the facts of the case are taken into account and fitted into the juridical formulations developed by the Supreme Courts, the decision is likely to stand the test of cassation, even if it is very possible that another court would have come to an opposite conclusion.

As a consequence, the volitional element is often inferred from the cognitive element and thus seems to be superfluous. Some scholars explain this practice by arguing that conditional intent focuses primarily or exclusively on knowledge. ${ }^{384}$ As proponents of so-called cognitive theories on intent, they argue that intention exists when the defendant continues to act despite the fact that he foresees the possible consequences. In short, conditional intent is acting despite knowledge. ${ }^{385}$ More specifically, wanting is deduced from the acting with awareness. When one realizes the possible consequences and continues anyway, he must have wanted and thus intended the result. The sum is that knowing and continuing equals wanting to do. ${ }^{386}$ Accordingly, they submit terms like 'accepting' and 'taking into the bargain, do not imply wanting, but knowing. ${ }^{387}$ Proponents of cognitive theories on dolus eventualis reject a volitional element, either in an attempt to theorize case-law or as a theory of what intent should look like. ${ }^{388}$

They argue that the difference between conditional intent and conscious negligence hinges not on the attitude of the actor, but on the awareness of the considerable risk. From this perspective, it follows that the actor who is consciously negligent is actually unaware. When the actor trusts a possible consequence will not occur, he is not aware of the risk tempore delicti. ${ }^{389}$ Actual knowledge is supposedly suppressed. Arguably, it is therefore better to talk about seemingly conscious negligence, because when the actor trusts in a good outcome, he is no longer aware of the danger. ${ }^{390}$ The proponents of this theory can be said to 'translate' the attitude of the actor into awareness. By 'translating' this trust into

20 February 2008 BGH NStZ 2008, 392 and HR 18 January 2011, LJN:BO6365. See IV.3.6.3. Nieboer 1991, pp. 154-155; Otte 2001; van Dijk, A.A. 2008; Vellinga, W.H. 1982, p. 79 and Strijards 1983, pp. 71-76.

Fischer, T. 2009, pp. 107-108 and van Dijk, A.A. 2008, pp. 217-218, 413 and 426.

Krey 2003, pp. 126-127, Weigend 1981, p. 665; van Dijk, A.A. 2008, pp. 217-221, 224 and 253; de Hullu 2006, pp. 218-219; Smidt 1881 I, pp. 80-81 and Strijards 1983, pp. 73-75 and 118. Van Dijk, A.A. 2008, p. 427.

Strijards 1996, p. 118 clearly positions his theory as an explanation of the outcomes in practice. However, most scholars are not clear whether their theory concerns 'is' or 'ought', see also IV.3.6.8.

Van Dijk, A.A. 2008, pp. 224-226; Strijards 1987, p. 9; Frisch 1983, p. 322-323 and Krey 2003, pp. $122-125$.

Schönke \& Schröder, H. 2006, pp. 279-280 and Morkel 1981. 
inadvertence, the volitional element becomes relevant through the backdoor. This explains why the outcomes that follow from the application of this theory hardly ever differ from those of prevailing opinion. ${ }^{391}$ Clearly, these scholars themselves would argue that it is prevailing opinion who 'translate' cognitive criteria into volitional terms.

In my opinion, this approach is a fiction. ${ }^{392}$ Trust in a good outcome does not negate awareness; it rather enforces it. If the accused trusted in a good outcome because he thought it would be unlikely that the harm would materialize, he is still aware of a risk. The decision on the risk demonstrates that he was aware of the risk. This view is also taken in an English case on recklessness. The (intoxicated) defendant wanted to show off his martial arts skills to his friends, boasting that he could kick at a window but just miss breaking the glass. The Court held that the defendant trusted in a good outcome. He had tried to minimize the risk by keeping a greater margin and apparently overestimated his capacities. However, he still must have been aware of a risk of breaking the window. ${ }^{393}$

\subsubsection{Acceptance inferred from foreseeability}

The cognitive theory is right however to signal that the practical approach to proving conditional intent can go far. In a lot of cases, the only aspect of conditional intent that is truly proven or argued for is the objective awareness of the risk, in other words, the foreseeability of the result. Not only is it inferred through the simple establishment that he acted anyway, that the defendant must have accepted this risk; preceding this, the defendant is presumed to be aware of this risk given the objective degree of the risk that implies that the average or reasonable person would have been aware. For example, it is merely proven that there was a risk of infection with HIV, which apparently warrants the assumption that the defendant knew this and since he had unprotected sexual intercourse anyway, he must have accepted the possibility of infection. ${ }^{394}$ The manner in which it is proven leads to serious doubt on whether the individual subjective state of mind of the defendant is taken into account. It can be questioned whether intention is established or attributed to the defendant. 395

391 Roxin 2006, pp. 455-456 and 468-470; Bohlander 2009, pp. 64-65; Gatzweiler 2008, pp. 152156; van Dijk, A.A. 2008, pp. 257-258 and Kelk 2005, p. 182.

392 See also Beulke 2008, p. 79.

393 Chief Constable of Avon and Somerset Constabulary v. Shimmen (1986) 84 Cr App R 7. Recklessness was accepted. Admitted, since Dutch law requires awareness of a considerable risk, this criticism is mitigated. In that perspective, the defendant who thought it was unlikely the harm would materialize can be said to have been aware only of a non-considerable risk. 4 November 1988 BGHSt 36, 1; Gatzweiler 2008, pp. 172-173; HR 18 January 2005, NJ 2005, 154; HR 20 February 2007, NJ 2007, 313; van Dijk, A.A. 2008, p. 394; Kelk 2005, p. 173 and Reijntjes in Groenhuijsen \& Simmelink 2003, p. 484.

Reijntjes in Groenhuijsen \& Simmelink 2003, p. 475 and de Jong, D.H. \& Kessler 1999. 
More examples of this approach can be seen in the context of drug offences. The intent to import drugs is established on the rule that everyone who is driving a vehicle by himself that contains a lot of drugs, tends to know that this vehicle contains drugs. ${ }^{396}$ Similarly, a person living in a house must have known about the presence of large quantities of drugs there, ${ }^{397}$ and an airplane passenger who carries a suitcase with a large quantity of drugs, tends to know of this presence. ${ }^{398}$ If the defendant knew the package was sent to him from Colombia, this presupposes knowledge that it might contain drugs. From this assumed knowledge, the acceptance automatically follows from the acting itself. ${ }^{399}$

The evidential presumption in these cases can be formulated as follows: it is general experience that drugs are imported from certain countries. When a defendant flies from these countries, the presumption is that he is aware of this risk. The circumstance that he transported an item of someone else without checking it, means that he accepted this risk. ${ }^{400}$ This can be seen as a form of liability by Garantenstellung, that is, extended responsibility based on the knowledge of a normal airline passenger. ${ }^{401}$ A related perspective in England is that the possible ignorance of possessing something is compensated by the control of the defendant over what he possesses. If the defendant had control over his luggage and thereby the opportunity to discover the possession, he is more likely to have been aware of the (risk of) possession. ${ }^{402}$ This approach is also taken in Dutch cases on the possession of child porn. A person who is familiar with computers has more control over what data is stored on his computer and thus it is easier to accept that he subjectively was aware of the (risk of) possession. ${ }^{403}$

On the one hand, it can be argued that there is an apparent risk in bringing something along for an acquaintance, especially from certain destinations, ${ }^{404}$ and if it would be accepted, it would provide 'professionals' with a formidable defence. On the other hand, an approach based on responsibility may prove to be problematic in some cases. Control is often assumed in cases where on closer inspection, this is not true. When luggage is checked in, the defendant no longer can control what is put into it. Does this mean that passengers are not only under a duty not to transport anything for others and leave luggage unattended, but also that they have to seal their luggage? The violation of these duties apparently brings about a finding of intent of im- or exporting any illegal item found in their possession. Intent in these

\footnotetext{
396 HR 25 November 1986, NJ 1987, 493 and HR 3 November 1998, LJN:AV1127.

397 HR 15 December 1998, NJ 1999, 203.

398 As the Court of Appeal held, preceding HR 2 October 2007, NJ 2007, 645.

399 HR 3 June 2003, NbSr 2003, 240.

400 De Jong, D.H. \& Kessler 1999, p. 385. See for example HR 22 October 1985, NJ 1986, 346 and HR 5 July 2011, NJ 2011, 327.

401 Kelk 2005, p. 188 and de Hullu 2006, p. 228.

402 Warner v. MPC [1969] 2 AC 256; Ashworth 2006, p. 108; Walsh 2005, p. 780 and Simester \& Sullivan 2007, pp. 153-155 and 617-618.

403 HR 28 February 2006, NJ 2006, 179.

404 HR 2 October 2007, NJ 2007, 645.
} 
contexts can thus be qualified as carelessness of not checking what is in your car or bag or taking insufficient precautions to avoid the risk. ${ }^{405}$ The attribution of intent based on the foreseeability of the risk or the violation of a duty of care, risks that the specific defendant is convicted for the most serious form of committing criminal conduct, whereas he was only negligent.

\subsubsection{Normative theories}

Although the Supreme Courts consistently hold that the judiciary needs to carefully assess all circumstances of the case, in practice, proof of the objective danger seems decisive. All other circumstances of factors identified earlier thus seem superfluous. If conditional intent can be fulfilled by proof of 'acting despite foreseeability', both the requirement of knowing and wanting seem to become illusory. This is why proponents of so-called normative theories argue that intent is attributed normatively. Intent is no psychological concept, but a legal fiction that is used to label the defendant. The psyche of the other is fundamentally unknowable. Knowledge on the psyche is deduced from non-psychological factors, such as the nature of conduct, its external manifestation and its circumstances. It is therefore not about a state of mind, but about the outcome of a process of attribution. ${ }^{406}$

Like cognitive theories, a normative theory of intent provides for an explanation of the application of the law in practice that lacks proof of the cognitive and volitional element.407 Other scholars present their views not exclusively as an explanation, but also or predominantly as a theory of what intent should look like. ${ }^{408}$ Explanatory theories are inclined to treat substance and evidence integrated, as if they are inextricably linked to each other. ${ }^{409}$ Whereas the doctrine of intent can hardly be assessed separately from the rules of evidence concerning it, and in practice, psychological elements easily fade into the background, the fact that conditional intent is established in a certain way does not make the concept normative. ${ }^{410}$ The substantive criteria of dolus eventualis and the way in which they are proven should be distinguished.

405 See de Jong, F., van Roomen \& Sikkema 2007, pp. 941-942 and annotator 't Hart in HR 19 November 1991, $N J$ 1992, 250. Kelk 2005, p. 188 therefore uses the term 'intent of vigilance'. This can be identified in HR 17 January 2012, LJN:BU4211 as well.

Frisch 1983 and Peters, A.A.G. 1966. See de Hullu 2006, p. 218; van Dijk, A.A. 2008, pp. 234 and 240; annotator Buruma in HR 24 April 2007, NJ 2007, 544 and Gatzweiler 2008, pp. 164 and $169-171$.

407 See for example de Jong, F. 2009, p. 357.

408 See de Hullu 2006, pp. 27 and 216-218, de Jong, D.H. 2004A and de Jong, D.H. 2004B, p. 78. Often, it is unclear whether proponents aim to explain practice or believe a normative concept is most appropriate. Gatzweiler 2008, p. 186 concludes from his legal comparison of intent that the trend is that normative approaches become more influential.

Van Dijk, A.A. 2008, p. 236; Schönke \& Schröder, H. 2006, p. 281 and Gatzweiler 2008, p. 158. See, for example, de Jong, D.H. 2004A, pp. 1054-1055.

410 Van Dijk, A.A. 2008, p. 235-239 and Reijntjes 2004. 


\subsubsection{Moderate objective approach}

The criteria of conditional intent may be assumed to a great extent, they remain subjective in substance. As noted, the presumptions of the cognitive and volitional limb of eventualis are based on the reasoning that a normal person, acting as the defendant did, would have intent, and since the defendant is a normal human being, he acted intentional too. The defendant therefore often needs to draw the court's attention to facts and circumstances that operate as contra-indications to the presumptions based on external evidence.

Proof of intent may be objective, but this does not make the concept normative. The conduct of the defendant is not measured against normative standards of due care, but against general experience, against what a normal person would do. ${ }^{411}$ The inference of intent from external circumstances only becomes normative when the actor is supposed to possess the knowledge of the general public, regardless of whether this knowledge was actually present. ${ }^{412}$ In this vein, a distinction has been made between an 'intersubjective' and a 'final' approach to proving fault. ${ }^{413}$ In the final approach, the step of referring to the state of mind of the actor is skipped and the intent is directly proven from external facts. The act itself demonstrates the intent so clearly that it suffices to ground intent. For example, conditional intent to kill someone is given by shooting a firearm in a crowded bar. In an intersubjective approach, which I equate with the earlier mentioned moderate objective approach to proving fault, ${ }^{414}$ the objective circumstances are used as a tool to construct the actual state of mind. The latter is therefore objective, not normative. 415

Usually the evidential assumptions will be correct and therefore efficient. In some cases, the act cannot be interpreted in any other way than that the result was foreseen and accepted. However, the application of general experience and objective logic to individuals might not lead to a correct result for every defendant. The individual defendant is possibly not a reasonable citizen. ${ }^{416}$ An intersubjective approach needs to be taken. A balance needs to be struck between general experience and individual, concrete circumstances, recognizing that the state of mind of the individual defendant is not necessarily that of the reasonable person. ${ }^{417}$

\footnotetext{
411 De Hullu 2006, p. 217.

412 Kwakman in Keulen, Knigge \& Wolswijk 2007, p. 292.

413 Annotator Buruma in and HR 10 October 2000, NJ 2001, 4 and HR 25 March 2003, NJ 2003, 552; annotator Mevis in HR 2 April 2002, NJ 2002, 421 and AG Jörg in HR 25 March 2003, NJ $2003,556$.

414 See III.7.2.

415 Kwakman in Keulen, Knigge \& Wolswijk 2007, pp. 305-307; Robroek 2010, p. 35 and de Jong, F. 2009, pp. 403 and 432.

416 Reijntjes 2004, p. 80.

417 De Hullu 2006, p. 262 and de Hullu in Borgers, Koopmans \& Kristen 1998, pp. 181-187. The English cases R. v. Stephenson [1979] EWCA Crim 1 and Elliot v. C [1983] 1 WLR 939 were criticized for equating a schizophrenic tramp and a subnormal young girl with a reasonable person.
} 
Criminal liability after all, should be based on an individual culpability. Dolus should not relate to averages or statistical categories, but to individual actors in distinct criminal cases. ${ }^{418}$ An acquittal for the intentional charge must follow if the court is not sure this particular defendant realized or accepted the risk. Intent should never be attributed normatively, the defendant held liable despite knowing or accepting the risk. The severe reproach and punishment made possible by intentional liability is only warranted due to the subjective connection between act and actor, that expresses a great degree of control and choice. A normative attribution of intent blurs the distinction between intent and negligence and thereby obstructs the functions of distinguishing in fault elements.

The correct evidential approach to dolus eventualis requires moderation in using objective evidence and requires the judiciary to be more reluctant in applying the assumptions based on objective awareness. First of all, this approach has only arisen from problems of evidence. Evidential problems can lead to the acquittal of those who intended a result, but given the fact that it is better to acquit 10 guilty than to convict one innocent, these problems must be accepted over the injustice of convicting persons who were unaware of the risk or did not accept it. Secondly, it is difficult for the defendant to rebut presumptions that arise from general experience and objective circumstances. Given the general rule that the prosecutor is supposed to prove all offence elements, the burden on the defendant should therefore be set low. If there is any doubt that the assumption may not be correct in a specific case, the court should carefully consider all the facts and circumstances. If this does not resolve the doubt, the defendant should be acquitted.

Furthermore, facts or general experience are not always known or true. ${ }^{419}$ When there are reasons to question the assumptions that are made in proving eventualis, these doubts should be addressed by reference to all the facts and circumstances of the case. By requiring courts to clearly substantiate their reasoning, logic and inferences in judgments, the Supreme Courts can safeguard this moderate objective approach to proving eventualis. ${ }^{420}$ Finally, even if the average citizen knows something, this does not necessarily mean that this defendant also realized this when he committed the offence. The inference of subjective knowledge from general experience requires the courts to be more cautious of the risk of attributing awareness.

Proving fault by reference to objective facts and circumstances is possible and unavoidable, but in order to make reliable conclusions on the defendant's individual culpability, this needs to be conducted with moderation and care. The careful consideration of all the facts of the case, the taking into account of individual,

418 Annotator 't Hart in HR 23 January 1996, NJ 1996, 400.

419 De Jong, D.H. \& Kessler 1999 and Kwakman in Keulen, Knigge \& Wolswijk 2007, pp. 309-312. See for example, HR 6 March 2012, LJN:BU3606.

420 See Kwakman in Keulen, Knigge \& Wolswijk 2007, pp. 299-300. This argument militates against a finding of fault by juries unless they also have to substantiate the reasons for their judgment. 
concrete circumstances, should not be seen as an inefficient blockade to convicting perpetrators.

Consider the case where the defendant was found in Schiphol in possession of 23 kilograms of cocaine. He had argued the Peruvian government had set him up. He wanted to have the tape with which the drugs were packed tested for fingerprints, but everything had been destroyed already. The Dutch Court of Appeal held that even if it were to be established that the defendant's fingerprints were not on the packets of drugs, this not necessarily means he was unaware of the drugs in his suitcase. The Supreme Court approved this reasoning and upheld the conviction. ${ }^{421}$ The ECtHR also did not find this reasoning unreasonable or arbitrary. ${ }^{422}$ It recognized the evidential approach for what it is; rebuttable presumptions of fact based on external circumstances and general experience. ${ }^{423}$ These presumptions were allowed because they could be rebutted and the Court of Appeal had relied on other evidence and factors, such as the fact that the defendant used a diplomatic passport, possibly to avoid detection. ${ }^{424}$ These and other facts of the case warrant a presumption of conditional intent, and in order to reliably ground his fault, the Court considered all the facts and circumstances, both of an incriminating and exculpating nature.

A moderate objective approach will also lead to an acquittal of the accused when appropriate. Consider the defendant who was found at Schiphol in possession of more than 1 kilogram of cocaine. The Dutch Court held that despite the fact that drugs were smuggled from notorious Aruba and that the suitcase was from a friend, the defendant was reasonably mistaken about the presence of drugs, as it was very difficult to notice the drugs in the suitcase - as confirmed by customs - and the suitcase was borrowed from a colleague marine and friend. ${ }^{425}$

This evidential approach should apply to all offences and to all fault elements. It was explained that German and Dutch law adapts its evidential approach according to the type of offence that is charged. The Hemmschwelle applies only to lethal offences, and in the Netherlands, much more is required to prove conditional intent in the context of road traffic offences than regarding drug offences. However, consistency requires that a careful evidential approach to eventualis is applied in the context of all intentional offences.

For that matter, a moderate objective approach should apply to other fault elements too, such as dolus directus and recklessness. I elaborated on this approach in the context of eventualis, because the intimate relationship of substance and

421 HR 3 November 1998, LJN:AV1127. See also de Jong, D.H. \& Kessler 1999.

422 Luis de Arriz Porras v. the Netherlands, appl. no. 49266/99, 18 January 2000. See also August Frederik Stuart v. the Netherlands, appl. no. 31716/96, 6 July 1999.

423 See Fokkens \& Machielse, note 5 on Opzet.

424 Moreover, the police records showed that the tape used to pack the drugs was the same tape used to seal the suitcase, which militates against the defendant's story.

$425 \mathrm{Rb}$. Arnhem 2 February 2009, $L J N$ :BH2293. Not only was the charge of intent negated, the strict offence that was charged alternatively was also negated, because the defendant could not even be reproached at all. The excuse of 'absence of all blameworthiness' applied, see IV.6.5. 
procedure is particularly evident here. Moreover, if the proposal to exclude dolus eventualis in a general part of criminal law for the EU is not adopted, a moderate objective approach to this fault element is a second best option, as it helps to keep the contents and proof of this concept within appropriate limits. I have the impression this approach is gaining popularity in Dutch case-law.

\section{ReCKLESSNESS}

In English law, recklessness is the conscious taking of an unreasonable risk. It straddles the borders of dolus eventualis and conscious negligence and has therefore often been compared with these continental fault elements. However, it is a concept of its own and the pertinent differences will be discussed. Most importantly, recklessness differs from eventualis, because it is not a lowest form of dolus but an independent kind of fault. Second, recklessness has no volitional requirement and finally, it is a partially normative concept.

\subsection{Rationale}

Recklessness has a similar function as dolus eventualis. As a middle ground of fault in between intent and negligence, it enables a more serious kind of criminal liability in cases that would otherwise be labelled as mere negligence. The reasoning behind the creation of this middle ground is the realization that foreseeing side-effects is more culpable than negligence. Awareness of risks grounds the increased reproach.

However, an important difference is that recklessness constitutes a separate form of fault, whereas eventualis is merely seen as the lowest degree of dolus. The English legal system operates with three kinds of fault: intent, recklessness and negligence, whereas on the continent only intent and negligence are applied. Since recklessness is not a type of dolus, it does not serve the purpose of facilitating the proof of intentional offences. The lack of dolus eventualis in English law leads to a stricter concept of intent and thereby stricter concepts of attempt, participation and so on. Nevertheless, recklessness is also often used in offences as an alternative fault element to intent, performing a similar function as eventualis. ${ }^{426}$

\subsection{Terminology}

In England, recklessness is often perceived as a high degree of negligence. ${ }^{427}$ In comparative legal analyses, recklessness has often been labelled an equivalent of luxuria, the most serious form of conscious or advertent negligence in Germany ('Leichtfertigkeit') and in the Netherlands ('roekeloosheid'). Roekeloosheid is an

426 See for example section 28(2) of the English Identity Cards Act 2006.

427 Ashworth 2006, p. 181 and Weigend 1981, p. 676. 
exact translation of recklessness. The Oxford English Dictionary refers to its cognate terms in (old) Dutch and German. ${ }^{428}$ The verb 'reck' - in Dutch: 'roeken' means to take care, to be concerned about something. It can also mean to regard and to take notice, but its use as being aware of something is now used only rarely. 'Reckless' means the lack of consideration, being careless, heedless or indifferent. From an etymological perspective, the comparison to negligence seems warranted. Like negligence, its core consists of carelessness.

In England however, the legal concept of recklessness requires awareness. Awareness strictly demarcates recklessness from negligence. The problem is that the negligent actor in Germany and the Netherlands can be aware or unaware of the risk. As explained before, foreseeing a risk but trusting in a good outcome leads to advertent negligence. Luxuria can (theoretically) also encompass cases of inadvertent negligence.

\subsection{Criteria}

Recklessness can be defined as follows: "(...a person acts) "recklessly" with respect to- i) a circumstance when he is aware of a risk that it exists or will exist; ii) a result when he is aware of a risk that it will occur; and it is, in the circumstances known to him, unreasonable to take the risk." ${ }^{29}$ In short, recklessness denotes the conscious taking of an unjustified risk. ${ }^{430}$ Reckless knowledge has already been discussed briefly; the focus here is on recklessness as to consequences.

Recklessness was held to mean "that the accused has foreseen that the particular kind of harm might be done and yet has gone on to take the risk of it." 431 This resembles a cognitive version of dolus eventualis, where the volitional element is established by the mere fact that the accused has acted despite knowledge. However, in contrast to eventualis, recklessness does not require that the actor must have accepted the possibility that the risk would materialize. Although there are old references in which it was argued that the defendant must have also been reckless or indifferent as to whether the risk occurred, recklessness in its current form includes no volitional element. ${ }^{432}$

In other words, dolus eventualis focuses on the actor's attitude towards the risk whereas recklessness focuses on awareness. ${ }^{43}$ In distinguishing dolus eventualis from negligence, the volitional element is decisive. If the actor was aware of the risk but he did not reconcile himself to that risk, there can (only) be advertent negligence. By contrast, the difference between recklessness and negligence is based on

\footnotetext{
428 See also the Dutch 'van Dale' dictionary.

429 Section 18(c) draft Criminal Code, Law Commission 1989, p. 51.

430 Smith, A.T.H. in Glazebrook 1978, p. 101.

431 R. v. Cunningham [1957] 2 All ER 412; Ashworth 2006, p. 182; Simester \& Sullivan 2007, p. 135 and Ormerod 2005, p. 103.

432 See IV.5.1.1.

433 Fletcher 1978, p. 447.
} 
awareness. In English law, the negligent actor is unaware of the risk. He cannot be acquitted of recklessness by arguing he trusted everything would be all right. The awareness of the risk is decisive, not whether he accepted it or not. Recklessness therefore subsumes cases that in Dutch and German criminal law are covered by dolus eventualis and advertent negligence. ${ }^{434}$

\subsection{Awareness}

The dominant type of recklessness applied in England is called subjective or advertent recklessness or by reference to its leading case: Cunningham recklessness. ${ }^{435}$ A second inadvertent type or 'objective' recklessness is named after another case. This so-called Caldwell recklessness has however been rejected and will be discussed in another subsection. In the case where this objective form of recklessness was rejected, the two defendants, aged 11 and 12, set fire to some newspapers and then put a large wheelie-bin over it. They did not contemplate the bin would catch fire and eventually lead to the burning down of a shop. The lack of awareness negated the charge of recklessly damaging property. ${ }^{436}$ The rationale of requiring awareness for recklessness is that risky action is only morally significant if the defendant acted, knowing the risk. ${ }^{437}$ Lack of background knowledge, ignorance, stupidity and gullibility are not the type of vices that can ground recklessness. ${ }^{438}$

Like the requirement of awareness in dolus eventualis, this requirement of recklessness hardly presents evidential difficulties in practice, since it can be inferred from objective facts and circumstances. In restoring the subjective character of recklessness, the House of Lords dismissed any fear that subjective recklessness would prevent convicting those who deserved punishment. Subjective recklessness would not preclude convicting the defendant when he asserts he never thought of a certain risk when everything showed that he did or must have done. ${ }^{439}$ I will return to the manner in which awareness can be proven in the next section.

\subsection{Unreasonable risk}

The defendant needs to be aware of a risk, which is in the circumstances known to him, unreasonable to take. In short, this requires that the defendant needs to be aware of any degree of risk. In addition however, this risk objectively needs to be

\footnotetext{
434 Bohlander 2009, p. 63.

435 Simester \& Sullivan 2007, p. 135; Ormerod 2005, p. 102 and R. v. Cunningham [1957] 2 All ER 412.

436 R. v. G. [2003] UKHL 50.

437 Tadros in Shute \& Simester 2002, p. 228 and Duff 1990, pp. 142 and 153.

438 Compare Tadros 2005, pp. 250-255.

439 R. v. G. [2003] UKHL 50 and Ormerod 2005, pp. 107-108.
} 
unreasonable. The defendant need not be aware that the risk is unreasonable, yet he does need to be aware of the essential facts underlying the valuation of the risk as unreasonable. ${ }^{440}$

\subsubsection{Unreasonable}

The risks that are relevant for recklessness are assessed normatively. As explained in the context of eventualis, this means that the relevance of a risk is not only judged according to the likelihood of its occurrence, but also to the social utility of the act relative to the nature and extent of the harm that is caused when the risk occurs. In other words, a small chance of great harm can be a relevant risk. ${ }^{441}$ The more valuable a legal interest is, the sooner a risk becomes relevant. The mentioned scenarios of HIV-infection lead to liability for recklessness in England. ${ }^{442}$ Even if the chance of infection is small, the harm caused is very serious and the risk taken therefore unreasonable. Moreover, there is no social utility in having unprotected instead of protected sexual intercourse.

The taking into account of these normative factors explains why there is no need for a threshold of probability. ${ }^{43}$ The chance of infecting someone with HIV need not be considerable to infer recklessness, when the risk is established normatively. In order to hold the defendant liable for infecting the victim under conditional intent, Dutch scholars therefore have proposed to take this approach too. A small chance can be unreasonable if it has no social utility. Recall the aforementioned case where the defendant was showing off his martial arts skills near a window. He broke the window because of an exaggerated belief in his own capacities. This means he thought there was only a minimal risk, but in light of the absence of social utility, this slight risk sufficed. ${ }^{444}$

The opposite is also true. The risk can be reasonable if the actor furthers a good cause. We take risks all the time, often even professionally. Driving a vehicle or operating an industrial machine in compliance with the pertinent rules may cause unwanted side-effects, but when they occur, this does not make us reckless. ${ }^{445}$ The risk can also be reasonable if the actor took precautions. The use of condoms does not negate any risk to HIV-infection, but it is no longer a risk a reasonable person

440 Simester \& Sullivan 2007, p. 134; Duff 1990, pp. 143 and 152; Norrie 2006B, p. 79 and section 18(c) draft Criminal Code, Law Commission 1989, p. 51, which has been judicially approved in R. v. G. [2003] UKHL 50.

441 Ashworth 2006, p. 182; Kessler Ferzan 2007, p. 2538; Simester \& Sullivan 2007, p. 134; Ormerod 2008, pp. 107-110 and Ormerod 2005, p. 102. See IV.3.4.5.

442 R. v. Dica [2004] EWCA Crim 1103.

443 Ormerod 2008, p. 108. In R. v. Brady [2006] EWCA Crim 2413, the plea that the risk should be obvious and significant was rejected.

444 Chief Constable of Avon and Somerset Constabulary v. Shimmen (1986) 84 Cr App R 7. See also Simester \& Sullivan 2007, pp. 134-135; Duff 1990, pp. 147-148 and IV.3.6.6.

445 See Williams 1953, p. 55. Compare Weigend in Klip 2011, p. 164: even a pessismist, constantly paranoid of all that could go wrong, would not be reckless for causing a reasonable risk. 
would not take. ${ }^{446}$ Even a considerable chance of a small risk does not necessarily constitute recklessness. If we consider the likelihood that this book bores its reader is probable, the harm that is inflicted is arguably still trivial. The action that produces this unwanted side-effect has social utility. After all, I explained how rethinking fault elements is useful on both a European and national level. In balancing the scales, the risk can therefore hardly be called unreasonable.

Finally, Weigend raises the question whether a person, who has a cold, repeatedly sneezes in a bus, being aware there may be a $95 \%$ chance of infecting another passenger with the flu virus, is reckless as to the bodily injury. ${ }^{447}$ As Spencer pointed out, "it is not reckless for a person who is suffering from an illness that is curable and minor, like a cold, or ordinary flu, or even mumps or measles, to run the risk of transmitting it to others if it would seriously disrupt the affairs of himself or other people to avoid it." 448 The aspect of unreasonableness thus also excludes trivial risks and harm from liability and thereby helps to prevent overcriminalization.

\subsubsection{Unjustified}

As an alternative to being reasonable, risks that are justified are also excluded from recklessness. A considerable chance of some harm occurring can be justified when a defence like necessity applies. The test of proportionality applied in justifications is similar to the test of reasonableness applied in recklessness. For example, the defendant needs to get his wife to hospital immediately. If necessity applies, the danger to traffic he caused as a side-effect is not only justified, it operates as a failure of proof defence to recklessness, resulting in an acquittal. Because recklessness is partly normative, good motives are relevant to this fault element. In contrast, if necessity would apply to an intentional act, the act would remain intentional. The application of the defence does not affect the neutral concept of intent; it justifies the act by negating its wrongfulness.

\subsubsection{Valuation}

In the context of dolus eventualis, the question was already raised what the consequence is of a difference between the subjective and objective perception of the risk. In practice, the defendant is unlikely to be successful in negating eventualis by arguing he thought the risk was possible but not considerable. What is exactly considerable is vague enough for courts to confirm it and often, a subjective perception is not even distinguished next to the objective chance. This practical

\footnotetext{
446 See Spencer 2004, p. 385.

447 Weigend in Klip 2011, p. 162.

448 Spencer 2004A, p. 385.
} 
approach to proving eventualis is similar to what is actually required by recklessness.

In recklessness, the awareness of the defendant must relate to the fact that there is a chance and secondly, to the essential circumstances that ground the conclusion that the risk is unreasonable. ${ }^{449}$ It need not relate to the unreasonableness of the risk. Whether this risk is in fact unreasonable is assessed objectively, independent of the valuation of the defendant. The question is whether a reasonable man having such foresight would have proceeded with his conduct notwithstanding the risk. ${ }^{450}$

This usually means that the defendant must at least know the legal interest that is possibly harmed. He need not have made the same valuation as is normatively made. If the defendant, for example, incorrectly thought that it was reasonable to risk the bodily integrity of the victim given the small chance of HIV infection, the risk is still unreasonable. In other words, the defendant can raise his subjective perception of the facts, but not his subjective value position. ${ }^{451}$ On the one hand, the defendant should be judged according to the circumstances as he believes them to be. ${ }^{452}$ On the other hand, what is reasonable is a normative criterion, established independently of the defendant's beliefs.

The fact that the defendant only needs to be aware of any degree of risk, which is in the circumstances known to him, unreasonable to take also means that if a person rejects the possibility that a risk will occur, because he believes that chance to be very small, he can still be convicted for recklessness. The driver, approaching a roadblock of police officers, may expect those officers to have been trained to get out of the way, but this does not make the risk reasonable. He is aware of a residual chance, which is unreasonable to take. In my opinion, there is no mistake on the factual circumstances. ${ }^{453}$ Provided there is at least some awareness, the assessment of the risk only takes into account the actual chance of hitting the police officer, not the subjective chance. Even if the driver believed the chance to be $5 \%$ and it is in reality $15 \%$, the risk could be considered unreasonable under the subjective chance too. After all, the nature of the possible consequence is very serious, and it is unlikely the driver furthered a good cause.

\subsection{Caldwell recklessness}

The House of Lords only applies a subjective concept of recklessness, requiring awareness. In a decision of 2003,454 the House overruled the interpretation of

\footnotetext{
449 See section 18(c) of the draft Criminal Code, Law Commission 1989, p. 51, which has been judicially approved in R. v. G. [2003] UKHL 50.

450 Simester \& Sullivan 2007, p. 134.

451 Norrie 2006B, p. 79.

452 Ashworth 2006, p. 159.

453 In contrast to Weigend in Klip 2011, p. 164. Note that attempt liability is impossible in this situations, as recklessness is insufficient for attempt, see R. v. Mohan [1976] QB 1.

454 R. v. G. [2003] UKHL 50.
} 
recklessness as objective or inadvertent recklessness, which was dominant since the Caldwell case of 1982. ${ }^{455}$ This type of recklessness will be discussed in short here in order to be comprehensive, because it helps to understand fault in general and recklessness in particular, because it has similarities with conscious negligence and because it can help explain why dolus eventualis and recklessness have often incorrectly- been equated.

Under objective recklessness, the definition of recklessness extended not only to awareness of the risk but also to failure to foresee an obvious risk. ${ }^{456}$ The defendant "either has not given any thought to the possibility of there being any such risk or has recognised that there was some risk involved and has nonetheless gone on to do it." 457 Because objective recklessness embraced gross negligence, the border with negligence was blurred. ${ }^{458}$ The reason behind criminalizing inadvertent recklessness was similar to the rationale of punishing negligence. It has been argued that those who fail to advert, such as the thoughtless or inconsiderate, are usually no less blameworthy than those who do advert. It can be called a duty or responsibility of citizenship to advert to and investigate the relevant risks when actively engaging in certain conduct. ${ }^{459}$

As is the case in negligence, the determination of whether or not the defendant ought to have realized the risks proved problematic. The test was to compare the defendant with a reasonable man, without any room to take into account any personal characteristics that might preclude the defendant from being able to advert. In the absence of a capacity-based exception, this created an objective standard of foreseeability that not everyone could meet. ${ }^{460}$ This has led to some controversial convictions on the basis of recklessness, for example of children or defendants with limited mental capacities. ${ }^{461}$ Some authors have therefore argued in the years preceding the 2003 decision, that the test should be adapted to include a capacity exception. ${ }^{462}$ The defendant should be compared to an individual with similar characteristics, but which characteristics should be taken into account remained uncertain. ${ }^{463}$ The House of Lords dismissed this middle ground, as they were confident that subjective recklessness would not preclude convicting the defendant who deserved punishment. ${ }^{464}$

Under Caldwell recklessness, there were two situations in which an actor could be found reckless; if the actor was aware of a risk and if the actor failed to be aware

R. v. Caldwell [1982] 1 All ER 961.

Ashworth 2006, p. 185.

R. v. Caldwell [1982] 1 All ER 961. See Halpin 2004, pp. 78-79.

Simester \& Sullivan 2007, p. 136.

Ashworth 2006, p. 185 and Amirthalingam 2004, p. 500.

Ashworth 2006, p. 186 and Ormerod 2005, p. 105.

Elliot v. C [1983] 1 WLR 939; R. v. Coles [1994] Crim LR 820 and R. v. Gemmell and Richards

[2002] EWCA Crim 1992.

462 Simester \& Sullivan 2007, p. 138.

463 Tadros in Shute \& Simester 2002, p. 228 and Tadros 2005, p. 260.

464 R. v. G. [2003] UKHL 50 and Ormerod 2005, pp. 107-108.
} 
of an obvious risk. The situation where the actor had given thought to the matter of risk and wrongly concluded there was no risk, did not qualify as any of these two situations and was thus considered as a loophole of criminal liability under Caldwell recklessness. In such a situation, the defendant was deemed to be negligent. ${ }^{465}$ Consider the person who builds a campfire and notices that the fire might spread to a nearby tent if he does not remove some loose dry grass next to the fire. He takes the necessary precautions and removes the grass, but inadvertently falls short of what was required: not all of the grass is removed and later, the fire does spread, burning down the tent. ${ }^{466}$ The loophole was criticized for excluding from recklessness the person who stupidly rejects a risk, whereas including the person who stupidly never thinks about it.

This loophole implies the common law also knows a concept such as 'conscious negligence' since in the given example the accused would be negligent although he was aware of the risk. The comparison with cognitive theories of intent forces itself upon us. ${ }^{467}$ I described how some scholars argue that trust in a good outcome negates the awareness of dolus eventualis tempore delicti. A similar reasoning applies here that someone can be aware of a risk at one point in time, but later rejects the possibility of the risk occurring for whatever reason. ${ }^{468}$ As argued before, trusting in a good outcome does not negate, but confirms the awareness of the risk. ${ }^{469}$

Whereas the House of Lords only explicitly abolished inadvertent recklessness in the context of criminal damage, a 2007 judgment of the Court of Appeal implied that advertent recklessness applies to all charges. ${ }^{470}$ The application of Caldwell recklessness to other offences is very rare to say the least. ${ }^{471}$ Recklessness thus has one general interpretation for each offence, furthering coherency, simplicity and clarity. In making clear that recklessness requires awareness, the demarcation with negligence is very clear again. Recklessness and culpa both revolve around the taking of unreasonable risks. ${ }^{472}$ The reckless actor was aware of the risk he has taken, whereas the negligent actor was unaware of the risk he created, whilst he should have and could have known. Awareness is the clear dividing line; there is no room for concepts as conscious negligence. ${ }^{473}$ Recklessness thus brings about a narrower concept of culpa, namely inadvertent negligence.

\footnotetext{
465 R. v. Reid [1992] 95 Cr App R. 391; Ormerod 2005, p. 129 and Brady 1996, pp. 185-186.

466 Winslade 1972, p. 32.

467 See IV.3.6.6. and Erenius, p. 78.

468 Brady 1980, p. 384 thus argues he is no longer aware of any continued risk.

469 I could accept that awareness is negated if the defendant, believing that the precautions he took were sufficient, thinks there is no longer any residual risk.

470 R. v. Heard [2007] EWCA Crim 125.

471 Ormerod 2008, p. 114 and Simester \& Sullivan 2007, p. 137. One exception remains today, namely that recklessness to some charges can be based on inadvertence, if the defendant did not contemplate a risk of causing harm because he was voluntarily intoxicated, see V.3.5.

472 Weigend 1981, pp. 676-677 and Weigend in Klip 2011, pp. 164-165.

473 Weigend 1981, pp. 692-693.
} 
Chapter IV

\section{DOLUS EVENTUALIS VERSUS RECKLESSNESS}

After having discussed the two fault elements that concentrate on liability for being aware of risks, I will juxtapose the two elements in more detail here. I will argue that in a general part of criminal law for the EU, the defendant who foresees that his actions may lead to a side-effect should not be held liable for intending to bring this about. Instead, we should hold him liable for recklessly causing side-effects. ${ }^{474}$

\subsection{Differences}

For a proper understanding, I will reiterate the major differences between the fault elements. This repetition appears to be necessary because in numerous legal discussions, recklessness and eventualis are equated. ${ }^{475}$

\subsubsection{Volitional element}

Recklessness and dolus eventualis seem very similar as they both deal with foreseen side-effects. Both concepts therefore deal with the awareness of risks, but eventualis additionally requires that the actor must have accepted the possibility that the risk would materialize. I have called this a volitional element and explained that recklessness requires no such volitional element. ${ }^{476}$ Accordingly, the demarcation with negligence either revolves around a volitional or a cognitive element. In distinguishing eventualis from negligence, the volitional element is decisive, whereas the difference between recklessness and negligence is based on awareness. Recklessness subsumes cases that in Dutch and German criminal law are covered by dolus eventualis and advertent negligence. Because recklessness focuses on the awareness of the risk without looking into the attitude of the defendant, it has been equated with mere advertent negligence. ${ }^{477}$ However, recklessness also covers cases where the actor did accept the risk, which would be eventualis on the continent. The defendant's disposition is just irrelevant to prove recklessness.

By contrast, it has been argued that recklessness does include a volitional element, enabling the equation of the two fault elements. ${ }^{478}$ The reading in of a volitional element into recklessness can be done in different ways. First and foremost, a direct appeal could be made to references of the House of Lords, in which Lord Bingham cites passages that can be read as referring to a volitional

\footnotetext{
474 See also Blomsma in Klip 2011.

475 Cassese 2007, p. 111; Arnold 2003, pp. 130-139 and Werle \& Jessberger 2005. See also Fletcher \& Ohlin 2005, p. 554.

476 Wirth 2003, p. 155; Ambos 1999, p. 21 and Taylor, G. 2004A \& 2004B.

477 Fletcher \& Ohlin 2005, p. 554

478 See, for example, Safferling 2008, pp. 367-368, 479 and 483; Pedain 2003, pp. 589-593 and the ICTY, which uses the elements interchangeably, including an element of acceptance in recklessness, according to Badar 2006, p. 347.
} 
element like indifference: "(...) should have recognised the probability of its taking fire and have been reckless as to whether or not it did so. (...) recognise the danger and regard it with indifference. (...) 'reckless' only requires foresight of possible consequences coupled with an unreasonable willingness to risk them." 479

The italicized words seem to indicate a volitional element in recklessness although it is unclear whether or not the authors intended to convey this. In other sources, one can discern a clear, explicit purpose to refer to recklessness as an attitude. ${ }^{480}$ Nonetheless, since prevailing opinion in England does not include a volitional element, no further-reaching conclusion must be drawn from these references. Recklessness may express, but does not require proof of indifference. ${ }^{481}$ With the overruling of objective, Caldwell recklessness, it is clear again that the distinction between recklessness and negligence is based on awareness. The previous existence of objective recklessness that was difficult to demarcate from negligence can explain why a distinguishing feature was sought in volition.

Another manner to equate the concept is to argue that when the actor acted despite realizing the risk, he must have accepted the risk that the result would materialize. ${ }^{482}$ This reasoning, familiar amongst proponents of cognitive theories on intent, is however erroneous. It can be said that awareness of a risk must lead in some way to taking a position. ${ }^{483}$ However, the fact that the defendant acted despite knowledge can also mean he trusted the risk would not materialize. The reasoning excludes this possibility.

\subsubsection{Normative risk}

Recklessness requires no volitional element, but it does limit the relevant risks normatively, by requiring that the risk must be unreasonable. The relevance of a risk is not only determined by the likelihood of its occurrence, but also by the nature and extent of the harm that is caused when the risk occurs related to the social utility of the act. The doctor is not reckless in carrying out a surgery. This is not because he does not take into the bargain that his patient might die, but because the risk he takes is reasonable. Whereas the concept of risk in eventualis is also exposed to normative influences in practice, there is no room to take into account the nature of and harm to the legal interests involved. The scope of the risk in recklessness is thus both broader and narrower than that in eventualis. The risk is

479 R. v. G. [2003] UKHL 50, $\S 9$ and 16. See also DPP v. Morgan [1976] AC 182: "recklessly not caring". My italicizations.

480 See for example, White 1961, pp. 594-595 and Edwards 1954, pp. 303-304 and the sources mentioned there.

481 Fitzgerald 1962, p. 55; Williams 1962, p. 57; Winslade 1970, pp. 137-140 and Brady 1980, p. 390.

482 Lareau 2001. Badar 2006, p. 335 notes that the ICTY applies this reasoning in ICTR Judgement, Prosecutor v. Blaškić, Case No. IT-95-14-A, A. Ch., 29 July 2004.

483 Weigend 1981, p. 669; Taylor, G. 2004A, p. 116-118 and Taylor, G. 2004B, p. 350. That is, if we exclude that in spur of the moment crimes, the defendant does not always have the time to form an attitude, see Taylor, G. 2004A, p. 221. 
broader because a small chance of a great harm can also be a relevant risk, whereas the risk in eventualis must be considerable. The scope of the risk in recklessness is narrower because it must also be unreasonable and is negated when a justification is accepted. ${ }^{484}$

\subsubsection{Tertium quid}

Finally, recklessness constitutes a separate form of fault in between intention and negligence, whereas eventualis is seen as the lowest degree of dolus. This reflects a fundamental difference in perspective on the relative culpability of foreseen sideeffects. The separation of foreseen from intended results in England implies that they are perceived as less culpable, whereas the equation as a form of intent in the Netherlands and Germany, implies that foreseen results are perceived as just as culpable.

The dichotomy of dolus and culpa can be juxtaposed with a tripartite system of fault that positions recklessness as a separate kind of fault in between intent and negligence. I will argue that such a tripartite system is to be preferred, because foreseen results should be clearly distinguished from wanted ones. After that, I will argue that the demarcation of fault elements should focus on awareness rather than volition. Finally, I will demonstrate that taking into account normative aspects has many advantages, especially in this day and age. Only the concept of recklessness can incorporate these aspects.

\subsection{Three instead of two}

\subsubsection{Intended versus foreseen results}

A EU general part should use a tripartite system of fault instead of merely distinguishing dolus from culpa. If we consider the continental dichotomy of fault by examples, it becomes apparent that the true distinctions in culpability, the degree of the reproach directed towards the defendant, are not two- but threefold. Cases of dolus directus and indirectus are so similar in culpability that they can be closely positioned alongside each other on the aforementioned spectrum. Consider the defendant who blew up an aeroplane. We do not distinguish the reproach, depending on whether he wanted to kill the pilot (directus) or whether he knew that the pilot would also die, even if he merely wanted to blow up the plane in order to collect the insurance (indirectus). Dolus indirectus is equated with dolus directus and in England, indirectus is not even seen as a separate form of intent.

Dolus eventualis and conscious negligence are also very similar in culpability. They both deal with the foresight of risks and only separated by a thin line of

484 In recklessness under section 2.02(c) of the Model Penal Code, American Law Institute 1985A, p. 226, the risk must be substantial as well as unjustifiable. 
volition. ${ }^{485}$ This explains why they can be positioned so close to each other on the spectrum and can be considered a pair, just like dolus directus and indirectus. For instance, if the accused blows up a building because it needs to make way for new housing, he knows there is a risk that tramps are sleeping or children playing in the building. By blowing up the building, he will kill anybody inside. If the actor accepts this risk and it occurs, he will be liable for eventualis, but if he trusts nobody will be killed, there can be only advertent negligence. The Dutch and German bifurcation of fault draws a strict line between these two cases, but in my opinion, this strict line is not appropriately based on a strict difference in culpability.

These pairs, directus and indirectus on the one hand, and eventualis and advertent negligence on the other, are thus very different from each other. ${ }^{486}$ There exists a fundamental difference between intending harm and foreseeing risks: the former is morally worse than the latter. ${ }^{487}$ Moreover, given the fact that they both deal with foreseen side-effects, advertent negligence is related closer to dolus eventualis than to inadvertent negligence, which is about unreasonable ignorance. ${ }^{488}$ Therefore, in terms of mens rea denoting the different levels of culpability, not just two, but three kinds of fault should be distinguished.

This is acknowledged in English law, where a distinction is made between intent, recklessness and negligence. Occasionally, this is also acknowledged on the continent. For example, the German legislator has enabled a punishment of up to five years for creating a certain danger to the Federal Republic of Germany with direct or indirect intent, whereas it enables a maximum penalty of only two years when the danger is brought about with dolus eventualis or serious negligence. ${ }^{489}$ The equation of the maximum punishment for an act committed with either the lowest form of intent or the most serious form of negligence is evidence that the culpability is perceived as similar.

\subsubsection{Dolus eventualis distorts intent}

Secondly, dolus eventualis distorts intent in both a legal and linguistic manner. I explained that dolus indirectus already is an extension of dolus directus. Given the fact that there is hardly any reason to distinguish in culpability between direct and indirectly willed consequences, this extension is not controversial in any of the Member States under investigation. However, eventualis does increase the strain on intent as acting in order to bring about. The core of intent either focuses on a very high degree of wanting (directus) or on a very high degree of knowledge, namely that a risk will certainly occur (indirectus), yet these elements of knowing and wanting are only present in a very diluted form in eventualis.

\footnotetext{
4855 March 2008 BGH BeckRS 2008, 05898 and 4 November 1988 BGHSt 36, 1. See IV.5.3.

486 Weigend 1981, p. 660-661 and Schünemann 1985, pp. 363-364.

487 Tadros 2005, p. 277. Compare Clark 2008, p. 525.

488 Peters, A.A.G. 1966, pp. 44-45 and Robroek 2010, p. 16.

$489 \$ 109 \mathrm{~g}(1)$ and (4) of the German Criminal Code.
} 
In general, continental lawyers are trapped in the dichotomy, engraved in stone by codification, that fault must be either dolus or culpa. ${ }^{490}$ Since there can be no middle form, an extension of dolus was the obvious choice to ensure adequate protection of legal interests and aggravation of liability for those actors that are more culpable than negligent ones. For example, with a few exceptions, the Dutch criminal code until 2006 only punished negligent offences with a maximum of nine months of imprisonment, even it the perpetrator caused death negligently. ${ }^{491}$ The criteria of eventualis, awareness and acceptance, may be rooted in knowing and wanting to ground it as a form of dolus, but they are very different from it. At most, they are diluted forms of knowing and wanting. The rationales of punishing dolus directus and indirectus, like the great degree of control over and choice for the outcome are also only present to a small extent in eventualis. Defendants do not have the same amount of control over foreseen side-effects as they have over intended results. The side-effects of my actions may be manifold, and my actions are not directed at them. Whether they occur or not, is often a matter of circumstances beyond my control.

One unified rationale has been advanced to capture all forms of dolus including eventualis. Continental scholars have submitted that the defendant is insufficiently motivated by the legal interests of others not only when he knows for certain that the result will occur or wants it to occur but also when he consciously reconciles himself with that possibility. ${ }^{492}$ However, this is such a diluted rationale that it can be said to apply to any fault element. After all, is the negligent actor, who fails to advert to the possible harming of other people's legal interest, not also insufficiently motivated by the legal interests of others? This rationale is therefore appropriate as a unitary reason for the fault requirement in offences - actus reum non facit nisi mens sit rea - but it is insufficient to explain the difference in culpability between dolus and culpa. All attempts to come up with a sound unified rationale for dolus that includes eventualis are doomed to fail, evidenced by the lack of consensus on a unified theory of dolus to this day.

In using eventualis to prove the defendant intended the damage he caused, we in fact prove far less than what we blame him for. We prove that the defendant consciously accepted that the risk might materialize, but we hold that he intended to harm the pertinent legal interest. He might have been aware of and reconciled himself with a lethal danger, but he is held to have intended death. This discrepancy of proof and label is unfair to the defendant. ${ }^{493}$ The defendant who foresaw a risk is equated with the intentional actor as far as stigma and legal consequences are

490 The ECJ apparently also only distinguishes between intention and (forms of) negligence in 26 May 1981, Case 157/80, Criminal proceedings against Siegfried Ewald Rinkau [1981] ECR $1395, \S 15$.

491 See Kamerstukken II 2001/02, 28 484, nr. 3. In the Road Traffic Act of 1994, maximum sentences for negligent offences had already been raised substantially.

492 Roxin 2006, p. 446 and Schönke \& Schröder, H. 2006, pp. 269, 281-283 and 351. See also Taylor, G. 2004A, p. 111.

493 See Weigend 1981, p. 692. 
concerned. As to the legal consequences, the difference between the two defendants can be taken into account in sentencing, but this is impossible when sentencing is mandatory.

Eventualis can be equated with dolus indirectus as to the creation of a danger. By being aware of a risk and continuing, the actor knows for certain he created an abstract or concrete danger. Whereas culpable, the intentional creation of danger should be punished less severely than the intentional violation of a legal interest. In the special part, this difference in the appropriate reproach is acknowledged. Generally, there exists a considerable lesser maximum punishment for offences of endangering a legal interest in comparison with violating the same legal interest. Creating a danger to life can never lead to life imprisonment, whereas murder can. 494

The distinction between intention and foresight also helps the law to motivate actors to inflict less damage to legally protected interests. Consider the hypothetical case where Witness is going to testify against Gangster. W's testimony is crucial for the prosecution to prove the charges made against G. The latter thus wants to make sure that $\mathrm{W}$ is not able to testify at his trial. He contemplates that he has two options of enabling this. First, he could kill W, which would be a certain way to prevent him from testifying against him. However, he could also have W incarcerated for a few days in a solitary spot. This brings about a risk that $\mathrm{W}$ might die, because he needs medical attention on a regular basis. Only if the law distinguishes between intending and foreseeing harm, can $\mathrm{G}$ be motivated by that law to choose the less violent course. ${ }^{495}$

A close match must be maintained between the perception of a legal concept of those who interpret it and those who are governed by it. The legal world may not deviate too much from the actual world. ${ }^{496}$ As far as normal language is concerned, eventualis is not properly labelled as intent. Arguably, the principle of legality may be invoked to restrict the scope of intent. ${ }^{497}$ Eventualis distorts what in normal language, philosophy and psychology is understood as intention. ${ }^{498}$ Such a broad concept of intent loses sight of the colloquial meaning of intent and the basic distinction of doing something purpose or not. This distinction is rooted very strongly in nature and society. If a child breaks something, he expects not to be punished if it was an accident: 'I did not do it on purpose.' The distinction in ethics is also one of the pillars on which our criminal law is build. At the heart of fault lies a true purpose to harm an interest that is protected by the law, which denotes the evilness of the actor.

\footnotetext{
494 See Weigend 1981, pp. 689-692; Stuckenberg 2007, p. 317 and Duff 2007, pp. 149-153.

495 Example derived from Simester in Simester \& Shute 1996, pp. 74-75. He however rejects this argument of 'marginal deterrence.'

496 See Horder 2006A, p. 16 and de Jong, F. 2009, pp. 311-313.

497 See de Jong, F. 2009, pp. 434-435.

498 R. v. Pearman (1985) 80 Cr App R 259: "It is offensive to common sense to suppose that simply because he could foresee it, he would be intending the offence to come about."
} 
When eventualis is used, one cannot only object to the extensive meaning of intent, but also to the concept of advertent negligence. This concept implies that negligence is not only about not foreseeing a risk where one should and could have, but also about foreseeing that risk. We can only explain why a concept encompasses two contrasting meanings by reference to its legal use. Thus, intention ought to bear the meaning it ports in ordinary usage. ${ }^{499}$ A restrictive interpretation of intent should be completed with a fault element of recklessness. A tripartite system of fault allows dolus and culpa to retain its contours. The least serious type of the former and most serious type of the latter are included in recklessness. ${ }^{500}$ Moreover, with three kinds of fault, there are more possibilities to distinguish the appropriate stigma and punishment. ${ }^{501}$

\subsection{Awareness over volition}

It could be argued that the demand for a system tripartite system of fault can also be met by disconnecting eventualis from dolus and labelling it as an independent tertium quid. Consider that in France, the similar concept of 'dol éventuèl' was not considered a form of intent but rather of negligence. In the 1994 Penal Code, the concept was transformed into an independent fault element of 'deliberately putting someone in danger'. ${ }^{502}$ This approach would meet the abovementioned objections against an extensive concept of intent. However, eventualis would remain problematic in use, as other objections remain.

\subsubsection{Dolus eventualis is controversial}

A general part of criminal law for the EU should be consistent. This means that the application of a concept should lead to foreseeable, clear outcomes. Similar cases should be solved similarly. I just argued that an extended meaning of intent is hardly foreseeable for laymen. In addition, I demonstrated that the outcome of applying eventualis to foreseen side-effects is also difficult to predict for lawyers. Since the application of eventualis leads to inconsistent results, the concept is disqualified from being used in a general part of criminal law for the EU.

It was explained that the concept has been controversial ever since it has been developed. Academic consensus is not to be expected any time soon, even though courts do agree on the scope and criteria of eventualis. The controversy is fuelled because its application varies according to the context. In the context of importing drugs, for example, the criteria of eventualis are very easily fulfilled, whereas its application is assessed with far more scrutiny in cases of fatalities (in traffic).

\footnotetext{
499 Taylor, G. 2004A, pp. 117 and 123. See also Brady 1980, p. 383.

500 Taylor, G. 2004A, p. 117 and Weigend 1981, pp. 687-692.

501 Gatzweiler 2008, pp. 168-169 and Weigend 1981, pp. 697-699.

502 Elliott 2001; Spencer \& Pedain in Simester 2005, p. 257 and Spencer in Horder 2007, p. 43.
} 
Nonetheless, even in cases with similar charges, facts and circumstances, intentional liability is accepted in one case but rejected in another. For example, in two cases, the defendant hit a person in the head with a firearm. Consequently, it fired and killed the victim. The Dutch Supreme Court quashed the conviction based on intent in one case, but upheld the conviction in another. ${ }^{503}$ It can be rebutted that eventualis is dependent on the precise circumstances of the case and the manner in which a court motivates its decision, but it can also be argued that dolus eventualis is prone to judicial whim.

I illustrated that dolus eventualis is connected more closely to culpa than to the other forms of dolus. It is therefore no surprise that similar cases are solved as eventualis in one and as conscious negligence in another case. Dolus and culpa bring about distinctly different consequences but are only distinguished by the volitional element. Most of the controversy and inconsistency surrounding eventualis therefore originates from its thin demarcating line with culpa. This element of taking into the bargain, approving of, accepting, being indifferent to or reconciling oneself to the risk materializing is difficult to grasp. It is hard to make concrete what constitutes acceptance and what is sufficient to negate this. I also demonstrated that its proof is contentious to the extent that many scholars have denied the existence of such a volitional element. ${ }^{504}$

\subsubsection{Controversy due to volition}

The existence of the volitional element in eventualis can be explained by the fact that fault in Germany and the Netherlands must always be either dolus or culpa. As mentioned before, continental lawyers seem trapped in the dichotomy of intent and negligence, unable to recognize a tertium quid. Although the first references to dolus eventualis in Germany do not refer to a volitional element, this has been included in time as a corollary of being a form of dolus. The core of fault, direct intent, focuses on a will. Other forms of dolus have therefore also been positioned in this evil will. ${ }^{505}$ Moreover, the dogma is that intent consists of knowing and wanting. 506 Therefore, any form of intent must include some degree of wanting. In eventualis, it is a very watered down form of weighing all the risks and reconciling oneself to the possible side-effects.

Accepting the risk is negated when the defendant trusted in a good outcome. This trust is juxtaposed with the mere hope in a good outcome, which is insufficient

503 HR 9 June 1998, NJ 1998, 731 and HR 24 February 2004, NJ 2004, 375 respectively. In 2 February 1960 BGH NJW 1960, 683, the situation was similar, but the defendant a police officer. Only negligence was established, just like in Hof Leeuwarden 11 August 2011 $L J N: B R 4891$.

504 Prittwitz 1993, p. 355. See IV.3.6.6. and IV.3.6.8.

505 Taylor, G. 2004A, pp. 103-105 and 110-111 and Weigend in Klip 2011, pp. 169-170.

506 Smidt 1881 I, p. 74; de Jong, D.H. \& Knigge 2003, p. 97; de Hullu 2006, p. 207; Schönke \& Schröder, H. 2006, p. 261 and Beulke 2008, p. 75. 
to negate the volitional element. Yet where do we strike the line between trust and hope? What is reconciling oneself with the possibility of the risk materializing? The concept is vague and hard to define in abstracto and even more difficult to grasp when applied in concreto. ${ }^{507}$ Intent is distinguished from negligence by the volitional element, but this does not provide for clear, foreseeable outcomes. Like many Dutch and German scholars have argued for on a national level, I will now argue that a volitional element should be rejected on the EU level too. Later, I will argue in favour of making awareness the lynchpin of fault.

\subsubsection{Proving fault from awareness or objective danger}

In proving fault, triers of fact can and should not always rely on what defendants tell them. In some cases, the defendant might remain silent. Even when he testifies, it is not always sensible nor allowed to rely solely on this statement. For these reasons, courts also infer fault from objective facts and circumstances, a practice familiar in EU law too. ${ }^{508}$

The inference of fault is based on the capacity to understand and recognize mental states of defendants. From conduct under certain circumstances and through rules of general experience, it can be inferred what the defendant thought and wanted. A precondition of this pronouncing upon the psyche of another is that these elements are basic in character and not profoundly psychological. For example, what somebody wanted can be inferred relatively easy, since underlying motives or end-goals of these wanted results are irrelevant. ${ }^{509}$ In contrast, I argued that the volitional element of eventualis, the diluted form of wanting, is hard to understand and therefore also hard to infer. Attitudes or dispositions are very intimate and they are hardly ever expressed through external acts.

The evidential difficulties became clear by taking a closer look at two of the most popular evidential approaches of the volitional element. A first is to reduce proof of eventualis to the mere awareness of the considerable chance that the offence element will be fulfilled. The degree of danger is directly associated with the question of whether or not the defendant accepted that risk. The more likely a risk was to materialize, the more likely it is accepted that the defendant has reconciled himself with that possibility. The more likely a risk was to materialize, the less likely a defendant will succeed in negating this aspect by arguing he trusted in a good outcome. ${ }^{510}$ This approach is popular in practice. It implies that the cognitive elements of eventualis, the likelihood of the risk materializing and its awareness by the defendant, are decisive in establishing eventualis. In other words,

\footnotetext{
507 Schünemann 1985, pp. 363-364; Taylor, G. 2004A, pp. 123-125 and Taylor, G. 2004B, p. 374 See also Stuckenberg 2007, p. 316 and Weigend 1981, pp. 660-661.

508 See III.7.2. and IV.3.6.2.

509 Van Dijk, A.A. 2008, pp. 240, 280-285, 289-290, 296-299, 302-303 and 375.

510 See IV.3.6.3.
} 
the volitional element follows from the cognitive and thus appears superfluous. It adds nothing to the threshold of criminal liability.

\subsubsection{Proof of volition by rules of general experience}

Secondly, in establishing the defendant's attitude to a risk of which he is aware, triers of fact attempt to reconstruct his attitude by drawing conclusions on the basis of rules of general experience. ${ }^{511}$ They try to assess what the disposition of a normal person in the shoes of the defendant would have been, given his behaviour and all other facts and circumstances of the case. This approach may be necessary in trying to establish the defendant's attitude, yet risks that the subjective attitude of the defendant is equated with the objective attitude of the reasonable person. In addition, applying general experience to infer attitudes leads to different solutions, which begs the question of how reliable such an approach is.

As a first example, consider that in Germany, a rule of general experience operates as a threshold of establishing the volitional element in lethal offences, namely the assumption called 'Hemmschwelle' that there exists a natural instinctive threshold for all against killing other people. This threshold does not exist in the Netherlands. In that Member State, another threshold operates as to conduct that creates serious risks to life and limb, namely the question whether the defendant also accepted the possibility he could die himself. ${ }^{512}$

As another example, consider the scenario that a driver of a vehicle is ordered to stop by a police officer for a check, but he wants to avoid this check as he has outstanding fines or is intoxicated. He therefore continues to drive and the officer has to jump aside to escape collision with the vehicle. The question then is whether the driver can be convicted for the attempt to kill the officer. This scenario was mentioned before in the context of how likely it is that the risk of hitting the police officer will occur. Here, the question is whether the driver also accepted the possibility of killing the officer. German courts consider that the defendant banks on the reaction of the police officer. They take as a rule that the defendant trusts the officer expects such actions and is mentally prepared to jump. This assumption is strengthened by the fact that these situations hardly ever lead to fatal results. There is therefore no acceptance of death and no liability based on dolus eventualis. In contrast, the rule of experience employed by Dutch courts in these cases seems to be opposite to that employed by German courts. After all, when we consider that in the Netherlands, the defendants in such cases are, as a rule, convicted for attempted killing, the rule of experience applied must be that the defendant does not count on a good outcome. ${ }^{513}$

511 This approach is also common in EU competition law to prove 'offence' elements, see Opinion of AG Kokott on 19 February 2009, Case C-8/08, T-Mobile Netherlands and Others [2009] ECR I-4529.

$512 \quad$ See IV.3.6.4

513 See IV.3.4.3. 
The application of these rules is thus unreliable, not only because the defendant's attitude is equated with the attitude of a reasonable person in his shoes, ${ }^{514}$ but also because of two contrasting rules, at most one can be correct. If such a rule of general experience is not true or does not apply to a specific case, the proof of intent becomes invalid. ${ }^{515}$ To some extent, the problems in these evidential approaches can be remedied. For example, I proposed that courts can be more explicit in assumptions based on common experience, be more critical of their application, or be very sensitive to those circumstances of the case that might indicate that the defendant deviated from the objectified person. However, these evidential approaches and its problems are inevitably connected to the use of the volitional element. As will be explained below, a legal concept that focuses on consciousness of risks avoids most of these evidential problems and is therefore the better option in a general part of criminal law for the EU.

\subsubsection{Is it warranted to distinguish by volition?}

Another objection to the use of a volitional element follows from its supposed justification. The volitional element as a requirement for dolus eventualis is grounded in the belief that an intentionally committed wrong can only be present when the actions of the perpetrator express his decision against the legal interest. By reconciling himself with the possibility of fulfilling the offence definition, by his indifference to the outcome, he has expressed his contempt for the legal interests of others and thereby also a hostile disposition to the legal order. ${ }^{516}$

If in contrast, the defendant thought everything would turn out alright, it is argued he did not act with this contempt. It is implicitly assumed that he would not have acted if he thought the risk would materialize, and he is therefore considered less culpable than the person who accepted the risk. ${ }^{517}$ However, this is speculation since we do not know what the actor would have done if he did not trust in a good outcome. His trust does not have to be based on his respect for the legal interest of others; it can also be based on the fact that he overestimates his own capacities to avoid, for example, a collision.

I question the supposed difference in culpability between dolus eventualis and conscious negligence, which should be considerable to legitimize the differences in legal consequences. Let us juxtapose a scrupulous, paranoid defendant with a frivolous one. Recall the example of the persons who have been contracted to blow up a building in order to clear the premises for a new building. Actor A has taken precautions to avoid the risk, such as fencing off the premises and conducting a check of the building just before detonating it. Nonetheless, he is very anxious that

\footnotetext{
514 Reijntjes 2004, p. 80.

515 De Jong, D.H. \& Kessler 1999.

516 Schönke \& Schröder, H. 2006, pp. 281-283 and Roxin 2006, p. 446.

517 Roxin 2006, pp. 447 and 1087.
} 
a person might die. He knows that a risk will always remain, and given his paranoid disposition, he merely hopes for the best. He has to accept the remaining possibility, since the job has to be done if money is to be earned. In contrast, actor B has ordered not even half of these precautions to be taken and frivolously trusts everything will be alright. Under Dutch and German law, the irrationally optimistic $\mathrm{B}$ cannot be convicted for intentional conduct when collateral damage in fact occurs, but the overly anxious pessimist A could. ${ }^{518}$

Considered from the perspective of a difference in culpability or concern for the legal interests of others, a contrary outcome would be expected. B is more culpable than A and has less concern for the wellbeing of potential victims, yet he cannot be held liable for intent, whereas A can. The conscientious actor is punished more severely for being pessimistic, whilst he is more likely to take precautionary measures and avoid risks altogether. If actor A was indifferent to the possibility of people dying in the explosion this would have shown contempt for the legal interests of others. But when the volitional element is merely fulfilled due to a reluctant acceptance on behalf of the defendant, this does not show a similar degree of contempt towards the legal interests of others. The frivolous actor is rewarded for his optimism, whilst his frivolous trust might even be understood as being insufficiently motivated by the interests of others. After all, would he have also trusted everything would be all right so easily if there were a possibility his son was in the building? To me, it is evident that the defendant would have considered the risk with more care and might not come to that frivolous conclusion so easily.

Thus, in some cases, less contempt and thereby culpability is expressed by fulfilment of the volitional element than its rejection. The distinction of culpability does not always coincide with that of the volitional element. If the deviation is serious, like in the example given above, the judiciary will circumvent the theoretical straightjacket. In such cases, it will apply volition normatively, with a view to the desired solution of the case. The frivolous actor is not acquitted of the intentional charges made against him, because trust in a good outcome is only accepted if it is reasonable and objectively understandable. ${ }^{519}$ The pessimist actor is considered not to deserve harsh punishment and is therefore deemed to have trusted in a good outcome, which can be read into the precautions he took to avoid the danger. 520

Many continental lawyers and practitioners welcome the uncertainty in using the volitional criterion. This element allows the triers of fact for discretion in attributing intentional liability where it seems warranted. ${ }^{521}$ The pessimist actor

518 Gatzweiler 2008, pp. 150-151 and 163 and Jakobs 1995, p. 862.

519 Gatzweiler 2008, pp. 174-179 and 186, who draws the attention to other Germano-Romanic legal systems with similar trends.

520 Compare the theory of 'nicht betätigten Vermeidungswillen' (Kaufmann) that makes decisive the omission of the actor to avoid the risk materializing, and the comparable theory of 'abgeschirmten Gefahr' (Herzberg), mentioned in Roxin 2006, pp. 459-460 and 465-467.

521 See AG Röling in HR 6 February 1951, NJ 1951, 475. For example, it enables the acquittal of the police officer who shot a fleeing burglar in the back at a range of three metres, see 6 March 2008 
would be acquitted because he is considered a 'basically decent' person. ${ }^{522}$ It is clear however, that this risks uncertainty and lack of foreseeability, inequality and liability based on character. Moreover, dolus becomes normative, whereas it expresses a reproach for a subjective relationship between act and actor. By attributing intention, the question on whether the defendant really had intention is surpassed and cases of negligence are included in the scope of intent. ${ }^{523}$

Finally, it can be doubted whether every defendant always takes a position on the occurrence of the risk. It is argued that awareness of the risk implies that the actor must have taken a position on it, but if we know that it is not always evident that someone has considered all the possible side-effects of his actions, ${ }^{524}$ then how can we accept that - in the heat of the moment - he has made the valuation and decided to act nonetheless? ${ }^{525}$ In many impulsive acts, the defendant will not have had the opportunity to make a decision. Many cases seem to imply no disposition at all. This does not mean that the defendant relied on a good outcome, but neither does it imply he must have accepted the risk. Nonetheless, the volitional element suggests that a decision is always made. The actor either accepted the risk or trusted in a good outcome. This explains that courts are forced to take a stand on a position that might be lacking. As a result, a fictional disposition is attributed to the defendant. 526

\subsubsection{Awareness is the better dividing line}

Whereas the border drawn by volition is uncertain and therefore difficult to apply, the border drawn by awareness is clearer and the different fault elements are therefore easier to apply. As noted, I propose a tripartite system of fault that uses recklessness as a middle category. ${ }^{527}$ The distinction of eventualis and advertent negligence is no longer relevant, since recklessness covers both fault elements. All these elements deal with side-effects that were foreseen by the actor. ${ }^{528}$

By rejecting the relevance of attitudes as to this risk, the contours of culpa become clear again. Culpa is limited to those cases where the defendant is unaware of the risk. This enables us to distinguish between the wicked and the stupid. 529 "It is clearly blameworthy to take an obvious and significant risk of causing injury to

BGH BeckRS 2008, 04800 and the similar case 25 March 1999 BGH JR 2000, 297. 
another. But it is not clearly blameworthy to do something involving a risk of injury to another if (...) one genuinely does not perceive the risk. Such a person may fairly be accused of stupidity or lack of imagination, but neither of those failings should expose him to conviction of serious crime or the risk of punishment."530 Even though it is accepted in this general part that inadvertent negligence may be punished, it is important to distinguish the wicked from the stupid. The difference in culpability between the two is an argument to clearly separate recklessness, based on advertence, from culpa, based on inadvertence.

\subsubsection{Easier to prove}

An important function of dolus eventualis is to facilitate proof. In general, an offence element that requires intention can be fulfilled by either proof of dolus directus, indirectus or eventualis. As a consequence, the prosecution generally only seeks to prove that the defendant acted with eventualis. This is easier to prove and explain by judges in their verdicts, because its cognitive and volitional aspects are very diluted in comparison to dolus (in)directus. It does not need to be proven that the actor knew something was almost certain to happen, merely that he was aware it was possible that a result could materialize. It also does not need to be proven that the actor wanted a result to occur; only that he accepted that this could happen.

The rejection of eventualis clearly limits the scope of dolus. Paradigm cases of eventualis can only amount to reckless liability and eventualis no longer suffices as proof for dolus directus or indirectus. This brings about that the two most serious forms of dolus need to be actually proven. On the one hand, this increases the burden of proof and may make just convictions more difficult. On the other hand, we should limit the label of liability to what is actually proven. If the accused is charged with intending to damage something, this should not be accepted upon proof of the conscious creation of a danger.

Moreover, the objective evidential approach that facilitates proof of fault can also be applied to dolus (in)directus. The prosecution often merely seeks to prove eventualis since he is not required to prove more. It is an economic decision. However, this does not mean the prosecutor would be unable to prove more serious forms of dolus by inferring purpose or knowledge from conduct, circumstances and so on. English criminal law restricts dolus to directus and indirectus too, yet is very able to prove these fault elements by reference to facts and circumstances. ${ }^{531}$ In the Netherlands, proof of dolus directus and indirectus is also easily inferred. For example, the ulterior intent of disposing over goods without paying for it (in full)

530 R. v. G. [2003] UKHL 50, $\$ 32$ per Lord Bingham of Cornhill.

531 Simester \& Sullivan 2007, p. 616 and Williams 1953, p. 142 submit that the claim of a defendant that he made a mistake or was ignorant as to an offence element is often seen as a general defence, like self-defence, because usually fault is established quite easily from the facts. 
was inferred from the general experience that someone who is in the financial situation of the defendant must have known he would not be able to pay. ${ }^{532}$

Recall as an example of an objective approach the judicial formula that the external manifestation of the act is so much directed at a certain consequence, that the only conclusion can be that the defendant accepted the consequences, barring contraindication. This formula is hardly controversial as it leads to the acceptance of eventualis in cases where the actor inflicted very serious violence upon somebody and then argued he did not intend this serious injury. For example, the defendant shot at the victim with a firearm, yet argued he only wanted to injure him, not kill him. We should not merely hold that the defendant consciously accepted the lethal risk, when we believe that he wanted to kill the victim. Eventualis is used too often, only because it suffices. ${ }^{533}$

In England, it is also common to infer knowledge and intent from the external manifestation of the act, after which it is up to the defendant to rebut the prima facie case against him. When consequences are very likely to follow from conduct, this may be used to infer intent, but other circumstances of the case can also be used to find knowledge or intent, such as that you are buying stolen goods when the price is ridiculously low and the location strange. ${ }^{534}$ There is no need to resort to eventualis to hold the accused liable for such an offence. A similar approach is conducted in the context of possessing drugs. The offence was interpreted as requiring knowledge on the drugs, but at the same time, the required knowledge is limited. It need not be specific, and could be presumed when found in possession of drugs. For the presumption to be rebutted the defendant not only has to make probable he was ignorant, but also that he had no reason to suspect he was possessing controlled substances. ${ }^{535}$

Not all cases that qualify under eventualis can be proven by reference to dolus directus or indirectus. Cases that are not merely proven by reference to eventualis for pragmatic reasons can be punished under recklessness. Proving recklessness is much more straightforward than proving eventualis as only the subjective awareness of any risk needs to be proven. The difficulties in proving that the defendant accepted the risk do not apply to recklessness. Awareness is much more basic in character, less profound and less intimate than the volitional element. As a consequence, it is much easier to be reliably proven from facts and circumstances. 536 The use of eventualis and advertent negligence implies this too, because the establishment of awareness necessarily precedes the question of attitude.

Secondly, proof of awareness does not require much. Awareness is fulfilled if the defendant knew the risk might occur. He need not continuously or even at the

HR 17 September 1990, NJ 1991, 58.

Weigend 1981, pp. 691-692.

534 Edwards 1954, pp. 295-298. See IV.2.5.3.

535 Warner v. MPC [1969] 2 AC 256. Codified as a defence in section 28(3) of the Misuse of Drugs Act 1971, see R. v. Lambert [2001] UKHL 37.

536 Vellinga, W.H. 1982, p. 78; van Dijk, A.A. 2008, pp. 285, 288-290 and 375. 
time of acting think about the risk. If the person knows something is dangerous like anyone else, it is no problem that at the moment of the crime he did not consciously reflect on the risk. Consider that the more evident knowledge is for someone, the less conscious he thinks about it. Awareness does not have to be explicit or conscious, as general awareness or background knowledge suffices. ${ }^{537}$ Awareness at one point in time suffices. When a defendant acts impulsively or in a bad temper, the state of mind is assessed at an earlier and calmer time in order to prevent acquittal. When the defendant closes his mind to the obvious, he can still be reckless. ${ }^{538}$

Extending the interpretation of dolus to eventualis is not the only way to upgrade liability for the causing of more harm than intended. If desired, this can be accomplished through the special part as well. The offence can be defined in a way that it not only covers the intentional causing of a serious harm but also the intent to cause a lesser harm which led to the more serious harm. For example, the English offence murder not only covers the intent to kill but also the intent to cause gross bodily harm, which results in death. .39

When we consider that the English prosecutor only needs to prove the lesser intent, the lack of dolus eventualis to the most serious form of homicide is put into perspective. When the conduct was objectively very dangerous and the defendant pleads he did not want to kill the victim, there is no need to use eventualis: it can be inferred reliably he wanted to inflict gross bodily harm. ${ }^{540}$ This technique is also used in other Member States in so-called result-based offences, where intent need not relate to the (more serious) result. The fault element as to this more serious harm, such as death during a robbery, can be either negligence, and in Dutch law even strict. Other ways of facilitating proof of liability for foreseen side-effects is to create offences of endangerment. Certain knowledge on a danger is the same as

537 Fokkens \& Machielse, note 4 on Opzet; Brady 1996, pp. 187-188 and 199; Ashworth 2006, pp. 183-185 and R. v. Stephenson [1979] EWCA Crim 1: "Proof of the requisite knowledge in the mind of the defendant will in most cases present little difficulty. The fact that the risk of some damage would have been obvious to anyone in his right mind in the position of the defendant is not conclusive proof of the defendant's knowledge, but it may well be and in many cases doubtless will be a matter which will drive the jury to the conclusion that the defendant himself must have appreciated the risk."

538 R. v. Stephenson [1979] EWCA Crim 1: "We wish to make it clear that the test remains subjective, that the knowledge or appreciation of risk of some damage must have entered the defendant's mind even though he may have suppressed it or driven it out." See also IV.2.5; R. v. Parker [1977] 1 WLR 600; Edwards 1954, pp. 301-303; Ormerod 2005, p. 103; Simester \& Sullivan 2007, pp. 135-136 and Ashworth 2006, pp. 183-185.

539 Ashworth 2006, p. 256.

540 This does not refute the argument on the moral and legal distinction between dolus (in)directus and eventualis. The broad scope of murder in England as including both the person who wanted to kill and the person who intented to inflict severe injuries has been criticized in England for decades and even given rise to a Law Commission proposal to restrure homicide offences. Even Public Prosecutors have expressed concern that juries tend to acquit defendants altogether because they feel the conviction and mandatory punishment for someone who 'only' intended to injure is inappropriate. 
knowing there is a possibility of harm. ${ }^{541}$ The evidential facilitation is that the actual risk need not have materialized.

A criminal legal justice system that respects both its functions of shield and sword should operate with a general part that is enforceable. This means that fault elements should be "simple and easy to apply and at the same time conceptually rich enough to enable a judge to make all those distinctions that must play a role in the administration of criminal justice." 542 Recklessness is able to strike this delicate balance. It is simple enough to apply and makes dolus more comprehensible too, whereas it meets the need of differentiating between those defendants that intend harm and those that merely foresee harm. On the one hand, recklessness extends liability in comparison to eventualis but on the other, being convicted of a reckless offence does not bring about the same severe legal consequences as being convicted of an intentional crime. Moreover, dolus is neither distorted in substance nor by procedure.

\subsection{Normative aspects}

The third category of arguments in favour of using recklessness for a general part of criminal law for the EU deals with the advantage of taking into account normative aspects. First, let us clear up again how this normative approach works. Recklessness requires actual awareness of any degree of risk, which is unreasonable. Whether a risk is reasonable is judged according to the social utility of the act relative to the nature of the activity and the degree of risk. This is why any risk suffices and there is no need for a threshold of probability. A small chance can be unreasonable if it has no social utility and presents the possibility of great harm. The more valuable a legal interest is, the sooner a risk becomes relevant. I already gave the example of having unprotected sexual intercourse. The chance of HIVinfection might be small, but the consequence very serious.

The risk can also be reasonable if the actor furthers a good cause that necessarily brings about a small chance of minimal harm. We take risks all day, often even professionally. Driving a vehicle or operating an industrial machine in compliance with the pertinent rules may cause unwanted side-effects, but when they occur, this does not make us recklessly liable. Recklessness thus protects paranoid actors with a vivid and pessimist imagination, as in the example above, against liability. The actor might have considered all possible effects of his actions, but liability not automatically follows when unlikely side-effects occur. ${ }^{543}$

A great chance of a small risk does not necessarily constitute recklessness either. I gave the example of the high likelihood that this book bores its reader, as a side-

\footnotetext{
541 Stuckenberg 2007, pp. 316-317. Offences of endangerment and result-based offences are also discussed in V.2.3.

542 Jareborg according to Ambos 2005, p. 178

543 See Prittwitz 1993, pp. 351-352.
} 
effect of purpose to design a general part of criminal law for the EU. This does not amount to an unreasonable risk. I argued that the aspect of unreasonableness excludes trivial harm from liability and thus helps to prevent over-criminalization. Such a safety valve is missing in the neutral concept of dolus. In principle any harm can be committed intentionally, unless aspects extrinsic to dolus, like the harm principle and justifications, preclude this.

The normative criterion of reasonableness thus enables both the extension and restriction of relevant risks. We take risks all day and that many of them are inevitable. Criminal liability should therefore be limited to the taking of risks, which are unreasonable, given the goal of the conduct and the nature and extent of the possible harm. Whereas the concept of dolus eventualis cannot provide for such a limitation, recklessness can. In the proposed tripartite system, recklessness and culpa both revolve around the taking of unreasonable risks. ${ }^{544}$ If a risk is objectively reasonable, there can be no liability, accept when the offence is strict. The difference between the two is that the reckless actor was aware of a risk inherent in his conduct. The negligent actor was unaware of the risk he created, whilst he should and could have known. Awareness is thus the clear dividing line. There is no room for confusing concepts as conscious negligence. Using recklessness brings about that culpa consists only of inadvertent negligence.

Whereas in eventualis, the attitude of the defendant is often irrelevant in practice, in recklessness, it is always irrelevant. If a person has taken an obvious or unreasonable risk, dolus eventualis is likely to be inferred, even if the defendant claims he trusted everything would be alright. When the risk and the possible harm were great, lay people do not attach much weight to the question of whether the defendant trusted in a good outcome. In practice, neither do continental lawyers. The reproach focuses on the conscious creation of an unreasonable risk. It is therefore logical, many continental scholars have tried to either explain the practical applications of dolus eventualis by reference to a normative concept or even advocated the use of such a concept. In many aspects, a normative concept of eventualis as for example Frisch has advocated, resembles recklessness. ${ }^{545} \mathrm{He}$ argued that intention is acting while being aware of a concrete danger that is normatively relevant. ${ }^{546}$ Both eventualis and recklessness give primacy to the objective assessment of risks. However, only the concept of recklessness is straight forward about this. In eventualis, the defendant's plea is rejected or circumvented by evidential approaches whereas in recklessness, the concept itself clearly determines that neither attitude, nor mistakes on the degree of the risk are relevant.

Since recklessness is distinguished from intent, the objections that can be made to making dolus a more normative concept do not apply. Dolus retains its purity by

\footnotetext{
544 Weigend 1981, pp. 676-677 and Weigend in Klip 2011, pp. 164-165.

545 Frisch 1983, in particular pp. 301, 322-323, 462-462, 474, 487-495 and 500. See also Strijards 1983 , pp. 102-103, who argues dolus eventualis is about a legally inacceptable chance, see IV.3.4.5. and IV.3.6.8.

546 Frisch 1983, pp. 487-494. See IV.3.4.5.
} 
dealing with normative issues in recklessness. The meaning of intent is not stretched to forms that lead to suspicion of normative influences. The tripartite system of fault elements provides us with a subjective or psychological concept of dolus and a predominantly objective concept of culpa. In between those two elements, recklessness is positioned, which is both subjective and objective in nature. It is subjective because it requires actual, personal awareness of the defendant that he takes any risk, but whether this risk is in fact unreasonable is assessed objectively, independent of the valuation of the defendant. ${ }^{547}$

This approach can be compared to the manner in which mistakes on normative elements influence dolus: if the defendant knows all the facts that are relevant for the assessment of the risk, the fact that he made a different valuation, for example, whether acting based on certain facts was unacceptable or indecent, does not negate dolus. ${ }^{548}$ Normative valuations are made by the legal order. These valuations prevail over individual considerations, since any other approach would make the scope of the law dependent on the will of the individual and thereby risk inequality and uncertainty to everyone. In EU competition law, a similar approach exists as to the facts and valuation underlying the anti-competitive nature of an agreement and the transnational character of its anti-competitive effect. ${ }^{549}$

Consider that a motor company accepts a risk of fatalities because it has calculated that a recall of all vehicles would cost more than what they expect to be convicted for in civil law as compensation. ${ }^{550}$ The fact that the company accepts the risk does not make this risk reasonable under criminal law. As a result, the company could be held liable for recklessness. This example demonstrates that the reproach in recklessness is not based solely on the awareness of the facts grounding a risk, but also on the fact that by acting, the defendant made a different valuation of this risk that the law prescribes. By favouring profit over human lives, the company' definition of with is reasonable differed grossly from what the legal order finds reasonable.

\subsection{Fault in attempt and participation}

This proposal has consequences to other important doctrines of criminal liability, such as attempt and participation. Both doctrines are not part of this particular

547 It is clear again how much this resembles a normative concept of dolus eventualis. De Jong, D.H. 2004B, p. 76 argues eventualis has both a psychological and normative part and Frisch 1983, pp. 487-494 distinguishes the knowledge of the risk (Vorsatzbegriff) from the normative appraisal of the risk (Vorsatzgegenstand). Frisch 1983 also argues on pp. 462-462, 474 and 495 that justifications therefore make risks reasonable, negating the objective part of dolus.

548 See IV.2.4.8

5497 June 1983, Cases 100-103/80, SA Musique Diffusion Française [1983] ECR 1825; Opinion of AG Mazák on 22 April 2010, Case 280/08 P, Deutsche Telekom, not yet reported, and 14 December 2006, Cases T-259-264 and 271/02 Raiffeisen Zentralbank Österreich, [2006] ECR II-5169.

550 I left out additional issues such as the loss of reputation by recalling vehicles on the one hand and by being convicted, both in criminal and civil law, on the other hand. 
research and are therefore not discussed in detail. ${ }^{551}$ However, many of the examples and cases in this book deal with attempt, which warrants a brief discussion of the question what fault element should be required in that context. In addition, the case in favour of using recklessness can be strengthened by pointing out the advantages it has in the context of participation.

\subsubsection{Attempt}

Coherency requires that fault should bear the same meaning in attempt as in completed offences. The rejection of dolus eventualis in completed offences thus brings about that this fault element should not suffice for attempt liability either. A subsequent question is whether attempt could instead be committed recklessly. ${ }^{552}$ Since recklessness also covers cases of conscious negligence, this would be an extension of attempt liability from a Dutch and German perspective. ${ }^{553}$ It would also be an extension from an English perspective, as recklessness does not suffice for attempt in English law. 554

I see no reason to deviate from the existing English approach. This has proven to work in practice and is coherent with fault in completed crimes, committed by one actor. This means that only dolus directus and indirectus suffice for attempt and participation. ${ }^{555}$ In other words, an actor can only be punished for being aware a risk may materialize when it facts does materialize. This more limited approach to fault in attempt also prevents the distortion of the concept. Linguistically and conceptually, attempt is strained if it can be committed by merely foreseeing sideeffects. Attempt is connected to a purpose, the only difference with a completed crime being that the actor failed to achieve his purpose. The defendant does not 'attempt' to bring about side-effects which he does not seek, except for those sideeffects which are certain to occur. Though dolus indirectus may also linguistically strain the concept of attempt, good reasons have been given to equate it with dolus directus, such as the certainty of the result and the lack of a moral difference between the two.

Consider the case where the accused wants to set fire to a house in order to kill the inhabitant, his arch enemy. He contemplates and accepts the possibility that firemen will die in the line of duty as well as that the fire might spread to neighbouring buildings resulting in even more fatalities. His plan does not work out as planned: his enemy succeeds in getting out of the house and the fire is extinguished before it can spread to the adjacent buildings. No one would deny that

\footnotetext{
551 See Keiler 2012, forthcoming.

552 See Weigend 1981, p. 699.

553 Beulke 2008, p. 247 and Bosch 2008, p. 174.

554 Weigend 1981, pp. 676 and 679.

555 Taylor, G. 2004A, p. 108. Some English authors argue that indirect intent does not suffice for attempt, like Ormerod 2008, p. 381. This issue has not been the object of much debate in Germany and the Netherlands since the lesser dolus eventualis also suffices.
} 
the defendant can be convicted of attempting to kill his enemy. But should he be held liable for attempting to kill the firemen and people living in the vicinity too? If attempt merely required dolus eventualis or recklessness, this would be possible. But where should one draw the line? Should he be held liable for attempting to kill all the firemen who rushed to the fire, all the inhabitants in a radius of half a mile? It seems more appropriate to convict the defendant for attempting to kill the person he wanted to kill.

By choosing this manner of killing his enemy, he also showed contempt for the interest of the firemen and neighbours because he consciously took the risk of killing them too. If this should be punished in addition to the attempt, convicting him of an offence of endangerment can also enable this. It is common for Member States to have an offence of exposing others to a risk to their life or limb by creating a fire. ${ }^{556}$ It follows that an important reason to criminalize recklessness in England is the fact that the risk materialized. This creates a significant contrast with its functional equivalent dolus eventualis, which is often used to ground an attempt.

Attempt should therefore be limited to dolus, with one final exception, namely when recklessness would have also sufficed for the complete offence. If the offence definition requires recklessness as to some elements, proof of recklessness as to those elements should also suffice for attempt liability. Some offence definitions require intention as to conduct and recklessness as to a circumstance. The offence of (statutory) rape can for example require intent as to the intercourse and recklessness as to the circumstance of age or consent. As recognized in English law, it would be absurd if the completed crime lets recklessness as to the consent or age suffice, but would require intent as to such a circumstance if the actor failed to penetrate. ${ }^{557}$ By contrast, in order to hold attempt liability, intention must relate to the penetration, but nothing more than recklessness would be required in relation to the circumstance of age or consent. It is very difficult to give a principled criterion for the exception. ${ }^{558}$ In general, it can be said that the exception only applies to offences that require recklessness as to a circumstantial element and intention as to another. In Dutch law, a similar rule exists. If negligence suffices as to an accompanying circumstance of an otherwise intentional offence, such as that the

556 See article 157 of the Dutch Criminal Code, $\$ \S 306 a-c$ of the German Criminal Code and section 3 of the English Criminal Damage Act 1971. The offences of endangerment in traffic in $\$ 315$ and following of the German Criminal Code can also be explained by reference to the aforementioned example that not stopping one's vehicle for a police officer who has to jump aside in order to avoid a collision, generally does not suffice to accept conditional intent as required for attempt liability.

557 R. v. Khan [1990] 1 WLR 815; Attorney-General's Reference no. 3 of 1992 [1994] 2 All ER 121; section 49(2) Draft Criminal Code, Law Commission 1989, p. 64 and Safferling 2008, pp. 413415. The offences of (statutory) rape in England currently however no longer require proof of fault as to the age or consent. Just like in Dutch law, the intent of an attempted statutory rape should thus relate only to the having sexual intercourse, not the age of the victim, see Mols \& Wöretshofer 1994, p. 16.

Duff 1995 makes an attempt, which did not however convince me. 
object was stolen, nothing more than negligence is required in relation to this circumstance for attempt liability. ${ }_{5} 59$

Restricting the scope of attempt and preparation ${ }^{560}$ to dolus (in)directus may be criticized as attaching too much weight to moral luck. After all, in such an approach, the liability of the defendant will hinge to an important extent on whether the risk materialized or not. The person who knows he is HIV-positive, could not be held liable for an attempted infection when having unprotected sexual intercourse. However, if we focus on the harm principle, the distinction in liability according to the outcome is legitimate. Alternatively, if criminal liability is considered appropriate, the legislator could choose to criminalize the creation of the risk itself.

\subsubsection{Participation}

In the context of participating in a crime, by for example, aiding the principal, it can also be asked what kind of fault element should suffice. The basic rule is that the intent of the participant must also relate to the specific offence that is committed by the principal. ${ }^{561}$ That rule can come under pressure in cases where the defendant, did not want to participate in an offence, but contributed to the offence by an innocuous act. It is also relevant in cases where the perpetrator commits a more serious or different offence than was agreed upon by the participant. It is tempting to hold all participants liable for these 'collateral offences' based on foreseeability, or on the idea that the more serious offence was of the same type or not entirely different from what was intended. However, every single participant can only be held liable for those offences he intended or at least foresaw.

As a lower limit, dolus eventualis is a popular concept in holding the participant liable for actions of the perpetrator. For example, this fault element as to death is easily established upon knowledge that the perpetrator took a firearm to a confrontation. ${ }^{562}$ The advantage of using recklessness as the lower limit here becomes obvious if we consider that under eventualis, the scope of aiding and abetting is too broad. One could imagine a cashier in a garden centre with a vivid imagination, who believes that some of his clients are terrorists. If the manure he sold is in fact used to make a bomb, he could be held liable for participation too.

Eventualis does not exclude the cashier from liability, leaving him to the whims of prosecutorial discretion. Recklessness would provide for an appropriate threshold to liability, because it also limits liability normatively. The degree of likelihood of the risk occurring and the nature of the risk are weighed against the social utility of the act that gives rise to the risk. The fact that selling manure is a legitimate act can

559 Intention must relate to the other offence elements, like selling, see HR 6 February 1990, NJ 1990, 417. In contrast to prevailing opinion, Mols \& Wöretshofer 1994, pp. 21-22 argue in favour of attempting other negligent offences too, like negligent killing.

561 Hamdorf 2007, p. 215.

562 HR 8 May 2001, NJ 2001, 480. 
offset the small chance that it will be used to make a bomb. The risk might become less acceptable if there are circumstances surrounding the sale that must have raised suspicion. ${ }^{563}$ Still, this suspicion must have entered the defendant's mind through facts known to him. The paranoid actor is thereby excluded from liability.

If it cannot be proven that what the defendant argued was a deviation from what was agreed upon, was foreseen by him, he can still be punished based on other forms of liability than participation. An alternative would be to convict him for (assisting in) the result based offence of robbery resulting in death. It suffices to prove that the defendant intended to assist the robbery, and the reasonable person would have foreseen this could lead to fatalities given the circumstances. These result-based offences are quite common, requiring negligence or even no fault at all as to the fatality and thereby reducing the strain to legal principles such as participation. 564

\subsection{Concluding remarks}

For all these reasons, a general part of criminal law for the EU should use three kinds of fault. Dolus encompasses those results that were wanted or known to occur with almost absolute certainty. Reckless is the actor who was aware of unreasonable risks and negligent is the actor who was unaware of unreasonable risks. This latter element, culpa, will be discussed in the next paragraph.

My proposal largely follows the English distinction in fault elements. Thus, consistency is ensured as the English legal system has proven to be enforceable. Other continental scholars, like Thomas Weigend ${ }^{565}$ and Bernd Schünemann, ${ }^{566}$ have also argued in favour of third fault element in between dolus and culpa. ${ }^{567}$ Referring to a possible general part of criminal law for the EU, Australian scholar Greg Taylor came to a very similar proposal. ${ }^{568}$ Finally, the Corpus Juris projects are in line with this proposal. 569 The popularity of this tripartite system of fault may be seen as an argument of authority.

As for its higher limit, recklessness is distinguished from dolus by probability. In 1979, Danish scholar Ross wrote that he believed that the trend of scholars to 'free themselves from the empty formulas on volition', would evolve into a sole focus on probability. ${ }^{570}$ The lower limit of dolus - dolus indirectus - labels sideeffects which are almost certain to follow from the wanted consequences as

\footnotetext{
563 Compare HR 30 June 2009, NJ 2009, 481.

564 Compare 27 January 2011 BeckRS 2011, 03958.

565 Weigend 1981. See also Weigend in Klip 2011.

566 Schünemann 1985, pp. 363-364.

567 Robroek 2010, pp. 18 and 29 refers to the Dutch Scholars Langemeijer and Wijnaendts Francken, who made similar proposals.

568 Taylor, G. 2004A and 2004B.

569 Delmas-Marty \& Vervaele 2000, p. 192.

570 Ross 1979.
} 
(indirectly) intended outcomes too. The probability is decisive in limiting dolus indirectus, as the defendant must know with a high degree of certainty that his conduct will result in the prohibited consequences. Since no one can ever know that a result is certain to follow, certain means almost certain or certain, barring some unforeseen intervention. ${ }^{571}$ Anything below this threshold is insufficient for dolus indirectus and brings us in the realm of recklessness. ${ }^{572}$

Being asked to criticize the proposal, Weigend raises some doubts as to the demarcation of dolus indirectus with recklessness by means of the degree of likelihood. ${ }^{573}$ First of all, such a quantitative demarcation would require us to secondguess as to what went on in the defendant's mind at a certain point in the past. This is correct, but can also be raised as a general problem in regard to proving fault. Moreover, the qualitative demarcation of volition leads to more problems. Using probability as the distinguishing feature is the lesser evil: inferring awareness is much easier and more reliable than volition. The attitude of a defendant is much harder to assess than subjective probability.

Secondly, Weigend argues that there exists no rational basis for placing the lower limit of certainty required for dolus indirectus at 99, 95, 90 or 89 percent certainty. Whereas it is indeed somewhat arbitrary to quantify a chance that is expressed qualitatively, I also explained that this is general problem of fault elements, which is most serious in the context of dolus eventualis. ${ }^{574}$ After all, it is much more difficult to reach consensus on what chance is 'considerable' than to agree on what almost certain is, expressed in a percentage. If pressed to put a number on almost certain, barring some unforeseen intervention, 99 percent to me seems most accurate. Only such a high degree of probability warrants the extension of dolus. Only in such a case, is it legitimate to equate the foresight of causing harm with the purpose to bring it about. . $^{575}$

Third, Weigend raises the question of whether or not the chance of dolus indirectus should also be assessed in a normative way. Should both quality and quantity of the risk matter? Should the nature of the possible harm be taken into account, just as in recklessness? He gives the example of a person having unprotected sexual intercourse whilst knowingly being infected with HIV. Could we imagine the normative risk to qualify as almost certain, given the seriousness of the possible consequences? ${ }^{976}$ The answer to this question must surely be negative: we should not claim that this defendant intended to infect the victim. This would run contrary to the nature of dolus, and dolus indirectus in particular. First of all, as

571 Ashworth 2006, p. 177; Williams 1953, p. 37; Ormerod 2005, p. 97; van Dijk, A.A. 2008, p. 347; Fokkens \& Machielse, note 2 on Opzet; Bohlander 2009, p. 64 and Beulke 2008, p. 78. This can be equated with the 'ordinary course of events' used in article 30 of the Rome Statute.

572 Simester \& Sullivan 2007, pp. 124-126; Law Commission 1989, pp. 192-193; Law Commission 1993, p. 10 and Williams 1953, p. 39.

573 Weigend in Klip 2011, p. 162.

574 See IV.3.4.4.

575 See IV.2.3.2.

576 Weigend in Klip 2011, p. 162. 
reiterated above, dolus indirectus is legitimized by the high degree of empirical probability, verging on certainty. Secondly, there is no room for normative aspects in dolus. In fact, by setting aside dolus eventualis, we enable dolus to retain or, depending on the pertinent legal system, reclaim its psychological character.

Finally, as far as demarcation is concerned, it could be argued that the concept of normative risks brings about an additional layer of assessment and thereby possibly an additional layer of problems. The practice in England has however not shown this to be a legitimate concern. I admit that problems of demarcation will remain to some extent, not so much because a tripartite system brings about an additional distinction, but because any categorization of fault elements and any criterion sparks legal debate. Discussion will remain as long as there is something to demarcate. ${ }^{577}$

Nonetheless, I have argued that in distinguishing fault by awareness rather than volition, the problems of demarcation will significantly decrease. Legal systems that apply a threefold distinction as opposed to a dichotomy of fault elements are less sensitive to differences in legal consequences and problems of demarcation. ${ }^{578}$ This implies that less pressure is put on the concepts of intent and negligence to inor exclude certain cases. ${ }^{579}$ The less pressure is put on it, the better the law becomes.

\section{CULPA}

Culpa denotes a culpable failure to be aware of the unreasonable risk entailed in one's conduct. ${ }^{580}$ The actor did not understand the possible consequences of his actions. Culpa therefore consists of a lack of knowledge or care, a psychological flaw. It is grounded in inadvertence. ${ }^{581}$ This lack of awareness is what separates culpa from recklessness. In a general part of criminal law for the EU, only inadvertent negligence should exist.

In addition, the inadvertence must be culpable, that is, reproachable. This means that a defendant is negligent when a reasonable person in the same circumstances would have been aware of the risks and would not have run those risks. ${ }^{582} \mathrm{Culpa}$ can therefore also be seen as punishment for the ability to do otherwise, the ability to behave carefully or in such a way to prevent the result. ${ }^{583}$ The intentional actor used his capacities in an incorrect manner, whereas the negligent actor did not use his capacities when he should have used them..$^{584}$

Weigend in Klip 2011, pp. 161 and 170.

Stuckenberg 2007, p. 315.

Weigend 1981, p. 687.

Smith A.T.H. in Glazebrook 1978, p. 101 and Politoff \& Koopmans 1991, p. 113.

De Hullu 2006, p. 243 and de Jong, D.H. \& Knigge 2003, p. 125.

Simester \& Sullivan 2007, pp. 145 and 148.

Van Dijk, A.A. 2008, pp. 54-55 and 61-62; Politoff \& Koopmans 1991, pp. 30 and 69 and Krey 2002, pp. 142-143.

Smidt 1881 I, p. 78. 


\subsection{Terminology}

The fault element culpa may be applied in EU criminal law to cover cases where the defendant negligently caused the fulfilment of a criminal offence. The perhaps more precise Latin translation, neglegentia, is not used because the juxtaposition of dolus and culpa is already quite common in many Member States. ${ }^{585}$ The term negligence will be used to refer to national concepts. By way of exception, this term is sometimes used for stylistic reasons, such as when culpa is referred to as an adjective. It will be made clear by the context whether it refers to the EU or national concept.

Culpa can be expressed in many different ways. Terms as 'carelessness', and 'lack of due' or 'reasonable care' all indicate that culpa is required. ${ }^{586} \mathrm{Culpa}$ usually relates to consequences and is discussed mostly in this context, also by me. Culpa hardly ever relates to conduct, ${ }^{587}$ and the criteria developed in the context of consequences cannot be directly applied to conduct-based negligent offences. ${ }^{588}$ Amongst others, since the violation of a duty of care need not have caused harm, the breach of duty itself triggers liability. Issues of causation therefore hardly play a role. ${ }^{589}$

If culpa is required as to circumstances, the objective suspicion that a circumstance is or would be fulfilled, like the criminal origin of goods, suffices for liability. ${ }^{590}$ This is apparent in phrases like 'reasonable ground to suspect', 591 'ought to know', ${ }^{592}$ or 'as he reasonably should suspect'. ${ }^{593}$ In many offences, intent relates to some elements whereas other elements only require negligence. ${ }^{594}$ It is not unusual that a circumstance can be fulfilled either by intent or negligence, evident in phrases like 'he knows or ought to know'. ${ }^{595}$ Dolus to circumstances is called

585 For example, negligence in the Netherlands is also called culpa, see de Hullu 2006, p. 243. Kelk 2005, pp. 168 and 171-172. See also Austin 1911, p. 432.

586 De Jong, D.H. \& Knigge 2003, pp. 124-125; Smidt 1881 I, p. 78; Keulen \& Otte 1999, p. 37 and Williams 1953, p. 98.

587 De Hullu 2006, pp. 247-248 and de Jong, D.H. \& Knigge 2003, pp. 124-125 implicitly reject this possibility.

588 Schönke \& Schröder, H. 2006, p. 294.

589 Beulke 2008, p. 248 argues that the requirement of causation must be replaced by one of recognisability of realization of the offence definition.

590 De Jong, D.H. \& Knigge 2003, p. 124; Nieboer 1991, p. 168; Pompe 1935, p. 73 and Visser in Borgers, Koopmans \& Kristen 1998, p. 68.

591 R. v. Forsyth [1997] EWCA Crim 751; Shute in Shute \& Simester 2002, pp. 192-194 and Keulen \& Otte 1999, p. 24.

592 See sections 1, 1A and 4 of the English Protection from Harassment Act 1997.

593 See for example articles 132 and 417bis of the Dutch Criminal Code.

594 'Pro parte doleus, pro parte culpoos' or 'Vorsatz-Fahrlässigkeits-Kombination', see de Hullu 2006, p. 249; Politoff \& Koopmans 1991, pp. 145-146; de Jong, D.H. \& Knigge 2003, p. 125 and Beulke 2008, p. 261.

595 See articles 98 and 225 of the Dutch Criminal Code; article 7 of the Dutch Road Traffic Act 1994; section 4(1)(b) of the English Animal Welfare Act 2006; Keulen \& Otte 1999, pp. 24-25 and Fokkens \& Machielse, note 3 on Culpa. Keulen \& Otte 1999, p. 41 submit most of the offences that that relate to circumstances are formulated this way. 
knowledge; the culpable lack of knowledge is a form of culpa. This lack of knowledge often consists of an unreasonable mistake or ignorance. As will be discussed in greater detail later, if the mistake had been reasonable, the reasonable person would have made it as well. The defendant therefore did not deviate from this standard and is not negligent.

In the beginning of the chapter, I explained the difference between the fault element of culpa and the implied element of every crime that is blameworthiness. The fault element is assessed on the first rung of criminal liability; the implied element on the third and final rung. I also argued that the implied element merely requires some degree of blame whereas in culpa, negligence must be gross. Blameworthiness operates as the minimum requirement of the principle of guilt, requiring a minimum amount of subjective blame in offences of strict liability, which do not require proof of any fault element. ${ }^{596}$ When fault is included in the offence definition, but it does not relate to all elements, the element as to which fault does not relate is called a 'strict element'.

In the Netherlands and Germany, this difference is linguistically difficult to make, as the terms 'Schuld/schuld' are often used for both meanings. For example, 'dood door schuld' refers to the offence of negligent killing, but 'afwezigheid van alle schuld' refers to an excuse that negates the blameworthiness of the actor. Finally, a terminological difficulty is that 'schuld(ig)' and 'guilt(y)' are also used to indicate factual guilt, which denotes that the defendant was the perpetrator.

\subsection{Rationale}

Culpa can be grounded in inadvertence and the ability to prevent the result. The actor is punished because he should and could have foreseen the consequences of his actions or omissions. ${ }^{597}$ The rationale in short can be dubbed 'failure despite capacity'. The negligent actor is not punished merely because he should have acted differently but because he also could ${ }^{598}$ This implies that the particular defendant had the opportunity to conform to the required standard. He is not punished for being unaware but because he could have been aware. The result was foreseeable. In order to satisfy concerns based on control and choice, individualised characteristics are taken into account. ${ }^{599}$

\subsubsection{A balanced approach}

By limiting culpa in this way, a balance is struck. On the one hand, legal interests must be adequately protected. Grounding liability on culpa affirms the norms, and

\footnotetext{
596 See V.2.3.5.

597 Van Dijk, A.A. 2008, pp. 47-48 and 55 and de Hullu 2006, p. 246.

598 See Fletcher 1971, p. 423.

599 Robinson in Dressler 2002, p. 1003.
} 
gives satisfaction to victims and their relatives. ${ }^{600}$ Some scholars argue crimes of negligence do not deter, because deterrence presupposes reflection. However, by criminalizing culpa, actors are motivated to exercise more care and are deterred from violating legal interests. It alerts people to their duties and the need to take special care in certain circumstances. ${ }^{601}$ It is therefore perfectly appropriate to require a legal subject to be careful under threat of punishment. Punishment is inflicted if the defendant failed to meet the standard, so this defendant and others will adapt their behaviour to the pertinent norms in the future.

On the other hand, a retributive perspective on punishment requires blameworthiness. From this point of view, the actor should be held liable for culpa only if subjective reproach can be directed against him. ${ }^{602}$ In this light, culpa is deemed to be problematic due to lack of awareness and consequently, a lack of sufficient control or choice. ${ }^{603}$ These objections have predominantly been fuelled by eighteenth and nineteenth century thinking on criminal law. In Cartesian dualism, the mind was separated from the body as subjective, requiring awareness. ${ }^{604}$ Fault needed to be based on a will ${ }^{605}$ or located in the psyche of the actor. ${ }^{606}$ Negligent offences were therefore seen as conflicting with these principles. ${ }^{607}$ Just like omission liability had to be reconciled with the traditional act requirement, there has been resistance to extending fault beyond will and awareness. As will be explained below, this resistance still lingers on in England and Germany.

In contrast, it is submitted that culpa does not derogate from subjectivist principles of liability. ${ }^{608}$ The reproach for the failure to advert is in fact grounded in the subject and his subjective capacities. ${ }^{609}$ The actor is not punished for being unaware but because he could have been aware. By being able to advert, the actor could have foreseen the harm. He is reproached for his ignorance because he has the power not to be ignorant. The negligent actor is not punished merely because he should have acted differently but because he also could. By being able to act otherwise, the actor could have avoided the act. ${ }^{610}$ The negligent actor is culpable

600 Robroek 2010, pp. 91-92, 121 and 167-169. See also Kelk 2005, p. 211.

601 De Jong, D.H. \& Knigge 2003, p. 135; Kamerstukken II 2001/02, 28 484, no. 3, p. 8; Ashworth 2006, p. 194; Hart 2008 (reprint 1967), pp. 156-157; Erenius 1976, p. 119 and Kadish 1989A, p.75.

602 See Robroek 2010, pp. 125-127 and 156-169 and Duff 1990, p. 155.

603 Robinson in Dressler 2002, p. 1002; Kadish 1989A, p. 75; Finkelstein 2000; Erenius 1976, p. 117; Duff 1990, p. 153; Green in Simester 2005 and van Dijk, A.A. 2008, pp. 170-171 and 249.

604 Erenius 1976, p. 126.

605 Koch 1998, pp. 54-55. See also Hart 2008 (reprint 1967), p. 133.

606 De Jong, D.H. 2007, pp. 10-11; de Jong, D.H. \& Knigge 2003, p. 124; Erenius 1976, p. 126 and Fletcher 1971, p. 407.

607 Visser in Borgers, Koopmans \& Kristen 1998, p. 72.

608 Compare Fletcher 1971, p. 417.

609 Fletcher 2002.

610 Kristen, Borgers \& Koopmans in Borgers, Koopmans \& Kristen 1998, pp. 11-12; van Dijk, A.A. 2008, pp. 54-55 and 61-62; Fletcher 1971, p. 415; Hart 2008 (reprint 1967), pp. 149-151; Duff 1990, p. 156 and Roxin 2006, p. 1088. 
because he has failed to take reasonable precautions when he has the capacity to do so. He has unreasonably, inexcusably fallen short of what is required from him, whereas he could have exercised his rational capacities. Therefore, he may be punished. ${ }^{611}$ By taking into account the individual capacities of the defendant and to make sure that the defendant is acquitted when he is not blameworthy, retributive concerns are met.

A rejection of fault based on inadvertence would offend basic sensibilities of justice, especially in cases of insensitive and arrogant (mis)perceptions of legal duties. ${ }^{612}$ I already submitted that the negligent actor, who fails to advert to the possible harming of other people's legal interests, can be just as insufficiently motivated by the legal interests of others as the intentional actor. After all, if he had cared for those interests, would he not have considered the danger he created to these interests? ${ }^{613}$ There may even be instances where inadvertence expresses more culpability. Consider the actor who thought about, but misjudged the risks of his actions and the actor who never thought about the risks, while he should have. ${ }^{614}$ Inadvertence is especially reprehensible in professional contexts, where the actor is supposed to know since he bears responsibility and can cause great harm. ${ }^{615}$

In Roman law, a distinction was made between dolus and casus. ${ }^{616} \mathrm{~A}$ distinction between harm caused wilfully and accidentally was made in the common law as well. ${ }^{617}$ Culpa could be located somewhere in between the two elements, ${ }^{618}$ but was not identified as relevant for criminal law. In the middle ages, however, criminal liability based on culpa became common, even if it remained controversial. ${ }^{619}$ The objections to negligence have quieted down in modern times, due to developments in our society that brought about different needs and shifting perceptions of the role of the state.

First of all, a classic liberal attitude on criminal law and the state no longer applies. In general, the focus of criminal law has moved towards victims of crime. From that perspective, negligence liability is important, because there are probably more victims of negligent than intentional crimes. Harm inflicted negligently also does not have to be less severe than harm inflicted intentionally. In fact, negligent conduct can cause great disasters. ${ }^{620}$ In a society where risks have increased in number and seriousness, great harm to many persons can occur when risks are

\footnotetext{
611 Ashworth 2006, pp. 192-193 and Kadish 1989A, p. 75. See also Robroek 2010, pp. 153 and 164.

612 Fletcher 1971, pp. 417-422.

613 See Duff 1990, pp. 161-163; Norrie 2006B, pp. 70-76; Brady 1980, p. 391; Brady 1996, pp. $192-$ 198; De Jong, D.H. \& Knigge 2003, p. 135 and Arzt in Stree a.o. 1978, p. 128.

614 De Jong, D.H. \& Knigge 2003, p. 135, Vellinga, W.H. 1982, pp. 115-116, Nieboer 1991, p. 165 and Fokkens \& Machielse, note 6 on Culpa. See IV.5.3.5.

615 See Kelk 2005, p. 210 and Kessler Ferzan 2007, p. 2541-2542.

616 Koch 1998, p. 48 and Vrijheid 1918, pp. 75-76.

617 Robinson 1980, p. 843.

618 De Jong, D.H. \& Knigge 2003, p. 123 and Keulen \& Otte 1999, p. 37.

619 Koch 1998, pp. 48-53.

620 Roxin 2006, p. 1062; Kelk 2005, pp. 209-211 and Simester \& Sullivan 2007, pp. 148 and 152.
} 
neglected. This warrants punishing those who fail to recognize danger where they should and fail to behave carefully, where appropriate. At the end of the $19^{\text {th }}$ century, when the Dutch discussed their criminal code in Parliament, it was already acknowledged that this code should also counter, and thus punish, apart from intentional wrongdoing, conduct which leads to great danger for the safety of persons and goods or cause great and irreversible harm because of the lack of due care, ${ }^{621}$ even though the seriousness of negligent offences was only relatively recently expressed by a significant increase in maximum penalties of negligent offences. ${ }^{622}$

When serious consequences have occurred, society wants to hold someone liable for this. ${ }^{623}$ Citizens require their government to prevent them from becoming the victims of other people's negligence. Criminal law is used in the expectation that its subjects will exercise more care and attempt to minimize risks. ${ }^{624}$ In the Dutch and German legal system, intentional offences have a negligent counterpart when the pertinent legal interest is considered important or when the legislator wanted to have a solution for evidential problems. ${ }^{625}$ Like all lesser forms of fault than intention, negligence too functions as a facilitator of proof to ensure a criminal conviction when important legal interests are infringed. When intention cannot be proven, usually a negligent offence is available to function as a safety net. ${ }^{626}$

On the other hand, the scope of liability must not extend so far that it infects action altogether and thereby cripples society. This is furthered by requiring that the carelessness must be gross. ${ }^{627} \mathrm{Culpa}$ is thereby distinguished from casus, as not all inadvertent acts are culpable. ${ }^{628}$ The act or omission of the defendant must fall considerably short of what is expected from a reasonable person in order to incur liability. In conclusion, as required by the criteria of synthesis set out in chapter two, a balance is struck between the different perspectives by taking the individual subjective capacities as the basis for the attribution and by making sure that only serious violations of duties of due care incur criminal liability. Punishment is only

\footnotetext{
621 Smidt 1881 I, p. 77.

622 In contrast to the maximum penalty of nine monts imprisonment, the negligent exposure to radiation leading to death was punished by legislator with a maximum of two years of imprisonment in 1970. In 1989, the same maximum was applied to negligently contaminating surface water, leading to death, see Kamerstukken II 2001/02, 28 484, no. 3, pp. 7-8. As mentioned before, the maximum penalties for negligent offences in the context of road traffic offences was raised in 1998, followed in 2006 by a more general increase of maximum penalties for negligent offences.

623 Buruma in Borgers, Koopmans \& Kristen 1998, p. 4; Kelk 2008B, pp. 26-27; de Jong 2007, pp. 10-11; Prittwitz 1993, pp. 314-321 and 379-380 and Spencer \& Brajeux 2010, pp. 10 and 18.

624 Although this effect is not proven by statistics, governments seem to keep believing in it.

625 Nieboer 1991, pp. 166-167.

626 Compare article 5 of Regulation 2988/95 of 18 December 1995 on the protection of the European Communities financial interests, OJ 1995 L 312/1.

627 See Robinson in Dressler 2002, p. 1003.

628 Finkelstein 2000, p. 914.
} 
appropriate when the harm is great, the risk is obvious and the defendant has the capacity to take the required precautions. ${ }^{629}$

\subsubsection{Popularity}

In conducting comparative legal research on negligence, one of the things that struck me was the difference in popularity of this fault element in the Member States under investigation. In short, negligence is a fault element in many criminal offences in Germany, whereas in English offences, negligence is relatively hardly ever required. There are multiple explanations for this. First of all, negligence is much more popular in Germany and the Netherlands because these legal systems only operate with two kinds of fault. If intent cannot be proven, negligence operates as a safety net. Most intentional offences therefore have a negligent counterpart.

In England, there is less need for negligence liability due to the concept of recklessness, which can operate as a safety net. Recklessness also covers cases that are labelled as conscious negligence on the continent. Negligence in England is limited to inadvertent negligence. Moreover, Caldwell recklessness was applied for some decades in English criminal law, allowing the defendant who had been unaware of the risk, to be convicted as reckless. Accordingly, in that time period there was even less need for negligent offences.

In comparison to the Netherlands, the greater popularity of negligence in Germany can be explained by the strict adherence to the principle of guilt, which, from a German perspective, precludes strict liability in criminal law. Crimes that do not require proof of fault are taboo in German criminal law. German criminal lawyers interpret this principle in a way that criminal liability should always require some fault, leaving them only with negligence to facilitate convictions. By contrast, strict liability is allowed in Dutch criminal law and also very popular in England. 630 For example, the safety net offence to intentional killing is assault occasioning death. Negligence is required as to death in German law, whereas the causing of death is a strict element in the Dutch Criminal Code. ${ }^{631}$ Rather than creating a negligent offence alongside the intentional one, the safety net offence in Dutch law is often a strict offence, which sidelines the need to introduce an additional negligent offence. ${ }^{632}$

The interpretation of the principle of guilt in Germany is so rigid that even negligence has and is still claimed to violate it. ${ }^{633}$ The general rule is that all offence elements require intention, liability based on negligence can only be provided by

629 Ashworth 2006, p. 194.

630 In those legal systems, the principle is no punishment without blameworthiness, rather than no punishment without negligence; an approach legitimized by the ECtHR and favoured here, see V.2.3.

$631 \$ 227$ of the German Criminal Code and Articles 301-302 of the Dutch Criminal Code.

632 De Hullu 2009, p. 276.

633 Koch 1998, pp. 29, 54-55 and 113-122. 
specific statutory prohibition. ${ }^{634}$ Nevertheless, an expansion of negligent liability is visible since the seventies. When criminal offences are created outside the criminal code, at least half of them criminalize negligence. ${ }^{635}$ In the Netherlands, a similar trend is visible. Traditionally, felonies were said to require intention and some could also, by way of exception, be committed with negligence. ${ }^{636}$ That picture has completely been reversed. The rule is now that felonies require intent or negligence. ${ }^{637}$ It even seems more felonies can be committed negligently than intentional. ${ }^{638}$ The self-evident nature of liability by negligence in Dutch criminal law can be illustrated by the relatively severe maximum penalties for offences committed with negligence. ${ }^{639}$

In contrast, English criminal lawyers also still seem uneasy with negligence. Research has shown that not even 5 percent of all offences triable in the Crown Court are crimes of negligence. ${ }^{640}$ The Law Commission did not include a definition of negligence in its draft Criminal Code, because it was unnecessary given the lack of crimes of negligence in the accompanying special part of the Code. ${ }^{641}$ An influential explanation for this unpopularity is the traditional view that negligence is not a form of mens rea. ${ }^{642}$ Negligence in England is inadvertent negligence. As noted, negligence is no mens rea from the perspective that it cannot be called a cognitive state of mind. It is rather a failure to comply with a standard of conduct. ${ }^{643}$ The traditional view has even led to negligence being seen as strict liability. ${ }^{644} \mathrm{~A}$ related reason is that negligence incorporates normative elements, which have no place in mens rea. This rigid perspective however fails to recognise that in 'state of minds' like recklessness, normative questions also play an important role. ${ }^{645}$

In the debate on whether or not strict liability is appropriate, we see similar arguments that can be made in the context of negligence. In the classic perspective, negligence can be termed a 'halfway house' between mens rea and strict liability. ${ }^{646}$

$634 \S 15$ of the German Criminal Code and $\S 10$ of the German Administrative Offences Act (OWiG).

635 Koch 1998, pp. 40-41 and 77-78; Roxin 2006, p. 1062; König in König \& Seitz 2006, note 1 on $\S 10$ OwiG and Hörster 2009, pp. 168-171.

636 Politoff \& Koopmans 1991, p. 113 and van Dijk, A.A. 2008, pp. 213-215. Compare Edwards 1954, p. 311 who also argued that negligence is appropriate for misdemeanours, whereas felonies require intention or knowledge.

637 Kessler 2001, pp. 185-186; Mevis 2006, pp. 592-593 and de Hullu 2006, p. 198.

638 Politoff \& Koopmans 1991, pp. 143-144.

639 De Hullu 2006, p. 256 and Robroek 2010, pp. 55-58. Again, it should be noted however that the most serious penalties are reserved for cases that would qualify as recklessness in English law.

640 Ashworth \& Blake 1996, p. 308.

641 Law Commission 1989, p. 191.

642 Ashworth 2006, p. 181; Williams 1953, p. 29; Halpin 2004, pp. 106-107 and Ormerod 2005, p. 91.

643 Williams 1953, pp. 85 and 88; Fletcher 1971, pp. 407-409 and 434-435; Fletcher 2007, pp. 102 and 312 and Halpin 2004, pp. 104-105.

644 Attorney-General's Reference no. 2 of 1999 [2000] EWCA Crim 91.

645 Huigens 2004, pp. 804-809 and Fletcher 2007, p. 102.

646 Williams according to Fletcher 2007, p. 102. 
It certainly is the lowest fault element available, and thereby a halfway house between more serious kinds of fault that require a will or awareness and strict liability. The concerns to negligence are remarkable, compared to the wide acceptance and use of strict liability in English law. ${ }^{647}$ Nonetheless, many scholars have paved the way for recognizing negligence as a fault element. ${ }^{648}$ Like in other Member States, the reluctance to negligent liability has therefore declined, ${ }^{649}$ even though it is still not as accepted as in Germany or the Netherlands.

\subsection{Criteria}

Negligence in all Member States is primarily based on a violation of a duty of care. The simplest set of criteria is found in England, where the breach of the duty must have caused the consequence and the degree of negligence must be such that it can be characterized as gross. ${ }^{650}$ The criteria in Dutch and German law are not different but more elaborate. They are best viewed as attempts to specify the general criteria mentioned above.

In Germany, negligence consists of a breach of a duty of care that led to an interference with or endangerment of the legal interest it protects, which was objectively foreseeable and the actor also subjectively, that is to his knowledge and abilities, could have foreseen and avoided. ${ }^{651}$ In a similar way, the ECJ has held that the defendant behaves negligently when he breaches his duty of care which he should have and could have complied with in view of his attributes, knowledge, abilities and individual situation. The Court held that 'serious negligence' requires that the breach of duty must be patent. 'Regular' negligence thus requires a simple breach of duty. 652

In Germany and the Netherlands, negligence is distinguished into an objective and a subjective part. Besides the violation of the duty of care that is causal for a consequence, the actor objectively should and subjectively could have foreseen and avoided this. ${ }^{653}$ The objective part includes the breach and its causal connection to the consequence. The subjective part is therefore better seen as an exceptional criterion that can negate culpa if it appears that this particular defendant, given his capacities, could not meet the standard expected from a reasonable person.

\footnotetext{
647 Bohlander 2009, p. 56.

648 See for example Hart 2008 (reprint 1967), pp. 136-157 and Robinson 1980.

649 For example, negligence is now the fault element in most English motoring offences, according to Ashworth 2006, p. 331. See also Spencer \& Brajeux 2010, pp. 20-21.

650 R. v. Adomako [1994] UKHL 6.

65120 November 2008 BGH NJW 2009, 1155; Beulke 2008, pp. 245-246 and Fischer, T. 2009, p. 108.

6523 June 2008, Case C-308/06, Intertanko a.o. v. Secretary of State for Transport [2008] ECR I-4057, §§75-77.

653 Fokkens \& Machielse, note 1 on Culpa; van Dijk, A.A. 2008, p. 39; de Hullu 2006, p. 245 and Schönke \& Schröder, H. 2006, pp. 162 and 296 and Beulke 2008, p. 246.
} 
In the Netherlands, the objective part is also called the normative or avoidable part and the subjective part dubbed blameworthy. ${ }^{654}$ Culpa can thus be defined as blameworthy considerable carelessness. ${ }^{655}$ The dichotomies of objective and subjective, could and should, avoidable and blameworthy, are useful for analytical purposes. They should not be considered absolute. The issues are usually merged in evidence, and, as will be discussed below, the subjective part is almost always simply assumed when the objective part is established. ${ }^{656}$

\subsection{Objective part}

The objective part of culpa is assessed first. For analytical purposes, I will use the phrasing that the fulfilment of this part leads to '(considerable) carelessness'. It consists of many aspects, of which the violation of a duty of care is most important in practice. If it is established that the actor breached this duty, he is generally considered to have been careless. The careless actor can only be held liable for culpa if the subjective part is also fulfilled. ${ }^{657}$ However, in general, culpa is accepted upon proof of carelessness. If a causal connection with the consequence can be made, the subjective part of culpa is hardly ever an obstacle to liability. Consider the defendant who exceeded the allowed amount of a certain substance in his produce. As a result of this breach of duty, he caused injuries to consumers that are attributed to him under negligence. The subjective part is only absent by exception and therefore generally assumed. In order to escape liability the defendant himself will have to make probable that he did everything that could be reasonably expected of him.

When taking a closer look at the objective part, one can identify other criteria besides causation and the violation of a duty, such as foreseeability and avoidability. Both elements follow from the requirement that the inadvertence must be culpable. The inadvertence is culpable if the result was foreseeable. The defendant should have been aware of the risk, because the reasonable person would have been aware. The inadvertence is also culpable if the defendant was able to do otherwise, to avoid the result. ${ }^{658}$ Many Dutch scholars treat the violation of the duty and foreseeability as two separate criteria that should both positively be proven. ${ }^{659}$ German scholars however treat foreseeability and avoidability as possible negations of the interim

654 Keulen \& Otte 1999, p. 36, Kelk 2005, p. 206 and de Hullu 2006, p. 245.

655 De Jong, D.H. \& Knigge 2003, p. 131 and de Hullu 2006, p. 245.

656 Van Dijk, A.A. 2008, pp. 71 and 83-84; de Hullu 2006, p. 245 and Keulen \& Otte 1999, p. 36.

657 This distinction follows the Dutch approach of culpa as considerable carelessness, which is blameworthy. The former is the objective, the latter the subjective part. See de Hullu 2006, p. 245; Fokkens \& Machielse, note 15 on Culpa and de Jong, D.H. \& Knigge 2003, pp. 130-135.

658 Van Dijk, A.A. 2008, pp. 54-55 and 61-62 and Politoff \& Koopmans 1991, p. 69 focus on the avoidability of the result. I also relate this aspect to the requirements of causation.

659 Kelk 2005, p. 206; Nieboer 1991, pp. 166 and 170 and de Jong, D.H. \& Knigge 2003, p. 131. 
conclusion of carelessness based on a violation of a duty, ${ }^{660}$ or see the violation of the duty of care as a specialis of the broader concept of foreseeability. ${ }^{661} \mathrm{I}$ also believe that the criteria are so much related to each other that they cannot be assessed independently. ${ }^{662}$ They are so interconnected, that many scholars not even attempt to distinguish them. In the end, these differences are not important because they do not change the outcome.

Nevertheless, I submit there exists in principle a proper relationship between the different criteria of the objective part of culpa and their order of assessment. The objective part centres on the question of carelessness. Each criterion mentioned above can contribute to this question. As a first step, a violation of a duty of care normally brings about that the actor has been careless. Since the actor violated his duty, he could foresee that the consequence would follow. However, this is not necessarily the case. Foreseeability is thus treated as a possible negation of the interim conclusion of carelessness. In a subsequent step of assessing the objective part of culpa, one could say that what the actor foresaw, he could have avoided, ${ }^{663}$ but this assumption can be negated by considerations of causation. Finally, the defendant is compared to the objective standard and it is assessed whether he fell considerable short of this standard. This order is followed in the subsequent discussion.

\subsubsection{Violation of a duty of care}

The breach of a duty of care can be inferred from the violation of norms. A violation of a norm does not necessitate a violation of a duty of care; the violation of a norm functions as an indication with different degrees of weight for a finding of a violation of duty of care. ${ }^{664}$ In this regard, norms can be distinguished into three types.

First of all, there are special norms that are laid down or grounded in law, such as speed limits in traffic. The legal status of a norm typically, but not necessarily brings about a breach of duty. ${ }^{665}$ More and more of these norms originate from the EU. For example, the violation of a duty of care in negligent killing can be based on exceeding the norm that sets the maximum hours a person is allowed to drive a truck each day. ${ }^{666}$ Through the breach of a duty of diligence, the violation of a norm that is supposed to protect a legal interest implies that the harm to that interest was

\footnotetext{
660 Roxin 2006, pp. 1067-1068; Beulke 2008, p. 251 and Schönke \& Schröder, H. 2006, p. 298.

661 Schönke \& Schröder, H. 2006, pp. 317-318 and Duttge 2006, p. 268.

662 Keulen \& Otte 1999, p. 43; Roxin 2006, p. 1066 and Beulke 2006, p. 249.

663 De Jong, D.H. \& Knigge 2003, p. 131 and Fokkens \& Machielse, note 3 on Culpa.

664 Roxin 2006, p. 1081.

6655 January 1922 RGSt 56, 343; 23 April 1953 BGHSt 4, 182 and Schröder 2006, p. 670.

666 Regulation 561/2006 of 15 March 2006 on the harmonisation of certain social legislation relating to road transport and amending Regulations 3821/85 and 2135/98 and repealing Regulation 3820/85, OJ 2006 L 102/1. See Schröder 2006, pp. 670-673.
} 
foreseeable. ${ }^{667}$ For example, if a driver of a truck exceeds the hours he is allowed to drive and falls asleep behind the wheel as a consequence, it was foreseeable that injuries or death could follow from this breach of a duty.

A second type of norms is not legally binding but nonetheless generally accepted within a certain environment, such as rules of the International Ski Federation on winter sports. Third and most controversial are the (unwritten) rules that are based on a general norm of due care under the rationale that interests of others should not be infringed upon. ${ }^{668}$ This third type can be established by reference to what a sensible and conscientious person in the environment and concrete situation of the actor would have foreseen. In that case, the violation of the duty and the general question of foreseeability cannot be separated. ${ }^{669}$ Whereas the violation of the first group of legal norms generally makes the actor careless, this second and third type of norms can merely indicate the objective part of negligence. ${ }^{670}$

In general, violating norms can facilitate but not necessitate foreseeability of the consequence. The defendant can be held to have violated a norm, but there is no negligence liability if it was not foreseeable. ${ }^{671}$ The opposite is also true, as compliance with norms does not preclude the finding that the consequence was foreseeable. ${ }^{672}$ Everything depends on the type of the norm, whether the violated interest was meant to be protected by the norm, the probability and nature of the harm and the other circumstances of the case. ${ }^{673}$ Nevertheless, practice shows that carelessness is often substantiated by proof of the violation of a norm. The mere violation of such a norm usually implies negligence, because other aspects of the objective part and the subjective aspects of negligence are assumed. Requirements of careful behaviour are increasingly formulated in detailed codes of conduct and safety regulations. The standard of care does not have to be established by reference to a reasonable person when specific legal norms are available. The emphasis is thus shifted from the question of foreseeability to the question as to whether the defendant obeyed the rules. ${ }^{674}$

I will demonstrate this by reference to fatalities in traffic in Dutch law. In a highly regulated field of law with many safety regulations, such as road traffic law, the violation of a norm can lead to a finding of negligence for the accident and concomitant consequences. Foreseeability of the accident is held to follow from the violation of the rule. ${ }^{675} \mathrm{An}$ infringement of traffic rules operates as a steppingstone

667 Duttge 2006, p. 268. See also Beulke 2008, pp. 248-249.

668 Fischer, T. 2009, pp. 109-110 and Kudlich 2005, p. 848. See also van Dijk, A.A. 2008, p. 43 and Fokkens \& Machielse, note 10 on Culpa.

669 Beulke 2008, pp. 249-251 and Nieboer 1991, p. 172.

670 Schröder 2006, p. 670.

671 See for example HR 29 June 2010, NJ 2010, 674.

672 Fischer, T. 2009, p. 110 and Roxin 2006, pp. 1068-1069, who submits that only in exceptional cases though, liability will follow.

673 Schönke \& Schröder, H. 2006, pp. 317-318 and Kudlich 2005.

674 De Jong, D.H. \& Knigge 2003, p. 134; Nieboer 1991, p. 173 and Vellinga, W.H. 1982, pp. 61-65.

675 Otte 2001, p. 2-3; Krabbe in Krabbe \& Harteveld 1999, p. 132 and van Kempen 2004, p. 1003. 
to carelessness and blameworthiness, resulting in negligence liability. ${ }^{676}$ A finding of negligently causing death is moreover facilitated by the fact that the pertinent offence does not require foreseeability of death, only the accident. ${ }^{677}$

The danger of this shift to obedience of rules is that negligence liability can become strict liability, not requiring any fault of the defendant as to the result. The mere non-compliance with a norm makes a person liable for all results that follow. On the one hand, speeding is considered to carry low stigma. Many people do not see the harm in it and speed regularly, but on the other hand, an accident is held to be foreseeable when it occurs. The difference can be justified from a victim's perspective or by the doctrine of versari in re illicita, which holds that the results that generally follow from conduct are appropriately attributed to the defendant. ${ }^{678}$ However, in order to take negligence seriously, it must be taken into account that the defendant who violated his duty not necessarily could foresee all the results that would follow from it.

The debate in the Netherlands thus focuses on the question which violations of norms allow for an inference of foreseeability. Specifically, there has been considerable debate on the question whether the mere violation of one traffic rule is sufficient to establish negligence. On the one hand, traffic rules are legal rules, created to prevent accidents from happening. On the other hand, this does not simply bring about that exceeding the speed limit slightly makes a lethal accident foreseeable. Some lawyers therefore argue that negligence should require the violation of multiple traffic rules or at least one very serious violation, like driving intoxicated and irresponsible speeding. ${ }^{679}$ This is issue is connected to the question on the required degree of carelessness, which is answered later.

The Dutch Supreme Court has held that it cannot be said that the mere violation of a rule must lead to a conclusion of (the objective part of) negligence, and that the circumstances of the case should be taken into account. ${ }^{680}$ It therefore did nothing more than confirm the general rule mentioned above, that the violation of a norm is an indication for a finding of carelessness. One violation may or may not be enough: the circumstances are decisive. Somewhat later, the Supreme Court approved a conviction of negligence based on a single violation of a traffic rule. The fact that the defendant drove a motor vehicle and the victim was a young child on a bicycle

\footnotetext{
676 Simmelink 2006, pp. 596-597 and de Jong, D.H. 2007, pp. 12-16.

677 Article 6 of the Dutch Road Traffic Act 1994. See Krabbe in Krabbe \& Harteveld 1999, pp. 131143. A mere causal connection between the accident and the (strict element of) death suffices. By contrast, see van Dijk, A.A. 2008, p. 37. See V.2.3.3. A more rigid version of the maxim holds that once a person has crossed a significant moral threshold, there is good reason to impose liability for any consequence that follows. Annotator Keijzer in HR 24 June 2008, NJ 2008, 442; AG Vellinga in HR 1 June 2004, NJ 2005, 252 and Krabbe in Krabbe \& Harteveld 1999, p. 134. 
was important. ${ }^{681}$ In other cases where the defendant also did not yield because he did not see the victim, this single violation did not suffice. ${ }^{682}$

It can be argued that the Supreme Court has not given us much to go on, that there is inequality before the courts in cases of similar violations, that the criterion of the circumstances of the case provide for too much discretion, but in the end, it is the only proper approach. No general rules can be given on which rules when violated would suffice and how serious the violations must be. Speeding does not have to be careless, but an accident can become foreseeable when the weather conditions are poor. ${ }^{683}$ Only in very gross violations will the result be foreseeable, in all other cases, the circumstances and the context are important. This is discussed in more detail, after two final comments relating to the violation of norms.

In England, conduct which resulted in unforeseen side-effects is not often criminalized by negligence. Some reasons and explanations for this have already been given. In this context, it can be added that the English legislator tends to rely far less on general principles like intent and negligence. Fault is also made objective by creating specific offences that criminalize the violation of norms that lead to harm. Rather than to suffice with one offence that criminalizes the negligent causing of death in traffic, ${ }^{684}$ the result of killing someone is criminalized separately when it is caused by, for example, driving unlicensed, whilst disqualified or whilst uninsured. ${ }^{65}$ Offences like this criminalize the violation of specific norms directly without the use of negligence. ${ }^{686}$

\subsubsection{Contra-indications}

So far, it has been explained that the decision of carelessness depends on the type of the norm, the scope of protection of the norm and the other circumstances of the case. Even if the violated norm is of the type that is laid down in a criminal statute and the result caused falls under the scope of protection of this norm, there may be circumstances negating the foreseeability of the risk or what should have been expected of the defendant in that particular situation. For example, it is evident that a risk of fire is smaller when it rains. Hence, circumstances can operate as contraindications of a finding of carelessness based on the violation of a legal norm.

The standard of careful conduct is established by a weighing of all the interests concerned. This consideration is normative, which is clear by the determination of this standard by reference to the legal interest involved. For instance, to risk the

\footnotetext{
681 HR 17 January 2006, NJ 2006, 303. See also HR 24 June 2008, NJ 2008, 442.

682 HR 27 May 2008, NJ 2008, 441 and HR 29 April 2008, NJ 2008, 440.

683 See den Harder 2006, pp. 126-129.

684 Section 1 of the English Road Traffic Act 1988.

685 Section 3ZB of the English Road Traffic Act 1988.

686 Compare Robroek 2010, pp. 169-193 who proposed to substitute negligent offences by offences that criminalize the violation of norms, which must be clearly described, whereby the harm caused is strict and aggravates the reproach.
} 
wellbeing of other human beings is unlikely to be permissible, however small the chance. This is evident in practice, where the seriousness of the consequence often influences the outcome. If the harm was serious, negligence liability is accepted easier. However, if the risk was hardly foreseeable, for example because the chance that the risk would materialize was very small, the fact that serious consequences occurred may not lead to a finding of negligence. The severity of the consequence and the legal interest involved are very important, but a finding of culpa may not predominantly, let alone exclusively, be based on these aspects. ${ }^{687}$ If it would, culpa would resemble risk liability.

Even if the risk was foreseeable, this does not necessarily imply that the defendant violated his duty of care. Culpa is about the taking of unacceptable risks: a risk that was foreseeable can still be socially acceptable, a reasonable person may have foreseen the risk, but still be allowed to act. Risks that are normally deemed unacceptable, such as exceeding the speeding limit, can be acceptable under certain circumstances. ${ }^{688}$ Consider the doctor who needs to get to hospital and the taxi driver who needs to get a pregnant woman to hospital. The risk inherent in speeding can however also be deemed acceptable in order to get away from a driver who leaves no distance or to signal another of the danger of losing their load. ${ }^{689}$ Justified or reasonable risks are not careless. ${ }^{690}$ More specifically, if the risk is acceptable, it remains foreseeable, but there no longer is a duty to behave differently. ${ }^{691}$ Offences of culpa thus have in common with offences of recklessness, that they are about the taking of unreasonable risks and therefore subsume all justifications.

The context is also important in establishing the standard. In cases of regulated sports and games, a duty of care is less likely to be violated. More is allowed, because the sport or game can provoke conduct which participants can expect and inevitably includes mistakes from time to time. ${ }^{692}$ Participants take into account violations of the rules of the game based on eagerness, excitement, absence of consideration, imperfect game technique and so on. ${ }^{693}$ It is 'all in the game'.694 Non-serious violations of the norms are unavoidable and accepted. The risk only becomes unacceptable when the norms are grossly violated. In general, offences that lead to exclusion of the game, also amount to a violation of the duty of due care. Abuse of the margin of allowed risk to enact revenge-fouls generally leads to liability. ${ }^{695}$

HR 1 June 2004, NJ 2005, 252; van Kempen 2004, p. 1007 and den Harder 2006, pp. 138-139.

De Jong, D.H. \& Knigge 2003, p. 132.

Burmann a.o. 2010, note 128 on $\S 3$ StVO.

Schönke \& Schröder, H. 2006, p. 179; Beulke 2008, p. 99; de Jong, D.H. \& Knigge 2003, p. 131 and Pompe 1935, p. 90.

691 Keulen \& Otte 1999, pp. 46-47.

692 HR 20 February 2004, LJN:AO1239 and HR 22 April 2008, NJ 2008, 375.

693 Berkl 2007, pp. 115-117 and 3 August 1961 BayObLGSt 1961, 180.

694 Kelk 2005, p. 153

695 Schönke \& Schröder, H. 2006, p. 338.
} 
In contrast, negligence is more likely to follow when similar acts have been committed outside such situations. For example, students used a heavy table in a dangerous way to play a game, severely wounding one student. The game was part of the students' tradition but lacked clear rules. The students were convicted of negligently inflicting serious bodily harm. ${ }^{696}$ The greater margin of what is allowed in the context of sports is framed here as an issue of culpa, but it can also be seen as an issue as to what the participants have consented to. The effect to a charge of negligence is the same, because if the result was justified due to consent, it cannot be negligent. ${ }^{697}$

A so-called 'principle of trust ${ }^{\prime} 998$ functions as an additional limitation to the scope of duties imposed on legal subjects. It implies that the actor does not have to take into account all possible errors of others, and that he, unless there are circumstances that indicate otherwise, may rely and adapt his conduct to the assumption that others in the field of conduct will behave carefully. ${ }^{699}$ The actor cannot be negligent for not fulfilling a duty that he is not required to perform. For example, an automobile driver may expect other participants in traffic to obey the traffic rules. A driver does not have to take into account that a pedestrian may just walk on the street. ${ }^{700}$ The principle also applies to business transactions, surgeries and so on. ${ }^{701}$

The principle is not absolute. As noted, circumstances may raise suspicions, giving rise to a duty. In addition, it does not apply in regard to children and impaired adults. ${ }^{702}$ The participant in traffic has to adapt his behaviour to errors of other participants that are evident or common and therefore to be expected. He is also required to take caution of technical defects and strange traffic situations. ${ }^{703}$ Finally, the principle is also precluded when the defendant violates a duty of care himself. If the motorist grossly exceeds the speed limit on a major road, he can no longer trust that other participants will yield to him or clear the crossing in time. ${ }^{704}$

The principle can also be found in EU law. Rules on the placing on the market of products have been harmonized in order to facilitate free movement of these goods within the EU. This harmonization is believed to bring about mutual trust. As a

\footnotetext{
696 HR 31 October 2006, NJ 2007, 79.

697 See also Annotator Keijzer in HR 22 April 2008, NJ 2008, 375.

6982 March 1982 BGH NJW 1982, 1756 and HR 25 May 2004, $L J N: A O 6452$.

69917 September 1958 BGHSt 12, 81

70012 July 1954 BGH VGS 1, 54 and Roxin 2006, p. 1070.

701 Beulke 2008, p. 251; Schönke \& Schröder, H. 2006, p. 306 and Roxin 2006, pp. 1071-1072. In 19 November 1997 BGHSt 43, 306, it was objectively clear that the colleague doctor had made many errors.

702 Beulke 2008, pp. 255-256; 24 March 2006 OLG Jena BeckRS 2006, 06007; §3(2a) of the German Road Traffic Regulation (StVO); Fokkens \& Machielse, note 12 on Culpa and Kelk 2005, p. 214.

70317 September 1958 BGHSt 12, 81 and Krabbe in Krabbe \& Harteveld 1999, p. 134.

704 HR 17 June 1980, NJ 1980, 580; HR 25 May 2004, LJN:AO6452; 10 December 1965 BGHSt 20, 135; Beulke 2008, pp. 250-251; Roxin 2006, pp. 1070-1071 and Schönke \& Schröder, H. 2006, pp. 327-329.
} 
result, the importer of goods that have been declared safe by the exporter in another Member State may trust that this declaration is correct. This is only negated in case he possesses specific knowledge that leads to serious doubts on this safety. ${ }^{705}$ The principle is arguably even stronger in EU law: the importer of a machine that caused serious injuries cannot be held liable for negligently causing these injuries, not just because he was not required to carry out additional checks, but even because he was not allowed to preform such a duty. Such additional checks would after all, restrict the free movement of goods.

Let us consider the case where someone walked by an apartment building. When he peeked through the opened front door, he saw that the hallway was full of combustible material. He decided to light the material, which led to a fire in the building, resulting in many deaths. We are not concerned with the liability of the person who lit the fire, but with the liability of the landlord who had been charged with negligently causing these deaths. The Prosecutor argued that he had been responsible for stacking the hallway full of material that originated from renovations. Moreover, the landlord had broken the state rules that required him to make sure the staircase, entrance and exit of the building were freely accessible and that these could be safely used in case of fire. Finally, the door was open because the lock was broken.

However, liability was rejected. The Court of Appeal emphasized that the landlord had not acted socially inappropriate, because he was allowed to trust that other persons would not abuse the source of danger created by him for criminal purposes. The Court distinguished three categories of possible sources of danger. If it concerns items that according to general experience bring about dangers to others, like weapons, there exists such a special duty on the keeper of the items. For example, if one does not properly ensure that a weapon is safeguarded against unauthorized handling, and a third one uses it for murder, the owner can be held liable for negligent killing. Secondly, there are also items, such as chemicals, that can be used in a socially appropriate manner without danger, but become dangerous in the hands of inexperienced persons. The duty to prevent possible abuse is then restricted to preventing abuse by inexperienced persons, for example by making sure children cannot reach them. The building material falls into yet another category because almost no danger arises from this. It was held that it cannot spontaneously combust and the risk that children would light it can be disregarded too. The landlord was not required to ensure that third parties would not set fire to the material. The result was not foreseeable as it falls so far outside the scope of what can be generally expected. ${ }^{706}$

In order for the defendant to be held liable for assisting the perpetrator, he must have intended to further the commission of the crime, which under dolus eventualis

7058 September 2005, Case C-40/04, Criminal proceedings against Yonemoto [2005] ECR I-7755. See also 11 May 1989, Case 25/88, Criminal proceedings against Wurmser and others [1989] ECR 1105.

70621 November 1996 OLG Stuttgart NStZ 1997, 190. 
or recklessness at least requires awareness of the risk. ${ }^{707}$ When the defendant was unaware or this awareness cannot be proven, the question can still be asked whether the assistance to the perpetrator was foreseeable. In the absence of liability for aiding and abetting, negligence liability can follow if the defendant is held to have been able to acknowledge the inclination to act of the intentional perpetrator. After all, the abovementioned landlord was charged with negligent killing. The doctors who allowed a very violent patient to have unsupervised leave could also be convicted of negligent killing. That mental patient killed two and wounded eight persons. ${ }^{708}$ If the risk was reasonable, such as the cashier who sold manure at the garden centre, in the absence of circumstances that should raise suspicion it might be used to create a bomb, the fact that it was used to make a bomb that killed people, was not foreseeable. Reasonable risks are not punished, regardless of whether the defendant was aware of it.

\subsubsection{Reasonable person}

The objective part of negligence, often expressed by the required nature and degree of care that the defendant should have taken, is established by reference to what can be expected from a sensible and conscientious person in the assessment of the danger ex ante, taking into account the concrete circumstances and the social role of the actor. ${ }^{709}$ The yardstick of the reasonable person, the successor of the bonus pater familias, ${ }^{710}$ has led to considerable debate on what individual characteristics should be taken into account. These characteristics can operate as to lower or heighten our expectations of a person. ${ }^{711}$

Individualised features that are taken into account to determine what degree of diligence could be expected from the defendant are amongst others his professional position, role, education and age. ${ }^{712}$ A professional is judged according to what a general person in that profession would do. For example, what could be expected from a reasonable doctor, building inspector or constructor? ${ }^{713}$ When the actor enters into special situations, accepts a function or takes part in traffic or sports, he must abide by the applicable rules and is considered to be competent to carry out the activity. He gives guarantees, on which others may rely. This 'Garantenstellung' concretizes the standard person to which the defendant is compared. A similar

707 I rejected dolus eventualis in this context too, see IV.5.5.2.

70813 November 2003 BGHSt 49, 1 and Roxin 2006, pp. 1072-1075. The Supreme Court quashed the acquittal.

7091 February 2005 BGH NStZ 2005, 446; Beulke 2008, p. 249; Schönke \& Schröder, H. 2006, p. 300. See also Fletcher 1971, pp. 417-425.

710 Erenius 1976, p. 154.

711 Fokkens \& Machielse, note 9 on Culpa.

712 Keulen \& Otte 1999, p. 43.

713 De Hullu 2006, p. 246 and 10 December 1965 BGHSt 20, 135 and 15 August 2002 OLG Karlsruhe BeckRS 2003, 06332. 
rationale for expecting more from a specific defendant is his prior experience with certain situations: forewarned, forearmed. ${ }^{714}$

The reasonable person is altered to have some individual characteristics. In other words, some subjective factors provide for a check on a basically objective test. ${ }^{715}$ The practical importance of this modification must not be exaggerated, as usually the question of negligence is answered by reference to the outward appearance of conduct. ${ }^{716}$ As mentioned, the mere violation of a norm usually suffices to ground liability. Moreover, the taking into account of individual characteristics is applied more often with a view to attribute negligence to a defendant than to acquit. Everyone is required to do what he can, so additional knowledge or capacities can ground carelessness. For example, if a person knows that a certain crossing is dangerous, he is required to adapt his behaviour to an even greater degree of carefulness. ${ }^{717}$

The individual features enumerated above should be distinguished from 'truly' individual characteristics that are only taken into account under the subjective part of culpa ${ }^{718}$ If the reasonable participant in traffic could have foreseen the danger, the fact that this particular defendant could not meet this standard does not affect the question of carelessness. The test here is still objective. The lack of the capacities that a normal person would have can at most negate culpa under its final subjective assessment. The exact demarcation of what characteristics are to be taken into account at what stage is difficult. This is even more so in English law, that does not generally recognize a subjective part. ${ }^{719}$ Let us first consider some examples of characteristics that are taken into account in the objective part.

A classic example of raising the bar of carefulness based on professional conduct is the case where a nurse prepared a syringe with a wrong substance. The patient was injected with this substance, as a result of which he died. The nurse was held negligently liable for this death, despite her claims that she had been overworked and less familiar with the surroundings, which were disorderedly moreover. A nurse of her education and experience should have been more careful, taking into account that she knew the importance of her job and that her work was not checked..$^{720}$ In a similar case, an intern at a pharmacy and had incorrectly prepared a prescription. She was also convicted of negligently causing death and serious

714 De Jong, D.H. \& Knigge 2003, p. 133-134; Schönke \& Schröder, H. 2006, p. 300 and Simester \& Sullivan 2007, p. 151.

715 Bohlander 2009, p. 32; van Dijk, A.A. 2008, p. 45 and Fokkens \& Machielse, note 9 on Culpa.

716 Fokkens \& Machielse, note 9 on Culpa with reference to a similar trend in Germany.

717 Beulke 2008, pp. 249-250; Schönke \& Schröder, H. 2006, pp. 303-304 and Roxin 2006, pp. 1084-86.

718 Bohlander 2009, pp. 55-56.

719 Simester \& Sullivan 2007, p. 151. As a consequence, many scholars have advocated of taking into account more individual features in the standard of the reasonable person, see Hart 2008 (reprint 1967), pp. 152-157; Simester \& Sullivan 2007, pp. 147-150 and Westen 2008B. 
bodily harm. ${ }^{721}$ Apparently, the fact that she was under supervision and clearly did not have a lot of experience was to no avail of her. As will be discussed shortly, when a person accepts a certain role, he is deemed to have the knowledge and competencies of a reasonable person in that role. He cannot claim that he does not meet the standard of the reasonable person.

First however, an important tendency in Dutch case-law should be noted. Increasingly, not the actor who is causally closest to the harm, but the employer, manager or legal entity behind this actor is held liable for negligently causing results. In the cases above, both defendants had claimed that their employer was co-responsible for the violation of the duty of care, but to no avail. However, in a case of 2002, a lower court acquitted a doctor for negligently causing death, based on considerations that the death could be attributed to a larger extent to the carelessness internal organization of the hospital then to the carelessness of the defendant, who did not check whether the syringe was correct. The defendant was fairly inexperienced, insufficiently instructed and under huge pressure of work..$^{722}$

In more recent cases that attracted a lot of public attention, the trend is visible too. In the first that will be discussed, a group of colleagues went on a day-trip to do some rafting. The activity however resulted in fatalities. An important reason for the fatalities was held to be the insufficient instruction of the supervisors. The firm and its director were therefore prosecuted and convicted, rather than the inexperienced actual supervisor of the fatal trip. ${ }^{723}$ It has been argued that if the 1963 case of the mistaken nurse would be tried today, the liability of the hospital would be assessed too. ${ }^{724}$ Enabling criminal liability of directors and legal entities protects the individual employee from becoming the fall-guy. From a perspective of prevention, more is to be expected when the company is (also) convicted. It is the company or its (direct) manager that created the conditions in which the defendant breached his duty. If (only) the employee would be convicted, it is to be expected that another employee will violate a duty of care in the future.

A legal presumption operates in the context of specialized and/or dangerous activities. The maxim 'imperitia culpae adnumeratur' entails that when a defendant takes on a task to which he is unqualified, he shall be deemed negligent. ${ }^{725}$ If people take up a specific role, more is expected from them regardless of whether they can personally meet the standard of care that is normal in that role. When someone undertakes conduct to which he is not up to due to a lack of expertise or capacities, the violation of a duty of care can already be grounded in that act. The reproach is

721

22 Rb. Den Haag 19 December 2002, $L J N$ :AF2320. In the similar Rb. Leeuwarden 23 December 1987, NJ 1988, 981, the hospital was convicted for negligent killing. Criminal liability of legal entities and their employees is not mutually exclusive, but generally, the Public Prosecutor will only bring charges against either one or the other, as is evident in the case mentioned below.

Hof Arnhem 20 July 2009, $L J N: B J 3107$.

Kelk 2005, p. 220. See also Strikwerda 2008.

Williams 1953, p. 83; Schönke \& Schröder, H. 2006, pp. 320-321; Roxin 2006, pp. 1082 and 1105. 
transferred to the moment where the actor ventured onto thin ice. Dangerous conduct is either undertaken under sufficient precautionary measures or not undertaken at all. When someone cannot assess the risk properly, he has to gain information and knowledge and when that is impossible, he has to abstain from the conduct. $^{726}$

An example is when a driver gets behind the wheel, knowing that he is prone to epileptic seizures. ${ }^{727}$ Another example is the doctor who carries out a surgery for which he is not qualified. ${ }^{728}$ The actor is required to put himself in a position to be able to act with diligence. If we take the example of the defendant who inadvertently causes injuries to another due to improper use of industrial equipment, two situations can therefore be distinguished, both of which lead to negligence liability. The professional is equated with the reasonable person, who would have foreseen the risk. The amateur is held liable for negligently causing the injuries too, because he took up a task for which he is not qualified. ${ }^{729}$

\subsubsection{Causation}

The requirement that the breach of a duty caused the consequence is considered an aspect of culpa rather than a specific independent doctrine. This is only evident in some judgments. ${ }^{730}$ For example, major and highly unusual deviations from what could be expected to happen and results that lie beyond all life experience are not foreseeable. ${ }^{731}$ Courts usually do not make explicit whether the defendant is acquitted due to a lack of causation or due to a lack of negligence, based on causal considerations. Partly due to this, the dogmatic positioning of causation can be debated. I already noted that causal questions are always closely connected to the fault element. In negligent offences, they are inextricably linked to each other. ${ }^{732}$ The concepts have moved towards each other. On the one hand, causation has moved towards culpa by becoming more of a normative concept, focusing less on the physical aspect only. On the other hand, culpa has moved towards causation. In

726 R. v. Adomako [1994] UKHL 6; 8 February 1957 BGHSt 10, 133; Beulke 2008, p. 249; Fischer, T. 2009, p. 110; Duttge 2006, p. 270; Roxin 2006, pp. 1076-1077 and de Jong, D.H. \& Knigge 2003, p. 134.

17 November 1994 BGHSt 40, 341 and Roxin 2006, p. 1077. See also van Dijk, A.A. 2008, pp. 68-70.

728 See 27 September 1983 BGHZ 88, 248.

729 However, if a consequence was not foreseeable to experts, the defendant was also not able to foresee it, see HR 29 June 2010, NJ 2010, 674.

730 R. v. Marsh [1997] 1 Cr App R 67 and R. v. Williams [2010] EWCA Crim 2552.

7316 June 1967 BGH GA 1969, 246; Bohlander 2009, p. 118 and Schönke \& Schröder, H. 2006, pp. 317 and 320 .

732 Annotator Knigge in HR 1 June 2004, NJ 2005, 252 and de Jong, D.H. \& Knigge 2003, pp. 89 and 127-129. See III.6.2. 
assessing culpa in relation to a consequence, this is objectified by referring to the carelessness of the behaviour. ${ }^{733}$

In offences where the result is objectified, made strict, this means no fault needs to relate to the result. In the context of (partially) strict offences, causation thus plays a more independent role. Causal requirements are not taken into account in the fault element, because fault is not an offence element. Liability for the strict result is not limited by culpa, but it is limited by the rules on causation. ${ }^{734}$ When the result is strict, it is only attributed as causal to the actions of the defendant if it was foreseeable. Foreseeability does not only constitute the overarching question of carelessness, it is also an element of causation. From a causal perspective, a result is easily accepted as foreseeable. By contrast, as an overarching criterion of culpa, there is more room for subjective elements in foreseeability, like the role and position of that particular actor. ${ }^{735}$ The actor can be held to have caused a result, but not held liable for negligently causing the result because it was not foreseeable.

For example, the defendant and his friends who had locked a mentally impaired juvenile in a sea container, without telling him when they would be back, were held to have caused his death. When they returned about two hours later, the victim had started a fire in the container and died due to carbon monoxide poisoning. It was foreseeable that the victim, who was a smoker, would either light a cigarette or try to make a fire to illuminate the pitch-black container. As a result, they were liable for the strict result of causing death in the course of wrongful deprivation of liberty. Negligent killing was however rejected. The fact that the defendant was underage at the time, led the Dutch Court of Appeal to believe that the result was not foreseeable to him. $^{736}$

To determine whether the breach of duty caused the consequence requires both a factual, objective and normative undertaking. After it has been assessed that careless behaviour is metaphysically a cause of the effect, a conditio sine qua non, normative considerations are taken into account to assess whether this behaviour should also be seen as the legal cause of the consequence. The question of normative attribution operates just as in intentional offences as a modification to factual causation. Nonetheless, the judiciary generally treats these issues as a one staged question of causation, whereby the question of attribution is answered normatively. ${ }^{737}$

Some principles of causal attribution are most relevant for negligent offences. ${ }^{738}$ First of all, the duty of care that was violated must serve to protect the legal interest that has been infringed. In traffic law, most rules aim to protect the safety of

\footnotetext{
733 De Jong, D.H. \& Knigge 2003, pp. 85 and 127-128.

734 Keulen \& Otte 1999, p. 40.

735 De Hullu 2006, pp. 247-248.

736 Hof Arnhem 21 October 2010, LJN:BO1426.

737 Fischer, T. 2009, p. 77; Puppe 2004; Schönke \& Schröder, H. 2006, pp. 188-189; Ormerod 2008, pp. 75-76 and Remmelink 1996, pp. 175-183.

738 See Schönke \& Schröder, H. 2006, p. 195.
} 
participants, which brings about that this criterion is usually fulfilled by not complying with the traffic regulations. ${ }^{739}$ The breach of duty must also be a direct consequence of the result, which excludes that speeding in Munich is causal for the accident in Berlin. ${ }^{740}$ The principle of own responsibility excludes liability when the victim under his own responsibility wanted or at least took into account the possibility of death, harm or endangerment. It focuses on the question who controlled the events, the victim or the defendant. ${ }^{741}$

This is not the place to discuss causation comprehensively. ${ }^{742}$ I will only elaborate on one of the most discussed criteria of reasonable attribution in the context of negligent offences, which requires that the breach of duty must be the cause of the result. In other words, the result must have been avoidable by duty conform conduct. ${ }^{743}$ This criterion excludes causation when it is almost certain that the result would have also occurred when the defendant would not have violated this duty of care. ${ }^{744}$ This can be called a test of 'lawful alternative behaviour'. ${ }^{745}$

This test of lawful alternative behaviour can be found as an exception to the presumption of (factual) causation in case-law of all legal systems under investigation. It even appears implicitly in a decision of the ECJ on Union liability. ${ }^{746}$ On this basis, in a German case where a drunken cyclist got under the wheels of a truck, causation was denied. The truck driver had not made sure there was enough space between the truck and the cyclist when overtaking. He had kept a distance of only $75 \mathrm{~cm}$. However, it was accepted that the cyclist would have also gotten under the wheels if the driver had kept a correct distance of 1 to 1,5 meters. ${ }^{747}$ The case resembles an old case in English law, where the driver of a horse cart did not hold the reins. A three-year-old child ran into the road, was struck by one of the cartwheels and killed. The driver was acquitted because it was held that he could not have prevented the child's death by using the reins. ${ }^{748}$ In a Dutch case, it was held that the defendant would have probably also not been able to see the little children on the street and thus avoid hitting them with his car, if he had sat

739 Beulke 2008, pp. 252-253 and Schönke \& Schröder, H. 2006, pp. 299 and 307.

740 Beulke 2008, pp. 252-253 and Simester \& Sullivan 2007, pp. 81-82.

74114 February 1984 BGHSt 32, 262; 20 November 2008 BGH NJW 2009, 1155; Schünemann in Szwarc 1996, pp. 12-15; Duttge 2006, p. 271 and van Dijk, A.A. 2008, pp. 44-46. Carelessness is not simply negated by the fact that the victims agreed to participate in a criminal offence, see R. v. Wacker [2002] EWCA Crim 1944, where the defendant was held liable for causing the suffocation of 60 illegal aliens, whilst being transported in his lorry to England. See Keiler 2012, forthcoming.

743 Beulke 2008, pp. 254-256 and Roxin 2006, pp. 1066-1067.

744 HR 18 May 2004, NJ 2004, 512; R v Marsh [1997] 1 Cr App R 67; Ormerod 2008, p. 77; 25 September 1957 BGHSt 11, 1; Beulke 2008, pp. 253-255 and Schönke \& Schröder, H. 2006, pp. 186 and 315. 7 April 1992, Case C-358/90, Compagnia Italiana Alcool Sas di Mario Mariano \& Co $v$. Commission [1992] ECR I-2457, §47.

74725 September 1957 BGHSt 11, 1.

748 R. v. Dalloway (1847) 2 Cox CC 273, mentioned by Ormerod 2008, p. 77. 
more upright behind the wheel. ${ }^{749}$ The test is applied everywhere when a finding of causation would affront common sense. However, in Germany, this test seems to be conducted much more often and with more success for the defendant.

In almost all cases, there is a theoretical possibility that the result would have happened anyway. For this reason, prevailing opinion in Germany requires that there must be a great degree of certainty that the result would have also happened without the violation of the norm. ${ }^{750}$ However and to the benefit of the accused, some German decisions imply that it must merely not be improbable that the result would have also occurred in order to acquit the defendant. ${ }^{751}$ Causation is often negated because in dubio pro reo is applied to this test. If there is doubt that the consequence would have also occurred, and this is based on more than merely theoretical circumstances, ${ }^{752}$ the doubt is settled in favour of the defendant. ${ }^{753}$

From a victim-oriented perspective, it can be argued that this creates an inappropriate and almost insurmountable burden to hold defendants liable. ${ }^{754}$ For example, consider the case where a 7-year-old walked on the side of the road in a dangerous way. When the driver of a car overtook him, he hit the child, killing him. The court did not attribute negligent killing. It held that even if the driver had already braked and moved to the middle of the road when he saw the child walking dangerously, the collision would have been unavoidable, even though if he had done that, the chance of death was estimated to be at most 15 percent. The court argued that this chance does not preclude - read: make it improbable - that the result would have also occurred in case of the lawful alternative behaviour. ${ }^{755}$

Hence, criminal policy concerns against the test have led to it being ignored in special statutes. ${ }^{756}$ It also led to a wider acceptance of Roxin's theory of increased risk which would already confirm the causal relationship if the actor's conduct considerably increased the risk of the result occurring. ${ }^{757}$ Roxin found it unacceptable that the lawful alternative allowed a person to endanger an object that was already endangered without having to fear attribution for its harming. Therefore, if it can be established that careful conduct would have increased the chances of avoi-

751 Schönke \& Schröder, H. 2006, pp. 316-317.

752 Beulke 2008, p. 258-259 and Remmelink 1996, pp. 187-188. For example, the doctors who violated their duty of care by letting a very violent individual have unsupervised leave cannot argue he could have also left the institution by using an unsecured window, see 13 November 2003 BGHSt 49, 1.

Rb. Groningen 21 March 2011, $L J N: B P 8488$ and Hof Leeuwarden 31 March 2012, $L J N: B V 8650$. 25 September 1957 BGHSt 11, 1; 12 January 2010 BGH NJW 2010, 1087 and Duttge 2006, 30 August 2000 BGH NStZ 2001, 29 and 20 November 1988 OLG Karlsruhe NStZ 1985, 225. Puppe in Schünemann a.o. 2001, pp. 291-292 and 297-301 and Schönke \& Schröder, H. 2006, p. 195.

24 March 2006 OLG Jena BeckRS 2006, 06007.

Schünemann 1985, p. 355.

Schönke \& Schröder, H. 2006, p. 195 and Roxin 2006, p. 1081. 
ding the harm, the violation has increased the risk to the harm and is causal for it. $^{758}$

From cases decided before Dutch courts, it can also be inferred there must be more certainty that the result would have also occurred without the violation of the duty. In a case, both the defendant and the victim returned at night from a fair and were intoxicated. The victim, wearing dark clothes, had sat down partially on an unlit public road when the defendant ran him over with his car. He submitted he had not seen the victim. Moreover, counsel argued he could impossibly have avoided the accident. Like the AG agreed, it can be questioned whether the defendant would have been able to avoid the accident if he would have been sober, yet this was an argument the court used to convict him of negligent killing. ${ }^{759}$ The lawful alternative is less likely to acquit the defendant because that violation need not be the only cause of the result. ${ }^{760}$ Moreover, both Dutch and English courts are reluctant to apply in dubio pro reo as strict as in Germany.

In England, the lawful alternative test is often sidelined by the aforementioned offences that criminalize the causing of a result whilst violating a norm. For example, when a person driving a vehicle kills someone, he can be held criminally liable without reference to negligence if he drove the car whilst disqualified or whilst uninsured. No fault or causation applies to this aggravating circumstance, precluding any lawful alternative test. Even if it is almost certain that the accident would have also happened if he had a licence or was insured, the defendant is convicted. ${ }^{761}$ A similar aggravation exists when a person has taken away a vehicle without permission of the owner. The causing of an accident with that vehicle aggravates liability, without requiring any fault for that accident. Liability is attributed, even if it was established that he could not have avoided the accident. ${ }^{762}$

In the Netherlands, the test is also sidelined by formulating broad duties of care. In traffic, it is forbidden to do anything that may cause a danger to others. ${ }^{763}$ This for example brings about that the defendant cannot argue he would have also run over the victim if he had adhered to the proper side clearance when overtaking. This side clearance may be provided in abstracto, but if the victim was intoxicated or a child, the proper side clearance is extended: the concrete duty is to observe sufficient clearance or not overtake at all, if you see the other participant in traffic is intoxicated or a child. Clearly, the child who was walking dangerously along the road would have never been killed if the defendant took the care that would have prevented the accident.

Puppe in Schünemann a.o. 2001, pp. 288 and 295.

HR 29 April 2008, NJ 2008, 439. In HR 18 May 2004, NJ 2004, 512, the Court of Appeal applied the yardstick that it must be probable that the result also had occurred without the breach of duty. Based on expert evidence, this was held to be probable and negligence negated.

HR 21 September 2010, $L J N$ :BM9407.

R. v. Williams [2010] EWCA Crim 2552 and sections 3ZB of the Road Traffic Act 1988.

R. v. Marsh [1997] 1 Cr App R 67 and section 12A(1) of the Theft Act 1968.

Article 5 of the Dutch Road Traffic Act 1994 (WVW). 
The proper approach is to treat the lawful alternative as an extraordinary exception to a finding of culpa. Only in exceptional cases, where it is very likely that the result would have also occurred, had the defendant not violated the norm, causation and thereby culpa should be negated. However, given the fact that causation is a normative concept and situations very diverse, it should perhaps not be attempted to construct a general criterion with too much precision.

\subsubsection{Gross carelessness}

After it has been established what the conduct of the defendant should have done or omitted, this is compared with the behaviour of the defendant. If the defendant's conduct met the requirements of due care, there is no culpa. He can only be held criminally liable if he falls below the standard. However, a mere failure to meet the proper standard of care incumbent upon him does not suffice. It is required that the defendant fell short of the standard by a considerable margin. ${ }^{764}$ In other words, the carelessness must be considerable ${ }^{765}$ or gross. ${ }^{766}$ Culpa must be lata. ${ }^{767}$

Culpa lata is contrasted with mere culpa levis, ${ }^{768}$ with is sufficient for civil but insufficient for criminal liability. ${ }^{769}$ Requiring mere culpa levis implies that any shortcoming of the accused is sufficient. The actor would then be compared to the most able, thoughtful, careful person. ${ }^{770}$ In contrast, the defendant is compared to the reasonable or normal person modified by the concrete circumstances and the social role of the actor. ${ }^{711}$ Culpa should be limited to prevent fears expressed towards negligence liability from being realized, such as that negligence liability can be imposed to all, even the law-abiding citizen and secondly, that can be imposed on everyone at least once. Human faults are inevitable, but gross carelessness not. ${ }^{772}$

Culpa must be of such a degree "that, in the opinion of the jury, the negligence of the accused went beyond a mere matter of compensation between subjects and showed such disregard for the life and safety of others as to amount to a crime against the State and conduct deserving punishment." 773 In other words, the requirement of lata denotes the contempt for the legal interests of others. This description has been admitted to be somewhat circular: if the conduct is seen as

\footnotetext{
764 De Jong, D.H. \& Knigge 2003, p. 124; Simester \& Sullivan 2007, p. 146 and Weigend 1981, p. 674-676.

765 HR 17 September 2002, NJ 2002, 549 and de Hullu 2006, p. 245.

766 R. v. Bateman (1927) 19 Cr App R 8.

767 De Jong, D.H. \& Knigge 2003, p. 136.

768 Austin 1911, p. 434 and Koch 1998, pp. 49-53.

769 De Jong, D.H. 2007, p. 3; R. v. Adomako [1994] UKHL 6; Tadros 2005, p. 245, Erenius 1976, pp. 44 and 113; Hart 2008 (reprint 1967), p. 137 and Schönke \& Schröder, H. 2006, pp. 323-324.

770 R. v. Adomako [1994] UKHL 6; de Hullu 2006, p. 244 and de Jong, D.H. \& Knigge 2003, p. 136.

771 Smidt 1881 I, p. 78.

772 Koch 1998 and Schönke \& Schröder, H. 2006, p. 323.

773 R. v. Adomako [1994] UKHL 6.
} 
criminal, it must be labelled as gross negligence. It is certainly very open, yet this is almost unavoidable and welcomed by courts because of its inherent discretion and duty to take into account all the circumstances in which the defendant was placed. ${ }^{774}$ It provides the discretion to exclude liability in cases where the actor clearly violated a norm which caused a consequence. Consider the case in which a police officer was in pursuit to arrest an alien. When he fired a warning shot against the applicable rules- he tripped and hit the alien, who was fatally wounded. The carelessness is evident but it was held not the be gross enough to accept negligence, taking into account that the defendant in his five year experience had never been in a similar situation and that he had not been sufficiently instructed in the practical use of a firearm. ${ }^{775}$

German criminal law in theory lets any degree of negligence suffice. ${ }^{776}$ Nonetheless, the scope of liability is limited to a similar extent, because it is also accepted that the degree of carefulness should not be overstrained, especially when reasonable and socially accepted risks are taken to serve important social interests, as doctors do. It is therefore argued that only in extreme cases when they have made a gross error of assessment in the context of their broad margin of appreciation, can criminal liability be considered. ${ }^{777}$ German law uses numerous ways to come to similar solutions as requiring a gross deviation from the required standard of care. ${ }^{778}$

A consequence of the fact that negligence itself does not need to be gross, is that German lawyers tend to equate gross negligence with luxuria, called 'Leichtfertigkeit' in German law. ${ }^{779}$ This luxuria, discussed below, requires a more serious deviation from the standard of care, but this exceeds the margin that qualifies in the Netherlands and England as 'gross negligence'. Luxuria also exists in the Netherlands where it is distinguished as serious negligence from 'regular' gross negligence. Culpa (lata) and the more serious luxuria should therefore be distinguished. ${ }^{780}$

774 Idem and Kadish 1989A, p. 76: "In the end it is a judgment call whether the negligence is so egregious that punishment and not merely civil liability is appropriate."

775 Hof Den Haag 23 June 1981, NJ 1981, 560.

776 Bohlander 2009, pp. 55 and 59-60 and Schönke \& Schröder, H. 2006, pp. 322-324. See also Arzt in Stree a.o. 1978, pp. 131-143.

777 Beulke 2008, p. 250.

778 Schönke \& Schröder, H. 2006, pp. 322-323 and Koch 1998, pp. 112-171. See also Roxin 2006, pp. 1077-1081.

77915 May 1992 BGHSt 38, 295; 9 November 1984 BGHSt 33, 66; Krey 2002, pp. 138-139, Roxin 2006, pp. 1092-1093 and Schönke \& Schröder, H. 2006, pp. 294 and 324. In part, this is due to the fact that 'Leichtfertigkeit' was said to resemble the civil law concept of gross negligence: 'grobe Fahrlässigkeit.'

780 See article 4(1) of Directive 2009/123 of 21 October 2009 amending Directive 2005/35 on shipsource pollution and on the introduction of penalties for infringements, OJ 2009 L 280/52: “(...) wenn sie auf Vorsätzlichkeit, Leichtfertigkeit oder grobe Fahrlässigkeit zurückzuführen sind." 


\subsection{Subjective part}

If culpa would include an advertent form of negligence, as in Germany and the Netherlands, it could be argued that this awareness is the subjective part of advertent negligence. ${ }^{781}$ However, culpa is about inadvertence only. The subjective part of it is not about awareness; it is about personal aspects of the reproach of culpa. This can be called subjective foreseeability and avoidability, ${ }^{782}$ which in turn is a question of blameworthiness. ${ }^{783}$ It is about the question whether the defendant can be reproached for violating the duty of care and causing the result, whether he could have obeyed the norm, whether he could foresee and prevent the consequences from occurring, whether he could have acted differently, given his individual capacities, skills, experience and knowledge, intelligence, age, education and physical condition. ${ }^{784}$ The defendant might not be able to exercise his diligence to the appropriate level - either permanently or only temporarily - because of intellectual or physical defect, lack of experience or capacity to react, sudden unexpected tiredness or feeling sick, being surprised or frightened and so on. ${ }^{785}$

\subsubsection{Assumed with the objective part}

As argued, these individual characteristics that are relevant in the subjective part should be distinguished from those that are already taken into account under the objective part of culpa. If the reasonable participant in traffic could have foreseen the danger, the circumstance that the particular defendant could not meet this standard does not affect the question of carelessness. The test here is still objective. The lack of the capacities that a normal person would have can at most negate culpa under its final subjective assessment. To illustrate this, consider that when an epileptic person drove a car, this constituted a violation of a duty of care, and it was objectively foreseeable that serious accidents could occur. A doctor had even warned him. However, his conviction was quashed because the court had dealt with the subjective part insufficiently. The Supreme Court held that this might be difficult to establish as the defendant was held to possess only a very limited degree of insight of his disease and its consequences. Moreover, he had driven for many years without problems and his own general practitioner had never warned him. ${ }^{786}$

\footnotetext{
781 Roxin 2006, pp. 1089-1090; Bohlander 2009, p. 117 and Fischer, T. 2009, p. 111.

782 Schönke \& Schröder, H. 2006, p. 321 and Roxin 2006, p. 1104.

783 Schönke \& Schröder, H. 2006, p. 317.

784 Roxin 2006, p. 1106; Hettinger 1988, p. 56 and van Dijk, A.A. 2008, pp. 46, 54-55, 61-63 and 196 and Politoff \& Koopmans 1991, p. 69.

785 Bohlander 2009, p. 118; Beulke 2008, p. 260 and Schönke \& Schröder, H. 2006, p. 320.

78617 November 1994 BGHSt 40, 341. In HR 24 November 1964, NJ 1965, 142, the driver had been assured by doctors he could drive safely. When he became unconscious while driving as a consequence of a diabetic attack, he was excused due to the absence of all blameworthiness.
} 
Which individual circumstances should be taken into account and to what extent is up for debate. ${ }^{787}$ There must be a limit as it would be unacceptable to measure every person to its own standards. ${ }^{788}$ In practice, such fears appear unwarranted. The subjective part is best seen as a highly unusual exception that is meant to make sure that defendants who cannot be blamed for their careless behaviour are not held criminally liable. After all, the subjective part of culpa is assumed after establishing the objective part. What is generally foreseeable to the average person is assumed to be also foreseeable to the individual defendant. Therefore, the establishment of the subjective part is usually fulfilled and hardly presents difficulties of proof. ${ }^{789}$ In theory, the judge may not automatically infer the blameworthiness from the carelessness, ${ }^{790}$ since this would render the criterion void, but practice tends towards this nonetheless. Like causation, it is usually discussed only by way of exception, for example, if the facts of the case indicate that this aspect might be lacking.

The subjective part is only absent in exceptional situations, where blameworthiness was lacking. In order to fulfil this element, any degree of blameworthiness suffices. In contrast to the objective part, the subjective part need not meet a certain threshold. The subjective part or blameworthiness refers to any degree of blame, whereas negligence must be gross. ${ }^{791}$ The assumption that the defendant was blameworthy must therefore be completely negated: every (relevant) ${ }^{792}$ degree of blame must be excluded. ${ }^{793}$ For example, in traffic, the driver is also required to act diligently on unexpected events. Only in extreme situations, liability does not follow. Cases where the subjective part is negated have in common that there is an enormous pressure on the defendant, similar as in excuses like duress. ${ }^{794}$

This low threshold can be explained by the fact that the objective component already requires a substantial deviation from the standard of care. The components are inextricably linked to each other and operate as communicating vessels. Because the degree of carelessness must be serious, the subjective element is rarely denied. ${ }^{795}$ Similarly, individual elements have already been taken into account in

787 Westen 2008B. There is also debate on the question whether some forms of incapacity, as in the example above, are not better dealt with by an excuse of insanity, see Momsen 2006, pp. 450454.

788 Fletcher 1971, p. 426 and Alexander \& Kessler Ferzan 2007.

789 Roxin 2006, pp. 1105-1106; Bohlander 2009, p. 118; Schönke \& Schröder, H. 2006, pp. 317 and 321-322; Fokkens \& Machielse, note 17 on Culpa; Otte 2007, p. 301; de Hullu 2006, pp. 247, 252-253 and 256 and Keulen \& Otte 1999, p. 54.

790 Keulen \& Otte 1999, pp. 49-50 and Schönke \& Schröder, H. 2006, p. 322.

791 AG Remmelink in HR 26 April 1977, NJ 1978, 200; van Dijk, A.A. 2008, pp. 38 and 197-203 and Vellinga, W.H. 1982, pp. 110-112 and 141-143.

792 See VIII.3.4.

793 Roxin 2006, pp. 1105-1106; annotator Knigge in HR 1 June 2004, NJ 2005, 252; de Jong, D.H. \& Knigge 2003, p. 137; de Jong, D.H. 2007, p. 5 and Otte 2001, pp. 18-22.

794 Koch 1998, pp. 138-140.

795 Van Dijk, A.A. 2008, p. 191. See also Kelk 2005, p. 219. 
the standard of the reasonable person. When someone else with the same function would not have made this error, there is not much room left for the defendant to make probable he was not able to avoid this error. ${ }^{796}$

\subsubsection{Negated by an excuse}

The subjective part is negated if it is assumed that the defendant could reasonably not have acted differently. ${ }^{797}$ Consider that a man is ironing clothes when he is called with news that his wife has had a serious accident at work. He rushes over to the hospital, forgetting to turn off the iron. Consequently, the house catches fire. It can be argued that the husband should not be blamed for his carelessness, because in this understandable situation of pressure, one does not think about the endangerment anymore. 798

An excuse also expresses that the actor could not reasonably behave differently. The subjective part is therefore typically negated by the application of an excuse..$^{799}$ Consider the Dutch case where a defendant, a police officer, drove as fast as possible to get to the scene of serious accident. Unfortunately, by driving so fast, she caused another accident. The behaviour was careless by reference to a reasonable police officer, but in this case, her lack of experience and training in driving in emergency situations was taken into account. This amounted to the application of an extralegal excuse called 'absence of all blameworthiness'. ${ }^{800}$

A similar excuse seems to be available in Germany. ${ }^{801}$ This general excuse operates as a safety net for all situations in which the defendant could not be required behave differently. Blameworthiness is an express element of negligence but also an implied element of every criminal charge. It is the lowest limit of guilt and required for any form of punishment: no punishment without guilt, either for an intentional, negligent or strict offence. The availability of this general excuse enables that this principle is safeguarded.

The Dutch and German cases in which the defence was developed are very similar. Both cases are situated around the turn of the previous century. The defendants were ordered to perform a task by their employer, which at the time was difficult to refuse for an employee. ${ }^{802}$ In the Dutch case, the defendant was told to deliver milk, which was diluted with water. He did not know the milk was diluted, but held liable anyway since the offence was strict. However, this conviction was quashed because he lacked blameworthiness. He did not know and he should not

\footnotetext{
796 De Hullu 2006, p. 256 and Otte 2001, pp. 18-22.

797 Kelk 2005, p. 206.

798 See Koch 1998, p. 137 and Roxin 2006, pp. 1107-1108.

799 De Jong, D.H. \& Knigge 2003, p. 132; Fokkens \& Machielse, note 15 on Culpa; Keulen \& Otte 1999, p. 37 and de Hullu 2006, pp. 251 and 253.

800 'Afwezigheid van alle schuld', see V.2.3. The case is mentioned in den Harder 2006, p. 134.

801 'Unzutmutbarkeit normgemäßen Verhaltens.'

802 Since the position of employees has changed, the scope of the excuse is nowadays smaller.
} 
have investigated the matter, given his subordinate position. ${ }^{803}$ In the German case, the defendant had to drive a horse-cart for his employer, but both knew that one of the horses was very hard, if not impossible to handle. One day, the horse got out of control again, causing all the horses to go wild. As a result, the cart ran over a passer-by who suffered a broken leg. The defendant was not convicted of negligently causing bodily harm. Although he could foresee the result, he could not be expected to disobey the instructions of his boss, since that could risk losing his livelihood. ${ }^{804}$

There is controversy in Germany on whether or not such an extralegal general defence exists. In the 1920's, it was widely accepted as an extralegal defence, but rejected by the Supreme Court in 1932 after which scholars followed. ${ }^{805}$ Some scholars explicitly explain the abovementioned case in light of the application of an excuse and/or conclude that negligence requires an element of 'Zumutbarkeit', which corresponds with blameworthiness. In contrast, others deny the application and existence of such a defence by arguing, amongst others, that this case had been solved by negating the objective part of negligence. ${ }^{806}$ In any event, it is at least accepted in Germany that the lack of blameworthiness should preclude liability for culpa. ${ }^{807}$ Culpa positively requires proof of blameworthiness, as follows from the requirement of subjective foreseeability and avoidability. The judiciary therefore seems to view this element as an order to the judge to carefully test the subjective part of negligence to the special circumstances. ${ }^{808}$

To make it abundantly clear, the possibility to raise absence of blame in order to escape liability should not distract from the general rule that negligence is generally established upon proof of violating a norm. As long as the judges motivate their decisions extensively with reference to the facts of the case, grounding their judgment in identified violations, these decisions will usually hold up in appeal or cassation. ${ }^{809}$ This implies that in a lot of cases, negligence is reduced to the objective violation of a norm, and thus does not differ from strict liability offences. After all, the absence of blame can also be raised successfully against a strict charge.

This practical application of negligence and the lack of a subjective part in England could also be used to argue against a specific subjective part of culpa. Moreover, even without a subjective part, the defendant cannot be convicted if he lacked any degree of blameworthiness due to the application of an excuse. However, even if a subjective part is established easily in practice, this does not mean that it is superfluous. It rather indicates that it is usually given, and only negated

\footnotetext{
803 HR 14 February 1916, NJ 1916, p. 681.

80423 March 1897 RGSt 30, 25. See also Bohlander 2009, pp. 118-119.

80511 November 1932 RGSt 66, 397 and Koch 1998, pp. 133-135.

806 Koch 1998, pp. 136-138; Bohlander 2009, p. 118; Schönke \& Schröder, H. 2006, p. 324; Beulke 2008, pp. 158 and 261; Roxin 2006, p. 1109 and Momsen 2006, pp. 447-448 and 455.

807 Schönke \& Schröder, H. 2006, p. 714 and Momsen 2006, pp. 447-449.

8089 May 1940 RGSt 74, 195 and Koch 1998, pp. 140-141.

809 Otte in a meeting on 22 April 2009.
} 
exceptionally. This is logical, if we consider that most persons can meet the standards required by the law.

The reproach of culpa is based on the finding that the defendant could have foreseen and avoided the result. It is a personal reproach against an individual. It is not assessed whether the act was performed careless, but whether the defendant was careless. The defendant should be aware of only what he can be aware of, which brings about that the law must not hold those defendants liable whose individual traits preclude them from being able to perceive risks. ${ }^{810}$ The lack of a subjective part in the English concept of negligence makes it difficult to ground an exception to negligent liability in the deficient capacities of the particular defendant. ${ }^{811}$ As a consequence, the English defendant that cannot meet the reasonable standard depends on the availability of defences. ${ }^{812}$ Defences are no satisfactory alternative to the subjective part, as they do not cover all the different forms and degrees of incapacity such as blindness or stupidity.

\subsubsection{Position in the framework of criminal liability}

In Germany, the subjective part of negligence is positioned in blameworthiness, the third rung on the ladder of criminal liability. It has been separated from the objective part of negligence, which is included in the level of the offence definition. Negligence is thus positioned on two levels of criminal liability. ${ }^{813}$ In Dutch law, negligence subsumes blameworthiness, which implies that the aspect of blameworthiness is assessed on the first rung of liability. Only a minority in Germany also treats the subjective individual capacities within the framework of the offence definition. ${ }^{814}$

The result of the negation of the subjective part in Dutch law is therefore an acquittal based on the failure of proof, not the lack of blameworthiness. If the accused could reasonably act differently, the offence definition is not fulfilled, even if that is due to the application of an excuse like duress or insanity. ${ }^{815}$ In England, neither a relationship between negligence and blameworthiness, nor a subjective part is clearly identified. As a result, not fulfilling any criterion of negligence only leads to a failure of proof.

The difference does not lead to very different results. In all Member States, the actor who is not blameworthy cannot be punished. The German approach is favoured, because it has the advantage that it allows for the taking of measures against defendants who are acquitted from a negligent charge due to the negation of

\footnotetext{
810 Westen 2008B, p. 147 and Hart 2008 (reprint 1967), pp. 152-157.

811 Simester \& Sullivan 2007, p. 151.

812 Since English law lacks a general defence of lacking blameworthiness, he depends on the existence of a similar statutory defence that applies to a single offence or statute.

813 Schönke \& Schröder, H. 2006, pp. 162 and 296 and Beulke 2008, p. 246.

814 Schönke \& Schröder, H. 2006, p. 297 and Beulke 2008, p. 246.

815 HR 19 February 1963, NJ 1963, 512 and Keulen \& Otte 1999, p. 50.
} 
the subjective part, like the epileptic driver above. Like a person found insane, he fulfilled the offence definition and is only excused, which precludes punishment but enables measures being ordered against him. If insanity would negate the negligent charge, this simple acquittal would imply no measures could be ordered. ${ }^{816}$

\subsection{Minus or aliud}

It has been questioned whether negligence relates to intent (and recklessness) as a minus or an aliud. As a minus, negligence is encompassed by intention. When intention or recklessness is proven, negligence may be proven too. ${ }^{817}$ When negligence is seen as an aliud, it cannot be established by proof of a more serious fault element. They are seen as mutually exclusive fault elements, since a person cannot be aware and unaware of a risk at the same time. ${ }^{818}$ The latter perspective has been challenged because it holds that culpa dolo exonerate. Proof of negligence negates the intentional charge, which would provide defendants with an unacceptable defence. ${ }^{819}$ Fault elements have been placed on a continuum to indicate a relationship of differing degrees of culpability. This also implies that culpa is the minus of dolus. ${ }^{820}$

The perspective of culpa as minus is currently most popular in the Netherlands, and apparently also in England. Whereas the English concept of negligence is limited to inadvertence, it can also be fulfilled by foresight. Recklessness brings about that the defendant may be more readily found to be negligent. ${ }^{821}$ In England, the lesser standard always incorporates the greater. Recklessness is also satisfied by knowledge or intention. ${ }^{822}$ By contrast, in Germany, the plus-minus perspective is rejected even though the continuum of culpability is accepted. ${ }^{823}$ Paragraph 18 of the Criminal Code implies by the wording 'at least negligent' that intent should be included as well, but the Supreme Court has held that intent and negligence are mutually exclusive. ${ }^{824}$ The practical relevance of this difference is minimal

816 Schönke \& Schröder, H. 2006, p. 300. See VII.7.1. for more reasons in favour or this approach and X.7.2. on the ordering of measures against the insane.

817 De Hullu 2006, pp. 263-265. See also Kelk 2005, p. 208 and Pompe 1935, p. 89.

81822 September 1953 BGHSt 4, 340; Fokkens \& Machielse, note 4 on Culpa and Strijards 1983, p. 315.

819 De Hullu 2006, p. 263 and van Dijk, A.A. 2008, pp. 39-40. See also Vellinga, W.H. 1982, p. 137.

820 Stuckenberg 2007, pp. 314-315; de Hullu 2006, pp. 263-265 and van Dijk, A.A. 2008, p. 151. See also Kelk 2005, p. 208 and Pompe 1935, p. 89.

821 R. v. Adomako [1994] UKHL 6; Attorney-General's Reference No. 2 of 1999 [2000] EWCA Crim 91 and Simester \& Sullivan 2007, p. 145.

822 Section 19(2) draft Criminal Code, Law Commission 1989, p. 52. This also has the procedural consequence that an allegation of knowledge or intention includes an allegation of recklessness; see section 19(1).

Fischer, T. 2009, pp. 109-110; Schönke \& Schröder, H. 2006, pp. 257-258 and Joecks \& Miebach 2006 , notes $100-103$ on $\$ 15$.

824 15 July 1975 BGH NJW 1975, 1893 and 22 September 1953 BGHSt 4, 340. 
however. Almost all negligent offences in Germany have an intentional counterpart. ${ }^{825}$ If both offences are charged, the defendant does not benefit from making intent probable. Moreover, the mere suspicion that the actor intended the result generally does not preclude a finding of negligence. ${ }^{826}$

\subsection{Luxuria}

A distinct, aggravated form of negligence exists in Germany and the Netherlands, called 'Leichtfertigkeit' and 'roekeloosheid' respectively. ${ }^{827}$ The Dutch concept only entered into force in 2006, operating as a fault element that increases the maximum penalty of negligent offences. ${ }^{828}$ Before that date, it was also already charged in order to increase the stigma and to influence the sentencing decision. The Dutch government therefore argued they did not introduce a new concept. ${ }^{829}$ 'Leichtfertigkeit' was already included in the 1962 draft of the German Criminal Code. The use of these fault elements is increasing in both countries ${ }^{830}$ When the offence definition requires nothing less than this serious negligence as to the result, it functions as a limitation of liability in comparison to simple negligence. These national concepts are quite similar and will be discussed as a candidate for the general part of European criminal law under the Latin term luxuria. ${ }^{831}$ On the contrary, this concept is absent in England, to which I will return later.

Some defendants are considered to be more culpable than the normal negligent actor. In some contexts, the defendant can have created such an obvious danger or great harm that he must be punished more severely. ${ }^{832}$ Recall the defendant who drove dangerously with a Porsche and caused a fatal accident. He was acquitted of intending to kill the victims. It was held that he did not accept this risk, as this would have implied he took into the bargain his own death too. ${ }^{833}$ In cases like this, where the actor is frivolous and can therefore not be held to have intended the fatalities he caused, the more severe penalty of luxuria has proven to be a good alternative for the intentional offence. Luxuria should be seen as compensation for

\footnotetext{
825 Bohlander 2009, p. 59.

82618 August 1983 BGHSt 32, 48; 17 April 1962 BGHSt 17, 210 and Roxin 2006, pp. 1091-1092.

827 Kamerstukken II 2001/02, 28 484, no. 3, pp. 12 and 24; Politoff \& Koopmans 1991, p. 151 and Roxin 2006, p. 1092.

828 Law of 22 December 2005, Stb. 2006, 11. See articles 307 and 308 of the Dutch Criminal Code and art. 175 Dutch Road Traffic Act 1994. In this research, case-law until March 2012 has been taken into account. Until then, the Dutch Supreme Court had not ruled on the concept.

829 Kamerstukken II 2001/02, 28 484, no. 7, p. 19.

830 Fischer, T. 2009, p. 127; Schönke \& Schröder, H. 2006, p. 324 and Bohlander 2009, pp. 54-55. See $\S \S 109 \mathrm{~g}(4), 138(3), 176 \mathrm{~b}, 178,218(2), 239 \mathrm{a}(3), 251,261(5), 264(4), 306 \mathrm{c}, 307(3), 308(3), 309(4)$, $316 \mathrm{a}, 316 \mathrm{c}(3)$ and 345 of the German Criminal Code.

831 See Vrijheid 1918, pp. 64-65 and 75, who notes that this term in Roman law was used in similar contexts as culpa lata.

832 Kamerstukken II 2001/02, 28 484, no. 3, pp. 10-12.

833 HR 15 October 1996, NJ 1997, 199. See IV.3.6.4.
} 
the gap that is created by having merely two and not three kinds of fault in the Continental Member States under investigation. It can be seen as a middle ground in between eventualis and negligence, even though it is generally treated as a qualified form of negligence. As such, luxuria also helps to prevent the further enlargement of dolus eventualis. ${ }^{834}$

\subsubsection{Criteria}

Luxuria applies under the same conditions as negligence, but these must be fulfilled to a higher degree. Luxuria requires a gross violation of the objective standard of care that exceeds the criterion of 'gross carelessness' required for simple negligence. ${ }^{835}$ The conduct is so careless, that the danger of the result to occur must have been obvious. ${ }^{836}$ Examples of luxuria as to death are excessive speeding, dangerous overtaking and/or racing on the public road. ${ }^{837}$ This high degree of carelessness can be established by reference to the nature of the duty or the legal interest involved, such as the violation of a particularly important duty. It can also be determined in relation to the enlarged danger that is created when compared to the basic offence. Consider a brutal act of violence during a robbery. ${ }^{838}$

In other words, luxuria requires an increased degree of objective foreseeability of the result. The higher degree of carelessness enables a quantitative distinction with simple negligence. Nevertheless, there remains widespread concern about the proper demarcation of luxuria. ${ }^{839}$ After all, the question of what duties must be violated to amount to simple negligence is already controversial, let alone what degree of carelessness amounts to luxuria. Preceding the adoption of luxuria in the Netherlands, there had been criticism in Parliament that charging luxuria would lead to more problems and that therefore the maximum penalties of certain negligent offences should have been simply raised. ${ }^{840}$ On the other hand, the inherent vagueness in this criterion can be welcomed too, if it is recalled that the concept was created to aggravate the punishment of certain negligent actors. The vagueness enables a functional attribution of fault: luxuria is present when the defendant should be punished more severely than the negligent actor.

In both Germany and the Netherlands, the concept is described as that the possibility of fulfilling the offence forces itself upon the actor, but he frivolously

\footnotetext{
834 Reijntjes in Groenhuijsen \& Simmelink 2003, p. 482 and Klip 2007B, p. 838.

835 Beulke 2008, p. 247; Koch 1998, pp. 227-231; de Jong, D.H. \& Knigge 2003, p. 137 and Kamerstukken II 2001/02, 28 484, no. 3, p. 10 and no. 7, p. 19.

836 Krey 2002, pp. 144-145 and Fischer, T. 2009, p. 112.

837 Klip 2007B and Kamerstukken II 2001/02, 28 484, no. 43, p. 5

838 Schönke \& Schröder, H. 2006, p. 325.

839 Roxin 2006, pp. 1093-1095; Koch 1998, pp. 227-231; Arzt in Stree a.o. 1978; Fokkens \& Machielse, note 8 on Culpa; de Jong, D.H., Kessler, Otte \& Wolswijk 2003, p. 272; de Hullu 2009, p. 259; Kelk 2005, pp. 211-212 and Klip 2007B, p. 842.

840 Kamerstukken II 2001/02, 28 484, no. 7, pp. 15-16; no. 34, pp. 4 and 8.
} 
disregards it. ${ }^{841}$ Recall that the defendant who acted with dolus eventualis did not care at all about that risk. The attitude of the defendant thus enables a qualitative distinction with eventualis. If the risk was obvious, and the defendant acted anyway, it can be assumed that if he trusted the result would not materialize, this must at least have been very frivolous.

Luxuria is thus regarded as the most serious form of conscious negligence. ${ }^{842}$ Some German scholars leave open the possibility that serious negligence can be fulfilled when the actor was unaware of the obvious risk. ${ }^{843}$ However, I doubt that any court would believe the defendant was ignorant of an obvious risk. After all, in dolus eventualis, awareness (and acceptance) of the risk is also simply inferred from its probability. Awareness can also be inferred under the doctrine of wilful blindness, when the defendant shuts his eyes to the obvious. ${ }^{844}$ By leaving open the possibility that the actor may have been unaware of something that was very obvious to anyone, German scholars avoid such approaches. In any event, it needs to be stressed that awareness is not a criterion of luxuria anywhere. It need not be proven that the defendant was aware of the risk and frivolously rejected it.

\subsubsection{Functional equivalents}

As noted, luxuria does not exist in English law. However, the comparison does not stop here. In England, causing death by 'careless driving' resembles negligence. ${ }^{845}$ A more serious punishment can be imposed if death was caused by 'dangerous driving. ${ }^{846}$ Like luxuria, dangerous driving exist when "the way he drives falls far below what would be expected of a competent and careful driver, and (...) it would be obvious to a competent and careful driver that driving in that way would be dangerous." ${ }^{447}$ The use of the aggravating element 'dangerous' in this context comes as no surprise. In the Netherlands, luxuria was also introduced in the context of causing fatalities in traffic in order to aggravate punishment for 'reckless (roekeloos) driving', conduct which usually falls short of intention. ${ }^{848}$ The Dutch

8419 November 1984 BGHSt 33, 66; Roxin 2006, p. 1093; Vogel in Tiedemann 2002, p. 128; Schönke \& Schröder, H. 2006, pp. 324-325; van Dijk, A.A. 2008, p. 185; de Hullu 2006, p. 244 and Fokkens \& Machielse, note 8 on Culpa.

842 Kelk 2005, pp. 211-212; de Jong, D.H., Kessler, Otte \& Wolswijk 2003, p. 273; Otte 2007, p. 299 and Kristen, Borgers \& Koopmans in Borgers, Koopmans \& Kristen 1998, p. 17.

843 Schönke \& Schröder 2010, note 205 on $§ 15$; Joecks \& Miebach 2003, note 187 on §15; König \& Seitz 2006, note 20 on $\S 10$ OwiG and Arzt in Stree a.o. 1978, p. 128. Luxuria thus exists when the defendant was either unaware of something that was very obvious to anyone or frivolously rejected the possibility that the risk would materialize.

844 See IV.3.4.3. and IV.2.5.3.

845 Sections 2(b) and 3(za) of the Road Traffic Act 1988.

846 Section 1 of the Road Traffic Act 1988.

847 Section 2(a) of the Road Traffic Act 1988.

848 Article 175(1) and (2) of the Dutch Road Traffic Act 1994. 
government explicitly mentioned 'notoriously dangerous conduct in traffic' as the category of careless conduct that qualified as luxuria. ${ }^{849}$

More importantly, the English legal system already has recklessness to fill the gap between dolus and culpa. Recklessness is a functional equivalent of luxuria. It is a broader concept, covering dolus eventualis, luxuria and lesser forms of conscious negligence. Therefore, it cannot be equated or translated by luxuria. However, this is implied when 'Leichtfertigkeit' is translated as recklessness, ${ }^{850}$ or vice versa. ${ }^{851}$ In EU law, recklessness is often translated into a form of luxuria like 'Leichtfertigkeit'. For example, the Directive on ship-source pollution refers to recklessness, next to intention and serious negligence. ${ }^{852}$ It has been explained that 'simple' negligence always must be 'gross' or 'serious' in the legal systems under investigation. The Directive thus simply enumerates all fault elements used in English law. Based on the English version, Member States were obliged to criminalize the discharge of polluting substances into any of the designated areas if done with intent, recklessness or (gross) negligence.

The Directive apparently aims to criminalize this whole spectrum of fault. The Dutch and German version of the Directive could therefore have sufficed by listing the two kinds of fault applied in those legal systems: 'opzettelijk of nalatig' and 'Vorsatzlich oder Fahrlässig'. Recklessness under English law would be covered by these Dutch and German fault elements; the scope of liability would be more or less the same in all versions. However, the difference between the English legal system that operates with three kinds of fault and its continental counterparts that know only two kinds has apparently been overlooked when all three fault elements were translated. In the Dutch version of the Directive, recklessness was translated as a national manifestation of luxuria called 'roekeloosheid'. ${ }^{853}$ Similarly, in the German version, the term 'Leichtfertigkeit' was used.

849 Kamerstukken II 2001/02, 28 484, no. 43, p. 5.

850 Krey 2002, pp. 12-13 and Jescheck in Thaman 2002, p. lvii (\$178). See also the Opinion of AG Kokott of 20 November 2007, Case C-308/06, Intertanko a.o. v. Secretary of State for Transport [2008] ECR I-4057, §141. The opinion was originally delivered in German. It thus reads in the English translation that "the standard of recklessness does exist in German criminal law," which is obviously incorrect. This can however also be explained by the possibility that these articles were translated by others from German. Weigend 1981, p. 688 also uses this translation, but only by want of a better one.

851 Opinion of AG Kokott in 3 June 2008, Case C-308/06, Intertanko a.o. v. Secretary of State for Transport [2008] ECR I-4057, explicitly in footnote 8 and R. v. Reid [1992] 95 Cr App R 391.

852 Article 4(1) of Directive 2009/123 of 21 October 2009 amending Directive 2005/35 on shipsource pollution and on the introduction of penalties for infringements OJ 2009 L 280/52. See also article 5(2b) of Framework Decision 2004/68 of 22 December 2003 on combating the sexual exploitation of children and child pornography, OJ 2004 L 13/44.

853 Roekeloosheid is a literal translation of recklessness, see IV.4.5. Serious negligence was translated as 'ernstige nalatigheid', which resembles simple negligence under Dutch law. 


\subsubsection{Reconsidering recklessness}

In deciding on the fault element in between dolus and culpa, I have argued in favour of recklessness. I rejected dolus eventualis, but did not yet consider luxuria in detail. Luxuria can be seen as compensation to the all or nothing approach of the continental dichotomy. Because it allows for the aggravation of punishment of the negligent actor who was particularly careless or frivolous, luxuria could also be seen as a third category of fault in between dolus and culpa, ${ }^{854}$ even though the Dutch legislator explicitly rejected this and positioned it as a qualified form of negligence. ${ }^{855}$ After all, recklessness also used to be seen as an aggravated form of negligence. ${ }^{856}$

Moreover, it has been created to provide for a middle ground of culpability in between intent and negligence, which is reflected in a range of punishment that also stands midway between intent and negligence. This observation confirms the belief that a dichotomy of fault is unsatisfactory, that it is too coarse to provide for a legitimate attribution of liability in all cases and that a tertium quid like recklessness is desirable. The adoption of luxuria can even be seen as the acknowledgment of this by the Dutch and German legislator. ${ }^{857}$ These legislators have increased the maximum punishment for negligent offences, either by qualifying it as luxuria or by a general increase of the negligent offence, in order to reflect the degree of culpability in consciously taking risks. By bringing the punishment of conscious negligence and dolus eventualis closer together, the legislator also undermines the supposed difference in culpability and strengthens my argument of combining the two fault elements under one fault element of recklessness. ${ }^{858}$

However, luxuria could also play this role of tertium quid. Luxuria relieves the tension of dolus eventualis and so mitigates an important set of arguments raised against it. It also takes away most of the tension in comparing the pessimist with the frivolous actor. Nonetheless, luxuria only mitigates the problems that recklessness solves. Despite the possibility of holding someone liable under luxuria, the distinction based on volition still applies and so does its controversy. The quantitative distinction to separate luxuria from advertent negligence based on how gross the carelessness was leads to uncertainty and inequality. Research of case-law concludes that the judgments vary considerably. ${ }^{859}$ Recklessness in contrast, draws a clear qualitative line with culpa by requiring awareness.

\footnotetext{
854 See Vogel in Tiedemann 2002, p. 141.

855 Kamerstukken II 2001/02, 28 484, no. 7, pp. 14-15.

856 Edwards 1954, p. 304 footnote 60 and Williams 1953, p. 52.

857 At the end of the nineteenth century, the Dutch legislator struggled with the question of whether or not there should be a middle ground in between intent and negligence, but decided against it. See Smidt 1881 I, pp. 79-80 and Otte 2001, p. 3.

859 Peters, M. 2010.
} 
Recklessness thus covers the following scenarios. In all of them, the actor is aware of a risk, that for example something will catch fire or someone may be hurt or killed. The Dutch-German fault categorization of these cases has been put in brackets. In the first scenario, the actor does not care at all whether the risk materializes (eventualis). In the second, he takes into the bargain the possibility that the result occurs, because he wants to bring about another result at all cost (eventualis). In the third, he hopes the result will not occur (conscious negligence). In the fourth case, this hope seems unreasonable given the obvious degree and nature of the risk (luxuria). In a fifth case, he incorrectly concludes the risk is justified (eventualis). 860

The different degrees of culpability that are inherent in these cases, manifested by the attitude and/or belief, are insufficient to warrant another distinction of fault. All these cases are rightly seen as cases of recklessness, whereby the culpable attitude of the defendant can be taken into account in sentencing. One might argue that the issue of volition is thereby relocated to sentencing, ${ }^{861}$ but this volition is taken into account in sentencing after establishing dolus eventualis too. In eventualis, volition is an issue of liability, but the particular degree of volition needs to be assessed in sentencing again as the defendant who approved of the result is more culpable than the one who merely acquiesced.

In a general part for criminal law, there exists no advertent negligence. Awareness demarcates recklessness from culpa. From this it follows, that the fault elements I propose for a general part of criminal law for the EU, largely follow English law. There are however some differences. For example, I argued against moral connotations in dolus, which are increasingly exceptional in England too. Furthermore, I argued in favour of including a subjective part in culpa, whereas this is de lege ferenda in England. Foreseeability of a prohibited circumstance or consequence is the lowest common denominator of fault, sufficient for criminal liability. Below this standard, there can be only room for liability by making exceptions to the fault requirement. It is to this issue I will now turn.

\footnotetext{
860 Even if the risk would be justified, it would not affect dolus eventualis. The offence would be justified.

861 Weigend 1981, p. 697.
} 


\section{Chapter V \\ Principles of menS REA}

\section{INTRODUCTION}

Mens rea is more than dolus, recklessness and culpa. It also includes those principles that determine the application of these fault elements. So far, it has been explained what the rationale and criteria of the specific fault elements are. Yet questions remain to be answered. For example, to which offence elements does fault apply? What is the effect of mistakes on fault? The answers to these questions follow from the general principles of mens rea. Under the headings of correspondence and contemporaneity, the most important principles of mens rea will be discussed. The former encompasses the fault requirement and the rule that fault should apply to all offence elements. The latter principle requires that the fault element and its related objective offence elements also coincide in time.

This chapter also focuses on the extension of criminal liability beyond paradigm cases. By their nature, principles state the basic rule, to which exceptions can be made, but these specific exceptions are nonetheless at odds with these principles. In order to release some of this pressure, doctrines and approaches have been advanced to justify and ground the extension of mens rea. For example, the fault requirement appears to be violated when an offence definition requires no fault at all. Nonetheless, so-called offences of strict liability have been considered necessary in modern criminal law, which has fuelled a reinterpretation of the fault requirement and the related principle of no punishment without guilt. Secondly, the principle of correspondence brings about that any mistake negates fault, which has given rise to fears of perpetrators escaping 'just' convictions. To overcome this, different strategies have been adopted, such as to demand that the mistake be reasonable for it to negate fault. Finally, the doctrine of actio libera in causa can be seen as an interpretation, modification or even exception to the principle of contemporaneity. It enables a finding of liability based on an act preceding the criminal conduct, despite the fact that the defendant did not intend to fulfil the objective offence elements at the time he committed the actus reus.

This chapter therefore deals with the ambit of mens rea. Well-known doctrines of criminal law are (re)considered. In this way, a more precise picture of mens rea will be provided. These doctrines can be seen exceptions to the rule or as interpretations or modification of the two principles. The decisive question is what amount of deviation from principle is allowed. In the language of human rights, when is the exception no longer a mere infringement, but also a violation of the principle? The structure of this chapter is as follows: I will first discuss a principle and its aspects, stating the normal rules. Subsequently, doctrines of criminal law that can be seen as manifestations or exceptions to the principle will be described. 
After having discussed the principle of correspondence in this way, the same approach will be taken to discuss the scope of the principle of contemporaneity. In a final paragraph, I will draw some general conclusions.

\section{CoRRESPONDENCE PRINCIPLE}

The correspondence principle can be divided into at least two aspects. It encompasses the maxim of 'actus non facit reum nisi mens sit rea', which has been dubbed the fault requirement. Also included is the 'referential principle', which holds that the fault elements of an offence definition should correspond or relate to the objective elements of the offence definition. In other words, mens rea must correspond with actus reus. ${ }^{1}$

\subsection{Fault requirement}

The fault requirement has been discussed already in detail in the previous chapter. It instructs the legislator to include fault elements into criminal offences and, under circumstances, allows the judge to read in these elements. The principle gives less guidance on the question of what specific fault element is required as to which part of the offence, but some general principles were identified. For example, if an offence element is typical for the offence, or if it is an essential element because it is the distinguishing feature with another offence, dolus should principally relate to it.

The most significant aspect of the fault requirement is the instruction to the legislator to include fault elements into an offence. This requirement is not met when an offence definition lacks any fault element. This 'strict liability' will be discussed in a third section. The additional question is whether courts are allowed to read in fault elements into these strict offences. In England, a 'presumption of mens rea' applies that fault is an element of every statutory offence. ${ }^{2}$ If an English statutory offence does not include any fault element, fault will be read in, unless Parliament has clearly indicated otherwise. ${ }^{3}$ Even when an offence was made strict explicitly, English courts can read in a fault element in offences of a 'truly criminal' character with severe penalties. ${ }^{4}$ The converse is also true, as the presumption can easily be displaced when the offence is regulatory, deals with

Simester \& Sullivan 2007, p. 187.

There are also common law offences, identified by the Courts over the centuries. Fault elements have already been defined in these offences, implying that the presumption of mens rea is not necessary here.

3 Sweet v. Parsley [1969] UKHL 1; B. v. DPP [2000] UKHL 13; Simester \& Sullivan 2007, p. 168; Law Commission 1989, p. 195 and Ormerod 2005, pp. 111 and 142.

4 Gammon v. Attorney-General of Hong Kong [1984] 2 All ER 503 and Ashworth 2006, p. 173. 
specialist or economic activity, aims to prevent public danger and there is low stigma in conviction. ${ }^{5}$ There is however no consistent approach. ${ }^{6}$

In the Netherlands, this presumption could be inferred from the basic rule that felonies require either intent or negligence. ${ }^{7}$ When the felony does not contain a fault element, the Dutch Supreme Court has been known to read in such element, based on this general rule. Examples are the possession of a firearm or child pornography. Possession was interpreted as to require knowledge. ${ }^{8}$ In Union law too, it is made explicit that in order to be liable for obtaining access to child pornography, the person must both intend to enter a site where this pornography is available and know that such images can be found there. Inadvertence is dismissed as an insufficient basis for criminal liability. ${ }^{9}$ It is obvious that otherwise the scope of criminal liability would be inappropriately wide.

The Dutch approach to distinguish felonies from and misdemeanours is comparable to the English one, since the presumption of mens rea depends on the seriousness of the offence. Regarding misdemeanours, no presumption of mens rea applies. The judge can read in fault when the wording of an offence suggests this, but he is not allowed to run counter to the clear purpose of Parliament to create strict liability. ${ }^{10}$ Like in England, the purpose of the legislator can be inferred from the context of the offence, such as the fact that its counterpart requires fault or because a due diligence defence has been included. ${ }^{11}$

The German legal system applies the strongest presumption of mens rea, namely that intent should always be required unless the offence lets negligence suffices. ${ }^{12}$ With a few exceptions, strict liability is out of the question. This allows for a completely different way of drafting legislation in comparison to England and the Netherlands. German offences do not mention intent, because it is presumed. The absence of fault elements in the offence definition does not imply they are strict.

No clear picture emerges from the case-law of the ECJ. A presumption of mens rea has not been identified and strict liability is not in itself incompatible with

$5 \quad$ Manchester 2006, p. 227; Simester \& Sullivan 2007, pp. 171-173 and Ormerod 2005, pp. 148156.

6 Williams 1953, p. 271, Ashworth 2006, p. 174, Virgo 2002, p. 13 and Ormerod 2005, p. 144.

7 The offence that requires fault is a felony and its counterpart that requires no fault is a misdemeanor, see Blom 2008, p. 122. Felonies used to require intent, see IV.6.2.1. Pompe 1935, p. 78 submitted that if intent is not included in a felony, it should be read in, unless a contrary indication is given.

$8 \quad$ HR 10 June 1986, NJ 1987, 85; HR 26 January 1999, NJ 1999, 537; HR 28 February 2006, NJ 2006, 179; de Hullu 2006, pp. 198-199 and Kessler 2001, pp. 184-186.

9 Recital 18 of the preamble of Directive 2011/93 of 13 December 2011 on combating the sexual absue and sexual exploitation of children and child pornography, and replacing Framework Decision 2004/68, OJ 2011 L 335/1. It leaves open the question whether Member States are nevertheless free to adopt stricter measures, including the criminalization of negligent access.

10 Van Bemmelen 1959, pp. 43-44.

11 Kessler 2001, pp. 193 and 251-252; Simester \& Sullivan 2007, pp. 176-177; Glazebrook 2001, p. 26 and Manchester 2006, pp. 218-219 and 223.

$12 \S 15$ of the Criminal Code and $\S 10$ of the Administrative Offences Act (OWiG). 
Union law. ${ }^{13}$ However, in most Union instruments that deal with subject-matters that are considered as part of criminal law by most of its Member States, fault elements are included and relate to all objective elements. In some cases however, the Union legislator explicitly made clear that fault should not relate to all offence elements. For example, in the context of insider dealing, it used to be required that the 'accused' intended to use his inside knowledge to make profit or minimize loss. This led to many evidential difficulties, prompting an explicit request of the EU Parliament to strike this fault element in the Directive on insider dealing and market manipulation. The wording of insider dealing was changed from 'taking advantage (with full knowledge of the facts)' to 'using'. The subject must still know or should have known he was in possession of inside information, but his actions need not be driven by a fraudulent intention. ${ }^{14}$

The ECJ confirmed this objective phrasing of the prohibited result based on a teleological interpretation of the Directive that focuses on efficient enforcement. It held that the "Community legislature opted for a preventative mechanism and for administrative sanctions for insider dealing, the effectiveness of which would be weakened if made subject to a systematic analysis of the existence of a mental element." It justified the doing away with the intent to abuse insider knowledge, based on the presumption that the professional capacity of the addressee of the norm and the context of insider dealing generally preclude the possibility that the subject did not know of the unfair advantage. ${ }^{15}$ It can be concluded that the fault requirement is also the rule in the EU, bringing about a presumption of mens rea. Nevertheless, like in most Member States, this does not rule out strict liability.

\subsection{Referential principle}

The referential principle holds that fault elements must relate to the objective elements of the offence definition. ${ }^{16}$ Fault is not assessed in a vacuum but in relation to objective offence elements of conduct, circumstances or results. ${ }^{17}$ The referential principle raises the question as to what objective elements fault must relate. For example, must intent in an offence definition relate to all the objective elements of that offence, ${ }^{18}$ or only to those offence elements that follow after the fault element? ${ }^{19}$

13 See 10 July 1990, Case C-326/88, Anklagemyndigheden v. Hansen and Søn I/S [1990] ECR I-2930; 2 October 1991, Case C-7/90, Criminal proceedings against Paul Vandevenne and others [1991] ECR I-4371, §12 and 27 February 1997, Case C-177/95, Ebony Maritime [1997] ECR I-1111, §36.

14 AG Kokott on 10 September 2009, Case C-45/08, Spector Photogroup NV [2009] ECR I-12073 and Directive 2003/6 of 28 January 2003 on insider dealing and market manipulation (market abuse), OJ 2003 L 96/16. 23 December 2009, Case C-45/08, Spector Photogroup NV [2009] ECR I-12073.

Compare Ashworth 2006, p. 197.

De Jong, D.H. \& Knigge 2003, p. 66 and de Hullu 2006, p. 196.

See Manchester 2006, p. 222 and Simester \& Sullivan 2007, p. 188.

This is the approach in the Netherlands, see Smidt 1881 I, p. 72 and Kelk 2005, p. 199. 
In Union law, the rule appears to be that intention should relate to all subsequent elements of the provision. ${ }^{20}$

On a rigid interpretation, the principle is also violated if fault does not correspond to each an every single offence element. It emphasizes the importance of the fault requirement and gives it extra significance, by not merely requiring that fault should be included in the offence, but to require that it should in principle relate to all offence elements. However, partial as opposed to full correspondence seems to be accepted in all Member States under investigation, ${ }^{21}$ and as illustrated above, in the EU. The exact ambit of the principle will become obvious in the discussion on strict liability below.

Strict liability is the most significant infringement of the correspondence principle and will be discussed first. Subsequently, I will demonstrate that the correspondence principle brings about that mistakes negate dolus and recklessness. In particular, I will show how this strict application of correspondence is mitigated by other legal concepts and doctrines. Related is the aspect of how specific the correspondence between the fault of the defendant and the objective elements should be. For example, must the defendant have intended to kill this particular individual or does a general intent to kill suffice? Must intention also relate to legal aspects? It will be determined what degree of dissonance between subjective perception and objective reality can still lead to criminal liability.

\subsection{Strict liability}

If liability is strict, no fault needs to be proven. The defendant's state of mind is irrelevant, although it can be taken into account in the decision to prosecute, the application of excuses and in sentencing. ${ }^{22}$ This strict liability is an exception to the fault requirement. However, the term also covers cases where fault needs to be proven, but not in relation to each and every single offence element. This form of strict liability is an exception to a rigid referential principle that fault needs to relate to all offence elements.

Strict liability is just one legislative technique to make criminal law applicable and enforceable, in other words, to avoid heavy demands of proof. ${ }^{23}$ In this section, similar techniques will be discussed, such as a presumption of fault. If fault is presumed, the prosecutor need not prove it. Provided the presumption can be rebutted, the defendant bears the burden of disproving it.

20 Explanatory Report on the Convention on the protection of the European Communities' financial interests, 23 June 1997 OJ 1997 C 191/1 and Report of 30 April 2004 from the Commission of the Framework Decision of 28 May 2001 combating fraud and counterfeiting of non-cash means of payment, COM (2004) 346 under 2.1.

21 Stuckenberg 2007, p. 209. See also Simester \& Sullivan 2007, pp. 187-188.

22 De Hullu 2006, p. 221.

23 See de Hullu in Borgers, Koopmans \& Kristen 1998, p. 181 and Nijboer 1989, pp. 366-368. 
Because strict liability is at odds with the aforementioned principles, it should be avoided. Alternatives may provide for almost the same practical benefits, with a lower cost to principles of mens rea. Nonetheless, I will explain that some alternatives even cast the net of criminal liability wider than necessary. Moreover, there remain legitimate reasons to use to strict liability in certain cases. I will demarcate this exceptional area.

\subsubsection{Terminology}

Since the term 'strict liability' is quite controversial, ${ }^{24}$ it is important to be clear about its meaning. Strict liability requires no proof of whatever kind of fault. Crimes of negligence are not strict liability. When fault is included in the offence definition, but it does not relate to all elements, the element as to which fault does not relate is a 'strict' or 'objectified element'. A common example is the consequence in a result-based offence. The actor must have intended an action, but he need not have foreseen or be able to foresee the consequence that followed. As will be explained in detail shortly, the German legal system rejects strict liability. Consequently, at least negligence is required as to the consequence.

Strict liability should also be distinguished from 'absolute liability', which means that a person can be convicted for an offence without proof of fault or proof of conduct. Absolute liability is therefore correctly used to refer to offences that criminalize state of affairs, ${ }^{25}$ or offences committed involuntarily. ${ }^{26}$ However, the term absolute liability is also used to express that all offence elements are strict, ${ }^{27}$ or express that in addition, it is to no avail for the defendant to prove that he lacked any degree of blame, ${ }^{28}$ or raise another defence. ${ }^{29}$ The ECtHR has used the term strict liability for this extreme form of liability, when no defence can be raised against the charge.${ }^{30}$ In contrast, the meaning of 'strict liability' used here does not preclude the availability of defences. It merely refers to the lack of fault elements in the offence. As will be discussed later, the principle of guilt and the presumption of innocence do not allow holding the blameless defendant criminally liable. The principle of guilt consists of an absolute core, a minimum threshold of blameworthiness. ${ }^{31}$

Like in R. v. Larsonneur [1933] 24 Cr App Rep 74.

Roberts in Simester 2005, pp. 152 and 171.

See Green in Simester 2005, p. 3; Duff in Simester 2005, p.125 and Ormerod 208, p. 152.

Simester \& Sullivan 2007, p. 185. See also Dolman 2006, p. 63 on the doctrine of 'le fait matériel.'

Green in Simester 2005, p. 4 and Ormerod 208, p. 152.

O'Halloran and Francis v. the UK, appl. nos. 15809/02 and 25624/02, 29 June 2007, §59.

The ECtHR also holds that dispensing with proof of fault may be legitimate, but not when it is coupled with a complete absence of the possibility for the defendant to escape liability by raising a defence. In that case, liability is 'strict' and violates article 6 of the ECHR. 
It is commonly assumed, that in Germanic law, the mere causing of a prohibited fact sufficed for criminal liability. ${ }^{32}$ This can be called 'Erfolgshaftung' 33 and in Napoleonic systems, reference was made to the doctrine of 'le fait matériel'. ${ }^{34}$ It was replaced by 'Schuldhaftung', which in addition to causing harm, requires fault for criminal liability. Without the presence of fault, the consequence is a coincidence, or as it was called in Roman law, casus. ${ }^{35}$ In the eighteenth and nineteenth century, the fault requirement was accepted as a cornerstone of criminal law, only to be put under pressure again with the emergence of the Industrial Revolution and subsequently, the Risk Society.

\subsubsection{Rationale}

Strict liability has been justified as far as it is used in regulatory offences. These crimes have been created since the end of the $19^{\text {th }}$ century as a means of dealing with rapidly changing social and industrial practices. ${ }^{36}$ The burden of criminal penalties is seen as a form of production expense for those who voluntarily initiate risk-creating activities. Some companies operate in spheres of such potential danger and wield such power, that it is not socially unfair to hold them to higher standards, as long a fair warning is given. Individuals can also be held to higher standards when maximum safety is an issue, such as in road traffic offences. ${ }^{37}$

However, this does not explain why this higher standard should go beyond the fault element of negligence. There is no evidence that strict liability offences are more deterrent than offences that require fault. ${ }^{38} \mathrm{~A}$ negligence standard has the advantage of communicating what level of precaution is required to secure immunity from conviction. Strict liability might lead actors to take more than reasonable precautions, but there is no evidence of this. In contrast, it is argued this is very unlikely as it is to be expected (corporate) actors will weigh the costs of precautions against the expected liability costs. Thus, persons are deterred from risk-taking altogether or are prepared to gamble. The real culprits are not deterred. ${ }^{39}$

In addition, strict liability arguably goes too far because it criminalises accidents and reasonable conduct. While it is perfectly understandable to focus on persons causally responsible for injurious outcomes in the law of torts, the stigma of criminal conviction demands something more to be imposed; actus non facit reum

\footnotetext{
32 However, see Politoff \& Koopmans 1991, p. 79 and Koch 1998, pp. 54-55.

33 Kelk 2005, p. 175.

34 De Hullu 2006, p. 199 and Fokkens \& Machielse, note 2 on Schuld.

35 De Jong, D.H. \& Knigge 2003, p. 43 and 123.

36 Simester \& Sullivan 2007, p. 167.

37 Simester \& Sullivan 2007, p. 182, Ormerod 2005, pp. 150-151 and Ashworth 2006, p. 167.

38 In Gammon v. Attorney-General of Hong Kong [1984] 2 All ER 503, Lord Scarman held that strict liability is only legitimate when it "can also be shown that the creation of strict liability will be effective to promote the objects of the statute by encouraging greater vigilance to prevent the commission of the prohibited act."

39 Simester \& Sullivan 2007, pp. 30, 33, 183 and 188 and Williams 1953, pp. 258 and 269.
} 
nisi mens sit rea. ${ }^{40}$ A person is convicted without being found culpable, whereas fault is one of the cornerstones of criminal liability. ${ }^{41}$

In an attempt to counter the controversy, it is argued that a conviction for regulatory offences is deemed to involve only a small sanction and hardly any stigma. ${ }^{42}$ Yet practice has shown the penalties for committing regulatory offences can be big, including prison sentences, and the stigma of the criminal procedure and conviction should not be underestimated. ${ }^{43}$ When a classic criminal principle like the fault requirement is abandoned and the offences in question are not criminal in character, the question of the ultimum remedium character of the criminal law comes up. Why should criminal law be applied and not civil liability? ${ }^{44}$ Do we not in fact want to stigmatize?

On the other hand, it has been argued that branding people without fault as criminals may lessen the respect for the law and the social condemnation of those who break it, ${ }^{45}$ but this does not seem to have happened yet. ${ }^{46}$ The general public does not experience strict liability as unfair because it is used mostly in a regulatory context. Therefore, in most cases it is legitimized by a presumption of fault. It needs not be proven that the driver knew he was driving too fast, because he is presumed to have known. He was trained to drive and know the rules relating to this activity, which imply that he was at least could and should have known he drove too fast. ${ }^{47}$

An important set of additional justifications is of a pragmatic character. Strict liability is more efficient as it strengthens the regulators hand of ensuring compliance and therefore prevention. By eliminating the need to prove fault, defendants can be held liable easier, reducing the costs of the enforcement procedure. ${ }^{48} \mathrm{~A}$ vast amount of offences can be committed strict, which brings about that it creates a substantial relieve for enforcement agencies. ${ }^{49}$ Strict liability prevents defendants from making easy claims of mistake like 'I did not know', that are hard for the prosecution to disprove. Given the specialist activities that are dealt with by regulatory offences, this ease of enforcement is a very welcome convenience for the prosecution. ${ }^{50}$ It can be rebutted however that for the more serious offences, evidence of fault is needed at the sentencing stage in any case, requiring proof at

40 Sullivan in Simester 2005, pp. 183 and 198-201 and Ashworth 2006, p. 166.

41 R. v. G [2003] UKHL 50 and Sweet v Parsley [1969] UKHL 1.

42 Ashworth 2006, p. 169 and Simester \& Sullivan 2007, p. 181.

43 Williams 1953, p. 267.

44 Robinson in Dressler 2002, p. 1004.

45 Tadros 2005, p. 73; Robinson in Dressler 2002, p. 1005; Williams 1953, p. 269 and Simester in Simester 2005, p. 41, who also state that "Thor's hammer was not meant for driving nails."

46 Simester \& Sullivan 2007, p. 181.

47 Compare also 23 December 2009, Case C-45/08, Spector Photogroup NV [2009] ECR I-12073, $\S 36$.

48 Simester in Simester 2005, p. 26. This applies to the investigation, the administrative decision and/or the procedure before a Court.

49 A popular legislative technique is to create fall-back offences that are strict, see Kessler 2001, p. 186 and de Hullu 2006, pp. 199-200.

50 Ashworth 2006, p. 168 and Simester \& Sullivan 2007, p. 182. 
that point. ${ }^{51}$ In EU competition law, no fault needs to be proven in order to hold the undertaking concerned liable under articles 101 and 102 TFEU, but it is needed to impose fines. ${ }^{52}$

Moreover, it is unjust to use issues of procedural convenience as a reason to change substantive law, an ineffective if deterrence does not increase. The facilitation of prosecution could also be reached through the less far-reaching method of reversing the burden of proof of negligent offences. ${ }^{53}$ This middle ground does away with the need for strict liability and would in fact meet the arguments of those who favour strict liability. After all, negligence does help to deter the indifferent and careless, ${ }^{54}$ and the defendant can explain himself by making probable reasonable conduct. I will consider this alternative to strict liability below in detail.

\subsubsection{Popularity}

The dogmatic criticism raised to strict liability is by large irrefutable. Nonetheless, strict liability is an accepted form of liability, because it is applied in regulatory contexts. In this context, the interest of an effective administration of offences is considered more important than dogmatic objections. This form of liability is very common in EU law and popular in English and Dutch criminal law.

Strict liability is not in itself incompatible with Union law. Concerns of efficiency are decisive. The ECJ seems more concerned that the implementation and enforcement of Union law is just as strict as similar national law. Penalties must be proportionate, but above all, effective and dissuasive. ${ }^{55}$ For example, in EU competition law, the elements of anti-competitiveness in article 101 TFEU and that of abuse of a dominant market position in article 102 TFEU do not require proof of fault. Undertakings cannot argue they did not know the effect or were incorrectly advised. ${ }^{56}$

Secondly, as explained in the introduction, the technique of minimum harmonization in the context of criminalizations implies that States are free to use

51 Ormerod 2005, p. 158; Wootton 1981, pp. 47-48 and Stuckenberg 2007, pp. 447-448.

52 Article 23 of Regulation 1/2003; article 14 of Regulation 139/2004; 25 March 1996, Order in Case C-137/95 P, SPO and others v. Commission [1996] ECR I-1611. This is also required under German and English Competition law, whereas in the Netherlands no fault is required, see Gritter 2003, pp. 137-138, 170-171 and 195.

53 Simester \& Sullivan 2007, p. 184 and Stuckenberg 2007, pp. 448-450. Compare Hörster 2009, pp. 69-90.

54 Ormerod 2005, pp. 159-161; Simester \& Sullivan 2007, pp. 179 and 185 and Williams 1953, p. 272.

5510 July 1990, Case C-326/88, Hansen \& Søn [1990] ECR I-2930, §§12 and 17 and 27 February 1997 Case C-177/95, Ebony Maritime [1997] ECR I-1111, §§36-37.

56 Eijsbouts a.o. 2010, pp. 164 and 175. The Commission has argued, in contrast, that there is no strict liability in competition law, because the "Commission's decisions do not impute liability to companies without its proof being established.” See 10 September 2009, Case C-97/08 P, Akzo Nobel [2009] ECR I-8237. However, this does not seem to preclude liability for offences with strict elements. 
wider offences definitions, including offence definitions that do not require fault as to each and every element. By contrast, implementation law is not supposed to require additional indications of intent. ${ }^{57}$ In other words, although EU legal instruments on substantive criminal law almost all require intention to each and every single offence element, Member States still fulfil their obligations by enacting new legislation of referring to existing legislation in which some elements are strict. Framework Decisions and Directives are the product of political negotiations, resulting in a minimum level on what parties could agree on in the Council (and Parliament). ${ }^{58}$ Whereas States agreed that the intentional offence should be criminalized, there may still have been considerable support to allow for some degree of strict liability, especially when this is already part of existing domestic law on the subject.

Nonetheless, the discretion of Member States to go further than the Union instrument is also limited by general principles of Union law. For example, Union law limits the discretion of Member States to create strict offences if they constitute an unjustified restriction to a fundamental freedom..${ }^{59}$ In addition, some support can be found for requiring nothing less than intention as to an element that is essential to the offence. ${ }^{60}$

Strict liability is very common in the English legal system. Most of the approximately 8000 offences in England are strict liability offences with relatively low penalties and almost half of the more serious offences contain a strict element. ${ }^{61}$ Whereas many English scholars have criticized strict liability, the English legislature has much less regard for subjective orthodoxy. The effect of strict liability mitigated through due diligence and special defences, and its use is diminished through the increase of negligent offences. Nonetheless, it is unlikely that this concept will be dismissed since it is so rooted in English law and to the satisfaction of many. ${ }^{62}$ In the Netherlands, strict liability or strict elements are also common in misdemeanours. ${ }^{63}$ By contrast, in German criminal law, strict liability is rejected altogether, even if it concerns regulatory law. However, there are a few exceptions to this rule, apparent in strict elements in German offences, which will

57 Second report from the Commission on the implementation of the Convention on the Protection of the European Communities' financial interests and its protocols, 14 February 2008, COM(2008) 77.

Although the effect is mitigated with the entroy into force of the Lisbon Treaty, that made the ordinary legislative procedure with qualified majority voting also applicable to criminal Directives, the need for consensus still reinforces the minimal character of Union legislation. 30 November 1977, Case C-52/77, Leonce Cayrol v. Giovanni Rivoira \& Figli [1977] ECR 2261. See the aforementioned examples of recital 18 of the preamble of Directive 2011/93 that states that penalties should only be applied to intentionally accessing a website containing child pornography and secondly, the intention to defraud the EU budget, mentioned in the explanatory Report on the Convention on the protection of the European Communities' financial interests, 23 June 1997, OJ 1997 C 191/1, see IV.2.4.5.

61 Ashworth 2006, pp. 20, 158 and 170 and Ashworth \& Blake 1996.

62 Hörster 2009, pp. 92-113.

63 De Hullu 2006, p. 243 and Blom 2008, p. 122. 
be discussed below. First, I will try to explain the extreme difference in perspectives.

Spencer, Pedain and Hörster have tried to explain the widespread use of strict liability in England, compared to Germany and France. ${ }^{64}$ First of all, they point at the doctrinal emphasis on the principle of guilt, which has constitutional status. ${ }^{65}$ This principle is interpreted very strict in Germany as no punishment without fault. ${ }^{66}$ Accordingly, strict liability is said to violate the principle of guilt. ${ }^{67}$ As argued below, a modern interpretation of this principle however merely requires that the person, who is held criminally liable, should be blameworthy.

They also explain the difference from the procedural point of view that on the continent, the fault of the defendant is established much easier. Since fault is established more difficult in England, it is much more tempting to do away with it altogether. They submit that the right to remain silent is respected more in England, because the defendant is only questioned after the prosecution evidence has been heard. Secondly, English tribunals of fact are not allowed to know about previous convictions of the defendant. ${ }^{68}$ Clearly, tribunals on the continent are not allowed to make evidential inferences out of this, but it will in practice influence the assessment of evidence. Moreover, it is possible to establish that a defendant probably did know that an item is a prohibited substance if he has been convicted previously of selling such substances. Finally, strict liability is deemed better for trials that juries and lay judges have to decide, as it is believed they might be easier fooled. By eliminating fault from the trial, they cannot be fooled on that respect.

Hörster adds that the differences must be sought in the predominantly utilitarian legal thinking and legal culture aimed at pragmatic goals of England, contrasted with the focus of German legal science on the limitation of criminal law and the countering of pragmatic goals. Finally, the low popularity of negligent offences in England must be mentioned. ${ }^{6}$ Some dispute that this fault element is mens rea. If negligence is not available as an offence element, the gap between strict liability and recklessness is great, resulting generally in favour of criminalizing strict.

It is generally argued that any idea of strict liability is rejected in German criminal law. The principle of guilt brings about that fault is always required, which is also laid down in $\$ \S 15$ and 18 of the Criminal Code. ${ }^{70}$ Others argue that strict elements are not precluded by the aforementioned. ${ }^{71}$ In fact, German criminal law

64 Spencer \& Pedain in Simester 2005, pp. 269-275 and Hörster 2009, pp. 29-44.

65 The German Constitutional Court deduces such a constitutional right from the interplay of paragraphs 1 and 2(I) of the Basic Law, as well as the principle of the Rechtstaat, see 19 February 2003 BVerfG NJW 2003, 1504.

66 See also Bohlander 2009, p. 31.

67 See also Politoff \& Koopmans 1991, pp. 71-72 and Nijboer 1989, p. 364.

68 See also Spencer in Tiedemann 2002, p. 439.

69 Hörster 2009, pp. 29-44. See IV.6.2.

70 Bohlander 2009, p. 60. See also $\$ 10$ of the German Administrative Offences Act (OWiG).

71 Fischer, T. 2009, p. 104. 
does include some strict elements. ${ }^{72}$ Examples are the non-provability of the dishonourable fact in slander, the commitment of an unlawful act fulfilling the offence elements with the offence of intoxication and death or serious bodily injury in the context of participating in a brawl. ${ }^{73}$

The rationale for requiring no fault as to these elements is that they have the character of risk elements. When someone takes a risk that is foreseeable to everyone that a serious consequence occurs, he can be punished for this, without requiring that his will is directed to this element. ${ }^{74}$ The attribution of consequences is not coincidental; the principle of guilt not violated. They are foreseeable realizations of the disallowed danger, which the defendant has intentionally or carelessly created. The actor has 'dem Zufall das Feld bereitet'. ${ }^{75}$ Very similar reasoning can be found in England to extend liability to more serious consequences and in the Netherlands to legitimize strict liability in result based offences. Strict liability is a popular device in these contexts, which will be discussed now.

The maxim of versari in re illicita is a derivative of the canonical rule 'versanti in re illicita imputantur omnia quae sequuntur ex delicto', which means that the person who commits a forbidden act, will be attributed everything that is a consequence of this act. Even unforeseen consequences that arise out of a trifle violation will be attributed to the actor. ${ }^{76}$ An influential example in English law is the so-called 'felony-murder rule' which was abolished in $1957,{ }^{77}$ but lives on in the crime of manslaughter by an unlawful and dangerous act. Required for conviction is that the accused committed a crime, which a reasonable person would realize presents a risk of some harm to another and it in fact caused death. ${ }^{78}$

In the English legal system, this maxim, labelled as the "thin ice'79 or 'malice principle' 80 allows for what is called 'constructive liability'. Once a person has crossed a significant moral threshold, such as intending to inflict serious bodily injury to a person, there is good reason to impose liability for consequences that are not too remote. The fault element as to a minor offence is coupled with the major harm caused in order to construct liability for a serious offence. For example, a person can also be found guilty of murder when the defendant only intended to inflict gross bodily harm but the defendant died.

Constructive liability is a functional equivalent of dolus eventualis in extending fault to unwanted, more serious consequences. On the continent, it would be argued

\footnotetext{
72 'Objektive Bedingungen der Strafbarkeit' or 'der Ahndbarkeit'. See Beulke 2008, pp. 50-51; Krey 2003, pp. 100-101 and Schönke \& Schröder, H. 2006, p. 211.

$73 \S \S 186,323 \mathrm{a}$ and 231 of the Criminal Code respectively. Other examples mentioned by Bohlander 2009, p. 60; Roxin 2006, p. 1037 and Weigend in Schünemann a.o. 2001, p. 1393.

74 Beulke 2008, p. 51.

75 Compare Koch 1998, pp. 93-95.

76 Politoff \& Koopmans 1991, pp. 71-72 and Stuckenberg 2007. pp. 517-520.

77 Section 1 of the Homicide Act 1957, see also Stuckenberg 2007 p. 518.

78 Simester \& Sullivan 2007, pp. 187-188, Ashworth 2006, pp. 87-88 and 160.

79 Husak in Simester 2005, pp. 98-99.

80 Ashworth 2006, pp. 87 and 160.
} 
that the defendant consciously accepted the risk of death when he intentionally inflicted serious bodily injury. In England, the offence of murder itself is drafted in a way to include the same cases without reference to an extended concept of dolus. Therefore, the lack of dolus eventualis in England does not bring about a more limited scope of murder.

Constructive liability clearly focuses on the (great) harm of the offence. Such an objective approach to liability becomes problematic when the difference between the intended result and the actual, more serious outcome is great. In order to reconcile it with subjective concerns, versari in re illicita has been watered down to attribute those consequences that are not too remote. For example, when the defendant foresaw to inflict some harm, this fault can be enough for a conviction of maliciously inflicting grievous bodily harm. ${ }^{81}$ The defendant is not liable for whatever consequences ensue, but only for those that are foreseeable. ${ }^{82}$ English, Dutch and German scholars express this condition in different ways. It can be said that the attributed consequence must be not that different in nature and degree from the intended harm, ${ }^{83}$ or that it must be typical for the danger that was created. ${ }^{84}$ In other words, some behaviour, like an armed robbery or dangerous driving, brings about an 'intrinsic risk' that can be attributed to the defendant. ${ }^{85}$

The abovementioned is also advanced to justify that the result is strict in some result based offences. ${ }^{86}$ In the Netherlands for example, the basic offence of theft is aggravated when it results in death, injury or damage. ${ }^{87}$ Fault need not relate to the more severe consequence. The 'objectifying' 88 , the disconnecting of fault from these severe results is justified because there is a subjective connection with the basic offence. When you want to take something with force, it can be expected that someone may get hurt. When you drive dangerously, accidents are likely to follow. In other words, it is not about liability based on bad luck. The fact that the more aggravated result is strict is justified because it was foreseeable to a reasonable person.

This reasoning however implies that it could also be argued that requiring culpa as to the aggravated result would have sufficed. ${ }^{89}$ By objectifying the result, the principle of correspondence has been put under more pressure than necessary. In

\footnotetext{
81 Section 20 of the English Offences Against the Person Act 1861, see Simester \& Sullivan 2007, p. 154.

82 Ashworth 2008A juxtaposes moderate constructivism with the unlawful act theory.

83 Horder 1997.

84 Stuckenberg 2007, p. 519 and Renzikowski 2000, p. 492.

85 Simester \& Sullivan 2007, p. 190 and Reid 2009, p. 183. Halpin 2004, p. 133 submits that dangerous driving, which should be avoided altogether, can be contrasted with conduct like driving that requires some precautions to be taken. De Jong, D.H. \& Knigge 2003, p. 88 submit that the more dangerous the conduct, the more foreseeable harmful consequences become.

86 Fokkens \& Machielse, note 2 on Schuld.

87 Articles 311 and 312 of the Criminal Code.

88 De Jong, D.H. \& Knigge 2003, p. 66.

89 See Stuckenberg 2007, pp. 448-450.
} 
Germany, this perspective is generally taken. The result need not be intended like the other offence elements, but it needs to have been foreseeable. Therefore, at least negligence is required. ${ }^{90}$ Like the aforementioned limited moderate constructivism, result based offences are legitimized because the severe consequence such as death is the realization of the risk inherent in a basic wrong like inflicting bodily harm. ${ }^{91}$

For example, in the case where two Hells Angels agreed that they would violently take the club jacket of a member of a rivalling motorcycle club, one of them stabbed this 'Outlaw' to death. This could not be attributed to the other Hells Angel under conditional intent, because it was accepted that although the lethal risk was foreseen, he had trusted in a good outcome. Nevertheless, the Hells Angel was convicted of the offence of infliction bodily injury resulting, negligently, in death. ${ }^{92}$ Notwithstanding strict elements in a few offences, strict liability is not applied in German criminal law. In most cases, the alternative of requiring negligence as to the result is believed to strike an appropriate balance between individual and societal concerns. In the next subsection, this and other functional equivalents to strict liability are discussed. I will argue that the alternative of requiring negligence cannot meet the demands underlying strict liability.

\subsubsection{Functional equivalents}

The alternatives to strict liability in substantive law are manifold. An even more objectivist approach than applying strict liability is to strike away the objective element altogether. There seems to be a trend of legislative action to create fall-back offences to use against persons who cannot be convicted for more serious offences. Rather than criminalizing the result, the conduct as such is punished. ${ }^{93}$ Requiring fault is hardly relevant when the fall-back offence relates to morally unobjectionable conduct. After all, the requirement of intention to the crime of eating pizza is hardly significant in precluding the conviction of those that do not deserve condemnation. Principles of criminalization, like the harm principle, are important to limit this type of criminal law. ${ }^{94}$

Similarly, striking offence elements altogether goes further than making them strict. In the context of trafficking in human beings, the EU legislator struck what may have otherwise been introduced as a (strict) offence element into national law. Article 2(4) of Directive 2011/36 holds that the consent of the traffickee to the

$\S 18$ of the Criminal Code. Some authors even argue that the few strict elements in German criminal law must be interpreted as to require negligence. Fault must relate to any element that grounds or increases the wrong, according to Roxin 2006, pp. 1038-1040. Beulke 2008, pp. 7-8 and 51. See $\$ 227$ of the German Criminal Code.

27 January 2011 BGH BeckRS 2011, 03958.

Spencer \& Pedain in Simester 2005, pp. 279-282. This also does away with proof of causation. Husak in Shute \& Simester 2002. There is great interest in these principles in English law, which can be explained by the popularity of strict liability and the focus on the specific, combined with scepticism on the general part, see Ashworth 2006, pp. 25-52 and Simester \& Sullivan 2007, pp. $581-596$. 
exploitation, like prostitution, is irrelevant. Instead of including the lacking consent to being prostituted as a strict element that needs to be proven, which would make a mistake on the consent of the trafficker irrelevant, Directive 2011/36 enables criminal liability even if the traffickee consented to the prostitution.

Secondly, if a basic offence already exists, this can also be charged. Dealing in narcotics for example, presupposes possession. Possession can be established easier than the intent to sell or distribute. The punishment of the basic offence can even be increased. Similarly, the offence element can include alternatives and be given a broad interpretation. ${ }^{95}$ The greater the scope of the objective element, the more likely the defendant's perception corresponds to it. Furthermore, I already explained that offences of negligence are easily established. The expansion of duties of care, in number and scope, facilitate convictions of negligence. Whereas I argued against this practice, negligence is established easily upon the mere violation of the duty. It can therefore be argued that it resembles strict liability. ${ }^{96}$

The prosecution's case is also facilitated by the creation of offences that criminalize the failing to present documentation that shows whether norms have been fulfilled. This is particularly important in professional, specialist contexts, in which the ability of an actor to document his conduct may be a legitimate condition of the overall regime by which that conduct is permitted and facilitated. ${ }^{97}$ By using a tachograph, the truck driver is able to demonstrate that he did not exceed the maximum hours a person is allowed to drive a truck each day. Not using the tachograph correctly consists of an offence on its own, which can be administratively fined..$^{98}$

Very common in German regulatory law are abstract offences of endangerment. It has been submitted that strict results have the character of such an offence. ${ }^{99}$ The basic wrong in a result based offence brings about a foreseeable risk. When it occurs, the result based offence can be charged. This risk is also criminalized in abstract offences of endangerment, with the difference that the risk need not materialize. An act that creates a risk to pollution suffices; the actual pollution need not be proven. ${ }^{100}$ In other words, rather than making the result strict, fault can be required as to the danger.

Besides the drafting of offences, there are also procedural devices that serve similar purposes as strict liability. They are intimately bound with substantive law. ${ }^{101}$ Many regulatory offences are outsourced from criminal law into administrative law. In this quasi-criminal field of law, the instrument of punishment

\footnotetext{
95 Hörster 2009, pp. 165-181.

96 Compare Koch 1998, pp. 84-85.

97 Simester in Simester 2005, p. 32.

98 See for example the Dutch 'Arbeidstijden besluit vervoer.'

99 Beulke 2008, p. 51; Schönke \& Schröder, H. 2006, p. 211 and Gropp in Weick 1999, p. 118.

100 Hörster 2009, pp. 166-168.

101 Williams 1953, p. 691 and Simester \& Sullivan 2007, p. 40.
} 
is appreciated as an effective tool in preventing violations, ${ }^{102}$ while many of criminal law's classic principles are seen as obstacles to the efficient enforcement of rules. By labelling the field of law as non-criminal, legal systems can relax substantive and procedural requirements. An example is the lowering of the evidential burden of proof. In Germany, the administrative authorities deciding on the penalties for regulatory offences may be easier persuaded of the defendant's guilt than the judiciary is in criminal law. ${ }^{103}$

Most important however, is the reversal of the burden of proof. In this situation, fault is presumed and the defendant has to make probable he lacked dolus or culpa. For a proper understanding of this reversal, it is necessary to first discuss the normal procedure of proof. The cardinal rule in criminal law is that the prosecution has the burden to prove all the elements of the offence. The judge or jury needs to be persuaded of the defendant's guilt beyond reasonable doubt. ${ }^{104}$ On the continent, a different term, 'conviction intime', is used for the same level of assurance. ${ }^{105}$ Absolute proof is not possible and therefore not required, but if there is a realistic or genuine doubt about his guilt, the defendant should be acquitted. ${ }^{106}$ The burden has been set this high because it is felt that it is better to acquit 10 guilty persons than to convict one person who is not guilty, given the punitive and stigmatic effect of criminal sanctions.

If the Prosecutor succeeds, then the burden is on the defendant to either raise reasonable doubt to the evidence provided, or to point at further evidence that may cast a doubt on the prosecution's case. For example, he can raise evidence which suggests the availability of a defence like duress. The presumption is that such a general defence is absent, ${ }^{107}$ so it is up to the defendant to raise this issue. He does not have to prove the presence of a defence beyond reasonable doubt: he merely has to prove that it is probable. ${ }^{108}$ This is called an evidential burden, in contrast to the

102 The Commission believes in the preventive effect of strong punishment as well as calculating offenders, when they state that in case of repeat offenders a stronger deterrent is necessary, see Report on Competition Policy 2008, 23 July 2009, COM (2009) 374. Applied for example in 12 December 2007, Cases T-101 and 111/05, BASF and UCB [2007] ECR II-4949 and 30 April 2009, Case T-13/03, Nintendo [2009] ECR II-975.

103 Hörster 2009, pp. 181-184. Nevertheless, strict liability is also rejected if it concerns punishment which is not of a criminal (but disciplinary) nature, see 19 February 2003 BVerfG NJW 2003, 1504

104 Woolmington v. DPP [1935] AC 462. 'Beyond reasonable doubt' is not 'beyond the shadow of a doubt', see Williams 1953, p. 693. It does not require absolute certainty, which is impossible, Hamer 2007, p. 148.

105 Spencer 1999, p. 362 and Delmas-Marty \& Vervaele 2000, p. 98. Another difference is that the judge on the continent also has a duty to actively investigate the charges made against the defendant.

106 Section 13(1)(a) and (4) draft Criminal Code, Law Commission 1989, p. 50; Williams 1953, p. 691 and Simester \& Sullivan 2007, p. 54.

107 Mevis 2006, pp. 600 and 615; Koopmans 2007, p. 54; de Jong, D.H. \& Knigge 2003, p. 54 and Strijards 1992, p. 67.

108 Section 13 (2) draft Criminal Code, Law Commission 1989, p. 50; Simester \& Sullivan 2007, p. 56; Mevis 2006, p. 632; Kelk 2005, p. 151 and de Hullu 2006, p. 355. 
probative burden of the Prosecutor. ${ }^{109}$ If the defence is assumed to be present, the burden of proof once again rests on the prosecution to refute this presence beyond reasonable doubt. ${ }^{110}$

The defendant thus always carries some burdens of proof, or onuses, in the criminal trial. A presumption that the defendant is guilty of the offence can also arise out of the facts of the case. If the facts of the case bring about a prima facie case against the defendant, it is reasonable to require him to provide for an explanation. When a person without a working permit is found working for the defendant, the presumption that the defendant employed this person calls for an explanation. ${ }^{111}$ Finally, it has been demonstrated that behaviour in certain circumstances is judicially interpreted as intending a result. In effect, proof of conduct brings about a presumption of dolus, such as hitting a person presumed intent to injure. It is up to the defendant to raise contrary indications.

The possession of stolen property and earlier similar conviction(s) can be used to presume that the defendant knew the pertinent goods were stolen too. ${ }^{112}$ Because this presumption can be rebutted, it creates a reversed onus for the defendant. The 'normal' burden of proof can also be reversed by a statutory defence. For example, an English Act places the probative burden on the defendant to prove that he had lawful authority or a reasonable excuse to carry an offensive weapon with him in a public place. ${ }^{113}$ Secondly, a burden can also be reversed by statutory presumptions. ${ }^{114}$ For instance, another English Act holds that if the defendant used violence prior to the sexual intercourse, the absence of consent is presumed. ${ }^{115}$

Reversed onuses can be legitimized by a combination of constructivist thinking, ease of prove and consent. Individuals who voluntary participate in a regulated activity that creates significant risks from which they intend to derive benefit are said to accept strict duties of care and the associated burden of having to explain themselves through reverse onuses. ${ }^{116}$ In competition law, undertakings that attend meetings during which agreements of an anti-competitive nature were concluded, are deemed to have tacitly approved of these agreements, the presumption which can only be rebutted by proving that the undertaking clearly expressed a different intention to the other participants in the meeting. ${ }^{117}$

\footnotetext{
109 Simester \& Sullivan 2007, p. 56.

110 Section 13(1)(b) draft Criminal Code, Law Commission 1989, p. 50.

111 Blum v. Austria, appl. no. 31655/02, 3 February 2005 and Müller v. Austria, appl. no. 12555/03, 5 October 2006.

112 Section 43(1) of the English Larceny Act 1916 (repealed); section 27(3) of the English Theft Act 1968 and Williams 1953, p. 697.

113 Section 1 (1) of the Prevention of Crime Act 1953. See also section 3(3) of the English Contempt of Court Act 1981.

114 Simester \& Sullivan 2007, p. 56 and Williams 1953, pp. 697-699.

115 Section 75 of the Sexual Offences Act 2003.

116 Dennis 2005, pp. 920-921 and Duff in Simester 2005, pp. 137-143.

117 See 25 January 2007, Cases C-403 and 405/04 P, Sumimoto Metal Industries [2007] ECR I-729; 7 January 2004, Cases C-204, 205, 211, 213, 217 and 219/00 P, Aalborg Portland [2004] ECR I-123 and 8 July 1999, Case C-199/92, Hüls [1999] ECR I-4287.
} 
In Germany, reverse onuses are also considered to violate the presumption of innocence and the Constitution. ${ }^{118}$ In Anglo-American law, much more presumptions and reversed onuses exist than in continental law. ${ }^{119}$ In 1996, around 40 percent of the most serious offences in English law place a probative burden of proof on the defendant or use a presumption that operates against the defendant. ${ }^{120}$ At present, it is only to be expected that this percentage has grown. ${ }^{121}$

Despite the close relationship of strict liability and reversed onuses, there exists an important distinction. If an offence is strict and no specific defence is made available to the charge, the perpetrator can only be acquitted if he makes probable that he acted with due diligence, in other words, that no reproach can be directed against him. In case of a mere reversal of the burden of proof, fault is presumed, but the defendant can rebut it. ${ }^{122}$ In both situations the defendant bears a burden of proof, but when the offence is strict, it is almost impossible for him to negate proof of that offence (element). If it is a defence for the defendant to prove he had no intention to defraud, his chances of acquittal are bigger than when intention is altogether irrelevant for conviction. ${ }^{123}$ Another difference is that reversed onuses are justified by the assumption that it is much easier for the defendant to present evidence that he did not act careless than it is for the prosecution to prove the negative, especially when it concerns something that lies peculiarly within his knowledge. ${ }^{124}$ This justification does not apply to strict liability.

Having discussed almost all functional equivalents to strict liability, including the procedural means of reversing the burden of proof, a specific alternative is now assessed in detail. It can be argued that the alternative in German law of requiring culpa hardly ever will make proof difficult, whereas it would make liability fairer. An important justification for making the consequence in a result based offence strict is that this consequence was normally foreseeable. In a regulatory context, this foreseeability can be grounded in the special knowledge of the actor who participates in that professional activity. This is advanced as a justification for imposing strict liability, just as it is argued that the driver of a vehicle implicitly consented to the legal regime of traffic..$^{25}$

23 October 1890 RGSt 21, 131; Bohlander 2009, p. 60 and Renzikowski 2000, p. 498.

Ashworth \& Blake 1996 and Fletcher 1971, pp. 404 and 436.

Ashworth \& Blake 1996. These offences are either triable on indictment or triable either way.

Padfield 2005, p. 19.

Robinson in Dressler 2002, p. 1004. In other words, strict liability creates an irrebuttable presumption of fault (but not of blameworthiness). See also Simester \& Sullivan 2007, p. 40. The difference does not exist when a strict offence is coupled with a defence of lacking negligence, like in sections 1 and 4 of the English Hunting Act 2004.

Section 352 of the English Insolvency Act 1986 in Attorney-General's reference no. 1 of 2004 [2004] EWCA Crim 1025.

Simester \& Sullivan 2007, p. 55.

See Glover 2007. This is also what Lord Bingham and the ECtHR suggest in O'Halloran and Francis $v$. the UK, appl. nos. 15809/02 and 25624/02, 29 June 2007. 
If this rationale is taken seriously however, then requiring culpa as to the consequence would also suffice. The prosecutor would hardly ever have a problem in proving that the result was a foreseeable consequence. ${ }^{126}$ Reversing proof of culpa could even further alleviate his burden of proof. Given the intrinsic risk in the conduct, it could be presumed that the result was negligent, culpa praesumptus, ${ }^{127}$ implying that the defendant makes probable that it could not be foreseen or avoided that the risk materialized.

By contrast, in strict liability, the defendant could only escape conviction by establishing due diligence or another defence. It is possible that in a particular situation, the result was not foreseeable and thus not negligent. If the defendant however has to establish that he did everything he could to avoid the harm, he can still be convicted for having caused an unforeseeable risk. For example, inflicting some harm does not always make the more serious harm foreseeable. A four-yearold-child had added 30 grams of salt to its pudding, thinking it to be sugar. The mother subsequently forced the child to eat the pudding. She recognized that the child would get a belly-ache and might become sick, but she did not know that this much salt would have lethal consequences. The German Supreme Court held that this lethal effect was also not generally known and acquitted her of (intentionally) inflicting bodily harm, (negligently) causing death. ${ }^{128}$ If the crime were one of strict liability, she would have probably been convicted.

Nevertheless, strict liability is not always based on a foreseeable relationship between conduct and result. In the context of exceeding the speed limit, the justification for not requiring that the defendant knew or could have known he drove too fast, can be that drivers have enough know-how because they have been instructed. ${ }^{129}$ However, a better explanation for the strict element is the effective administration of an enormous amount of violations. Strict liability and reversed onuses have become so common in legal systems, that a dogmatic justification is not even sought. The interests of effective enforcement dominate.

Only in Germany, intent or negligence is required as to the speeding. ${ }^{130}$ Intent can be inferred from excessive speeding of 50 percent or more, any less can at most qualify for negligence. Whereas it is to be expected that negligence is accepted easily based on the function of the driver, it may thus also be the case that in slight transgressions, negligence cannot be proven. ${ }^{131}$ From an enforcer's perspective this may induce fear that many perpetrators will challenge their administrative fine in court and even worse, are likely to be successful.

\footnotetext{
126 See Bohlander 2009, pp. 32-34 and Hörster 2009, pp. 186-225.

127 Compare Stuckenberg 2007, pp. 534-537.

128 16 March 2006 BGH NStZ 2006, 506; Bohlander 2009, pp. 31-32 and $\$ 227$ of the Criminal Code.

129 Fokkens \& Machielse, note 2 on Schuld.

$130 \quad$ s 3 and 49(1) of the Road Traffic Regulation (StVO).

131 Burmann a.o. 2010, notes 126-127 on $\$ 3$ of the Road Traffic Regulation (StVO) and Senge 2006, note $12 \mathrm{a}$ on $\$ 10$ of the Administrative Offences Act (OWiG).
} 
In fall-back offences, it can also hardly be said that the defendant could have foreseen the result. They are created with the primary goal to facilitate proof. This is even accepted in Germany. For example, if the defendant participated in a brawl, death or serious bodily injury that occurs as a result of this brawl is strict. ${ }^{132}$ As in other Member States, such an offence also aims to facilitate the attribution of the serious consequence to all the participants. In brawls, it is often difficult to pinpoint who did and foresaw exactly what.

Moreover, strict liability is also used to do away with issues of fault altogether, because the legal interest deserves as much protection as possible. An example of the latter is the age of minor, with whom the defendant had sexual intercourse. The rationale of these offences is to protect the minor, also from temptation that originates from themselves. ${ }^{133}$ If negligence would be required as to the age, this would often be negated if the minor had pretended to be older. Strict liability imposes a heavier burden to check the age of a sexual partner. Only if the defendant did all he could be asked to do, can he escape liability. This may rightly be criticized from many perspectives, but it does offer the widest scope of protection. In the Union context, the protection of financial interests of the Union, competition and the integrity of financial markets are also given most weight. For instance, strict liability in insider dealing is upheld, because adding a fault element to this offence would weaken the integrity of the financial market an investor confidence. ${ }^{134}$ The ECJ has therefore not only allowed for the use strict liability, ${ }^{135}$ it has even legitimized its use.

Finally, it is perfectly rational to strictly construe an evaluative element like 'dangerous' (driving) or 'indecent'. What counts as a certain standard must be determined independent of the particular defendant. ${ }^{136}$ Thus, although culpa with or without a reversed burden of proof may be a legitimate alternative for strict liability in offences, where the result is made strict because it is foreseeable, this cannot be an alternative for strict liability in many other instances. Strict liability is also used to alleviate the enforcement of offences and to ensure the greatest level of protection for certain interests. Unless concerns of individual fault are considered to outweigh these public interests, strict liability must be included in the EU legislator's toolbox.

\subsubsection{Valuation}

Strict liability and reversed onuses are allowed in EU criminal law as long as it remains possible for the defendant to rebut blameworthiness. In other words, the

$132 \$ 231$ of the German Criminal Code.

133 Article 245 of the Dutch Criminal Code and Section 5 of the English Sexual Offences Act 2003, see Kelk 2005, p. 200; de Hullu 2006, pp. 342-343; R. v. G. [2008] UKHL 37. In contrast, intent must relate to the age of the victim in $\$ 176$ of the German Criminal Code, see V.3.1. 23 December 2009, Case C-45/08, Spector Photogroup NV [2009] ECR I-12073, §37.

1352 October 1991, Case C-7/90, Criminal proceedings against Paul Vandevenne and others [1991] ECR I-4371, §18.

136 Simester in Simester 2005, pp. 42-44. 
lower limit of the principle of guilt does not consist of culpa. There is no such general principle of nulla poena sine culpa in EU criminal law, where culpa means (at least) negligence. By contrast, the maxim is that there may be 'no punishment without blameworthiness'. ${ }^{137}$ From ECtHR case-law on article 6, minimum requirements can be deduced. A presumption of fact or law may not create an irrebuttable presumption of guilt. In other words, article 6(2) at least requires that a defence can be raised against the charge. The defendant who is not blameworthy may not be convicted. ${ }^{138}$ National courts have applied these minimum requirements into national case-law. ${ }^{139}$ Blameworthiness forms the core of the guilt principle as enshrined in article 6 ECHR.

It is important and therefore warranted to recall the distinction between fault and blameworthiness. The latter is an element of every criminal offence, even a strict one. It is an implied element, meaning that it is assumed to be present with the fulfilment of the offence. It can however be rebutted by the application of an excuse. It is a more basic reproach than the reproach in committing an act negligently or intentionally. Negligent offences require gross negligence, whereas strict offences only require some degree of blame. ${ }^{140}$ As mentioned before, this also means that it is more difficult for the defendant to make probable that he was not blameworthy at all than to rebut the inference of negligence.

If the defendant makes probable that (any) degree of blame was absent, that the mistake was unavoidable, he cannot be convicted of a strict offence. ${ }^{141}$ Another important way to negate blameworthiness in strict liability offences is to provide a 'due diligence' defence. It imposes on the defendant a burden to prove he had no fault and took all the reasonable precautions and exercised all due diligence to avoid the commission of the offence. ${ }^{142}$ In many English statutes such a defence is specifically available to a charge, but it can also be raised in contexts where the law does not specifically provide for such a defence. ${ }^{143}$ In Dutch law, a due diligence defence is seen as a species of the general excuse 'absence of all blameworthiness',

13717 May 1984, Case 83/83, Estel NV v. Commission [1984] ECR 2195, §43: “Consequently, it must be declared that any mistake made by Estel regarding the method for the adjustment of its quotas in accordance with article 10 of Decision 1831/81 was not excusable, and that the Commission has not committed a breach of the principle invoked." The principle is that of nulla poena since culpa, see $\$ 39$. As mentioned before, Union (case-)law does not preclude strict liability. See Salabiaku v. France, appl. no. 10519/83, 7 October 1998 and Spronken 1989.

HR 11 October 1989, NJ 1990, 812 and in the context of forfeiture, HR 1 April 2003, NJ 2003, 497; Ormerod 2005, p. 149 and Ashworth 2006, p. 173.

Vellinga, W.H. 1982, p. 114; de Hullu 2006, p. 266 and Mevis 2006. p. 599. See III.4. and IV.6.1. HR 20 January 1959, NJ 1959, 102 and NJ 1959, 103; de Hullu 2006, p. 201; de Jong, D.H. \& Knigge 2003, pp. 43-44 and Kelk 2005, pp. 200 and 222. In Pham Hoang v. France, appl. no. 131919/87, 25 September 1992 and Salabiaku v. France, appl. no. 10519/83, 7 October 1988, the defendant could also be acquitted if he made probable that he made an unavoidable error.

Ashworth 2006, p. 164 and Ormerod 2005, p. 163.

Horder 2006A, pp. 237-276, see also Law Commission 2010, p. 148 and Ormerod 2005, p. 156. See section 3 of the Contempt of Court Act 1981; section 8(5) of the Health Act 2006; section 41(11) of the Human Fertilisation and Embryology Act 1990. 
derived from the general principle that a blameless person cannot be punished. If a company exercised due diligence to prevent contamination of its produce with dead bugs or that it contained too high levels of toxin, it will not be punished for it. ${ }^{144}$ The required degree of diligence is flexible and appears to be lower for inexperienced individuals. Against a strict charge, a person was for example allowed to rely on the advice of his garage manager that his tyres still had enough profile. ${ }^{145}$

Under article $6 \mathrm{ECHR}$, the availability of such a defence is connected to the qualification of the charge as criminal. Article 6 applies when the charge is criminal. This autonomous concept does not attach much weight to national labels and focuses on the nature of the offence and/or the severity of the (possible) punishment. ${ }^{146}$ Therefore, administrative fines can also be tested to the requirements of the presumption of innocence. If the charge made against the defendant is criminal, the use of reverse onuses, presumptions and strict liability can be put to a test of legitimacy and proportionality.

Article 6(2) ECHR provides for a minimum level of safeguarding the presumption of innocence, just like article 48(1) CFR. ${ }^{147}$ This presumption protects against error in the criminal process and serves as counterweight to the immense power and resources of the state, compared to the defendant. ${ }^{148}$ It encompasses the rule in dubio pro reo and second, it implies that the defendant must be regarded as innocent until proven guilty. The prosecution has to prove all offence elements beyond reasonable doubt. The defendant does not have to prove his innocence. ${ }^{149}$ The principle that the prosecution has to prove all offence elements is not absolute. Rebuttable presumptions of fact and law are allowed within reasonable limits, taking into account the interests of using those presumptions and the rights of the defence. 150

In England, a similar test is applied. The difference is that English courts not merely consider whether article 6 has been violated, they are under a duty to reinterpret the English law in conformity with the Convention. ${ }^{151}$ This brings about that courts can read in a fault element in an offence of strict liability and that they can mitigate a reverse onus by holding that the defendant does not carry a probative

144 HR 2 February 1993, NJ 1993, 476. Smedleys Ltd. v. Breed [1974] AC 389 can be contrasted with this, but under current English law, the defendant would have been acquitted by due diligence under section 21 of the Food and Safety Act 1990 as well, see Reid 2009, p. 177. 
burden of proof, ${ }^{152}$ but one of lesser assurance, an evidential burden. ${ }^{153}$ If this cannot be read down in the offence, a declaration of incompatibility should follow. However, it seems that courts are not hesitant to read down, even when the Parliament clearly intended to reverse a probative burden. ${ }^{154}$ The English judiciary has great discretion in interpreting legislation, even if this interpretation is at odds with the legislative purpose. This is fuelled by the fact that a declaration of incompatibility does not affect the validity of the provision. ${ }^{155}$

Nonetheless, the test in English law is similar to that of the ECtHR. It assesses whether the reverse onus is imposed for a legitimate aim and is it proportionate to the achievement of that aim. ${ }^{156}$ The focus of the test is on proportionality. The factors of assessment are the interests of the criminal justice system and the defendant's right to a fair trial, the seriousness of the offence and possible sentence, the relative ease of proof for one party and the likelihood of the risk of convicting innocent defendants by reverse onuses. ${ }^{157}$ One of the underlying principles is that reverse burdens in offences of a regulatory nature are less problematic, because the conviction carries little stigma or punishment. Therefore, less protection against erroneous conviction is required. ${ }^{158}$

Another important factor is to assess what offence elements should normally be proven by the prosecutor, because they are seen as the essential elements, core or 'gravamen' of the offence. ${ }^{159}$ An offence element that is essential to characterize the wrong of the offence should in principle not be made strict or presumed. It is up to the prosecution to prove that the defendant had fault as to these elements. ${ }^{160}$ The idea is that regarding these elements, at most an evidential burden may be imposed on the defendant. However, this is only one factor and does not necessarily warrant that conclusion. Other considerations, such as the fact that it is much easier for the defendant to disprove a fact are taken into account too. For example, the gravamen

152 A probative burden of proof does not require proof beyond reasonable doubt like the prosecutor, but to the civil law standard of 'on the balance of probabilities', see section13(4)(b) draft Criminal Code, Law Commission 1989, p. 50 and Williams 1953, pp. 707-713.

153 R. v. Lambert [2001] UKHL 37; Sheldrake v. DPP [2004] UKHL 43; Hamer 2007; Simester \& Sullivan 2007, p. 57; Ashworth 2006, p. 83 and Ormerod 2005, p. 26.

154 Dennis 2005, p. 926.

155 Section 4(6) of the Human Rights Act 1998.

156 Note that this is similar to the requirements the ECHR set regarding reverse onuses, see Blum v. Austria, appl. no. 31655/02, 3 February 2005 and Müller v. Austria, appl. no. 12555/03, 5 October 2006.

157 Simester \& Sullivan 2007, p. 57.

158 Hamer 2007, p. 170.

159 R. v. G. [2008] UKHL 37 and Hamer 2007, pp. 151-152, the latter who argues 'gravamen' means "a matter central to the wrongfulness of the alleged misconduct", "matters that are crucial (...) to the criminality of the offence."

160 R. v. G. [2008] UKHL 37 per Lord Hope of Craighead: “(...) article 6(2) does not proscribe offences of strict liability, so long as the prosecution bears the burden of proof of all the elements that constitute the offence." Compare Kessler 2001, pp. 210-214 and Roxin 2006, pp. 1038-1040. 
of an offence can be 'not to $v$ without a licence'. Since it is very easy for the defendant to prove that he did have a licence, a probative burden is upheld. ${ }^{161}$

By treating these English factors as an operationalization of the 'reasonable limits' requirement of the ECtHR, it can be determined not only what type of burden may be imposed on the defendant, but also whether the burden may be reversed at all and whether in a specific instance, strict liability stays within the limits defined by the principle of guilt and presumption of innocence.

\subsubsection{Traffic offences}

For most Member States dealing with traffic offences, the interest of effective enforcement dominates dogmatic individual concerns. Because offences like speeding are committed in enormous volumes, the effective enforcement of these offences has led many Member States to lower the safeguards of criminal law, both in substantive and procedural law. In this subsection, I will demonstrate that allowing for strict liability or reversing the burden of proof in this context strikes a more appropriate balance between the competing interests than if one were to adopt alternatives of a more procedural nature.

In a group of Member States to which the Netherlands belongs, the registered owner of a vehicle is fined for (minor) traffic offences committed with that vehicle. ${ }^{162}$ Since it need not be established who drove when the offence was committed, this greatly facilitates investigation and prosecution of traffic offences. In contrast, in Germany, drivers generally have to be identified before they can be fined. Only under certain circumstances, can the registered car owner be fined for illegal parking. ${ }^{163}$

The liability of the registered owner is rationalized in different ways. First, if the owner lends his car to someone else, he arguably assumes responsibility for traffic violations committed by that person. ${ }^{164}$ Second, it is legitimate to impose a burden on the owner to recover the fine from the actual driver. ${ }^{165}$ It even appears the registered car owner is presumed to be the perpetrator, although courts avoid this terminology. ${ }^{166}$ This presumption is controversial because it is hardly rebuttable;

R. v. Lambert [2001] UKHL 37; Hamer 2007, p. 165 and Dennis 2005, pp. 911-913 and 920.

Lord Bingham in Brown v. Stott [2001] 2 WLR 817, cited in O'Halloran and Francis v. the UK, appl. nos. 15809/02 and 25624/02, 29 June 2007.

$\$ 25 a$ of the German Road Traffic Act (StVG). This fine is formally labelled the compensation of the procedural costs rather than a punishement, so as to exclude it from the scope of the principle of guilt, see 1 June 1989 BVerfG NJW 1989, 2679.

Simmelink 2007.

See HR 15 July 1993, NJ 1994, 177.

The Dutch Supreme Court rejected that this violates the principle of guilt, arguing that the registered car owner is not blamed for committing an offence but is only made liable for the payment of the fine. The only risk that the registered car owner faces, is that he will not succeed in recovery of the fine from the actual driver if he does not take (civil) measures or proceedings, see HR 15 July 1993, NJ 1994, 177. 
the possibilities for exculpation are very slim. In the Netherlands, the registered car owner can only successfully argue he was not driving, if he can also prove that he could not reasonably prevent this. ${ }^{167}$ This appears to be a due diligence defence. In any event, it sufficed for the ECtHR, who held that this system of liability does not leave the defendant without any means of defence. The Court held that the presumption was proportionate, attaching great weight to practical arguments in favour of such a system, such as the aim of road safety, the aim that traffic offence should not go unpunished, and that this system prevented the judicial authorities from becoming overburdened. ${ }^{168}$

Another popular approach is to require the registered owner to disclose the name of the actual driver under threat of fines. This duty to disclose can be explained as a corollary of taking the approach to punish the actual driver. The approach avoids punishing the innocent, but in doing so creates other problems. Under English law, the owner of a vehicle receives a notice in which he is required under threat of fines to give the name of the driver. If the owner cannot provide the information, he will be liable for this offence unless he can show that he exercised due diligence in trying to establish who drove. ${ }^{169}$

Two registered car owners appealed before the ECtHR, invoking the presumption of innocence and its derivative rights to remain silent and not incriminate oneself. After all, if the owner was driving himself, the threat of fine could be seen as a coercion to incriminate himself. Nonetheless, the Court did not see a violation. Both rights under article 6 are relative, allowing for proportionate infringements, assessed on the basis of specific criteria. First of all, the nature and the degree of the compulsion were held to be criminal in nature. One of the applicants argued he would have not received such a high fine (GBP 750) if he had pleaded guilty to the offence of speeding itself. However, the Court argued that the compulsion flowed from the fact that by driving a motor vehicle, the owner subjects himself to the regulatory regime and has thus accepted numerous obligations, including the duty to provide the identity of the actual driver. Secondly, the Court held that the nature of this inquiry was limited as only the identity was sought. This simple fact would not prove that that person had in fact committed the offence, so its use was also limited. Finally, the defendant could escape liability by pleading due diligence. ${ }^{170}$

In holding no violation, the Court continued an earlier endorsement of such a system. ${ }^{171}$ The public interest in effectively enforcing traffic regulations played an important role again. The Court understood the practical need to enforce these offences, the impact it would have if the Court held a violation and construed a

167 Articles 8 and 9 of the Dutch Administrative Enforcement of Road Traffic Offences Act (WAHV).

168 Falk v. the Netherlands, appl. no. 66273/01, 19 October 2004.

169 Section 172 of the Road Traffic Act 1988.

170 O'Halloran and Francis v. the UK, appl. nos. 15809/02 and 25624/02, 29 June 2007.

171 Weh v. Austria, appl. no. 38544/97, 8 April 2004. 
legal reasoning to legitimize this system. This reasoning can however be criticized. First of all, the 'implicit consent' of the owner to the duty to give the identity of the driver is questionable. In any event, I believe that aspect should not be given this much weight. ${ }^{172}$ Secondly, the name of the driver is in fact very important for the conviction, because the question whether a traffic offence like speeding itself has been committed is hardly ever debatable. It can therefore be disputed that the inquiry and the use of the evidence would have been limited.

In my opinion, the coercion to disclose the name of the driver therefore violates the right not to incriminate oneself. On the one hand, this right would only apply if the registered owner was also the driver. However, the proof of the pudding is in its eating: only by confessing that he was the driver, could it be established that the threat of the fine coerced the driver to incriminate himself. Hence, of the two approaches considered so far, I submit that only the system where the registered owner is fined for the offence is in line with article 6 ECHR. If infringes upon the presumption of innocence but does not violate it, given the low penalty and stigma in relation to the grave public interests and the availability of a due diligence defence.

In the EU, it is believed that facilitating the cross-border administration or prosecution of traffic offences can reduce the number of casualties in traffic. Therefore, fines for road traffic offences should also be enforced if they are committed with a vehicle registered in another Member State than the State where the offence took place. In order to facilitate enforcement, a Framework Decision was created on the mutual recognition of financial penalties. ${ }^{173}$ The specific approach of every Member State to traffic offences is thereby respected: the State in which the fined person resides, must enforce the penalty.

However, Germany refuses to enforce penalties that it considers not to be in line with its criminal legal principles. The enforcement of a fine issued by the Dutch authorities to the registered car owner, residing in Germany, clashes with the German interpretation of the principle of guilt. As a result, the German implementation law enables its authorities to reject the execution of such fines. ${ }^{174}$ The enforcement of an Austrian fine for failing to disclose the details of the driver is also considered to violate legal principles, such as the right to remain silent or privilege towards relatives. ${ }^{175}$ This illustrates that mutual recognition is put under pressure in the absence of a sufficient level of harmonisation.

172 See also the dissenting opinion of Judge Myjer.

173 Framework Decision 2005/214 of 24 February 2005 on the application of the principle of mutual recognition to financial penalties, OJ $2005 \mathrm{~L}$ 76/16.

$174 \S 87 \mathrm{~b}(3)$ under 9 of the Code on Mutual Legal Assistance (IRG).

175 Schünemann and Roger 2010, who criticize German implementation law for not explicitly making this a ground of refusal. See also Böse 2010. 


\subsubsection{Concluding remarks}

I demonstrated that the ECtHR and both the Dutch and English legal system interpret the principle of guilt as no punishment without blameworthiness. In the German legal system, however, the principle of guilt brings about an absolute requirement of fault and injunction on strict liability. German scholars acknowledge that the ECtHR allows for strict liability and reversed presumptions, but reject them based on their view of the principle of guilt, as safeguarded in the German Constitution. ${ }^{176}$ The German approach can be labelled as classical, by reference to the principles of criminal law developed in the eighteenth and nineteenth century as opposed to the later, 'modern' interpretations of these principles, required by the different context in which criminal law is supposed to operate. ${ }^{177}$

In all criminal legal systems, the focus is increasingly shifted to instrumental reasons of efficiency. It is to be expected therefore that criminal law will become less and less subjective. The principle of guilt and presumption of innocence will be eroded further, as they are under pressure in fields of law like competition law and administrative criminal law and by measures of dispossession and the confiscation of illegally obtained advantage. ${ }^{178}$ In a synthesis, this trend, the approval of strict liability and reversed onuses by the ECtHR and ECJ, as well as its popularity in many Member States carry great weight.

In deciding in favour or against strict liability, the question is what weight should be given to the fact that a limited interpretation of the principle of guilt violates the German 'constitutional tradition', especially when this is contrasted with the very lenient, instrumental approach to strict liability by the European courts in Strasbourg and Luxembourg. It may be expected that the taboo on strict liability is perceived by Germany as a fundamental aspect of its legal system that may result in this State using the emergency brake procedure under article 83(3) TFEU, but such considerations of feasibility play no role at this stage. Be that as it may, it should not be overlooked that both the European Council and Parliament have expressed themselves in favour that "EU criminal legislation should, as a general rule, only prescribe penalties for acts which have been committed intentionally." Liability based on serious negligence should be allowed by way of exception, but strict liability is taboo. ${ }^{179}$

176 Vogel in Tiedemann 2002, pp. 137-138; Hörster 2009, p. 226 and Stuckenberg 2007, pp. 448450 .

177 See de Hullu in Borgers, Koopmans \& Kristen 1998, p. 184. Vogel in Tiedemann 2002, pp. $137-$ 138 juxtaposed legal systems that use strict liability and presumptions of guilt like France and England as 'classical' with 'modern' legal systems like Germany that do not use such concepts because of the principle of guilt.

178 De Hullu in Borgers, Koopmans \& Kristen 1998, pp. 184-186.

179 Draft Council conclusions on model provisions, guiding the Council's criminal law deliberations, Brussels, 27 November 2009, 16542/2/09 REV 2 and EP Committee on Civil Liberties, Justice and Home Affairs, in its draft report on harmonisation of criminal law in the EU of 18 January 2012, no. 2010/2310. 
Whether strict liability should be allowed depends on the context of the offence and its penalty. The special part is therefore very important. The case against strict liability is strong if a public prosecutor only deals with serous transnational crimes with severe penalties. It is therefore obvious that most Directives and Framework Decisions that require Member States to take criminal measures require at least (serious) negligence. However, if offences of a more regulatory nature are to be prosecuted, including fraud against the EU, much more of the justifications and pragmatic reasons in favour of strict liability apply. For example, it can be imagined that financial offences would be very hard to prosecute if intention had to relate to each and every single offence element. Strict liability is also justified by an appeal to protect particularly vulnerable interests, like the interests of children against sexual exploitation or the victims of trafficking in human beings. Given the focus of European criminal law on both categories of offences, strict liability should not be precluded. For example, one could envision that the age of the child or the abuse of trust is made strict.

Nevertheless, it should not be overlooked that strict liability can become problematic in light of the principle of guilt, which is the underlying principle of retribution. It risks convicting the blameless, even if a defence is available, just because the defendant is unable to meet this high threshold of proving he could not help himself at all. Only by proving fault, the convicted person can be said to be truly guilty. Moreover, it is at least questionable whether strict liability can deter. Strict liability and its functional equivalents create exceptions to many important principles of criminal law. It can therefore be argued that merely providing minimum requirements, as the ECtHR does, is unsatisfactory. As long as the defendant is not totally deprived of the possibility to raise exculpating grounds, it seems every fault element may be presumed or made strict. The ECtHR takes into account relevant factors such as the defendant's right to a fair trial, the seriousness of the offence and possible sentence, the relative ease of proof for one party and the likelihood of the risk of convicting innocent defendants by reverse onuses, but it attaches much more weight to instrumental interests. As noted, the ECJ seems to put even more and exclusive emphasis on reasons of efficient prosecution.

In order to remedy this situation, I propose to adopt two strategies. First of all, strict liability and its functional equivalents should only be used when the court or legislator applying it has established that this is necessary. Article 5(4) TEU holds that "the content and form of Union action shall not exceed what is necessary to achieve the objectives". Unlike the Council and EP, I do not propose to preclude strict liability. There may be overriding reasons not to require proof of dolus, recklessness or culpa as to each and every single offence element. This can be reasons of efficiency or the widest protection of particularly vulnerable interests. Given the importance of the fault requirement and the principle that the Prosecutor proves all elements of the offence, the need for derogation must nevertheless be clearly established and subsequently, it must be argued why a lesser alternative would not suffice to secure convictions in these cases. 
Consider EU fraud. When the Union is confronted with misappropriation of its subsidies on a large scale and the European Public Prosecutor's Office encounters significant difficulties in establishing convictions, the Union legislative can solve these problems in different ways. It can lower the required fault element from dolus to culpa, eliminate fault altogether, create presumptions or reverse onuses and so on. It should be clearly substantiated why and to what extent derogations from principles of criminal law are necessary. I have demonstrated that in many result based offences, there are no good reasons to impose strict liability. Requiring culpa and reversing the burden of proof will also convict those who deserve to be punished and can be deterred.

Secondly, the dichotomous approach of the ECtHR to these techniques as either being in violation of the Convention or not, should be replaced by a more nuanced approach, whereby these techniques can also be mitigated, for example by reading in fault elements or defences or by lowering the burden of proof put on the defendant, requiring him only to raise some facts that may cast doubt on the presumption, as is common in England. Faced with only the option of holding a violation or not, a court would feel pressured to approve of the strict practice, as is evident in ECtHR case-law. In conform interpretation, the court has more options than to simply condemn or approve a manifestation of strict liability. The ECJ has held that Member States have to apply implemented EU law in accordance with the requirements of the protection of fundamental rights. In other words, in order to avoid a violation of human rights, which would be incompatible with Union law, Courts have to interpret, as far as possible, the pertinent provision in conformity with that human right. ${ }^{180}$ More weight can be attached to interests of the defendant, which would otherwise be dismissed as not reaching the high threshold required to hold a violation. The principle of guilt or the presumption of innocence do not have to be violated in order to limit strict liability.

By requiring that it should be proven why these techniques are necessary, and by enabling judicial control over this question, it can be expected they will become less self-evident. More consideration will be given to their application, and more often an alternative will be applied that burdens the defendant less. Considering that the ECJ held that "the essential characteristic of insider dealing thus consists in an unfair advantage being obtained from information to the detriment of third parties who are unaware of it," 181 more weight should be given to this feature in justifying why the element is made strict and a lesser alternative would not suffice in securing convictions. The argument that the subjects of these norms will have this intent, does not suffice to do away with its proof, because it confirms that the Prosecutor's burden is not problematic and strict liability therefore not necessary. It is therefore to be applauded that the proposed new Directive on insider dealing and

18013 July 1989, Case 5/88, Wachauf v. Federal Republic of Germany [1989] ECR 2633, §19.

18123 December 2009, Case C-45/08, Spector Photogroup NV [2009] ECR I-12073. 
Chapter V

market manipulation requires intention in order for criminal penalties to be imposed. ${ }^{182}$

\subsection{Mistake on the offence definition}

The referential principle requires that fault must relate to all offence elements. If the offence definition requires dolus to an offence element, dolus as to this element must be established. The accused cannot be convicted of something that is not proven. He cannot be convicted of murder if the victim did not die. Similarly, he cannot be convicted for murder if he thought the victim was a deer. Dolus and recklessness presuppose knowledge, and a mistake or ignorance is its opposite of not-knowing. Therefore, it is 'inexorable logic' that a mistake of fact negates dolus or recklessness. ${ }^{183}$

In contrast, not every mistake negates culpa. The essence of culpa is having made an unreasonable mistake. Therefore, only a reasonable mistake negates negligence, because this is a mistake the reasonable person could have also made. ${ }^{184}$ By negating dolus or recklessness, negligence liability remains unaffected. For example, if the defendant thought the victim was a deer, he can still be liable for negligent homicide. ${ }^{185}$ To avoid negligence liability, the mistake must have been reasonable. ${ }^{186}$

\subsubsection{Terminology}

I already introduced the distinction between mistakes on the offence definition and mistakes as to the legal prohibition. ${ }^{187}$ The distinction coincides with the more often used distinction between a mistake of fact and a mistake of law, error facti and error iuris. The latter can be defined as an informational flaw relating to the existence, sense, purpose, scope or application of the legal norm that underlies the charge. A mistake of fact can then be defined as a flaw that relates to something with is subject to such a norm, to something that has no independent normative character. ${ }^{188}$

182 Proposal for a Directive on criminal sanctions for insider dealing and market manipulation, Brussels 20 October 2011, COM (2011) 654.

183 R. v. Reid [1992] 95 Cr App R. 391; DPP v. Morgan [1975] 2 All ER 347 in Ormerod 2006, pp. 181-185; Fletcher 1978, p. 687; Bohlander 2009, p. 71 and Strijards 1983, pp. 105-106. See also the Corpus Juris in Delmas-Marty \& Vervaele 2000, p. 192 and Delmas-Marty 1997, p. 66.

184 Ormerod 2005, pp. 126 and 291; de Jong, D.H. \& Knigge 2003, p. 132 and Strijards 1983, p. 289. See also the Corpus Juris in Delmas-Marty \& Vervaele 2000, p.192 and Delmas-Marty 1997, p. 66 .

$185 \$ 16(1)$ of the German Criminal Code; §11(1) of the German Administrative Offences Act (OWiG) and Badar 2005, p. 238.

1866 June 1952 BGHSt 3, 105 and Beulke 2008, p. 88

187 See IV.2.4.6.

188 Strijards 1983, pp. 59-62 and 345. 
However, the distinction between fact and norm is not always clear. Offence elements can consist of both factual and normative aspects. Usually therefore, the labels mistake of fact and mistake of law are used functionally to distinguish between mistakes that can affect fault and mistakes that cannot. ${ }^{189}$ This terminology focuses more on the effect than the character of the mistake. The decisive principle is that a mistake on any aspect - factual or legal - can negate fault if that aspect is an offence element to which fault relates. Recall that when a legal aspect is included in the offence definition, like the wrongfulness of the appropriation, a mistake of the actor as to a claim in civil law operates as a failure of proof defence, negating the required dolus. ${ }^{190}$

In German law, the terms 'mistakes of fact and law' have been replaced by 'mistakes on the offence definition' and 'mistake as to the legal prohibition'. ${ }^{191}$ I will adapt this terminology because it is the least problematic. The mistakes discussed here are failure of proof defences because they can negate an offence element. In England, all mistakes used to be seen as complete defence, independent of mens rea. However, since the case of Gladstone Williams, ${ }^{192}$ a mistake is predominantly seen as a failure of proof defence. ${ }^{193}$

The category of mistakes on the offence definition can negate fault. Two subcategories were identified: a mistake as to elements as to which dolus or recklessness is required will negate these fault elements. In contrast, mistakes as to offence elements that require proof of culpa must be reasonable in order to negate culpa. The second category is called 'mistakes as to the legal prohibition'. Unlike the term suggests, it does not only relate to mistakes on the scope or application of the prohibition. It is best understood as the mirror image of the other category, encompassing all mistakes that cannot negate a fault element. Mistakes that do not relate to the offence definition are irrelevant to fault, because fault relates only to the offence definition. In addition, a mistake can relate to an offence element, but if that element is strict, the subjective perception of the defendant as to the element is irrelevant.

Mistakes as to the legal prohibition relate to the implied element of blameworthiness, not fault. As a consequence, these mistakes must be excusable or unavoidable in order to excuse the defendant. The same, high standard, applies to mistakes on the scope of law or on the facts that would ground a defence. These putative defences are treated like mistakes as to the legal prohibition and discussed in the

189 Strijards 1983, pp. 105-106 and Stuckenberg 2007, pp. 332-333.

190 See IV.2.4.7.

191 'Tatbestandsirrtum' and 'Verbotsirrtum', see Weigend in Schünemann a.o. 2001, p. 1390; Arzt 1976, p. 659; Stuckenberg 2007, pp. 332-333; Beulke 2008, p. 320 and van den Wyngaert in Cullen 2003, pp. 319-320 See also the Corpus Juris in Delmas-Marty \& Vervaele 2000, p. 192 and Delmas-Marty 1997, p. 66.

192 R. v. Gladstone Williams [1983] EWCA Crim 4. However, see already Williams 1953, pp. 135136.

193 Simester \& Sullivan 2007, pp. 607 and 618; Ashworth 2006, p. 188. See Weigend in Schünemann a.o. 2001, p. 1390. 
next chapter. In the debate on which elements should be considered as factual and which as legal, the categorization is therefore very important for the defendant's possibilities to escape liability. By labelling something as a 'legal mistake', a mistake on something that is not part of the offence definition, the mistake is no longer relevant to fault and can at most exculpate when excusable.

\subsubsection{Overcoming the inexorable logic}

The inexorable logic described above brings about that a mistake negates fault and thereby the pertinent offence definition. From the perspective of facilitating the prosecution of intentional and reckless offences, it is deemed problematic that the defendant is able to claim that he made a mistake or just simply did not know. This was already demonstrated in the context of offences of ulterior intent. Even when the defendant is believed, there is reluctance to let him benefit from a mistake that a reasonable person would probably not have made.

English law therefore sometimes requires that the mistake made must be reasonable, but this rides roughshod over dolus and recklessness, resulting in negligence liability. Dogmatically, requiring a reasonable mistake means that one is punished for intention for being (seriously) negligent. ${ }^{194}$ One would risk convicting and stigmatizing the person who did not know as intentional actor and the person who did not foresee as reckless. Therefore, in crimes requiring knowledge, the defendant cannot be convicted, however negligent his ignorance. The subjective standard of a genuine mistake, however unreasonable it may be, may risk easily fabrication and thus abuse of the defence, ${ }^{195}$ but as will be discussed below, this risk must not be exaggerated and secondly, it is better to acquit ten guilty than to convict one innocent person. There is only one rule that is acceptable. Since the case of Morgan, ${ }^{196}$ the English judiciary accepts this rule of German and Dutch criminal law that a mistake of fact negates intention, regardless of whether it could be avoided or whether it is reasonable. ${ }^{197}$

On the contrary, the English legislature overrules these decisions by introducing objective requirements for mistaken belief. Fuelled by extremely low conviction rates on rape charges, it was feared that defendants like Morgan could be acquitted of rape if they held an honest belief of consent. ${ }^{198}$ In the case of Morgan, a woman was forced to undergo sexual acts. The defendants argued they thought the woman consented, based on the remarks of her husband that she would resist to enhance her satisfaction. In the Sexual Offences Act 2003, Morgan is effectively reversed,

\footnotetext{
194 Stuckenberg 2007, pp. 339-340.

195 Simester \& Sullivan 2007, p. 619.

196 DPP v. Morgan [1975] 2 All ER 347; Ormerod 2005, pp. 290-291 and Simester \& Sullivan 2007, p. 618 .

197 Bohlander 2009, p. 71 and Fischer, T. 2009, p. 115.

198 See Ashworth 2006, pp. 189-190 and Ormerod 2006, p. 185.
} 
requiring the actor to hold a reasonable belief that the other consents. ${ }^{199}$ It has already been submitted that if an element is essential to the offence, dolus should relate to it. Rape should include the lack of consent and dolus should relate to it.

The risk of providing defendants with an easy excuse must not be exaggerated. First of all, any mistake must be honest. ${ }^{200}$ Courts can reject ignorance based on facts and circumstances of the case or the defendant's history that suggests he did not know. This fear, expressed in the context of consent as to rape, seems unwarranted, since the convictions in Morgan were upheld, as the House of Lords did not accept the men had an honest belief. ${ }^{201}$ Moreover, it has already been submitted that wilful blindness also amounts to knowledge, which is dolus indirectus. If it can be inferred from the facts and circumstances of the case that the victim probably did not consent to intercourse, the court can infer that the defendant must have been aware of this obvious risk. By not taking any further steps to negative this suspicion, he closed his eyes to an obvious risk and is legally held to have known the victim did not consent. ${ }^{202}$

Secondly, the application of dolus eventualis to intentional charges prevents many mistakes from negating intent. In the Netherlands, most claims of mistake are rejected by finding dolus eventualis. ${ }^{203}$ Eventualis is far less sensitive to mistakes than the other forms of dolus. It does not require knowledge that a circumstance is present or that a result will follow. It merely requires a diluted form of knowledge, namely awareness of a risk that the offence element is fulfilled. For example, if the defendant shot dead a human, thinking it was a scarecrow, his ignorance negates the intention. But if he considered and accepted the possibility that it was in fact a human, he is liable under dolus eventualis. ${ }^{204}$ Since recklessness also deals with awareness of a risk, the abovementioned also applies to reckless offences. The difference is that proof of recklessness does not suffice to accept intent, like dolus eventualis. An offence can however also be drafted so as to include recklessness as an alternative fault element alongside intent. Assault, for example, is the intentional or reckless application of unlawful force. ${ }^{205}$

In other words, the defendant must be completely ignorant of the possibility that an offence element is fulfilled to negate knowledge. If he merely made a mistake on the degree of the risk, he still was aware of that risk. Even when the defendant claims he was completely ignorant, this can be refuted by reference to the fact that a

199 Section 1 of the Sexual Offences Act 2003; Ashworth 2006, pp. 189-190 and Ormerod 2006, p. 185. Another example is the offence of unauthorised disclosure of information in section 27 of the Identity Cards Act 2006. It is a defence for the person charged with the offence to show that he believed, on reasonable grounds, that he was authorised to disclose the pertinent information.

200 Williams 1953, p. 148.

201 The House of Lords also held in Warner v. MPC [1969] 2 AC 256 that no Court would believe the defendant who argues he did not know that he carried drugs.

202 See Stuckenberg 2007, p. 443.

203 Strijards 1983, p. 143.

204 Bohlander 2009, p. 71; Badar 2005, pp. 236-237 and Schönke \& Schröder, H. 2006, p. 350.

205 R. v. Gladstone Williams [1983] EWCA Crim 4. 
normal person would know, or that it is general experience. For example, the dangerousness of certain conduct, like stabbing, is clear for everyone. What everyone knows, the defendant is assumed to know as well. ${ }^{206}$ Knowledge can also be established by reference to the experience or professional position of the defendant. This approach stays closer to the individual state of mind. ${ }^{207}$ As noted, fault can be inferred from external circumstances. Sometimes a statute even creates a presumption of fault.

A third set of reasons to substantiate that a mistake not necessarily provides defendants with an easy defence is that mistakes to normative elements like 'reprehensible', 'indecent' or 'obscene' are often irrelevant. The mistaken view of the defendant that something is not indecent is irrelevant, because what counts as a certain standard must be determined independent of the particular defendant. ${ }^{208}$ As explained before, a mistake is only relevant and thus negates intent if it concerns the facts underlying the valuation of a normative element. A similar approach applies to recklessness. Any mistaken valuation about whether or not the risk was reasonable is irrelevant. The knowledge of the defendant merely needs to relate to the facts that are essential for making the valuation of reasonableness. ${ }^{209}$

Already mentioned as well, is the approach that is popular in Germany to focus on the layman perception of normative offence elements. In order for mistakes on normative elements to negate intention, an additional requirement must be fulfilled. Since they resemble mistakes on legal aspects, intention is not so easily negated. The defendant does not have to understand the element as a lawyer would understand it. Intent only requires that the defendant understood the element from a layman's point of view. Any mistake that does not negate this basic knowledge is irrelevant to intent. 210 Such an irrelevant mistake is called a 'mistake of subsumption'. ${ }^{211}$ It is an erroneous belief that conduct does not fulfil an offence definition. An example is the actor who lets out the air out of all tires of his neighbour's car, incorrectly thinking it would not be qualified as criminal damage. ${ }^{212}$ The mistake is irrelevant for intention because it relates to a specific, legal interpretation of an offence. It falls outside the scope of the element as the

206 Strijards 1983, p. 175 and Strijards 1987, p. 102. Keulen \& Otte 1999, p. 27 call this 'normaliteitssyllogisme', which means that 1) a normal person, acting as the defendant did, would have intent, 2) the defendant is a normal human being, 3) so he had intent. Strijards 1983, pp. 145-146 and 175-176.

208 Compare Simester in Simester 2005, pp. 42-44.

209 See IV.2.4.8. and IV.4.5.3. respectively.

210 This is called "Parallelwertung in der Laiensphäre", see IV.2.4.8.; Krey 2003, pp. 138-141; Arzt 1976, pp. 664-665; Beulke 2008, p. 86 and Badar 2005, p. 237. This leaves open only the possibility of excusing the defendant if it was unavoidable, see Krey 2003, pp. 142-145 and Roxin 2006, p. 486.

211 "Subsumtionsirrtum". Subsumption means the qualification of conduct under an offence definition, see Beulke 2008, pp. 5 and 334.

212 Krey 2003, pp. 142-145 and Beulke 2008, p. 85. Another popular example concerns the person who removes from his tab some of his consumed beers to decrease his bill, thinking this does not qualify as an offence. 
layman understands it and thus falls outside the requirements of what intention should relate to.

One of the difficulties of this approach is to distinguish what elements are normative and what are elements are not. It can be said that normative elements are given meaning by an additional value judgment, whereas the opposite category of descriptive elements are factual and concrete. Descriptive elements are perceivable by means of human senses, whereas normative elements cannot be perceived and must be intellectually understood. ${ }^{213}$ The problem is that strictly speaking, all descriptive elements get somewhat of a normative character by putting them in a legal provision. A strict distinction is therefore often hardly possible. ${ }^{214}$

However, on closer inspection, it turns out that if the defendant knew all the relevant facts or circumstances, it is generally accepted that the defendant understood the element as a layman would have. Therefore, one can argue that only ignorance of the underlying facts can amount to a relevant mistake. ${ }^{215}$ This confirms the simple rule stated above that only mistakes as to the facts underlying the valuation of a normative offence element negate fault. Since a mistake on the scope or meaning of descriptive elements also does not negate intention, ${ }^{216}$ the principle can be deduced that mistakes as to the valuation, scope or meaning of offence elements do not negate intention.

Fourth, the correspondence principle brings about that a mistake as to elements that are not part of the offence definition are irrelevant. For example, since the identity of the victim is usually not part of the offence definition, fault need not relate to it and a mistake on that matter is irrelevant. In other words, since dolus usually relates to abstract legal interests, the scope of relevant mistakes is limited. These types of mistakes are discussed in detail below. A related strategy to overcome mistakes is to interpret objective elements in a broad way. The broader the element as to which intent must relate, the more likely the subjective coincides with the objective, the less room there is for mistakes. ${ }^{217}$

\subsection{Unintended outcomes}

Under the broader label of 'unintended outcomes', I will discuss two heavily discussed issues of correspondence that revolve around the question how specific fault must be. Roughly stated, in the first situation, the defendant mistakes the identity of his victim, killing $\mathrm{Y}$ rather than $\mathrm{X}$. In the second situation, he misses $\mathrm{X}$

\footnotetext{
213 Beulke 2008, p. 45 and Roxin 2006, p. 485-486 and 497.

214 Fischer, T. 2009, p. 114; Arzt 1976, p. 649; Schönke \& Schröder, H. 2006, pp. $175-176$ and 262 .

215 See also Arzt 1976, p. 665: "the lay defendant with full factual knowledge did grasp the normative implications sufficiently correctly for a layman."

216 Fischer, T. 2009, p. 116 and Beulke 2008, p. 85.

217 For example, the offence element of 'good' in theft is interpreted broad as to include virtual goods, see Hof Leeuwarden 10 November 2009, NJ 2010, 616.
} 
and kills Y. In both situations, the question is whether the defendant should be held to have intended the death of $\mathrm{Y}$ as well, or whether he should be held liable for recklessness or culpa at best.

The abovementioned situations deal with the more general question of how specific intent must be. Does the concretization of the intent to a specific person matter, or should it only relate to the species of the legal interest involved? ${ }^{218}$ Both approaches can be positioned on one side of a spectrum. I will conclude by arguing in favour of a middle ground in which fault is principally general. Deviations from what the actor planned are irrelevant to intent, unless the actual outcome is of another kind as the planned outcome.

\subsubsection{Error in persona vel obiecto}

The first situation is discussed in Dutch and German law under the heading of error in persona vel obiecto. English law reaches the same conclusions by a somewhat different approach that is discussed in detail later. Consider that the defendant wants to harm X, but at the time he inflicts harm, he mistakes Y for X. Hamlet thought the person standing behind the curtain was Claudius. After he stabbed him, he found out it was Polonius. This is called a mistake of person, an error in persona. If the defendant erred on the quality of an object, for example when he thought he was importing heroine, not cocaine, this is an error in obiecto. Both examples seem to create problems for the principle of correspondence, because fault did not relate to the specific objective element that was fulfilled. Considering that a mistake of fact negates intent, the question is whether these mistakes also negate intent.

The answer is negative. In general, the mistakes are seen as irrelevant. The doctrine gives an interpretation of the correspondence principle, focusing on the question how precise the object must be, what deviation between the state of mind and reality is relevant. Not all deviations have legal consequences. Both errors mentioned are unlikely to preclude intent. The defendant who shot $\mathrm{Y}$, thinking it to be $\mathrm{X}$, is held to have intended death. ${ }^{219}$ The defendant who thought he was importing cocaine but was in fact importing heroin, will be convicted too. ${ }^{220}$

In contrast, some legal acknowledgement can be found for making the error in persona relevant. It can be argued that the actor would not have shot if he knew he shot the actual victim. Hamlet mourned that he had mistaken Polonius for Claudius. If the actor knew in advance that he would kill his son rather than his enemy, he

218 Bohlander 2010A, pp. 617-618.

219 Krey 2003, pp. 150-151; Bohlander 2009, p. 62; Fischer, T. 2009, p. 114; HR 8 April 1997, NJ 1997, 443; Fokkens \& Machielse, note 7 on Opzet; Strijards 1983, pp. 221-225 and Brouns 1988, pp. 32-33.

220 Van Dijk, A.A. 2008, pp. 289-290 and 375; Warner v. MPC [1969] 2 AC 256; Gatzweiler 2008, pp. 146-148 and Weber 2009, notes 302 and 371-373 vor 29ff. BtMG and note 28 on $\$ 29$ BtMG. 
would not have acted. ${ }^{221}$ It strains the common sense meaning of the word 'intend' to say that the defendant wanted to kill his son, as this was the very last thing he desired. ${ }^{22}$ However, it is clear that desires and motives are irrelevant to dolus and it is no longer a condition for dolus (eventualis) that the actor would have continued if he knew the (particular) result would occur. ${ }^{223}$ The fact that the defendant regrets his mistake should only be incorporated in sentencing.

The restriction of mistakes is related to the idea that liability is warranted for those consequences that are typical for the danger that was created. ${ }^{224}$ Why should the mistake in identity matter if the defendant wanted to kill a person? The principle of correspondence requires that the fault and result and more or less compatible. What has happened objectively should in its essential features be in line with what the actor tempore delicti thought would happen. ${ }^{25}$ Thus, a mistake about the identity of the object is irrelevant as long as the objects are of the same nature or kind. ${ }^{226}$ On the continent, this is labelled as the doctrine of dolus generalis. It holds that the precise object of intent need not be specified as long as it is of the same kind. ${ }^{227}$

A classic example is that the actor shoots a human, believing it to be a scarecrow. This mistake negates his awareness of the nature of the object. At most he can be held negligently liable for shooting a human being. ${ }^{228}$ Crimes against the person are of a completely different nature than crimes against the property, so the mistake is relevant. ${ }^{229}$ The doctrine is compatible with most offence definitions, which require after all that the defendant intended to kill $a$ human being. This makes the identity of victim irrelevant. ${ }^{230}$ Superfluously, the English legislator sometimes expressly includes in the offence definition that intent need not relate to a particular object. Offence definitions that criminalize hacking for example, state that intent need not relate to a particular computer, program or data. ${ }^{231}$ The relevance of mistakes depends on the offence definition. The more concrete the legal interest, the more elements included in the offence definition, the more sensitive it is to mistakes. ${ }^{232}$

Sometimes the object does need to have a certain quality. If it is a special offence to assassinate a representative of a foreign state, the actor who thought this

221 Stuckenberg 2007, pp. 357-359 and Roxin 2006, p. 531. However, see 25 October 1990 BGHSt 37,214 , where the father instigated persons to kill his son, discussed later.

222 Bohlander 2009, pp. 62-63 and Bohlander 2010A, p. 618.

223 See Roxin 2006, pp. 460-461.

224 See V.2.3.3.

225 Beulke 2008, p. 89; Williams 1953, p. 105 and Simester \& Sullivan, p. 157.

22623 January 1958 BGHSt 11, 268; Ormerod 2006, pp. 44-45 and 245-247; Williams 1953, p. 104 and Law Commission 1989, p. 202.

Politoff \& Koopmans 1991, p. 123.

228 Roxin 2006, p. 535; Bohlander 2009, p. 72 and Beulke 2008, p. 89.

229 Horder 2006B, p. 392.

230 Strijards 1983, p. 223; Bohlander 2009, pp. 62-63; Krey 2003, pp. 150-153 and Beulke 2008, p. 89.

231 Sections 1 and 3 of the Computer Misuse Act 1990.

232 Strijards 1983, pp. 131-133 and 171-172. 
representative was a national, made a relevant mistake. ${ }^{233}$ Another example of a relevant mistake is the case where the actor is caught on an airport in possession of drugs, but argues he thought he was transporting something else, like gold or weapons. ${ }^{234}$ However, the relevance of mistakes can be circumscribed by applying dolus eventualis, ${ }^{235}$ wilful blindness or recklessness. ${ }^{236}$ For example, it can be held that the defendant must have been aware of the risk of importing drugs since he transported an item of someone else from a notorious destination without checking it.

The mirror image of such a mistake can give rise to impossible attempt, for example if the actor thought he was importing heroine but in fact was importing flower. ${ }^{237}$ Such a 'reversed mistake' is an erroneous assumption of offence elements, a false impression that incriminating circumstances are present. Another example is that the defendant thinks an already dead person is still alive. This particular case will be discussed later.

\subsubsection{Aberratio ictus}

Situations of 'attacks gone astray', 238 hitting someone else than planned are labelled in Germany and the Netherlands as aberratio ictus. For example, the defendant may miss his target or a third party may intervene. Like situations of error in persona, they can only be relevant in Dutch and German law when the deviation is not already encompassed by dolus eventualis. ${ }^{239}$ If the actor consciously took the risk of hitting someone else, like the person $\mathrm{Y}$ who was standing behind the targeted person $\mathrm{X}$, intent can be established as to the actual result. If a defendant, inexperienced in the use of firearms, shoots at someone in a store or crowded bar, intent is established as to the actual victim. ${ }^{240}$ It is therefore argued that true cases of aberratio ictus are cases where the risk was not foreseen, when for example, the victim just happened to walk in at the time of shooting. ${ }^{241}$

Since these cases of aberratio ictus deal with unforeseen results, the actual result can amount to culpa at most. The defendant is held liable for attempting to

$233 \S 102$ of the German Criminal Code, see Krey 2003, pp. 152-153; Beulke 2008, p. 88; Simester \& Sullivan 2007, p. 157 and Tadros 2005, p. 590.

234 R. v. Taaffe [1984] AC 539.

235 Gatzweiler 2008, p. 147 and Beulke 2008, p. 89.

236 Horder 2006B, p. 392 and Simester \& Sullivan, p. 157.

237 R. v. Shivpuri [1986] UKHL 2; Simester \& Sullivan 2007, p. 615; 17 October 1996 BGHSt 42 , 268; Fischer, T. 2009, pp. 113-116; Stuckenberg 2007, pp. 372-373 and Beulke 2008, pp. 88 and 325.

238 Bohlander 2010A, p. 599.

239 De Hullu 2006, pp. 214-215; Fokkens \& Machielse, note 7 on Opzet; 16 October 2008 BGH NStZ 2009, 210; 10 April 1986 BGHSt 34, 53; Krey 2003, pp. 156-157 and Beulke 2008, pp. 90-91.

2401 September 1992 BGHSt 38, 353 and Hof Den Haag 20 July 2009, LJN:BJ3063. See also HR 9 May 1995, NJ 1995, 501.

241 Politoff \& Koopmans 1991, pp. 126-127; Strijards 1983, pp. 226-227; Puppe 2009, p. 92 and Beulke 2008, p. 89. 
kill the intended victim X, but only for negligently killing the actual victim Y, if he should have foreseen the intervention. The intent as to the envisaged victim remains unaffected, but because he did not die, there can only be attempt liability. ${ }^{242}$ In other words, the intent in these cases is individualized and attached to the person aimed at. ${ }^{243}$ This relevance of aberratio ictus can be criticized by comparing it to the irrelevance of an error in persona. Based on a constructivist rationale, both actors have crossed a moral threshold. Further, both actors intended to kill $a$ person and the offence definition is usually no more specific. ${ }^{244}$

In an attempt to rebut this, the situations are contrasted. In the middle ages, the difference was explained by the fact that in case of error in persona, there was an element of premeditation, whereas this was lacking in cases of aberratio ictus. ${ }^{245}$ Nowadays, however, treating both actions as intentional killing still allows one to differentiate between the two killings because premeditation is a factor increasing punishment, which for example turns manslaughter into murder in the Netherlands. Currently, the argument is that in aberratio ictus, the actor does not kill the person individualized as target whereas in error in persona, the actor does in fact hit the person he wanted to hit. The offender had the same person in sight he killed in the end. 246

However, since dolus is always generalis, not requiring individualization, why should it matter here? The difference in relevance can therefore better be sought in considerations of causation. Bohlander thinks that the reasoning behind the doctrine is that the actor wanted to shoot a physical person and missed, which makes it a relevant physical deviation in the imagined causal chain, breaking the intent to the actual consequence. ${ }^{247}$ This causal deviation distinguishes it from error in persona, but is unpersuasive to legal systems that do not require that intent should encompass the causal chain of events in its essential features, like the Dutch.

This therefore partially explains why neither practitioners nor scholars in the Netherlands any longer seem to support relevancy of aberratio ictus. Another important explanation is that dolus eventualis is applied extensively. Dolus eventualis as to a second victim was even established when the defendant had shot the first victim at very close range. Apparently, the bullet went through his torso, hitting this second victim as well. ${ }^{248}$ Since most of these deviations are covered by dolus eventualis, aberratio ictus is rarely discussed. Even in the dogmatic German

242 Strijards 1983, p. 227 and 31 May 1920 RGSt 54, 349.

243 Politoff \& Koopmans 1991, pp. 125-127; Bohlander 2009, pp. 73-74; Beulke 2008, pp. 89-90; Fischer, T. 2009, p. 114; 10 April 1986 BGHSt 34, 53 and 25 October 1990 BGHSt 37, 214.

244 Krey 2003, pp. 154-155; Stuckenberg 2007, p. 361 and Bohlander 2010A, p. 599.

245 Laingui according to Vrolijk 2004, p. 189.

246 Krey 2003, pp. 156-157 and Badar 2005, p. 239-240. See also Bohlander 2009, p. 74 and 25 October 1990 BGHSt 37, 214.

247 Bohlander 2009, p. 74. Bohlander 2010A, p. 600, adds that it must to some extent also be based on subconscious attitudes to motive, although this is no different in the irrelevant error in persona. See also Puppe 2009 and Badar 2005, p. 240.

HR 22 September 1998, NJ 1998, 911. 
legal system, courts are very willing to invoke dolus eventualis to sideline aberratio ictus in cases where they do not want to give the defendant the benefit of merely negligence liability. ${ }^{249}$

Finally, aberratio ictus is hardly relevant in Dutch law, because the idea of dolus generalis is embraced. The latter can be juxtaposed with the focus of many German scholars, not courts, on the specific object of the intent. In fact, in both States, the solution of attempt and negligence liability rarely applies. It only applies when first of all, the object or subject of the conduct had been individualized and secondly, the actual result was unforeseen. If the intent was not individualized, there can be no aberratio ictus. The normal rules of intent apply and just as in error in persona, the deviation is irrelevant, intent not negated. Dolus is generalis. The defendant wanted to kill a human being and he did. ${ }^{250}$ In German law, it is argued as well that if a fleeing criminal shoots at pursuing officers, the court will and should not consider whether he wanted to hit a specific officer. ${ }^{251}$ If the actor shoots in a crowd, there simply is a direct intent as to whomever he hits. ${ }^{252}$

From a German perspective, unplanned victims of car bombs and poisoned drinks can also be treated as irrelevant deviations, because the defendant did not have the victim 'in his sight'. In more causal terms, the actor could not control which person would be harmed, and secondly, the modus operandi worked as planned. ${ }^{253}$ In the Netherlands, the unplanned victim of a poisoned cake would already be included in the dolus eventualis of the defendant if he accepted the risk that the intended victim's wife would eat the cake. ${ }^{254}$

Above, I mentioned that German courts are sometimes also willing to invoke dolus eventualis to sideline aberratio ictus and convict the defendant of the intentional rather than mere negligent offence. A similar pragmatic solution is to label situations as error in persona when the German court believes the deviation should be irrelevant. ${ }^{255}$ Third, mere negligence liability as to the actual result is avoided by applying the doctrine of dolus alternativus. ${ }^{256}$ For example, an offender is being pursued by a police officer and his dog. Hoping to kill at least one of them, he fires his last bullet in their direction. Alternative intentions may coexist which enables the courts to hold that when the dog is killed, the defendant is liable for

249 Puppe 2009, p. 92, illustrating that eventualis was established very easily in 16 October 2008 BGH NStZ 2009, 210.

250 Kelk 2005, p. 204.

251 However, see Beulke 2008, p. 91. For absurd applications of the doctrine, see Bohlander 2009, p. 74.

252 See 4 February 1998 BSG NJW 1999, 236; Beulke 2008, p. 85 and Schmitz 2000, pp. 302-304 and 317-321.

253 Krey 2003, pp. 156-159; and Puppe 2009, p. 92 and Schönke \& Schröder, H. 2006, p. 275. In 7 October 1997 BGHSt 44, 91, a bomb was attached to the car of the intended victim's neighbour. Fortunately, it did not explode. Intent was unaffected and led to attempt liability. HR 19 June 1911, $W$ 1911, 2903.

255 Hsu 2007, p. 44. Courts also sometimes label what should qualify as an error in obiecto as an aberratio ictus, in order to make the mistake relevant.

256 Stuckenberg 2007, p. 359 and Puppe 2009, p. 92. 
intentional destruction of goods and for the attempt to kill the officer. When the officer is killed, he is liable for killing him and for attempted destruction of goods. ${ }^{257}$

Finally, the negation of intent in situations of aberratio ictus can be mitigated by applying an offence that requires culpa or less as to the result. If it cannot be proven that the actor had dolus eventualis as to hitting the actual victim, a result-based offence can also be charged. Consider the German case where members of the Rote Armee Fraktion (RAF) robbed a bank and were on the run from the police. The pursuit continued inside a shopping mall, where shots were fired. The defendant had aimed for a police officer but missed and killed a civilian. The fact that the defendant must have seen the civilian or the general experience that malls are crowded was insufficient to establish eventualis if the shooter thought he had a clear line of sight. Instead, the actual death was attributed to him through the resultbased offence of robbery causing death, which only requires luxuria as to the death. To establish this, the mere use of a weapon in a crowded mall was sufficient. ${ }^{258}$

Since situations of aberratio ictus hardly ever lead to mere negligence liability, it could be argued they are just as irrelevant to intent as an error in persona. An error in persona is relevant only if the intended and actual objects differ in nature. It is submitted that in cases of aberratio ictus, this approach should also be taken. After all, in the discussion about aberratio ictus there is only consensus that when the objects differ, intent as to the actual outcome must be negated. ${ }^{259}$ For example, if the defendant threw a rock at someone, but misses and breaks a window, he did not intend to break this window. ${ }^{260}$ This approach has also been taken by the German Supreme Court. The defendant had tried to make X a suspect to divert attention away from herself, but in doing so, Y became a suspect. The Court held this aberratio ictus to be irrelevant and convicted for the intentional offence. The legal order is a protected legal interest of the offence as well, and this is harmed no matter who is falsely accused in the end. ${ }^{261}$

Only when the actual and planned victim differ clearly in nature or, in exceptional situations of for example a ricochet, ${ }^{262}$ can it be warranted and necessary to negate intent as to the actual victim, resulting in combination of attempt and negligence liability. This means that the actual victim is killed in an unintended way and thus becomes an unintended victim in a legal meaning too. I thus propose to adopt the same approach to cases of error in persona and aberratio ictus. By focusing on the nature of the legal interest involved and/or the way the

257 Krey 2003, pp. 130-131; Beulke 2008, p. 83; Schmitz 2000, pp. 301-302 and Roxin 2006, pp. 480-481.

25815 May 1992 BGHSt 38, 295 and $\S 251$ of the German Criminal Code.

259 Hsu 2007, p. 72 and Roxin 2006, pp. 516-517. According to Bohlander 2010A, p. 605, the aberratio is irrelevant in Spain too if the legal interests were of equal value and nature.

260 R. v. Pembliton (1874) L. 2 C.C.R. 119.

2613 May 1956 BGHSt 9, 240.

262 Puppe 2009, p. 92, referring to 16 October 2008 BGH NStZ 2009, 210. 
unforeseen result was brought about, the approach resembles the English one, which is discussed now.

\subsubsection{Transferred fault}

In England, cases of aberratio ictus and error in persona are not distinguished. ${ }^{263}$ They are both generally irrelevant to the defendant's intent. Intent is 'transferred' from the intended to the actual victim, provided it is of the same kind. In case the identity of the victim is mistaken, it is transferred from the intended to the actual victim. In the example in the introduction of John, when the police officer (Y) intervened in the line of fire and was killed by the bullet aimed at his commissioner $(\mathrm{X})$, the intent directed to the death of that commissioner $(\mathrm{X})$ is transferred to the police officer (Y). ${ }^{264}$ English law concentrates on the result and convicts on the basis of 'sufficient similarity' between intention and result. ${ }^{265}$ The rationale for this transfer is also that deviations of the harm intended should be irrelevant if the intended and actual result of sufficiently similar in nature and degree. ${ }^{266}$ In that case, the actor can properly be treated as if he had the intent for the offence committed. ${ }^{267}$

Whereas the principle, known on the continent as dolus generalis, that intent is abstract or 'impersonal' and need not be individualized as to the specific victim, lies at the heart of the doctrine, ${ }^{268}$ the 'transfer' of intent in fact implies the opposite. The specific intent as to X must be transferred by Y. However, if the intent would be general, it need not be transferred. The 'transfer' of intent becomes superfluous if it is considered that criminal law usually punishes abstract intentional consequences, such as killing a person, rather than a specific individual. ${ }^{269}$ There exists an 'indiscriminate malice' when the defendant shoots into a crowd or detonates a bomb. The victim is not individualized. ${ }^{270}$

Leaving terminology aside, if intent cannot be transferred because the result was too different in nature from what was intended, negligence liability can be upgraded in a similar way as in continental Europe, namely through result based offences and other forms of constructive liability. Since English law knows no concept of dolus eventualis, this cannot be used to limit the scope of a doctrine.

263 See Horder 2006B, p. 383 and Law Commission 1989, p. 159.

264 Williams 1953, p. 104; Horder 2006B, pp. 390-392; Blackstone 1769 (1979), p. 201 and R. v. Pembliton (1874) L. 2 C.C.R. 119. By contrast, the deviation is relevant if the result is different in nature from what was intended. This is called the 'no-translation rule'; fault can be transferred but not translated.

265 Ashworth 2006, p. 198.

266 Horder 1997; Horder 2006B, p. 385 and Ashworth 2008A, p. 255.

267 Robinson 1984, pp. 620 and 647: 'substituting' fault.

268 Horder 2006B, p. 383.

269 Tadros 2005, p. 256; Williams 1953, pp. 101 and 108 and Bohlander 2010A, p. 617.

270 Attorney-General's Reference no. 3 of 1994 [1998] AC 245. See also Bohlander 2010A, pp. 566567. 
Recklessness can fulfil the same function, but only to a lesser extent. If the defendant foresaw that he could kill someone else, he was reckless as to the result. The important distinction is that recklessness is no form of intent. Proving recklessness cannot preclude the negation of intent. Therefore, proving recklessness would only lead to a lesser form of liability such as manslaughter, instead of murder. If one wants to reflect in the verdict that the defendant who missed and killed someone else is just as culpable as the person whose plan turned out as planned, the doctrine of transferred fault is necessary.

\subsubsection{Multiple-actor scenarios}

When more actors are involved, things become even more complex. It seems the general gist in multiple-actor scenarios is that the liability of the participant, principal by proxy, joint principal and so on is connected to the person who directly brings about the unintended result. ${ }^{271}$ The person who induces another to steal one of Van Gogh's 'Sunflowers' but steals a Picasso painting, is also liable as an instigator of theft. The intent of instigator need not be more specific than that of the perpetrator. $^{272}$ A true case concerns the defendant who had induced another to kill his son. To this end, he had informed him on the habits of his son and gave him a photograph. After asking the 'hit man' if he could identify his son, he left the dark place where his son was about to enter. However, a neighbour entered and was fatally shot. The error in persona was irrelevant to both the perpetrator and instigator. ${ }^{273}$

Some German scholars oppose this solution in favour of attempt liability for the instigator. One argument is that otherwise, the instigator would be liable for two murders, if the actor shot the 'correct' person after the error. ${ }^{274}$ Another example used to illustrate that the scope of liability is too broad is the German case where the victim was held liable for the attempted murder on himself. The victim belonged to a group of burglars who had agreed in advance that they would shoot at persons that would pursue them in order not to get arrested. One of the burglars had mistaken the victim for a pursuer and shot him. He survived, but was also held liable as co-perpetrator of this attempted murder. ${ }^{275}$ Other German scholars aim to limit liability by applying a criterion based on the degree to which the defendant

1 January 1859 RG GA 1859, 322; Bohlander 2010B, p. 159 and Hamdorf 2007, p. 221.

Hamdorf 2007, pp. 215-220.

25 October 1990 BGHSt 37, 214. Compare AG van Dorst in HR 29 April 1997, NJ 1997, 654. In that case however, the error in objecto of the perpetrators did not preclude liability of the instigator under a reasoning of conditional intent. The Dutch Supreme Court held that by instigating the thieves to take away a colour photocopier, he had accepted the possibility that they would in fact steal a black and white one.

Roxin 2006, pp. 534-535.

23 January 1958 BGHSt 11, 268. 
left the actual identification of the victim to the direct perpetrator. ${ }^{276}$ There is authority in English law to limit the scope of secondary liability in the case where the perpetrator deliberately kills the wrong victim. This is positioned as a relevant deviation in the causal chain of events. ${ }^{277}$

\subsubsection{Conclusion}

Cases that are typically discussed under the heading of error in persona and aberratio ictus should be treated as irrelevant in principle. Intent as to the actual outcome can only be negated if this was of a different nature than the intended outcome. This approach can explain the outcomes of most cases in all Member States under investigation, reached by either transferring fault, a normative equation of interests or by reverting to dolus generalis. ${ }^{278}$

I rejected the extreme position that a mistake or deviation is always relevant, since this is at odds with the neutral character of dolus. The intended act need not be desired. It also affronts common sense to hold that the defendant negligently killed the person he wanted to kill, because it turned out to be someone else. This does not change in case the mistaken victim is someone close to the defendant. Fault need not be more specific than required by the offence definition. Fault, dolus in particular, is general in nature. Concretization of the object is only relevant if the offence definition makes it relevant, such as offences that aim to protect public officials.

Therefore, only situations where the unintended outcomes differ in nature from that intended are relevant, the yardstick of nature being the offence definition. A clear example is when the defendant attempts to kill, but fails, resulting only in damaging an object. The combination of attempt and negligence liability may also be warranted if John, who wanted to kill the police commissioner but missed, 'only' seriously injured the police officer who jumped in front of the commissioner. It follows that the extreme position of not holding any mistake relevant must be rejected too. It completely sidelines the correspondence principle that fault must relate to all offence elements. It would allow the defendant to be convicted although the offence definition is not fulfilled. It would lead to liability based on the traditional versari in re illicita, and attribute whatever consequences occur.

None of the extreme perspectives are applied in the Member States under investigation. The German legal system can be juxtaposed with the Dutch and the English legal as attaching most weight to the concretization of the outcome. However, the underlying principles are the same everywhere and the outcomes in case-law do not differ very much. I thus conclude that neither error in personae nor aberratio icti are hardly ever relevant. The error in persona is irrelevant in all three Member States, which makes the theoretical relevance of aberratio ictus

276 Bohlander 2010B, p. 156 and Hamdorf 2007, p. 217

277 Bohlander 2010B, p. 148.

278 See Stuckenberg 2007, pp. 353-356. 
remarkable. There is no satisfactory justification to treat liability for the 'unintended', actual outcome in these cases differently. ${ }^{279}$

In German theory, the aberratio ictus is distinguished to negate intent as to the actual victim. However, it has been demonstrated that there are many ways to avoid mere negligence liability. Dolus eventualis, for example, significantly limits the scope of aberratio ictus. Did the defendant not foresee that the bodyguard would try to catch the bullet meant for his target? The same result is reached by applying the doctrine proposed here. When a situation of aberratio ictus is held to be relevant in Germany, this will usually also be the outcome under the test proposed here. For example, when a hunter misses his target and kills another hunter, the fact that he aimed at an object of a different nature, negates his intent.

The doctrine proposed here is consistent and simple. In the general part of criminal law for the EU that I propose, dolus eventualis is rejected and recklessness does not suffice to fulfil a requirement of intent. This brings about that in order to hold the defendant intentionally liable for the bodyguard's death, the doctrine is necessary. In other words, a coherent general part without gaps of criminal liability requires the doctrine. That doctrine is simply based on the idea that mens rea is generalis: it need not be made concrete as to the specific object or way a result is brought about. When the harm intended is identical to the harm caused, a deviation from what the actor specifically intended is irrelevant. The approach does not distinguish between the two situations discussed or consider whether other concepts like dolus eventualis can apply.

All tests or doctrines lack precision to some extent. In the test proposed here, there can also be debate about how different the legal interests involved must be. This question must be answered in the context of what the specific offence definition requires and second, in light of the underlying principles of the test. What is most important is to have a solution that works. The controversy is inevitable in scenarios that are exceptional and complex. ${ }^{280}$ I will not dwell on even more exceptional and complex situations in which for example, unintended victims are injured in an unintended way. ${ }^{281}$ It is not the task of a general part to give a solution to any imaginable problem. ${ }^{282}$

\footnotetext{
279 The distinction between cases of error in persona and aberratio ictus does remain relevant for the liability as to the planned, intended victim. In an error in persona, for example when the intended victim was on holiday, the attempt was impossible, which is not criminal in all Member States. By contrast, missing the intended victim is a paradigm example of attempt.

280 Compare Bohlander 2010A.

281 See Horder 2006B, pp. 383-390. Consider for example the case where a burglar ate from the poisoned cake, see Hsu 2007, p. 88 or a bum who had found it in the dumpster, see Williams 1953, p. 106.

282 Tiedemann in Tiedemann 2002, p. 6.
} 


\section{Principle of CONTEMPoraneity}

So far, it has become clear that every offence includes a fault element, unless the legislator expressly indicated otherwise. The fault element relates to all elements of the offence definition, unless it is clear that it does not relate to some or any of these elements. This can be inferred from the wording or context of the offence and more clearly, by express indication of the legislator or courts. The principle of contemporaneity, also called concurrence ${ }^{283}$ or coincidence, ${ }^{284}$ adds another level to the relationship between the fault and objective element(s) of the offence definition. ${ }^{285}$

The principle requires that mens rea and actus reus coincide or coexist in time. In other words, the question of whether or not the actor had intention must only be assessed by reference to the time of the commission of the offence. The defendant is not liable for handling stolen goods if he only becomes aware after buying them that the goods he bought in good faith are stolen. There is also no intent to kill, if the actor inadvertently kills someone and then is happy with the result. Knowledge after the fact, dolus subsequens, ${ }^{286}$ as well as knowledge (only) previous to the act, dolus antecedens, is insufficient from a perspective of contemporaneity. ${ }^{287}$ This principle reflects the law's interest in judging the culpability of the act rather than the general character of the actor. Criminal liability is principally only interested in the state of mind of the actor at the time of the commission of the offence. It rejects culpability based on character, where the act is only of importance as it shows a certain disposition, as it manifests a 'guilty' character. ${ }^{288}$

A rigid interpretation of the principle may imply that the pertinent actus reus and mens rea elements must co-exist during the whole sequence of events, even up to the moment the final result occurs. However, the attribution of a consequence does not require the intention to be present until the consequence occurs. ${ }^{289}$ The time of committing the offence is assessed by reference to the act that led to the result, not the time when the result occurred. ${ }^{290}$ It is therefore irrelevant if fault becomes absent, for example when the defendant repents, before the result is completed. Consider that actor decided he wants to kill the victim with a bomb and attaches the bomb to the car of the victim. There is coincidence of mens rea an actus reus. Normally, this would remain intact until the result occurs, but this is not

\footnotetext{
283 Simester \& Sullivan 2007, p. 159.

284 Ormerod 2005, p. 117.

285 The principle of contemporaneity presupposes correspondence and is therefore often treated as part of correspondence, like by Stuckenberg 2007, p. 209 and Simester \& Sullivan 2007, p. 187.

28614 June 1983 BGH NStZ 1983, 452.

287 Bohlander 2009, p. 68; Schönke \& Schröder, H. 2006, p. 269; Krey 2003, pp. 130-133; Fischer, T. 2009, p. 105 and Beulke 2008, p. 76.

288 Robinson in Dressler 2002, p. 999; Kelk 2005, pp. 172-173; Politoff \& Koopmans 1991, pp. 22-26; Krey 2003, pp. 14-15; Schönke \& Schröder, H. 2006, p. 203 and Beulke 2008, p. 140.

289 Hettinger 2006, p. 291.

$290 \$ 8$ of the German Criminal Code.
} 
required. It could be imagined that the defendant repents his actions, decides to undo his work yet returns to the car too late.

The principle merely requires a 'scintilla temporis', a moment in time at which all these elements are all present. ${ }^{291}$ This point is not fixed. In result based offences, mens rea can coincide with actus reus in just about any point in time as long as the actus reus is not completed. In other offences, the requirement may be less flexible, For instance, in an offence like theft, the ulterior intent of appropriation needs to be present when the actor takes away the property. ${ }^{292}$ If this ulterior intent was lacking at that time, there can be no liability for theft. Even when the defendant decides to appropriate after he has taken the property away, there can only be liability for the lesser offence of embezzlement.

In many more cases, the requirement of contemporaneity may become an obstacle to liability. To remedy the harsh implications of a rigid interpretation of the principle, several interpretations and doctrines are applied, which are discussed now. The issues almost exclusively dealt within the context of dolus. In negligent offences, contemporaneity is not an issue because the violation of the duty of care always precedes the result. It will be illustrated that as a result, no other doctrines are necessary to ground negligence liability.

\subsection{Dolus antecedens and subsequens}

Fault that precedes or follows only after the commission of the offence does not meet the requirement of contemporaneity. As a consequence, fault cannot be proven. An example of dolus antecedens is the defendant who forgot about the (minor) age of the person he had sex with. He had knowledge before the act, but at the time of acting, he was ignorant. There was no coincidence, not even during a very short period.

As an acquittal would be considered inappropriate, there are multiple options to convict the defendant for the intentional offence. First of all, in most Member States the minor age of the victim is strict, which also sidelines the requirements of contemporaneity. The example must therefore be considered under German law, where fault also relates to the age of the victim. ${ }^{293}$ Second, even in cases where the court not simply dismissed the defendant's claim as incredible, liability could be based on a reasoning of latent knowledge. After all, the fact that the defendant knew in advance implies that he was also subconsciously aware tempore delicti ${ }^{294}$

Mens rea needs to coincide at one point in time before the actus reus is completed, otherwise fault is subsequens. By extending the actus reus, the possibility for mens rea to coincide is also extended. A first way in which this was

\footnotetext{
291 Simester \& Sullivan 2007, p. 159 and Ormerod 2005, p. 116.

292 Bohlander 2009, p. 70.

$293 \$ 176$ of the German Criminal Code. See V.2.3.4.

294 See IV.2.5.1.
} 
done was by applying the 'continuous act' theory. The actus reus can also consist of an ongoing course of conduct. Fault does not have to be present at the inception of the actus reus as it can be superimposed upon an existing act as long as it continues. In an English case, the defendant possessed mens rea when he realised that he parked his car on a police officer's foot, which constituted the actus reus of assault, of which he was convicted. The defendant left his car on the foot after realization. He could not have been liable for assault, had he only realised this after this continuous act had ended. ${ }^{295}$

A second and related way of extending the actus reus is based on creating danger that brings about a continuing duty. In another English case, the defendant was held liable for not preventing the spreading of the fire after he realised he caused it. In other words, the creation of the danger did not complete the actus reus because it was held to continue as an ongoing danger. At one point, the defendant realizes this danger, and actus reus and mens rea coincide. It sufficed that the defendant possessed the required fault element at any time, provided this was a time where preventive steps could still be taken. ${ }^{296}$ Two acts are joined as one; the first is negligent and after realization, the subsequent lack of taking actions grounds an intentional omission.

\subsection{Dolus generalis}

Under the heading of dolus generalis, cases are discussed in which the actor mistakenly believes he has achieved his goal. He therefore does not know that the result is really achieved by his subsequent act. The case of Thabo Meli is often mentioned. ${ }^{297}$ The defendants thought they had killed the victim, but he only died when the defendants wanted to dispose of the body by dropping him into a cliff. The problem is that strictly speaking there was intention at the time of the first act, but no longer at the second act. Mens rea and actus reus thus do not seem to coincide in time.

These cases can be difficult to distinguish from cases of dolus antecedens, where mens rea also precedes the actus reus. The only way to safely do so is by reference to its effect. Whereas dolus antecedens is used to label cases where fault is not relevant, cases of dolus generalis are used to label those cases where the problem of contemporaneity is overcome. ${ }^{298}$ In this section, I will therefore explain why and how this problem is overcome. Only a few German scholars believe that cases discussed under this heading are problematic and argue the first act should be seen as a failed attempt and the second one as causing the result negligently.

Fagan v. MPC [1969] 1 QB 439 and Edge 1995, p. 89.

R. v. Miller [1982] UKHL 6 and Edge 1995, p. 86-88. Both ways of extension are included in s. 23 of the draft Criminal Code, Law Commission 1989, p. 53.

R. v. Thabo Meli [1954] 1 All ER 373. Compare HR 14 June 1960, NJ 1960, 597.

See Roxin 2006, p. 522. 
It will become clear again that the concept of intent in Germany is much more specific than in other Member States. 'Vorsatz' is not general in character. Often, intent must not only also relate to the specific identity of the victim but also to the manner in which the result is brought about. In contrast, dolus is generalis in the Netherlands: the fault element should relate to the end, not the means. In one case, the defendant had strangled the victim and, thinking he had killed him, put him in a ditch. Autopsy revealed however, that the victim had drowned. The court saw no problem in establishing intent as to the death of the victim, regardless of which act killed him. The intent to kill sufficed. ${ }^{299}$

In England, the problem is overcome by approaching the two acts as a 'single transaction'. The series of events is seen as a single course of conduct whereby the presence of mens rea at any stage during the events suffices. In the aforementioned case of Thabo Meli, the whole sequences of events was held to be one complex single transaction, rendering the fact that mens rea preceded the actus reus uncomplicated. ${ }^{300}$ The English and Dutch approach can be connected to each other by arguing that dolus generalis brings about that the two acts form one sequence of conduct. 301

In Germany, these deviations also generally do not negate intent, although this is based on a different, causal reasoning. In principle, a causal aberration is considered relevant in Germany, because intent must also relate to the causal chain of events in its essential features. Rejecting the doctrine of dolus generalis, the German Supreme Court held that problems of contemporaneity can be overcome if the causal deviation was not serious enough to be relevant. Intent must merely relate to the causal chain of events in its essential features, bringing about that what is still within the parameters of what can be ordinarily foreseen in the normal course of events is irrelevant to the question of contemporaneity. ${ }^{302}$ Deviations that still lead to the wanted consequence in a similar way are not substantial and attributed as the completed offence. For example, the defendant planned to shoot the victim but the shot was fired beforehand..$^{303}$ The deviation is also irrelevant when the victim is thrown of a bridge to drown but already dies because he hits a pole or boat. ${ }^{304}$

\footnotetext{
299 HR 26 June 1962, NJ 1963, 11. See de Jong, D.H. \& Knigge 2003, p. 66; Kelk 2005, pp. 201-202 and Fokkens \& Machielse, note 6 on Opzet.

300 Simester \& Sullivan 2007, p. 161; Ashworth 2006, pp. 162-163 and Ormerod 2005, p. 117. Article 56 of the Dutch Criminal Code refers to the concept of a 'continuing act', which applies when two offences are similar in nature and based on the same intent. However, this concept is only relevant to sentencing and is in fact based on the assumption that the defendant committed more than one criminal offence.

301 See Beulke 2006, p. 93 and Sancinetti in Schünemann a.o. 2001, p. 352.

30221 April 1955 BGHSt 7, 325; 30 June 1988 BGH NJW 1989, 176; Bohlander 2009, pp. 68-69; Krey 2003, pp. 134-135 and 148-149 and Beulke 2008, pp. 92-94.

303 Fischer, T. 2009, pp. 114-115 and Roxin 2006, p. 524. Compare the dogma 'intended outcomes are never too remote', mentioned in III.6.2.

304 Beulke 2008, p. 93; Schönke \& Schröder, H. 2006, p. 274 and Krey 2003, pp. 70-71.
} 
In one case, the defendant had attacked the victim with conditional intent to kill, putting sand in her mouth in order to make her stop screaming. After erroneously thinking she was dead, the defendant threw the victim in a liquid manure pit, causing her death. The German Supreme Court confirmed the conviction for intentional killing, submitting that the deviation was not serious enough to be legally relevant. ${ }^{305}$ In conclusion, intent is also only negated in exceptional circumstances in Germany. It is also recognized that such a defendant should not benefit from his mistake. ${ }^{306}$ Some scholars have argued these deviations should always be relevant, implying that intent must cover the whole and exact chain of events, which would therefore always result in a double conviction of negligent killing and attempted killing. Nonetheless, this is only a minority opinion. ${ }^{307}$ The outcomes are therefore similar to those in England and the Netherlands, but the paths to get there are very different.

After all, in the Netherlands, the circumstance that the actor completed his goal by other means is irrelevant. Fault need not relate to the specific manner of causation. ${ }^{308}$ As an alternative to the single transaction theory, the problem of contemporaneity is also solved in England by holding that an act was also a cause of the prohibited consequence. ${ }^{309}$ However, the important difference is that mens rea is not connected to causation. Problems of causation do not affect intent. Today, only a few Dutch scholars still adhere to the German view that intention should encompass the causal chain of events in its essential features, favouring the double charge of attempt and negligence when the deviation is considerable. ${ }^{310}$ This view became less and less popular and several exceptions and doctrines were devised to overcome what were considered unjust acquittals of the completed intentional offence. In the end, the consensus was to disconnect intention from causation altogether. ${ }^{311}$

It is submitted that the German view that would only hold the defendant liable for the attempted offence and the negligent result if the deviation is considered to be substantial is too refined and results in awkward verdicts. How can someone be convicted of attempting to kill a person who died? A person can only be killed once. ${ }^{312}$ Even if in most cases of dolus generalis, the deviation will be at least foreseeable according to general experience and thus be irrelevant, this criterion of foreseeability can be criticized as inconsistent. After all, the question of intent is answered not by reference to what the defendant foresaw but by reference to what

\footnotetext{
30526 April 1960 BGHSt 14, 193.

306 Sancinetti in Schünemann a.o. 2001, pp. 349-350 and 362-363.

307 Hettinger in Seebode 1992, pp. 243-248; Fischer, T. 2009, p. 115 and Stuckenberg 2007, pp. 349-351.

308 Fokkens \& Machielse, note 6 on Opzet; Kelk 2005, p. 201 and Strijards 1983, pp. 212-213.

309 Simester \& Sullivan 2007, p. 162 and Ormerod 2005, p. 117. Compare Hettinger in Seebode 1992, pp. 250-251.

310 Like Politoff \& Koopmans 1991, pp. 125-126.

311 Strijards 1983, pp. 200-213.

312 Compare annotator Pompe in HR 26 June 1962, NJ 1963, 11 and annotator Röling in HR 14 June 1960, NJ 1960, 597.
} 
could be foreseen. The standard is understandable with a view to the desired outcome, but it includes normative aspects resembling negligence into the concept of intent. It is legitimate, even necessary to take normative aspects into account in questions of causation, but the appropriate framework for these aspects is an independent concept of causation, disconnected from dolus (and culpa). The German judiciary increasingly recognizes this, even if not yet formally embraced by the Supreme Court. ${ }^{313}$

I therefore submit that dolus should not relate to the causal chain of events. The cases of dolus generalis can lead to complete liability based on the two approaches described above. When the deviation is very serious, cases can be excluded from (complete) liability based on rules of objective attribution: dolus is not affected. As mentioned in the beginning of this chapter, the acceptance that rules on causation are dependent on the concomitant fault element does not bring about that causation is part of mens rea. It does not imply that causal problems affect fault. Causation can negate liability, not fault. This is increasingly recognized in Germany, not only in the context of negligent, but also more and more in the context of intentional offences. ${ }^{314}$ The actor either intended to kill the victim and legally caused his death, or he intended to kill the victim but did not legally cause the death, resulting in mere attempt liability.

\subsection{Reversed dolus generalis}

In the cases mentioned above, the second act, rather than the first one brought about the intended result. In the converse situation, the intended consequence is already caused by the preceding act. For example, the actor wants to kill his neighbour at night by entering his house and shooting him. However, when he drives through the street in the afternoon, he negligently hits the neighbour with his car, killing him. It is uncontroversial that this does not suffice for intent, so only negligence liability applies. This can be contrasted with the situation where the perpetrator entered his neighbour's house in order to kill him. He gave the victim a hit on the head to stun him first, but this preparatory act already killed him. It would be unsatisfactory to hold this defendant liable only for negligent killing.

The less the two acts can be distinguished in time, space or modus quo, the more evident intentional liability seems to become. If the first and second act can be seen as a sequence of events, these cases would be treated in the Netherlands and England as cases of dolus generalis, bringing about that although objectively, the actus reus was already fulfilled in the first stage, this does not lead to problems of contemporaneity. The defendant will be convicted of the completed intentional offence, because he brought about the consequence he intended.

313 Schönke \& Schröder, H. 2006, pp. 188-191; Hsu 2007, p. 45 and Roxin 2006, pp. 511-515.

314 Schönke \& Schröder, H. 2006, pp. 188-189 and Krey 2003, pp. 62-63. See for example, 13 November 2003 BGHSt 49, 1 and 24 March 2006 OLG Jena BeckRS 2006, 06007. 
These cases are primarily discussed in Germany. ${ }^{315}$ If the defendant accepted the chance that the victim would already die by the preceding act, he is liable for dolus eventualis. ${ }^{316}$ In other cases, the solution of intentional or negligence liability is determined by the distinction between attempt and preparatory acts. Preparation is not punishable in Germany. Only when the actor enters the attempt phase, are his actions directed at the result and thus intentional. The attempt phase must be passed to establish an irrelevant deviation. The killing of the neighbour by the smack to the head is therefore seen as a relevant deviation from the causal chain of events, negating intention..$^{317}$

In a case where the defendant planned to drug and tie up his wife, transport her to a secret location and kill her there, it could not be established when the wife died. Giving the defendant the benefit of the doubt, it was assumed that she already died by the tying up or drugging. Since the German Supreme Court, contrary to the trial court, thought the tying up and drugging should not yet be considered to be in the attempt phase for murder, the deviation was held to be relevant. As a consequence, the defendant could at most be held liable for negligent homicide or unlawful imprisonment causing death. ${ }^{318}$

This case can be contrasted with two cases in which the killing was held to be intentional. The defendants wanted to hang the victim to simulate suicide, but he already died by the strangulation that was meant to subdue him. ${ }^{319}$ In the other case, the plan was to shoot air in the veins of the victim, but the victim already died by the previous beating that was directed at breaking his resistance. In that case, the Supreme Court not only referred to the irrelevant deviation in the causal chain of events, but also argued that the two acts form a unity, which resembles the English approach of a single transaction. ${ }^{320}$

Problems of contemporaneity can be overcome by trying to bridge the gap between the act where the actus reus occurred and the act where mens rea occurred. By arguing that there is one sequence of events, there is no problem of contemporaneity. Another strategy to upgrade what would otherwise be mere negligence liability is to allow for an exception to the principle of contemporaneity. To this I now turn.

\subsection{Actio libera in causa}

If the offender lacks the required fault element at the time of acting, for example due to intoxication, this problem can be overcome by applying the doctrine of actio

\footnotetext{
315 Roxin 2006, p. 526: 'umgekehrte dolus generalis.'

316 Wolter 2006. Just like in cases of dolus generalis, when the disposing of the body is also meant 'to make sure', see Sancinetti in Schünemann a.o. 2001, p. 350.

31712 December 2001 BGH NJW 2002, 1057; Bohlander 2009, pp. 69-70; Stuckenberg 2007, pp. 379-380; Beulke 2008, p. 93; Schönke \& Schröder, H. 2006, p. 275 and Roxin 2006, p. 478.

31812 December 2001 BGH NJW 2002, 1057 and Bohlander 2009, pp. 69-70.

3196 May 1954 BGH GA 1955, 123.

32010 April 2002 BGH NStZ 2002, 475.
} 
libera in causa. This means 'conduct, which is free in origin' 321 and is translated in English by 'prior fault'. In the Netherlands, the terms dolus and culpa in causa are often used. ${ }^{322}$ Fault is located in an earlier time, compensating the lack of fault tempore delicti.

The doctrine of prior fault signifies that a person should not be allowed to take advantage of any failure of proof defence to criminal liability if the relevant condition or circumstances was brought about by his or her own fault. ${ }^{323}$ For example, the offence of careless driving is held to be already complete when the defendant continues to drive while feeling drowsy, so as to avoid the problem that the behaviour was involuntary when he in fact did fall asleep and caused an accident. ${ }^{324}$ In an earlier mentioned German case, the epileptic person has been warned not to drive. Nonetheless, he drove, had an epileptic fit and caused a fatal accident, injuring many more. ${ }^{325}$

Prior fault comes in many shapes and forms. Here, it is discussed as an exception to the principle of contemporaneity. I already discussed its specific role in establishing culpa, which can be grounded after all, in the fact that the defendant took on a responsibility for which he knew he was unqualified. In negligent offences, the doctrine of actio libera in causa is superfluous, because the concept of the violation of the duty of care is already quite broad. The violation of the duty of care always precedes the result. 326 The aforementioned epileptic driver was convicted by the District Court of negligent killing, as the participation in traffic with his disease was a violation of a duty of care, and it was objectively foreseeable that accidents could occur. ${ }^{327}$

The example of the drowsy actor indicates that the doctrine does not only deal with the lack of mens rea. It can also prevent offenders from relying on defences that negate the voluntariness of the act. Consider that the actor became incapable of understanding the wrongfulness of his actions and committed an offence. The lack of blameworthiness as a result of a mental disorder can also be overcome by prior fault, limiting or even precluding the defence of insanity. Liability can even be based on the act of getting in the state of mind that gave rise to the defence. This will be discussed in detail in the next chapter and to some extent in the context of intoxication below.

Right now, I focus on how problems of correspondence in situations of prior fault can be overcome. Least controversial is the intentional actio libera in causa,

321 De Hullu 2006, p. 330: "de van oorsprong vrije handeling."

322 Strijards 1987, pp. 44-46. The latter is most commonly used.

323 Ashworth 2006, p. 163 and Fletcher 2007, p. 97.

324 Simester \& Sullivan 2007, p. 163. See also Hart 2008 (reprint 1967), p. 94 and de Hullu 2006, pp. 324-325.

32517 November 1994 BGHSt 40, 341.

32622 August 1996 BGHSt 42, 235; 19 February 1997 BGH NStZ 1997, 228; Krey 2003, pp. 40-41 and Hirsch 1997.

32717 November 1994 BGHSt 40, 341. The German Supreme Court quashed the decision for not dealing with the subjective part of negligence sufficiently, see IV.6.5. 
which holds the actor liable for the criminal act although the mens rea for that act was lacking when the actor committed the offence. Liability is based on the prior situation, in which the defendant intentionally created the circumstances that would negate fault with a view to facilitating the planned offence. For example, the defendant intoxicates himself to gain the courage to kill. ${ }^{328}$ Even if it is accepted that fault was lacking tempore delicti, it is still appropriate to hold the perpetrator liable for the offence based on his prior fault. After all, it is only for the prior fault that mens rea is lacking tempore delicti. ${ }^{329}$

In addition, there is a subjective connection between the two events. At the time of the actio libera, the intention was already aimed at the specific offence which the actor wanted to whilst being intoxicated. ${ }^{330}$ The defendant wanted to kill the person -then he got intoxicated- and he killed the person. There is mens rea, only it exists prior to the actual actus reus. The problem of contemporaneity is therefore similar as in cases of dolus generalis mentioned above and could be dogmatically solved by viewing the two events as one sequence of events. ${ }^{331}$ The alternative is to view the grounding of fault in the actio libera as a legitimate exception to the principle.

A negligent actio libera in causa exists when the actor causes the defect intentionally or negligently and thereby does not think about the possibility to commit a specific offence, which he subsequently does. ${ }^{332}$ As noted, it is doubted whether this doctrine is necessary as to negligent offences, because the prior fault can ground the violation of the duty of care. Under both the doctrine of actio libera as well as that of culpa, liability is limited to those results that were foreseeable according to general experience. ${ }^{333}$ This is related to the rationale underlying constructive liability; creating a danger, like intoxication, brings about typical dangers. If the actor does not take the necessary precautions to minimize or avoid the risk from materializing, he may be held liable for it. If foreseeability would not be required, the doctrine would allow for liability based on the stricter versari in re illicita, grounding liability for whatever consequences ensue from the preceding act. ${ }^{334}$

\subsection{Intoxication}

The ways in which the doctrine of actio libera grounds liability can be illustrated in the context of intoxication. Intoxication is a generic concept for losing one's sound mind through intoxicants such as alcohol and drugs. The attitude of society in regard to intoxicants, especially alcohol, has always been ambivalent. Whereas

\footnotetext{
328 Beulke 2008, pp. 144-145 and Roxin 2006, p. 914.

329 Ashworth 2006, p. 91.

3304 May 1962 BGHSt 17, 259; Hettinger 1988, pp. 193 and 197 and Beulke 2008, p. 146.

331 See Hettinger 1988, p. 213, who also mentions the German approach of viewing this as an irrelevant deviation in the causal chain of events.

332 Beulke 2008, p. 147 and 21 July 1992 BGH StV 1993, 356.

333 Schönke \& Schröder, H. 2006, pp. 407-408 and Roxin 2006, pp. 915-916.

334 See V.2.3.3.
} 
driving under the influence of alcohol is regarded as very blameworthy, drinking itself is seen as socially acceptable or even desirable conduct. The legal problems are just as ambivalent. On the one hand, it is accepted that the intoxication may rob the defendant of his ability to be aware of and appreciate danger correctly. Intoxication may cause the defendant to act out of character or even rob him of any control over his actions. On the other hand, it is commonly rejected that the defendant should be able to benefit from the fact that he created these circumstances himself. A perpetrator should not be allowed to escape liability if he got intoxicated with a view to raise a defence. Otherwise, legal interests would be insufficiently protected. As a result, the exculpating effect of intoxication is severely limited.

The outcome of the comparative legal analysis resembles that of dolus generalis. In all three Member States, the problem of contemporaneity is generally overcome, leading to similar outcomes in terms of adjudication and sentencing, but the path to liability is very different. ${ }^{335}$ These differences not only reflect a difference in approach to the doctrine of prior fault, but also to the nature of fault in general. The question of whether or not intoxication can affect intent is directly related to the question to which elements it must relate and to what extent. The more specific intent is, relating to causal aspects or a specific identity of the victim, the more sensitive it is to mistakes.

An important difference can be made as to the effect of intoxication. In England, the issue is treated predominantly in the context of the lack of mens rea. Intoxication can support a claim that the defendant was ignorant of a risk or that he made a (very unreasonable) mistake. ${ }^{336}$ By contrast, in Germany, intoxication is usually discussed as a problem of blameworthiness. It not necessarily affects intent, but certainly can give rise to an excuse like insanity. In the Netherlands, intoxication is treated in the light of both mens rea and blameworthiness. Defendants raise intoxication as a failure of proof defence and as an excuse, although without much success. The difference can be explained by the fact that in Dutch law, a strict distinction is made between mens rea and blameworthiness. The German focus on the excuse can be explained by the circumstance that intoxication is more likely to constitute a mental disorder or diminished responsibility than it will negate fault. The significant differences in national law warrant a separate discussion.

It is submitted that intoxication can affect both fault and the capacity to be held blameworthy. The person, who is so intoxicated that he is excused, can still act intentional and vice versa. ${ }^{337}$ The difference is important, for if a legal system would only recognize that intoxication can negate mens rea, it can have no effect in the context of strict liability offences. I will now discuss the various ways in which

\footnotetext{
335 Albrecht 1998, p. 86.

336 Simester \& Sullivan 2007, pp. 628 and 638; Ashworth 2006, p. 217 and Ormerod 2005, p. 273. This does not preclude that intoxication can give rise to an excuse like insanity, see Law Commission 1995, pp. 64-67.

337 Gatzweiler 2008, p. 142; van Dijk, A.A. 2008, p. 299; 22 November 1990 BGH NStZ 1991, 126 and 14 December 2004 BGH BeckRS 2005, 00267.
} 
the pertinent legal systems acknowledge and overcome legal problems relating to intoxication. It is important to note that in all three legal systems, a prerequisite for intoxication to affect fault is that it must be severe enough to really negate intention. By consuming just a few drinks, the accused's intention or knowledge is unlikely to be affected. Nonetheless, that threshold is difficult to determine in abstracto and clearly varies per State.

\subsubsection{English law}

The English approach to intoxication can best be viewed as a compromise to the dilemma. A middle way is chosen between negating mens rea due to intoxication and holding intoxicated mistakes irrelevant to mens rea. This is done by partially recognizing the fault-negating effect of intoxication. If the intoxication crosses the threshold of severity and affects mens rea, the defendant is not held liable for the serious offence due to a lack of fault. Nonetheless, he is held liable for a lesser offence that also requires mens rea, albeit in a more basic form, like recklessness. Like the partial defence of provocation can negate a charge of murder, resulting in liability for the less serious offence of manslaughter, voluntary intoxication can negate the 'specific intent' required for murder, but the defendant will still be convicted of the 'basic intent offence' of manslaughter. ${ }^{338}$

Two important limitations of the doctrine should be addressed. English law requires that the intoxication must have been powerful enough to negate the mens rea, for example to completely remove awareness of what one is doing. Even if the defendant was less capable to resist temptation, he still acted intentionally. A drunken intent is after all, still an intent. ${ }^{339}$ Secondly, if the intoxication was involuntary, the normal rules of correspondence apply. Hence, he is acquitted if fault was lacking. Intoxication is involuntary when the intoxicant was slipped, for example in a drink, without the defendant's knowledge, when it was forced upon him or when the intoxicant was taken in good faith for medicinal purposes. ${ }^{340}$ It is involuntary only if the defendant was unaware that he was taking it, not if he underestimated the amount or effect it would have on him. ${ }^{341}$

The doctrine only enables inculpation when fault is absent due to voluntary intoxication. In that case, the subsequent question is whether the crime charged is one of 'specific' or 'basic' intent. In offences of specific intent, the normal rules of correspondence apply, which brings about that the defendant can be acquitted of that charge due to a lack of fault. In contrast, crimes of 'basic intent' are governed

338 See Taylor, R. 2007, p. 347 and Simester 2008, p. 12.

339 R. v. Kingston [1994] UKHL 9; Ashworth 2006, p. 217; Simester \& Sullivan 2007, p. 108; Ormerod 2008, p. 295 and Simester 2008, pp. 3-7.

340 R. v. Kingston [1994] UKHL 9; R. v. Hardie [1984] EWCA Crim 2; Law Commission 1993, pp. 85-86; Law Commission 1995, pp. 11 and 79-87; Law Commission 2009, pp. 77-78 and Ormerod 2005, pp. 249 and 272-273. See also section 6(5) of the Public Order Act 1986.

Ormerod 2005, pp. 275-276; Ashworth 2006, p. 217 and Law Commission 1995, pp. 30-31. 
by another regime of 'Majewski', in order to prevent simple acquittals. In these offences of basic intent, intoxication is irrelevant to mens rea. It cannot negate mens rea. Instead, it will even constitute mens rea. ${ }^{342}$ If a defendant failed to foresee a risk because he was intoxicated, he may be treated as having foreseen that risk in an offence of basic intent. ${ }^{343}$ The voluntary intoxication is treated as a substitute for the fault element normally required..$^{344}$

Usually, this brings about that intoxicated persons are deemed reckless. ${ }^{345}$ The intoxication constitutes recklessness, based on the premise that the intoxication brings about that the defendant knowingly takes a risk as to his future actions. The prosecutor need not prove an actual state of mind and can rely on the self-induced intoxication. ${ }^{346}$ It is this second step that has attracted a lot of criticism, and scholars have argued for the possibility that the prosecution would still have to prove recklessness. After all, so it is argued, proof of recklessness is not so difficult with intoxicated persons. A momentarily realization of the risk suffices. ${ }^{347}$ An increasingly popular alternative view is that the prosecutor must prove that the defendant would have had mens rea but for being intoxicated. ${ }^{348}$ Nonetheless, this liability based on hypothetical mens rea can also be criticized. It may even be questioned whether the English approach is really something different than a normative restriction of the relevance of intoxication. In the end, all that the English rules generally do is mitigate an intentional charge to liability for the lesser reckless offence. 349

This distinction also gave rise to the question what crimes of specific and basic intent are. The matter is not settled; no principled distinction can be made. ${ }^{350}$ The simplest, most workable distinction is to require (direct) intent for offences of specific intent and recklessness or less for offences of basic intent. ${ }^{351}$ Nevertheless, doubt has been casted on this distinction. The only safe way is of defining crimes of specific intent is follow a list of precedents, where voluntary intoxication has been

342 DPP v. Majewski [1976] UKHL 2; Simester \& Sullivan 2007, pp. 628-629; Ormerod 2005, p. 276; Ormerod 2006, p. 187 and Ashworth 2006, pp. 212-213.

343 Taylor, G. 2004A, p. 115 and Simester \& Sullivan 2007, p. 141.

344 R. v. Kingston [1994] UKHL 9, see also DPP v. Majewski [1976] UKHL 2.

Simester \& Sullivan 2007, p. 633, Ashworth 2006, p. 213, Ormerod 2005, p. 128 and section 22(1) draft Criminal Code, Law Commission 1989, p. 52. See also section 6(5) of the Public Order Act 1986.

346 Law Commission 1993, p. 82.

347 Simester \& Sullivan 2007, pp. 633-634 and 640-641; Ashworth 2006, p. 218 and Ormerod 2005, p. 278.

348 R. v. Brady [2006] EWCA Crim 2413; Law Commission 2009, p. 56; Simester 2008, pp. 3-7; Child 2009, p. 500 and James 2007, p. 297. See section 6(5) of the Public Order Act 1986. A comparison can be made with the English so-called 'partial defences', discussed in X.3.6., which can reduce a charge of murder into the lesser manslaughter.

350 Ormerod 2006, p. 195 and Law Commission 1995, p. 49.

351 DPP v. Majewski [1976] UKHL 2; R. v. Heard [2007] EWCA Crim 125; Lynch 1982, p. 138; Simester \& Sullivan 2007, pp. 630-631, Simester 2008, pp. 9-11 and Ormerod 2008, p. 298. 
held to be able to negate mens rea. ${ }^{352}$ Notwithstanding this 'unprincipled'353 distinction, which cannot be justified in strict logic, ${ }^{354}$ it has been argued that is has proved workable. ${ }^{355}$ Most offences are underpinned by a lesser offence of basic intent. ${ }^{356}$ The approach thus enables a form of mitigation; it strikes a middle ground between granting no defence at all and to granting a complete defence. It forms a midway course between the possibility of negating mens rea because of intoxication and holding intoxication irrelevant to criminal liability.

\subsubsection{Dutch law}

In the Netherlands, intoxication is hardly ever experienced as a problem of correspondence, because of the general nature of intent. The less specific intent is, the less sensitive it is to (intoxicated) mistakes. Therefore, intoxication will only negate fault in very exceptional circumstances. In a case where the defendant took drugs and became psychotic, he thought his family was the devil and needed to be killed. This illusion does not however necessarily preclude a court from finding that he wanted to kill the victims. He was mistaken on the identity of the victims, but not as to the fact that he was killing. ${ }^{357}$

Just like in England, the intoxication must have been powerful enough powerful enough to negate fault. The threshold of when it is accepted that fault is absent is even higher in the Netherlands. In practice, proof of intent is simply inferred objectively from the (violent) act, the proof of which can only be rebutted if the defendant makes probable he did not understand the nature of his actions and consequences at all. ${ }^{358}$ In a rare case, the Court of Appeal acquitted the defendant who had, when drunk, stolen a bicycle, because the Court did not think the ulterior intent of appropriation was proven. 359

Because proof of intent does not require much, the substitution of fault by the prior act of intoxication is hardly ever necessary. Moreover, even if the intoxication did cross the threshold, a lenient test applies. If the defendant can be blamed for the lack of fault, for example, because he knew that he should not take alcohol in a combination with medicine, it is held he voluntary brought himself in that situation and dolus in causa is attributed to him. ${ }^{360}$ Finally, luxuria can be accepted upon

352 Ormerod 2005, pp. 279-280 and Law Commission 1995, pp. 27-30.

353 Ormerod 2006, p. 198; Ormerod 2005, p. 278 and Law Commission 1995, p. 42.

354 Even the House of Lords admitted this, see DPP v. Majewski [1976] UKHL 2.

355 Simester \& Sullivan 2007, p. 632 and Law Commission 1995, pp. 8-9.

356 Ashworth 2006, p. 213.

357 HR 9 December 2008, NJ 2009, 157

358 HR 14 December 2004, NJ 2006, 448; de Hullu 2006, p. 218 and de Jong, D.H. \& Knigge 2003, p. 112.

359 HR 3 February 1959, NJ 1959, 111. In Rb. Amsterdam 9 June 2011, LJN:BQ7589, mentioned below, the Court also rejected the intentional offence and convicted for negligence.

360 In HR 11 October 2011, $L J N$ :BR2983, the conviction was quashed because the Court failed to sufficiently motivate why it believed the defendant knew this. 
proof of intoxication, which resembles the approach in England to accept recklessness in these cases. ${ }^{361}$

This leaves open the possibility that intoxication can lead to a lack of blameworthiness. Similar as a mental disorder, the intoxication can be so severe that the defendant is no longer capable to make morally responsible decisions. The use of intoxicants can lead to hallucinations that qualify the defendant as insane. In this context, the doctrine of actio libera in causa explicitly applies. It precludes the defendant from relying on the defence which would have otherwise excused him. ${ }^{362}$ The rationale for the precluding of the defence is based on the constructivist rationale that once the defendant has created a situation, the danger that is typical to follow from it, was foreseeable. Just like prior fault in England is grounded in the association of drunkenness with disorder and violence, ${ }^{363}$ in the Netherlands, people are held to know the possible consequences of using intoxicants, so they cannot rely on these effects to their advantage. ${ }^{364}$ The defendant can for example not claim that previous experience with intoxicants like cannabis did not cause any serious mental disorders. ${ }^{365}$

No subjective connection is required between intoxication and the reaction it would have on the defendant or offence committed. The criterion is simply whether the defendant can be blamed, allowing for a very pragmatic approach. In one case, a tourist had been indulging in the different narcotics available in Amsterdam, like alcohol, cannabis and MDMA. In an unexpected hallucination of blind panic, he jumped out of the window of his apartment on top of another tourist who was sitting on the terrace. The victim became paraplegic and will never walk again. The defendant was held to be legally insane at the time, but could not rely on the defence. It sufficed to note that it is generally known that narcotics influence the state of mind, that effects can differ according to the person and that combined use is even more unpredictable. The court even held that it felt it was important to make clear that life threatening conduct, committed while intoxicated, will be punished with imprisonment. 366

By contrast, the precluding of the defence cannot be grounded in cases where the previous conduct was not reprehensible. Consider cases where the defendant was unaware of the side-effects of medicines because they were not mentioned on the leaflet or by the doctor or by the effects of the combined use of them. Given these circumstances, he should have also not been aware. ${ }^{367}$ In this normative way, Dutch law also separates between voluntary and involuntary intoxication. In conclusion, the case of the tourist makes it abundantly clear that the Dutch approach

\footnotetext{
361 Kamerstukken II 2001/02, 28 484, no. 3, p. 7.

362 HR 14 December 2004, NJ 2006, 448 and HR 9 December 2008, NJ 2009, 157.

363 Simester 2008, pp. 7-9.

364 HR 9 June 1981, NJ 1983, 412 and Strijards 1987, pp. 78-81.

365 HR 12 February 2008, NJ 2008, 263.

366 Rb. Amsterdam 9 June 2011, $L J N$ :BQ7589. See also Rozemond 2006, p. 75.

367 HR 21 September 1999, NJ 1999, 790 and HR 16 November 1965, NJ 1966, 404.
} 
to intoxication is highly restrictive and highly normative. Dogmatic arguments are raised to justify intentional liability, but when these arguments no longer suffice, pragmatic normative reasons are advanced just as easily to ground what is considered the most appropriate outcome.

\subsubsection{German law}

In Germany, there is most room for intoxication as a failure of proof defence. Due to its rigid subjectivist approach to mistakes, it is unquestioned that a mistake due to voluntary intoxication also negates intent. ${ }^{368}$ German courts are likely to accept or, important in practice, to give the defendant the benefit of the doubt that he did not intend the result he brought about. In cases where the intoxicated defendant became violent upon provocation, this mental condition often operates in his favour, possibly negating the intent to kill. In the case where the defendant had killed the victim by hitting him several times on the head with a shovel, the Supreme Court upheld the mere conviction for negligent bodily harm occasioning death, pointing out that amongst other, the high level of alcohol in the defendant's blood might militate against intention. 369

Even the foreseeability required in negligent offences can be rejected due to intoxication. ${ }^{370}$ Many judgments therefore reflect an approach to intoxication that is completely different from the other two Member States. The German Supreme Court approves of these decisions if all elements of intent are carefully considered in the light of the relevant circumstances, even when 'a different outcome might appear to be a more accurate reflection of reality'. ${ }^{371}$ Convictions are quashed if the decision does not clearly ground why intent is accepted despite intoxication. ${ }^{372}$

However, acquittals are also quashed if the decision does not clearly ground why intent is rejected. In some recent decisions, the Supreme Court is taking a less lenient approach towards intoxicated defendants. It quashed the negation of intent in two cases, because courts failed to clearly substantiate which element of eventualis was diminished by the intoxication and to what extent. ${ }^{373}$ The Supreme Court seems to have increased the threshold of when intent is affected and thereby brought its approach more in line with Dutch and English law. First of all, it acknowledged that only when the intoxication was very severe, is it possible that the defendant did not foresee the risk. ${ }^{374}$ Secondly, it recently acknowledged that intoxicants tend to lower inhibitions and therefore unlikely negate the volitional

\footnotetext{
368 Schönke \& Schröder, H. 2006, p. 353.

36915 April 1997 BGH NStZ-RR 1997, 233. See IV.3.6.4.

370 In 19 March 1997 BGH NStZ-RR 1997, 296 the Supreme Court however quashed the acquittal, holding that the lethal risk was foreseeable to the defendant.

37123 June 2009 BGH NStZ 2009, 629.

37222 April 2009 BGH NStZ 2009, 503.

37327 August 2009 BGH NStZ-RR 2009, 372 and 13 January 2010 BGH NStZ 2010, 276.

37424 February 2010 BGH NStZ-RR 2010, 214.
} 
element of dolus eventualis. ${ }^{375}$ This implies that it no longer adheres to the contrary view that was adopted in the abovementioned case of the defendant who hit the victim on the head with a shovel.

Like in Dutch law, if the intoxicated defendant is considered to have acted intentionally or negligently, this leaves open the question whether he should be excused for killing. The normative approach of the Dutch to simply preclude the defence in case of voluntary intoxication is unacceptable in Germany. The capacity to be blamed, to be morally held responsible is laid down in the Criminal Code and requires contemporaneity: it must be present at the time of the commission of the offence. ${ }^{376}$ This brings about that the defendants who lacked the capacity to see the wrongfulness of their actions or to act in accordance with this appreciation tempore delicti are excused for their crime, however great the reproach is for the preceding intoxication.

Besides a full excuse, the sentence of the defendant who is less capable of understanding the wrongful nature of his actions can be mitigated as a form of 'diminished responsibility'. 377 In respect of alcohol intoxication, it appears that in practice, the question of whether or not the excuse or mitigation applies is used to be assessed almost exclusively by the level of alcohol that is measured or estimated to have been in the blood of the defendant. In principle, a level of 3 will excuse and a level of 2 will mitigate. ${ }^{378}$ In more recent years, more factors are taken into account, such as alcohol habituation, physical condition, personality, the pertinent offence and situation. 379

There is a tendency of the judiciary to restrict the excuse-friendly guidelines on alcohol percentage, especially for persons used to alcohol. In one case, even a possible blood alcohol level of 4.5 did not give rise to exculpation. ${ }^{380}$ Some practitioners argue that intoxicated perpetrators were fully capable of seeing the wrongfulness of their actions in order to reach a higher sentence. ${ }^{381}$ As far as violent alcohol induced offences are concerned, the defendant usually does not benefit from the excuse. Research has shown that alcohol can be linked to violent offences but from a certain level of 2.9 on, this connection rapidly decreases. This implies that in practice, usually only the ground of mitigation applies to alcohol

37513 January 2010 BGH NStZ 2010, 276.

376 \$20 of the German Criminal Code: "Schuldunfähigkeit."

$377 \$ 21$ of the German Criminal Code. In his translation, Bohlander 2009, p. 42 uses the term 'diminished responsibility' for 'verminderte Schuldfähigkeit', which should not be confused with the partial defence to murder under English law, which is discussed in X.3.6.2.

378 Krey 2002, pp. 2-3 and Bohlander 2009, p. 134. In 22 November 1990 BGHSt 37, 231 the preference for relying on these levels is explained.

37922 October 2004 BGH NStZ 2005, 329; 6 June 2002 BGH NStZ 2002, 532; Roxin 2006, pp. 890-891; Schönke \& Schröder, H. 2006, pp. 392-393 and Bohlander 2009, p. 134.

38024 July 1997 BGH StV 1998, 258 (level of 3.79); Renzikowski 2000, p. 506 and Joecks \& Miebach 2006, note 64 on $\$ 323 \mathrm{a}$.

381 Fischer, B. \& Rehm 1998, p. 99. 
induced violent offences. This facultative mitigation is not likely to follow when the intoxication was brought about blameworthy. ${ }^{382}$

Nonetheless, the application of the excuse is still wide, especially when considering that when the excuse cannot be ruled out, it applies in dubio pro reo. ${ }^{383}$ As a compensation therefore, a special offence of 'Rauschtat' has been created that punishes with up to five years of imprisonment the defendant who intentionally or negligently got intoxicated and committed a wrongful act, for which he cannot be punished due to the excuse. ${ }^{384}$ Conduct which in itself is innocent is punished. The committing of the unlawful act is strict; the actor only needs to have intent or negligence as to the intoxication. ${ }^{385}$ Clearly, the Rauschtat is hard to reconcile with German doctrine. As mentioned, strict liability was said to be out of the question in criminal law. Secondly, the offence enables the punishment of an excused and therefore blameless person. The offence is accepted as an inevitable product of the fundamental legal dilemma surrounding the capacity of the intoxicated offender, intended to express and uphold both the principles of mens rea as well as the value that harmful conduct should not go unpunished even when committed in a severely altered state of mind. ${ }^{386}$

Nevertheless, the maximum penalty of five years imprisonment, has given rise to ongoing concern about letting offenders get off too easily. Just as in other legal systems, it is deemed unacceptable if the defendant, who at the time of intoxication intends or is negligent as to the commission of an act committed in a state of incapacity, could not be punished for an intentional or negligent offence. ${ }^{387}$ It has been proposed to increase the maximum sentence to the maximum for the wrongful act committed. It has also been suggested that intoxication as a temporary 'disorder' should not be excluded from the excuse, which after all, although not literally, deals with constitutional, continuous deficiencies of the mind. However, no reform has ever been enacted. ${ }^{388}$

The most relevant proposal in this context is to ground liability on the doctrine of actio libera in causa. There are different perspectives on how far this doctrine should go that were already mentioned above. A narrow and least controversial perspective uses prior fault in scenarios where the actor intentionally got intoxicated

27 March 2003 BGH NJW 2003, 2394; Renzikowski 2000, p. 500; Schönke \& Schröder, H. 2006, pp. 403 and 416-417; Beulke 2008, p. 143 and Fischer, B. \& Rehm 1998, p. 97. See also $\$ 7$ of the Military Criminal Law Act (Wehrstrafgesetz).

18 August 1983 BGHSt 32, 48.

$\$ 323 \mathrm{a}$ of the German Criminal Code and 122 of the Administrative Offences Act (OWiG). Compare Law Commission 1995, pp. 42-45.

Hettinger 1988, pp. 38-39; Senge 2006, notes 23-24 on $\$ 122$ of the Administrative Offences Act (OWiG). The issue is controversial: some have argued that the defendant should have at least been able to foresee that he would commit such an unlawful act when intoxicated, see Joecks \& Miebach 2006, notes 50-52 on \$323a; Roxin 2006, pp. 1037-1039 and Kühl 2007, note 13 on $\S 323 a$.

Fischer, B. \& Rehm 1998, pp. 98-99. See also Fletcher 1978, p. 847-848 and 852.

Hirsch 1997. See also Renzikowski 2000, pp. 476-479 and Albrecht 1998, p. 87.

Renzikowski 2000, pp. 487-505; Hettinger 1998 pp. 444-449 and Roxin 2006, p. 922. 
in order to facilitate the planned offence. If the defendant became intoxicated with a view to gain courage or lose the aforementioned capacity, liability should still follow. ${ }^{389}$ At the other side of the continuum there are those who argue that prior fault applies when the offender cannot reasonably exclude the possibility of future offences at the time of intoxication, without even basing it on subjective indicators such as previous experience with becoming violent. ${ }^{390}$

The application of the actio libera in causa is hardly as controversial as its dogmatic grounding. ${ }^{391}$ It is either based on arguments that view the intoxication and the offence as one act, or viewed as an exception to the aforementioned requirement. For example, the causing of the defence can be seen as the beginning of the commission of the offence definition, the intentional setting in motion of a chain of events. ${ }^{392}$ In the end, it seems no rationale is satisfactory, ${ }^{393}$ but this does not prevent the German Supreme Court from applying it. ${ }^{394}$ If the actor's intention was already aimed at the specific offence at the time of intoxication, he is convicted for the intentional offence and the excused rejected. ${ }^{395}$ The Rauschtat and the controversial application of the actio libera in causa reflect very well that intoxication may not always lend itself for dogmatically consistent solutions. Realizing that normative considerations play an important role in every legal approach towards intoxicated defendants, it would be perhaps simpler to accept these rules as a legitimate exception to the principles of mens rea.

\subsubsection{Synthesis}

In the end, the solution that would be most appropriate for the EU, depends on the more general choices made as to how specific fault should be and whether defences can be limited or precluded by considerations of actio libera in causa. In the context of defences, the consensus is that they can be limited in the extreme cases where the intoxication was intentionally brought about in order to commit the offence in that state. The defendant is not allowed to rely on any excuse like insanity. In less extreme cases, it is submitted that an excuse can also be rejected. As will become clear in the next chapter, excuses are concerned with a normative judgment, taking

\footnotetext{
389 Conditional intent as to the offence also sufficed in 13 September 2001 BGH NStZ 2002, 28.

390 Fischer, B. \& Rehm 1998, p. 97; von Heintschell-Heinegg 2009, notes 71-75 on §20; Hettinger 1988, pp. 190-194 and Daly 1978, p. 391.

391 Roxin 2006, p. 914 and Schönke \& Schröder, H. 2006, pp. 403-404.

392 See 24 November 1967 BGHSt 21, 381. Beulke 2008, pp. 144-147 favours the exception model, which is rejected by Roxin 2006, p. 915.

39322 August 1996 BGHSt 42, 235; Hettinger 1988, pp. 437-465 and Schönke \& Schröder, H. 2006, p. 406.

39419 February 1997 BGH NStZ 1997, 230 and 7 June 2000 BGH NStZ 2000, 584. Beulke 2008, p. 146 submits however that the view that actio libera in causa should be rejected altogether is gaining ground.

3954 May 1962 BGHSt 17, 259; 1 June 1962 BGHSt 17, 333; 24 November 1967 BGHSt 21, 381 and Beulke 2008, p. 146.
} 
all circumstances of the case and the defendant into consideration. A strict temporal focus on the time when the offence was committed is not in line with this normative character. When the defence is rejected, the lesser degree of blameworthiness can, but need not be taken into account in sentencing.

In this chapter, the question is how the actor, who could not form mens rea at the time he committed the offence because he was heavily intoxicated, can be held liable. First of all, whereas the voluntariness of the intoxication plays a role in defences and in sentencing, it is irrelevant in the context of a psychological concept of dolus. Secondly, it is reiterated that in result based offences of culpa, intoxication presents no problems of contemporaneity. In fact, culpa or luxuria can be grounded in the intoxication. This brings about that intoxication is relevant only to dolus and recklessness. In principle, all Member States acknowledge that intoxication can negate fault, but the situations in which this will actually be accepted differ considerably. It is submitted that the awareness and volitional aspects of fault should not be held to be negated by intoxication too easily. Whether the mistake was brought about by stupidity or intoxication, the defendant should be completely ignorant for the mistake to negate knowledge. After all, a drunken intent is also intent. Moreover, there are numerous ways to overcome the inexorable logic that a mistake negates fault. For example, mistakes on normative elements are hardly relevant. The fact that the drunken actor does not consider his exposure indecent does not affect his intent. ${ }^{396}$

Another method to attribute intention was discussed, namely the actio libera in causa. Intention or recklessness as to a crime is not negated when it was already present before the intoxication. This is even accepted in the German legal system and moreover, consistent with the principle of correspondence and the concept of dolus advocated here. Dolus is present in case of an intentional actio libera in causa, where the defendant got intoxicated in order to commit the crime. However, dolus should not be held present by a prior fault of recklessness or negligence. The foreseeability of committing an(y) offence whilst intoxicated does not suffice for the specific form of intent required in the actual offence. This approach, which was identified in Dutch law, substitutes a standard of intent by one of negligence. If the prior fault as to the offence is one of recklessness, for example because the defendant knew he had a tendency for violent behaviour when drunk, he should be convicted for the reckless offence only. There is no reason to fear that defendants may get off too easily as usually, the intoxicated defendant still intended to hurt the victim and there is thus no need to resort to a mere offence of recklessness.

\section{Concluding ReMARKS}

All problems that have been raised in this chapter followed from the strict application of legal principles. Whereas it is accepted that fault should always be an 
element of the offence definition, instrumental reasons are deemed legitimate to override this requirement. Whereas it is accepted that mens rea and actus reus should coincide in time, it is often deemed inappropriate to negate intention when this relationship is lacking. The principles of correspondence are considered to be obstacles to reaching liability or a more serious form of criminal liability. As a consequence, attempts have been made to reformulate correspondence or make permissible exceptions to it. The underlying goal of this 'rethinking' is simple; to enable liability and ground this in legal principle.

This rethinking has been fuelled by two developments in the last century. First of all, criminal law has expanded from the classic mala in se, to an enormous array of regulatory offences. This context warranted a more relaxed application of the principles, based in necessity and grounded in its quasi-criminal character. For example, proof of fault appeared particular difficult here and penalties are of a less criminal character. Together with this growth, scholarly interest in criminal law has also significantly increased. Without this interest, the problems of reconciling desired outcomes with the principles that generally apply would probably not have been positioned so sharp.

The most important conclusion is that the outcomes are more or less the same everywhere. The only difference concerns the legal reasoning underlying the outcome. This is a quite familiar conclusion in comparative legal research, which proves that the Member States of the European Union to a large extent share the same beliefs about mens rea in criminal law. The different approaches that are taken to ground the same outcomes reflect a different way of legal thinking, but this does not differ so much that a general part of EU criminal law is impossible to identify.

The legal thinking that is common in Germany can be juxtaposed with that of the Dutch. In Germany, the principles of correspondence are taken very seriously. Criminal law is tried to be kept pure, and in order to facilitate this, regulatory forms of criminal conduct are outsourced into administrative law. Every possible legal problem receives intricate attention, leading to often complex legal reasoning to reconcile outcome with principle. ${ }^{397}$ The Dutch, by contrast, focus almost only on outcome. Pragmatic concerns simply outweigh any problems of legal theory. Many dogmatic problems are not clearly identified, let alone legitimized. This may lead one to question whether a requirement of contemporaneity even applies in this legal system. ${ }^{398}$ The English approach to these issues is largely pragmatic as well, but since the nineteen sixties, there are many scholars who focus on the subjective requirements of criminal law. As a result, the dogmatic grounding of outcomes in principle has received more attention than in the Netherlands.

An additional reason that can explain the comparative lack of dogmatic attention in the Netherlands is that the concept of fault is quite broad. Intent must relate to an abstract result. What specific legal interest was harmed and in what way this was

397 Stratenwerth in Eser \& Fletcher 1988, pp. 1072-1073.

398 It is hardly ever explicitly discussed as a general principle in Dutch textbooks on criminal law. 
brought about is irrelevant and thus already excludes many problems of correspondence. In contrast, German criminal law adheres to a more specific concept of intent. Amongst others, it requires that intent must relate to the causal chain of events in its essential features. I have explained that this leads to many problems of correspondence in the context of aberratio ictus and dolus generalis. In turn, these problems have given rise to complex solutions and strategies to avoid or mitigate the outcome dictated by principle. The overall picture of criminal liability becomes highly complicated and therefore hard to grasp. Such a situation is undesirable in a general part of criminal law that aims to be simple, foreseeable and enforceable. Therefore, dolus should be treated as generalis, and not relate to the specific identity of the victim of the modus quo.

The yardstick for assessing correspondence is the offence definition. Fault does not relate to more than the offence definition requires. In homicide, the identity of the victim is irrelevant, so the error in persona is irrelevant to intent. On the contrary, when the status of the victim, like a civil servant, is included in the offence definition, fault must relate to it as well, unless it has been made clear that the element is strict. Such offences are the exception that confirms the rule of dolus generalis. Mistakes on legal aspects are usually irrelevant because the offence definition only rarely includes legal or normative aspects. If it does, fault only relates to the underlying circumstances. The defendant does not have to understand these elements like a lawyer would. Dolus is neutral.

This positivist criterion for assessing correspondence of what is included in the offence definition is not decisive. More normative factors have also been identified. For example, fault should relate to the essential aspects of the offence, to those elements that give the offence its typical character. This brings about that the offence definition cannot be drafted in a way that makes the essential element strict. The essential character of an offence element can even determine the degree of fault and the scope of contemporaneity. Consider the appropriation in theft. In contrast to the labelling of this appropriation as wrongful, the defendant must have intended to appropriate for himself or someone else. Nothing less than dolus directus suffices as to the appropriation. Secondly, this intention must exist at the time he took the object, like a car, away. The actus reus of taking away cannot be stretched to create a moment of contemporaneity, when the defendant only later decides to appropriate the car instead of for example merely using it for a joyride.

The rules of correspondence ring hollow if they are sidelined by procedural means. If dolus needs to relate to all offence elements, but this is easily proven or the burden of proof is reversed, the position of the defendant is not much better than in strict liability. Other normative limitations can be derived from principles of criminalization. These limitations to what can be criminalized make sure that the special part is kept within appropriate limits. After all, to overcome or avoid problems of correspondence, sometimes fallback offences are created that criminalize conduct that is in itself innocent. Examples are the carrying of objects, which can be used for a burglary and the German offence of intoxication. In 
deciding whether to use criminal law or other measures, the Institutions and Member States should focus on these principles of criminalization. ${ }^{399}$

Some issues of correspondence nonetheless remain problematic. It is for example difficult to reconcile strict liability with the fault requirement. Cases of actio libera in causa also seem to present an insurmountable legal problem. The idea that the person who creates the conditions that preclude his liability should not be allowed to rely on this is strong. It is accepted in general that the intoxicated person should be held liable, the victim protected, but this liability apparently cannot be reconciled with contemporaneity. In cases like these, it is simpler and more straightforward to accept that liability is an exception to principle based on legitimate interests. This is to be preferred over fine-grained solutions that are too sophisticated to apply or principled yet unsatisfactory negations of liability, which in turn require special criminalization to punish the defendant.

399 See draft Council conclusions on model provisions, guiding the Council's criminal law deliberations, Brussels, 27 November 2009 16542/2/09 REV 2 and EP Committee on Civil Liberties, Justice and Home Affairs, draft report on harmonisation of criminal law in the EU of 18 January 2012, no. 2010/2310. 

Part 3

\section{Defences}



This part is structured as follows. First, I will demarcate the object of research by explaining that defences do not deny the offence charged. Instead, they negate one of the two implied elements of criminal liability: wrongfulness or blameworthiness. Furthermore, the defences discussed in this part are of general application, deal with a case on its merits and completely negate liability when they are accepted.

In comparative legal research, such a demarcation should never be too strict. The apparent unavailability of a particular defence in a legal system requires an investigation into legal concepts or doctrines that fulfil an equal or similar function. For instance, the English defence of loss of control diminishes the charge to a lesser offence and thereby partially fills the gap left by the unavailability of a defence like self-defence-excess. Although loss of control does not negate liability and therefore does not qualify as a complete defence in this research, it will be assessed, for it fulfils a similar function.

In chapter VII, defences will be demarcated from what can be called the offence part of criminal liability. Defences are not a rebuttal of the offence charged: they affirm that the offence definition has been fulfilled, but raise circumstances that the offence should nevertheless be justified or the defendant excused. In some cases, raising a defence simply implies the charge is denied, no different than when the defendant argues he did not intend to kill the victim. I will solve this apparent inconsistency by identifying normative criteria to categorize elements within the offence and defence part of criminal liability. In this way, an even clearer picture will emerge of what defences are.

The distinction between justifications and excuses is paramount or at least wellknown in all legal systems under investigation. This distinction will be put under close scrutiny. It will be argued that even if the implications of the distinction are rejected, such as the assumption that all participants in justified conduct are justified, there are still good reasons to make the distinction. Accordingly, the discussion of specific defences will be structured along the lines of justifications and excuses. This means that the rationale of justifications and the element of wrongfulness it negates will be explained, after which self-defence, necessity and so on will be discussed. The chapters on excuses will also start with a general discussion on its rationale and its mirror image of blameworthiness, before going into the specific excuses.

Perhaps needless to say, is that the results of the research are presented again in a manner that emphasizes what defences should look like in EU criminal law. The common ground of the investigated legal systems is taken as a starting point, and only national differences and controversial issues are explicitly addressed. Choices in favour of approaches are then made by reference to the criteria mentioned in chapter II. 



\section{Chapter VI \\ WHAT ARE DEFENCES?}

There are many defences in criminal law, but only one specific category is discussed here. A defendant can argue he did not commit the offence; that it has happened too long ago; that evidence was obtained unlawfully or that an offence element should be interpreted more restrictively. All of these claims are not considered to be defences in the meaning of this research. In this book, a defence is a claim that does not deny the charge or the validity of the legal proceedings, but argues that the fundamental requirements for criminal liability of wrongfulness and/or blameworthiness are absent. ${ }^{1}$ Several distinctions can be made to demarcate defences from other claims.

\section{Affirmative Defences}

First and foremost, a failure of proof defence can be distinguished from an affirmative defence. Only the latter defences are properly labelled defences. A failure of proof defence seeks to negate the offence charged. The defendant argues, for example, that he had an alibi or that he did not intend to cause a result. ${ }^{2}$ In contrast, by raising an affirmative defence one does not deny that an offence has been committed. Instead, the defendant aims to present additional reasons why, all things considered, this offence should not lead to criminal liability. For example, accepting self-defence does not negate that the aggressor was intentionally killed. It does however reject that the conduct was wrongful in the circumstances. Self-defence affirms the charge, yet negates criminal liability.

It can be argued that a denial of a fault element, when compared with an alibi, is also partially an affirmative defence. The defendant who rejects that he intended to kill someone, at least concedes that he killed that person. He argued 'I did it, but I did not do it on purpose'. Affirmative defences however, do not militate against the charge at all. A plea does not only become a failure of proof defence when it completely negates all elements of the charge, but also when it only rejects one element of the charge. This can be the conduct, the causal requirement, the fault element and so on.

A defence relates to the framework of criminal liability, because it denies its second or third tier, namely that the conduct was wrongful or the defendant blameworthy. The raising of an alibi or the denial of fault relates to the first tier of the framework, because it refutes that the offence definition is fulfilled. Defences are rejections of the second and third tier of criminal liability, consisting of the

See Strijards 1987, p. 18 and Ormerod 2008, p. 269.

Simester \& Sullivan 2007, p. 19 and Leverick 2006, p. 22. 
so-called implied elements of wrongfulness and blameworthiness. Without wrongful conduct and a blameworthy actor, there can be no criminal liability. The dichotomy coincides with the dichotomy of defences, that of justifications and excuses. As will be explained later in detail, wrongfulness is negated by justifications, blameworthiness by excuses.

However, if we consider that some offences include the elements of wrongfulness and blameworthiness, the distinction between failure of proof and affirmative defence is put under pressure. In these cases, a defence normally considered to be affirmative operates as a failure of proof defence. For example, self-defence is considered to be an affirmative defence, yet if the defendant is charged with an offence that includes wrongfulness, raising self-defence implies a rejection of the charge, just like denying intention or raising an alibi. In that context, self-defence therefore seems to be a failure of proof rather than a defence that affirms the charge.

Nevertheless, it will be explained later, that although such a formal perspective on defences undermines the basic distinction, the distinction is still valid and useful. Decisive for the classification and demarcation of defences in this research is its effect of negating wrongfulness or blameworthiness. Sometimes wrongfulness and blameworthiness are already included in the first tier of criminal liability. The circumstance that self-defence denies the charge does not mean it should be treated like a failure of proof defence. In some cases, it does, but this does not alter the general classification of self-defence as an affirmative defence. The problem will be discussed further in the next chapter.

\section{General DEFenCes}

This research only deals with defences of general application. Many defences formulate an exception to a specific criminal offence and are therefore often included in a subsection of the pertinent offence. These 'statutory' defences will not be considered in this book, unless this is necessary for a comprehensive legal comparison. They do not qualify as general defences of criminal law and therefore have not right of existence in a general part of criminal law for the EU. For these reasons, a defence based on the parental right of chastisement is excluded too. Even if a defendant this defence is still available in this day and age, it can only be raised against a charge of inflicting bodily injury. ${ }^{3}$

The term general should not be misunderstood to mean that the defence must be able to apply to each and every single offence. First of all, there are combinations of defences and offences that are hardly imaginable, like self-defence in relation to fraud. If a general part of European criminal law would only apply to offences of a

3 The general trend is to make such a defence unavailable, outlawing all forms of corporal punishment of children, see section 58 of the Children Act 2004; article 1:264 of the Dutch Civil Code and $§ 1631(2)$ of the German Civil Code. Nevertheless, there is much support for the view that light forms of chastisement can be disqualified as injury. 
regulatory nature, self-defence would not need to be included. It would also be unlikely that insanity and duress would ever be relevant. Against regulatory offences, a defendant is most likely to raise a mistake of law, a necessity type defence or a plea of due diligence.

Secondly, the application of some general defences has been restricted. For example, duress in England cannot be raised against a charge of murder. The terminology that will be used in this regard is that the defence of duress is 'inapplicable' or 'unavailable' to a charge of murder in England. In contrast, duress is 'applicable' to murder in the Netherlands, which means that it can be 'accepted' or 'rejected' after assessing on the merits of the particular case. ${ }^{4}$ If duress applies to murder, but the defendant is not allowed to rely on it because of his special position in law or because he can be reproached for bringing about the situation of duress, it will be argued the defence is 'precluded'.

The concept of general defences is common on the continent, but less so in England. This is related to the aforementioned unfamiliarity and scepticism to a general part of criminal law in England. The recognition of general defences is difficult for a legal culture that focuses on the specific. Moreover, the recognition of affirmative defences depends on the distinction between offence on the one hand and wrongfulness and blameworthiness on the other. Whereas wrongfulness and blameworthiness are now recognized by prevailing opinion in England, they are still not as self-evident as in legal systems on the other side of the Channel.

\section{Substantive defences}

By limiting the scope of this research to substantive defences, defences based on jurisdiction, statute of limitations, immunities, entrapment and so on are excluded. A defence must relate to the merits of a case. These defences relate to the precluding of criminal proceedings, not the assessment of criminal liability. The drafters of the Rome Statute therefore used the term 'grounds excluding criminal liability'. 5 The fact that a head of state may not be prosecuted does not mean he did not commit an offence. ${ }^{6}$ These defences fall outside the realm of the framework of criminal liability. They do not relate to the offence, wrongfulness or blameworthiness. ${ }^{7}$

Infancy can therefore also be excluded from the scope of defences of this book. It is assessed only in relation to the abstract age of the defendant at the time of the offence. Similar defences, like insanity, can also be argued to relate to something more fundamental than offence, wrongfulness or blameworthiness. Nevertheless, it requires an assessment as to the effect of the mental disorder on the offence and the offender, which makes it a defence that is judged on the merits of the case.

I can also contrast a rejection a priori and in abstracto with a rejection in concreto.

Ambos 1999, p.2 and Ambos 2006, p. 661.

Knigge in Remmelink 1987, pp. 291-293; Strijards 1987, p. 20-32; Duff 2007, pp. 179-191 and

Beulke 2008, pp. 51 and 176.

$7 \quad$ Bohlander 2009, pp. 17 and 146. 
A plea to the fundamental freedoms of Union law, like free movement of goods and service, neither is a defence in this meaning. Just like the argument that a criminalization violates a human or constitutional right, it is a plea of noncompatibility with higher-ranking law. Moreover, when accepted, that claim sets aside the norm as such, rather than its mere application to a specific case. For example, the automatic expulsion of EU citizens after a criminal conviction is incompatible with article 33 of Directive 2004/38 on free movement. In relation to these EU citizens, offences that criminalize the being found on a territory whilst having been declared an undesirable alien, like article 197 of the Dutch criminal code, should be set aside. The EU citizen is neither acquitted because he is justified for committing the offence, nor because he is excused, but because the norm must be set aside under the principle of supremacy of Union law. ${ }^{8}$

Because some defences not relate to wrongfulness or blameworthiness, it has been argued in Germany and the Netherlands that a fourth tier should be added to the framework of criminal liability, dealing with the worthiness and/or need to punish. This fourth element should explain why defendants were not punished or not even prosecuted, despite the fact that they fulfilled all elements of criminal liability. ${ }^{9}$ The withdrawal from attempts and the exclusion of punishment for the person who obstructs the punishment of a relative have also been placed in this context. ${ }^{10}$ Such a fourth element has however never been accepted by the judiciary or prevailing opinion in the two States. There was no practical need to acknowledge this, as the possibilities not to punish or prosecute are already covered by law. ${ }^{11}$ In addition, it is argued that a fourth element does not deal with the conditions of criminal liability, but with conditions of punishment. ${ }^{12}$

Nevertheless, in EU law, a 'defence' of de minimis non curat praetor has generally been accepted. If the harm caused by the offender is minimal, he will not be prosecuted or punished. The Commission will not take action in situations where the competition was not appreciably restricted or trade not appreciably affected. ${ }^{13}$ In concentration control, a 'SIEC'-test is applied too: only mergers that 'significantly impede effective competition' are declared incompatible with the internal market and are prohibited. ${ }^{14}$ Given the OLAF's limited resources, the Office also selects

15 July 1964, Case 6/64, Flaminio Costa v. ENEL [1964] ECR 585.

Vrij (reprint of 1947) in Buruma 1999 and Roxin 2006, pp. 1041-1050. See also Knigge 1993, pp. 36-37; Kelk 2005, pp. 32-34 and 146-147 and Schönke \& Schröder, H. 2006, p. 155. Similarly, 'pure' defences are said to preclude punishment although wrongfulness and blameworthiness are not negated, see de Hullu 2006, pp. 293-294 and Vellinga, W.H. 1982, pp. $223-225$.

Roxin 2006, pp. 1041-1042 and \$258(6) of the German Criminal Code.

Knigge in Remmelink 1987, p. 299; Kelk 2005, p. 301 and de Hullu 2006, p. 361.

Knigge 1993, p. 41 and Kelk 2005, pp. 32-34 and 146-147.

25 November 1971, Case C-22/71, Béguelin [1971] ECR 949. It should be noted that actions are sometimes taken without the actual restriction of competition. Any threat to competition may suffice.

Regulation 139/2004 of 20 January 2004 on the control of concentrations between undertakings, OJ 2004 L 24/1. State-aid in article 107 TFEU is another example. 
which cases it will investigate. The extent as to which the EU budget has likely been affected is an important factor in this policy decision. ${ }^{15}$ Finally, Member States should apply a proportionality check to prevent European Arrest Warrants from being issued for offences which, although they qualify for surrender, are not serious enough to justify the measures which an execution of such a warrant requires. ${ }^{16}$

At the same time, the above-mentioned makes clear that de minimis does not qualify as a defence. It does not relate to the elements of criminal liability and it merely has the procedural consequence that either no legal action is taken against the offender or that he is not punished. In national law too, the principle is only relevant in sentencing and the decision to prosecute. ${ }^{17}$ It generally does not affect criminal liability, save for the cases, where a de minimis infringement of an interest is interpreted as not fulfilling the pertinent offence element. ${ }^{18}$ For example, the German Criminal Code excludes from the scope of sexual offences, sexual acts that are of insufficient relevance to the respective legal interest protected. ${ }^{19}$ Such defences relate to the interpretation of the offence and are therefore not affirmative. Some Union legal instruments also allow Member States to exclude trifle cases from criminalization. For example, Framework Decision 2004/757 allows Member States to stipulate that the personal consumption of small quantities of drugs falls outside the scope of that Framework Decision. ${ }^{20}$

\section{CoMPlete DEFENCES}

The defences discussed in this book aim to completely negate criminal liability. As a consequence of this complete negation, the defendant cannot be punished. As will be explained, the defendant who is held insane can still be institutionalized in a mental hospital, but he cannot be punished. In contrast to complete defences, so-called partial defences only reduce criminal liability to a lesser offence. Partial defences are common in the English legal system. For example, acceptance of the aforementioned partial defence of loss of control reduces a charge of murder to the

15 This is laid down explicitly in article 5(1) of the Amended Proposal for a Regulation amending Regulation (EC) No 1073/1999 concerning investigations conducted by the European Anti-fraud Office (OLAF) and repealing Regulation (EURATOM) No 1074/1999, 17 March 2011, COM(2011) 135.

16 Report of the Commission on the implementation since 2007 of the Council Framework Decision of 13 June 2002 on the European arrest warrant and the surrender procedures between Member States, 11 April 2011, COM(2011) 175, pp. 7-8.

17 German Prosecutors are not always obligated to prosecute, see $\$ \S 153$ and $153 \mathrm{a}$ of the Code of Criminal Procedure.

18 Schönke \& Schröder, H. 2006, p. 178 and Horder 2001, pp. 25-30.

$19 \$ 184(1)$ of the German Criminal Code. See also $\$ \$ 247$ and 248 of that Code.

20 Article 2(2) of Framework Decision 2004/757 of 25 October 2004 laying down minimum provisions on the constituent elements of criminal acts and penalties in the field of illicit drug trafficking, OJ 2004 L 335/8. 
lesser offence of manslaughter. Although these partial defences are not considered proper defences, some of them will nevertheless be discussed in order to make the legal comparison between the Member States comprehensive. Loss of control, for example, partially fills the gap created due to the unavailability of self-defenceexcess in English law.

Criminal liability should be separated from punishment. Punishment presupposes criminal liability, but criminal liability does not necessitate punishment. In other words, criminal liability enables, but not necessarily brings about punishment. For example, the defendant can be convicted, yet not punished. ${ }^{21}$ The convicted person may be happy that he is not imprisoned or fined, but the conviction already stigmatizes him. The establishment of criminal liability communicates to that person and the public that he is a criminal. In any general part of criminal law, rules on sentencing are therefore distinguished from rules on criminal liability.

This distinction and the concept of affirmative, complete defences are not selfevident from a historical perspective. Self-defence already existed long before the recognition of the concept, but was generally treated in the context of pardoning the intentional killing, rather than negating criminal liability altogether. The insight that a defence negates wrongfulness or blameworthiness, elements essential to criminal liability, was not developed until the end of the $19^{\text {th }}$ century. ${ }^{22}$

\section{Conclusion}

From the demarcation of this part of the research, it has become clear that defences are affirmative to the charge, can apply in theory to all offences, relate to the wrongfulness of the actor or blameworthiness of the act, and when accepted therefore completely negate criminal liability. Accepting a defence means that whereas the actor has apparently satisfied all elements of the offence charged, there are reasons, all things considered, lying within the nature of the conduct or the personal circumstances of the actor, not to hold him criminally liable.

Defences exist because the legal order only punishes conduct that is, all things considered, wrongful and only those defendants that are blameworthy. The availability of defences is essential to ensure this. Usually, the offence is wrongful and the offender blameworthy, so this is assumed with the fulfilment of the offence definition. This explains that the principles of wrongfulness and blameworthiness can be safeguarded by the creation of general principles. By treating defences as general legal principles, the legislator does not have to include this possibility into every criminalization. In addition, general defences facilitate the certainty and fore-

\footnotetext{
21 Article 9a of the Dutch Criminal Code and section 12 of the English Powers of Criminal Courts (Sentencing) Act 2000.

22 Vrolijk 2004, p. 193-196 and Witteman 1997, pp. 216-218.
} 
seeability of criminal liability. They increase the consistency of the law and enable the development of theory.

The creation of general rules on defences is however not only convenient. The recognition of wrongfulness and blameworthiness as general elements of criminal liability through general defences guarantees its non-derogatory normative status in law. There can be no liability, hence no punishment, without a wrongful act committed by a blameworthy actor. Defences distinguish these two elements of criminal liability as something, which the legislator cannot simply circumvent, as something more fundamental than an offence definition or statutory defence. Regardless of the manner in which the legislator has drafted an offence, a defence will always negate liability based on the fundamental principles of wrongfulness and blameworthiness. 



\section{Chapter VII \\ OFFENCES AND DEFENCES}

After demarcating and defining 'defences', the subject is investigated by contrasting it with the offence definition, which is the mirror image of defences in many ways. In the framework of criminal liability, as introduced in the beginning of the previous chapter, the offence definition was distinguished as the first tier of criminal liability. Defences cover the second and third tier of that framework. When the offence definition has been fulfilled, it is assumed that the act is wrongful and the actor blameworthy, the assumption only to be negated by the acceptance of a defence. In other words, offences inculpate, whereas defences exculpate. The offence part of criminal liability is paradigm, whereas defences provide for the exception. The offence defines the specific conditions of criminal liability, whereas defences refer to the general requirements for criminal liability, which are wrongfulness and blameworthiness.

In this chapter, the legal differences between offence and defence will be discussed. There exist some general rules on dealing with inculpating aspects of liability that do not, or at least apply differently, to the exculpating aspects of criminal liability. First, it will be argued that the principle of legality applies in a different way regarding defences. Second, whereas the Prosecutor must prove all elements of the offence, the defendant has to raise a defence if he wants to rely on it. Third, the acceptance of a defence is reflected in Dutch judgments to separate this special acquittal from the 'normal' case where the offence could not be proven.

Fourth, in order to rely on a defence and escape liability, the defendant must at least be aware of the circumstances that ground this defence, such as the fact that he was being attacked in self-defence. If the absence of the defence is part of the offence however, it is implied this is not required. Finally, the rules on mistake differ in relation to defences. I already mentioned that an honest mistake on the offence definition can negate intention, and if reasonable also negligence. A mistake on the facts that, if correct, would give rise to a defence, however only excuses the defendant and only if it was reasonable.

These differences bring about that the categorization of offence and defence has important legal consequences. It is therefore problematic that although the dichotomy is widely accepted in all Member States, controversy remains. First of all, some offences include the absence of defences into their definition. Most clearly, this is done by including in the offence "without lawful authority or reasonable excuse". Secondly, it has already been explained that reckless and negligent offences imply the absence of justifications. When these offences are charged, raising a defence amounts to a denial of the offence. The defendant does not argue

Sections 7(1), 7(2), 8(2) and 8 (3) of the English Animal Welfare Act 2006; section 4(1) of the English Aviation Security Act 1982 and section 2(1) of the English Child Abduction Act 1984. 
he should be justified or excused. Instead, he formally argues he did not commit the offence definition: the affirmative defence becomes a failure of proof defence. This raises questions regarding the aforementioned ramifications of the categorization. If the defence operates as a denial of the charge, should a mistake on self-defence negate intention? Should the prosecutor prove the absence of self-defence? Must the defendant no longer be aware of the justifying circumstances?

Accordingly, it is disputed whether a principled distinction can be made between elements that belong to one or the other category. Some authors deny this, arguing that the distinction between offence and defence depends on accidents of legislative drafting or judicial whim. ${ }^{2}$ It will be argued however, that there can be good reasons to include the absence of a defence into an offence definition. If, for example, the absence of consent is what gives the offence is essential character, like in rape, it should be included into the offence definition. This criterion for what should be included into the offence definition was already introduced in the last chapter, where I argued that elements essential to the offence in question may never be made strict. Essential are all those elements that give the offence its typical character and that separate it from other offences. The scope of the category of defences can be deduced a contrario.

This perspective enables one to retain the paramount distinction between offence and defence. It provides for a solution to the abovementioned questions on the ramifications of the distinction. It will be argued that if the absence of a defence is included into the offence definition because it is essential to it, the defence should be treated as a failure of proof defence. If the absence of a defence is included in the offence definition for other reasons, it should be treated as an affirmative defence. The fact that the defence formally operates as a denial of the charge, as a failure of proof defence, does not change the general rules on defences mentioned above, such as that the defendant must have acted in awareness of the circumstances that gave rise to it.

\section{Legality}

I will now first discuss in more detail the ramifications of pigeonholing elements as an offence or defence element, starting with the principle of legality. This principle encompasses several rules governing the interpretation and application of offence definitions. The principle aims to safeguard the position of the defendant vis-à-vis the state. It traditionally emphasizes that his position may not be deteriorated by ambiguity in law or by extensive interpretation of offence elements. Therefore, retroactive application of offences is only allowed, as long as it benefits the

2 See Williams 1982; Gardner 2004, pp. 817-819; Sangero 2006, p. 28 and Simester \& Sullivan 2007, p. 607. 
defendant. ${ }^{3}$ Extensive interpretation is also only allowed as long as it benefits the defendant. The question discussed here is whether these rules should also apply to defences.

\subsection{Limiting defences}

An influential perspective is that the rationale of legality also applies to defences. From that perspective, the judicial creation and extension of defences is unproblematic: this limits, rather than extends the scope of liability. ${ }^{4}$ It also follows that existing defences cannot be abolished or restricted ex post facto, because this would retroactive aggravate criminal liability and thus deteriorate the position of the defendant. ${ }^{5}$ Nevertheless, there are other considerations relevant here. Just like some conditions of defences have been applied more leniently over the years, ${ }^{6}$ others have been applied stricter. ${ }^{7}$

Moreover, retroactive penalisation has been accepted when it concerns manifestly illegal acts. Consider that preceding the unification of Germany, border guards who had been ordered to shoot GDR citizens trying to flee the communist regime, were justified under (at least the practice of) the law. Nonetheless, after the unification of Germany, they were held criminally liable because it was patently clear that they committed serious crimes. ${ }^{8}$ Concerns of retroactive penalisation were outweighed by the manifest illegality of the shooting of unarmed civilians. As laid down in article 7(2) ECtHR and 49(2) CFR, the limitation to the rule of nonretroactivity applies to both offence and defence. When conduct is considered to be 'criminal according to the general law recognized by civilised nations', a defence that existed at the time the offence was committed may be withheld, just like an offence definition that did not exist at that time may be applied. Accordingly, the German Supreme and Constitutional Courts held that the pertinent justification was clearly in violation with higher (international) law. ${ }^{9}$

In Anglo-American law, a distinction is made between so-called 'conduct' and 'decision rules'. The principles of legality do not apply to defences because defences are not part of the guiding message of criminal law and are solely designed to direct court rulings. This would imply defences can be retroactively abolished. However,

3 This principle of lex mitior is recognized as a general principle of criminal law by the ECJ, see 1 June 1999, Case C-319/97, criminal proceedings against A. Kortas [1999] ECR I-3143.

4 De Hullu 2006, p. 85; Kelk 2005, pp. 123-124 and Bohlander 2009, p. 81.

5 Schünemann 1985, pp. 367-368.

6 For example, in the Dutch and English concepts of self-defence, prior fault is now less likely to preclude the defence, see IX.3.4.5.

7 For example, the German Courts have applied the condition of proportionality stricter over the years, see Fletcher 1978, pp. 573-574 and IX.3.5.

Bohlander 2009, pp. 81-82 and 120.

3 November 1992 BGHSt 39, 1; 25 March 1993 BGHSt 39, 168; 20 March 1995 BGHSt 41, 101 and 24 October 1996 BVerfGE 95, 96. These convictions were approved by the ECtHR, see K.-H. W. v. Germany, appl. no. 37201/97, 22 March 2001. 
more often, a more precise distinction is made, whereby only excuses are excluded from the protecting scope of legality. It is argued that excuses are not intended to direct an individual's behaviour. They contain only a decision rule for the judge. Justifications, in contrast, do constitute guiding norms or conduct rules for legal subjects. The principle of legality thus applies to the offence definition and justifications, but not to excuses. ${ }^{10}$ This categorization is criticized. It is hard to reconcile the impulsive nature of excuses with a situation where an actor plans his behaviour in line with case-law on excuses. ${ }^{11}$ Nevertheless, a person under duress can also make well-considered decisions. ${ }^{12}$ For example, the person who is coerced to rob a bank under threat of serious injury may very well trust he can later rely on the excuse of duress. The distinction thus does not appear useful in this regard.

\subsection{Extending and creating defences}

It is settled that courts can no longer create new offences, but whether courts can create defences remains an open question. In one approach, courts may create defences because this benefits the defendant. ${ }^{13}$ Moreover, by creating a defence, the court can prevent that blameless persons are convicted. For example, the Dutch Supreme Court created the excuse of lack of all blame to ensure that the blameless defendant could be acquitted. They felt obligated to do so, because without the excuse, the defendant would be convicted. This would violate the principle of guilt, the cardinal rule of criminal law hat no one may be punished without being held blameworthy. A conviction of a blameless person would diminish the public's respect for the law. If no excuse had been created, officials would have had to bend the rules in order to acquit the defendant. ${ }^{14}$

The contrasting approach is to preclude courts from creating offences. First of all, third parties affected by the defendant's conduct also need to be protected by a clear and foreseeable scope of criminal liability. ${ }^{15}$ Furthermore, it is argued that the state of defences has reached a state of maturity and consolidation. Consider that the Dutch Supreme Court created the abovementioned defence in 1916. Since it functions as a safety-net to acquit blameless defendants, it is highly unlikely that it will be necessary to create an excuse again.

10 Ashworth 2006, p. 72, 97 and 136; Alldridge 1990; Sangero 2006, pp. 23-25; Robinson 1990 and Fletcher 1998, pp. 87-88. See also German scholar Hruschka in Byrd \& Hruschka 2007, p. 323.

11 Ormerod 2005, p. 248, Fletcher 1978, p. 811-812, Fletcher 1985, p. 971 and Alldridge 1990, pp. 499-501.

12 Duff in Shute \& Simester 2002, p. 74. See also Horder in Shute \& Sullivan 2002, pp. 284-286 and Horder 2006A, pp. 26 and 107.

Sangero 2006, p. 24 and Fletcher 2007, p. 146.

See Horder 2006A, p. 19.

Schönke \& Schröder, H. 2006, p. 589 and Roxin 2004, p. 178. 
Given that state of maturity, it is believed that the stability of social norms and the separation of state powers militate against a further judicial activity. ${ }^{16}$ This approach is clearly visible in England, where the legislator tends to be seen as the supreme authority and the court as devoid of authority. ${ }^{17}$ If situations fall under the scope of criminalization and no defence has been created by statute, English courts are inclined to hold the defendant liable, submitting that it is up to Parliament to change the law. In discussing the specific defences, it will be illustrated that English courts avoid the extension, let alone creation of defences, because of respect for the legislator's authority and secondly, because of fear that such recognition would undermine the importance of the protection of legal interests and the authority of legal norms. ${ }^{18}$

This strict approach is somewhat mitigated. First of all, I already described how unlegislated excuses have been applied as denials of mens rea. By enriching concepts like intention with elements of blameworthiness, English courts were able to acquit the defendant who could not rely on a specific defence, but should not be held criminally liable because he was not blameworthy. However, this approach has correctly been criticized and has become much less popular. ${ }^{19}$ Secondly, there is some authority for the judicial creation of defences. In the case of Kingston, Lord Mustill recognized the ability of courts to develop new defences. He argued that if the judicial creation of defences is the proper medium to adapt the criminal law to the needs of modern times, the courts should not be deterred by the novelty of it. ${ }^{20}$

In contrast, the Dutch and German courts consider themselves less restrained to alter the scope of criminal liability by modifying or creating defences. It is generally accepted in Germany and the Netherlands that courts may create defences. ${ }^{21}$ From this perspective, a common law system should therefore not be understood as implying great lawmaking power of courts. In fact, generally, the competence of the courts to determine the scope of criminal liability is limited severely by the creation of elaborate offence definitions and defences, in which all possible situations are dealt with comprehensively. In part, this seems the result of a struggle between the legislator and courts, in which the former uses its relatively new competences quite extensively in an over reactive effort to compensate the traditional powers of the latter.

The Dutch courts created two extra-legal defences in order to make sure that the defendant is not punished unless he has committed a wrongful act and has been

16 See Kelk 2005, p. 249; Vellinga, W.H. 1982, p. 223 and Sangero 2006, p. 24.

$17 \quad$ Fletcher 1978, p. 569.

18 This will be made clear in the context of discussing necessity, self-defence-excess and duress.

19 See Fletcher 1975, p. 316 and IV.2.4.1.

20 R. v. Kingston [1994] UKHL 9 and Ormerod 2005, p. 324. The case dealt with the question whether involuntary intoxication could be a complete defence. In any event, the defendant did not meet the conditions of this possible defence. Ashworth 2006, p. 72 argues that the approach of English courts is inconsistent; one time they create a new defence, other times they deem it a task for the legislator.

2124 October 1996 BVerfGE 95, 96; Fletcher 2007, p. 146 and de Hullu 2006, p. 85. 
held to be blameworthy. ${ }^{22}$ Therefore, the reluctant approach of English courts can also be explained by the fact that although wrongfulness and blameworthiness are increasingly acknowledged as implied elements of criminal liability, this is still not always the case..$^{23}$ Only if these elements are recognized as fundamental elements of criminal liability, will courts see it as their duty to ensure them, if necessary by creating a defence. Since blameworthiness follows from the principle of guilt, as enshrined in article 6 ECHR, English courts could increase their competence to create defences by relying on their power to interpret domestic law in conformity with the ECHR. ${ }^{24}$

\subsection{Guidelines}

It is submitted that the principle of legality should apply to criminal liability, irrespective of whether something is part of the offence or defence. After all, general principles of criminal law determine the scope of criminal liability, just like offences. By giving a defence a new, stricter, interpretation, the de facto result is an increase of the scope of criminal liability. The decision to restrict the scope of offences by adding offence elements or through the raising of general defences can sometimes be a mere technical issue. ${ }^{25}$ The focus should therefore not be on a distinction of offence or defence, justification or excuse, conduct or decision rules, but on the scope of criminal liability.

The abolition or creation of a defence occurs only in extreme circumstances. The abolition of a defence is only allowed when it would otherwise leave manifestly criminal conduct unpunished. The creation of a defence is only appropriate if this is necessary to ensure lawful conduct and blameless defendants are not punished. In practice more important are therefore the judiciary's possibilities to extend and limit defences.

Whether this scope of liability may be limited or extended can be assessed in concreto by applying some guidelines. ${ }^{26}$ First, when extending or limiting a defence, it must remain true to its essential character. ${ }^{27}$ This means for example, that self-defence may not be limited by requiring strict proportionality between the offence and the danger sought to avert. If this would be the case, the woman who is about to be raped would not be justified in using lethal force. Conversely, selfdefence should also not be extended to encompass the use of force against attacks

Absence of all blameworthiness is discussed in IV.6.5. and V.2.3., lack of material wrongfulness in IX.4.6.

23

24

Section Compare Fletcher 1978, pp. 569, 573 and 747.

Section 3 of the Human Rights Act 1998. See Horder 2006A, p. 37.

3 November 1992 BGHSt 39, 1; 22 August 1996 BGHSt 42, 235 and de Hullu 2006, p. 85. See $\S 103(2)$ of the German Constitution.

Most of the following guidelines can be found explicitly in Re C. (A minor) [1995] UKHL 15 and Horder 2006A, pp. 16-17.

See Schönke \& Schröder, H. 2006, p. 589 and Horder 2006A, p. 17. 
that have long ended, because this would blur the line with revenge. This guideline explains why the scope of defences has remained very consistent in the last decades.

Second, the legislator's purpose is decisive. Judicial action can be warranted if the legislator explicitly left a matter to the courts to interpret. For example, the Dutch and German legislator used short and open definitions of defences so that the courts and academics could interpret and develop them. By contrast, conscious inactivity of the legislator should usually lead to the conclusion that the courts cannot intervene. If the given situation has not been excluded from the scope of criminalization, the presumption is that the legislator saw no room for defences, which the court has to respect. ${ }^{28}$

Finally, the court must ask itself what will be the (future) consequences of extending defences. If finality and certainty on an issue cannot be achieved, the solution is inefficient. For example, in Germany, the creation of an extra-legal excuse of absence of all blameworthiness was rejected with the argument that it is so vague that it would lead to problems concerning legal certainty. ${ }^{29}$ Courts should also be cautious that the extension of defences does not invite people to seek the limits of the law and to raise unmeritorious claims. Citizens must be encouraged "to seek redress through political or bureaucratic processes rather than resorting to 'self-help', especially when the latter entails the use of force."30

\section{BURDEN OF PROOF}

The offence-defence distinction also influences the burden of proof. In general, the prosecutor carries the burden of proving the offence charged, whereas the defendant must make probable that a defence applies. As noted, if the Prosecutor succeeds in proving the elements of the offence, it is assumed that the act is wrongful and the defendant blameworthy. The presumption is therefore that a general defence is absent, and it is up to the defendant to raise this issue. This is practically convenient, because otherwise the prosecutor would always have to prove that all possible defences are absent. ${ }^{31}$

This does not place an undue burden on the defendant. It is obvious that the defendant, who knows about any possible defence, raises this. Moreover, the burden of the defendant is not so difficult to meet, as he merely has to make the defence probable, rather than prove it. In addition, this burden rests not only on the defendant. In Germany and the Netherlands, the judge has an active task in investigating whether a defence applies, particularly if this is raised by the facts. ${ }^{32}$ It could therefore be argued that the defendant merely has to raise the defence. 
If the judge thinks the facts as stated by the defendant are not unlikely, any doubt should tip the scales in favour of the defendant. ${ }^{33}$ Again, it seems that the German judges attach most weight to the principle of in dubio pro reo. German judges are most likely to accept facts and circumstances that can ground a defence. They even tend to consider all alternative scenarios to the prosecutor's case, accepting any scenario that cannot be refuted. The effect seems to be that the defendant is rewarded for remaining silent and not helping to make the facts clear. In contrast, in the Netherlands, courts expect cooperation and helpfulness in regard to the checking of the validity of the submitted facts from defendants who raise a defence. ${ }^{34}$ Probably the most common reason for rejecting defences is that the court does not believe that the scenario as submitted by the defendant is probable. ${ }^{35}$

\section{JUDGMENT}

When a defence applies to a charge, the offence is justified or the defendant is excused. In the Netherlands, the application of a defence is incorporated into the judgment. If a justification or excuse applies, the verdict is not one of acquittal, but a 'discharge of all legal proceedings'. ${ }^{36}$ In Germany and England, however, the acceptance of a defence leads to an acquittal, just as it would when the offence definition is not proven. ${ }^{37}$

The special judgment can be explained by reference to the Dutch scheme of judicial decision-making, which distinguishes between the question of whether or not the charge is proven and the subsequent questions whether this conduct and the defendant are also punishable. ${ }^{38}$ The scheme formalizes the three-tiered framework of criminal liability. It creates a binding order of assessing legal cases, an order which is not binding in the other two States but also follows nonetheless from the logical fact that the application of defences is only relevant after assessing that the offence definition is fulfilled. After all, only an offence can be justified or excused. ${ }^{39}$

The special verdict has a communicative function. When the only available verdict is an acquittal, this does not capture the difference between the person who was innocent and the person who did commit an offence but was excused. For

33 HR 17 November 1992, NJ 1993, 267; Kelk 2005, p. 251; de Hullu 2006, p. 355-356; 23 October 1890 RGSt 21, 131; 5 October 1990 BGH NJW 1991, 503; 14 August 1998 BayObLG NStZ-RR 1999, 9 and Schönke \& Schröder, H. 2006, p. 652. De Hullu 2006, p. 356 Blomsma \& Klip 2009. It was therefore exceptional for the Court to accept facts because they could not be excluded in Rb. Groningen 9 September 2010, NJ 2011, 52. Ontslag van alle rechtsvervolging, see article 352(2) of the Code of Criminal Procedure. The German judgment must nevertheless must mention the grounds for acquittal, see $\$ 267(5)$ of the Code of Criminal Procedure. Article 350 of the Code of Criminal Procedure. The second question of the scheme is omitted, namely whether the charge also qualifies as an offence. 
example, no difference is made between the defendant who was acquitted because the judge did not believe he killed the victim and the defendant who killed the victim because he was insane. The verdict makes clear that the latter defendant does not walk out free, as measures can be ordered against him. ${ }^{40}$ The communicative function of the law is not only important in distinguishing offence from defence, but also in making clear the difference between a justification and excuse. In the next chapter, I will return to this matter.

\section{Defensive purpose}

In order for a defence to apply, does it suffice that its conditions are objectively fulfilled or should the defendant also be aware of this? Consider that the defendant is walking in the park at night, looking for someone to beat up. At one point, he hears a jogger running towards him. He picks up a large stick from the ground and hits the jogger with it, resulting in serious injuries. On the face of it, the situation seems simple. The defendant fulfilled the offence of inflicting serious bodily harm.

However, things may radically change if we consider that the jogger was in fact a mugger, who was about to rob our defendant. In that case, the conditions of selfdefence were objectively present, whereas the defendant was ignorant of it. This situation is called an unknowing justification or a reversed putative justification. ${ }^{41}$ Another example is the situation where the defendant walks in the park and sees that an old lady is being mugged. Aware that there is a situation of self-defence, he relies on the law's opportunity to use force and injures the mugger. However, his purpose in using force was not to defend the old lady, but to beat someone up.

It will be argued that the conditions of a defence should not only have been met in reality but also in the defendant's mind at the time he committed the offence. Subsequently, it can be asked what kind of mental element is required. Regarding self-defence for example, should the defendant aim to act in defence of someone's life, or should it suffice that he realized the requirements of the justification were met? The first question has attracted most debate in England, whereas in Germany, where a mental requirement has been accepted as self-evident, lawyers have focused more on the subsequent question of whether or not awareness suffices. Nonetheless, the issue hardly comes up in practice, because it is uncommon for all the other conditions of a defence to be fulfilled whereas the defendant was unaware of this and/or acted with a different purpose. This explains why in the Netherlands, it is not really perceived as a relevant problem. ${ }^{42}$

40 The term 'discharge of all legal proceedings' is therefore unfortunate, because it implies that no measures can be ordered against the insane.

41 Christopher 1995; Fischer, T. 2009, p. 120 and Beulke 2008, p. 326.

42 Ter Haar \& Meijer 2009, p. 78 submit that there are hardly any decisions where the defensive purpose is named explicitly as a requirement, referring to Rb. Zwolle-Lelystad 22 June 2009, $L J N: \mathrm{BJ} 0512$ as the exception. 


\subsection{Dual requirement}

Three approaches can be taken. ${ }^{43}$ The first approach focuses merely on the question whether or not the criteria of a defence have been met objectively, that is, in reality. The subjective beliefs of the defendant on whether or not self-defence was applicable are irrelevant. This approach, which can also be called the 'deeds theory', emphasizes that the defendant was objectively justified. The defendants above objectively prevented the mugger from robbing him and the old lady respectively. The objectively justified act can be seen as beneficial to the legal order and should therefore be encouraged, regardless of the mental state of the actor. His actions are therefore justified. ${ }^{44}$

The second approach, by contrast, focuses on the reasons why the act was carried out. This 'reasons theory' brings about that the defendants above cannot be justified. The perpetrator who was ignorant of the justifying circumstances was not acting as a private law enforcer, but as a common criminal. He aimed to harm the legal order, not protect it. ${ }^{45}$ The approach brings about that in the opposite situation of putative defence, to be discussed in the next paragraph, the defendant is also justified if he mistook a jogger for a mugger. Although the conduct was not right in fact, it is justified because it was (subjectively) done for the right reasons.

The first and second approach can be labelled utilitarian and deontological respectively. The third approach of 'dual requirement' cumulates the objective and subjective conditions. It requires conduct to be carried out under the justifying circumstances and with the pertinent lawful purpose. In order to be justified, the actor needs to act for what he believes to be good reasons and which are in fact good reasons. A single focus on consequences fails to consider the intrinsic properties of actions, but we also should not go as far as to never take into account the consequences of our actions. Like actus reus is just as important as mens rea, criminal liability should reflect the objective and the subjective, the harm and the state of mind. The defendant who intervened and objectively helped the old lady only because he wanted to hurt the mugger is therefore not justified. ${ }^{46}$

This dual requirement should apply in a general part of criminal law for the EU. In order for a defence to apply, its conditions should in reality be fulfilled: a mere subjective approach does not suffice. Leaving aside for now the possibility of being excused when the conditions of a defence are only subjectively present, an act can only be justified if the conditions of the justification are objectively met. It is not justified to defend yourself against an imaginary attack. A justification implies the

43 Leverick 2006, pp. 23-41; Robinson \& Darley 1998; Robinson 1997 and Robinson in Simester \& Smith, A.T.H. 1996.

44 See Roxin 2006, pp. 642-644 and 719; Schönke \& Schröder, H. 2006, pp. 585 and 668 and Machielse 1986, pp. 588-589.

45 Ter Haar \& Meijer 2009, p. 77 and Sangero 2006, p. 97. See also Tadros 2005, pp. 121-123 and Horder 2006A, p. 69.

46 Leverick 2006, pp. 24-30 and Tadros 2005, pp. 274-280. In contrast, Robinson 1997, p. 14 argued that taking advantage of the law is not the same as breaking it. 
action was correct and desirable. ${ }^{47}$ The subsequent question thus becomes whether a subjective fulfilment of the criteria of defences is required too. The simplest argument to demonstrate that the criteria should also be subjectively fulfilled is to point out that de lege lata defences in all three Member States require a defensive purpose, as has been made explicit in the context of self-defence, ${ }^{48}$ necessity ${ }^{49}$ and duress. ${ }^{50}$

The dual requirement is also grounded in the distinction between offence and defence. It is argued that the objective absence of an objective definitional element suffices for an acquittal, but in order to rely on a defence, its conditions must be met, both in fact as in the mind of the actor. In other words, the elements of the offence need to be objectively present to convict, whereas the elements of the defence must also be subjectively present to acquit. The additional subjective requirement for defences is logical if it is considered that conduct that is perfectly legal should not be punished, whereas conduct that is prima facie wrong is justified only when it is done for the right reasons. Defences are exceptions that enable special treatment only to those who merit special treatment: acting for the right purpose is essential to merit special treatment. ${ }^{51}$

The dual requirement can also be grounded in the so-called belief principle. In England, a subjective requirement is referred to as the Dadson principle, after the case against the constable Dadson who shot and wounded a fleeing thief. Such force was justifiable only against a person who had two previous convictions. The thief had two previous convictions, but Dadson did not know this and was therefore convicted. ${ }^{52}$ This is in line with the principle that the defendant should be judged on the facts or circumstances as he believed them to be. ${ }^{53}$ As noted, ignorance of an offence element negates a fault element like intent. This belief principle also applies to the defence, bringing about that every medal has its reverse. The defendant cannot be convicted for an offence of recklessness unless he was aware of the danger, but he can also not be acquitted on grounds of self-defence if he was not aware of the pertinent justifying circumstances.

47 Leverick 2006, p. 28. Or at least permissible, see VIII.3.4.

482 October 1953 BGHSt 5, 245; Beulke 2008, pp. 115 and 122; Fischer, T. 2009, p. 293; HR 8 May 1990, NJ 1991, 579; HR 8 June 2010, NJ 2010, 339; de Hullu 2006, p. 304 and Fokkens \& Machielse, pp. 276-277, note 6 on art. 41.

4911 December 1997 BGH NStZ-RR 1998, 173; 15 January 1952 BGHSt 2, 111; Beulke 2008, p. 105; HR 14 December 1976, NJ 1977, 174; HR 29 March 1988, NJ 1989, 162; Dolman 2006, p. 236 and 323; Fokkens \& Machielse, note 9 on art. 40 and section 36(3) of the English Road Traffic Act 1972.

50 Bohlander 2009, p. 126; Beulke 2008, p. 152; Roxin 2006, pp. 976-977 and Schönke \& Schröder, H. 2006, p. 706.

51 Or at least acting in knowledge of the justifying circumstances, see Fletcher 1978, pp. 556-568 and 576; Fletcher 1975, pp. 320-321; Tadros 2005, pp. 265-266 and 275 and Sangero 2006, pp. 28-29 and 219-221.

52 R. v. Dadson (1850) 169 ER 407. See Simester \& Sullivan 2007, p. 610 and Ashworth 2006, p. 155 .

53 R. v. Gladstone Williams [1983] EWCA Crim 4; Ormerod 2005. p. 339; Ashworth 2006, p. 141; Simester \& Sullivan 2007, p. 142 and Law Commission 1993, pp. 69 and 77. 
Chapter VII

\subsection{Purpose versus mere awareness}

If we accept that defences, justifications in particular, can also be distinguished into an objective and a subjective part, a subsequent, perhaps even more controversial question deals with the required degree of such a mental element. ${ }^{54}$ There is consensus that the defendant cannot rely on a defence if he is not aware that these conditions are met. ${ }^{55}$ Does this suffice or need his actions also be guided by the purpose of the justification?

Given the Dadson principle, it seems that English courts merely require awareness. ${ }^{56}$ In addition however, the Dutch and German Supreme Courts require a 'genuine' defensive purpose. ${ }^{57}$ This can be contrasted with the position of scholars. Most German and many Dutch scholars seem to favour mere awareness, ${ }^{58}$ whereas many English scholars argue in favour of an additional purpose. ${ }^{59}$ To make things even more complex, some scholars differentiate between justifications. One justification can require a purpose whereas for another, mere awareness would suffice. ${ }^{60}$

In fact, additional arguments in favour of a defensive purpose can be derived from the criteria and aspects of self-defence. A genuine purpose follows from the rule that the defence does not apply to cases where the defendant reprehensibly created the circumstances of self-defence in order to enact revenge. His purpose was not to defend himself. From an etymological approach, the term self-defence also implies one is consciously and purposely defending himself. Third, one of the many rationales of self-defence is grounded in the doctrine of double effect. Aquinas distinguished self-defence from punishment by the intention with which the attacked person harms his aggressor. The intention must be to fend off the attack, not to make the aggressor suffer. Only then is the suffering of or injury to the aggressor merely a permissible side-effect. ${ }^{61}$

In any event, true purpose or mere awareness, the difference between the two is put into perspective. First of all, the purpose requirement is mitigated by holding that it need not be the only purpose. ${ }^{62}$ In the context of self-defence for example,

Sangero 2006, p. 30; Alexander 2004, p. 853 and Fletcher 1978, p. 565.

See Fletcher 1978, p. 559.

11 December 1997 BGH NStZ-RR 1998, 173; Roxin 2006, pp. 640-641; HR 8 May 1990, NJ 1991, 579; Machielse 1986, pp. 590-591, who mentions more case-law that implies such purpose. See Bohlander 2009, p. 80; Schönke \& Schröder, H. 2006, pp. 584-585; Roxin 2006, pp. 640641 and annotator Buruma in HR 10 February 2004, NJ 2004, 286.

Smith, J.C. 1989, p. 40; section 27(1) Law Commission 1993, p. 106 and Tadros 2005, p. 291. Fletcher 1998, p. 137 submits that the consensus amongst Western legal systems includes awareness as well as purpose.

See for example Schünemann 1985, pp. 372-374 and Roxin 2006, pp. 976-977.

Fletcher 2007, p. 14 and Smith, J.C. 2002, pp. 958-959.

11 December 1997 BGH NStZ-RR 1998, 173; Roxin 2006, pp. 640-641 and Sangero 2006, p. 233. 
German courts also accept that other motives like anger played a role next to the defensive purpose, as long as this defensive purpose is not completely pushed into the background. ${ }^{63}$ Secondly, it is unlikely that the defendant will reveal his true or primary purposes, which leaves intact the reasonable presumption that someone acting in a situation of self-defence acted with a (law-abiding) defensive purpose. ${ }^{64}$

Finally, the discussion on a defensive purpose seems limited to justifications. This is logical because their objective focus on the valuation of conduct makes any additional subjective element controversial. As will be explained later, excuses centre not on the conduct itself, but on the reasons of the defendant for acting. By their nature, excuses thus already require specific reasons for acting. For example, in order for an offender to be excused under duress, it must be established that he could not reasonably act any differently due to the specific pressure he was under. Because of these subjective conditions, duress does not apply to the defendant who committed the offence because he hated the victim, even though the reasonable person would not have been able to act differently.

\subsection{Negligent offences}

If it is accepted that self-defence requires a defensive purpose, this seems to bring about that only offences that are committed with dolus (directus) can be justified. After all, if the defendant wants to save himself, he usually also wants to hit and therefore injure the aggressor. However, self-defence can also apply to offences committed with lesser fault elements. Although usually, negligent offences will not have been committed with a defensive purpose, this is not impossible. For example, one can defend oneself with a wooden plank, not knowing that it had a rusty nail, which caused unforeseen injuries. The defender may have used a firearm, believing it to be an alarm gun. ${ }^{65}$ Finally, he may have merely wanted to hit the aggressor on the head with a firearm, but in doing so the weapon fired. ${ }^{66}$

These examples have in common that the defendant wanted to defend himself, and in order to do so, aimed to do commit an offence, which inadvertently led to the fulfilment of a more serious offence. Applying the principles proposed in the previous chapter, it can be argued he was at least negligent as to these results, possibly even reckless. These offences can nevertheless be justified under selfdefence. In Germany, the approach is taken that if the defensive force would have also been justified when it was intentional, self-defence also applies to the negligent

6311 September 1995 BGH NStZ 1996, 29; 6 October 2004 BGH NStZ 2005, 332 and Roxin 2006, p. 977.

64 Sangero 2006, p. 234.

65 AG and annotator de Hullu in HR 31 October 2000, NJ 2001, 11; AG Vellinga in HR 10 February 2004, NJ 2004, 286; Strijards 1987, p. 59; Machielse 1986, pp. 597-599; 30 June 2004 BGH NStZ 2005, 31 and Bohlander 2009, p. 80.

6621 December 1977 BGHSt 27, 313. In the Netherlands, this sometimes qualifies as conditional intent, see IV.5.3.1. 
use of force. ${ }^{67}$ Defendants are also acquitted by negating negligence, based on the rationale that the aggressor bears the inherent risk of defensive force. For example, in a case, the aggressor was throwing bricks from a short distance at the officer who wanted to arrest him. The officer aimed to shoot him in the legs, but at that moment, the suspect just bended over to take another brick and got hit fatally. ${ }^{68}$

\subsection{Unknowing justification}

This leaves us with the question of what to do in case the defendant was unaware of the circumstances that gave rise to a defence. Whereas German courts find complete liability, ${ }^{69}$ many German scholars argue that only liability for (impossible) attempt should follow; ${ }^{70}$ a view that can also be found in other Member States. ${ }^{71}$ The defendant believes he has committed an offence when in fact he has not done so. This is similar as a reversed mistake, which also leads to liability for an impossible attempt. ${ }^{72}$ That outcome makes sure that other parties are not allowed to act against the actor, who is objectively justified. ${ }^{73}$ It would also bring about that the scope of liability is more limited as not all offences can be attempted. ${ }^{74}$ The consequence of the absence of a defensive purpose in the Netherlands is unclear. Usually it is simply held that there was no situation of self-defence, resulting in complete liability. ${ }^{75}$

The most popular view thus seems to be that of complete liability. However, this does not also mean that the defendant should always be held liable. Consider the real-life example of Motti Ashkenazi, who stole a backpack on a Jerusalem beach, which turned out to be full of explosives on a timer. He reported this to the police as a result of which he saved numerous lives. ${ }^{76}$ Since at the time he committed the crime he lacked the defensive purpose required for self-defence or necessity, he can be held liable for theft. However, given the circumstances, it would have been highly undesirable to punish him. A similar hypothetical example exists when the actor breaks a window in the night, but in doing so he saves the owner's life because he smells a gas leak when he awakes. The actor lacks the defensive purpose that is

21 March 2001 NStZ 2001, 591; 19 September 1973 BGHSt 25, 229 and Schönke \& Schröder, H. 2006, pp. 620-623 and 668.

30 June 2004 BGH NStZ 2005, 31. See also 21 December 1977, BGHSt 27, 313; 25 March 1999 BGH JR 2000, 297; Roxin 2006, p. 677-678 and 1099 and Beulke 2008, p. 116.

Beulke 2008, pp. 97-98 and Fischer, T. 2009, p. 315.

Roxin 2006, pp. 719 and 774-775; Bohlander 2009, pp. 80 and 139; Schönke \& Schröder, H. 2006, pp. 668 and 698; and Fischer, T. 2009, pp. 119, 293 and 311.

Westen 2008A, pp. 576-579.

See Christopher 1995, pp. 234-238; Smith, J.C. 1989, pp. 41-44; Funk 1999; Beulke 2008, p. 326 and Stuckenberg 2007, pp. 374-375.

Roxin 2006, pp. 644-645. Compare Christopher 1995, pp. 239-245.

\$23(1) of the German Criminal Code; article 45 of the Dutch Criminal Code and section 1(4) of the English Criminal Attempts Act 1981.

Machielse 1986, pp. 590-591.

See Robinson 1997, pp. 14-15. 
required for a justification and the act is therefore wrongful. ${ }^{77}$ From this perspective, it would be useful to grant a European Public Prosecutor the discretion not to prosecute.

\section{Putative Defences}

A putative justification is the mirror image of an unknowing justification. In the aforementioned example, the defendant did not know the victim was a mugger and could therefore not rely on self-defence. A putative justification would exist if the defendant, walking in the park at night, mistook a jogger for a mugger and injured him by way of pre-emptive strike. Whereas the unknowing justification deals with the question whether a subjective requirement should also be required, a putative defence revolves around the question how important it is that the conditions of a defence are also objectively fulfilled. Can the belief of the actor in the justifying circumstances serve as a replacement for their non-existence in reality? ${ }^{78}$

In a purely subjective perspective, this is answered affirmative. The mistake is irrelevant. The defendant is justified or excused just as he would when his perception of reality would have been correct. Under this approach, no distinction can therefore be made between a regular and a putative defence. A defence that seemed necessary to the defendant is necessary in law. It does not matter whether the objective, real circumstances are different from the circumstances as he believed them to be. The opposite approach is to simply reject the defence in case of a mistake. A mere objective perspective identifies and separates desirable conduct, which is truly justified, from putative justifications, which cause harm and should be discouraged.$^{79}$ Regardless of the nature of the mistake, the defence does not apply and the defendant is criminally liable.

In between the two extremes, an approach exists that makes the mistake relevant, but only holds the defendant liable when the mistake was unreasonable. In fact, all Member States would agree that there can be no criminal liability when the putative defence was reasonable. ${ }^{80}$ The English standard of 'reasonable' is similar to the German one of 'unavoidable' and the Dutch one of 'excusable'. ${ }^{81}$ I will discuss and highlight the problems of the national solutions, after which I argue in favour of this middle ground, which can be grounded in all legal systems under investigation. It will become clear that mistakes on defences are treated very differently from mistakes on the offence definition.

Beulke 2008, p. 326.

See Sangero 2006, p. 285.

Robinson 1997, pp. 6-9 and 12-14.

See Perron in Arnold a.o. 2005, p. 1037.

See also Fletcher in Eser \& Fletcher 1987, p. 70. The standard requires more than in culpa, see IV.6.5.1. 


\subsection{The distinction}

Before I discuss the different approaches, two distinctions need to be introduced. First of all, putative justifications and putative excuses can be identified. Both types of mistakes should be treated under the same rule. I will generally refer to putative justifications and discuss some important aspects of putative excuses in the end of this paragraph. Secondly, mistakes on the facts giving rise to a defence are distinguished from mistakes on the scope or existence of a defence. In many legal systems, the distinction is made with a view to attach different criteria and legal consequences to the two types of mistakes. On the contrary, I will argue in favour of one simple rule of excusing the defendant who makes a reasonable mistake on a defence.

The former category deals with factual mistakes on the circumstances, that if present, would in fact justify or excuse the defendant. Let me illustrate the distinction by reference to self-defence. Arguably, all mistakes on the necessity of self-defence are mistakes on the facts giving rise to a justification. By mistaking the jogger for a mugger, the defendant incorrectly assumes a wrongful attack is imminent and therefore errs that self-defence is necessary. Cases of error in persona are also treated as a mistake on the facts giving rise to self-defence. After all, the jogger who is mistaken for a mugger is conceptually closely related to cases in which a third party is mistaken for the intended victim. Cases of aberratio ictus, where the defendant misses the intended victim and hits an innocent third party, should be treated equally. For example, the defendant might miss the mugger and hit a jogger who just happens to pass by.

As will be explained in this paragraph, the defendant will only be excused for these mistakes, if they are considered to have been excusable, all things considered. In all of these cases, the defendant violates the personal autonomy of an innocent victim. This can never be justified, all the more because that would imply the victim could not defend himself. The legal order can at most forgive the defendant for his mistake. This will not be the case if the defendant can be reproached for not being more diligent, either because he should have made sure he was really attacked by that person or because by shooting in a crowded place at the aggressor, he should have foreseen others could be harmed.

Mistakes as to the legal limits of a defence deal with mistakes on the scope of defences or even on the existence of defences. The defendant may err that the attack in self-defence need not be wrongful or he may even think there exists a defence of self-help. Mistakes on normative elements of the defence are also included in this second category. For example, the condition that the degree of force applied in selfdefence must be proportionate is normative. A mistake on what is proportional is a mistake on what is allowed by law. Mistakes as to the legal limits of a defence can also only excuse the defendant.

The distinction between mistakes is grounded in the fact that the actor who is mistaken on the facts giving rise to a recognized justification in principle acts in 
conformity with the value judgments of the legal order. After all, he would be justified if the mistaken facts were correct. In contrast, a mistaken belief in a non-existing defence implies that the actor is led by value judgments that are not those of the legal order. ${ }^{82}$ The law sets the rules of conduct. The defendant is not allowed to substitute his values judgments for those of the legal order. To do so would exculpate those with irrational and dangerous views on what is proportionate. ${ }^{83}$ This explains that mistakes on the scope or existence of defences will hardly ever be forgiven.

\subsection{Negation of fault}

The aforementioned distinction shows a great resemblance with the distinction between mistakes on the offence definition and mistakes as to the legal prohibition. In German law, mistakes on the facts giving rise to a justification are treated as if they were mistakes on the offence definition. In short, this means that a putative justification will negate intent if the facts would have justified the conduct, when actually present. For example, self-defence would have applied if the jogger was in fact a mugger. The mistake negates the intent to injure the jogger.

Secondly, there may be a negligent counterpart of the offence charged. If the mistake was reasonable in the circumstances, it will also negate negligence in Germany. After all, negligence consists of an unreasonable mistake. By contrast, if it is not deemed reasonable in the circumstances that the actor mistook the jogger for a mugger, he will be held liable for the negligent infliction of bodily injury. Negligence liability is warranted because the actor can be reproached for not assessing the situation better. As a compromise, the approach thus enables that a mistake on the defence does not completely negate liability, but does lower criminal liability from intentional to negligent. Unreasonable mistakes merely amount to negligence liability.

To illustrate a mistake on the facts giving rise to a justification, consider the case where the defendant shot the aggressor immediately when he thought he reached for his gun. The German Supreme Court held that this was a mistake on the necessity of shooting, because he could have threatened again, fired another warning shot or waited to see whether the aggressor would also really pull out a gun, arm it and aim it. Intention was therefore negated. Subsequently, it was held that negligence liability should also be dismissed since the defendant could not be reproached the violation of the duty of care in these circumstances. ${ }^{84}$

In contrast, a mistake on the scope or existence of a justification is treated as a mistake as to the legal prohibition. Therefore, rather than negating the fault element, the defendant is excused if the mistake was excusable, or as the Germans would

826 June 1952 BGHSt 3, 105; Roxin 2006, p. 627 and Beulke 2008, p. 167 and 171.

83 Ormerod 2005, p. 334; Ashworth 2006, p. 149 and Law Commission 1993, p. 66.

849 May 2001 BGH NStZ 2001, 530. 
state, unavoidable. ${ }^{85}$ Like any defence that falls short of its conditions, avoidable mistakes can at most mitigate the sentence. ${ }^{86}$ An example of a mistake on the scope of a justification is the defendant's mistake that the justification of necessity allowed for excessive speeding in order to save a parakeet. ${ }^{87}$ Whereas the underlying facts are well recognized, the defendant makes the mistake of incorrectly weighing the pertinent interests. This mistaken valuation can only be excused when it was unavoidable. ${ }^{88}$

Support for this German approach as to mistakes on the facts giving rise to a justification can be found in English law. ${ }^{89}$ It is however controversial in Germany itself, ${ }^{90}$ and should be rejected in my opinion. First of all, it is inappropriate not to require that a mistake on the facts giving rise to a justification must be reasonable. Treating these mistakes like mistakes on the offence definition neglects the difference between offence and defence. The actor who is making a mistake on the offence definition is not aware he is committing a criminal offence. However, the fact that the defendant committed a prima facie wrong warrants that he should be especially diligent in assessing whether the circumstances giving rise to a defence are actually present. ${ }^{91}$ This diligence must result in requiring that the mistake is reasonable.

The approach of letting an honest mistake negate intent is also problematic because it brings about that the defendant who was mistaken, however unreasonable, about the consent of the victim will not be convicted of rape. ${ }^{92}$ Since there is no comparable negligent offence, the actor is even acquitted. Even if this legal loophole were removed by making negligence liability available, ${ }^{93}$ convicting the mistaken defendant of merely this offence would send a strange signal. It should also be noted that the German approach only negates intent and negligence. If a putative defence were raised against a strict charge, there would be no fault element to negate and thus no legal possibility to exclude liability. This is no lacuna in the German legal system that rejects strict liability, but it will be a lacuna in EU law, which does accept this form of liability.

5 September 1988 BGHSt 35, 347; 6 June 1952 BGHSt 3, 105; 15 November 1994 BGH NStZ 1995, 177; 29 June 1995 BGH NStZ 1996, 132; 7 March 1996 BGH NStZ 1996, 338; Beulke 2008, pp. 161-162, 166 and 172 and Schönke \& Schröder, H. 2006, pp. 353-354. $\S 49$ (1) of the Criminal Code. Compare Weigend in Tiedemann 2002, p. 414. 18 April 1990 OLG Düsseldorf NJW 1990, 2264.

Schönke \& Schröder, H. 2006, pp. 698-699 and Fischer, T. 2009, p. 312.

In England, an honest mistake on the necessity of self-defence acquits, see R. v. Gladstone Williams [1983] EWCA. Moreover, Smith, J.C. 2002, pp. 960-961; Ormerod 2006, p. 469 and Sangero 2006, pp. 290-293 suggest that a grossly unreasonable belief in the necessity of selfdefence could still give rise to a conviction of manslaughter based on gross negligence.

Fischer, T. 2009, p. 118; Beulke 2008, pp. 162 and 166 and Schönke \& Schröder, H. 2006, p. 353. Beulke 2008, pp. 168-169; Hörnle 2000, pp. 369-370; Stuckenberg 2007, pp. 496-497 and Sangero 2006, pp. 286-287.

'Nötigen' in $\$ 177$ of the German Criminal Code implies the lack of consent.

Hörnle 2000, pp. 356-358 and 378-380. See also Roxin 2006, pp. 626-629 and Fletcher in Eser, Hassemer \& Burkhardt 2000, pp. 252-253. 
Leaving aside for now whether the mistake should be reasonable or not, the German solution can be criticized for not distinguishing correctly between dolus on the one hand and wrongfulness on the other. The approach neglects the fact that the defendant, who kills in self-defence, intentionally kills the aggressor. It makes no sense to hold that the accused who mistakenly believed he was attacked, did not intend to kill the person he thought to be an aggressor. The German approach implies that intention must relate to wrongfulness of one's conduct, to the nonexistence of justifying circumstances. It implies that dolus is malus. ${ }^{94}$

This did follow from the theory that treated wrongfulness, the non-existence of justifications, as 'negative offence elements' as to which intent must relate. If the defendant thought his conduct was justified, intent as to a negative offence element was lacking. ${ }^{95}$ However, this theory is now generally rejected and these implications are commonly rejected. In fact, prevailing opinion appreciates that intent is purged by considering consciousness of wrongdoing as an element of blameworthiness, rather than intent. ${ }^{96}$ It is inconsistent with this view to treat a mistake on the facts giving rise to a justification as negating intent. Instead, the only approach consistent with this view is the approach that is most popular in the other two Member States and supported here, which treats all types of putative defences as mistakes on the legal prohibition. This means that only a reasonable mistake can excuse. ${ }^{97}$ In conclusion therefore, the German approach must be rejected, because it is neither consequent nor just. ${ }^{98}$

\subsection{Honest or reasonable mistake}

The approach to putative defences in English law also seems to be inconsistent. For some defences an honest or genuine belief suffices, whereas other defences require the mistake to be reasonable. From case law, it can be inferred that self-defence requires a genuine mistake, whereas duress and consent require a reasonable mistake. ${ }^{99}$ Although general approaches to putative defences have been advanced, such as a genuine ${ }^{100}$ or reasonable ${ }^{101}$ mistake for all defences, it must be concluded that de lege lata, the requirement of putative defences must be considered in the context of each defence. ${ }^{102}$

\footnotetext{
94 Roxin 2006, p. 629 and Stuckenberg 2007, pp. 364-365 and 496-497. See IV.2.4.6.

95 The 'Gesamt-unrechts-Tatsbestand' basically consisted of an amalgamation of the offence definition and wrongfulness, see Krey 2003, pp. 12-13; Beulke 2008, p. 43; Fischer, T. 2009, pp. 81-82 and Schönke \& Schröder, H. 2006, p. 155.

96 Arzt 1976, p. 657. This is called the limited theory of guilt. See X.5.3.

97 Stuckenberg 2007, pp. 366-367; Beulke 2008, p. 166; Schönke \& Schröder, H. 2006, pp. 162 and 353; Arzt 1976, p. 657 and Bohlander 2009, p. 76.

98 Fletcher in Eser, Hassemer \& Burkhardt 2000, pp. 248-249.

99 Simester \& Sullivan 2007, pp. 636 and 675.

100 Section 41 draft Criminal Code, Law Commission 1989, p. 60.

101 Ashworth 2006, pp. 229-230 and Ormerod 2005, p. 127.

102 Ormerod 2005, p. 293 and Simester \& Sullivan 2007, pp. 619-620.
} 
As far as putative self-defence is concerned, the approach is similar to that in Germany. Mistakes on the facts giving rise to self-defence need not be reasonable to acquit, but a mistake on its scope should be reasonable. In Germany, intent is also negated by any mistake on the necessity to defend oneself. Only if the defendant was mistaken on the scope of self-defence, the mistakes must have been reasonable in order to excuse him. The rationales for not requiring a reasonable mistake are also similar to those advanced in Germany. Since the mistake would have justified his conduct, if it were correct, the defendant aimed to act in conformity with the legal order. Secondly, a requirement of reasonableness would deter people of helping others. ${ }^{103}$

The English law on self-defence allows such force to be used as is reasonable in the circumstances as the accused believed them to be, whether reasonably or not. Mistakes on the necessity to apply defensive force should be assessed purely subjective on the basis of the danger he took to be present. Any genuine mistake on the facts giving rise to self-defence will acquit. ${ }^{104}$ On the contrary, a mistake on the scope of self-defence, like the question whether or not the response was proportionate, must be reasonable to acquit. ${ }^{105}$ The belief principle does not apply here. Normative standards such as proportionality should not be the object of subjective assessment. ${ }^{106}$

Since an honest mistake on the facts giving rise to a justification can acquit the defendant, the scope of exculpation seems wider than in Germany, where only intent was negated, leaving open negligence liability for unreasonable mistakes. However, in practice, liability is not as easily rejected as in Germany. First of all, experience shows the lack of a requirement of reasonableness has not resulted in a disquieting number of acquittals. ${ }^{107}$ In effect, unreasonable beliefs are unlikely to be accepted as credible. The reasonableness of a belief can indicate that it is genuinely held, ${ }^{108}$ so the unreasonableness of the belief might indicate it was not honestly held. ${ }^{109}$

Secondly, in England, the defendant cannot rely on a putative defence that was caused by voluntary intoxication. Thus, when voluntarily intoxicated, the defendant should be judged on the facts as they were. ${ }^{110}$ Finally, if the actor was unsure of the circumstances, the doctrine of wilful blindness can operate to preclude the

103 Sangero 2006, pp. 288-289.

104 R. v. Gladstone Williams [1983] EWCA.

105 Section 76 of the Criminal Justice and Immigration Act 2008; R. v. Owino [1996] 2 Cr App R 128; DPP v. Armstrong-Braun [1998] 163 JP 271; R.v. O’Grady [1987] EWCA Crim 2; Simester \& Sullivan 2007, pp. 621, 623 and 706; Ormerod 2005, pp. 329-330 and Dingwall 2007, pp. 130-131.

106 Sullivan in Shute \& Simester 2002, pp. 223-224. See also IV.2.4.8. and IV.4.5.3.

107 Ormerod 2006, p. 454.

108 Section 76(4a) Criminal Justice and Immigration Act 2008.

109 R. v. Gladstone Williams [1983] EWCA Crim 4 and Sangero 2006, p. 288.

110 Section 76(5) of the Criminal Justice and Immigration Act 2008; R. v. O'Grady [1987] EWCA

Crim 2; R. v. Hatton [2005] EWCA Crim 2951 and Spencer 2006, p. 267. 
exculpatory operation of his honest mistake. ${ }^{111}$ Doubt is not considered to be ignorance, just a lesser form of knowledge. German scholars also argue that whereas these mistakes may negate direct or indirect intent, they do not negate dolus eventualis. Nonetheless, the German Supreme Court has accepted putative self-defence in the case where the defendant drove into three men whom he thought might want to beat him up. ${ }^{12}$ Moreover, only in Germany in dubio pro reo applies in a way that incredible or even absurd claims of the defendant are accepted as honest mistakes.

Be that as it may, it is submitted that a putative justification should be reasonable to acquit, in particular that only a reasonable mistake as to the necessity of selfdefence should suffice. As submitted before, the committing of a prima facie wrong warrants that the defendant should be especially diligent in assessing whether the circumstances giving rise to a defence are actually present. Requiring a reasonable mistake is necessary in order to strike a fair balance between the interests of offender and defender. ${ }^{113}$ If any mistake allows for the use of force, the interests of the innocent person who is unreasonably mistaken for an aggressor are not respected. . $^{114}$

The reasonableness requirement can also be deduced from article 2 ECHR, because under this article an exception to the right of life must be based on a reasonable belief in the need to sacrifice a life in self-defence. ${ }^{115}$ English law is thus not in line with the aggressor's right to life, which may only be sacrificed if it is absolutely necessary, whereas a defendant in England can be acquitted even if his attack turns out to be completely unnecessary. ${ }^{116}$ The English government have ignored this problem in legislating section 76 of the Criminal Justice and Immigration Act 2008, probably due to the public pressure on allowing the maximum scope of force for householders defending themselves against burglars.

The United Kingdom has been brought before the ECtHR by relatives of persons shot in putative self-defence numerous times. Arguably, the UK failed to protect its citizens' right to life from state agents or private individuals. ${ }^{117}$ The situation in Northern Ireland has led to a lot of complaints to the ECtHR and in the 'war against terrorism', cases like the shooting of Jean Charles de Menezes in the London Underground in 2005 may be dealt with by the ECtHR in the future. ${ }^{118}$ Nonetheless,

\footnotetext{
111 Sangero 2006, p. 288. See IV.2.5.3.

112 Fischer, T. 2009, pp. 119-120 and Roxin 2006, pp. 638-639.

113 Horder in Shute \& Sullivan 2002, pp. 292-293 and Leverick 2006, pp. 165-166.

114 Leverick 2002A, p. 349.

115 McCann and others v. the United Kingdom, appl. no. 18984/91, 27 September 1995. See Smith, J.C. 2002, Ashworth 2006, p. 147 and Leverick 2002B.

116 Ormerod 2005, p. 332.

117 A Member State can also indirectly violate article 2 by not providing adequate protection for its citizens by sanctioning - not necessarily by criminal means - a violation of the right to life, see Leverick 2006, pp. 190-192.

118 De Menezes was misidentified as a suspect of attempted bombings on the previous day. The family of the deceased settled the matter with the Metropolitan Police.
} 
the UK has not often been held to have violated art. 2 ECHR. This is because the ECtHR has interpreted English law in such a way that it is in fact in line with their requirements. ${ }^{119}$

For example, in Brady v. the UK, ${ }^{120}$ the application was declared inadmissible because -according to the ECtHR - the English court had held that the defendant was mistaken for good reasons. The ECtHR looks at the facts of the case at hand, rather than the domestic legal framework. Domestic law does not have to be formulated identically to the test in art. 2, as long as the substance of the right is protected by it. The Court only assesses whether a concrete case violated a right under the Convention. In the cases against the United Kingdom, the Court held that the facts of the case could indicate a reasonable belief in the necessity of selfdefence. Although the English courts only tested the cases against an honest belief, the ECtHR decided this honest mistake was held for good reasons. ${ }^{121}$

The lack of a reasonableness requirement in English law can also be explained by reference to the fact that when the defendant would be convicted of murder, this brings about a mandatory life sentence, meaning that he will always have to serve a minimum period of 15 years of detention. ${ }^{122}$ If the mistake would need to be reasonable and it was unreasonable, there would be no possibility for the defendant to escape the severe mandatory penalty. This is undesirable, because even when the mistake is unreasonable, the reproach that can be made against that defendant is still not as serious as that to the 'normal' murderer, like the hired assassin. ${ }^{123}$ Doing away with the mandatory sentence would solve this and other problems relating to defences. ${ }^{124}$

\subsection{Justification or excuse}

If a mistake on the facts giving rise to a justification leads to an acquittal, this should not be based on the negation of a fault element like intent or negligence. What is it based on then? Is the acquittal based on the fact that a putative justification makes the act justified? Or does it excuse the actor? This question is related to the question whether the mistake must be reasonable or honest to acquit. When the mistake only needs to be honest, putative self-defence is logically a normal case of self-defence. It does not matter whether the defender was mistaken or not, as the circumstances are taken into account as he believes them to be. Both putative and regular self-defence justify the conduct.

119 Leverick 2002A, pp. 351-357 and de Than 2001, p. 419. Moreover, some applications were not considered in substance because domestic remedies were not exhausted.

120 Brady v. the United Kingdom, appl. no. 55151/00, 3 April 2001.

121 McCann and others v. the United Kingdom, appl. no. 18984/91, 27 September 1995 and Leverick 2006, pp. 185-187.

122 See the detailed sentencing guidelines in Schedule 21 of the Criminal Justice Act 2003.

123 See Sangero 2006, p. 282.

124 See X.3.6. 
On the contrary, by requiring that a putative justification must be reasonable, the putative and regular defence are clearly distinguished. On an objective utilitarian approach that looks at the end-result, the mistake can only be an excuse, because there is no harm avoided or greater good furthered. In contrast to a justified harm, injuring the putative aggressor is objectively wrong. ${ }^{125}$ As will be discussed in detail below, an excuse applies when the defendant could not reasonably have acted any differently. If it is accepted that a putative justification can only excuse, it follows that a putative defence must be reasonable or in other words, unavoidable. For example, in Dutch law, a putative justification excuses when the mistake is reasonable. ${ }^{126}$ This rule, which is also popular in the common law world, ${ }^{127}$ applies to all justifications in principle and is therefore simple to apply. The offence charged and defence raised may change the outcome, but not the test.

In fact, the rule is not even that different from the German approach of negating fault. I explained that if the mistake on the facts giving rise to a justification is reasonable, it also negates negligence liability in Germany. In other words, under both tests, a reasonable mistake acquits. The difference is that less is required to negate negligence than to excuse the defendant. This is logical, because blameworthiness is harder to negate than culpa. ${ }^{128}$ This can be illustrated by contrasting two cases. In the above-mentioned German case where the defendant thought the victim was reaching for a gun, this mistake was held to be reasonable given the threatening circumstances. In a Dutch case however, the defendant who made such a mistake was not excused for shooting the victim under putative selfdefence, even though the victim had already threatened him with a knife earlier that day. ${ }^{129}$ Only in exceptional circumstances will the mistake be held reasonable in the Netherlands. ${ }^{130}$

Nonetheless, it seems that Dutch courts are increasingly lenient in allowing a putative justification like self-defence to negate liability. As long as the defendant is not acting for reasons that oppose the values of the legal order, mistakes will not easily lead to criminal liability. For example, putative defence was accepted in the case where more than ten persons assaulted the defendant. He had used force against approaching police officers in civilian clothing, who had in fact wanted to stop the fighting. In such a hectic situation, the mistake was held to be excusable. ${ }^{131}$ Another defendant feared repercussions of a motorcycle club after he had stabbed some of their members. While he was driving, he was forced into the kerb by police

125 Robinson 1982, pp. 224 and 239-240; Fletcher 1978, p. 696 and Smith, J.C. 1989, p. 10.

126 De Jong, D.H. \& Knigge 2003, p. 181; Strijards 1983, pp. 188-190 and Fokkens \& Machielse, note 4 on Uitsluiting en verhoging van strafbaarheid.

127 Sangero 2006, pp. 40 and 283; Horder 1998, p. 147; Leverick 2006, p. 165 and Fletcher 1998, pp. 90-91 and 161-162.

128 See IV.6.5.

129 Rb. Rotterdam 15 April 2008, $L J N: B D 1263$.

130 Fokkens \& Machielse, note 7 on art. 41.

131 Hof Den Haag 9 February 2009, LJN:BH2267. 
officers who tried to arrest him. Not knowing they were police officers, he 'defended' himself with a firearm. This mistake was also held to be excusable. ${ }^{132}$

Some Dutch courts even seem to suggest that the actor is justified. ${ }^{133}$ By not making clear that the actor is excused due to his reasonable mistake, ${ }^{134}$ these decisions fuel minority opinions that view putative self-defence as actual selfdefence. ${ }^{135}$ In England and Germany too, a reasonable mistake in self-defence has been categorized within self-defence as a justification. ${ }^{136}$ I concede that it can be difficult to separate the putative from the regular defence. Consider that the aggressor is using an unloaded or fake firearm. Should the defendant merely be excused under putative defence for using defensive force or should he be justified under actual self-defence?

The acceptance of mistakes as actual justifications follows from an objective ex ante assessment of justifications. For example, many scholars in Germany hold that the question of whether there is a danger, giving rise to necessity or self-defence must be carried out objectively ex ante. This brings about that if a danger or attack reasonably seemed to be present tempore delicti, the defendant does not have to rely on a putative version of necessity or self-defence when it turns out ex post there was really no danger or attack. ${ }^{137}$ If the firearm reasonably seemed real or loaded, an attack existed. Another example drawn from German law is the justification of presumed consent. The consent based on reasonable indications does not become a mistake when it turns out later that the person concerned would not have consented, had he been able to express his opinion. ${ }^{138}$

If justifications ought to guide conduct, they should be assessed objectively ex ante. It can therefore be argued that a justification should apply when this seems reasonable tempore delicti. ${ }^{139}$ However, if we focus on the position of the other party, such as the presumed aggressor, it would be better to merely excuse the defendant. When the defendant mistakes that he is being attacked, equalling putative to actual self-defence would prejudice the presumed aggressor, which is all the more problematic if that person is not at fault for the mistake. A putative justification must be categorized as an excuse in order to enable this presumed aggressor to defend himself and in order for third parties to be able to intervene on behalf of the presumed aggressor. After all, if the putative defender would be justified, this implies that any person defending himself against the unnecessary use of force cannot rely on self-defence. Self-defence is possible only against a

132 Hof Den Haag 28 February 1997, NJ 1997, 373.

133 Ter Haar \& Meijer 2009, pp. 88-91. See for example, Rb. Alkmaar 8 July 2008, LJN:BD6660.

134 See for example Hof Arnhem 21 January 2009, LJN:BH1023.

135 Like de Hullu 2006, pp. 312-313 and less explicit, Machielse 1986, p. 507, 539 and 693.

136 Like Roxin 2006, pp. 636-637. See also Tadros 2005, pp. 281 and 289-291; Fletcher 1985, pp. 971-982 and Fletcher 1978, pp. 696 and 762-769.

137 See Bohlander 2009, p. 110; Roxin 2006, pp. 659 and 730 and Beulke 2008, p. 114. In contrast, Fischer, T. 2009, p. 305 favours an objective ex post evaluation.

138 Roxin 2006, pp. 636-637 and 822 and Beulke 2008, p. 132. See IX.5.4.2.

139 Husak 1989, pp. 508-518. 
wrongful, that is, non-justified attack. This also follows from the principle to be discussed in the next chapter, that two opposing actors cannot both be justified. Only one of the two acts can be lawful. ${ }^{140}$

\subsection{Error in persona and aberratio ictus}

In case the defendant is mistaken about the identity of the aggressor or if he misses the actual aggressor and hits a hostage, the view that a reasonable mistake can excuse is also most appropriate. The English doctrine that transfers defences, just like fault, from the intended to the actual object ${ }^{141}$ in these cases of error in persona and aberratio ictus must be rejected too. It is erroneous because it brings about that the defendant would be justified in harming or killing an innocent, with all the aforementioned ramifications. Whereas dolus is generalis, justifications surely are not. Whereas the identity of the object is usually irrelevant for the offence definition, a justification like self-defence gets its justificatory character from the fact that it is directed against a wrongful aggressor. An offence committed against an innocent third party can only be excused. ${ }^{142}$

The German approach to these cases must be rejected as well. In the case where the defendant not only hit the aggressor but also the aggressor's wife, he was acquitted through two particular approaches that have both been rejected. First, from this aberratio ictus, attempt liability followed as to the actual aggressor and negligence was established as to the injuries to the wife, who tried to restrain the aggressor. The attempt was justified by self-defence, but this did not rub off on the negligent wounding of the wife of the aggressor, because she was not part of the attack. In a next step, this mistake was treated like a mistake on the facts giving rise to a justification, which enabled the court to hold that the injuries to the wife were not negligent because the mistake was reasonable. After all, the defendant must have been in an emotional state and could not see anything at all. ${ }^{143}$ It is submitted that the most straightforward approach to an acquittal would be to excuse the defendant for the intentional injuries inflicted upon the wife since the mistake is not reproachable. ${ }^{144}$ A general part of criminal law for the EU should try to avoid unnecessary difficult doctrine.

140 Fletcher 1978, pp. 763-767; Fletcher 1998, pp. 90-91 and 161-162; Horder 1998, p. 147; Leverick 2006, p. 165; Ashworth 2006, p. 230 and Greenawalt 1984, p. 1922. See VIII.3.6.

141 Simester \& Sullivan, p. 157; section 24(2) of the draft Criminal Code, Law Commission 1989, p. 53 and Williams 1953, p. 107.

142 See section 24(2) of the draft Criminal Code, Law Commission 1989, p. 53; section 32(2), Law Commission 1993, p. 112 and Bohlander 2010A.

14330 November 1923 RGSt 58, 27.

144 If the collateral damage was unreasonable, complete liability for the intentional offence should follow, taking into account the special circumstances in sentencing. 
Chapter VII

\subsection{The distinction reconsidered}

A putative defence should excuse, regardless of whether it is a mistake on the facts giving rise to the defence or whether it is a mistake on the scope of the defence. The defendant, who fatally shot a thief in the erroneous belief that the pertinent legal provisions allowed him to shoot at thieves, could invoke the excuse too. ${ }^{145}$ By contrast, the German approach is founded on the distinction between mistakes on the facts giving rise to a justification and mistakes on the scope or existence of a justification. The English approach is founded on this distinction too, as often, only the mistakes of the second category need to be reasonable.

However, that distinction is not always easy to make and gives rise to overlap. For example, mistakes on normative elements, like proportionality in self-defence, are considered to be mistakes on the scope of a justification. However, if the defendant overestimated the nature and degree of aggressive force directed against him, a mistake on what degree of force is proportionate as a response can also be viewed as a factual mistake. ${ }^{146}$ Because the distinction is difficult to make, inconsistency and uncertainty can be avoided by applying one solution to both types of putative defences.

Nevertheless, the difference between the two categories of putative defences is relevant. A mistake on the scope of a defence can be seen as a species of a mistake as to the legal prohibition, which brings about even stricter requirements apply in order to excuse the defendant. A mistake on the conditions of a defence, such as the mistaken belief that the law allows one to shoot at thieves, is unlikely to be accepted as reasonable. Like a mistake of law, the mistake is even considered to be irrelevant, unless very special circumstances apply, such as that the chief of police had told the defendant that he could shoot at thieves. The broader defence of mistake as to the legal prohibition will be discussed in the chapter on excuses.

\subsection{Putative excuses}

Another distinction was made between putative justifications and putative excuses. Both categories should also be treated under one simple rule, which holds that the defendant is excused if the mistake was reasonable or unavoidable. The difference is that a putative excuse often appears to be a pleonasm; a mistake about a mistake. After all, most excuses already consist of a form of mistake. Self-defence-excess and duress can be viewed as putative versions of self-defence and necessity respectively. ${ }^{147}$ Duress is about what the defendant reasonably believed the threat to

\footnotetext{
145 HMG 6 October 1978, NJ 1979, 1. The justification is article 42 of the Dutch Criminal Code.

1461 July 1952 BGHSt 3, 194 and 9 May 2001 BGH NStZ 2001, 530. See Bohlander 2009, p. 76.

147 Schönke \& Schröder, H. 2006, pp. 353, 669 and 671; Fischer, T. 2009, p. 301 and Sangero 2006, p. 297.
} 
be and had good cause to fear. ${ }^{148}$ This means that both a correct and incorrect but reasonable belief qualify as regular duress. The defence of superior orders consists of a mistake too, namely on the legality or competence of the order. ${ }^{149}$ A reasonable mistake excuses the defendant under the defence; a lawful superior order would simply justify the actor. If excuses are framed to negate liability for reasonable mistakes, it follows that a mistake that is reasonable either qualifies as the excuse or is rejected. ${ }^{150}$ There is no room left to excuse on the basis of a putative excuse.

Moreover, both mistaken and true facts have the same effect on the actor, namely that of psychological coercion. ${ }^{151}$ From a psychological perspective, there is thus no reason to separate putative duress from regular duress. However, if only the subjective perspective would be relevant, the normative character of duress is neglected. The law has set the limits of what can be excused, limits, which cannot be made dependent on the defendant's perception of the law. Otherwise, any frailty of the defendant would lead to offences go unpunished. Normative aspects keep excuses within acceptable limits, making sure the interests of victims are also taken into account. Hence, even if there are mistakes that are not already encompassed by the regular excuse, these mistakes must always comply with the general rule of putative defences to negate criminal liability. For example, in order to excuse the defendant under duress, the mistaken fear must be unavoidable. ${ }^{152}$

Other putative excuses cannot acquit the defendant under any circumstances. Insanity and infancy do not include any subjective requirement. The defendant need not be aware of the circumstances giving rise to the defence, the assessment of the defence is purely objective. Therefore, the mistake of the defendant that the conditions of the defence are in fact fulfilled is of no influence to criminal liability. ${ }^{153}$ It can thus be concluded that the scope of putative excuses is much smaller than that of putative justifications. It can now also be concluded on the issue of mistakes in criminal law, that only mistakes on the offence definition can be relevant to fault; all others mistakes can at best excuse the defendant.

\section{The DISTINCTION UNDER PRESSURE}

In the previous paragraphs, several ramifications of the distinction between offence and defence were identified. The principle of legality has been developed with a

148 R. v. Graham [1981] EWCA Crim 5; Ormerod 2008, p. 329; Ashworth 2006, p. 222 and Beulke 2008, p. 154.

149 Nieboer 1991, p. 264. See X.6.

150 See Cleiren \& Nijboer 2008, note 19 on Boek I Titel III Inleidende opmerkingen.

151 Like Strijards 1987, pp. 118-119. See Roxin 2006, p. 987.

$152 \S 35(2)$ of the German Criminal Code; Roxin 2006, pp. 987-988 and Schönke \& Schröder, H. 2006, pp. 702 and 713; Dolman 2006, p. 177; R. v. Graham [1981] EWCA Crim 5; R. v. Howe [1986] UKHL 4 and R. v. Hasan [2005] UKHL 22.

153 Stuckenberg 2007, pp. 367-368. This is an argument in favour of seeing insanity as an exemption rather than an excuse, see X.7.6. 
view to apply to the offence definition. It can also be applied to defences, but only in a more limited fashion due to the different nature of defences. Secondly, the burden of proof depends on whether something is part of the offence definition or not and third, the application of an affirmative defence can bring about a special verdict, different from the acquittal that follows upon negation of an offence element.

In order to be held liable, the objective and subjective elements of an offence need to be proven. In order to be justified or excused, the conditions of a defence must also be fulfilled both objectively and subjectively. In dealing with deviations between objective reality and subjective perception, it became clear that such deviations can negate liability when they concern the offence definition, but that this is the exception when they relate to a defence.

First, if an offence definition is fulfilled only objectively, for example because the defendant was ignorant of a circumstance that the offence requires knowledge on, the defendant is acquitted for his mistake. ${ }^{154}$ In contrast, the defendant cannot rely on a defence if he is unaware that it applies to his situation. Second, if the defendant thinks he has fulfilled the offence definition, whereas this is objectively incorrect, there can be liability for impossible attempt at most. However, if the defendant mistakenly believes he has met the conditions of a defence, this is a putative defence and can at most excuse when reasonable.

\subsection{Non-ideal offences}

Because of these differences, the dichotomy of offence and defence is practically important. At the same time however, the dichotomy is put under pressure, when the absence of a defence is included in the offence definition. This can be the case when the offence includes terms like 'without lawful purpose' or the elements of wrongfulness and blameworthiness that defences negate. For example, in the Netherlands, wrongfulness is read into an offence element like ill-treatment. ${ }^{155}$ In England too, it is an essential element of all crimes of violence that the violence or threat thereof should be unlawful. ${ }^{156}$ We will call these 'non-ideal offences', as opposed to the ideal offence underlying the aforementioned structure of the offence, in which an affirmative defence either justifies the act or excuses the actor. ${ }^{157}$

Two important categories of non-ideal offences are reckless and negligent offences. Recklessness and culpa require an unreasonable risk. When a justification is accepted, this brings about the risk was reasonable. A justification therefore denies the offence elements of recklessness ${ }^{158}$ and culpa. When accepted, it leads to

See V.2.4

'Mishandelen' in article 300 of the Dutch Criminal Code, see Kelk 2005, p. 154.

R. v. Gladstone Williams [1983] EWCA; Ormerod 2006, p. 453 and Law Commission 2006, p. 3.

Koopmans 2007, pp. 88-89 and Nieboer 1991, pp. 240-241. See also Gardner J. 2007, p. 151.

158 See IV.4.5. 
an acquittal. ${ }^{159}$ It is accepted in all three Member States that a justified risk is not careless. For example, if the attacked person negligently injures the aggressor with a warning shot, the acceptance of self-defence negates culpa. I also explained that an excuse negates the subjective part of culpa. ${ }^{160}$ Negligent offences therefore subsume justifications and excuses, wrongfulness and blameworthiness. ${ }^{161}$

In these non-ideal offences, the acceptance of an affirmative defence brings about that the offence definition is not fulfilled. The defence negates an element of the offence. Justifications and excuses thus operate as a failure of proof defence, which implies they are treated like any other denial of the charge, such as an alibi or the claim that mens rea was lacking. These offences raise the question whether the distinction between offence and defence holds up. It is questioned whether the distinction is not arbitrary, depending merely on how the offence definition is drafted. I will however explain that there is in fact a material way to distinguish offences from defences. What should be encompassed by an offence is a normative question, not merely one of positive law.

Given the important ramifications of whether an element belongs to the offence or defence, it makes a lot of difference to the defendant whether the absence of a defence has been included into the offence definition or not. In general, the defendant will benefit when this is included in the offence definition. In contrast to the regular situation, it implies that the defendant needs not be aware that the justifying circumstances are fulfilled and that a putative defence negates intent. ${ }^{162}$ Furthermore, when the implied elements of wrongfulness and blameworthiness are expressly included in the offence definition, they form part of the prosecutor's case. This implies that the prosecutor has to prove the absence of all defences and that the defendant does not carry any burden of proof. ${ }^{163}$

The concept of non-ideal offences has attracted most attention in the Netherlands. This is quite logical if we consider the procedural significance of the question under Dutch law. I already mentioned that of the three States, only a Dutch verdict distinguishes between an acquittal due to lack of proof and a 'discharge' because of the acceptance of an affirmative defence. When the offence is non-ideal, the application of a justification leads to an acquittal rather than a discharge. ${ }^{164}$ In

159 Roxin 2006, p. 1077; Schönke \& Schröder, H. 2006, pp. 299, 305 and 319; Beulke 2008, p. 99; Ormerod 2005, pp. 318-319 and Williams 1953, p. 574; Pompe 1935, p. 90; Dolman 2006, p. 88; Keulen \& Otte 1999, pp. 46-47 and Krabbe in Krabbe \& Harteveld 1999, p. 133.

160 HR 19 February 1963, NJ 1962, 512; de Hullu 2006, p. 251 and Keulen \& Otte 1999, p. 50. See also IV.6.5.

161 Koopmans 2007 pp. 100-103; de Hullu 2006, p. 257; Kelk 2005, p. 207 and Krabbe in Krabbe \& Harteveld 1999, p. 131.

162 In German law, both mistakes on the offence definition and on the facts giving rise to a justification negate intent, regardless of the offence definition, see VII.5.2.

163 Simester \& Sullivan 2007, pp. 58-59. On p. 608, they mitigate this difference by arguing that the prosecutor also bears the ultimate burden of disproving affirmative defences.

164 Article 352 of the Dutch Code of Criminal Procedure; de Hullu 2006, p. 66 and Koopmans 2007 pp. 88-103. 
the other two Member States, the offence is also not justified: it is not fulfilled. The difference is however hardly noticed, since the verdict is always an acquittal.

Practically more important is that Dutch courts can generally reject a failure of proof defence easier than a justification or excuse. ${ }^{165}$ Therefore, much less motivation is also required from courts when they reject a justification or excuse that formally operates as a failure of proof. ${ }^{166}$ For substantive law, this is important because the more difficult it is for courts to reject a defence, the wider the substantive scope of the defence tends to be. For example, the Dutch Supreme Court has in effect widened the scope of self-defence by quashing convictions for insufficiently motivating why self-defence did not apply.

\subsection{Affirmative or failure of proof defence}

Although the application of defences to non-ideal offences implies that they should be treated as failure of proof defences, often they are treated not any different than affirmative defences applying to ideal offences, thus requiring a defensive purpose, which the defendant has to raise it and so on. For example, even though self-defence often operates as a failure of proof defence, it is generally recognized and treated as a justification. ${ }^{167}$

The practical consequences of a justification, having the effect of denying the charge, has generally been accepted not to be an inconsistency of the three tiered framework of criminal liability and not even an exception, but as a technical legal issue with implications only for procedural aspects of law. No one would argue that it would no longer be up for the defendant to raise self-defence or that he need not act with a view to apply self-defence. Otherwise, the defendant, who unknowingly injured a mugger, would be acquitted of the charge of inflicting (wrongful) injuries, whereas he would have been convicted of any other offence that does not require wrongfulness, like homicide.

Another example is the application of consent to offences against the person. The permission of the person who was injured negates the express offence element of wrongfulness. However, the circumstance that consent technically negates an offence element does not bring about that it is no longer treated as an affirmative defence: the defendant will only be able to rely on consent if he was aware of the other person's permission for the injury. ${ }^{168}$ By contrast, in other contexts, consent not only technically operates as a failure of proof defence, but is also treated as

165 Articles 358(3) and 359(2) of the Dutch Code of Criminal Procedure.

166 Koopmans 2007, pp. 85-87 and 129 and Keulen \& Otte 1999, pp. 55-56. This difference has been mitigated by case-law and the extension of the duty to motivate in article 359(2) of the Code of Criminal Procedure, but never abolished completely, see Koopmans 2007 pp. 116-135. Schönke \& Schröder, H. 2006, p. 176; Sangero 2006, p. 41 and Machielse 1986, pp. 699 and 702.

16810 July 1962 BGHSt 17, 359; Roxin 2006, p. 571; Beulke 2008, p. 130 and Fischer, T. 2009, p. 275 . 
such. For example, rape is characterized by sexual intercourse without consent. ${ }^{169}$ The absence of consent is an offence element and interpreted as such, not as the negative of the defence. If the defendant thought the other person consented, he did not intend to rape her. ${ }^{170}$ The question can be asked why consent is considered as a justification in one offence and as a failure of proof in another, if in both cases they technically negate the charge. I will now attempt to explain the difference.

\section{REAFFIRMING THE DISTINCTION}

It can be explained why and when an affirmative defence, that may seem to operate as a failure of proof defence, nevertheless should be considered and treated as an affirmative defence. This explanation attempts to remove the doubt, caused by nonideal offences, on the distinction between offence and defence. It affirms the framework of criminal liability by giving normative criteria on what should be included in the offence and what should be included in the defence part of criminal liability.

The explanation is grounded on two assumptions. First, the non-ideal offence element like wrongfulness can be distinguished from the implied element. The offence element can be given a specific meaning and thus be distinguished from the broader implied element. In this way, the affirmative defence does not negate the specific meaning that is included in the offence, but relates to the broader implied element. Justifications and excuses retain their affirmative character with all the aforementioned implications.

Secondly, this specific meaning follows from the typical character of the offence, wording or purpose of the legislator. In Directives that includes wrongfulness, the specific meaning of this element is often explicitly defined. ${ }^{171} \mathrm{~A}$ non-ideal offence element can be given a specific meaning if it gives the offence its essential character, like the lack of consent in rape. When a defence like consent negates that specific meaning, it should be treated as a failure of proof defence. Other justifications that are raised against this offence operate as affirmative defences, because they do not deny the essence of the offence. In this way, a dogmatic explanation is provided why in most cases, the application of a justification or excuse does not bring about that the conditions of that defence are made more lenient, just because it technically denies the charge.

169 See Section 1 of the English Sexual Offences Act 2003. $\$ 177$ of the German Criminal Code and article 242 of the Dutch Criminal Code refer to coercion, which vitiates and is therefore the opposite of consent, see HR 13 September 2005, LJN:AT5834.

170 If consent were treated as an affirmative defence, this putative defence could only negate liability if the mistake was reasonable. English law also requires a reasonable belief in the consent of the other, but this is put forwards simply as a statutory exception to the normal rules on mistakes on the offence definition, see V.2.4.2.

171 See article 2(a) of Directive 2008/99 of 19 November 2008 on the protection of the environment through criminal law, OJ 2008 L 328/28. 


\subsection{Different meanings of non-ideal elements}

Starting with the first assumption, a minority opinion in the Netherlands argues that when wrongfulness is included in offence definitions, it has a specific meaning. It is argued that a general definition of wrongfulness cannot be upheld for all offences. The purpose of including wrongfulness into an offence like the deprivation of freedom is different from its inclusion in crimes of dishonesty. Wrongfulness is therefore often included into offence definitions in many different ways, by terms such as 'unlawful', 'wrongful', 'without permission', 'without necessity', 'without a licence', 'ill-treatment' and so on.

This doctrine of 'facet wrongfulness' holds that the meaning of wrongfulness always depends on its wording and context. The term 'facet' refers to the feature that wrongfulness only represents one aspect or facet of the broad concept of wrongfulness. This restricted meaning of wrongfulness in a specific offence should thus be distinguished from the broader meaning of wrongfulness as an implied element, which is negated by the application of justifications. In other words, it is denied that the offence element absorbs the implied element. Instead, the express and the implied element coexist.

The approach creates at least two different concepts of wrongfulness. One concept of wrongfulness is expressly included into the offence definition and has a specific meaning depending on the pertinent offence; another concept of implied wrongfulness is negated by justifications that do not relate to the specific meaning of the express element. The offence element of wrongfulness does not absorb all justifications. The offence definition is argued to contain only one specific meaning of wrongfulness. Most justifications therefore do not negate the offence definition, but retain their status as an affirmative defence. ${ }^{172}$

A similar proposal has been made as to negligent offences. The common view in the Netherlands is that the subjective part of negligence, which consists of blameworthiness, belongs to the offence definition. Therefore, the negation of this part by an excuse implies a denial of the offence. ${ }^{173}$ To overcome this implication and its ramifications, it has been argued that the concept of negligence could also be made narrower by excluding from it blameworthiness. In other words, the subjective part of negligence would be moved from the first to the third tier of liability in the structure of the criminal offence. An excuse would not deny proof of the charge but negate the question on the blameworthiness of the actor, which would remain on the third tier of the framework. Excuses would then operate as affirmative defences rather than as a failure of proof. ${ }^{174}$

This reasoning is already incorporated in the German structure of the criminal offence. Prevailing opinion in Germany views the subjective part of negligence as

\footnotetext{
172 Kelk 2005, pp. 125-127; Fokkens \& Machielse, notes 1-4 on Wederrechtelijkheid and Machielse 1986, pp. 698-699.

173 Fokkens \& Machielse, note 8 on Schuld and Mevis 2006, pp. 607 and 632.

174 See de Jong, F. in Boone a.o. 2004 and Vellinga, W.H. 1982, pp. 69-73, 121-123 and 294-295.
} 
belonging to blameworthiness. When an excuse is accepted to a negligent charge, the defendant is excused rather than the charge negated. I mentioned before that only this approach dogmatically enables the taking of measures against an insane person who committed a negligent offence. ${ }^{175}$ This positioning should therefore be favoured in European criminal law.

\subsection{Essential element of the offence}

In order to determine whether a justification or excuse denies the specific meaning of the non-ideal offence element or whether it operates as an affirmative defence, one has to determine the specific meaning. This is done by reference to the typical character of the offence, wording or purpose of the legislator. In Dutch law, the meaning of wrongfulness must be explained in each offence by reference to the 'typical wrong' that the legislator aimed to combat by legislating this offence. ${ }^{176}$ This typical wrong or character of an offence is referred to in England usually as the 'essential element of the offence'. Just like in Germany, the offence definition should embody the typical infringement of a legal interest. Every offence has its individual label and characterizes its typical content of wrong in comparison to other offences and non-criminal conduct. ${ }^{177}$

For example, in most offences against property, the lack of consent is an essential element. The offence's typical character lies in the fact that something is done against the will or without permission of the party concerned. ${ }^{178}$ Therefore, the prosecutor should prove this; intention must be negated if the defendant was unaware of its absence and so on. In contrast, consent operates as an affirmative defence against the charge of inflicting bodily injury, because the typical wrong of the offence is the injury itself. The qualification of the injury as wrongful is not essential to its character. The German Supreme Court held that if wrongfulness does not constitute an essential part of the offence, its inclusion in the offence definition should be considered merely as a redundant referral to the implied element, as a reminder of the legislator to the judge that he must consider that a justification might apply. ${ }^{179}$

This offence-specific approach can also explain why in relation to the same offence, a justification sometimes becomes a failure of proof, whereas another justification would simply justify the act. For example, the offence of damaging goods requires, amongst others, proof that the damage was inflicted wrongfully. ${ }^{180}$

175 Roxin 2006, p. 1104; Beulke 2008, p. 342 and Bohlander 2009, p. 55. See IV.6.5.3.

176 Fokkens \& Machielse, note 3 on Wederrechtelijkheid.

177 R. v. Hunt [1987] AC 352; Beulke 2008, pp. 38 and 42; Schönke \& Schröder, H. 2006, pp. 169170 and Kelk 2005, pp. 85-86 and 129-131. De Hullu 2006, p. 183 argues this 'Typizität' is not popular in the Netherlands.

178 Beulke 2008, p. 126.

17918 March 1952 BGHSt 2, 194 and Smith, J.C. 1989, pp. 45-47.

180 Article 350 of the Dutch Criminal Code. Intent need not relate to the wrongfulness. 
Wrongfulness in this context can be interpreted in line with the essence and purpose of the offence as damage that is carried out without permission. This explains why consent of the owner in regard to the damage operates as a failure of proof defence. On the contrary, other justifications cannot negate the offencespecific meaning of wrongfulness and therefore can only justify the actor. Consider the defendant who needed to protect himself against an attack of an unleashed dog. He succeeded in defending himself, but in doing so wounded the dog. The damage is wrongful in the meaning that the owner did not consent to it, but the defendant may invoke the justification of necessity to justify his actions. ${ }^{181}$

The defendant who raises the consent of the owner in regard to the charge of inflicting wrongful damage thus need not even have known the owner consented to the damage. He can also not be convicted if he incorrectly thought the owner consented. By contrast, the defendant who protects himself against the dog does need to have been (at least) aware of the facts giving rise to necessity. Even though formally, the justification becomes a failure of proof defence, it still requires a defensive purpose. Moreover, if he was mistaken on the need to protect himself, this putative defence can only excuse the defendant, if that mistake was reasonable.

In the previous chapter, it was already explained that wrongfulness is included into offence definitions that relate to behaviour that is frequently carried out in accordance with the law, such as the destruction of property, sexual intercourse, the access to information systems and the detention of persons. Wrongfulness appropriately restricts the scope of the offence so it includes the essential wrong, safeguarding its typical character. If the absence of consent would not be an offence element, rape would be much too broad. If the deprivation of freedom need not to be wrongful, police officers would commit multiple offences a day. ${ }^{182}$

In that context, it was argued that dolus must relate to wrongfulness if it is an essential element of the crime. In this context, it is stressed that essential offence elements should be included into the offence definition. It does not suffice to argue that someone who has sexual intercourse can invoke consent as a defence. It would be inappropriate for the police officer to invoke his official powers as a defence. Clearly, it is sensible to draft offence definitions so that they encompass the most common situations, leaving the rare situations for defences. ${ }^{183}$ Thus, in some cases, the defence should be included in the offence definition. It would it be inefficient to require all those people to raise the lack of wrongfulness as a defence to the offence. ${ }^{184}$

181 Self-defence can only be applied to human aggressors, see IX.3.4.1. Another example is that articles 405-407 of the Dutch Criminal Code refer to acts committed 'without necessity'. In those offences, necessity operates as a failure of proof, whereas other justifications should be considered as affirmative defences.

18 March 1952 BGHSt 2, 194; de Hullu 2006, pp. 180-181; Bosch 2008, p. 165 and Mevis 2006, p. 591. See IV.2.4.7.

183 Nieboer 1991, pp. 229-230 and de Hullu 2006, p. 278.

184 See Koopmans 2007, p. 91. 
However, the decision of what to include in the offence should not be a mere matter of drafting ease and efficiency. Requiring the actors above to raise a defence would also violate the typical character of the offence. In other words, the offence should encompass actions, which there are prima facie reasons not to perform. It explains why a defence such as consent is sometimes part of the offence, such as absence of consent in rape, and sometimes not, like in assault. The reason for this is that there is a general reason not to assault people, whereas there is no general reason not to have sexual intercourse. The harm sought to criminalize is sexual intercourse without consent, not plain sexual intercourse. Without wrongfulness in the offence definition, innocent conduct would be criminal. ${ }^{185}$

The distinction of offence and defence appreciates the difference between typical wrong and atypical situation of justification. Criminal law should communicate that there has been committed no offence. It is inappropriate to require the defendant to raise a defence because that would imply that although the conduct is generally wrong, it was justified in his circumstances. Instead, the conduct was not wrong at all. The distinction of offence and defence is crucial to the project of criminal law in communicating morally significant distinctions. In conclusion, the application of defences to non-ideal offences therefore not undermines, but strengthens the distinction of offence and defence. It is useful and relevant to make the distinction. Now, it will be considered whether it is also useful and relevant to distinguish affirmative defences into justifications and excuses.

185 Campbell in Dennis 1987, pp. 81-84; Gardner 2004, pp. 819-821; Duff 2004, pp. 830-831; Mevis 2006, p. 616; de Jong, D.H. \& Knigge 2003, p. 92 and Strijards 1987, pp. 2-4 and 15-17. 



\section{Chapter VIII JUSTIFICATIONS AND EXCUSES}

The categorization of defences into justifications and excuses is very common in western criminal law. It is accepted in the Dutch, German and EU legal system and even if not accepted generally in England, it is at least well known. The application of a justification means that criminal law acknowledges other norms that can prevail over the violation of the criminal norm. The application of an excuse is to adjust the requirements that apply to normal people in normal situations to the specific (abnormal) situations or people. Criminal law does not want to impose an unbearable burden.

The bifurcation plays an important conceptual and normative role in theory and practice. It makes a fundamental distinction between wrongfulness and blameworthiness, between right and wrong, between act and actor, between an objective evaluation of all things considered and subjective reasons for acting. A justification is the mirror image of wrongfulness, whereas the acceptance of an excuse negates blameworthiness. The dichotomy coincides with the second and third tier on the ladder of criminal liability. The fundamental character of wrongfulness and blameworthiness warrant a special position on the framework of criminal liability. Wrongfulness and blameworthiness are derived and thus influenced by the principle of harm and guilt respectively. A justification is based on the principle "no punishment without wrongfulness'; an excuse if based on the principle 'no punishment without guilt'. ${ }^{1}$

Before it will be discussed what the individual justifications and excuses of EU criminal law should look like, the dichotomy as such will be put under closer scrutiny. In more detail, it will be explained what justifications and excuses have in common, in what ways they differ and most importantly, what practical legal consequences this brings about. The consequences of the dichotomy have been questioned, and as a result, the dichotomy as such too. In this chapter, that criticism will be addressed, after which it will be concluded that even if some of the consequences are less important than generally accepted, there are many dogmatic and practical reasons to uphold the distinction of justification and excuses.

\section{Historic ORIGins}

The distinction of justification and excuse can be traced back to many sources. Already in 1625, Grotius discussed whether wars could be justified. His concept of wars included what we would now include in self-defence. The term 'causa justifica' or justifying reason was introduced. In 1793, Gentz, a student of Kant,

Nieboer 1991, pp. 239 and 260-261. 
used the example of two shipwrecked persons fighting for a plank that is only large enough to support one of them in order to illustrate the difference between justifications and excuses. When Kant himself discussed this case in 1797, he argued that the necessity of the situation does not make what is unjust lawful. However, no law can demand from a person that he sacrifices himself. Necessity knows no law. The certain threat of death will always weigh heavier that the possible death penalty. Thus, the act of violent self-preservation is not justified, 'inculpable', 'unsträflich', but merely excused, 'impunible', 'unstrafbar'.

The dichotomy is so self-evident in German and Dutch law that it is incorporated in legislation and case-law. The incorporation of the dichotomy in legislation is most visible in the provisions of certain defences in the Criminal Code of Germany. When the justification of self-defence applies, the pertinent paragraph holds that the result is that the defendant does not act wrongful. If he is excused for exceeding the limits of self-defence, the defendant will not be punished. The acceptance of the excusing form of necessity, which will be called duress, is that blameworthiness is lacking. ${ }^{3}$ By contrast, the 1871 Imperial German Criminal Code did not yet make the distinction. The three partite structure of criminal liability was not introduced before the beginning of the twentieth century. ${ }^{4}$ Although currently self-evident, the dichotomy is therefore only recognized for about a century in law. ${ }^{5}$

In the Netherlands, the distinction was also not made before the twentieth century. The Dutch Criminal Code was drafted at the end of the nineteenth century, which explains why the Code does not differentiate between justification and excuses, merely stating in defences that "he who ... is not punishable." Only after the Code had been enacted was the dichotomy acknowledged by scholars and applied to the existing defences by the judiciary. ${ }^{6}$ The Dutch Code of Criminal Procedure of 1921 does incorporate the dichotomy. The judicial model of decisionmaking in article 350 follows the three-tiered structure of criminal liability, separating the question of punishability of the act from that regarding the actor. This is commonly accepted to relate to the implied elements of wrongfulness and blameworthiness and therefore also to justifications and excuses. ${ }^{7}$

Even though the distinction is not such an important part of criminal legal doctrine in England as it is in Germany, in recent decades that difference has greatly diminished. Whereas two decades ago, English law still appeared to lack interest in the distinction for want of practical relevance, ${ }^{8}$ it has gained popularity

Hruschka in Byrd \& Hruschka 2007. This would nowadays therefore be called duress, to emphasize the excusatory nature of the conflict of interests.

$\S \S 32,33$ and 35 of the German Criminal Code respectively.

Eser in Eser \& Fletcher 1987, pp. 37-41.

Roxin 2006, p. 963 submits the dichotomy has been accepted in German scholarship since approximately 1930 .

6 Fokkens \& Machielse, note 2 on Uitsluiting en verhoging van strafbaarheid; Kelk 2005, p. 249 and Nieboer 1991, pp. 242-243.

7 De Hullu 2006, pp. 273-274 and Vellinga, W.H. 1982, pp. 45-46.

8 See Eser in Eser \& Fletcher 1987, p. 19 and Fletcher in Eser \& Fletcher 1987, p. 78. 
since then. It can be expected that this trend towards acceptance of the dichotomy and its implications will only continue in the years to come. It would be tempting to ascribe this trend to the influence of German legal thinking, as a result of German scholars publishing in English, Anglo-American scholars doing research on German law or by the interaction of German and Anglo-American scholars. ${ }^{9}$ It has nevertheless also been submitted that the distinction of justification and excuse has its roots in the common law distinction between justifiable and excusable homicide. ${ }^{10}$ The homicide is merely excused when the defendant was not an innocent person defending himself against an aggressor, but someone participating in a quarrel, who needed to kill his adversary to avoid immediate death. ${ }^{11}$

The lesser influence of the dichotomy in English law can be explained by a number of reasons. First and foremost, English lawyers and especially English courts are less concerned with dogmatic reasoning than they are with finding an acceptable outcome. To an English judge, the legal reason for the outcome is subsidiary. It does not matter whether the defendant is acquitted because of a justification or excuse. ${ }^{12}$ To some, it does not even matter whether the defendant is acquitted because he is justified, because he lacks intent or because he cannot be said to have caused the crime. ${ }^{13}$ The conceptualization of justifications and excuses is therefore only perceived as important as far as it brings about different legal consequences.

Secondly, the division of actus reus and mens rea is the traditional dichotomy in English law. As noted, when justifications and excuses came to the fore, they were often pigeonholed with actus reus and mens rea respectively. One result is that fault elements and blameworthiness are still often not clearly separated. This has been illustrated by cases where the defendant who acted under duress was said not to have acted with intent. Blameworthiness needs to be separated from mens rea in order to carve out conceptual space for excuses. This is increasingly recognized in English law, which therefore seems to make a similar development as in German and Dutch law. Just like German and Dutch law soaked off fault elements from the concept of blameworthiness (Schuld/schuld), English law now increasingly distinguishes blameworthiness from the concept of mens rea. ${ }^{14}$

9 For instance Bohlander 2008, Fletcher 1978 and Eser \& Fletcher 1987 respectively.

$10 \quad$ Fletcher in Eser \& Fletcher 1988, pp. 797-798; Fletcher 1998, p. 131 and Fletcher 1978, p. 857.

11 Finkel \& Parrott 2006, pp. 207-208 and Blackstone 1979, pp. 183-188.

12 Re A. (Children) [2000] EWCA Civ 254 per Robert Walker LJ: "I do not think it matters whether these defences are regarded as justifications or excuses."

13 Airedale National Health Service Trust v. Bland [1992] UKHL 5 per Bingham M.R.: "For present purposes I do not think it greatly matters whether one simply says that that is not an unlawful act, or that the doctor lacks criminal intent, or that he breaches no duty or that his act did not cause death."

14 See III.5. and IV.2.4.1. 


\section{ConTroversy}

There is now widespread consensus in the legal systems under investigation that defences either relate to the wrongfulness of the act or the blameworthiness of the actor. Defences are therefore either justifications or excuses. Nevertheless, this does not mean that the matter is uncontroversial. Even in the Netherlands and Germany, the demarcation of the categories, their rationale and the implications are all highly debated. First, whereas the classification of defences is generally accepted, numerous examples have been given to question this. For example, whereas duress is an excuse, it has also been argued that where there is great disparity between the interest that saved and sacrificed, like when an actor is compelled under a threat of death to give the key of a safe, the actor should be justified rather than excused.

Secondly, attempts have been made to describe the rationale or character of a justification and excuse. These will be discussed in detail in the first paragraphs of chapters IX and X. Monistic theories aim to give an all-encompassing rationale, which is applicable to all justifications or excuses. For example, justifications are often described as a conflict of interests. By contrast, it has been argued that when a consenting party waives her interest, there is no conflict of interests. As a result, pluralistic theories have gained popularity, such as that a justification consists of either a superior or an absent interest. ${ }^{15}$

Third, the dichotomy brings about some implications. Amongst others, it is accepted that excuses only operate personal, whereas justifications are universal. A justification thus applies to all perpetrators and accomplices of an offence. However, as will also be explained in more detail below, in some situations, a justification should operate only personally. Therefore, whereas these practical implications make the categorization of defences highly relevant, they are controversial too. ${ }^{16}$

As a result of all the controversy, English scholars in particular, have criticized the dichotomy and advanced other categorizations instead. ${ }^{17}$ The dichotomy sits much easier with US scholars, which can in part be explained by the Model Penal Code's recognition of the dichotomy. Amongst these alternative categorizations, one often finds a separate category of mental condition defences. As will be explained at the end of this chapter, I also believe there are good reasons to distinguish so-called exemptions like insanity from justifications and excuses. There are also Dutch scholars who have put the dichotomy in perspective. ${ }^{18}$ In German law, by contrast, one will almost only find proposals to modify or extend the dichotomy. The dichotomy as such is widely accepted.

See IX.1.

For example, Gur-Arye 1986, pp. 71-89 denies the implications of the distinction.

Simester \& Sullivan 2007, pp. 611-612; Ormerod 2005, pp. 248-249 and Ormerod 2008, p. 271.

Like Knigge 1993, pp. 37-39 and de Hullu 2006, pp. 271, 274-276, 298 and 360. 


\section{DifferenCES}

I will now discuss the differences between justification and excuse and practical consequences thereof in detail. I will assess whether the criticism vented against these differences is warranted, after which I conclude which differences hold up.

\subsection{Communication}

The most fundamental rationale of the distinction is that a justification negates the wrongfulness of the act; an excuse negates the blameworthiness of the actor. ${ }^{19}$ This brings about a communicative difference. A conviction communicates the reproach towards the perpetrator, makes clear that he should be condemned for doing what he did. Preventive purposes are served by making clear that this conduct is criminal, signalling that it will be punished. A difference can be made between acquitting the defendant who did not commit the crime at all, and acquitting the defendant who committed the crime but was justified in doing so, because of, for example, selfdefence.

The dichotomy of justification and excuse enables an even more nuanced communication. There is a moral difference between having acted, all things considered, in accordance with the legal order and merely being excused because you cannot be blamed for having infringed the norms of the legal order. The defendant who raises an excuse confirms the wrongdoing and merely seeks to assert an explanation for his conduct. Not only lawyers can understand this difference. ${ }^{20}$ Because of the natural character of this difference, it is therefore both feasible and desirable for courts to explain why someone is granted a defence. ${ }^{21}$ This can be done by creating a special verdict, such as 'not guilty by reason of insanity', 22 but it can also be done simply by explaining clearly in the judgment why the defendant is acquitted. ${ }^{23}$

In legal terms, wrongfulness constitutes the law's socio-ethical condemnation of the act, whereas blameworthiness constitutes a social-ethical reprimand against the actor. $^{24}$ The acceptance of an excuse makes clear to the defendant and the public that what he did was wrong, whereas the acceptance of a justification denies that what the defendant did was wrongful in the eyes of the legal order. The distinction can explain why it is relatively easier for a court to excuse a defendant than to justify his conduct. An excuse does not deny the prima facie wrong of the offence; it also

19 Krey 2003, pp. 12-13; Schönke \& Schröder, H. 2006, p. 578; Simester \& Sullivan 2007, p. 609; Ashworth 2006, p. 97; Ormerod 2005, p. 248; de Jong, D.H. \& Knigge 2003, p. 55 and Fokkens \& Machielse, note 13 on art. 41.

20 Eser in Eser \& Fletcher 1987, pp. 26-27.

21 Leverick 2006, pp. 40-41; Tadros 2005, pp. 120 and 266; Greenawalt 1984, pp. 1900-1901 and Robinson 1982, pp. 245-248.

22 See Section 2 of the Trial of Lunatics Act 1883.

23 See Eser in Eser \& Fletcher 1987, p. 27.

24 Krey 2003, pp. 12-13 and 18-19 and Fischer, T. 2009, p. 65. 
does not deny the wrongfulness of the act all things considered. The excuse does not threaten the general application of norms and thereby the authority of the legislator. Instead, it strengthens the general injunction by admitting its wrongful character.

The effect of the dichotomy has been summarized as that it "gives a clearer response to the public at large as to how they should relate to an acquittal, and holds greater educational value, clarity, and guidance for behaviour." 25 If the distinction is not made, there is a danger that the public believes that excused conduct is labelled as legal or justified. Because of that danger, courts may become unwilling to excuse the defendant, fearing that this message will be misinterpreted. The result of such fears is that excuses are framed very limited or rejected altogether. ${ }^{26} \mathrm{~A}$ clear-cut example is the conviction of an English court of the crew of the Mignonette, who ate the cabin boy when they were cast away to feed upon his body. The excuse of duress was rejected because the court feared the public would misunderstand their acquittal as a vindication of their actions. ${ }^{27}$

\subsection{Rationale and conditions}

Another implication of the categorization is that it affects its rationale and conditions. ${ }^{28}$ Theoretical structuring influences the law as it is. For example, to categorize self-defence as an excuse would limit the defence to only the most important interests and impose a strict duty to retreat, because only then the actor does not have any alternative. ${ }^{29}$ By focusing on the justificatory nature of selfdefence, stricter limits are placed on proportionality. It has also been argued that if a defence is a justification, the fact that the defendant can be reproached for causing the conditions of his defence is not relevant, because it does not change the justified character of his conduct. In contrast, this prior fault does affect an excuse like duress because the person who acts wrongful cannot be exculpated if he has done something blameworthy. ${ }^{30}$

\subsection{Enabling measures}

From a German and Dutch point of view, the dichotomy facilitates the distinction between measures and punishment. Punishment presupposes blameworthiness, whereas measures merely require a wrongful act. Therefore, by excusing the insane, they cannot be punished, but measures of rehabilitation or incapacitation can be ordered against them. It is also sometimes argued that forfeiture of assets, the losing

Sangero 2006, p. 15.

See also Sangero 2006, p. 16 and Tadros 2005, p. 266.

R. v. Dudley and Stephens (1884) 14 QBD 273 and Fletcher 2007, pp. 321-324. See IX.4.5.3.

Fletcher 1978, p. 855.

Sangero 2006, p. 38 and Fletcher 1978, p. 855.

De Hullu in Verbruggen, Verstraeten, van Daele \& Spriet 2005, p. 55 and Roxin 2006, p. 751. 
of rights and civil compensation is still possible when the defendant is excused, in contrast to when the act is justified. ${ }^{31}$ Defendants therefore prefer to be justified rather than merely excused. However, it is clear that measures can also be taken in all three legal systems without the establishment of a wrongful act. The deprivation of illegally obtained advantage for example, can also relate to offences that have never been charged or proven. ${ }^{32}$ Secondly, a person can also be admitted to a mental hospital based on other fields of law, which do not require a (wrongful) act.

The perspective one takes on this supposed distinction is very much related to the perspective one takes on the nature of justified conduct. Does a justification make conduct right or does it merely make it not wrongful? Does the acceptance of a justification communicate that the conduct is commendable or merely that it is permissible? The latter, in my eyes correct view, brings about that the abovementioned implication also collapses. Even when the defendant sacrifices a lesser interest of a third party in justifying necessity, it can still be fair to require him to compensate that third party. ${ }^{33}$ The wrongfulness of the act is not completely negated. A degree of wrongfulness, sufficient for compensation in civil law remains. Similarly, the application of an excuse does not preclude blameworthiness in a civil law sense. ${ }^{34}$

\subsection{Complete or partial negation of the implied element}

There is another way to frame the abovementioned question. This is to ask whether a justification completely negates or merely diminishes the implied element of wrongfulness. Both questions are controversial in all three States. Broadly speaking, three approaches are taken. Obviously, the first is to argue in favour of complete and the second in favour of partial negation of wrongfulness. Both approaches thus agree that the justification of conduct at a minimum implies that it is permissible. The controversy relates to the question whether justified conduct can also be right, and thus, whether wrongfulness is also completely negated. A third, differentiated approach, is to argue that in some instances justified conduct is right, whereas in other it is merely permissible.

In contrast to this controversy regarding justifications, it is widely accepted that excuses do not completely negate the reproach of blameworthiness, but abstain from this reproach due to empathy for the situation of coercion or conflict. The effect of an excuse like duress is that it limits the degree of blameworthiness to a degree that falls short of the threshold for criminal liability. This is the common

31 See Fletcher 1978, p. 761; Robinson 1982, p. 290; Simester \& Sullivan 2007, p. 608 and Ormerod 2005, pp. 247-248. Under the old common law, an excusable homicide still led to the forfeiture of the actor's property, see Sangero 2006, p. 33 and 35.

32 See Harry van Offeren v. the Netherlands, appl. no. 19581/04, 5 July 2005.

33 Fletcher 1978, p. 761.

34 Fokkens \& Machielse, note 13 on art. 41 and note 1 on Schuld; Schönke \& Schröder, H. 2006, p. 590 and Roxin 2006, pp. 613-615. 
view in German law. ${ }^{35}$ By contrast, a justification does not operate in degrees; it is either wrongful or justified. Its acceptance thus completely negates the implied element of wrongfulness. ${ }^{36}$ This perspective brings about that a justification is viewed as commendable or right conduct.

In contrast, prevailing opinion in the Netherlands seems to be that both justifications and excuses only reduce wrongfulness and blameworthiness to a level insufficient for criminal liability, implying that a residue of wrongfulness and blameworthiness is left. If a complete negation would be required, too much may be demanded before a defence would be accepted. ${ }^{37}$ Accordingly, it has been submitted that justified conduct is permissible, not good or right conduct. ${ }^{38}$ Many German scholars also argue that justified conduct is merely permissible conduct. ${ }^{39}$ The acceptance of a justification communicates that the actor's conduct is not censured and thereby tolerated. It does not communicate a positive valuation of the act. 40

In English law, the issue is hardly ever related to the impact on the implied elements of criminal liability, which is obvious, given the lack of a clear recognition of the implied elements. It is simply argued by some that the justification implies the actor did the right thing, whereas more argue it merely implies that conduct is permissible. ${ }^{41}$ The most popular approach in England is a differentiated one. It is argued that in some instances, a justification legalizes the behaviour or harm caused. In other instances, it is perceived as only permissible. Self-defence, for example, is considered right when the defendant used only moderate force against a serious attack. By contrast, it tends to be considered as merely permissible when the force used to avert the attack was less proportionate or when the defendant provoked the attack. ${ }^{42}$ Some German scholars take a similar approach. ${ }^{43}$

35 Eser in Eser \& Fletcher 1988, pp. 57-58 and Schönke \& Schröder, H. 2006, pp. 626-627 and 701. Other excuses like insanity and mistake of law are said to completely negate all blameworthiness.

36 Schönke \& Schröder, H. 2006, p. 171.

37 De Hullu 2006, p. 274-275; den Harder 2006; Strijards 1987, pp. 36-37 and Fokkens \& Machielse, note 1 on Schuld. See also Kelk 2005, p. 250-252. The Dutch legal terminology for excuse, 'schulduitsluitingsgrond', implies the opposite. Van Dijk, A.A. 2008, pp. 16-17 and Cleiren \& Nijboer 2008, note 2 on Boek I Titel III Inleidende opmerkingen. See Hof Amsterdam 9 December 2005 LJN:AU7731. In contrast, see AG Remmelink in HR 1 March 1983, NJ 1983, 468 and Strijards 1987, p. 37. Beulke 2008, p. 96.

40 Roxin 2006, p. 600 and Schönke \& Schröder, H. 2006, pp. 579-582.

41 A residue or remainder of wrongfulness also follows from the consideration that the justified killing in self-defence does not eliminate the prima facie reasons against killing, see Campbell in Dennis 1987 and Gardner 2004, p. 819. Partial negation is also accepted by US scholars Fletcher in Eser \& Fletcher 1987, p. 111; Greenawalt 1984, p. 1905 and Husak 1989, p. 500. Horder 2006A, pp. 99-101; Robinson 1982, p. 214; Husak 1999, p. 52 and Duff 2004, p. 832. Günther in Seebode 1992. See also Roxin 2006, pp. 600-601 and Mitsch 2007, p. 201. 
Another differentiated approach in England separates strong from weak justifications. ${ }^{44}$ This also resembles the distinction made in German law between proper justifications like self-defence on the one hand that ground a 'right to interfere', and weaker justifications like presumed consent on the other, that merely provide for a 'licence to act'. The latter do not affect the wrongfulness of the act, but lead to the conclusion that it would be unfair to punish the defendant. ${ }^{45}$ This second differentiated approach differs from the previous one by holding all accounts of self-defence as right conduct, completely negating wrongfulness, regardless of the specific circumstances of the case. This subtle distinction between the complete negation and partial reduction of implied elements lacks direct practical relevance and is no longer made in the following sections. It will simply be stated that the acceptance of a justification or excuse negates wrongfulness or blameworthiness respectively.

\subsection{Personal and universal application}

Perhaps the most important practical implication of the dichotomy is that justifications are believed to have a universal character, whereas excuses operate only personally. This means that if someone is justified, a third party may assist that person, whereas if that someone is merely excused, a third party may not intervene. For example, if the defendant helped someone who was using force in self-defence, he will not be liable for aiding and abetting. In contrast, if that someone was coerced to injure another, the defendant will be liable for helping that excused actor. The defendant was not personally coerced to injure the victim. ${ }^{46}$

Whereas it is generally accepted that excuses apply only personally, ${ }^{47}$ the question whether justifications also apply to other participants or accomplices is again very controversial. This is often accepted based on the perspective that justified conduct is said to produce a net benefit and therefore no wrong. It should therefore be supported by the legal order, by making clear that others are allowed to help the justified actor. Moreover, a justification relates to the conduct, not to a specific defendant. Whereas excuses apply because of the understandable subjective reasons for a defendant to commit a crime, justified conduct is objectively right. It should therefore apply to all perpetrators of that conduct. This is reflected in the national doctrines on participation. Participation is only possible in a wrongful act,

\footnotetext{
$44 \quad$ Dressler 1987, p. 1161 and Duff 2004, p. 832.

45 Bohlander 2009, pp. 78-79.

46 Ormerod 2008, p. 269; Fletcher 1978, pp. 761-762; Tadros 2005, pp. 281-282; Sangero 2006, p. 13; 20 June 1932 RGSt 66, 288; Roxin 2006, p. 964; Schönke \& Schröder, H. 2006, pp. 578 and 701; Bernsmann 1996, p. 184; Bosch 2008, pp. 171 and 184; Kelk 2005, p. 300 and Fokkens \& Machielse, note 14 on art. 41.

47 R. v. Quick [1973] QB 310; \$29 of the German Criminal Code; Bohlander 2009, p. 115 and Beulke 2008, p. 148. In contrast, see Husak 1989, pp. 493-495 and 519-520.
} 
so a justification applies to all participants. ${ }^{48}$ Liability of the participant is derived from the wrongful act. Liability is thus accessorial in a limited way, for it does not require criminal liability of the principal, who may be excused. ${ }^{49}$

Prevailing opinion in Germany follows this reasoning strictly and holds that justifications are universal. On the contrary, the most popular approach in England and the Netherlands is a differentiated one. Although as a rule, a justification operates to all participants and accomplices, there may be instances where this is not the case. A differentiation can be made with a view to the role of the individual defendant. For example, a justification is not universal when two people use force against an attacker, whereby one of them exceeds the amount of proportionate force. It can only be argued that the other is justified. Or, consider that one of the defenders is a police officer. Whereas the other, a citizen, is required to retreat, the police officer is not. The fact that the police officer is justified in using force, does not rub off on the citizen, which is inconsistent with a universal application of justifications. It has therefore been argued that all defences should be assessed according to each participant or individual. After all, defences always appeal to exceptional circumstances, which are predominantly determined by specific circumstances of the case for a specific defendant. ${ }^{50}$

It can even be argued that a justification always operates personally, if we recall that every justification requires a defensive purpose. As explained before, the defendant must at least be aware of the justifying circumstances. A defensive purpose implies that a justification is personal, based on the subjective beliefs of the person who relies on it. ${ }^{51}$ If an old lady is being mugged, the defendant who uses force against the mugger for the joy of beating this person up will not be justified if he does not know the lady was being attacked. It can be concluded therefore, that even though the implication is well known and often applied, it is by no means a general rule. It seems inconsistent with the requirement of a defensive purpose and fails to appreciate other personal features of justifications. Accordingly, it should be rejected in a general part of EU criminal law.

\subsection{Incompatibility}

The incompatibility rule holds that two opposing parties cannot both be justified. Justifications are therefore 'incompatible'. Self-defence against self-defence is impossible. This already follows from the condition of that justification that the

\footnotetext{
$48 \quad$ Beulke 2008, p. 100.

49 Bohlander 2009, pp. 167-168.

50 De Hullu 2006, p. 358 and Holland 1989, p. 244. Article 50 of the Dutch Criminal Code has been interpreted as meaning that all defences operate personal, see de Hullu 2006, pp. 358-359 and Nieboer 1991, pp. 242-243, but it has also been argued that is says nothing more than that personal defences only operate personally, see Kelk 2005, pp. 250 and 301.

51 It could also be argued that a defensive purpose is inconsistent with the universal character of a justification and should therefore not be required. See VII.4.
} 
attack that is averted must be wrongful. Since a justified attack is not wrongful, the party opposing that attack cannot rely on self-defence. In other words, when a person is justified in infringing a legal interest of another in necessity or selfdefence, that person cannot rely on self-defence to stop the infringement. This condition, like the rule of incompatibility, prevents escalation of conflicts and makes sure that the message of the law is univocal: only one of two opposing parties can be justified. ${ }^{52}$ In contrast, self-defence can be applied against the actor who is merely excused, such as the person who is coerced under duress to rob you.

The incompatibility of justifications is generally accepted in the Netherlands ${ }^{53}$ and in Germany, ${ }^{54}$ but whereas many US scholars also argue in favour of it, ${ }^{55}$ there is hardly any support for it in English law. ${ }^{56}$ The rule follows from the other implications. If a justification completely negates wrongfulness and operates universally, it may not be resisted. ${ }^{57}$ If the force was justified under self-defence, the victim has to endure or tolerate this and others are not allowed to intervene. If conduct is merely excusable, the victim and others are allowed to act against the excused actor. ${ }^{58}$ That implication was rejected because in some situations where two actors act jointly against another, only one of those actors can be justified. A personal application of justifications is however not inconsistent with the incompatibility rule. The rule is also in line with the communicative difference between justifications and excuses and therefore adopted.

\subsection{Order of assessment}

From the structure of criminal liability, it follows that the logical order of assessing defences is that justifications precede excuses. As laid down in article 350 of the Dutch Code of Criminal Procedure, the judge must determine first whether the act was wrongful before investigating the blameworthiness of the defendant. It needs to be asked what the defendant can be blamed for. A person cannot be reproached to have done something good. Conversely, what is justified need no longer be excused. Justifications are therefore assessed before excuses. ${ }^{59}$ This order of assessment

\footnotetext{
52 Or both actors can be excused, see Sangero 2006, pp. 284-285 and Fletcher 1978, p. 767.

53 HR 27 May 1986, NJ 1987, 8; AG Knigge in HR 28 March 2006, NJ 2006, 509; Mevis 2006, p. 621; Kelk 2005, p. 284 and Fokkens \& Machielse, note 8 on art. 41.

548 May 1990 BGH NStZ 1990, 435; 26 October 1993 BGHSt 39, 374 and Roxin 2006, pp. 661662.

55 Greenawalt 1984; Robinson 1982, pp. 273-275; Fletcher 1978, p. 830 and Husak 1999, p. 43.

56 Tadros 2005 , p. 291 even rejects it.

57 It has thus also been argued that 'permissible justifications' might conflict, see Husak 1999, p. 55 .

58 Krey 2003, pp. 18-19; Schönke \& Schröder, H. 2006, p. 578 and Beulke 2008, p. 100.

59 Strijards 1987, p. 40; Pompe 1935, p. 18; Peters, A.A.G. 1966, p. 144; Nieboer 1991, p. 74; van Dijk, A.A. 2008, p. 13; Dolman 2006, p. 89; de Hullu 2006, p. 356; Schönke \& Schröder, H. 2006, p. 701; Beulke 2008, p. 27; Daly 1978, p. 381; Husak 2005, p. 291; Hall 1976, p. 640; Greenawalt 1984, p. 1899; Fletcher 1985, p. 958; Fletcher 1978, p. 798 and Baron 2005.
} 
warrants the analogy of the three pillars of criminal liability with three rungs of a ladder, ${ }^{60}$ or with three stories of a building. ${ }^{61}$

Again, whereas many US scholars accept this, there exists no general rule on the hierarchy of defences in English law. ${ }^{62}$ This reluctance to incorporate the distinction can also be explained by the preference for 'flat legal reasoning'. In contrast to an ordered, three tiered structure of criminal liability, English law used to, and still tends to apply a 'holistic approach' in assessing criminal liability, whereby order of assessing the elements of criminal liability is irrelevant. The main elements of the crime, actus reus and mens rea are put on the same footing, and the order of assessing is considered immaterial. ${ }^{63}$

In contrast, the logic mentioned above dictates that the order of assessment is accepted. Moreover, a binding order of assessing criminal liability can make the scope of criminal liability clearer, more consistent, more rational and better to be predicted. It facilitates a critical evaluation of criminal decisions by higher courts and scholars, which would again strengthen values of consistency and certainty.

\subsection{Conclusion}

It can be concluded that although the line of criticism raised against some differences of justifications and excuses is legitimate, most of them hold up. Even if in legal comparison, it is not accurate to state that only the application of an excuse enables measures, that only justifications completely negate their mirror image or that a justification always operates universally, there are still many other differences that warrant making the distinction between justification and excuse. ${ }^{64}$

It has been argued that the dichotomy, by making a distinction between condemning the act and condemning the defendant, enables important communicative functions of the law. If that difference is not made, there is a risk that excuses are applied restrictively. Further, the conditions of individual defences are influenced by the category to which they belong. Amongst others, the justificatory defences have stricter requirements of proportionality. It has also been confirmed that justifications are incompatible and that the distinction is important to structure the order of legal reasoning. Therefore, the distinction is useful. It serves a practical purpose and should be maintained in a general part of criminal law for the EU.

Horder 2006A, pp. 99-101. See also III.4.

Eser in Eser \& Fletcher 1987, p. 23.

Ormerod 2008, p. 269 and Baron 2005.

Eser in Eser \& Fletcher 1987, pp. 22-23; Fletcher in Eser \& Fletcher 1987, pp. 74-75 and 81-83 and Fletcher 1985, p. 951.

Another difference accepted in German law is that a mistake on the facts underlying a justification is said to negate intention whereas similar mistakes relating to excuses, can at most excuse. This was rejected for a general part of EU criminal law in VII.5. Putative defences should be treated alike. 


\section{Chapter IX JUSTIFICATIONS}

After discussing the rationale(s) of justifications, the meaning and requirements of its mirror image, wrongfulness, will be explained. Subsequently, it will be argued what self-defence, necessity and consent should look like in a general part of criminal law for the EU. This synthesis will be presented from the common ground of the different sources, pausing at significant legal differences. A choice will be made in favour of one of those approaches or even another one, taking into account the aforementioned criteria such a consistency and legal certainty.

\section{Rationale}

Whereas offences are static, justifications bring a dynamic element of social change into the doctrine of the criminal offence. ${ }^{1}$ Whereas offence definitions either prohibit or command certain conduct, the permissive rules enshrined in justifications recognize that in exceptional cases, the conduct is not wrongful. The criminalization therefore does not apply in concreto. ${ }^{2}$ Justifying conduct means that the general norm was not meant to apply to this special case or these kinds of special cases. ${ }^{3}$ Alternatively, it means that criminal law acknowledges other norms that can prevail over the violation of the criminal norm. All things considered, the infringement of the legally protected interest is permitted. ${ }^{4}$

An all-encompassing rationale for justifications holds that "all justifications constitute an appropriate means to a proper end." 5 Under the lesser evils theory, the harm caused is outweighed by the need to avoid an even greater harm or to further a greater societal interest. ${ }^{6}$ It seems that the currently, the most popular approach is the compromise of a pluralist theory of justifications, which combines the latter theory of 'superior interest' with one that includes justifications like consent under the limb of 'absent interest'. After all, it has been argued that in consent, there is no conflict of interests. The waiver of legal protection simply brings about that there is no infringed interest. ${ }^{8}$

Roxin 2006, pp. 615-616.

Eser in Eser \& Fletcher 1987, pp. 46-47.

Bosch 2008, p. 164.

Nieboer 1991, p. 244 and Schönke \& Schröder, H. 2006, p. 157.

Sangero 2006, p. 89.

Robinson 1982, p. 214; Tadros 2005, p. 271 and Roxin 2006, p. 616.

Eser in Eser \& Fletcher 1987, pp. 48-49; Schönke \& Schröder, H. 2006, pp. 580-581 and 590591; Roxin 2006, p. 615-618 and Sangero 2006, p. 90.

$8 \quad$ Like Roxin 2006, pp. 545-555 and Ashworth 2006, p. 318. 
This view can however be put into perspective by focusing on the legitimate purpose of the activity that is consented to. When a patient consents to surgery, two interests can be juxtaposed. On the one hand, the patient is sure to be in pain after the surgery and risks a further deterioration of his medical condition is the surgery does not have the desired result. However, if he does not consent to surgery, the consequences for his health may even be worse. The patient, or someone else when is he incapable to decide, thus chooses in favour of the lesser of two evils. ${ }^{9}$

All justifications can thus be covered by the lesser evils theory. What makes the justified conduct, all things considered, at least permissible to the legal order, is the belief that it objectively creates a net benefit. In other words, every justification is based on a weighing of interests, which results in choosing in favour of the prevailing interest. It follows that proportionality is a general rule of all justifications. In contrast, excuses centre on the personal reasons that forgive the defendant for exceeding the objective limits of proportionality.

The fact that someone is allowed to kill in order to avert being raped does not mean that the justification of self-defence allows for disproportional conduct. Instead, the weighing of interests is not merely concerned with the contrasting legal interests involved, which are in this case, the life of the aggressor versus the sexual and/or bodily integrity of the attacked person. More abstract interests are also important, including the reproach that can be made against the aggressor for creating the conflict, as well as the harm to the legal order which the completion of the wrongful attack would bring about. The lack of a wrongful attack in necessity thus also explains why the requirements of proportionality are stricter with regard to that justification.

\section{WrongFulNESS}

As noted, implied elements of criminal liability like wrongfulness and blameworthiness seek to impose the application of certain substantive values that are not necessarily contained in the individual statute. Although to some extent, positive law also safeguards this, these values are not all of legislative origin. Rather, they can be traced back to a legal tradition. As a product of legal, political, philosophical and moral experience, it serves as a protection against unfettered and arbitrary state power versus the individual. They are a minimum condition for just punishment. ${ }^{10}$

Wrongfulness in this meaning ensures that only conduct that violates the norms of the legal order, all things considered, is punishable. An additional control takes place on the level of wrongfulness. Because wrongfulness is required for criminal liability, justifications can preclude liability. The implied element of wrongfulness does not refer to the illegality of the conduct, the fulfilment of the offence definition,

9 If there is no legitimate purpose to contrast, consent does not apply, see IX.5.3.

10 Naucke 1984, pp. 316-320. 
but to the material wrongfulness. ${ }^{11}$ The act is only wrongful in a material way when it expresses a social damaging violation of a legal interest that should be fought by the criminal law. ${ }^{12}$ Material wrongfulness is indicated upon acceptance of the fulfilment of the offence definition, but given only when no justifications apply. ${ }^{13}$

\section{Self-defence}

On the one hand, self-defence is the most popular and self-evident defence of all. ${ }^{14}$ On the other hand, its scope and application consistently give rise to controversy, evidenced by much public debate and an enormous amount of case-law on the topic. First, it will be explained that this controversy follows from contrasting views on the rationale of self-defence. By exclusively focusing on the person attacked, or by forfeiting the rights of the aggressor, self-defence can become a very broad defence, justifying even the most serious offences. By taking into account the whole legal order, more limitations on the defence seem warranted. It will be explained that self-defence is a justification, grounded in the weighing of interests. All interests or rationales should therefore be taken into account.

Subsequently, the conditions of the justification will be discussed. This will again be done in an integrated manner, focusing on what the concept should look like in the EU, whilst highlighting national differences. It is concluded that the national legal criteria have been moving towards each other. After all, in comparison to a few decades ago, the German scope of self-defence has been restricted, whereas the Dutch concept has been extended. Nowadays, the concepts find each other in the middle. As a result, the most significant difference between the Member States is that there exists no excusatory form of self-defence in England. This problem will be addressed in the chapter on excuses.

\subsection{Rationale}

Self-defence has been grounded in diverging rationales. Accordingly, there exist different views on the question what the ideal or dominant rationale of self-defence should be. Monistic theories are losing ground to theories that ground self-defence in a combination of rationales. ${ }^{15}$ In England, self-defence is most often based on the autonomy of the attacked person and the culpability of the aggressor. The double rationale that is prevailing in the Netherlands and Germany is based on the natural

11 De Hullu 2006, p. 179; Strijards 1987, pp. 1-11; Kelk 2005, p. 124; Bosch 2008, p. 170; Schönke \& Schröder, H. 2006, pp. 137-138 and Schönke \& Schröder, H. 2006, p. 171.

12 Roxin 2006, pp. 601-602.

13 Kelk 2005, pp. 123-124; Fischer, T. 2009, p. 81 and Beulke 2008, p. 41.

14 Müssig 2003, p. 224; Leverick 2006, p. 1 and Leverick 2007, pp. 563-564.

1514 June 1972 BGHSt 24, 356; Roxin 2006, p. 656; Schönke \& Schröder, H. 2006, pp. 639-640; annotator Keijzer in HR 8 April 2008, NJ 2008, 312 and Machielse 1986, pp. 523-524. 
right to defend oneself on the one hand and the preservation or protection of the whole legal order on the other. ${ }^{16}$

\subsubsection{Natural right}

First and foremost, defending oneself can be seen as a natural right. This rationale has been dominant until the $19^{\text {th }}$ century, after which the rationale of the legal order grew in importance. ${ }^{17}$ Historically, it is grounded in the right of self-preservation of man. ${ }^{18}$ It is argued that before the formation of societies, personal survival was essential. A natural right existed to defend oneself against attacks from others. In the narrative of the contract between the individual and the state, the individual transferred his freedom to the state, in return for protection. With the emergence of societies, the authorities aimed to strengthen their power, the monopoly of violence in particular, by suppressing all forms of taking the law into one's own hand, including self-defence. Only when the central governing authority had become strong enough, was it seen fit to recognise selfdefence. ${ }^{19}$

Nonetheless, it has also always been clear that the state cannot always intervene in time. A legal system cannot uphold the right to life, protected under article 2 ECHR, without a right to self-defence. The contract between state and citizen therefore does not exclude their natural right of self-preservation. According to Hobbes, the obligation of citizens to their government lasts "as long, and no longer, than the power lasteth by which (the government) is able to protect them". ${ }^{20}$ Selfdefence is a subsidiary right. Only when it is absolutely necessary to defend yourself, is this allowed, which explains that in order to rely on self-defence, one must not have been able to retreat or get (official) help.

Currently, the state monopoly of violence is threatened by the decreasing trust of citizens that their state will safeguard their interests. ${ }^{21}$ If the law is not enforced or offenders are let off too easily, citizens feel the need to take the law into their own hands. For example, if the police are reluctant or refuse to take away stolen property from the thief, the citizen feels coerced to do this himself. Secondly, excessive violence inflicted against the aggressor can be explained by lacking confidence that he will get his desert through the criminal justice system.

The natural right to defend oneself focuses on the autonomy of the attacked person. The autonomy of the person relates to more than just his life, although it is

16 De Hullu 2006, p. 299 and Machielse 1986, pp. 523 and 710.

Beulke 2008, p. 112 and Machielse 1986, p. 523.

See Blackstone 1769 (reprint of 1979), p. 186.

See Sangero 2006, pp. 30-31; Strijards 1987, p. 57 and Pawlik 2002, pp. 278-280.

Dressler in Shute \& Simester 2002, p. 272. See also Sangero 2006, pp. 77-79; Fletcher 1978, p. 867; Pawlik 2002, pp. 278-280 and Kelk 2005, p. 284.

21 See Stichting Maatschappij, Veiligheid en Politie 2008, pp. 32-33, 54-55 and 59; Buruma 2005, p. 440 and Leverick 2006, pp. 138-139. 
the most important aspect of it. It also includes his bodily integrity, liberty and property. ${ }^{22}$ The attacked person is entitled to give priority to his own interests when they are in conflict with those of another, because they are his own interests and therefore more valuable to him. ${ }^{23}$ Moreover, the attack is wrongful. The attacked person does not have to tolerate this wrongful attack, ${ }^{24}$ expressed by the adage that "Right should never give way to Wrong."25

\subsubsection{Legal order}

At the same time, the right to life also concerns the life of the aggressor. Whereas the right to life is not absolute, it does greatly restrict the use of deadly force by requiring a high threshold of necessity and proportionality. ${ }^{26} \mathrm{~A}$ single focus on the interests of the attacked person would not require proportionality. It would suffice that the defensive force, of whatever degree and for whatever danger, is necessary for the protection of the autonomy of the attacked person. ${ }^{27}$ In other words, this limitation to the right of self-defence can only be based on a rationale that concentrates on other interests as well, such as those of the legal order as a whole. ${ }^{28}$ Excessive injury to the aggressor may harm the legal order. Only this perspective can explain the upper limit of proportionality in both self-defence and self-defenceexcess.

Accordingly, the focus on the rationale determines the scope of the defence. By focusing on the natural right to defend oneself, one will be more inclined to accept that someone reacts very violently. Self-defence will be framed as a broad defence. On the other hand, if we focus on the legal order and the monopoly of violence of the state, one will be more inclined to demand that the citizen avoids confrontation and respects the interests of the aggressor. ${ }^{29}$ No Member State under investigation focuses only on the autonomy of the attacked person. The idea that self-defence also protects the legal order has become increasingly important. Any infringement of the autonomy of an individual can also be seen as an infringement of the legal order. ${ }^{30}$ The adage that right should never give way to wrong has therefore also been positioned in this context. ${ }^{31}$ The rationale enables the use of force by private

Sangero 2006, p. 98.

Sangero 2006, p. 60 and Leverick 2006, pp. 50-51.

Beulke 2008, p. 112; 'braucht nicht zu dulden.'

Sangero 2006, p. 61; Smidt 1881A, p. 379 and Fletcher 1973, p. 379.

Ashworth 1975, p. 283 and Sangero 2006, pp. 42-43.

Fletcher 1973, p. 381.

Sangero 2006, p. 70; Roxin 1981, pp. 74-77; Pawlik 2002, p. 260; Perron in Arnold a.o. 2005, pp. 1023-1024; Schönke \& Schröder, H. 2006, pp. 675-676 and annotator Keijzer in HR 8 April 2008, NJ 2008, 312.

29 Annotator Buruma and AG Knigge in HR 28 March 2006, NJ 2006, 509; Machielse 1986, pp. 481-482 and Roxin 1981, p. 76.

$30 \quad$ Pawlik 2002, p. 297.

31 Schönke \& Schröder, H. 2006, pp. 639-640; Beulke 2008, p. 112 and Fischer, T. 2009, p. 285. 
individuals to prevent crime, ${ }^{32}$ deterring aggressors from committing wrong. ${ }^{33}$ It also justifies the right to help a third party who is being attacked, as defending the third party protects the legal order. ${ }^{34}$

The broader question is what portrayal of man and society we have. If we only grant citizens a role of a witness calling the police, the portrayal of man is especially consumptive and non-active. If we want to emphasize own responsibility in the fight against crime, the citizen needs to have possibilities. ${ }^{35}$ There is a tendency in Member States to increasingly entrust private individuals with law-enforcement tasks. The scope of their competences, including self-defence, should therefore be sufficiently wide. Governments encourage its citizens to contribute actively in the prevention of crime. To quote former English Secretary of State for Justice Jack Straw: "Lawabiding citizens should not be put off tackling criminals by fear of excessive investigation. The law should be seen as supporting them right from the start." 36 With that aim, the Dutch Government also issued an instruction to law enforcement agencies not to arrest those acting within the lawful limits of self-defence. ${ }^{37}$

\subsubsection{Forfeiture}

A rationale that concentrates on the culpability of the aggressor has been labelled the classic and most common rationale for self-defence in Anglo-American law. The rationale focuses on the aggressor's rights in two possible ways, the first of which is an approach of forfeiture. The aggressor, by his conduct, loses his right to life or at least the right to claim this right. This approach has been criticised and a more appropriate variation - that of reduction - has been put forward. In this approach, the aggressor does not lose his rights, but because the aggressor is responsible for the danger, the value of his rights is reduced when balancing the competing interests at stake. ${ }^{38}$ This responsibility can range from weak, consisting of a mere causal connection to the danger to strong, for example, when the aggressor intended to harm the defendant's interests. The stronger the responsibility, the greater the reduction of the aggressor's interest. ${ }^{39}$ The rationale thus explains why in the situation where the life the aggressor is juxtaposed with

Sangero 2006, p. 67.

Roxin 2006, pp. 654-655 and Roxin 1981, pp. 73-74.

Sangero 2006, p. 98.

Stichting Maatschappij, Veiligheid en Politie 2008, pp. 92-93.

'Reforms to give public confidence in tackling criminals', Ministry of Justice, 19 December 2007, www.justice.gov.uk/news/ newsrelease191207a.htm.

37 Instruction on how to act regarding a plea of self-defence, Council of Procurators-General, 13 December 2010, Stcrt. 2010, no. 20474.

38 Sangero 2006, pp. 44-45 and 61, Leverick 2006, pp. 2 and 46-47; Fletcher 1978, p. 858 and Fletcher 1973, p. 377.

39 As will be explained below, the lower limit is causal or legal responsibility, excluding selfdefence against infants and involuntary acts. 
the life of the attacked person, the latter is objectively justified in favouring his own.

Only implicit references to forfeiture can be found in German and Dutch literature. ${ }^{40}$ The acceptance that the interest of the attacked person may outweigh those of the aggressor is usually explained by the fact that the attack was wrongful: right should not give way to wrong. However, by this focus on 'right', the rights of the aggressor are easily overlooked. As a result, in Germany, the scope of selfdefence is sometimes very wide. Moreover, it is submitted that the idea of forfeiture is strongly rooted in popular sentiment. Many people seem to think that the aggressor, the criminal, should have fewer rights than the attacked person, the victim. For example, disproportionate injuries inflicted upon a burglar are believed to be acceptable as caused by his own criminal conduct. The risk inherent in selfdefence should be taken by the person who gave rise to it. ${ }^{41}$ In law, this is recognized by justifying the defendant who, in a situation of self-defence, negligently inflicted more serious injuries than intended. ${ }^{42}$

It may not always be easy to distinguish this from the view that self-defence is punishment or that it constitutes a down-payment on the expected punishment. After all, courts tend to take the harm inflicted upon the aggressor into account when sentencing him. ${ }^{43}$ From that point of view, the aggressor gets what he deserves. Taking the law into one's own hands is considered appropriate to a large extent. However, such a perspective exceeds the scope of self-defence. The justification allows for the defending of legal interests, not the punishment of those who threaten or violate these interests. ${ }^{44}$ The state has the monopoly on punishing criminals. If it were different, the punishment of the criminal would depend on the discretion of the attacked person. The power of the individual under self-defence is limited. He only acts as a substitute for the state with a view to limit the violation of the legal interests of others and/or to enable the investigation and prosecution of crime.

\subsubsection{Weighing of interests}

All legal systems struggle with the fundamental dilemma to strike a balance between contrasting public interests. The English Crown Prosecution Service stated that "on the one hand the rule of law and the Queen's peace must be maintained and violence discouraged. On the other hand, the involvement of citizens in the prevention and investigation of crime is to be encouraged where it is responsible

40 See annotator Keijzer in HR 8 April 2008, NJ 2008, 312; Engländer 2008, pp. 51-52 and 62-63; Erb 2005, pp. 593-598; Beulke 2008, p. 115 and Schönke \& Schröder, H. 2006, pp. 639 and 653.

$41 \quad$ See 21 December 1977 BGHSt 27, 313; Beulke 2008, p. 116; Bohlander 2009, p. 122 and Roxin 2006, pp. 677-678.

42 See VII.4.3.

43 See $\$ 60$ of the German Code of Criminal law and Sangero 2006, pp. 188-191.

44 See also Roxin 1981, pp. 73-75. 
and public-spirited."45 Just like Dutch and German law attempt to construe the rationale of self-defence by balancing diverging perspectives, Israeli scholar Sangero proposed to balance all the different rationales and interests in search of the prevailing interest. ${ }^{46}$ Self-defence is about striking a balance between competing interests. In other words, self-defence is about proportionality. It should not focus merely on the interests of the defendant or on the interests of the legal order. All rationales are needed to explain the scope of self-defence in law. These rationales are taken into account as 'abstract legal interests' alongside the specific legal interests of the persons involved. ${ }^{47}$

First, the legitimate interests of the attacked person and of the aggressor are weighed, because both have a legitimate interest not to be injured or harmed. On a second level, the abstract interests come into play. A reduction concerning the interests of the aggressor may follow from his responsibility for creating the (wrongful) situation. This way, the theory can support the application of selfdefence to the person who creates more harm than he prevents, for example when using deadly force to prevent rape or by killing multiple aggressors. ${ }^{48}$ The converse is also true. For example, when the attacked person gave his consent to the attack, the factor of his autonomy does not work to justify self-defence against the attack. ${ }^{49}$

It is also accepted widely within the EU that different rationales determine the scope of self-defence. The interests or rationales of self-defence are interrelated. ${ }^{50}$ After all, a violation of the autonomy of one person also injures the legal order. The legal order also stands in direct relationship to the culpability of the aggressor, because an intentional injury harms the legal order even more. ${ }^{51}$ The theory mentioned here is clearer about this than the double rationale of Dutch and German law, which tries to ground all aspects in either the legal order or the natural right. It is able to include the aspects of forfeiture into self-defence and in line with the general view of justifications as serving the prevailing interest.

\subsection{Scope}

Self-defence is a general defence, which suggests it should apply to all offences. ${ }^{52}$ It used to be considered merely in the case of homicide and other serious violent

45 CPS:'Self-defence and the prevention of crime’, www.cps.gov.uk/legal/section5/chapter_d.html.

46 Sangero 2006, p. 73. Compare Schönke \& Schröder, H. 2006, p. 639.

$47 \quad$ Sangero 2006, pp. 93-106.

48 Sangero 2006, pp. 75 and 94.

49 Sangero 2006, pp. 100-101.

50 Roxin 2006, pp. 654-656 and Schönke \& Schröder, H. 2006, p. 640.

$51 \quad$ Sangero 2006, p. 96.

52 The general character of defences is somewhat controversial in England. Ormerod 2005, p. 342 suggests that although Courts have difficulty recognizing self-defence as constituting a defence to crimes generally, they should. The Law Commission 1993, pp. 68-69 agrees with him. 
offences, but that connection was already let go more than a century ago. ${ }^{53}$ The ECJ has even recognized it as a possible defence in competition law. ${ }^{54}$ Thus, although it is usually applied to charges of violent offences, ${ }^{55}$ other offences are not necessarily excluded. On the principle that a greater includes the lesser, the defendant should be allowed a non-forceful response when an act of force would have been justified. ${ }^{56}$ The threat of force and other non-violent means to avert the attack are more considerate to the interests of the aggressor and are therefore more likely to meet the requirements of proportionality.

On the other hand, when compared to the broader justification of necessity, self-defence is characterized by the use of force directed against an aggressor. Therefore in principle, self-defence is limited in scope to offences that aim to protect a legal interest of the aggressor. Individual interests of third parties and public legal interests cannot be infringed under self-defence. ${ }^{57}$ This explains why the use of a firearm against the aggressor can be justified under self-defence, whereas the illegal possession of firearms cannot. The offence of illegal possession of firearms aims to protect a more general legal interest of public safety. ${ }^{58}$

Nevertheless, the illegal possession can be justified under another defence like necessity. In all three Member States, the possession will be justified if it is closely related to its use in a situation of self-defence, such as arming oneself with a view to avert an attack in the near future. ${ }^{59}$ This justification under the broader defence of necessity therefore puts the distinction in perspective. ${ }^{60}$ Only in England, such preparatory acts have also been justified under self-defence. ${ }^{61}$ This difference can be explained by the restricted scope of other compulsion defences in England. Since

53 Machielse 1986, pp. 520 and 588; Roxin 2006, p. 657; Finkel \& Parrott 2006, pp. 207-208; Blackstone 1979, pp. 183-188 and Fletcher 1998, p. 131.

547 June 1983, Cases 100-103/80, SA Musique Diffusion Française [1983] ECR 1825.

55 Strijards 1987, p. 54; Machielse 1986, p. 544 and Law Commission 1993, p. 68.

56 Simester \& Sullivan 2007, p. 705.

57 Roxin 2006, pp. 716-717. See also Schönke \& Schröder, H. 2006, p. 650 and Beulke 2008, p. 115 .

58 The distinction between individual and public legal interests may be difficult to apply, because offences often aim to protect both individual and public interests, see IX.5.3.1. The scope of selfdefence can be extended to offences that also aim to protect a public legal interest, by way of exception to the principle or by looking which interests, public or individual interests of the aggressor, were actually infringed by the defendant's conduct. Compare R. v. Renouf (1986) 82 Cr App R 344.

59 See R. v. Salih [2007] EWCA Crim 1750 and 13 January 2010 BGH NStZ-RR 2010, 140.

60 HR 23 October 1984, NJ 1986, 56; 19 March 1986 BGH NStZ 1986, 357; Roxin 2006, pp. $717-$ 718 and 1001; Fischer, T. 2009, pp. 291-292 and Sangero 2006, pp. 120 and 128.

61 Attorney-General's Reference no. 2 of 1983 [1984] EWCA Crim 1; Ormerod 2005, pp. 340-341; Lanham 2005, pp. 85-97 and Ashworth 2006, p. 142. See also section 44(5) draft Criminal Code, Law Commission 1989, p. 62 and section 29(2), Law Commission 1993, p. 110. 
necessity is restricted to very severe dangers and duress does not apply to murder, lawyers tend to widen the scope of self-defence. ${ }^{62}$

Besides offences that protect public legal interests, the scope of self-defence also does not extend to the infringement of individual legal interests of persons other than the aggressor. Self-defence does not apply to 'collateral damage', the infringing of interests of persons who are not part of the attack. ${ }^{63}$ Exceptions have been made for objects of third parties that are damaged or destroyed in the course of selfdefence. For example, self-defence has been accepted when the aggressor uses goods of a third party to attack the defender, who is then necessitated to use force against these goods. Nevertheless, many have submitted that the better approach is to apply only necessity-type defences to such cases. ${ }^{64}$

After all, the precluding of self-defence does not rule out that the collateral damage is justified by necessity, (presumed) consent or excused under duress. It has been argued, for example, that if a third party is used as a shield by the aggressor and is killed, the shooter cannot rely of self-defence, but can be excused under duress. ${ }^{65}$ The issue can also be approached as an aberratio ictus, a situation where the attacked person misses the aggressor and hits a third party. This collateral damage can be excused as a form of putative self-defence if it was unavoidable. ${ }^{66}$ In any event, in contrast to the sacrifice of goods of third parties, it is more appropriate to excuse the actor than to justify such acts, since the latter would imply that it is objectively permissible to sacrifice the life and limb of third parties, that this third party would have to tolerate the infringement and would not be allowed to defend himself.

\subsection{Criteria}

The criteria for self-defence can be deduced from the legal definitions in $\$ 32$ of the German Criminal Code and article 41 of the Dutch Criminal Code. ${ }^{67}$ As to English law, self-defence has a variety of sources. ${ }^{68}$ English case-law on self-defence has been codified in section 76 of the Criminal Justice and Immigration Act 2008. The codification intends to clarify the operation of the different existing defences in

Sangero 2006, pp. 109, 119 and 162. Machielse 1986, p. 527 also noted that in the Netherlands, cases now considered to be paradigm examples of necessity have been classified as self-defence before due to a limited interpretation of necessity.

Schönke \& Schröder, H. 2006, p. 650 and Beulke 2008, p. 115. See HR 11 January 2011, NJ 2011, 339. This seems to be neglected in HR 22 February 2011, NJ 2011, 107, where the defendants hit third parties and not the aggressor.

This is discussed as aggressive necessity in IX.4. See Bohlander 2009, pp. 102-103; Schönke \& Schröder, H. 2006, pp. 650-651 and Roxin 2006, p. 718. Bohlander 2009, pp. 102-103; Fischer, T. 2009, p. 293 and Sangero 2006, p. 280. See VII.5.1.

$\S 15$ of the German Administrative Offences Act $(\mathrm{OWiG})$ is identical to $\S 32$.

Ormerod 2005, p. 329. 
English law, such as the common law defence and section 3 of the Criminal Law Act 1967, which grants persons the power to use force as is reasonable in the circumstances in the prevention of crime or in arresting offenders or suspects. ${ }^{69}$

It follows that the scope of self-defence in England is wider, as the use of force necessary to effectuate an arrest by citizens is laid down in Dutch and German law as procedural competences. ${ }^{70}$ These competences are distinguished from the justification discussed here, even if they can give rise and are similar to situations of self-defence. The purpose of an arrest is to facilitate the investigation, not to avert an imminent attack. The purpose of using force in self-defence is to make the aggressor flee, not to hand him over to the authorities..$^{71}$ Moreover, self-defence in Dutch and German law can bring about that crime is prevented, but the justification primarily relates to the protection of specific legal interests.

In order for self-defence to justify a criminal offence, the attack that is averted by that offence must be wrongful, of human origin, infringe an individual interest and be imminent. In other words, self-defence must be necessary. Moreover, the defendant must at least be aware of these facts and act in line with the requirements of proportionality. In short, self-defence must be necessary and proportionate. It will be explained that the categorization of the criteria of self-defence into the limbs of necessity and proportionality is useful, but by no means self-evident.

In England, the force applied must be reasonable and force is only reasonable when it is necessary and proportionate..$^{72}$ This unification of necessity and proportionality into one requirement of reasonableness is an example of the flat legal reasoning mentioned before. English law tends to sweeps within one inquiry aspects that would otherwise be distinguished. ${ }^{73}$ However, unification is undesirable because it shadows the distinction of the two important limbs of selfdefence, ${ }^{74}$ which not only serves an analytical purpose but has legal consequences too, such as in the context of mistakes. As noted, in order to negate liability by a claim of putative self-defence in German and English law, a mistake as to the necessity merely needs to be genuine, whereas a mistake as to proportionality also needs to be reasonable. ${ }^{75}$

Nevertheless, a strict distinction can be difficult to make. Amongst others, the so-called issue of subsidiarity can be said to belong to either of the two limbs. In EU and Dutch law, 'subsidiarity' is not only used as an alternative term for necessity but more specifically to refer to the requirement of 'least intrusive means'. This

69 Section 5 of the Criminal Damage Act 1971 creates a defence to the offence of destruction or damaging of property or threats thereof. It falls outside the scope of section 76 .

$70 \$ 127$ of the German Code of Criminal Procedure and article 53 of the Dutch Code of Criminal Procedure. The German Civil Code also includes some provisions on self-help, see $\S \S 229$ and 230; Roxin 2006, pp. 802-803 and IX.3.4.5.

71 Machielse 1986, pp. 561-563.

72 Ormerod 2005, p. 334. See section 76(3) Criminal Justice and Immigration Act 2008.

73 Fletcher in Eser \& Fletcher 1987, p. 89.

$74 \quad$ Sangero 2006, pp. 111 and 146.

75 See VII.5.3. 
means that in defending himself or another person, the defendant should choose to use the means that are least intrusive to the interests of the aggressor. ${ }^{76}$ For example, if using his fists would suffice to avert the attack, the defendant is not allowed to use a weapon. It is argued that self-defence consists of a test of double necessity: it should have been both necessary to defend the pertinent interest and to commit the specific offence. ${ }^{77}$ The offence can only be justified if it was the least intrusive means to avert the attack.

This choice of what type of defensive means should be used is however closely connected to the subsequent question of proportionality of how one should use this least intrusive means. For example, if a firearm may be chosen, the defendant can subsequently choose to fire a bullet at the leg or torso of the aggressor. As a result of this close connection, proportionality is often understood to encompass not only the intensity of the defence (proportionality) but also the choice of defensive means (subsidiarity). ${ }^{78}$ In Germany, the least intrusive means is also discussed in close relation with the intensity of the defence, the latter therefore dubbed proportionality stricto sensu.$^{79}$ Here, proportionality will also be discussed in this broad meaning, including the choice of defensive means.

Necessity and proportionality mutually influence each other. The less is required from necessity, the more is required from proportionality. For example, when the refusal of someone to leave the premises would allow for the use of force against him under necessity, the nature and intensity of the use of force will be severely limited under the requirement of proportionality. This interrelationship is in line with the rationale of self-defence as balancing interests and the tendency to be discussed below, that the criteria of self-defence are more likely to be considered as factors than as absolute conditions.

Until a couple of years ago, significant differences could be identified between the national legal concepts of self-defence. The justification still has the widest scope in Germany, although it has become more restricted in recent decades. In the last decade, Dutch law case-law has also lost most of its sharp edges. ${ }^{80}$ The requirements of necessity and proportionality have become less absolute, more dependent on the others conditions of self-defence and the specific circumstances of the case. As a result, the law of the three Member States has considerably moved closer to each other.

76 In EU law, this refers to the least intrusive means of infringing the free movement of goods, persons, capital and services, see 23 October 1997, Case C-189/95, Franzén [1997] ECR I-5909. A scheme of expensive licenses existed in Sweden, required to import, produce and sell alcoholic beverages. The ECJ held there were also other less intrusive measures available to the trade between Member States to further public health.

77 Machielse 1986, p. 646. See also Ten Voorde 2008, p. 796.

78 Machielse 1986, p. 661; de Hullu 2009, pp. 314-318 and Fletcher 1978, p. 870.

79 See Roxin 2006, pp. 674-683; Beulke 2008, pp. 115-117 and Schönke \& Schröder, H. 2006, pp $651-652$. 
There exists consensus in Europe on most criteria of self-defence. ${ }^{81}$ Two conditions are more controversial, namely the scope of interests that can be defended and whether there must be proportionality between the attack and the defensive force. German law on self-defence strictly speaking does not require proportionality, but it will be demonstrated that in effect, a proportionate relationship between attack and defensive force is required. Secondly, the German concept of self-defence is in theory also relatively broad because any legal interest may be defended in self-defence. Nevertheless, it will be demonstrated that this does not lead to different outcomes in criminal liability in comparison to the legal systems that do limit the interests that may be defended.

\subsection{Necessity}

The first requirement for self-defence, necessity, can be divided into several aspects. The necessity requirement logically excludes situations where the attacked person has a reasonable alternative. By requiring that the attack is imminent and there is no possibility of retreat, it can be said that the attacked person had no alternative than to use force. Other aspects of necessity include the nature of the attack, which must be wrongful and threaten a legitimate interest. 82

A popular approach is to treat the criteria of necessity not just as absolute conditions, but as factors that influence the proportionality requirement. This is appropriate because in the end, any justification and self-defence in particular revolves around proportionality. On the one hand, the approach enables that the defence is broad enough to encompass new situations that should be justified. On the other hand, the proportionality requirement safeguards that only actions that were proportionate in light of the imminence and wrongfulness of the attack, the possible alternatives to the offence as well as other facts and circumstances are in fact justified.

\subsubsection{Wrongful attack}

Only a wrongful attack can give rise to self-defence. In other words, there must be an attack and that attack must be wrongful. An attack can be defined as an

\footnotetext{
81 Compare Witteman 1997, pp. 262-270.

82 Compare 12 July 1962, Case 16/61, Modena v. High Authority [1962] ECR 289, at p. 303: "Legitimate self-protection presupposes an action taken by a person which is essential in order to ward off a danger threatening him. The threat must be immediate, the danger imminent, and there must be no other lawful means of avoiding it." The condition that the attack must be wrongful was added by the judgment of 18 March 1980, Joined cases 154, 205, 206, 226 to 228, 263 and 264/78, 39, 31, 83 and 85/79, Valsabbia and others v. Commission [1980] ECR 907, $\S 138$.
} 
immediate threat to legally protected interests through human behaviour. ${ }^{83}$ Attacks of an animal only qualify under self-defence if a human has incited it. In that case, the animal can be equated with any other tool the aggressor could have used to attack. In other cases, defensive force against animals can only be justified under necessity. ${ }^{84}$ Animals are no subjects of the law and can therefore not act. ${ }^{85}$

An attack will also almost always consist of an intentional act. It is however accepted that the attack may be negligent as well, for example, when the aggressor is pulling the trigger of a loaded gun, which he believes to be unloaded. ${ }^{86}$ Whereas the terms used in national codes resembling 'attack' may be said to imply intent, the will or even awareness to attack is not required. Even attacks that do not meet the threshold of culpa are sometimes said to qualify. For example, a driver may be exercising due care and can thus not be said to act negligently. However, he still threatens to hurt other participants in traffic. It has been argued self-defence can also be applies against such a person. ${ }^{87}$

As explained before, when the aggressor is not blameworthy because he is excused, he still acts wrongfully. Only justifications negate the wrongfulness of the attack. ${ }^{88}$ The circumstance that the aggressor is excused, for instance, because he is coerced under duress to kill the defendant does not preclude the defendant's right to self-defence. This implies that self-defence is not grounded in the blameworthiness of the aggressor. By contrast, there are minority views that do focus on the reproach that can be made against the aggressor, requiring that the aggressor is blameworthy or even acts with some degree of fault. ${ }^{89}$

The outcome of these perspectives are however similar. First, the minority opinion holds that the attacked person may defend himself against the excused aggressor under necessity. ${ }^{90}$ Secondly, the fact that prevailing opinion allows selfdefence against an insane or negligent aggressor still brings about that other requirements of self-defence are stricter. For example, the attacked person is required whenever possible to retreat or get help and use even more moderate force against excused aggressors. Blameworthiness and fault on the part of the aggressor

83 Bohlander 2009, p. 100; Roxin 2006, p. 657; Schönke \& Schröder, H. 2006, p. 640 and Fletcher 2007, p. 268.

17 June 1901 RGSt 34, 295; 26 February 1960 BGHSt 14, 152; Beulke 2008, p. 102; Roxin 2006, pp. 657-658; Schönke \& Schröder, H. 2006, p. 640; de Jong D.H. \& Knigge 2003, p. 171; Machielse 1986, p. 540 and Strijards 1987, pp. 61-62. pp. 547 and 572; Re A. (Children) [2000] EWCA Civ 254; Ormerod 2005, p. 338; Horder 1998, p. 145 and Simester \& Sullivan 2007, p. 704. See Sangero 2006, p. 59 and IX.3.1.3.

90 Like Sangero 2006, pp. 51, 54 and 129 and Engländer 2008, p. 264. Views like these are also mentioned in Beulke 2008, p. 113; Roxin 2006, pp. 661-665 and Machielse 1986, p. 641. 
thus do not ground self-defence, but still influence the decision whether the conduct of the defendant was justified. ${ }^{91}$

The requirement that the attack must be unlawful ${ }^{92}$ or wrongful expresses that self-defence is a fight of right against wrong. ${ }^{93}$ It serves to exclude from the defence situations wherein public officials carry out their official tasks of, for example, arrest. ${ }^{94}$ The ECJ therefore also held that the defence "cannot be pleaded against a public authority acting lawfully within the legal framework of its powers." 95 Because the attack must be wrongful, no self-defence is allowed against a justified act. As noted, the incompatibility of justifications thus follows from this criterion.

The requirement that the attack must be wrongful does not require however that the aggressor fulfil a criminal offence. ${ }^{96}$ For example, a light blow against somebody's body that does not cause him pain is not a criminal offence, but it does give rise to self-defence. The attacked person will however have to behave in a manner that is proportional to this minor aggression. Another example is the attempt to injure a person, which is also not punishable under Dutch law, but does trigger a right to self-defence for the attacked person. ${ }^{97}$ A wrongful attack can therefore be labelled as the non-justified infringement of a legal interest. ${ }^{98}$ An aggression that is at odds with the mandates of the legal order as a whole will in principle qualify. ${ }^{99}$

Under this reasoning, it could also be argued that self-defence is available against aggressors that are 'innocent' ${ }^{100}$ because they cannot be said to have acted. For example, the aggressor was sleepwalking, had an epileptic fit or was used by

91 Schönke \& Schröder, H. 2006, pp. 648 and 661; Roxin 2006, pp. 683-686; Beulke 2008, pp. 117-119 and 153-154 and Fokkens \& Machielse, note 8 on art. 41. In German law, when the aggressor in not blameworthy, the requirements of proportionality are increased in a three staged manner, discussed in IX.3.4.5.

92 This is the term most often used in England, see Law Commission 1993, pp. 106-108.

93 Machielse 1986, p. 570.

94 Fokkens \& Machielse, p. 278, note. 6 on art. 41. The fact that the arrest was illegal almost never makes it a wrongful attack, allowing for the use of force self-defence. First of all, the powers of arrest merely require reasonable suspicion, see article 27 of the Dutch Code of Criminal Procedure and section 24 of the English Police and Evidence Act 1984. An arrest is not illegal because the defendant did not commit the crime. This is controversial in Germany, see Beulke 2008, p. 123 and Schönke \& Schröder, H. 2006, pp. 613-614. Secondly, there are other, more proportionate means, like legal remedies such as habeas corpus to protect the right to freedom, see Sangero 2006, pp. 134-135; Ormerod 2005. p. 339 and Law Commission 1993, p. 73.

9518 March 1980, Joined cases 154, 205, 206, 226 to 228, 263 and 264/78, 39, 31, 83 and 85/79, Valsabbia and others v. Commission [1980] ECR 907, §138.

9614 March 1989 BGH NStZ 1989, 431; Roxin 2006, p. 669; Schönke \& Schröder, H. 2006, p. 647; HR 8 June 2010, NJ 2010, 339; Fokkens \& Machielse, note 6 on art. 41; Machielse 1986, pp. 546-547 and 582-583; Strijards 1987, p. 62; section 44(1) draft Criminal Code, Law Commission 1989, p. 61; Ormerod 2005, p. 338, Ormerod 2006, p. 459 and Simester \& Sullivan 2007, p. 704.

97 De Hullu 2006, pp. 301-302.

9814 August 1992 BayObLG NJW 1993, 211.

99 Bohlander 2009, p. 102 and Beulke 2008, p. 114.

100 The term 'innocent' is also used for excused aggressors, see Leverick 2007, p. 569. 
someone else as a pawn. However, even if the attack may be wrongful, prevailing opinion denies that this constitutes an attack. The lack of a voluntary act means that there is no human conduct. Similarly problematic are insanity and infancy, which can be considered an exemption, reflecting that the actor is not a subject of the law. Like an animal, their attacks would not qualify under self-defence. ${ }^{101}$

Again however, the outcome would not be so different, as the defendant could apply (some) defensive force against the child or insane based on necessity. ${ }^{102}$ The practical relevance of these much debated but rare cases thus deals with the question which defence applies: self-defence or a necessity type defence. A different solution is to characterize the conduct of the person who uses the innocent aggressor as a pawn as an (indirect) unlawful attack, against which the attacked person may defend himself by turning towards the pawn. ${ }^{103}$ Self-defence could also be made available in these cases by focusing more on the autonomy of the individual and much less on the responsibility of the aggressor for the act. Under the rationale of the autonomy of the attacked person, the (lacking) responsibility of the aggressor for the attack may be held irrelevant. ${ }^{104}$ The Law Commission simply solved the issue by including involuntary actions, actions from minors and excused actions as acts that would otherwise not be criminal, but do justify self-defence. ${ }^{105}$

\subsubsection{Legitimate interests}

Self-defence is not aimed at the prevention of crime. On the one hand, an attack need not be a crime to give rise to self-defence. On the other, the interests that may be defended in self-defence are limited. Due to this limitation, self-defence is demarcated from a general right to fight wrong. ${ }^{106}$ There is a tendency to widen the scope of interests that may be defended with force, which is limited at the same time by emphasizing that more restraint may be warranted when one defends interests that are less important and/or less personal to the defendant.

The wrongful attack needs to be aimed at a legitimate interest of the attacked person. It is undisputed that interests like a person's life, liberty, body and property qualify as legitimate interests that can be defended against wrongful attacks under self-defence. ${ }^{107}$ The interests that allow for the severe instrument of self-defence clearly belong to the most important and fundamental legal interest the law aims to protect. No threshold exists as to how severe the attack on these interests must be.

101 See X.7.6; Re A. (Children) [2000] EWCA Civ 254; Horder 1995, p. 436; Machielse 1986, pp. 547-548 and 641-642 and Fokkens \& Machielse, note 8 on art. 41.

102 Beulke 2008, p. 112; Schönke \& Schröder, H. 2006, p. 650; Roxin 2006, pp. 658-659 and Machielse 1986, pp. 633-634.

103 Fokkens \& Machielse, note 8 on art. 41.

104 See Horder 1998, p. 145.

105 Section 44(3) draft Criminal Code, Law Commission 1989, pp. 61-62 and section 27(3) Law Commission 1993, p. 108.

106 Schönke \& Schröder, H. 2006, p. 640; Pawlik 2002, p. 261 and Roxin 1981, p. 75.

107 Sangero 2006, p. 123 and Roxin 2006, pp. 669-670. 
For example, no distinction is made between a short or long-lasting deprivation of liberty and between a severe in comparison to a normal assault. The severity of the attack does play a role in the context of proportionality. In general, the less severe the attack, the less severe the defensive force may be.

The scope of legitimate interests is the widest in Germany, where the starting point is that any individual legal interest can be defended. ${ }^{108}$ On the contrary, Dutch law exclusively lists the interests that can be defended. The two legal systems are illustrative of the two distinct approaches in Europe in this regard. ${ }^{109}$ For example, in the Netherlands, the 'honour' of a person is commonly restricted to sexual integrity, as a species of an attack on the body. ${ }^{110}$ It does not allow for self-defence against insults or provocations. ${ }^{111}$ By contrast in Germany, one is allowed to defend oneself against insults. However, this does not mean that the person using force in response to an insult will be justified in self-defence. The justification will often be rejected, because the use of force against an insult will not be held to be necessary, let alone proportionate. ${ }^{112}$ In other contexts, this approach also applies, which brings about that the wide scope of legitimate interests in Germany does not often lead to different outcomes in comparison to the other Member States.

The differences in these contexts are also mitigated in other ways. In contrast to Germany, ${ }^{113}$ trespass cannot give rise to self-defence in the Netherlands. ${ }^{114}$ However, it is assumed that this will usually bring about an immediate danger to life, body and/or property and thus qualify for self-defence. ${ }^{115}$ When the attacked person is inside his own house, he can in principle not be required to retreat. Moreover, trespass is a criminal offence, enabling the powers of arrest and use of reasonable force to effectuate that arrest. ${ }^{116}$ The proposal ${ }^{117}$ to introduce a legal presumption that a situation of self-defence is present when someone trespasses was therefore rejected as superfluous by almost all Dutch practitioners and scholars. ${ }^{118}$

108 Beulke 2008, p. 114 and Perron in Arnold a.o. 2005, pp. 1025-1027. See 14 August 1992 BayObLG NJW 1993, 211, where the blocking of a car from moving forward was also held to qualify for self-defence.

109 Witteman 1997, pp. 221-223.

110 Fokkens \& Machielse, note 6 on art. 41.

111 HR 22 January 2008, RvdW 2008, 171 and de Hullu 2006, p. 300. Such insults could give rise to a duel, which was criminalized as a mitigating lex specialis in the Dutch Criminal Code until 2006.

11214 February 1952 BGHSt 3, 217. In contrast, ripping a piece of paper that is insulting to the person concerned can be justified.

113 15 May 1979 BGH MDR 1979, 985; 29 January 1982 BGH StV 1982, 219 and Roxin 2006, p. 669.

114 HR 14 April 1998, NJ 1998, 662.

115 HR 27 May 2008, NJ 2008, 510; de Hullu 2006, p. 301 and Sangero 2006, pp. 266-267 and 271.

116 Article 138 of the Dutch Criminal Code; Rozemond 2006, p. 98 and Machielse 1986, pp. 560564.

117 Kamerstukken II 2007/08, 31407 no. 2 and Stichting Maatschappij, Veiligheid en Politie 2008, pp. 15 and 51-52. Compare articles $122-6$ of the French Penal Code and article 43 of the Criminal Code of the Dutch Antilles.

118 Annotator Borgers in HR 27 May 2008, NJ 2008, 510 and Machielse 2008. 
The advantage of the German approach is that it does not preclude self-defence a priori. It emphasizes the relationship between the interest that is attacked and the appropriate aversion of this attack. ${ }^{119}$ The advantage of a limited list of interests that can be protected is that it communicates clearly that some interests such as honour are $a$ priori excluded from protection and balancing. This strengthens certain values such as freedom of speech and prevents infractions based on non-recognized (illegitimate) interests. The choice for one or the other approach is less important because it does not tend to change the outcome of criminal cases.

If it is considered that the above-mentioned legal interests of a third party may also be defended, then self-defence is perhaps not the best label for this justification. ${ }^{120}$ The justification is not derived from the attacked person, because the third party may defend his interests even if the attacked person himself is unaware of the attack. ${ }^{121}$ On the other hand, if the attacked person explicitly does not want to be helped or if the circumstances clearly indicate this, self-defence is not allowed under the rationale of the autonomy of the attacked person. ${ }^{22}$ The case for defence of another is bolstered by the rationale of the legal order and the circumstance that the motivation is altruism rather than egoism. However, when third parties intervene, the chances increase that this party mistakenly assesses the situation. ${ }^{123}$

In contrast to individual legal interests, public legal interests are a matter of state officials only. The rationale of individual protection and the legitimate exception to the injunction on taking the law into one's own hands do not apply. If public interests could be defended, this would lead to scenes the State has exactly wanted to prevent by taking the monopoly on force. More damage can be done to the legal order if individuals could act as voluntary police officers. Self-defence is thus not allowed against for example driving intoxicated, but if an individual is at peril as a result of this, self-defence can apply. ${ }^{124}$

This strict limitation made by German scholars can be juxtaposed with the aforementioned tendencies of States to privatise public tasks, including those of law enforcement and to emphasize that citizens are co-responsible to create a safer society. As noted, citizens can rely on legal provisions that allow for the use of force necessary to arrest offenders. In addition, differences are put into perspective if we take into account that precluding self-defence again often merely implies that the justification of necessity is the better legal basis. ${ }^{125}$ For example, the private citizen

119 Favoured by Sangero 2006, p. 127 and 132 and Witteman 1997, p. 262 too.

120 De Hullu 2006, p. 299; Beulke 2008, p. 114; R. v. Duffy [1967] 1 QB 63 and Sangero 2006, pp. $1-2$.

121 Sangero 2006, pp. 242-243.

122 Beulke 2008, p. 115; Schönke \& Schröder, H. 2006, p. 649; Roxin 2006, pp. 654 and 713 and 2 October 1953 BGHSt 5, 245 .

123 Sangero 2006, pp. 243-249 and 263-265.

124 Roxin 2006, pp. 654 and 669-672 and Schönke \& Schröder, H. 2006, pp. 639-643.

125 See Roxin 2006, pp. 673-674. Moreover, exceptions are made in Germany for the direct interests of the state. 
was justified under necessity to detain a spy in order to keep him from fleeing with secrets over the border. ${ }^{126}$

\subsubsection{Imminence}

Self-defence only applies against attacks that are imminent, have begun or are on-going. ${ }^{127}$ In those cases, the attacked person cannot wait for the official authorities to protect his interest. Therefore, it is necessary to make an exception to the injunction on the use force by private individuals. In order to avert the attack, to minimize the harm, he must act himself, leaving aside for now other alternatives such as retreating. ${ }^{128}$ The difficulty lies in determining the limits of this temporal requirement: when does the attack start and when it end? It is located in between two facets. On the one hand, self-defence may be performed at its earliest when danger is already close. It may be performed on the other hand only as long as the attack continues, otherwise it would be retaliation.

To start with the latter facet, the right to self-defence ends with the end of the attack. The attack is on-going until the aggression had been factually completed either by abandoning the attempt, by its failure or by causing the definite violation of the protected interest, so there is no more further harm to be avoided. The completion of the legal elements of an offence is not constitutive, as the person whose bag is stolen may pursue the thief and use force to regain possession in selfdefence. The attack will be on-going until the thief has secured full and safe possession of the bag. ${ }^{129}$

If the criteria that determine the beginning of the attack are too strict, defensive force can become useless. ${ }^{130}$ When the attack has already started, some harm may have already been inflicted and the defendant may no longer be able to stop the attack. In the absence of other options, the defendant must be allowed to avert any harm to a protected legal interest. The criterion is therefore that the attack or danger thereof should be imminent, not that the interest is actually infringed. ${ }^{131}$ Under the criterion that the danger is imminent, one is allowed a pre-emptive strike. ${ }^{132}$ In one case, the defendant had been warned that an infamous gang was on their way to his

126 Roxin 2006, p. 729 and Beulke 2008, p. 104.

127 Schönke \& Schröder, H. 2006, p. 644. The terminology in Germany is that the attack must be current (gegenwärtig), in the Netherlands that it must be immediate (ogenblikkelijk).

128 Kaufman 2007, pp. 354-359.

12912 February 2003 BGHSt 48, 207; Bohlander 2009, p. 101; Schönke \& Schröder, H. 2006, p. 645; Roxin 2006, p. 668; Sangero 2006, pp. 257-260; Machielse 1986, pp. 551-555 and Fokkens \& Machielse, pp. 280-281, note 7 on art. 41.

1307 November 1972 BGH NJW 1973, 255; Fokkens \& Machielse, p. 277, note 6 on art. 41; Machielse 1986, p. 552; Rozemond 2006, p. 99 and de Hullu 2009, p. 312.

131 HR 2 February 1965, NJ 1965, 262 and HR 30 March 1976, NJ 1976, 322 and de Hullu 2006, p. 303. See also Machielse 1986, pp. 552-553.

132 R. v. Deana (1909) 2 Cr App R 75; Ashworth 2006, p. 145; Ormerod 2005, p. 336 and Simester \& Sullivan 2007, p. 708. 
house and that they were armed with firearms. The Court of Appeal held that the defendant opened fire and therefore rejected self-defence. The Dutch Supreme Court quashed this judgment. ${ }^{133}$

In contrast, the mere fear of an attack cannot warrant self-defence. ${ }^{134}$ There is a grey area between mere fear and imminent danger, which puts great weight on the circumstances of the case and gives the judge a lot of discretion. ${ }^{135}$ An imminent danger can be distinguished from mere fear by viewing this danger as reasonable fear. Danger is assessed objectively with a reference to a third person or external manifestations. There can be no attack when the will to harm a legal interest is not yet made known externally. ${ }^{136}$ The danger needs to be real, to be capable of infringing the interests. Hence, an impending danger of black magic is not included: a mere subjective fear of the defendant is irrelevant. ${ }^{137}$ Likewise, the real intentions of the aggressor are less important than what impression the defender could reasonably have gotten. ${ }^{138}$ This objective approach to external manifestations bears resemblance to the test for attempt, ${ }^{139}$ but the attack does not have to qualify as an attempt yet in order for a pre-emptive strike to be justified. ${ }^{140}$ It has been submitted that an imminent attack immediately precedes an attempt. It is normally situated at the end of the preparatory stage, just before attempt would start, such as reaching for a firearm or approaching the person threateningly. ${ }^{141}$

Proposals have been made to widen the imminence requirements to encompass attacks that can no longer or only very difficult be repelled later, like an attack that is announced for the following day. For example, it has been argued that it should be about the imminence of the necessary response. ${ }^{142}$ In contrast, most German scholars argue that this 'quasi self-defence' can only be justified under necessity where it does suffice that the need to act is imminent. ${ }^{143}$ Similarly, it has been argued the focus of self-defence has been too much on one-off adversarial encounters. In the context of women who kill their abusive partners, there may have been no immediate danger. However, if they would need to wait until another attack would follow, they would have most likely failed in the attempt to repel the attack. Self-defence should be available, based on the question whether the defendant has had a fair and reasonable opportunity to do other than (s)he did. ${ }^{144}$ However, this

HR 21 December 2004, NJ 2007, 469. See also Buruma 2005, pp. 440-441.

HR 8 February 1932, NJ 1932, p. 617.

Machielse 1986, p. 553 and Ashworth 2006, p. 142. See also Sangero 2006, p. 157.

Roxin 2006, p. 667 and 9 January 1985 BayObLG NJW 1985, 2600.

HR 18 September 1989, NJ 1990, 291; de Hullu 2006, p. 304 and Strijards 1987, pp. 62-63.

Machielse 1986, p. 557.

Rozemond 2006, p. 100 and Roxin 2006, pp. 665-666.

Strijards 1987, p. 62 and Machielse 1986, pp. 558-559.

7 November 1972 BGH NJW 1973, 255; 19 September 1973 BGHSt 25, 229; Roxin 2006, pp. 665-667 and Schönke \& Schröder, H. 2006, p. 644.

See Sangero 2006, pp. 157-158.

Schönke \& Schröder, H. 2006, p. 640 and 644-646; Roxin 2006, p. 668; Beulke 2008, p. 113 and Fischer, T. 2009, p. 291.

Horder in Shute \& Sullivan 2002, p. 290. See also Sangero 2006, p. 340. 
test resembles that of duress, which is submitted to the better framework for assessing these cases.

The best approach, similar to the aforementioned one on legitimate interests, is to apply a low threshold to the criterion of imminence. At the same time, the period of time that remains until the interests will be infringed is taken into account in assessing what alternative exists and what degree of force would suffice. For instance, the less imminent the attack, the more likely there is a possibility of retreat, which the defendant can therefore have been expected to use. By contrast, the more imminent the attack becomes, the more should be allowed. For example, the immediacy of the situation demands that the attacked person decides what to do in a short time period. This influences the proportionality test, as one cannot judge everything 'to a nicety' in a short period of time. This approach fits in best with the courts' broad and flexible approach to this requirement, as well as the view of selfdefence as requiring a balancing of all the interests and criteria. It enables the most important overarching criterion of proportionality to play a major role.

\subsubsection{Possibility to retreat}

The use of force in self-defence seems to be only necessary when there are no alternatives, one of which is to avoid or end the confrontation by retreating. This implies that if there is a possibility to retreat or get help, one should use it. The person, who was attacked at his door, should have therefore closed the door. Instead, he armed himself and confronted the aggressor in his front yard. ${ }^{145}$ A focus on the monopoly of violence brings about a strict duty to retreat or avoid conflict. In ancient English law, a duty to retreat applied to attacks that were not classified as a felony. ${ }^{146}$ The Dutch Supreme Court also for a long time applied the rule that selfdefence is not necessary when there is a possibility to retreat. ${ }^{147}$ By contrast, a strict duty to retreat has never been part of the German law on self-defence, since right should never give way to wrong. ${ }^{148}$

Currently, an absolute duty to retreat no longer exists in any of the three Member States. It is therefore more appropriate to talk about a possibility to retreat. English and Dutch law have moved towards German law, by considering the possibility to retreat as a factor. It is no longer an independent condition, which requires a certain threshold to be met, but a flexible factor that is interrelated with the other conditions of self-defence. Most notably, the possibility of retreat does not necessarily preclude the justification, but it can influence what amount of force is allowed. The weight of the duty to retreat also depends on the other conditions of self-defence, such as the blameworthiness of the aggressor or the defendant himself. For example, a real duty to retreat may exist when the aggressor is an infant or the defendant provoked the

145 HR 16 September 2008, $L J N: B D 1728$.

146 Sangero 2006, pp. 198-199.

147 De Hullu 2006, p. 305, referring to HR 18 June 1957, NJ 1957, 446.

148 Roxin 2006, p. 657 and Perron in Schönke \& Schröder 2010, note 40 on $\$ 32$. 
aggressor. ${ }^{149}$ In other words, the requirement of retreat is assessed according to the facts and circumstances of every case. As a consequence, the scope of self-defence has become broader than it was. ${ }^{150}$ A second reason why this criterion has become broader is that Dutch courts are required to better substantiate why they rejected self-defence based on a possibility to retreat. ${ }^{151}$ By quashing convictions for rejecting the defence on insufficient grounds, the condition in effect becomes more lenient.

The requirement gives some general guidelines. In principle, quickly giving way to, ducking away and getting directly available help, which is not capable of interpretation as giving up the legal interest, can be required from the attacked person. Getting (official) help is only required when this help is immediately available without extraordinary efforts. ${ }^{152}$ The attacked person cannot be required to retreat when the path of retreat endangers the attacked person, when retreat would merely gain time or when it is hardly possible. ${ }^{153}$ In principle, a person attacked at home also has no duty to withdraw. ${ }^{154}$

The defender is not required to run away or avoid certain places, even if he knows that he may run into trouble. ${ }^{155}$ The modern rationale for this rule is that retreat harms the legal order as it "constitutes a retreat of law and order before the aggressor who violates the law." 156 A strict duty to retreat would bring about that right gives way to wrong. ${ }^{157}$ If it were different, this would encourage aggressive and threatening behaviour. The defendant is therefore less likely to be reproached for not retreating and/or seeking the confrontation if he was acting lawful. ${ }^{158}$ An example of this is the case, where the defendant could not use his right of way because a trailer blocked the driveway. He would have moved it himself, if he had not been having an argument with its owner for some time. Knowing there was a

149 Leverick 2006, p. 82; Fokkens \& Machielse, pp. 274-275, note 3 on art. 41; Bohlander 2009, p. 104 and Schönke \& Schröder, H. 2006, pp. 652 and 655.

150 HR 21 December 2004, NJ 2007, 469; HR 21 November 2006, NJ 2006, 650; HR 6 October 2009, NJ 2010, 301; HR 15 November 2011, NJ 2011, 542; de Hullu 2006, pp. 306 and 316; Machielse 1986, p. 710; R. v. Bird [1985] EWCA Crim 2; Duffy v. Chief Constable of Cleveland Police [2007] EWHC 3169; section 44(7) draft Criminal Code, Law Commission 1989, p. 62; Leverick 2006, p. 72 and Bohlander 2009, p. 104.

The Dutch Supreme Court has quashed many judgments for this reason in the last years. See for example, HR 12 July 2011, $L J N:$ BQ6720. 5 October 1965 BGH VRS 30, 281; 11 January 1984 BGH NJW 1984, 986; Roxin 2006, p. 680 and Schönke \& Schröder, H. 2006, pp. 655-656.

153 HR 15 January 2008, RvdW 2008, 120; Kelk 2005, p. 288 and Sangero 2006, pp. 197 and 202203.

154 Ashworth 2006, p. 144; Ashworth 1975, p. 294; Sangero 2006, pp. 185 and 269-270 and de Hullu 2009 , p. 315. Of course, this is different when aggressor and defender are living together. In R. v. Hussey (1925) $18 \mathrm{Cr}$ App R 160, even deadly force against an unlawful eviction was allowed, but as Leverick 2006, pp. 137-140 submits, this would not be the outcome when tried today. Ashworth 2006, p. 144; Ormerod 2005, pp. 336-338 and Simester \& Sullivan 2007, p. 707.

156 Sangero 2006, p. 194.

157 Machielse 1986, p. 655 and annotator Buruma in HR 28 March 2006, NJ 2006, 509.

158 Blomsma \& Klip 2009. 
risk the owner would react violently, he went into the owner's greenhouse to ask him to move his trailer, only to be told to get out of there. The defendant however stayed where he was and was attacked, after which he defended himself by stabbing the victim with a pair of scissors. ${ }^{159}$

Because the adage that right should not give way to wrong is deeply rooted in German law, it has a very weak retreat requirement. German courts have legitimized a lenient approach by arguing that the law does not require a 'humiliating retreat'. ${ }^{160}$ The German Supreme Court even held in the case where a schoolboy who had been bullied numerous times before, brought a knife to school and stabbed his bullies, that this defendant was not required to get help of teachers since this would be a shameful retreat. ${ }^{161}$ Whereas the rationale of the humiliating retreat is also clearly present in English ${ }^{162}$ and Dutch ${ }^{163}$ law, it is submitted that the 'dishonour' of retreat is insufficient to justify the retreat rule, especially in this extreme way. Such a wide scope of self-defence fails to respect the interests of the aggressor and, in combination with a pre-emptive strike, runs the risk of over stimulating self-assertion. ${ }^{164}$ Accordingly, in as far as the requirement is weaker than in England and the Netherlands, it must be rejected.

The more relaxed approach to retreat can better be explained in light of the abovementioned shift from a strict monopoly on violence to a society where the responsibility to fight crime is shared between state and citizens. ${ }^{165}$ Helping others cannot be reconciled with a duty to retreat. It has always been accepted that public officials cannot be required to retreat, as it is their duty to protect the legal interests of others. ${ }^{166}$ However, private individuals can also act in self-defence with a view to help others or even use force with a view arrest a suspect. In the current, hardened and complex multicultural society with lots of violence in places of entertainment, against shopkeepers, bus drivers, ambulance personal and other officials, there will not be a lot of understanding for judicial decisions that apply a strict duty to retreat to the detriment of the defender. ${ }^{167}$

\footnotetext{
159 HR 29 April 1997, NJ 1997, 627. See also HR 28 March 2006, NJ 2006, 509.

16026 May 1964 BGH GA 1965, 147. See also Fischer, T. 2009, p. 295.

16124 July 1979 BGH NJW 1980, 2263. In contrast, see Hof Amsterdam 22 July 2008, LJN: BD8276, where even self-defence-excess was rejected and Roxin 2006, p. 681.

162 "It is undoubtedly distasteful to retreat; but it is ten times more distasteful to kill." Beale, cited in Sangero 2006, p. 196 and Leverick 2006, p. 77.

163 De Hullu 2009, p. 316 submits that in Dutch Parliament, it was already argued in 1900 that the defendant should not be required to use every possibility to retreat, as this would imply the 'cowardly giving up of one's legal interests.'

164 Compare Ashworth 2006, p. 145 and Leverick 2006, p. 82.

165 Stichting Maatschappij, Veiligheid en Politie 2008, p. 24.

166 Sangero 2006, pp. 197 and 202-203; Hof Amsterdam 9 December 2005, LJN:AU7731; Hof Arnhem 20 November 2008, $L J N: B G 4942$.

167 Ter Haar \& Meijer 2009, p. 45.
} 


\subsubsection{Prior fault}

If the defendant sought the confrontation or provoked the aggressor, he is partially responsible for the situation of self-defence. The approach to this prior fault is located in between two extreme positions. On the one hand, prior fault does not change the fact that there was a situation of self-defence. This extreme view would argue in favour of making prior fault irrelevant. On the other hand, it would offend common sense to acknowledge an unrestricted right for the defender who is responsible for creating the conditions of the defence.

Therefore, a middle ground has been chosen in all Member States. The defence is only rejected in serious cases of prior fault, to be discussed below. In all other cases, the degree of prior fault influences the weight of the other requirements of self-defence. Just like the other criteria of necessity, prior fault is therefore an independent factor that plays a relevant, but not necessarily decisive role. ${ }^{168}$ For example, the defendant who expects an aggressive response is expected to consider the alternatives to self-defence with more caution, thus increasing the weight of a duty to retreat or get help. ${ }^{169}$ This illustrates again that self-defence consists of a 'total judgment' of all the circumstances of the case. ${ }^{170}$

Another example of how prior fault operates as a corrective mechanism is that it limits the degree of force that is justified. In Germany, a three-staged approach applies to cases of prior fault. The blameworthy causing of a situation of selfdefence requires that the attacked person does his utmost to evade the attack or find help. If this is not possible, he should exercise more restraint in the choice of the weapon of defence and its use. He will have to restrict himself to defensive force before moving towards a counter-attack. ${ }^{171}$ For example, the defendant who returned armed to the place of argument in order to settle the score was required to threaten with a weapon before using it and subsidiary, to use it in a non-lethal way. This increased duty applied even if it meant that he risked more injuries. Only if all else fails, can lethal force be justified, because the defendant is not required to undergo serious interferences such as serious bodily injury or death. ${ }^{172}$

168 R. v. Nicholas Rashford [2005] EWCA Crim 3377; Bohlander 2009, p. 111; Schönke \& Schröder, H. 2006, p. 665; Roxin 2006, p. 691; HR 28 March 2006, NJ 2006, 509; annotator de Hullu in HR 31 October 2000, NJ 2001, 11; de Hullu in Verbruggen, Verstraeten, van Daele \& Spriet 2005, p. 50; annotator Buruma in HR 7 February 2006, NJ 2006, 508 and Rozemond 2006, p. 152.

170 De Hullu 2006, pp. 309-310.

171 14 June 1972 BGHSt 24, 356; 15 May 1975 BGHSt 26, 143; 7 July 1987 BGH NStZ 1988, 450; 10 November 2010 BGH NStZ-RR 2011, 74; Schönke \& Schröder, H. 2006, pp. 652 and 655; Roxin 2006, pp. 689-690; Eisele 2001, p. 146 and Schünemann 1985, p. 369. 'Schutzwehr' and Trutzwehr.'

1727 March 2002 BGH NStZ 2002, 425. See also 21 March 1996 BGHSt 42, 97; 26 October 1993 BGHSt 39, 374; 12 December 1975 BGHSt 26, 256; Roxin 2006, pp. 686 and 690-691; Schönke \& Schröder, H. 2006, p. 665 and Fischer, T. 2009, pp. 299-300. The concrete requirements are determined by reference to the concrete situation, which takes into account all circumstances, including the weapons used, strength and characteristics of the participants. 
In recent decades, the role of prior fault in the three national legal systems has moved towards each other. In Germany, prior fault has never been a significant limitation of self-defence. Due to a narrow focus on the need to defend oneself tempore delicti and the maxim that right should never yield to wrong, in general, at most more is required from the other requirements of self-defence in such cases. In the other two States, the concept has been treated less as an absolute condition and also more as a corrective mechanism. The limiting effect of prior fault is also applied more leniently. For example, nowadays the defence is also not likely to be rejected just because the defendant did not exercise more caution by getting help or leaving a place, when he feared an attack. ${ }^{173}$

The question of whether or not the prior fault must lead to a rejection of the defence depends on all the circumstances of the case. Important issues are the degree of prior fault and the seriousness of the attack. The more prior fault, the more restricted the right to self-defence. The more serious the attack or the interest endangered, the less rigid the other requirements will be. ${ }^{174}$ Prior fault can be distinguished in kinds. The defendant can have created the conditions of selfdefence with a view to apply the justification. For example, the defendant aimed to create the conditions for self-defence in order to lawfully inflict violence upon his enemy. Less serious is the case where he foresaw the risk that the aggressor would be provoked. In a negligent form, the question is whether the reaction of the aggressor was foreseeable to a reasonable person. ${ }^{175}$

The defence is usually rejected in cases where the purpose of the defendant was to incite an attack. In such a case, another requirement of self-defence will not be fulfilled, namely that of defensive purpose. ${ }^{176}$ In Germany, the defence is precluded in these cases through the notion of abuse of rights. ${ }^{177}$ However, courts are very reluctant to accept that it was the purpose of the defendant to abuse the defence by creating the conditions of self-defence. For example, the returning to a crowded small bar, armed with a shotgun, to confront the person who had attacked him and perhaps had his missing money, was labelled as an intentional provocation, (only) verging on a purposeful provocation. Therefore, the defence is hardly ever precluded. ${ }^{178}$

The mere fear of the defendant that the aggressor may attack him will not necessarily preclude the subsequent necessary application of force. ${ }^{179}$ Consciously

173 HR 22 February 2011 NJ 2011, 107 and HR 7 December 2010, NJ 2010, 677.

174 Schönke \& Schröder, H. 2006, p. 665; Roxin 2006, p. 691 and ter Haar \& Meijer 2009, p. 142.

175 Strijards 1987, pp. 44-46 writes about 'dolus' and 'culpa in causa'. The most serious form of prior fault is labelled in Germany as 'Absichtsprovokation'. See also annotator Keijzer in HR 2 February 2010, NJ 2010, 282; Beulke 2008, p. 120; Roxin 2006, pp. 687-688 and Schönke \& Schröder, H. 2006, pp. 662-663.

176 Bohlander 2009, pp. 104-105; Beulke 2008, pp. 118-120 and ter Haar \& Meijer 2009, pp 84-85.

17714 June 1983 BGH NStZ 1983, 452; Beulke 2008, p. 120; Fischer, T. 2009, pp. 298-299 and Kelk 2005 , p. 288.

17826 October 1993 BGHSt 39, 374.

179 R. v. Nicholas Rashford [2005] EWCA Crim 3377; Ormerod 2008, p. 369 and HR 28 March 2006, NJ 2006, 509. 
seeking out the confrontation will often preclude a finding of self-defence, ${ }^{180}$ but it is not required prima facie that a defendant should avoid certain places. The circumstances are decisive. It is unreasonable to hang around your enemy's house and might even indicate violent intention under the guise of self-defence. By contrast, one cannot be required to stay away from his workplace, just because he is likely to be confronted with his enemy. ${ }^{181}$

The question is not only whether a risk was taken, but also whether that risk was reasonable. Consider the ambulance man who knows he enters a dangerous situation but has to in order to help a victim. If he is attacked, he may defend himself. ${ }^{182}$ The legal order aspects of the defendant's actions can outweigh the concomitant prior fault. In the above-mentioned case, the defendant knew that there was a considerable risk that the persons who were blocking his right of way would be provoked by him asking them to move. It was however perfectly lawful for him to ask this. Conduct, which is perfectly legal and invites violence, cannot preclude self-defence. ${ }^{183}$ If it were to be any different, the aggressive would limit the freedom and rights of others.

Prior fault does not preclude self-defence as it does in for example duress, because the force is directed against the aggressor who acts wrongful, not against an innocent third party. ${ }^{184}$ Only an actio illicita in causa, conduct, which is illegal in origin, can negate self-defence. ${ }^{185}$ The justification is therefore usually rejected in cases where criminals foresaw a violent encounter, like a rip-deal. The rationale of the legal order militates against application, as there is no right against wrong. ${ }^{186}$ In certain circumstances, conduct, which is not wrongful, but clearly socially unacceptable, can also give rise to limitations of self-defence under prior fault. Consider the football supporter who, dressed in the club's outfit, goes to the supporter's home of the rivalling club. ${ }^{187}$

By giving more weight to lawful motives of the defendant in particular, and by applying a more lenient approach to prior fault in general, the Dutch judiciary has widened the scope of self-defence in the last years. This can be contrasted with the perspective that citizens are supposed to exhaust legal remedies to safeguard their

180 HR 24 October 1989, NJ 1990, 353.

181 See also de Hullu 2006, pp. 309-311 and Rozemond 2006, pp. 106-108.

182 De Jong D.H. \& Knigge 2003, p. 173 and Strijards 1992, p. 272.

183 HR 29 April 1997, NJ 1997, 627; HR 28 March 2006, NJ 2006, 509; section 44(6) draft Criminal Code, Law Commission 1989, p. 62; section 27(7), Law Commission 1993, p. 108; 12 January 1978 BGHSt 27, 336; 21 March 1996 BGHSt 42, 97 and Beulke 2008, p. 120.

184 Leverick 2006, pp. 120-121.

185 See Sangero 2006, p. 336 and Hruschka 2001, p. 880.

186 See Rb. Zwolle 29 May 2008, LJN:BD1958 and BD9248 and HR 27 May 1986, NJ 1987, 8 and Machielse 1986, pp. 615-617.

187 A similar case was HR 1 July 1987, NJ 1989, 389. Another example is a Nazi that attends a meeting of Jewish WWII survivors, see Robinson 1985, pp. 40-42 and Leverick 2006, p. 123. Roxin 2006, pp. 687-693 and Schönke \& Schröder, H. 2006, pp. 662-664 argue that although the criterion of socially adequate conduct is commonly applied in Germany, it does not provide a clear line of demarcation. The criterion should therefore be restricted to wrongfulness. 
rights instead of taking matters into their own hands. In the context of offences against property, it was explained that this perspective led to a wide interpretation of intent as to the wrongfulness, enabling the conclusion that these persons committed offences against property. ${ }^{188}$ In Germany, citizens have rights of selfhelp under civil law that can provoke the aggressor. Because this self-help is lawful, the defendant may defend himself regardless of the provocation. 189

In English law too, the strict rule that seemed to preclude self-defence in most cases of prior fault has recently been widened by holding that "the mere fact that a defendant goes somewhere in order to extract revenge from the victim does not of itself rule out the possibility that in any violence that ensues self-defence is necessarily not available as a defence." 190 The threshold for precluding the defence is set high, which brings about that in most cases, the requirements of the defence are only made stricter. In other words, a yes or no test is replaced by approach that takes into account all the circumstances of the case.

Prior fault is least likely to preclude self-defence in Germany, and when it operates as a corrective mechanism in lesser cases than purposeful prior fault, it also not often leads to a rejection of the defence. As another middle way, negligence liability is sometimes established. To illustrate this, consider the case where $\mathrm{G}$ had been injured in a fight and in revenge, he wanted to inflict similar injuries on $\mathrm{M}$, the person responsible for this. He asked the defendant to take care of this by shooting $M$ in the legs. The defendant lured $M$ into a secluded area and then tried to hit him to facilitate the intended shooting. However, $\mathrm{M}$ saw it coming and hit the defendant (in self-defence) with a cosh, striking him to the ground. At that point, he wanted to hit the defendant who was still lying on the floor seriously wounded again, uttering the words, "You pig, I will kill you." The defendant then took the gun and fatally shot M. The German Supreme Court held that self-defence was not precluded because of the defendant's previous attack. The justification should be connected, not to when he tried to hit M, but to the point of time he was lying at the ground, when M's situation of self-defence had ended. The defendant at that time acted to defend himself, whereby the previous attack is irrelevant. The defence was limited due to the prior fault, but these stricter requirements were met since it was established that the defendant could do nothing else but shoot $\mathrm{M}$ at that time. $\mathrm{He}$ was thus justified in killing $\mathrm{M}$, but in order to overcome an outright acquittal of the defendant, he was held liable for negligent killing, as the intended severe wounding could and did in fact result in the death of M. ${ }^{191}$

The case recognized that bad men can be justified in self-defence too. It would however strain everybody sense of justice if the defendant would be acquitted. In fact, he was also held liable. As a middle ground solution to these cases, prior fault

\footnotetext{
188 See IV.2.4.7.

1895 April 2011 BGH BeckRS 2011, 09435. See $\$ \S 229$ and 230 of the German Criminal Code.

190 R. v. Nicholas Rashford [2005] EWCA Crim 3377, in contrast to R. v. Brown [1973] NI 96, cited in Sangero 2006, p. 321.

19122 November 2000 BGH NStZ 2001, 143 and Schönke \& Schröder, H. 2006, p. 665.
} 
neither precludes the defence nor is irrelevant. Liability is grounded in the prior unlawful act, the actio libera or illicita in causa. ${ }^{192}$ The approach resembles that of German lawyers in cases of dolus generalis, where a complex sequence of events was also separated into two acts. If the victim was killed by what the defendant thought to be the disposing of the body, he is liable for the failed attempt to kill and the negligent killing. Dolus is assessed in relation to the exact time when the actus reus was fulfilled. ${ }^{193}$ In both contexts, the requirements of criminal liability are rigidly assessed by reference to the offence, which is narrowly interpreted as the killing itself, rather than the whole sequence of events and the circumstances leading up to it. It is awkward to hold that a result like death is both wrongful and lawful. ${ }^{194}$

It can be concluded that there exists consensus that prior fault should not preclude self-defence except for cases where it was the defendant's purpose to abuse the justification. In all other situations, self-defence can, but need not be rejected. Even if self-defence is no longer precluded a priori so easily, a significant degree of prior fault most likely will result in the rejection of self-defence, even if there was a situation of self-defence tempore delicti. Merely guidelines can be given as everything depends on the circumstances. Amongst others, an important factor for the effect of prior fault is whether or not the conduct that gave rise to the situation of self-defence was lawful.

This approach applies to all criteria of necessity. The imminence requirement, the duty to retreat and the interests that can be protected currently function more as a factor in assessing self-defence, than as cumulative criteria with a high threshold. The questions of necessity are not as decisive as they have been in the past. Selfdefence therefore revolves around proportionality. The balancing of all factors is usually conducted in the context of proportionality. Possible alternatives and not very immediate dangers influence what is allowed as proportionate force. Only proportionate defensive force is in line with the protection of the legal order. Finally, the dividing line between self-defence as a justification and the excuse of excessive self-defence is drawn by proportionality.

192 Schönke \& Schröder, H. 2006, p. 665; Mitsch 2001, pp. 751-755 and Sangero 2006, pp. 328-337. Although often used interchangeably, an actio libera is about an act, which was free in origin, see V.3.4., whereas an actio illicita was wrongful to begin with, see Hruschka 2001, pp. 880881. There is controversy on whether or not the German Supreme Court has recognized this doctrine, since the fourth Senate has rejected it and other Senates also not explicitly recognize it, see Roxin 2006, p. 694 and Fischer, T. 2009, p. 300.

193 See V.3.2. Robinson 1985 (US) proposed a similar solution that should apply to all defences where the actor has in way generated the conditions of his defence. See also Gur-Arye 1986, pp. 78-79.

194 Mitsch 2001, p. 755 however argues that the fact that the solution is hard to ground in theory, should not distract us from the argument that this solution is acceptable as fair. 


\subsection{Proportionality}

The second limb of self-defence consists of a proportionality standard that assesses the relationship between the offence committed and the amount of harm likely to be suffered by the defendant, or likely to result if the defendant had not intervened with force. ${ }^{195}$ Simply put, it is about weighing the interests of the aggressor against those of the defendant, but it will become clear that the balancing is more complex. In evaluating the proportionality of the defendant's actions, one has to take into account all the circumstances, including in particular the nature and degree of the force used, the seriousness of the evil to be prevented and the possibility of preventing it by other means. ${ }^{196}$ For example, how likely is it that the victim will gain full compensation for his injury if he avoids the use of force? How probable is the occurrence of the danger? ${ }^{197}$

It should be stressed that it is not required that force must be exactly in proportion with the attack: it may not be disproportionate. As long as the defensive force was not a disproportionate response to the attack, the defendant will be justified. It is not required that the anticipated evil should have been greater than the force used to avert this. For instance, lethal force can be justified even when the danger to the attacked person was of severe bodily harm or less, as in rape. ${ }^{198}$ This can be grounded in the reproach that can be made against the aggressor and because the defendant cannot be required to make a perfect weighing of interests in an urgent situation.

First, it is argued that the interests of the aggressor carry less weight, because the attack emanates from him, or that his interests are not only juxtaposed with those of the attacked person but also the legal order as a whole, which is attacked by him. ${ }^{199}$ Since force applied in necessity relates to a third party, rather than a wrongful aggressor, it requires that the interest that is saved should be (significantly) more important than the interest sacrificed. ${ }^{200}$ Secondly, the defendant's actions are not weighed on a gold balance. Because of the urgency of the situation, the immediate necessity of action and the emotions brought about by attacks of basic legal interests like life and limb, the defendant is not required to judge everything to a nicety. ${ }^{201}$ As discussed in detail later, this leaves room to accommodate mistakes on proportionality in the justification.

195 Ashworth 2006, p. 140.

196 S. 76(7a) Criminal Justice and Immigration Act 2008 and Ormerod 2005, pp. 333-334.

197 Sangero 2006, p. 175.

19811 September 1995 BGH NStZ 1996, 29; Sangero 2006, pp. 168, 183 and 196-197 and Leverick 2006, pp. $157-158$.

199 Roxin 2006, p. 655.

200 Sangero 2006, p. 168.

201 Machielse 1986, p. 661 and 713; annotator van Veen in HR 1 March 1983, NJ 1983, 468 and Ashworth 2006, p. 148. See also 20 September 1920 RGSt 55, 82. 


\subsubsection{Least intrusive means}

Proportionality can be divided into different aspects. It has been noted that one aspect deals with the least intrusive means of defence, after which it is questioned in what way the defendant should have used this means. For example, the defendant should use his fists rather than a weapon if that will suffice to repel the attack. Secondly, he should shoot at the leg of the aggressor instead of the torso or head. ${ }^{202}$

However, in German law, it is required first and foremost that the means must be capable of either ending or at least hindering the attack. This element of adequacy or suitability is easily met. Only what is clearly not adequate to end the danger is excluded from self-defence, like the destruction of goods that have no relation to the attack. The defendant does not have to be certain that his actions will in fact be able to avert the attack. What suffices is the possibility that by this action the attack is diminished in intensity or postponed. Thus, the defendant is allowed to defend himself with force against a superior opponent or great number of opponents, even if he accepts the possibility he might get the worst of it. ${ }^{203}$

The requirement that the least intrusive means should be chosen is seriously mitigated by the rule that the defendant is allowed to take the means that are most likely to be effective. ${ }^{204}$ The least intrusive means must still promise the immediate and final cessation of the attack, estimated ex ante. The defendant is not required to use less intrusive means if its usefulness to defend is doubtful. ${ }^{205}$ In other words, in choosing the means, the risk that a means might not be effective enough does not have to be taken by the attacked person. ${ }^{206}$ For example, if the aggressor was already so close that shooting in the foot might not stop him, lethal force can be accepted. ${ }^{207}$

\subsubsection{Proportionality stricto sensu}

In the subsequent issue of proportionate application of the means chosen, the same considerations apply. Threatening with a weapon is also only required if the circumstances allow for it. ${ }^{208}$ German courts easily reject that the defendant should have threatened first. For example, it is argued that this would have brought

202 Fletcher 1978, p. 870; 11 September 1995 BGH NStZ 1996, 29 and Beulke 2008, p. 115.

203 Beulke 2008, p. 115; Schönke \& Schröder, H. 2006, pp. 651-652; Bohlander 2009, p. 10; Roxin 2006, pp. 674-675 and Fischer, T. 2009, p. 294.

204 Annotator van Veen in HR 1 March 1983, NJ 1983, 468. See also Fletcher 1978, p. 870.

205 Roxin 2006, pp. 674-675 suggests that a stricter approach is taken in newer case-law. The old formula in case-law is that the chosen means must avert the danger with certainty; the formula in newer case-law is that lesser means are not required if its effect is doubtful.

20611 September 1995 BGH NStZ 1996, 29; 10 February 2000 BGHSt 45, 378; 25 October 2001 BGH NStZ 2002, 140; Roxin 2006, pp. 674-675 and Schönke \& Schröder, H. 2006, p. 653.

20726 May 1964 BGH GA 1965, 147.

20814 June 1972 BGHSt 24, 356; 13 March 2003 BGH NStZ 2004, 615; 9 August 2005 BGH NStZ 2006, 152; 30 June 2004 BGH NStZ 2005, 31 and Roxin 2006, p. 676. 
about the risk of losing the knife, which would then be used against him. ${ }^{209}$ The defendant does not have to accept the risk of getting injured. ${ }^{210}$ Only in cases of prior fault and innocent aggressors will the choice and means of use be more limited. ${ }^{211}$ More emphasis will be put on the duty to threaten and to apply force as least intrusive as possible, always however with the limitation that the lesser use must still be able to sufficiently protect the defendant's interests.

What means qualify as least intrusive and what application of this means is proportionate is assessed by reference to the strength of the attack, the dangerousness of the aggressor and the available means, taking into account all the circumstances of the situation. ${ }^{212}$ Because of the enormous weight of the circumstances of the case, the approach to proportionality, like that of necessity is very factual and casuistic. ${ }^{213}$ Both aspects are established ex ante objectively by reference to a reasonable criterion figure at the time of the attack, being aware of all objectively knowable circumstances as they were at the time, rather than they turned out to be ex post. ${ }^{214}$ This ex ante yardstick also brings about that the balancing should be about evaluating the anticipated results for the aggressor and the attacked person. The defendant's conduct does not become disproportionate because the harm to the aggressor was more serious than anticipated. Courts nonetheless tend to take into account the actual consequences of the defence, placing too much focus on chance. As an unfortunate result, the defendant bears the risk of defensive action. ${ }^{215}$

\subsubsection{Objective standard}

Despite the objective standard, individual characteristics can lower and raise the proportionality requirement. For example, disparity of strength, size and relationship between defender and aggressor can explain why the use of weapons against an unarmed aggressor can be proportionate. On the contrary, a trained boxer can be expected to use his fists. ${ }^{216}$ 'Garantenstellung' indicates that a defendant has a certain function, to which norms apply and therefore more can be expected from him. He guarantees his conduct, on which others may rely. A police officer is for example deemed to be better in assessing situations and responding

\footnotetext{
20912 January 1978 BGHSt 27, 336.

21015 May 1979 BGH MDR 1979, 985 and 25 November 1980 BGH NStZ 1981, 138.

21121 March 1996 BGHSt 42, 97.

21228 February 1989 BGH NJW 1989, 3027; 9 August 2005 BGH NStZ 2006, 152; Beulke 2008, pp. 115-116; Schönke \& Schröder, H. 2006, pp. 651-652.

213 Kelk 2005, p. 290 and Machielse 1986, p. 664.

21425 June 2009 BGH NStZ 2009, 626; Schönke \& Schröder, H. 2006, p. 651; Beulke 2008, p. 116 and Roxin 2006, p. 678.

215 Sangero 2006, p. 174 and Blomsma \& Klip 2009. Compare Machielse 1986, p. 663-664.

21625 November 1980 BGH NStZ 1981, 138; Law Commission 2004, pp. 76-77; Roxin 2006, pp. 659, 676 and 678; HR 23 October 1984, NJ 1986, 56 and de Hullu 2006, pp. 306-307.
} 
appropriately. ${ }^{217}$ In cases where a not very proportionate response of a police officer was justified, this is often grounded in the lack of education and experience. The question is what can be expected from a police officer in the position and rank, age, education and experience of the defendant. ${ }^{218}$ In contrast, other individual characteristics, such as unusual short-temper, are not taken into account as they would conflict with the normative character of proportionality and self-defence. ${ }^{219}$

What if the defendant thought it was proportionate to seriously harm the aggressor whereas this moderate objective standard does not allow for this? As mentioned before, such a mistake in the context of proportionality must be reasonable to negate liability. A mistake on the scope of proportionality can be distinguished from a mistake on the facts giving rise to self-defence. When the defendant for instance believes that his property outweighs the life of the aggressor, he errs in believing that he can shoot a firearm at a thief. This mistake is treated like a mistake on the legal limits of a prohibition. Since the law sets the rules of conduct, mistakes on these rules are unlikely to excuse the defendant, let alone justify the conduct.

Nonetheless, the concept of proportionality allows for mistakes within limits. Since the valuation of the defendant's actions may only not be disproportionate, it can also be argued that as long as such a mistake is reasonable, self-defence will apply without reference to any putative form. The requirement is lenient because "detached reflection cannot be demanded in the presence of an uplifted knife." 220 If the defendant for example thought it was proportionate to shoot the thief in the leg in order to prevent him from steeling a very valuable object, this will not be considered disproportionate, even if it turns out later that the thief would have also been apprehended soon otherwise.

A second type of mistake exists when the defendant is overpowered by emotions like fear or rage and exceeds what is proportionate in the given situation. This mistake is also not putative self-defence but called self-defence-excess. ${ }^{221}$ This is recognized as a general defence of the excusatory type in Germany and the Netherlands, based on the understanding that the defendant could not act reasonable because of the emotions caused by the attack. The mistake is excused since it is not blameworthy in the specific circumstances. Conduct, which is not disproportionate, can be justified, but even if it is, it may be excused within certain limits of disproportionality. Through the excuse, excessive force does not have to bring about criminal liability.

217 Ashworth 2006, p. 148 and Tadros 2005, p. 354. See AG Remmelink in HR 2 February 1982, $N J$ 1982, 384. On the other hand, a police officer is also required to engage in unpredictable, threatening situations. By focusing on the duty to engage and help others the proportionality requirement is relaxed.

219 Tadros 2005, p. 355.

220 Holmes J, cited in Ashworth 2006, p. 148.

221 Schönke \& Schröder, H. 2006, p. 353; Fischer, T. 2009, p. 301 and Sangero 2006, p. 297. 
The lack of such an excuse in English law can explain why there is a tendency to include more acts of excessive force into the English justification of self-defence. In the absence of other legal solutions that allow for an acquittal, courts are lenient in applying the test of proportionality. ${ }^{222}$ The law enables this by stating that "evidence of a person's having only done what the person honestly and instinctively thought was necessary for a legitimate purpose constitutes strong evidence that only reasonable action was taken by that person for that purpose." 223

After all, the exclusion of the excuse can lead to harsh results, especially if we consider that the defendant was attacked and that intentional killing will result in a mandatory 'life' sentence for murder, which always brings about a minimum of 15 years of imprisonment. ${ }^{224}$ This harshness is also mitigated by not prosecuting in those cases where the degree of force was not very far beyond the threshold of what is reasonable. ${ }^{225}$ Secondly, the defendant is only required to raise evidence that suggests the availability of self-defence. After this threshold has been met, it is up to the prosecution to prove the absence of self-defence. Only when the jury are sure that the force used by the defendant was disproportionate, they are allowed to find him guilty. ${ }^{226}$ Another important mitigation consists in the existence of two partial defences that can reduce a charge of murder to the less serious manslaughter. These defences with similar rationales as self-defence will be discussed together with selfdefence-excess.

\subsubsection{Developments}

The existence of self-defence-excess in Dutch law has been advanced as an explanation for a relatively stricter test of proportionality. ${ }^{227}$ Disproportionate conduct that should not be punished can be excused under self-defence-excess. Nevertheless, in recent years, a clear relaxation of the requirement is visible in the Netherlands. By quashing many convicting judgments for rejecting self-defence as disproportionate on insufficient grounds, the Dutch Supreme Court again indirectly extended the scope of proportionality. Because of this and changing perceptions, Dutch courts are increasingly lenient in allowing self-defence. The jeweller who saw he was being robbed, took a gun, descended the stairs and started shooting could rely on the defence. ${ }^{228}$ So could the defendant who pursued a burglar with a

222 Horder 2006A, pp. 56-57. See also Perron in Arnold a.o. 2005, p. 1034.

223 Section 76(7) Criminal Justice and Immigration Act 2008, which codifies R. v. Palmer [1971] AC 814.

224 Sangero 2006, p. 297 and Kaye 1997, pp. 451-455. Schedule 21 (11) of the Criminal Justice Act 2003 reads: "Mitigating factors that may be relevant to the offence of murder include - the fact that the offender acted to any extent in self-defence."

225 CPS: 'Self-defence and the prevention of crime', www.cps.gov.uk/legal/section5/chapter_d.html.

226 R. v. Martin [2001] EWCA Crim 2245.

227 De Hullu 2006, p. 307.

228 Rb. Breda 8 May 2003, LJN:AF8365. 
baseball bat, caught up with him and in overpowering him, inflicted him serious injuries. $^{229}$

An opposite trend exists in Germany, as a result of which the national concepts of self-defence have moved towards each other. Whereas traditionally, proportionality was foreign to the German concept of self-defence, it can now be concluded that this is also an important limitation to self-defence. ${ }^{230}$ An example that is most often advanced to illustrate the lack of a proportionality requirement is that of the farmer who caught schoolboys stealing his apples. He would be acquitted based on self-defence for shooting at them, because this was the only way of stopping them. Clearly, this gave rise to quite some controversy, as the property rights to apples seem to be favoured over the lives of the young boys. ${ }^{231}$ In order to avoid such outcomes, Dutch Parliament explicitly included a proportionality requirement. $^{232}$ By contrast, German law traditionally puts great weight on the dogma that right should never yield to wrong, focussing on necessity. Theft constitutes an on-going attack, and if there were no other means of ending the attack, even lethal force was allowed to secure property. ${ }^{233}$ Any other solution would imply that the farmer has to accept the loss, thus yield to wrong. ${ }^{234}$ Dutch scholars from the end of the $19^{\text {th }}$ and beginning of the $20^{\text {th }}$ century also did not think much of a proportionality requirement, because this would unduly favour wrong to the detriment of right. ${ }^{235}$

Nonetheless, even in Germany, it was increasingly recognized that the lack of such a requirement could lead to absurd outcomes that can hardly be said to serve the legal order. ${ }^{236}$ The legal order is after all, concerned with the interests of the aggressor too. Consequences that are blatantly disproportional to the threatened harm can be disallowed as disproportionate under the doctrine of abuse of rights, even when it was the only option available. ${ }^{237}$ These 'socio-ethical limitations' of proportionality are grounded however not in the general test of proportionality ('Verhaltnismäßigkeit') but in the concept of 'Gebotenheit', which also translates as Perron in Arnold a.o. 2005, p. 1038; Jäger 2006, p. 42; Dannecker in Tiedemann 2002, pp. 156157 and Sangero 2006, pp. 74, 127 and 170.

In 20 September 1920 RGSt 55, 82, a farmer had shot at thieves who were fleeing with his fruit. He was justified because they did not respond to his warnings. The German Supreme Court saw no problem of proportionality.

Smidt 1881A, p. 379 and de Hullu 2006, p. 298.

Schönke \& Schröder, H. 2006, pp. 639 and 651.

See 20 September 1920 RGSt 55, 82.

Machielse 1986, pp. 662 and 713.

Roxin 2006, p. 684 and Schünemann 1985, p. 367. See also Hruschka 2003, p. 223.

5 May 1892 RGSt 23, 116; Beulke 2008, p. 118; Sangero 2006, pp. 65 and 170-172; Fletcher 1978, pp. 871-873; Fletcher 1973, p. 385 and Fletcher 2007, pp. 140 and 202. 
proportionality, ${ }^{238}$ yet has also been related to the limb of necessity. ${ }^{239}$ By separating these two concepts, it can be insisted that self-defence does not require a general test of proportionality. ${ }^{240}$ Instead, the limitations merely take the sharp edges of the justification, by excluding clearly unacceptable applications, such as the farmer shooting at kids stealing fruit. ${ }^{241}$

The German legislator foresaw in particular limitations as necessary when children and madmen attack, trifle attacks or when the defendant was also partially responsible for the situation. ${ }^{242}$ In addition, it is accepted that the right to selfdefence should be limited in cases of great discrepancy between the interests involved and, more controversial, in cases of a special familiar or marital relationships. ${ }^{243}$ The same three staged approach applies as discussed in the context of prior fault above, of which the third is a strict(er) test of proportionality. ${ }^{244}$

On the other hand, it seems that this limitation is again applied very mildly by doctrine and jurisprudence. Prevailing opinion still would allow killing to save property. The farmer may not shoot the schoolboy who is about to steal an apple, but the man who is running away with a box of diamonds may be shot. Moreover, under German law, mistakes on the facts underlying the balancing of interest can negate intent. This is reinforced by in dubio pro reo, since it is also common in this context to assume the facts to the benefit of the defendant if there is any doubt.

For example, in a case, two junkies broke into a pharmacy. When the defendant, a neighbour, noticed this, he took his gun and shouted that they had to come out and surrender. The junkies came out and fled, not responding to the warning shots of the defendant. One of them was hit in the back by a bullet and severely injured. The Supreme Court held that it was clear that a shot fired with the intent to injure could not be justified, since the junkies had only been able to take syringes with them. However, it was accepted that the defendant had only wanted to give warning shots, whereby it was held that the victim could be hit by a ricochet. To me, this seems implausible, given the defendant's experience in shooting and the distance between

238 Roxin 1981, pp. 77-78; Roxin 2006, pp. 679 and 683-685; Beulke 2008, p. 117; Schönke \& Schröder, H. 2006, p. 658. In the Dutch provision on self-defence, 'geboden' also denotes proportionality, see Smidt 1881A, p. 379 and de Hullu 2006, p. 298. The German legislator wanted to expressly include the socio-ethical limitations by including the word 'geboten' in the Code's provision of self-defence, but this was struck in a later draft of the 1962 Criminal Code, see Roxin 2006, pp. 683-685.

See for example 16 July 1980 BGH NStZ 1981, 22. See also Roxin 2006, pp. 684-685 and Schönke \& Schröder, H. 2006, p. 658.

24025 June 2009 BGH NStZ 2009, 626 and Beulke 2008, p. 118.

241 Beulke 2008, p. 118.

242 Roxin 2006, p. 683 and Schünemann 1985, pp. 369-370.

243 However, an abused woman should not be limited in her right to defend herself, especially if the attack is serious, see 25 September 1974 NJW 1975, 62; Roxin 2006, pp. 701-704 and Schönke \& Schröder, H. 2006, pp. 661-662. In 18 April 2002 BGH JZ 2003, 50, the Supreme Court even leaves open whether this limitation based on marriage still applies.

24425 September 1974 BGH NJW 1975, 62; Beulke 2008, pp. 118-120; Bohlander 2009, pp. 104105; Roxin 2006, pp. 685-708 and Schönke \& Schröder, H. 2006, pp. 660-666. 
him and the victim. Secondly, it was argued that even if he did aim at the victim, it could be that the defendant was mistaken on the facts that allowed for a different valuation. Shooting would be allowed if something of great value was stolen, which mistake would thus negate his intent. Moreover, if he had taken care to minimize the harm, negligence liability would also be negated. ${ }^{245}$

This leniency could prove to be problematic with a view to the right of life under article 2 ECHR, which does not allow for exceptions based on the defence of property. $^{246}$ Self-defence is limited in this context because the property is considered less important than the bodily integrity, including the bodily integrity of the aggressor. ${ }^{247}$ On the other hand, the right to property rings hollow without the possibility to defend it by force. ${ }^{248}$ Prevailing opinion in Germany takes the view that article 2 is of no relevance to the right to self-defence since it only regulates conduct of official authorities. ${ }^{249}$ This enables the justification of the person who uses lethal force to protect property. However, this view is incorrect. Under so-called indirect horizontal application of human rights, the state is also required to guarantee the right to life by prevention and prosecution of individuals who violate this right. 250

Another reading of article 2 ECHR is that it only precludes purposeful killing. The German translation of article 2 reads 'Absichtliche Tötung', killing with dolus directus, so it is argued that German law is in line with the ECHR. This version of article 2 is stricter than the English text that refers to intentional killing, but on both readings, killing with dolus eventualis or recklessness is not covered by article 2 , allowing deadly force where the risk of death was only taken for granted. ${ }^{251}$ The ECtHR has however made clear that a state can also be convicted for violating article 2 if lives are lost due to recklessness or dolus eventualis. ${ }^{252}$ Some argue that to preclude life threatening force in response to serious infringements of property would violate the basic principles of the German law on self-defence, ${ }^{253}$ others argue that the difference is practically irrelevant given the reluctance of the

24515 May 1979 BGH MDR 1979, 985. See also 25 March 1999 BGH JR 2000, 297.

246 Bernsmann 1996, p. 178; Simester \& Sullivan 2007, pp. 708 and 713 and Ormerod 2005, p. 332.

247 See Smidt 1881A, pp. 378-379 and Machielse 1986, p. 625. Kelk 2005, p. 285 submits that more is allowed in a materialistic culture as that of the US.

Sangero 2006, p. 252; R. v. Hussey (1925) 18 Cr App Rep 160 and de Hullu 2006, pp. 300-301.

Roxin 2006, pp. 697-698; Beulke 2008, p. 118; Fischer, T. 2009, p. 298 and Schönke \& Schröder, H. 2006, pp. 666-667.

250 Witteman 1997, p. 271 argues that most EU Member States disagree with the German view too.

251 Roxin 2006, pp. 698-699.

252 Öneryildiz v. Turkey, appl. no. 48939/99, 30 November 2004, §93: “Where it is established that the negligence attributable to State officials or bodies on that account goes beyond an error of judgment or carelessness, in that the authorities in question, fully realising the likely consequences and disregarding the powers vested in them, failed to take measures that were necessary and sufficient to avert the risks inherent in a dangerous activity (...), the fact that those responsible for endangering life have not been charged with a criminal offence or prosecuted may amount to a violation of Article 2 (...)."

Roxin 2006, p. 698. 
judiciary to allow deadly self-defence in order to avert attacks to property. ${ }^{254}$ The latter is most probable as Germany, to my knowledge, has never been held to violate article 2 .

It can be concluded that the scope of defensive force is still the widest under German law. It should be noted however, that from a legal historical and European comparative perspective, the lenient German approach to self-defence, which has been mitigated to a large extent, is quite unusual. Self-defence was quite a restrictive defence in Germany until a very broad version was included in the Prussian Criminal Code of 1851. It has been argued therefore that a proportionality principle could easily be included in the German tradition of selfdefence. ${ }^{255}$

Secondly, even if the so-called socio-ethical limitations are not labelled as a principle of proportionality, they do constitute a limit of proportionality on selfdefence. The situation in Germany generally does not differ from that in other countries where a principle of proportionality is expressly formulated. Proportionality is expressly taken into account in the Netherlands, indirectly through reasonableness in England and de facto in Germany. The German judge is by now moreover just as sceptical towards the use of firearms against trifle attacks as his counterparts in England. This similarity facilitates the creation of a EU concept of self-defence. ${ }^{256}$

\section{NeCESSITY}

Legal interests can conflict in many diverging situations. The right to free speech of one person can conflict with the freedom of religion of the other. The freedom to transport goods without restrictions between Member States can be at odds with public health. The application of necessity implies that it can be justified to sacrifice one interest in order to serve another. The defence applies in a situation of actual danger to legally protected interests, which danger can only be averted by infringing less valuable interests of third parties. In other words, a sacrifice is justified when it is the only reasonable alternative and when the served interest outweighs the sacrificed interest. Only then is the act of saving deemed to be 'the appropriate means to reach the legitimate goal. ${ }^{, 257}$

Justified necessity must be distinguished from the excuse duress, although it will become clear, that in the end, only a gradual distinction can be made. ${ }^{258}$ In England in particular, there is disagreement on whether cases should be dealt under the doctrine of necessity or the similar duress by circumstances. English appellate

\footnotetext{
254 Perron in Arnold a.o. 2005, pp. 1024-1025. See also Schönke \& Schröder, H. 2006, pp. 666-667.

255 Witteman 1997, pp. 264-265. Compare Weigend in Tiedemann 2002, p. 414.

256 See Perron in Arnold a.o. 2005, pp. 1019-1021, 1036-1037 and 1039.

257 Beulke 2008, p. 102.

258 Dolman 2006, p. 175; de Hullu 2006, p. 289 and Rozemond 2006, p. 81.
} 
courts have agreed that there is no real distinction between the two defences. ${ }^{259}$ It is argued that both revolve around the infringement of the freedom of choice of the actor. The two can however be separated by focusing on the nature of the pressure to commit the offence. In duress, the pressure arises from the danger (to life or limb), whereas in necessity, the pressure arises from the necessity to choose. ${ }^{260}$

More often, necessity is distinguished from duress by focusing on its justificatory character. In a necessity plea, the focus is on the value of the defendant's act, claiming that by breaking the law more benefit was obtained than if it had been followed. The choice made in necessity is objectively right or at least the lesser of two evils. In duress, by contrast, the actor is only excused for making the wrong, but understandable choice. ${ }^{261}$ For instance, the person who is speeding to get his injured father to hospital can be juxtaposed with the person who is speeding because a criminal tells him to at gunpoint. In other words, necessity applies if the legal rule does not apply in concreto, whereas duress applies when compliance with the law could not reasonably be required. ${ }^{262}$ Other differences will become apparent in discussing the two defences, such as the lack of a (strict) proportionality requirement and more room to take into account individual characteristics in duress.

Necessity itself can be distinguished into an aggressive and a defensive form. As far as the damage or destruction of objects is concerned, the difference between aggressive and defensive necessity is laid down in German law. ${ }^{263}$ Decisive is whether the interest that is sacrificed belongs to a third party or the person who created the danger. The normal case of necessity is aggressive. It is aggressive, because it harms a legitimate interest of third party. The defence is not aimed at the person who is the source of the threat or danger. ${ }^{264}$ An example is the use of someone else's umbrella to fend off an attack by a dog. Since the impending injury to the defendant would be disproportionally high in comparison to the damage caused to the umbrella, the third party is not entitled to refuse another to interfere with his object. This is based on solidarity of the legal order that requires a certain tolerance of the individual in circumstances, leaving intact the civil legal duty to compensate. $^{265}$

When the infringed interest belongs to the person who gave rise to the conflict, defensive necessity may apply. A classic example is the harming or killing of a dog that attacks. Since this does not qualify as a human attack, it was explained that self-defence cannot justify this. The owner of the dog did however create the need

R. v. Shayler [2001] EWCA Crim 1977 and R. v. Quayle and others [2005] EWCA Crim 1415. Dolman 2006, pp. 174-175, 183, 188, 233-239, 302 and 310. See also Holland 1989, p. 262.

Re A. (Children) [2000] EWCA Civ 254; Simester \& Sullivan 2007, p. 721; Law Commission 1993, pp. 63-64 and Rozemond 2006, p. 81.

Dolman 2006, p. 188.

$\S \S 228$ (defensive) and 904 (aggressive) of the German Civil Code.

Leverick 2006, p. 6 and Sangero 2006, pp. 68, 118 and 128.

$\$ 904$ of the German Civil Code; Bohlander 2009, p. 107; Schönke \& Schröder, H. 2006, p. 675 and Beulke 2008, p. 103. 
to use force by leaving him unleashed. Other cases that fall outside the scope of self-defence can also be justified in this context. Consider the aforementioned aggressor, who is insane or under the age of criminal liability. Many scholars argue that self-defence cannot justify the use of defensive force against these aggressors, but defensive necessity can. The difference with other cases of necessity is that more is allowed when the sacrifice concerns an interest that is connected the origin of the danger. Because the person whose interests are infringed also gave rise to the conflict, it is only fair he has to bear the consequences of his own actions. ${ }^{266}$ As will be discussed later, the more lenient approach to proportionality in defensive necessity can explain why someone is allowed to sacrifice the life of another in order to save their own.

\subsection{Rationale}

Necessity is most easily understood as a justification of lesser evils. Faced with two unpleasant alternatives, the defendant decides to break the law in order to avoid a more serious evil to himself or others. In this conflict of duties or interests, the defendant is justified for saving the prevailing interest. ${ }^{267}$ The outcome of necessity, all things considered, must outweigh its disadvantages. The interest must be furthered that is prevailing from the objective perspective of the legal order.

Saving the prevailing interest thus furthers the legal order. When sacrificing an interest is the only reasonable means to save the prevailing interest, the offence committed is therefore not wrongful. Whereas self-defence is grounded for a large part in the individual autonomy, necessity is grounded in the collective good of the legal order. If the defendant saved his own life by breaking a window of a burning building, he is not justified because of a right to save his own life. He is justified because the legal order values his life over a window. ${ }^{268}$

It has been perceived as problematic that in necessity, the defendant substitutes his weighing of interests for that made by the legislator. After all, by criminalizing conduct, the legislator already noted a conflict of interests and decided in favour of one. The law may even indicate that necessity is precluded in favour of a system of exemptions. Against the acceptance of necessity it is argued that the power of the law is affected by recognizing that it does not always apply, possibly undermining the validity and authority of rules. ${ }^{269}$ Instead, it is argued that justice must be done though the heavens fall: fiat justitia ruat caelum. However, this perspective leads to

266 Bohlander 2009, p. 107; Roxin 2006, pp. 758 and 775-778; Beulke 2008, p. 102 and Machielse 1986, pp. 524-528. See IX.3.4.1.

267 Fokkens \& Machielse, note 5 on art. 40; Machielse in Balkema a.o. 1995, pp. 227-231; Leijten in Groenhuijsen, Mulder \& Remmelink 1992; 25 March 1952 BGHSt 2, 242; Beulke 2008, p. 102; Ormerod 2005, p. 315 and Simester \& Sullivan 2007, p. 716.

268 See Fletcher 1998, p. 138.

269 Simester \& Sullivan 2007, pp. 714-715. 
absurd consequences and does not apply in any of the legal systems under investigation.

In contrast, the availability of the defence shows that the legal system acknowledges that necessity knows no law: necessitas non habet legem. There will simply always be cases, in which the offence definition is fulfilled, but the defendant should not be held liable, because all things considered, he did the right thing for society. It is beneficial to the legal order that the defendant achieves the greater good rather than slavishly follow the letter of the law. ${ }^{270}$ It is accepted that not all situations can be foreseen and encompassed in legal provisions. As such, necessity is a paradigm example of the importance of general principles to criminal law.

This approach to legislation has only become more important in current society. In this day and age, it is impossible to anticipate all developments that affect the balancing of interests currently laid down in the law. For example, new insights may show that the interest protected by a norm, such as environmental protection, detriments another norm that is considered more important now, like food safety. Similarly, new insights may show that the interest protected by a norm is actually better protected by breaking the letter of the law. The likelihood that legal subjects find themselves in a conflict of duties is exacerbated by the fact that within the EU, numerous actors are creating norms. Vast amounts of norms originate from the EU institutions, Member States, (non-)governmental organizations and so on.

The contrasting approach is to legislate very elaborately and to update the relevant provisions as soon as necessary. With a focus on foreseeability and legal certainty, possibly combined with a lack of trust that the citizen and the judge will balance the competing interests appropriately, the legislator aims to capture all possible conflicts in legislation. However, this is not only very time-consuming; it is also impossible, as in practice, unforeseen situations always tend to occur. Moreover, extensive legislation may create such an enormous and incomprehensible amount of norms, that it operates counterproductive from the perspective of foreseeability. Such legislation only serves to strengthen the legislator's power over that of the judiciary.

From a perspective of deterrence, the maxim that necessity knows no law also reflects that punishing the defendant for serving the prevailing interest is counterproductive. The defendant should not be deterred from committing the offence if it furthered the common good. After all, on an objective utilitarian perspective, the defendant did the right thing. ${ }^{271}$ By contrast, from a deontological perspective, it can be argued that a good end never justifies bad means. ${ }^{272}$ Necessity is more than a utilitarian calculation; otherwise the killing of one person to harvest his organs in order to save multiple patients would be justified.

The question already arose what it means to do the 'right thing', what it means to be justified. In this context, the views on whether the defendant's actions in

270 Simester \& Sullivan 2007, p. 716; Williams 1953, p. 567 and Dolman 2006, p. 245.

271 Simester \& Sullivan 2007, p. 717. Compare Dolman 2006, p. 157.

272 Williams 1953, p. 570. 
necessity are correct or merely permissible also differ greatly. ${ }^{273}$ The general guideline here is also that the clearer it is that the protected interest outweighs the sacrificed, the stronger the character of the justification will be. Since necessity presupposes that the act is objectively, all things considered, right, many view necessity as a strong justification in comparison to self-defence, which after all, only requires that the defensive force was not disproportionate. ${ }^{274}$

The most extreme view is that the application of necessity brings about a duty to act. $^{275}$ For example, a father failed to throw his children out of a burning house, which would have been prevented their deaths. The fall would probably not lead to any and certainly not to serious injuries. The German Supreme Court held that, in choosing between certain death and possible injury, the father is not only allowed to choose the least of evils in necessity, he is even obligated to act, and failure to comply with this duty brings liability for an omission in the picture. ${ }^{276}$

Seen as the right thing to do, it logically follows that the person acting in necessity cannot be countered by necessity or self-defence. The party concerned has to take the harm. ${ }^{277}$ Necessity is therefore also seen as an expression of the principle of solidarity. People are asked to take into account that they might also themselves be in such a situation, which makes it close to one's own individual interest. ${ }^{278}$ The requirement to take the loss of the lesser interest need not only be grounded in altruism. In defensive necessity, this is also based, similar to selfdefence, on the fact that the 'victim' gave rise to the situation that necessitated the defence.

Necessity is based on a weighing of interests, so just like self-defence, all the different rationales can be taken into account as factors in one rationale that balances all the interests. ${ }^{279}$ Such a multifaceted rationale is recognized in Germany. By shaping the current defence not as a mere weighing of goods, but as a weighing of interests, it becomes clear that the relative weight of the conflicting legal interests is merely one issue to take into account. ${ }^{280}$ Other aspects, like the aforementioned responsibility of the person whose interest is sacrificed for creating the situation can adjust this starting position. The fault of the victim can tip the scales in favour of the defendant. Conversely, the prior fault of the defendant or his special position can bring about that he has to take the loss.

Dolman 2006, p. 123; Dressler 1987, p. 1161 and Roxin 2006, p. 727. See VIII.3.4.

Horder 1998, p. 155; Bohlander 2009, p. 107 and Schönke \& Schröder, H. 2006, p. 675.

275 Ormerod 2005, p. 322. In R. v. Bourne [1939] 1 KB 687, it was held in the context of abortion meant to save the life of the mother: "In such a case he is not only entitled, but it is his duty (JHB: my italicization) to perform the operation with a view to saving her life."

277 Schönke \& Schröder, H. 2006, p. 675. See VIII.3.5.

278 Fischer, T. 2009, p. 305 and Roxin 2006, p. 727.

279 See Roxin 2006, p. 728.

280 Roxin 2006, p. 735 and Schönke \& Schröder, H. 2006, p. 685. 


\subsection{Sources}

Necessity, or vis, used to be considered only as vis absoluta and vis compulsiva. The former entails a negation of the voluntary act requirement. ${ }^{281}$ The textbook example is that someone pushes the defendant against a window, which breaks as a result. The defendant did not move: he was moved. Such a case is about the complete, often physical impossibility to act differently. This absolute impossibility to act differently is contrasted with duress, also known as vis compulsiva, a relative impossibility to act differently. In situations of vis compulsiva, the coercion is not physical, only moral. The defendant had a theoretical choice to act differently, but could not reasonably be expected to act this way because of the overwhelming pressure on him. ${ }^{282}$ This moral coercion already could exculpate the defendant in the nineteenth century. The justification of necessity has only been developed in the twentieth century on the basis of duress.

There used to be quite some fear that the acceptance of necessity would undermine the validity and authority of rules. The defence was not encompassed in older Criminal Codes, which implied that it was unavailable. ${ }^{283}$ In time, necessity nonetheless found its way through the application of duress. At first therefore, necessity was only allowed in cases where the defendant had to avert an immediate danger to his or another person's life. Only this could bring about the required irresistible psychological pressure. Not until later, the essence of necessity as a conflict of interests was acknowledged in Germany and the Netherlands. ${ }^{284}$ In England, by contrast, the defence is often still limited to dangers that qualify under duress.

Article 40 of the Dutch Criminal Code is now accepted to encompass both duress and necessity. Until 1923, however, this was uncertain. The legislator of the 1886 Code, which currently still applies, probably had not carefully considered the matter. ${ }^{285}$ In 1923, the Supreme Court accepted that necessity could also arise in absence of an irresistible pressure, based on the choice in favour of the most valuable interest, rather than personal danger to life and limb. ${ }^{286}$ The defendant, an optician, had sold a pair of glasses to a person who had apparently lost his. He sold them after opening hours, which was criminalized. The question was whether he was allowed to let his duty to help this person prevail over the duty to abide the legal rule on opening times. The Court held that the duty to help should prevail and acquitted the defendant based on necessity, which was held to be a part of article $40 .^{287}$

281 Bohlander 2009, p. 37; Schönke \& Schröder, H. 2006, p. 703; Strijards 1987, pp. 91 and 121 and Nieboer 1991, p. 268.

282 Dolman 2006, pp. 96-97.

283 Dolman 2006, pp. 100-101.

284 Dannecker in Tiedemann 2002, p. 159 and Dolman 2006, pp. 102-105 and 111-117.

285 Dolman 2006, pp. 227 and 309.

286 Dolman 2006, p. 177.

287 HR 15 October 1923, NJ 1923, p. 1329. See Dolman 2006, pp. 230-231. The Dutch High Military Court had already held in 1915 that necessity could arise from a conflict of duties. A marine 
A similar development occurred in Germany. The old Criminal Code of 1871 only included a provision similar to duress and the necessity type-justifications of the (current) Civil Code that entered into force in 1900 only dealt with the lawful destruction of goods. 288 The lack of a general defence of necessity meant that the actor could not be justified in the situation that required a violation of something different than goods, such as causing bodily injury. For example, medically indicated pregnancy terminations could be excused for the mother, but the doctor could rely on no such exculpation, even though the conduct was viewed as appropriate. This lacuna prompted the Supreme Court in 1927 to recognize and apply necessity to the doctor who performed an abortion on a woman who became suicidal because she was pregnant. Like the Dutch Supreme Court had done a few years ago, the defence was based on the principle of weighing of goods and duties, accepting the newly found distinction between justifications and excuses. ${ }^{289}$

Initially, necessity was recognized in cases of medically indicated pregnancy terminations, but today it applies to collisions of interests of all nature. ${ }^{290}$ In the 1927 case, the defence was read into an excuse that resembles duress. Later, it was also labelled an extra-legal defence. ${ }^{291}$ The current $\$ 34$ of the German Criminal Code on necessity only entered into force in $1975 .{ }^{292}$ Medically indicated terminated pregnancies are now covered by $\$ 218 \mathrm{a}$ of the Criminal Code, leaving open only exceptional situations to the general defence. ${ }^{293}$ There exist many more specific rules on necessity-type situations in German law. ${ }^{294}$ The generalis retreats in favour of the specialis, but the general defence can also correct the application of special defences in certain cases. ${ }^{295}$

In contrast to the development in Germany and the Netherlands, in England, the fear that a broad acceptance would deteriorate the authority of the law and lead to anarchy persists to this day. It is feared that if individuals were allowed to be the judge of when to dispense with the letter of the law, they "would be too ready to avail themselves of exceptions which they might suppose to apply to their

officer, also the ship physician, was ordered to report the names of the marines who had a venereal disease. He was allowed to let his duty of secrecy prevail over the offence of noncompliance with orders, see Dolman 2006, pp. 215-216. In general, lower Courts had already been more generous in accepting necessity as a defence before 1923, carefully constructing (or masking) their verdicts with words that resembled the doctrine of dures, see Dolman 2006, p. 309.

$288 \$ \S 228$ and 904 of the German Civil Code and Roxin 2006, p. 723.

28911 March 1927 RGSt 61, 242 and Roxin 2006, pp. 723-725. See also Schönke \& Schröder, H. 2006, p. 676 and Bohlander 2009, pp. 106-107.

290 Beulke 2008, p. 104. See for example, 13 November 1958 BGHSt 12, 299.

291 See Roxin 2006, p. 725 and for example, 29 May 1959 BGHSt 14, 1.

$292 \S 16$ of the Administrative Offences Act (OWiG) is identical.

293 In the Netherlands, there also exist special rules on euthanasia, but necessity can still be invoked in cases that fall beyond the scope of the those rules, see HR 9 November 2004, NJ 2005, 217.

294 Listed by Roxin 2006, p. 727.

295 Bohlander 2009, p. 107 and Roxin 2006, pp. 775-778. See also Dolman 2006, p. 89. 
circumstances."296 "The law regards with the deepest suspicion any remedies of self-help, and permits those remedies to be resorted to only in very special circumstances. The reason for such circumspection is clear - necessity can very easily become simply a mask for anarchy." 297

Moreover, it was feared that this defence would expose innocent persons to great danger. This explains why English courts still adopt a persistently restrictive approach to necessity, which will become even clearer in the following discussion of its conditions. ${ }^{298}$ By using conditions that belong to the defence of duress, courts reject necessity. For example, Shayler disclosed secret MI5 information, based on the necessity of protecting the public by revealing malpractice of the Security Service. The Court of Appeal held the defence could not apply, amongst others because there was no threat to the life of persons for which the defendant is responsible. ${ }^{299}$

On the one hand, it was recognized that it would be unfair and useless to punish those who acted under necessity (or duress). On the other hand, it was believed to be impossible to define these cases, so it was thought better to leave hard cases to the clemency of the crown, parole boards or prosecutorial discretion. ${ }^{300}$ This solution reflects a more general legal approach popular in England to solve, or better mitigate, issues of liability through sentencing and administrative discretion than through a general part of criminal law. Doctrinal inconsistencies are not perceived as very problematic because unfair outcomes can be mitigated by the executive. More recent cases seem to show courts have become less reluctant, ${ }^{301}$ perhaps under influence of continental law.

Dismissing a strong reliance on the executive, I favour the application of necessity. After all, it is important to reflect in the judgment that the act served the general good. Necessity should matter to criminal liability, not merely to sentencing. The difference is important to both the accused and the public, because punishment entails stigmatization, whereas the application of necessity entails approval. ${ }^{302}$ Moreover, criminal liability is a matter of adjudication. Just like the executive should not judge on whether the offence definition is fulfilled, the executive should also not be the judge of when wrongfulness or blameworthiness is of an insufficient degree. The defendant should not be left at the mercy of administrative discretion. He is entitled to a debate on his liability in a court. Only an open debate can ensure a consistent and thus fair application of the law. ${ }^{303}$

\footnotetext{
296 Nineteenth century lawyer Stephen, still cited in Re A. (Children) [2000] EWCA Civ 254.

297 Southwark London Borough Council v. Williams [1971] 2 All ER 175 per Edmund Davies LJ.

298 Ormerod 2005, p. 316.

299 R. v. Shayler [2001] EWCA Crim 1977. Accepted by the House of Lords in R. v. Shayler [2002] UKHL 11, criticized by Gardner, S. 2005, p. 374 as unconvincing.

300 Re A. (Children) [2000] EWCA Civ 254 and R. v. Howe [1986] UKHL 4.

301 Ormerod 2005, p. 323.

302 See Dolman 2006, pp. 107 and 110. In R. v. Pommell [1995] EWCA Crim 7, Kennedy LJ found an absolute discharge unsatisfactory, because the stigma of conviction would remain. 
Hence, the existence of necessity as a general defence has often been denied in case-law, but roughly since the nineties its existence has been recognized in English case-law, even if courts are inclined to adopt a restrictive approach. The English parliament has never even debated about the defence, yet it has increasingly included statutory defences of necessity. ${ }^{304}$ An example is section 36(3) of the Road Traffic Act 1972, which holds that a person is not to be convicted of driving on a footway or bridleway in contravention of subsection (1), if he proves that the motor vehicle was so driven "for the purpose of saving life or extinguishing fire or meeting any other like emergency". In addition, a common law defence of necessity is said to exist, which is held to apply in different contexts as a negation of the offence element 'unlawfully'. ${ }^{305}$ In 1977, the Law Commission deemed a general defence of necessity undesirable, but later it repeatedly submitted that necessity and other common law defences should be retained. ${ }^{306}$

\subsection{Criteria}

Like in self-defence, the criteria of necessity can be categorized in two limbs. The first limb requires, amongst others, that the defence is necessary, because the danger cannot be averted by other, less intrusive means. Because only the prevailing interest may be served, proportionality requires that the served interest outweighs the sacrificed interest. The defence is also influenced by concepts such as prior fault and the special position of the defendant.

The scope of necessity in England remains imprecise ${ }^{307}$ due to the restrictive and offence-by-offence approach of courts, the lack of Parliamentary intervention and finally, the confusion stemming from the interchangeable use of necessity and duress (by circumstances). As a result, the English concept of necessity is often said to include conditions that only apply to duress in the other Member States, which makes it considerably stricter in scope. Instead, necessity should be differentiated from duress and therefore does not require, amongst others, a threat to serious injury or worse that overrides the defendant's will.

In comparison, the recognition of necessity as a general defence in the Criminal Codes of Germany and the Netherlands and the consistent interpretation by the courts, make it much easier to identify the scope of necessity in these Member States. As a consequence, the English conditions of necessity will receive less weight in constructing a general defence of necessity for the EU. Nevertheless, the

304 Re A. (Children) [2000] EWCA Civ 254. See Simester \& Sullivan 2007, pp. 713-715 and Ormerod 2005, pp. 315-317.

305 R. v. Bourne [1939] 1 KB 687, see Re A. (Children) [2000] EWCA Civ 254 and Law Commission 1977, pp. 21-22.

306 Law Commission 1977, pp. 30-32; section 4(4) and 45 draft Criminal Code, Law Commission 1989, pp. 44 and 62 and section 36 Law Commission 1993, pp. 64 and 114-115.

307 Re A. (Children) [2000] EWCA Civ 254 per Brooke and Robert Walker LJJ. 
general restrictive approach to the justification common in England will be extensively considered in discussing the different conditions.

\subsection{Subsidiarity}

A situation of necessity exists when there is a present danger for life, limb, freedom, honour, property or another legal interest, that can only be averted by impacting other legal interests. ${ }^{308}$ First, it will be discussed which legal interests may legitimately be served under necessity. Second, the concept of present or imminent danger will be explained. Third, the sacrifice of an interest can only be justified if it was adequate to serve the prevailing interest and if it was the least intrusive means. The final aspect considered here is any prior fault of the defendant in creating the situation of necessity.

\subsubsection{Legitimate interests}

As far as self-defence is concerned, it was explained that some legal systems chose to exclusively list the interests that may legitimately be protected by the use of force. As far as necessity is concerned however, all interests may give rise to protection. The German provision on necessity lists some legal interests but makes clear that a danger to any other legal interest may also qualify. ${ }^{309}$ The served interest need not even be protected by the criminal law. In this way, necessity is for instance also available to the employee who obeys irregular orders in order not to lose his job. ${ }^{310}$ As noted, the restriction of the defence to avert only serious threats to life and limb has been abolished, allowing all interests to be protected. In England, the defence is also not confined to serious threats in mostly medical contexts, but there are only a few cases where necessity was accepted without identifying such a serious threat. ${ }^{311}$

By contrast, in Union law on the free movement of goods, persons, services and capital, the interests that may be served to the detriment of these freedoms, such as public health, are exclusively mentioned in the pertinent primary or secondary legislation. As noted in the context of self-defence, such an approach emphasizes the exceptional character of limitations to free movement. If any interest could be taken into account this would invite Member States to make more exceptions and detriment the force of the rule. Nonetheless, the approach is less rigid. Interests can be added by the ECJ under the rule of reason doctrine, such as consumer and

\footnotetext{
308 Beulke 2008, p. 104.

309 Schönke \& Schröder, H. 2006, p. 680 and Fischer, T. 2009, p. 305.

310 Roxin 2006, pp. 728-729. See also Schönke \& Schröder, H. 2006, p. 680.

311 Ormerod 2005, pp. 316-317.
} 
environment protection. By adding interests, the Court makes sure the possible restrictions keep up with the demands of a changing society. ${ }^{312}$

\subsubsection{Imminence}

The danger or conflict of interests can arise due to human conduct but it can also arise outside of human conduct. For example, natural sources can also trigger necessity. ${ }^{313}$ The origin of the danger does not matter, although some origins bring about that special rules apply. What is important is that the danger or conflict must give rise to a necessity to act immediately. If this temporal requirement is not fulfilled, the application of the justification is not necessary. Official authorities or even the legislator would be able to solve the conflict. Hence, the breaking of the law by the defendant would be premature and therefore unnecessary.

The scope if imminence can be quite broad. Consider the case that put necessity and duress in the picture in England. The court was asked to rule on the legality of a proposed surgery of conjoined twins, which would surely bring about death of Mary. If nothing was done however, Jodie would surely die within months as well. The danger to the life of Jodie was imminent, but not so imminent that a court could not be asked to consider whether the taking of Mary's life would be justified. ${ }^{314}$ In such cases of medical necessity, there is the opportunity and time for doctors to place the relevant facts before the court. This opportunity is not at odds with the imminence requirement. Only some degree of urgency is required. ${ }^{315}$

The requirement is therefore broader than in the context of self-defence. Selfdefence requires an acute concentration of the danger, which means that at least an immediate situation of infringement of a legal interest is at hand. ${ }^{316}$ Necessity requires an imminent danger, not an attack. An attack may not yet be imminent, whereas the danger already is. This is why the arming yourself in anticipation of a wrongful attack does not qualify under self-defence, but it does qualify under necessity. ${ }^{317}$

German courts have accepted that the danger is imminent if harm is not yet directly pending, but a later averting of that danger will not be possible or only with much more risks. In other words, one can seriously fear that the (normal) continuance of a situation will lead to occurrence or an increase in harm if counter-

312 Eijsbouts a.o. 2010, pp. 100-101. See for example, 20 September 1988, Case C-302/86, Commission v. Denmark [1988] ECR I-4607. Compare IX.3.4.2.

313 Dolman 2006, pp. 176 and 185; Bohlander 2009, p. 110; Re A. (Children) [2000] EWCA Civ 254 and Williams 1953, p. 573.

314 Re A. (Children) [2000] EWCA Civ 254.

315 Simester \& Sullivan 2007, p. 716.

316 Roxin 2006, p. 732; Beulke 2008, p. 105; Strijards 1987, pp. 51-52 and Re A. (Children) [2000] EWCA Civ 254: "The principle is one of necessity, not emergency."

317 See Roxin 2006, pp. 732-733 and Schönke \& Schröder, H. 2006, p. 683. 
measures are not immediately taken. ${ }^{318}$ For example, if separating the conjoined twins would have been postponed further, the risk that neither of the twins would have survived would have increased too. Secondly, the danger is imminent if it is a permanent danger that can be realised at any time without warning. Consider a crumbling building: no one knows at what point it will actually cave in. ${ }^{319}$ In both situations, the defendant must make his choice to act or endure the harm immediately. The condition is therefore better understood as imminence to act. ${ }^{320}$ This is also the Dutch ${ }^{321}$ and English ${ }^{322}$ perspective on the matter.

In Germany, the imminence requirement of necessity is equated with that of duress. ${ }^{323}$ In contrast, many English and Dutch scholars submit that the character of necessity brings about that reflection is possible, whereas duress is much more impulsive. ${ }^{324}$ In any event, there is consensus that some time for reflection is allowed in necessity. This follows from the requirement to meticulously weigh the competing interests and to carefully consider whether there are alternatives to committing an offence. ${ }^{325}$ Although there was urgency in deciding on the case of the conjoined twins, time was taken to make the right choice. Reflection is desirable because it ensures that the defendant makes the correct decision. The imminence to act must therefore not be seen as requiring a split-second decision. The requirement is broad and is thus closely related to other conditions of necessity. For example, if more time appeared to be available to solve the conflict, often more alternatives could still be chosen.

Nonetheless, imminence has been given an upper limit by arguing that situations of general necessity that linger over a longer period or affect many are excluded from necessity. There has to be a concrete and more or less acute situation of necessity. The general lack of housing therefore, does not allow for squatting. ${ }^{326}$

31811 March 1927 RGSt 61, 242; Roxin 2006, pp. 732-733; Beulke 2008, p. 104 and Schönke \& Schröder, H. 2006, p. 683. Compare R. v. Bourne [1939] 1 KB 687.

319 Bohlander 2009, p. 111; Beulke 2008, p. 105; Fischer, T. 2009, p. 306 and Schönke \& Schröder, H. 2006, p. 683.

320 Compare 5 March 1954 BGHSt 5, 371 and Schönke \& Schröder, H. 2006, p. 683.

321 Dolman 2006, p. 246 and Cleiren \& Nijboer 2008, note 5b on Overmacht.

322 Compare R. v. Hudson and Taylor [1971] EWCA Crim 2 and Ashworth 2006, p. 222. US scholar Robinson 1989, p. 189 submitted that "the proper focus is not on the timing of the threat but rather on the timing of the act needed to avoid the threat."

323 Roxin 2006, pp. 969-970; Bohlander 2009, p. 124 and Beulke 2008, p. 152.

324 Law Commission 1993, p. 64; Ormerod 2005, p. 325; Simester \& Sullivan 2007, pp. 674-675; Kelk 2005, p. 278 and de Hullu 2006, p. 288.

325 HR 10 February 1987, NJ 1987, 662; Fokkens \& Machielse, note 9 on art. 40; 15 January 1952 BGHSt 2, 111; 25 March 2003 BGHSt 48, 255 and Roxin 2006, p. 725. Bohlander 2009, p. 126 and Schönke \& Schröder, H. 2006, pp. 706 and 713 submit this duty will usually only be relevant when the defendant made the wrong choice, thus to the test the reasonableness of putative necessity.

326 Southwark London Borough Council v. Williams [1971] 2 All ER 175. In Hof Den Bosch 3 March 2009, $L J N:$ BH4471 necessity was accepted over a longer period of time for the numerous times the defendant broke the same law. The Dutch Supreme Court quashed the 
Neither does poverty allow for stealing. ${ }^{327}$ It is argued that necessity is not meant to justify cases that arise regularly. An essential feature of defences is that they apply only to exceptional circumstances where the implications of wrongfulness and blameworthiness are not warranted. Hence, in recurring situations defences cannot solve what the legislator should solve. ${ }^{328}$ "Where a social problem is structural and continuous, it must be addressed through the legislative and political process." 329

Examples of recurring situations are euthanasia and abortion. They used to be tested under necessity as extraordinary cases but are governed by special rules now, because these conflicts occur often and have therefore been addressed by the legislator. ${ }^{330}$ However, the examples also show that a 'structural problem' or 'recurring situation' may not always be so easy to identify. At what point does a problem become structural? Should the defendant be held criminally liable because the legislator did not yet address the recurring conflict? The answer of English courts would be a frank 'yes'. Problems affecting many in society, like the use of cannabis to relieve pain, call for legislative action. If the legislator did not want to change the law to accommodate these people, the courts do not see any room to allow for the defence of necessity. ${ }^{331}$

By contrast, Dutch and German courts camouflage pragmatic reasons with the doctrinal cloak of imminence. Necessity has never been accepted when an offence has been committed because the actor found himself in needy circumstances. ${ }^{332}$ The courts deny that the need to act was imminent, yet this is not the true reason for rejecting it. After all, the fact that the danger is imminent for many does not change the fact that it is also imminent for the specific defendant. Hunger can constitute an imminent need to act. Rather, necessity is precluded when it affects many, because of underlying fears of undermining the legal order. After all, if the specific defendant would be allowed to act, so would others. ${ }^{333}$ English courts seem to attach most weight to these considerations and are also most open about them.

It is therefore also imprecise to argue that necessity requires an exceptional situation. It would be more accurate to submit that pragmatic reasons militate

acquittal for not substantiating why every single event charged was justified, see HR 12 July 2011, NJ 2011, 578.

Kelk 2005, p. 279; de Hullu 2006, p. 288; Ormerod 2005, p. 317; Simester \& Sullivan 2007, p. 723 and Williams 1953, p. 576.

328 Dolman 2006, p. 332 and Roxin 2006, pp. 748 and 773-774, the latter who therefore criticizes 13 November 1958 BGHSt 12, 299 for accepting 'economic necessity', a term which was coined by Williams 1953, pp. 572 and 576 .

329 Simester \& Sullivan 2007, p. 723.

330 See articles 293(2) and 296(5) of the Dutch Criminal Code; section 1 of the Abortion Act 1967; \$218a of the German Criminal Code and Kelk 2005, p. 280.

331 R v. Quayle and others [2005] EWCA Crim 1415.

332 Fokkens \& Machielse, note 11 on art. 40.

333 See Schönke \& Schröder, H. 2006, p. 694. 
against the acceptance of necessity when acceptance brings about that multiple offenders would be justified. After all, this would undermine the validity of the norm. For example, necessity was also accepted to quash an administrative 'fine' for not paying a parking ticket. The defendant had bought a ticket and picked up four children. When they were all strapped in and ready to go, one of them had to pee, so she had to take them all back inside and return again. As a result she was 8 minutes late and found a 'ticket'. The court held it was a situation of necessity, rejecting the argument that the defendant could have been faster or have left the other three children in the car. ${ }^{334}$ It can hardly be said that the case deals with a very exceptional situation. Judgments like these merely elaborate extensively and explicitly on the exceptional circumstances of the case, so others cannot derive rights from it.

Secondly, normative factors that influence the weighing of interests play an important role. Much weight is given to the valuation of interests as conducted by the legislator and other governmental institutions. For the same reason, results of legal proceedings must be accepted and can only be resisted with legal remedies. Unlawful prosecution or measures of deportation can therefore not be justifiably resisted by criminal offences. ${ }^{335}$ The valuation may be incorrect or out-dated but needs to be followed anyway; otherwise the authority of the whole legal order could be affected. The valuation of interests is therefore a normative, not an objective exercise. ${ }^{336}$

\subsubsection{No other means of aversion}

Necessity can only justify a criminal offence if it was the only reasonable way to solve the conflict of interests. If it was possible not to commit the offence or only a less serious offence, the defence does not apply. As in self-defence, the question of alternatives can be divided into the aspects of adequacy and subsidiarity. The means of defence must be able or adequate to end the danger and secondly, the least intrusive available means must be chosen. ${ }^{337}$ In Union law, these requirements are framed as that the measure that conflicts with a freedom must be appropriate for securing the attainment of the objective pursued and secondly, that it does not go beyond what is necessary in order to attain it. ${ }^{338}$

In the context of the freedom of movement in the internal market, the measure of restriction must be appropriate or able to serve the interest it seeks to protect. In Cassis de Dijon, the German government argued that fruit liquor should have a

334 Rb. Den Haag 1 December 2009, LJN:BL4483. See also Schönke \& Schröder, H. 2006, p. 688.

335 Beulke 2008, p. 110 and Schönke \& Schröder, H. 2006, p. 692.

336 Compare HR 11 January 1977, NJ 1977, 458. The defendant had argued that selling soft-drugs was absolutely necessary to prevent the selling of hard-drugs in a youth centre. The Court held, that even if the correctness of this argument was accepted, the defence failed, because the defendant weighed the interests differently from the legislator. Bohlander 2009, p. 111 and Re A. (Children) [2000] EWCA Civ 254.

3388 September 2005, Case C-40/04, criminal proceedings against Yonemoto [2005] ECR I-7755, $\S 55$. 
minimum alcoholic percentage of $25 \%$ to be allowed on the market, which precluded Cassis de Dijon from being sold in Germany. The ECJ held that this restriction could not be justified by the aim of public health, since it was not adequate to serve that interest. The arguments of the German Government that that strong liquors tend less easily induce tolerance than highly alcoholic beverages was questioned, especially since most of the 'strong' drinks are diluted with soft-drinks before consumed. ${ }^{339}$

Just like in the context of self-defence, the principle of adequacy implies that a defensive purpose is required. It implies that the offence was committed with a view to protect the prevailing interest. A burglar can therefore not rely on necessity for breaking a window if, by chance, this helped to save a family from carbon monoxide poisoning. ${ }^{340}$ The principle is not strict in the legal systems of the three Member States. After all, the defendant who exceeded the speed limit to get a person to hospital did not know whether this would save that person. On the one hand, the measures taken by the actor do not have to avert the danger with certainty, but on the other hand, they may also not be merely improbable. It is only required that the violation of the norm at least increases the chances of saving the interest of higher value. ${ }^{341}$ In general, acts of protest, like 'house occupations', throwing a brick at the police or pulling the emergency break of a train, cannot serve the prevailing interest. ${ }^{342}$

Subsidiarity in a narrow meaning is the condition of the least intrusive means. If an ambulance is directly available, it is not necessary to exceed the speed limit to get someone to the hospital. The ECJ explained that the measure that conflicts with a freedom may not go beyond what is necessary. It can only be justified if it is necessary in order to attain an authorised objective that cannot be achieved by means that place less of a restriction on the free movement of goods within the Union. ${ }^{343}$ A restriction to competition is assessed by an 'indispensability test', which means that it may not restrict competition more than absolutely necessary. 344

In a German case, a journalist who took a knife on board a passenger aircraft to expose the failure of security measures could not rely on necessity, since the carrying the knife on board was no longer necessary for the goal. He could have made his point by giving the knife away after passing security checks. By bringing the knife on board, he actually created a danger. ${ }^{345}$ The Dutch journalist who exposed failing security measures on an airport was convicted for carrying a false employee pass after his investigative reports had ended, because this was no longer

339

20 February 1979, Case C-120/78, Rewe-Zentral (Cassis de Dijon) [1979] ECR I-649. Fokkens \& Machielse, note 9 on art. 40; Dolman 2006, p. 323 and de Hullu 2009, p. 299. Roxin 2006, p. 734; Fischer, T. 2009, p. 307 and Schönke \& Schröder, H. 2006, p. 683.

Respectively, 7 July 1982 OLG Düsseldorf NJW 1982, 2678; HR 14 December 1976, NJ 1977, 174 and HR 29 March 1988, NJ 1989, 162. See also Machielse 1986, p. 592; Dolman 2006, p. 236 and Strijards 1987, p. 52.

20 June 2002, Joined Cases C-388/00 and C-429/00, Radiosistemi [2002] ECR I-5845, §42.

Art 101(3) TFEU and Eijsbouts a.o. 2010, pp. 167-168.

25 October 2005 OLG Düsseldorf NStZ 2006, 243. 
necessary. ${ }^{346}$ Hacking into automated systems is also often done with a view to prove that they are protected insufficiently. This purpose is however exceeded when the hacked data is published online, exposing it with the risk of abuse.

Alternatives to committing the offence include legal remedies, the possibility of retreat or getting official help. ${ }^{347}$ When multiple interests of equal value can be sacrificed, for example, when any car will suffice, the actor may choose any arbitrarily. This is only different when a third party volunteers his interest or when the actor can avert the danger by sacrificing his own interest or that of the beneficiary. However, proportionality is the decisive condition, which means that the actor does not have to refrain from sacrificing goods of third parties if he could also avert the danger by taking for granted personal bodily injury. ${ }^{348}$ Similarly, a duty to take the risk of losing the legal interest can follow from the special position of the defendant. Police men, fire-fighters, sailors, doctors and parents vis-à-vis children are more likely required to take certain risks. That a fire-fighter is expected to risk his life does not however bring about that he is also required to sacrifice himself, if for example death or serious injury is certain. ${ }^{349}$

In some situations, committing an offence cannot be justified, even if it is the only solution available to the defendant. When the actor has a special duty to respect the law at the expense of a more valuable legal interest, the necessity of violating the norm is excluded beforehand. ${ }^{350}$ This can follow from the circumstance that the legislator already considered the possibility that interests would conflict and decided in favour of one interest. For instance, the defendant charged for not fulfilling her duty to earmark her animals, could not rely on the rule that prohibits animal cruelty because earmarking had already been considered an exception to that prohibition by the legislator. ${ }^{351}$ Legislating is a method of permanently solving conflicts.

Moreover, when the legislator has provided for clear exceptions to a norm and/or the possibility to apply for a permit or exemption, this generally excludes other means of solving the conflict of interests. ${ }^{352}$ If there is no such procedure, the assumption is that the legislator saw no room for a defence in general. ${ }^{353}$ Sometimes

346 Hof Amsterdam 28 April 2011, LJN:BQ2981. The Court of Appeal tested this and other charges not to necessity but to the freedom of speech under article 10 ECHR. He was acquitted of other charges. By contrast, see HR 27 June 1995, NJ 1995, 711.

Beulke 2008, p. 105; Roxin 2006, p. 764 and Schönke \& Schröder, H. 2006, pp. 675-676 and 684. They submit that the duty to retreat and to get help has more weight than in self-defence, because it is not a situation of right against wrong.

351 HR 16 September 2008, NJ 2008, 512.

352 Dolman 2006, p. 164 and de Hullu 2006, p. 289. Compare in EU competition law, 30 September 2003, Joined Cases T-198/98 and T-212/98-214/98, Atlantic Container Line and Others $v$. Commission [2003] ECR II-3275, §§1110-1122 and 1381-1385. 
the Union or national legislator explicitly precluded any exceptions. ${ }^{354}$ In any event, not using the legal alternative of applying for a permit seems to bring about that the condition of subsidiarity was not met. For the purpose of comparing national approaches, we will take a look at the offences of cultivating or possessing cannabis for medicinal purposes. In the Netherlands, the fact that a permit was refused does not always preclude the defence, but it the defendant did not even apply for one, subsidiarity is generally lacking. ${ }^{355}$ However, it has been made clear in this specific context that even if the defendant omitted to apply for a permit, the justification is not necessarily precluded. Under exceptional circumstances, it can still apply. ${ }^{356}$

The case is as follows; two defendants, a person suffering from multiple sclerosis (MS) and his wife, were charged with cultivating cannabis. This has always been criminal in the Netherlands, tolerated by the Public Prosecution's Service only in small quantities for own consumption. In the recent decade, the Dutch government has not only come down on large scale cultivation but also on the aforementioned cultivation for personal use. The Drugs Act allows for an exemption to the injunction, which, according to the Public Prosecutor, implies that necessity is precluded. The defendants did not even apply for the exemption. The Court of Appeal and Supreme Court allowed the defendants to rely on necessity nevertheless, because the defendants knew that applying for the exemption would be unsuccessful, as only companies could be given a permit. In other words, there was no real alternative available to the defendants.

Furthermore, if the legislator made available a procedure for exceptions, necessity is not precluded; it merely means that the justification can only be accepted in exceptional circumstances. Necessity was accepted because the circumstances were held to be exceptional. First, it was established that cannabis helped to relieve pain and prevent spastic seizures and that at some point, this is the only substance that can help MS-patients. Second, it was established that the medicinal cannabis available in pharmacies did not have the desired effect. Third, the danger of cannabis sold in 'coffee shops' was that they were full of fungi, bacteria and pesticides, to which MS-patients are very sensitive. Moreover, the defendants would not be able to afford cannabis from a coffee shop in the quantities the MS-patient needed it. Taking all this into account, both the Court of Appeal and the HR held that the conflict of interests - the criminal offence versus the relieving of pain and prevention of spasticity - could be settled in favour of the latter. This means the defendants were (from then on) justified to grow cannabis.

354 In Hof Leeuwarden 22 July 2011, $L J N$ :BR2402, the Court of Appeal refers to the Dutch legislator who explicitly rejects an exception because the offence is an implementation of an EU Directive that does not allow for exceptions.

355 HR 19 April 1983, NJ 1983, 572.

356 HR 16 September 2008, NJ 2010, 5 and HR 18 May 2010, NJ 2010, 289. This is a general rule in all contexts, see HR 12 July 2011, $L J N$ :BP5971. 
A somewhat stricter approach seems to be taken in Germany. Whereas it is also argued that the defence can be rejected for not applying for a permit, ${ }^{357}$ the defence has been accepted in cases where the defendant did not use this possibility, similar to the above-mentioned Dutch case. In one case, the German court held that a permit would never be given to an individual since exceptions to the Drugs Act must be grounded in a public interest. The defendant can therefore not be required to use this possibility. ${ }^{358}$ The same court argued later that only in exceptional circumstances, the accused can rely on necessity for growing and possessing cannabis. The court emphasized the fact that the need must be so exorbitant and atypical, that it can be said that this case falls outside the scope of what the legislator has foreseen. In other words, since the legislator has not made these exceptions possible, it is presumed that the weighing of interests has already been conducted to the detriment of the consumer. Necessity in general is therefore precluded. ${ }^{359}$ Nevertheless, seriously ill persons can be justified for growing and possessing cannabis, if they made sure that cannabis as a pain killer is the ultimum remedium. ${ }^{360}$

Most weight is given to the presumed intention of the legislator in England. Defendants cannot rely on necessity for cultivating, possessing or supplying others with cannabis in order to alleviate pain based on pragmatic concerns that this contravenes the legislative policy and scheme on a continuing and regular basis. The acceptance of necessity would hamper effective enforcement and create a parallel market in which no prescription was needed. The fact that the exemption scheme does not allow for such an exception is said to indicate that the legislator did not allow for such a possibility. It is up to the legislator to change policy, for accepting the possibility of relying on necessity "would involve a positive invitation to the jury to act contrary to the law and to take over the role of the legislative authorities." 361 Conversely, this implies that when new legislation is being drafted, or when Union legislation that allows for the prohibited conduct still needs to be implemented, the judge needs to anticipate this legislative purpose in favour of the defendant. ${ }^{362}$

In conclusion, if the legislator foresaw a conflict of interests by providing a statutory defence or exemption procedure, or if he provided for the exact conditions of conduct in some other way, this is generally considered to exclusively regulate all possible conflicts and thus precludes necessity. The legislator's authority to settle conflicts of interests is applied strictly. The separation of powers and the principle

35730 June 2005 BVerfG 2 BvR 1772/02 and Fischer, T. 2009, p. 306.

35818 November 2002 KG (Kammergericht) Berlin BeckRS 2009, 22705. In contrast, in 30 June 2005 BVerfG 2 BvR 1772/02, the law was interpreted in a way that did not preclude the defendant from applying for a permit. 25 May 2007 KG (Kammergericht) Berlin NJW 2007, 2425. See also Roxin 2006, pp. 746-747. Körner 2007, notes 1426-1427 on \$29 BtMG. See 28 April 2004 AG (Amtsgericht) BerlinTiergarten NStZ-RR 2004, 281 and 24 June 2004 OLG Karlsruhe NJW 2004, 3645.

361 R v. Quayle and others [2005] EWCA Crim 1415.

362 See Hof Den Bosch 3 March 2009, LJN:BH4471. Whether the implementation period is still running, should be irrelevant from this perspective. 
of legal certainty require that the judiciary does not undermine that authority. On the other hand, the defendant may still be justified in case of exceptional circumstances that the legislator did not foresee. Necessity should not be precluded because there will always be situations that the legislator did and could not foresee. It enables the legal system to keep up with changing views in society. The strict English approach is therefore rejected in favour of an approach that allows for each case to be assessed on its merits. Such an approach is in line with the trend that conditions of defences no longer set an absolute threshold that needs to be met, but operate as one factor amongst many others that mutually influence each other. This trend is also evident in prior fault, a limiting factor of necessity discussed now.

\subsubsection{Prior fault}

The role of prior fault in necessity is similar to that role in self-defence. First of all, causing or provoking the situation of necessity does not necessarily rob the defendant of the possibility of relying on necessity. For example, although the defendant caused an accident, he can still be justified in leaving the scene of that accident when he has to run away in order to escape being beaten up by the victim. ${ }^{363}$ In favour of making prior fault irrelevant to the application of necessity, it is argued that the justified conduct does not change the prevailing quality of the interest when the actor is to blame for getting into a situation of necessity. In other words, the result is more important than the origin. ${ }^{364}$ It is only likely that the defence will be rejected when the defendant intentionally created a situation of necessity in order to abuse the defence, just like in self-defence. ${ }^{365}$

It could be argued that prior fault is more likely to preclude necessity in the Netherlands and England. In English law, such a restrictive approach is in line with the similar restrictive approach to prior fault in the context of duress and the restrictive approach to necessity in general. However, since both approaches have been rejected, prior fault's limiting effect on necessity should not be given great weight either. In the Netherlands, prior fault could also preclude necessity if the actor foresaw or at least could have foreseen that he would get himself into a situation of necessity or in a situation where he would have to break the law. ${ }^{366}$ However, considering the Dutch Supreme Court's relaxation of the limiting role of prior fault in self-defence and duress, it can be expected that currently, prior fault will also no longer always preclude necessity.

Prior fault should therefore operate as it already operates in German law, namely as an independent condition, a factor that influences the other criteria of the

363 Bohlander 2009, p. 111; Roxin 2006, pp. 751-752; Schönke \& Schröder, H. 2006, p. 695 and Fischer, T. 2009, p. 307.

364 Roxin 2006, p. 751 and Machielse in Balkema a.o. 1995, pp. 234-240.

365 See also Fischer, T. 2009, p. 307.

366 HR 9 June 1987, NJ 1988, 318; Dolman 2006, pp. 165-167 and 249 and Fokkens \& Machielse, note 9 on art. 40 . 
defence, such as the weighing of interests under proportionality. ${ }^{367}$ If the actor foresaw that he would create a danger to himself, the weight of his interests can be minimized in balancing the conflicting interests, up to the point that the conclusion must be that a relatively light interference of his own interest has to be taken rather than averted. If the driver in the aforementioned example foresaw the traffic accident and the subsequent risk of being beaten up, he is less likely to be justified in fleeing the scene of the accident. Although he should not tolerate a beating, he had to take the risk of being attacked over fleeing in fear of what might happen. His prior fault brought about that his interest to bodily integrity was no longer prevailing. ${ }^{368}$ A second example is that if the defendant foresaw a conflict of interests, this implies he had more time to consider and more time to use alternative means of solving the conflict. This approach of prior fault is favoured because it enables the flexibility to differentiate cases. Unlike the other approaches, it does not bring about any serious objections and finally, it fits in best with the role of prior fault in the context of other defences, like self-defence.

A third, less popular, way to deal with prior fault is to ground liability for the prior conduct under the doctrine of actio illicita in causa. ${ }^{369}$ Like in the German law on self-defence, the judiciary and scholars sometimes accept necessity but also hold the defendant liable for a negligent offence. Just like the abovementioned more popular approach, this solutions strikes a middle ground between precluding the defence altogether and holding it irrelevant. An example concerns the truck driver who got stuck in a road where he was not supposed to drive. He needed to dump his load, which was an offence but still brought about less damage than not doing so, for this would have destroyed the truck. Nevertheless, the driver was convicted for negligently dumping the manure under actio illicita in causa. ${ }^{370}$ The application of the doctrine in this context is specifically criticized for not stimulating the defendant to save the prevailing interest. The law should make sure that the actor who is to blame for causing a situation still protects the prevailing interest. ${ }^{371}$

Necessity and the related 'force majeure'372 is also a common defence in many fields of EU law. Usually, the defence is statutory, laid down explicitly in a Regulation or Directive to apply to that specific conduct. ${ }^{373}$ The scope of the defence is stricter in EU law than in national criminal law. First, prior fault tends to

\footnotetext{
367 Beulke 2008, pp. 106-107 and Roxin 2006, p. 751.

368 Roxin 2006, pp. 752-753.

369 Beulke 2008, pp. 106-107.

37026 May 1978 BayObLG NJW 1978, 2046. See Hruschka 2001, pp. 870-872.

371 Roxin 2006, p. 754

372 See Dannecker 1993, p. 241

373 See article 12 of Regulation 561/2006 of 15 March 2006 on the harmonisation of certain social legislation relating to road transport, OJ 2006 L 102 and article 10(2) of Regulation 3887/92 of 23 December 1992, OJ 1992 L 391, as well as article 48 of Regulation 2419/2001 of 11 December 2001, OJ 2001 L 327, both 'laying down detailed rules for applying the integrated administration and control system for certain Community aid schemes.' See also article 45 of the Statute of the Court of Justice.
} 
preclude the legal subject from relying on that concept. If the actor foresaw the conflict of interest or if it was foreseeable, the defence is rejected. For example, the general dangers of the market are foreseeable and should therefore be borne by companies. ${ }^{374}$ In general therefore, only unforeseeable circumstances can give rise to necessity. Secondly, force majeure often also requires that the actor exercised all due care. ${ }^{375}$ This brings about that the EU defence is hard to classify as in some ways, it resembles the justification necessity, but in other ways it is similar the excuse of due diligence that can be raised in offences of strict liability. The defence is therefore only of limited relevance to our synthesis.

\subsection{Proportionality}

Since necessity is based on the concept of lesser evils or prevailing interest, proportionality plays a decisive role. The actor should choose the lesser of two evils. By committing the criminal offence, more should be preserved than otherwise would have gone lost. ${ }^{376}$ To establish whether the defendant's actions are justified, all the interests involved, all the circumstances of the case and all conditions and factors of necessity are considered. The condition of proportionality can be labelled a weighing of interests. It does not, however, consist of an abstract valuation of legal interests, but a concrete test based on the circumstances of the case. All interests that are directly and indirectly involved should be weighed. In particular the following must be taken into account; the nature, origin, intensity and proximity of the danger, nature and scope of threatened damage, the relationship in value and rank between colliding interests, special duties to endure danger or to protect interests, the end-goal of the actor, the benefits for society, prior fault, the possible irreplaceability of the damage and the chance of saving one or both interests. ${ }^{377}$

Like in self-defence, the condition of proportionality takes into account to what extent the other conditions of necessity are fulfilled. Prior fault can for example, bring about that the balancing scales are adjusted. Secondly, a lenient criterion such as that of adequacy is put into perspective by requiring more under the heading of proportionality. If the means used to avert the danger is unlikely to be successful, it will less likely be proportional to use. The numerous aspects of proportionality and its close relationship to the other conditions of necessity show that the effort to give an all-encompassing description of this condition is doomed to fail. ${ }^{378}$ Let us focus therefore on the most debated aspects of this balancing exercise.

\footnotetext{
374 Dannecker 1993, p. 240.

3759 November 1995, Case C-235/94, Bird [1995] ECR I-3933; 11 July 2002, Case C-210/00, Käserei Champignon Hofmeister [2002] ECR I-6453, §79 and 18 January 2005, Order in Case C-325/03 P, Zuazaga Meabe [2005] ECR I-403. See also X.4.4.2.

376 Dolman 2006, pp. 239 and 310.

377 Beulke 2008, p. 106 and Dolman 2006, p. 252.

378 Bohlander 2009, p. 113; Roxin 2006, p. 736 and Schönke \& Schröder, H. 2006, pp. 685-686.
} 
The most important difference with self-defence is that after all aspects are balanced, the protected interest must outweigh the sacrificed interest. For the offence to be justified, it must positively be established that it was proportional. It does not suffice to argue that it was not disproportional. ${ }^{379}$ The difference was explained by the fact that necessity is not about right against wrong. It is about right against right and about safeguarding the prevailing interest. The interest that is sacrificed in necessity generally belongs to a third party, not a wrongful aggressor. Only if the person affected by the defendant's actions is somehow responsible for causing the situation of necessity, will the condition of proportionality be applied more leniently. ${ }^{380}$ To equate the proportionality requirement of necessity with that of self-defence is therefore to neglect the different nature of the justifications. ${ }^{381}$

The exact degree of proportionality remains controversial. Some submit that the balancing exercise requires that the protected interest substantially outweighs the sacrificed interest, ${ }^{382}$ whereas others argue that the difference between the conflicting interests must not be great, only evident. It is only required that "on an evaluation of all circumstances of the case it is clearly of higher importance, leaving no doubt in the mind of the average reasonable person." 383 Some include into necessity that the saved interest must at least be equal to or greater than the sacrificed interest. ${ }^{384}$ This brings about, that situations in which interests of equal value conflict, can also be solved under necessity. However, generally these situations are considered to give rise to a defence sui generis called 'collision of duties'. For example, when a father can only save one of his two drowning children, there is no prevailing interest. Necessity does not apply and the saving of one at the expense of the other is justified on the principle that the law cannot ask the impossible: impossibilium nulla obligatio est. ${ }^{385}$

\subsubsection{Legal interests}

It is evident that the interest to life usually outweighs a conflicting interest concerning an object. The protection of life and limb almost always prevails over

Fokkens \& Machielse, pp. 274-275, note 3 on art. 41 and Sangero 2006, pp. 196-197. Kelk 2005, p. 284; Machielse 1986, pp. 524-528; Cleiren \& Nijboer 2008, note 6b on Overmacht and Glazebrook 1972, p. 89. See IX.4.1.

According to the criteria of necessity as submitted by Stephen in 1887, the evil inflicted must merely not be disproportionate to the evil avoided. These criteria have been subscribed to in $\mathrm{Re}$ A. (Children) [2000] EWCA Civ 254.

Beulke 2008, p. 106. Compare 'wesentlich' in $\$ 34$ of the German Criminal Code.

Bohlander 2009, p. 113. See also Roxin 2006, pp. 766-767 and 783-784; Schönke \& Schröder, H. 2006, pp. 696-697 and Kelk 2005, p. 278. Dannecker in Tiedemann 2002, p. 158 submits the pertinent position of the ECJ is unclear.

Strijards 1987, pp. 49-50.

Bohlander 2009, p. 95; Schönke \& Schröder, H. 2006, pp. 611-612 and Roxin 2006, pp. 778782. See 28 May 2002 BGH NStZ 2002, 548. 
all other rights. For example, a doctor is justified in breaking his duty to remain silent by disclosing the HIV-positive state of a person to his sexual partner. ${ }^{386}$ The weighing of interests encompasses more than the abstract weight of the conflicting interests, but it is an obvious starting point. After all, if the human life would always prevail, a terrorist's demands would also have to be followed. ${ }^{387}$ Any interest can be legitimately protected under necessity, but the weight of that interest influences the final decision of justification or not. A justification under necessity is most likely to follow for protecting serious legal interests, just as it is most likely to follow when only regulatory rules are infringed, evident by the example of speeding to save a seriously injured person.

The exercise is another illustration of the authority of the legislator, because much weight is put on the valuation of legal interests by that legislator. First, the legal protection of an interest indicates that it is important. Secondly, there can be no weighing of interests when the norm implies that it should also be respected at the expense of more valuable interests. Third, the legal valuation is evident in the different ranges of sentencing to offences. Since homicide can be punished more severely than (illegal) abortion, the legislator apparently values the life of the born more than that of the unborn. This valuation should also be the starting point of a weighing of interests in necessity. In many other cases however, the legislator's valuation is not so evident and therefore less helpful. Amongst others, the range of sentencing of offences is not always very different. ${ }^{388}$

The legislator's view is not absolute because sometimes the subjective of an interest needs to be taken into account. A good can have more weight if it is very personal, has sentimental value, is irreplaceable or when a lot of work has been put into it. ${ }^{389}$ However, the subjective valuation can only be taken into account as far as the legal order recognizes this. The assessment must remain objective in essence. For example, the defendant's perspective that the life of his parakeet was so important that it was proportional for him to exceed the speed limit with more than $50 \mathrm{~km} / \mathrm{h}$ was considered to be a mistake and can therefore only excuse when reasonable. ${ }^{390}$ Conversely, if the defendant stands in no close relation to the protected interest, this will also negatively influence the weight of that interest. ${ }^{391}$

\footnotetext{
3868 July 1999 OLG Frankfurt am Main NJW 2000, 875.

387 Roxin 2006, pp. 737-738 and Schönke \& Schröder, H. 2006, p. 687.

388 Roxin 2006, pp. 736-737; Fischer, T. 2009, p. 307; Schönke \& Schröder, H. 2006, pp. 695-696 and Dolman 2006, pp. 163, 168 and 241.

389 Roxin 2006, pp. 757-758; Schönke \& Schröder, H. 2006, p. 687 and Dolman 2006, pp. 175 and 244.

39018 April 1990 OLG Düsseldorf NJW 1990, 2264. Offences committed based on conscientious grounds can also be rejected because an objective situation of necessity was lacking, see for example Hof Leeuwarden 3 August 2011, LJN:BR4247 and BR4250.

391 Compare Nieboer 1991, p. 258 and Machielse 1986, p. 606.
} 


\subsubsection{Concrete interference}

Besides the abstract valuation of the interest, it is also important to consider the concrete interference with that interest, in other words, the likelihood and intensity of the interference. As far as the intensity is concerned, it is obvious that an object can be merely damaged or completely destroyed. An infringement can also be reparable or irreparable and permanent or transitory. A minor interference of a higher valued interest can be justified to save a serious interference of a lesser valued interest. ${ }^{392}$

The second aspect concerns the likelihood that the conflicting interests will be infringed or saved. There exists hardly a threshold of how likely it must be that the danger in fact will lead to an infringement of the protected legal interest. As long as the interference is not totally improbable, it is deemed necessary to save the interest. The risk is assessed normatively. Therefore, even if fatal consequences are perhaps only ten percent, this can still not be risked since it is so serious. ${ }^{393}$ Similarly, there exists no real threshold of adequacy as to how likely it must be that the defendant's actions will in fact save the prevailing interest. This absence is compensated under the weighing of interests. The less likely it is that the danger will occur, the more serious the interference of the sacrificed interest should be. The smaller the chance of successfully protecting the prevailing interest, the less likely the act will be justified. ${ }^{394}$

This explains why the defendant is justified to exceed the speeding limit to take an injured person to hospital, if it is almost certain that person will otherwise die. In that case, the concrete danger to the life of one person outweighs the abstract danger to the lives of other participants in traffic. ${ }^{395}$ In contrast, if the injuries of the person were neither life threatening nor urgent, the defendant is not justified in creating an abstract danger to others by exceeding the speed limit. ${ }^{396}$ Things may again change if the abstract danger is realized. It is unlikely that the defendant will be justified for causing an accident, certainly not if fatalities are the result.

392 Roxin 2006, pp. 737-738; Schönke \& Schröder, H. 2006, pp. 687-688 and Simester \& Sullivan 2007 , p. 718.

393 See IV.3.4.5.

39424 June 2004 OLG Karlsruhe NJW 2004, 3645; Roxin 2006, pp. 730 and 742; Fischer, T. 2009, p. 305; Beulke 2008, p. 106 and Schönke \& Schröder, H. 2006, pp. 682-688.

395 Roxin 2006, pp. 742-743 and Schönke \& Schröder, H. 2006, p. 688. See also 28 April 2004 AG (Amtsgericht) Berlin-Tiergarten NStZ-RR 2004, 281, where a seriously ill person was justified in growing and possessing marihuana. The Drugs Act serves the abstract interest of public health, which was not concretely endangered whereas the defendant's concrete interest was furthered.

396 HR 20 January 1976, $N J$ 1976, 206. Or driving whilst intoxicated, see 16 April 1987 OLG Koblenz NJW 1988, 2316. 


\subsubsection{Joint risky ventures}

If the victim of an offence is the source of the danger, less is required from the proportionality requirement. This can be illustrated by reference to the controversial situations known as 'joint risky ventures'. ${ }^{397}$ The term 'joint' reflects that all persons concerned agreed upon a venture, which they know harbours risks, like mountaineering, sailing or diving. The joint risky venture presupposes solidarity, which brings about mutual obligations. On the one hand, there exists a duty to help each other if necessary. This can be used to ground omission liability. On the other hand, a duty can exist to take the danger, especially if one person becomes a threat to the whole group. This can justify the sacrifice of that person's interests.

Cases that are labelled as joint risky ventures are characterized by the fact that multiple persons are jointly in danger, whereby one has to be killed or sacrificed to save all. Equal interests of different persons are at stake and every person can only safeguard his interest at the expense of the equal interest of the other. ${ }^{398}$ Classic is the aforementioned hypothetical of two shipwrecked men. There is only one plank in the water, which is also only large enough to support one of them. If one of the two persons manages to secure the plank, the danger of drowning that endangers them both is realized for the one without the plank.

Almost everyone agrees that the person who survives should not be held criminally liable for causing the death of the other. ${ }^{399}$ Kant argued that neither man would have a moral right to push the other off the plank, but that this does not mean one should be criminally liable for doing so. After all, such criminal law would not deter: the certain evil of drowning would be outweighed by the uncertain evil of receiving the death penalty. ${ }^{400}$ This became evident in the case against Dudley and Stephens. ${ }^{401}$ The crew of the yacht Mignonette were cast away in a storm, compelled to use an open boat without much provisions. After some time, two of the crew, Dudley and Stephens, killed the cabin boy to feed upon his body. They claimed that if they had not killed the weakened boy, all would have died. In order to emphasize that their conduct was illegal, the men were convicted and sentenced to death. This mandatory penalty was however reduced to six months imprisonment. ${ }^{402}$ Later people saw the trial as a charade, doubting whether other seafarers would be influenced by it. ${ }^{403}$ The decision is generally accepted to be

397 Term used by Bernsmann 1996, p. 183 to denote what is called in German 'Gefahrengemeinschaft' and in Dutch 'gevaargemeenschap'. This is not to be confused with the concept of 'joint criminal enterprise.'

Roxin 2006, p. 739; Schönke \& Schröder, H. 2006, p. 686 and Dolman 2006, p. 162.

Roxin 2006, p. 1025.

400 Finkelstein 2001, pp. 280-281 and Fletcher 1998, p. 84. Compare Roxin 2006, pp. 1025-1028.

401 R. v. Dudley and Stephens (1884) 14 QBD 273.

402 On the death penalty and the power of the Queen to grant mercy, see Simpson 1984, pp. 235 and 242 .

403 Gardner, S., 1986, pp. 435-436 and Simpson 1984, in particular pp. 240-241. 
wrong. Dudley and Stephens should have been acquitted rather than being made an example to others.

The controversy of joint risky ventures therefore concerns the correct solution, more specifically whether the actor can be justified and if so, it this can be grounded in necessity? It is problematic that prevailing opinion on necessity requires the prevailing interest to outweigh the sacrificed interest. In the case of one life versus the other, necessity would thus not apply. Instead, the aforementioned defence of collision of (equal) interests may apply. ${ }^{404}$

Problematic is also that more in general, the acceptance of a justification implies that the opposing parties could not both be justified. After all, if it is accepted that the person who is being pushed off the plank has a right of self-defence against the aggressor, that aggressor cannot at the same time be justified by necessity to push him off. If both would be justified, both would be allowed to resist each other and to throw the other off. It is argued therefore, that the 'aggressor' can at most be excused under duress. ${ }^{405}$

Justifying the defendant for killing an innocent person is also problematic from the point of view that a justification communicates that what the defendant did was right or at least permissible. Hence, the point of view that the defendant in these cases should merely be excused is popular. ${ }^{406}$ Most of the cases mentioned are therefore also often discussed in the context of duress. However, applying an excuse implies that a(n arbitrary) third party is allowed to take action in these cases. ${ }^{407}$ Hence, in the end, many scholars therefore do not use existing defences and the categories of justification and excuse to solve these cases. ${ }^{408}$

Necessity is not only rejected because when two lives conflict, there is no clear prevailing interest; it is also rejected based on a prohibition on such a quantification or valuation of lives. Every life has the same value, which also means that a doctor may not sacrifice a patient with small chances for survival to save one or more with high chances, that the madmen may not be sacrificed to save the Nobel price winner. Neither may the lives of some be sacrificed to save the lives of many. For example, if a runaway carriage threatens to run over several people on one track, the trackman would not be allowed to switch the track so only one person would be killed. ${ }^{409}$

The existence of this taboo in German law may be explained as a result of experiences during WWII. An example given to ground the prohibition is that

404 Politoff \& Koopmans 1991, pp. 168 and 172.

405 Nieboer 1991, p. 258 and Finkelstein 2001, pp. 280-281.

406 Kelk 2005, pp. 275-276; Beulke 2008, pp. 107-108; Schönke \& Schröder, H. 2006, pp. 686-689 and Bernsmann 1996, p. 183. In Re A. (Children) [2000] EWCA Civ 254, reference is made to the Canadian case of Perka, where Wilson $\mathrm{J}$ said that killing in necessity for self-preservation would at best be an excuse. "It could not possibly be declared by the court to be rightful." Roxin 2006, p. 762

408 See Cleiren \& Nijboer 2008, note 5d on Overmacht; de Hullu 2006, p. 289; Clarkson 2004; Roxin 2011, p. 563 and Roxin 2006, p. 742.

409 Roxin 2006, pp. 738-739; Schönke \& Schröder, H. 2006, p. 686; Fischer, T. 2009, p. 308 and Kelk 2005, pp. 275-276. 
doctors cooperated with Nazis to kill mental patients, because of fear that if they rejected, others would replace them and spare none..$^{410}$ It can also be explained by the great influence of deontology in Germany, which leads to a rejection of purpose oriented utilitarian thinking, of which necessity is an expression. To most people, the revulsion against intentional killing can be so strong that we are unwilling to consider utilitarian reasons for it. ${ }^{411}$ In England, this has led to the rule, which will be discussed in detail later, that duress cannot apply to murder. Based on the case against Dudley and Stephens, the same used to be accepted in regard to necessity, but the ruling in the case of the conjoined twins is often interpreted as that a necessity plea is now possible to a charge of murder. ${ }^{412}$

Nonetheless, it can also be argued that the danger is realized in regard to all when nothing is done. In doing so, the case can be distinguished from the normal case of necessity where a danger can only be averted at the expense of another. It can be argued that whereas in the normal case, the sacrifice of an equal interest is wrongful, in a joint risky venture, an equal interest can be sacrificed because if nothing is done both interests are lost. By sacrificing, more is preserved than lost by doing nothing. ${ }^{413}$ In other words, the interests are not equal; either the interest of one or the interests of both are violated. It cannot be prohibited to minimize an evil that cannot be prevented. Reasonable law cannot prohibit that at least one human is saved when the saving of both is impossible. ${ }^{414}$

This line of reasoning is most convincing in cases where the victim has already been designated by the situation. Consider the case where a mountaineer holds his fellow-climber after he had slipped and is dangling over a cliff. Not being able to recover him, the danger exists that both will fall to their death, necessitating the mountaineer to drop his fellow-climber. ${ }^{415}$ Another case that is often referred to but never dealt with by a court - is the death of a young man during the Zeebrugge ferry disaster. During the evacuation of the Herald of Free Enterprise, a young man was preventing the way of escape for people because he was immobile, frozen on the ladder. Apparently petrified or in shock, he was pushed off the ladder, fell in the water and was never to be seen again.

In cases where either one dies or all will die, the victim poses a threat to the person who has to sacrifice him. ${ }^{416}$ A comparison can therefore be made to aggressive and defensive necessity. As mentioned before, defensive necessity is characterized by the fact that the sacrificed interest belongs to the person who gave

410 See Roxin 2006, p. 740, euphemistically called the Euthanasia-case.

411 Williams according to Brooke LJ in Re A. (Children) [2000] EWCA Civ 254.

412 See X.4.5.1.

413 Dolman 2006, pp. 162 and 240.

414 Roxin 2006, p. 740.

415 In Re A. (Children) [2000] EWCA Civ 254 such a case is mentioned. Joe Simpson miraculously survived by landing on a snowy ice bridge 100 feet below and told the mountaineer Simon Yates: 'You did right.'

416 Re A. (Children) [2000] EWCA Civ 254; Ormerod 2005, pp. 320-322; Simester \& Sullivan 2007, pp. 720-721 and Ashworth 2006, pp. 151-152. 
rise to the danger. The person hanging on a rope or blocking the only escape route probably also did not choose to be the source of the danger, but he is the reason the danger exists. In the German civil provisions on necessity, it is recognized that the interests of that person are less deserving of protection and therefore carry less weight. As a consequence, the requirement of proportionality is more lenient. ${ }^{417}$ Hence, the life of the defendant can be argued to outweigh that of the person giving rise to the danger.

A similar way to approach this is to argue that sacrificing the life of third parties, persons who are not related to the danger, can never be justified because of principles of autonomy and human dignity. By taking these principles into account as abstract interests in a weighing of competing interests, more weight is given to the preservation of their interests. In Germany, it is argued that in case of regular or 'aggressive' necessity, where the actor interferes with an interest of an innocent third party, the principle of autonomy brings about a stricter test of proportionality. An interference with the interests of third parties can only be justified when the prevailing interest is much more valuable, because by sacrificing an interest of a third party, the legal order as such is also infringed. ${ }^{418}$ For example, a rich woman is not allowed to rip an umbrella out of the hands of a poor woman when it starts raining all of a sudden, in an effort to save her expensive dress. ${ }^{419}$

If a simple weighing of the interests that are directly involved would suffice, fundamental rights and principles such as human autonomy and dignity would be violated. ${ }^{420}$ By giving important values such as human dignity special weight, it can be said that the act of necessity is, in a socio-ethical perspective, the right means to a right goal. ${ }^{421}$ In England, these examples are also given to emphasize the relationship of sacrificing interests of those who gave rise to the danger. A necessity plea cannot be invoked when a personal right of a non-consenting person is overridden who poses no threat to the person or property of others. The autonomous person who posed no threat cannot be hurt. Only when the defendant's response is addressed to the source of peril and the victim's interests are served as well, does the defence allow for the infliction of personal harm. ${ }^{422}$

Nevertheless, some German scholars argue that in these situations where the victim would have died anyway, the defendant can merely be excused. They argue that necessity must be rejected. After all, fault on behalf of the victim for creating the situation, let alone a mere associative connection to the danger cannot ground a right to interfere with his life and a duty to tolerate this infringement. Prior fault

\footnotetext{
$417 \S 228$ of the German Civil Code; Schönke \& Schröder, H. 2006, pp. 688-689; Roxin 2006, pp. 775-777; Roxin 2011, pp. 558-559 and Machielse 1986, pp. 524-528. Schönke \& Schröder, H. 2006, pp. 685 and 691-692 and Roxin 2006, pp. 618, 744-745 and 766.

419 Roxin 2006, pp. 620-621. See also Simester \& Sullivan 2007, pp. 717-718.

420 Schönke \& Schröder, H. 2006, p. 697.

421 Roxin 2006, pp. 724-726 and Fletcher 1998, p. 138. See also Schönke \& Schröder, H. 2006, p. 676 .

422 Simester \& Sullivan 2007, pp. 719-721.
} 
and special duties can bring about a duty to take a risk, but not a duty to sacrifice. ${ }^{423}$ Moreover, some seem to suggest that no defence should apply on this basis at all. They point out the danger in using the argument that the victim is doomed, which could also be invoked to kill the terminally ill to save other patients. ${ }^{424}$

The German Constitutional Court held unconstitutional and void, the law that would permit the shooting down of a hijacked plane if necessary to prevent it from being used for a terrorist attack like those of September $11^{\text {th }}, 2001$. The Court refused to consider the fact that the passengers in such a situation were already doomed. The (innocent) ${ }^{425}$ passengers would become mere means to an end, and by using people as objects, the human dignity and right to life, which enjoy the highest protection, would be violated. ${ }^{426}$ The Court thus put much weight on the prohibition on the quantification and valuation of lives, rejecting the perspective that victims, who are designated to die in any event, may be sacrificed.

Again, the rejection of necessity in Germany does not imply that liability should follow. Many German scholars have rejected the decision in favour of justifying the shooting down. ${ }^{427}$ Moreover, the German Constitutional Court left open what the decision under criminal law should be for the individual who shot down the airplane. There seems to be consensus that it should be possible to shoot down the airplane, even if the legal grounding is highly controversial. ${ }^{428}$

Nevertheless, in England a principally different approach is taken. The principle that it can be justified to sacrifice the person who gives rise to the danger, to sacrifice the interest that will be lost in an event, prevails over concerns against the weighing of lives. It has been argued that necessity would apply to the abovementioned scenario in England. The English Government has in fact made clear that it reserves the right to shoot down the airplane. ${ }^{429}$ In the case of Re A (Children), the court was asked to rule on the legality of a proposed surgery of conjoined twins. Jodie and Mary were conjoined at the abdomen and both sisters relied on Jodie's heart. The two evils were the following; if Mary and Jodie would be separated, Mary would surely die, as she was incapable of independent existence. However, if they would not be separated, Jodie's heart would eventually fail within months, leading to the death of both sisters.

\footnotetext{
423 Beulke 2008, p. 108 and Schönke \& Schröder, H. 2006, pp. 686-687.

424 Fischer, T. 2009, p. 309 and Roxin 2006, p. 742.

425 If the airplane is unmanned or only occupied by persons who want to use it as a weapon, it may be shot down. This was also the case in 2003 when a confused individual threatened to use a hijacked sports plane as a weapon on Frankfurt, see Kersten 2005, p. 661. The threat was however not executed and the plane landed safely.

42615 February 2006 BVerfG NJW 2006, 751. See also Beulke 2008, pp. 108-109, Schönke \& Schröder, H. 2006, p. 687.

427 Overview in Roxin 2011, p. 552.

428 Sinn 2004, p. 591 and Kersten 2005, p. 663.

429 Bohlander 2006 and Ormerod 2005, p. 322. The Royal Air Force appears to have carried out such an exercise in July 2010.
} 
A balance was struck in favour of separation, because Mary was imperilling the life of Jodie and destined to die in any case. She remained alive only by 'draining the lifeblood' out of Jodie. Only Jodie had a chance of survival. Thus, although 'innocent', Mary posed a threat to Jodie's life, which could only be taken away by sacrificing her life. By emphasizing the fact that Mary was designated to die and the source of the danger, the court distinguished this case from other similar cases, like that of Dudley and Stephens, where someone else could have been sacrificed too. ${ }^{430}$ The cabin boy was selected because he was weak and had no children, but he was an autonomous person who posed no threat to the defendant. ${ }^{431}$

In conclusion, it is clear that the fact that the victim gave rise in some way to the danger or conflict is of influence in deciding whether or not the defendant should be held liable. The more the victim resembles the wrongful attacker, the more the degree of force used against him will resemble that which is allowed in self-defence. Whereas it is agreed the individual defendant should not be held liable, some ground this in necessity, whereas others merely excuse the defendant under duress. The choice depends on the individual case and the implications of accepting a justification or excuse to that case. It is clear that duress would allow for more in this context: the more lenient proportionality requirement of duress not necessarily requires that the saved interest clearly outweighs the sacrificed. A third group of scholars ground the solution in supralegal defences, sometimes even avoiding the justification-excuse dichotomy.

Finally, a problem is that one can almost never be sure that it is necessary to sacrifice an interest. In reality, it is very difficult to ascertain whether action must immediately be taken and that there are no other means of averting the danger. At the moment the castaways start fighting over the plank, they do not know whether a ship would have passed them in time. As an alternative that at least buys some time, they may for example agree that one person will be treading water so the other can rest on the plank, and that they regularly switch positions. ${ }^{432}$ Also, it cannot always be sure that the airplane will be used as a weapon, that the situation of the passengers is hopeless. The problem of these cases is therefore often not just one of proportionality, but also one of subsidiarity. ${ }^{433}$

\subsection{Lack of material wrongfulness}

Necessity is sometimes seen as the genus of which duress and self-defence are a species. ${ }^{434}$ Consider that in German and Dutch law, duress is labelled as 'excusing'

430 Re A. (Children) [2000] EWCA Civ 254; Ormerod 2005, pp. 320-321; Ashworth 2006, p. 154 and Simester \& Sullivan 2007, p. 711-712.

431 Simester \& Sullivan 2007, p. 721. Nevertheless, the defendants maintained that the cabin boy was in fact designated to die in any event, which was also accepted by the Prosecutor, see Simpson 1984, pp. 60-67 and Williams 1977, p. 96.

43315 February 2006 BVerfG NJW 2006, 751; Roxin 2006, p. 742; Roxin 2011, p. 561; Meyer 2004, p. 207 and Sinn 2004, p. 591.

434 Re A. (Children) [2000] EWCA Civ 254 and Williams 1953, p. 574. 
and 'psychological necessity' respectively. Most differences with duress and selfdefence have been mentioned, so the delimitation of necessity with the defence of 'lack of material wrongfulness' remains. ${ }^{435}$ This defence, only recognized in Dutch law, has very much in common with necessity, but is also broader.

Its most important difference with necessity is that it does not consist of a conflict of two or more interests. By pleading the defence, the actor instead argues that although he violates the law would, he is serving the interest protected by that norm better than by complying with it. ${ }^{436}$ In other words, there is a conflict of norms, but not a conflict of interests. Although his conduct formally fulfils the offence definition, substantively this conduct is not wrongful. In some cases, conduct that literally breaks the law actually favours or minimizes the harm it seeks to avoid. The defence brings up for discussion the criminal offence, rather than allowing for the justification of some extraordinary cases.

The origin of the defence lies in a case called after its defendant, the "veterinary surgeon'. The surgeon had broken a rule that prohibited bringing healthy cattle into contact with cattle that had been infected with foot-and-mouth disease. He acknowledged these facts, but asserted that by doing so, the cattle had been better off than by complying with the rule. After all, the healthy cattle were almost sure to get infected too and by infecting them at a time when they were not giving milk, they did not become as ill as they would have, when infected later. Veterinarians shared this view in general at the time. The Dutch Supreme Court accepted this view as well and concluded that the conduct was not wrongful, as a consequence of which the conviction was quashed. ${ }^{437}$

Although it is generally assumed that the Court accepted the surgeon's defence as 'the lack of material wrongfulness', the Supreme Court made no such explicit reference. The annotator who was also a judge in the case favours this interpretation $^{438}$ and several lower courts have accepted it explicitly. ${ }^{439}$ The Supreme Court never got a chance again to say anything about this defence, as subsequent cases never got further than a Court of Appeal. One of them concerns a mother who had taken a mobile phone from her son and turned it in to the police, because it had been stolen. She wanted to protect her son, while at the same time teach him a lesson and return the phone to its rightful owner. However, the elements of the offence of handling stolen goods had been met. The Court of Appeal however held that by acting as she did, she furthered the goal of the offence, namely the prevention of people benefiting from the crime of another. In other words, she

\footnotetext{
435 'Het ontbreken van materiële wederrechtelijkheid.'

436 Strijards 1987, pp. 48-49; Dolman 2006, p. 315 and Annotator van Veen in HR 3 July 1972, NJ 1973,78 . As a second category, the defence has also been raised (to no avail) by the defendant who was forced to commit the offence because of a higher interest, based on his conscience or political reasons, see Bosch 2008, p. 170 and Wolswijk 1998, p. 244.

439 Kelk 2005, pp. 139 and 142.
} 
acted contrary to the law, but not contrary to the purpose of the criminalization and was therefore justified based on the absence of wrongfulness. ${ }^{440}$

Just like necessity, the defence is hardly ever accepted because it undermines the validity of the norm, or because an alternative like an exemption procedure has not been used. ${ }^{441}$ In the time there still existed a general prescription, the law provided for a procedure, granting an exemption from military service on conscientious grounds. If the defendant did not use this possibility, courts had an easy job of rejecting necessity for the refusal to take part in military service or to obey orders. ${ }^{442}$ Third, the defence fails if the conduct was not adequate to serve the prevailing interest. From that point of view, acts of civil disobedience are the most ineffective form of resistance. ${ }^{443}$ It should be emphasized that the defence is often pleaded but hardly ever accepted by courts. ${ }^{444}$ It is unpopular amongst Dutch scholars, ${ }^{445}$ who have argued to alternatively acquit the defendant in these cases by expanding the scope of necessity or by creatively interpreting the offence definition.

In England, it is also recognized that sometimes the goal of a law can best be achieved by breaking its letter. ${ }^{446}$ "It requires clear and unambiguous language before the courts will hold that a statutory provision was intended to apply to cases in which more harm will, in all probability, be caused by complying with it than by contravening it." 447 In the Netherlands, the defence also operates as a failure of proof defence when the offence charged is result based, since the defendant asserts there has not been an infringement of the protected interest. ${ }^{448}$ It has been argued that such a creative, restrictive interpretation of offence elements should also be applied to offences in which the conduct is central and where concrete harm does not have to be caused. This enables the court to acquit the defendant without reference to the controversial defence of absence of wrongfulness. ${ }^{449}$ Restrictive interpretation is said to be the better option because it avoids a conflict of norms, rather than solve it. ${ }^{450}$

Another alternative to the recognition of a specific defence is to neglect the difference and treat these cases as necessity. In England, cases in which the defendant argues he serves the protected interests better by violating the criminal norm are also considered in the context of necessity. Consider the case in which the

440 Hof Arnhem 6 April 2009, $L J N$ :BI1487. In contrast, see HR 20 February 2007, NJ 2007, 464, where the conduct of the defendant was less laudable. 245-248 and de Hullu 2006, pp. 287 and 336.

Fokkens \& Machielse, note 7 on Wederrechtelijkheid.

445 AG van Dorst in HR 27 June 1995, NJ 1995, 711; AG Wortel in HR 4 December 2007, $L J N: B B 5377$ and de Hullu 2006, p. 339.

446 Simester \& Sullivan 2007, p. 716 and Williams 1953, pp. 567 and 569.

447 Glazebrook 1972, p. 93.

448 Fokkens \& Machielse, note 7 on Wederrechtelijkheid and Wolswijk 1998, pp. 244-246.

449 De Hullu 2006, pp. 336-339; de Hullu 2009, pp. 348-351; Strijards 1987, pp. 72-75 and Kelk 2005, pp. 136-151.

450 Dolman 2006, pp. 314-315. See also de Jong, D.H. \& Knigge 2003, pp. 50-51. 
accused was found in illegal possession of a firearm. He sought to justify this by asserting that he had taken the gun from someone who told him he wanted to use it on a person. He asserted the value of saving life over the letter of the gun-control laws, while at the same time furthering the ultimate goals of gun laws, namely keeping weapons out of the wrong hands. ${ }^{451}$

Legal interests can also belong to the same legal subject or exist in different risks to the same legal interest. Consider that a fireman has to throw a child out of a burning building (into a safety net) to save it from certain death, but in doing so risks severe injury. Necessity is applied in Germany to these cases although most German scholars prefer to solve such cases under presumed consent. ${ }^{452}$ The application of necessity to a case where strictly speaking no interests are in conflict, begs the question whether this should be a condition for the application of necessity. ${ }^{453}$ Dutch courts preclude necessity in cases where the protected interest is the same as the interest the violated provision aims to serve. ${ }^{454}$ This can be overcome by making the interests involved very specific, creating a conflict of interests. Euthanasia, for example, could be assessed under necessity by creating the conflicting interest of 'quality of human life. ${ }^{455}$ In the example of the child in the burning building, the interests of bodily integrity can be juxtaposed with that of life. It can be concluded therefore that the defence of 'lack of material wrongfulness' is a relic of the past and superfluous.

\section{Consent}

An offence, consented to by the victim does not bring about criminal liability. When the person concerned waives the protection of his legal interest, he should not be considered a 'victim'. There is no violation of his legal interests, no conflict of interests, no sacrifice of interests for a greater good. Therefore, it is often submitted that consent is not a justification. ${ }^{456}$ The wrong is not justified; there is no wrong at all. The person who consents is not wronged: volenti non fit iniuria. ${ }^{457}$

The same conclusion is also substantiated in a formal way. Consent often applies to non-ideal offences that include wrongfulness as an express offence element. Technically, consent therefore negates an offence element and acquits the defendant

451 R. v. Pommell [1995] EWCA Crim 7 and Simester \& Sullivan 2007, pp. 714-715.

452 Beulke 2008, p. 111 and 28 July 1970 BGH JZ 1973, 173. Like Roxin 2006, pp. 772-773 and Schönke \& Schröder, H. 2006, pp. 679-680.

453 De Hullu 2006, p. 339 submits that with the evolution of necessity into a reasonable and careful consideration of interests, this distinction no longer has to be made. Pompe had also argued in favour of extending necessity, see annotator Taverne in HR 27 June 1932, NJ 1933, 918.

454 See for example, Hof Leeuwarden 11 March 2010, $L J N$ :BL7271.

455 Strijards 1987, pp. 50-51. Compare Airedale National Health Service Trust v. Bland [1992] UKHL 5.

456 Ashworth 2006, p. 318 and Roxin 2006, pp. 545-555. Compare de Jong, D.H. \& Knigge 2003, pp. 50-51.

457 Remmelink 1996, p. 933. The maxim can be traced back to Ulpian: "Nulla iniuria est, quae in volentem fiat", see Roxin 2006, pp. 539-540. 
because the offence definition is not fulfilled. ${ }^{458}$ However, other justifications also operate as failure of proof defences. As noted, self-defence also formally negates a charge of intentionally inflicting wrongful bodily injury, or any reckless or negligent offence for that matter. No one has questioned that self-defence is a justification.

It will be argued that consent can operate as a justification and as a failure of proof defence. General principles can be deduced, which give meaning to the element of wrongfulness, irrespective of whether it is implied or express included in the offence. Some differences exist when consent operates as a failure of proof defence, which will be presented after discussing the rationale and conditions of consent as a justification.

\subsection{Rationale}

The justificatory force of consent is most often grounded in the victim's autonomy or individual right to self-determination. ${ }^{459}$ When the victim approves of the defendant's actions, this is viewed as a waiver of protection by the law. ${ }^{460}$ Similarly, it is argued that the legal order need not protect interests that have been consciously given up. ${ }^{461}$ It is agreed that the victim can only waive protection regarding individual legal interests. Consent can therefore not justify offences that (also) protect public legal interests. ${ }^{462}$ Therefore, those that argue that almost all offences also aim to protect public legal interests, submit there can be almost never be a waiver of protection. Accordingly, they reject the defence. ${ }^{463}$

In a similar way, a liberal perspective on consent can be juxtaposed with a moralistic one. An extreme liberal approach would allow consent to apply to all offences, whereas from a more paternalistic perspective, consent needs to be limited with a view to public policy. ${ }^{464}$ On the one hand, moralism is not a proper basis for the deployment of criminal law in a modern plural democracy. On the other, even hardcore liberals concede that there are cases where the Government must intervene. Consider the case of the 'Rotenberg cannibal', who killed, slaughtered and ate his consenting victim. ${ }^{465}$

458 Politoff \& Koopmans 1991, p. 60.

459 Roxin 2006, pp. 541, 558 and 582; Fletcher 1975, p. 305; Ormerod 1994, pp. 938-939 and Strijards 1987, p. 70.

460 Bohlander 2009, p. 82; Schönke \& Schröder, H. 2006, p. 595 and Fletcher 1975, p. 305.

461 Schönke \& Schröder, H. 2006, p. 593. See Strijards 1987, p. 69.

462 Beulke 2008, p. 127.

463 Strijards 1987, pp. 68-69 and Nieboer 1991, p. 259. See Roxin 2006, pp. 539-540.

464 Simester \& Sullivan 2007, pp. 685-686 and Ashworth 2006, p. 318. See Nieboer 1991, pp. 259260.

46522 April 2005 BGH NJW 2005, 1876; Simester \& Sullivan 2007, pp. 701-703 and Ormerod 1994, p. 939. 


\subsection{Criteria}

Consent is limited by several cumulative conditions. As follows from a moralist perspective, the act consented to must not violate public policy. The rationale of autonomy explains why the actor must be the sole disposer over the individual legal interest that is at stake and third, that the consenting party must be capable to give his consent. Mistakes on behalf of the victim are usually reproached to the defendant, because only foreseen consequences can be consented to.

The cumulative conditions of consent often overlap. Consider that the victim consented to a fight with the defendant, as a result of which he died. Under the first condition, the victim cannot consent to his killing because that offence also serves a public interest. Secondly, consent can be rejected because the seriousness of the harm violates public policy. As a third stumbling block to acceptance of the defence, the victim would have probably not have consented if he knew this would be the consequence of the challenge. Even if he consented to the possibility of serious injuries, it is unlikely he would consent to his death. In legal comparison, this overlap mitigates the different approaches to individual conditions. Even if one condition would be fulfilled in one State but not in another, the plea is likely to fail in that State under a subsequent condition too.

\subsection{Waived interests}

The application of consent is limited to those legal interests where the legal order creates the possibility for the protected person to use his right to self-determination to abdicate legal interests. In short, consent is limited to offences that aim to protect individual interests and to cases where consent does not violate public policy. ${ }^{466}$

\subsubsection{Individual legal interests}

From the rationale of individual autonomy, it follows that the consenting party can only waive legal protection if he is the only bearer of the interest that is affected. For consent to apply, it is required that the pertinent offence only aims to protect an individual interest. The person concerned has no title to give consent when it concerns the violation of a legal interest that is public, even if he is directly concerned by the act. For example, perjury, fraud and double marriage can be consented too, but remain criminal, since the offence aims to protect public interests. ${ }^{467}$

\footnotetext{
466 Beulke 2008, p. 127-128; Bohlander 2009, p. 83 and Cleiren \& Nijboer 2008, note 11 on Boek I Titel III Inleidende opmerkingen.

46714 May 1970 BGHSt 23, 261; 22 April 2005 BGH NJW 2005, 1876; Schönke \& Schröder, H. 2006, p. 594; Roxin 2006, pp. 555-556 and Beulke 2008, p. 128.
} 
Often, an offence aims to protect not only an individual but also a public legal interest. ${ }^{468}$ In that case too, the consent of the person directly concerned does not justify the offence. For the defence to apply, the consenting person must be the only bearer of the interest. ${ }^{469}$ In other words, the consent can negate the infringement of the individual interest, but it cannot affect the concomitant violation of the public aspect of the offence. For example, killing on desire is still criminal because it violates the public interest of sanctity of life. ${ }^{470}$ In the case against the Rotenberg Cannibal, consent did not apply because the prohibition to kill also serves a public legal interest that the victim cannot abdicate. ${ }^{471}$

Exceptions to the limitation are made if the public aspect of the interest that is violated is relatively trivial, like in a false accusation. If the individual aspect of the offence is dominant and the offence is not very serious, like insult, the undeniable freedom of the individual to determine, within certain limits, which suffering he wants to bear must bring about that consent applies. ${ }^{472}$

\subsubsection{Public policy limitations}

Even if the offence is considered to merely serve individual interests, it cannot always be consented to as public policy concerns may override the consent of the party concerned. Consider again the act of killing on desire: human life is an individual legal interest, but the taboo on taking human life outside situations of self-defence brings about that consent cannot apply. ${ }^{473}$ If consent could apply to homicide, killing on desire would not have been drafted as a specific offence.

If the conduct leads to the death of the consenting party, or if it creates a concrete endangerment to that party's life, the threshold of public policy is exceeded. ${ }^{474}$ Consent was therefore rejected in the case where the defendant argued that the victim had asked to be tied to a bed and poured with gasoline, after which she was asked to play with a lighter. It was held that even if this consent was accepted as credible, it could not negate a conviction for killing the victim. ${ }^{475}$ The weight attached to the sanctity of human life in England and Germany explains why the scope of necessity, duress and consent is limited. The lack of such an explicit limitation in Dutch law reflects a more pragmatic approach, evidenced by the lack of a priori restrictions to necessity and duress and the legalization of euthanasia. Nevertheless, consent to being killed in other situations is legally irrelevant too.

\footnotetext{
468 Kelk 2005, p. 152 and Krey 2002, pp. 8-9.

46914 May 1970 BGHSt 23, 261.

470 HR 27 November 1984, NJ 1985, 106 and Schönke \& Schröder, H. 2006, p. 594.

47122 April 2005 BGH NJW 2005, 1876.

472 Kelk 2005, p. 152 and Roxin 2006, pp. 556-557.

$473 \$ \$ 216$ and 228 of the German Criminal Code; Bohlander 2009, p. 83 and Beulke 2008, p. 128 Compare article 3:40 of the Dutch Civil Code.

47420 November 2008 BGH NJW 2009, 1155 and Roxin 2006, pp. 560-561.

47520 June 2000 BGH NStZ 2000, 583.
} 
In principle, severe and irreversible injuries can also not be consented too. ${ }^{476}$ The restriction of the individual right to self-determination is warranted because it helps general prevention. It also helps society to protect individuals against themselves, since victims tend to rely heavily on public funds. ${ }^{477}$ In this context, the scope of consent is limited the most in England, which is not surprising given the general emphasis on public policy in English criminal law. The rule under English law is that consent cannot be a defence when the harm intended or inflicted is 'actual bodily harm' or worse. ${ }^{478}$ Actual bodily harm need not involve any injury of any significance. 479

Hence, when two people agree to fight in England, their consent does not negate a charge of assault when actual bodily harm is the result. ${ }^{480}$ In contrast, it is accepted in Germany that people can consent to fights that do not result in serious injuries. ${ }^{481}$ Apparently, public policy does not militate against this fact. It is unlikely that such a defence would acquit the defendant in the Netherlands. ${ }^{482}$ Even if it would, in order to ground liability, it could be argued that this offence of affray (also) aims to protect a public legal interest that cannot be consented to.

It has been suggested in England to apply a wider scope of consent by including harm that falls short of serious injury. ${ }^{483}$ However, the aforementioned difference is put into perspective if we consider that public policy considerations cannot only limit but also extend the scope of consent. On the one hand, the seriousness of the harm is at odds with applying consent, but on the other, lawful or legitimate reasons for committing an offence can compensate this, allowing the consenting party to waive legal protection nonetheless. ${ }^{484}$ More can be consented to in the pursuit of acceptable goals. Even serious bodily harm can be consented, explaining why patients can consent to complex medical operations, tattooing and violent sports. ${ }^{485}$ The purpose of conduct can compensate the seriousness of the offence in all Member States under investigation. It is therefore impossible and unnecessary to identify an absolute threshold on the seriousness of the harm in the context of the public policy restriction.

\footnotetext{
476 Simester \& Sullivan 2007, p. 697 and Roxin 2006, pp. 559-560.

477 Roxin 2006, pp. 560-561.

478 Simester \& Sullivan 2007, pp. 686-687.

479 Simester \& Sullivan 2007, p. 696. Bodily harm under sections 20 and 47 of the Offences Against the Persons Act 1861 even includes psychiatric injury and its effect, see R. v. Dica [2004] EWCA Crim 1103.

480 Attorney General's Reference No. 6 of 1980 [1981] EWCA Crim 1.

481 See 8 May 1990 BGH NStZ 1990, 435 and Schönke \& Schröder, H. 2006, p. 648.

482 Peters, A.A.G. 1966, pp. 142-143 however mentions such a non-published decision of a Dutch Court of Appeal of 1964.

483 Simester \& Sullivan 2007, pp. 701-702.

484 R. v. Dica [2004] EWCA Crim 1103. Spencer 2004, p. 448 suggests that even if one may not consent to the deliberate infliction of harm, the victim may consent to running the risk of that harm.

485 Roxin 2006, p. 559; R. v. Brown [1993] 2 All ER 75; R. v. Dica [2004] EWCA Crim 1103 and Allen 1994, pp. 187 and 192.
} 
What act is considered to be unacceptable to the legal order used to be determined quite paternalistic. Only generally accepted morals were held to be valid. For example, sado-masochistic activities were held to violate these public morals and could not be consented to. ${ }^{486}$ If the reasons for acting seemed inappropriate to the legal order, consent could not apply. ${ }^{487}$ This moralizing approach is however increasingly abandoned and the weight has been shifted to the more objective criterion of seriousness of the harm or danger. ${ }^{488}$ Sado-masochistic motivations do not vitiate the consent of the person concerned: this is only vitiated if the act creates a concrete danger to life. ${ }^{489}$ This approach leaves more room for the individual right to self-determination and free sexual development. However unreasonable the interference may be to the average person, consent is valid as long as no serious harm is inflicted upon the consenting party. 490

It can be argued that although English law also focuses on the severity of the harm, the England judiciary still takes the most paternalistic approach. After all, in contrast to the German case mentioned above, a group of homosexuals engaging in consensual sado-masochistic activities were convicted in 1993 of inflicting serious bodily injury. Consent was held not to be a defence to the charges of assault, despite the fact that the acts were carried out in private and no permanent injuries were sustained, "because public policy required that society be protected by criminal sanctions against a cult of violence which contained the danger of the proselytization and corruption of young men and the potential for the infliction of serious injury." 491 Before the ECtHR, the defendants argued that their rights under art. 8 ECHR had been violated. However, the ECtHR dismissed the complaint by ruling that it is a duty of the State to criminalize violent conduct in order to protect public health. Like the Court of Appeal confirmed in another case, it considered that serious violence does not become a lawful activity because it enables the actor to achieve sexual gratification. 492

The conviction of the men attracted much criticism. The case has been explained by reference to the underlying fear of judges that applying consent to the case would imply approval of the conduct. ${ }^{493}$ By comparing it with the case in which the defendant burned his initials into his wife buttocks with her consent, it has been argued that English law is internally inconsistent and occasionally irrational.

4863 January 1928 RG JW 1928, 2229 and 12 October 1928 RG JW 1929, 1015.

48723 February 1940 RGSt 74, 91 and 29 January 1953 BGHSt 4, 24.

488 Roxin 2006, pp. 565-567; Beulke 2008, p. 130; Cleiren \& Nijboer 2008, note 11 on Boek I Titel III Inleidende opmerkingen.

48926 May 2004 BGHSt 49, 166; 11 December 2003 BGHSt 49, 34; Beulke 2008, p. 130 and Roxin 2006, p. 566.

4902 December 1976 BGH NJW 1978, 1206 and Roxin 2006, p. 562.

491 R. v. Brown [1993] 2 All ER 75.

492 R. v. Dica [2004] EWCA Crim 1103 and Laskey, Jaggard and Brown v. the United Kingdom, appl. nos. 21627/93, 21826/93 and 21974/93, 20 January 1997. See also Simester \& Sullivan 2007, p. 700 and K.A and A.D. v. Belgium, appl. nos. 42758/98 and 45558/99, 17 February 2005. 
Although medical assistance was needed, the husband could rely on his wife's consent. The court held that there are recognized exceptions to the rule that consent cannot apply to inflicting bodily injury. A comparison was made to tattooing, the respect for the privacy of the matrimonial home emphasized. ${ }^{494}$

In any event, it has become clear that the English approach to consent differs from the German approach. The English approach is to vitiate consent to all degrees of bodily injury, unless it is committed for a lawful purpose, whereas the Germans only vitiate consent to serious bodily injury if it is not committed for a lawful purpose. In other words, consented injuries are either 'wrongful, unless' or 'lawful, unless' ${ }^{495}$ The different starting points bring about that the scope of consent is in fact most restricted in England. Results will however not be very different in the majority of cases, because the principle rule is that dangers or actual infringements to the bodily integrity can be consented to. The more laudable the purpose of the conduct or the overall situation, the more serious the danger or harm may be. Finally, the condition of public policy is by definition highly normative and casuistic, making it difficult to deduce general principles from the extreme cases that have been compared.

\subsection{Capacity}

The consenting party must possess the capacity to consent. He must have the necessary intellectual and moral maturity to make a free and informed decision and that he understands the nature and consequences of what he is consenting to. ${ }^{496}$ First of all, an element of personal capacity can be distinguished, related mostly to the abstract ability to make decisions. Especially when the consenting party is minor or suffering from a mental disorder, this narrow meaning of capacity can be questioned. Sane adults can also be incapable of giving their consent, for example, when they are in a coma. In cases like this, German doctrine applies the fiction of presumed consent.

The difficult and possibly stigmatizing question on whether the victim is capable to give his consent is often left undecided by simply grounding the rejection of consent in not fulfilling other conditions. For example, the question of whether the victim of the Rotenberg Cannibal was capable to consent to his killing and eating was left undecided, since the defence could already be rejected by arguing that the

\footnotetext{
494 Simester \& Sullivan 2007, p. 686 referring to R. v. Wilson [1997] QB 47.

495 Compare $\$ 228$ of the German Criminal Code, translation by Bohlander 2008, p. 153: "Whosoever causes bodily harm with the consent of the victim shall be deemed to act lawfully unless the act violates public policy, the consent notwithstanding."

496 Section 74 of the Sexual Offences Act 2003; Simester \& Sullivan 2007, p. 685; 7 September 1998 BayObLG NJW 1999, 372; Bohlander 2009, p. 84; Fischer, T. 2009, p. 275 and Beulke 2008, p. 128.
} 
prohibition to kill and to desecrate a corpse also serve a public legal interest that the victim cannot abdicate. ${ }^{497}$

In addition, a more concrete element of being correctly informed on the scope of the consent is required. In order to be capable to give consent, the consenting party must have been properly informed so it can be said that he foresaw the act and its consequences. Mistakes due to insufficient or incorrect information will negate consent. Moreover, the consent must have been voluntary. If he was coerced in some way, the consent is not free. Any force, deception or error negates the voluntariness of consent. 498

\subsubsection{Intellectual and moral maturity}

Capacity in a narrow meaning requires that the consenting party has the intellectual and moral maturity to oversee the consequences of actions. In general, adults that are properly informed are assumed to have capacity, unless there is reason to assume otherwise. As long as the person concerned is capable to give consent, this does not have to be reasonable. For instance, medical treatment may be refused, even if it leads to death. ${ }^{499}$ By contrast, certain persons are unable to waive the protection of the law. If the person involved is mentally abnormal or a minor, scepticism on the validity of consent is appropriate. ${ }^{500}$ In sexual offences against vulnerable persons, for example, the consent of the victim is made irrelevant by an irrebuttable presumption that the victim is incapable to give his or her consent freely and responsibly. ${ }^{501}$

There exists a strong relationship with the capacity to be held blameworthy or to commit crimes, which is clear in the context of insanity and infancy. However, the capacity to consent does differ from the lacking capacities in insanity or infancy. ${ }^{502}$ In contrast to infancy, usually no absolute threshold of age applies. The capacity to give a free, informed consent depends also on the individual maturity and the reasonableness of the consented act. When the consequence may be serious, the minor will generally need to be older to be able to give his consent. This can be compensated again if the purpose is legitimate like in medical surgery. ${ }^{503}$ The

498 Cleiren \& Nijboer 2008, note 11 on Boek I Titel III Inleidende opmerkingen.

499 Re C. (Adult: refusal of treatment) [1994] 1 WLR 290. See also 19 October 1971 BVerfG 32, 98.

500 Kelk 2005, p. 152.

501 Roxin 2006, p. 557; R. v. C. [2009] UKHL 42 and section 30 of the Sexual Offences Act 2003. By contrast, in recital 10 of the preamble of Directive 2011/93 of 13 December 2011 on combating the sexual absue and sexual exploitation of children and child pornography, and replacing Framework Decision 2004/68, OJ 2011 L 335/1, the disability itself does not automatically constitute the impossibility to consent.

502

503 Schönke \& Schröder, H. 2006, pp. 595-596 and 22 January 1953 BGHSt 4, 88.

Simester \& Sullivan 2007, pp. 695-696; Elliott and de Than 2007; 10 February 1959 BGHSt 12, 379; Roxin 2006, p. 574; Bohlander 2009, pp. 85-86 and Schönke \& Schröder, H. 2006, pp. 594-596. 


\section{Justifications}

capacity to consent is also related to, but not similar to the capacity to conclude legal acts under civil law. ${ }^{504}$

Nevertheless, in certain areas of law, special rules on the capacity to consent apply, often constituting of a specific age. ${ }^{505}$ In English law, a minor under 13 years cannot consent to sex, even if the partner is also a minor. The scope of statutory rape is therefore wide. The 15 -year-old boy who had consensual intercourse with a 12-year-old girl was convicted of statutory rape. ${ }^{506}$ This approach can be contrasted with the more flexible Dutch approach. In the Netherlands, the sexual abuse of minors can be justified by consent. This is not easily accepted, but it does apply when the parties involved are both minors. The smaller the difference in age, the more likely the consenting intercourse will not be held to be abuse. ${ }^{507}$ The Union leaves this issue to the discretion of its Member States. ${ }^{508}$

\subsubsection{Presumed consent}

In German law, the doctrine of presumed consent operates as a justification sui generis, ${ }^{509}$ based on customary law. It constitutes a legal explanation of cases where no liability follows despite the fact that the person concerned did not consent. Consider emergency cases where the patient is unconscious and in dire need of medical treatment. 510 The doctor is justified to operate if he may presume the patient would consent if he could. These cases must be distinguished from cases of consent by a representative, such as consent of a parent on behalf of a minor. Both deal with persons who are incapable of giving their consent, but the inability to give consent in presumed consent is of a more temporary nature. ${ }^{511}$ Clearly, presumed consent cannot apply if the person concerned had already made known what he wanted if he would end up in the situation he is in.

The right to self-determination brings about that presumed consent may only be applied in dire circumstances. It can only apply if it is impossible to receive a

504 R. v. Hinks [2000] UKHL 53; 7 September 1998 BayObLG NJW 1999, 372 and Bohlander 2009, pp. 84-85. See $\S \S 104$ and 107 of the German Civil Code and articles 3:32 and 3:34 of the Dutch Civil Code.

505 Roxin 2006, p. 578 and Schönke \& Schröder, H. 2006, pp. 596-597. For example, the sexual offender must, amongst others, be 25 years to consent to voluntary castration, which can mitigate his sentence in German law, see section 2(3) of the Castration Act (Kastrationsgesetz).

506 Section 5 Sexual Offences Act 2003 and R. v. G. [2008] UKHL 37. She had told him she was fifteen, but the element of age is strict. The conviction is less controversial if it considered that the girl argued she did not consent. See also G. v. the UK, appl. no. 37334/08, 30 August 2011.

507 Article 247 of the Dutch Criminal Code; HR 24 June 1997, NJ 1997, 676; Kelk 2005, p. 153 and de Hullu 2006, p. 338.

508 Article 8 of Directive 2011/93, mentioned above.

50925 March 1988 BGHSt 35, 246; Fischer, T. 2009, p. 275 and Schönke \& Schröder, H. 2006, p. 602 .

510 Bohlander 2009, pp. 88-89; Beulke 2008, p. 131 and Kuhlen in Schünemann a.o. 2001, p. 333. Compare Mevis 2011, p. 554.

511 Roxin 2006, pp. 578-580 and Schönke \& Schröder, H. 2006, pp. 596-598. 
genuine consent and when a later operation, when desired, would seriously limit the chances of saving an important interest of the patient. For example, a doctor had to perform a Caesarean section and had asked the patient beforehand, if she wanted to be sterilized at the same time. She had refused. The doctor, however, due to complications during surgery, feared that renewed pregnancy might have lethal consequences and sterilized anyway. The German Supreme Court rejected presumed consent because the risk of future lethal consequences was only small and could be prevented by contraceptives. Moreover, a future operation, to which she could consent, would not have presented an increased risk for the patient. ${ }^{512}$

The weight of the right to self-determination also brings about that the presumed consent of the person concerned must be established by reference to his individual interests, needs, wishes and values. It is a judgment of probability on his hypothetical will, not an objective evaluation of what is best for a reasonable person like in necessity. The reasonable person will only be taken as a starting point if there are no individual desires known and no concrete indications to the contrary. Unlike the defence of necessity, it is therefore not about an objective evaluation, but about an ex ante judgment of probability on the hypothetical will of the party concerned. Just like an actual consent, this need not be reasonable. ${ }^{513}$

By contrast, in England, medical treatment upon incompetent patients and competent but unconscious adults is justified by necessity under a rationale of best interests. For example, a court decided that the sterilisation of a mentally retarded sexually active woman would be in her best interests. ${ }^{514}$ It does not seem possible to presume consent. For example, a man lapsed into a coma and died. Shortly before his death, a sample of his sperm was collected to be used for insemination. However, in the absence of a written consent of the donor, the responsible authority prohibited this. Fortunately for the wife, she could rely on the Union right to freedom of services to be inseminated in a Belgium clinic. ${ }^{515}$ In the Netherlands, these cases are also solved by an objective standard. If medical intervention is reasonably necessary given the circumstances, wrongfulness will be negated based on the rights that come with a doctor's profession. ${ }^{516}$

This approach does not clearly distinguish the defence from necessity. That justification is about the objective general benefit. The autonomy of the patient is only taken into account as a factor in the weighing of interests. By contrast, consent is based on the autonomy of the person concerned. Hence, by treating these

5124 October 1999 BGHSt 45, 219; Roxin 2006, p. 826; Beulke 2008, p. 131; Bohlander 2009, pp. 88-89 and Schönke \& Schröder, H. 2006, pp. 602-603.

513 This also brings about that the fact that it later turned out that the party concerned would have not consented does not make the surgery wrongful. It is about the assessment ex ante. See 4 October 1999 BGHSt 45, 219; 25 March 1988 BGHSt 35, 246; Roxin 2006, pp. 594 and 823825; Beulke 2008, pp. 131-132 and Schönke \& Schröder, H. 2006, pp. 602-603. F. v. West Berkshire HA [1989] 2 WLR 1025; Chan \& Simester 2005, p. 127 and Rogers 2001, pp. 517-518.

515 R. v. Human Fertilisation and Embryology Authority, ex parte Blood [1997] 2 All ER 687.

516 See Mevis 2011; Kelk 2005, pp. 157-160 and de Hullu 2006, p. 337. 
situations as presumed consent, the subjective will of the person concerned is given most weight. Nevertheless, presumed consent is hardly ever relevant. It cannot apply to the mentally incompetent patients in the aforementioned cases, because they cannot consent at all. These cases must be dealt with under necessity in Germany too. Moreover, in most cases, the objective presumption that someone wants to be operated will turn out to be correct, therefore not generating any dispute. Disputes are most likely to arise in cases where people would have rejected surgery based on their religious beliefs if they could have expressed their will. In any event, doctors who operate on these persons in emergency situations should not be held liable.

\subsubsection{Free and informed consent}

The consenting party can only be deemed to have been capable to waive legal protection of his interest, if he made the decision voluntarily and in full knowledge of the relevant facts and circumstances. The object of consent is the act and its consequences. The consenting party must have a correct perception of this. ${ }^{517}$ Possible consequences must at least be taken for granted by the party concerned; he cannot consent to some risk he does not know or trusts will not occur. ${ }^{518}$ For example, he may have consented to a lesser harm of bodily injury, but not to the risk on, let alone occurrence of death. After discussing the role of regulated activities, I will discuss the different ways in which the free and informed decision may come under pressure.

In some contexts, the law assumes what the consenting party foresaw. When bodily injuries are for example incurred in the context of violent sports like boxing, it is assumed that the party concerned foresaw and consented to this possibility. ${ }^{519}$ In non-violent sports like football, it is also accepted that the participants to some extent expect to be harmed. The rules of the pertinent game or sport form an important regulating principle. In all Member States, serious fouls on the playing field have led to a trial on the question whether criminal liability is warranted. On the one hand, the intentional or reckless infliction of bodily injury in non-violent sports constitutes a grave foul and is therefore not consented to. ${ }^{520}$ On the other hand, it is accepted that the participants of the activity consented to violations of the rules of the game that the participants take into account, which are based on inter alia over eagerness, excitement, absence of consideration, stupor, imperfect game technique or failing control over the body. Injuries are accepted as consented to

517 Article 3(2) CFR; 22 January 1953 BGHSt 4, 88 and 12 October 1999 BGH NStZ 2000, 87.

518 Schönke \& Schröder, H. 2006, p. 594.

519 Simester \& Sullivan 2007, pp. 697-699.

520 HR 22 April 2008, NJ 2008, 375. 
when they are a typical and thus foreseeable consequence of playing the game or within its bounds of tolerance. ${ }^{521}$

The perception of the consenting party can be distorted for many reasons. Amongst others, a free and informed decision can be absent due to mistakes, deception, coercion, provocation or intoxication. ${ }^{522}$ Regarding intoxicated mistakes, the consenting party must possess the necessary ability to judge and peace of mind to oversee the scope of his declaration and to weigh the pros and cons. This allows the German judge to reject consent in drunken challenges to fight, ${ }^{523}$ mitigating the aforementioned difference that in England and the Netherlands, consensual fights would already be excluded under the other conditions. In general, it is logical that the more complex and far-reaching the consent of the party concerned is, the more likely it will be affected by mistakes.

Informed consent presupposes that a doctor is clear about the necessity, goal and risks of surgeries. ${ }^{524}$ Therefore, when the doctor lied to the patient about the actual need for surgery, namely to remove an instrument that had been left behind in the patients body after the last surgery, he was liable for inflicting bodily injury. ${ }^{525}$ Not every misconception of the patient will vitiate his freedom to choose, as errors about accompanying circumstances are irrelevant. The exact demarcation is casespecific. ${ }^{526}$ Secondly, ignorance on behalf of patients due to improper information also need not vitiate consent if it is established that he patient would have also given his consent if he had properly been informed. ${ }^{527}$ Similarly, in English law, the appropriation of theft is not 'dishonest' if the actor took something away believing the other would consent if he knew of the appropriation and its circumstances. ${ }^{528}$

In the perspective that only misconceptions on 'essential' elements of the activity consented to may vitiate consent, it can also be argued that sexual intercourse with a prostitute does not become rape because the defendant did not pay. ${ }^{529}$ By contrast, there was a mistake on the essential nature of the activities in the case where a woman believed she was medically examined for breast cancer, when in fact it was the other party's purpose to gratify his sexual needs. ${ }^{530}$

5213 August 1961 BayObLGSt 1961, 180; Berkl 2007, pp. 115-117; HR 20 February 2004, $L J N$ :AO1239; HR 22 April 2008, NJ 2008, 375; Kelk 2005, p. 153; R. v. Barnes [2004] EWCA Crim 3246 and Simester \& Sullivan 2007, pp. 697-699. R. v. Bree [2007] EWCA Crim 804; Fokkens \& Machielse, note 10 on Wederrechtelijkheid and Cleiren \& Nijboer 2008, note 11 on Boek I Titel III Inleidende opmerkingen. 22 January 1953 BGHSt 4, 88 and 12 October 1999 BGH NStZ 2000, 87.

52428 November 1957 BGHSt 11, 111; 10 February 1959 BGHSt 12, 379; 1 February 1961 BGHSt 16, 309 and Hof Amsterdam 16 December 2010, LJN:BO7707.

52520 January 2004 BGH JR 2004, 469.

52629 June 1995 BGH NStZ 1996, 34; Bohlander 2009, p. 86; Beulke 2008, p. 129; Roxin 2006, pp. 581-587 and Schönke \& Schröder, H. 2006, p. 599.

527 This is called hypothetical consent in Germany, see 15 October 2003 BGH JZ 2004, 799; Beulke 2008, p. 132; Roxin 2006, pp. 590-592 and Kuhlen in Schünemann a.o. 2001, p. 333.

528 Section 2(1b) Theft Act 1968. See also section 5(2a) of the Criminal Damage Act 1971.

529 R. v. Linekar [1994] EWCA Crim 2 and Simester \& Sullivan 2007, p. 694.

530 Spencer 2007, p. 491. 
Furthermore, the consent to sex is not vitiated when the defendant failed to disclose he was infected with a sexually transmitted disease. ${ }^{531}$ Nevertheless, it is clear that the victim did not consent to grievous bodily harm by being infected with HIV as a result of unprotected sex..$^{532}$

Force or threats that exclude the freedom of choice clearly vitiate consent. ${ }^{533}$ More controversial is whether lesser forms of coercion also invalidate consent. Whereas some refer to a relatively high threshold that is similar to the threat of duress or the threat in offences of coercion, ${ }^{534}$ others argue that if a deception can vitiate consent, lesser degrees of coercion surely must negate consent as well. ${ }^{535}$ In England, pressure falling short of physical harm, such as non-physical threats or circumstances may suffice to vitiate consent. ${ }^{536}$ Again, the demarcation of relevant from irrelevant limitation to the freedom of choice is case-specific. ${ }^{537}$

In some cases, the law presumes that coercion of some kind precludes a free consent. For example, the English Sexual Offences Act 2003 creates rebuttable presumptions that consent should be vitiated in case of the use of force or when the complainant was asleep or unconscious. The presumption that consent is not given freely can also not be refuted in cases where the defendant impersonates a person known personally to the complainant. ${ }^{538}$ In Framework Decision 2004/68 on combating the sexual exploitation of children, the consent of a child "shall not be considered valid, if for example superior age, maturity, position, status, experience or the victim's dependency on the perpetrator has been abused in achieving the consent." 539 In the Directive on trafficking in human beings, the consent of victims to any offence of human trafficking is irrelevant. ${ }^{540}$ There is an irrebuttable presumption that the victims are in a situation in which they cannot choose freely.

\subsection{Affirmative or failure of proof defence}

As explained earlier in this chapter, it can become controversial whether a defence should be considered as a failure of proof or affirmative defence. Regarding consent,

\footnotetext{
531 R. v. EB [2006] EWCA Crim 2945.

532 R. v. Dica [2004] EWCA Crim 1103 and R. v. Konzani [2005] EWCA Crim 706.

533 Bohlander 2009, p. 88 and Cleiren \& Nijboer 2008, note 11 on Boek I Titel III Inleidende opmerkingen.

534 Roxin 2006, pp. 588-589.

535 Schönke \& Schröder, H. 2006, pp. 599-600.

536 R. v. Olugboja [1981] EWCA Crim 2. See also Simester \& Sullivan 2007, pp. 689-691.

537 Schönke \& Schröder, H. 2006, pp. 599-600.

538 Sections 75-76 of the Sexual Offences Act 2003. See also Spencer 2007, p. 491.

539 Framework Decision 2004/68 of 22 December 2003 on combating the sexual exploitation of children and child pornography, OJ 2004 L 13/44.

540 Article 2(4) of Directive 2011/36 of 5 April 2011 on preventing and combating trafficking in human beings and protecting its victims, and replacing Framework Decision 2002/629, OJ 2011 L 101/1.
} 
this controversy is very clear. ${ }^{541}$ Consent can negate offence elements of wrongfulness, culpa and even elements such as 'offensive'. For example, the operator of a cinema was charged with an offence against the public decency for showing a pornographic movie. The Dutch court held that when people have been warned about the explicit content of a movie and wish to view it nonetheless, their consent negates the offensiveness of the conduct. ${ }^{542}$

It is accepted that consent operates as a failure of proof defence to negligent offences. This is logical because culpa absorbs the justification. Consent thus determines whether someone acted negligently. ${ }^{543}$ There is however no consensus on how this operates in detail. It can be questioned whether consent extends the scope of the allowed risk or whether under a principle like self-endangerment, the result should not be attributed to the defendant if the risk or harm was consented to by the party concerned. ${ }^{544}$ The latter view is popular in Germany. ${ }^{545}$ For example, when the actor supplied the victims with narcotics, they may be assumed to have consented to the risks in using it. If those risks materialize, they cannot be attributed to the actor. However, the consent is also only valid if it is based on a correct perception of the relevant facts by the victim. The defendant, who (inadvertently) supplied pure heroine to a person asking for cocaine, was therefore held liable for (negligently) causing the ensuing death. ${ }^{546}$

A minority argues that consent should always be considered as a failure of proof defence. It is argued that consent should not be considered to be a justification because there is no conflict of interests. The waiver of legal protection simply brings about that there is no infringed interest. ${ }^{547}$ As argued before, by focusing on the legitimate purpose of the activity that is consented to, consent can also be seen as a conflict and weighing of interests. A patient accepts the pain and risks of surgery because it is a lesser evil than letting his illness deteriorate. Even if this view is rejected, consent can be labelled a justification under a dualist rationale of superior and absent interest.

\subsubsection{Distinguishing feature}

Prevailing opinion in Germany and the Netherlands holds that in some cases, consent negates the offence whereas in other cases, it justifies the offence. The guidelines developed in the beginning of this chapter also apply here. When an

541 R. v. Brown [1993] 2 All ER 75; Simester \& Sullivan 2007, pp. 607-608; Livings 2007; Mevis 2006, p. 630; Dolman 2006, p. 314 and Schönke \& Schröder, H. 2006, p. 319.

542 HR 28 November 1978, NJ 1979, 93.

543 HR 31 October 2006, NJ 2007, 79 and Mevis 2006, p. 630.

544 Roxin 2006, pp. 568, 820 and 1098-1102.

54514 February 1984 BGHSt 32, 262; 20 November 2008 BGH NJW 2009, 115; Berkl 2007 and Beulke 2008, pp. 257 and 342.

54629 April 2009 BGH NStZ 2009, 504.

547 Like Roxin 2006, pp. 545-555 and Ashworth 2006, p. 318. See Beulke 2008, p. 125 and Schönke \& Schröder, H. 2006, p. 592, who reject this view. 
offence includes wrongfulness in its offence definition, it implies that consent operates as a failure of proof defence rather than a justification. If the character of the offence is however that something is done against the will or without permission of the party concerned, consent operates as a failure of proof. For example, the absence of consent is usually an offence element in offences against the property. By contrast, if the offence element of wrongfulness is not essential to the offence, like in the offence of inflicting bodily harm, consent can only justify the offence. ${ }^{548}$

This approach is also evident in the German doctrine on official authorisation, which can be considered to be a specific manifestation of consent. A doctrinal distinction is made between authorized conduct that is not as such materially forbidden, like driving. This even has social use and is made subject to authorization only to ensure the actor abides by the proper standards. On the other hand, there is the authorisation of conduct, which is materially forbidden as such and thus constitutes an exemption to a general ban on the basis of some higher-raking interest, like manufacturing weapons of war. Authorisations in the category of prima facie legal conduct negate the offence definition whereas authorisations of the second category operate as a justification. ${ }^{549}$

\subsubsection{Defensive purpose}

The distinction is relevant because the conditions of consent as a failure of proof defence are more lenient than those of the consent as a justification. First of all, the general ramifications of defences that operate as a failure of proof apply. As mentioned, if consent operates as a failure of proof defence, a mistaken belief in consent can negate intention and the defendant need not be aware of the permission. ${ }^{550}$ From this difference relating to the defensive purpose, an implication specific to consent is accepted in Germany. It is argued that if the defendant must know of the consent, this brings about that the victim must have made his consent externally known, which can range "from actual desire on the one hand to reluctant acquiescence on the other," 551 On the contrary, since this awareness is irrelevant when consent operates as a failure of proof, the person concerned need not have made his will known. ${ }^{552}$

548 Beulke 2008, pp. 125-126; Bohlander 2009, pp. 77 and 214 and de Hullu 2006, pp. 336-337. See Roxin 2006, pp. 540-548.

549 Bohlander 2009, pp. 89-90 and Schönke \& Schröder, H. 2006, p. 605.

5503 October 1978 BayObLG NJW 1979, 729 and Beulke 2008, p. 127.

551 R. v. Olugboja [1981] EWCA Crim 2. The will may be expressed to a third party, but the acquiescence must be distinguished from quite submission or surrender, see also R. v. Bree [2007] EWCA Crim 804; Simester \& Sullivan 2007, p. 689; Williams 1953, p. 611; Schönke \& Schröder, H. 2006, p. 598; Beulke 2008, p. 130 and Roxin 2006, pp. 570 and 579-580.

3 October 1978 BayObLG NJW 1979, 729 and Beulke 2008, p. 127. 


\subsubsection{Capacity to consent}

German scholars add another difference specifically related to consent. The requirement of having the capacity to consent is much more lenient when it operates as a failure of proof defence. What is required is a voluntary, 'natural will', which can also exist with infants and the insane that lack the capacity to justify an offence by consent. For example, the absence of consent is implied in the offence element 'abducted'. Even an insane person can consent to being abducted and negate this offence. ${ }^{553}$ Since a mere natural will is generally less sensitive to errors, deceptions are less likely to vitiate consent when it operates as a failure of proof defence. It is even argued that deficiencies in the will by coercion, deception or mistake are irrelevant to the failure of proof defence. ${ }^{554}$

\subsubsection{Contextual approach}

Some scholars argue that the required degree of capacity depends on the legal interest as to which the consent relates and the other circumstances of the case. As mentioned, this is also the approach when consent operates formally as a justification. Therefore, even if consent operates as a failure of proof, more than a natural will could be required. For example, a natural will suffices to negate offences of coercion and theft and can therefore be given by a child or insane person. In contrast, they need to have a better understanding of what they are consenting too in offences like insult and privacy violations. ${ }^{555}$

This contextual approach is gaining ground, mostly because the classification of consent as a failure of proof or affirmative defence is controversial. In Germany, there exists controversy on the categorisation of offences like insult, bodily injury and damaging goods. ${ }^{556}$ One could even argue that consent operates in different ways in the same offence. After all, the infliction of bodily injury constitutes a prima facie wrong, as to which the absence of consent is no essential element. However, it would be inappropriate to argue that the doctor who operates with consent is justified. In fact, no court in the Member States under investigation would hold that an offence is fulfilled. ${ }^{557}$

The approach is an example of how the conditions of consent are increasingly treated in a contextual way, with regard to the legal interest to which it relates, or

55313 May 1969 BGHSt 23, 1; Beulke 2008, p. 127 and Bohlander 2009, pp. 82-83.

554 Roxin 2006, p. 542 and 815-816; Bohlander 2009, pp. 82-83 and Schönke \& Schröder, H. 2006, pp. 592-593.

555 Schönke \& Schröder, H. 2006, pp. 592-593 and Roxin 2006, pp. 572-574.

556 Roxin 2006, pp. 551-553. See also Beulke 2008, p. 126.

557 Roxin 2006, pp. 552-553. Compare Mulder in Balkema a.o. 1995, pp. 275-276 and Mevis 2011, pp. 549-552. 
the circumstances under which the defendant acts, ${ }^{558}$ rather than by reference to its formal operation to the charge. The legal interest involved, the character of the offence and the question whether consent relates to conduct that is prima facie legal or not, are similar criteria to properly distinguish consent as a failure of proof defence from the justification.

\subsection{Conclusion}

In conclusion, the operation of consent and its ramifications remains controversial. This is not problematic however. First, there is consensus on the essence of consent and secondly, most of the differences are put into perspective. The different approaches to conditions do not necessarily lead to different outcomes, because the conditions are very case-specific and overlap. For example, even if persons can consent to bodily injuries incurred by fighting, the defence can still be rejected because an intoxicated victim lacked the capacity to consent. It can also be rejected because of the seriousness of the harm, either under public policy or based on the argument that even if the victim consented to the possibility of injuries, it is unlikely he would consent to such serious injuries.

As far as the operation of consent as an affirmative or failure of proof defence is concerned, the differences are also put into perspective. In the exceptional cases where the defendant is ignorant of the consent, prosecution or punishment is unlikely to follow, regardless of its operation. After all, there is objectively no harm. Conversely, a putative justification must be reasonable to preclude liability, but as a failure of proof defence, unreasonably assuming that the victim consented can also still amount to negligence liability, if available.

Finally, the general defence of consent is not explicitly regulated, whereas special manifestations of consent, such as in the context of medicine, have been regulated. These specific regulations take into account all the special circumstances of that context. Nonetheless, the general principle of consent, as a failure of proof or affirmative defence, is flexible enough to do justice to the differing contexts. At the same time, it remains coherent enough to be considered a general principle of criminal law. It recognizes that someone's interests may be sacrificed, based on the autonomous will of that person. In principle, the general welfare or legal order need not be furthered, but the limitations of public policy also safeguard that the legal order may not be harmed.

558 Westen 2008A, pp. 568-573. He gives the example of rape. In some circumstances, the sexual intercourse is already a prima facie wrong, regardless of the consent. 



\section{Chapter X \\ EXCUSES}

This chapter will also start with a discussion of the rationale(s) of excuses, followed by the meaning and requirements of its mirror image blameworthiness. Subsequently, it will be argued what self-defence-excess, duress, superior orders, mistake of law and insanity should look like in a general part of criminal law for the EU. Already in the previous chapter, I identified and discussed a due-diligence like excuse that is based on the fact that blameworthiness is an implied element of every crime, including offences of strict liability.

\section{RATionale}

Excuses follow from both retributive and preventive theories on punishment. First and foremost, they are the manifestation and guarantee of the principle that there can be no punishment without guilt. Excuses have been created to make sure that those defendants, who cannot be blamed for their wrongdoing, should not be punished.

Secondly, the application of excuses serves a preventive purpose by communicating that the criminal law has been violated. This defendant is merely excused for committing the wrongful offence. The defendant is distinguished from the general population, and he can thus be spared condemnation and punishment without undercutting the general condemnatory and deterrent functions of criminal law. ${ }^{1}$ It may even be argued that the threat of punishment does not operate as a deterrent to the excused. Consider the defendant who was threatened by death to commit an offence. On the other hand, it has also been argued that the infliction of punishment on the excused serves to strengthen the conformity to law of everyone. ${ }^{2}$ In this perspective, by not making any exceptions to the infliction of punishment upon committing an offence the prohibition and its deterrent effect are strengthened. Those who seek to limit the scope of specific excuses often advance this competing claim.

Different monistic theories of excuses have been advanced. Character theories can be distinguished from theories that centre excuses on the inhibited capacity to act or choose. The basic claim of an excuse within the character theory is that 'although I did it, I was not really myself'. In the normal case, the committing of a wrongful act reflects a reproachable disposition that is hostile towards the legal order. The application of an excuse precludes this inference from the act to the

\footnotetext{
1 Robinson 1982, pp. 226 and 229. It can also be argued on a deontological approach, see Kant in Fletcher 1998, p. 84.

$2 \quad$ Hart 2008 (reprint 1967), pp. 19 and 40-45 and Fletcher 1978, pp. 813 and 816.
} 
actor's character. ${ }^{3}$ The theory has been attacked as punishing people not for what they did but for whom they are. Criminal liability should be about acts rather than character. The defendant must be punished for what he did, not for what he is or has become. $^{4}$

It can be rebutted, however, that under this theory, we are not judging the whole character, but that we are inferring character from a single deed. The theory is not over-inclusive, because bad character does not warrant criminal responsibility when no wrong has been committed. Secondly, if a wrong has been committed but the defendant has not shown in any way bad character, he can also not be criminally liable. What matters is not just the conduct or just the choice to engage in such conduct, but the character traits that can be inferred from the defendant's conduct. ${ }^{5}$

Framed in another way, an excuse represents a limited, temporal distortion of the actor's character. If the defendant has undergone a fundamental shift in character for which he is not responsible, the actions performed as a consequence of that shift do not reflect sufficiently badly upon his settled character. For example, excessive reactions to an attack in a state of despair do not reflect on the defendant's settled character. Actions performed when intoxicated do not reflect on the defendant's settled character as actions performed sober. Nonetheless, the defendant has no excuse if he was responsible for his shift in character, which is the case when he voluntarily intoxicated himself and possibly, when he provoked the attack. ${ }^{6}$

The basic claim of an excuse within the capacity or choice theory is 'I did it but I could not have done otherwise. I had no real choice.' ${ }^{7}$ In other words, the defendant was incapable to conform to the norms of the legal order. ${ }^{8}$ As noted, the inability to act or choose otherwise need not be absolute. That would already preclude the voluntariness of the act. Excuses are said to relate to the moral or normative voluntariness of the conduct. ${ }^{9}$ One is entitled to an excuse if the opportunities for doing otherwise than breaching the criminal law were unfairly diminished. The law cannot ask of anyone more than they can be legitimately expected to do, either intellectually or emotionally. ${ }^{10}$

The two theories seem to perfectly fit excuses like duress and self-defenceexcess. The capacity and choice theories preclude other defences as excuses. For example, offences committed because of political, cultural or religious convictions spring from the actor's character, not from the distorting effect of surrounding

Fletcher 1978, p. 799; Tadros 2005, p. 293 and Beulke 2008, p. 151.

See Krey 2003, pp. 14-15; Schönke \& Schröder, H. 2006, p. 203 and Beulke 2008, p. 140.

Tadros 2005, p. 29; Fletcher 1978, p. 800; Duff 2002, p. 152 and Horder 2006A, p. 118.

Fletcher 1978, p. 802 and Tadros 2005, pp. 297 and 305-306.

Simester \& Sullivan 2007, p. 12 and Dressler in Shute \& Simester 2002, pp. 276-277.

Horder 2006A, p. 9 focuses on the reasons for the defendant's actions. Van Dijk, A.A. 2008, pp. 11 and 33 focuses on the lack of control.

9 Fletcher 1978, pp. 802-803. See also Ashworth 2006, p. 224 and Hart 2008 (reprint 1967), pp. 20-21 and 30 .

10 Bohlander 2009, p. 115. See also de Jong, D.H. \& Knigge 2003, pp. 44-45 and Politoff \& Koopmans 1991, p. 193. 
circumstances. A cultural defence or civil disobedience therefore does not excuse the actor. They reflect his settled character. These offences are voluntary in the deepest sense. One is compelled by their character rather than compelled by circumstances. ${ }^{11}$

Other excuses, like mistake of law and its derivates, like (incompetent) superior orders and putative justifications, do not seem to fit so nicely in any to the two theories. These defences excuse because of unavoidable ignorance of the criminality or wrongfulness of the conduct. Another theory of excuses could therefore focus on the injustice of punishing unavoidable violations of the law. ${ }^{12}$ Nonetheless, the theories come a long way in explaining these types of excuses. First, due to his ignorance, the wrongful conduct is not exemplary of the defendant's normal lawabiding disposition. Secondly, the requirement that only unavoidable mistakes excuse the defendant reflects that the defendant did everything the law could legitimately expect him to do.

As a third category of excuses, insanity can be mentioned. It is clearly an excuse of incapacity, but under the capacity theory, insanity is not always an excuse. Only if the disorder was transient rather than permanent, can the offence committed under the influence of a mental disorder be said not to reflect on the defendant's settled character. Under the theory of choice, insanity does not qualify as an excuse. The defendant had no choice to act differently because of his disorder, but this is a circumstance internal to the defendant. When discussing insanity, it will be argued that insanity should sometimes be seen as an exemption rather than an excuse.

The rationale of excuses can also be drafted in a manner that includes all three categories. Blameworthiness is grounded in the capability of humans to choose freely and correctly between right and wrong. ${ }^{13}$ The latter ability to distinguish right from wrong, the insight of wrongfulness, is an element of blameworthiness. Excuses should therefore be understood as denying the capacity of the defendant to appreciate the wrongfulness of one's actions and the capacity to act accordingly. The inclusion of the insight of wrongfulness makes clear that unavoidable mistakes of law are included. The capacity to act accordingly refers to both external and internal reasons for not being able to comply with the norms.

\section{BLAMEWORTHINESS}

Being held blameworthy means you are the proper object of a socio-ethical reproach. ${ }^{14}$ The reproach is based on the subjective relationship of the actor to the wrongful conduct, which focuses on its volitional aspects. If the particular

Fletcher 1978, p. 806.

Fletcher 1978, pp. 805-806.

18 March 1952 BGHSt 2, 194.

Fokkens \& Machielse, notes 1 and 3 on Schuld. 
defendant could reasonably avoid the offence, he is blameworthy. ${ }^{15}$ Blameworthiness is connected to moral considerations, which will often coincide, but it remains a legal, not a moral concept. On the one hand, this means that the law does not demand heroism from defendants. Acting morally blameworthy is insufficient for criminal liability. On the other hand, particularly in the regulatory field of law, there can also be criminal liability without any moral blameworthiness. ${ }^{16}$

It has already been explained that blameworthiness should be distinguished from mens rea. The latter was explained to be an analytical tool of the offence that encompasses fault elements and its related principles. It is true that fault elements, like intention, increase the reproach that can be made to the defendant. However, blameworthiness deals with an aspect of liability that is more fundamental. Even crimes of strict liability require that the defendant is blameworthy. It is an absolute principle of criminal law, allowing for no exceptions, that the blameless may not be punished. This is the lower limit of criminal liability. ${ }^{17}$ The principle of no punishment without guilt therefore refers not only to factual guilt, but more importantly, to the rule that there can be no punishment without normative guilt, without blameworthiness.

This interpretation is in line with the case-law of the European and Dutch courts and not contrary to English case-law. ${ }^{18}$ In German law, however, the principle of guilt is said to encompass more. First of all, it is said to preclude strict liability. This interpretation of the principle implies that liability may not be based on anything less than negligence. The dogma would thus literally hold that there can be no punishment without negligence: nulla poena sine culpa must be taken literally.

The correct view differs. Although the subjective part of culpa consists of blameworthiness, it has also been explained that the reproach of culpa goes further. Culpa must be lata, serious, whereas any degree of blameworthiness suffices for criminal liability. ${ }^{19}$ In practice, this is shown when the defendant caused a casualty in traffic. Even if the reproach is not severe enough to ground negligence for this killing, he may still be convicted of the strict offence of dangerous driving. ${ }^{20}$

Furthermore, the principle of guilt is interpreted so broad in Germany that it gives rise to a principle that punishment may not exceed the degree of blameworthiness. The latter implied that if an excuse is rejected, but the fulfilment of its essential conditions has reduced the level of blameworthiness, this must be taken into account by mitigating the sentence. An example is the obligation to

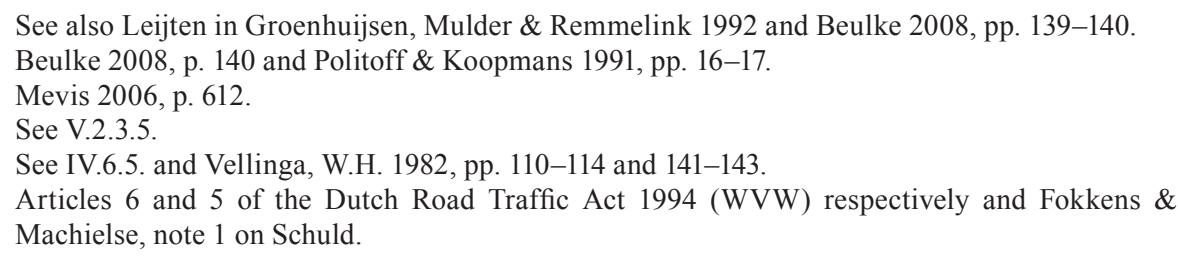


mitigate the punishment of the person who committed the offence under the influence of a mental disorder, which was however not severe enough to deny his responsibility for the offence completely. Although all courts tend to mitigate the sentence when a defence is fulfilled to some extent, yet rejected, only in German law, an obligation for courts to mitigate exists when it concerns an excuse. ${ }^{21}$ In discussing insanity, this principle will be discussed in more detail. Finally, the principle is also said to preclude the liability of legal entities. ${ }^{22}$ This issue is dealt with in a related research project. ${ }^{23}$

The principle is paramount in German criminal law and given constitutional status by the Constitutional Court, who firmly anchored it in the constitutional rights of human dignity, the free development of one's personality and the principles of 'Rechtsstaat'. ${ }^{24}$ The Constitutional Court has gone even so far to hold that supranational law cannot alter the principle. EU law must therefore be interpreted in line with the principle. ${ }^{25}$ From such a point of view, the more limited application of the broader principle, evident in the expansion of crimes of strict liability and the rejection of punishment according to guilt, can be described as erosion or undermining of the principle.

However, this development should be seen as the manifestation of a dynamic principle in a changing society, in which views on responsibility also change. For example, individual responsibility by natural persons is no longer exclusive. Concerns of dealing efficiently with high numbers of violations and protecting particularly vulnerable interests warrant strict liability. Finally, an obligatory mitigation of punishment along the lines of reduced blameworthiness is at odds with a continued hardening of society and the criminal justice system, which focuses predominantly on the seriousness of the harm or danger caused. ${ }^{26}$

Moreover, it can be argued that the force and application of the principle of guilt has also been expanded. For example, the expansion of strict liability offences has increased the reliance on the principle. It is irrelevant for the defendant to argue that he lacked the intent or negligence in violating the norm, because this is not required by these offences. By doing away with fault, more emphasis rests on blameworthiness as the minimum requirement of a subjective connection between act and actor. The defendant can only be exculpated by making probable an excuse. In a professional context, for example, the defendant is therefore likely to plead a due diligence defence, arguing he did everything that could reasonably be expected of him. The

21 Tiedemann in Tiedemann 2002, pp. 13-15 submits that in Spain the fulfilment of the essential conditions of a defence also leads to obligatory mitigation.

22 See Krey 2002, pp. 96-99 and Streng 2007, p. 153. See also Nieboer 1991, pp. 39-40.

23 See Keiler 2012, forthcoming.

24 Articles 1(1) and 2(1) of the German Constitution; 26 February 1969 BVerfGE 25, 269; 25 October 1966 BVerfGE 20, 323; 24 October 1996 BVerfGE 95, 96 and Renzikowski 2000, p. 488.

2530 June 2009 BverfG 2 BvE 2/08.

26 See Fokkens \& Machielse, note 1 on Schuld; Stolwijk 1999 and Vellinga, W.H. 1982, pp. $9-10$. 
acceptance of these defences by most notably Dutch courts thus shows a compensating trend. This function of blameworthiness as a leftover category to exculpate explains the continued importance of the principle of guilt.

\section{Self-DEFENCE-EXCESS}

Self-defence is a justification limited by proportionality. If the defendant exceeds these limits, he can still be excused under self-defence-excess. Since this excuse is not recognized in England, its functional equivalents in English law will also be discussed. I will conclude that not these equivalents, but the excuse should be included in a general part of criminal law for the EU.

Two forms of the excuse can be distinguished. In intensive excess, the degree of necessary force is exceeded. For example, the attacked person uses a knife or firearm to defend himself when the attack could have also been averted with his fists. ${ }^{27}$ The other form deals, not with proportionality, but with the necessity of the attack, which usually ends after the attack. In extensive excess, the defendant either continues after the attack has ended or only reacts after the attack has ceased. ${ }^{28}$ Consider the defendant who continued or even only started to kick the aggressor when he was no longer a threat, lying injured on the ground. Extensive excess is not accepted in Germany, but it will be explained that the scope of excess does not differ considerably.

\subsection{Rationale}

Self-defence-excess presupposes a situation of self-defence. It has therefore been argued that the excuse can be based on a rationale like the protection of the legal order, just like the justification. On the other hand, it can be argued that the defence exceeds the rationales of self-defence. In extensive excess, the autonomy of the attacked person and the legal order are no longer in need of defence. In intensive excess, the lack of proportionality is also at odds with the legal order as a whole. The rationale for self-defence-excess thus differs from that of self-defence. Hence, the exceeding of the scope of lawful defensive force cannot be justified. ${ }^{29}$ Dogmatically, the defendant cannot be justified because this would preclude others from defending themselves against him. If the attacked person exceeds the limits of lawful defensive force, the original aggressor and third parties on behalf of him, may act in self-defence against that person.

The rationale of excess is based more on general theories of excuse grounded in reasonableness and comprehensibility. The question is what we could reasonably

27 Bohlander 2009, pp. 121-122; Beulke 2008, pp. 155-157 and Roxin 2006, p. 998.

28 Van Dijk, A.A. 2008, p. 27 and HR 4 March 2008, NJ 2008, 158. The latter is sometimes distinguished in Dutch law as 'late excess', see de Hullu 2006, p. 306.

Roxin 2006, p. 994. 
expect of the defendant in that situation. The defendant deserves consideration given the psychologically exceptional situation he is in, which strongly diminished his capacities to act otherwise. ${ }^{30}$ Its character is therefore one of excuse, which is widely recognized, ${ }^{31}$ although some have argued it is better to view excess as a defence on its own without categorizing it as a justification and excuse. ${ }^{32}$ The wrongful character of the excessive force and the reproach against the actor are diminished to an extent that punishment is no longer appropriate. ${ }^{33}$

An additional rationale for excess is that acting in self-defence should not be too risky. If the defendant exceeds the limits of the justification for understandable reasons, he should not be punished. The general interest is served if the defender does not have to worry too much about the legal consequences of his actions. Without it, citizens might be less willing to help each other. With the availability of excess, the risk of self-defence is therefore attributed to the aggressor. ${ }^{34}$ Furthermore, punishment would not be in line with special and general preventive goals. There is no such need to deter the actor by punishing him, because he acted due to fear caused by the attack and the victim is not an innocent party. ${ }^{35}$

\subsection{Criteria}

For intensive excess to excuse the defendant, self-defence should have been necessary although the limits of proportionality were exceeded. Secondly, this exceeding must have been a consequence of the state of mind, which in itself should have been a consequence of the unlawful attack. The criteria of self-defence thus also apply to the excuse. If a situation of self-defence did not exist, because the attack was not wrongful or the interest attacked not within the scope of legitimate interests, the excuse can also not apply. The defence must also have been necessary in order to invoke intensive excess. ${ }^{36}$

30 De Hullu 2006, pp. 307-309; Fokkens \& Machielse, note 10 on art. 41; de Jong D.H. \& Knigge 2003, p. 175 and Schönke \& Schröder, H. 2006, p. 670.

31 Machielse 1986, p. 678 and Schönke \& Schröder, H. 2006, p. 669.

32 Like AG Machielse in HR 12 April 2005, NJ 2005, 364. See also de Hullu 2006, p. 309; Knigge 1993, p. 36 and Roxin 2006, pp. 991-994. The wording of the defence in the Dutch and German Criminal Codes leaves room for debate.

33 Machielse 1986, p. 675 and Beulke 2008, p. 155. See Roxin 2006, p. 993.

34 Fokkens \& Machielse, note 10 on art. 41; de Jong D.H. \& Knigge 2003, p. 175 and Bohlander 2009, p. 122.

35 Roxin 2006, pp. 992-993.

36 HR 20 September 2005, NJ 2006, 104; HR 7 February 2006, NJ 2006, 508; HR 27 May 2008, NJ 2008, 510 and de Hullu 2006, pp. 307-308. 
Chapter X

\subsection{Necessity}

In extensive excess, Dutch courts often distinguish two periods. Usually, the use of force during the attack is justified by self-defence, but the use of force committed in the period after the attack has ended is only excused. ${ }^{37}$ Extensive excess is problematic in light of the necessity requirement. If the attack has ended, the defence is no longer necessary. This makes it more controversial and therefore explains why it is not recognized in Germany. However, this problem is overcome by requiring that a situation of self-defence must have existed at one point in time. For excess to apply, there should be or have been a situation of self-defence. ${ }^{38}$ Accordingly, the Dutch Supreme Court quashes judgments that imply that there can be no excess if the situation of self-defence has ended. ${ }^{39}$

In Germany however, the judiciary constantly precludes the excuse in these situations, arguing that only an actual situation of self-defence can be exceeded. For excessive self-defence to apply the attack must still be wrongful; a situation of necessity must exist. ${ }^{40}$ However, the recognition of extensive excess in Germany is not that far away, if we consider that courts apply a broad scope of imminence that includes situations of extensive excess into intensive excess. They accept that the imminence of an attack continues until its definitive termination. When a repetition of the attack might be feared, the attack is still imminent and the force is judged as intensive excess. ${ }^{41}$ Moreover, necessity is approached quite lenient in general. The defence is not precluded because the defendant could have withdrawn by fleeing or the precautionary calling in the police. ${ }^{42}$

If the attack has definitively ended, the defendant cannot be excused, even if he did not realize the attack had ended. In that case however, the lenient German rules of mistake apply that negate intentional liability. After all, extensive excess and putative self-defence are not easy to separate. Extensive excess also has the character of a mistake. Due to emotions caused by the attack, the defendant does not realize the attack has ended or fears it is not over yet. In German law therefore, the defensive force that continues after the attack has objectively ended will not be held to be intentional. The negligent liability that remains can be negated because fear and other affects can play a role in assessing the mistake as unavoidable. ${ }^{43}$ The

37 See, for example, HR 27 May 2008, NJ 2008, 510.

38 HR 18 May 1993, NJ 1993, 691; Strijards 1987, p. 96; Rozemond 2006, p. 109 and Fokkens \& Machielse, note 12 on art. 41.

39 Like in HR 4 March 2008, NJ 2008, 158. Lower Courts still often omit to address the possibility of extensive excess, see Blomsma \& Klip 2009. 23 January 2003 BGH NStZ 2003, 599; 13 November 2008 BGH NStZ-RR 2009, 70; Roxin 2006, pp. 998-999 and Beulke 2008, p. 156.

4124 October 1919 RGSt 54, 36; 11 July 1986 BGH NStZ 1987, 20; 24 October 2001 NStZ 2002, 141 and Roxin 2006, p. 999.

4215 November 1994 BGH NStZ 1995, 177 and Schönke \& Schröder, H. 2006, p. 670.

4324 October 2001 BGH NStZ 2002, 141 and Roxin 2006, p. 999. 
defendant in a situation of extensive excess will therefore be exculpated under both Dutch and German law.

In choosing the proper approach to the similar outcome, it should be taken into account that the German rules on putative defences have already been rejected in favour of one simple rule of excusing the actor who makes a reasonable mistake about the facts underlying a justification. This exculpation should thus be the result of including extensive excess in the excuse. One yardstick should apply to extensive excess and the similar putative self-defence. Moreover, there are no good reasons to apply a different approach to extensive in regard to intensive excess either. Just like many German scholars argued, it is for example incorrect to submit that the required psychological pressure is absent when the attack has ended. In fact, the psychological situation is similar to that of intensive excess. ${ }^{44}$

\subsection{State of mind}

The exceeding of the limits of proportionality must have been a consequence of a relevant state of mind, which in itself should have been a consequence of the wrongful attack. The required states of mind can be distinguished into sthenic and asthenic feelings. Asthenic affects are passive feelings like fear, confusion and desperation that paralyze powers and make people weak, whereas sthenic emotions are active like anger, rage and indignation. ${ }^{45}$ The defence in the Netherlands covers both categories, whereas German law excludes the latter category. ${ }^{46}$ The German provision on excess enumerates the asthenic affects that can give rise to the defence, whereas the Dutch provision uses a more generic term to include both types of emotion in all manifestations. The German scope of excess thus seems smaller as it does not encompass 'sthenic' affects like rage and anger, but I will explain the difference is mitigated in numerous ways.

German scholars often ground the exclusion of sthenic affects on the belief that it might set free latent feelings of aggression. Moreover, aggressive emotions generally are considered more dangerous and should therefore be restricted for the sake of the protection of (the aggressor's) legal interests. By contrast, fearful emotions are exemplary, not incendiary and are therefore to be treated more mildly. ${ }^{47} \mathrm{~A}$ comparison can be made with the English defence of 'loss of control', discussed below. Although its predecessor could also apply to cases where the defendant had

44 Schönke \& Schröder, H. 2006, pp. 671-672; Beulke 2008, p. 156 and Roxin 2006, pp. 999-1000. See also Motsch 2003, pp. 92-101.

45 Remmelink 1996, p. 326.

46 Fokkens \& Machielse, p. 286, note 13 on art. 41; Machielse 1986, p. 682; 3 February 1993 BGHSt 39, 133; Beulke 2008, p. 155; Bohlander 2009, p. 122 and Schönke \& Schröder, H. 2006, p. 670. In German law, sthenic affects can only in exceptional cases excuse the defendant under insanity, see 12 December 1996 BGH NStZ 1997, 232. 
lost his temper, the current defence will almost only be successful when the defendant acted out of fear or panic.

Nonetheless, the difference between the Dutch and German defence is seriously mitigated because of the German rule that sthenic affects may also play a role, as long as the asthenic emotion is still also causal for the excessive use of force. ${ }^{48}$ Conversely, it will be explained below that in Dutch law, many sthenic affects, such as unreasonable anger and revenge are also excluded. Furthermore, the aforementioned German rules on mistake can also apply to mistakes caused by rage and anger, negating even negligence liability when the mistake was unavoidable. ${ }^{49}$ Finally, the so-called 'heat of passion statute' of $\$ 213$ of the German Criminal Code brings about a mandatory sentencing scheme of one to ten years of imprisonment for killings committed in provoked rage.

Starting with the first mitigation of the difference, in both States a criterion of double causation applies. The attack should have caused the affect and subsequently, the affect must be the cause of the exceeding of the limits of self-defence. ${ }^{50}$ This causal connection is strictest in the Netherlands, where it has been held that the excess should be the direct consequence of the affect, meaning that it was of overriding importance. If the excessive force, like hitting and kicking an aggressor who is lying on the ground, was not caused by an emotion like fear as a result of the attack, but simply out of feelings of aggression, induced by alcohol, not the attack, the excuse will be rejected. ${ }^{51}$ In Germany, the attack must not necessarily be the predominant cause of the loss of control as it suffices that it is co-causal for the exceeding. ${ }^{52}$ Moreover, this loose connection is accepted easily under in dubio pro reo..$^{53}$

The inclusion of sthenic affects in Dutch law is also mitigated because Dutch courts often reject the defence when sthenic affects like revenge and hostility played a role. If those feelings already existed before the attack, the attack itself is not considered to be the main cause of those feelings. Courts can thus easily reject the defence by referring to a long-term conflict that existed between aggressor and defendant. ${ }^{54}$ It is also held that the exceeding of proportionate force is not mainly caused by a relevant state of mind when the defendant displayed rational and

\footnotetext{
$48 \quad$ Roxin 2006, pp. 995-997.

49 Bohlander 2009, p. 122 and Schönke \& Schröder, H. 2006, p. 670.

$50 \quad$ HR 13 June 2006, NJ 2006, 343; Fokkens \& Machielse, note 13 on art. 41; Kelk 2005, p. 291; Strijards 1987, pp. 96-97 and de Hullu 2006, p. 308.

51 Hof Amsterdam 22 March 2001, NbSr 2001, 5. See also HR 13 June 2006, NJ 2006, 343; HR 22 January 2008, RVDW 2008, 171 and HR 31 March 2009, NJ 2009, 177. pp. 995-997 and Schönke \& Schröder, H. 2006, p. 670.

53 Roxin 2006, p. 996. See also Schönke \& Schröder, H. 2006, p. 670.

54 De Hullu 2006, p. 308. HR 31 March 2009, NJ 2009, 177; Hof Leeuwarden 4 May 2009, $L J N: \mathrm{BI} 3144$ and $\mathrm{Rb}$. Utrecht 1 October 2008, $L J N$ : BF7595.
} 
purposive behaviour, either during the excessive use of force or immediately following it. ${ }^{55}$

A long timeframe between the attack and the defensive force will lead to a rejection of the defence in both States. ${ }^{56}$ The approach of Dutch courts is however the strictest. Some time in between is allowed, but in general, the excused force should have started (almost) immediately after the causing of the given state of mind. ${ }^{57}$ Consider the defendant who was attacked at the entrance of his house by someone with a large knife. He went upstairs to get a samurai-sword, which took at most fifteen seconds. The Court of Appeal judged that this timeframe ruled out that the excessive violence - the use of the sword - was caused by an emotional state of mind as a direct result of the attack. ${ }^{58}$

Co-causal or predominant cause, it is accepted that the degree of the affect must be severe, because it must have caused the defendant to exceed the limits of selfdefence. The normal psychological processes must be seriously inhibited due to the attack. There must be such an extent of emotion that the defendant could only cope with the situation in a substantially diminished way. ${ }^{59}$ The comparison with the excuses of insanity and the partial defence of diminished responsibility forces itself upon us. ${ }^{60}$ The difference is that for excess to apply, the affect should be caused by the attack itself, not because of the psychological condition of the defendant. This means that individual characteristics such as a short fuse or a paranoid disposition will preclude the application of the excuse, unless they only played a subordinate role in causing the disproportionate reaction. ${ }^{61}$

The criterion of a 'subordinate role' again allows for normative leeway. For example, the woman who stabbed her ex husband to death was diagnosed as borderline with very dependent traits and could not even remember the stabbing anymore. She was excused anyway, as it was held that the state of mind was primarily caused by the attack of her ex husband. ${ }^{62}$ In another case, a group of drunken people had entered a closed restaurant, which was run by a family. When

55 HR 27 May 2008, NJ 2008, 510. AG Vellinga disagreed, submitting that a state of mind, like fear and anger are reconcilable with rational and purposive behaviour. Moreover, defensive mechanisms require controlled behaviour in order to be effective. See also HR 7 December 1999, NJ 2000, 263 and HR 8 April 2008, NJ 2008, 233, where the defendant calmly conversated after the excessive use of force.

56 Roxin 2006, pp. 1000-1001.

57 De Hullu 2006, p. 308.

58 HR 16 September 2008, $L J N$ : BD1728. See also HR 12 April 2005, NJ 2005, 364. HR 13 June 2006, NJ 2006, 343 can be contrasted with this case.

5916 August 1994 BGH NStZ 1995, 76; 30 May 1996 NStZ-RR 1997, 65; Roxin 2006, p. 996 and Schönke \& Schröder, H. 2006, p. 670.

60 See R. v. Martin [2001] EWCA Crim 2245.

6129 May 1991 BGH NStZ 1991, 528; HR 12 December 2006, NJ 2007, 245; Machielse 1986, pp. 683-686; Strijards 1987, p. 99; de Hullu 2006, p. 312; Siesling \& Ten Voorde 2007, pp. 554-555 and Kelk 2005, p. 291.

62 Hof Den Haag 24 November 2005, LJN:AV1104. See also Rb. Almelo 31 March 2009, $L J N$ :BH9975 and by contrast, Rb. Utrecht 1 October 2008, $L J N$ : BF7598. 
the group started to injure members of his family, the defendant stabbed a person of a group. It was assumed he acted because of an emotional state of mind caused by this attack, even if this state of mind could have existed before or have been amplified by the family history. The family had fled Azerbaijan during the war there. ${ }^{63}$

In determining what room exists for individual characteristics, the question is what we could expect from the defendant and what excess is acceptable? ${ }^{64}$ We can expect more from some and less from others. The excuse can be rejected because the specific defendant should have restrained himself. For example, a prison guard could not rely on the defence. Considering his profession, he should not have reacted to the blow in his face by punching the victim in the head after he was restrained on the floor. ${ }^{65}$ The lack of control that made the defendant exceed the limits must have been caused by a 'socially accepted cause', 66 and it must be grave enough to allow for such an excessive use of force. For example, the stealing of your purse is no reason to 'lose it'.67 In this way, the difference with German law that preludes sthenic affects is mitigated too. Anger can qualify as a relevant state of mind, but the excuse will be rejected if the anger was unreasonable.

In conclusion, the simplest and therefore preferred approach is not to limit the defence in type of affects that can qualify, but to set a threshold of severity. This open approach, which was also taken in the context of self-defence, where it was decided not to restrict that defence a priori to certain interests, leaves room to take into account the special circumstances of the case in deciding to reject or accept the excuse. Just like the causal requirement, this provides the trier of a criminal case with considerable discretion, allowing him to take into all circumstances of the case. This explains why the defendant that was defending his disabled brother is treated more leniently than the drunken actor who inflicted severe injuries upon his enemy. ${ }^{68}$

\subsection{Proportionality}

The use of force in intensive excess is disproportionate, so self-defence does not apply. If the abovementioned conditions are met, the actor can nevertheless be excused. Proportionality demarcates the justification from the excuse. It determines where self-defence ends and excess begins. The criterion is, as always, assessed normatively. Abstract guidelines are therefore hard to give. Depending on the circumstances, the use of deadly force against an unarmed aggressor can be propor-

Rb. Utrecht 24 June 2008, $L J N$ : BD5317.

De Hullu 2006, pp. 307-308.

Hof Den Haag 25 February 2009, $L J N$ :BH4016.

Van Dijk, A.A. 2008, p. 27.

See Rb. Amsterdam 6 March 2008, $L J N$ :BC5916.

HR 13 June 2006, NJ 2006, 343. 
tionate or disproportionate. ${ }^{69}$ The defendant can be justified or excused. The line can become vague, allowing a lot of discretion to the court, which is criticized for giving rise to seemingly arbitrary judgments. ${ }^{70}$

The court can also hold that the force was so disproportionate that the defendant cannot be excused. ${ }^{71}$ In other words, proportionality also forms the upper limit of self-defence-excess. In the case where a senior man grabbed the defendant by the testicles, the defendant hit the man on the head with a heavy vase, as a result of which he died. The Dutch Supreme Court in effect held that the attack of the man may have caused the defendant to exceed the limits of what is proportional, but this was so disproportionate that it could not excuse. ${ }^{72}$

\subsection{Partial defences in English law}

Self-defence in an excusatory form is not available in England, which is remarkable when compared to other Anglo-American countries. For example, in Australia, excess used to be recognized as a partial defence, reducing murder to manslaughter. The excuse was deemed necessary to reflect, in comparison to the 'regular murderer', the lesser degree of blameworthiness of the accused who, in order to defend himself against an attack, exceeds the amount of proportionate force required to avert the attack and thereby kills the aggressor. ${ }^{73}$ Nevertheless, the English Court of Appeal, ${ }^{74}$ the UK Privy Council ${ }^{75}$ and the House of Lords ${ }^{76}$ considered the doctrine and explicitly rejected it. In 1987, the Australian High Court themselves rejected the doctrine, because it was too complex. ${ }^{77}$

The Australian High Court held that it remained open for the defendant to plead provocation, a defence discussed below, and secondly, that if the intent to kill or cause serious bodily harm was lacking, he can only be held liable for manslaughter, not murder. This reasoning was also adopted in England. ${ }^{78}$ If the second argument is understood as that intent can be negated by good motives, this must be rejected. Intent is neutral; the moral enrichment of intent should be rejected. ${ }^{79}$

In the case where the House of Lords rejected the availability of excess, a soldier shot three bullets at a car driving at high speed towards a control point, because he feared the car would hit one of his fellow soldiers. A fourth bullet hit and killed a

\footnotetext{
69 HR 8 April 2008, NJ 2008, 233; Hof Arnhem 31 March 2009, LJN:BH9163; Hof Arnhem 21 May 2008, $L J N: B D 2016$ and Hof Leeuwarden 9 April 2009, $L J N: \mathrm{BI} 2091$.

Machielse 1986, p. 685 and Buruma 2005, pp. 445-446.

See, for example, 4 August 2009 BGH NStZ 2010, 82.

HR 8 April 2008, NJ 2008, 312.

Viro v. The Queen (1978) 141 CLR 88. See Ormerod 2005, p. 342.

R. v. McInnes [1971] 1 WLR 1600.

R. v. Palmer [1971] AC 814.

R. v. Clegg [1995] UKHL 1.

Zecevic v. DPP (1987) 162 CLR 645. See Sangero 2006, pp. 298-302.

R. v. Clegg [1995] UKHL 1 and Law Commission 2004, p. 75.

See IV.2.4.1. and Kaye 1997, pp. 452-453.
} 
passenger of the car. It turned out however that he only shot this fourth bullet when the car had passed them, thus in a situation that no longer subjectively or reasonably qualifies as one of self-defence. In Dutch law, this could be a situation of extensive excess. The question for the House of Lords was not whether excess could be excuse but whether excess should be recognized as a partial defence, reducing murder to manslaughter. This was rejected in favour of the English all or nothing approach of either justifying the actions of the accused under self-defence or not. ${ }^{80}$

Murder in English law is the unlawful killing of someone with an intention to cause death. The most serious form of homicide also includes the killing of someone with the mere intention to inflict grievous bodily harm. Murder is punished with mandatory life imprisonment. Nowadays, life is no longer life, but the convicted person will in principle serve at least fifteen years in prison. ${ }^{81}$ In cases where the victim dies as a result of disproportionate defensive force, the unavailability of excess thus brings about that the defendant receives a harsh sentence. To avoid this, the limits of proportionality in self-defence have been stretched relatively wide.

The circumstance that English law does not require the mistake in putative selfdefence to be reasonable can also be viewed in this perspective. The law allows such force to be used as is reasonable in the circumstances as the accused believed them to be, whether reasonably or not. If the defendant was ignorant that the attack ended, he is therefore acquitted for applying the force that would have been proportionate if he had been correct. In other words, this lenient approach on putative self-defence covers most cases of extensive excess. By holding that the disproportionate violence was a result of a misjudgement of the severity of the attack, courts can also include some cases of intensive excess.

In situations that exceed these stretched limits of self-defence, the defendant however only has two options to try to evade the life sentence, namely by pleading two partial defences that reduce a charge of murder to manslaughter. ${ }^{82}$ The first of these defences that only apply to murder is called loss of control. Loss of control is the successor of provocation, which has concomitantly been abolished. The second partial defence to murder is diminished responsibility. Even though they do not negate criminal liability and only apply to murder, these partial defences perform a function comparable to excess and their conditions are similar to excess.

\subsubsection{Loss of control}

With the Coroners and Justice Act 2009, the defence of provocation under section 3 of the Homicide Act 1957 was replaced in October 2010 by the very similar defence

R. v. Clegg [1995] UKHL 1.

Schedule 21 of the Criminal Justice Act 2003. See Ashworth 2006, p. 253 and Law Commission 2004, pp. 26-27.

The defences can also be legitimized from a more instrumental, crime control perspective, by considering that they also help to prevent jurors from acquitting altogether in hard cases, see Law Commission 2004, pp. 85-88. 
of loss of control. ${ }^{83}$ The old and new defence are therefore discussed simultaneously, whilst identifying the differences. The English Government by and large followed the Law Commission's proposals regarding the reform of provocation. The term loss of control denotes best that the actor had enormous difficulty in exercising self-control. ${ }^{84}$ The defence partially has the character of an excuse. ${ }^{85}$ It is a concession to human frailty, or even a moral warrant for retaliation in anger. ${ }^{86}$

The defence has been said to consist of two tests. A first, subjective test requires that the killing was the result of loss of self-control, and the loss of self-control was caused by a qualifying trigger like an attack or a provocation. Just as in excess, a criterion of double causation applies. ${ }^{87}$ The new defence no longer uses the word provocation but narrowly lists as a possible 'qualifying trigger' thing(s) said or done which constituted circumstances of an extremely grave character, and caused the defendant to have a justifiable sense of being seriously wronged. ${ }^{88}$

The striking of the term 'provocation' already indicates that the defence has shifted away from partially condoning anger. The new defence excludes from it killing after losing one's temper or outrage due to sexual infidelity. At the same time, it is broadened by including fear of serious violence inflicted by the victim on the defendant or someone else as a qualifying trigger of the loss of self-control. ${ }^{89}$ The Law Commission had advocated this, in order to enable abused women and people who exercise excessive force in self-defence with a defence. ${ }^{90}$ Acting out of panic for (further) aggression thus seems to be the strongest evidence that the defendant should be able to rely on excess or loss of control in all three Member States.

The loss of self-control is a state of mind that leads the defendant to kill whereas this is disproportionate. Self-control can be described as a "faculty (...) that enables persons to do what they judge best in the face of strong inclinations to the contrary." 91 In order for the defence to apply, the provocation must have given rise to violent inclinations and it must have undermined the self-control, which would otherwise have refrained him from acting in that way. Like the emotion in excess, the loss of self-control must be very severe. In theory, the loss of self-control must be complete. A reduction is insufficient, which is what is meant when it is said someone

83 Section 56(1) of the Coroners and Justice Act 2009 and the Coroners and Justice Act 2009 (Commencement No. 4, Transitional and Saving Provisions) Order 2010.

Horder 1992, p. 161.

Holton \& Shute 2007, p. 70; Simester \& Sullivan 2007, p. 369 and Horder 2005, p. 124.

Horder 1992, pp. 20, 56, 160 and 194-195.

Holton \& Shute 2007, p. 59.

Section 54(1)(b) of the Coroners and Justice Act 2009.

Section 55(3), (4) and (5) of the Coroners and Justice Act 2009.

Law Commission 2006, pp. 78 and 88-89. See also Holton \& Shute 2007, pp. 72-73. In section 59 of its Draft Criminal Code, the Law Commission 1989, p. 68 proposed to include excessive force as a separate partial defence alongside provocation.

91 Holton \& Shute 2007, p. 55. 
'snapped'. 92 Just like the emotion in excess, rational or purposive behaviour and time in between the provocation and the killing can indicate there was no such loss of self-control or that is was not causal for the murder. ${ }^{93}$ Loss of selfcontrol is also inconsistent with motives of revenge or punishment. ${ }^{94}$ Just as in the Netherlands, (premeditated) revenge killings can be distinguished from provoked killings when "there had not been time for the blood to cool and for reason to resume its seat." 95

Nevertheless, it follows from case law that a delayed reaction does not always preclude the defence. ${ }^{96}$ Research has shown that despite clear indications of premeditation or less severe forms of provocation, juries reached a verdict of manslaughter. This thus goes further than excess. One has to keep in mind however that a rejection of the defence would bring about the mandatory life sentence for murder. Especially if the defendant is a 'battered woman', who has been abused by the victim for years, the requirements of the defence were therefore stretched in order to be able to be more flexible in sentencing. ${ }^{97}$ In the new defence, any temporal limitation has been struck. ${ }^{98}$

A second, more normative test requires that the loss of self-control was understandable, similar as in excess. The defence of provocation required that the provocation must be enough to make a reasonable man do as the defendant did. ${ }^{99}$ The reasonable man standard has been made more specific in the new defence of loss of control, predominantly by codifying case-law. It is presumed the provoked person normally has a certain level of self-control. The defendant is compared to the person of his sex and age, with a normal degree of tolerance and self-restraint and in the circumstances he was in. ${ }^{100}$ Persons who lack sufficient self-control - such as a habitually aggressive or violent person - will not be able to avail themselves of the defence, ${ }^{101}$ just as they would not be able to rely on self-defence-excess if this was the main cause of the excessive use of force.

Just as in excess, there is only limited room to take into account individual characteristics. Factors that affect the gravity of the provocation can be relevant, but

Holton \& Shute 2007, pp. 51-58, 61-63 and 70-71 and Tadros 2005, p. 303.

Horder 1992, p. 68 and Horder 2005, p. 125. Compare R. v. Duffy [1949] 1 All ER 932.

Section 54(4) of the Coroners and Justice Act 2009; R. v. Ahluwalia [1992] EWCA Crim 1 and Holton \& Shute 2007, p. 63.

Ashworth 2006, p. 265. In Dutch law, premeditation is usually accepted if the defendant had some time to reflect on his intentions. If there was some time to reflect, excess is automatically rejected, see Hof Arnhem 1 October 2008, $L J N$ : BF3995 and Hof Amsterdam 21 April 2009, $L J N$ :BI1783. R. v. Ahluwalia [1992] EWCA Crim 1 and Simester \& Sullivan 2007, pp. 355-356.

Horder 2006A, pp. 148-149; Horder 2005, pp. 123-125; Mitchell 2007 and Law Commission 2006 , pp. $80-81$. The defence is even available if the defendant was voluntarily intoxicated, see Simester \& Sullivan 2007, p. 368 and Ormerod 2008, pp. 504-505.

Section 54(2) of the Coroners and Justice Act 2009; Holton \& Shute 2007, p. 64 and Simester \& Sullivan 2007, p. 355.

Section 3 of the Homicide Act 1957.

Section 54(1)(c) of the Coroners and Justice Act 2009.

Holton \& Shute 2007, pp. 58-60 and Ashworth 2006, p. 267. 
characteristics that affect the defendant's level of self-control more generally are almost all irrelevant. An example of such a relevant factor is an impotent person who is being teased about his condition, or a black man being called a 'nigger'. ${ }^{102}$ Only gender and age are characteristics that may affect in law the defendant's level of self-control. ${ }^{103}$ People who have less self-control because of some psychological or psychiatric condition will have to rely on the defence of diminished responsibility. ${ }^{104}$

The concept of killing in provocation is familiar to Dutch and German law too. In the Criminal Code that applied in the Netherlands before 1886, when the current Code entered into force, killing and the infliction of injuries was excused if provoked by serious violence of another. ${ }^{105}$ When the current Dutch Code was drafted, provocation had originally been proposed as a mitigating factor, reducing the maximum penalty for intentional killing by half. Similar as the English defence, it was also perceived as a concession to human frailty and included a requirement of double causation. ${ }^{106}$ However, the Minister withdrew it after debate in Parliament, because the distinction between what was and what was not provocation remained too vague. ${ }^{107}$ Moreover, with the enactment of self-defence-excess, provocation became superfluous for the most part.

As mentioned before, German law does include a rule on provoked killings, which mitigates the difference with the Dutch defence of excess that anger and other sthenic affects are excluded as causes of the excessive force. Paragraph 213 of the Criminal Code applies if the defendant killed because he was angered by the injuries or serious insults of the victim towards himself or a relative. In that case, the defendant can be punished with at least one and at most ten years of imprisonment. Similar as the English defence and self-defence-excess, it also includes a requirement of double causation ${ }^{108}$ and the provocation need not be the only factor to cause the state of mind. ${ }^{109}$ In contrast to excess, the provocation may

102 DPP v. Camplin [1978] UKHL 2; Attorney General for Jersey v. Holley [2005] UKPC 23; Virgo 2005, p. 533; Elvin 2006, p. 820; Tadros 2005, pp. 350-352 and Ashworth 2006, p. 273. This distinction is not always easy to make, as is evident in for example R. v. Mohammed [2005] EWCA Crim 1880, see Simester \& Sullivan 2007, p. 370.

103 Attorney General for Jersey v. Holley [2005] UKPC 23, codified in Section 54(1)(c) of the Coroners and Justice Act 2009, overruling R. v. Smith (Morgan) [2000] UKHL 49, which also allowed for depression to be taken into account.

104 Elvin 2006, pp. 828-829; Law Commission 2006, pp. 85-87 and Ashworth 2006, p. 271.

105 Article 321 of the Code reads: "Le meurtre, ainsi que les blessures et les coups sont excusables, s'ils ont été provoqués par des coups ou violences graves envers les personnes.” Machielse 1986, p. 678 called this a mitigating factor.

106 Smidt 1881AI, p. 429. In contrast, a complete loss of control was not required, but the affect should make it difficult for the defendant 'to control his will.'

107 Smidt 1881AI, pp. 428-434 and Smidt 1881A, p. 380. See also Machielse 1986, pp. 609 and 637.

108 Eser 1981, p. 431.

10914 July 1977 BGH NJW 1977, 2086. 
have happened at an earlier point in time. It has been held that a state of mind due to provocation can last for several hours. ${ }^{110}$

In comparison to English sentencing, German law also applies mandatory sentencing to homicide. This means that if $\$ 213$ does not apply, the defendant who killed intentionally will at least be incarcerated for five years and for life if the motives qualify the act as murder. ${ }^{111}$ However, §213 also applies to 'an otherwise less serious case of intentional killing.' This broad category is designed for all those cases where another sentencing regime is warranted. It can be based on cases falling short of provocation or general defences, cases where the victim can be reproached in some way and even acting with mere conditional intent. ${ }^{112}$

\subsubsection{Diminished responsibility}

Just like loss of control, the major rationale for diminished responsibility is the mandatory life sentence for murder. ${ }^{113}$ It is however far less popular than loss of control, for it stigmatizes the defendant as not being sane. The defence is only a concession to abnormal human frailties. ${ }^{114}$ Even more important, the partial defence can have the paradoxical effect that the defendant can be deprived of his freedom for a longer period of time than when he had been convicted for murder. If the convicted person's disorder is seen as a continuing threat for the public, he may be incarcerated for a very long time or institutionalized. ${ }^{115}$

The amended version of the defence, also in force as of October 2010, demands that the abilities to understand the nature of one's conduct, to form a rational judgment and to exercise self-control are substantially impaired. ${ }^{116}$ Required is a recognized medical condition, which gives the experts opinion more weight than before. ${ }^{117}$ The scope of abnormality was and still is wider than that of insanity under English law. ${ }^{118}$ For example, included in the old and new version of the defence is

\footnotetext{
110 Eser 1981, p. 431.

$111 \S \S 212$ and 211 of the German Criminal Code respectively.

112 Schönke \& Schröder 2010, note 1 on $\$ 213$ and Eser 1981, p. 432. See, for example, the tragic case in 5 December 2007 BGH NStZ 2008, 338.

113 Ormerod 2008, p. 514 and Law Commission 2004, p. 85.

114 Horder 1992, p. 162.

115 See Law Commission 2006, pp. 95-96.

116 Section 52 of the Coroners and Justice Act 2009 and Law Commission 2006, pp. 102-103. The Law Commission's proposal was only not followed in regard to their suggestion to include developmental immaturity as a ground for partial exculpation.

117 The influence of experts was already quite large, but it remains an issue for the jury. Consider that serial killer Peter Sutcliffe (the "Yorkshire Ripper") was convicted of murder by the jury, notwithstanding the unanimous expert evidence on his paranoid schizophrenia. See Quick \& Wells 2006, pp. 520-521.

118 Ormerod 2008, pp. 511-512 and Ashworth 2006, p. 278. See also Hart 2008 (reprint 1967), p. 192.
} 
also 'irresistible impulse'. ${ }^{119}$ A test of double causation also applies. The defendant must have killed because his mental faculties were substantially impaired as a result of an abnormality of mental functioning due to a recognised medical condition. The abnormality need not be the predominant cause; it only needs to be an operative and more than trivial cause. ${ }^{120}$

The partial defence not only fills the gap left by the unavailability of excess. In English law, there also is no defence of partial insanity, or diminished capacity, as I call it. ${ }^{121}$ This all-or-nothing approach in insanity makes this partial defence relevant in homicide cases falling short of complete insanity. Diminished responsibility does not require that capacities are totally impaired, merely that they are substantially impaired. ${ }^{122}$ It can therefore be concluded that if English law would recognize partial insanity and excess, like German and Dutch law, there would be hardly any use anymore for diminished responsibility. Only in a few cases would the mandatory life sentence be perceived as a sentence that is too harsh in the circumstances.

To many English scholars and practitioners, the better solution would be to do away with the mandatory sentence altogether. After all, if it were not for the mandatory sentence, English courts could take into account the lesser reproach in mitigation. Both the limits of self-defence and the partial defences have been stretched to their limits to avoid the life sentence. ${ }^{123}$ In general, the more discretion the judiciary has in sentencing, the less it will feel necessitated to stretch legal principles. ${ }^{124}$ After all, in the end, any sentence imposed must be proportionate. ${ }^{125}$ The partial defences have been dubbed a 'half-hearted concession' to the need to provide more flexibility in sentencing because of the mandatory penalty for murder. ${ }^{126}$ If the mandate of the Law Commission had included a reconsideration of the mandatory sentence, its proposals would have probably looked differently. ${ }^{127}$ Law Commissioner Horder favoured the abolition of the mandatory life sentence for murder, and thus also the two partial defences. ${ }^{128}$

119 Ormerod 2008, p. 510; Simester \& Sullivan 2007, pp. 657-659 and Hart 2008 (reprint 1967), p. 202. Irresistible should not be taken literally in an absolute sense, see R. v. Byrne [1960] 3 All ER 1.

$120 \quad$ Virgo 2003, pp. 541-542.

121 See X.7.5.5.

122 Law Commission 2006, pp. 109-110.

123 Ashworth 2006, p. 263. Pleas of both partial defences falling short of acceptance may however be taken into account as mitigating factors under Schedule 21(11) of the Criminal Justice Act.

124 An example from German Law is the case where a former spy was charged with two murders. In order to avoid the mandatory sentence for principals, the Court held that the defendant was merely an aider of the KGB, who was the real principal, see Bohlander 2009, p. 162. The Dutch judiciary relatively has the most discretion, being only limited in the maximum punishment that can be imposed.

125 The principle of proportionate sentences is a general principle of EU law, laid down in article 49(3) CFR. Fixed penalties may violate this principle, see Klip 2012, p. 325.

126 See Horder 2005, pp. 139-140; R. v. Kingston [1994] UKHL 9 and Mitchell 2007, p. 341.

127 Power 2006, pp. 871-872.

128 Horder 2005, pp. 123-140. See also Horder 2006A, pp. 96-98 and Horder 1992, pp. 186-197. 
The partial defences thus only apply to murder. The defendant may however have exceeded the limits of defensive force also with less serious consequences. If the defendant uses disproportionate force against the aggressor, who as a result suffers serious injuries, the defendant cannot rely on any defence. On the one hand, this can be taken into account in sentencing, but on the other hand this fails to recognize that the blameless defendant may not be punished. If the defendant could not reasonably act differently than he did, it would violate the principle of guilt to convict him, even if his sentence is significantly mitigated. The blameless may not be punished, and it would also be at odds with the principle of guilt to convict that defendant without punishing him. Criminal liability stigmatizes the blameless defendant as a criminal, as a murderer. For a general part of criminal law for the $\mathrm{EU}$, the more principled approach of a general defence of self-defence-excess is therefore to be preferred.

\section{Duress}

The availability of a defence of duress is the acknowledgment that there may be instances where the defendant was under such a pressure that he could not reasonably be expected to abide by the law. The defence has a strong normative component. The defendant must not only be unable to resist the pressure, neither should he resist that pressure.

Traditionally, these situations arise when the defendant was threatened that if he did not commit a certain offence, he or someone close to him, would be killed or seriously injured. In practice, the defence is often raised against charges of perjury and against charges of collaborating in some way with (enemy) armed forces. ${ }^{129}$ Duress can however also arise out of circumstances, similar as in necessity. Whereas the application of necessity implies that on an objective evaluation of all things considered, the defendant did the right of permissible act, duress concerns agent-specific reasons for acting. ${ }^{130}$ The offence is merely excused because the committing of the wrongful offence by the defendant is understandable in the specific circumstances.

\subsection{Rationale}

The rationales for duress are manifold. Under a character-based rationale, the conduct in duress does not reflect the personality of the actor. ${ }^{131}$ More often, duress is based on a general theory of capacity and choice, holding that the defendant could

\footnotetext{
129 As far as the legal systems under investigation are concerned, the collaboration with armed forces generally concerns WWII. More modern cases can be found in international criminal law, see ICTY Judgment, Prosecutor v. Erdemović, Case No. IT-96-22-A Ch., 7 October 1997.

130 Re A. (Children) [2000] EWCA Civ 254. See also Horder 1998, p. 160 and Bohlander 2006.

131 Dolman 2006, p. 151.
} 
not act differently in the situation. ${ }^{132}$ This is also called the rationale of psychological pressure. Duress concerns cases where the actor through external circumstances is abnormally coerced in his freedom to choose, as a result of which he cannot be expected to act in conformity with the norm. The abnormal psychological pressure negates the reproach of blameworthiness or diminishes this to an extent insufficient for punishment. ${ }^{133}$

It is often said that the pressure, arising from circumstances or threats, overbore the actor's will. However, this is hardly ever the case. The choice must be coerced, but it remains voluntary. ${ }^{134}$ The relative pressure of duress brings about that the defendant could not be expected to act differently. This is contrasted with the absolute pressure in for example involuntary acts, where the defendant could literally not act differently and is therefore said not to have acted at all. Threats of third parties could always be resisted, but to require so would imply that the law requires heroism from its subjects. It is therefore agreed that in duress, the 'will' remains free, but the motive is not free. Coactus attamen voluit. ${ }^{135}$ Literally: although I was forced, I wanted what I did. ${ }^{136}$ Related to this rationale is the view of the defence as a concession to human frailty in cases where virtually no one can be expected to act differently. The law cannot demand self-sacrifice or heroism from people. ${ }^{137}$

It is also argued that because the human urge to self-preservation is irresistible, the law cannot influence the defendant to act differently. Criminal law should not be applied against the person who will not be influenced by it. The threat of punishment will not be able to change the actor from acting differently, as was already illustrated by the example of the plank of Carneades. The actor will choose the possibility of a death penalty in the near future over a certain and imminent death. In other words, duress excuses the actor because special deterrence is ineffective against him. Punishment is also not expected to change the behaviour of others. Paradoxically, this implies that the stronger the temptation or pressure to commit a crime, the stronger the law's threat should be in order to counterbalance. $^{138}$

This rationale is necessary to explain duress because the rationale based on choice or psychological pressure does not suffice. A single focus on the pressure on

132 Ashworth 2006, p. 224 and Simester \& Sullivan 2007, p. 676.

133 Dolman 2006, p. 156; 26 April 1932 RGSt 66, 222; 11 November 1932 RGSt 66, 397; Bohlander 2009, p. 123; Schönke \& Schröder, H. 2006, p. 701 and Roxin 2006, pp. 964-966 and 1014.

134 DPP for Northern Ireland v. Lynch [1975] UKHL 5; Ashworth 2006, p. 225; Horder 2006A, pp. 90 and 95; Roxin 2006, pp. 965-966 and Dolman 2006, pp. 97-99 and 320.

135 Fokkens \& Machielse, note 2 on art. 40 and Remmelink 1996, p. 926.

136 Mulder in Groenhuijsen, Mulder \& Remmelink 1992.

137 Bohlander 2009, p. 123 and Dolman 2006, p. 317.

138 Remmelink 1996, p. 298; Pompe (1928) in Kelk 2008A, p. 14; Roxin 2006, pp. 964-965; Krey 2002, pp. 106-107; R. v. Hasan [2005] UKHL 22; Finkelstein 2001, pp. 280-281; Fletcher 1998, p. 84; Fletcher 1978, p. 825; Simester \& Sullivan 2007, p. 665 and Williams 1953, pp. 596 and 600 . 
the defendant fails to recognize the normative requirement of duress that the defendant should not have resisted the pressure. The rationale of psychological pressure does not explain why duress is limited or precluded in situations of prior fault, when the defendant has to bear a danger because of his (official) position or when he made an avoidable mistake. A police officer may have been just as unable to resist the pressure as any other person. The psychological pressure in these situations is the same, regardless of whether the situation was actually present or only in the mind of the actor. Neither is the limitation of interests that can be saved logical from the perspective of this pressure. ${ }^{139}$

A middle ground, popular in Germany, explains excuses like duress by a double diminishment of blameworthiness. The blameworthiness of the defendant is not only diminished because he could reasonably not act differently, it is also diminished because the actor saves a legal interest. This saving limits or counterbalances the wrong of the offence and thereby indirectly the blameworthiness. ${ }^{140}$ It is supposed to explain some of the aforementioned features that could not be explained by a pure psychological rationale, but not all. Moreover, it suffers from some fallacies. For example, why should the so-called diminished wrong be assessed merely by reference to the interest the actor saves? It is very well possible that he has caused more harm by sacrificing a much more valuable interest. ${ }^{141}$

Like in necessity, the restricted scope of duress can also be explained by fear that a broader scope of compulsion defences may cause anarchy and erosion of the prohibitive norms. ${ }^{142}$ It is feared that the defence has great potential for abuse and runs counter to the goal of protection of the legal interests of innocents. ${ }^{143}$ It will become clear that these fears are particularly influential in England. They outweigh the aforementioned consideration that the urge to self-preservation is irresistible, as a result of which duress cannot apply to a charge of murder. In the Netherlands too, it can be said that the judiciary is very reluctant to accept the defence of duress, and that whereas it is raised quite often, it is hardly ever accepted. ${ }^{144}$

An additional fear is that by excusing the defendant, so-called 'quasijustificatory effects' arise. There exists an important communicative difference between justifications and excuses. It is feared that the public does not always appreciate this. It is feared the public will interpret the excuse as a justification, a judicial declaration that what the defendant did was right and that if others do this

139 Roxin 2006, pp. 965-966, 972, 977-978, 987 and 1015-1016. See also Schönke \& Schröder, H. 2006, pp. 627-628 and 702 .

140 Krey 2003, pp. 24-25. See also Roxin 2006, p. 966; Moos 2004, p. 898 and Schönke \& Schröder, H. 2006, pp. 627-628 and 701 .

141 Roxin 2006, pp. 966-967. The rationale should therefore assess whether the wrong is diminished by reference to both the served and sacrificed interest. This would also explain a proportionality requirement.

142 Sangero 2006, pp. 109, 119 and 162.

143 ICTY, Joint Separate opinion of Judges McDonald and Vohrah, Prosecutor v. Erdemović, Case No. IT-96-22-A Ch., 7 October 1997, \$75.

144 Kelk \& Kool 2004A, p. 103. 
in the future, they will not be criminally liable. This fear is said to become realistic in recurring situations, like in medical contexts, considering that the medical profession tends to keep itself up to date on relevant legal developments. ${ }^{145}$

This fear played an important role in the case against Dudley and Stephens, which occurred in a time when ships still regularly perished in open water. It was feared that an acquittal for any reason would have been seen as a vindication of their cannibalism, with the risk that others sailors would believe they are allowed do the same. Thus, the men were convicted but granted a pardon. ${ }^{146}$ Against this, it can be argued that situations of duress are characterized by the fact that the actor is not influenced by the prohibition or its punishment. Neither is punishment said to have a general deterrent effect. ${ }^{147}$ It may be questioned whether the fear is legitimate, as the general public may very well understand the basic difference between a justification and an excuse. This communicative difference is already encompassed in the wording of the two categories of defences. It can be emphasized by explicitly excusing the defendant or justifying the act, rather than simply acquitting him, as is the case in Dutch verdicts. ${ }^{148}$

In conclusion, duress can be explained by reference to varying rationales and perspectives. Duress consists of both a psychological and normative rationale, evident by the existence of a psychological and a normative limb in the Dutch concept of duress. The psychological pressure seems to be the most characteristic feature of duress; the most important reason to excuse the defendant. However, a normative aspect is also needed to fully comprehend the (limits of the) defence.

\subsection{Sources}

In article 8 of Directive 2011/36, a special form of duress is recognized. It excludes punishment of victims of trafficking in human beings for offences which they have been compelled to commit as a direct consequence of being trafficked. In a more general form, duress is recognized in all legal systems under investigation. English law distinguishes two forms of duress; first, duress by threats, also called duress per minas, which is duress in response to threats from another person and second, duress by circumstances, where the pressure to avert dire consequences arose from other than human conduct. ${ }^{149}$ Both are developed in case-law. An old-fashioned subcategory of duress under common law is marital coercion. It used to be a

145 Gardner, S., 1986, pp. 431-434 and Fletcher 1978, pp. 824-825.

146 Gardner, S., 1986, pp. 434-436; Fletcher 2007, pp. 321-324 and Simpson 1984, in particular pp. 240-241. The case is generally referred to in the context of necessity, but it is submitted that the claim of the Dudley and Stephens was in fact the excusatory claim of duress, see Simester \& Sullivan 2007, p. 719 and Fletcher 1973, p. 373.

147 The conviction of the defendant cannot encourage others, see Gardner, S., 1986, pp. 437-438.

148 An alternative would be to simply make the reasons for acquittal explicit in the judgment.

149 Ashworth 2006, p. 219; Ormerod 2005, pp. 297-298; Blackstone 1769 (reprint 1979), p. 30; Williams 1953, p. 592 and Simester \& Sullivan 2007, p. 666. 
presumption that any crime committed by a wife in the presence of the husband was done under coercion of the husband. At present, the wife has to prove this coercion, although moral and emotional pressures suffice. ${ }^{150}$ The Law Commission was right in recommending its abolition. ${ }^{151}$

The distinction of duress by threats and duress by circumstances was also made in German and Dutch law, although they are now both treated under the heading of duress. The pressure must arise from something external of the person, but this can be of human or other origin. Duress thus covers what in England is called duress by threats and duress by circumstances. ${ }^{152}$ In Germany, 'Nötigungsnotstand', similar to duress by threats, used to be a special defence in the old Criminal Code. It is still sometimes separated from other forms of 'excusable necessity' to emphasize that the actor is brought into distress by a third party. Both forms are however covered by the current provision on duress and therefore the same conditions apply. ${ }^{153}$

\subsection{Criteria}

On a first glance, the national formulas of duress seem to differ, but it will become clear that the criteria of duress are quite similar in all Member States. The defendant committed the offence because he was impelled by an imminent danger or threat to important legal interests, such as his life and limb. Therefore, he could not be expected to have acted differently. Like in other defences, prior fault and the special position of the defendant influences the scope of duress. So does proportionality, which places an upper limit on what offence can be excused in comparison to the threat.

Like self-defence-excess relates to self-defence, duress relates to necessity. The criteria of duress largely follow those of necessity. Some will be repeated shortly, but mostly only the differences will be highlighted. It has been submitted that the criteria are of less absolute application than in necessity, because duress only excuses the defendant, ${ }^{154}$ but it will become clear that some conditions are also stricter in the context of duress, like the role of prior fault.

The criteria of duress are therefore also discussed under two limbs of subsidiarity and proportionality. An alternative categorization would be to consider the conditions under a psychological and a normative limb. This is the dominant approach in the Netherlands, where it is argued that duress requires a pressure of

150 Section 47 Criminal Justice Act 1925; Law Commission 1977, p. 18; Ashworth 2006, pp. $228-$ 229; Blackstone 1769 (reprint 1979), pp. 28-29 and Simester \& Sullivan 2007, p. 677-678.

151 Section 42(6) Draft Criminal Code, Law Commission 1989, pp. 61 and 230 and Law Commission 1977, pp. 17-18.

152 Dolman 2006, pp. 176-177 and Bohlander 2009, pp. 116 and 124-125.

153 Beulke 2008, pp. 153-154; Bernsmann 1996, pp. 180 and 187 and Roxin 2006, pp. 755-756. The Supreme Court also already held that both had the same rationale, see 11 November 1932 RGSt 66, 397.

154 Kelk 2005, pp. 267 and 278. 
such a nature that the defendant could not resist it and neither should he have resisted it. ${ }^{155}$ Like in culpa, 'could' and 'should' denote a subjective and normative limb. ${ }^{156}$ The individual defendant is excused for committing the offence because he could not resist the pressure and a reasonable person in his shoes should have also not resisted, taking into account other normative factors such as his (official) position and prior fault. In other words, the actor must have insufficient control to act differently and this lack of control must be caused by something that is generally accepted as such a cause. ${ }^{157}$

In England, a similar two-staged test is applied. The first part of the direction on duress deals with the question whether the defendant was impelled to act as he did because of the fear that otherwise he would be seriously injured or killed. If that question is answered affirmatively, the subsequent question is whether a 'sober person of reasonable firmness, sharing the characteristics of the defendant,' would have also been impelled to commit the offence. ${ }^{158}$ By separating the issue in two stages, it is clear that after it has been established that the defendant could not resist the pressure, normative considerations enable the assessment of whether or not he also should not have resisted that pressure. In Germany, such a normative second stage is laid down in a test of what can legitimately be expected of the defendant. A difference is that in Germany, the (academic) focus of normative considerations is on duties to take the danger based on official position or special relationships. The English focus on the yardstick of the reasonable person, more specifically which individual characteristics should be taken into account.

Against the categorization into a psychological and normative limb, it can be argued that it is too imprecise. After all, every excuse can be argued to consist of a psychological and normative part. For example, in self-defence-excess, the defendant must have also been pressured by the attack to commit the offence, while normative aspects give the excuse its limits. Secondly, it can also be argued that the normative question overshadows the psychological. For example, in German law there is a tendency to accept that the defendant could not resist the pressure if a threat was made to life and limb of a relative. In other words, when a special relationship between persons is established, the psychological pressure in concreto does not have to be established. ${ }^{159}$

It is also argued more in general, that for the defence to apply, it is only required to establish that the defendant should not have acted differently. After all, the defendant literally 'could' always act differently. By contrast, the coercion needs to be understandable, not absolute. For example, a woman was very ill and according to the

155 HR 30 November 2004, NJ 2005, 94.

156 In culpa, the normal order is to assess first what the actor should (not) have done. Subsequently, it is considered whether the individual defendant could meet this standard. In duress, the order is reversed.

157 Van Dijk, A.A. 2008, p. 23; Rozemond 2006, p. 77 and de Hullu 2006, p. 283.

158 R. v. Graham [1981] EWCA Crim 5 and Law Commission 2006, pp. 112-113.

159 Roxin 2006, p. 976 and Schönke \& Schröder, H. 2006, p. 705. 
doctor, she should not be disturbed in her sleep, but the neighbour's singing bird kept her awake. When the neighbour refused to take the bird in the house, the woman's husband felt pressured to kill it. He could have acted differently, but the application of duress implies he should not have acted differently in these circumstances. ${ }^{160}$ In conclusion, any categorization of criteria has its disadvantages and uncertainties. Regardless of which dichotomy is applied, debate is possible as to which category a criterion belongs. Like in self-defence and necessity, subsidiarity and proportionality are distinguished here for analytical purposes.

\subsection{Subsidiarity}

Duress requires that the defendant could not be expected not to commit the offence because he was impelled by an imminent danger or threat to the life or limb of himself or persons close to him. This includes a lot of criteria. Successively, it will be discussed which interests can be protected under duress, which sources can trigger a pressure, what the relationship of this pressure should be with the offence and how imminent the threat, the danger, or better, the need to commit the offence must be. Then, the general requirements of adequacy and subsidiarity, already discussed in the context of necessity, will be discussed, after which normative limitations arising from special positions, relationships and prior fault will come to the fore.

\subsubsection{Legitimate interests}

Like in self-defence, two approaches can be taken as to the endangered interests that qualify for duress. Either the interests that can be protected under duress are limited or they are not. In England and Germany, the interests that may be protected are limited to the most serious ones. The danger that is averted must be directed against life, limb or personal liberty of the defendant or that of a relative or a person who is close to him. The narrowly defined enumeration of interests is explained by reference to its exceptional character, the fear of undermining the authority of the law and its psychological rationale, which presupposes that only the gravest threats can compel the defendant to break the law. ${ }^{161}$

Analogous extension to other interests has been rejected: a threat to property or reputation is insufficient. The interests must determine the physical existence of the human. Obviously, threats to life qualify; the scope of 'limb' is up for more debate. Usually it is argued the threat should be one of serious physical injury. ${ }^{162}$ Some

160 Dolman 2006, pp. 185 and 189 and van Bemmelen 1955, pp. 149-152.

161 R. v. Hasan [2005] UKHL 22; Ormerod 2005, p. 298; Bohlander 2009, pp. 123-124; Schönke \& Schröder, H. 2006, p. 702 and Roxin 2006, p. 972.

162 Law Commission 2006, p. 113 and Fischer, T. 2009, p. 314. Psychological interferences are excluded, see Schönke \& Schröder, H. 2006, p. 702, even if this is understood to be (grievous) bodily harm under the English Offences Against the Person Act 1861, see Ormerod 2005, p. 298. 
even submit this must be comparable to a threat to life. ${ }^{163}$ Others are more lenient, arguing that the danger to the bodily integrity may not be minor, which would the case when the threat constitutes a simple blow. ${ }^{164}$ Infringements or threats thereof to physical freedom can also give rise to duress in Germany. However, lawful infringements on this freedom need to be countered with legal alternatives. In the absence or exhaustion of legal remedies, the infringement needs to be taken. ${ }^{165}$

The threat must be directed against the defendant personally, his family, someone close to him or a person for whom he has responsibility or for whom the situation makes him responsible. ${ }^{166}$ The group of persons 'close to the actor' seems more limited in Germany by focusing on a lasting and current relationship, similar to relatives. Close friends, colleagues, neighbours and the ex-girlfriend are therefore excluded. ${ }^{167}$ From the perspective of the psychological rationale, this limitation seems unwarranted. Whereas blood is thicker than water, a person may be more compelled to save his best friend than the family member he never met. In fact, one may also be compelled to save other persons, and the law should not discourage citizens from helping each other. What if persons threaten that they will seriously injure children if the defendant does not comply with their demands? It would be very understandable if the defendant were to succumb to the threat, even if he did not know the children personally. In my opinion, duress should not be precluded in such cases. ${ }^{168}$

The contrary approach is not to exclude any interests from being protected under duress a priori, but to limit the scope of the defence through the other conditions, such as proportionality. The most popular approach in the Netherlands is to first consider the subjective impression of the threat to the actor. In contrast to its French roots, duress in Dutch law is no longer limited to the threat of specific legal interests. ${ }^{169}$ It is clear however that the more serious and personal the nature of the threat, the more likely the actor could in fact not resist. Secondly, the subsequent normative question is whether the defendant should have resisted. The defendant will therefore also not be excused for committing a serious offence if he was compelled to do so due to mere moral pressure. ${ }^{170}$

163 Bohlander 2009, p. 124 and Beulke 2008, p. 151.

16411 November 1932 RGSt 66, 397; Schönke \& Schröder, H. 2006, p. 702 and Roxin 2006, p. 973.

165 Schönke \& Schröder, H. 2006, pp. 702-703 and Roxin 2006, pp. 973-975. Lord Simon of Glaisdale in DPP for Northern Ireland v. Lynch [1975] UKHL 5 was uncertain whether 'unjustified imprisonment' should be included in duress.

166 Ashworth 2006, pp. 221-222; Ormerod 2005, p. 300; Law Commission 2006, p. 113; Simester \& Sullivan 2007, p. 673; Fokkens \& Machielse, note 2 on art. 40; Beulke 2008, p. 151 and Fischer, T. 2009 , p. 314.

167 Roxin 2006, pp. 975-976 and Schönke \& Schröder, H. 2006, p. 705.

168 Compare the case discussed by Tieks 2012, pp. 74-77.

169 Originally, the danger or threat also needed to concern the defendant or persons close to him, see Fokkens \& Machielse, notes 2 and 17 on art. 40. As a result, the emphasis is on the intensity of the effect of the pressure, like fear or desperation, on the defendant. 
Hence, the difference between the two approaches is mitigated, just as in selfdefence. There will hardly be a difference in outcome. ${ }^{171}$ Even if the object of the threat easily qualifies as a legitimate interest, the defence can still be rejected under the limb of proportionality or normative considerations regarding subsidiarity. Like in English and German law, the defendant can for example be required to resist the threat that his leg will be broken as this not necessarily compels the reasonable person to kill. ${ }^{172}$ In all legal systems, the rule is that the more serious the crime coerced to commit, the more irresistible the threat needs to be. ${ }^{173}$

It is therefore unwarranted to fear that this approach will lead to the acquittal of the defendant in cases where this is unacceptable. By contrast, there may be instances where the application of duress is warranted, but impossible because the threat does not relate to life or limb. Only this approach enables the excusing of the defendant who was threatened that an object of great personal value, like a painting of his deceased mother, would be destroyed if he did not assist in stealing a large diamond. Not excluding legal interests from the defence a priori enables flexibility and fair outcomes. The approach emphasizes the mutual relationship between the different conditions, which is also clear in other defences, and aligns it closer to its cognate necessity.

The approach also does justice to the essence of duress and excuses. Duress is about the irresistibility to withstand the pressure. It is not the danger itself that amounts to duress, but the impression it makes on the actor. He is excused because the threat of punishment could not change his conduct. By allowing any legitimate interest to be protected by duress, we correctly focus on the psychological pressure the threat has on the defendant. Excuses in general also deal with the question what could be expected of this specific defendant, not with an average citizen. Duress is not limited to what most people would consider irresistible forms of coercion, but tailored to the specific defendant. The fact that normative considerations put a limit to the extent in which the norm can be modified to the specific defendant does not change this, whereas these normative conditions make sure that, all things considered, the defendant made a choice for which he cannot be blamed.

\subsubsection{Source of the danger}

The threat or danger need not originate from human action necessarily; it can also originate from objects or nature. ${ }^{174}$ The pressure need not be actual force or the threat thereof. Circumstances can also amount to an irresistible pressure. ${ }^{175}$ Any force, urge, threat or pressure to which a legal subject cannot offer resistance

171 See the illustrations of Tieks 2012, pp. 67-70.

172 Ormerod 2005, p. 299; Roxin 2006, p. 973 and Schönke \& Schröder, H. 2006, p. 702.

173 R. v. Abbott [1977] AC 755 and Horder 2006A, p. 95.

174 Bohlander 2009, pp. 124-125; Beulke 2008, p. 152; Roxin 2006, p. 969; Fischer, T. 2009, p. 314 and Dolman 2006, pp. 177 and 318.

175 Dolman 2006, p. 318. 
suffices. ${ }^{176}$ In the past, Dutch and German law distinguished between the defendant who was coerced by another person and the defendant who acted under circumstances that arose outside of human conduct. ${ }^{177}$ As noted, English law still distinguishes duress by threats from duress by circumstances by the origin of the pressure.

The two forms of duress in English law have the same conditions, save for the so-called condition of nomination. In contrast to duress by circumstances, the threat must be aimed at coercing the defendant to commit a particular offence. Robbing a bank would for example not qualify under duress by threats if the defendant was merely coerced to pay back money by a notorious criminal, who threatened to kill him if he would not pay within a specific timeframe. ${ }^{178}$ Others argue that nomination should not be a requirement. ${ }^{179}$ The fact that the nature of the source is no longer relevant in the Netherlands and Germany can explain why nomination also appears to be irrelevant.

Still relevant in all Member States however, is the condition that the pressure should originate from an extraneous source. Any coercion that arises from characteristics of the defendant himself does not qualify for duress. ${ }^{180}$ For example, the defendants who were having suicidal thoughts because of their imprisonment were not excused for breaking out of prison. ${ }^{181}$ In another case, by contrast, the defendant broke the law because of fear that his wife would otherwise commit suicide. Duress was accepted because the suicidal tendencies were external to the defendant. ${ }^{182}$

In a European context, the concept of force majeure also only applies to "circumstances, extraneous to the operator concerned."183 Circumstances are hardly ever extraneous because they need to be outside the actor's control in a material or physical sense or otherwise situated outside his sphere of responsibility. ${ }^{184}$ For example, in one case, a substantial amount of oil had been lost by a broken pipeline and could not be retrieved. Article 14 of Directive 1992/12 allows for the exemption of excise duties for mineral oils that have gone lost as a result of, inter alia, force majeure. Given the fact that the company had control over the pipelines, the AG held that force majeure would probably not apply, leaving this for the national judge. The ECJ held that, although the fact that an undertaking is

\footnotetext{
176 Fokkens \& Machielse, note 1 on art. 40.

177 Roxin 2006, p. 969 and Dolman 2006, pp. 176-177.

178 Ashworth 2006, p. 220 and Ormerod 2005, p. 305. In contrast, the coercion to commit a robbery would be specific enough; it need not specify what bank.

179 Simester \& Sullivan 2007, p. 669.

180 Ormerod 2005, p. 301; Law Commission 2006, p. 113; Fischer, T. 2009, pp. 305-306; Roxin 2006, p. 1007; Holland 1989, pp. 265-267; Dolman 2006, p. 323 and Mevis 2006, pp. 620-621.

181 R. v. Andrew Rodger and Keith John Rose [1997] EWCA Crim 1760.

182 R. v. Martin (Colin) [1988] EWCA Crim 2.

18318 December 2007, Case C-314/06, Société Pipeline Méditerranée et Rhône [2007] ECR I-12273, $\S 23$.

184 Idem, $\$ 40$.
} 
responsible for an installation does not rule out force majeure, the defence would probably fail because of the lack of due diligence in supervising and checking the safety of the pipelines. ${ }^{185}$

Regardless of some exceptions, existential urges of consciousness and doctrinal persuasions can therefore only be acknowledged as excuses sui generis. ${ }^{186}$ In Germany, defendants will not be punished for acts of conscience under article 4 of the Constitution that holds the freedom of faith and conscience as inviolable. ${ }^{187}$ In the Netherlands, appeals to necessity or duress are often accompanied or substituted by the claim that a conviction for an offence of for example insulting someone would violate the freedom of speech under article 10 ECHR. ${ }^{188}$

The external condition also brings about that overreactions as a result of physical or mental disorders cannot qualify as duress and can only be accepted within the framework of insanity. ${ }^{189}$ For example, in a seemingly typical case of battered women syndrome, the defence was rejected as the defendant was judged partially insane. ${ }^{190}$ However, duress is also accepted in cases where the psychological condition of the defendant is an important cause of the offence. In two similar cases, the son had been involved in the killing of his tyrant father. Both defendants were excused under duress. The finding that the defendants neither could nor should have acted differently was partially grounded in the personality of the defendants as a result of years of abuse. ${ }^{191}$

Like in self-defence-excess, there must be a causal connection between the external event and the pressure, as well as between the pressure and the offence. ${ }^{192}$ The actor committed an offence because he could not reasonably resist the pressure and this lack of control must be caused by something that is generally accepted as such a cause. ${ }^{193}$ The cases above can be explained by the rule, similar as in excess, that as long as any internal condition does not overshadow the external cause of coercion, duress can be accepted. ${ }^{194}$ The pressure in duress often consists of a

185 Idem, $\$ 37$ and the opinion of AG Kokott of 18 July 2007.

186 Dolman 2006, p. 209; Strijards 1987, pp. 89-91; Holland 1989, p. 287 and Roxin 2006, p. 1007. As an exception, duress was accepted to the charge of insulting the Crown Prince in Hof Amsterdam 29 March 2004, NbSr 2004, 161. The defendant felt coerced to direct attention to the possible role played by the Prince's future father-in-law during the military regime in Argentina. Roxin 2006, p. 1007 and 20 December 1960 BVerfGE 12, 45.

188 Rejected in Hof Amsterdam 29 March 2004, NbSr 2004, 161, see above, where duress was accepted. The claim of a violation of art. 10 ECHR was accepted in Hof Amsterdam 28 April 2011, $L J N: B Q 2981$.

189 Strijards 1987, pp. 94-95 and Dolman 2006, p. 181. For example, kleptomania is rejected as a psychological pressure in Hof Arnhem 13 March 2009, LJN:BH6016.

190 Kelk 2005, p. 272.

191 Rb. Maastricht 20 February 2001, NbSr 2001, 299 and Hof Amsterdam 26 September 2000, NJ 2000, 746. See also Hof Den Bosch 18 February 2009, $L J N:$ BH3824.

192 Strijards 1987, pp. 91-93 and Nieboer 1991, p. 268.

193 Van Dijk, A.A. 2008, p. 23 and Rozemond 2006, pp. 76-77.

194 R. v. Z. [2003] EWCA Crim 191; Ormerod 2005, pp. 301-302; Law Commission 2006, p. 114 and HR 13 June 1989, NJ 1990, 48. 
combination of internal and external factors. ${ }^{195}$ In addition, it is possible to view the conduct of the victims above as the external cause of the internal malfunctioning.

The condition of the external cause is also put into perspective by taking into account individual characteristics of the defendant in assessing duress. Since duress is about a pressure which the defendant reasonably could and should not resist, he is compared to the reasonable person. The question is what can reasonably be required of the defendant and to what extent he should have resisted the urge to commit the offence charged. First of all, the pressure need not be absolute or insurmountable. The defendant is not compared to the diligentissimus pater familias or persons of special virtue: heroism is not required. ${ }^{196}$ Instead, the defendant is merely compared to 'a sober person of reasonable firmness, sharing the characteristics of the defendant.' 197

Certain characteristics of the defendant should be taken into account when assessing whether or not he should have resisted the pressure. In England, characteristics such as pregnancy, age, gender and even 'recognized' mental disorders are taken into account. ${ }^{198}$ In the Netherlands, age also limits what can legitimately be expected of a person. The case where a 17 -year old boy was being sexually abused by an older man is often mentioned. He wanted to end the abuse when he got a girlfriend, but the man wanted to hear nothing about it and threatened to tell his parents. In despair, the boy attacked the man with an axe, seriously injuring him. He was excused on grounds of duress, taking into account the childlike nature of the boy. ${ }^{199}$ Besides age, the Dutch judge takes into account the defendant's education, personality, societal status, development and so on. ${ }^{200}$

On the other hand, the external cause condition and the standard of the reasonable person militate against modifying this person with too many individual characteristics. It has been argued that reasons for (overre)acting that lie in the personality of the defendant, such as a timid, susceptible or vulnerable character should be excluded as internal sources and dealt with by insanity. ${ }^{201}$ Thus, charac-

195 Holland 1989, pp. 267-268 and 272-273 and 278; Kelk 2005, pp. 264 and 269-272.

196 Simester \& Sullivan 2007, p. 677; Ormerod 2005, p. 310; de Hullu 2009, pp. 293-294; Dolman 2006, pp. 97-99 and Kelk 2005, p. 266.

197 R. v. Graham [1981] EWCA Crim 5.

198 R. v. Bowen [1996] EWCA Crim 1792; Ashworth 2006, p. 221; Ormerod 2005, pp. 307-308 and Simester \& Sullivan 2007, p. 671.

199 Rb. Rotterdam 3 April 1941, NJ 1941, 665, mentioned in Kelk 2005, p. 268 and Holland 1989, p. 259.

200 HR 6 December 2011, $L J N$ :BR1146; Strijards 1987, pp. 93-94; de Hullu 2006, p. 284 and Dolman 2006, p. 193.

201 R. v. Bowen [1996] EWCA Crim 1792; Ashworth 2006, p. 221; Ormerod 2005, pp. 307-308; Simester \& Sullivan 2007, p. 671 and Dolman 2006, pp. 178, 181 and 319. In contrast, Stam \& ten Voorde 2009 argue in favour of more room to take into account disorders, like post-traumatic stress disorders into duress. 
teristics, which bear on the defendant's capacity to withstand duress, including mental disorders, increasingly tend to be excluded. ${ }^{202}$

\subsubsection{Imminent danger}

The concept of danger and its imminence are almost identical to those in necessity. ${ }^{203}$ Again, it is not so much about the imminence of the danger as about the imminence of the need to act. Even if the threat will not be executed immediately, the need to commit the offence can be imminent, like when the defendant was coerced to give false evidence in trial. The danger was present at the time the defendant had to testify. ${ }^{204}$ The imminence requirement is lenient because it is directly related to the question whether or not alternatives were open to the defendant. If the threat is not reasonably expected to be carried out immediately or almost immediately, it can be argued that the defendant could have taken evasive action like getting official help. ${ }^{205}$ For example, in cases where the defendant was the victim of domestic abuse, duress is usually rejected, not because the danger was not imminent, but because alternatives have not been used. ${ }^{206}$

\subsubsection{No other means of aversion}

The criminal offence must be capable of ending the danger and at the same time, be the least intrusive means. The conditions are similar to those in necessity. ${ }^{207}$ It is not required that the defendant is certain the danger will be ended by committing the offence, but it should be capable of ending the danger, because one should reconcile oneself to the inevitable. ${ }^{208}$ Secondly, the defendant's actions must constitute the least intrusive means of all alternatives. There must have been no evasive action the defendant could reasonably take, such as going to the authorities. For example, the person who is threatened by death not to testify against a criminal can attempt to receive official protection. When the danger can only be averted by interferences with interests of third parties, the lightest should be chosen and they

202 As proposed by the Law Commission 2006, pp. 129-130. Ormerod 2005, p. 308 signals a move towards the proposal of the Law Commission. See also R. v. Bowen [1996] EWCA Crim 1792: "In most cases it is probably only the age and sex of the accused that is capable of being relevant."

203 Bohlander 2009, p. 124; Beulke 2008, p. 152 and Roxin 2006, pp. 969-970.

204 R. v. Hudson and Taylor [1971] EWCA Crim 2 and 5 March 1954 BGHSt 5, 371. See also 15 May 1979 BGH NJW 1979, 2053.

205 R. v. Hasan [2005] UKHL 22; Law Commission 2006, p. 113; Simester \& Sullivan 2007, p. 669; Schönke \& Schröder, H. 2006, pp. 703 and 712; Fischer, T. 2009, p. 314; Hof Den Bosch 20 June 2001, NbSr 2001, 230 and de Hullu 2006, p. 283.

20612 July 1926 RGSt 60, 318 and 25 March 2003 BGHSt 48, 255.

20721 May 2005 BGH NStZ 1992, 487; Bohlander 2009, p. 125; Beulke 2008, p. 152 and Schönke \& Schröder, H. 2006, p. 703.

208 Roxin 2006, p. 966; Schönke \& Schröder, H. 2006, p. 706 and Dolman 2006, p. 191. 
should only go as far as necessary. For example, the defendant can also refuse to testify rather than to commit perjury. 209

The question of what alternatives the defendant should have used is influenced by the question of how promising the means were. If one's life or limb is endangered, the defendant should not be reproached for using the more promising means. Moreover, alternatives have in practice proven not to always be effective. For example, in case of domestic abuse, the police cannot always help, a woman might be reluctant to leave her children and the abuser sometimes finds the victim in a woman's refuge centre. ${ }^{210}$ Only if there truly was no alternative at all, it can be said that the defendant could not act differently. However, this is not required. Duress is not vis absoluta, it is vis compulsiva. It is only required that there was no reasonable alternative.

The duty and possibility to investigate alternatives depends on the nature of the offence. The more serious the offence one is coerced to commit, the more the actor should carefully weigh alternatives. ${ }^{211}$ This also depends on the severity of the danger. The less severe the danger, the more the actor should be diligent in trying to find another way out. ${ }^{212}$ The circumstances of the deliberation are important, such as the available time to reflect, and the question whether this could be done in peace. The yardstick is what a reasonable person could be asked to do. Reasonable shortcomings or mistakes in the duty to test alternatives are covered by duress, not putative duress. $^{213}$

Consider the case where a person woke up in the middle of the night to see two people he vaguely knew in the process of killing the owner of the house. Terrified they would kill him too, he complied with their demand to become part of the killing and strangled the man. The coercers had thought this would prevent him from talking to the police, but he did in fact report it to the police. As it was uncertain who killed the man, he was convicted for attempted killing. The German Supreme Court however quashed the decision. It held that the coerced person generally has a duty to evaluate to the best of his ability all alternatives in order to apply the least intrusive. Even stricter tests are required when the infringement of an interest is very serious. However, in extreme cases, such a careful test cannot be required. It is essential whether the actor had the opportunity to contemplate and whether alternatives are very likely to come to mind or in contrast, did not come up at all. The Court took into account that the defendant was still intoxicated, just like the attackers, which also implied a greater danger towards the defendant. He found himself surprised in an extremely threatening situation. In exceptional cases, the

20926 April 1932 RGSt 66, 222. Compare 5 March 1954 BGHSt 5, 371 and R. v. Hudson and Taylor [1971] EWCA Crim 2.

210 Roxin 2006, pp. 970-972 and Ormerod 2005, pp. 309-310.

21129 March 1963 BGHSt 18, 311 and Roxin 2006, p. 971.

212 Beulke 2008, p. 152.

213 Beulke 2008, p. 154; R. v. Graham [1981] EWCA Crim 5; Ormerod 2008, p. 329 and Ashworth 2006, p. 222. 
actor may be required to risk his own life, but not in this case where the life of the victim would have probably also been lost if the defendant had refused to carry out the demanded act. ${ }^{214}$

Just like in necessity, there can be situations where the defendant has to take the danger even if the offence is the least intrusive or only means of avoiding the danger. Again, this includes situations in which the legislator already foresaw the danger and created limited room for exceptions to the prohibition, for example by means of an exemption procedure. It also includes situations in which legal remedies were to no avail. For example, the defendant may not use force to end the unlawful deprivation of freedom by public officials. ${ }^{215}$ These normative considerations are explicitly positioned as an aspect of subsidiarity in Germany under the heading of 'Zumutbarkeit'. They are taken into account to assess whether the offence was necessary or that he could be required to act in conformity with the violated norm. It 'can legitimately be expected' 216 of someone to take the danger if he caused the danger himself or if it arose out of a special legal relationship or duty. 217

There may be other situations where the defendant has to take the danger. The defendant may be under a legal obligation to suffer the danger. This is usually based on a position or office, which requires the subject to protect individuals and the common good, such as police and firemen, doctors, sailors, and so on. ${ }^{218}$ The dangers one is required to take must be related to the profession or duties of the actor. $^{219}$ The exact scope of the obligation must be found through reference to the purpose of the respective office, in other words, the interest that the office protects and the dangers typically concerned with its exercise. There is no general duty identical to all these positions. ${ }^{220}$ Moreover, the actor is not required to accept lethal or life-threatening harm, even if the danger is specific to the office. Dangers that go above and beyond what could be expected and which sacrifice is grossly disproportionate in relation to the saved interest are not to be taken. Heroism is never required. The restriction requires a duty to accept dangers, but not to consciously sacrifice one's life. ${ }^{221}$

21 May 1992 BGH NStZ 1992, 487.

Roxin 2006, p. 980 and Schönke \& Schröder, H. 2006, pp. 703 and 709-710.

Compare Dressler in Shute \& Simester 2002, p. 278: "The defence of duress requires us to determine what conduct we (...) may legitimately expect of our fellow threatened humans."

$\S 35(1)$ second sentence of the German Criminal Code; Beulke 2008, p. 152; Schönke \& Schröder, H. 2006, pp. 704-706 and Roxin 2006, p. 971.

Bohlander 2009, p. 127-128; Fischer, T. 2009, p. 316; Roxin 2006, p. 979 and Schönke \& Schröder, H. 2006, pp. 708-709.

14 June 1938 RGSt 72, 246; Roxin 2006, p. 980 and Schönke \& Schröder, H. 2006, p. 709.

Bohlander 2009, pp. 127-128 and Schönke \& Schröder, H. 2006, p. 709.

Roxin 2006, p. 980; Bohlander 2009, p. 125; Schönke \& Schröder, H. 2006, p. 709 and Dolman 2006, pp. 204-205. Fischer, T. 2009, p. 316 and Pawlik 2004, p. 1053 exclude the soldier; he can be required to sacrifice his life. 
A similar duty to take the danger can also be grounded in familiar relationships, such as those of a husband towards his wife and children. It can also follow from joint risky ventures and resistance groups in totalitarian states. ${ }^{222}$ During WWII, a member of the Dutch resistance was coerced to give up several of his co-members, who died in imprisonment. If he would not help the occupiers, two children would be tortured. Although more could be expected of him, the pressure was accepted as that he could and should not have acted differently. 223

It has become clear that the scope of a defence can be extended as well as limited by modifying the yardstick of the reasonable person through the taking into account of individual characteristics of the defendant. We expect less from the victim of domestic violence than from a police officer. ${ }^{224}$ Apparently, the focus in German law is on such characteristics that limit duress, whereas in English and Dutch law, relatively more attention is paid to those features that extend the scope of what could be required of the defendant.

\subsubsection{Prior fault}

A duty to take the danger can also be grounded in prior fault. In England, this is usually discussed in the context of people joining a criminal enterprise or becoming indebted to drug dealers who have a violent reputation. As a rule, duress is precluded when, because of the voluntary association with criminals, the defendant foresaw or should have been able to foresee the risk of being subjected to any compulsion by threats of violence. ${ }^{225}$ It used to be required that the foresight or foreseeability of coercion related to the crime of the type with which he is charged or an offence of the same or similar character. ${ }^{226}$ Later however, any compulsion was held to suffice, further limiting the scope of duress under the influence of the public policy argument that association with criminals should be discouraged and that people in criminal organizations should not benefit from the defence. ${ }^{227}$

In Germany, a strict approach also seems to be taken. After all, the law explicitly states that prior fault brings about that the actor should take the danger, leaving open only the possibility of mitigation. The person who shot a border guard when he was caught attempting to flee the GDR was not excused under duress, because he could foresee the danger he got himself into by attempting to flee whilst being

222 Roxin 2006, p. 985; Schönke \& Schröder, H. 2006, p. 710-711 and Dolman 2006, pp. 204-205.

223 De Hullu 2006, pp. 284-285.

224 Mevis 2006, p. 620 and Fokkens \& Machielse, note 6 on art. 40.

225 R. v. Hasan [2005] UKHL 22 and R. v. Ali [2008] EWCA Crim 1726. See Ashworth 2006, p. 223; Ormerod 2005, p. 304 and Simester \& Sullivan 2007, p. 672. See also ICTY, Separate and dissenting opinion of Judge Cassese, Prosecutor v. Erdemović, Case No. IT-96-22-A Ch., 7 October 1997, $\S 16$ and 50.

226 R. v. Baker and another [1999] EWCA Crim 913 and R. v. Z. [2003] EWCA Crim 191. See also Law Commission 1977, pp. 13-14.

227 R. v. Hasan [2005] UKHL 22; Leverick 2006, p. 11 and Ormerod 2005, pp. 341-342. Criticized as "unacceptably wide" by Ibbetson 2005, p. 531. 
armed. ${ }^{228}$ However, it can be deduced from German case-law that not all forms of prior fault will preclude the defence. When comparing the situations where the courts required the defendant to suffer the danger to himself with the situations that were held to be outside of what could legitimately expected of the defendant, the pattern that is to be discerned, is that duress is more likely to be rejected if the defendant is in some way involved in the origin of the danger or collaborated with the source of the danger, such as joining a criminal organization. ${ }^{229}$ The mere causing of a danger does not suffice to preclude duress. This causing must in some way be blameworthy or unreasonable, or else the person who gives an incriminating testimony would also have to bear the ensuing threats by the persons affected by it. $^{230}$

Some German scholars differentiate, holding that the intentional causing of a situation of duress will preclude the defence, whereas in lesser forms of prior fault, the specific circumstances of the case matter, such as the degree of the fault, the danger and the consequences of the offence. Dutch law also takes such a nuanced approach. ${ }^{231}$ As was accepted already in the context of self-defence, prior fault is nowadays treated in Dutch law as a corrective mechanism that may, but need not preclude the defence. ${ }^{232}$ It is only assessed after the other conditions of duress have been established. For example, the defendant had gone to the house of her ex-boyfriend, who had left her for someone else. When a fight broke out, she took a knife and killed him. The Dutch Supreme Court quashed the rejection of the defence based on prior fault, submitting that this reasoning did not preclude that she had acted under duress. ${ }^{233}$

This approach to assess the legal consequence of prior fault according to the degree of the fault and all the circumstances of the case is most consistent with the effect of prior fault in the context of other defences. It also fits in best with treating prior fault under the criterion of what can legitimately be expected of the defendant, like in German law. In the end, that question also takes into account all circumstances. $^{234}$ The scope of prior fault in English law neglects important normative distinctions, again because of fears of sending the wrong message. There is no reason to assume the nuanced approach will have that consequence.

2286 July 2000 BGH NJW 2000, 3079.

229 Bohlander 2009, pp. 125-126.

230 Bohlander 2009, pp. 126-127; Schönke \& Schröder, H. 2006, p. 707 and Roxin 2006, pp. 981982. Beulke 2008, p. 152 argues that the conduct that gives rise to the danger must be objectively wrongful.

231 Schönke \& Schröder, H. 2006, pp. 707-708. HR 9 June 1987, NJ 1988, 318; HR 13 June 1989, NJ 1990, 48; HR 10 October 1995, NJ 1996, 356 and Fokkens \& Machielse, note 9 on art. 40.

232 In many trials following WWII, the prior fault of joining the enemy armed forces precluded the availability of a defence for orders given afterwards.

233 HR 13 June 1989, NJ 1990, 48; HR 30 November 2004, NJ 2005, 94; Kelk 2005, p. 282; de Hullu 2006, pp. 295-296 and 330 and Rozemond 2006, pp. 77-80 and 151.

234 Fischer, T. 2009, p. 315. 


\subsection{Proportionality}

Duress can excuse the actor who saved his life at the expense of multiple lives. Duress can also excuse the actor who killed to prevent serious bodily injury. A strict test of proportionality therefore does not seem to be required. Necessity requires the evil avoided to be considerably greater or at least clearly greater than that inflicted, whereas duress merely requires that the offence is not disproportionate to the threat averted. Duress does not require that the defendant did the right thing: his actions merely need to be understandable. On the other hand, some proportionality is required because of the normative character of duress and the general preventive goals of punishment it is said to uphold. For example, killing in order to prevent reparable bodily injury cannot be excused. ${ }^{235}$

Duress and necessity on the one hand, and self-defence and self-defence-excess on the other hand, are distinguished by proportionality. The use of force that went beyond the degree necessary to avert a wrongful attack can be excused under selfdefence-excess. Cases that are not covered by necessity due to a disproportionate relationship between the sacrificed and the saved interest can be excused under duress. In essence, both defences excuse the defendant because he could not be expected to restrain himself. In self-defence-excess this is due to a wrongful attack. In duress, this is due to the threat or circumstances. ${ }^{236}$ Secondly, both duress and self-defence-excess are limited by placing an upper limit on proportionality. When the use of force or aversive measures goes beyond this upper limit, the wrongful attack or pressure can only be taken into account in sentencing.

An important difference is that the justification of self-defence, like the excuse duress, also merely requires that the use of force is not disproportionate. The excuse of self-defence-excess can even apply to disproportionate responses to wrongful attacks. In terms of disproportionate conduct, more can therefore be excused under self-defence-excess than under duress. The difference is explained by the fact that in self-defence, the force is directed against the source of the wrongful attack, not a third party. Secondly, by defending an individual legal interest, the legal order is defended too.

It is generally accepted that duress is an excuse. ${ }^{237}$ The actor has not served the clearly prevailing interest. The interference is not lawful or socially useful but socially harmful and wrongful. ${ }^{238}$ Controversy on the categorization of duress can be explained by the fact that in case-law, the distinction between necessity and

235 Ormerod 2005, p. 324; Law Commission 1993, p. 63; Roxin 2006, pp. 980-986; Bernsmann 1996, p. 185; Beulke 2008, p. 155; Roxin 2006, pp. 985-986 and Strijards 1987, pp. 92-93.

236 Compare the English defence of loss of control in X.3.6.1.

237 R. v. Hasan [2005] UKHL 22; Ormerod 2005, p. 298; 3 March 1930 RGSt 64, 30; Roxin 2006, pp. 963-965 and explicitly laid down in $\S 35$ of the German Criminal Code.

238 Roxin 2006, pp. 963-964. 
duress as justificatory and excusatory is not always explicitly made. ${ }^{239}$ Secondly, situations of necessity are treated in England often as situations of duress (by circumstances). ${ }^{240}$ Most important in this context, is that there are instances where the defence comes closer to a justification. This is the case when there is great disparity between the threat and what is required, for example when an actor is compelled under a threat of death to give the key of a safe. In these cases, one may be inclined to say the defendant is justified. ${ }^{241}$

The more the proportionality of the defendant's conduct approaches that of necessity, the more likely it is seen as a justification. Particularly in cases where the proportionality of the conduct is self-evident, it is common for duress to be based on the view that what the defendant did was in fact a reasonable response to extreme pressure. ${ }^{242}$ Therefore, it seems reasonable to conclude that although the paradigm cases of the justification and the excuse are clear and the theoretical borders strict, borderline cases put the distinction in perspective. They warrant the view that the distinction between necessity and duress and perhaps even between justification and excuse is gradual.

There is, however, an important reason not to equate these instances of duress with necessity. For example, if the defendant would be coerced under threat of death to break a window, this might seem justified, but that would imply that the owner cannot act in self-defence, that he has to take the harm. In order to allow the owner to defend his interest, the coerced actor must be considered as excused. The owner would be allowed to act in self-defence against the person coerced with death, who is therefore excused, but this right would be seriously limited with a view to the situation that person is in. ${ }^{243}$ Hence, just like the different fault elements, duress and necessity can be placed on a continuum, but they should be considered as separate general principles of criminal law with their specific character and consequences.

The weighing of interests is conducted very similar as in necessity. The judge has to take into account the threatened and infringed legal interest as well as the nature, degree and gravity of the danger. For example, a very uncertain danger of bodily harm will not likely excuse certain death of another. Similarly, the expected success of the means used to avert the danger plays a role. ${ }^{244}$ The weighing of legal interests is primarily objective, but there is room for the actor to attach more weight to his own interests than those of others. Since duress is about agent-specific

239 De Hullu 2006, p. 281. In addition, article 40 of the Dutch Criminal Code is said to include both necessity and duress.

240 Law Commission 2006, pp. 112 and 125.

241 Simester \& Sullivan 2007, p. 666; Law Commission 2006, p. 125; Clarkson 2004, p. 85; Roxin 2006, pp. 755-756; Machielse 1986, p. 526 and Holland 1989, p. 263. By contrast, Schönke \& Schröder, H. 2006, p. 693.

242 Ashworth 2006, p. 224.

243 Beulke 2008, pp. 153-154 and Roxin 2006, p. 756. This approach is similar to that of selfdefence against infants and insane aggressors see IX.3.5.2.

244 Dolman 2006, pp. 189-191 and Roxin 2006, pp. 985-986. 
reasons for acting, there is more room for these considerations than in necessity. It is a rule of general experience that someone is more likely to be pressured to save his own interests.

The greater the weight given to the other criteria of duress, the less important the condition of proportionality becomes. Proportionality is less likely to become a stumbling block to accepting duress if the interests that can legitimately protected are already limited to the most serious ones of life and limb. Most offences are not disproportional in relation to these protected interests. Even the offence of homicide is not disproportional if the defendant killed in order to save his own life or that of a relative. Only in England, a different perspective is taken on this issue, which will be discussed below. It has already been explained that in the Netherlands, where the interests are not limited, normative considerations including proportionality play a more important role in limiting the defence.

A second example concerns the conditions that are encompassed in Germany under the heading of what can legitimately be expected of the defendant. Under this heading of subsidiarity, grossly disproportionate actions are excluded from duress by positioning it as a reason to require the actor to take the danger. ${ }^{245}$ For example, in the aforementioned case where the defendant shot and killed a GDR border guard, the Supreme Court held that the defendant should have taken the danger because he knew the risk in trying to flee the GDR. He should however have also taken the danger, given the importance of the border guard's life. The manner in which he tried to avert the danger to his family when discovered was so disproportionate that he should have resisted the pressure to commit that offence. ${ }^{246}$

The following two subsections deal with the questions whether duress should also apply to homicide and torture. Both issues can be approached from the point of view that holds it impossible to take torture and homicide into account in a weighing of interests. In other words, these actions can never be excused under duress as they are absolutely prohibited. No exception can be made; any balancing is taboo.

\subsubsection{Murder}

In discussing joint risky ventures in the context of necessity, it was already made clear that in Germany and England, the sanctity of human life brings about a prohibition on the weighing of human lives. If this taboo would not exist, a slippery slope argument is that an innocent person could be sacrificed so his organs could be used to prolong the lives of others. However, in cases where the victim was doomed anyway, the taboo seemed less self-evident. It was concluded that the killing of innocent persons in cases of joint risky ventures should not amount to criminal

245 In the German concept of self-defence, disproportionate conduct is excluded from the defence too, officially not by a requirement of proportionality, but by so-called socio-ethical limitations on self-defence, grounded amongst others in special relationships or prior fault, see IX.3.5.4.

2466 July 2000 BGH NJW 2000, 3079. Nevertheless, he only received a sentence of one year of imprisonment. 
liability. The application of an excuse, like duress, may be favoured over that of a justification as it communicates merely that the defendant should not be blamed for sacrificing the victim.

The rule that duress cannot apply to murder denotes the significance of the taboo in English law. The limitation is considerable, given the broad scope of murder in English law, which includes the intentional infliction of grievous bodily harm resulting in death. Unlike other legal systems, the English legal system makes no concession to human frailty and requires a heroic self-sacrifice. Like in necessity, it was feared that otherwise this would provide criminals with a formidable defence, leaving the innocent victims without protection. Thus, under no circumstances, the law should recognize that anyone has the liberty to choose that one innocent citizen should die rather than another. ${ }^{247}$ Blackstone is often cited: "And therefore though a man be violently assaulted, and hath no other possible means of escaping death, but by killing an innocent person; this fear and force shall not acquit him of murder; for he ought rather to die himself, than escape by the murder of an innocent."248

There are numerous references of ancient and contemporary authority against recognizing a defence to murder, based on the sanctity of life and the desirability of dealing with hard cases by executive discretion, like in Dudley and Stephens. The rule was explicitly recognized in the 1985 case of Howe, ${ }^{249}$ overruling Lynch. ${ }^{250}$ In the case of Lynch, as interpreted by the House of Lords in Howe, duress was said to apply in cases of murder, not to the actual killers, but it would apply to aiders and abettors. The difference can be explained by the mandatory life sentence that follows when duress is precluded to a charge of murder. This sentence was probably considered too harsh for aiders and abettors, who are convicted for murder, just like the actual killer. Therefore, in order to avoid this, they could rely on duress in relation to murder. Compare that in German law, murder is also punished with a mandatory life sentence. If the defendant is an aider or abettor, the life sentence may be mitigated.

Nevertheless, holding that there is no reasonable justification for leaving the distinction in tact, in Howe, the House of Lords saw themselves placed before the choice of extending the defence to all participants, or withholding the defence of duress to any party otherwise guilty of murder. After considering that the latter was the generally accepted view before Lynch and finding that the reasons for this exclusion were still applicable, the House of Lords ruled that duress was no defence

R. v. Howe [1986] UKHL 4; Ashworth 2006, pp. 227 and 275 and Ormerod 2005, p. 312.

Blackstone 1769 (reprint 1979), p. 30. However, Blackstone 1769 (reprint 1979), p. 186 also argued in discussing the case of Carneades that the universal principle of self-preservation brings about that the defendant who preserves his own life at the expense of another man's should be excused. 
to murder. If a change regarding the current law was to be made, this should be done by Parliament.

English law seems inconsistent, as duress is also not applicable to attempted murder, ${ }^{251}$ but it is applicable to incitement and conspiracy to murder. ${ }^{252}$ It is also probably not applicable to (some forms of) treason, ${ }^{253}$ and conspiracy. ${ }^{254}$ The rule is also striking in comparison to the partial defences of diminished responsibility and loss of control. Partial defences only apply to murder, reducing the charge to manslaughter. Why should the person who is coerced to preserve innocent life receive a life sentence for murder, whereas the person who killed because of loss of self-control is only liable for manslaughter? ${ }^{255}$ The impossibility to raise duress against a murder charge explains why the killing of persons who abused the defendant, usually the wife or child, over a long period of time, is treated under the partial defence of loss of control. ${ }^{256}$ This is however an unsatisfactory compromise, not enabling the complete acquittal of those defendants that would be excused under Dutch and German law.

Currently, it is questioned in England whether the rule against the application of duress to murder still exists. Although in the case of the conjoined twins, only Brooke LJ squarely based his decision on grounds of necessity, ${ }^{257}$ the ruling is often interpreted as that a necessity plea is now possible to a charge of murder. ${ }^{258}$ Necessity and duress by circumstances are considered interchangeable defences in English case-law, which implies authority to apply duress to murder as well. ${ }^{259}$ The courts however still preclude duress to murder, admitting that this may lead to undesirable results. For example, a thirteen-year-old boy who participated in a murder with his father out of fear for his violence could not rely on duress. ${ }^{260}$ In any event, most English scholars have argued in favour of making available duress to murder. ${ }^{261}$ The Law Commission has retracted its previous proposal to treat this as

251 Simester \& Sullivan 2007, p. 665 and 670; Law Commission 2006, p. 112 and Ormerod 2005, pp. 297 and 313.

252 Ormerod 2005, p. 313.

253 R. v. Hasan [2005] UKHL 22; Simester \& Sullivan 2007, p. 665; Law Commission 2006, p. 112; Law Commission 1977, p. 16 and Ormerod 2005, p. 297.

254 R. v. Abdul-Hussain [1998] EWCA Crim 3528.

255 Compare Horder 2006A, p. 93 and Law Commission 2006, p. 124.

256 See X.3.6.1.

257 Re A. (Children) [2000] EWCA Civ 254 and Simester \& Sullivan 2007, p. 720.

258 Ormerod 2005, p. 324. 'Sometimes,' according to Simester \& Sullivan 2007, p. 721. Ward LJ emphasized in Re A. (Children) [2000] EWCA "the unique circumstances for which this case is authority." Rogers 2001, p. 517 submits that it is likely however that in a future case this case will be used as authority.

259 It is submitted that the claim of the men in Dudley and Stephens was in fact the excusatory claim of duress by circumstances, see Simester \& Sullivan 2007, p. 719 and Fletcher 1973, p. 373.

260 R. v. Wilson [2007] 2 Cr App R 31. He could only rely on a partial defence.

261 Simester \& Sullivan 2007, p. 670 and Law Commission 1977, pp. 8, 14 and 16 and Law Commission 2006, p. 14. 
a partial defence to murder 262 and now tries to strike a compromise by advocating in favour of its availability coupled with a reversed burden of proof. ${ }^{263}$

Exceptions to the right of life are considered to be exclusively listed in article 2 ECHR. The only defence that can exculpate the defendant for infringing the right to life seems to be self-defence: a life may only be sacrificed if this is absolutely necessary to avert an unlawful attack. Therefore, neither necessity, nor duress seems to qualify as an exception to article 2 ECHR. However, I know of no cases in which a State was convicted for excusing the defendant who killed in duress. In contrast, article 2 strengthens the conclusion that the right to life is not absolute. It may therefore be concluded that article 2 does not preclude intentional killing in situations of duress or necessity.

In the Netherlands and Germany, duress is not precluded against a charge of homicide. Whether the defendant will be excused depends on the circumstances, such as the nature of the threat. All circumstances are taken into account in a balancing exercise, after which a judgment follows on the question whether the defendant could legitimately be expected not to kill the victim. Clearly, duress is only accepted to a murder charge in extreme circumstances. Since the right to life is so important, even more restraint is required from the defendant. ${ }^{264}$ Hence, whereas there will not be many instances where the intentional killing of a third party will be excused, there are no convincing reasons to exclude duress from homicide a priori. If joint risky ventures are considered as instances of duress, they present good examples why the defence should be available. It was explained in that context that the law should not and cannot require heroism. Moreover, omitting to sacrifice the doomed victim leads to unacceptable results when all involved may perish.

\subsubsection{Ticking bomb scenarios}

Fuelled by terrorist attacks and counter-measures, since the last decade much debate has been taking place on whether or not there are situations in which torture should be allowed. What if a bomb will go off and the person who knows its location refuses to tell where it is? Should it be allowed to torture this person in order to prevent the killing of many innocent victims? For our purposes, we will limit the debate regarding these ticking bomb scenarios to the question of whether or not the person who tortures the terrorist can be excused by duress. In the end, the question boils down to whether or not exceptions can be made to the prohibition of torture. In other words, the question is whether duress can be raised against torture.

The above-mentioned ticking bomb scenario is usually hypothetical, although similar situations have occurred in practice. Different variations to the hypothetical exist, prompting one to be clear on the scenario that is used. In this discussion, a

262 See Law Commission 2006, pp. 14 and 111, also rejected in R. v. Howe [1986] UKHL 4.

263 Law Commission 2006, pp. 133-137.

264 See HR 6 December 2011, $L J N$ :BP9394, in which case the defendant killed a very young child. 
timed bomb is placed somewhere, unknown to the authorities. It will explode within a short amount of time, killing many civilians, unless a bomb squad deactivates it. The terrorists have warned the authorities that a bomb will explode, without making demands that need to be fulfilled to stop the explosion. The location remains unknown, but the authorities know that a suspect they currently have detained knows the location of the bomb. In order to make him disclose the location of this bomb, the order is given to torture him. Shortly after the torture has commenced, the suspect confesses the location of the bomb, which is deactivated just in time.

The strongest hypothetical will be taken as a starting point, which means all facts that are uncertain in reality are assumed. It is assumed that the suspect in fact knows the location of the bomb; that he discloses this because of torture; that it would otherwise not be known where the bomb had been located; that the suspect does not stall time by giving false locations; that the torture does not leave any permanent physical damage and so on. This enables us to focus on other arguments, of which in the end, the absolute prohibition on torture seems to carry most weight. ${ }^{265}$

This hypothetical makes the case in favour or torture very strong, sidelining many arguments that would otherwise be raised against the use of torture. In practice, it will however hardly ever be possible to exclude these uncertainties. The suspect may thus have been tortured to no avail because he gave incorrect information or worse, because he had nothing to do with it. By accepting the inevitable uncertainties, serious spill-over effects are risked that may even fuel hate and terrorism. Even after eliminating uncertainties on information and effectiveness, dangerous slippery slopes remain by relaxing the absolute prohibition on torture. In the war on terror, torture has been institutionalized by some States. It may even be used for lesser threats and against other persons, such as the terrorist's wife or child: once a principle has a price, all that is left is the bargaining. ${ }^{266}$

A second level of the debate deals with which defence should or should not apply. In general, the more one is tempted to morally legitimize torture, the more one is inclined to apply a justification. By arguing in favour of an excuse, the act itself is condemned. ${ }^{267}$ The contrasting view is to hold the defendant liable and punish him. In between these extreme positions, solutions have been advanced like holding the defendant liable, but to mitigate his punishment or to not punish him at all either by judicial or executive discretion. ${ }^{268}$

Some emphasize the importance of distinguishing between the State and the individual defendant, usually to argue that only the State is precluded to torture. ${ }^{269}$ The argument that by torturing the terrorist one in fact sacrifices the ideals and

265 Ginbar 2008, introduction and Ohlin 2008, p. 271 both applied the same method.

266 See Kutzj 2007, p. 255.

267 Like in joint risky ventures, it has also been argued that the defendant should not be held criminally liable without reference to a justification or excuse.

268 Respectively Gaeta 2004 and Gross 2004. See the case against Daschner mentioned below.

269 Gaeta 2004 and Klip 2007A, p. 349. Compare Spronken 2011, p. 49 and section 134 of the Criminal Justice Act 1988. The distinction can also be related to the aforementioned view in Germany that human rights treaties like the ECHR only lay down obligations to States. 
beliefs one seeks to protect is strongest in respect to the State as an actor. I already explained that in holding the Air Security Act null and void, the German Constitutional Court left open the possibility that the individual who shot down a hijacked airplane might be excused. A distinction can be made between the ex post application of defences and the ex ante operation of legal provisions or policy regarding these scenarios. ${ }^{270}$ In general, the application of legal provisions that would apply ex ante is favoured. ${ }^{271}$

If the defendant was ordered by a state official to torture the suspect, it may be questioned whether he can be acquitted based on the defence of superior orders. However, both the Statute of the International Criminal Court and the United Nations Convention against Torture and Other Cruel, Inhuman or Degrading Treatment or Punishment explicitly preclude this. Self-defence has been advanced as the correct solution, ${ }^{272}$ as the bomb also constitutes an (usually) immediate and wrongful attack. This solution has however also been rejected because something which is absolutely forbidden can never be a proportionate means of self-defence. ${ }^{273}$

Duress is advanced because the application of an excuse makes clear that torture is wrong. ${ }^{274}$ As became clear in the context of joint risky ventures, the application of an excuse avoids controversial questions on the weighing of lives versus the human dignity of the terrorist. Secondly, duress focuses on the fact that a great dilemma coerced the defendant to act as he did. The application of duress can become problematic when the condition is applied strictly that the threat or danger must relate to someone close to the actor like a relative. ${ }^{275}$ However, I already rejected such a strict approach. Duress thus seems to be the best candidate for exculpating the defendant.

If it is accepted that the conditions of a defence like self-defence or duress can apply to the ticking bomb scenario, it can still be deliberated on a third level, whether it should be allowed to make exceptions to the prohibition of torture by excusing the defendant under duress. Human dignity, which includes the right not to be tortured, can be considered an absolute or non-derogable right that may not be infringed. Therefore, it is argued that it cannot be weighed against other interests that are protected, such as the lives of the innocent people who would be hit by the bomb. ${ }^{276}$ This also seems to be the approach taken by the ECtHR, based on the fact

270 Kadish 1989B.

271 Roxin 2006, p. 757; Kinzig 2003, p. 808; Schönke \& Schröder, H. 2006, p. 693; Ginbar 2008, p. 341; Robinson 1989, p. 190 and Dershowitz 2002, p. 477, the latter who has argued in favour of 'torture warrants.'

272 Erb 2005.

273 Roxin 2006, pp. 706-708; Roxin in Arnold a.o. 2005, p. 465; Jessberger 2005, p. 1072; Kinzig 2003, p. 811 and Polzin 2008, p. 173.

274 Ambos 2008 and Ohlin 2008 therefore favour the ex post application of an excuse over the ex ante abstract relaxation of torture. See also See Shany 2007, p. 862.

275 Ohlin 2008, pp. 296-297 and Schönke \& Schröder, H. 2006, pp. 667-668.

276 Roxin 2006, pp. 770-772 and Fischer, T. 2009, pp. 289-290. 
that article 3, like other anti-torture provisions, is considered an absolute injunction, unlike for example, the right to life under article 2 of the ECHR. ${ }^{277}$

The ECtHR had the chance to rule on the admissibility of torture in a similar situation. In the case of Gäfgen, ${ }^{278}$ the claimant had been threatened to be tortured. In order to find out the whereabouts of the child abducted by Gäfgen, a German police commissioner named Daschner ordered the threat and, if that would have been necessary, execution of torture. Gäfgen had confessed to the abduction but refused to tell where the child was. Therefore, Daschner feared that if the abducted child was not set free within limited time, he might suffocate. After some threats with physical injuries had been made, Gäfgen confessed where he had kept the child. Upon arrival, it turned out however, that Gäfgen had already killed the child. This demonstrated that the strongest argument against torture is that one can never be certain that it will be effective. Daschner was convicted as guilty, but only received a fine and a conditional prison sentence.

The Grand Chamber of the ECtHR, overruling the Fifth Chamber, held that the conviction of Daschner was not sufficient redress for Gäfgen, who could therefore still claim to be the victim of a violation of article 3.279 The trial as a whole was however considered to be fair by both Chambers, since the evidence made under threats was excluded and his conviction based primarily on his confession during trial. In a dissenting opinion, the slippery slope aspect of this reasoning was identified, namely that a State could accept the conviction of an individual agent in order to secure a conviction. To avoid this, all evidence obtained as a result of the pressure should be excluded. The ECHR may have given the impression that inhuman or degrading treatment is allowed under specific circumstances. ${ }^{280}$ Nevertheless, the case presents no authority for excusing the person who feels the irresistible urge to torture a suspect. In fact, Daschner was not exculpated. The judgment focused on the allowance of evidence obtained under pressure, not on the criminal liability of Daschner. ${ }^{281}$

Perspectives that do excuse or even justify the torturer emphasize the importance of the conflicting interests of the innocent victims. They juxtapose the terrorist's right not to be tortured with the victim's right to security. The human dignity of the terrorist is contrasted with the human dignity of the victim to put its absolute character in perspective. ${ }^{282}$ It can also be argued that, like the doomed victim in a joint risky venture, the terrorist is the source of the peril. He is even

277 See also article 4 CFR.

278 Gäfgen v. Germany, appl. no. 22987/05, 30 June 2008 and 1 June 2010.

279 The mere threat of torture was also held to qualify under article 3. A fortiori, a separate category of 'torture-light' or 'other forms of degrading treatment' cannot be argued to fall outside the scope of the absolute prohibition. Compare Shany 2007, pp. 856-857 and 868.

280 Spronken 2011, pp. 48-49.

281 Just like in A and others v. Secretary of State for the Home Department [2005] UKHL 71. See also Weigend in Buruma a.o. 2008.

282 See Erb 2005, pp. 593-599; Brugger 2000, pp. 669-676 and Wagenländer 2005, pp. 155-170 and 199-201. Compare Isensee 1983. 
culpable because he chose to be the source of the danger. ${ }^{283}$ Finally, a strict prohibition may in fact be the reason why detainees are tortured in secret. Governments do torture. The idea is that regulating torture would limit these harms by institutional oversight. ${ }^{284}$

In conclusion, despite utilitarian sympathies, I believe that the defendant who tortured in the aforementioned ticking bomb scenario should be held criminally liable. It is very likely that someone could not resist the pressure, but the defence of duress is normative, requiring that in the end, the defendant was also not required to resist the pressure. The absolute injunction on torture brings about that he should have resisted. From a legal point of view, the absolute injunction militates against any other solution than criminal liability. No defence can apply. Morally, there are very good reasons for the absolute prohibition. Practically, the dangers of legalizing torture in whatever form are just too great. In the end, much more would be sacrificed than gained.

This does not mean that the person who tortured must be severely punished. The extreme pressure on the defendant that would qualify under duress can, as always, operate in a mitigating way. A middle ground has to be found between doing justice to the diminished blameworthiness of the defendant on the one hand and the risk that a too lenient punishment would be experienced as a licence to torture or a price worth paying on the other. The former perspective should however be most important so that the individual offender is not used as a means, to become an example for others.

\section{Mistake as to the legal prohibition}

A mistake of law does not exculpate. This 'ignorantia juris neminem excusat', ${ }^{285}$ is the principle rule in all Member States. However, exceptions to this rule have been accepted, most clearly in Germany, but even in the English legal system, which is commonly believed to still rigidly apply the maxim. It will be argued that an excusable, that is, unavoidable mistake as to the legal prohibition can excuse the defendant.

The availability of the excuse follows from the principle that only the blameworthy may be punished. Mistakes of law should negate criminal liability if the defendant cannot be blamed for the error. The contrasting view that these mistakes can affect fault is rejected. In principle, the insight of the illegality or wrongfulness of one's conduct is an element of blameworthiness, not part of dolus, recklessness or culpa.

283 See Moore 1989, p. 323; Ambos 2008, p. 277 and Ohlin 2008, p. 305.

284 See Shany 2007, p. 854; Dershowitz 1989, p. 192 and Dershowitz 2000, p. 477.

285 Blackstone 1769 (reprint 1979), p. 27. Williams 1953, p. 384 uses the terms 'ignorantia juris non excusat', Stuckenberg 2007, p. 341 the terms 'error iuris nocet.' 
After demarcating the category of mistakes that can be considered to excuse the defendant, the arguments in favour and against the excuse will be discussed. In the third section, it will be explained when a mistake can be deemed to be unavoidable and thus excuse. These requirements coincide with those that can be deduced from EU case-law on the principle of legality.

\subsection{Two categories of mistakes}

In the previous chapter, it was explained that what is commonly called a mistake of law can be better termed a mistake as to the legal prohibition. This was defined as an informational flaw relating to the existence, sense, purpose, scope or application of the legal norm that underlies the charge. The defendant is fully aware of the factual circumstances of his conduct, but erroneously believes this to be lawful. Since the term mistake of law is so common and because it facilitates reading, I will use both terms in one meaning. The mistakes discussed here can involve anything from a minor mistake on the meaning or scope of an offence to complete ignorance of a norm. ${ }^{286}$ Usually in practice, the defendant argues that he relied on (semi-)official information which proved to be wrong, on provisions from another jurisdiction or on the moral judgment of a minority of the population. ${ }^{287}$

The label 'mistake as to the legal prohibition' can also be used to distinguish those mistakes that do not relate to the offence definition. As noted, there is no general requirement that mens rea should relate to the criminalization. It does not have to be proven the defendant knew what he did was criminalized. Specifically, dolus need not relate to the wrongfulness of illegality of the conduct. However, some offences deviate from the normal case. In some non-ideal offences, the offence description requires knowledge on a point of (civil) law. ${ }^{288}$

I already discussed how mistakes on a legal entitlement to property can negate the intention in offences that relate to its appropriation or destruction. If wrongfulness is an essential element of the offence, fault must relate to it. Any mistake on the element is a mistake on the offence definition. ${ }^{289}$ For example, the defendant who was ignorant of the necessity of a permit to export cows did not have the required fault for conviction of that offence. The absence of a permit is an essential element of the offence, because it gives the otherwise lawful conduct its criminal character. ${ }^{290}$

Secondly, the law provides for extraordinary rules on mistakes on legal aspects in the context of specific offences. ${ }^{291}$ For example, in German law, the defendant

\footnotetext{
286 Politoff \& Koopmans 1991, pp. 161-162.

287 Arzt 1976, p. 662.

288 See IV.2.4.6.

289 See IV.2.4.7

29026 June 1996 BayObLG NStZ-RR 1996, 341 and Schönke \& Schröder, H. 2006, p. 366. See IX.5.5.

291 Spencer in Tiedemann 2002, pp. 444-445.
} 
need not know the officer's conduct is lawful in order to be liable for resisting them. The law does however provide for a defence in the case the defendant made an unavoidable mistake on the lawfulness of the officer's actions and he could not, under the circumstances known to him, have been expected to use legal remedies to defend himself against the erroneously perceived unlawful act. ${ }^{292}$

A general defence of mistake of law may operate beyond these two manifestations of mistakes on legal aspects. ${ }^{293}$ It thus encompasses mistakes on the scope or application of the prohibition that are irrelevant to the offence definition. Just like mistakes on defences, these mistakes on legal aspects are external to the offence definition and can only excuse the defendant when they were unavoidable. To emphasize, two categories of mistakes exist. The first relates to an offence element, the second to the implied element of blameworthiness. Whether we should call the second category 'mistakes of law', 'mistakes as to the legal prohibition' or 'mistakes on elements external to the offence definition' is less important than its condition: only when the defendant cannot be blamed for the mistake, will he be excused.

That a mistake of law can excuse is accepted in the Netherlands and Germany, but not until the nineteen fifties. ${ }^{294}$ German Criminal Code has codified the defence. ${ }^{295}$ In the Netherlands, it is treated, just like putative defences, as a specialis of the defence 'lack of all blameworthiness'. ${ }^{296}$ By contrast, utilitarian legal systems like the English remain very reluctant to let defendants benefit from a mistake of law. The maxim that such mistakes do not exculpate is therefore still the strongest, and English courts have not officially accepted the defence. Only the first category of mistakes is acknowledged. Hence, a mistake of law can only preclude liability if it negates the fault element of an offence or if the law so provides. ${ }^{297}$

In the absence of explicit exceptions created by the legislator, ${ }^{298}$ there is hardly any room to let mistakes as to the legal prohibition exculpate in England. However, there is some support for such a defence, ${ }^{299}$ and as will be described, English law includes some functional equivalents to the defence, such as reliance on abuse of process when public authorities gave rise to the mistake. ${ }^{300}$ A second approach that puts the absence of the defence is the tendency to treat mistakes on legal aspects,

$\$ 113(4)$ of the Criminal Code. See Beulke 2008, p. 320 and Bohlander 2009, pp. 94-95.

Compare section 21 of the draft Criminal Code, Law Commission 1989, p. 52.

HR 22 November 1949, NJ 1950, 180 and 18 March 1952, BGHSt 2, 194. Before that time, mistakes on non-criminal law could also exculpate.

$\$ 17$ of the German Criminal Code and $\$ 11(2)$ of the Administrative Offences Act (OWiG). See Fischer, T. 2009, p. 120.

Van Dijk, A.A. 2008, pp. 77-80; Politoff \& Koopmans 1991, pp. 161-162 and Vellinga, W.H. 1982, pp. 162-163.

Section 21 of the draft Criminal Code, Law Commission 1989, p. 52.

See for example the limited exceptions in section 21 of the Theft Act 1968 and 5(2) of the Criminal Damage Act 1971.

99 Williams 1953, p. 387; Ashworth 2006, pp. 232-234 and Ashworth 2011.

Spencer in Tiedemann 2002, pp. 444-445. 
especially if they concern civil law, as mistakes on the offence definition, thereby simply negating mens rea. ${ }^{301}$ Finally, reasonable mistakes generally reduce the sentence of the defendant. ${ }^{302}$

It can be argued that German courts have also based their preferences regarding mistake of law on pragmatic policy considerations. Like the English courts mentioned above, German courts can also be said to manipulate the categorisation of mistake of fact or law with a view to the desired end result. Notwithstanding German doctrine's effort to strictly demarcate and theorize the two categories, the smooth change between the categories has enabled courts to choose as they please without having to fear that their judgments would be quashed. Regardless of the distinctions that have been applied in German law, of mistakes on civil and criminal law; on mala in se and mala prohibita; on fact and law; on the offence definition and the legal prohibition, there was always consensus that the outcome was correct. It is therefore probable that the final question is and has always been, also in Germany, on the worthiness of punishment. ${ }^{303}$

\subsection{Rationale}

Since the principle rule is that mistake of law is no excuse, it is appropriate to take the rationales against such an excuse as a starting point of discussion. First of all, the mistake questions the legal order and the self-evidence of the norm greatly. The criminal law is an objective code of ethics, which must prevail over individual convictions. ${ }^{304}$ The taking into account of individual insights in law and duty violates legal certainty, legality, the state authority and so on. If a defendant would be acquitted because he thought the law were thus and so, the law actually becomes thus and so. ${ }^{305}$

A second rationale is the utilitarian argument that it is desirable to encourage knowledge of the law rather than to promote ignorance of it. ${ }^{306}$ By not excusing the mistaken defendant, people may be encouraged to get to know the law, omitting behaviour, which they doubt might be illegal, just as strict liability offences are said to encourage carefulness. ${ }^{307}$ The exclusion of an excuse is therefore coupled with a duty to know the law. It used to be argued that everybody is presumed to know the

301 Lim Chin Aik v. the Queen [1963] AC 160; Smith, A.T.H. in Eser \& Fletcher 1988, pp. 10971100 and Simester \& Sullivan 2007, pp. 624-627. In line with prevailing opinion in the Member States, Ormerod 2008, p. 289 submits however that this is wrong, because awareness of wrongfulness is not part of mens rea.

302 Ashworth 2011, p. 11.

303 See 18 March 1952 BGHSt 2, 194; Tischler 1984, pp. 354-366 and Arzt 1976, pp. 647-650.

304 Ormerod 2005, p. 121.

305 Alldridge 1986, p. 48.

306 Simester \& Sullivan 2007, p. 728, Ashworth 2006, p. 233; Williams 1953, p. 385 and Stuckenberg 2007, pp. 469-470.

307 Stuckenberg 2007, pp. 462 and 488-491. 
law, but this has long been generally rejected. ${ }^{308}$ In this perspective, the ignorance of the law as such is reprehensible. ${ }^{309}$

It can be argued that the assumption that everybody knows the core criminal norms is plausible. They reflect widely shared cultural, societal and religious morals so that only an insane, or 'exotic' person can honestly be mistaken on these norms ${ }^{310}$ However, this does not apply to the great amount of regulatory law that has been created in the last century. ${ }^{311}$ It is a fiction to assume knowledge by publication, not only because of the number of legislation but also because most of them play no role in citizen's lives. Moreover, these rules can be very technical and are therefore often already difficult for lawyers. Instead, a duty to know the law is accepted, particularly in relation to norms that are of relevance to the actor. ${ }^{312}$ Accordingly, the defendant is still culpable for failing to ascertain the law before embarking on a course of conduct, especially if that conduct is specialized and aimed at gaining profit. ${ }^{313}$

Third and more pragmatically, one can point at the danger of abuse of such a defence $^{314}$ and the difficulty to disprove ignorance. ${ }^{315}$ The enforcement of legal norms is feared to become inefficient if everyone would argue they did not know the wrongfulness of their actions. The prosecutor would have a hard time proving awareness. ${ }^{316}$ This concern has been advanced as an important explanation for the general irrelevancy of mistakes of law in England. ${ }^{317}$ By contrast, it has been submitted that experience has shown that the knowledge of wrongfulness is not so hard for the Prosecutor to prove. Secondly, requiring a mistake of law to be reasonable invalidates the fears of abuse and promoting ignorance. ${ }^{318}$

Excusing a mistake of law has been positioned as a necessary corollary of taking serious a criminal law system based on blameworthiness. ${ }^{319}$ A legal subject should only be convicted if he was able to see the wrongfulness of his conduct and thereby had a chance and choice to avoid the criminal conduct. It would be unjust, unfair and also useless to punish he who does not know and should not know he is

\footnotetext{
308 Williams 1953, p. 385.

309 Smith, A.T.H. in Eser \& Fletcher 1988, pp. 1114-1115.

310 Stuckenberg 2007, p. 452 and Arzt 1976, pp. 647-648. Ignorance that the conduct is wrong is a condition of insanity in English law.

311 Simester \& Sullivan 2007, p. 728; de Jong, D.H. \& Knigge 2003, p. 101, de Hullu 2006, p. 345 and Kelk 2005, pp. 223-224.

312 Stuckenberg 2007, pp. 451-460 and 467-469; Simester \& Sullivan 2007, p. 728; Ashworth 2006, p. 233 and Arzt 1976, pp. 650-651. See IV.2.4.6.

313 Simester \& Sullivan 2007, p. 728. See also Kelk 2005, p. 210 and 225.

314 Williams 1953, p. 385.

315 Simester \& Sullivan 2007, p. 728; Ormerod 2005, p. 121 and Politoff \& Koopmans 1991, pp. $156-157$.

316 Stuckenberg 2007, pp. 464-465.

317 Youngs 2000, pp. 339 and 344.

318 Ashworth 2011, p. 3.

319 Youngs 2000, pp. 339 and 344; Fletcher in Eser, Hassemer \& Burkhardt 2000, p. 238; Vellinga, W.H. 1982, p. 52; Holland 1989, pp. 254-255.
} 
committing a criminal offence. ${ }^{320}$ The defendant who makes an unavoidable mistake did not choose to act unlawful and is therefore not disloyal to the legal order. ${ }^{321}$ The defendant need not have intended to act against the norms of the legal order, but when he did not know and could not know his conduct was illegal, he should not be blamed for this. Accordingly, insight of wrongfulness is viewed as an aspect of blameworthiness.

\subsection{Only an unavoidable mistakes excuses}

Everyone is supposed to know the law, so the absence of knowledge is the exception. ${ }^{322}$ Every excuse is by nature exceptional. Hence, the mistake must be excusable in order to excuse. Only the defendant who acted in excusable ignorance as regards the legality of his actions will be acquitted. ${ }^{323} \mathrm{~A}$ reasonable mistake would probably also suffice, but it does not reflect the exceptional nature and limited scope of the excuse. Therefore, a mistake as to the legal prohibition must be unavoidable or invincible 324 to exculpate the defendant. The criterion is normative, not factual, and refers to the question whether the defendant can be reproached for his ignorance. ${ }^{325}$

By framing the defence in a more positive way, criminal liability can be said to require insight of wrongfulness. It is recognized in Germany and the Netherlands that the insight of acting wrong or the consciousness of wrongdoing is neither irrelevant nor part of intention. It is an element of blameworthiness, and the lack of insight of wrongfulness, when unavoidable, negates the blameworthiness for committing the criminal offence. ${ }^{326}$ The dogmatic foundation of the defence as an aspect of blameworthiness is most evident in German law. In the Netherlands, this is simply accepted and largely undisputed as a given. The legal debate concentrates only on the scope of excusable mistakes.

What is required from this insight of wrongfulness? It does not suffice that the defendant knows his conduct is morally reprehensible, but the defendant also need not have knowledge of the (specific) legal provision or its criminal (rather than

\footnotetext{
320 Politoff \& Koopmans 1991, pp. 156-157; Arzt 1976, p. 651 and Stuckenberg 2007, pp. 482-484.

32118 March 1952 BGHSt 2, 194.

322 Bohlander 2009, p. 119.

323 HR 23 May 1995, NJ 1995, 631.

324 Arzt 1976 uses the distinction vincible-invincible. In 18 March 1952 BGHSt 2, 194 the language used is that when the mistake was invincible (unüberwindlich), the offence or conduct was unavoidable (nicht vermeidbar).

325 Stuckenberg 2007, p. 455 and Schönke \& Schröder, H. 2006, p. 366. Ashworth 2011, p. 6 favours a lesser negligence-based standard.

32618 March 1952 BGHSt 2, 194; 6 December 1956 BGHSt 10, 35; 25 February 1998 BVerfG 1 BvR 299/89; Fischer, T. 2009, p. 121 and Vellinga, W.H. 1982, p. 52. 'Unrechtseinsicht' and 'Unrechtsbewusstsein' respectively.
} 
administrative) character. ${ }^{327}$ The insight is given with the knowledge that the harming of a specific legal interest is wrong. For example, insight of wrongfulness exists when the person who knowingly received stolen goods thought he would only be criminally liable if he had bought them. After all, the actor knows that he is harming the legal interest of property, which is protected by that offence. ${ }^{328}$

\subsubsection{Duty to gain insight}

To establish criminal liability, the defendant needs to recognize or at least be able to recognize the general wrongfulness of his actions. ${ }^{329}$ The standard of unavoidable mistakes does not bring about a duty to know the law, but an obligation nonetheless to perform or inform himself to the best of his ability. ${ }^{330}$ Gaps in one's knowledge can be remedied and the defendant must therefore have duly exerted his conscience. ${ }^{331}$ The threshold of avoidability is therefore high. The defendant must have applied all of his intellectual and moral powers and consult experts if need be. ${ }^{332}$ Only if this also did not make him appreciate the unlawfulness of his actions, the error was insuperable, the crime unavoidable. ${ }^{333}$

Important is whether the actor could have been able to gain knowledge on the wrongfulness by reflecting or inquiring, taking into account the circumstances, his social status, role and individual capacities, including experience and education. ${ }^{334}$ For instance, in general, the actor is expected to be able to know the relevant norms of conduct that falls within his profession. ${ }^{335}$ Relevant knowledge that is lacking, he is expected to acquire. He can be reproached for failing to have done so. Consider the case in which the defendant was held responsible for causing the drowning of

32718 March 1952, BGHSt 2, 194; 25 June 2008 BGH BeckRS 2008, 13797; Fischer, T. 2009, p. 121; Schönke \& Schröder, H. 2006, p. 362; Beulke 2008, p. 163 and Christian \& Others v. The Queen (The Pitcairn Islands) [2006] UKPC 47. In 8 March 1993 OLG Stuttgart NStZ 1993, 344 the defendants could not rely on the belief that the manipulation of the speedometers was merely an administrative offence.

328 Beulke 2008, p. 163 and Schönke \& Schröder, H. 2006, p. 362. See also 19 May 1999 BGHSt 45, 97.

32918 March 1952, BGHSt 2, 194 and 25 June 2008 BGH BeckRS 2008, 13797.

330 Kessler in Borgers, Koopmans \& Kristen 1998, p. 89; 2 February 2000 BGH NStZ 2000, 364 and 27 January 1966 BGHSt 21, 18. Even if the advice received would have been incorrect, the defendant can still not be excused. The omission to consult is a violation of duty of care and makes the mistake of law blameworthy.

331 Conscientious objections do not qualify as a mistake of law because the actor very well knows he is violating the norm, see Holland 1989, pp. 298-299.

332 Youngs 2000, p. 342 and Bohlander 2009, pp. 120-121.

33318 March 1952, BGHSt 2, 194 and Bohlander 2009, pp. 20-22. See also 17 May 1984, Case 83/83, Estel NV v. Commission [1984] ECR 2195, §35.

33428 June 2005, Cases C-189/02 P, C-202/02 P, C-205/02 P to C208/02 P and C-213/02 P, Dansk Rørindustri and others v. Commission [2005] ECR I-5425; Cantoni v. France, appl. no. 17862/91, 15 November 1996; Fischer, T. 2009, p. 123 and Beulke 2008, p. 165.

335 Van Anraat v. the Netherlands, appl. no. 65389/09, 6 July 2010, §81; Vellinga, W.H. 1982, p. 199 and Schönke \& Schröder, H. 2006, p. 367. 
two children in the pool he was exploiting. Their deaths were caused by a lack of adequate supervision, a duty that was clearly stated in legal rules. The court held that the defendant could not be excused because he was ignorant of these rules. Instead, he should have informed himself about the applicable rules and/or searched advice from an expert. ${ }^{336}$ Inexperience therefore limits the requirements set on the actor, but only to the point that there can not be said to be any prior fault in getting involved inexperienced. ${ }^{337}$

Depending on circumstances, the actor may be required to gain information from a public authority, a counsel, an expert, or even to consult case-law. ${ }^{338}$ Courts almost always consider a mistake of law avoidable if the actor took no steps at all to inform himself concerning the legal situation, whilst having the opportunity to do so. ${ }^{339}$ By contrast, reliance on erroneous yet reasonable information is the paradigm example of unavoidable mistakes of law. ${ }^{340}$ The information relied on must be reasonable to excuse the defendant. This often means that the ignorant defendant should have consulted an expert or authoritative person, on which advice they can reasonably rely. ${ }^{341}$ By informing oneself on the legality in this way, the defendant generally has fulfilled its duty, making any mistake excusable. ${ }^{342}$ The ECJ held that where the ignorant defendant acted in good faith to determine the arrangements applicable, Member States are free to preclude an excuse under the error iuris nocet doctrine. Nonetheless, the promotion of fundamentals freedoms can bring about that the sanction imposed on him should at least be mitigated. ${ }^{343}$

\subsubsection{Official advice}

In general, Dutch and German courts allow defendants to rely on advice or information given by official authorities, whereas scepticism is demonstrated when defendants argue they relied on the incorrect advice of a lawyer. This advice is less likely to be accepted as reasonable, which is obvious considering the subjective role of the lawyer. The dilemma is that usually, people seek advice in good faith from lawyers, expecting this to be reliable, whereas others may only seek to hide behind

336 HR 22 August 2006, NJ 2006, 484. See also Hof Den Haag 3 June 2005, LJN:AY4771 and 3 December 1995 BGH NStZ 1996, 236.

337 Fischer, T. 2009, pp. 122-123.

338 Cantoni v. France, appl. no. 17862/91, 15 November 1996; Fischer, T. 2009, p. 124; Schönke \& Schröder, H. 2006, pp. 368-369 and van Dijk, A.A. 2008, pp. 77-80.

339 If the defendant did not have the opportunity to find out, the mistake will be held unavoidable and excuse him, see HR 26 April 1977, NJ 1978, 200; HMG 6 October 1978, NJ 1979, 1; Vellinga, W.H. 1982, pp. 198-199 and Politoff \& Koopmans 1991, p. 159.

340 Arzt 1976, p. 671.

341 HR 18 March 2003, NJ 2004, 291; HR 13 December 1960, NJ 1961, 416; 13 September 1994 BGHSt 40, 257 and 15 December 1999 BGH NStZ 2000, 307.

3422 February 2000 BGH NStZ 2000, 364.

34312 July 2001, Case C-262/99, Paraskevas Louloudakis v. Elliniko Dimosio [2001] ECR I-5547, $\S 76$. 
insincere lawyers. ${ }^{344}$ The result of this dilemma is that the advice of a lawyer is not by mere force of the profession trustworthy. ${ }^{345}$

The Dutch Supreme Court identified several factors to assess whether the defendant could reasonably rely on the advice, such as the independence and impartiality of the advisor, the specific expertise of the advisor, the complexity of the subject matter on which advice is being sought, the manner and circumstances in which the advice was sought and the position of the defendant himself. ${ }^{346}$ In English law, however, a mistake of law based on legal advice never seems to be able to exculpate the actor. ${ }^{347}$

In contrast, all courts considered are more lenient towards defendants who rely on the authority of public officials, official statements, judicial decisions and toleration. ${ }^{348}$ For example, the defendant should be able to reasonably rely on the head of police when he incorrectly told the defendant he possessed the correct papers for driving a motorcycle. ${ }^{349}$ In another case, the defendant was allowed to rely on a notification from the Ministry of Justice concerning the handing in of illegal weapons. Since his firearm was not included on the list of illegal weapons, he thought it was allowed. ${ }^{350}$ The ECJ held relevant a mistake on the legality of the undertaking's actions since it could not be ruled that this mistake was induced by a communication from the Commission. ${ }^{351}$ The statement of an official need not be made explicit. A defendant may also rely on a long-standing tolerating of his conduct by official authorities, including the Commission. ${ }^{352}$

Advice and information of public authorities also generally precludes liability in England, although not by means of the excuse that is mistake of law. In England, insight of wrongfulness is not connected to blameworthiness. Such dogmatic reasoning is absent, which can again be explained by the lack of a general recognition of blameworthiness as a third pillar of criminal liability. Instead, if the advice or information of the official authorities led or contributed to the error of the defendant, the proceeding against the defendant can be stayed, based either on a

344 Arzt 1976, p. 673. See also Fokkens \& Machielse, note 5 on Schuld and Kelk 2005, p. 226.

34515 December 1999 BGH NStZ 2000, 307.

346 HR 4 April 2006, NJ 2007, 144. Compare 15 December 1999, BGH NStZ 2000, 307; Fischer, T. 2009, p. 124 and Beulke 2008, p.165. An example of a German case in which the defendant was excused for relying on advice of a lawyer ob the scope of an offence is 8 November 1965 NJW $1966,1227$.

347 Simester \& Sullivan 2007, p. 624.

348 Only when the public authority was clearly incompetent or tells the defendant so is he required to gain information elsewhere, see 2 February 2000 BGH NStZ 2000, 364.

349 HR 22 November 1949, NJ 1950, 180.

350 HR 23 May 1995, NJ 1995, 631.

35116 December 1995, Cases 40-48, 50, 54-56, 111, 113-114/73, Suikerunie and others $v$ Commission [1975] ECR 1663.

35212 November 1987, Case 344/85, Ferriere San Carlo v. Commission [1987] ECR 4435; HR 24 October 1961, NJ 1962, 37 and HR 14 April 1987, NJ 1988, 60. 
reliance argument, 'good faith', the doctrine of estoppel or 'abuse of process'. ${ }^{353}$ The underlying principle of trust that expectations raised by a Government should reasonably be fulfilled, unless there are strong reasons not to, is also acknowledged in the Netherlands as a procedural principle that can take away the right of the Public Prosecutor to prosecute. ${ }^{354}$

\subsubsection{Unpublished legislation}

A relatively uncontroversial category of unavoidable mistakes concerns the situation in which the defendant was unable to have known the provision, because it was not yet published. In all legal systems under investigation, liability can only be based on rules that have been properly published before the crime took place. A Dutch court has even accepted that the defendant could not reasonably know the new rules, because they had not yet been published in the professional literature. ${ }^{355}$ If new legislation enters into force in Germany, the standard of avoidability is also somewhat relaxed unless the purpose of the law is abundantly clear from the mere wording. 356

It is a defence in England for an accused charged with an offence created by a statutory instrument to prove that at the time of the offence, the instrument had not been published, nor reasonable steps taken to bring its contents to the notice of the public of the accused. ${ }^{357}$ If the defendant would be punished, this would be at odds with the principle of legality, given the conceptual similarity of this situation with retroactive application of the law. ${ }^{358}$ In both cases, the defendant could not know the law tempore delicti. Where the continental sources refer to the principle of guilt as bringing about the exculpatory function of mistakes of law, English law generally only refers to the principle of legality. 359

In the European context, mistakes of law are also generally considered in the context of legality. Hence, legal acts that bind individuals cannot be upheld against that individual if they have not been made publicly available. ${ }^{360}$ The difference is that liability is precluded because that would violate the principle of legality. In deciding whether the defendant may be held criminally liable, it is assessed whether the criminalization was foreseeable. The ECtHR has held that article 7 ECHR is "satisfied where the individual can know (...) what acts and omissions will make him criminally liable." 361 The conditions to satisfy the requirements of legality are

353 Simester \& Sullivan 2007, pp. 627-628, Ashworth 2006, pp. 235-236; Westen 2007, p. 243 and Ormerod 2005, p. 294.

354 Koopmans 2007, pp. 38-41.

355 Remmelink 1996, p. 383 and Vellinga, W.H. 1982, p. 197.

356 Bohlander 2009, p. 121 and Schönke \& Schröder, H. 2006, p. 369.

357 Section 3(2) of the Statutory Instruments Act 1946, see Ormerod 2005, p. 294.

358 Simester \& Sullivan 2007, pp. 627-628.

359 See also Ashworth 2011 and VII.1.1.

36026 November 1998, Case C-370/96, Covita AVE v. Elliniko Dimosio [1998] ECR I-7711, §27.

361 Kononov v. Latvia, appl. no. 36376/04, 17 May 2010, §185. 
identical to that of the principle of guilt. In cases where a Dutch or German court will hold the mistake to be unavoidable, the ECJ and ECtHR will generally hold that the criminalization was not foreseeable. Under both approaches, criminal liability is not upheld against the defendant, since that would violate the fundamental human rights of guilt or legality.

\subsubsection{Other considerations}

I will end this section on the scope of unavoidable mistakes by listing some more factors that are relevant to the question of avoidability. First, the character of the pertinent norm is important. The further away the prohibition is from the core of criminal law, the less strict the requirements of avoidability should be. ${ }^{362}$ Second, courts are clearly also more lenient when it concerns omissions, such as in the case of a woman who did not know she had a legal obligation to report her husband's plans for committing robbery. ${ }^{363}$

Finally, the time spent in a Member State can be of importance for the foreign defendant, when the law of his mother country does not criminalize the conduct.364 For example, an Italian, working temporarily in Germany, shot protected birds. This was illegal in Germany, but not in Italy. The mistake was deemed unavoidable and the defendant excused. ${ }^{365}$ In contrast, similar considerations have been held to be irrelevant to the question of liability in English law. ${ }^{366}$ It can be doubted whether other courts will be so lenient too. Should the German student, who consumed an alcoholic beverage in public in Maastricht, be excused because that is not a crime in Germany? Can the defendant not be said to be under a duty to get to know the law of the country he studies in? However, is this still a reasonable duty when one travels and crosses numerous Member States? ${ }^{367}$

\subsection{Conclusion}

By excusing only in exceptional circumstances the defendant who made an unavoidable mistake, a compromise is struck between the arguments in favour and against the relevancy of mistakes of law. In this way, most arguments against the relevance of mistakes of law to criminal liability can be countered. First of all, the excuse requires informing oneself of the scope and content of the law. This duty

362 Schönke \& Schröder, H. 2006, pp. 367-368; Bohlander 2009, pp. 120-121 and Badar 2005, p. 243. See also van Dijk, A.A. 2008, pp. 77-80.

363 Arzt 1976, p. 677.

364 Fischer, T. 2009, p. 123. By contrast, a mistake is easily held to be avoidable if the offence was punishable under the law of the foreigner's country too, like in 19 May 1999 BGHSt 45, 97.

365 Unreported case mentioned by Arzt 1976, pp. 674-675.

366 Simester \& Sullivan 2007, p. 624, referring to a nineteenth century case, where a foreigner committed the offence of buggery, which was not an offence in his own country.

367 See Peristeridou 2013, forthcoming. 
encourages citizens to get to know the law. The diligence in assessing the lawfulness of one's conduct demonstrates loyalty to the values of the legal order. The obligation to perform to the best of one's ability replaces the incorrect assumption that everyone knows the law. A mistake of law is not blameworthy in itself, it is only so when the defendant could have known the law. As submitted above, the ability to know the law can be grounded in the criminal nature of the norm and the Garantenstellung of the defendant.

The threshold of avoidability has been deduced mostly from German law, but the Dutch law follows its basic principles. The threshold is even higher in England, ${ }^{368}$ implying that the mistaken defendant will be less likely to escape liability there. Nonetheless, it has become clear that the paradigm examples of unavoidable mistakes, those based on official advice or caused by the lack of publication of the pertinent norm, will not lead to criminal liability in any of the Member States under investigation. ${ }^{369}$ Even if a mistake of law is not explicitly recognized as such, English law includes functional equivalents to reach the same or a similar outcome. Similarly, even though it is uncertain whether the European Commission also acknowledges this defence, there is a tendency to solve these cases by the principle of opportunity. ${ }^{370}$ In contrast, it can be presumed that the less paradigm cases of mistakes of law will usually lead to criminal liability in all legal systems discussed, even if the defendant's chances are - again - best in Germany.

The advantage of recognizing mistake of law as an excuse is that it does not affect the validity of the norm. The mistake confirms the norm by merely excusing the defendant. Second, the exceptional character of an excuse emphasizes that insight of wrongfulness is usually given: the threshold of accepting an unavoidable mistake is high. Third, the normative framework of the excuse allows for a nuanced, normative assessment of the blameworthiness of the defendant. Fears that the defence would be abused, accepted too often or that the prosecutor could not disprove ignorance are therefore unwarranted, evidenced by practice in Germany and the Netherlands.

If it is recognized that the unavoidable mistake negates blameworthiness and that blameworthiness is an implied element of all crimes, these mistakes of law need to excuse the defendant. Merely mitigating the defendant's sentence, as is often the case in England, does not suffice. The principle of guilt applies to all aspects of criminal liability, including the wrongfulness of one's actions. If unavoidable mistakes would be irrelevant, the blameless defendant would be held criminally liable.

Excusing the defendant is consistent with the other rules on mistakes. The general rule applicable to all mistakes, including those on the offence definition and defences, is that unavoidable mistakes at least excuse. For example, the defendant

368 Bohlander 2009, p. 119. In other words, insight of wrongfulness is established easier and negated more difficultly.

369 See also section 2.04(3) of the Model Penal Code and article 122-3 of the French Penal Code.

370 Vogel in Tiedemann 2002, p. 134. 
can even be acquitted of a strict offence when he made an excusable mistake. Secondly, putative defences are often considered to be or treated as if they were a mistake of law. Third, the defence of superior orders, discussed below, is considered to be a specialis of mistake of law, negating liability for those who make an excusable mistake on the lawfulness of orders. Since those manifestations of mistake of law can exculpate, why should a 'normal' mistake of law be irrelevant to criminal liability? Finally, considering that it is neither feasible nor desirable to strictly separate the different categories of mistakes, one general rule for all mistakes on aspects external to the offence definition is preferred.

\section{SUPERIOR ORDERS}

A defendant who erroneously relies on the lawfulness of a superior order can be excused under the defence of superior orders. The often-used term 'superior orders' seems incomplete, because it does not refer to the unlawful nature of the order. It fails to distinguish between the excusatory and the justificatory form of the defence. After all, if the order had been lawful in reality, not just from the perspective of the defendant, the defendant would be justified for committing an offence by obeying the order. It appears to be more precise therefore to refer to unlawful superior orders.

\subsection{Superior orders as a justification}

The justification of lawful superior orders is only recognized explicitly in the Netherlands, ${ }^{371}$ which explains why the excuse of superior orders is not labelled more extensively as 'wrongful', 'unlawful' or 'incompetent superior orders' in England and Germany. It may be assumed that the defence is so self-evident in those States, that it was not considered necessary to create a specific defence. After all, the justification states the obvious. If a person commits an offence because he is obliged to do so because of a superior order of greater weight, he is not punishable. ${ }^{372}$ The key question deals with the border between the excuse and criminal liability.

In the Netherlands, it has also been argued that the justificatory defence is superfluous. Just like the similar defence that justifies the person who committed an offence because of the execution of a contrasting legal duty or public task, ${ }^{373}$ it has been persuasively argued that defendants can also escape criminal liability based on other legal grounds. Amongst others, both justifications can be seen as a

\footnotetext{
371 Article 43(1) of the Dutch Criminal Code.

372 Nieboer 1991, p. 256. See Kelk 205, p. 297 for an example of the legal duty justification.

373 Article 42 of the Dutch Criminal Code.
} 
specialis of necessity. ${ }^{374}$ The actor is in a conflict of duties, of which he can only execute one. This similarity is an argument to reject the specific justifications. ${ }^{375}$

Secondly, the offence definition can be interpreted to exclude the conduct from the scope of the offence. This can be based on the legislator's purpose of excluding conduct by officials based on legal duties or superior orders from the scope of the offence. ${ }^{376}$ Moreover, in non-ideal offences, the express element of wrongfulness can simply be negated because of the legal duty or order, which implies that the actor was not acting 'without right'. 377 Third, the legal duty or superior order is often already taken into account in the decision to prosecute. ${ }^{378}$ As argued above, a government should not be allowed to prosecute a person for doing what it told him to do. 379

In sum, it is therefore logical that the justifications hardly ever appear in caselaw. ${ }^{380}$ Dutch scholars generally have accepted that the justifications are unnecessary, but see no objection to their existence from the perspective of clarity of legislation. ${ }^{381}$ Even though the Dutch legislator recently proposed to extend the defence of legal duty in order to make sure that public authorities and legal entities can also rely on it when criminal liability is extended to the public domain, ${ }^{382}$ it is safe to conclude that these two justifications will not be missed in a general part of criminal law for the EU, evidenced by English and German practice.

\subsection{Rationale}

Like the justifications mentioned above, the rationale of the excuse of superior orders is grounded in the starting point that conduct on authority or order of the government should not be criminal. Subordinates must be able to rely on the correctness of orders. ${ }^{383}$ The excusatory form of the defence in particular also

HR 20 September 1976, NJ 1977, 49 and de Hullu 2006, pp. 320 and 323.

By contrast, it is argued that the defence of a legal duty differs from necessity, because it does not require a correct weighing of interests. Instead, the focus of that defence is on the competence of the actors. Therefore, the test is not whether the offence was necessary, but whether it could reasonably be deemed necessary, according to Knigge 1993, p. 32. In Germany too, officials are allowed a margin of error in the exercise of their duties, provided they acted with due diligence, see Roxin 2006, pp. 789-792.

Strijards 1987, pp. 65-67; Kelk 2005, p. 296 and Nieboer 1991, p. 255.

Kelk 2005, p. 296.

De Hullu 2006, p. 318 and van Rest 1991, p. 1. See also Knigge 1993, p. 31.

See van Rest 1991, pp. 85-86.

De Hullu 2006, p. 31 and Strijards 1987, p. 67.

De Hullu 2006, p. 320. The justification of legal duty has been labelled a product of $19^{\text {th }}$ century legalism, an inheritance of the French influence on Dutch law, see Remmelink according to Kelk 2005, p. 296 and Fokkens \& Machielse, note 1 on art. 42.

Kamerstukken II 2007/08, 30 538, no. 6. Both proposals seem to have been put on hold.

De Hullu 2006, p. 322 and van Rest 1991, p. 129. 
serves a practical purpose of promoting obedience to public orders. ${ }^{384}$ The reason for this scheme lies in the hierarchy between superior and subordinate, in which the former should have the final say. When the subordinate could refuse fulfilment in case of any doubt or objections, this would cripple state authority. ${ }^{385}$ In the context of offences committed by armed forces, the defence also helps to reduce responsibility to a narrow circle of people, namely those who issued the orders. ${ }^{386}$ Under the abolished doctrine of 'respondeat superior', a soldier was granted a limitless defence for all conduct ordered by a superior officer.

However, due to the experiences of the two world wars, these rationales have been watered down. The promotion of lawfulness has become more important at the expense of the promotion of obedience. Certain crimes like crimes against humanity should be combated with all means. Therefore, individuals have become criminally responsible for war crimes too, denying them to hide behind illegal orders. Hence, the contrasting approach is to require that a soldier must weigh every order and refuses to carry out illegal acts, or do so on his own risk. Soldiers are only obliged to obey lawful orders. ${ }^{387}$

The problem with this strict approach is that an investigation into the legality of orders is often not only undesirable but also impossible. ${ }^{388}$ Even if there is an opportunity to weigh the order against countervailing interests, the defendant is sometimes put before an impossible choice. For example, it used to be argued that it is a harsh position 'for the soldier to either disobey and be shot by a courtmartial, or obey and be hanged by a judge'. ${ }^{389}$ Generally, disobedience is no longer punished by death and the subordinate should also be able to escape liability for disobedience by making probable the unlawfulness of the order. ${ }^{390}$ However, the harsh position may still occur in some military or criminal organizations. ${ }^{391}$

In order to find a compromise between these competing interests, a limited defence of superior orders is generally accepted. On the one hand, the individual is expected to recognize the unlawfulness of the most serious crimes. He is supposed to refuse to carry out orders to do the manifest illegal. On the other hand, it is recognized that the individual is not always capable to judge the legality of his

Cleiren \& Nijboer 2008, note 3 on Bevoegd en onbevoegd gegeven ambtelijk bevel; van Rest 1991, p. 127; Fokkens \& Machielse, note 3 on art. 43 and Williams 1953, pp. 392-393.

Roxin 2006, p. 795, Bohlander 2009, p. 94; Schönke \& Schröder, H. 2006, p. 618 and Kelk 2005, p. 299.

386 Williams 1953, pp. 392-393.

387 Eden 1991, pp. 641-643.

388 Kelk 2005, p. 299 and Eden 1991, pp. 641-643.

389 Dicey in Williams 1953, p. 389 and Eden 1991, p. 641. Of course, things have changed now, but on both sides of the equation so that the dilemma remains.

390 Or the reasonable belief in the unlawfulness of the order, see art. 131 and 132 of the Dutch Military Criminal Code (Wetboek van Militair Strafrecht).

391 See for example, ICTY Judgment, Prosecutor v. Erdemović, Case No. IT-96-22-A Ch., 7 October 1997. 
actions. Given the importance of obedience, the defendant should be able to rely on the legality of that order when it turns out he made an unavoidable mistake.

The defence is included in the Dutch Criminal Code, ${ }^{392}$ whereas German law has regulated the concept through case-law and several legislative instruments. ${ }^{393}$ It can be seen as a species of mistake of law. The defendant who relies on the excuse after all also makes an unavoidable mistake on the legality of his actions. It is therefore no surprise that the defence is in principle unavailable in English law. ${ }^{394}$ Again, the authority of the law outweighs the arguments in favour of the defence. It is a constitutional principle in English law that officials cannot suspend the operation of the law. 395

Nevertheless, defendants in England have again been able to escape liability by denying mens rea. The order can for example function to show that the defendant was acting reasonable, negating negligence. ${ }^{396}$ In cases where insubordination would bring about harm to the subordinate, the defendant may also claim duress. ${ }^{397}$ This possible overlap of superior orders with duress is accepted outside England too. ${ }^{398}$ However, when the defendant is executing an illegal order because he fears what will happen if he refuses, he is not mistaken on the legality of the orders. He can therefore not rely on superior orders.

\subsection{Scope}

The defence is most often discussed in the context of orders given to soldiers by their superiors. It can however also apply to other public officials who have been ordered by their superiors. More controversial is whether citizens can also rely on the defence vis-à-vis public officials. ${ }^{399}$ The incidental subordination of a random citizen is accepted in the Netherlands. ${ }^{400}$ For example, the public prosecutor can also issue

392 Art. 43(2). See also art. 38 of the Dutch Military Criminal Code (Wetboek van militair strafrecht) and art. 11(3) of the Dutch Act on International Crimes (Wet Internationale Misdrijven).

393 See, $\S 63(2)$ of the law on Federal Public Officials Act (Bundesbeamtengesetz); $\$ 11(2)$ of the Soldiers Act (Soldatengesetz); §5(1) of the Military Criminal Law Act (Wehrstrafgesetz); $\$ 3$ of the International Criminal Code (Völkerstrafgesetzbuch); §7(2) of the Immediate Force Act (Unmittelbarer Zwang-Gesetz), §97(2) of the Execution Act (Strafvollzugsgesetz) and §30(3) of the Civic Service Act (Zivildienstgesetz).

394 R. v. Clegg [1995] UKHL 1 and Ormerod 2006, p. 458.

395 Simester \& Sullivan 2007, p. 679 and Wallerstein 2010, p. 120.

396 Ormerod 2008, p. 357. See also Eden 1991, pp. 641 and 647-648 and Green 1976, pp. 30-31.

397 See R. v. Howe [1986] UKHL 4 and Wallerstein 2010.

398 Kelk 2005, p. 299. Compare the ICTY Judgment, Prosecutor v. Erdemović, Case No. IT-9622-A Ch., 7 October 1997.

399 Bohlander 2009, pp. 91-92 submits that only public officials rely on superior orders, whereas private citizens can rely on 'official authorizations.'

400 HR 3 May 1988, NJ 1989, 165; Fokkens \& Machielse, note 1 on art. 43 and de Hullu 2006, p. 321. 
orders to telecom services. ${ }^{401}$ The emphasis is on the official capacity of the issuer of the order. The authority must stem from public law, not a private agreement. ${ }^{402}$

In fact, an excuse similar to this defence has been accepted in the context of strict liability offences in the Netherlands and Germany. The excuse was partially grounded in the subordinate position of the defendant vis-à-vis his private master. It has been held that since this would jeopardize his livelihood, the defendant could not be required to check the lawfulness of his master's orders to distribute diluted milk or to drive a horse cart with a horse that was difficult, if not impossible to handle. The offence was therefore unavoidable. ${ }^{403}$

\subsection{Criteria}

In the excuse of superior orders, the defendant erroneously believes he is entitled to commit an offence because of the superior order. This mistake cannot be reproached to him, because it was unavoidable. The nature of excuses is that it could not be expected of the defendant to choose or act differently. In other words, only if the offence was unavoidable, the defendant should be excused. As a mistake of law, it will not easily be deemed unavoidable. Depending on the circumstances, the actor has a duty to check and weigh the lawfulness of his actions.

The mistake on the lawfulness of the order can relate to different issues, such as the competence of the issuer, the balancing of (conflicting) interests and the fulfilment of the order's conditions. ${ }^{404}$ If the mistake relates to the competence of the issuer, it can be excusable when the incompetent order normally falls within the scope of things, of which the issuer is competent to order the subordinate. For example, although the order from the public prosecutor to arrest someone is unlawful because not all legal conditions are met, this order still is within the scope of subordination of the police officer. ${ }^{405}$ This would be different if a security guard gave the order. Everyone is assumed to know that this person is never competent to issue such an order, which makes it possible to hold such a mistake avoidable.

Secondly, the mistake can relate to the balancing of the perpetrating a crime on the one hand versus disobedience on the other. The order to commit a criminal offence does not make the order incompetent or wrongful as such. After all, the commission of a crime always runs counter to the letter of the law, but can be lawful, all things considered. If the interest of complying with the order is greater than that of complying with the criminal law, the order is justified, because it is 'lawful', 'not wrongful' or in Dutch terms, 'competent'.406 For example, an

$401 \quad$ Kelk 2005, p. 298.

402 Fokkens \& Machielse, note 1 on art. 43 and van Rest 1991, p. 89.

403 HR 14 February 1916, NJ 1916, p. 681 and 23 March 1897 RGSt 30, 25. See IV.6.5.

404 Van Rest 1991, pp. 122 and 209-210 and van den Bosch in Remmelink 1987, p. 65.

405 Fokkens \& Machielse, note 4 on art. 43.

406 In contrast, many provisions in German law, which are drafted identically, imply that the committing of a criminal offence based on a superior order can only excuse. See for example 
infiltrator can be justified if the interest of public health and the criminal investigation are more important than the reasons against committing the offence. ${ }^{407}$

The excuse discussed here deals with those situations where the defendant made an incorrect assumption that the order was lawful, for which he can be reproached. A paradigm example of such a blameworthy mistake is the mistake that the order to rape someone is lawful. Even if the subordinate believes he is thereby shortening the war and minimizing casualties, this can never be considered a lawful act. Sometimes, certain crimes are explicitly precluded from the defence. German law and the Rome Statute, for example, state that genocide and other crimes against humanity cannot be excused under superior orders. ${ }^{408}$ The exclusion avoids any discussion on the weighing of competing interests and the blameworthiness of mistakes.

Third, the issuer can erroneously believe the conditions to give the order are met. ${ }^{409}$ If the subordinate knows the issuer is mistaken, he needs to inform his superior. If he suspects the order may be unlawful, a duty to investigate arises, similar as in mistake of law. The subordinate is under an obligation to raise his doubts to his superior. However, if the superior confirms the lawfulness of the order, he must in principle carry out the order. ${ }^{410}$ Regardless of whether the order turns out to be unlawful, the subordinate has met the duty, so he cannot be held criminally liable. ${ }^{411}$ For private citizens, this implies for example, that when someone without a driver's licence is told by a police officer to move a vehicle because it is parked incorrectly, he must inform the officer. If the police officer persists, the defence should be available. 412

The subordinate is therefore in principle not required to assess the legality of orders given to him. The focus of the defence is on the competence of the orders, rather than the weighing of interests. It would clearly be inefficient and undesirable if the subordinate would check whether all the conditions of an order are met and whether the superior made a correct valuation of all interests. This only changes when the circumstances raise doubts and thereby require additional investigation on the lawfulness. In German law therefore, the subordinate may in principle rely on an order, unless he positively knows it is unlawful or if it would be so glaringly

$\S 11(2)$ of the Soldiers Act (Soldatengesetz).

407 Van Rest 1991, p. 110.

408 Article 33(2) Rome Statute; art. 11(3) of the Dutch Act on International Crimes (Wet internationale misdrijven) and $\$ 63(2)$ of the German Federal Public Officials Act (Bundesbeamtengesetz). See also art. 2(3) of UN treaty on torture of 10 December 1984.

409 Van den Bosch in Remmelink 1987, p. 65.

$410 \S 63(2)$ of the law on Federal Public Officials Act (Bundesbeamtengesetz). See Beulke 2008, p. 158 and 31 January 1964 BGHSt 19, 231.

411 Compare that if the official advice turns out to be incorrect, the defendant has also met the duty required to rely on a mistake of law.

412 Fokkens \& Machielse, note 4 on art. 43 and van Rest 1991, pp. 109-110 and 145. 
obvious that any diligent civil servant would have been expected to notice it. ${ }^{413}$ In that case, the ignorance of the wrongfulness is blameworthy.

The condition of an unavoidable mistake can be deduced from the 'manifest illegality principle'. ${ }^{414}$ This principle, which strikes a compromise between promoting obedience and lawfulness, is laid down in article 33 of the Rome Statute and can also be found in the British Manual of Military Law. ${ }^{415}$ Although English law does not acknowledge the defence, it has been argued too that a military officer should have a defence if he did not know the order was illegal and it was not so manifestly illegal that he ought to have known it. ${ }^{416}$ If the defendant was ordered to commit an offence that was blatantly illegal, he will be unsuccessful in claiming that he made an unavoidable mistake on the lawfulness of the order. Even a confirmation of the lawfulness of the order by the superior does not relieve him of his own personal responsibility. ${ }^{417}$

Like any putative justification, the mistake must be excusable, which means that is must be understandable to the average person. ${ }^{418}$ An objective yardstick is therefore applied, requiring that the mistake should not only be honest, but also reasonable. ${ }^{419}$ Blind, uncritical execution of an order that should raise suspicion as to its lawfulness at least, cannot qualify. ${ }^{420}$ Some Dutch scholars have however argued that no more than a subjective test is required. In favour of such a test, it can be argued that a subjective test would distinguish the defence from other putative justifications. If the yardstick would be objective, the added value of the excuse may be doubted..$^{421}$

Whereas this is true, I do not agree that the defence should be subjective. The excuse of superior orders is in fact no more than a specific codification of a mistake on the facts giving rise to the defence of lawful superior orders. Like any putative justification and like any excuse, the yardstick must be normative. It would be inconsistent to apply a different yardstick for this particular putative justification. A deviation cannot be grounded in the aim of the defence to promote obedience, ${ }^{422}$ since that is not its only rationale. Just like its more general category of mistake of law, which includes all putative justifications, the competing rationales of the defence have been consolidated into the ground rule that only excusable, that is, unavoidable and understandable mistakes will excuse the defendant.

\footnotetext{
413 Bohlander 2009, p. 93 and Beulke 2008, p. 157.

414 Eden 1991, p. 644.

415 Eden 1991, p. 648.

416 Ormerod 2005, p. 328.

417 The explicit exclusion of crimes like genocide also avoids any discussion inherent in the German rule that a confirmation of the unlawful order makes it binding to the subordinate.

418 Strijards 1987, p. 116.

419 See Green 1976, pp. 238-241.

420 Kelk 2005, p. 299; de Hullu 2006, p. 323 and van Rest 1991, pp. 137-138, 142-143 and 210.

421 Knigge 1993, pp. 32 and 37; Fokkens \& Machielse, note 4 on art. 43 and van Rest 1991, pp. 132135.

422 Knigge 1993, p. 32.
} 


\subsection{Conclusion}

The defence of superior orders is a species of and operates under the same conditions as other mistakes of law. Then why was this specific putative justification codified? The mistake in regard to a superior order is the only putative justification explicitly regulated by the Dutch Criminal Code. ${ }^{423}$ Its codification can be explained by purposes of legality. By explicitly setting the limits of the excuse, it is made clear that manifestly illegal acts will always be punished. Legal subjects are warned that they cannot simply rely on an order, and that they are required to investigate the lawfulness of the order under circumstances.

Nevertheless, if the excuse of mistake of law is accepted, including putative justifications, there is no need to regulate unlawful superior orders. The difference with other putative justifications is that the official authority issuing the order is partially responsible for the mistake. As a result, the threshold of an unavoidable mistake may be easier met. Nevertheless, the simple condition of excusable or unavoidable mistakes is both flexible and clear enough to reach just outcomes. Even if codification of the defence is desired, it is submitted that foreseeability, certainty and consistency would be better furthered by drafting the defence in a simple matter as an excusable mistake on the lawfulness of the order. The concept is scattered in German and to a lesser extent also in Dutch law over several provisions, some of which are contradictory and formulated needlessly complex. Instead, the defendant should simply be excused if he erroneously believed he was entitled to commit an offence because of the superior order and this mistake cannot be reproached to him.

\section{INSANITY}

Insanity is a defence that exculpates the defendant who, at the time of committing the offence, due to a mental disorder, did not have the capacities to be held responsible in law.

\subsection{Rationale}

Insanity has a twofold rationale. On the one hand, it guarantees that those that are not responsible for their actions are not punishable. On the other hand, it enables that the public is protected against those defendants. The latter rationale is remarkable in comparison to other defences and will be discussed first. In all three States, the insane defendant can be compulsory admitted to and/or treated in a

423 Strijards 1987, p. 116 and de Hullu 2006, p. 344. Van Rest 1991, pp. 176-178 and 212 calls this systematically inconsistent. 
mental hospital. ${ }^{424}$ This has been an important reason to create the insanity defence in England. If the insane would simply be acquitted, they would have to be set free, possibly committing other offences. ${ }^{425}$ By framing insanity as an excuse, Dutch and German courts can impose measures upon these perpetrators of wrongful acts. As will be explained later, measures can be imposed to excused defendants.

Measures that can be imposed upon the mentally disordered include the deprivation of the defendant's freedom for an indefinite time. ${ }^{426}$ As long as the danger remains and/or treatment is necessary, the defendant can be detained in a mental hospital. This brings about that by pleading an insanity defence, the defendant risks being detained in a mental hospital for the rest of his life. ${ }^{427}$ Even if he is not detained indefinitely, he is likely to be deprived of his freedom for a longer time than if he would have been convicted and imprisoned. ${ }^{428}$ Most defendants therefore view these measures as a punishment worse than prison. ${ }^{429}$

If the stigma inherent in being labelled insane is also taken into account, ${ }^{430}$ the abolitionist argument against the insanity defence is unwarranted. Defendants generally do not feign a mental disorder to escape imprisonment. By contrast, they are more likely to accept a guilty plea or feign sanity to escape the feared measures. ${ }^{431}$ The insanity defence is only rarely raised and hardly ever accepted. After all, only in cases where the death penalty may be imposed or the defendant is certain to be incarcerated for life, can the defendant benefit from faking a mental disorder. ${ }^{432}$

The rationale of public protection also explains the tendency to hold the obviously insane as fully responsible, only to facilitate a long prison sentence. Since

424 Section 37 of the Mental Health Act 1983; art. 37 and 37a of the Dutch Criminal Code and $\S 63$ of the German Criminal Code.

425 R. v. Hennessy [1989] 2 All ER 9 and Ashworth 2006, p. 101

426 See art. 38e of the Dutch Criminal Code; $\$ 67 \mathrm{~d}$ of the German Criminal Code and section 41 of the Mental Health Act 1983.

427 Ashworth 2006, pp. 206-207. Although acceptance of the defence in England no longer results in the mandatory indefinite detention in a special hospital of the defendant, unless and until the Home Secretary ordered release, the risk of indefinite detention still deters defendants from pleading insanity, see also Simester \& Sullivan 2007, p. 643; Mackay, Mitchell \& Howe 2006, p. 400 and Ormerod 2008, p. 278.

428 The average time of treatment in cases of compulsory admission is about 8,5 years according to the Dutch Ministry of Justice. See also Perlin in Botkin, McMahon \& Francis 1999, p. 48.

429 Politoff \& Koopmans 1991, pp. 99-102; Peters, A.A.G. 1966, p. 239 and Groenhuijsen in Groenhuijsen, Mulder \& Remmelink 1992, p. 5.

430 Simester \& Sullivan 2007, p. 643 and Ormerod 2005, p. 257. For example, it is often argued that 'battered women syndrome' should be accepted within the framework of self-defence of duress, because treating it as a plea of insanity would be demeaning and stigmatizing on the woman, see Dressler in Shute \& Simester 2002, pp. 276-281 and Wannop 1995, pp. 253 and $268-272$.

431 Ashworth 2006, pp. 101 and 206-207; Ormerod 2005, p. 257 and Perlin in Botkin, McMahon \& Francis 1999, p. 53.

432 Norrie 2006B, p. 196 and Buchanan 2000, p. 67. In England, the defendant therefore also is more likely to feign a disorder in order to escape a murder charge based on diminished capacity. 
the nineteen thirties, Dutch law enabled the compulsory admission to a mental hospital, but the confidence of the courts in these measures remained low until the nineteen-sixties. As a result of this, long prison sentences were still given to the mentally impaired. ${ }^{433}$ The fear that the perpetrator would commit other crimes has been dominant in shaping the insanity defence in all three Member States. As explained later, the distinction between insanity and automatism is made in England by establishing whether there is a risk of recurrence. If there is such a risk, insanity is accepted to enable measures to prevent recidivism.

However, the defence is not always a necessary condition of incapacitating the criminally insane. Certainly nowadays, measures can also be taken regardless of a verdict of not guilty by reason of insanity. The compulsory admission to a mental hospital can follow after application of insanity, a conviction and even without a criminal trial having taken place. ${ }^{434}$ Particularly in England, the efficient disposal of the defendant is considered much more important than labels such as 'not guilty by reason of insanity ${ }^{435}$ or a simple acquittal. The flexibility of the English legal system for example enables that people, whose insanity defence failed, can still be transferred from prison to a mental hospital. ${ }^{436}$

Since an insanity defence is not strictly necessary for public protection, the other rationale, based on the capacities of criminal responsibility should be considered most important. The criminal legal system is directed at human beings as subjects of the law. Goals of prevention and retribution can only be served if these subjects have basic capacities of understanding and controlling their conduct. These capacities give agents the possibility and choice to stay outside the realm of criminal liability. Moreover, criminal law cannot communicate to those who do not understand the norms. The basic capacities presuppose that there can be communication between the legal system and the defendant. ${ }^{437}$

The fact that a human being has certain capacities makes it possible to hold him responsible under the criminal law. In order to be subjects of the criminal law, human beings must possess basic capacities. They deal with the question whether the actor can be a subject of the law, which is a precondition of holding the actor criminally liable. The agent is liable for causing harm, but he can only be held accountable in the first place, because he possesses the capacities to be a subject of the law. These preconditions do not deal with the question whether the actor committed the offence

433 HR 10 September 1957, NJ 1958, 5; HR 12 November 1985, NJ 1986, 327; Hofstee in Remmelink 1987, pp. 198-199 and 209-212 and Kelk \& Kool 2004B.

434 Stree in Schönke \& Schröder, H. 2006, p. 935; Simester \& Sullivan 2007, p. 655; Norrie 2006B, pp. 195-196; Williams 1953, p. 314-315; de Kogel \& Nagtegaal 2006, p. 50 and the Dutch Act on the special commitment in psychiatric hospitals (Wet BOPZ).

435 Section 2 of the Trial of Lunatics Act 1883 and sections 1 and 5 of the Criminal Procedure (Insanity and Unfitness to Plead) Act 1991. In procedures before a Magistrate's Court, the unamended common law applies. The result of a successful defence is a simple acquittal, see Ormerod 2005, pp. 256 and 268.

436 Norrie 2006B, pp. 195-196 and Section 47 of the Mental Health Act 1983.

437 Tadros 2005, pp. 136-137; Ormerod 2005, p. 4 and Ashworth 2006, pp. $26-27$ and 247. 
and can be blamed for this, but with the more fundamental question whether the actor can even be held responsible under criminal law. A human being normally possesses these capacities, which warrants the assumption of the law that acts are voluntary and actors are sane. Insanity is the negation of the latter assumption. It will be explained that not much is needed to meet the threshold. Hence, only in very exceptional circumstances shall a perpetrator be held not punishable. ${ }^{438}$

\subsection{Related issues}

In order to understand the concept and context of insanity, some things have to be explained. These do not directly determine the scope of the insanity defence, but they are highly relevant in understanding its scope and rationale.

\subsubsection{Two-lane approach}

Measures are separated from punishment in the Netherlands and Germany by a so-called two-lane approach. Punishment can be inflicted upon the punishable; measures can be ordered against the (partially) irresponsible. Blameworthiness warrants retribution and thereby punishment, whereas preventive considerations are taken into account in measures. The negation of blameworthiness by insanity precludes punishment, but a measure can be imposed if it has been established that the defendant committed a wrongful offence. Measures thus fill the gap created by the inability to punish the insane. ${ }^{439}$

Recently, the ECtHR rejected this formal distinction of measures and punishment in German law, holding that the measure of preventive detention can constitute a punishment under articles 5 and 7 of the Convention. ${ }^{440}$ As explained before, European criminal law applies an autonomous concept of what is punishment, correctly focusing more on the effect and nature than on the label. Compulsory institutionalization and treatment can be experienced as a sanction graver than the mere deprivation of liberty by imprisonment. If these measures can be seen as a punishment, the principle of guilt also militates against ordering such measures against the excused. The two-lane approach is an attempt to bring the incapacitation of dangerous but insane perpetrators in line with criminal theory.

438 Tadros 2005, pp. 139 and 370; Ormerod 2008, p. 269; Simester \& Sullivan 2007, pp. 643 and 730; Roxin 2006, pp. 911-914, 964 and 1014; Bohlander 2009, pp. 17 and 22-23; Schönke \& Schröder, H. 2006, pp. 13 and 126 and de Hullu 2006, p. 104.

439 Schönke \& Schröder, H. 2006, p. 138; Krey 2003, pp. 20-21; Beulke 2008, p. 138; Hofstee in Remmelink 1987, pp. 199-200 and Politoff \& Koopmans 1991, pp. 99-102.

440 M. v. Germany, appl. no. 19359/04, 17 December 2009 and Haidn v. Germany, appl. no. 6587/04, 13 April 2011. After these decisions, the German Constitutional Court revised its earlier opinion and held the preventive detention unconstitutional, see 4 May 2011 BVerfG NStZ 2011, 450. The legislator was given two years to adapt legislation. In the mean time, the persons in preventive detention are not set free. 


\subsubsection{Punishment according to guilt}

In German law, the distinction of punishment and prevention is relatively strict. Another example of this is the recognition of the maxim of punishment according to guilt. This holds that the defendant must be punished according to the degree of blameworthiness for the offence: the punishment may not exceed nor fall short of the degree of blameworthiness of the actor. ${ }^{441}$ Blameworthiness determines the lower and upper limit of punishment. Only in between those limits, are preventive purposes taken into account. ${ }^{442}$

Whereas prevailing opinion in the Netherlands and England also subscribes to the basic principle that there can be no punishment without blameworthiness, it does not object that the degree of punishment may exceed the degree of blameworthiness. ${ }^{443}$ As a rule, the level of blameworthiness is a factor in sentencing in those States too, but it does not oblige to mitigation. In other words, whereas there is consensus amongst the three States that blameworthiness is an absolute minimum condition for punishment, it is controversial to what extent it also dictates the level of punishment. ${ }^{444}$ It is uncontroversial that blameworthiness legitimizes punishment and that retribution is the distinguishing feature of punishment. ${ }^{445}$ However, in Dutch and even more so in English law, preventive considerations also play an important role in establishing the appropriate punishment. ${ }^{446}$ Union law requires proportionality between the offence and sanction. ${ }^{447}$ If the degree of blameworthiness is considered to (co-)determine the gravity of the offence, punishment should be made dependent on this level of guilt. Nevertheless, Union law seems to allow for similar discretion because in establishing the appropriate penalty, regard must be taken to the objectives pursued by it. ${ }^{448}$

\subsubsection{Unfit to plead}

The defence of insanity is related to the procedural matter of being fit to plead or fit to stand trial. ${ }^{449}$ The latter is about the competence to stand trial. It deals not with

$441 \S 46$ of the German Criminal Code. See Krey 2002, pp. 96-97 and 112-113; Streng 2007, p. 153 and Jescheck in Thaman 2002, pp. xxxix-xl.

44227 October 1970 BGHSt 24, 132; Krey 2002, pp. 114-123 and Streng 2007, p. 155.

443 HR 24 July 1967, NJ 1969, 63; HR 12 November 1985, NJ 1986, 327; Fokkens \& Machielse, note 10 on Schuld and Politoff \& Koopmans 1991, p. 193. I infer that this is not accepted in England from my inability to find a source that either confirmed or refuted this.

444 In Germany, these aspects are labelled as 'Strafbegründungschuld' and 'Strafbemessungsschuld' respectively, see Beulke 2008, p. 139 and Schönke \& Schröder, H. 2006, p. 203.

445 Hofstee in Remmelink 1987, pp. 202 and 212 and Van Bemmelen 1959, p. 17.

446 Pompe 1935, pp. 7-8; Hofstee in Remmelink 1987, p. 202; Mooij in Raes \& Bakker, F.A.M. 2007, p. 32 and Politoff \& Koopmans 1991, pp. 99-102.

447 Art. 49(3) CFR and 21 September 1989, Case C 68/88, Greece v. Commission [1989] ECR 2965.

448 Opinion of AG van Gerven of 5 December 1989, Case C-326/88, Hansen \& Søn [1990] ECR I-2930.

449 Art. 16(1) of the Dutch Code of Criminal Procedure; $\$ \S 205$ and 206a of the German Code of Criminal Procedure; s. 4 Criminal Procedure (Insanity) Act 1964 and Simester \& Sullivan 2007, p. 644. 
the question of sanity at the time of the commission of the offence, but with sanity at the time of the trial. It is therefore not a substantive defence that negates the blameworthiness of the actor or wrongfulness of the offence charged. ${ }^{450}$ It can merely suspend or stay the proceedings against the defendant when it is established that the defendant does not understand the charge or the course of the trial, or is incapable to participate sensibly in the trial and instruct his lawyer. ${ }^{451}$

The threshold is strictest in the Netherlands, where the defendant is only held to be unfit to plead when he does not understand the tenor of the charges brought against him. ${ }^{452}$ Moreover, the concept only applies to those defendants that became insane after the commission of the offence. ${ }^{453}$ The concept is broadest in England. More weight is attached to the defendant's capacity to defend himself. This can be explained by, amongst others, the relative inactivity of the trier of fact in such an adversarial legal system. ${ }^{454}$

The proceedings are suspended because people who are unfit to stand trial cannot be given a fair trial. The defendant lacks the equality of arms to refute the public prosecutor. To try and punish these persons would be sort of a trial in absentia. ${ }^{455}$ On the other hand, the victims and society will not be done justice, as long as the proceedings are suspended. It can also be argued that the defendant is withheld a trial and that his freedom is restrained without a decision in iura regarding the question whether or not he committed the offence and whether this can be attributed to him. ${ }^{456}$ This can explain why in English law, the jury decides whether the defendant fulfilled the actus reus if he is found unfit to plead. If the jury finds that the defendant did not commit the actus reus, he is simply acquitted. ${ }^{457}$

The defendant who is found unfit to plead is committed in a psychiatric hospital. The difference with the person held to be insane is that the treatment of this person is aimed at making him fit to stand trial. ${ }^{458}$ In practice, the high threshold of a finding of unfitness to plead implies that those persons will never be able to plead, so they are kept in the hospital for a very long time. ${ }^{459}$ In German law, the

450 Ormerod 2008, pp. 272 and 278 and Bal \& Koenraadt 2004, pp. 1-2.

4518 February 1995 BGH NJW 1995, 1973; 24 February 1995 BVerfG NJW 1995, 1951; Ormerod 2005, p. 251 and Simester \& Sullivan 2007, p. 645.

452 Art. 16(1) of the Code of Criminal Procedure; HR 5 February 1980, NJ 1980, 104 and Bal \& Koenraadt 2004, p. 45.

453 Hof Amsterdam 27 August 2010, LJN:BN5666 and Bal \& Koenraadt 2004, pp. 24-29 and 38-41. For defendants who were already suffering from a mental disorder tempore delicti, other procedural guarantees apply, such as full representation by a lawyer. See art. 509a-e of the Dutch Code of Criminal Procedure.

454 See also Bal \& Koenraadt 2004, pp. 74-75.

455 Compare $\$ 231 \mathrm{a}$ of the German Code of Criminal Procedure.

456 Bal \& Koenraadt 2004, p. 3.

457 S. 4(5) and 4a of the Criminal Procedure (Insanity) Act 1964; Simester \& Sullivan 2007, p. 645; Ormerod 2005, pp. 255-255 and Ormerod 2008, p. 274.

458 Art. 16(2) of the Dutch Code of Criminal Procedure.

459 Bal \& Koenraadt 2004, p. 2. 
distinction between the suspension and complete staying of proceedings is made explicitly. ${ }^{460}$

\subsection{Criteria}

The conditions of the insanity defence ${ }^{461}$ differ in the Member States under investigation; yet in essence require that the offence should be attributable to the mental disorder. This means that first of all, it needs to be established that the defendant was suffering from a mental disorder when he committed the offence. The national defences give different enumeration of disorders that can qualify under insanity. Although this limitative enumeration seems to have been an attempt to limit the evolving influence of psychiatry on liability, ${ }^{462}$ it will become clear that nowadays in practice, almost all disorders that are medically recognized can qualify under the defence.

Secondly, it is assessed whether the disorder should be deemed the legal cause of the offence. This question is partly psychological, for it takes into account the state of mind of the defendant, generally through the assessment of expert advice on how the disorder has affected the defendant. The defence is made more specific in English and German law by requiring that the mental disorder has substantially impaired the defendant's capacities to be held responsible. Cognitive, evaluative and volitional capacities can be distinguished, some of which qualify under English, some of which qualify under German law.

The second question is however also a legal, normative, question, whereby more factors are relevant than the pertinent disorder and the affect it presumably had on the defendant. For example, there may be countervailing reasons against accepting the defence, such as the prior fault of getting in a situation where the defendant lost his mind. Moreover, the judge is not bound by the expert advice and has the final say. ${ }^{463}$ The Dutch defence emphasises the importance of the normative aspect by focusing on 'attribution'.

Again, it will become clear that of the three States under investigation, the scope of the defence is most narrow in England, whereas it is the widest in Germany. The English rules on insanity originate from the case in 1843 against Daniel M'Naghten who attempted to assassinate the British Prime Minister, but fired a pistol at the back

$460 \$ \$ 205$ and 206a of the German Code of Criminal Procedure.

461 Art. 39 of the Dutch Criminal Code; $\$ 20$ of the German Criminal Code and R. v. M'Naghten [1843-1860] All ER Rep 229.

462 Lackner in Eser \& Fletcher 1988, pp. 916-917.

463 Machielse \& Remmelink in Fokkens \& Machielse, notes 11-12 on art. 39; van Leeuwen 1986, pp. 6-9 and 23; 22 October 2004 BGH NStZ 2005, 329; Roxin 2006, pp. 899-900 and Schönke \& Schröder, H. 2006, p. 386. Simester \& Sullivan 2007, p. 648 argues that although at least two medical practitioners are required to reach an insanity verdict in England, they use legal, not medical criteria. 
of his secretary, who died five days later. ${ }^{464}$ Following the public outcry as a result of his acquittal based on insanity, the House of Lords gave some guidelines to limit the defence. The reluctance to allow insanity as an excuse and the desire to incapacitate dangerous perpetrators has always shaped the English doctrine on insanity. Again, this reluctant and pragmatic approach will make the English defence interesting to compare with the more principally grounded defence in for example German law.

\subsection{Mental disorder}

It is obvious that in order to be labelled insane, the defendant must have suffered from a mental disorder. This 'mental disorder' has been formulated in many different ways in national law. In England for example, section 1(2) of the Mental Health Act 1983 defines a mental disorder as "any disorder or disability of the mind". The common law defence of insanity, by contrast, refers to a 'disease of the mind'. The Dutch criminal code refers to two manifestations of mental abnormality and the German even to four. Such extensive categorization makes the different mental disorders that may qualify under insanity more concrete. However, it will be argued that for a general part of EU criminal law, a simple reference to a mental disorder will suffice.

\subsubsection{The origin of the disorder}

It is common to separate disorders according to their origin. In national law, congenital and physical origins have been distinguished. The distinction between disorders present from birth and those acquired later in life has been common in Anglo-American law since the Middle Ages. ${ }^{465}$ Dutch law separates a 'pathological disorder' from the 'arrested development of the mental faculties'. The latter category includes those cases of idiocy and imbecility that are congenital or originated at a young age. By contrast, a pathological disorder is believed to occur later in life. ${ }^{466}$ In the German defence, a separate category of disorders also refers to the arrested development of mental faculties. ${ }^{467}$

The abovementioned separation in Dutch law also aims to distinguish deviations that have a physical origin from those that do not. In German law, a similar distinction used to be made. Under the old Criminal Code, disorders that could not be traced back to bodily defects could not excuse. It was feared that the floodgates would be opened if other disorders would be included. Nevertheless, this category was included as a possible disorder by the German judiciary and it is now included

R. v. M'Naghten [1843-1860] All ER Rep 229.

Buchanan 2000, p. 85.

Kamerstukken II 1979/1980, 11 270, no. 12 pp. 12-14; de Hullu 2006, p. 326 and Kelk 2005, p. 257.

Bohlander 2009, p. 134. 
in the current legal provision. After all, disorders need not have a biological origin to impair the capacities for criminal responsibility. ${ }^{468}$ The dichotomy of physical and mental is outdated, ${ }^{469}$ and even if a biological origin of a disorder cannot yet be detected, this does not mean the disorder does not exist. ${ }^{470}$

The origin of the disorder may be relevant to the question whether man is biologically or genetically determined to commit crime. If human action is causally determined, rather than based on free will and choice, no one could ever act differently than he in fact does. It would also be improper to punish people for these actions. The three legal systems consistently avoid this debate by simply assuming the indeterminist perspective, that man has free will. It is not argued that man has free will, but as long as the contrary has not been proven, he is treated as if he has free will. Raising the insanity defence implies that the assumption is rebutted in a concrete case. ${ }^{471}$

Therefore, for insanity to apply, the origin of the disorder, as far as a condition of a biological or congenital origin is no longer relevant. This seems to make the distinction superfluous. Nonetheless, the underlying rationale of the distinction still operates, because if the disorder has a biological origin, it is accepted easier that it has severely impaired the defendant's capacities not to commit the offence. Disorders that have no biological origin only exculpate by exception. ${ }^{472}$ English law is in line with this synthesis, as any internal disorder, which affected the faculties of memory, reason or understanding can qualify. It is immaterial whether the disease had a mental or physical origin, whether it was curable or not, or whether it was temporary or permanent. ${ }^{473}$

However, the English defence requires that the disorder must have originated from within the defendant. Defects that are caused by a factor external to the defendant are excluded from insanity as (sane) automatism. The latter term is used in England to denote involuntary acts like sleepwalking, reflexes and situations of vis absoluta and are contrasted with insanity, also called insane automatism. In effect, the distinction of internal and external factors is fuelled by the pragmatic fear that defects originating from an internal factor are of a more continuous character and may therefore recur, whereas an external factor usually has a transient effect. Treatment of the perpetrator is believed necessary in order to prevent this recurrence and since automatism does not allow for the taking of measures, insanity is the appropriate outcome. Thus, when a person is sleepwalking and commits

\footnotetext{
468 Roxin 2006, pp. 887-888 and Schönke \& Schröder, H. 2006, pp. 387-389.

469 Strijards 1987, p. 82 and Fokkens \& Machielse, note 3 on art. 39.

470 Schönke \& Schröder, H. 2006, p. 387.

471 Simester \& Sullivan 2007, p. 730; Fletcher 1978, p. 802; Ashworth 2006, 26-27 and 247; Kelk 2005, pp. 168 and 253; Beulke 2008, pp. 138-139; Schönke \& Schröder, H. 2006, pp. 203-206 and Fischer, T. 2009, pp. 68-70.

472 Roxin 2006, pp. 901-902 who rejects this, submitting it should be about the severity of the disorder, not its origin.

473 R. v. Kemp [1957] 1 QB 399; R. v. Sullivan [1984] AC 156 and Simester \& Sullivan 2007, p. 649.
} 
violence, the primary concern of courts is to avoid this from happening again, resulting in a finding of insanity. ${ }^{474}$

Because insanity includes paradigm cases of automatism, including epilepsy, it has been criticized as excessively broad. ${ }^{475}$ Moreover, the distinction leads to absurd differences in the context of diabetes. Diabetes can result in automatism when the defendant becomes hypoglycaemic, because taking insulin without sufficient food is regarded as an external factor. By contrast, it can also result in insanity when the defendant becomes hyperglycaemic because he failed to take insulin, resulting in the internal condition of a high blood sugar level. ${ }^{476}$

Epileptic and hyper- or hypoglycaemic seizures as well as sleepwalking should be addressed under the voluntary act requirement, like in Dutch and German law. Treating these actors as insane is not in line with objective medical expertise and thus problematic with a view to fair labelling and art. 5 ECHR when measures are ordered against these persons that deprive them of their liberty. ${ }^{477}$ Recurrence could also be prevented by medicines. It is therefore to be applauded that in more recent judgments of lower English courts, automatism is accepted for sleepwalking. ${ }^{478}$ The distinction between internal and external origin of the disorder should therefore be rejected. The origin of the disorder can be of influence to other conditions, such as the manner in which the defendant's capacities are impaired, but it should not be relevant to preclude disorders.

\subsubsection{Affect and intoxication}

A second category in German law deals with a 'profound consciousness disorder'. This is a limitation of the consciousness of oneself or one's surroundings and thereby a limitation of self-determination. ${ }^{479}$ In practice, it can be distinguished in an affect or intoxication. An affect is "an explosive reaction based on an extreme emotional state where no deliberate decision-making occurs anymore, for example, extreme rage, hate, shock, panic or fear." 480 Dutch law excludes from insanity such affects. These states of minds can be taken into account in self-defence-excess. ${ }^{481}$ The impossibility to take into account under self-defence-excess in German law sthenic affects, like revenge and rage, thus explains this wider scope of insanity in part.

474 Bratty v. Attorney-General for Northern Ireland [1963] AC 386; R. v. Burgess [1991] 2 QB 92; Hill v. Baxter [1958] 1 QB 277; Ashworth 2006, pp. 100-101; Buchanan 2000, p. 101 and Ormerod 2005, p. 260. Ormerod 2005, p. 264 and Ormerod 2008, pp. 279 and 286.

476 R. v. Quick [1973] QB 310 and R. v. Hennessy [1989] 2 All ER 9 respectively. See also Ashworth 2006, p. 208 and Simester \& Sullivan 2007, pp. 649-651.

477 Winterwerp v. the Netherlands, appl. no. 6301/73, 24 October 1979; Simester \& Sullivan 2007, p. 33 and Ashworth 2006, pp. 209-210.

478 Ormerod 2008, p. 282 and Mackay \& Mitchell 2006, p. 903.

479 Schönke \& Schröder, H. 2006, p. 388.

480 Bohlander 2009, p. 133.

481 De Hullu 2006, p. 326 and Fokkens \& Machielse, note 8 on art. 39. 
Nevertheless, the theoretical possibility that an affect qualifies as a disorder under the defence, does not mean insanity will also be accepted. A complete exculpation is limited in German case-law only to very extreme cases of affects, which must after all be 'profound'. The 'normal' primitive and explosive reactions do not qualify. Factors that may lead to acceptance are a short duration with a sudden beginning and end, a confused way of thinking, incoherent conduct and (partial) loss of memory. The final decision on the acceptance of insanity therefore depends on the other conditions and all the circumstances of the case. ${ }^{482}$

Similarly, intoxication may qualify in German law as a disorder that can lead to the acceptance of insanity, but it will hardly ever excuse the defendant. In practice, affects and intoxication are most often only mitigated under the defence of diminished capacity, which will be discussed below. ${ }^{483}$ In the Netherlands and England, intoxication is not explicitly mentioned as a cause of disorder. ${ }^{484}$ Even though it is accepted that intoxication may qualify under insanity, it was already explained that the defence is generally precluded based on the prior fault of getting voluntarily intoxicated. ${ }^{485}$ By contrast, the German emphasis on the principle of guilt brings about that the defendant must have been blameworthy tempore delicti. If this was not the case, the defendant is excused, however great the reproach is for the preceding intoxication.

Nevertheless, the different approaches hardly ever lead to different outcomes. In Germany, the excuse is rejected if the intoxication was not severe enough to qualify for the complete defence. If it amounts to diminished capacity, to be discussed below, the facultative mitigation is generally not applied. Secondly, under an actio libera in causa, liability has been grounded in an earlier point of time. ${ }^{486}$ Finally, when the defendant is excused for the crime committed, he can still be held liable for the offence of 'Rauschtat' and punished with up to five years of imprisonment. ${ }^{487}$ The result is that an intoxicated defendant will hardly ever benefit from his intoxication. ${ }^{488}$

\subsubsection{Other disorders}

Other disorders like neuroses, perversions and personality disorders are categorized in Germany in a final category of 'other serious mental abnormalities'. ${ }^{489}$ Included

\footnotetext{
48218 September 2002 BGH NStZ-RR 2003, 8; Schönke \& Schröder, H. 2006, pp. 389-390 and Roxin 2006, p. 894.

483 Schönke \& Schröder, H. 2006, p. 412. This should not be confused with the English partial defence to murder of diminished responsibility.

484 In the original proposal of the Dutch defence insanity, intoxication was also listed as a possible cause leading to the defence. After lively discussion, an amendment was accepted that removed this cause from the defence, see de Hullu 2006, p. 324 and van Kalmthout 1998, p. 104.

485 R. v. Quick [1973] QB 310. See V.3.5.

486 Bohlander 2009, p. 134 and Roxin 2006, p. 895.

$487 \S \S 323 \mathrm{a}$ of the German Criminal Code and 122 of the Administrative Offences Act (OWiG).

488 See V.3.5.

489 Bohlander 2009, p. 135 and Schönke \& Schröder, H. 2006, pp. 398-399. Simester \& Sullivan 2007, p. 656 propose to include any other serious mental disorder in the English insanity defence.
} 
can be paedophilia, pyromania, kleptomania, extreme jealousy and so on. ${ }^{490}$ It may be feared that such a wide scope of possible disorders may lead to a defence that excuses all. However, it is again clear that only very severe disorders will qualify. ${ }^{491}$ Usually, the defendant is argued to have been able to exercise restraint and that he was therefore still able to appreciate the wrongfulness of his conduct. ${ }^{492}$

\subsubsection{Conclusion}

In conclusion, there is no need to create categories or to limit the condition of mental disorder. It does not matter whether the disorder is said to have a biological origin, whether it exists since birth or whether it was temporary or lasting. One could therefore simply refer to the categorization of disorders made in ICD-10 and DSM-IV, which already carries great weight. ${ }^{493}$ On the other hand, those categorizations have not been made with a view to exculpate but with a view to treat. Included are therefore also disorders that would never lead to the application of insanity, such as premature ejaculation and non-dependent vitamin abuse. ${ }^{494}$

This does not have to be a problem, if it is considered that the establishment of a mental disorder is not the only condition that needs to be fulfilled to accept insanity. In fact, the disorder must have also affected the offender at the time of committing the offence in a manner that makes it relevant to the defence of insanity. First of all, a mental disorder is only relevant as to the effect on the actions that underlie the offence charged; there is no such thing as general insanity. ${ }^{495}$ In order to make sure that the defence says something about the actor in relation to the act, rather than merely something about the actor, the defendant must therefore have suffered from the disorder tempore delicti. Secondly, the mental disorder must have also substantially impaired the capacities to be held responsible in criminal law. If this was not the case, the complete defence does not apply. The ways in which a disorder needs to influence these capacities are discussed now.

\subsection{Capacities}

The capacities that can be impaired by a mental disorder are distinguished into three categories. Evaluative and cognitive capacities require that the actor has the

\footnotetext{
490 Roxin 2006, pp. 897-898.

49123 September 2009 BGH NStZ-RR 2010, 7.

492 Roxin 2006, pp. 898-899.

493 Schönke \& Schröder, H. 2006, p. 399. ICD-10 refers to the latest, tenth edition of the International Statistical Classification of Diseases and Related Health Problems. DSM-IV refers to the latest edition of the Diagnostic and Statistical Manual of Mental Disorders. Buchanan 2000, pp. 95, 110 and 123

495 Bohlander 2009, pp. 132 and 117; Schönke \& Schröder, H. 2006, p. 403; Bosch 2008, pp. 167 and 203; Tadros 2005, pp. 324-328 and section 35(2) draft Criminal Code Law Commission 1989, p. 59 and 222 .
} 
ability to reason and distinguish right from wrong. He must be able to reflect on and understand the nature of his acts and have basic moral insights. Volitional capacities entail that the actor is able to control and direct his behaviour, that he is capable to develop and execute reasonably complex plans of action.

All States under investigation aim to explain the offence by reference to the disorder. In England and Germany, the offence is explained through the impairment of the defendant's capacities. This effect of the disorder is the connection between disorder and offence, bringing about a two-staged test. For example, the defendant committed the offence because he did not know what he did was wrong. He did not know what he did was wrong because he suffered from a mental disorder.

By contrast, Dutch law directly seeks to explain the offence by reference to the disorder. There is no specific effect required. As a result, more attention is paid to the required degree of causation between the disorder and the offence. ${ }^{496}$ Secondly, an additional condition of attribution applies. A disadvantage of the lack of references to incapacities is that it neglects that insanity is a defence of incapacity by virtue of mental disorder. I will now first explain the two alternatives in German and English law.

In German law, the offender is excused when the mental disorder made him incapable of appreciating the unlawfulness of the actions or to act in accordance with this appreciation. In English law, the defence applies if the defendant was unaware of the nature and quality of his act(s) or if he did not know tempore delicti that he was committing something, which is wrong.

\subsubsection{Evaluative capacities}

The two alternatives in German law are generally described as that the defendant lacks the capacity of insight and restraint. The former is the evaluative capacity to appreciate the wrong or unlawfulness of the act. This is similar to the second alternative under English law, that the defendant did not know he was committing a wrong. ${ }^{497}$ In both States, it has therefore been pointed out that this alternative overlaps with the defence of mistake of law. Given that a mistake of law also excuses, it may even be perceived as superfluous. ${ }^{498}$ However, the alternative in insanity highlights the special position of the offender compared to the sane actor who made an intellectual mistake. ${ }^{499}$ The mistake of law made by the insane is unavoidable because he suffered from a mental disorder, not because, let's say, an official authority misinformed him. Most importantly, excusing the defendant in

496 Particularly on the question whether this should be one of mere simultaneity. See Bosch 2008, pp. 167, 173 and 203; Mooij 2004, p. 1085; van Leeuwen 1986, pp. 6 and 20 and Strijards 1987, pp. 82-84.

497 Fokkens \& Machielse, note 8 on art. 39.

49817 November 1994 BGH NStZ 1995, 183; Roxin 2006, p. 900; Schönke \& Schröder, H. 2006, p. 386-387 and 400-402 and Williams 1953, p. 327.

$499 \quad$ Bohlander 2009, p. 116. 
these situations under a mistake of law would not allow the court to impose measures upon him in the same criminal procedure. ${ }^{500}$

The capacity is also accepted if the defendant knows that what he does formally violates the law, but he believes to act under some higher moral authority. ${ }^{501}$ The scope of the first alternative is thus very narrow. For example, in cases where the defendant acted out of a 'divine command', or thinking he was someone else, the defendant still knows that what he is doing is wrong. The effect is that the clearly insane, such as a person suffering from severe schizophrenia or a multiple personality disorder, will not be declared legally insane. ${ }^{502}$ Given that English law on insanity also does not include another alternative effect to accommodate these cases, like the impairment of volitional capacities described below, it has been argued that the English defence requires reform. .03

\subsubsection{Cognitive capacities}

The second alternative in English law, that the defendant is unaware of the nature and quality of his act(s), is very narrow in scope too. The ignorance on the conduct must relate to physical aspects of the circumstances and consequences attending his conduct in order to qualify. For example, the defendant thinks he is cutting a loaf of bread when he is in fact killing someone. ${ }^{504}$ This criterion therefore considerably overlaps with the failure of proof defences relating to fault elements, arguing for example that dolus is lacking because the defendant made a mistake. ${ }^{505}$

In Dutch law, it is accepted that when the defendant does not understand the nature of his actions and consequences at all, intent will be negated. This occurs however only in very exceptional circumstances, such as states of acute disassociation. ${ }^{506}$ Pragmatically, this is because the negation of the fault element leads to an acquittal and precludes the court from ordering measures against the defendant. ${ }^{507}$ Dogmatically, even if the defendant believes he is an avenger of evil, he still appreciated that he was killing another man with an axe. ${ }^{508}$ Hence, just like

500 Schönke \& Schröder, H. 2006, p. 387.

501 Simester \& Sullivan 2007, p. 652; Ormerod 2005, p. 263 and Williams 1953, p. 325. Ormerod 2008 , p. 286 submits that some juries do however accept the defence in cases where the defendant does believe it was not morally wrong.

502 Simester \& Sullivan 2007, pp. 643 and 652-654 and Ormerod 2005, p. 265.

503 Ormerod 2005, p. 264; Ormerod 2008, pp. 279 and 286; Williams 1953, p. 328 and Tadros 2005, pp. 324-328.

504 Simester \& Sullivan 2007, p. 651 and Ormerod 2008, p. 285.

505 Williams 1953, pp. 318-321.

506 Stevens \& Prinsen 2009. See, for example, Rb. Assen 12 June 2002, LJN:AE3911 and Rb. Leeuwarden 31 October 2002, NbSr 2002, 321.

507 HR 22 July 1963, NJ 1968, 217; HR 14 December 2004, NJ 2006, 448; HR 19 June 2007, NJ 2008, 169; HR 9 December 2008, NJ 2009, 157; de Hullu 2006, p. 218; Kelk 2005, p. 258; de Jong, D.H. \& Knigge 2003, p. 112 and van Dijk, A.A. 2008, pp. 299-301.

Hof Den Bosch 6 January 2009, $L J N$ :BG8922. 
the aforementioned examples of divine command will not qualify under this limb of English insanity defence, ${ }^{509}$ they will not preclude intent in the Netherlands. ${ }^{510}$

In English law, it is also recognized that when the defendant does not understand the nature and quality of his actions, this may already affect the question of whether or not the defendant had the required intent for the offence. ${ }^{511}$ However, the cognitive incapacity is treated as a form of insanity to highlight the specific reason for the mistake and most importantly, to enable measures to be imposed upon the defendant. ${ }^{512}$ If a mistake as to the offence definition is accepted, but this originates from a disease of the mind, the defendant can only be held to be insane. The approach in Germany seems to be that such mistakes also at best excuse the defendant. ${ }^{513}$

Regardless of whether the cognitive capacities affect the fault of the offence or are relevant under the insanity defence, it is clear that this capacity will hardly ever be deemed to have been absent. It is so fundamental that it when it is absent, we are most likely dealing with a person suffering from such a severe mental disorder, that he will not be able to function in everyday life. He is most likely already in a mental hospital.

\subsubsection{Volitional capacities}

The second alternative under German law deals with the incapacity of the defendant to act in accordance with the norms of the legal order. It applies if the defendant was unable to resist his urges. It makes clear that a perpetrator can know that what he does is wrong, but is unable to restrain himself and act accordingly. The difference with duress is that the origin of the irresistible pressure lies within the defendant. In duress, the origin of the pressure lies in a factor external to the defendant. 514

In German law, the capacity of restraint is not easily rejected. The threshold is only met when all of the defendant's powers could still not bring about a motivation to act in conformity with the norm. Similar as in conditional intent, when the offence involved is one of very serious injury or death, there is even a stronger

\footnotetext{
509 Simester \& Sullivan 2007, p. 651.

510 Van Dijk, A.A. 2008, p. 299.

511 R. v. Horseferry Road Magistrate's Court ex parte K [1997] QB 23 is criticized for holding that insanity is based solely on the absence of mens rea. In English law, insanity can also be based on the ignorance of wrongfulness. Moreover, the view of the court led to the obviously incorrect finding that insanity is no defence to offences of strict liability, see Ormerod 2008, p. 289; Ashworth 2006, p. 208 and Simester \& Sullivan 2007, pp. 178 and 652.

512 Ormerod 2005, p. 263 and Williams 1953, pp. 322 and 326.

51311 November 1952 BGH NJW 1953, 111; 9 July 1957 BGH NJW 1957, 1484 and 24 June 2008 BGH BeckRS 2008, 13794.

514 See Strijards 1987, p. 35. The distinction in the origin of disorders, in contrast to the origin of the pressure, was rejected above. The mental disorder can arise by an internal or external factor. For instance, post traumatic stress syndrome is the result of an external cause such a combat in war. The pressure the defendant however feels as a result of the disorder is always internal.
} 
presumption that the defendant could resist the impulse. ${ }^{515}$ In Dutch law too, the foundation of insanity has been argued to be the psychological freedom to be able to choose not to commit a crime and to be able to act accordingly. ${ }^{516}$ If the defendant could not inhibit his conduct or control it, insanity may apply. This is perceived as a less fundamental ability than being aware of what one is doing, which would negate intent. 517

The capacity of restraint resembles what has been called an irresistible impulse test in Anglo-American law. ${ }^{518}$ This test has been proposed to be included in the English defence of insanity as an additional alternative criterion. If desires are sufficiently strong for an agent of good character not to be capable to resist them, the defendant ought to be provided with a defence. ${ }^{519}$ However, this test has always been rejected because it is feared that it is extremely difficult or even impossible to distinguish between an impulse which is irresistible because of insanity and one that is irresistible because of greed, jealousy and so on. ${ }^{520}$ Another fear is that it is impossible to distinguish between an irresistible impulse and an impulse, which was merely not resisted by the defendant. ${ }^{521}$ This perspective can also explain the restricted scope of the English defence of duress.

By contrast, an irresistible impulse has been adopted in the English defence of diminished responsibility. ${ }^{522}$ As explained, this is a defence only to murder, resulting in a conviction for the lesser offence of manslaughter when it is accepted. This defence applies when the defendant's mental faculties were substantially impaired as a result of an abnormality of mental functioning due to a recognised medical condition. It differs from the test in the German concept of insanity because the threshold is not so high. The impulse need not be absolutely irresistible. It is sufficient that the defendant had substantially more difficulty controlling it than someone not suffering from a mental condition. ${ }^{523}$ By including this irresistible impulse, the scope of the defence is wider than that of insanity, and thus provides for a defence in borderline cases that fall short of insanity. ${ }^{524}$ However, the defence only applies to murder.

In conclusion, this limited recognition of the irresistible impulse by virtue of a mental disorder in the context of murder and its recognition in German and Dutch criminal law point at the acceptance of irresistible impulse in insanity. There are no

\footnotetext{
515 Schönke \& Schröder, H. 2006, pp. 401-402 and Roxin 2006, pp. 899-900.

516 Mevis 2006, pp. 618-619.

517 HR 9 March 2010, NJ 2010, 160.

518 Fokkens \& Machielse, note 8 on art. 39

519 Tadros 2005, pp. 341 and 346 and the Royal Commission on capital punishment, according to Ormerod 2005, p. 269.

520 Ormerod 2005, p. 266. See also R. v. Byrne [1960] 3 All ER 1 and Williams 1953, pp. 292, 330331 and $342-346$.

$521 \quad$ Hart 2008 (reprint 1967), p. 202.

522 Ormerod 2008, p. 288 and 510 and Simester \& Sullivan 2007, pp. 657-659.

523 R. v. Byrne [1960] 3 All ER 1; Ormerod 2008, p. 511 and Simester \& Sullivan 2007, pp. 657659.

524 Ormerod 2008, p. 512; Ashworth 2006, p. 278 and Hart 2008 (reprint 1967), p. 192.
} 
good reasons to preclude insanity in a general part of criminal law for the EU in cases where the perpetrator could not resist the impulses resulting from his mental disorder, provided it is established that he could not resist the impulse at all, given his mental condition.

\subsubsection{Attribution}

Three categories of capacities have been identified, of which at least one must be substantially impaired in order to accept insanity. These are first, the cognitive capacity to be aware of the nature of one's conduct, second the evaluative capacity to appreciate the criminal relevance of this conduct and finally, the volitional capacity to restrain oneself from contrasting urges or to choose freely. These three aspects coincide with the medical questions on the relevance of the disorder on the offence. ${ }^{525}$

The English defence is further limited by another condition, namely that of a 'defect of reason'. In order to exculpate, it must be shown that the defendant's power of reasoning was substantially impaired and that that was the reason for his failure to recognise the nature and quality of his act or that it was wrong. ${ }^{526}$ This condition can be traced back to an outdated focus of insanity on conduct displaying a lack of reason. It makes the defence too narrow because there can be instances where the defendant is perfectly capable to reason, but his volitional capacities are substantially impaired nonetheless. .527

By contrast to the specific impairment of capacities, Dutch law directly seeks to explain the offence by reference to the disorder. The three capacities have also been identified in the Netherlands as conditions of sanity. ${ }^{528}$ Nevertheless, the defence only deals with the question whether the offence should be attributed to the defendant, given the fact it was committed under the influence of the mental disorder. Conduct, which cannot be attributed to the actor due to a mental disorder, cannot be punished. The criterion of attribution makes clear that the assessment of the defence is in the end a legal, normative decision. ${ }^{529}$ This much is also accepted in the other two States. ${ }^{530}$ For example, in England, the greater the fear of recidivism, the more likely a finding of insanity will follow.

A judge can, but is not required to excuse the defendant. The most clear-cut example of when a judge would not excuse, are cases of prior fault. If the defendant

525 Van Leeuwen 1986, pp. 19-21 and Cleiren \& Nijboer 2008, note 3f on Boek I Titel III Niettoerekenbaarheid.

526 Tadros 2005, pp. 332-333. See R. v. Sullivan [1984] AC 156.

527 Norrie 2006B, p. 177.

528 Van Hamel in 1927 according to Kelk 2005, p. 257.

529 De Hullu 2006, p. 323-329; Stam \& ten Voorde 2009, p. 545 and Fokkens \& Machielse, notes $10-11$ on art. 39. Application of the defence is therefore also termed non-attribution, 'niettoerekening.'

530 Roxin 2006, pp. 899-900; Schönke \& Schröder, H. 2006, p. 386 and Simester \& Sullivan 2007, p. 648. 
is to blame for becoming mentally disordered, there might be a causal connection, but the defence will be rejected. ${ }^{531}$ Consider the Dutch case of the defendant who became so paranoid as a result of the taking of cocaine that he killed his grandmother. The court not only held that it was general experience that this substance is dangerous and can affect the will, but also held that the defendant already experienced strange effects from the taking of cocaine before. A prior fault reasoning was therefore easy to construe. ${ }^{532}$

The Royal Commission on capital punishment has proposed a similar test in England. That Commission proposed to simply leave it to jury to determine if the defendant was suffering tempore delicti from a mental disorder to such a degree that he ought not to be held responsible. ${ }^{53}$ It can be argued however that the problem of such an open defence is that it does not give any direction to determine responsibility. The test begs the question when the disorder is of a degree that it ought to negate responsibility. ${ }^{534}$

The answer is when it significantly impairs the capacities of the defendant to be held responsible in law. Suffering from a mental disorder is not the same thing as lacking the capacities to be held responsible in criminal law. A comparison can be made with the voluntary act requirement, which relates to the same basic capacities to be held responsible in law. The act is only deemed involuntary when the absolute minimum of capacities for responsibility in criminal law is absent. ${ }^{535}$ Only behaviour, which is uncontrollable, or which proceeds from severely impaired consciousness is deemed involuntary. ${ }^{536}$ The act requirement is accepted when a residual element of control remained. ${ }^{537}$

Again, this test of significant impairment may be criticized as giving insufficient direction, but it is submitted that such a simple phrasing of the defence is most appropriate, allowing for the court to rely on the latest medical expertise, whilst retaining the final say. Insanity should apply when at the time of committing the offence, due to a mental disorder, the defendant did not have the capacities to be held responsible in law. The defence should not give more direction, for in the end, insanity is a normative, legal question. Insanity should therefore not be straight jacketed into a tight legal definition. Secondly, a demand to give more direction apparently would fail to appreciate the complexity of the decision inherent in deciding whether someone can be held responsible to the law. The retroactive establishment of mental disorders and its effect on the capacities of the defendant tempore delicti is a very difficult enterprise. Moreover, it is difficult to quantify the

De Hullu 2006, pp. 325 and 328-329; Kelk 2005, p. 253 and van Netburg 1994, p. 11.

HR 9 June 1981, NJ 1983, 412. See also Rozemond 2006, p. 75. He did, however, only receive a punishment of two years imprisonment.

Ormerod 2008, p. 291.

Compare Buchanan 2000, p. 94 on the product test that used to be applied in US law.

See Tadros 2005, pp. 139 and 370 and Roxin 2006, pp. 964 and 1014.

Ashworth 2006, p. 99 and Simester and Sullivan 2007, p. 105.

Ashworth 2006, p. 100; Ormerod 2005, p. 272; Ormerod 2008, p. 271 and Simester and Sullivan 2007, pp. 105-107. 
effect of a mental disorder on the capacities of the defendant. It is easier to identify that the disorder affected a capacity than to identify the point at which that defendant can no longer be said to be responsible..$^{538}$

\subsubsection{Diminished capacity}

The latter issue brings up the question what to do when the defendant's capacities have been impaired by the disorder, but not to the extent of legal irresponsibility. The disorder was for example not severe enough or it did not have such a severe effect on the defendant to conclude he should not be excused. In these cases, courts can decide to take into account the partial impairment of the pertinent capacities as mitigating. These cases are much more common that the application of the complete defence of insanity. ${ }^{539}$ Many defendants suffer from personality disorders, which generally only qualify under the defence that is called 'diminished capacity'. ${ }^{540}$

Mitigation follows because the defendant who was not completely sane bears less blame for the offence than a sane actor ceteris paribus. The punishment may be mitigated accordingly. At the same time, the dangerousness of the defendant expressed by the offence warrants treatment, which may be ordered on grounds of the verdict of partial insanity. In practice, a sentence of years of imprisonment is combined with a compulsory admission and treatment in a mental hospital.

In the Netherlands and Germany, the defendant can rely on the defence of diminished capacity. In Germany, this is made explicit in $\$ 21$ of the Criminal Code. In the Netherlands this is accepted too, notwithstanding that the Dutch Code does not imply this and the legislator did not envisage it. ${ }^{541}$ In English law, insanity is considered an all-or-nothing defence. The aforementioned defence of diminished responsibility only applies to the offence of murder. Despite this difference, in all three Member States, the defendant can only be excused when he can rely on the complete defence of insanity. Like any defendant who falls just outside the confines of a complete defence, the sentence of the defendant can and is usually diminished, provided the judge has that discretion. ${ }^{52}$ The defence of diminished capacity therefore does not qualify as a defence under the conditions set out in the beginning of this chapter. It is merely a ground for mitigation.

In Germany, the mitigating effect of diminished capacity has received the most attention. First of all, the Supreme Court requires lower courts to investigate the possibility of diminished capacity and to motivate sufficiently when rejecting it. ${ }^{543}$

\footnotetext{
538 Buchanan 2000, pp. 77-80.

539 De Hullu 2006, p. 332 and Roxin 2006, p. 902.

540 Mooij 2004, p. 1085. The term is taken from the translation of $\$ 21$ of the German Criminal Code on www.iuscomp.org.

541 De Hullu 2006, p. 259.

542 Attorney-General's Reference no. 37 of 2004 [2004] EWCA Crim 1854; Beulke 2008, pp. 143144; Roxin 2006, p. 902 and de Hullu 2009, p. 292.

543 See for example, 8 December 2009 BGH NStZ-RR 2010, 105.
} 
Secondly, the mitigation is facultative, like in any other situation where the defendant just falls short of the conditions of a defence. However, it has been argued that the maxim 'punishment according to guilt' brings about that the refusal to mitigate must be the exception. ${ }^{544}$

Only German law explicitly provides for the possibility to mitigate the sentence when the threshold of an excuse is not met. Besides this diminished capacity, the German Criminal Code holds that when the defendant cannot rely on duress because he should have accepted the danger or when he made a mistake of law that was avoidable, the sentence may be mitigated. ${ }^{545}$ If the maxim were taken seriously, one would expect an obligatory mitigation in these cases where the defendant is less blameworthy than the general offender. However, this facultative mitigation is interpreted as a confirmation that mitigation in cases of lesser blameworthiness should be the rule. ${ }^{546}$

\subsection{Exemption or excuse}

In German law, the insanity defence is firmly anchored as an excuse. First of all, the defence is said to negate the 'capacity to be held blameworthy'. ${ }^{547}$ Secondly, the defence is based on the principle of guilt and the related punishment according to blameworthiness. The insanity defence thus excuses the defendant. Diminished capacity is translated as diminished blameworthiness and results in a mitigation of punishment. In English and Dutch law, the insanity defence is also usually categorized as an excuse, which therefore negates the blameworthiness of the actor when accepted.

However, insanity is perhaps better labelled as an exemption. Exemptions are distinguished from excuses as 'non exculpatory defences', or 'out-and-out denials of responsibility'. ${ }^{548}$ After all, in order to be subjects of the criminal law, human beings must possess basic capacities. The agent is liable for causing harm, but he can only be held accountable in the first place, because he possesses the capacities to be a subject of the law. Insanity negates the assumption that the defendant possesses these capacities. These preconditions of criminal responsibility do not deal with the question whether the actor committed the offence and can be punished

544 This refusal may only be based on countervailing considerations of blameworthiness, such as prior fault in getting into a state of diminished capacity, see 26 May 2004 BGH NStZ 2004, 619; Roxin 2006, pp. 906-907 and Schönke \& Schröder, H. 2006, pp. 415-417. See $\$ \S 17$ and 35(1) and (2) of the German Criminal Code.

546 In the Corpus Juris of Delmas-Marty 1997, p. 66, the avoidable mistake of law had to be mitigated, whereas the Corpus of Delmas-Marty \& Vervaele 2000, p. 192 refers to facultative mitigation.

547 'Schuldfähigkeit', see $\$ 20$ of the German Criminal Code. In classic doctrine, it was called Zurechnungsfähigkeit, see Beulke 2008, pp. 316-317. Toerekenings(vatbaarheid) is still used in Dutch law.

548 Robinson 1982 and Horder 2006A, p. 9 respectively. 
for this, but with the more fundamental question whether the actor can even be held responsible under criminal law. From the aforementioned viewpoint of the framework of criminal liability as a ladder, the pertinent question is whether we should try to climb the ladder at all. In other words, dogmatically, the issue of responsibility precedes that of wrongdoing and blameworthiness. Whereas an excuse denies accountability or blameworthiness, an exemption denies something more fundamental, namely responsibility. Excuses concern defendants who are not to blame for their conduct but who have the capacities to be fully responsible. An exemption denies that the perpetrator is a person who can be held responsible under the law. ${ }^{549}$

Insanity thus resembles legal concepts such as infancy and immunity. In extreme cases, the insane can be equated to animals. ${ }^{550}$ It is therefore common in Anglo-American law to categorize insanity as an exemption. ${ }^{551}$ Ruiz-Jarabo Colomer, Advocate General at the ECJ, also argued "the intrinsic grounds include those for exonerating a defendant who lacks the indispensable requirements for accountability (grounds relating to lack of criminal responsibility, such as being under age or mental disorder)." ${ }^{552}$ Insanity and diminished capacity are also labelled as exemptions in the annex of Decision 2009/316. ${ }^{553}$

Infants are not accountable, because their capacities have not matured. The criminal law operates with a presumption of irresponsibility, based on the infant's lack to distinguish properly between right and wrong. The minimum age of criminal responsibility ranges from ten years in England, twelve years in the Netherlands, to fourteen years in Germany. ${ }^{554}$ Those under that age are categorically assumed to lack the capacities to be held responsible in law. When children are older, their (evaluative) capacities are assessed. In German law, juveniles between fourteen and eighteen can be held liable if they have the maturity to appreciate the consequences

549 Tadros 2005, pp. 124, 136-139 and 370 and Fletcher 1985, pp. 958-959.

550 Tadros 2005, p. 134. See also Leverick 2006, pp. 22-23 and Husak 2005, p. 297.

551 Ashworth 2006, p. 241; Horder 2006A, p. 9; Gardner, J. 2007, pp. 131-132; Westen 2006, p. 348; Duff 2007, pp. 284-290; Leverick 2006, pp. 21-22 and Tadros 2005, pp. 116, 124 and 370. See Fletcher 1985, pp. 836 and 958-959; Husak 2005 and Beulke 2008, p. 313. Section 50 of the Children and Young Persons Act 1983 labels infancy as an irrebuttable presumption of irresponsibility.

552 Opinion of AG Colomer of 8 June 2006, C-150/05, van Straaten v. the Netherlands and Italy [2006] ECR I-9327, §65.

553 Decision 2009/316 of 6 April 2009 on the establishment of the European Criminal Records Information System (ECRIS) in application of art. 11 of Framework Decision 2009/315, OJ 2009 L 93/33. I substituted 'diminished responsibility' with 'diminished capacity' in order to avoid confusion with the English partial defence.

554 Section 50 of the Children and Young Persons Act 1983, articles 486-487 of the Dutch Code of Criminal Procedure and $\S 19$ (1) of the German Criminal Code respectively. The yardstick is the age tempore delicti, see Schönke \& Schröder, H. 2006, p. 381. The ECtHR has held that the minimum age of ten years need not violate article 6 , although many have argued in favour of a higher threshold, see S.C. v. UK, appl. no. 60958/00, 15 June 2004. 
of their actions and are capable of recognising the unlawfulness of their conduct. 555 This middle ground is no longer applied in Dutch and English law, but the Dutch judge used to investigate whether the child understood the wrong of its behaviour. ${ }^{556}$ In English law, a rebuttable presumption of irresponsibility for children until the age of fourteen existed. Now abolished, this doli incapax allowed the child to be tried if the prosecution could prove it knew the behaviour was seriously wrong. ${ }^{557}$

Both infancy and insanity deal with an objective situation of irresponsibility. Unlike defences, no subjective requirement is required of being aware that its conditions are fulfilled. No mistake on the application of the defence can be relevant. ${ }^{558}$ By categorizing infancy and insanity as exemptions, one can conceptually separate between blameworthiness on the one hand, which is negated by excuses, and the capacities necessary for criminal responsibility on the other. The rationale for exculpating the insane perpetrator differs from that of excusing sane perpetrators. He is not exculpated because he met the standard of what could reasonably be expected of him in the given situation. Rather, he is exculpated because he is unable to meet the standard of the law at all.

Insanity has been distinguished from other excuses by prevailing opinion in Germany as well. 'Normal' excuses do not negate the reproach of blameworthiness, but abstain from this reproach due to empathy for the situation of coercion or conflict. In other words, the effect of an excuse like duress is that it limits the degree of blameworthiness to a degree that falls short of the threshold for criminal liability. By contrast, insanity completely negates blameworthiness, just like infancy and unavoidable mistake of law. ${ }^{559}$ In Dutch law, it is recognized too that a mental disorder can precede the question on blameworthiness, because insanity can negate intention.

However, even though in the Netherlands and Germany, infancy has generally been discussed in close connection with insanity, ${ }^{560}$ infancy is generally treated as a ground barring prosecution, and insanity as an excuse. ${ }^{561}$ An advantage of treating insanity as an excuse seems to be that it facilitates the establishment of accessorial liability. An excuse only operates personal, so it would not affect the liability of other perpetrators or accomplices. By contrast, if it is held that the insane actor

$\S 3$ of the Juvenile Court Act (Jugendgerichtsgesetz). See Beulke 2008, p. 144.

Art. 38 (old) of the Dutch Criminal Code; Strijards 1987, p. 34; Pompe 1935, p. 101 and de Hullu 2006, p. 105.

Ashworth 2006, p. 203; Simester \& Sullivan 2007, p. 663-664 and Ormerod 2005, p. 296. Abolished by Section 34 of the Crime and Disorder Act 1998; CPS v. P. [2007] EWHC 946 and R. v. T. [2008] EWCA Crim 815.

See VII.5.7.

Schönke \& Schröder, H. 2006, pp. 626-627 and 701; Beulke 2008, p. 150 and Roxin 2006, pp. 913, 964-966, 987 and 1014. See also Beulke 2008, pp. 313 and 316-317 and Schönke \& Schröder, H. 2006, p. 158.

$\S 19$ of the German Criminal Code on infancy precedes the provision on insanity. See also de Hullu 2006, pp. 104-105; Strijards 1987, pp. 33-35 and Knigge 1983, p. 11.

Articles 467-468 of the Dutch Code of Criminal Procedure; de Hullu 2006, p. 106; Nieboer 1991, pp. 233-235; Roxin 2006, p. 912 and Schönke \& Schröder, H. 2006, p. 381. 
cannot commit an offence, comparable to a six-year-old, there is no wrongful attack to derive liability from to the persons who have aided or instigated his conduct. Nevertheless, the instigator could be held liable under the concept of perpetration by means. ${ }^{562}$

A second advantage of the perspective that insanity only affects the blameworthiness is that the conduct of the insane perpetrator is wrongful and can be averted by self-defence. If the insane cannot legally commit a wrongful attack because he is no subject of the law, this would preclude self-defence against him. Nevertheless, as explained before, defensive force of a third party could also be based on necessity. It can also be said that the insane defendant is not punished because insanity is framed as an excuse. The blameless cannot be punished. Nevertheless, by viewing it as an exemption, the same result would be reached. After all, the irresponsible are also unpunishable.

Finally, it is logical to prioritize the issue of responsibility over the issue of liability. The agent is only liable for causing harm, if he can be held accountable in the first place, because he possesses the capacities to be an addressee of the criminal law. ${ }^{563}$ However, since defendants prefer to be acquitted on other grounds, insanity is often only assessed after it has been established that the defendant has committed a wrongful act. ${ }^{564}$ In that order of assessing liability, insanity resembles more an excuse.

It is submitted that insanity can be both an exemption as well as an excuse. ${ }^{565} \mathrm{It}$ can even be a failure of proof defence if it is accepted that the disorder is the reason why the defendant did not foresee. ${ }^{566}$ If the insanity is sufficiently severe such as to deny the responsibility of the defendant altogether, it is an exemption. If that is not the case, insanity can still play a role in the realm of excuses by answering the question whether the defendant could have acted differently. ${ }^{567}$ Furthermore, the character of the defence is influenced by the specific capacity that is impaired by the disorder. When cognitive capacities such as being aware of the nature of one's conduct are impaired, the defence looks more like an exemption. When a volitional capacity, the ability to choose is impaired, the defence resembles most an excuse like duress. ${ }^{568}$

\footnotetext{
562 In other words, by 'innocent agency', 'mittelbare Täterschaft' or 'doen plegen'. Another solution can be found in article 5.04 of the Model Penal Code, which simply holds that the irresponsibility of the other is immaterial to the liability of the solicitor, see the American Law Institute 1985.

563 Fletcher 1985, pp. 958-959.

564 In the Netherlands, it has thus often been argued the defence should be assessed last, see Dolman 2006, p. 316 and 321; Fokkens \& Machielse, note 5 on Uitsluiting en verhoging van strafbaarheid and Vellinga, W.H. 1982, pp. 155-156. See also Horder 2006A, pp. 102-103.

565 Tadros 2005, p. 322.

566 Robinson 1982, pp. 205-206. See also the reference to Dutch law above.

567 Tadros 2005, p. 372 and Duff 2007, p. 286. See also Westen 2008A, p. 581.

568 In other words, insanity is an exemption when an analogy is made with infancy, but an excuse when an analogy is made with duress, see Fletcher 1978, p. 836.
} 
If the defendant permanently suffers from a very severe disorder, this has the character of an exemption. The defendant is never a proper addressee of the law. If the disorder was of a transient nature, it has more of an excusatory character. After all, under the capacity theory, only if the disorder was transient, can it be said that the defendant's conduct does not reflect on his settled character. ${ }^{569}$ Finally, the character of insanity depends on which aspect one focuses. By focusing on the condition of impaired capacities, the requirement that fundamental capacities must be negated to accept insanity, its character of exemption is strongest. ${ }^{570}$ By focusing on the requirement that the disorder must have affected the actions underlying the offence charged, it becomes clear that insanity is not some general statement on the actor's responsibility, but that is says something about the act in relation to the actor, which therefore resembles more the structure of excuses.

569 Tadros 2005, p. 134 submits that status-responsibility (which an exemption negates) cannot simply be determined at the point when a person acts, as it persists over time. Attributionresponsibility (which an excuse negates) is determined in relation to the pertinent event. I reject this narrow scope of exemptions. After all, exemptions like infancy and immunity are judged according to the pertinent offence as well. 


\section{Part 4}

\section{Conclusion}





\section{Chapter XI Conclusion}

\section{General Conclusions}

I have submitted what mens rea and defences in a general part of European criminal law should look like. These general principles of European criminal law have been constructed out of the fragments of substantive criminal law of the European Union, including the ECHR and its case law. In order to complete this puzzle of a general part, I identified more pieces by looking at the legal systems of its Member States. The decision, which pieces would fit in the puzzle, was determined by conditions such as consistency, coherency and enforceability.

This decision was greatly facilitated by the considerable consensus of investigated legal systems: mens rea and defences are, for the most part, quite similar everywhere. For instance, in each of these legal systems, negligence leads to criminal liability and self-defence acquits the defendant. Moreover, the rationales underlying these legal principles are more or less identical. This considerable consensus greatly facilitated the synthesis, which is built upon the common ground of the pertinent legal systems. It would have become very difficult to identify the general principles of mens rea and defences for EU criminal law if many significant differences would have been identified. In fact, in many regards, the differences between the Member States are getting smaller and smaller. For example, the law on self-defence in the Netherlands and Germany is clearly moving towards each other. The traditionally wide scope of self-defence in German law is limited more and more, whereas the traditionally stricter scope of self-defence in Dutch law is clearly broadened in recent years.

It became clear that many of the different views on what general principles should look like do not necessarily coincide with national borders. Certainly, strict liability is most controversial in Germany and therefore completely rejected in law. Nevertheless, strict liability is controversial in every Member State. As a result, one can find more or less the same arguments in favour of and against strict liability in every Member State. The same conclusion can be drawn in other contexts. Concerning the question whether or not it should be allowed in law to torture terrorists, or shoot down hijacked airplanes, the same arguments are made in favour and against it in all legal systems under investigation. It can thus be concluded that a common European criminal doctrine is very much alive. This has been evolving since the end of the nineteen seventies, when legal comparison and international scholarly cooperation on substantive criminal law started to become more popular. ${ }^{1}$

$1 \quad$ See for example Fletcher 1978. 
It is clear that all Member States share the same fundaments of criminal law; all face the same dilemmas in searching for an appropriate balancing of the interests of the individual defendant and public security. The Union is built on the fact that all Europeans share similar traditions and values, it is founded on a considerable degree of similarity between States, citizens and culture. ${ }^{2}$ Certainly, criminal law reflects the basic values, customs and choices of any given society, which brings about significant differences. However, in the larger perspective, the European societies have much more features in common. This is the result, not only of the approximation of some minimum rules relating to the general part of substantive criminal law by the ECJ and ECtHR, but also from the aforementioned scholarly cooperation, paralleled by an ongoing strengthening of judicial and police cooperation in criminal matters and cross-fertilisation of European with national criminal law.

The conclusion is thus also that a general part of EU criminal law can be made. Given the great similarities between national legal concepts, only a few significant differences exist, requiring a fundamental choice. It will come as no surprise that most of these differences concern a clash of English law with its continental counterparts. These differences concern the contrasting fault elements of dolus eventualis and recklessness, the question whether liability requires proof of mens rea as to each and every single offence element, and a more general difference regarding the scope of defences. They reflect the different legal cultures and can therefore also be explained by these national peculiarities. I will explain the three differences and shortly summarize how a choice was made. By explaining the differences, general conclusions on the legal systems under investigation and the general part of criminal law of the EU will become clear. Following this, I will summarize the answer to the main question of this research, what mens rea and defences should look like in a general part of criminal law for the EU.

\subsection{Recklessness instead of dolus eventualis}

From studying the fault elements in the legal systems under investigation, it can be concluded that the most serious and the least serious fault elements are very similar. The national differences really only concern the causing of side-effects by actions, the realization of risks of which the defendant is aware. The Dutch and German legal systems apply dolus eventualis to ground liability in these cases, the lowest form of intent. The Latin term is used to reflect that the concept follows from a merger of different national concepts and is a candidate to be applied in a general part of criminal law for the EU.

Compare the recital of Framework Decision 2008/947 of 27 November 2008 on the application of the principle of mutual recognition to judgments and probation decisions with a view to the supervision of probation measures and alternative sanctions OJ 2008 L 337/102: "This presupposes that there is an understanding of freedom, security and justice on the part of the Member States which is identical in its essential elements (...)." 
This concept of dolus eventualis is alien to English law. Instead of distinguishing intent from negligence, English law creates a fault element that is located in between intent and negligence, namely recklessness. It is functionally equivalent to dolus eventualis, but at the same time very different as it is not a form of intent. Recklessness is a broader concept that also includes the Dutch and German fault elements of conscious negligence and its aggravated form, luxuria. For a general part of criminal law for the EU, a choice was made for recklessness, a choice in favour of three instead of two major categories of fault. In a general part of criminal law for the EU, the accused who foresees that his actions may lead to a side-effect should not be held liable for intending to bring this about. Instead, we should hold him liable for recklessly causing side-effects.

In short, the choice in favour of recklessness followed from the requirements of consistency and fair labelling. The use of recklessness keeps dolus within proper limits. The functional equivalent, the extended concept of dolus eventualis is rejected because it distorts the meaning of intent, it is very different from dolus directus and indirectus and it leads to inconsistent outcomes. Fault should not be distinguished based on attitude, but based on awareness. This reflects the difference in culpability better and is easier to prove in practice. Together with its explicit normative elements, recklessness is best equipped to deal with foreseen side-effects in this day and age. I will readdress this choice when I describe all fault elements below.

\subsection{Strict liability}

Secondly, German criminal law does not allow for liability without proof of a fault element like intent or negligence. This can be contrasted with the popularity of strict liability in the Netherlands and England. Many arguments in favour of strict liability have been vitiated and many arguments against strict liability have correctly been raised. Moreover, there are many alternatives to striking fault as an element of an offence definition. Nonetheless, the choice was made not to preclude strict liability altogether, in line with the case-law of the ECJ and ECtHR.

The principle of guilt as interpreted by the ECtHR does not militate against strict liability. In contrast, the German injunction on strict liability follows from a broader interpretation of that principle as literally meaning nulla poena sine culpa: no punishment without (at least) negligence. I called this the fault requirement. The principle is given constitutional status in Germany. The German Constitutional Court has even gone as far to hold that EU law cannot alter such a principle and must therefore be interpreted in line with it. This interpretation is rejected however, because the more limited approach of the ECtHR carries more weight in the synthesis. The constitutional tradition of one Member State is not given absolute weight, because otherwise all that could be established are lowest common denominators. 
Secondly, that broad interpretation in German law neglects the difference between fault and blameworthiness. It has been explained that blameworthiness should be distinguished from mens rea. The latter is an analytical tool of the offence that encompasses fault elements and its related principles. If one fails to make this distinction, as in some English cases, the negation of blameworthiness by an excuse risks being interpreted as a negation of fault, leading to inconsistency in judging similar cases. The interpretation of an excuse as a denial of intention is wrong, because the fact that the defendant was coerced under duress to injure someone does not negate the fact that he intended to injure someone. For example, even though terrorists coerced him, John did intend to kill the police commissioner.

It is true that fault elements, like intention, increase the reproach that can be made to the defendant in comparison to a negligent offence. However, blameworthiness deals with an aspect of liability that is more fundamental. Even crimes of strict liability require that the defendant is blameworthy. It is an absolute principle of criminal law, allowing for no exceptions, that the blameless may not be punished. This is the lower limit of criminal liability. The principle of no punishment without guilt therefore refers to the rule that there can be no punishment without blameworthiness.

Even though there are good reasons to always require some fault in an offence definition, it would be inaccurate to state that such a principle is widely recognized in the EU. ${ }^{3}$ Fault may be the standard, but strict liability is certainly no longer the exception in Dutch and English criminal law. This is allowed by the ECJ and ECtHR and should be seen as the manifestation of a dynamic principle in a changing society, in which views on responsibility also change. For example, criminal law now deals with a much wider scope of violations of norms than it used to. Concerns of dealing efficiently with high numbers of, for example, traffic violations may warrant strict liability.

Functional equivalents to strict liability are offences of endangerment, fall back or basic offences, duties to prove that the norms have been complied with and reversed onuses. These alternatives can also give rise to doctrinal objections, questioning whether the reasons for criminalization are legitimate and whether the presumption of innocence is not violated. An alternative that can give the same benefits at an apparently lesser cost to the fair administration of justice is requiring culpa and reversing the burden of proof. If a result is made strict because it is foreseeable, then requiring culpa, possibly even by presuming it, would also lead to liability, whilst having the advantage that it could acquit those who could not foresee the result. After all, if the crime were one of strict liability, the claim that the risk was unforeseeable is not a defence. Only a due diligence defence could preclude a conviction. Nevertheless, strict liability is not always based on a foreseeable relationship between conduct and result. It is also used to simply alleviate the enforcement of offences and to ensure the greatest level of protection 
for vulnerable interests such as those of young children. Culpa (praesumptus) therefore not always appears to be a sufficient alternative to do away with strict liability.

The question of whether or not strict liability and its equivalents of reverse onuses should be allowed in European criminal law is a matter that is to be assessed in the context of every offence. The case against strict liability is stronger in relation to serious offences with severe penalties. As a rule, an element that gives the offence its character must not be made strict. However, other considerations also need to be taken into account, like the ease for the defendant to prove something. Even if the element is essential to the offence, the defendant can be required to prove that he, for example, did something whilst being licensed to do so. In general, the defendant's right to a fair trial should be weighed against the interests of the criminal justice system in securing convictions. Since many offences in European criminal law are of a regulatory nature or aim to protect vulnerable interests, the use of strict offence elements may very well be legitimate.

The manner in which the ECtHR carries out this weighing of interests is insufficient, because it only sets minimum requirements. Faced with only the option of holding a violation of article 6 ECHR or not, the Court feels pressured to approve of strict practices. Instead, courts should also be able to interpret an offence or burden of proof in conformity with fundamental rights. By conform interpretation, which is common to the ECJ and English courts, courts have at their disposal more options to strike the appropriate balance between the rights of the defendant and the interests of efficient enforcement of criminal law. If possible, the court should read in fault elements or defences or lower the burden of proof put on the defendant. In conclusion, strict liability and its alternatives may be used in European criminal law, but only when it is established that this is necessary, because lesser alternatives do not suffice. If lesser alternatives do suffice, courts may be able to reinterpret the offence in such a way.

\subsection{The scope of defences}

A third important difference is that the scope of defences in England is generally much more restrictive than in Germany or the Netherlands. After all, unlike in the other two Member States, the excuses self-defence-excess, mistake of law and superior orders are unavailable in England. Moreover, necessity, duress and insanity are much stricter in scope in English than in Dutch and German law.

This difference can be explained by the sceptical approach of English law to defences and general principles of law. First and foremost, fears persist that accepting some defences and extending others would deteriorate the authority of the norms and the legislator. It is feared that defences will be abused, hampering efficient prosecution of criminals. English law recognizes that there are cases in which the defendant should not be punished severely or not at all, but prefers to 
enable this by procedural means, such as prosecutorial discretion, by sentencing or by granting the convicted person a pardon. ${ }^{4}$

In addition, there exists a more general reluctance of English law to apply general principles of criminal law. The preference on the specific over the general is clearly visible in the tendency of English law to rely on specific measures rather than to deal with cases by general defences. Instead of leaving exceptional matters to a coherent and comprehensive set of defences, the legislator often tends to draft offences very detailed, already making explicit any available defence by including it into the criminalization. As a result, there is less room for general defences.

Another reason for the restrictive scope of defences is the circumstance that wrongfulness and blameworthiness are not firmly anchored as prerequisites of liability in English criminal law. By firmly anchoring these implied elements in criminal theory as absolute conditions of criminal liability, the number and scope of existing defences would certainly augment. It follows that reducing the sentence of the excused defendant is insufficient, as criminal liability should not be imposed at all. If it were acknowledged that the insight of the illegality of one's conduct is an element of blameworthiness, the recognition of mistake of law as an excuse would follow. Moreover, if the distinction between justification and excuse would be appreciated better, some of the paranoia regarding defences would be taken away. For instance, excusing the defendant for making an unavoidable mistake of law does not entail an approval of those actions, or a statement that those actions are in fact lawful. Instead, the excuse denotes that the defendant is only excused for his wrongful actions. An excuse thereby reinforces the norms.

The unavailability of self-defence-excess, mistake of law and superior orders is partially counterbalanced by functional equivalents. A relatively broader scope of justified self-defence and putative self-defence, as well as the availability of two specific defences that can reduce a charge of murder to manslaughter mitigate the unavailability of self-defence-excess. A mistake of law cannot excuse the defendant in England, but this is counterbalanced by the fact that in paradigm cases of mistake of law, such as mistakes based on incorrect advice of official authorities, the proceedings against the defendant, if instituted at all, will be stayed. Secondly, mistakes on aspects of civil law are sometimes held to negate mens rea. Superior orders is a species of mistake or law, and therefore also no excuse in England. Nevertheless, Courts sometimes acquit defendants by negating mens rea or by accepting a related defence like duress, if the defendant by his disobedience would risk injuries.

These features of English law can however be criticized. First of all, the legal concepts that fill the gap are almost all inconsistent with criminal doctrine. Since intention is neutral, since intention is generally not required as to the illegality of the conduct, it is inconsistent to negate this when the defendant was ignorant of the norm or mistaken on the legality of an order by a superior. Another example is that 
if a mistake on the facts giving rise to self-defence need not be reasonable, no difference can be made between actual and putative self-defence.

Secondly, the partial defences of loss of control and diminished responsibility and other means of mitigating the sentence fail to recognize the importance of criminal liability and its difference with sentencing. If the conduct was not wrongful or the defendant not blameworthy, this should be reflected in criminal liability. The communicative function of criminal law requires the conviction to distinguish between the guilty and the excused. Excused conduct should not be punished at all and does not deserve the stigma of a criminal conviction, even if the convicted person is not punished. Criminal liability can therefore be defined as the punishability of a responsible actor for committing an offence. It implies that the defendant's conduct is not justified and the defendant not excused. Sentencing by contrast is the valuation of the seriousness of a specific criminal offence, taking into account the actor, his state of mind and his motives.

Third, leaving the circumstances with the executive violates the division of state powers. Criminal liability is a matter of adjudication. The defendant should not be left at the mercy of administrative discretion. He is entitled to have liability debated in an open court. An open debate on liability in court is also in the interest of the victim and the public, who will better understand the reasons for or against liability. The decision can be controlled by a higher or Supreme Court and everyone else, thus furthering consistency and hence fairness.

Fourth, even if the English approach would be accepted, the availability of prosecutorial discretion and discretion sentencing does not provide for sufficient protection of the defendant. Whereas harsh outcomes can be neutralized or mitigated in other ways, in many cases the defendant is still punished whilst he would not have been liable under Dutch or German law. Fuelled by deterrence, English law favours to send out a strong signal that the law is so and so over concerns of individual fairness. This is however at odds with more retributive views on punishment. Moreover, prosecutorial discretion can only afford some relief in a legal system that enables such discretion. In contrast, the scope of defences is thus much more important in a system that operates on the principle that the prosecutor is required to bring charges for every crime.

From the perspective that criminal law must be enforceable, many of the fears that gave rise to the restrictive approach have been defused by looking at the practice of Dutch and German law, where no such fears materialized. Fears of abuse are overestimated, because it is overlooked that the threshold of for example excusing the defendant under a mistake of law is very high. Secondly, the concern that people are encouraged to remain ignorant of the law by recognizing the defence is unfounded. If the defendant failed to make sufficient enquiries on the lawfulness of his conduct, his ignorance will not be excused. Third, the concern that accepting the defence in a case sends a wrong signal to the public. As noted, excusing the defendant for making an unavoidable mistake of law does not invalidate, it rather reinforces the norm. 
English scholars are well aware of this and less reluctant to a broader role for general defences. Even English Courts have recognized the problems of the restrictive approach to defences. ${ }^{5}$ In more recent cases, they have become more adventurous therefore in extending the scope of defences, signalling a possible trend that would result in a move towards the other two Member States under investigation. For the reasons mentioned above, the general part of criminal law for the EU should have a broad range of possible defences, comparable with Dutch and German law.

In Dutch and German law, the scope of defences is quite similar. There are a few more defences recognized in Dutch law, which on closer inspection are however superfluous as more specific variations of general defences like necessity. Secondly, the taboo on killing persons outside the scope of self-defence is not as strong in the Netherlands as it is in Germany and England. This is evident by the possibility to raise necessity and duress against a charge of intentional killing.

Nevertheless, German law has the widest scope of defences. For example, traditionally, self-defence does not require proportionality. In legal comparison, it could therefore be argued that the wide scope of German defences insufficiently regards the interests of the victims of crime. It follows from the positive obligation of the State to safeguard the right to life under article 2 ECHR that disproportionate force may not be justified in self-defence. The wide scope of defences not only follows from the broad conditions of defences. The lenient approach as to in dubio pro reo also significantly favours the defendant concerning the acceptance of defences. The least amount of doubt on the actual facts may lead a Court to take hypothetical facts that are most favourable to the defendant as a starting point. This can lead to absurd assumptions and thereby outcomes that are difficult to agree with.

As regards most issues in this research, Dutch law can be located in between the pragmatic approach of English law and the dogmatic approach of German law. Dutch law adheres to the importance of dogmatic criminal law and accepts most of the dogmatic principles one can find in German law. However, it draws a line where dogmatics threatens to violate an appropriate outcome or lead to absurd legal approaches. ${ }^{6}$ As evident in dealing with intoxicated actors, Dutch law quite pragmatically establishes criminal liability without even addressing possible doctrinal problems. This middle position makes Dutch law tempting for any compromise, as long as simplicity and enforceability are considered as no less important criteria than consistency.

The influence of German criminal law on the outcome of this research has nevertheless been significant. This can be explained by the fact that much of the general principles discussed in this research have important roots in Germany. Moreover, the more elaborate the discussion on general principles becomes, the more one looks at the details of an issue, the more likely only German law has something to say about it. After all, an important feature of German law is to

R. v. G. [2003] UKHL 50 and R. v. Pommell [1995] EWCA Crim 7.

Compare Stratenwerth in Eser \& Fletcher 1988, pp. 1072-1073. 
elaborate thoroughly on all possible legal questions, real or hypothetical. If these German perspectives were consistent with the general concept developed by comparing all legal sources, they simply complemented and elaborated the general principle of European criminal law. English criminal law has also left its mark on the synthesis. It did so in a significant way by favouring a third fault element of recklessness over the watered down form of intention called dolus eventualis.

\section{MENS REA}

Although often equated with fault elements, mens rea refers also to the principles that determine the application of these elements, such as the correspondence principle. It is an analytical tool to pigeonhole offence elements and criminal doctrines into a subjective category, as opposed to a category of more objective offence elements.

\subsection{Rationale}

By requiring mens rea, the legal subject is recognized as an autonomous, sensible person, who can be held accountable for the choices he makes. From a historical perspective, requiring fault for criminal liability can be explained as a counter reaction to liability that is merely based on harmful outcomes. It must be seen as a protective principle that aims to exclude from criminal liability those persons who cannot be reproached for the criminal act they committed. A man is only guilty when his mind is also guilty. In other words, the wrong expressed by a criminal offence consists not only of the act or consequence, but also by the concomitant state of mind.

The development of mens rea allowed criminal law to be made more rational, grounding liability and thereby punishment in retribution and deterrence, which have been introduced in the second chapter as criteria of this synthesis. Both views on punishment value the subjective connection between act and actor. The more culpable the actor is, the stronger the case for retribution and deterrence becomes. For example, the intentional actor deserves to be punished more severely and is assumed more likely to reoffend. Since a negligent actor may also reoffend, it is warranted to criminalize culpa too. All other things being equal, the reproach against the negligent actor, expressed in punishment, is nonetheless always of a lesser degree. By contrast, it is widely accepted that punishment that is merely based on unfortunate outcomes is neither deserved nor useful for deterrence. Mens rea is thus a precondition for retributive and deterrent criminal law. Strict liability is based only on pragmatic reasons of efficient enforcement.

Providing an overarching rationale of mens rea is made difficult by the circumstance that fault elements have interrelated, yet different rationales. The rationale of intention must explain why the intentional actor is punished more 
severely than the negligent one. At the same time, intention is considered the paradigm form of criminal conduct. 'An offence which was not committed intentionally', like negligence, is the exception to the rule, particularly in European criminal law. ${ }^{7}$ Consequently, lawyers seek to justify the use of negligence as a legitimate exception to or by identifying common rationales with intention.

Due to its paradigm nature, it is tempting to refer to the rationale of intention as that of mens rea in general. The importance of mens rea for criminal liability is obvious when the evilness evident in the person who kills with dolus directus is contrasted with the person who caused someone to die but through no fault at all. However, mens rea includes many other fault elements. It is hard to establish a general rationale, as the maxim actus reus non facit mens sit rea also does not tell us what kind of fault is required. From a perspective that tries to identify the minimum criteria of a rule, it would be understandable to refer to mens rea's lower limit, which is culpa. In that perspective, the rationale of mens rea could also be determined by focusing on the reasons against strict liability.

More is achieved by combining these different approaches and by identifying common ground. The person who acts intentionally has a great degree of control over the criminal outcome. He deserves the most severe punishment because he knows what he is doing and chooses to fulfil the offence definition. This autonomous choice reflects hostility towards the legal interests of the other and the legal order. In negligent acts, the perpetrator also possesses, albeit to a more limited degree, the possibility to control the act, to avoid the result. The perpetrator was not aware that he created a risk, but given his individual capacities he is reproached for not using his faculties where he could. It can even be said that by not adverting to the possibility that the legal interests of others would be violated, he expresses indifference towards them.

In sum, mens rea is punished because it denotes a sufficient degree of control over and choice for his actions, which to some also shows that he is insufficiently motivated by the interests of his fellow citizens to a degree that is worthy of moral indignation. By requiring mens rea, it is safeguarded that the defendant is only held liable if he had the capacity and opportunity to do otherwise. The law treats people as subjects who choose their own acts and are only punished for their culpable choices. The retributive reproach against the individual defendant is grounded in his mens rea. As noted, it would be unfair to punish the defendant who cannot be reproached for what he did. Moreover, it would have little use. Neither this defendant, nor other persons are deterred from committing similar acts if it is a matter of luck. Without mens rea, without any degree of control, the legal subject is not influenced by the law to adapt his behaviour. In other words, both retributive and preventive goals of punishment can only be fulfilled if criminal liability and punishment follow upon establishing mens rea. ECR 1395. 
Culpa is generally considered a legitimate fault element for criminal liability. Those that reject culpa as a sufficient kind of mens rea are most likely to argue against this common ground, emphasizing the differences with dolus. It could be argued that only the subjective part of culpa, that is hardly relevant in practice, is really a form of mens rea. Culpa is hardly compatible with mens rea as a state of mind, as subjective elements, relating to the mental psychological area and the conceptual universe of the actor. This would allow us to define mens rea in a straightforward way as a principle that enables that "criminal liability should be imposed only on persons who are sufficiently aware of what they are doing and of the consequences it may have, that they can fairly be said to have chosen the conduct and its consequences." ${ }^{8}$ For a general part of criminal law however, such a narrow definition of mens rea would not reflect the practice of the Member States. In fact, even if mens rea is the rule for criminal offences and for very good reasons, strict liability is possible too.

The differences between fault elements, ranging from very psychological to very normative, make it extremely hard to draw general conclusions relating to all of them. It seems almost inevitable that a general rationale focuses on either its higher or lower limit. A rationale is doomed to be either general yet vague, or to be more specific but not applicable to all fault elements and doctrines discussed in this chapter. This may be accepted as less problematic if it is recalled that mens rea is merely an analytical tool, a legal tool to pigeonhole legal criteria and doctrines.

Of greatest importance are the different fault elements themselves. A system that would use one single fault element of for example, negligence, leaving distinctions of culpability to sentencing, must be rejected. The distinction between fault elements is fundamental to communicate differences in moral reproaches. Criminal liability is one of the most fundamental communicative tools to reaffirm the norms and to express condemnation. The degree to which punishment is warranted and necessary is reflected by the degree of culpability, the kind of fault. The intentional actor is more culpable and thus deserves more punishment. Moreover, criminal liability is not only a tool, but also a right, a safeguard. Requiring intention for criminal liability ensures that only those persons who chose the criminal act are punished. In some cases, requiring merely culpa is also acceptable from a retributive and deterrent point of view, and in yet other cases, there can be good reasons to do away with proof of fault altogether. The context of mens rea is important. The appropriate fault element always depends on the actus reus, the interests of the defendant and the interests of society.

\subsection{Actus non facit reum nisi mens sit rea}

Mens rea has become even more difficult to grasp in modern society. The dichotomy of actus reus and mens rea used to coincide with the dualist view, strictly

$8 \quad$ Ashworth 2006, p. 158. 
separating mind from body, which has been largely rejected by now. Fault and conduct can often not be separated. As noted, negligence is not a state of mind. The psychological aspects of other fault elements are put under pressure by the manner in which they are proven. What is left is a collection of legal concepts and principles that are considered to belong to mens rea or the subjective side of the offence, because we are accustomed to the categorization and it facilitates legal analysis. Although distinctions have turned out to be relative and borders fluent, this does not necessitate their abolition. The separation of the objective from the subjective still applies to most criminal legal concepts. Attempt, for example, belongs to neither category yet also to both, including objective and subjective elements.

In addition, it appears that the dichotomy still has normative force. By forcing the applier of law to categorize offence elements, it forces him to consider whether an act indeed does not make a man guilty unless his mind is also guilty. The exercise of categorization enables us to see whether an actus reus and a mens rea exists, and if not, to take appropriate steps, like to read in such elements. Criminal law is therefore founded on the assumption that no punishment should follow unless the defendant committed a harm, which can be subjectively attributed to him. The maxim also implies an interrelationship, expressed in the principle of correspondence. The rules of this principle can only be applied by first assessing what is actus reus, what is mens rea.

The interrelationship seems to have changed. Whereas actus reus and mens rea should in principle still be proven for criminal liability and correspond, extensive interpretations and exceptions have loosened this relationship. The number of occasions in which actus reus and mens rea are not cumulative but alternative criteria of criminal liability have increased, most notably with the rise of strict liability. In many instances, the relationship of actus reus and mens rea can thus be characterized as one of 'communicating vessels'. This means that when there are hardly any objective elements required to hold someone liable, more should be required from the subjective elements of the offence definition to ensure that the liability of the defendant is warranted and vice versa. For instance, close or direct consequences can facilitate the inference of a fault element like intention. When someone is shot from close range, it is easily accepted that the results caused were intended.

From the perspective of this research, the trend in criminal law is to ground criminal liability less on morally defective choices and more on the harm caused. This objectivist influence in criminal law is not only evident by making offence elements strict, it is no less clear in the procedural context. Fault elements are proven by means of objective evidence such as conduct and circumstances. Finders of fact increasingly rely almost exclusively on the external manifestation of conduct. Objective and normative approaches even gain ground where it concerns 'genuine psychological' state of minds like intention. So-called rules of general experience were exposed as means to attribute intention normatively. They are camouflaged as objective knowledge that is supposed to reveal the defendant's subjective knowledge, but they are highly influenced by considerations such as the harm 
involved. From the perspective of other principles than mens rea and defences, more subjectivist tendencies can be discerned. For example in attempt, liability may increasingly be linked to the actor's intention rather than actual actions. Both tendencies manifest a trend towards the extension of the scope criminal liability and the facilitation of its proof.

\subsection{Fault elements}

Finally, I will summarize the findings on what fault elements should look like in European criminal law and make some concluding observations. Three fault elements can be distinguished: dolus, recklessness and culpa. Dolus encompasses those results that were wanted or known to occur with almost absolute certainty. Reckless is the actor who was aware of unreasonable risks. Negligent is the actor who was unaware of unreasonable risks.

The most serious fault element, paramount for criminal liability as it expresses the greatest degree of control and choice over the fulfilment of the offence definition is dolus. The most serious form of this intention concentrates on the will of the actor to bring about a certain result. An example of this dolus directus is the case where the actor detonates a bomb in a small flying aeroplane, because he wants to kill the pilot. A slightly less serious form of intent is dolus indirectus. Conduct is also deemed intentional if the actor knows it will almost certainly bring about consequences that he does not desire or primarily aim at. A textbook example is the person who blows up the aforementioned aeroplane in order to collect the insurance money. He does not want the pilot to die, but he knows this is a certain result of the bomb exploding, barring some unforeseen intervention. Dolus is indirectus because the actor does not aim directly at the killing of the pilot and crew, but at another goal that does not form part of the offence definition, the payment of insurance.

These examples deal with consequences. If dolus relates to circumstances, it is common to refer to knowledge. Dolus can thus be defined as acting "with respect to i) a circumstance when he hopes or knows that it exists or will exist; ii) a result when he acts either in order to bring it about or being aware that it will occur in the ordinary course of events." ${ }^{\prime 9}$ In essence, dolus directus is about wanting; indirectus is about knowing. The two forms of dolus are equated because they are morally indistinct. Moreover, it turned out, that although they are conceptually each other's mirror image, they are at times hard to separate. This is possible nonetheless by applying a test of failure, or by distinguishing between means and side-effects. For the person who wants to collect the insurance money, the death of the pilot and crew of the airplane he blows up is not a necessary condition. If they survive, he would not consider his plans as failed.

The lowest standard of fault, culpa, is about a normative failure to advert to and avoid a certain risk, which in fact materialised. It communicates the reproach that

9 Section 18(b) of the draft Criminal Code, Law Commission 1989, p. 51. 
the actor has violated a duty of care that caused harm, whereas he should and could have foreseen and avoided this. An example is serious carelessness by a person responsible for maintenance of an aircraft, which crashes as a result. A lesser kind of fault does not exist, but offences can also be strict. Strict liability was discussed above.

In between dolus indirectus and culpa, the question is what foresight of sideeffects should amount to. The choice was between the continental dolus eventualis and the English recklessness. I have criticized dolus eventualis and made suggestions to alter the concept, with a view to either 'improve' the law or to explain the outcomes in practice. In addition, these suggestions also made clear how recklessness differs and could be a better alternative. For example, in eventualis, the defendant must be aware of both the risk and the fact that it is considerable. However, the awareness of the risk is often inferred from the objective chance, the foreseeability of the risk. This led me to suggest that if theory is to follow practice, eventualis should not require subjective awareness of a considerable risk. Recklessness strikes a middle ground and requires awareness of a risk, but its valuation as considerable or unreasonable is conducted normatively. This approach is comparable to the practical approach to dolus eventualis, which would make theory consistent with practice.

By considering examples of the different degrees of intention, it became clear that there is a significant difference between dolus directus and indirectus on the one hand, and dolus eventualis and conscious negligence on the other. There exists a fundamental difference between intending harm and foreseeing risks: the former is more culpable than the latter. Furthermore, both directus and indirectus require a high degree of either wanting something or knowing something, whereas these elements are only present in a very diluted form in eventualis. In addition, the rationales of punishing dolus directus and indirectus, like the great degree of control over and choice for the outcome are also only present to a small extent in eventualis. It has more in common with conscious negligence, which also deals with the foresight of risks. The supposed difference between the two, accepting the risk and trusting everything will be alright, does not follow clearly from case-law.

Dolus eventualis distorts intent in both a legal and linguistic manner. Much more than indirectus, dolus eventualis strains the legal and colloquial meaning of intent as acting in order to bring about. In using eventualis to prove the defendant intended the damage he caused, we in fact prove far less than what we blame him for. We prove that the defendant was aware of and reconciled himself with a lethal danger, but we hold that he intended to cause death. This discrepancy of proof and label is unfair to the defendant. In other words, the intentional creation of danger should be punished less severely than the intentional violation of a legal interest. Intention should be distinguished from foresight by creating three kinds of fault, rather than two.

As a tertium quid in between dolus and culpa, recklessness criminalizes the foresight of unreasonable side-effects. It is also about knowledge, but distinguished 
from dolus indirectus by the degree of the likelihood of that side-effect occurring. Conceptually, another advantage of applying recklessness is that the distinction with culpa is also strictly drawn by awareness. By doing away with conscious negligence, culpa no longer includes the conflicting concepts of awareness and ignorance. Culpa is (reprehensible) ignorance. The defendant is reproached because he should and could have foreseen what the reasonable man would have foreseen. This strict distinction furthers a consistent legal framework with foreseeable outcomes.

It can therefore be concluded that fault is about volition, knowledge or reproachable ignorance, the latter which is often equated as foreseeability. Fault can be very subjective but also very normative. In general, it can be concluded that mens rea has become more normative in the last century. The normative concept of risk in recklessness fits in perfectly with modern risk society, as do negligent offences, which are increasingly popular. Intention is also influenced by normative considerations. More and more scholars have argued in favour of a normative fault element to criminalize the foresight of legally relevant risks. I agree in favour of a normative fault element, but one of recklessness rather than intent. In doing so, a strict distinction can be made with dolus, which can, depending on the national perspective, remain subjective or become more subjective again.

As far as circumstances are concerned, recklessness can also be applied. Reckless knowledge should apply when the defendant knows there might be a risk that a prohibited circumstance is present, but refrains from checking it. This should be distinguished from actual knowledge. The English concept of wilful blindness is at odds with this strict separation. Just as dolus eventualis is often held to suffice for knowledge, English law has also deemed it appropriate to equate suspicion with knowledge, if that suspicion is coupled with a deliberate failure to use readily available and effective means that he knows of to resolve the suspicion. Whereas such a perpetrator may be very culpable indeed, it is submitted that this degree of culpability should be treated as a serious form of reckless knowledge, and to be taken into account in sentencing.

As an alternative to rejecting dolus eventualis in favour of recklessness, this fault element should be proven in a moderate objective manner, which would overcome many of the problems identified in proving intentional charges. This second best option is provided, since it can be expected that the restriction of intent and the creation of another fault element may give rise to resistance in many continental legal systems. In addition, it is likely that England will not participate in the creation of a general part of European criminal law, for example in the context of a European Public Prosecutor's Office. ${ }^{10}$ In that case, much of the political weight in favour of applying recklessness would cease to exist.

I explained that eventualis is primarily used to facilitate proof. Merely diluted forms of knowing and wanting need to be proven. However, on top of that, these

10 See the European Union Act 2011. 
watered down conditions are accepted easily in practice, often without any actual connection to the specific state of mind of the defendant. As explained, this moderate objective approach, which should be applied to all fault elements, safeguards that dolus eventualis is kept subjective. Objective circumstances and conduct may be used to infer the awareness and acceptance of risks, but moderation is required in order to prevent that the individual defendant is equated with the average person. Even though most people would have been aware in specific circumstances, dolus eventualis should only be inferred if the court is certain this individual defendant was also aware. The approach urges the judiciary to be more reluctant and cautious in applying assumptions based on general experience or a reasonable person standard.

After all, facts or general experience are not always known or true. Moreover, problems of evidence should not be shifted on to the defendant. Considering how hard it is to disprove objective assumptions, the fact that the burden of proving fault rests of on the Prosecutor and the principle that it is better to acquit ten guilty than to convict one innocent person, any doubt that the assumption may not be correct in a specific case, should carefully be considered by reference to all the facts and circumstances of the specific case and the specific defendant. By requiring courts to clearly substantiate their reasoning, logic and inferences in judgments, this moderate objective approach can be controlled and enforced by higher courts.

\subsection{Relevant factors}

In discussing the different fault elements, several factors have surfaced that determine the scope of criminal liability. They determined the scope because they influence the question whether the fault element can be accepted or must be rejected. Two sets of factors are distinguished, one procedural and one substantive. The procedural set of factors became particularly evident in discussing dolus eventualis and strict liability. Rules and customs on how fault elements are proven are decisive to the question of criminal liability. If it is easily accepted that the defendant accepted that the risk would materialize, this criterion of dolus eventualis does not provide for a serious threshold against criminal liability. If it is inferred automatically from acting whilst being aware of the risk, this criterion even becomes superfluous. Finally, by identifying reversed onuses as a procedural alternative to strict liability, it became clear again that substantive criteria can be put under pressure by procedural means. Fault can be required, but if this is presumed, the defendant is hardly better off than if liability is strict.

Particular aspects have been identified, such as how careful the judiciary is in considering all the circumstances of the case and how certain the judiciary is in accepting something as generally known, or as considerable. When intentional lethal offences are charged in Germany, the Courts are required to give a particularly careful consideration of all the diverging perspectives that are possible, but I have submitted that such an approach should be adopted in relation to all 
offences and to all fault elements. Reasons of expediency in dealing with vast amounts of criminal cases may not overrule the presumption of innocence and other safeguards that aim to convict only the guilty. In inferring the knowledge and volition of the defendant from the actions of a reasonable person, one needs to make sure that this is in fact the state of mind of the particular defendant. Otherwise, fault would not be inferred objectively but attributed normatively. The explicit and elaborate grounding of the reasons in favour of criminal liability can function as a quality check for the Courts that they made the correct decision, allowing other jurists and the public to control this. Since such a motivation is generally not required from juries, this quality check appears to be incompatible with juries deciding on mens rea.

Another important aspect in this regard is the principle of in dubio pro reo. It can be said that this is taken seriously only in Germany, but it can also be said that this is taken too seriously in Germany This became evident in the assessment of the volitional element in dolus eventualis and the causal requirements in culpa. Although the required level of assurance is similar in theory in all three Member States, attitudes clearly differ. In the context of defences, the German judiciary also often takes a very lenient approach to in dubio pro reo, accepting the circumstances that are most beneficial to the defendant, without there being any factual reason to do so. It has been argued that this can lead to absurd assumptions, that seem to overlook the fact that criminal law not only aims to protect the defendant but also the public. As explained in the second chapter, if the criminal law clearly fails to protect its citizens, it loses its credibility. This also has the risk that, as a reaction, the criminal legal system with all its guarantees is sidelined.

The second set of factors that determines the scope of criminal liability is substantive in character, meaning that they deal with the requirements of the fault elements themselves. Obviously, the national differences relating to the criteria of fault elements are important, but so is the national character of fault. The criteria of the element and the outcomes of most criminal cases are not so different amongst the three Member States, but in solving issues of criminal liability, distinctly different characters of fault appear. In England for example, dolus turned out to be sensitive to moral connotations, requiring intent as to the illegal nature of the conduct. In contrast, dolus was positioned as a neutral concept, which strengthened the distinction between the offence definition, wrongfulness and blameworthiness, on which the framework of criminal liability is built.

In addition, dolus and fault in general, were presented in the final section as general concepts. They need not relate to more specific elements than required by the offence definition. Offences in principle do not individualize the object of the crime like the victim or the way in which a result should be brought about. As a result, fault should also not relate to it. Mistakes will negate intention or awareness, but only in as far as this is relevant to the pertinent offence. Thus, John can be held to have intended to kill the police officer, because he wanted to kill a human being and succeeded. It would not be any different if he had mistaken the police officer 
for the police commissioner. The offence is to kill a human being, not to assassinate a police commissioner. Dolus is neutral and general, much like it is generally considered in the Netherlands. I rejected the opposing trends in England and Germany that are at odds with its neutral and general character respectively. Nevertheless, this need not lead to much controversy, as the outcomes are almost identical in all approaches.

A final set of categories can be identified and labelled 'legal culture'. German criminal law attempts to account for all the rules of criminal liability into an allencompassing and consistent legal framework. English legal culture traditionally focuses only on the fairness and utility of the outcome of a case. The Dutch are positioned somewhere in between. It can be concluded that the legal thinking and culture of a Member State influences the scope of criminal liability. For example, some legal outcomes are difficult to reconcile with principles of mens rea, yet are accepted as fair. Should the intoxicated killer benefit from his intoxication and merely be held liable for negligent killing? The most straightforward manner to approach cases like these is to accept them as an exception, grounded in the interests of the legal order. By trying to reconcile these cases with the rule, unnecessary complex legal rules are created that serve only pure academic interests. As noted in chapter II, a general part must be simple and easy enough to apply. Cases like these make clear that mens rea often does not lend itself to be captured in straightforward rules and definitions. ${ }^{11}$ As Dressler accurately formulated, "there are times when we may scratch our heads and concede that our culpability system is imperfect. But isn't the real question whether, in the vast majority of cases, our current culpability system works well?"12

\section{Defences}

The defences in this legal research do not negate the offence charged, but one of the two implied elements of criminal liability wrongfulness or blameworthiness. They are general because in principle, they can be raised to any offence charged. The defences deal with a case on its merits and assess the question of criminal liability. When accepted, they therefore do not bar proceedings or mitigate sentencing, but completely negate criminal liability. It is accepted that when the plea to a defence fails, the fact that the defendant or his actions did meet the fundamental conditions of the defence will generally lead to a mitigation of the sentence.

Just like mens rea, defences enable courts to ground liability and thereby punishment in retribution and deterrence. A justified offence is right or permissible. There is no use in deterring the perpetrator or others to do what is at least permissible. Many excuses are based on the presumption that in some circumstances a person cannot be deterred by the criminalization and the sanction. Already in the

\footnotetext{
$11 \quad$ Halpin 2004, p. 148.

12 Dressler 2000, p. 962.
} 
case of the shipwrecked sailors, who ate the cabin boy, it was accepted that the possibility of a death penalty for their actions was incapable of operating as a deterrent to their cannibalism. For this reason, it is also useless to preclude an excuse like duress to homicide charges. Because someone can only be blamed for doing something wrong, there is not retributive goal in punishing the person who committed a justified act. Excuses are the tailpiece of the principle that the blameless cannot be punished.

Defences serve both pragmatic and normative goals. Defences safeguard the fundamental legal principles that criminal liability may not be imposed without wrongfulness and blameworthiness. The recognition of these general elements of criminal liability through defences guarantees its non-derogatory normative status in law. Defences acknowledge the implied elements of criminal liability as something that the legislator cannot simply circumvent, as something more fundamental than an offence definition or statutory defence. Regardless of the manner in which the legislator has drafted an offence, a defence will always negate liability based on the fundamental principles of wrongfulness and blameworthiness.

It is also convenient to safeguard these principles by including them in defences, because typically when an offence is committed, that offence was wrongful and the offender blameworthy. These implied elements are assumed with the fulfilment of the offence definition, their absence seen as the exception. It is therefore a matter of efficiency and drafting ease that the absence of these implied elements need not be included in every offence definition. In addition, because defences are treated as general principles of law, they gain in coherency and consistency. Accordingly, values such as fair warning, clarity and predictability are served.

In some offences, the legislator did include the absence of wrongfulness and/or blameworthiness in the offence definition. Again, this can be explained in a pragmatic and normative manner. In some offences, the committing of an offence whilst not acting wrongful is not so exceptional. For instances, police officers often have to inflict injuries in their work. It would be inefficient for the police officer to invoke his official powers as a defence, so many offences, like the infliction of bodily injury and the deprivation of liberty, include wrongfulness as an offence element. It is sensible to draft offence definitions so that they encompass the most common situations, also if that includes the absence of defences.

However, the decision of what to include in the offence is not merely matter of drafting ease and efficiency. The offence should not only encompass the most common situations but also the typical character of the offence. If the typical character of the offence constitutes conduct that is wrongful, this should be included in the definition. For instance, rape is criminal not because having sexual intercourse is criminal, but because having sexual intercourse without consent is criminal. The lack of consent is essential to the offence because it gives the offence its typical character. By contrast, killing as such is criminal. The circumstance that the victim was not killed in self-defence need not be included in the offence definition. An offence should include all the elements that make it a typical wrong. 
In a regulatory context, this means that an offence should have all those elements that make it possible to clearly distinguish it from other offences.

\subsection{The distinction with the offence}

Accordingly, this typical character of the offence enables a principled distinction between offence and defence. This was questioned by the existence of offences that include wrongfulness or blameworthiness in its definition, like the lack of consent in rape or the wrongful infliction of bodily injury. When these offences are charged, it this seems that a justification is treated like the negation of a charge. The defence is not affirmative but a failure of proof defence, and thus does not seem to differ from a denial of intent or an alibi. Culpa absorbs the element of wrongfulness and blameworthiness, making any justification or excuse a failure of proof defence. These examples can be called non-ideal offences, in contrast to the ideal or normal case where the defence is the exception and not part of the offence.

A principled distinction is very important in dealing with these non-ideal offences, because the inclusion of elements into the offence or defence part of criminal liability brings about several implications. First of all, the inclusion of an implied element into non-ideal offences has the procedural consequence that the Prosecutor must prove the absence of the defence, whereas in the ideal case, the defendant would have had to make probable the defence. Secondly, in Dutch law, verdicts distinguish acquittals as a result of the failure to prove the charge from acquittals due to the acceptance of a defence. By contrast, if the absence of the defence is part of the offence and it is accepted, a simple acquittal follows.

Although there is not much support for this differentiation, a special verdict is recognized as very useful in communicating why the defendant is acquitted. Due to the special verdict, the defendant and the public will better appreciate the difference between offence and defence and between justification and excuse. After all, there is a difference between being acquitted, because you did not intentionally kill someone or because you did so in self-defence. There also is a difference between having acted, all things considered, in accordance with the legal order and merely being excused because you cannot be blamed for having infringed the norms of the legal order. Special verdicts of having acted justified or being excused can thus improve the communicative function of the law and furthermore prevent that defences are limited because of the fear that excusing the defendant would send the wrong signal of approval of the conduct.

Another difference of elements that belong to the offence or defence is that the protective function of the principle of legality is traditionally developed in the context of offence definition. As a result, when the absence of defences is included in the offence definition, the defendant is in a somewhat better position. Nevertheless, it has been argued that the principle of legality should apply to criminal liability, irrespective of whether something is part of the offence or defence. After all, defences determine the scope of criminal liability, just like offences. For 
example, by giving a defence a new, stricter, interpretation, the de facto result is an increase of the scope of criminal liability.

In order to rely on a defence and escape liability, the defendant must be aware of the circumstances that ground this defence, such as the fact that he was being attacked in self-defence. Moreover, he must act with a view to defend himself. By contrast, if the absence of the defence is part of the offence, this is apparently not required. If wrongfulness is an offence element, the defendant will be acquitted also if he was unaware that objectively a situation of self-defence existed.

More relevant in practice is the final difference concerning mistakes. An honest mistake on the offence definition can negate intention, and if reasonable also negligence. A mistake on the facts that, if correct, would give rise to a defence, however only excuses the defendant, and only if it was reasonable. Therefore, if the absence of the defence is included in the offence definition, any mistake on the defence would already acquit the person, whereas in the ideal case, that mistake would have to be excusable in order to negate criminal liability.

The most important question that followed from these implications was whether defences in relation to non-ideal offences should be treated as negations of those offences with the abovementioned ramifications or be treated as affirmative defences, notwithstanding that their absence is included as an element in the offence. The answer to this question is a differentiated one, based on the aforementioned principled distinction of offence and defence. Simply put, the lack of a defence can be included in the offence definition for two reasons. In the first situation described above, the absence of a defence is included because it is an essential offence element. The absence of a defence is treated as an offence element. By contrast, in other situations, the absence of a defence is included for other reasons, such as a reminder to the Court that a defence may very well apply in that context. In those situations, the inclusion of wrongfulness and blameworthiness has no consequences for the assessment of defences. A defensive purpose still needs to be proven, a mistake still needs to be reasonable to excuse.

Defences should therefore only be treated as failure of proof defences when they negate a specific meaning of wrongfulness or blameworthiness. The specific meaning can be deduced from the wording, context and purpose of the offence. For example, in Dutch law, the damage to goods must have been inflicted wrongfully. Wrongfulness in this context can be interpreted restrictively in line with the essence and purpose of the offence as damage that is carried out without permission. This explains why consent of the owner in regard to the damage operates as a failure of proof defence. In contrast, other justifications would not negate the offence-specific meaning of wrongfulness and therefore justify the actor. Consider that the defendant would have to sacrifice the goods of the owner without his permission in a situation of necessity. That damage would be wrongful in the meaning that the owner did not consent to it, but the defendant may invoke the justification of necessity to justify his actions. 
This approach can explain why in most cases, the application of a justification or excuse does not bring about that the conditions of that defence are made more lenient, just because it technically denies the charge. In the offence of damaging goods, raising self-defence or necessity would not be treated like the denial of intent, just because wrongfulness is an offence element. The application of defences to non-ideal offences therefore not undermines, but strengthens the distinction of offence and defence. It is useful and relevant to make the distinction.

\subsection{Justifications and excuses}

Another bifurcation in criminal law that is both common and criticized is the difference between justifications and excuses. It makes a fundamental distinction between wrongfulness and blameworthiness, between right and wrong, between act and actor, between an objective evaluation of all things considered and subjective reasons for acting. A justification is the mirror image of wrongfulness, whereas the acceptance of an excuse negates blameworthiness. The dichotomy coincides with the second and third tier on the ladder of criminal liability. Wrongfulness and blameworthiness are derived and thus influenced by the principle of harm and guilt respectively. A justification is based on the principle "no punishment without wrongfulness', an excuse is based on the principle 'no punishment without guilt'.

The categorization of defences into justifications and excuses is accepted in the Dutch, German and EU legal system and even if not accepted generally in England, it is at least well known. Whereas the dichotomy was introduced in Germany and the Netherlands about a century ago, in England, it is still not widely accepted. Although England increasingly moves towards the continental perspective, English law generally has not been very interested in the distinction between justification and excuse. First of all, the dichotomy of actus reus and mens rea is more influential in England. Justifications and excuses are often included into actus reus and mens rea respectively. The implied elements of wrongfulness and blameworthiness do not enjoy widespread recognition, whereas this is required to carve out a conceptual space for justifications and excuses. Secondly, many practitioners and scholars believe that the distinction has no practical legal consequences and is therefore irrelevant in a practice based legal culture like the English.

However, the distinction does have practical legal consequences. It can be concluded that although the line of criticism raised against some differences of justifications and excuses is legitimate, most of them hold up. Even if it is not accurate to state that only the application of an excuse enables measures, even if is not generally accepted that only justifications completely negate its mirror image of wrongfulness and even if has been demonstrated that a justification not always operates universally, there are still many other differences that warrant making the distinction between justification and excuse. The distinction is useful. It serves a practical purpose and should therefore be included in a general part of criminal law for the EU. 
First of all, by making a distinction between condemning the act and condemning the defendant, the dichotomy enables important communicative functions of the law. If that difference is not made, there is a risk that excuses are applied restrictively because it is feared that an excuse implies approval of the conduct. Further, the conditions of individual defences are influenced by the category to which they belong. Amongst others, the justificatory defences have stricter requirements of proportionality. It has also been confirmed that justifications are incompatible. A defendant cannot raise a justification against justified conduct. Two opposing parties cannot both be justified. Finally, the distinction is important to structure the order of legal reasoning. It makes no sense to assess the blameworthiness of the actor before it is established that the offence is wrongful.

\subsection{General principles governing defences}

From the research on defences, some principles applicable to all defences can be deduced. First of all, proportionality is the most important aspect of all defences. It captures and balances all factors into one normative end judgment on the wrongfulness of the act or the blameworthiness of the defendant. This normative condition is very flexible, because it can take into account many aspects, including the manner and degree in which the other criteria of a defence have been fulfilled. Justifications are based on the saving of a prevailing interest and revolve therefore around the weighing of interests under proportionality. Nevertheless, in effect, all defences revolve around proportionality. Proportionality not only distinguishes justification from excuse, it also distinguishes the excused actor from the guilty one. Proportionality not only separates the justification of self-defence from the excuse self-defence-excess, it not only separates necessity from duress. Proportionality also constitutes the upper limit of self-defence-excess and duress: what is grossly disproportionate cannot be excused.

Secondly, all defences are affected to some extent by the special position or capacities of the defendant, as well as the question whether the defendant is somehow to blame for causing the circumstances giving rise to the defence. The special position of the defendant makes concrete what is lawful and what the legal order expects from that defendant. This can be either more or less than what is expected from the reasonable person. Circumstances preceding the offence also influence this normative judgment. Neither mens rea, nor defences should be merely assessed by reference to the exact time when the offence is committed. Instead, that offence should be assessed by reference to all relevant circumstances. If the defendant can be reproached for creating the circumstances of the defence, less will be allowed. Conversely, if the overall purpose of the defendant's actions was laudable, the assessment of the defence will be conducted more leniently.

These two conclusions explain why a choice was made in the context of all defences not to apply very strict triggering conditions. These include not setting a strict threshold of what legal interests can be saved or sacrificed under a defence 
and not precluding the defence for any degree of prior fault. Requiring more from other conditions, such as proportionality, compensates these lenient triggering conditions. For example, the fact that duress can also apply to the saving of less serious interests than life and limb is compensated by the fact that committing an offence to save these less important interests will hardly ever be proportionate.

This approach thus leads to acceptable outcomes, because it neither precludes a defence in cases where this would otherwise be impossible due to strict triggering conditions, nor does it necessitate an acquittal when this is considered inappropriate. For example, if prior fault not necessarily precludes self-defence, the mere fact that the defendant foresaw he could encounter his enemy does not preclude the defence when he is in fact attacked by his enemy. At the same time, if the defendant would have sought out the confrontation, self-defence will be rejected. This high degree of prior fault would militate against reliance on the defence.

Finally, the scope of the general part determines the availability of defences. Some defences are by their nature only available to crimes of violence. Hence, if a general part of European criminal law would only apply to offences of a regulatory nature, self-defence would not need to be included. It would also be unlikely that insanity and duress would ever be relevant. Against offences affecting the financial interests of the Union, a defendant is most likely to raise a mistake of law, a necessity type defence or a plea of due diligence. Since I concluded in chapter II that the scope of a general part of criminal law for the EU may range from trafficking in human beings to violations of fishing quota, no such limitation was applied. It became clear that the pertinent offence affects the conditions of each defence, most notably through the requirement of proportionality. The more serious the offence committed, the less likely it will be justified or excused. In some legal systems, specific defences are unavailable when they are raised against very serious offences, such as duress against murder or superior orders against genocide. As noted above and explained in more detail below, I argued against such an abstract and $a$ priori limitations to defences.

\subsection{Justifications}

Justifications negate the wrongfulness of the act. These defences are characterized by the weighing of competing interests. By precluding criminal liability, justifications enable that the prevailing interest will be saved.

\subsubsection{Self-defence}

Self-defence clearly illustrates that justifications are about the weighing of competing interests. In order to establish whether and to what extent defensive force is justified, one has to take into account the autonomy of the defendant, the reproach that can be made against the aggressor and the legal order as a whole, which both enables and limits the right to self-defence. Given the increasingly popular view 
that the responsibility to fight crime is shared between the state and its citizens, the latter rationale and thereby the scope of self-defence has been widened in recent years. It is therefore unwarranted to argue that the law does not allow victims of crime to protect themselves, the more because the defendant can also be excused if he cannot be reproached for exceeding the limits of proportionality.

In order for self-defence to justify a criminal offence, the attack that is averted by that offence must be wrongful, of human origin and be imminent. In other words, self-defence must be necessary. A duty to retreat does not exist; at most a possibility of safe retreat can be required. Even more important, the offence committed to avert or stop the attack must be proportionate in relation to the harm avoided. More specifically, the defendant must choose the least intrusive means of defence and apply them in a manner that is least intrusive to the aggressor's interests, as long as it is still capable of protecting the defendant's interests sufficiently. Self-defence differs from the justification necessity because it does not require strict proportionality between attack and reaction. It is merely required that the defensive force used by the defendant is not disproportionate to the attack.

The synthesis of self-defence was facilitated because the national concepts have grown towards each other in recent decades. Amongst others, the Dutch justification has been widened due to a reduction of the relevancy of prior fault, whereas in Germany, proportionality is accepted in practice as a proper limitation of selfdefence. This brings the scope of self-defence in line with the right to life as protected by article 2 ECHR, which would be violated if lethal force against a thief were justified. That article also militates against the wide scope of putative selfdefence in English law, where even an unreasonable mistake on the facts giving rise to self-defence can justify the offence.

A second difference of the English concept is that its scope of proportionality is relatively wide. This can be explained by the lack of an excuse of self-defenceexcess in English law, which would otherwise enable the acquittal of persons who exceeded the proportionate degree of defensive force. By accepting the excuse, the wider scope of self-defence under English law is rejected. In this way, the difference between justified conduct and wrongful conduct by an excused actor is reinforced.

\subsubsection{Necessity}

Necessity is grounded in the rationale of protecting the legal order as a whole. By saving the prevailing interest, there is a net benefit. The legislator cannot foresee all instances where it may be justified to break the letter of the law, and given the enormous amount of norms from national and European origin, a legal subject is increasingly likely to find himself in a conflict of duties. However, the scope of necessity is under pressure due to competing considerations. Particularly in England, it is feared that the recognition of the justification undermines the validity and authority of rules and the legislator. As a consequence, the scope of the English justification is relatively narrow. 
In Germany and the Netherlands, the defence was developed out of the related excuse duress. In England, by contrast, necessity is still closely related to duress. It is often equated with duress and given the same strict conditions, such as that it may only be invoked to protect life and limb of the defendant or someone close to him. Nevertheless, a clear trend exists to recognize and distinguish necessity properly from duress. This coincides with the increased acceptance of the fundamental distinction between justifications and excuse and makes both concepts more coherent and consistent.

A situation of necessity exists when there is a present danger for life, limb, freedom, honour, property or another legal interest, that can only be averted by impacting other legal interests. The danger need not be as imminent as the attack in self-defence, explaining why arming oneself in anticipation of a feared attack can be justified under necessity. On the other hand, the condition serves to exclude from the defence situations that affect many people or are recurring. Even though the danger can certainly be imminent to many, the defence is precluded for pragmatic reasons that this would invite many people to break the law, deteriorating the enforceability of the law. In these cases, the legislator is the appropriate authority to take action and if it omits to do so, it is assumed the legislator thus did not see room for exceptions. Similarly, if there already exists an exemption procedure to obtain a permit, it is assumed the legislator already exclusively dealt with all possible conflicts. The fear that necessity may lead to anarchy also leads to a strict condition of subsidiarity. Only when the breaking of the law is absolutely necessary, only when all else has failed, including the fulfilment of lesser offences, can this be justified.

Like in self-defence, the conditions of subsidiarity, including the absence of prior fault, should be treated as factors in a balancing of interest. This emphasizes again the enormous importance of the proportionality requirement in the final assessment of necessity. Unlike in self-defence, the conduct of the defendant must actually outweigh the sacrificed interest. The difference can be explained by the fact that the sacrificed interest in necessity generally belongs to an innocent third party, who bears no blame for the conflict. Conversely, when the victim can be blamed for giving rise to the situation of necessity, the proportionality requirement is more lenient. This also opens up a possibility to apply necessity to cases where a life has to be sacrificed in order to save that of another.

A related defence exists in the Netherlands, called lack of all wrongfulness. This offence deals with situations where there is a conflict of norms, but not one of interests. The defendant claims that by fulfilling the offence definition, he in fact furthered the interest that that offence is trying to protect. Such cases are included in necessity in other States. Similarly, necessity can also account for the more specific justifications in Dutch law of legal duty and lawful superior orders. These defences are only recognized in the Netherlands and even there, the overlap with necessity led to the conclusion these justifications are superfluous. 


\subsubsection{Consent}

A third defence that should be included in a general part of criminal law for the EU is consent. Consent recognizes that someone's interests may be sacrificed, based on the autonomous will of that person. On the one hand, the general welfare or legal order need not be furthered, but on the other hand, it may also not be harmed. Therefore, the act consented may not violate public policy. Consent applies if the consenting party is the sole disposer over the individual legal interest at stake and is capable of giving his consent. The latter implies that the defendant is generally able to consent and was aware of the possible consequences of the act he consented to in the concrete case.

In cases where the person is not able to give his consent to for example a surgery, Germany applies the justification of presumed consent, whereas this is treated under necessity or a related defence in England and the Netherlands. Presumed consent is about the presumed subjective will of the person concerned, not about what is objectively in his best interest under necessity.

This also reflects a general difference between the English and German approach to consent. German law focuses on the autonomy of the person concerned, whereas English law relatively puts more weight on the legal order as a whole, and thus generally applies a more restrictive scope of consent. In the end however, these different approaches hardly ever lead to different outcomes, most notably because the criteria of consent overlap. Consent is rejected in similar cases, even if this is based on different criteria. Defendants are also acquitted in similar cases, even if this is not always based on consent. As a result, no explicit choice is made in regard to the different approaches.

Consent can operate as a justification and as a failure of proof defence, just like self-defence and necessity. If it operates as a failure of proof, some criteria are applied differently. It is incorrect to disqualify consent as a justification on this basis or by arguing that it is not about a conflict of interests, as no interest is violated. In consent, a conflict of interests can also be identified. For example, a patient accepts the pain and risks inherent in surgery because it is a lesser evil than letting his illness deteriorate.

\subsection{Excuses}

Excuses deny that the defendant could have reasonably avoided committing the offence. They are grounded in the principle that there can be no punishment without blameworthiness, which is also safeguarded as an essential condition for criminal liability under art. 6 ECHR. Punishment would not only be unfair but also useless, as the criminalization cannot motivate the defendant in these circumstances to comply with the legal norms. The excuse denotes that the conduct is wrong and thereby confirms the norm. Most often, excuses are grounded in the fact that the 
conduct does not reflect on the settled or normal character of the defendant or on the fact that the defendant did not have a choice to act differently.

Mens rea is also explained as reflecting that the actor had sufficient control and choice over his actions. The difference with excuses lies in the degree of control and choice. Whereas an excuse sets out the minimum requirements for criminal liability, mens rea determines the level of the reproach. Even if an offence is strict, the defendant can escape liability if he can show that he could not reasonably act differently. An excuse aims to guarantee that the blameless are not punished. By contrast, the defendants who cannot rely on an excuse are blameworthy. In fact, their mens rea can increase the reproach that can be made against them: the negligent actor was able to avoid the violation of the legal interest; the intentional actor even chose to violate a legal interest.

\subsubsection{Self-defence-excess}

Sometimes the defendant cannot be blamed for exceeding the limits of self-defence. This is recognized in Dutch and German law by the excuse of self-defence-excess. The defendant is forgiven for either having exceeded the limits of proportionality or for having continued to use defensive force when this was no longer necessary. He may even only have started to use force after the attack had ended. Excess thus forms an exception to the proportionality or imminence requirement of justificatory self-defence. All other conditions of self-defence need to have been fulfilled, such as that the attack was wrongful.

Situations of extensive excess, where the defendant uses force only after or even after the attack has ended, are not included in the German defence, but often the defendant will nonetheless be exculpated. The German Courts apply a broad scope of necessity, only considering that the force is no longer necessary when the attack has definitely ended. Second, the lenient German rules on putative self-defence can apply where excess is not accepted. Extensive excess should be included in the excuse because there are no good reasons to separate these situations from those where the defendant reacted disproportionate. The condition should therefore be that a situation of self-defence must have existed at one point in time.

A specific condition of excess is that the exceeding of the limits of self-defence must have been a consequence of a certain state of mind, which in itself should have been a consequence of the wrongful attack. The attack needs to be the explanation for the excessive force. The attack must have caused certain affects, which brought about that the defendant had no real choice but to commit the offence. Therefore, the attack must be a sufficiently important reason for bringing about the state of mind of the defendant and subsequently, that state of mind must also be so severe that it cannot be argued the defendant should have restrained himself.

Two categories of these states of mind can be distinguished. Asthenic affects like fear, confusion and desperation can be contrasted with so-called sthenic 
emotions like anger, rage and indignation. The latter affects are excluded from the German defence, but in practice, the difference with Dutch law is, again, not so great. After all, unreasonable anger and revenge are also excluded from the defence in Dutch law. Secondly, in German law, anger and rage may play a role as long as an asthenic emotion is still also causal for the excessive use of force. Third, the German rules on putative self-defence fill part of the gap and finally, there is obligatory mitigation of punishment for those who kill because of rage provoked by a wrongful attack. In overcoming these differences, the simplest and therefore most workable solution is to include these affects in the defence.

In English law, excess is unavailable. As a result, the limits of justificatory selfdefence are sometimes stretched to acquit the defendant. The lenient English rule that putative self-defence does not require a reasonable mistake also partially fills the void. In addition, there are two defences that fulfil a similar function and share many of its conditions. These partial defences however only apply to murder, reducing that charge to manslaughter. Their most important function is to avoid the mandatory life imprisonment that follows upon a conviction for murder. It shows that a mandatory reduction of a sentence can be an alternative to excusing the defendant. It also demonstrates the enormous influence of sentencing rules on criminal liability.

However, if the defendant is blameless, mitigation does not suffice. This violates the principle that there can be no punishment without blameworthiness. Even the conviction itself is at odds with the principle of guilt, since the blameless is stigmatized. The focus on sentencing fails to recognize the importance of criminal liability and its difference with sentencing. Moreover, mandatory sentencing puts a lot of pressure on general principles of criminal law. Defences are stretched beyond foreseeable limits in order to avoid harsh outcomes dictated by minimum sentences. Finally, the principled approach to adopt self-defence-excess was favoured over the English partial defences, because a defence should apply to all charges, not just murder.

\subsubsection{Duress}

Duress excuses the defendant who could not and should not have acted differently. It is based first and foremost on the psychological pressure on the defendant that made it almost impossible for him not to commit the offence. Because of this inability, the defendant is not blameworthy. It would also be useless to punish the defendant from a utilitarian perspective because the threat of punishment cannot deter the actor in such a situation. Secondly, duress is limited in a normative way, by taking into account the interests of others than the defendant. Amongst others, duress will be rejected if the offence was very disproportionate or when the defendant is expected to take the risk because of his profession.

Duress can arise out of threats made against life and limb, but also out of other circumstances. In the latter context, duress starts where the limits of proportionality 
of the necessity defence are exceeded. Required is that the defendant committed the offence because he was impelled by an imminent danger or threat to important legal interests. It is not about the imminence of the danger, but about the imminence to act. In line with the defences of necessity and self-defence, the interests that can be protected should not be limited a priori to a danger to life and limb of himself or someone close to him. Other conditions of duress, like proportionality, already enable a rejection of the defence is rejected in cases where minor interests are protected by committing serious offences. Prior fault like joining a criminal organization should also be treated like in other defences. It is should be treated as a factor that influences the other conditions of the defence, not necessarily precluding duress.

The source of the pressure needs to be extraneous to the defendant, but the line between what is internal and what is external is controversial and not always easy to draw. The criterion should not be applied rigidly. Because the pressure often consists of a combination of internal and external factors, at least one external cause can be identified. As long as the external cause of the pressure is not overshadowed by internal causes, duress can be accepted. Moreover, individual characteristics that influence the impact of the cause on the defendant can be taken into account. Finally, some specific applications of duress have been considered. Because of the absolute prohibition on torture, duress cannot apply to such a charge. In contrast, duress should be available to homicide charges, even if killing an innocent third party will hardly ever be excused. The right to life in not absolute and there are no convincing reasons to limit duress in this way. John should be allowed to rely on duress for killing the police officer, as no penalty could have deterred him from doing anything to save his family.

\subsubsection{Mistake as to the legal prohibition, putative defences and superior orders}

Mistakes as to the legal prohibition, also called mistakes of law, do not exculpate. It is feared that otherwise, the norms become what the defendant thinks they are and ignorance would be promoted. Nevertheless, some exceptions have been recognized in German and Dutch law and even in English law, many situations will not lead to criminal liability. As mentioned, English Courts can stay proceedings or will negate mens rea. The conclusion is therefore that some mistakes of law should exculpate the defendant. In fact, mistakes that were unavoidable must excuse the defendant.

This approach follows from the fundamental principle that only the blameworthy may be punished. Mistakes of law should negate criminal liability if the defendant cannot be blamed for the error. He should only be convicted if he was able to see the wrongfulness of his conduct and thereby had a chance and choice to avoid the criminal conduct. It would be unjust, unfair and useless to punish the person who does not know and should not know he is committing a criminal offence. The insight of the illegality or wrongfulness of one's conduct is an element of blameworthiness. It is not an element of the offence and hence never part of dolus, 
recklessness or culpa. In a consistent general part of criminal law, these mistakes do not affect fault, but they do affect criminal liability.

Fears of allowing for the excuse are neutralized or mitigated because of its excusatory nature. First of all, an excuse does not override or set aside, it confirms the norm. Secondly, only excusable, that is, unavoidable mistakes of law will excuse. The defendant has a duty to get to know the law, the scope of which depends on the individual circumstances. Only in limited cases, will the excuse therefore be unavoidable. For example, it can be excused when the mistake is the result of incorrect advice of public officials competent to give advice on that matter. As another example, the defendant may be excused for not knowing something was prohibited, if this is due to the fact that the pertinent legislation had not been published. The principle of legality strengthens this conclusion.

Putative defences are treated like mistakes as to the legal prohibition because of the conceptual similarity: in both cases, the defendant thinks that what he does is lawful. In a consistent general part, such an unavoidable mistake should therefore also excuse the defendant. When the defendant is mistaken on the scope of an existing defence or believes that a non-existing defence applies, he is also mistaken that what he does is in line with the legal order.

Another category of putative defences are mistakes on the facts that, if present, would give rise to a justification or excuse, such as the mistaken belief of the defendant that he was attacked by someone. If correct, this would give rise to selfdefence. These putative defences occur most often and are most likely to be accepted. The two categories of putative defences are often distinguished with a view to attach different criteria and legal consequences to the two types of mistakes. For example, it is common in German law to negate the intention of the defendant who makes such a mistake on the facts regarding a justification. On the contrary, I argued in favour of one simple rule of excusing the defendant who makes a reasonable mistake on a defence. It is inconsistent and absurd to justify the person acting in actual self-defence, whereas to negate intent for the person who is mistaken that someone is attacking him. This defendant still intended to injure this person.

More importantly, the excuse is the more appropriate outcome since it communicates that the conduct of the defendant was wrong and thus takes into account the position of third parties, allowing them to intervene or defend themselves. Finally, an excusable mistake must be unavoidable or at least reasonable. Such a requirement of reasonableness is in line with article 2 ECHR in regard to putative self-defence and it follows in general from the distinction between offence and defence. After all, the fact that the defendant committed a prima facie wrong warrants that he should be diligent in assessing whether the circumstances giving rise to a defence are actually present.

The defence of superior orders is also generally understood to be a mistake of law, namely the mistaken belief of the defendant on the legality of the orders. If acting on legal orders is seen as a justification, the excusable mistake that the orders 
were lawful is a putative defence. This specific defence is reinforced by the rationale that the subordinate should obey superior orders. Otherwise, the hierarchical relationship would be jeopardized and the subordinate compelled to re-evaluate every decision made by his superior. Since the mistake must be unavoidable, the fear that defendants would be excused for committing clearly illegal acts is again unwarranted. Since the defence can be encompassed by the general scheme of excusing unavoidable mistakes of law, including putative defences, it does not need to be explicitly regulated.

\subsubsection{Insanity}

Insanity exculpates the defendant who, at the time of committing the offence, due to a mental disorder, did not have the capacities to be held responsible in law. This is based on the rationale that those who are not responsible should also not be punished, either on a retributive or utilitarian view on punishment. Secondly, the defence was created in order to enable that measures can be taken to protect society and treat or incapacitate the perpetrator. The defendant who is acquitted cannot be deprived of his freedom, but the perpetrator who is excused by reasons of insanity can be institutionalized in a mental hospital. Be that as it may, the bifurcation between punishment and measures may prove to be artificial, not in the least in the eyes of the perpetrators.

In order to accept the defence, the defendant must have been suffering from a mental disorder when he committed the offence. There is not need to create categories or to limit the mental disorders that can qualify. This broad scope is limited by the other conditions of insanity, such as that the disorder must have substantially impaired the capacities to be held responsible in criminal law. In order to be held responsible in criminal law, the perpetrator must know what he is doing and that this was wrong. He must also be able to restrain himself from committing the offence. Although these capacities seem related to denials of fault and pleas of mistake of law or duress respectively, the insanity defence sets the threshold of these conditions very high and highlights the specific reason for it, namely the mental disorder, in contrast to an intellectual mistake or external coercion. Only when the capacities are substantially impaired is the complete defence accepted. In cases where the capacities were only diminished, mitigation may apply. The exact border between exculpation and mitigation is hard to draw and also depends on normative considerations. For example, if the defendant is somehow to blame for the impairment of his capacities, insanity is less likely to be accepted.

Because of this denial of fundamental capacities to be held responsible, insanity can be equated with infancy and treated as an exemption, rather than as an excuse. There do not appear to be any practical reasons to treat infancy as an excuse except that a defendant generally prefers to be acquitted on other grounds, which would imply that the issue is assessed in the final stage of criminal liability rather than a first. It has been submitted that insanity can be both an exemption and an excuse, 
depending on the seriousness and timeframe of the impairment, the capacities involved and the aspect of the defence on which one focuses.

\section{FinAL WORDS}

I have argued what mens rea and defences should look like, based on certain criteria. As noted in the beginning of this book, it is very well possible that you disagree with some of my choices. You may give more weight to a criterion or underlying interest than I have done and subsequently, make a different choice. For example, you could argue that strict liability should never be allowed by adhering more weight to the interests of the individual defendant and less to efficiency concerns, by focusing more on the principle of guilt as understood in German law than in the case-law of all other legal systems under investigation, or by focusing more on the critical opinions of scholars than the condoning attitude of practitioners.

As law is a normative science, this was to be expected. I tried to make my choices as transparent as possible and provide the reader with the consequences of alternative solutions. The fact that our opinions may differ is not problematic. In fact, this book aims to stimulate the debate on what mens rea and defences should look like in European criminal law. Given the rapid pace in which European criminal law is expanding and evolving, this debate is long overdue. 



\section{Summary}

This book is about mens rea and defences in European criminal law. In short, mens rea encompasses the subjective elements of a crime, like intention, as well as the doctrines that govern its application. Defences, distinguished in justifications and excuses, refer to those situations where the defendant should not be held liable, even though he formally committed an offence. The central question of this research is what mens rea and defences should look like in a general part of criminal law for the European Union.

European criminal law is a multi-layered patchwork of legislation and case-law of European and national origin. In the past decades, the process of European integration has influenced all fields of law, and eventually also criminal law. Whereas the creation and enforcement of criminal liability used to be purely a national matter, European legislation now requires Member States to criminalize all sorts of harmful conduct. However, this legislation does not determine the full scope of criminal liability, omitting to define general principles of criminal law. For example, the Union refers to 'intention' in its legislation, but it has not determined what qualifies as such. In chapter I, it is explained that as a result of this lacunae, Member States apply their own national legal principles like intention, negligence and necessity when implementing Union legislation. As national concepts differ, the scope of criminal liability also varies throughout the Union. This is contrary to the purpose of Union legislation, which is the convergence of legal systems by approximation.

Chapter I also lists other reasons for this research, such as the development of a supranational European criminal justice system, in which a European Public Prosecutor directly enforces EU criminal law. Furthermore, this book may guide the Union legislator and judiciary in identifying general principles of substantive criminal law and promote a thorough debate on the contents of these principles throughout the EU. The results of the research can be of assistance to acceding and candidate countries, showing what the EU standards in criminal law are. Finally, this research can foster the understanding of national authorities of substantive criminal law in other Member States. In this way, mutual trust between judges, prosecutors and police officers in the EU will increase, which is essential to further integration and cooperation in criminal matters.

Chapter II explains the methodology. In a first stage of the research, I established what mens rea and defences look like in national and Union law. After all, a general part of European criminal law should be construed out of the legal traditions of the Member States and the fragments of criminal law originating from Union law. A significant part of this research thus consists of comparative legal research. For practical reasons, the comparison is limited to the Dutch, English and German legal systems. In a second stage, I compared the data from the first stage and made a 
synthesis of mens rea and defences. The synthesis is based upon fundamental rights and the common ground of mens rea and defences in national and Union law. In choosing between competing approaches to legal concepts, I applied certain criteria, such as that a general part of European criminal law should be consistent, coherent and enforceable. In subsequent parts, the results of the synthesis are presented and defended. The book does not describe in detail all concepts of mens rea and defences as they are applied in the different legal systems under investigation.

The second part of this book presents what mens rea in European criminal law should look like. Chapter III explains what mens rea means by demarcating it from related legal concepts. Mens rea and defences are positioned in a framework of criminal liability, consisting of the offence definition, wrongfulness and blameworthiness. By separating blameworthiness from the offence definition, a clear distinction can be made between excuses and elements of mens rea. Mens rea is contrasted with actus reus. Actus reus, the criminal act, ensures that thoughts alone or not punished. Both terms are used as analytical tools to categorize the elements of the offence definition. The term mens rea is used as encompassing not only the 'subjective' elements of the offence definition, but its related doctrines and principles as well. Mens rea and actus reus relate to each other as communicating vessels, meaning that if less is required from actus reus, more should be required from mens rea.

The dichotomy of actus reus and mens rea coincides with that of objectivism and subjectivism. The two are extreme perspectives on what should be most important for criminal liability: the conduct and harm on the one hand, or morally defective choices and fault on the other. The analytical distinction is also important as regards evidence of the offence charged. Because mens rea requires us to look inside of the mind of a person, problems of proving mens rea appear unavoidable. To avoid such problems, objectivists do not ground fault in the actual state of mind of an individual person. Fault is rather equated with or inferred from the so-called 'reasonable person'. In a more moderate version of this approach, knowledge on the psyche is deduced from non-psychological factors like the conduct and circumstances of the case, interpreted by making use of rules of general experience.

Chapter IV takes a closer look at what I call fault elements, like intention and negligence. A distinction is made between intention and negligence to reflect the difference in culpability. The intentional killer is more culpable and should therefore be punished more severely than the person who caused a person to die negligently. In addition, fault elements can limit criminal liability, as some crimes can only be committed intentionally. It is argued that a general part of criminal law for the European Union should operate with three kinds of fault; dolus, recklessness and culpa. I discuss these fault elements in descending order of seriousness. Dolus is the most serious fault element, paramount for criminal liability as it expresses the greatest degree of control and choice over the fulfilment of the offence definition. The most serious form of dolus concentrates on the will of the actor to bring about a 
certain result. A seemingly less serious form of intent is dolus indirectus. Consequences are also deemed to have been intended by the actor if he knows his conduct will almost certainly bring about consequences that he does not desire or primarily aim at. In essence, dolus directus is about wanting; indirectus is about knowing. The two forms of dolus are often separated as reflecting a difference in culpability, but they should be equated because they are morally indistinct. Although they are conceptually each other's mirror image, they are at times hard to separate. This is possible nonetheless by applying a test of failure, or by distinguishing between means and side-effects.

It is emphasized that dolus should be a neutral concept. It does not encompass any bad motives; it is not negated by the application of a justification or excuse. In some offences, like theft and genocide, the intent of the defendant also relates to a motive that need not be achieved for him to be held liable. These offences may question the rule that dolus is neutral. However, such an ulterior intent constitutes merely a very general motive and is not necessarily the ultimate goal of the crime. The offence definition distinguishes an ulterior intent from motives that are irrelevant to dolus by including the former as an offence element to which dolus directus must relate.

Dolus is also neutral from the perspective that it does not relate to the illegality of the conduct. People are assumed to know the law or at least are obligated to get to know the law. Mistakes on the legality or wrongfulness of conduct can only amount to a negation of blameworthiness and is discussed as an excuse in part 3 of the book. Wrongfulness is therefore an implied element of criminal liability and assumed when the offence definition is fulfilled. Sometimes, the offence definition does include wrongfulness or other legal aspects, but this again confirms that dolus as such is neutral. It turned out to be unwarranted to fear that this provides defendants with a simple exculpatory claim, which is hard to refute. There exist numerous approaches that limit the intent-negating effect of mistakes of law, many of which can also be adopted in the framework of criminal liability that is proposed in this book.

Fault elements are primarily discussed in relation to consequences. If dolus relates to circumstances, it is common to refer to knowledge. The defendant does not need to consciously or continuously reflect on a circumstance, like the minor age of a person he has sexual intercourse with. Subconscious or latent knowledge can suffice, but it does not suffice to suspect a circumstance may be present. Nonetheless, numerous strategies are identified to equate suspicion with actual knowledge. It is argued that only if the defendant failed to resolve his suspicion because he was virtually certain it would be confirmed, this may be equated with knowledge as a form of dolus indirectus. Other forms of suspicion may warrant criminal liability, but if so, this should be explicitly included in the offence definition. By including it in a separate offence definition, the difference in culpability can be reflected in liability and in sentencing. 
Paragraph 3 of chapter IV deals with the concept of dolus eventualis. It relates to the foresight of side-effects of conduct. Being aware of the risk that a consequence may occur or a circumstance may be present, the actor takes this risk for granted and acts anyway. In contrast to English law, Dutch and German law did not create a separate fault element in between intention and negligence but extended the concept of dolus. The concept makes sure that those who knowingly take risks can also be punished as intentional actors, which is especially important if no negligent offence exists. Most importantly in practice, the concept facilitates proof of intention as most intentional offences require proof of nothing more than dolus eventualis.

This weakest form of intention is said to consist of a cognitive element of awareness of a risk and a volitional element of taking the risk for granted. This enables Dutch and German scholars to argue that intention is about knowing and wanting. Although the concept is almost similar in Dutch and German law, a distinction can be made in the cognitive criterion of being aware of a risk. This is illustrated by cases in which HIV-infection is the consequence of having unprotected sexual intercourse. Intention is accepted in Germany because the chance that the other person will be infected need not be considerable, in contrast to Dutch law.

The volitional element of taking the risk into the bargain is what separates dolus eventualis from conscious negligence. In the latter fault element, the defendant is also aware of a risk, but trusts in a good outcome. It is difficult to prove the volitional element of dolus eventualis because it concerns an inner disposition of the actor, which is therefore mostly hidden from us. Given the enormous significance of the volitional element, this is problematic. In order to avoid dealing with such complicated psychological processes, courts prefer to focus on the externalization of the presumed disposition. If it was very probable that a risk would occur, the volitional element is also easily accepted. In cases where the risk was less probable, all circumstances are important to infer whether the defendant accepted the risk or not. It becomes obvious that German courts are generally more reluctant to accept the volitional element than Dutch courts. Amongst others, this follows from the application of a presumed threshold against killing others and the importance of in dubio pro reo in Germany.

The ways in which the volitional element is proven in practice has led scholars to conclude that a volitional element is irrelevant and that dolus eventualis is really about the awareness of risks. Although I reject this theory, it is right in stressing the practical importance of the foresight of the risk. If the defendant foresaw the risk is and acted anyway, the volitional element hardly presents problems of proof. What is even more problematic from a subjectivist perspective is that foresight is proven by reference to foreseeability. In other words, the awareness of the risk is deduced from the circumstance that a reasonable person would have been aware. The assumption is that the defendant is more or less a reasonable person, so he was also aware of the risk. Even if this approach may be correct in the majority of cases, the attribution of intent based on foreseeability presents a danger that the specific 
defendant is convicted for the most serious form of committing criminal conduct, whereas he was only negligent.

By contrast, it is argued that a balance needs to be struck between general experience and individual, concrete circumstances, recognizing that the state of mind of the individual defendant is not necessarily that of the reasonable or average person. When it concerns proof of fault elements, objective evidence should only be used in moderation. The judiciary is urged to be more reluctant and critical in applying assumptions based on general experience. After all, facts and rules of general experience are not always known or true. Problems of evidence should not be shifted on to the defendant. Any doubt that the assumption may not be correct in a specific case, should carefully be considered by reference to all the facts and circumstances of the specific case and the specific defendant. Such an evidential approach is advocated as a second best solution to rejecting dolus eventualis altogether in favour of the concept, familiar in English law, of recklessness.

Recklessness is the conscious taking of an unreasonable risk. As it straddles the borders of dolus eventualis and conscious negligence, it has often been compared with these fault elements. However, recklessness differs from eventualis, because it is not a form of dolus but an independent kind of fault. Moreover, recklessness includes an explicit normative aspect and no volitional requirement. Recklessness also requires awareness of a risk. The chance that the risk materializes need not be considerable, but this can be taken into account in the wider ranging criterion that the risk must be unreasonable. In assessing its reasonableness, the harm that occurs if the risk materialized and the social utility of the conduct is also taken into account. The defendant must be aware of every circumstance that is taken into account. By contrast, whether this risk is in fact unreasonable is assessed objectively, independent of the valuation of the defendant.

Next, I argue in favour of using recklessness instead of dolus eventualis in European criminal law. First, there is a significant difference between dolus directus and indirectus on the one hand, and dolus eventualis and conscious negligence on the other. Intending harm is, all other things being equal, more culpable than foreseeing risks. Furthermore, dolus directus and indirectus require a high degree of either wanting something or knowing something, whereas these elements are only present in a diluted form in eventualis. The rationales of punishing dolus directus and indirectus, like the great degree of control over and choice for the outcome are also only present to a small extent in eventualis. It has more in common with conscious negligence, which also deals with the foresight of risks. The supposed difference between eventualis and conscious negligence, accepting the risk and trusting everything will be alright, does not follow clearly from case-law.

Secondly, dolus eventualis distorts intent in both a legal and linguistic manner. Much more than dolus indirectus, dolus eventualis strains the legal and colloquial meaning of intent as acting in order to bring about. In using eventualis to prove the defendant intended the damage he caused, we in fact prove far less than what we 
blame him for. This discrepancy of proof and label is unfair to the defendant. The intentional creation of danger should be punished less severely than the intentional violation of a legal interest. For these reasons, intention should be distinguished from foresight by applying three kinds of fault, rather than two. As a tertium quid in between dolus and culpa, recklessness criminalizes the foresight of unreasonable side-effects. It is also about knowledge, but distinguished from dolus indirectus by the degree of the likelihood that the side-effect will occur.

Another advantage of applying recklessness is that the distinction with culpa can be drawn strictly by awareness. Negligence in German and Dutch law includes not only unconscious negligence but also conscious negligence. By doing away with conscious negligence, culpa does not encompass the contrasting concepts of awareness and ignorance. Instead, culpa is (reprehensible) ignorance. The defendant is reproached because he should and could have foreseen what a reasonable person would have foreseen. This strict distinction furthers a consistent legal framework with foreseeable outcomes. A distinct form of negligence is discussed as luxuria. German and Dutch law consider this the most serious form of conscious negligence, which can increase the maximum penalty in relation to simple negligence. It is a recognition that the dichotomy of dolus and culpa is insufficient to reflect different degrees of culpability. As a functional equivalent to recklessness, luxuria could also be adopted as a separate fault element to criminalize the foresight of risks. However, it is concluded that recklessness is the better option, because it provides for a clearer demarcation of fault elements.

Chapter $\mathrm{V}$ discusses several principles that determine the application of mens rea. The correspondence principle encompasses the rule that every offence should require fault and the rule that fault should apply to all offence elements. Modern forms of liability, like strict liability, are presented as exceptions to these principles. With some exceptions, strict liability is rejected in German law as unconstitutional, but it is not precluded in all other legal systems under investigation. The principle of nulla poene sine culpa only brings about an absolute prohibition of punishing the blameless. It does not bring about that there may never be punishment without proof of fault. It is concluded that strict liability can be used in European criminal law, but only under strict conditions of subsidiarity and proportionality. Amongst others, this means that no lesser alternative can achieve similar results and that serious offences may not be strict.

Mistakes on offence elements negate dolus and, if they are reasonable, also culpa. In order to avoid unwarranted acquittals, numerous strategies are applied in the legal systems under investigation in order to limit the exculpatory effect of mistakes. Recalling the concepts discussed in the context of knowledge, it is reiterated that only complete ignorance generally negates fault. Second, normative offence elements only require awareness of the underlying facts, not the valuation. Finally, since dolus is neutral, mistakes as to aspects that are not included in the offence definition are simply irrelevant. Special categories of mistakes concern error in persona vel obiecto and aberratio ictus. Since dolus is a general concept, 
not requiring individualization of the victim, these mistakes need not negate this fault element.

The contemporaneity principle requires mens rea and actus reus to coincide in time. Problems of contemporaneity may arise when, for example, the defendant may believe he has already achieved his goal, whereas in reality he only achieves it at a later stage. It could be argued that in this decisive later stage, he no longer intends the consequence. It can also be argued that defendants that are intoxicated whilst committing an offence lack the required dolus. Several strategies are discussed to overcome such claims and find fault. Although the solutions to the problems presented by the principles of mens rea are solved very differently in the legal systems under investigation, the outcomes are quite similar: no problem of contemporaneity is likely to negate fault. Either multiple events are seen as one whole in order to negate the problem, or the problem of dolus is recognized and an exception made to the principle under a doctrine of actio libera in causa. Problems also hardly ever arise if dolus is viewed as a neutral and general fault element.

Part 3 discusses what defences should look like in European criminal law. After delineating the object of research in more detail in chapter VI, the differences between offence and defence are discussed in chapter VII. Some offences put the distinction under pressure by including wrongfulness or blameworthiness in its definition. In contrast to the regular situation and to the benefit of the defendant, these offences imply that the prosecutor must prove the absence of the defence, that the defendant need not have been aware that the conditions of the defence were fulfilled and that the principle of legality offers him more protection. A mistake on the facts that, if correct, would give rise to a defence, can negate intent, even if the mistake was unreasonable.

The most important question that follows from these implications is whether defences in relation to these atypical offences should be treated as negations of the charge with the abovementioned ramifications, or that they should nonetheless be treated as regular, affirmative defences. The answer to this question is differentiated, based on the aforementioned principled distinction of offence and defence. Simply put, the absence of a defence, that is wrongfulness or blameworthiness, can be included in the offence definition for two reasons. In the first situation, the absence of a defence is included because it is an essential offence element. The absence of a defence is treated as an offence element. By contrast, wrongfulness or blameworthiness are also often included for other reasons, such as a reminder to the court that a defence may very well apply in that context. In those situations, the inclusion of wrongfulness and blameworthiness in the offence definition has no consequences for the assessment of defences. The defendant still has to make probable he acted with the purpose the defence aims to protect and a mistake still needs to be reasonable in order to excuse him. In other words, defences should only be treated as a denial that the defendant fulfilled all the elements of the offence definition when they negate a specific meaning of wrongfulness or blameworthiness. This approach can explain why in most cases, the application of a 
justification or excuse does not bring about that the conditions of that defence are made more lenient, just because it technically denies the charge.

Chapter VIII discusses the categorization of defences into justifications and excuses. It makes a fundamental distinction between wrongfulness and blameworthiness, between right and wrong, between act and actor, between an objective evaluation of all things considered and subjective reasons for acting. A justification is the mirror image of wrongfulness, whereas the acceptance of an excuse negates blameworthiness. Although this continental distinction is becoming more and more accepted in England, it generally has not attracted much interest there. Many practitioners and scholars believe that the distinction has no practical legal consequences and is therefore irrelevant. However, the distinction does have practical legal consequences. Even though some differences are legitimately criticized, most of them hold up. Even if it is not accurate to state that only the application of an excuse enables measures, even if it is not generally accepted that only justifications completely negate its mirror image and even if it has been demonstrated that a justification does not always operate universally, there are still many other differences that warrant making the distinction between justification and excuse. The distinction is useful. It serves a practical purpose and should therefore be included in a general part of criminal law for the EU.

First of all, by making a distinction between condemning the act and condemning the defendant, the dichotomy enables important communicative functions of the law. If that difference is not made, fears can arise that an excuse also implies approval of the conduct with the result that they are applied restrictively. Furthermore, the conditions of individual defences are influenced by the category to which they belong. Amongst others, the justificatory defences have stricter requirements of proportionality. It is also confirmed that justifications are incompatible: a defendant cannot raise a justification against justified conduct. Finally, the distinction is important to structure the order of legal reasoning. It makes no sense to assess the blameworthiness of the actor before it is established that the offence is wrongful.

Chapter IX discusses the justifications of European criminal law. Justifications negate the wrongfulness of the act and are characterized by the weighing of competing interests. By precluding criminal liability, justifications enable that the prevailing interest will be saved. In order for self-defence to justify a criminal offence, the attack that is averted by that offence must be wrongful, imminent and of human origin. In other words, self-defence must be necessary. A duty to retreat does not exist. At most, not using a possibility to safely retreat can influence the other requirements of self-defence. Even more important, the offence committed to avert or stop the attack must be proportionate in relation to the harm avoided. More specifically, the defendant must choose the least intrusive means of defence and apply them in a manner that is least intrusive to the aggressor's interests, as long as it is still capable of protecting the defendant's interests sufficiently. Self-defence differs from the justification necessity because it does not require strict proportio- 
nality between attack and reaction. It is merely required that the defensive force used by the defendant is not disproportionate to the attack.

Necessity is grounded in the rationale of protecting the legal order as a whole. By saving the prevailing interest, there is a net benefit for the legal order. The legislator cannot foresee all instances where it may be justified to break the letter of the law, and given the enormous amount of norms from national and European origin, a legal subject is increasingly likely to find himself in a conflict of duties. A situation of necessity exists when there is a present danger for life, limb, freedom, honour, property or another legal interest, that can only be averted by affecting legal interests of others. The danger need not be as imminent as the attack in the framework of self-defence. On the other hand, the condition serves to exclude from the defence situations that affect many people or are recurring. Even though the danger can certainly be imminent to many, the defence is precluded so as not to invite all these people to break the law, deteriorating the enforceability of the law. The fear that necessity may lead to anarchy also led to a strict condition of subsidiarity. Only when the breaking of the law is absolutely necessary, only when all else has failed, including the fulfilment of less serious offences, can this be justified.

A third defence that should be included in a general part of criminal law for the EU is consent, even though it often operates as the abovementioned denial of the offence definition. Consent recognizes that someone's interests may be sacrificed, based on the autonomous will of that person. The general welfare or legal order need not be furthered, but it may also not be harmed. Therefore, the act consented may not violate public policy. Consent applies if the consenting party is the sole disposer over the individual legal interest at stake and is capable of giving his consent. The latter implies that the defendant is generally able to consent and was aware of the possible consequences of the act he consented to in the concrete case.

Chapter X deals with excuses. These defences attack the assumption that the defendant could have reasonably avoided committing the offence. It is grounded in the principle that there can be no punishment without blameworthiness, which is also safeguarded as an essential condition for criminal liability under art. 6 ECHR. First of all, sometimes the defendant cannot be blamed for exceeding the limits of self-defence. This is recognized in Dutch and German law by the excuse of selfdefence-excess. The void that exists due to the lack of such an excuse in England is filled in different ways, but only partially. Moreover, the excuse of self-defenceexcess is the most consistent and principled option.

In self-defence excess, the defendant is excused for either having exceeded the limits of proportionality or for having continued to use defensive force when this was no longer necessary. It is also even possible to excuse him when he only started to use force after the attack had ended. Excess thus forms an exception to the proportionality or imminence requirement of justificatory self-defence. All other conditions of self-defence need to have been fulfilled, such as that the attack was wrongful. As a specific condition of excess, the exceeding of the limits of self- 
defence must have been a consequence of a certain state of mind, like fear or confusion, which in itself should have been a consequence of the wrongful attack. Although aggressive emotions like anger are excluded from the German defence, in practice, the difference with Dutch law is not so great. The simplest and therefore most workable solution is to include these emotions in the defence.

Duress excuses the defendant who could not and should not have acted differently. It is based on the psychological pressure on the defendant that made it almost impossible for him not to commit the offence. However, duress is also limited in a normative way, by taking into account the interests of others than the defendant. It is required that the defendant committed the offence because he was impelled by an imminent danger or threat to important legal interests. In line with the defences of necessity and self-defence, the interests that can be protected should not be limited a priori to life and limb of himself or someone close to him. The condition of proportionality will exclude cases where minor interests are protected by committing serious offences. The source of the pressure needs to be extraneous to the defendant, but the line between what is internal and what is external is not always easy to draw and therefore controversial. It is submitted that the criterion should not be applied rigidly.

Mistakes as to the legal prohibition, also called mistakes of law, in general do not exculpate. Nevertheless, mistakes that were unavoidable must excuse the defendant. This follows from the fundamental principle that only the blameworthy may be punished. The defendant should only be convicted if he was able to see the wrongfulness of his conduct and thereby had a chance and choice to avoid the criminal conduct. It would be unjust, unfair and useless to punish the person who does not know and should not know he is committing a criminal offence. Fears of allowing for the excuse are neutralized or mitigated because of its excusatory nature. First of all, an excuse does not override or set aside, but confirms the norm. Secondly, only excusable, that is, unavoidable mistakes of law will excuse. The defendant has a duty to get to know the law, the scope of which depends on the individual circumstances. Therefore, the mistake will be held unavoidable only in exceptional cases.

Putative defences are treated like mistakes as to the legal prohibition because of the conceptual similarity: in both cases, the defendant thinks that what he does is lawful. When the defendant is mistaken on the scope of an existing defence or believes that a non-existing defence applies, he is also mistaken that what he does is in line with the legal order. Another category of putative defences consists of mistakes on the facts that, if present, would give rise to a justification or excuse. The defence of superior orders is also generally understood to be a mistake of law, namely the mistaken belief of the defendant on the legality of the orders. Such a putative defence does not need explicit regulation, as it falls under the general scheme of excusing unavoidable mistakes of law.

Insanity exculpates the defendant who, at the time of committing the offence, due to a mental disorder, did not have the capacities to be held responsible in law. 
The defence also enables the taking of measures to treat or incapacitate the perpetrator and protect society. Insanity requires that the defendant must have been suffering from a mental disorder when he committed the offence. There is no need to create categories or to limit the mental disorders that can qualify. This broad scope is limited by the other conditions of insanity, such as that the disorder must have substantially impaired the capacities to be held responsible in criminal law. In order to be held responsible in criminal law, the perpetrator must know what he is doing and that this is wrong. He must also be able to restrain himself from committing the offence. Only when these capacities are substantially impaired is the complete defence accepted. In cases where the capacities were only diminished, the sentence may be mitigated. Because of this denial of fundamental capacities to be held responsible, insanity can be equated with infancy and treated as a so-called exemption, rather than as an excuse. It has been submitted that insanity can be both an exemption and an excuse, depending on the seriousness and duration of the impairment, the capacities involved and the aspect of the defence on which one focuses.

Part 4 consists of a conclusion, in which the most significant proposals of the previous parts are reiterated. These include the choice in favour of recklessness to the detriment of dolus eventualis, the conditional acceptance of strict liability and the embrace of a wide scope of defences. The conclusion also summarizes what mens rea and defences should look like in European criminal law, focusing on some of the most significant differences between the investigated legal systems. Finally, it is recognized that the reader may reach different conclusions based on a different valuation of the criteria for synthesis. For example, one may attach more weight to the interests of the defendant than I have done. Nevertheless, this will further the much-needed debate on the content of substantive criminal law of the EU. 



\section{SAMENVATting}

Opzet, schuld en strafuitsluitingsgronden in het Europees strafrecht

Dit boek gaat over mens rea en strafuitsluitingsgronden in het Europees strafrecht. Mens rea omvat de subjectieve elementen van een misdrijf, zoals opzet en schuld, evenals de doctrines die de toepassing van deze elementen bepalen. Strafuitsluitingsgronden, te onderscheiden in rechtvaardigingsgronden en schulduitsluitingsgronden, verwijzen naar die situaties waarin de verdachte niet aansprakelijk kan worden gesteld, ook al heeft hij formeel een strafbaar feit gepleegd. De centrale vraag van dit onderzoek is hoe mens rea en strafuitsluitingsgronden vorm gegeven zouden moeten worden in een algemeen deel van strafrecht voor de Europese Unie.

Europees strafrecht is een multi-gelaagde lappendeken van wetgeving en jurisprudentie van Europese en nationale herkomst. In de afgelopen decennia heeft het proces van Europese integratie alle gebieden van het recht beïnvloed, en uiteindelijk ook het strafrecht. Terwijl het scheppen en handhaven van strafrechtelijke aansprakelijkheid van oorsprong een puur nationale aangelegenheid is, zijn lidstaten tegenwoordig ook op grond van Europese wetgeving verplicht om bepaalde vormen van schadelijk gedrag strafbaar te stellen. Deze wetgeving bepaalt echter niet de volledige reikwijdte van strafrechtelijke aansprakelijkheid, doordat zij nalaat de algemene beginselen van het strafrecht te definiëren. De Unie verwijst bijvoorbeeld naar 'opzet' in haar wetgeving, maar geeft niet aan wat daaronder verstaan moet worden. In hoofdstuk I wordt uitgelegd dat als gevolg van deze lacunes de lidstaten hun eigen nationale rechtsbeginselen, zoals opzet en noodweer, toepassen wanneer zij Europese wetgeving implementeren. Omdat deze nationale concepten verschillen, varieert ook de reikwijdte van strafrechtelijke aansprakelijkheid in de Unie. Dit is in strijd met het doel van EU-wetgeving, namelijk het dichter bij elkaar brengen van rechtsstelsels door harmonisatie.

Hoofdstuk I noemt ook andere redenen voor dit onderzoek, zoals de ontwikkeling van een supranationaal Europees strafrecht, waarin een Europees Openbaar Ministerie het Europees strafrecht direct handhaaft. Bovendien kan dit boek de Europese wetgevende en rechterlijke macht ten dienste staan bij het identificeren van algemene beginselen van het materiële strafrecht en een diepgaand debat over de inhoud van deze beginselen in de hele Unie bevorderen. De uitkomsten van het onderzoek kunnen nuttig zijn voor toetredende landen en kandidaat-lidstaten, door te laten zien wat de EU-normen in het strafrecht zijn. Ten slotte kan dit onderzoek de kennis van nationale autoriteiten ten aanzien van het materiële strafrecht in andere lidstaten bevorderen. Dit zal het wederzijds vertrouwen tussen rechters, officieren van justitie en politie vergroten, wat essentieel is voor verdere integratie en samenwerking in strafzaken. 
Hoofdstuk II legt de methodologie van het onderzoek uit. In een eerste fase van het onderzoek is vastgesteld hoe mens rea en strafuitsluitingsgronden zijn vormgegeven in de nationale rechtsstelsels en het recht van de Unie. Immers, een algemeen deel van Europees strafrecht dient gebaseerd te worden op de juridische tradities van de lidstaten en de fragmenten van het strafrecht die uit Unierecht af te leiden zijn. Een belangrijk deel van dit onderzoek bestaat dus uit rechtsvergelijkend onderzoek. Om praktische redenen moest ik de vergelijking beperken tot het Nederlandse, Engelse en Duitse rechtssysteem. In een tweede fase heb ik de gegevens van de eerste fase vergeleken en een synthese gemaakt van mens rea en strafuitsluitingsgronden. Deze synthese is gebaseerd op fundamentele mensenrechten en de overeenkomsten van mens rea en strafuitsluitingsgronden in het nationale en Unierecht. Om een keuze tussen concurrerende perspectieven op juridische begrippen te maken, heb ik bepaalde criteria toegepast, zoals dat een algemeen deel van Europees strafrecht consistent, duidelijk en handhaafbaar moet zijn. In de daarop volgende delen worden de resultaten van deze synthese gepresenteerd en verdedigd. Het boek beschrijft niet in detail alle concepten van mens rea en strafuitsluitingsgronden zoals die worden toegepast in de verschillende rechtsstelsels die onderzocht zijn.

Het tweede deel van dit boek presenteert hoe mens rea er in het in Europees strafrecht uit zou moeten zien. Hoofdstuk III legt uit wat mens rea betekent door het af te bakenen van daarmee verband houdende juridische begrippen. Mens rea en strafuitsluitingsgronden worden in een kader van strafrechtelijke aansprakelijkheid gepositioneerd dat bestaat uit de delictsomschrijving, wederrechtelijkheid en verwijtbaarheid. Door verwijtbaarheid van de delictsomschrijving te onderscheiden, wordt het verschil duidelijk tussen schulduitsluitingsgronden en elementen van mens rea. Mens rea wordt gecontrasteerd met actus reus. Dit laatste, het strafbare gedrag, zorgt ervoor dat gedachten alleen niet strafbaar zijn. Beide termen worden gebruikt als instrumenten om de elementen van de delictsomschrijving te categoriseren. De term mens rea omvat in dit boek niet alleen de 'subjectieve' elementen van de delictsomschrijving maar ook de bijbehorende doctrines en beginselen. Mens rea en actus reus staan tot elkaar in verhouding als communicerende vaten, wat betekent dat als minder wordt vereist van actus reus, meer zou moeten worden geëist van mens rea.

De tweedeling van de actus reus en mens rea valt samen met die van objectivisme en subjectivisme. Dit zijn extreme perspectieven op wat er het meest van belang is voor strafrechtelijke aansprakelijkheid: het gedrag en de schade enerzijds, of verwerpelijke keuzes en fouten anderzijds. Het analytische onderscheid is ook van belang ten aanzien van het bewijs van het tenlastegelegde. Omdat mens rea vereist dat we in de geest van een persoon moeten kijken, lijken problemen inzake het bewijs van mens rea onvermijdelijk. Om dergelijke problemen te vermijden baseert een objectivist mens rea niet op de werkelijke psyche van een individuele persoon. Mens rea wordt daarentegen gelijkgesteld met of afgeleid van de zogenaamde 'redelijke persoon'. In een meer gematigde versie van deze 
benadering wordt kennis over de psyche afgeleid van niet-psychologische factoren, zoals het gedrag en de omstandigheden van het geval, geïnterpreteerd met behulp van regels van algemene ervaring.

In hoofdstuk IV wordt nader ingegaan op de verschillende subjectieve elementen. Opzet en schuld worden onderscheiden om een verschil in verwerpelijkheid uit te drukken. Degene die opzettelijk iemand doodt, is verwerpelijker en moet daarom strenger worden gestraft dan degene door wiens schuld een persoon om het leven komt. Daarnaast kunnen subjectieve elementen strafrechtelijke aansprakelijkheid beperken, omdat sommige delicten alleen met opzet kunnen worden gepleegd. Ik verdedig het standpunt dat een algemeen deel van het strafrecht voor de Europese Unie drie soorten subjectieve elementen zou moeten toepassen; dolus, recklessness en culpa. Ik bespreek deze elementen in aflopende volgorde van ernst. Dolus is het meest ernstige type, een paradigma van strafrechtelijke aansprakelijkheid omdat het de grootste mate van controle en keuze over de uitvoering van de delictsomschrijving uitdrukt. De ernstigste vorm dolus concentreert zich op de wil van de dader om een bepaald resultaat te bereiken. Een ogenschijnlijk minder ernstige vorm van dit opzet is dolus indirectus. Het opzet van de dader wordt ook geacht gericht te zijn op gevolgen die hij niet wenst of probeert te bereiken, indien hij weet dat zijn handeling vrijwel zeker zal leiden tot die gevolgen. In essentie is dolus directus willen; indirectus bestaat vooral uit weten. De twee vormen van dolus worden vaak gescheiden op grond van een verschil in verwerpelijkheid, maar ze zouden gelijk gesteld moeten worden omdat ze moreel niet te onderscheiden zijn. Alhoewel zij conceptueel elkaars spiegelbeeld zijn, zijn deze twee vormen van dolus soms moeilijk te scheiden. Dit is toch mogelijk door een zogenaamde test van falen toe te passen of door een onderscheid te maken tussen middelen en neveneffecten.

Benadrukt wordt dat dolus een neutraal concept dient te zijn. Het omvat geen slechte motieven en wordt niet tenietgedaan door de toepassing van een rechtvaardigings- of schulduitsluitingsgrond. In sommige delicten, zoals diefstal en genocide, heeft de intentie van de verdachte ook betrekking op een motief dat niet bereikt hoeft te worden om hem aansprakelijk te stellen. Deze delicten kunnen het neutrale karakter van dolus in twijfel trekken. Echter, een dergelijk verdergaand opzet vormt slechts een zeer algemeen motief en is niet noodzakelijkerwijs het uiteindelijke doel van het misdrijf. De delictsomschrijving onderscheidt een verdergaand opzet van motieven die irrelevant zijn voor dolus door de eerste als een bestanddeel in het delict op te nemen, waarop dolus directus betrekking moet hebben.

Dolus is ook neutraal vanuit het perspectief dat het geen betrekking heeft op de onrechtmatigheid of wederrechtelijkheid van de gedraging. Mensen worden verondersteld de wet te kennen of in ieder geval de plicht te hebben om de wet te kennen. Rechtsdwaling kan strafrechtelijk alleen relevant zijn als een ontkenning van verwijtbaarheid en wordt besproken als een schulduitsluitingsgrond in het derde deel van het boek. Wederrechtelijkheid is dan ook een impliciet element van straf- 
rechtelijke aansprakelijkheid en wordt aangenomen wanneer de delictsomschrijving is vervuld. Soms zijn wederrechtelijkheid of andere juridische aspecten wel expliciet opgenomen in de delictsomschrijving, maar dit bevestigt wederom dat dolus als zodanig neutraal is. De vrees dat dit verdachten voorziet van een eenvoudig verweer dat moeilijk te weerleggen is, bleek ongegrond. Er bestaan talrijke benaderingen die het effect van rechtsdwaling op het ontkennen van dolus beperken, waarvan een groot deel ook kan worden toegepast in het kader van de strafrechtelijke aansprakelijkheid die wordt voorgesteld in dit boek.

Subjectieve elementen worden vooral besproken in relatie tot gevolgen. Als dolus betrekking heeft op omstandigheden, spreekt men over wetenschap of kennis. De verdachte hoeft niet bewust of continu na te denken over een omstandigheid, zoals de minderjarige leeftijd van een persoon met wie hij geslachtsgemeenschap heeft. Onderbewuste of latente kennis volstaat, maar een enkel vermoeden dat een omstandigheid aanwezig kan zijn, niet. Toch bestaan er verschillende perspectieven die het mogelijk maken om een vermoeden gelijk te stellen met daadwerkelijke kennis. Er wordt gesteld dat alleen indien de verdachte zijn vermoeden niet verder uitzoekt, omdat hij vrijwel zeker is dat het zou worden bevestigd, dit kan worden gelijkgesteld met wetenschap als een vorm van dolus indirectus. Andere vormen van wantrouwen kunnen aanleiding geven tot strafrechtelijke aansprakelijkheid, maar als dat de bedoeling is, moet dit expliciet worden opgenomen in de delictsomschrijving. Door dit element in een andere delictsomschrijving op te nemen, kan het verschil in verwerpelijkheid worden weerspiegeld in de aansprakelijkheid en strafmaat.

Paragraaf 3 van hoofdstuk IV behandelt dolus eventualis, dat in het Nederlands recht bekend staat als voorwaardelijk opzet. Dit heeft betrekking op het voorzien van neveneffecten van handelingen. Bewust van het risico dat een gevolg kan intreden of een omstandigheid aanwezig kan zijn, neemt de dader dit risico voor lief en handelt desalniettemin. In tegenstelling tot het Engelse recht kent het Duitse en Nederlandse recht geen apart subjectief element dat tussen opzet en schuld gepositioneerd kan worden. In plaats daarvan past men een extensief concept van dolus toe. Dolus eventualis maakt het mogelijk ook diegenen die willens en wetens risico's nemen als opzettelijke daders te straffen, hetgeen vooral belangrijk is als er geen delict bestaat dat nalatigheid strafbaar stelt. De vergemakkelijking van het bewijs van opzet door dolus eventualis is in de praktijk het belangrijkst, omdat de meeste opzettelijke delicten niets meer vereisen dan bewijs van dolus eventualis.

Van deze zwakste vorm van opzet wordt gezegd dat zij uit een cognitief en volitief element bestaat, namelijk het bewustzijn van een risico respectievelijk het op de koop toe nemen van dit risico. Dit maakt het mogelijk voor Duitse en Nederlandse geleerden om te stellen dat opzet uit weten en willen bestaat. Hoewel het concept in het Duitse en Nederlandse recht nagenoeg identiek is, kan een onderscheid worden gemaakt inzake het cognitieve aspect van het bewustzijn van een risico. Dit wordt geillustreerd door gevallen waarin hiv-infectie het gevolg is van onbeschermde geslachtsgemeenschap. In Duitsland wordt voorwaardelijk opzet 
aangenomen, omdat de kans dat de andere persoon zal worden besmet, niet aanmerkelijk hoeft te zijn, in tegenstelling tot het Nederlandse recht.

Het volitieve element van het op de koop toe nemen van het risico onderscheidt dolus eventualis van bewuste roekeloosheid. In het laatstgenoemde subjectieve element is de verdachte zich ook bewust van een risico, maar vertrouwt hij op een goede afloop. Het is moeilijk om het wilselement van dolus eventualis te bewijzen, omdat het gaat om een innerlijke attitude van de dader, die dus meestal voor ons verborgen blijft. Gezien de enorme betekenis van het element, is dit problematisch. Om niet te hoeven omgaan met zulke ingewikkelde psychologische processen, richten rechterlijke instanties zich liever op de veruiterlijking van de veronderstelde attitude. Als het zeer waarschijnlijk was dat het gevolg zou intreden, wordt het wilselement ook gemakkelijk geaccepteerd. In gevallen waar het risico minder waarschijnlijk was, moeten alle omstandigheden betrokken worden in het oordeel of de verdachte het risico wel of niet heeft geaccepteerd. Het wordt duidelijk dat Duitse rechters over het algemeen minder geneigd zijn om dit wilselement aan te nemen dan hun Nederlandse collega's. Dit komt onder andere doordat in Duitsland wordt verondersteld dat eenieder een afkeer heeft van het doden van anderen en doordat het beginsel van in dubio pro reo daar zeer serieus wordt genomen.

Vanwege de manieren waarop het wilselement in de praktijk wordt bewezen, concluderen veel geleerden dat dit element niet relevant is en dat dolus eventualis dus in realiteit over het bewustzijn van risico's gaat. Hoewel ik deze theorie verwerp, legt zij terecht bloot dat het in de praktijk veelal gaat om het voorzien van risico's. Als de verdachte het risico voorzag en toch heeft gehandeld, wordt het wilselement makkelijk aangenomen. Nog problematischer vanuit een subjectivistisch perspectief is dat voorzien wordt afgeleid van voorzienbaarheid. Het bewustzijn van een risico wordt bewezen aan de hand van de omstandigheid dat een redelijk persoon zich er ook bewust van zou zijn geweest. De veronderstelling is dat de verdachte min of meer een redelijk persoon is, en dat hij zich dus ook bewust was van het risico. Zelfs als deze aanpak in de meeste gevallen tot het juiste resultaat leidt, brengt de toerekening van opzet op basis van voorzienbaarheid het gevaar met zich mee dat de specifieke verdachte wordt veroordeeld voor de meest ernstige vorm van het plegen van crimineel gedrag, terwijl hij enkel nalatig is geweest.

Daarentegen wordt gesteld dat er een evenwicht moet worden gevonden tussen regels van algemene ervaring en individuele, concrete omstandigheden, onderkennende dat de gemoedstoestand van de individuele verdachte niet noodzakelijkerwijs dezelfde is als die van de redelijke of gemiddelde persoon. Bij het bewijzen van subjectieve elementen moet objectief bewijs alleen met mate worden gebruikt. Bovendien zou de rechterlijke macht terughoudend en kritisch moeten zijn met aannamen op basis van regels van algemene ervaring. Immers, feiten en regels van algemene ervaring zijn niet altijd bekend of waar. Bewijsproblemen mogen niet worden afgewenteld op de verdachte. Indien in een specifiek geval twijfel bestaat over de juistheid van een aanname, moeten alle feiten en omstandigheden van het 
concrete geval en de specifieke verweerder in het oordeel betrokken worden. Een dergelijke bewijsrechtelijke aanpak wordt bepleit als de op één na beste oplossing voor het Europees strafrecht. Het verdient de voorkeur om dolus eventualis in het geheel niet over te nemen in een algemeen deel van strafrecht voor de EU. In plaats daarvan zou een concept dat bekend is in het Engels recht moeten worden toegepast, namelijk dat van recklessness.

Recklessness, niet te verwarren met het Nederlandse roekeloosheid, bestaat uit het bewust nemen van een onredelijk risico. Omdat het deels dolus eventualis en bewuste schuld omvat, is het vaak met deze subjectieve elementen vergeleken. Recklessness verschilt echter van dolus eventualis, omdat het geen vorm van opzet is, maar een onafhankelijke vorm van mens rea. Bovendien kent recklessness geen wilselement, maar wel een expliciet normatief aspect. Recklessness vereist ook dat de verdachte zich bewust is van een risico. De kans dat het gevolg zal intreden hoeft niet aanmerkelijk te zijn, maar dit kan wel degelijk relevant zijn in de context van de ruimere voorwaarde dat het risico onredelijk moet zijn. Bij de beoordeling van de redelijkheid van het risico wordt ook rekening gehouden met de schade die ontstaat als het risico zich verwezenlijkt, alsmede het maatschappelijk nut van de gedraging die het risico in het leven roept. De verdachte moet zich bewust zijn van elke omstandigheid die in aanmerking wordt genomen. Daarentegen wordt de vraag of dit risico onredelijk is objectief beoordeeld, onafhankelijk van de waardering van de verdachte.

Vervolgens pleit ik ervoor om recklessness in plaats van dolus eventualis een plaats te geven in het Europese strafrecht. Ten eerste is er een significant verschil tussen dolus directus en indirectus aan de ene kant, en dolus eventualis en bewuste schuld aan de andere kant. Opzettelijk een inbreuk maken op rechtsgoederen is, ceteris paribus, verwerpelijker dan het voorzien van risico's. Bovendien vereisen dolus directus en indirectus een hoge mate van ofwel willen of weten, terwijl deze elementen slechts in zeer verdunde vorm aanwezig zijn in eventualis. De ratio om dolus directus en indirectus te straffen, zoals de grote mate van controle over en de keuze voor het resultaat zijn ook alleen in geringe mate aanwezig in eventualis. Het heeft meer gemeen met bewuste schuld, dat ook over het voorzien van risico's gaat. Het veronderstelde verschil tussen eventualis en bewuste schuld, het aanvaarden van het risico en het vertrouwen dat alles goed komt, volgt niet duidelijk uit de rechtspraak.

Ten tweede vervormt dolus eventualis het concept van opzet op zowel een juridische als een taalkundige manier. De betekenis van opzet in de wet en het dagelijks taalgebruik als handelen om tot stand te brengen wordt door dolus eventualis enorm onder druk gezet, veel meer dan door dolus indirectus. Door eventualis te gebruiken om te bewijzen dat de verdachte de schade die hij heeft veroorzaakt beoogde, bewijzen we in feite veel minder dan wat we hem verwijten. Dit verschil van bewijs en etiket is oneerlijk tegenover de verdachte. Met andere woorden, opzettelijke gevaarzetting van een rechtsgoed zou minder zwaar bestraft moeten worden dan de opzettelijke inbreuk op een rechtsgoed. Om deze redenen 
moet opzet onderscheiden worden van het voorzien van risico's door drie vormen van mens rea toe te passen, in plaats van twee. Als een tertium quid tussen dolus en culpa criminaliseert recklessness het voorzien van onredelijke neveneffecten van handelen. Het gaat ook om bewustzijn, maar onderscheidt zich van dolus indirectus door de mate van waarschijnlijkheid dat het neveneffect optreedt.

Een ander voordeel van het toepassen van recklessness is dat het onderscheid met culpa strikt kan worden gemaakt door het criterium van bewustzijn. Schuld in het Duitse en Nederlandse recht omvat naast onbewuste schuld ook bewuste schuld. Door bewuste schuld af te wijzen, omvat culpa niet de contrasterende concepten van bewustzijn en onwetendheid. In plaats daarvan is culpa verwijtbare onwetendheid. De verdachte wordt verweten dat hij had moeten en had kunnen voorzien wat een redelijk persoon zou hebben voorzien. Dit strikte onderscheid bevordert een consistent wettelijk kader met voorzienbare uitkomsten. Een aparte vorm van schuld, bekend in Nederland als roekeloosheid, wordt besproken als luxuria. Duits en Nederlands recht beschouwen dit als de meest ernstige vorm van bewuste schuld, dat de maximale straf kan doen oplopen in verhouding tot eenvoudige schuld. Het is een erkenning dat de tweedeling van dolus en culpa onvoldoende de verschillende gradaties van mens rea aanduidt. Als functioneel equivalent van recklessness zou luxuria ook kunnen worden gebruikt als een apart subjectief element dat het voorzien van risico's strafbaar stelt. Ik concludeer echter dat recklessness de betere optie is, omdat het een duidelijkere afbakening van subjectieve elementen mogelijk maakt.

In hoofdstuk $\mathrm{V}$ worden de beginselen besproken die de toepassing van mens rea bepalen. Het beginsel van correspondentie omvat de regels dat elk delict een subjectief element moet bevatten en dat dit element betrekking moet hebben op alle bestanddelen van het delict. Moderne vormen van aansprakelijkheid, zoals risicoaansprakelijkheid, worden als uitzonderingen op deze principes gepresenteerd. Op enkele uitzonderingen na wordt risico-aansprakelijkheid in het Duitse recht afgewezen als ongrondwettelijk, maar alle andere rechtsstelsels die in het onderzoek betrokken zijn sluiten dit niet uit. Uit het beginsel van nulla poene sine culpa vloeit enkel een absoluut verbod voort om de persoon te straffen die geen verwijt kan worden gemaakt. Het beginsel dicteert niet dat er nimmer straf mag volgen zonder bewijs van een subjectief element. Geconcludeerd wordt dat risico-aansprakelijkheid toegepast mag worden in het Europese strafrecht, maar alleen onder strikte voorwaarden van subsidiariteit en proportionaliteit. Dit betekent onder andere dat er geen minder verregaand alternatief vergelijkbare resultaten kan bereiken en dat ernstige strafbare feiten niet bestraft mogen worden zonder bewijs van mens rea.

Feitelijke dwaling ten aanzien van een bestanddeel van de delictsomschrijving kan dolus ontkennen, en indien de dwaling redelijk was, ook culpa. Om onterechte vrijspraken te voorkomen worden in de onderzochte rechtsstelsels verschillende strategieën toegepast om het effect van dwaling te relativeren. Verwijzend naar de concepten die in de context van kennis zijn besproken, wordt er nogmaals op gewezen dat alleen volledige onwetendheid doorgaans tot een ontkenning van mens 
rea leidt. Bovendien vereisen normatieve bestanddelen slechts bewustzijn van de onderliggende feiten, niet hun waardering. Ten slotte brengt het neutrale karakter van dolus met zich mee dat dwaling ten aanzien van aspecten die niet zijn opgenomen in de delictsomschrijving, irrelevant zijn. Bijzondere categorieën van dwaling betreffen error in persona vel obiecto en aberratio ictus. Omdat dolus een algemeen concept is en geen individualisering van het slachtoffer vereist, doen deze vormen van dwaling niets af aan dit subjectieve element.

Het gelijktijdigsheidsbeginsel vereist dat mens rea en actus reus overeenkomen in tijd. Problemen van gelijktijdigheid kunnen ontstaan wanneer de verdachte bijvoorbeeld denkt dat hij zijn doel al bereikt heeft, terwijl hij in werkelijkheid dat pas op een later tijdstip bereikt. Men zou kunnen stellen dat in dit beslissende latere stadium, hij niet langer opzet heeft op het gevolg. Er kan ook worden gesteld dat veel verdachten die dronken zijn op het moment dat zij een strafbaar feit plegen, geen opzet hebben op dat feit. Verschillende strategieën worden besproken om dergelijke verweren te verwerpen en het subjectieve element aan te nemen. Hoewel de problemen die door de beginselen van mens rea worden opgeworpen heel anders worden opgelost in de onderzochte rechtsstelsels, lijken de uitkomsten veel op elkaar: een probleem van gelijktijdigheid leidt doorgaans niet tot een ontkenning van mens rea. Ofwel worden meerdere gebeurtenissen als één geheel gezien om te ontkennen dat er een probleem is, of het probleem wordt erkend en er wordt een uitzondering gemaakt op het beginsel op grond van de leer van actio libera in causa. Problemen ontstaan vaak ook niet eens indien dolus wordt beschouwd als neutraal en algemeen subjectief element.

Deel 3 beschrijft hoe de strafuitsluitingsgronden van het Europese strafrecht eruit zouden moeten zien. Nadat in hoofdstuk VI het object van onderzoek verder is afgebakend, worden in hoofdstuk VII de verschillen tussen delictsomschrijving en strafuitsluitingsgrond besproken. Sommige strafbare feiten zetten het onderscheid tussen de twee onder druk door de opname van wederrechtelijkheid of verwijtbaarheid in de delictsomschrijving. In tegenstelling tot de normale, 'ideaaltypische', situatie en ten gunste van de verdachte impliceren deze delicten dat de officier van justitie de afwezigheid van een strafuitsluitingsgrond moet bewijzen, dat de verdachte zich er niet bewust van hoefde te zijn dat aan alle voorwaarden van de strafuitsluitingsgrond was voldaan en dat het legaliteitsbeginsel hem meer bescherming biedt. Een feitelijke dwaling die, indien juist, zou leiden tot aanvaarding van een strafuitsluitingsgrond, kan het opzet ontkennen, zelfs indien de dwaling onredelijk was.

De belangrijkste vraag die hieruit volgt, is of strafuitsluitingsgronden die betrekking hebben op niet-ideaaltypische delicten moeten worden behandeld als ontkenningen van het tenlastegelegde met de bovengenoemde gevolgen of dat ze toch behandeld moeten worden als normale strafuitsluitingsgronden. Het antwoord op deze vraag is gedifferentieerd, gebaseerd op het eerder genoemde principiële onderscheid van delictsomschrijving en strafuitsluitingsgronden. Simpel gezegd kan de afwezigheid van een strafuitsluitingsgrond, te weten wederrechteljkheid en 
verwijtbaarheid, om twee redenen in de delictsomschrijving worden opgenomen. In de eerste situatie is de afwezigheid van een strafuitsluitingsgrond opgenomen omdat het een essentieel element van het delict is. De afwezigheid van een strafuitsluitingsgrond wordt behandeld als een bestanddeel. Daarentegen worden wederrechtelijkheid en verwijtbaarheid vaak ook om andere redenen opgenomen, zoals een herinnering aan de rechter dat het goed mogelijk zou kunnen zijn dat een strafuitsluitingsgrond van toepassing is in die context. In die situaties heeft het opnemen van wederrechtelijkheid en verwijtbaarheid in de delictsomschrijving geen gevolgen voor de beoordeling van strafuitsluitingsgronden. De verdachte moet nog steeds aannemelijk maken dat hij handelde met het doel dat de strafuitsluitingsgrond beoogde te beschermen en een vergissing moet nog steeds redelijk zijn om hem te verontschuldigen. Met andere woorden, strafuitsluitingsgronden worden alleen behandeld als ontkenningen van het tenlastegelegde wanneer zij een specifieke betekenis van wederrechtelijkheid of verwijtbaarheid ontkennen. Deze benadering kan verklaren waarom in de meeste gevallen de toepassing van een rechtvaardigings- of schulduitsluitingsgrond er niet toe leidt dat de voorwaarden van die strafuitsluitingsgronden soepeler worden beoordeeld, enkel en alleen omdat het technisch gezien een ontkenning is van het tenlastegelegde feit.

In hoofdstuk VIII wordt ingegaan op de indeling van strafuitsluitingsgronden in rechtvaardigings- en schulduitsluitingsgronden. Hiermee wordt een fundamenteel onderscheid gemaakt tussen wederrechtelijkheid en verwijtbaarheid, tussen goed en kwaad, tussen de handeling en dader, tussen een objectieve evaluatie van alle omstandigheden en subjectieve redenen voor het handelen. Een rechtvaardiging vormt het spiegelbeeld van wederrechtelijkheid, terwijl de aanvaarding van een schulduitsluitingsgrond verwijtbaarheid ontkent. Hoewel dit continentale onderscheid in toenemende mate in Engeland wordt geaccepteerd, is men er daar in het algemeen niet erg in geïnteresseerd. Veel geleerden en mensen uit de praktijk zijn van mening dat het onderscheid in de praktijk geen juridische gevolgen heeft en daarom niet relevant is. Echter, het onderscheid kan wel degelijk praktische juridische gevolgen hebben. Hoewel enkele verschillen terecht worden bekritiseerd, houden de meesten van hen stand. Ook al is het niet juist om te stellen dat alleen de toepassing van een schulduitsluitingsgrond maatregelen mogelijk maakt, ook al wordt het niet algemeen aanvaard dat alleen rechtvaardigingsgronden volledig hun spiegelbeeld ontkennen en ook al is aangetoond dat een rechtvaardigingsgrond niet altijd universeel werkt, zijn er nog vele andere verschillen die het maken van een onderscheid tussen rechtvaardigings- en schulduitsluitingsgronden legitimeren. Het onderscheid is nuttig. Het dient een praktisch doel en moet daarom worden opgenomen in een algemeen deel van strafrecht voor de EU.

In de eerste plaats faciliteert de tweedeling belangrijke communicatieve functies van de wet, door een onderscheid te maken tussen de veroordeling van de daad en de veroordeling van de verdachte. Als dat verschil niet wordt gemaakt, kan de vrees ontstaan dat een schulduitsluitingsgrond goedkeuring van het gedrag impliceert, met als gevolg een restrictieve toepassing van schulduitsluitingsgronden. 
Vervolgens worden de voorwaarden van individuele strafuitsluitingsgronden beïnvloed door de categorie waartoe zij behoren. Rechtvaardigingsgronden bevatten bijvoorbeeld striktere eisen van proportionaliteit. Bevestigd wordt ook dat rechtvaardigingsgronden onverenigbaar zijn: een verdachte kan geen rechtvaardigingsgrond inroepen tegen gerechtvaardigd gedrag. Ten slotte is het onderscheid van belang omwille van de volgorde van juridisch redeneren. Het heeft geen zin om de verwijtbaarheid van de dader te beoordelen alvorens is vastgesteld dat het delict wederrechtelijk is.

Hoofdstuk IX beschrijft de rechtvaardigingsgronden van het Europese strafrecht. Rechtvaardigingsgronden ontkennen de wederrechtelijkheid van de handeling en worden gekenmerkt door het afwegen van tegenstrijdige belangen. Door strafrechtelijke aansprakelijkheid uit te sluiten, maken rechtvaardigingsgronden het mogelijk dat het zwaarst wegende belang gered wordt. Om een strafbaar feit te rechtvaardigen op grond van noodweer, moet met dit strafbare feit een aanval worden afgewend die wederrechtelijk en van menselijke oorsprong is en ogenblikkelijk dreigt. Met andere woorden, noodweer moet noodzakelijk zijn. Een vereiste om zich te onttrekken aan de aanval bestaat niet, hooguit kan het niet benutten van zo'n mogelijkheid de andere voorwaarden van noodweer beïnvloeden. Nog belangrijker is dat het delict dat de verdachte begaan heeft om de aanval af te wenden of te stoppen, in verhouding moet staan tot de zodoende vermeden schade. Meer specifiek moet de verdachte kiezen voor het minst ingrijpende middel van verdediging en dit toepassen op een manier die het minst ingrijpend is voor de belangen van de agressor, zolang dat middel en die toepassing de verdachte nog in staat stelt zijn belangen adequaat te beschermen. Noodweer verschilt van de rechtvaardigingsgrond noodtoestand, omdat het geen strikte proportionaliteit vereist tussen aanval en reactie. Vereist is alleen dat het strafbare feit dat de verdachte pleegt niet in wanverhouding staat tot de aanval.

Noodtoestand is gegrond in de ratio van de bescherming van de rechtsorde als geheel. Door het zwaarst wegende belang te redden, ontstaat er een nettovoordeel voor de rechtsorde. De wetgever kan niet alle gevallen voorzien waarin het gerechtvaardigd kan zijn om de letter van de wet te overtreden, en gezien de enorme hoeveelheid normen van nationale en Europese afkomst wordt het steeds waarschijnlijker dat een rechtssubject zich voor een conflict van plichten gesteld ziet. Een noodtoestand bestaat wanneer er een actueel gevaar voor het leven, lichamelijke integriteit, vrijheid, eer, goederen of een ander rechtsgoed dreigt, dat alleen kan worden afgewend door rechtsgoederen van anderen aan te tasten. Het gevaar hoeft niet zo ogenblikkelijk te zijn als de aanval in het kader van noodweer. Aan de andere kant beoogt de voorwaarde situaties uit te sluiten van rechtvaardiging die veel mensen beïnvloeden of van terugkerende aard zijn. Ook al kan het gevaar zeker ook voor vele mensen tegelijk ogenblikkelijk zijn, de strafuitsluitingsgrond wordt in deze gevallen uitgesloten om al deze mensen niet uit te nodigen de wet te overtreden, wat de handhaving van de wet immers enorm zou bemoeilijken. De angst dat noodtoestand kan leiden tot anarchie heeft ook geleid tot een strikt 
subsidiariteitsvereiste. Pas als het overtreden van de wet absoluut noodzakelijk is, alleen als al het andere heeft gefaald, met inbegrip van het plegen van minder ernstige strafbare feiten, kan dit worden gerechtvaardigd.

Een derde rechtvaardigingsgrond die moet worden opgenomen in een algemeen deel van het strafrecht voor de EU is toestemming, ook al is dit vaak verwerkt in de delictsomschrijving als een eerdergenoemde ontkenning van het tenlastegelegde. Toestemming erkent dat iemands belangen kunnen worden opgeofferd op grond van de autonome wil van die persoon. Het algemeen welzijn of de rechtsorde hoeft niet te worden bevorderd, maar mag ook niet worden benadeeld. Daarom mag het strafbare feit waarmee het slachtoffer heeft ingestemd de openbare orde niet schenden. Toestemming vindt alleen toepassing als de instemmende partij de enige is die vermag te beschikken over het individuele rechtsgoed dat geschonden wordt en in staat is om daarmee in te stemmen. Dit laatste houdt in dat de verdachte over het algemeen in staat moet zijn om toestemming te geven en zich bewust was van de mogelijke gevolgen van het feit waarmee hij in het concrete geval heeft ingestemd.

Hoofdstuk X gaat over schulduitsluitingsgronden. Deze strafuitsluitingsgronden vormen een ontkenning van de veronderstelling dat de verdachte redelijkerwijs het plegen van het misdrijf had kunnen vermijden. Het is gebaseerd op het beginsel dat er niet gestraft mag worden zonder verwijtbaarheid, wat ook wordt gewaarborgd als een essentiële voorwaarde voor strafrechtelijke aansprakelijkheid op grond van artikel 6 EVRM. In de eerste plaats kan het overschrijden van de grenzen van noodweer de verdachte soms niet verweten worden. Dit wordt in het Nederlandse en Duitse recht erkend door de schulduitsluitingsgrond van noodweerexces. De leemte die bestaat door het ontbreken van een dergelijke schulduitsluitingsgrond wordt in Engeland op verschillende wijzen opgevuld, maar slechts gedeeltelijk. Bovendien vormt noodweerexces de meest consistente en principiële oplossing.

In noodweerexces wordt de verdachte verontschuldigd voor het overschrijden van de grenzen van proportionaliteit of voor het doorgaan met defensief geweld wanneer dit niet langer nodig was. Hij kan zelfs ook verontschuldigd worden indien hij pas begonnen is geweld uit te oefenen nadat de aanslag was afgelopen. Noodweerexces vormt dus een uitzondering op de vereisten van evenredigheid of ogenblikkelijkheid van de rechtvaardigingsgrond noodweer. Aan alle andere voorwaarden van noodweer moet zijn voldaan, zoals dat de aanval wederrechtelijk was. Als specifieke voorwaarde van noodweerexces moet de overschrijding van de grenzen van noodweer het gevolg zijn van een bepaalde gemoedstoestand, zoals angst of verwarring, wat zelf weer het gevolg moet zijn van de wederrechtelijke aanval. Hoewel agressieve emoties zoals woede zijn uitgesloten in het Duitse concept, is het verschil met de Nederlandse strafuitsluitingsgrond niet zo groot. De eenvoudigste en daarmee meest werkbare oplossing is om ook deze gemoedstoestanden op te nemen in de strafuitsluitingsgrond.

Psychische overmacht verontschuldigt de verdachte die zich niet anders kon en zich niet anders hoefde te gedragen. Het is gebaseerd op de psychologische druk op 
de verdachte die het bijna onmogelijk voor hem maakte om het strafbare feit niet te plegen. Psychische overmacht wordt echter ook op een normatieve manier beperkt door rekening te houden met de belangen van anderen dan de verdachte. De verdachte moet het strafbare feit hebben gepleegd omdat hij werd gedwongen door een dreigend gevaar of bedreiging van belangrijke rechtsgoederen. In lijn met de strafuitsluitingsgronden noodtoestand en noodweer, moeten de belangen die beschermd kunnen worden niet a priori worden beperkt tot lijf en leven van de verdachte of één van zijn naasten. De voorwaarde van de proportionaliteit zal die gevallen uitsluiten waarin niet zwaarwegende belangen zijn beschermd door het plegen van ernstige strafbare feiten. De druk die op de verdachte wordt uitgeoefend, moet zijn oorsprong vinden buiten de persoon van de verdachte, maar de scheidslijn tussen interne en externe oorzaken is niet altijd gemakkelijk te trekken en daarom controversieel. Gesteld wordt dat het criterium niet strikt moet worden toegepast.

Rechtsdwaling verontschuldigt over het algemeen niet snel. Toch moeten onvermijdbare vergissingen leiden tot het verontschuldigen van de verdachte. Dit vloeit voort uit het fundamentele beginsel dat alleen een verwijtbare dader mag worden gestraft. De verdachte mag alleen worden veroordeeld als hij in staat was om de wederrechtelijkheid van zijn gedrag in te zien en daarmee een kans en de keuze had om het criminele gedrag te vermijden. Het zou onrechtvaardig, oneerlijk en nutteloos zijn om de persoon te straffen die niet weet en niet zou moeten weten dat hij een strafbaar feit pleegt. De vrees dat rechtsdwaling tot onterechte vrijspraken leidt, wordt geneutraliseerd of verzacht door zijn schulduitsluitende aard. Allereerst plaatst een schulduitsluitingsgrond een norm niet buiten toepassing of heeft het daar voorrang op, maar het bevestigt de norm. In de tweede plaats zal alleen een verschoonbare, dat wil zeggen, onvermijdbare rechtsdwaling verontschuldigen. Er rust een plicht op de verdachte om de wet te kennen, waarvan de omvang afhankelijk is van de individuele omstandigheden. Om die reden zal de dwaling slechts in uitzonderlijke gevallen als onvermijdbaar worden gezien.

Putatieve strafuitsluitingsgronden worden als rechtsdwaling behandeld vanwege van hun conceptuele gelijkenis. In beide gevallen denkt de verdachte dat wat hij doet in overeenstemming is met het recht. Als de verdachte zich vergist over de reikwijdte van een bestaande strafuitsluitingsgrond of van mening is dat een nietbestaande strafuitsluitingsgrond van toepassing is, vergist hij zich ook dat wat hij doet in lijn is met de rechtsorde. Een andere categorie van putatieve strafuitsluitingsgrond betreft vergissingen betreffende feiten die, indien ze correct waren, tot aanvaarding van een rechtvaardigings- of schulduitsluitingsgrond zouden hebben geleid. Het onbevoegd gegeven ambtelijk bevel kan ook worden gezien als een rechtsdwaling, namelijk de onjuiste veronderstelling van de verdachte over de wettigheid van zijn orders. Zo'n putatieve strafuitsluitingsgrond behoeft geen expliciete regelgeving, omdat het onder de algemene regeling van het verontschuldigen van onvermijdbare rechtsdwaling valt.

Ontoerekeningsvatbaarheid verontschuldigt de verdachte die, op het moment van het plegen van het misdrijf, als gevolg van een psychische stoornis niet over het 
vermogen beschikte om in rechte verantwoordelijk te worden gehouden. De strafuitsluitingsgrond maakt het ook mogelijk om maatregelen te nemen met het oog op behandeling en/of incapacitatie van de dader en bescherming van de samenleving. Ontoerekeningsvatbaarheid vereist dat de verdachte ten tijd van het plegen van het delict leed aan een psychische stoornis. Het is niet nodig om stoornissen die in aanmerking komen te beperken. Dit brede toepassingsgebied wordt beperkt door de andere voorwaarden van ontoerekeningsvatbaarheid, zoals dat de stoornis de capaciteiten van de verdachte om verantwoordelijk te worden gesteld in het strafrecht aanzienlijk moet hebben verminderd. Om aansprakelijk gesteld te kunnen worden in het strafrecht, moet de dader weten wat hij doet en weten dat dit verkeerd is. Hij moet ook in staat zijn om zichzelf te weerhouden van het plegen van het strafbare feit. Pas als dit vermogen aanzienlijk wordt aangetast, kan straf volledig worden uitgesloten. In gevallen waarin dit vermogen alleen verminderd was, kan er slechts strafvermindering volgen. Vanwege deze ontkenning van de fundamentele capaciteiten die nodig zijn om aansprakelijk te worden gesteld, kan ontoerekeningsvatbaarheid worden gelijkgesteld met het niet strafrechtelijk aansprakelijk stellen van minderjarigen en dus behandeld worden als een soort vervolgingsuitsluitingsgrond, in plaats van als een schulduitsluitingsgrond. Gesteld wordt dat ontoerekeningsvatbaarheid zowel een vervolgings- als een schulduitsluitingsgrond kan zijn, afhankelijk van de ernst en de duur van de aantasting van zijn vermogens en het aspect van de strafuitsluitingsgrond waarop men de aandacht richt.

Deel 4 bestaat uit een conclusie, waarin de belangrijkste voorstellen van de vorige delen worden herhaald. Deze omvatten de keuze voor recklessness in plaats van dolus eventualis, het voorwaardelijke accepteren van risico-aansprakelijkheid en de erkenning van een breed scala aan strafuitsluitingsgronden. De conclusie vat tevens samen hoe opzet, schuld en strafuitsluitingsgronden eruit zouden moeten zien in het Europees strafrecht, waarbij een aantal van de meest significante verschillen tussen de onderzochte rechtsstelsels benadrukt wordt. Tot slot wordt erkend dat de lezer tot andere conclusies kan komen op basis van een andere waardering van de criteria die gebruikt zijn voor de synthese. Zo kan men meer belang hechten aan de belangen van de verdachte dan ik heb gedaan. Niettemin zal dit het broodnodige debat over de inhoud van het materiële strafrecht van de Europese Unie bevorderen. 



\section{SELECTED BibliograPHY}

\section{Primary sources}

\section{Legislation}

\section{EU Legislation}

Directive 91/308 of 10 June 1991 on prevention of the use of financial system for the purpose of money laundering, OJ 1991 L 166/72;

Regulation 3887/92 of 23 December 1992 laying down detailed rules for applying the integrated administration and control system for certain Community aid schemes, OJ 1992 L 391;

Convention on the protection of the European Communities'financial interests, 26 July 1995, OJ 1995 C 316/49;

Regulation 2988/95 of 18 December 1995 on the protection of the European Communities financial interests, OJ 1995 L 312/1;

Regulation 2419/2001 of 11 December 2001 laying down detailed rules for applying the integrated administration and control system for certain Community aid schemes, OJ 2001 L 327;

Framework Decision 2002/475 of 13 June 2002 on combating terrorism, OJ 2002 L 164/3;

Framework Decision 2002/584 of 13 June 2002 on the European arrest warrant and the surrender procedures between Member States, OJ 2002 L 190/1;

Regulation 1/2003 of 16 December 2002 on the implementation of the rules on competition laid down in Articles 81 and 82 of the Treaties, OJ 2003 L 1/1;

Directive 2003/6 of 28 January 2003 on insider dealing and market manipulation (market abuse), OJ 2003 L 96/16;

Regulation 139/2004 of 20 January 2004 on the control of concentrations between undertakings OJ 2004 L 24/1;

Framework Decision 2004/68 of 22 December 2003 on combating the sexual exploitation of children and child pornography, OJ 2004 L 13/44;

Directive 2004/38 of 29 April 2004 on the right of citizens of the Union and their family members to move and reside freely within the territory of the Member States amending Regulation (EEC) No 1612/68 and repealing Directives 64/221/EEC, 68/360/EEC, 72/194/EEC, 3/148/EEC, 75/34/EEC, 75/35/EEC, 90/364/EEC, 90/365/ EEC and 93/96/EEC, OJ 2004 L 158/77;

Framework Decision 2005/214 of 24 February 2005 on the application of the principle of mutual recognition to financial penalties, OJ 2005 L 76/16;

Framework Decision 2005/222 of 24 February 2005 on attacks against information systems, OJ 2005 L 69/67; 
Framework Decision 2004/757 of 25 October 2004 laying down minimum provisions on the constituent elements of criminal acts and penalties in the field of illicit drug trafficking, OJ 2004 L 335/8;

Directive 2005/35 of 7 September 2005 on ship-source pollution and on the introduction of penalties for infringements, OJ 2005 L 255/11;

Directive $2005 / 60$ of 26 October 2005 on the prevention of the use of the financial system for the purpose of money laundering and terrorist financing, OJ 2005 L 309/15;

Regulation 561/2006 of 15 March 2006 on the harmonisation of certain social legislation relating to road transport and amending Regulations 3821/85 and 2135/98 and repealing Regulation 3820/85, OJ 2006 L 102/1;

Directive 2006/24 of 15 March 2006 on the retention of data generated or processed in connection with the provision of publicly available electronic communications services or of public communications networks and amending Directive 2002/58, OJ 2006 L 105/54;

Framework Decision 2008/947 of 27 November 2008 on the application of the principle of mutual recognition to judgments and probation decisions with a view to the supervision of probation measures and alternative sanctions OJ 2008 L 337/102;

Framework Decision 2008/919 of 28 November 2008 amending Framework Decision 2002/475 on combating terrorism, OJ 2008 L 330/21;

Directive 2008/99 of 19 November 2008 on the protection of the environment through criminal law, OJ 2008 L 328/28

Framework Decision 2008/913 of 28 November 2008 on combating certain forms and expressions of racism and xenophobia by means of criminal law, OJ 2008 L 328;

Decision 2009/316 of 6 April 2009 on the establishment of the European Criminal Records Information System (ECRIS) in application of article 11 of Framework Decision 2009/315, OJ 2009 L 93/33;

Directive 2009/123 of 21 October 2009 amending Directive 2005/35 on ship-source pollution and on the introduction of penalties for infringements, OJ 2009 L 280/52;

Directive 2011/36 of 5 April 2011 on preventing and combating trafficking in human beings and protecting its victims, and replacing Framework Decision 2002/629, OJ 2011 L $101 / 1$

Directive 2011/93 of 13 December 2011 on combating the sexual absue and sexual exploitation of children and child pornography, and replacing Framework Decision 2004/68, OJ 2011 L 335/1.

\section{Dutch legislation}

Act on International Crimes (Wet Internationale Misdrijven);

Act on the special commitment in psychiatric hospitals (Wet bijzondere opnemingen in psychiatrische ziekenhuizen);

Administrative Enforcement of Road Traffic Offences Act (WAHV: Wet Administratiefrechtelijke Handhaving Verkeersvoorschriften);

Civil Code (Burgerlijk Wetboek); 
Criminal Code (Wetboek van Strafrecht)

Code of Criminal Procedure (Wetboek van Strafvordering)

Military Criminal Code (Wetboek van Militair Strafrecht);

Road Traffic Act 1994 (WVW: Wegenverkeerswet 1994);

Law of 22 December 2005, Stb. 2006, 11;

Instruction on how to act regarding a plea of self-defence, Council of Procurators-General,

13 December 2010, Stcrt. 2010, no. 20474.

\section{English legislation}

Offences Against the Persons Act 1861;

Trial of Lunatics Act 1883;

Larceny Act 1916;

Prevention of Crime Act 1953;

Homicide Act 1957;

Criminal Procedure (Insanity) Act 1964;

Law Commission Act 1965;

Criminal Justice Act 1967;

Theft Act 1968;

Misuse of Drugs Act 1971;

Criminal Damage Act 1971;

Road Traffic Act 1972;

Forgery and Counterfeiting Act 1981;

Criminal Attempts Act 1981;

Contempt of Court Act 1981;

Aviation Security Act 1982;

Mental Health Act 1983;

Children and Young Persons Act 1983;

Child Abduction Act 1984;

Police and Evidence Act 1984;

Public Order Act 1986;

Insolvency Act 1986;

Road Traffic Act 1988;

Criminal Justice Act 1988;

Human Fertilisation and Embryology Act 1990;

Food and Safety Act 1990;

Computer Misuse Act 1990;

Criminal Procedure (Insanity and Unfitness to Plead) Act 1991;

Criminal Justice and Public Order Act 1994;

Protection from Harassment Act 1997;

Crime and Disorder Act 1998;

Human Rights Act 1998;

Powers of Criminal Courts (Sentencing) Act 2000; 
Anti-terrorism, Crime and Security Act 2001;

Criminal Justice Act 2003;

Sexual Offences Act 2003;

Hunting Act 2004;

Children Act 2004;

Animal Welfare Act 2006;

Identity Cards Act 2006;

Fraud Act 2006;

Health Act 2006;

Criminal Justice and Immigration Act 2008;

Coroners and Justice Act 2009;

Coroners and Justice Act 2009 (Commencement No. 4, Transitional and Saving Provisions) Order 2010;

European Union Act 2011.

\section{German legislation}

Administrative Offences Act (OWiG: Ordnungswidrigkeitengesetz);

Castration Act (Gesetz über die freiwillige Kastration);

Civic Service Act (Zivildienstgesetz);

Civil Code (BGB: Bürgerliches Gesetzbuch);

Code of Criminal Procedure (StPO: Strafprozeßordnung);

Code on Mutual Legal Assistance (IRG: Gesetz über die internationale Rechtshilfe in Strafsachen);

Constitution/ Basic law (GG: Grundgesetz);

Criminal Code (StGB: Strafgezetzbuch) and its enactment law (Einführungsgesetz StGB 1974)

Execution Act (Strafvollzugsgesetz);

Federal Public Officials Act (Bundesbeamtengesetz);

Immediate Force Act (Unmittelbarer Zwang-Gesetz);

International Criminal Law Act (VStGB: Völkerstrafgesetzbuch);

Juvenile Court Act (Jugendgerichtsgesetz);

Military Criminal Law Act (Wehrstrafgesetz);

Road Traffic Regulation (StVO: Straßenverkehrs-Ordnung);

Road Traffic Act (StVG: Straßenverkehrsgesetz);

Soldiers Act (Soldatengesetz).

\section{Other}

French Penal Code

Rome Statute

Statute on the International Criminal Court, Rome, 17 July 1998;

UN treaty on torture, New York, 10 December 1984. 


\section{Case law}

\section{ECtHR Case law}

Winterwerp v. the Netherlands, appl. no. 6301/73, 24 October 1979;

Öztürk v. Germany, appl. no. 8544/79, 21 February 1984;

Pham Hoang v. France, appl. no. 131919/87, 25 September 1992;

McCann and others v. the United Kingdom, appl. no. 18984/91, 27 September 1995;

Cantoni v. France, appl. no. 17862/91, 15 November 1996;

Laskey, Jaggard and Brown v. the United Kingdom, appl. nos. 21627/93, 21826/93 and 21974/93, 20 January 1997;

Salabiaku v. France, appl. no. 10519/83, 7 October 1998;

August Frederik Stuart v. the Netherlands, appl. no. 31716/96, 6 July 1999;

Luis de Arriz Porras v. the Netherlands, appl. no. 49266/99, 18 January 2000;

K.-H. W. v. Germany, appl. no. 37201/97, 22 March 2001;

Brady v. the United Kingdom, appl. no. 55151/00, 3 April 2001;

Västberga Tax Aktiebolag and Vulic v. Sweden, appl. no. 39985/97, 23 July 2002;

Weh v. Austria, appl. no. 38544/97, 8 April 2004;

S.C. v. UK, appl. no. 60958/00, 15 June 2004;

Falk v. the Netherlands, appl. no. 66273/01, 19 October 2004;

Öneryildiz v. Turkey, appl. no. 48939/99, 30 November 2004;

Blum v. Austria, appl. no. 31655/02, 3 February 2005;

K.A and A.D. v. Belgium, appl. nos. 42758/98 and 45558/99, 17 February 2005;

Harry van Offeren v. the Netherlands, appl. no. 19581/04, 5 July 2005;

Müller v. Austria, appl. no. 12555/03, 5 October 2006;

O'Halloran and Francis v. the UK, appl. nos. 15809/02 and 25624/02, 29 June 2007;

Gäfgen v. Germany, appl. no. 22987/05, 30 June 2008 and and 1 June 2010;

Sergey Zolotukhin v. Russia, appl. no. 14939/03, 10 February 2009;

M. v. Germany, appl. no. 19359/04, 17 December 2009;

Kononov v. Latvia, appl. no. 36376/04, 17 May 2010;

Van Anraat v. the Netherlands, appl. no. 65389/09, 6 July 2010;

Haidn v. Germany, appl. no. 6587/04, 13 April 2011;

G. v. the UK, appl. no. 37334/08, 30 August 2011;

\section{ECJ Case law}

12 July 1962, Case 16/61, Modena v. High Authority [1962] ECR 289;

15 July 1964, Case 6/64, Costa v. ENEL [1964] ECR 585;

12 November 1969, Case 29/69, Erich Stauder v. City of Ulm [1969] ECR 419;

25 November 1971, Case C-22/71, Béguelin [1971] ECR 949;

14 May 1974, Case 4/73, Nold v. Commission [1974] ECR 491;

30 November 1977, Case C-52/77, Leonce Cayrol v Giovanni Rivoira \& Figli [1977] ECR 2261; 
Selected bibliography

20 February 1979, Case C-120/78, Rewe-Zentral (Cassis de Dijon) [1979] ECR I-649;

13 December 1979, Case 44/79, Lisotte Hauer v. Land Reinland-Pfalz [1979] ECR 3727;

18 March 1980, Joined cases 154, 205, 206, 226 to 228, 263 and 264/78, 39, 31, 83 and 85/79, Valsabbia and others v. Commission [1980] ECR 907;

26 May 1981, Case 157/80, Criminal proceedings against Siegfried Ewald Rinkau, ECR [1981] 1395;

7 June 1983, Cases 100-103/80, SA Musique Diffusion Française [1983] ECR 1825;

8 November 1983, Cases C-96-102, 104, 105, 108 and 110/82, IAZ and others v. Commission [1983] ECR 3369;

17 May 1984, Case 83/83, Estel NV v. Commission [1984] ECR 2195;

10 July 1984, Case 63/83, Regina v. Kent Kirk [1984] ECR 2689;

8 October 1987, Case 80/86, criminal proceedings against Kolpinghuis Nijmegen BV [1987] ECR 3969;

12 November 1987, Case 344/85, Ferriere San Carlo v. Commission [1987] ECR 4435;

18 November 1987, Case 137/85, Maizena [1987] ECR 4587;

20 September 1988, Case C-302/86, Commission v. Denmark [1988] ECR I-4607;

11 May 1989, Case 25/88, Criminal proceedings against Wurmser and others [1989] ECR 1105;

13 July 1989, Cases 5/88, Wachauf v. Federal Republic of Germany [1989] ECR 2633;

21 September 1989, Case 68/88, Greece v. Commission [1989] ECR 2965;

21 September 1989, Cases 46/87 and 227/88, Hoechst AG v. Commission [1989] ECR 2859;

18 October 1989, Case C-374/87, Orkem SA v. Commission [1989] ECR I-3283;

10 July 1990, Case C-326/88, Anklagemyndigheden v. Hansen and Søn I/S [1990] ECR I-2911;

18 June 1991, Case 260/89, ERT [1991] ECR I-2925;

2 October 1991, Case C-7/90, Criminal proceedings against Paul Vandevenne and others [1991] ECR I-4371;

27 November 1991, Case C-273/90, Meico-Fell v. Hauptzollamt Darmstadt [1991] ECR I-5569;

7 April 1992, Case C-358/90, Compagnia Italiana Alcool Sas di Mario Mariano \& Co v. Commission [1992] ECR I-2457;

9 November 1995, Case C-235/94, Bird [1995] ECR I-3933;

16 December 1995, Cases 40-48, 50, 54-56, 111, 113-114/73, Suikerunie and others $v$. Commission [1975] ECR 1663;

29 February 1996, Case C-193/94, Criminal proceedings against Sofia Skanavi and Konstantin Chryssanthakopoulos [1996] ECR I-929;

25 March 1996, Order in Case C-137/95 P, SPO and others v. Commission [1996] ECR I-1611;

27 February 1997, Case C-177/95, Ebony Maritime [1997] ECR I-1111;

23 October 1997, Case C-189/95, Franzén [1997] ECR I-5909;

26 November 1998, Case C-370/96 Covita AVE v. Elliniko Dimosio [1998] ECR I-7711;

1 June 1999, Case C-319/97, criminal proceedings against A. Kortas [1999] ECR I-3143;

8 July 1999, Case C-199/92, Hüls [1999] ECR I-4287; 
Selected bibliography

28 March 2000, Case C-7/98, Dieter Krombach v. André Bamberski [2000] ECR I-1935;

12 July 2001, Case C-262/99, Paraskevas Louloudakis v. Elliniko Dimosio [2001] ECR I-5547;

20 June 2002, Joined Cases C-388/00 and C-429/00, Radiosistemi [2002] ECR I-5845;

11 July 2002, Case C-210/00, Käserei Champignon Hofmeister [2002] ECR I-6482;

30 September 2003, Joined Cases T-198/98 and T-212/98-214/98, Atlantic Container Line and Others v. Commission [2003] ECR II-3275;

7 January 2004, Cases C-204, 205, 211, 213, 217 and 219/00 P, Aalborg Portland [2004] ECR I-123;

14 October 2004, Case C-36/02, Omega Spielhallen [2004] ECR I-9641;

18 January 2005, Order in Case C-325/03 P, Zuazaga Meabe [2005] ECR I-403;

3 May 2005, C-387, 391 and 403/02, Criminal proceedings against Silvio Berlusconi and others [2005] ECR I-3565;

26 May 2005, Case C-498/03, Kingscrest Associates Ltd, Montecello Ltd v. Commissioners of Customs and Excise [2005] ECR I-4427;

16 June 2005, Case C-105/03, Criminal proceedings against Maria Pupino [2005] ECR I-5285;

28 June 2005, Cases C-189/02 P, C-202/02 P, C-205/02 P to C208/02 P and C-213/02 P, Dansk Rorindustri and others v. Commission [2005] ECR I-5425;

8 September 2005, Case C-40/04, Criminal proceedings against Yonemoto [2005] ECR I-7755;

13 September 2005, Case C-176-03, Commission v. Council [2005] ECR I-7879;

25 October 2005, Case C-551/03 P, General Motors v. Commission [2006] ECR I-3173;

28 September 2006, Case C-150/05, van Straaten v. the Netherlands and Italy [2006] ECR I-9327;

14 December 2006, Cases T-259-264 and 271/02, Raiffeisen Zentralbank Österreich, [2006] ECR II-5169;

25 January 2007, Cases C-403 and 405/04 P, Sumimoto Metal Industries [2007] ECR I-729;

23 October 2007, Case C-440/05, Commission v. Council [2007] ECR I-9097;

12 December 2007, Cases T-101 and 111/05, BASF and UCB [2007] ECR II-4949;

18 December 2007, Case C-314/06, Société Pipeline Méditerranée et Rhône [2007] ECR I-12273;

3 June 2008, Case C-308/06, Intertanko a.o. v. Secretary of State for Transport [2008] ECR I-4057;

17 July 2008, Case C-66/08, Szymon Kozlowski [2008] ECR I-6041;

20 November 2008, Case C-209/07, Competition Authority v. Beef Industry Development Society Ltd and Barry Brothers (Carrigmore) Meats Ltd [2008] ECR I-8637;

30 April 2009, Case T-13/03, Nintendo [2009] ECR II-975;

4 June 2009, Case C-8/08, T-Mobile Netherlands and Others [2009] ECR I-4529;

10 September 2009, Case C-97/08 P, Akzo Nobel [2009] ECR I-8237;

6 October 2009, Cases C-501, 513, 515 and 519/06 P, GlaxoSmithKline Services and others v. Commission [2009] ECR I-9291;

23 December 2009, Case C-45/08, Spector Photogroup NV [2009] ECR I-12073;

14 October 2010, Case 280/08, P Deutsche Telekom, not yet reported. 
Selected bibliography

\section{Dutch Case law}

HR 19 June 1911, $W$ 1911, 2903;

HR 14 February 1916, NJ 1916, p. 681;

HR 15 October 1923, NJ 1923, p. 1329;

HR 8 February 1932, NJ 1932, p. 617;

HR 27 June 1932, NJ 1933, 918;

HR 29 April 1935, NJ 1936, 50;

HR 23 March 1936, NJ 1936, 563;

Rb. Rotterdam 3 April 1941, NJ 1941, 665;

HR 22 November 1949, NJ 1950, 180;

HR 6 February 1951, $N J$ 1951, 475;

HR 18 March 1952, NJ 1952, 314;

HR 9 November 1954, $N J$ 1955, 55;

HR 18 June 1957, NJ 1957, 446;

HR 10 September 1957, $N J$ 1958, 5;

HR 20 January 1959, NJ 1959, 102;

HR 20 January 1959, $N J$ 1959, 103;

HR 3 February 1959, NJ 1959, 111;

HR 14 June 1960, $N J$ 1960, 597;

HR 13 December 1960, NJ 1961, 416;

HR 24 October 1961, NJ 1962, 37;

HR 13 February 1962, NJ 1962, 430;

HR 26 June 1962, NJ 1963, 11;

HR 19 February 1963, NJ 1962, 512;

HR 22 July 1963, $N J$ 1968, 217;

HR 24 November 1964, NJ 1965, 142;

HR 2 February 1965, NJ 1965, 262;

HR 16 November 1965, NJ 1966, 404;

HR 24 July 1967, NJ 1969, 63;

HR 9 February 1971, NJ 1972, 1;

HR 3 July 1972, NJ 1973, 78;

HR 18 November 1975, NJ 1976, 164;

HR 20 January 1976, NJ 1976, 206;

HR 30 March 1976, NJ 1976, 322;

HR 20 September 1976, NJ 1977, 49;

HR 14 December 1976, NJ 1977, 174;

HR 11 January 1977, NJ 1977, 458;

HR 26 April 1977, $N J$ 1978, 200;

HR 21 February 1978, NJ 1978, 384;

HMG 6 October 1978, NJ 1979, 1;

HR 28 November 1978, NJ 1979, 93;

HR 16 January 1979, NJ 1979, 210; 
HR 5 February 1980, NJ 1980, 104;

HR 17 June 1980, NJ 1980, 580;

HR 9 June 1981, $N J$ 1983, 412;

Hof Den Haag 23 June 1981, NJ 1981, 560;

HR 5 January 1982, NJ 1982, 232;

HR 2 February 1982, NJ 1982, 384;

HR 1 March 1983, NJ 1983, 468;

HR 19 April 1983, NJ 1983, 572;

HR 25 October 1983, NJ 1984, 300;

HR 23 October 1984, NJ 1986, 56;

HR 27 November 1984, NJ 1985, 106;

HR 22 October 1985, NJ 1986, 346;

HR 12 November 1985, NJ 1986, 327;

HR 27 May 1986, NJ 1987, 8;

HR 10 June 1986, NJ 1987, 85;

HR 9 September 1986, NJ 1987, 259;

HR 25 November 1986, NJ 1987, 493;

HR 24 March 1987, NJ 1987, 705;

HR 14 April 1987, $N J$ 1988, 60;

HR 9 June 1987, NJ 1988, 318;

HR 1 July 1987, NJ 1989, 389;

Rb. Leeuwarden 23 December 1987, NJ 1988, 981;

HR 29 March 1988, NJ 1989, 162;

HR 3 May 1988, NJ 1989, 165;

HR 17 May 1988, NJ 1989, 230;

HR 28 February 1989, NJ 1989, 687;

HR 13 June 1989, NJ 1990, 48;

HR 18 September 1989, NJ 1990, 291;

HR 11 October 1989, NJ 1990, 812;

HR 24 October 1989, NJ 1990, 353;

HR 30 January 1990, NJ 1990, 445;

HR 6 February 1990, $N J$ 1990, 417;

HR 8 May 1990, NJ 1991, 579;

HR 17 September 1990, NJ 1991, 58;

HR 16 October 1990, NJ 1991, 153;

HR 26 March 1991, NJ 1992, 196;

HR 19 November 1991, NJ 1992, 250;

HR 8 July 1992, NJ 1993, 13;

HR 17 November 1992, NJ 1993, 267;

HR 19 January 1993, NJ 1993, 491;

HR 2 February 1993, NJ 1993, 476;

HR 18 May 1993, NJ 1993, 691;

HR 15 July 1993, NJ 1994, 177; 
HR 9 May 1995, NJ 1995, 501;

HR 23 May 1995, NJ 1995, 631;

HR 27 June 1995, NJ 1995, 662;

HR 27 June 1995, NJ 1995, 711;

HR 10 October 1995, NJ 1996, 356;

HR 23 January 1996, NJ 1996, 400;

HR 18 June 1996, NJ 1996, 750;

HR 15 October 1996, NJ 1997, 199;

Hof Den Haag 28 February 1997, NJ 1997, 373;

HR 8 April 1997, NJ 1997, 443;

HR 29 April 1997, NJ 1997, 627;

HR 29 April 1997, NJ 1997, 654;

HR 24 June 1997, $N J$ 1997, 676;

HR 14 April 1998, NJ 1998, 662;

HR 21 April 1998, NJ 1998, 610;

HR 9 June 1998, NJ 1998, 731;

HR 22 September 1998, NJ 1998, 911;

HR 3 November 1998, $L J N$ :AV1127;

HR 15 December 1998, NJ 1999, 203;

HR 26 January 1999, NJ 1999, 537;

HR 21 September 1999, NJ 1999, 790;

HR 9 November 1999, NJ 2000, 145;

HR 7 December 1999, NJ 2000, 263;

HR 23 January 2000, NJ 2001, 327;

HR 27 June 2000, NJ 2000, 605;

Hof Amsterdam 26 September 2000, NJ 2000, 746;

HR 10 October 2000, NJ 2001, 4;

HR 31 October 2000, NJ 2001, 11;

HR 14 November 2000, NJ 2001, 37;

Rb. Maastricht 20 February 2001, NbSr 2001, 299;

Hof Amsterdam 22 March 2001, NbSr 2001, 5;

HR 8 May 2001, NJ 2001, 480;

Hof Den Bosch 20 June 2001, NbSr 2001, 230;

Hof Leeuwarden 22 July 2011, LJN:BR2402;

HR 2 April 2002, NJ 2002, 421;

HR 11 June 2002, NbSr 2002, 208;

$\mathrm{Rb}$. Assen 12 June 2002 LJN:AE3911;

HR 17 September 2002, NJ 2002, 549;

Rb. Leeuwarden 31 October 2002, NbSr 2002, 321;

HR 3 December 2002, NJ 2004, 353;

Rb. Den Haag 19 December 2002, LJN:AF2320;

HR 18 March 2003, NJ 2004, 291;

HR 25 March 2003 NJ 2003, 552; 
HR 25 March 2003, NJ 2003, 556;

HR 1 April 2003, NJ 2003, 497;

Rb. Breda 8 May 2003, $L J N$ :AF8365;

HR 3 June 2003, NbSr 2003, 240;

HR 24 June 2003, NJ 2003, 555;

HR 10 February 2004, NJ 2004, 286;

HR 17 February 2004, NJ 2004, 323;

HR 20 February 2004, $L J N$ :AO1239;

HR 24 February 2004, NJ 2004, 375;

Hof Amsterdam 29 March 2004, NbSr 2004, 161;

HR 18 May 2004, NJ 2004, 512;

HR 25 May 2004, $L J N$ :AO6452;

HR 1 June 2004, NJ 2005, 252;

HR 9 November 2004, NJ 2005, 217;

Rb. Breda 10 November 2004, LJN:AR5394;

HR 30 November 2004, NJ 2005, 94;

HR 14 December 2004, NJ 2006, 448;

HR 21 December 2004, NJ 2007, 469;

HR 18 January 2005, NJ 2005, 154;

HR 12 April 2005, NJ 2005, 364;

Hof Den Haag 3 June 2005, LJN:AY4771;

HR 13 September 2005, LJN:AT5834;

HR 20 September 2005, NJ 2006, 104;

Hof Den Haag 24 November 2005, LJN:AV1104;

Hof Amsterdam 9 December 2005, LJN:AU7731;

HR 17 January 2006, NJ 2006, 303;

HR 7 February 2006, NJ 2006, 508;

HR 28 February 2006, NJ 2006, 179;

HR 28 March 2006, NJ 2006, 509;

HR 4 April 2006, NJ 2007, 144;

HR 13 June 2006, NJ 2006, 343;

HR 22 August 2006, NJ 2006, 484;

HR 31 October 2006, NJ 2007, 79;

HR 21 November 2006, NJ 2006, 650;

HR 5 December 2006, NJ 2006, 663;

HR 12 December 2006, NJ 2007, 245;

HR 20 February 2007, NJ 2007, 313;

HR 20 February 2007, NJ 2007, 464;

HR 24 April 2007, NJ 2007, 544;

Rb. Haarlem 15 June 2007, LJN:BA7326;

HR 19 June 2007, NJ 2008, 169;

HR 2 October 2007, NJ 2007, 645;

Rb. Almelo 19 October 2007, $L J N$ :BB6018; 
HR 4 December 2007, $L J N$ :BB5377;

Rb. Almelo 4 January 2008, $L J N$ :BC1180;

HR 15 January 2008, NJ 2008, 609;

HR 15 January 2008, $R v d W 2008,120$;

HR 22 January 2008, $R v d W$ 2008, 171;

HR 12 February 2008, NJ 2008, 263;

HR 4 March 2008, NJ 2008, 158;

$\mathrm{Rb}$. Amsterdam 6 March 2008, $L J N$ :BC5916;

HR 8 April 2008, NJ 2008, 233;

HR 8 April 2008, NJ 2008, 312;

Rb. Rotterdam 15 April 2008, $L J N$ :BD1263;

HR 22 April 2008, NJ 2008, 375;

HR 29 April 2008, NJ 2008, 439;

HR 29 April 2008, NJ 2008, 440;

Hof Arnhem 21 May 2008, $L J N: B D 2016$;

HR 27 May 2008, NJ 2008, 441;

HR 27 May 2008, NJ 2008, 510;

Rb. Zwolle 29 May 2008, $L J N: B D 1958$;

Rb. Zwolle 29 May 2008, $L J N$ :BD9248;

HR 30 May 2008, NJ 2008, 318;

HR 24 June 2008, NJ 2008, 442;

Rb. Utrecht 24 June 2008, $L J N$ : BD5317;

Rb. Alkmaar 8 July 2008, LJN:BD6660;

Hof Amsterdam 22 July 2008, LJN: BD8276;

HR 16 September 2008, $L J N$ :BD1728;

HR 16 September 2008, NJ 2008, 512;

HR 16 September 2008, NJ 2010, 5;

Hof Arnhem 1 October 2008, $L J N$ : BF3995;

Rb. Utrecht 1 October 2008, LJN: BF7595;

Rb. Utrecht 1 October 2008, LJN: BF7598;

Hof Arnhem 20 November 2008, LJN:BG4942;

HR 9 December 2008, NJ 2009, 157;

Hof Den Bosch 6 January 2009, LJN:BG8922;

Hof Arnhem 21 January 2009, $L J N$ :BH1023;

Rb. Arnhem 2 February 2009, $L J N$ :BH229;

Hof Den Haag 9 February 2009, $L J N$ :BH2267;

HR 10 February 2009, NJ 2009, 111;

Hof Den Bosch 18 February 2009, LJN:BH3824;

Hof Den Haag 25 February 2009, $L J N$ :BH4016;

Hof Den Bosch 3 March 2009, LJN:BH4471;

Hof Arnhem 13 March 2009, LJN:BH6016;

HR 31 March 2009, NJ 2009, 177;

Hof Arnhem 31 March 2009, $L J N$ :BH9163; 
Rb. Almelo 31 March 2009, LJN:BH9975;

Hof Arnhem 6 April 2009, $L J N: B I 1487$;

Hof Leeuwarden 9 April 2009, LJN:BI2091;

Hof Amsterdam 21 April 2009, $L J N$ :BI1783;

Hof Leeuwarden 4 May 2009, $L J N$ :BI3144;

Rb. Zwolle-Lelystad 22 June 2009, LJN:BJ0512;

HR 30 June 2009, NJ 2009, 481;

Hof Den Haag 20 July 2009, $L J N: B J 3063$;

Hof Arnhem 20 July 2009, $L J N: B J 3107$;

Hof Amsterdam 3 September 2009, LJN:BJ6879;

HR 29 September 2009, NJ 2010, 117;

HR 6 October 2009, NJ 2010, 301;

Hof Leeuwarden 10 November 2009, NJ 2010, 616;

Rb. Den Haag 1 December 2009, LJN:BL4483;

HR 2 February 2010, NJ 2010, 282;

HR 9 March 2010, NJ 2010, 160;

Hof Leeuwarden 11 March 2010, $L J N$ :BL7271;

HR 18 May 2010, NJ 2010, 289;

HR 8 June 2010, NJ 2010, 339;

HR 29 June 2010, NJ 2010, 674;

Hof Amsterdam 27 August 2010, LJN:BN5666;

Rb. Groningen 9 September 2010, NJ 2011, 52

HR 21 September 2010, $L J N$ :BM9407;

Hof Arnhem 21 October 2010, $L J N$ :BO1426;

HR 26 October 2010, $L J N: \mathrm{BO} 2514$;

HR 7 December 2010, NJ 2010, 677;

Hof Amsterdam 14 December 2010, LJN:BO9264;

Hof Amsterdam 16 December 2010, LJN:BO7707;

HR 11 January 2011, NJ 2011, 339;

HR 18 January 2011, $L J N$ :BO6365;

HR 22 February 2011, NJ 2011, 107;

Rb. Groningen 21 March 2011, $L J N: B P 8488$;

HR 22 March 2011, $L J N$ :BP2715;

Hof Amsterdam 28 April 2011, LJN:BQ2981;

Rb. Amsterdam 9 June 2011, LJN:BQ7589;

HR 5 July 2011, NJ 2011, 327;

HR 12 July 2011, $L J N$ :BQ6720;

HR 12 July 2011, $L J N: B P 5971 ;$

HR 12 July 2011, NJ 2011, 578;

Hof Leeuwarden 3 August 2011, LJN:BR4247 and BR4250

Hof Leeuwarden 11 August 2011, $L J N$ :BR4891;

HR 11 October 2011, $L J N$ :BR2983;

HR 15 November 2011, NJ 2011, 542; 
Selected bibliography

HR 6 December 2011, $L J N$ :BP9394;

HR 6 December 2011, $L J N: B R 1146$;

HR 17 January 2012, $L J N$ :BU4211;

HR 28 February 2012, $L J N$ :BR2342;

HR 6 March 2012, $L J N: B U 3606$;

Hof Leeuwarden 31 March 2012, LJN:BV8650.

\section{English and UK Case law}

R. v. M'Naghten [1843-1860] All ER Rep 229;

R. v. Dalloway (1847) 2 Cox CC 273;

R. v. Dadson (1850) 169 ER 407;

R. v. Sleep [1861-1873] All ER Rep 248;

R. v. Pembliton (1874) L. 2 C.C.R. 119;

R. v. Dudley and Stephens (1884) 14 QBD 273;

R. v. Deana (1909) 2 Cr App R 75;

R. v. Hussey (1925) 18 Cr App R 160;

R. v. Bateman (1927) 19 Cr App R 8;

R. v. Larsonneur [1933] 24 Cr App R 74;

Woolmington v. DPP [1935] AC 462;

R. v. Bourne [1939] 1 KB 687;

R. v. Steane [1947] KB 997;

R. v. Duffy [1949] 1 All ER 932;

R. v. Thabo Meli [1954] 1 All ER 373;

R. v. Cunningham [1957] 2 All ER 412;

R. v. Kemp [1957] 1 QB 399;

Hill v. Baxter [1958] 1 QB 277;

R. v. Byrne [1960] 3 All ER 1;

DPP v. Smith [1961] AC 290;

Lim Chin Aik v. the Queen [1963] AC 160;

Bratty v. Attorney-General for Northern Ireland [1963] AC 386;

R. v. Duffy [1967] 1 QB 63;

Sweet v. Parsley [1969] UKHL 1;

Fagan v. MPC [1969] 1 QB 439;

Warner v. MPC [1969] 2 AC 256;

R. v. Hudson and Taylor [1971] EWCA Crim 2;

R. v. Palmer [1971] AC 814;

R. v. McInnes [1971] 1 WLR 1600;

Southwark London Borough Council v. Williams [1971] 2 All ER 175;

R. v. Quick [1973] QB 310;

R. v. Brown [1973] NI 96;

R. v. Smith [1974] QB 354;

Smedleys Ltd. v. Breed [1974] AC 389; 
DPP for Northern Ireland v. Lynch [1975] UKHL 5;

DPP v. Majewski [1976] UKHL 2;

DPP v. Morgan [1975] 2 All ER 347;

DPP v. Morgan [1976] AC 182;

R. v. Mohan [1976] QB 1;

R. v. Abbott [1977] AC 755;

R. v. Parker [1977] 1 WLR 600;

DPP v. Camplin [1978] UKHL 2;

R. v. Stephenson [1979] EWCA Crim 1;

Attorney General's Reference No. 6 of 1980 [1981] EWCA Crim 1;

R. v. Olugboja [1981] EWCA Crim 2;

R. v. Graham [1981] EWCA Crim 5;

R. v. Caldwell [1982] 1 All ER 961;

R. v. Miller [1982] UKHL 6;

Elliot v. C [1983] 1 WLR 939;

R. v. Gladstone Williams [1983] EWCA Crim 4;

Attorney-General's Reference no. 2 of 1983 [1984] EWCA Crim 1;

R. v. Moloney [1984] UKHL 4;

R. v. Hardie [1984] EWCA Crim 2;

R. v. Taaffe [1984] AC 539;

R. v. Sullivan [1984] AC 156;

Gammon v. Attorney-General of Hong Kong [1984] 2 All ER 503;

R. v. Bird [1985] EWCA Crim 2;

Gillick v. West Norfolk \& Wisbech Area Health Authority [1985] UKHL 7;

R. v. Pearman (1985) 80 Cr App R 259;

R. v. Shivpuri [1986] UKHL 2;

R. v. Howe [1986] UKHL 4;

Chief Constable of Avon and Somerset Constabulary v. Shimmen (1986) 84 Cr App R 7;

R. v. Nedrick [1986] EWCA Crim 2;

Westminster City Council v. Croyalgrange Ltd and another [1986] 2 All ER 353;

R. v. Hancock and Shankland [1986] AC 455;

R. v. Renouf (1986) 82 Cr App R 344;

R.v. O'Grady [1987] EWCA Crim 2;

R. v. Hunt [1987] AC 352;

R. v. Martin (Colin) [1988] EWCA Crim 2;

R. v. Hennessy [1989] 2 All ER 9;

F. v. West Berkshire HA [1989] 2 WLR 1025;

R. v. Khan [1990] 1 WLR 815;

R. v. Burgess [1991] 2 QB 92;

R. v. Ahluwalia [1992] EWCA Crim 1;

Airedale National Health Service Trust v. Bland [1992] UKHL 5;

R. v. Reid [1992] 95 Cr App R 391;

Attorney-General's Reference no. 3 of 1992 [1994] 2 All ER 121; 
R. v. Brown [1993] 2 All ER 75;

R. v. Yip Chiu-Cheung [1994] UKPC 2;

R. v. Linekar [1994] EWCA Crim 2;

R. v. Adomako [1994] UKHL 6;

R. v. Kingston [1994] UKHL 9;

Re C. (Adult: refusal of treatment) [1994] 1 WLR 290;

R. v. Coles [1994] Crim LR 820;

R. v. Clegg [1995] UKHL 1;

Re C. (A minor) [1995] UKHL 15;

R. v. Pommell [1995] EWCA Crim 7;

R. v. Owino [1996] 2 Cr App R 128;

R. v. Bowen [1996] EWCA Crim 1792;

R. v. Marsh [1997] 1 Cr App R 67;

R. v. Horseferry Road Magistrate's Court ex parte K [1997] QB 23;

R. v. Wilson [1997] QB 47;

R. v. Forsyth [1997] EWCA Crim 751;

R. v. Human Fertilisation and Embryology Authority, ex parte Blood [1997] 2 All ER 687;

R. v. Andrew Rodger and Keith John Rose [1997] EWCA Crim 1760;

DPP v. Armstrong-Braun [1998] 163 JP 271;

Attorney-General's Reference no. 3 of 1994 [1998] AC 245;

R. v. Woollin [1998] UKHL 28;

R. v. Abdul-Hussain [1998] EWCA Crim 3528;

Attorney-General's Reference no. 2 of 1999 [2000] EWCA Crim 91;

R. v. Baker and another [1999] EWCA Crim 913;

R. v. Lee [2000] EWCA Crim 53;

B. v. DPP [2000] UKHL 13;

R. v. Smith (Morgan) [2000] UKHL 49;

R. v. Hinks [2000] UKHL 53;

Re A. (Children) [2000] EWCA Civ 254;

Brown v. Stott [2001] 2 WLR 817;

R. v. Lambert [2001] UKHL 37;

R. v. Shayler [2001] EWCA Crim 1977;

R. v. Martin [2001] EWCA Crim 2245;

R. v. Gemmell and Richards [2002] EWCA Crim 1992;

R. v. Wacker [2002] EWCA Crim 1944;

R. v. G. [2003] UKHL 50;

R. v. Z. [2003] EWCA Crim 191;

R. v. Dica [2004] EWCA Crim 1103;

Sheldrake v. DPP [2004] UKHL 43;

Attorney-General's reference no. 1 of 2004 [2004] EWCA Crim 1025;

Attorney-General's Reference no. 37 of 2004 [2004] EWCA Crim 1854;

R. v. Barnes [2004] EWCA Crim 3246;

R. v. Hasan [2005] UKHL 22; 
A and others v. Secretary of State for the Home Department [2005] UKHL 71;

R. v. Konzani [2005] EWCA Crim 706;

R. v. Quayle and others [2005] EWCA Crim 1415;

R. v. Mohammed [2005] EWCA Crim 1880;

R. v. Hatton [2005] EWCA Crim 2951;

R. v. Nicholas Rashford [2005] EWCA Crim 3377;

Attorney General for Jersey v. Holley [2005] UKPC 23;

R. v. Saik [2006] UKHL 18;

R. v. Brady [2006] EWCA Crim 2413;

R. v. EB [2006] EWCA Crim 2945;

Christian \& Others v. The Queen (The Pitcairn Islands) [2006] UKPC 47

R. v. Wilson [2007] 2 Cr App R 31;

R. v. Heard [2007] EWCA Crim 125;

R. v. Bree [2007] EWCA Crim 804;

R. v. Salih [2007] EWCA Crim 1750;

CPS v. P. [2007] EWHC 946;

Duffy v. Chief Constable of Cleveland Police [2007] EWHC 3169;

R. v. G. [2008] UKHL 37;

R. v. T. [2008] EWCA Crim 815;

R. v. Ali [2008] EWCA Crim 1726;

R. v. C. [2009] UKHL 42;

R. v. Williams [2010] EWCA Crim 2552.

German Case law

1 January 1859 RG GA 1859, 322;

23 October 1890 RGSt 21, 131;

5 May 1892 RGSt 23, 116;

23 March 1897 RGSt 30, 25;

17 June 1901 RGSt 34, 295;

24 October 1919 RGSt 54, 36;

31 May 1920 RGSt 54, 349;

20 September 1920 RGSt 55, 82;

5 January 1922 RGSt 56, 343;

30 November 1923 RGSt 58, 27;

12 July 1926 RGSt 60 , 318;

11 March 1927 RGSt 61, 242;

3 January 1928 RG JW 1928, 2229;

12 October 1928 RG JW 1929, 1015;

3 March 1930 RGSt 64, 30;

26 April 1932 RGSt 66, 222;

20 June 1932 RGSt 66, 288;

11 November 1932 RGSt 66, 397; 
Selected bibliography

14 June 1938 RGSt 72, 246;

23 February 1940 RGSt 74, 91;

9 May 1940 RGSt 74, 195;

15 January 1952 BGHSt 2, 111;

14 February 1952 BGHSt 3, 217;

18 March 1952 BGHSt 2, 194;

25 March 1952 BGHSt 2, 242;

6 June 1952 BGHSt 3, 105;

1 July 1952 BGHSt 3, 194;

11 November 1952 BGH NJW 1953, 111;

23 December 1952 BGH NJW 1953, 431;

22 January 1953 BGHSt 4, 88;

29 January 1953 BGHSt 4, 24;

23 April 1953 BGHSt 4, 182;

22 September 1953 BGHSt 4, 340;

2 October 1953 BGHSt 5, 245;

5 March 1954 BGHSt 5, 371;

6 May 1954 BGH GA 1955, 123;

12 July 1954 BGH VGS 1, 54;

21 April 1955 BGHSt 7, 325;

22 April 1955 BGH NJW 1955, 1688;

3 May 1956 BGHSt 9, 240;

6 December 1956 BGHSt 10, 35;

8 February 1957 BGHSt 10, 133;

9 July 1957 BGH NJW 1957, 1484;

25 September 1957 BGHSt 11, 1;

28 November 1957 BGHSt 11, 111;

23 January 1958 BGHSt 11, 268;

17 September 1958 BGHSt 12, 81;

13 November 1958 BGHSt 12, 299;

10 February 1959 BGHSt 12, 379;

29 May 1959 BGHSt 14, 1;

2 February 1960 BGH NJW 1960, 683;

26 February 1960 BGHSt 14, 152;

26 April 1960 BGHSt 14, 193;

20 December 1960 BVerfGE 12, 45;

1 February 1961 BGHSt 16, 309;

23 February 1961 BGH NJW 1961, 1172;

3 August 1961 BayObLGSt 1961, 180;

12 January 1962 BGHSt 17, 87;

17 April 1962 BGHSt 17, 210;

4 May 1962 BGHSt 17, 259;

1 June 1962 BGHSt 17, 333; 
10 July 1962 BGHSt 17, 359;

6 February 1963 BGHSt 18, 246;

29 March 1963 BGHSt 18, 311;

26 May 1964 BGH GA 1965, 147;

5 October 1965 BGH VRS 30, 281;

8 November 1965 NJW 1966, 1227;

10 December 1965 BGHSt 20, 135;

2 February 1966 BGH NJW 1966, 787;

27 January 1966 BGHSt 21, 18;

25 October 1966 BVerfGE 20, 323;

6 June 1967 BGH GA 1969, 246;

26 July 1967 BGH NJW 1967, 2319;

24 November 1967 BGHSt 21, 381;

26 February 1969 BVerfGE 25, 269;

13 May 1969 BGHSt 23, 1;

14 May 1970 BGHSt 23, 261;

28 July 1970 BGH JZ 1973, 173;

27 October 1970 BGHSt 24, 132;

19 October 1971 BVerfG 32, 98;

14 June 1972 BGHSt 24, 356;

7 November 1972 BGH NJW 1973, 255;

19 September 1973 BGHSt 25, 229;

25 September 1974 NJW 1975, 62;

15 May 1975 BGHSt 26, 143;

15 July 1975 BGH NJW 1975, 1893;

12 December 1975 BGHSt 26, 256;

2 December 1976 BGH NJW 1978, 1206;

14 July 1977 BGH NJW 1977, 2086;

21 December 1977 BGHSt 27, 313;

12 January 1978 BGHSt 27, 336;

26 May 1978 BayObLG NJW 1978, 2046;

3 October 1978 BayObLG NJW 1979, 729;

15 May 1979 BGH MDR 1979, 985;

15 May 1979 BGH NJW 1979, 2053;

24 July 1979 BGH NJW 1980, 2263;

16 July 1980 BGH NStZ 1981, 22;

25 November 1980 BGH NStZ 1981, 138;

29 January 1982 BGH StV 1982, 219;

2 March 1982 BGH NJW 1982, 1756;

7 July 1982 OLG Düsseldorf NJW 1982, 2678;

14 June 1983 BGH NStZ 1983, 452;

23 June 1983 BGH NStZ 1984, 19;

18 August 1983 BGHSt 32, 48; 
Selected bibliography

27 September 1983 BGHZ 88, 248;

11 January 1984 BGH NJW 1984, 986;

14 February 1984 BGHSt 32, 262;

9 November 1984 BGHSt 33, 66;

9 January 1985 BayObLG NJW 1985, 2600;

19 March 1986 BGH NStZ 1986, 357;

10 April 1986 BGHSt 34, 53;

11 July 1986 BGH NStZ 1987, 20;

16 April 1987 OLG Koblenz NJW 1988, 2316;

7 July 1987 BGH NStZ 1988, 450;

4 August 1987 BGH NJW 1988, 79;

25 March 1988 BGHSt 35, 246;

30 June 1988 BGH NJW 1989, 176;

15 September 1988 BGHSt 35, 347;

4 November 1988 BGHSt 36, 1;

20 November 1988 OLG Karlsruhe NStZ 1985, 225;

28 February 1989 BGH NJW 1989, 3027;

14 March 1989 BGH NStZ 1989, 431;

1 June 1989 BVerfG NJW 1989, 2679;

18 April 1990 OLG Düsseldorf NJW 1990, 2264;

26 April 1990 BGH NJW 1990, 2832;

8 May 1990 BGH NStZ 1990, 435;

5 October 1990 BGH NJW 1991, 503;

25 October 1990 BGHSt 37, 214;

22 November 1990 BGH NStZ 1991, 126;

22 November 1990 BGHSt 37, 231;

29 May 1991 BGH NStZ 1991, 528;

7 November 1991 BGH NStZ 1992, 125;

15 May 1992 BGHSt 38, 295;

21 May 1992 BGH NStZ 1992, 487;

7 July 1992 BGH NStZ 1995, 587;

21 July 1992 BGH StV 1993, 356;

14 August 1992 BayObLG NJW 1993, 211;

1 September 1992 BGHSt 38, 353;

3 November 1992 BGHSt 39, 1;

3 February 1993 BGHSt 39, 133;

8 March 1993 OLG Stuttgart NStZ 1993, 344;

25 March 1993 BGHSt 39, 168;

26 October 1993 BGHSt 39, 374;

28 April 1994 BGH NStZ 1994, 483;

16 August 1994 BGH NStZ 1995, 76;

13 September 1994 BGHSt 40, 257;

15 November 1994 BGH NStZ 1995, 177; 
17 November 1994 BGHSt 40, 341 and NStZ 1995, 183;

8 February 1995 BGH NJW 1995, 1973;

24 February 1995 BVerfG NJW 1995, 1951;

20 March 1995 BGHSt 41, 101;

29 June 1995 BGH NStZ 1996, 34 and 132;

11 September 1995 BGH NStZ 1996, 29;

21 November 1995 BGH NStZ-RR 1996, 97;

3 December 1995 BGH NStZ 1996, 236;

7 March 1996 BGH NStZ 1996, 338;

21 March 1996 BGHSt 42, 97;

30 May 1996 NStZ-RR 1997, 65;

26 June 1996 BayObLG NStZ-RR 1996, 341;

2 July 1996 BGH NStZ-RR 1996, 355;

22 August 1996 BGHSt 42, 235;

17 October 1996 BGHSt 42, 268;

24 October 1996 BVerfGE 95, 96;

21 November 1996 OLG Stuttgart NStZ 1997, 190;

12 December 1996 BGH NStZ 1997, 232;

19 February 1997 BGH NStZ 1997, 228;

19 February 1997 BGH NStZ 1997, 230;

27 February 1997 BGH NStZ-RR 1997, 199;

19 March 1997 BGH NStZ-RR 1997, 296;

15 April 1997 BGH NStZ-RR 1997, 233;

24 July 1997 BGH StV 1998, 258;

7 October 1997 BGHSt 44, 91;

19 November 1997 BGHSt 43, 306;

11 December 1997 BGH NStZ-RR 1998, 173;

16 December 1997 BGH NStZ-RR 1999, 6;

4 February 1998 BSG NJW 1999, 236;

25 February 1998 BVerfG 1 BvR 299/89;

26 February 1998 BGH NStZ-RR 1998, 235;

14 August 1998 BayObLG NStZ-RR 1999, 9;

7 September 1998 BayObLG NJW 1999, 372;

25 March 1999 BGH JR 2000, 297;

19 May 1999 BGHSt 45, 97;

7 July 1999 BGH NStZ 1999, 507;

8 July 1999 OLG Frankfurt am Main NJW 2000, 875;

4 October 1999 BGHSt 45, 219;

12 October 1999 BGH NStZ 2000, 87;

15 December 1999 BGH NStZ 2000, 307;

2 February 2000 BGH NStZ 2000, 364;

10 February 2000 BGHSt 45, 378;

7 June 2000 BGH NStZ 2000, 584; 
20 June 2000 BGH NStZ 2000, 583;

6 July 2000 BGH NJW 2000, 3079;

30 August 2000 BGH NStZ 2001, 29;

22 November 2000 BGH NStZ 2001, 143;

7 February 2001 BGHSt 46, 279;

21 March 2001 NStZ 2001, 591;

8 May 2001 BGH NStZ 2001, 475;

9 May 2001 BGH NStZ 2001, 530;

13 September 2001 BGH NStZ 2002, 28;

24 October 2001 NStZ 2002, 141;

25 October 2001 BGH NStZ 2002, 140;

11 December 2001 BGH NStZ 2002, 315;

12 December 2001, BGH NJW 2002, 1057;

21 February 2002 BGH NStZ 2002, 481;

7 March 2002 BGH NStZ 2002, 425;

18 April 2002 BGH JZ 2003, 50;

28 May 2002 BGH NStZ 2002, 548;

6 June 2002 BGH NStZ 2002, 532;

15 August 2002 OLG Karlsruhe BeckRS 2003, 06332;

18 September 2002 BGH NStZ-RR 2003, 8;

18 November 2002 KG Berlin BeckRS 2009, 22705;

23 January 2003 BGH NStZ 2003, 599;

12 February 2003 BGHSt 48, 207;

19 February 2003 BVerfG NJW 2003, 1504;

13 March 2003 BGH NStZ 2004, 615;

25 March 2003 BGHSt 48, 255;

27 March 2003 BGH NJW 2003, 2394;

26 June 2003 BGH NStZ 2004, 35;

7 August 2003 BGH NJW 2003, 3283;

18 September 2003 BVerwG NVwZ-RR 2004, 426;

15 October 2003 BGH JZ 2004, 799;

13 November 2003 BGHSt 49, 1;

11 December 2003 BGHSt 49, 34;

20 January 2004 BGH JR 2004, 469;

28 April 2004 AG Berlin-Tiergarten NStZ-RR 2004, 281;

26 May 2004 BGHSt 49, 166;

26 May 2004 BGH NStZ 2004, 619;

24 June 2004 OLG Karlsruhe NJW 2004, 3645;

30 June 2004 BGH NStZ 2005, 31;

6 October 2004 BGH NStZ 2005, 332;

22 October 2004 BGH NStZ 2005, 329;

14 December 2004 BGH BeckRS 2005, 00267;

1 February 2005 BGH NStZ 2005, 446; 
22 April 2005 BGH NJW 2005, 1876;

21 May 2005 BGH NStZ 1992, 487;

30 June 2005 BVerfG HRRS 2005, 588;

25 October 2005 OLG Düsseldorf NStZ 2006, 243;

15 February 2006 BVerfG NJW 2006, 751;

16 March 2006 BGH NStZ 2006, 506;

21 May 2005 BGH NStZ 1992, 487;

9 August 2005 BGH NStZ 2006, 152;

24 March 2006 OLG Jena BeckRS 2006, 06007;

13 March 2007 BGH BeckRS 2007, 06625;

25 May 2007 KG Berlin NJW 2007, 2425;

1 June 2007 BGH BeckRS 2007, 10549;

5 December 2007 BGH NStZ 2008, 338;

20 February 2008 BGH NStZ 2008, 392;

5 March 2008 BGH BeckRS 2008, 05898;

6 March 2008 BGH BeckRS 2008, 04800;

24 June 2008 BGH BeckRS 2008, 13794;

25 June 2008 BGH BeckRS 2008, 13797;

17 September 2008 BGH BeckRS 2008, 21295;

16 October 2008 BGH NStZ 2009, 210;

13 November 2008 BGH NStZ-RR 2009, 70;

20 November 2008 BGH NJW 2009, 1155;

22 April 2009 BGH NStZ 2009, 503;

29 April 2009 BGH NStZ 2009, 504;

23 June 2009 BGH NStZ 2009, 629;

25 June 2009 BGH NStZ 2009, 626;

30 June 2009 BverfG 2 BvE 2/08;

4 August 2009 BGH NStZ 2010, 82;

12 August 2009 BGH BeckRS 2009, 25029;

27 August 2009 BGH NStZ-RR 2009, 372;

23 September 2009 BGH NStZ-RR 2010, 7;

8 December 2009 BGH NStZ-RR 2010, 105;

17 December 2009 BGH NStZ 2010, 571;

12 January 2010 BGH NJW 2010, 1087;

13 January 2010 BGH NStZ 2010, 276;

13 January 2010 BGH NStZ-RR 2010, 140;

24 February 2010 BGH NStZ-RR 2010, 214;

25 March 2010 BGH NStZ 2010, 515;

25 June 2010 BGH NJW 2010, 2963;

10 November 2010 BGH NStZ-RR 2011, 74;

15 December 2010 BGH NStZ 2011, 210;

27 January 2011 BeckRS 2011, 03958;

5 April 2011 BGH BeckRS 2011, 09435; 
Selected bibliography

4 May 2011 BVerfG NStZ 2011, 450;

22 March 2012 BGH BeckRS 2012, 07957.

Other case law

Viro v. The Queen (1978) 141 CLR 88;

Zecevic v. DPP (1987) 162 CLR 645;

ICTY Judgment, Prosecutor v. Erdemović, Case No. IT-96-22-A Ch., 7 October 1997;

ICTR Judgment, Prosecutor v. Blaškić, Case No. IT-95-14-A, A. Ch., 29 July 2004.

\section{Official documentation}

\section{EU Documents}

Explanatory Report on the Convention on the protection of the European Communities' financial interests, 23 June 1997, OJ 1997 C 191/1;

Resolution of 30 July 1999 on criminal procedure in the European Union (Corpus Juris), OJ 1999 C 219/106;

Proposal for a Directive on the criminal-law protection of the Community's financial interests, Brussels 23 May 2001, COM (2001) 272, as amended by COM (2002) 577;

Green Paper on criminal-law protection of the financial interests of the Community and the establishment of a European Prosecutor, 11 December 2001, COM 2001/715;

Communication from the Commission: Notice - Guidelines on the application of Article 81(3) of the Treaty, 27 April 2004, OJ 2004 C 101/97;

Report from the Commission based on Article 11 of the Framework Decision 2002/475 of 13 June 2002 on combating terrorism, 8 June 2004, COM (2004) 409 and it's annex SEC (2004) 688;

Report from the Commission based on Article 11 of the Framework Decision 2002/475 of 13 June 2002 on combating terrorism, 6 November 2007, COM (2007) 681 and its annex SEC (2007) 1463;

Report of 30 April 2004 from the Commission of the Framework Decision of 28 May 2001 combating fraud and counterfeiting of non-cash means of payment, COM (2004) 346;

Second report from the Commission on the implementation of the Convention on the Protection of the European Communities' financial interests and its protocols, 14 February 2008, COM(2008) 77;

EP recommendation of 7 May 2009 to the Council on development of an EU criminal justice area, no. 2009/2012;

Report on Competition Policy 2008, 23 July 2009, COM (2009) 374;

Draft Council conclusions on model provisions, guiding the Council's criminal law deliberations, Brussels, 27 November 2009, 16542/2/09 REV 2;

Council document 16798/09 of 27 November 2009;

Resolution of the Council of 30 November 2009 on a Roadmap for strengthening procedural rights of suspected or accused persons in criminal proceedings, OJ 2009 C 295/1; 
The Stockholm Programme - an open and secure Europe serving and protecting citizens, 4 May 2010, OJ 2010 C 115/1;

Proposal for a Directive on attacks against information systems and repealing Framework Decision 2005/222, 30 September 2010, COM (2010) 517;

Amended Proposal for a Regulation amending Regulation (EC) No 1073/1999 concerning investigations conducted by the European Anti-fraud Office (OLAF) and repealing Regulation (EURATOM) No 1074/1999, 17 March 2011, COM(2011) 135;

Report of the Commission on the implementation since 2007 of the Council Framework Decision of 13 June 2002 on the European arrest warrant and the surrender procedures between Member States, 11 April 2011, COM(2011) 175;

Communication from the Commission on the protection of the financial interests of the European Union by criminal law and by administrative investigations, 26 May 2011, COM (2011) 293;

Discussion paper of the Hungarian Presidency for the Justice Minister's lunch - Towards an EU Criminal Policy, 7 June 2011, no. 11155/11;

Commission Communication: Towards an EU Criminal Policy: Ensuring the effective implementation of EU policies through criminal law, 20 September 2011 COM (2011) 573 ;

Proposal for a Directive on criminal sanctions for insider dealing and market manipulation, Brussels 20 October 2011, COM (2011) 654;

EP Committee on Civil Liberties, Justice and Home Affairs, draft report on harmonisation of criminal law in the EU of 18 January 2012, no. 2010/2310;

\section{Dutch documentation}

Kamerstukken II 1979/1980, 11 270, no. 12;

Kamerstukken II 1991/92, 22 268, no. 5,

Kamerstukken II 2001/02, 28 484, no. 3, 7, 34 and 43.

Kamerstukken II 2007/08, 30 538, no. 6;

\section{SECONDARY SOURCES}

\section{Literature}

(Not differentiated by origin)

Albrecht, H.-J. (1998). Addiction, Intoxication, Criminal Law and Criminal Justice: An Introduction European Addiction Research, 4(3), 85-88;

Alexander, L. (2004). Unknowingly Justified Actors and the Attempt / Succes Distinction. Tulsa Law Review, 39, 851-859;

Alexander, L., \& Kessler Ferzan, K. (2007). Fletcher on the Fault of Not Knowing. Unpublished manuscript, San Diego;

Alldridge, P. (1986). Necessity and Mistake of Law in the Draft Criminal Code. The Liverpool Law Review, 8(1), 37-52; 
Alldridge, P. (1990). Rules for Courts and Rules for Citizens. Oxford Journal of Legal Studies, 10, 487-504;

Alldridge, P. (1999). Scientific expertise and comparative criminal procedure. International Journal of Evidence \& Proof (3), 141-164;

Allen, M.J. (1994). Consent and Assault. Journal of Criminal Law, 58, 183-200;

Ambos, K. (1999). General Principles of Criminal Law in the Rome Statute. Criminal Law Forum, 10, 1-32;

Ambos, K. (2002). Der Allgemeine Teil des Völkerstrafrechts - Ansätze einer Dogmatisierung. Berlin: Duncker \& Humblot GmbH;

Ambos, K. (2005). Is the Development of a Common Substantive Criminal Law for Europe Possible? Some preliminary reflections. Maastricht Journal of European and Comparative law, 12(2), 173-191;

Ambos, K. (2006). Remarks on the General Part of International Criminal Law. Journal of International Criminal Justice, 4(4);

Ambos, K. (2008). Special Issue the Law of Cruelty: Torture as an International Crime - II Can We Ever Justify or Excuse Torturers? May a State Torture Suspects to Save the Life of Innocents? Journal of International Criminal Justice, 6, 261-287;

Amirthalingam, K. (2004). Caldwell Recklessness is Dead, Long Live Mens Rea's Recklessness. Modern Law Review, 67, 491-500;

Arnold, R. (2003). The Mens Rea of Genocide under the Statute of the International Criminal Court. Criminal Law Forum, 14, 127-151;

Arzt, G. (1976). Ignorance or Mistake of Law. American Journal of Comparative Law, 24, 646-679;

Ashworth, A. (2006). Principles of Criminal Law. Oxford: Oxford University Press;

Ashworth, A. (2008). A change of normative position: determining the contours of culpability in normal law. New Criminal Law Review, 11(2), 232-256;

Ashworth, A., \& Blake, M. (1996). The Presumption of Innocence in English Criminal Law. Criminal Law Review, 306-317;

Ashworth, A.J. (1975). Self-Defence and the right to Life. The Cambridge Law Journal, 34, 282-307;

Ashworth, A.J. (2008). Diminished responsibility: defendant diagnosed as suffering from alcohol dependency syndrome but having sustained no brain damage as a result. Criminal Law Review, 2008, 976-978;

Ashworth, A.J. (2011). Ignorance of the Criminal Law, and Duties to Avoid it. Modern Law Review, 74(1), 1-26;

Asp, P., Bitizilekis, N., \& Others. (2009). A Manifesto on European Criminal Policy. Zeitschrift für Internationale Strafrechtsdogmatik, 4(12), 707-716;

Van Asperen De Boer, C. (2007). Kans bijt rechter niet. Nederlands Juristenblad, 82(36);

Austin, J. (1911). Lectures on Jurisprudence of the Philosophy of Positive Law. London: John Murray;

Badar, M.E. (2005). Mens rea - Mistake of Law \& Mistake of Fact in German Criminal Law: A Survey for International Criminal Tribunals. International Criminal Law Review, 5, 203-246; 
Badar, M.E. (2006). Drawing the Boundaries of Mens Rea in the Jurisprudence of the International Criminal Tribunal for the Former Yugoslavia. International Criminal Law Review, 6, 313-348;

Badar, M.E. (2007). The Concept of Mens Rea in International Criminal Law.Unpublished manuscript, Galway;

Badar, M.E. (2009). Dolus eventualis and the Rome Statute without it? New Criminal Law Review, 12(3), 433-467;

Bakker, F.S. (2011). Voorbedachte raad. Delikt en delinkwent, 16(3), 220-246;

Bal, P., \& Ippel, P. (1982). Waarheen met het strafrecht? Met Habernas op weg. Recht en Kritiek, 8(4), 434-462;

Bal, P.L., \& Koenraadt, F. (2004). Het psychisch onvermogen terecht te staan. Den Haag: Boom Juridische uitgevers;

Baron, M. (2005). Is Justification (Somehow) Prior to Excuse? A Reply to Douglas Husak. Law and Philosophy, 24(6), 595-609;

Bassiouni, C. (1999). Negotiating the Treaty of Rome on the Establishment of an International Criminal Court. Cornell International Law Journal, 32(3), 443-469;

Van Bemmelen, J.M. (1955). Op de grenzen van het strafrecht. Haarlem: H.D. Tjeenk Willink \& Zoon N.V.;

Van Bemmelen, J.M. (1959). Ons Strafrecht - in theorie en praktijk. Haarlem: H.D. Tjeenk Willink \& Zoon N.V.;

Berkl, M. (2007). Der Sportunfall im Lichte des Strafrechts. Baden-Baden: Nomos Verlagsgesellschaft;

Bernsmann, K. (1996). Private Self-defence and Necessity in German Penal Law and in the Penal Law Proposal - Some Remarks. Israel Law Review, 30, 171-187;

Beulke, W. (2008). Wessels/Beulke: Strafrecht Allgemeiner Teil (38 ed.). Heidelberg: C.F.Müller Verlag;

Blackstone, W. (1769 (reprint 1979)). Commentaries on the Laws of England - A Fascimile of the First Edition of 1765-1796 - Volume IV of Public Wrongs (1769). Chicago: University of Chicago Press;

Blom, T. (2008). Opiumwetgeving en drugsbeleid. Deventer: Kluwer;

Blomsma, J.H. (2011). Fault Elements in EU Criminal Law: the Case for Recklessness. In A. H. Klip (Ed.), Substantive Criminal Law of the European Union (pp. 135-159). Antwerpen: Maklu;

Blomsma, J.H., \& Klip, A.H. (2009). Noodweer en noodweerexces. Delikt en delinkwent, 39(2), 156-174;

Bohlander, M. (2006). Of Shipwrecked Sailors, Unborn Children, Conjoined Twins and Hijacked Airplanes - Taking Human Life and the Defence of Necessity. Journal of Criminal Law, 70(2);

Bohlander, M. (2008). The German Criminal Code - A Modern English Translation. Portland, Oregon: Hart Publishing;

Bohlander, M. (2009). Principles of German Criminal Law. Oxford: Hart Publishing; 
Bohlander, M. (2010(A)). Transferred malice and transferred defenses: a critique of the traditional doctrine and arguments for a change in paradigm. New Criminal Law Review, 13(3), 555-624;

Bohlander, M. (2010(B)). Problems of Transferred Malice in Multiple-actor Scenarios. The Journal of Criminal Law, 74, 145-162;

Borgers, M.J. (1998). Culpa pecuniae - De verhouding tussen het schuldbegrip en het wederrechtelijk verkregen voordeel. In M. J. Borgers, I. M. Koopmans \& F. G. H. Kristen (Eds.), Verwijtbare uitholling van schuld? (pp. 93-109). Nijmegen: Ars Aequi Libri;

Bosch, M. (2008). Beginselen van strafrecht. Deventer: Kluwer;

Van Den Bosch, T.W. (1987). De toepassing van strafuitsluitingsgronden in het militaire strafrecht. In J. Remmelink (Ed.), Naar eer en geweten - Liber amicorum (pp. 59-70). Arnhem: Gouda Quint BV;

Böse, M. (2010). Der Rechtsstaat am Abgrund? - Zur Skandalisierung des EU-Geldsanktionengesetzes. Zeitschrift für Internationale Strafrechtsdogmatik, 5(10), 607-613;

Botkin, J.R., Mcmahon, W.M., \& Francis, L.P. (1999). Genetics and Criminality - The Potential Misuse of Scientific Information in Court. Baltimore: United Book Press;

Bottke, W. (1996). Sinn oder Unsinn kriminalrechtlicher AIDS-Prävention? Zugleich Versuch eines vorläufigen Resümees. In A. J. Szwarc (Ed.), AIDS und Strafrecht (pp. 277-320). Berlin: Duncker \& Humblot;

Brady, J.B. (1980). Recklessness, Negligence, Indifference and Awareness. Modern Law Review, 43, 381-399;

Brady, J.B. (1996). Recklessness. Law and Philosophy, 15(2), 183-200;

Brouns, P.J.H.M. (1988). Opzet in het wetboek van strafrecht. Arnhem: Gouda Quint BV;

Brugger, W. (2000). May Government Ever Use Torture? Two Responses From German Law. American Journal of Comparative Law, 48(4), 661-678;

Buchanan, A. (2000). Psychiatric Aspects of Justification, Excuse and Mitigation - The Jurisprudence of Mental Abnormality in Anglo-American Criminal Law. London: Jessica Kingsley Publishers;

Burmann, M., Heß, R., Jahnke, J., \& Janker, H. (Eds.). (2010). Burmann/Heß/Jahnke/Janker - Straßenverkehrsrecht. München: C.H. Beck Verlag;

Buruma, Y. (1998). Het schuldig subject. In M. J. Borgers, I. M. Koopmans \& F. G. H. Kristen (Eds.), Verwijtbare uitholling van schuld? (pp. 1-9). Nijmegen: Ars Aequi Libri;

Buruma, Y. (1999). Een strafrechtelijke ideeëngeschiedenis van de 20ste eeuw. In Y. Buruma (Ed.), 100 Jaar Strafrecht: Klassieke Teksten Van De Twintigste Eeuw (pp. 11-46). Amsterdam: Amsterdam University Press;

Buruma, Y. (2005). Noodweer. Delikt en Delinkwent, 2005(4), 436-447;

Cadoppi, A. (1996). Towards a European Criminal Code? European Journal of Crime, Criminal Law and Justice, 7(1), 2-17;

Campbell, K. (1996). Objective Standards in Provocation and Duress. The King's College Law Journal, 7, 75-89; 
Cane, P. (2007). The General/Special Distinction in Criminal Law, Tort Law and Legal Theory. Law and Philosophy, 26, 465-500;

Canestrari, S. (2004). Die Struktur des dolus eventualis - Die Unterscheidung zwischen bedingtem Vorsatz und bewusster Fahrlässigkeit und die neuen Risikophänomenologien. Goltdammer's Archiv für Strafrecht, 151(4), 210-227;

Cassese, A. (2007). The Proper Limits of Individual Responsibility under the Doctrine of Joint Criminal Enterprise. Journal of International Criminal Justice, 5, 109-133;

Cavanaugh, T.A. (2006). Double-effect Resoning. Oxford: Oxford University Press;

Chan, W., \& Simester, A.P. (2005). Analysis - Duress, Necessity: How many Defences? The King's College Law Journal, 16(1), 121-132;

Child, J. (2009). Drink, Drugs and Law reform: A Review of Law Commission Report No. 314. Criminal Law Review(7), 488-501;

Christopher, R.L. (1995). Unknowing Justification and the Logical Necessity of the Dadson Principle in Self-Defence. Oxford Journal of Legal Studies, 15, 229-252;

Clark, R.S. (2008). Drafting a General Part to a Penal Code: some thoughts inspired by the negotiations on the Rome Statute of the International Criminal Court and by the Courts first substantive law discussion in the Lubanga Dyilo confirmation proceedings. Criminal Law Forum, 2008(19), 519-552;

Clarkson, C.M.V. (2004). Necessary Action: A New Defence. Criminal Law Review, 81-95;

Cleiren, C.P.M. (2007). De actualiteit van de 'traditionele' leerstukken opzet en schuld. Strafblad, 5, 291-293;

Cleiren, C.P.M., \& Nijboer, J.F. (Eds.). (2008). Tekst \& Commentaar Strafrecht (7 ed.). Deventer: Kluwer;

Commission, L. (1977). Criminal Law - Report on defences of general application (No. Law Com. No. 83);

Commission, L. (1989). Criminal Law - A Criminal Code for England and Wales - Volumes 1 and 2 - Report and Commentary Draft Criminal Code Bill (No. Law Com No 177);

Commission, L. (1993). Legislating the Criminal Code - Offences against the Person and General Principles (No. Law Com. No. 218);

Commission, L. (1995). Legislating the Criminal Code - Intoxication and criminal liability (No. Law Com No. 229);

Commission, L. (2004). Partial Defences to Murder - Final Report (No. Law Com no. 290);

Commission, L. (2005). A New Homicide Act for England and Wales? A Consultation Paper (No. Law Com CP 177);

Commission, L. (2006). Murder, Manslaughter and Infanticide: Project 6 of the Ninth Programme of Law Reform: Homicide (No. Law Com No 304);

Commission, L. (2009). Intoxication and Criminal Liability (No. Law Com No 314);

Commission, L. (2010). Criminal Liability in Regulatory Contexts: A Consultation Paper. London;

Cruz, P.D. (1999). The Techniques of Comparative Law. In P. d. Cruz (Ed.), Comparative Law in a Changing World (pp. 211-235). London: Cavendish Publishing Limited;

Daly, F. (1978). Intoxication and crime: a comparative approach. International and Comparative Law Quarterly, 27, 378-412; 
Dannecker, G. (1993). Justification and Excuses in the European Community - Adjucation of the Court of Justice of the European Community and Tendencies of the National Legal Systems as a Basis for a Supranational Regulation. European Journal of Crime, Criminal Law and Justice, 1(3), 230-245;

Dannecker, G. (2002). Rechtfertigungs- und Entschuldigungsgründe in einem europäischen Allgemeinen Teil. In K. Tiedemann (Ed.), Wirtschaftsrecht in der Europäischen Union - Rechtsdogmatik - Rechtsvergleich - Rechtspolitik (pp. 147-168). Berlin: Carl Heymanns Verlag KG;

Delmas-Marty, M. (1997). Corpus Juris - introducing penal provisions for the purpose of the financial interests of the European Union. Paris: Economica;

Delmas-Marty, M. (2003). The Contribution of Comparative Law to a Pluralist Conception of International Criminal Law. Journal of International Criminal Justice, 1(1), 13-25;

Delmas-Marty, M., \& Vervaele, J.A.E. (2000). The implementation of the Corpus Juris in the Member States - Penal provisions for the protection of European Finances. Antwerpen: Intersentia;

Dennis, I. (2005). Reverse Onuses and the Presumption of Innocence: In Search of Principle. Criminal Law Review, 901-936;

Dershowitz, A.M. (1989). Is It Necessary to Apply Physical Pressure to Terrorists - And to Lie about It? Israel Law Review, 23(2), 192-200;

Dershowitz, A.M. (2002). Shouting Fire - Civil Liberties in a turbulent age. Boston: Little, Brown and Company;

Van Dijk, A.A. (2008). Strafrechtelijke aansprakelijkheid heroverworgen. ApeldoornAntwerpen: Maklu;

Dingwall, G. (2007). Intoxicated Mistakes about the Need for Self-Defence. Modern Law Review, 70(1), 127-138;

Dolman, M.M. (2006). Overmacht in het stelsel van strafuitsluitingsgronden. Nijmegen: Wolf Legal Publishers;

Dressler, J. (1987). Justifications and Excuses: A Brief Review of the Concepts and the Literature. The Wayne Law Review, 33(4), 1155-1175;

Dressler, J. (2000). Does One Mens Rea Fit All?: Thoughts on Alexander's Unified Conception of Criminal Culpability. California Law Review, 88, 955-964;

Dressler, J. (2002). Battered Women Who Kill Their Sleeping Tormenters: Reflections on Maintaining Respect for Human Life while Killing Moral Monsters. In S. Shute \& A. P. Simester (Eds.), Criminal Law Theory: Doctrines of the General Part (pp. 259282). Oxford: Oxford University Press;

Dubber, M.D. (2006). Comparative Criminal Law. In M. Reimann \& R. Zimmermann (Eds.), The Oxford Handbook of Comparative Law (pp. 1288-1325). Oxford: Oxford University Press;

Duff, R.A. (1990). Intention, Agency and Criminal Liability: Philosophy of Action and the Criminal Law. Oxford: Basil Blackwell Ltd;

Duff, R.A. (1995). Recklessness in Attempts (Again). Oxford Journal of Legal Studies, 15(2), 309-325; 
Duff, R.A. (2002). Virtue, Vice, and Criminal Liability: Do We Want an Aristotelian Criminal Law? Buffalo Criminal Law Review, 6, 147-184;

Duff, R.A. (2004). Rethinking Justifications. Tulsa Law Review, 39, 829-850;

Duff, R.A. (2007). Answering for Crime - Responsibility and Liability in the Criminal Law. Oxford: Hart Publishing;

Duttge, G. (2006). Rechtsprechungsübersicht zur (strafrechtlichen) Fahrlässigkeit Kontinuität und Wandel seit der Jahrtausendwende -. Neue Zeitschrift für Strafrecht, 266-274;

Eden, P. (1991). Criminal Liability and the Defence of Superior orders. South African Law Journal, 108, 640-655;

Edge, P.W. (1995). Contemporaneity and moral congruence: actus reus and mens rea reconsidered. The Liverpool Law Review, 17(1), 83-95;

Edwards, J.L.J. (1954). The Criminal Degrees of Knowledge. Modern Law Review, 17, $294-$ 314 ;

Eijsbouts, W.T., Jans, J.H., L.A.J., S., \& Prechal, A. (2010). Europees Recht - Algemeen Deel (3 ed.). Groningen: Europa Law Publishing;

Eisele, J. (2001). Notwehrrecht bei rechtwidrigem Vorverhalten und fahrlässiger Tötung. Neue Zeitschrift für Strafrecht, 416-418;

Elliott, C. (2001). French Criminal Law. Abingdon: Willan Publishing;

Elliott, C., \& De Than, C. (2007). The Case for a Rational Reconstruction of Consent in Criminal Law. Modern Law Review, 70(2), 225-249;

Elvin, J. (2006). The Doctrine of Precedent and the Provocation Defence: A Comment on R v James. Modern Law Review, 69(5), 819-842;

Engländer, A. (2008). Grund und Grenzen der Nothilfe. Tübingen: Mohr Siebeck;

Enoch, D., \& Marmor, A. (2007). The Case against Moral Luck. Law and Philosophy, 26, 405-436;

Enschedé, C.J. (1990). Een Uniform Europees Strafrecht? Arnhem: Gouda Quint BV;

Erb, V. (2005). Notwehr als Menschenrecht - Zugleich eine Kritik der Entscheidung des LG frankfurt am Main im “Fall Daschner”. Neue Zeitschrift für Strafrecht, 25(11), 593602 ;

Erenius, G. (1976). Criminal negligence and individuality. Stockholm: P.A. Norstedt \& Söners Förlag;

Eser, A. (1981). Die Tötungsdelikte in der Rechtsprechung zwischen BVerfGE 45, 187 und BGH-GSSt 1/81 - 2. Teil-. Neue Zeitschrift für Strafrecht(11), 429-432;

Eser, A. (1987). Justification and Excuse: A Key Issue in the Concept of Crime. In A. Eser \& G. P. Fletcher (Eds.), Rechtfertigung und Entschuldigung - Rechtsvergleichende Perspektiven (Vol. I, pp. 17-66). Freiburg im Breisgau: Eigenverlag Max-PlanckInstitut für ausländisches und internationales Strafrecht;

Eser, A. (1997). The Importance of Comparative Legal Research for the Development of Criminal Sciences. In R. Blancpain (Ed.), Law in motion: recent developments in civil procedure, constitutional, contract, criminal, environmental, family \& succession, intellectual property, labour, medical, social security, transport law (pp. 492-517). Den Haag: Kluwer; 
Eser, A., \& Fletcher, G.P. (1987). Rechtfertigung und Entschuldigung - Rechtsvergleichende Perspektiven (Vol. I). Freiburg im Breisgau: Eigenverlag Max-Planck-Institut für ausländisches und internationales Strafrecht;

Eser, A., \& Fletcher, G.P. (1988). Rechtfertigung und Entschuldigung - Rechtsvergleichende Perspektiven (Vol. II). Freiburg im Breisgau: Eigenverlag Max-Planck-Institut für ausländisches und internationales Strafrecht;

Fahl, C., \& Winkler, K. (2007). Definitionen Strafrecht. München: Verlag C.H. Beck;

Feenstra, R. (2002). Vergelding en vergoeding - Enkele grepen uit de geschiedenis van de onrechtmatige daad. Deventer: Kluwer;

Feller, S.Z. (1989). Not Actual Necessity but Possible "Justification"; Not "Moderate Pressure", but Either "Unlimited" or "None at All". Israel Law Review, 23(2), 201215;

Fijnaut, C. (1999). De Uitbreiding van de Europese Unie en de Strafrechtsvergelijking. In H. U. J. d'Oliviera (Ed.), De meerwaarde van de rechtsvergelijking (pp. 201-214). Deventer: Kluwer;

Fijnaut, C.J.C.F. (2001). Rechtsvergelijking en strafrecht(wetenschap): enkele methodologische beschouwingen. - Preadvies uitgebracht voor de Nederlandse Vereniging voor Rechtsvergelijking op 18 december 2001 te Tilburg. In J. Van Erp (Ed.), Nederlandse Vereniging voor Rechtsvergelijking no 61: Nederlandse Vereniging voor Rechtsvergelijking;

Finkel, N.J., \& Parrott, W.G. (2006). Emotions and Culpability: How the Law is at odds with Psychology, Jurors, and Itself. Washington, DC: American Psychological Association;

Finkelstein, C. (2000). The Inefficiency of Mens Rea. California Law Review, 88, 895-920;

Finkelstein, C. (2001). Two Men and A Plank. Legal Theory, 7, 279-306;

Fischer, B., \& Rehm, J. (1998). Intoxication, the Law and Criminal Responsibility - A Sparkling Cocktail at Times: The Case Studies of Canada and Germany. European Addiction Research, 4(3), 89-101;

Fischer, T. (Ed.). (2009). Strafgesetzbuch und Nebengesetze (56 ed.). München: C.H.Beck;

Fitzgerald, P.J. (1962). Carelessness, indifference and recklessness: Two Replies I. Modern Law Review, 25, 49-55;

Fletcher, G.P. (1971). The Theory of Criminal Negligence: A Comparative Analysis. University of Pennsylvania Law Review, 119(3), 401-439;

Fletcher, G.P. (1973). Proportionality and the Psychotic Aggressor: A Vignette in Comparative Criminal Theory. Israel Law Review, 8, 367-390;

Fletcher, G.P. (1978). Rethinking Criminal Law. Boston, Toronto: Little, Brown and Company;

Fletcher, G.P. (1985). The Right and the Reasonable. Harvard Law Review, 98, 949-982;

Fletcher, G.P. (1987). The Right and the Reasonable. In A. Eser \& G. P. Fletcher (Eds.), Rechtfertigung und Entschuldigung - Rechtsvergleichende Perspektiven. Freiburg im Breisgau: Eigenverlag Max-Planck-Institut für ausländisches und internationales Strafrecht; 
Fletcher, G.P. (1988). Introduction from a common lawyer's point of view. In A. Eser \& G. P. Fletcher (Eds.), Rechtfertigung und Entschuldigung - Rechtsvergleichende Perspektiven (pp. 795-799). Freiburg im Breisgau: Eigenverlag Max-Planck-Institut für ausländisches und internationales Strafrecht;

Fletcher, G.P. (1998). Basic Concepts of Criminal Law. New York: Oxford University Press; Fletcher, G.P. (2000). Deutsche Strafrechtsdogmatik aus ausländischer Sicht. In A. Eser, W. Hassemer \& B. Burkhardt (Eds.), Die Deutsche Strafrechtswissenschaft vor der Jahrtausendwende - Rückbesinnung und Ausblick (pp. 235-253). München: C.H. Beck Verlag;

Fletcher, G.P. (2002). The Fault of Not Knowing. Theoretical Inquiries in Law, 3, 265-282;

Fletcher, G.P. (2007). The Grammar of Criminal Law - American, Comparative, and International - Volume One: Foundations. Oxford: Oxford University Press;

Fletcher, G.P., \& Ohlin, J.D. (2005). Reclaiming Fundamental Principles of Criminal Law in the Darfur Case. Journal of International Criminal Justice, 3, 539-561;

Fokkens, J.W., \& Machielse, A.J.M., Noyon/ Langemeijer/ Remmelink: Wetboek van Strafrecht - losbladig commentaar, Deventer: Kluwer;

Frisch, W. (1983). Vorsatz und Risiko. Köln: Carl Heymanns Verlag KG;

Frisch, W. (2009). Die Strafrechtliche AIDS-Diskussion: Bilanz und neue empirische Entwicklungen. In J. C. Joerden, U. Scheffler, A. Sinn \& G. Wolf (Eds.), Vergleichende Strafrechtswissenschaft - Frankfurter Festschrift für Andrzej J. Szwarc zum 70. Geburtstag (pp. 495-521). Berlin: Duncker \& Humblot;

Funk, T.M. (1999). Justifying Justifications. Oxford Journal of Legal Studies, 19;

Gaeta, P. (2004). May Necessity Be Available As A Defence For Torture In The Interrogation of Suspected Terrorists? Journal of International Criminal Justice, 2(3);

Gardner, J. (1996). Justifications and Reasons. In A. P. Simester \& A. T. H. Smith (Eds.), Harm and Culpability (pp. 103-129). Oxford: Clarendon Press;

Gardner, J. (2004). Fletcher on Offences and Defences. Tulsa Law Review, 39, 817-827;

Gardner, J. (2007). Offences and Defences - Selected Essays in the Philosophy of Criminal Law. Oxford: Oxford University Press;

Gardner, S. (1986). Instrumentalism and Necessity. Oxford Journal of Legal Studies, 6(3), 431-438;

Gardner, S. (2005). Direct Action and the Defence of Necessity. Criminal Law Review, 371380 ;

Gatzweiler, C. (2008). Rechtsvergleichende Untersuchung zur Unterscheidung von Vorsatz und Fahrlässigkeit in Spanien, Mexiko, Argentinien, Kolumbien und Deutschland. Aachen: Shaker Verlag;

Ginbar, Y. (2008). Why not torture terrorists? Moral, practical, and legal aspects of the 'ticking bomb' justification for torture. Oxford: Oxford University Press;

Glazebrook, P.R. (1972). The necessity plea in English criminal law Cambridge Law Journal, 30(1), 87-119;

Glazebrook, P.R. (2002). Case and Comment - Human Rights, Burden of Proof, Retrospectivity and Precedent in the House of Lords. The Cambridge Law Journal, 61(1), 1-52; 
Gleß, S. (2002). What should be the conditions for a European Corpus Iuris Criminalis? In J. M. Smits, M. G. Faure \& H. E. G. S. Schneider (Eds.), Towards a European Ius Commune in Legal Education and Research (pp. 125-128). Antwerpen: Intersentia;

Glover, R. (2007). Regulatory offences and reverse burdens: the 'licensing approach'. Journal of Criminal Law, 71(3), 259-277;

Greco, L. (2009). Neue Wege der Vorsatzdogmatik - Eine Auseinandersetzung mit drei neuen Monographien zum Vorsatzbegriff. Zeitschrift für Internationale Strafrechtsdogmatik(13), 813-821;

Green, L.C. (1976). Superior orders in national and international law. Leyden: A.W. Sijthoff; Green, S.P. (2005). Six Senses of Strict Liability: A Plea for Formalism. In A. P. Simester (Ed.), Appraising Strict Liability (pp. 1-20). Oxford: Oxford University Press;

Greenawalt, K. (1984). The Perplexing Borders of Jusitification and Excuse. Columbia Law Review, 84(8), 1897-1927;

Gritter, E. (2003). Effectiviteit en aansprakelijkheid in het economisch ordeningsrecht. Den Haag: Boom Juridische uitgevers;

Groenhuijsen, M.S. (1992). Materiële dogmatiek en de modernisering van het strafrecht. In M. S. Groenhuijsen, G. E. Mulder \& J. Remmelink (Eds.), De Schets nader bekeken Beschouwingen naar aanleiding van de Schets materieel strafrecht van W. Nieboer (pp. 1-19). Arnhem: Goude Quint BV;

Gröning, L. (2010). A Criminal Justice System or a System Deficit? Notes on the System Structure of the EU Criminal Law. European Journal of Crime, Criminal Law and Criminal Justice, 18(2), 115-137;

Gropengießer, H. (2008). Der Haustyrannenmord. Berlin: Duncker \& Humblot;

Gropp, W. (1999). On the Way to a Criminal Law of the European Union? In G. Weick (Ed.), Competition or Convergence - The Future of European Legal Culture (pp. 111-120). Frankfurt am Main: Peter Lang;

Gross, O. (2004). Are Torture Warrants Warranted? Pragmatic Absolutism and Official Disobedience. Minnesota Law Review, 88, 101-175;

Günther, H.-L. (1992). Klassifikation der Rechtfertigungsgründe im Strafrecht. In M. Seebode (Ed.), Festschrift für Günter Spendel zum 70. Geburtstag am 11. Juli 1992 (pp. 189-202). Berlin: Walter de Gruyter \& Co;

Gur-Arye, M. (1986). Should the Criminal Law Distinguish between Necessity as a Justification and Necessity as an Excuse? The Law Quarterly Review, 102(1), 71-89;

Haar, R.T., \& Meijer, G.H. (2009). Noodweer. Deventer: Kluwer;

Hall, J. (1976). Comment on Justification and Excuse. American Journal of Comparative Law, 24, 638-645;

Halpin, A. (2004). Definition in the Criminal Law. Portland, Oregon: Hart Publishing;

Hamdorf, K. (2007). The Concept of a Joint Criminal Enterprise and Domestic Modes of Liability for Parties to a Crime - A Comparison of German and English Law. Journal of International Criminal Justice, 5, 208-226;

Hamer, D. (2007). The Presumption of Innocence and Reverse Burdens: A Balancing Act. The Cambridge Law Journal, 66(1), 142-171; 
Den Harder, W. (2006). Aanmerkelijk onvoorzichtig - De ondergrens van de schuld in het verkeersstrafrecht. Alblasserdam: Haveka;

Hart, H.L.A. (2008 (reprint 1967)). Punishment and Responsibility. Oxford: Oxford University Press;

Herzberg, R.D. (1996). Die Strafrechtliche Haftung für die Infizierung oder Gefährdung durch HIV. In A. J. Szwarc (Ed.), AIDS und Strafrecht (pp. 61-91). Berlin: Ducker \& Humblot;

Hettinger, M. (1988). "Actio libera in causa": Strafbarkeit wegens Begehungstat trotz Schuldunfähigkeit? Berlin: Duncker \& Humblot;

Hettinger, M. (1992). Der sog. dolus generalis: Sonderfall eines "Irrtums über den Kausalverlauf'? In M. Seebode (Ed.), Festschrift für Günter Spendel zum 70. Geburtstag am 11. Juli 1992 (pp. 237-256). Berlin: Walter de Gruyter \& Co;

Hettinger, M. (2006). Notiz zum "dolus generalis". Goltdammer's Archiv für Strafrecht, 153(5), 289-294;

Hirsch, H.J. (1997). Anwendbarkeit der Grundsätze der actio libera in causa. Neue Zeitschrift für Strafrecht, 230-232;

Hofstee, E.J. (1987). Straf naar de mate van schuld? In J. Remmelink (Ed.), Naar eer en geweten - Liber amicorum (pp. 195-214). Arnhem: Gouda Quint BV;

Holland, W.A. (1989). Gewetensbezwaren en strafuitsluitingsgronden. Arnhem: Gouda Quint BV;

Holton, R., \& Shute, S. (2007). Self-Control in the Modern Provocation Defence. Oxford Journal of Legal Studies, 27(1), 49-73;

Horder, J. (1992). Provocation and Responsibility. Oxford: Clarendon Press;

Horder, J. (1994). Rethinking Non-Fatal Offences against the Person. Oxford Journal of Legal Studies, 14(3), 335-351;

Horder, J. (1995). Review Article - Redrawing the Boundaries of Self-Defence. Modern Law Review, 58, 431-441;

Horder, J. (1996). Crimes of Ulterior Intent. In A. P. Simester \& A. T. H. Smith (Eds.), Harm and Culpability (pp. 153-172). Oxford: Clarendon Press;

Horder, J. (1997). Two histories and four hidden principles of mens rea. Law Quarterly Review, 113, 95-119;

Horder, J. (1998). Self-Defence, Necessity and Duress: Understanding the Relationship. Canadian Journal of Law and Jurisprudence, 11(1), 143-165;

Horder, J. (2001). How Culpability Can, and Cannot, be Denied in Under-age Sex Crimes. Criminal Law Review, 15-30;

Horder, J. (2002). Killing The Passive Abusers: A Theoretical Defence. In S. Shute \& A. P. Simester (Eds.), Criminal Law Theory: Doctrines of the General Part. Oxford: Oxford University Press;

Horder, J. (2005). Reshaping the Subjective Element in the Provocation Defence. Oxford Journal of Legal Studies, 25, 123-140;

Horder, J. (2006(A)). Excusing Crime. Oxford: Oxford University Press;

Horder, J. (2006(B)). Transferred Malice and the Remoteness of Unexpected Outcomes from Intentions. Criminal Law Review, 383-398; 
Hörnle, T. (2000). Der Irrtum über das Einverständnis des Opfers bei einer sexuellen Nötigung. Zeitschrift für die gesamte Strafrechtswissenschaft, 112(2), 356-380;

Hörster, M. (2009). Die strict liability des englischen Strafrechts - Zugleich eine Gegenüberstellung mit dem deutschen Straf- un Ordnungswidrigkeitenrecht. Berlin: Duncker \& Humblot;

Hruschka, J. (2001). Bestrafung des Täters trotz Rechtfertigung der Tat? Zeitschrift für die gesamte Strafrechtswissenschaft, 113(4), 870-884;

Hruschka, J. (2003). Die Notwehr im Zusammenhang von Kants Rechtslehre. Zeitschrift für die gesamte Strafrechtswissenschaft, 115(2), 201-223;

Hruschka, J. (2007). On the History of Justification and Excuse in Cases of Necessity. In B. S. Byrd \& J. Hruschka (Eds.), Kant and Law (pp. 323-335). Burlington: Ashgate;

Hsu, Y.-A. (2007). “Doppelindividulisierung” und Irrtum. Berlin: Duncker \& Humblot; Huigens, K. (2004). Fletcher's Rethinking: A Memoir. Tulsa Law Review, 39, 803-816;

De Hullu, J. (1998). Bedreigingen voor het schuldbeginsel? In M. J. Borgers, I. M. Koopmans \& F. G. H. Kristen (Eds.), Verwijtbare uitholling van schuld? (pp. 179187). Nijmegen: Ars Aequi Libri;

De Hullu, J. (2005). De invloed van eigen schuld op de beoordeling van strafuitsluitingsgronden. In F. Verbruggen, R. Verstraeten, D. van Daele \& B. Spriet (Eds.), Strafrecht als roeping- Liber Americorum Lieven Dupont (Vol. I, pp. 41-56). Leuven: Universitaire Pers Leuven;

De Hullu, J. (2006). Materieel strafrecht - Over algemene leerstukken van strafrechtelijke aansprakelijkheid naar Nederlands recht. Deventer: Kluwer;

De Hullu, J. (2009). Materieel strafrecht - Over algemene leerstukken van strafrechtelijke aansprakelijkheid naar Nederlands recht (Vol. 4). Deventer: Kluwer;

Husak, D. (2005). A Liberal Theory of Excuses. Ohio State Journal of Criminal Law, 287299;

Husak, D. (2005). Strict Liability, Justice, and Proportionality. In A. P. Simester (Ed.), Appraising Strict Liability (pp. 81-104). Oxford: Oxford University Press;

Husak, D.N. (1989). Justifications and the Criminal Liability of Accessories. Journal of Criminal Law \& Criminology, 80(2), 491-519;

Husak, D.N. (1999). Conflicts of Justifications. Law and Philosophy, 18, 41-68;

Husak, D.N. (2002). Limitations on Criminalization and the General Part of Criminal Law. In S. Shute \& A. P. Simester (Eds.), Criminal Law Theory: Doctrines of the General Part (pp. 13-46). Oxford: Oxford University Press;

Ibbetson, D. (2005). Duress Revisited. The Cambridge Law Journal, 64, 530-532;

Institute, A.L. (1985(A)). Model Penal Code and Commentaries (Official Draft and Revised Comments) - Part I, General Provisions $\S \S 1.01$ to 2.13. Philadelphia, PA: The American Law Institute;

Institute, A.L. (1985(B)). Model Penal Code and Commentaries (Official Draft and Revised Comments) - Part I, General Provisions $\S \S 3.01$ to 5.07.;

Isensee, J. (1983). Das Grundrecht auf Sicherkeit. Berlin/New York: Walter de Gruyter;

Jäger, C. (2006). Zurechnung und Rechtfertigung als Kategorialprinzipien im Strafrecht. Heidelberg: C.F. Müller Verlag; 
Jakobs, G. (1995). Das Strafrecht zwischen Funktionalismus und "alteuropäischem" Prinzipiendenken. Zeitschrift für die gesamte Strafrechtswissenschaft, 107(4), 843876 ;

Jakobs, G. (2002). Gleichgültigkeit als dolus indirectus. ZStW, 114(Heft 3);

James, M. (2007). Recklessness: Intoxication and Assault. The Journal of Criminal Law, 71(4), 296-298;

Janssen, S.L.J. (2003). Onbeschermde seks en opzet: geen normatieve uitleg, wel normativeren. Nederlands Juristenblad, 78(37), 1954;

Jescheck, H.-H. (2002). Intoduction. In S. Thaman (Ed.), The German Penal Code - as amended as of December 19, 2001. Buffalo, New York: William S. Hein \& Co.,Inc.;

Jessberger, F. (2005). Bad Torture - Good Torture? - What International Criminal Lawyers May Learn from the Recent Trial of Police Officers in Germany. Journal of International Criminal Justice, 3, 1059-1073;

Joecks, W., \& Miebach, K. (Eds.). (2003). Münchener Kommentar zum StGB; Band 1. München: C.H. Beck Verlag;

Joecks, W., \& Miebach, K. (Eds.). (2006). Münchener Kommentar zum StGB; Band 4. München: C.H. Beck Verlag;

De Jong, D.H. (2003). De aanmerkelijke kans. In M. S. Groenhuijsen \& J. B. J. M. Simmelink (Eds.), Glijdende Schalen - Liber amicorum (pp. 217-224). Nijmegen: Wolf Legal Publishers;

De Jong, D.H. (2004(A)). Het weten en willen van een 'normaal mens' in het strafrecht. Delikt en Delinkwent, 34(7), 1050-1069;

De Jong, D.H. (2004(B)). Het strafrechtelijk opzetbegrip: normatief of niet? - I. Het strafrechtelijk opzet anno 2003: vooral een psychologisch of vooral een normatief begrip? Rechtsgeleerd magazijn Themis, 165(2), 76-78;

De Jong, D.H. (2007). Onbewuste schuld - Een probleem bij de kwalificatie of bij de straftoemeting? Deventer: Kluwer;

De Jong, D.H., \& Kessler, M. (1999). Opzet in de Opiumwet: bewijs en inhoud. Nederlands Juristenblad, 74, 385-391;

De Jong, D.H., \& Kessler, M. (2002). De HIV-test voor het voorwaardelijk opzet en andere leerstukken. Nederlands Juristenblad, 87(45/46), 2230-2237;

De Jong, D.H., Kessler, M., Otte, M., \& Wolswijk, H.D. (2003). Verhoging van de strafmaxima op culpose misdrijven. Delikt en Delinkwent, 33(3), 258-280;

De Jong, D.H., \& Knigge, G. (2003). Het materiële strafrecht. Deventer: Kluwer;

De Jong, F. (2004). Facetten van schuld en gronden voor strafuitsluiting. In M. M. Boone \& others (Eds.), Discretie in het strafrecht (pp. 139-158). Den Haag: Boom Juridische Uitgevers;

De Jong, F. (2009). Daad-Schuld. Bijdrage aan een strafrechtelijke handelingsleer met bijzondere aandacht voor de normativering van het delictsbestanddeel opzet. Den Haag: Boom Juridische Uitgevers;

De Jong, F., Van Roomen, T., \& Sikkema, E. (2007). Objectiverende tendensen binnen het voorwaardelijk opzet. Delikt en Delinkwent, 37(9), 929-958; 
Kadish, S.H. (1989(A)). Act and Omission, Mens Rea, and Complicity: Approaches to Codification. Criminal Law Forum, 1(1), 65-89;

Kadish, S.H. (1989(B)). Torture, the State and the Individual. Israel Law Review, 23(2), 345-356;

Van Kalmthout, A. (1998). Intoxication and Criminal Responsibility in Dutch Criminal Law. European Addiction Research, 4(3), 102-106;

Van Kalmthout, A.M., \& Tak, P.J.P. (2003). Ups en Downs van de minimumstraffen. Nijmegen: Wolf Legal Publishers;

Kaufman, R.P. (2007). Self-Defense, Imminence, and the Battered Woman. New Criminal Law Review, 10(3), 342-369;

Kaye, M. (1997). Excessive Force in Self-Defence after R v Clegg. Journal of Criminal Law, 61, 448-457;

Keijzer, N. (1987). Enkele opmerkingen omtrent de praesumptio innocentiae in strafzaken. In J. Remmelink (Ed.), Naar eer en geweten - Liber amicorum (pp. 235-253). Arnhem: Gouda Quint BV;

Keiler, J. (2012). Actus reus and participation in European Criminal Law: Forthcoming;

Kelk, C. (2005). Studieboek materieel strafrecht. Deventer: Kluwer;

Kelk, C. (2008(B)). Strafrecht binnen menselijke proporties. Nijmegen: Boom Juridische Uitgevers;

Kelk, C., \& Kool, R.S.B. (2004). (Psychische) overmacht. Delikt en Delinkwent, 34(1), 100109 ;

Kelk, C., \& Kool, R.S.B. (2004). Sanctieoverwegingen in relatie tot de mate van (on) toerekenbaarheid en de ernst van de feiten. Delikt en Delinkwent(6), 653-663;

Van Kempen, P.H.P.H.M.C. (2004). De ondergrens van culpa. Delikt en Delinkwent, 34(9), 996-1014;

Kersten, J. (2005). Die Tötung von Unbeteiligten - Zum verfassungsrechtlichen Grundkonflikt des §14 III LuftSiG. Neue Zeitschrift für Verwaltungsrecht, 24(6), 661-663;

Kessler Ferzan, K. (2007). Holistic Culpability. Cardozo Law Review, 28(6), 2523-2543;

Kessler, M. (1998). Afwezigheid van alle schuld in de economische rechtspraak. In M. J. Borgers, I. M. Koopmans \& F. G. H. Kristen (Eds.), Verwijtbare uitholling van schuld? (pp. 81-92). Nijmegen: Ars Aequi Libri;

Kessler, M. (2001). Subjectieve bestandsdelen in bijzondere wetten. Deventer: Gouda Quint;

Keulen, B.F., \& Otte, M. (1999). Opzet en schuld. Nijmegen: Ars Aequi Libri;

Khan, A. (2002). Intention in Criminal Law: Time to Change? Statute Law Review, 23(3), 235-239;

Kindhäuser, U. (2005). Gleichgültigkeit als Vorsatz? In J. Arnold, B. Burkhardt, W. Gropp, G. Heine, H.-G. Koch, O. Lagodny, W. Perron \& S. Walther (Eds.), Menschengerechtes Strafrecht - Festschrift für Albin Eser zum 70. Geburtstag (pp. 345-358). München: C.H. Beck Verlag;

Kindhäuser, U., Neumann, U., \& Paeffgen, H.-U. (Eds.). (2010). Strafgesetzbuch. München: C.H. Beck Verlag; 
Kinzig, J. (2003). Not kennt kein Gebot? Zeitschrift für die gesamte Strafrechtswissenschaft., 115(4), 791-814;

Klip, A.H. (2002). Conditions for a European Corpus Iuris Criminalis. In J. M. Smits, M. G. Faure \& H. E. G. S. Schneider (Eds.), Towards a European Ius Commune in Legal Education and Research (pp. 109-123). Antwerpen: Intersentia;

Klip, A.H. (2007(A)). Zijn er omstandigheden waaronder folteren toelaatbaar is? Delikt en Delinkwent, 25(4), 339-349;

Klip, A.H. (2007(B)). Roekeloosheid. Delikt en Delinkwent, 37(8), 822-842;

Klip, A.H. (2012). European Criminal Law (2 ed.). Antwerpen: Intersentia;

Knigge, G. (1987). Het subsociale en de structuur van het strafbare feit. In J. Remmelink (Ed.), Naar eer en geweten - Liber amicorum (pp. 289-300). Arnhem: Gouda Quint $\mathrm{BV}$

Knigge, G. (1993). Strafuitsluitingsgronden en de structuur van het strafbare feit: Vereniging voor de vergelijkende studie van het recht van België en Nederland;

Koch, A. (1998). Die Entkriminalisierung im Bereich der fahrlässigen Körperverletzung und Tötung. Berlin: Duncker \& Humblot;

De Kogel, C.H., \& Nagtegaal, M.H. (2006). Gewelds- en zedendelinquenten met een psychische stoornis. Een inventarisatie van wetgeving en praktijk in het forensisch psychiatrisch systeem en het gevangenissyteem in Engeland, Duitsland, Canada, Zweden en België. Den Haag: Boom Juridische Uitgevers/WODC;

König, P., \& Seitz, H. (2006). Gröhler: Ordnungswidrigkeitengesetz (14 ed.). München: C.H. Beck Verlag;

Koopmans, F.A.J. (2007). Het beslissingsmodel van 348/350 Sv. Deventer: Kluwer;

Körner, H.H. (2007). Betäubungsmittelgesetz - Arzneimittelgesetz (6 ed.). München: C.H. Beck Verlag;

Van Kouwen, W., \& Bruinberg, K. (2006). Supreme Court of the Netherlands, Criminal Division (Hoge Raad der Nederlanden, Strafkamer) - HIV Transmission: Criminalisation. Journal of Criminal Law, 70(6), 485-489;

Krabbe, H.G.M. (1999). De artikelen 5 en 6 - Gevaar veroorzaken, hinderen en schuld aan verkeersongeval. In A. E. Harteveld \& H. G. M. Krabbe (Eds.), De Wegenverkeerswet 1994 - Een strafrechtelijk commentaar (pp. 131-143). Deventer: Gouda Quint;

Krey, V. (2002). German Criminal Law - General Part - Volume I - Basics. Stuttgart: Verlag W. Kohlhammer;

Krey, V. (2003). German Criminal Law - General Part - Volume II - Legal Elements of the Intentional Offence Committed by Action. Stuttgart: Verlag W. Kohlhammer;

Kristen, F.G.H. (1998). Schuldeffecten in strafrechtelijk effectenrecht. In M. J. Borgers, I. M. Koopmans \& F. G. H. Kristen (Eds.), Verwijtbare uitholling van schuld? (pp. 47-63). Nijmegen: Ars Aequi Libri;

Kristen, F.G.H. (2004). Misbruik van voorwetenschap naar Europees recht. Nijmegen: Wolf Legal Publishers;

Kudlich, H. (2005). Bestimmung der Sorgfaltspflicht beim Umgang mit Feuer und Zigaretten sowie beim Alleinlassen von Kleinkindern. Juristische Schulung, 2005(9), 848-850; 
Kugler, I. (2002). Direct and Oblique Intention in the Criminal Law. Hampshire: Ashgate; Kühl, K. (2007). Lackner/Kühl Strafgesetzbuch Kommentar (26 ed.). München: Verlag C.H. Beck;

Kuhlen, L. (2001). Objektive Zurechnung bei Rechtfertigungsgründen. In B. Schünemann, H. Achenbach, W. Bottke, H. Bernhard \& H.-J. Rudolphi (Eds.), Festschrift für Claus Roxin zum 70. Geburtstag (pp. 331-347). Berlin: Walter de Gruyter;

Kutzj, C. (2007). Torture, Necessity and Existential Politics. California Law Review, 95, 236-276;

Kwakman, N.J.M. (2007). De opzet van het opzet. In B. F. Keulen, G. Knigge \& H. D. Wolswijk (Eds.), Pet af: Liber Amicorum D.H. de Jong (pp. 289-313). Nijmegen: Wolf Legal Publishers;

Lackner, K. (1988). Insanity and Prevention: On Linking Culpablilty and Prevention in the Concept of Insanity. In Rechtfertigung und Entschuldigung - Rechtsvergleichende Perspektiven (pp. 895-926). Freiburg im Breisgau: Eigenverlag Max-Planck-Institut für ausländisches und internationales Strafrecht;

Lanham, D. (2005). Offensive Weapons and Self-Defence. Criminal Law Review, 85-97;

Lareau, F. (2001, 2 december 2001). The Distinction between Conscious Negligence and Recklessness. from www.lareau-law.ca/article-consciousnegligence.html;

Van Leeuwen, A.M.H. (1986). Altijd onvoltooid. Over toerekeningsvatbaarheid. Arnhem: Gouda Quint;

Leijten, J.C.M. (1992). Verwijt in het strafrecht. Een notie. In M. S. Groenhuijsen, G. E. Mulder \& J. Remmelink (Eds.), De Schets nader bekeken - Beschouwingen naar aanleiding van de Schets materieel strafrecht van W. Nieboer. Arnhem: Gouda Quint $\mathrm{BV}$;

Lensing, H. (2008). Enkele opmerkingen over HIV-arresten en voorwaardelijk opzet in rechtsvergelijkend perspectief. In Y. Buruma, J. Fleuren, P. H. van Kempen, F. Kusters \& T. Mertens (Eds.), Op het rechte pad - Liber amicorum Peter J.P. Tak (pp. 339-355). Nijmegen: Wolf Legal Publishers;

Leverick, F. (2002(A)). Is English Self-Defence law incompatible with Article 2 of the ECHR? Criminal Law Review, 347-362;

Leverick, F. (2002(B)). The Use of Force in Public or Private Defence and Article 2: A Reply to Professor Sir John Smith. Criminal Law Review, 963-967;

Leverick, F. (2006). Killing in Self-Defence. Oxford: Oxford University Press;

Leverick, F. (2007). Defending Self-Defence. Oxford Journal of Legal Studies, 27(3), 563579 ;

Livings, B. (2007). A Different Ball Game - Why the Nature of Consent in Contact Sports Undermines a Unitary Approach. Journal of Criminal Law, 71(6);

Lynch, A.C.E. (1982). The mental element in the actus reus. The Law Quarterly Review, 98(1), 109-142;

Maccormick, N. (1990). Reconstruction after Deconstruction: A Response to CLS. Oxford Journal of Legal Studies, 10, 539-558;

Machielse, A.J.M. (1986). Noodweer in het strafrecht - Een rechtsvergelijkende en dogmatische studie. Baarle-Nassau: Em. de Jong B.V.; 
Machielse, A.J.M. (2004). Onbeschermde seks en opzet op levensberoving. Ars Aequi, 53(4), 155-160;

Machielse, A.J.M. (2008). Initiatief voor nog meer noodweer? Ars Aequi, 2008, 118-120;

Mackay, R.D., \& Mitchell, B.J. (2006). Sleepwalking, Automatism and Insanity. Criminal Law Review, 901-905;

Mackay, R.D., Mitchell, B.J., \& Howe, L. (2006). Yet More Facts about the Insanity Defence. Criminal Law Review, 399-411;

Manchester, C. (2006). Knowledge, Due Diligence \& Strict Liability in Regulatory Offences. Criminal Law Review, 213-228;

Van der Meer, I.J.K. (1998). De presumptio innocentiae en het bewjis in ontnemingszaken. In M. J. Borgers, I. M. Koopmans \& F. G. H. Kristen (Eds.), Verwijtbare uitholling van schuld? (pp. 111-120). Nijmegen: Ars Aequi Libri;

Mevis, P.A.M. (2006). Capita Strafrecht - Een thematische Inleiding (5 ed.). Nijmegen: Ars Aequi Libri;

Mevis, P.A.M. (2011). Verdient het beroepsrecht van de arts codificatie als strafuitsluitingsgrond in het Wetboek van Strafrecht? Ars Aequi, 60(7), 549-557;

Meyer, A. (2004). Wirksamer Schutz des Luftverkehrs durch ein Luftsicherungsgesetz? Zeitschrift für Rechtspolitik, 37(6), 203-207;

Miebach, K., \& Sander, G.M. (Eds.). (2003). Münchener Kommentar zum StGB; Band 3. München: C.H. Beck Verlag;

Mitchell, B. (2007). Distinguishing between Murder and Manslaughter in Practice. The Journal of Criminal Law, 71(4), 318-341;

Mitsch, W. (2001). Notwehr gegen fahrlässig provozierten Angriff - BGH, NStZ 2001, 143. Juristische Schulung, 751-755;

Mitsch, W. (2007). Der "Kannibalen-Fall”. Zeitschrift für Internationale Strafrechtsdogmatik, 197-203;

Mols, G.P.M.F., \& Wöretshofer, J. (1994). Poging en voorbereidingshandelingen (2 ed.). Nijmegen: Ars Aequi Libri;

Momsen, C. (2006). Die Zumutbarkeit als Begrenzung strafrechtlichter Pflichten. BadenBaden: Nomos;

Mooij, A.W.M. (2004). Handeling, wilsvrijheid en toerekeningsvatbaarheid. Delikt en Delinkwent, 34(10), 1070-1094;

Mooij, A.W.M. (2007). Vrijheid en verantwoordelijkheid; een wijsgerig-antropologische beschouwing. In B. C. M. Raes \& F. A. M. Bakker (Eds.), De psychiatrie in het Nederlandse recht (pp. 31-36). Deventer: Kluwer;

Moore, M.S. (1989). Torture and the Balance of Evils. Israel Law Review, 23(2), 280-344;

Moos, R. (2004). Der allgemeine übergesetzliche Entschuldigungsgrund der Unzumutbarkeit in Deutschland und Österreich. Zeitschrift für die gesamte Strafrechtswissenschaft, 116(4), 891-914;

Morkel, D.W. (1981). Abgrenzung zwischen vorsätzlicher und fahrlässiger Straftat. Neue Zeitschrift für Strafrecht, 176-179;

Motsch, T. (2003). Der straflose Notwehrexzess (Vol. 140). Berlin: Duncker \& Humblodt; 
Mulder, G.E. (1992). De wil in het opzet. In M. S. Groenhuijsen, G. E. Mulder \& J. Remmelink (Eds.), De Schets nader bekeken - Beschouwingen naar aanleiding van de Schets materieel strafrecht van W. Nieboer. Arnhem: Gouda Quint BV;

Mulder, G.E. (1995). Opmerkingen over de betekenis van de termen vrijspraak en ontslag van rechtsvervolging. In J. P. Balkema, M. Barels, J. A. W. Lensing, A. J. M. Machielse \& H. J. B. Sackers (Eds.), Dynamisch strafrecht (pp. 269-279). Arnhem: Gouda Quint;

Müssig, B. (2003). Antizipierte Notwehr - Das Prinzip der Abwehr rechtswidriger Angriffe als Kriterium objektiver Zurechnung. Zeitschrift für die gesamte Strafrechtswissenschaft, 115(2), 224-248;

Van Netburg, C.J. (1994). Eigen schuld!? 'Culpa in causa' bij wettelijke strafuitsluitingsgronden. Den Haag: WODC;

Nieboer, W. (1991). Schets materieel strafrecht. Arnhem: Gouda Quint BV;

Nijboer, J.F. (1989). Schuldbegrip en schuldbeginsel als oriëntatiepunten in het strafrecht. Recht en kritiek, 15(4), 363-383;

Nijboer, J.F. (2005). Comparative Criminal Law \& Procedure - An Introduction. Deventer: Kluwer;

Nilsson, H.G. (2011). How to combine minimum rules with maximum legal certainty? Europarättslig Tidskrift (4), 663-675;

Norrie, A. (2006(A)). Between Orthodox Subjectivism and Moral Contextualsim: Intention and the Consultation Paper. Criminal Law Review, 486-501;

Norrie, A. (2006(B)). Crime, Reason and History; A Critical Introduction to Criminal Law (2 ed.). Cambridge: Cambridge University Press;

Ohlin, J.D. (2008). Special Issue the Law of Cruelty: Torture as an International Crime Can We Ever Justify or Excuse Torturers? The Bounds of Necessity. Journal of International Criminal Justice, 6, 289-308;

Ormerod, D. (1994). Consent and Offences against the Person: Law Commission Consultation Paper no. 134. Modern Law Review, 57, 928-940;

Ormerod, D. (2005). Smith \& Hogan: Criminal Law (11 ed.). Oxford: Oxford University Press;

Ormerod, D. (2006). Smith \& Hogan: Criminal Law - Cases and Materials. Oxford: Oxford University Press;

Ormerod, D. (2008). Smith \& Hogan: Criminal Law (Vol. 12). Oxford: Oxford University Press;

Ormerod, D., \& Williams, D.H. (2007). Smith's Law of Theft. Oxford: Oxford University Press;

Otte, M. (2001). Opzet en schuld in het verkeer. Deventer: Gouda Quint;

Otte, M. (2007). Roekeloos in het verkeersstrafrecht. Strafblad, 5, 293-302;

Packer, H.L. (1964). Two Models of the Criminal Process. University of Pennsylvania Law Review, 113(1), 1-68;

Pawlik, M. (2002). Die Notwehr nach Kant und Hegel. Zeitschrift für die gesamte Strafrechtswissenschaft, 114(2), 259-299; 
Pawlik, M. (2004). §14 Abs. 3 des Luftsicherheitsgesetzes - ein Tabubruch? Juirstenzeitung, 59(21), 1045-1055;

Pedain, A. (2003). Intention and the Terrorist Example. Criminal Law Review, 579-593;

Peristeridou, C. (2013). The principle of legality in European Criminal Law: Forthcoming;

Perlin, M.J. (1999). "Big ideas, images and distorted facts": The Insanity Defense, Genetics, and the 'Political World'. In J. R. Botkin, W. M. McMahon \& L. P. Francis (Eds.), Genetics and Criminality - The Potential Misuse of Scientific Information in Court (pp. 37-66). Baltimore: United Book Press;

Perron, W. (2005). Rechtsvergleichende Betrachtungen zur Notwehr. In J. Arnold, B. Burkhardt, W. Gropp, G. Heine, H.-G. Koch, O. Lagodny, W. Perron \& S. Walther (Eds.), Menschengerechtes Strafrecht - Festschrift für Albin Eser zum 70. Geburtstag (pp. 1019-1039). München: C. H. Beck Verlag;

Peters, A.A.G. (1966). Opzet en schuld in het strafrecht. Deventer: Kluwer;

Peters, A.A.G. (1999 (reprint 1972)). Het rechtskarakter van het strafrecht. In Y. Buruma (Ed.), 100 Jaar Strafrecht: Klassieke Teksten Van De Twintigste Eeuw. Amsterdam: Amsterdam University Press;

Philipps, L. (2001). An der Grenze von Vorsatz und Fahrlässigkeit - Ein Modell multikritieller computergestützter Entscheidungen - In B. Schünemann, H. Achenbach, W. Bottke, H. Bernhard \& H.-J. Rudolphi (Eds.), Festschrift für Claus Roxin zum 70. Geburtstag (pp. 365-378). Berlin: Walter de Gruyter;

Politie, S.M.V.E. (2007). Tussen eigen verantwoordelijkheid en eigenrichting - Standpunt van de Stichting Maatschappij, Veiligheid en Politie (SMVP) - Rapport van de projectgroep 'Noodweer' van de Stichting Maatschappij, Veiligheid en Politie (SMVP). Dordrecht: Stichting Maatschappij, Veiligheid en Politie;

Politoff, S.I., \& Koopmans, F.A.J. (1991). Schuld. Arnhem: Gouda Quint BV;

Pols, M.S. (1999 (reprint 1889)). Het begrip van strafbare handeling - Bijdrage tot de leer van opzet en schuld. In Y. Buruma (Ed.), 100 Jaar Strafrecht: Klassieke Teksten Van De Twintigste Eeuw (pp. 179-190). Amsterdam: Amsterdam University Press;

Polzin, J.P. (2008). Strafrechtliche Rechtfertigung der Rettungsfolter? Hamburg: Verlag Dr. Kovac;

Pompe, W.P.J. (1928). De persoon des daders in het strafrecht. In C. Kelk (Ed.), Gedachten van Willem pompe over de mens in het strafrecht (pp. 9-24). Nijmegen: Boom Juridische Uitgevers;

Pompe, W.P.J. (1935). Handboek van het Nederlandsche strafrecht. Zwolle: N.V. Uitgeversmaatschappij W.E.J. Tjeenk Willink;

Power, H. (2006). Provocation and Culture. Criminal Law Review, 871-888;

Prittwitz, C. (1993). Strafrecht und Risiko - Untersuchungen zur Krise von Strafrecht und Kriminalpolitik in der Risikogesellschaft. Frankfurt am Main: Vittorio Klostermann;

Puppe, I. (2001). Brauchen wir eine Risikoerhöhungstheorie? In B. Schünemann, H. Achenbach, W. Bottke, B. Haffke \& H.-J. Rudolphi (Eds.), Festschrift für Claus Roxin zum 70. Geburtstag am 15. Mai 2001. Berlin: Walter de Gruyter;

Puppe, I. (2004). Verantwortlichkeit von Klinikärzten für von Untergebrachtem bei Ausgang begangene Straftaten Neue Zeitschrift für Strafrecht, 554-556; 
Puppe, I. (2009). Aberratio ictus und dolus alternativus - Anmerkung zu BGH 4 StR 369/08 - Urteil vom 16. Oktober 2008. HRRS, 2009(3), 91-93;

Quick, O., \& Wells, C. (2006). Getting Tough with Defences. Criminal Law Review, 514525;

Reichel, P.L. (2002). Comparative Criminal Justice Systems. Upper Saddle River, New Jersey: Pearson Education Inc.;

Reijntjes, J.M. (2003). Het aantonen van opzet - Over de verhouding tussen vorm en materie in het strafrecht. In M. S. Groenhuijsen \& J. B. J. M. Simmelink (Eds.), Glijdende Schalen - Liber amicorum (pp. 473-490). Nijmegen: Wolf Legal Publishers;

Reijntjes, J.M. (2004). Het strafrechtelijk opzetbegrip: normatief of niet? - II. Opzet of toerekening? Rechtsgeleerd magazijn Themis, 165(2), 79-82;

Reitz, J.C. (1998). How To Do Comparative Law. American Journal of Comparative Law, 46, 617-636;

Remmelink, J. (1996). Mr. D. Hazewinkel-Suringa's Inleiding tot het Nederlandse Strafrecht (15 ed.). Arnhem: Gouda Quint;

Remmelink, J. (1999 (reprint 1986)). Actuele stromingen in Nederlands strafrecht. In Y. Buruma (Ed.), 100 Jaar Strafrecht: Klassieke Teksten Van De Twintigste Eeuw (pp. 83-118). Amsterdam: Amsterdam University Press;

Remmelink, J. (2001). Moord en euthanasie. Nederlands Juristenblad, 76(19);

Renzikowski, J. (2000). Die Verschärfung des §323a StGB - Preisgabe des Schuldprinzips? Zeitschrift für die gesamte Strafrechtswissenschaft, 112(3), 475-517;

Van Rest, P.H.S. (1991). Het ambtelijk bevel als strafuitsluitingsgrond: beschouwingen over art. 43 Sr. Arnhem: Gouda Quint;

Ristviki, M. (2005). Latin: The Common Legal Language of Europe? Juridica International, 199-202;

Roberts, P. (2005). Strict Liability and the Presumption of Innocence: An Exposé of Functionalist Assumptions. In A. P. Simester (Ed.), Appraising Strict Liability (pp. 151-194). Oxford: Oxford University Press;

Robinson, P.H. (1980). A Brief History of Distinctions in Criminal Culpability. The Hastings Law Journal, 31(4), 815-853;

Robinson, P.H. (1982). Criminal Law Defenses: A Systematic Analysis. Columbia Law Review, 82(2), 200-291;

Robinson, P.H. (1984). Imputed Criminal Liability. The Yale Law Journal, 93(4), 613-676;

Robinson, P.H. (1985). Causing the Conditions of One's Own Defense: A Study in the Limits of Theory in Criminal Law Doctrine. Virginia Law Review, 71(1), 1-63;

Robinson, P.H. (1989). Letter to the Editor - Symposium on the Report of the Commission of Inquiry into the Methods of Investigation of the General Security Service Regarding Hostile Terrorist Activity. Israel Law Review, 23(2), 189-191;

Robinson, P.H. (1990). Rules of Conduct and Principles of Adjudication. University of Chicago Law Review, 57, 729-771;

Robinson, P.H. (1993). Should the Criminal Law Abandon the Actus Reus- Mens Rea Distinctions? In S. Shute, J. Gardner \& J. Horder (Eds.), Action and Value in Criminal Law (pp. 187-211). Oxford: Clarendon Press; 
Robinson, P.H. (1996). Competing Theories of Justification: Deeds v. Reasons. In A. P. Simester \& A. T. H. Smith (Eds.), Harm and Culpability (pp. 45-70). Oxford: Clarendon Press;

Robinson, P.H. (1997). The Bomb Thief and the Theory of Justification Defenses. Criminal Law Forum, 8(3), 1-18;

Robinson, P.H. (2002). Mens Rea. In J. Dressler (Ed.), Encyclopedia of Crime and Justice (pp. 995-1006). Farmington Hills, Michigan: Gale;

Robinson, P.H. (2002). The Modern General Part: Three Illusions. In S. Shute \& A. P. Simester (Eds.), Criminal Law Theory: Doctrines of the General Part (pp. 74-102). Oxford: Oxford University Press;

Robinson, P.H. (2005). Justification Defenses in Situations of Unavoidable Uncertainty: A Reply to Professor Ferzan. Law and Philosophy, 24, 775-784;

Robinson, P.H., \& Darley, J.M. (1998). Testing Competing Theories of Justification. North Carolina Law Review, 76, 1095-1143;

Robroek, R. (2010). Onbewuste culpa: een analyse van de ondergrens van strafrechtelijke aansprakelijkheid. Tilburg: Celsus Juridische Uitgeverij;

Roef, D. (2001). Strafbare overheden - Een rechtsvergelijkende studie naar de strafrechtelijke aansprakelijkheid van overheden voor milieuverstoring. Antwerpen: Intersentia;

Roef, D. (2004). Strafrechtelijke verantwoordelijkheid in de risicomaatschappij. In E. Vos \& G. v. Calster (Eds.), Risico en voorzorg in de rechtsmaatschappij (pp. 201-226). Antwerpen: Intersentia;

Rogall, K. (2008). Ist der Abschuss gekaperter Flugzeuge widerrechtlich? Neue Zeitschrift für Strafrecht, 28(1), 1-5;

Rogers, J. (2001). Necessity, private defence and the killing of Mary. Criminal Law Review, $515-526$;

Rogers, J. (2002). A Criminal Lawyer's Response to Chastisement in the European Court of Human Rights. Criminal Law Review, 98-113;

Rogers, J. (2005). Criminal Liability for the Transmission of HIV. The Cambridge Law Journal, 64, 20-23;

De Roos, T.A. (2006). Voorwaardelijk opzet. In C. P. M. Cleiren, T. A. De Roos \& M. A. H. v. d. Woude (Eds.), Jurisprudentie Strafrecht Select (pp. 251-268). Den Haag: Sdu Uitgevers;

Ross, A. (1979). Über den Vorsatz - Studien zur dänischen, englischen, deutschen und schwedischen Lehre und Rechtsprechung. Baden-Baden: Nomos Verlagsgesellschaft;

Roxin, C. (1981). Die "sozialethischen Einschränkungen" des Notwehrrechts -Versuch einer Bilanz. Zeitschrift für die gesamte Strafrechtswissenschaft, 93(1), 68-104;

Roxin, C. (2004). Die strafrechtliche Beurteilung der elterlichen Züchtigung. Juristische Schulung, 2004(3), 177-180;

Roxin, C. (2005). Kann staatliche Folter in Ausnahmefällen zulässig oder wenigstens straflos sein? In J. Arnold, B. Burkhardt, W. Gropp, G. Heine, H.-G. Koch, O. Lagodny, W. Perron \& S. Walther (Eds.), Menschengerechtes Strafrecht - Festschrift für Albin Eser zum 70. Geburtstag (pp. 461-471). München: C.H. Beck Verlag; 
Roxin, C. (2006). Strafrecht Allgemeiner Teil - Band I Grundlagen - Der Aufbau der Verbrechenslehre (4 ed. Vol. 1). München: C.H. Beck Verlag;

Roxin, C. (2011). Der Abschuss gekaperter Flugzeuge zur Rettung von Menschenleben. Zeitschrift für die Internationale Strafrechtsdogmatik(6), 552-563;

Rozemond, K. (2006). De methode van het materiële strafrecht. Nijmegen: Ars Aequi Libri; Rozemond, K. (2007). Constructivisme, liberalisme en HIV-besmetting - Een repliek aan Spong en van Dijk. 82(29), 1835-1836;

Rozemond, K. (2007). Hoe groot moet de kans zijn? Nederlands Juristenblad, 82(18);

Ryan, S. (2007). Risk-taking, Recklessness and HIV Transmission: Accommodating the Reality of Sexual Transmission of HIV within a Justifiable Approach to Criminal Liability. The Liverpool Law Review, 28, 215-247;

Safferling, C.J.M. (2008). Vorsatz und Schuld: Subjektive Täterelemente im deutschen und englischen Strafrecht. Tübingen: Mohr Siebeck;

Sancinetti, M.A. (2001). "Dolus generalis" und "strafrechtliches Glück”. In B. Schünemann, H. Achenbach, W. Bottke, H. Bernhard \& H.-J. Rudolphi (Eds.), Festschrift für Claus Roxin zum 70. Geburtstag (pp. 349-364). Berlin: Walter de Gruyter;

Sangero, B. (2006). Self-Defence in Criminal Law. Portland, Oregon: Hart Publishing;

Schild, W. (1993). Vorsatz als "sachgedankliches Mitbewußtsein" - Kritische Bemerkungen zur strafrechtswissenschaftlichen Begriffsbildung. In F. Dencker \& others (Eds.), Beiträge zur Rechtswissenschaft: Festschrift für Walter Stree und Johannes Wessels zum 70. Geburtstag (pp. 241-266). Heidelberg: Müller;

Schmitz, R. (2000). Der dolus alternativus. Zeitschrift für die gesamte Strafrechtswissenschaft, 112(2), 301-333;

Schönke, A., \& Schröder, H. (Eds.). (2006). Strafgesetzbuch Kommentar (27 ed.). München: C.H. Beck Verlag;

Schönke, A., \& Schröder, H. (Eds.). (2010). Strafgesetzbuch Kommentar (28 ed.). München: C.H. Beck Verlag;

Schröder, C. (2006). Zur Europäisierung der Fahrlässigkeits- und Unterlassungsdelikte. Neue Zeitschrift für Strafrecht, 669-673;

Schultz, H. (1992). Eventualvorsatz, bedingter Vorsatz und bedingter Handlungswille. In M. Seebode (Ed.), Festschrift für Günter Spendel zum 70. Geburtstag am 11. Juli 1992 (pp. 303-316). Berlin: Walter de Gruyter \& Co;

Schünemann, B. (1985). Die deutschsprachige Strafrechtswissenschaft nach der Strafrechtsreform im Spiegel des Leipziger Kommentars und des Wiener Kommentars. Goltdammer's Archiv für Strafrecht, 341-380;

Schünemann, B. (1996). AIDS und Strafrecht - Ein Überblick. In A. J. Szwarc (Ed.), AIDS und Strafrecht (pp. 9-59). Berlin: Duncker \& Humblot;

Schünemann, B. (2005). Die Rechtsprobleme von Aids - Ein Nachruf?. In J. Arnold, B. Burkhardt, W. Gropp, G. Heine, H.-G. Koch, O. Lagodny, W. Perron \& S. Walther (Eds.), Menschengerechtes Strafrecht - Festschrift für Albin Eser zum 70. Geburtstag (pp. 1141-1154). München: C.H. Beck Verlag;

Schünemann, B., \& Roger, B. (2010). Die Karawane zur Europäisierung des Strafrechts zieht weiter - Zur demokratischen und rechtsstaatlichen Bresthaftigkeit des 
Selected bibliography

EU-Geldsanktionengesetzes. Zeitschrift für Internationale Strafrechtsdogmatik, 5(9), 515-523;

Seebode, M. (1992). Festschrift für Günter Spendel zum 70. Geburtstag am 11. Juli 1992. Berlin: Walter de Gruyter \& Co;

Senge, L. (Ed.). (2006). Karlsruher Kommentar zum OWiG. München: C.H. Beck Verlag;

Shany, Y. (2007). The prohibition against torture and cruel, inhuman, and degrading treatment and punishment: can the absolute be relativized under existing international law? Catholic University Law Review, 56, 837-869;

Shapira-Ettinger, K. (2007). The Conundrum of Mental States: Substantive Rules and Evidence Combined. Cardozo Law Review, 28(6), 2577-2596;

Shute, S. (2002). Knowledge and Belief in the Criminal Law. In S. Shute \& A. P. Simester (Eds.), Criminal Law Theory: Doctrines of the General Part (pp. 171-206). Oxford: Oxford University Press;

Sieber, U. (1999). Memorandum on a European Model Penal Code. European Journal of Law Reform, 1, 445-471;

Siekmann, H. (2005). Das Unrechtsbewustsein der DDR-"Mauerschützen”. Berlin: Duncker \& Humblot;

Siesling, M., \& Ten Voorde, J. (2007). Verruiming van Noodweerexces? Delikt en Delinkwent, 2007(5), 546-558;

Simester, A.P. (1996). Why Distinguish Intention from Foresight? In A. P. Simester \& A. T. H. Smith (Eds.), Harm and Culpability (pp. 71-101). Oxford: Clarendon Press;

Simester, A.P. (2005). Appraising Strict Liability. Oxford: Oxford University Press;

Simester, A.P. (2005). Is Strict Liability Always Wrong? In A. P. Simester (Ed.), Appraising Strict Liability (pp. 21-50). Oxford: Oxford University Press;

Simester, A.P. (2005). Responsibility for Inadvertent Acts. Ohio State Journal of Criminal Law, 2, 601-606;

Simester, A.P., \& Smith, A.T.H. (1996). Harm and Culpability. Oxford: Clarendon Press;

Simester, A.P., \& Sullivan, G.R. (2007). Criminal Law Theory and Doctrine (3 ed.). Oxford: Hart Publishing;

Simmelink, J.B.H.M. (2006). Dood en letsel in het verkeersrecht (artikel 6 WVW 1994). Delikt en Delinkwent, 36(5), 581-608;

Simmelink, J.B.H.M. (2007). Kentekenaansprakelijkheid: risico of vermoeden van schuld. Verkeersrecht, 55(3), 65-68;

Simpson, A.W.B. (1984). Cannibalism and the common law (1 ed.). Chicago: University of Chicago Press;

Sinn, A. (2004). Tötung Unschuldiger auf Grund §14 III Luftsicherungsgesetz - rechtmäßig? Neue Zeitschrift für Strafrecht, 24(11), 585-593;

Van Sliedregt, E. (2008). Ten to one. A contemporary reflection on the presumption of innocence. Den Haag: Boom Juridische Uitgevers;

Smidt, H.J. (1881(A)). Geschiedenis van het wetboek van strafrecht -Eerste deel. Haarlem: H.D. Tjeenk Willink;

Smidt, H.J. (1881(B)). Geschiedenis van het wetboek van strafrecht - Tweede deel. Haarlem: H.D. Tjeenk Willink; 
Smith, A.T.H. (1978). On Actus Reus and Mens Rea. In P. R. Glazebrook (Ed.), Reshaping the Criminal Law - Esssays in honour of Glanville Williams (pp. 95-107). London: Stevens \& Sons;

Smith, A.T.H. (1988). Error and Mistake of Law. In A. Eser \& G. P. Fletcher (Eds.), Rechtfertigung und Entschuldigung - Rechtsvergleichende Perspektiven (Vol. II, pp. 1076-1124). Freiburg im Breisgau: Eigenverlag Max-Planck-Institut für ausländisches und internationales Strafrecht;

Smith, C.E. (2009). Het normatieve karakter van de rechtswetenschap: recht als oordeel. Rechtsfilosofie en rechtstheorie, 202-225;

Smith, J.C. (1989). Justification and Excuse in the Criminal Law. London: Stevens \& Sons;

Smith, J.C. (2002). The Use of Force in Public or Private Defence and Article 2. Criminal Law Review, 958-962;

Smits, J.M. (2006). Comparative Law and its Influence on National Legal Systems. In M. Reimann \& R. Zimmermann (Eds.), The Oxford Handbook of Comparative Law (pp. 477-512). Oxford: Oxford University Press;

Spencer, J.R. (1999). The Corpus Juris project - Has it a future? In The Cambridge Yearbook of European Legal Studies (Vol. 2, pp. 355-372). Oxford: Hart Publishing;

Spencer, J.R. (2002). Brief Comments from an English perspective. In K. Tiedemann (Ed.), Wirtschaftsrecht in der Europäischen Union - Rechtsdogmatik - Rechtsvergleich Rechtspolitik (pp. 435-448). Berlin: Carl Heymanns Verlag KG;

Spencer, J.R. (2004). Liability for reckless infection - parts 1 and 2. New Law Journal, 384385 and 448 ;

Spencer, J.R. (2006). Drunken Defence. The Cambridge Law Journal, 65, 267-269;

Spencer, J.R. (2007). Intentional Killings in French Law. In J. Horder (Ed.), Homicide Law in Comparative Perspective. Oxford: Hart Publishing;

Spencer, J.R. (2007). Three new cases on consent. The Cambridge Law Journal, 66, 490493;

Spencer, J.R., \& Brajeux, M.A. (2010). Criminal liability for negligence - A lesson from across the Channel? International and Comparative Law Quarterly, 59, 1-24;

Spencer, J.R., \& Pedain, A. (2005). Approaches to Strict Liability and Constructive Liability in Continental Criminal Law. In A. P. Simester (Ed.), Appraising Strict Liability (pp. 237-284). Oxford: Oxford University Press;

Spong, G. (2003). Godett en het onschuldsbeginsel. Nederlands Juristenblad, 88(33),?;

Spong, G., \& Van Dijk, J.-H. (2007). De verraderlijke spelonken van het voorwaardelijk opzet. Nederlands Juristenblad, 82(25);

Spronken, T. (1989). Presumptie van Onschuld: De Salabiaku-zaak - Europees Hof voor de rechten van de Mens, 7 oktober 1988, De zaak Salabiaku tegen Frankrijk;

Spronken, T. (2011). De zaak Gäfgen: de dillema's van het folterverbod. Tijdschrift voor strafrecht, 2011(1), 45-49;

(Eur. Court H.R., Series A, vol. 141-A). NJCM-bulletin: Nederlands tijdschrift voor de mensenrechten, 14(4), 495-503; 
Stam, M., \& Ten Voorde, J.M. (2009). Getraumatiseerde veteranen in het strafrecht. Over de doorwerking van posttraumatische stressstoornis bij veteranen in enkele schulduitsluitingsgronden. Delikt en Delinkwent, 41(6), 539-562;

Stephen, J.F. (1890). A General View of the Criminal Law of England. London: Macmillan and $\mathrm{Co}$;

Stevens, L., \& Prinsen, M.M. (2009). Afwezigheid van opzet bij de geestelijk gestoorde verdachte - Het gedragskundig oordeel vanuit juridisch perspectief. Expertise en Recht(5/6), 113-118;

Stolwijk, S.A.M. (1999). Verdwijnt de schuld uit het strafrecht? Een tweetal schulduitsluitingsgronden. Justitiële verkenningen, 25(5), 19-24;

Stolwijk, S.A.M. (2009). Een inleiding in het strafrecht in dertien hoofdstukken (3 ed.). Deventer: Kluwer;

Streng, F. (2007). Sentencing in Germany: Basic Questions and New Developments. German Law Journal, 8(2), 153-171;

Strijards, G.A.M. (1983). Facetten van dwaling in het strafrecht. Arnhem: Gouda Quint;

Strijards, G.A.M. (1987). Strafuitsluitingsgronden. Zwolle: Tjeenk Willink;

Strijards, G.A.M. (1992). Hoofdstukken van materieel strafrecht (Vol. Uitgeverij Lemma). Utrecht;

Stuckenberg, C.-F. (2007). Vorstudien zu Vorsatz und Irrtum im Völkerstrafrecht. Berlin: De Gruyter Recht;

Sullivan, G.R. (2002). Knowledge, Belief and Culpability. In S. Shute \& A. P. Simester (Eds.), Criminal Law Theory: Doctrines of the General Part (pp. 207-226). Oxford: Oxford University Press;

Sullivan, G.R. (2005). Strict Liability for Criminal Offences in England and Wales Following Incorporation into English Law of the European Convention on Human Rights. In A. P. Simester (Ed.), Appraising Strict Liability (pp. 195-218). Oxford: Oxford University Pres;

Tadros, V. (2002). Recklessness and the Duty to Take Care. In S. Shute \& A. P. Simester (Eds.), Criminal Law Theory: Doctrines of the General Part (pp. 227-258). Oxford: Oxford University Press;

Tadros, V. (2002). The system of the criminal law. Legal Studies, 22(3), 448-467;

Tadros, V. (2005). Criminal Responsibility. Oxford: Oxford University Press;

Tadros, V. (2006). The Homicide Ladder. Modern Law Review, 69(4), 601-618;

Tanghe, T. (2007). De reikwijdte van de HIV-arresten. Strafblad, 2007, 303-311;

Taylor, G. (2004(A)). Concepts of Intention in German Criminal Law. Oxford Journal of Legal Studies, 24(1), 99-127;

Taylor, G. (2004(B)). The Intention Debate in German Criminal Law. Ratio Juris, 17(3), $346-380$;

Taylor, R. (2007). The Nature of "Partial Defences"and the Coherence of (Second Degree) Murder. Criminal Law Review, 345-359;

Ten Voorde, J.M. (2007). Cultuur als verweer. Nijmegen: Wolf Legal Publishers;

Ten Voorde, J.M. (2008). De Garantenstellung van politieambtenaren bij vuurwapengebruik en de aanname van de noodweer. Delikt en Delinkwent, 38(7), 781-802; 
Thaman, S. (2002). The German Penal Code - as amended as of December 19, 2001. Buffalo, New York: William S. Hein \& Co.,Inc.;

De Than, C. (2001). European Court of Human Rights - Mistaken belief in Self-Defence May Justify Use of Lethal Force - Brady v United Kingdom (3 April 2001). Journal of Criminal Law, 65, 417-457;

Tiedemann, K. (2002). Grunderfordernisse einer Regelung des Allgemeinen Teils. In K. Tiedemann (Ed.), Wirtschaftsrecht in der Europäischen Union - Rechtsdogmatik Rechtsvergleich - Rechtspolitik (pp. 3-22). Berlin Carl Heymanns Verlag KG;

Tieks, G.J. (2012). Psychische overmacht en entschuldigender Notstand: Een NederlandsDuitse rechtsvergelijking. Tilburg: Celsus juridische uitgeverij;

Tischler, W.G. (1984). Verbotsirrtum und Irrtum über normative TatbestandsmerkmaleDogmengechichte eines Abgrenzungsproblem. Berlin: Duncker \& Humblot;

Tridimas, T. (2006). The General Principles of EU Law. Oxford: Oxford University Press;

Triffterer, O. (2002). Der lange Weg zu einer internationalen Strafgerichtsbarkeit. Zeitschrift für die gesamte Strafrechtswissenschaft, 114(2), 321-371;

Vellinga, W.H. (1982). Schuld in spiegelbeeld - afwezigheid van alle schuld. Arnhem: Gouda Quint BV;

Verheijen, E.A.M. (2006). Nederlands strafrechtelijke waarden in de context van de Europese Unie. Nijmegen: Wolf Legal Publishers;

Van Verseveld, A. (2011). Mistake of law - Excusing perpetrators of international crimes. Amsterdam;

Virgo, G. (2003(A)). Constructing Manslaughter in Drug Abuse Cases. The Cambridge Law Journal, 62, 12-14;

Virgo, G. (2003(B)). Diminished Responsibility Expanded. The Cambridge Law Journal, $62,540-543$;

Virgo, G. (2005). Provocation Restrained. The Cambridge Law Journal, 64, 532-535;

Visser, M.J.C. (1998). Uitholling van het schuldbeginsel bij zorgplichtbepalingen door schending van het lex certa-beginsel. In M. J. Borgers, I. M. Koopmans \& F. G. H. Kristen (Eds.), Verwijtbare uitholling van schuld? (pp. 65-80). Nijmegen: Ars Aequi Libri;

Vogel, J. (2002). Voraussetzungen und Ausschluss der subjektiven Zurechnung. In K. Tiedemann (Ed.), Wirtschaftsrecht in der Europäischen Union - Rechtsdogmatik Rechtsvergleich - Rechtspolitik (pp. 125-146). Berlin: Carl Heymanns Verlag KG;

Von Heintschell-Heinegg, B. (Ed.). (2009). Beck'scher Online-Kommentar (Vol. 10). München: C.H. Beck Verlag;

Vrij, M.P. (1999 (reprint 1947)). Ter Effening - Het subsociale als het derde element van het delict. In Y. Buruma (Ed.), 100 Jaar Strafrecht: Klassieke Teksten Van De Twintigste Eeuw. Amsterdam: Amsterdam University Press;

Vrijheid, H.M. (1918). Schuld en schuldverband in het Romeinsche Strafrecht. Amsterdam: A.H. Kruyt;

Vrolijk, M. (2004). Recht door Gratie: Gratie bij doodslagen en andere delicten in Vlaanderen, Holland en Zeeland (1531-1567). Hilversum: Verloren; 
Wagenländer, G. (2005). Zur strafrechtlichen Beurteilung der Rettungsfolter (Vol. 173). Berlin: Duncker \& Humblot;

Wallerstein, S. (2010). Why English law should not incorporate the defence of superior orders. Criminal Law Review, 109(2), 109-126;

Walsh, C. (2005). Magic Mushrooms and the Law. Criminal Law Review, 773-783;

Wannop, A.L. (1995). Battered Women Syndrome and the Defense of Battered Women in Canada and England. Suffolk Transnational Law Review, 19, 251-272;

Weber, K. (2009). Betäubungsmittelgesetz - Verordungen zum BtMG. München: C.H. Beck Verlag;

Weigend, T. (1981). Zwischen Vorsatz und Fahrlässigkeit. Zeitschrift für die gesamte Strafrechtswissenschaft, 93, 657-700;

Weigend, T. (2001). Zur frage eines “internationalen” Allgemeinen Teils. In B. Schünemann, H. Achenbach, W. Bottke, H. Bernhard \& H.-J. Rudolphi (Eds.), Festschrift für Claus Roxin zum 70. Geburtstag (pp. 1375-1399). Berlin: Walter de Gruyter;

Weigend, T. (2002). Bemerkungen zum "Allgemeinen Teil" der "Europa-Delikte". In K. Tiedemann (Ed.), Wirtschaftsrecht in der Europäischen Union - Rechtsdogmatik Rechtsvergleich - Rechtspolitik (pp. 407-426). Berlin: Carl Heymanns Verlag KG;

Weigend, T. (2004). Der Entwurf einer Europäischen Verfassung und das Strafrecht. Zeitschrift für die gesamte Strafrechtswissenschaft, 116(2), 275-303;

Weigend, T. (2006). Strafrecht und Zeitgeist. In U. Sieber \& H.-J. Albrecht (Eds.), Strafrecht und Kriminologie unter einem Dach (pp. 44-65). Berlin: Duncker \& Humblot;

Weigend, T. (2008). Deutschland als Folterstaat? In Y. Buruma, J. Fleuren, P. H. van Kempen, F. Kusters \& T. Mertens (Eds.), Op het rechte pad Liber amicorum J.P. Tak (pp. 321-338);

Weigend, T. (2011). Comments on Jeroen Blomsma's Case for Recklessness. In A. H. Klip (Ed.), Substantive Criminal Law of the European Union (pp. 161-171). Antwerpen: Maklu;

Werle, G., \& Jessberger, F. (2005). 'Unless Otherwise Provided' - Article 30 of the ICC Statute and the Mental Element of Crimes under International Criminal Law. Journal of International Criminal Justice, 3, 35-55;

Westen, P. (2006). An Attitudinal Theory of Excuse. Law and Philosophy, 25, 289-375;

Westen, P. (2007). Two rules of legality in criminal law. Law and Philosophy, 26(3), 229305 ;

Westen, P. (2008(A)). Offences and defences again. Oxford Journal of Legal Studies, 28(3), 563-584;

Westen, P. (2008(B)). Individualizing the Reasonable Person in Criminal Law. Criminal Law and Philosophy, 2008(2), 137-162;

White, A.R. (1961). Carelessness, indifference and recklessness. Modern Law Review, 24, 592-595;

Williams, G. (1962). Carelessness, indifference and recklessness: Two Replies II. Modern Law Review, 25, 55-58;

Williams, G. (1977). A Commentary on R. v. Dudley and Stephens. Cambrian Law Review, 8, 94-99; 
Williams, G. (1982). Offences and Defences. Legal Studies, 2(3), 247-252;

Williams, G. (1983). Convictions and Fair Labelling. The Cambridge Law Journal, 42, $85-95$;

Williams, G.L. (1953). Criminal Law - The General Part. London: Stevens \& Sons Limited; Van der Wilt, C.J. (2007). De Hoge Raad vertilt zich wederom aan de HIV-problematiek. Delikt en Delinkwent, 45(6), 589-603;

Van der Wilt, H.G. (2006). Genocide, Complicity in Genocide and International v. Domestic Jurisdiction Journal of International Criminal Justice, 2(4), 239-257;

Winslade, W.J. (1970). Recklessness. Analysis, 30(4), 135-140;

Winslade, W.J. (1972). Brady on Recklessness. Analysis, 33(1), 31-32;

Wirth, S. (2003). Germany's New International Crimes Code: Bringing a Case to Court. Journal of International Criminal Justice, 1, 151-168;

Wittemann, F. (1997). Grundlinien und Grenzen der Notwehr in Europa. Frankfurt am Main: Peter Lang Europäischer Verlag der Wissenschaften;

Wolswijk, H.D. (1998). Ontbreken van materiële wederrechtelijkheid in het milieustrafrecht. Milieu \& Recht, 25(11), 244-249;

Wolter, J. (2006). Zum ungekehrten dolus generalis - Subjektive Zurechnung eines beendeten (tauglichen) Versuchs bei objektiver Zurechnung der Vollendung. Goltdammer's Archiv für Strafrecht, 153(5), 406-411;

Wootton, B. (1981). Crime and the criminal law (2 ed.). London: Stevens \& Sons;

Youngs, R. (2000). Mistake of Law in Germany - Opening Up Pandora's Box. Journal of Criminal Law, 64, 339-344;

Zieschang, F. (2001). Chancen und Risiken der Europäisierung des Strafrechts. Zeitschrift für die gesamte Strafrechtswissenschaft, 113(2), 255-270;

Zweigert, K., \& Kötz, H. (1998). An introduction to comparative law (T. Weir, Trans.). Oxford: Clarendon Press.

\section{Various}

Süddeutsche Zeitung, 17 August 2010;

'Reforms to give public confidence in tackling criminals', Ministry of Justice, 19 December 2007, www.justice.gov.uk/news/ newsrelease191207a.htm;

CPS:'Self-defence and the prevention of crime', www.cps.gov.uk/legal/ section5/chapter_d. html;

www.rijksoverheid.nl/onderwerpen/tbs/behandelduur-tbs;

www.iuscomp.org. 


\section{Curriculum Vitae of Jeroen Blomsma}

Jeroen received a degree in Dutch law at Maastricht University in 2005. After working for a unit of the Dutch Public Prosecutor's office that deals with international judicial cooperation, he returned to his alma mater in 2006 to lecture in criminal law. Amongst others, he has taught courses on European criminal law and international cooperation in criminal matters.

In 2007, he started working on this $\mathrm{PhD}$ research. He attended two specialization courses on European criminal law that year: one in Brussels by the Institute of European Studies, and one in Sicily at the International Institute of Higher Studies in Criminal Sciences. Since 2007, he also is the secretary of the editorial board of a Dutch Commentary on international cooperation in criminal matters. 



\section{School of Human Rights Research SERIES}

The School of Human Rights Research is a joint effort by human rights researchers in the Netherlands. Its central research theme is the nature and meaning of international standards in the field of human rights, their application and promotion in the national legal order, their interplay with national standards, and the international supervision of such application. The School of Human Rights Research Series only includes English titles that contribute to a better understanding of the different aspects of human rights.

Editorial Board of the Series:

Prof. dr. J.E. Goldschmidt (Utrecht University), Prof. dr. D.A. Hellema (Utrecht University), Prof. dr. W.J.M. van Genugten (Tilburg University), Prof. dr. M.T. Kamminga (Maastricht University), Prof. dr. P.A.M. Mevis (Erasmus University Rotterdam), Dr. J.-P. Loof (Leiden University) and Dr. O.M. Ribbelink (Asser Institute).

For previous volumes in the series, please visit http://shr.intersentia.com.

Published titles within the Series:

45. Marloes van Noorloos, Hate Speech Revisited. A comparative and historical perspective on hate speech law in the Netherlands and England \& Wales ISBN 978-1-78068-032-3

46. Hanneke Senden, Interpretation of Fundamental Rights in a Multilevel Legal System. An analysis of the European Court of Human Rights and the Court of Justice of the European Union ISBN 978-1-78068-027-9

47. Otto Spijkers, The United Nations, the Evolution of Global Values and International Law ISBN 978-1-78068-036-1

48. Karin Veegens, A Disrupted Balance? Prevention of terrorism and compliance with fundamental legal rights and principles of law - the Dutch antiterrorism legislation ISBN 978-1-78068-042-2

49. Antenor Hallo de Wolf, Reconciling Privatization with Human Rights ISBN 978-1-78068-049-1

50. Marie-José van der Heijden, Transnational Corporations and Human Rights Liabilities ISBN 978-9-40000-195-4

51. Marthe Lot Vermeulen, Enforced disappearance ISBN 978-1-78068-065-1

52. Vera Vriezen, Amnesty Justified? ISBN 978-1-78068-075-1

53 Maite San Giorgi, The Human Right to Equal Access to Heath Care ISBN 978-1-78068-081-1

54. Jeroen Blomsma, Mens rea and defences in European Criminal Law ISBN 978-1-78068-104-7 
